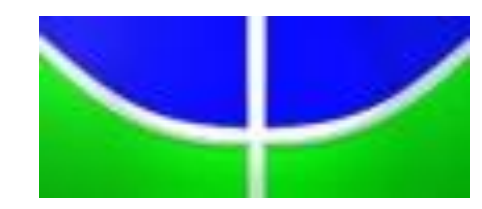

UNIVERSIDADE DE BRASÍLIA
PÓS-GRADUAÇÃO EM GEOGRAFIA

\title{
ESTUDO DOS PADRÕES ESPAÇO-TEMPORAIS DE OCORRÊNCIA DA DIARREIA NO SEMIÁRIDO BRASILEIRO
}

Marcus Andre Fuckner

Tese de Doutorado 
UNIVERSIDADE DE BRASÍLIA

PÓS-GRADUAÇÃO EM GEOGRAFIA

\title{
ESTUDO DOS PADRÕES ESPAÇO-TEMPORAIS DE OCORRÊNCIA DA DIARREIA NO SEMIÁRIDO BRASILEIRO
}

\author{
Marcus Andre Fuckner \\ Orientador: Dr. Osmar Abilio de Carvalho Júnior \\ Coorientadora: Dra. Helen da Costa Gurgel
}

Tese de Doutorado

Brasília-DF: Novembro / 2015 


\title{
ESTUDO DOS PADRÕES ESPAÇO-TEMPORAIS DE OCORRÊNCIA DA DIARREIA NO SEMIÁRIDO BRASILEIRO
}

\author{
Marcus Andre Fuckner
}

Tese de Doutorado submetida ao Departamento de Geografia da Universidade de Brasília, como parte dos requisitos necessários para a obtenção do Grau de Doutor em Geografia, área de concentração Gestão Ambiental e Territorial, opção Acadêmica.

Aprovado por:

Osmar Abilio de Carvalho Junior, Doutor (UnB)

(Orientador)

$\overline{\text { Beatriz Susana Ovruski de Ceballos, Doutora (UEPB) }}$

(Examinadora Externa)

Jean-Michel Martinez, Doutor (IRD)

(Examinador Externo)

Laurent Durieux, Doutor (CGEE)

(Examinador Externo)

Renata Bley da Silveira de Oliveira, Doutora (ANA) (Examinadora Externa)

Brasília-DF, 23 de novembro de 2015 


\section{FUCKNER, MARCUS ANDRE}

Estudo dos padrões espaço-temporais de ocorrência da diarreia no semiárido brasileiro, 337 p., 297 mm, (UnB-GEA, Doutor, Geografia, 2015).

Tese de Doutorado - Universidade de Brasília. Departamento de Geografia.

1. Diarreia 2. Semiárido

3. Precipitação 4. Abastecimento de Água

I. UnB-GEA II. Título (série)

É concedida à Universidade de Brasília permissão para reproduzir cópias desta tese e emprestar ou vender tais cópias somente para propósitos acadêmicos e científicos. $\mathrm{O}$ autor reserva outros direitos de publicação e nenhuma parte desta tese de doutorado pode ser reproduzida sem a autorização por escrito do autor.

Marcus Andre Fuckner 
A Deus, que me criou e sustém. 


\section{AGRADECIMENTOS}

Aos meus pais, Edilio e Enilce, pela educação e pelas orações.

A Bíblia, pela fonte de sabedoria.

A Geografia, por me encantar cada dia mais.

A minha irmã Andreiza e meus sobrinhos Thiago e Daniel.

Ao meu grande amigo Anderson Barreto.

A Ângela Silva, por me animar a entrar no curso de doutorado.

A Dra. Ana Helena Germoglio, por me estimular a não desistir.

A Universidade de Brasília, pelo acolhimento e aprendizado.

Aos colegas cobaias do Curso de Doutorado, saudade.

Ao Dr. Osmar Abilio, por aceitar meu projeto, minhas ideias e pela orientação.

A Dra. Helen Gurgel, pela orientação, confiança e encorajamento.

A Agência Nacional de Águas, pelas oportunidades de crescimento pessoal e profissional.

Ao Dr. Jean-Michel Martinez, por acreditar no projeto e auxílio com os dados de satélite.

As Secretarias Estaduais de Saúde do Rio Grande do Norte e da Paraíba, SESAP e SES, pelo acesso aos dados não publicados de DDA que constituíram o núcleo da pesquisa.

A ANA, EMPARN, CAERN, CAGEPA, MI, MDS e SNIS, por prontamente atenderem e fornecerem dados não publicados de fundamental relevância para a pesquisa.

A Dra. Lúcia Cony e Dra. Marília Peluzo, pelo ensino e aprimoramento do método de pesquisa.

Ao Dr. Christovam Barcellos e Dr. Pierre Mazzega, pelas contribuições ao desenvolvimento da pesquisa quando da qualificação.

Ao Dr. Christovam, Dr. José Attayde, Dr. Jean-Michel, Dr. Alexandre Linhares, Elizabete Juliatto, Regina Generino e Cristina Santos, pelas contribuições objetivas ao delineamento da pesquisa e discussão.

Ao Dr. Laurent Durieux e ao Projeto RELAIS, pela oportunidade de cursar o Doutorado Sanduíche.

Ao CNPQ, pela bolsa de Doutorado Sanduíche no exterior.

Aos professores Lucas, Elvice, João e Marie-Line, pelas aulas de francês.

Ao IRD, por ter me acolhido na França.

A Missifany Silveira, André Fenner e Paulo Peiter pelo companheirismo e alegria em Montpellier.

A Nathan Andrade, pelo auxílio com o inglês.

Aos meus muitos amigos e amigas, por este Brasil e mundo, por acreditarem que eu consigo.

A Dra. Beatriz Ceballos, Dra. Renata Bley, Dr. Jean-Michel e Dr. Laurent, membros da banca final, pela contribuição ao aprimoramento desta tese de doutorado. 


\section{RESUMO}

As doenças diarreicas constituem um grande problema de saúde pública no Brasil e no mundo e sua maior ou menor ocorrência está associada a uma série de variáveis ambientais. Esta pesquisa baseou-se na análise de séries temporais da ocorrência de doenças diarreicas agudas (DDA) por semana epidemiológica de 2002 a 2014, sobre todas as faixas etárias da população, indistintamente, em uma área da região semiárida brasileira, que compreendeu 74 municípios dos estados do Rio Grande do Norte e da Paraíba. Foi estudada a relação da DDA com indicadores como a qualidade da água dos reservatórios de abastecimento público, a distribuição da precipitação na região e as diferentes fontes de abastecimento de água, envolvendo indicadores como o nível de água dos reservatórios, a quantidade de carros-pipa em operação e o volume de água fornecido à população. Os resultados obtidos apontaram que a maior ocorrência da DDA na região está associada ao período de chuvas em cada ano, observado pela análise da influência do material inorgânico em suspensão na resposta espectral da água dos reservatórios de abastecimento urbano, utilizando imagens de sensoriamento remoto. A ocorrência da doença esteve associada notadamente às primeiras chuvas de cada ano, tendo sido verificada, a partir de análise de correlação cruzada, uma defasagem de três a quatro semanas em média entre o início das chuvas e o aumento nos casos registrados, com coeficientes de correlação entre as séries anuais variando de 0,35 a 0,83. Esses resultados parecem indicar a influência da precipitação na contaminação das fontes de água e maior transporte e circulação dos patógenos. Em relação ao abastecimento de água foi verificado que a existência de um manancial de água de boa qualidade parece não ser a variável que contribui para a ocorrência de menores taxas da doença, mas sim, características físicas e operacionais dos sistemas adutores de abastecimento e a disponibilidade contínua de água à população, em quantidade adequada, ao longo do tempo, principalmente em períodos de escassez hídrica como ocorrido de 2012 a 2014. Os resultados obtidos com o recorte espacial na região semiárida estimularam a realização de um estudo complementar da distribuição espaço-temporal das internações por diarreia e gastroenterites relacionando-a aos tipos climáticos do país e, envolvendo todos os munícipios brasileiros. Os resultados permitiram observar que há padrões mais definidos do comportamento das internações em regiões onde há presença de duas estações do ano bem características, uma chuvosa e outra seca, sendo que nas demais regiões, a exemplo do Sul do país, não há um comportamento único predominante. O padrão ligado a estação chuvosa foi verificado principalmente nas regiões Norte e Nordeste e, à estação seca, no Centro-Oeste e Sudeste. A pesquisa concluiu que fatores como a sazonalidade e a agregação de variáveis meteorológicas e daquelas ligadas ao abastecimento de água são importantes para o estudo das doenças diarreicas no Brasil, sobretudo como subsídios para um maior entendimento dos padrões de sua ocorrência na região semiárida.

Palavras-chave: diarreia, semiárido, precipitação, séries temporais, abastecimento de água. 


\begin{abstract}
The diarrheal illnesses constitute a great public health problem in Brazil and throughout the world and their degree of occurrence is associated with a number of environmental variables. This research was based in time series analysis of the occurrence of acute diarrheal diseases (ADD) by epidemiological week from 2002 to 2014, of all age groups of the population, indistinctly, in an area of the Brazilian semiarid region, which included 74 municipalities in the States of Rio Grande do Norte and of Paraíba. It was studied the relationship of the ADD with indicators such as water quality of public water supply reservoirs, the distribution of rainfall in the region and the different sources of water supply, involving indicators such as the water level in the reservoirs, the amount of water trucks in operation and the volume of water supplied to the population. The results showed that the greater occurence of ADD in the region is related to the rainy season each year, observed by analyzing the influence of suspended inorganic matter in the spectral signatures of water in urban supply reservoirs, using remote sensing images. The occurrence of the disease was associated especially with the first rains of each year, having been determined from cross-correlation analysis, a lag of three to four weeks on average between the onset of the rains and the increase in reported cases, with correlation coefficients between the annual series ranging from 0.35 to 0.83 . These results appear to indicate the influence of rainfall on the contamination of water sources and most transport and movement of pathogens. Regarding the water supply was found that the existence of a good water source does not seem to be the variable that contribute to lower occurrence rates of the disease, but rather physical and operational characteristics of the adductors systems of supply and continuous availability of water to the population in adequate amounts, over time, particularly in times of water shortage as occurred in 2012 to 2014 . The results obtained with the study area in the semiarid region stimulated the realization of an additional study of the spatial and temporal distribution of hospitalizations for diarrhea and gastroenteritis relating to the climatic types of the country and involving all Brazilian municipalities. The results allowed to observe that there are more defined patterns of hospital admissions in regions where there is the presence of two well-defined seasons, one rainy and one dry, and in other regions, such as the South of the country, there is not a single dominant pattern. The pattern linked to the rainy season was mainly observed in the North and Northeast regions, and in the dry season, in the Midwest and Southeast. The research concluded that factors such as seasonality and the aggregation of meteorological variables and those related to water supply are important in the study of diarrheal diseases in Brazil, especially as subsidies for a better understanding of the patterns of their occurrence in the semiarid region.
\end{abstract}

Keywords: diarrhea, semiarid, rainfall, time series, water supply. 


\section{RÉSUMÉ}

Les maladies diarrhéiques sont un problème majeur de santé publique au Brésil et dans le monde. Leur degré d'occurrence est associé à un certain nombre de variables environnementales. Cette recherche est basée sur l'analyse des séries chronologiques de l'occurrence des maladies diarrhéiques aiguës (MDA) par semaine épidémiologique de 2002 à 2014, de tous les groupes d'âge de la population, sans distinction, dans une zone de la région semi-aride du Brésil, qui comprenait 74 municipalités dans les états de Rio Grande do Norte et de Paraiba. Nous avons étudié la relation entre la MDA avec des indicateurs tels que la qualité de publics réservoirs d'approvisionnement en eau, la distribution des précipitations dans la région et les différentes sources d'approvisionnement en eau, présentant des indicateurs tels que le niveau d'eau dans les réservoirs, la quantité de camions-citernes dans le fonctionnement et le volume d'eau fourni à la population. Les résultats ont montré que la prévalence de la MDA dans la région est associée à la saison des pluies chaque année, observée en analysant l'influence des matériaux inorganiques en suspension dans la réponse spectrale des réservoirs d'approvisionnement en eau urbaine, en utilisant des images de télédétection. L'occurrence de la maladie a été associée surtout avec les premières pluies de chaque année, ayant été déterminé à partir de l'analyse de corrélation croisée, un décalage de trois à quatre semaines en moyenne entre le début de la saison des pluies et l'augmentation des cas rapportés, avec des coefficients de corrélation entre la série annuelle allant de 0,35 à 0,83 . Ces résultats semblent indiquer l'influence des précipitations sur la contamination des sources d'eau et le plus grand transport et la circulation d'agents pathogènes. En ce qui concerne l'approvisionnement en eau, il a été constaté que l'existence d'une bonne source d'eau ne semble pas être le variable qui contribue à la baisse des taux d'occurrence de la maladie, mais plutôt des caractéristiques physiques et opérationnelles des systèmes adducteurs et la disponibilité continue de l'eau à la population en quantité suffisante, au fil du temps, en particulier dans les périodes de pénuries d'eau observé de 2012 à 2014. Les résultats de l'étude dans la région semi-aride ont stimulé une étude complémentaire de la distribution spatio-temporelle des hospitalisations pour diarrhée et la gastro-entérite concernant les types climatiques du pays et impliquant toutes les municipalités brésiliennes. Les résultats ont montré qu'il ya des configurations plus définies de comportements d'hospitalisations dans les régions où il ya la présence de deux saisons bien distinctes, l'une pendant la saison des pluies et une autre lors d'une saison sèche, et dans d'autres régions, comme au Sud du pays, il n'y a pas de comportement unique prédominant. Le modèle lié à la saison des pluies a été observé principalement dans les régions du Nord et du Nord-est et dans la saison sèche dans le Centre-ouest et le Sud-est. La recherche a conclu que les facteurs tels que la saisonnalité et l'agrégation de variables météorologiques et ceux liés à l'approvisionnement en eau sont importants pour l'étude des maladies diarrhéiques au Brésil, en particulier pour une meilleure compréhension de leur présence dans la région semi-aride.

Mots clés: diarrhée, semi-aride, précipitation, les séries chronologiques, l'approvisionnement en eau. 


\section{SUMÁRIO}

1 INTRODUÇÃ

1.1 DEFINIÇÃO DO RECORTE TEMÁTICO DE ESTUDO ........................................

1.2 ESCOLHA DO RECORTE GEOGRÁFICO …………..........................................

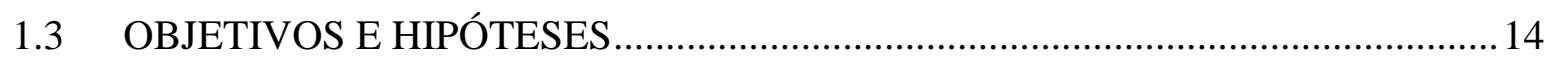

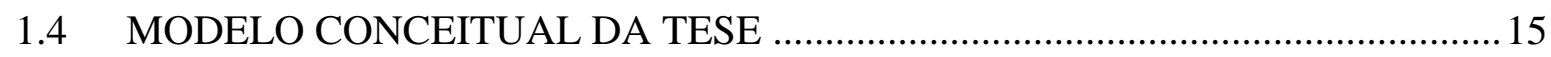

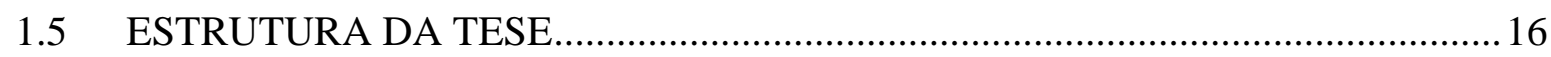

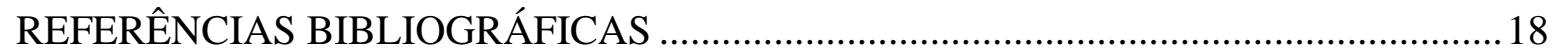

2 ANÁLISE TEMPORAL DA QUALIDADE DA ÁGUA DE RESERVATÓRIOS DE ABASTECIMENTO HUMANO POR SENSORIAMENTO REMOTO E DA OCORRÊNCIA DE DOENÇA DIARREICA AGUDA EM UM RECORTE ESPACIAL DO SEMIÁRIDO BRASILEIRO ENTRE 2002 E 2012 .....................................................21

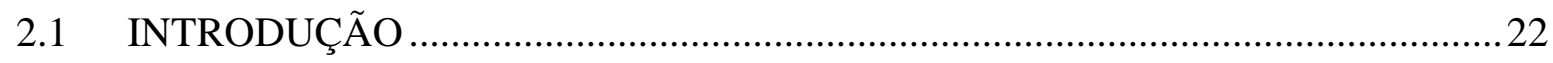

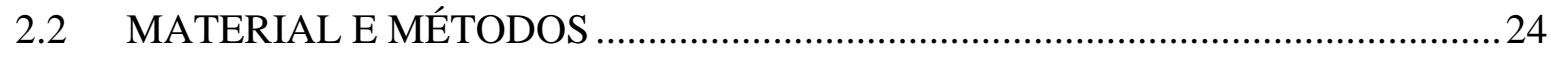

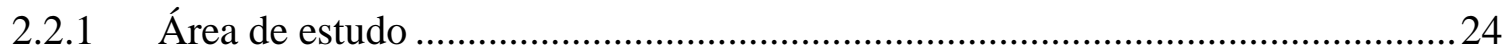

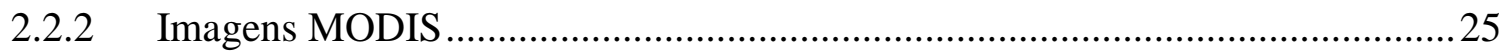

2.2.3 Dados Fluviométricos, Pluviométricos e de Doença Diarreica Aguda ...............29

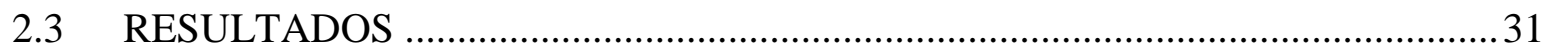

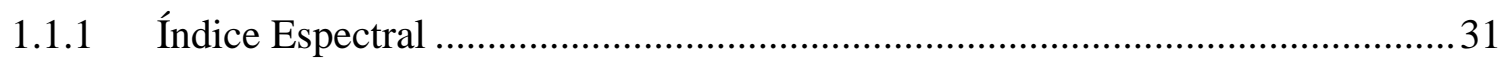

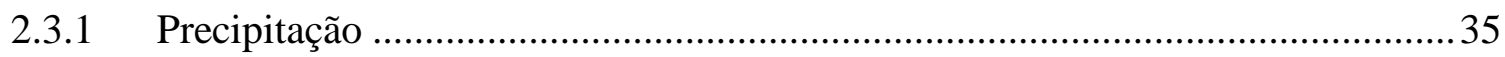

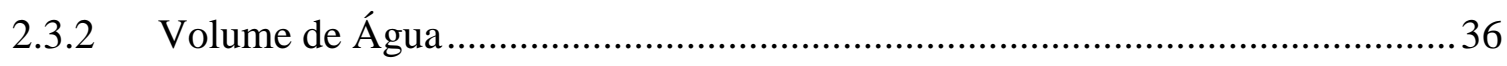

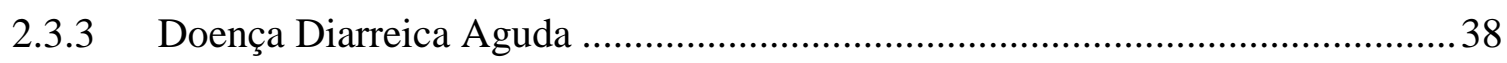

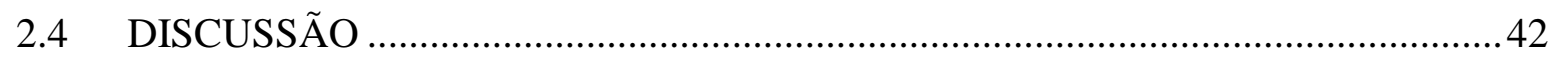

2.5 CONSIDERAÇÕES FINAIS ...................................................................... 47

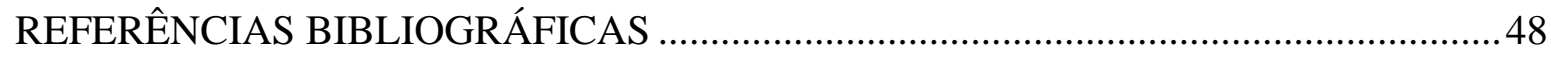


3 COMPORTAMENTO INTRA E INTERANUAL DE OCORRÊNCIA DA DOENÇA DIARREICA AGUDA POR SEMANA EPIDEMIOLÓGICA NO SEMIÁRIDO BRASILEIRO ENTRE 2002 E 2012 ..................................................................................53

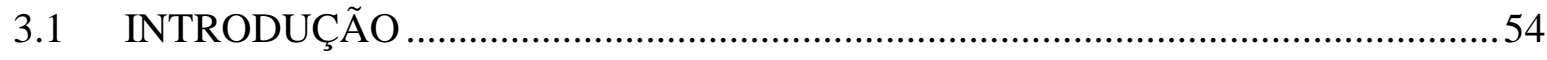

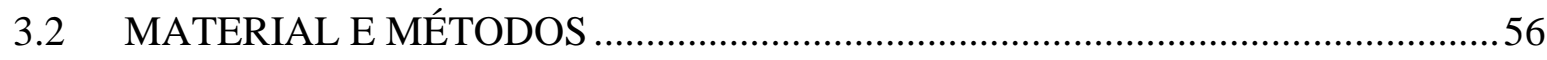

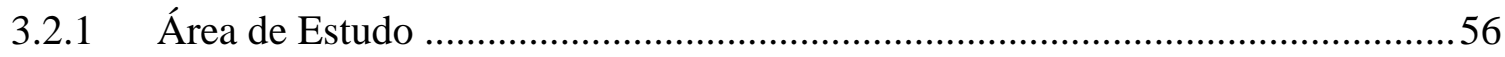

3.2.2 Séries Temporais de Ocorrência de DDA …........................................................58

3.2.3 Séries Temporais de Dados Meteorológicos …................................................59

3.2.4 Análise de Correlação Cruzada entre as Variáveis Meteorológicas e DDA ......59

3.2.5 Análise do Padrão Intra e Interanual de Ocorrência da DDA .............................61

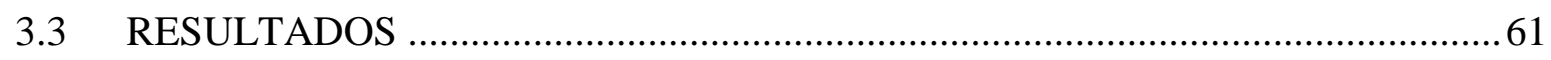

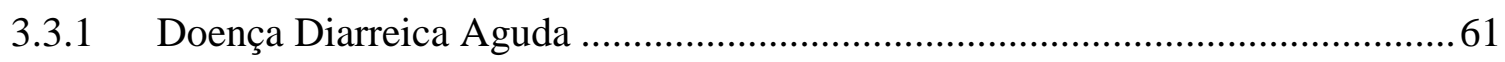

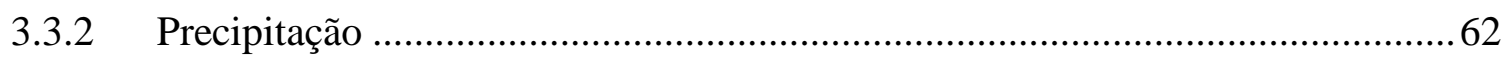

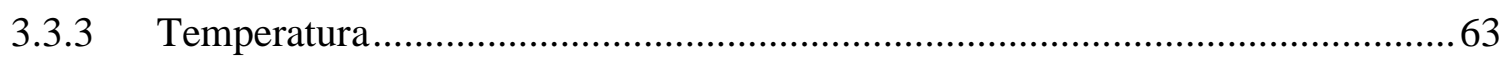

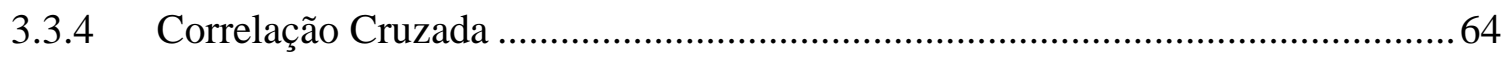

3.3.5 Padrão Intranual de Ocorrência da DDA e Distribuição da Precipitação............68

3.3.6 Padrão Interanual de Ocorrência da DDA e Distribuição da Precipitação ..........71

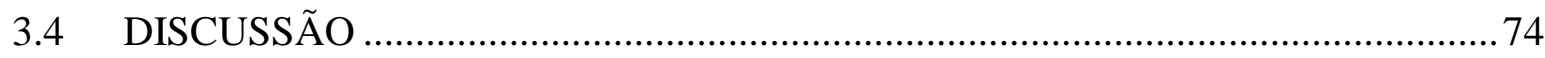

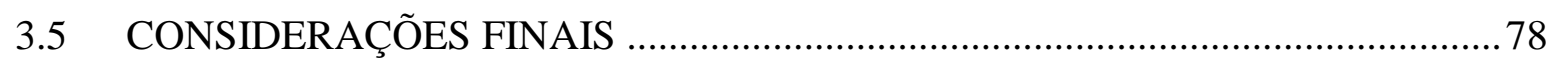

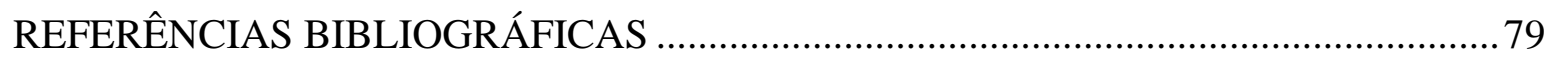

4 PADRÕES ESPAÇO-TEMPORAIS DAS CONDIÇÕES DE ABASTECIMENTO DE ÁGUA E DA INCIDÊNCIA DA DOENÇA DIARREICA AGUDA EM UM RECORTE ESPACIAL DO SEMIÁRIDO BRASILEIRO DE 2002 A 2014 .....................86

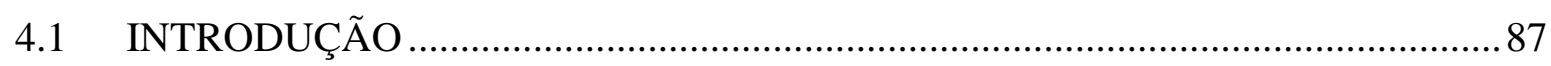

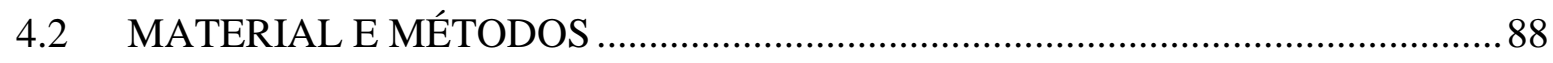

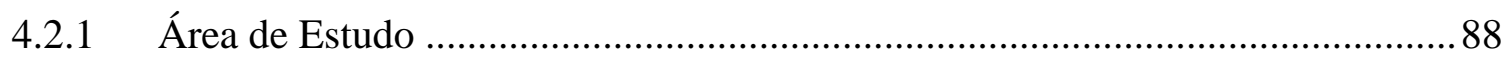


4.2.2 Dados dos Sistemas de Abastecimento de Água ............................................. 91

4.2.3 Dados de Notificações de Doenças Diarreicas Agudas ....................................... 94

4.2.4 Análise Situação dos Sistemas de Abastecimento e Taxas de DDA...................94

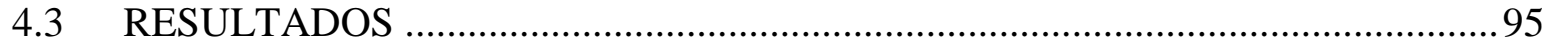

4.3.1 Análise Espaço-Temporal da Situação de Abastecimento de Água....................95

4.3.2 Análise Espaço-Temporal das Taxas de DDA ............................................... 102

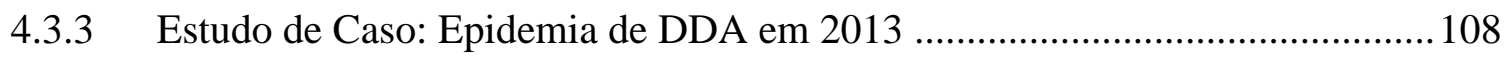

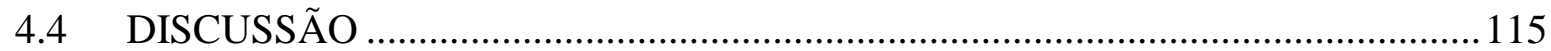

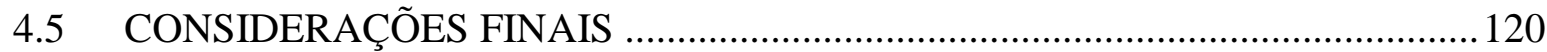

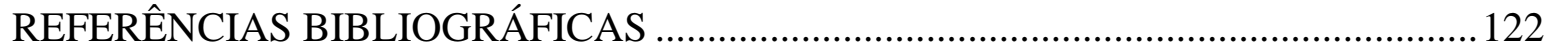

5 ESTUDO DOS PADRÕES ESPAÇO-TEMPORAIS DAS INTERNAÇÕES POR DIARREIA E GASTROENTERITE NO BRASIL ENTRE 1998 E 2012 ..................... 128

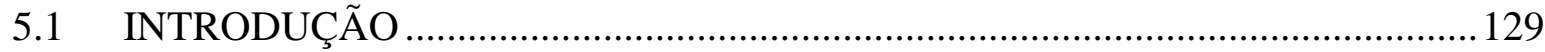

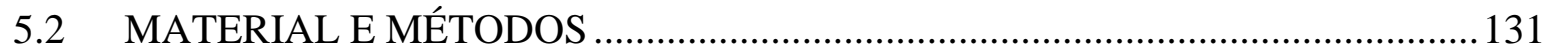

5.2.1 Dados de Internações por Diarreia e Gastroenterite de Origem Infecciosa

Presumível

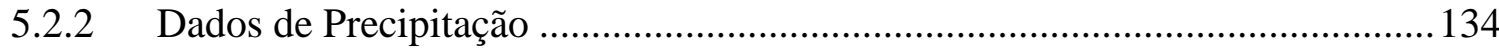

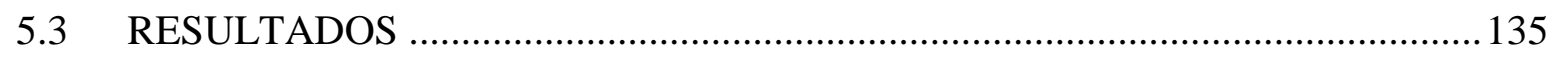

5.3.1 Distribuição Espacial das Internações por DGOIP no Brasil ............................ 135

5.3.2 Distribuição Temporal das Internações por DGOIP no Brasil .......................... 138

5.3.3 Distribuição Temporal da Precipitação Pluviométrica no Brasil ..................... 141

5.3.4 Padrões das Internações por DGOIP e da Precipitação e Temperatura nas

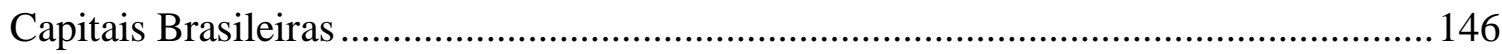

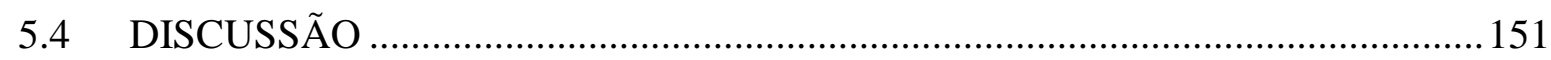

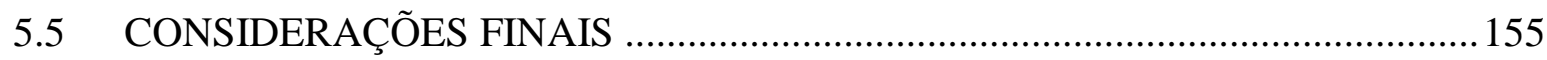

REFERÊNCIAS BIBLIOGRÁFICAS ................................................................... 157 


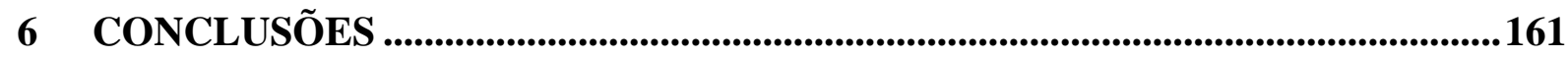

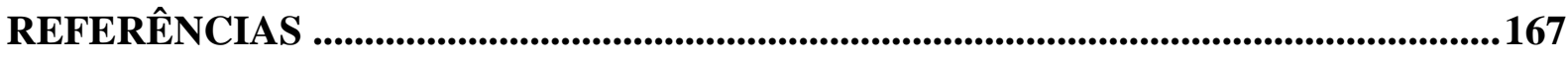

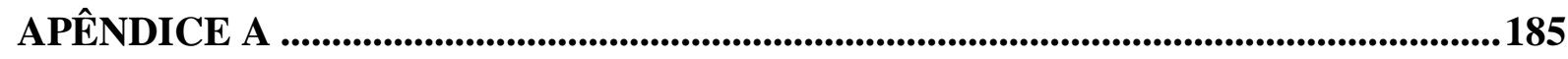

APÊNDICE B................................................................................................................................... 189

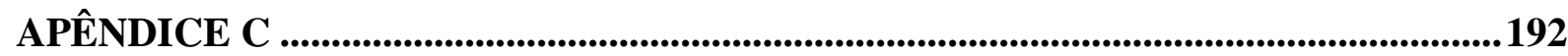

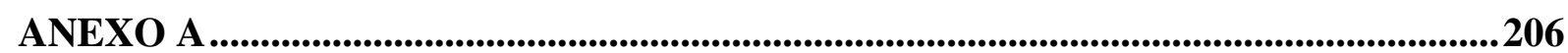

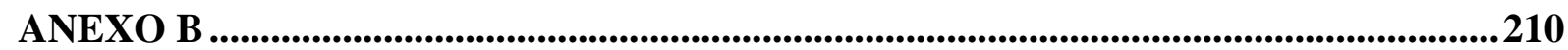




\section{LISTA DE FIGURAS}

Figura 1.1: Taxa de casos (A) e óbitos (B) atribuídos à DDA por cem mil habitantes por região geográfica (2001-2010).

Figura 1.2: Divisão Hidrográfica Nacional. .......................................................................

Figura 1.3: Balanço hídrico qualiquantitativo por microbacia no Brasil. ............................... 6

Figura 1.4: Tipologia de manancial de abastecimento urbano de água no Brasil (2010). .........8

Figura 1.5: Tipologia de tratamento da água de abastecimento urbano no Brasil (2010).........9

Figura 1.6: Índice de atendimento total de água (A) e índice de coleta de esgoto (B) no Brasil (2013).

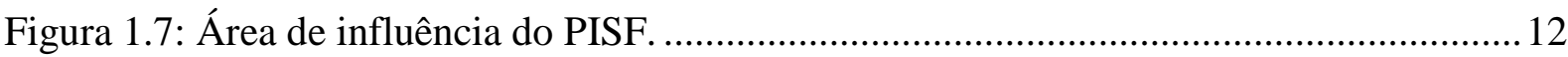

Figura 1.8: Fontes de abastecimento urbano de água na RHANO....................................... 13

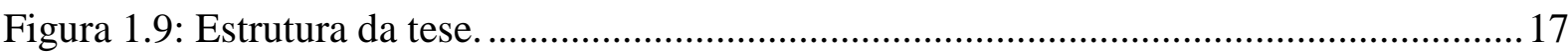

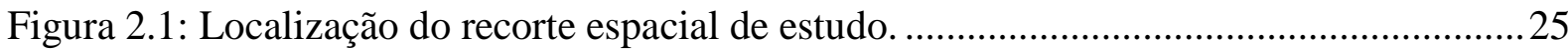

Figura 2.2: Açudes ARG em São Rafael e Itajá (RN) (A), EPB em Boqueirão (PB) (B) e

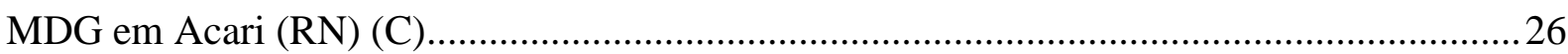

Figura 2.3: Reflectância de sensoriamento remoto medida por espectroradiômetro no açude

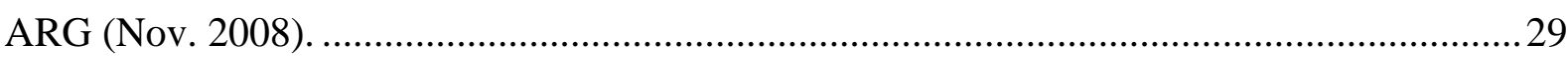

Figura 2.4: Índice espectral do açude ARG jusante (A) e montante (B) (2002-2012)............ 32

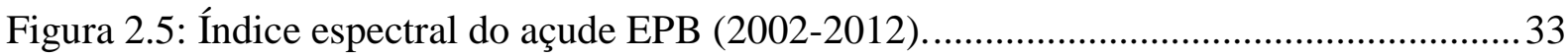

Figura 2.6: Máscara definida para os reservatórios de estudo................................................. 34

Figura 2.7: Precipitação mensal (mm) registrada em estações próximas aos açudes ARG (A) e EPB (B) (2002-2012).

Figura 2.8: Série histórica volumétrica $\left(\mathrm{hm}^{3}\right)$ dos açudes ARG (A), EPB (B) e MDG (C) (2002-2012)

Figura 2.9: Casos de DDA nos 22 municípios abastecidos pelo açude ARG (2002-2012) (A) e 17 municípios abastecidos pelo açude EPB (2006-2012) (B). 38

Figura 2.10: Séries temporais de DDA na área abastecida pelo açude ARG e índices espectrais das imagens MODIS para o açude ARG jusante (A) e montante (B) (2002-2012).

Figura 2.11: Atendimento da população urbana pela rede geral de abastecimento de água (A) e modalidades de atendimento de água dos domicílios rurais (B) (2010). 
Figura 3.1: Localização da área de estudo

Figura 3.2: Casos de DDA por semana epidemiológica nas áreas de estudo no RN (20022012) (A) e PB (2006-2012) (B).

Figura 3.3: Precipitação acumulada $(\mathrm{mm})$ por semana epidemiológica: valor médio para a área de estudo no RN (2002-2012) (A) e PB (2006-2012) (B) 63

Figura 3.4: Temperatura máxima diária do ar $\left({ }^{\circ} \mathrm{C}\right)$ : média por semana epidemiológica na área de estudo (2002-2012).

Figura 3.5: Análise de correlação cruzada entre as variáveis DDA e precipitação para os municípios da área de estudo no RN (2002-2012) e PB (2006-2012).

Figura 3.6: Total de casos de DDA e precipitação acumulada média ( $\mathrm{mm})$ por semana epidemiológica na área de estudo no RN (2002-2005) e somatório (RN e PB) (2006-2012).. 69 Figura 3.7: Série temporal dos casos de DDA e precipitação acumulada por semana epidemiológica nas áreas de estudo no RN (A) e PB (B) (2006-2012). 72

Figura 3.8: Comparação de dados normalizados da precipitação anual e taxa anual de DDA (A) e da precipitação anual e temperatura anual (B) na área de estudo no RN (2002-2005) e completa (2006-2012)

Figura 4.1: Localização da área de estudo.

Figura 4.2: População residente e população urbana (\%) nos municípios da área de estudo (2010).

Figura 4.3: Total de domicílios segundo categorias de abastecimento de água em 2000 (A) e 2010 (B).

Figura 4.4: Índice de atendimento urbano de água (2013) (A) e total de domicílios rurais segundo categorias de abastecimento de água (2010) (B). 98

Figura 4.5: Índice de atendimento total de água por município em 2007 (A) e 2013 (B). Figura 4.6: Média de carros-pipa em operação em 2013 (A) e 2014 (B) por mil habitantes. 100 Figura 4.7: Número de cisternas construídas entre 2003 a 2010 (A) e 2011 a 2014 (B) por cada cem habitantes.

Figura 4.8: Incidência (casos por cem mil habitantes) da DDA por município nas áreas de estudo no Rio Grande do Norte (2002-2014) e Paraíba (2006-2012). 104

Figura 4.9: Taxa média de DDA por município (2002-2014). 106 
Figura 4.10: Municípios da área de estudo em ordem decrescente segundo a taxa média de DDA (2002-2014) e manancial de abastecimento de água.

Figura 4.11: Comportamento da precipitação no semiárido brasileiro em relação à probabilidade de ocorrência (2012-2014).

Figura 4.12: Série histórica de nível (m) da LDB (A) e volume $\left(\mathrm{hm}^{3}\right)$ do açude MDG (B) (2002-2014)

Figura 4.13: Casos de DDA por semana epidemiológica em toda a área de estudo no RN (A) e nas áreas abastecidas pela LDB (B) e açudes ARG (C) e MDG (D) (2002-2014).

Figura 4.14: Precipitação acumulada mensal $(\mathrm{mm})$ em estações selecionadas na área de estudo (2013).

Figura 4.15: Volume de água produzido e taxa de DDA do município de Acari (2010-2014).

Figura 4.16: Volume de água $\left(\mathrm{m}^{3}\right)$ produzido pelos açudes MDG e Dourado e casos de DDA: valores mensais para os municípios de Acari e Currais Novos (2010-2014).

Figura 5.1: Taxas de anos de vida ajustados por doenças diarreicas por país por cem mil habitantes (2004).

Figura 5.2: Distribuição regional, etária e anual das internações por DGOIP no Brasil (1998-

Figura 5.3: Taxa média de internações por DGOIP por município (A) e mapa de autocorrelação espacial da taxa de internações (B) (1998-2012). 138

Figura 5.4: Trimestre de maior número de internações por DGOIP por município (1998-

2012): mapa temático pontual qualitativo (A) e coleção de mapas (B).

Figura 5.5: Trimestre de maior (A) e menor (B) precipitação média no Brasil (1977-2006).143

Figura 5.6: Totais trimestrais pluviométricos no Brasil (1977-2006). 145

Figura 5.7: Totais trimestrais de internações por DGOIP nas capitais brasileiras (1998-2012).

Figura 5.8: Climogramas trimestrais das capitais brasileiras (1961-1990).

Figura 6.1: Esquema das condições ambientais observadas na área de estudo no semiárido brasileiro. 


\section{LISTA DE TABELAS}

Tabela 1.1: Categorias de doenças relacionadas à água e saneamento.

Tabela 2.1: Informações de referência dos reservatórios de estudo

Tabela 2.2: Classificação de qualidade das imagens MODIS processadas pelo MOD3R

Tabela 3.1: Patógenos causadores de diarreia.

Tabela 3.2: Dados da correlação cruzada entre as variáveis DDA e precipitação para os municípios estudados do RN, PB e somatório entre eles.

Tabela 3.3: Ocorrência dos fenômenos El Niño e La Ninã segundo o ONI (2002-2012)........ 74

Tabela 4.1: Características dos sistemas integrados de abastecimento de água da área de estudo.

Tabela 5.1: Matriz de decisão elaborada para seleção do trimestre de maior número de internações por DGOIP (trimestre modal).

Tabela 5.2: Matriz de correlação linear de Pearson $(r)$ entre os totais trimestrais de internações por DGOIP nas capitais brasileiras (1998-2012). 148

Tabela 5.3: Coeficientes de correlação linear de Pearson $(r)$ entre as séries trimestrais de internações por DGOIP (1998-2012) e de totais trimestrais de precipitação (A) e médias trimestrais de temperatura (B) (1961-1990).

Tabela 5.4: Trimestre (comportamento interanual) de maior número de internações por DGOIP nas capitais brasileiras (1998-2012). 


\section{LISTA DE SIGLAS E ABREVIATURAS}

ABINAM - Associação Brasileira da Indústria de Água Mineral AESA - Agência Executiva de Gestão das Águas do Estado da Paraíba AIH - Autorização de Internação Hospitalar

AMJ - Abril-Maio-Junho

ANA - Agência Nacional de Águas

ANEEL - Agência Nacional de Energia Elétrica

ARG - Armando Ribeiro Gonçalves

ASA - Articulação no Semiárido Brasileiro

ASO - Agosto-Setembro-Outubro

BAM - Belém-Ananindeua-Marituba

CAERN - Companhia de Águas e Esgotos do Rio Grande do Norte

CAGEPA - Companhia de Água e Esgotos da Paraíba

CBHSF - Comitê da Bacia Hidrográfica do Rio São Francisco

CEBDS - Conselho Empresarial Brasileiro para o Desenvolvimento Sustentável

CGEE - Centro de Gestão e Estudos Estratégicos

CHLA - Clorofila-A

CID - Classificação Internacional de Doenças

CNRH - Conselho Nacional de Recursos Hídricos

CNPq - Conselho Nacional do Desenvolvimento Científico e Tecnológico

COPASA - Companhia de Saneamento de Minas Gerais

COSANPA - Companhia de Saneamento do Pará

COTER - Comando de Operações Terrestres do Exército Brasileiro

CPRM - Companhia de Pesquisa de Recursos Minerais

CPTEC - Centro de Previsão do Tempo e Estudos Climáticos 
DALY - Disability-adjusted life years

DATASUS - Banco de Dados do Sistema Único de Saúde

DDA - Doença Diarreica Aguda

DGOIP - Diarreia e Gastroenterite de Origem Infecciosa Presumível

DJF - Dezembro-Janeiro-Fevereiro

DNAEE - Departamento Nacional de Águas e Energia Elétrica

DNOCS - Departamento Nacional de Obras Contra as Secas

DOL - Distúrbios Ondulatórios de Leste

EMPARN - Empresa de Pesquisa Agropecuária do Rio Grande do Norte

ENSO - El Niño Oscilação Sul

EPB - Epitácio Pessoa (Boqueirão)

EOS - Earth Observing System

ETA - Estação de Tratamento de Água

FMA - Fevereiro-Março-Abril

GOES - Geostationary Operational Environmental Satellite

HUAB - Hospital Universitário Ana Bezerra

IBGE - Instituto Brasileiro de Geografia e Estatística

IDH - Índice de Desenvolvimento Humano

IET $_{M}$ - Índice de Estado Trófico Modificado

IGARN - Instituto de Gestão das Águas do Rio Grande do Norte

INMET - Instituto Nacional de Meteorologia

INPE - Instituto Nacional de Pesquisas Espaciais

IRD - Institut de Recherche pour le Développement

JAS - Julho-Agosto-Setembro

JFM - Janeiro-Fevereiro-Março

JJA - Junho-Julho-Agosto 
LDB - Lagoa do Bonfim

LISA - Local Indicators of Spatial Association

MAM - Março-Abril-Maio

MCid - Ministério das Cidades

MCT - Ministério da Ciência e Tecnologia

MDDA - Monitorização das Doenças Diarreicas Agudas

MDG - Marechal Dutra (Gargalheiras)

MDS -Desenvolvimento Social e Combate à Fome

MI - Ministério da Integração Nacional

MJJ - Maio-Junho-Julho

MODIS - Moderate-resolution Imaging Spectroradiometer

MOD3R - MODIS Reflectance Retrieval over Rivers

MS - Ministério da Saúde

NASA - National Aeronautics and Space Administration

ND - Não Definido

NDJ - Novembro-Dezembro-Janeiro

NDVI - Normalized Diference Vegetation Index

NTU - Unidades Nefelométricas de Turbidez

OMS - Organização Mundial de Saúde

OMJ - Oscilação Madden-Julien

OND - Outubro-Novembro-Dezembro

ORE-HYBAM - The Environmental Research Observatory: Geodynamical, hydrological and biogeochemical control of erosion/alteration and material transport in the Amazon basin P1MC - Programa Um Milhão de Cisternas Rurais

PB - Paraíba 
PISF - Projeto de Integração do Rio São Francisco com Bacias Hidrográficas do Nordeste Setentrional

PNRH - Plano Nacional de Recursos Hídricos

PNSB - Pesquisa Nacional de Saneamento Básico

PSF - Programa Saúde da Família

RELAIS - Regional Epidemiological Landscape Amazon Information System

RHANO - Região Hidrográfica do Atlântico Nordeste Oriental

RIDE - Região Integrada de Desenvolvimento do Distrito Federal e Entorno

RIMA - Relatório de Impacto Ambiental

RMBH - Região Metropolitana de Belo Horizonte

RN - Rio Grande do Norte

RNQA - Rede Nacional de Monitoramento da Qualidade das Águas Superficiais

SAAE - Serviço Autônomo de Águas e Esgoto

SEMARH - Secretaria do Meio Ambiente e dos Recursos Hídricos do Estado do Rio Grande do Norte

SES - Secretaria de Estado da Saúde da Paraíba

SESAP - Secretaria de Estado da Saúde Pública do Rio Grande do Norte

SIG - Sistema de Informação Geográfica

SIH - Sistema de Informações Hospitalares

SIM - Sistema de Informações sobre Mortalidade

SINAN - Sistema de Informações de Agravos de Notificação

SISAGUA - Sistema de Informação de Vigilância da Qualidade da Água para Consumo

Humano

SISAM - Sistema de Informações Ambientais

SIVEP - Sistema de Informações de Vigilância Epidemiológica

SIVEP-DDA - Sistema de Informações de Vigilância Epidemiológica da Doença Diarreica Aguda 
SNIS - Sistema Nacional de Informações sobre Saneamento

SON - Setembro-Outubro-Novembro

SR - Sem Registros

SRTM - Shuttle Radar Topography Mission

SUDEMA - Superintendência de Administração do Meio Ambiente

SUS - Sistema Único de Saúde

SVS - Secretaria de Vigilância em Saúde

TM - Thematic Mapper

TSM - Temperatura da Superfície do Mar

UEPB - Universidade Estadual da Paraíba

UFRN - Universidade Federal do Rio Grande do Norte

UHE - Usina Hidrelétrica

UnB - Universidade de Brasília

UNWWAP - United Nations World Water Assessment Programme

UTC - Universal Time Coordinated

UTM - Universal Transversa de Mercator

VCAN - Vórtices Ciclônicos em Altos Níveis

WGO - World Gastroenterology Organization

WHO - World Health Organization

WLVARC - World Lake Vision Action Report Committee

ZCIT - Zona de Convergência Intertropical 


\section{INTRODUÇÃO}

\subsection{DEFINIÇÃO DO RECORTE TEMÁTICO DE ESTUDO}

O ideário higienista de preocupação com a vinculação de condicionantes ambientais e a qualidade de vida nas cidades têm suas raízes nas teorias de Hipócrates (Século V a. C). Atribuise à teoria hipocrática, por exemplo, a compreensão da importância do consumo da água pura, tanto para a ingestão quanto para os banhos. A influência dessas ideias tornou-se evidente com o surgimento dos sistemas de abastecimento de água nas cidades, dos aquedutos e dos balneários especializados (FERREIRA et al., 2003).

O clássico trabalho de John Snow demonstrou, em 1855, que a transmissão do cólera se dá pela água. Acreditava-se, até então, que as doenças eram transmitidas pelo ar a partir dos odores, e foi na tentativa de controlá-los que surgiram os métodos de desinfecção da água e dos esgotos (ROSSIN, 1976). Snow estudou uma epidemia do cólera em Londres que afetou a população abastecida por um poço contaminado por esgotos (SNOW, 2008). A partir daí trabalhos científicos envolvendo a qualidade das águas, variáveis ambientais e a distribuição espacial de epidemias passaram a ser executados por diversos pesquisadores, ampliando a formação profissional e o alcance das estratégias de políticas públicas na área de saúde. Um total de 1415 espécies de micro-organismos são considerados patogênicos para o homem, podendo causar 115 diferentes doenças infecciosas (TAYLOR et al, 2001).

Vulnerabilidades ou barreiras ambientais permitem ou impedem a difusão de epidemias no espaço. A adoção do espaço geográfico como categoria de análise de eventos de saúde permite vincular a Geografia com a Epidemiologia (CZERESNIA; RIBEIRO, 2000). Sorre (1951) observou que há uma relação entre as doenças e as características geográficas, físicas e biológicas do lugar onde se encontram, mostrando-nos aí o objeto de estudo da Geografia Médica (atualmente conhecida como Geografia da Saúde). Também apontou para a importância da Cartografia em tais estudos. Com o positivismo lógico, a Geografia da Saúde passou a enfatizar a análise espacial de dados geográficos e a adoção de modelos socioecológicos. Uma variável ambiental, como a água, por exemplo, pode se transformar em fator crítico de exposição, entretanto a contaminação não atinge a todos de forma indiferenciada. 
Dados da Organização Mundial de Saúde (OMS) estimam que 2 milhões e 200 mil mortes por ano podem ser atribuídas a doenças relacionadas com a água contaminada, falta de saneamento e higiene (PRÜSS et al., 2002), considerando ainda que os incidentes são subestimados, particularmente em populações pobres. Estes valores reduziram-se grandemente nas últimas décadas, pois constituíam cerca de 4,6 milhões em 1980 e três milhões em 1990.

A OMS constatou ainda que quase $10 \%$ de todas as doenças no mundo poderiam ser prevenidas através da melhoria no abastecimento de água, saneamento, higiene e na gestão dos recursos hídricos (PRÜSS-ÜSTÜN et al., 2008). Há uma série de doenças relacionadas à água e saneamento, as quais podem ser agrupadas nas categorias apresentadas na Tabela 1.1.

As diarreias estão associadas diretamente a todas as categorias de doenças apresentadas na tabela, exceto à "Relacionadas com Água". Para a OMS a categoria diarreia inclui ainda algumas doenças mais severas como o cólera, a febre tifoide, e a disenteria, todas estas que possuem mecanismo de transmissão fecal-oral. Estimativas da OMS apontam que o saneamento inadequado, más condições de higiene e beber água de qualidade duvidosa contribuem para $88 \%$ das doenças diarreicas (WHO, 2009).

Tabela 1.1: Categorias de doenças relacionadas à água e saneamento.

\begin{tabular}{l|l}
\hline \multicolumn{1}{c|}{ Categoria de Doença } & \multicolumn{1}{c}{ Causa/Origem } \\
\hline Transmitidas pela Água & $\begin{array}{l}\text { Ingestão de água contaminada contendo bactérias patogênicas ou vírus; inclui } \\
\text { cólera, febre tifoide, amebíase, disenteria bacilar e outras doenças diarreicas }\end{array}$ \\
\hline Com Base na Água & $\begin{array}{l}\text { Parasitas encontrados em organismos aquáticos; inclui esquistossomose, } \\
\text { dracunculíase e outros helmintos }\end{array}$ \\
\hline $\begin{array}{l}\text { Relacionadas Com } \\
\text { Água }\end{array}$ & $\begin{array}{l}\text { Micro-organismos com ciclos de vida associados a insetos que vivem ou se } \\
\text { reproduzem na água; inclui dengue, chikungunya, zika, malária, filariose } \\
\text { linfática, oncocercose e febre amarela }\end{array}$ \\
\hline Relacionadas com & $\begin{array}{l}\text { Contato direto ou indireto com patógenos associados a excrementos e/ou vetores } \\
\text { que se reproduzem em excrementos; inclui tracoma e a maioria das doenças } \\
\text { transmitidas pela água }\end{array}$ \\
\hline $\begin{array}{l}\text { Coleta e } \\
\text { Armazenamento de }\end{array}$ & $\begin{array}{l}\text { Contaminação que ocorre durante ou depois da coleta da água, frequentemente } \\
\text { devido a erros de projeto, depósito inapropriado e/ou higiene e manuseio } \\
\text { inadequado }\end{array}$ \\
\hline $\begin{array}{l}\text { Relacionadas com } \\
\text { Toxinas }\end{array}$ & $\begin{array}{l}\text { Bactérias produtoras de toxinas, como cianobactérias, que estão associadas à } \\
\text { eutrofização dos corpos d'água superficiais e causam doenças hepáticas e } \\
\text { gastrointestinais }\end{array}$ \\
\hline
\end{tabular}

Fonte: Adaptado de Montgomery e Elimelech (2007). Tradução do autor.

A doença diarreica aguda (DDA) constitui ainda no Brasil um grave problema de saúde pública. A incidência da doença diarreica no país aumentou consideravelmente ao longo da década de 2000, alcançando em 2010, sobre toda a população, um total de 4,341 milhões de 
casos registrados (MS/DATASUS, 2015), isto, desconsiderando o fato de que a doença é subnotificada em todo o país.

O simples aumento no número de casos deve ser analisado com cuidado, pois pode estar associado a questão da acessibilidade aos serviços de saúde de nível primário e à expansão de programas como o de Monitorização de Doenças Diarreicas Agudas (MDDA), principalmente em municípios considerados pequenos, acessibilidade esta que tem aumentado em função de políticas públicas como o Programa Saúde da Família (PSF) (ESCOREL et al., 2007).

A Figura 1.1 apresenta a evolução das taxas de casos de DDA* (A) e de óbitos (B) por região geográfica do Brasil ao longo da década do ano 2000. Todas as regiões geográficas apresentaram elevação nas taxas de DDA ao longo do período de análise, havendo apenas um decréscimo considerável em 2007. Apenas a Região Nordeste apresentou estabilização nas taxas de casos de DDA a partir de 2007, equiparando-se, em 2010, às taxas apresentadas pela Região Sudeste.

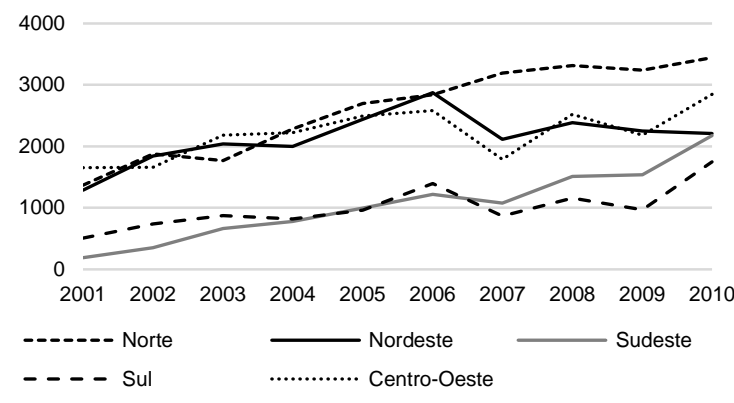

A

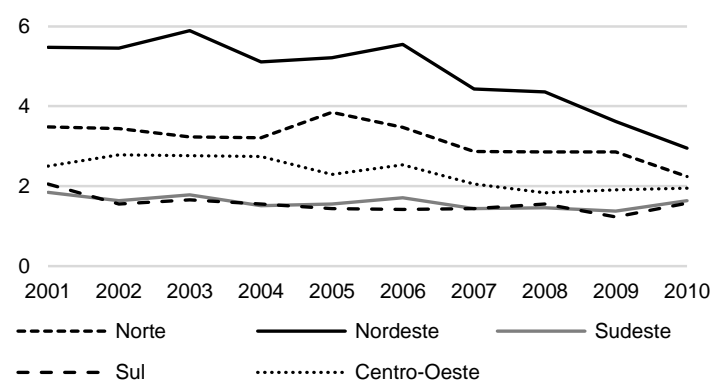

B

Figura 1.1: Taxa de casos (A) e óbitos (B) atribuídos à DDA por cem mil habitantes por região geográfica (2001-2010).

Fonte: Elaborado pelo autor a partir de dados do SIVEP (MS/DATASUS, 2015).

Comportamento diferenciado em relação à taxa média de casos foi observado na taxa de óbitos atribuídos à $\mathrm{DDA}^{\dagger}$. Todas as regiões geográficas apresentaram taxas decrescentes de óbitos ao longo de 2001 a 2010. Sastry e Burgard (2005), entre outros autores, apontam que o fator chave para a redução da mortalidade por diarreia no Brasil, principalmente a infantil e,

\footnotetext{
* Casos de DDA sobre todas as faixas etárias da população, indistintamente, obtidos em totalização anual a partir de planilhas mensais repassadas pelas secretarias estaduais de saúde até 2006 e através do Sistema de Informações de Vigilância Epidemiológica (SIVEP) de Monitorização das Doenças Diarreicas Agudas (MDDA) da Secretaria de Vigilância em Saúde (SVS) do Ministério da Saúde (MS) a partir de 2007 (MS/DATASUS, 2015).

† Óbitos atribuídos conforme a Classificação Internacional de Doenças (CID) 10, no capítulo I "Algumas doenças infecciosas e parasitárias: Diarreia e gastroenterite de origem infecciosa presumível" do Sistema de Informações sobre Mortalidade (SIM), vinculado ao Banco de Dados do Sistema Único de Saúde (DATASUS) (MS/DATASUS, 2015).
} 
notadamente na Região Nordeste, aquela que apresentava historicamente a maior taxa de óbitos, foi a introdução da terapia de reidratação oral, com o uso de soro caseiro, entre outros métodos. A partir de 2006, a introdução da vacinação contra o rotavírus no calendário infantil contribuiu para a redução da morbidade e mortalidade por diarreia e gastroenterites (LINHARES; JUSTINO, 2014).

Ao estudarmos o problema da DDA em diferentes escalas espaciais e ao longo do tempo, observa-se que características ligadas ao regime climático das diferentes regiões do país aparecem como tendo grande relevância para explicar o comportamento da doença. De semelhante modo, variáveis ligadas ao abastecimento de água e ao saneamento básico, ou seja, menor cobertura de saneamento e piores condições de abastecimento de água tendem a estar associados à uma maior ocorrência de DDA e, vice-versa. No entanto, são necessários estudos mais aprofundados para a compreensão dos padrões de ocorrência desse problema no país.

Neste sentido, esta pesquisa de doutorado tem como foco estudar mecanismos ligados à água e ao clima que favorecem a ocorrência da DDA. É necessário haver uma maior preocupação dos agentes públicos e da comunidade científica no sentido de relacionar a saúde dos indivíduos com condições ambientais mais gerais, como o regime de chuvas, o comportamento sazonal das condições do tempo, a qualidade da água de mananciais de abastecimento e a disponibilidade contínua de água para o uso humano. Essas questões, dentre outras, são discutidas ao longo da tese.

\subsection{ESCOLHA DO RECORTE GEOGRÁFICO}

O Brasil dispõe de $12 \%$ das reservas de água doce do mundo, mas enfrenta problemas crônicos relacionados à água para preservação dos ecossistemas e produtividade econômica. A distribuição geográfica dos recursos hídricos no Brasil é desigual; enquanto a Região Hidrográfica $^{*}$ do Atlântico Nordeste Oriental (RHANO) apresenta disponibilidade hídrica

\footnotetext{
* Uma Região Hidrográfica é o espaço territorial brasileiro compreendido por uma bacia, grupo de bacias ou sub-bacias hidrográficas contíguas com características naturais, sociais e econômicas homogêneas ou similares. A Divisão Hidrográfica Nacional foi instituída pelo Conselho Nacional de Recursos Hídricos (CNRH) através da Resolução CNRH n 32/2003 (CNRH, 2003). Além dessa proposta, em doze regiões, há outras divisões hidrográficas, como a do extinto Departamento Nacional de Águas e Energia Elétrica (DNAEE), instituída em 1972, com oito bacias, ainda utilizada para a codificação de estações fluviométricas; a de Pfafstetter (1989), que utiliza critérios hidrológicos para a codificação de trechos de drenagem na América do Sul; a divisão do Plano Nacional de Recursos Hídricos (PNRH) e; a divisão para fins de gestão de recursos hídricos, visando à formação de comitês de bacia e unidades de gerenciamento.
} 
(computada pelas vazões com 95\% de permanência no tempo) inferior a $100 \mathrm{~m}^{3} / \mathrm{s}$ a Região Hidrográfica Amazônica alcança vazões da ordem de 74 mil m³/s (Figura 1.2) (ANA, 2011).

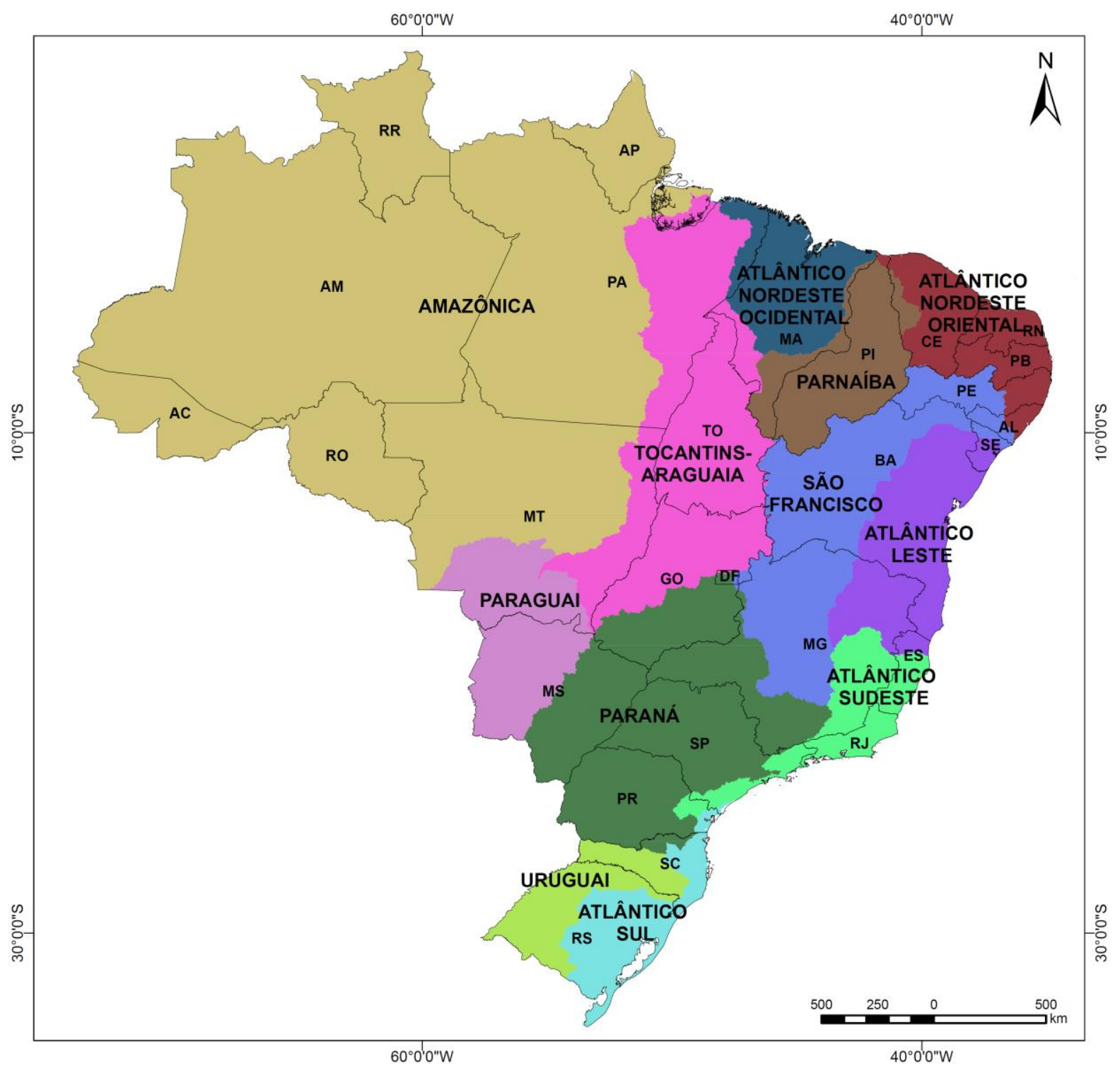

Figura 1.2: Divisão Hidrográfica Nacional.

Fonte: Elaborado pelo autor a partir de dados de CNRH (2003).

A gestão de recursos hídricos é um processo cuja complexidade aumenta devido aos seus usos múltiplos e à medida que os efeitos da degradação da qualidade dos corpos d'água tornam-se mais severos. Considerando a disponibilidade de água para os diferentes usos e a demanda por Região Hidrográfica, a RHANO possui o maior saldo deficitário do país (Figura 1.3). A RHANO é constituída pelas bacias hidrográficas que deságuam no trecho Nordeste do Atlântico, limitada pelas regiões hidrográficas do Parnaíba, a oeste, e do São Francisco, ao sul. 
A maior parte dos municípios pertence ao semiárido, área instituída para fins de desenvolvimento e controle (MI, 2005).

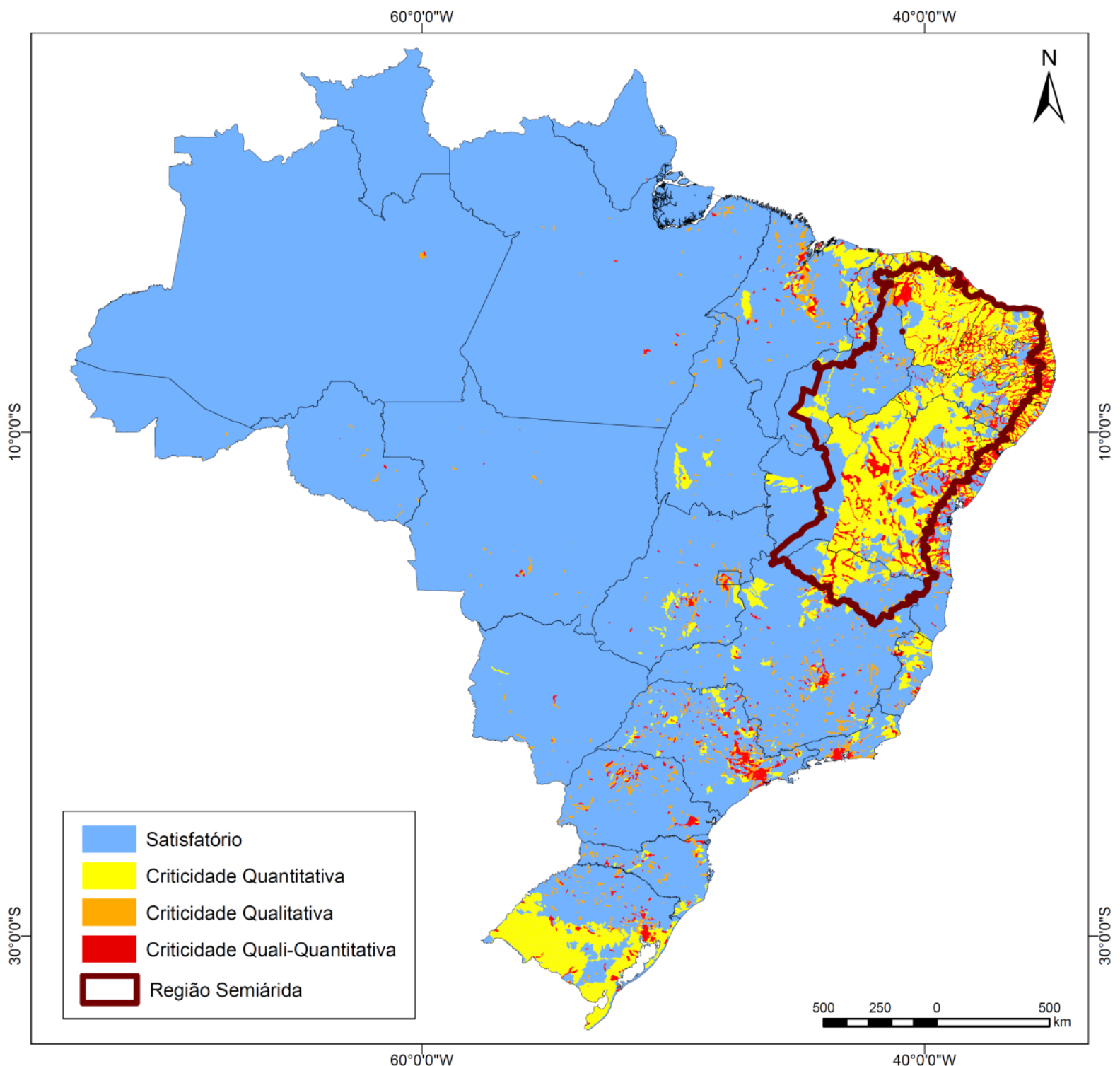

Figura 1.3: Balanço hídrico qualiquantitativo por microbacia no Brasil.

Fonte: Elaborado pelo autor a partir de dados de ANA (2015) e MI (2005).

O semiárido brasileiro carece de disponibilidade hídrica devido à incerteza e irregularidade das chuvas, o baixo potencial em disponibilidade de águas subterrâneas e a intermitência dos rios, fatores estes que são agravados devido ao quadro de fragilidade institucional na gestão dos recursos hídricos locais. Para garantir o suprimento de água foi criada ao longo do tempo uma infraestrutura hídrica de aproximadamente setenta mil reservatórios de usos múltiplos, denominados regionalmente como açudes. Os reservatórios 
exercem um efeito regularizador das vazões naturais ao acumular parte das águas disponíveis nos períodos chuvosos de forma a atenuar eventuais deficiências nos períodos de estiagem. São construídos por iniciativas públicas, sobretudo federais*, particulares ou de cooperação e correspondem, em inúmeros locais, à única fonte de abastecimento disponível.

A disponibilidade de água pode ser considerada o principal problema do semiárido brasileiro. Na região, há necessidade constante de se gerenciar os conflitos de interesses existentes entre os setores usuários dos recursos hídricos. A bacia hidrográfica do Piranhas/Açu é a maior bacia hidrográfica totalmente localizada na região semiárida brasileira (e na RHANO), com 43 mil km² e cujo curso d'água principal é de domínio da União. O marco regulatório da gestão dos recursos hídricos na bacia, cuja demanda é superior à disponibilidade, o que não ocorre na maior parte das bacias hidrográficas do país, foi determinado pela Resolução n 687/2004 (ANA, 2004). Esta resolução determinou, entre outros parâmetros, o volume mínimo de água no Rio Piranhas a ser entregue pelo Estado da Paraíba (PB) ao Rio Grande do Norte (RN) na fronteira. No entanto, nem sempre as condicionantes são cumpridas, o que demanda esforços de regulação e fiscalização pelo poder público. Na bacia estão localizados 554 reservatórios com mais de vinte hectares de área do espelho d'água (ANA, 2013a) e ela compreende 147 cidades (102 na PB e 45 no RN), 77 destas abastecidas exclusivamente por reservatórios (ANA, 2011).

Os diferentes tipos de fontes de abastecimento de água das áreas urbanas brasileiras e os sistemas aquíferos existentes no Brasil são apresentados na Figura 1.4. O suprimento de água provém de captações em cursos ou corpos d'água superficiais ( $47 \%$ das cidades), de poços subterrâneos (39\%) ou por fontes de abastecimento mistas (14\%) (ANA, 2011). Os municípios que utilizam fontes subterrâneas para abastecimento de água estão localizados, em sua maioria, em locais onde há sistemas aquíferos com boa disponibilidade hídrica, destacando-se o caso das bacias sedimentares Amazônica, do Paraná e do Parnaíba. Os municípios que utilizam fontes mistas recorrem tanto à água superficial como à subterrânea para compor o abastecimento da população e, frequentemente estão localizados nas franjas das bacias sedimentares.

\footnotetext{
* Um reservatório federal (ou da União) é um corpo d'água lêntico natural ou artificial que se localiza em um curso d'água federal - curso d'água que banha mais de um País ou Unidade da Federação, em toda a sua extensão - ou que foi construído pela União. Para a determinação do curso d'água principal de uma bacia considera-se a maior área de drenagem da bacia hidrográfica a montante, calculada a cada confluência, e não simplesmente o nome do rio ou aquele que possui a maior extensão. Consideram-se também reservatórios da União, segundo a Constituição da República Federativa do Brasil de 1988, aqueles localizados em terras da União, como Terras Indígenas e algumas categorias de Unidades de Conservação federais.
} 


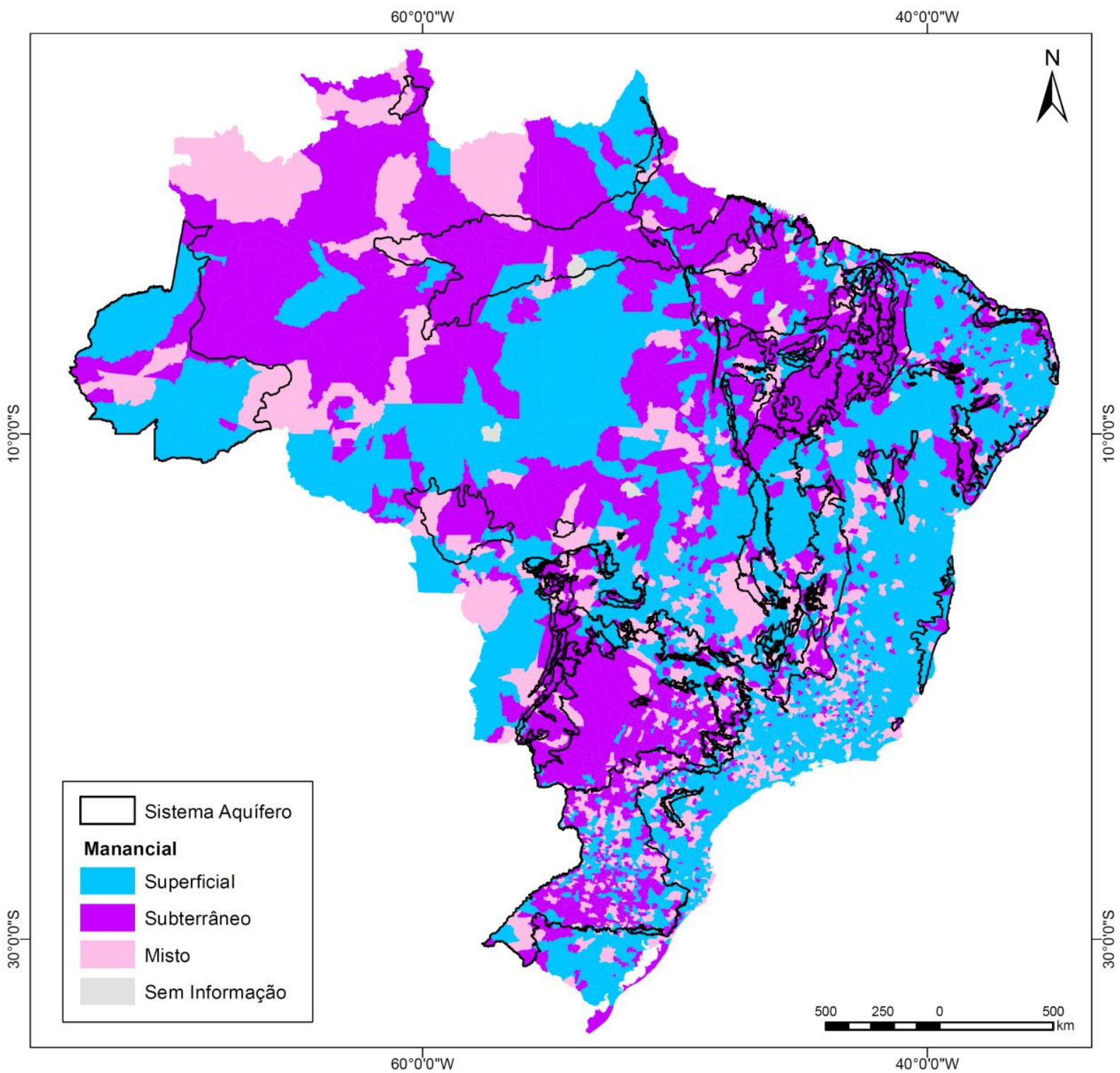

Figura 1.4: Tipologia de manancial de abastecimento urbano de água no Brasil (2010). Fonte: Elaborado pelo autor a partir de dados de ANA (2011; 2013b).

A Figura 1.5 apresenta o tipo de tratamento de água para abastecimento urbano empregado pelas operadoras de abastecimento no Brasil*. As águas subterrâneas, geralmente menos propensas à contaminação, são submetidas a tratamento de simples desinfecção na maioria dos municípios que utilizam esse tipo de manancial. Em alguns casos, não recebem qualquer tratamento.

\footnotetext{
* No Atlas Brasil de Abastecimento Urbano de Água (ANA, 2011) foram reunidas informações sobre o abastecimento de água das áreas urbanas em $99 \%$ dos munícipios brasileiros. As informações da existência de problemas de tratabilidade da água informados pelas operadoras de abastecimento ou do emprego de métodos avançados de tratamento não foram utilizadas, pois as mesmas foram informadas apenas em alguns Estados (nenhum Estado do Nordeste possui informação do emprego de métodos avançados, por exemplo).
} 


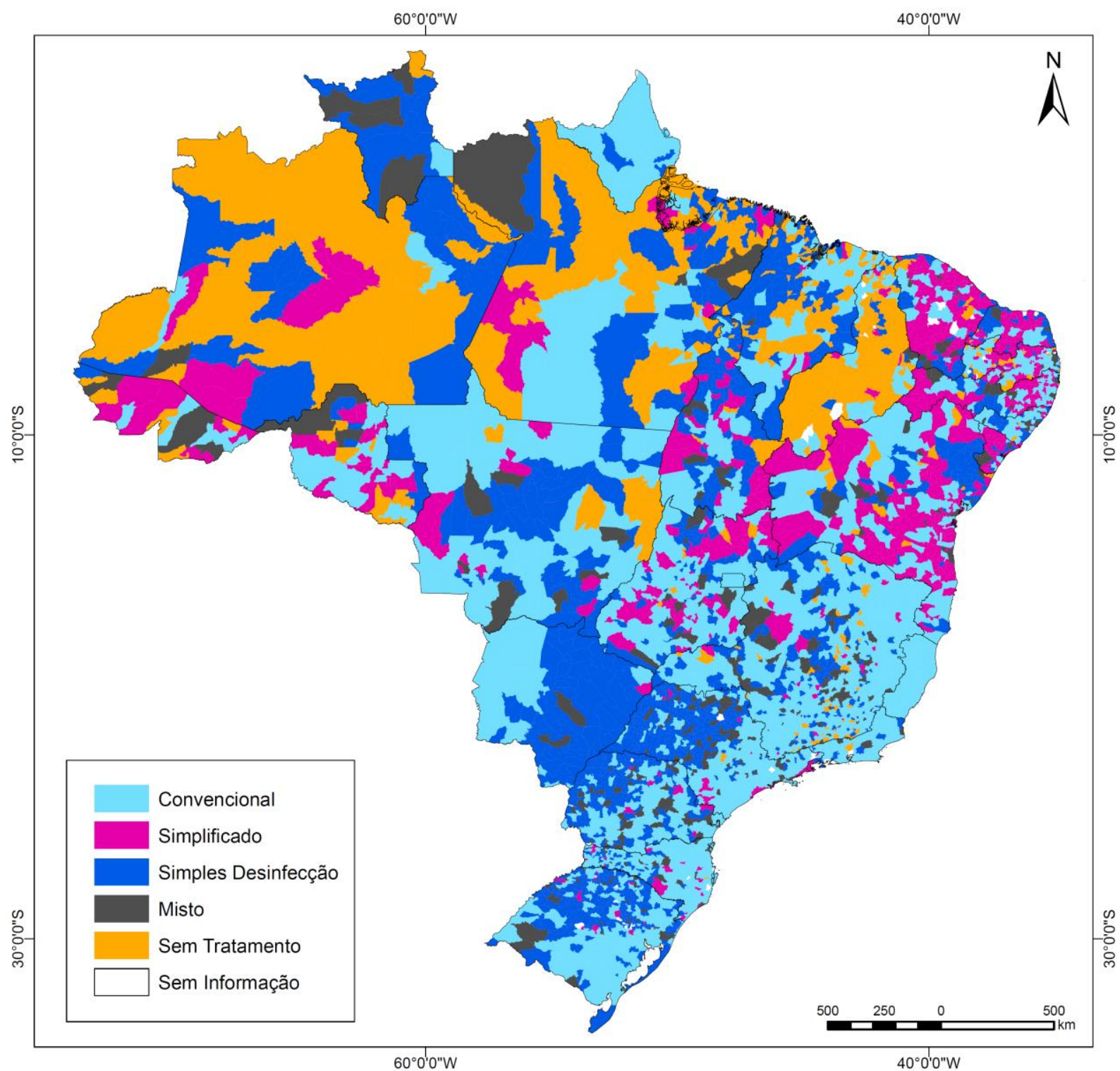

Figura 1.5: Tipologia de tratamento da água de abastecimento urbano no Brasil (2010).

Notas: 330 municípios onde há diferentes métodos de tratamento aplicados às fontes de água que abastecem no mínimo $25 \%$ da população urbana foram classificados na categoria "Misto". Foram excluídas da análise as fontes de água que abastecem menos de $5 \%$ da população urbana de cada município.

Fonte: Elaborado pelo autor a partir de dados de ANA (2011, em revisão).

No semiárido, muitos municípios dispõem apenas de tratamento simplificado da água. Além disso, não há universalização do abastecimento de água e a maioria dos municípios apresenta baixos índices de coleta de esgoto (Figura 1.6). A Região Centro-Sul possui os melhores indicadores de atendimento de água do país enquanto o destaque para a coleta de esgoto é o Estado de São Paulo. 
Os sistemas de abastecimento urbano podem ser isolados, quando abastecem a(s) área(s) urbana(s) de um único município, a partir de um ou mais mananciais de água, ou integrados, quando abastecem mais de um município. Os sistemas integrados são construídos para atender principalmente as demandas de regiões metropolitanas e de regiões com baixa disponibilidade hídrica, como é o caso do semiárido brasileiro. Os sistemas integrados utilizam adutoras para o transporte da água de um município para o outro. Em 2011 existiam 256 adutoras em funcionamento nos municípios brasileiros, 150 destas localizadas na Região Nordeste do Brasil, conforme levantamento da ANA (2011).

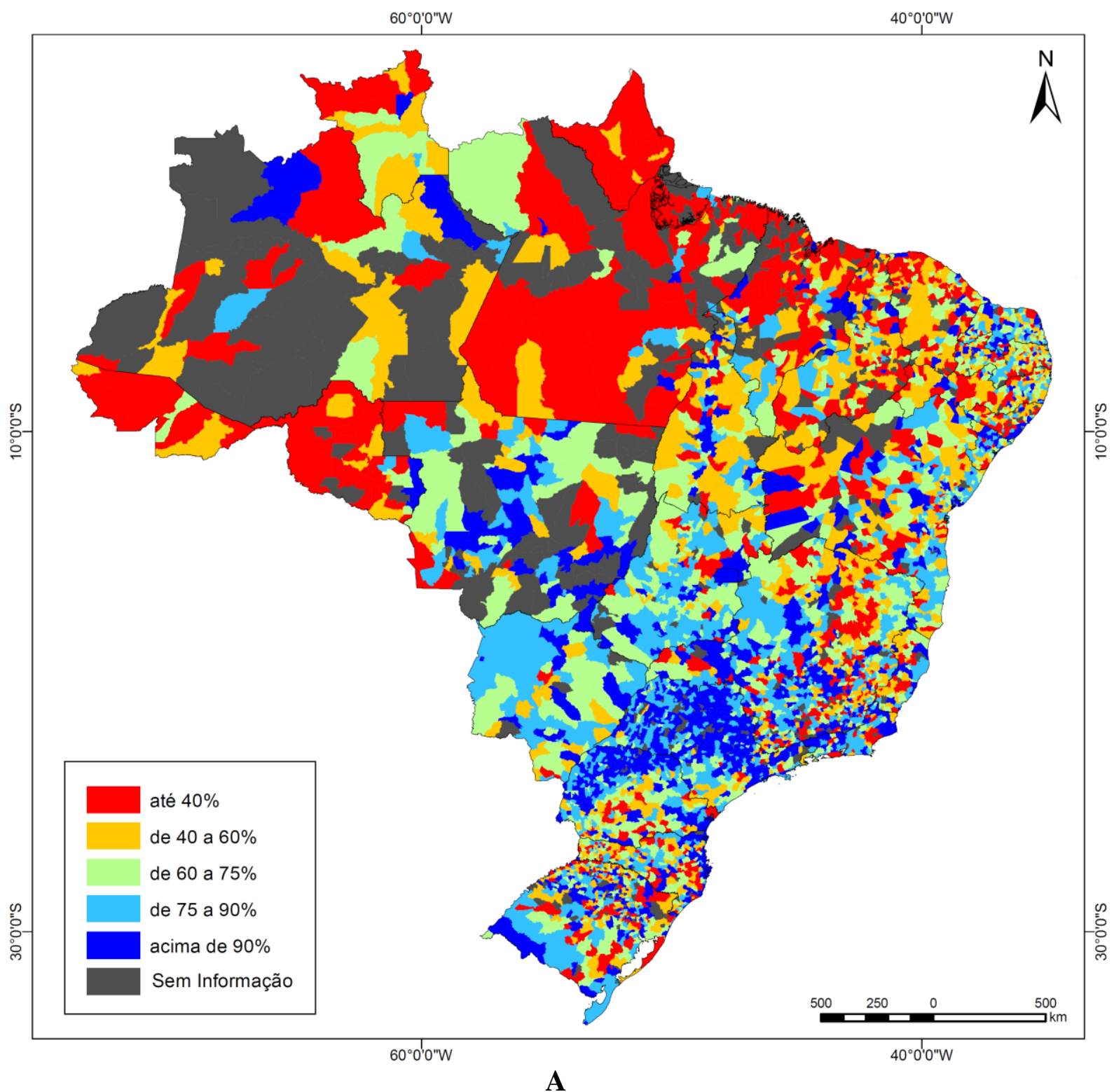

Figura 1.6: Índice de atendimento total de água (A) e índice de coleta de esgoto (B) no Brasil (2013) (continua). 


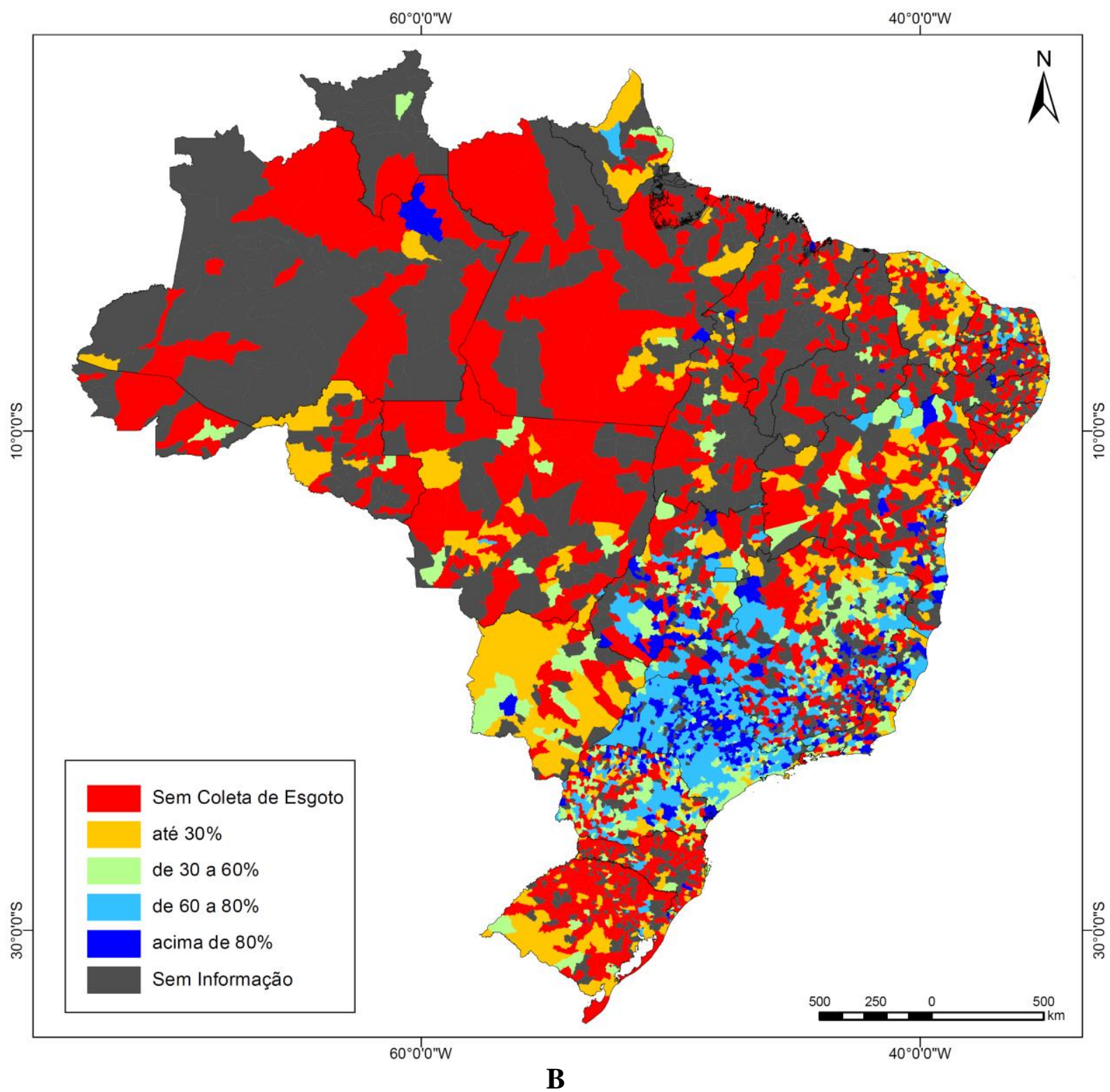

Figura 1.6: Índice de atendimento total de água (A) e índice de coleta de esgoto (B) no Brasil (2013).

Nota: O índice de atendimento total de água corresponde a razão percentual entre a população atendida com abastecimento de água e a população total do município. O índice de coleta de esgoto corresponde ao volume de esgoto coletado dividido pelo volume de água consumido já subtraído do volume de água tratado exportado (MCid/SNIS, 2014).

Fonte: Elaborado pelo autor a partir de dados do MCid/SNIS (2014).

Estudo da ANA publicado em 2011 apontou que, somente no Nordeste, 60\% das cidades necessitam de ampliação do sistema de abastecimento de água ou conexão a um sistema integrado para atender à demanda e $14 \%$ necessitam da adoção de um novo manancial. São os maiores índices dentre as regiões do país. O abastecimento satisfatório atende $18 \%$ da população, sendo necessários investimentos estimados de 9,1 bilhões de reais para solução de problemas de abastecimento a cerca de cinquenta milhões de habitantes em 2025 (ANA, 2011). 
Como uma tentativa de contribuir para o aumento da disponibilidade hídrica na RHANO encontra-se em curso o Projeto de Integração do Rio São Francisco com Bacias Hidrográficas do Nordeste Setentrional (PISF), conhecido popularmente como Transposição do Rio São Francisco. O PISF, um empreendimento do governo federal, sob a responsabilidade do Ministério da Integração Nacional (MI), visa assegurar a oferta de água, em 2025, a aproximadamente doze milhões de habitantes em 390 municípios dos estados de Pernambuco, Ceará, Paraíba e Rio Grande do Norte (ANA, 2005), a partir de dois eixos de adução de água, Norte e Leste (Figura 1.7). O PISF pretende aumentar a disponibilidade e melhorar a qualidade da água garantindo um volume permanente de água nos reservatórios e diminuindo assim os conflitos existentes (MI, 2004).

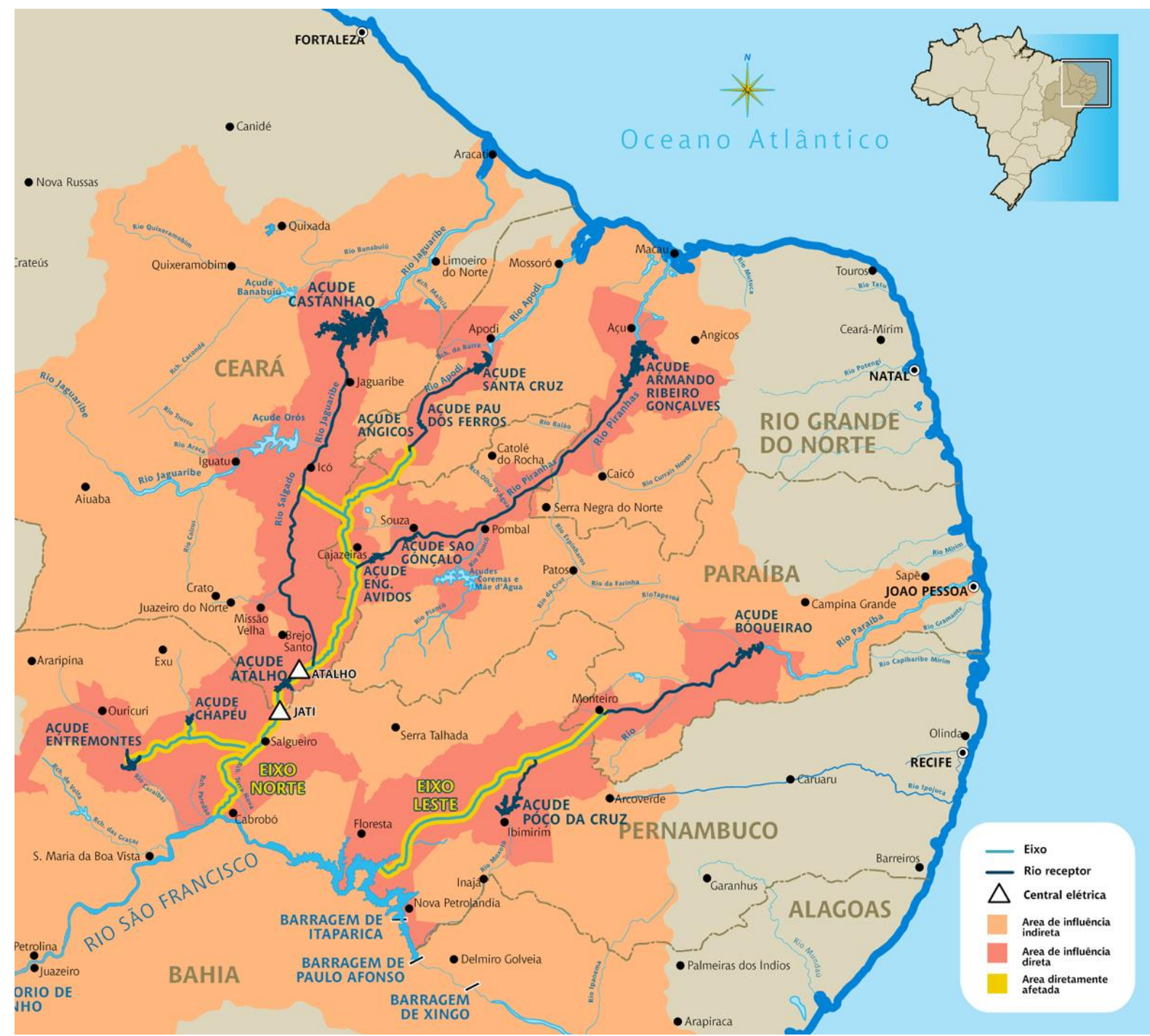

Figura 1.7: Área de influência do PISF.

Fonte: MI (2004). 
Uma análise detalhada da infra-estrutura de abastecimento de água da RHANO foi efetuada para a definição do recorte espacial de estudo (Figura 1.8). Foram adotados os seguintes critérios: municípios cujas áreas urbanas dependem exclusivamente de água proveniente de um único reservatório, para definição da fonte de abastecimento de água de um determinado território e da população sob risco; reservatórios que alimentam sistemas integrados de abastecimento de água; reservatórios com área do espelho d'água superior a cem hectares e reservatórios localizados nas bacias hidrográficas que receberão aporte do PISF. O recorte temporal foi definido a partir da disponibilidade dos dados de DDA.

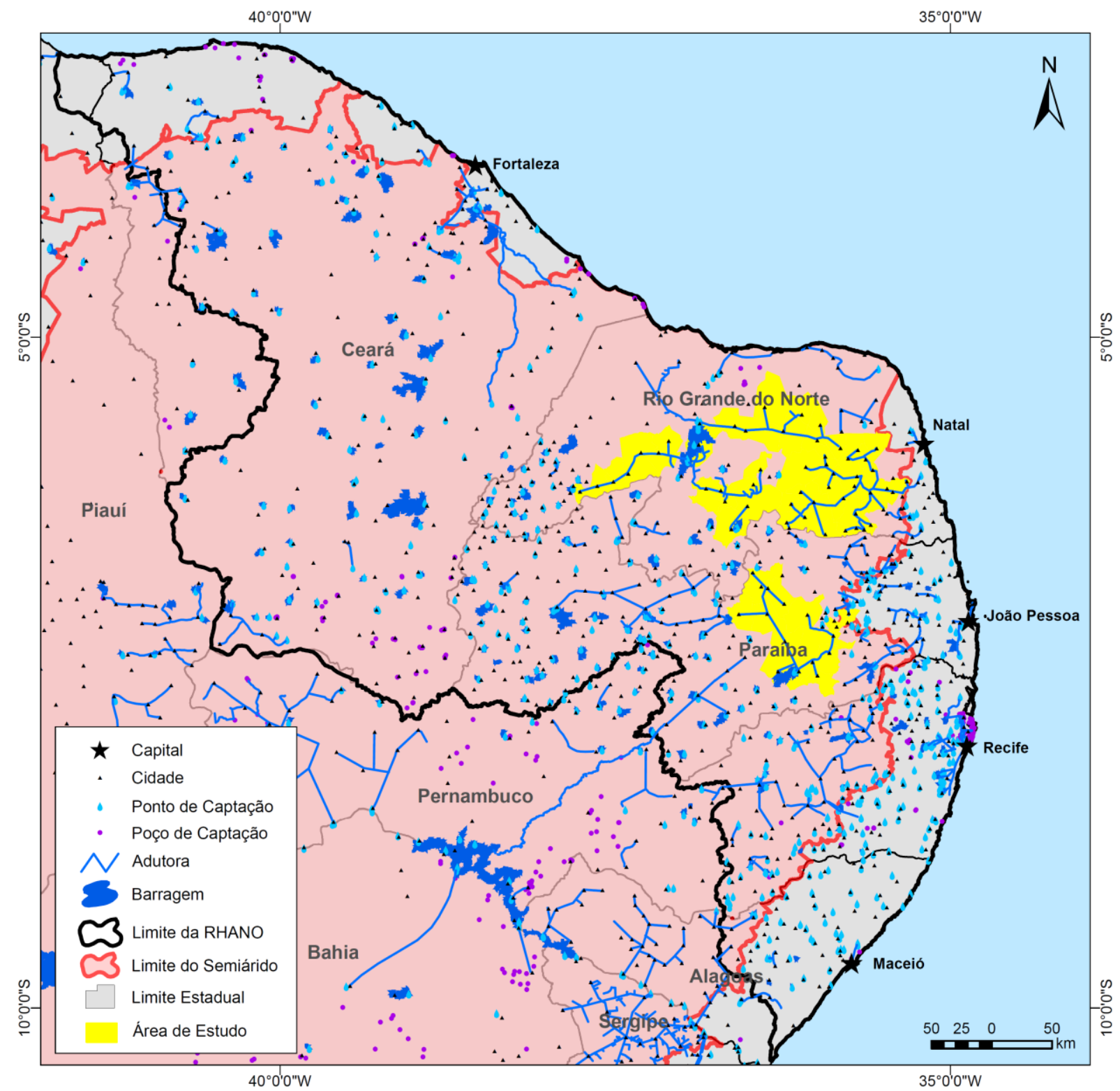

Figura 1.8: Fontes de abastecimento urbano de água na RHANO.

Fonte: Elaborado pelo autor a partir de dados de MI (2005), ANA (2011) e CPRM (2013). 


\subsection{OBJETIVOS E HIPÓTESES}

O objetivo geral da pesquisa é identificar padrões e tendências espaço-temporais de ocorrência das doenças diarreicas a partir de sua observação conjunta com variáveis ambientais relacionadas ao clima e ao abastecimento de água, em um recorte espacial do semiárido brasileiro e em todo o território nacional, utilizando séries temporais de dados entre 1998 e 2014.

Os objetivos específicos são:

a) Efetuar uma análise temporal da qualidade da água de reservatórios através de metodologias baseadas em sensoriamento remoto, em mananciais de abastecimento de municípios de um recorte espacial do semiárido e, associar os dados obtidos com os padrões de ocorrência de DDA na população abastecida por esses mananciais, entre 2002 e 2012;

b) Estudar, com o auxílio de métodos estatísticos multivariados, de que modo o comportamento da precipitação pluviométrica pode explicar a ocorrência interanual e sazonal da DDA em um recorte espacial do semiárido brasileiro entre 2002 e 2012;

c) Analisar a distribuição espaço-temporal das taxas de incidência da DDA em um recorte espacial do semiárido entre 2002 e 2014 e sua relação com as diferentes fontes de abastecimento de água;

d) Analisar o comportamento sazonal das internações hospitalares por diarreia no território brasileiro a partir de uma série histórica entre 1998 e 2012, associando as internações com as características do clima em diferentes regiões do país.

A hipótese principal da pesquisa de tese é de que a ocorrência da diarreia está associada a fatores como a dinâmica climática, as formas de abastecimento de água e a qualidade da água dos reservatórios de abastecimento da população.

As hipóteses secundárias levantadas na pesquisa, associadas a cada um dos objetivos específicos, correspondem, na mesma ordem, a: 
a) Maiores concentrações de clorofila-a (Chla) em determinado período do tempo e em reservatórios específicos, bem como menor quantidade de água disponível, estão associadas à maior ocorrência de DDA na população por eles abastecida;

b) $\mathrm{O}$ comportamento intra e interanual da precipitação pluviométrica e da temperatura estão correlacionados com os padrões de ocorrência da DDA na área de estudo;

c) Existem questões chave ligadas ao abastecimento de água que explicam o comportamento espacial das taxas de DDA na área de estudo e das epidemias da doença;

d) O padrão temporal da ocorrência das doenças diarreicas no Brasil está associado ao comportamento climático das diferentes regiões do país.

\subsection{MODELO CONCEITUAL DA TESE}

Segundo a classificação dos estudos epidemiológicos proposta por Lima-Costa e Barreto (2003), este estudo pode ser classificado como estudo ecológico, um delineamento dos estudos analíticos que examinam a existência de associação entre uma exposição e uma doença ou condição relacionada à saúde. A revisão bibliográfica efetuada por Andreazzy et al. (2007) destacou os estudos ecológicos como sendo adequados para o estudo das relações entre as condições de saneamento e a saúde.

Suertegaray (2002), por sua vez, ao tratar acerca das categorias de análise geográfica que podem elucidar a questão supracitada, observou que o estudo da relação sociedade-natureza e do espaço-tempo são a base para compreender as inter-relações entre a incidência das doenças de veiculação hídrica e a sociedade urbanizada.

A variação na ocorrência da diarreia foi observada no espaço e no tempo, tendo sido estudada a relação entre a doença e potenciais variáveis explicativas segundo análises espaciais de dados geográficos e análises estatísticas de dados multivariados. A análise é efetuada segundo uma abordagem indutiva, partindo de um recorte espacial definido no semiárido brasileiro e alcançando todo o território nacional.

Foi adotada uma metodologia de análise da DDA que buscou identificar barreiras ou vulnerabilidades ambientais que permitem sua difusão temporalmente. Foram estudadas 
tendências desse agravo e sua relação com fatores ambientais (BARCELLOS; BASTOS, 1996). O nível de agregação dos dados escolhido foi o município, pois ele serve como referência de dados primários na área de saúde.

A tese se enquadra no campo de pesquisa da saúde ambiental e, ao estudar os padrões espaço-temporais de ocorrência das doenças diarreicas, busca compreender de que modo condicionantes ambientais atuam no favorecimento ou não da doença, tais como a qualidade e quantidade de água disponível nos reservatórios de abastecimento, o regime sazonal e interanual da precipitação e, as condições e a disponibilidade ou não de água para a população urbana ou rural proveniente de diversas fontes como a rede geral, açudes marginais, cisternas e carros-pipa.

\subsection{ESTRUTURA DA TESE}

A tese encontra-se estruturada em um capítulo introdutório que engloba aspectos norteadores da pesquisa, objetivos propostos, relevância do tema e estruturação do trabalho (Capítulo 1). Este capítulo também apresenta um panorama síntese da ocorrência das doenças diarreicas no país.

Os capítulos 2 a 5 da tese compreendem os resultados obtidos com a pesquisa, apresentados em ordem cronológica conforme o desenvolvimento de suas hipóteses e seus contextos espaciais e temporais (Figura 1.9). Os recortes de análise de cada capítulo no espaço e no tempo foram variados e seguiram limitações impostas pela disponibilidade de dados. Em resumo, a pesquisa seguiu um caráter indutivo, selecionando uma área estudo de caso particular no semiárido brasileiro e, tendo em vista os resultados obtidos, contemplou uma análise do problema de pesquisa em todo o território nacional.

Os capítulos foram elaborados segundo o formato de artigos científicos, compreendendo revisões de pesquisas científicas relacionadas àquele tema, os objetivos, conjuntos de dados e métodos específicos, bem como resultados, discussões, considerações finais e referências bibliográficas. 


\section{ESPAÇO}

TEMA

TEMPO

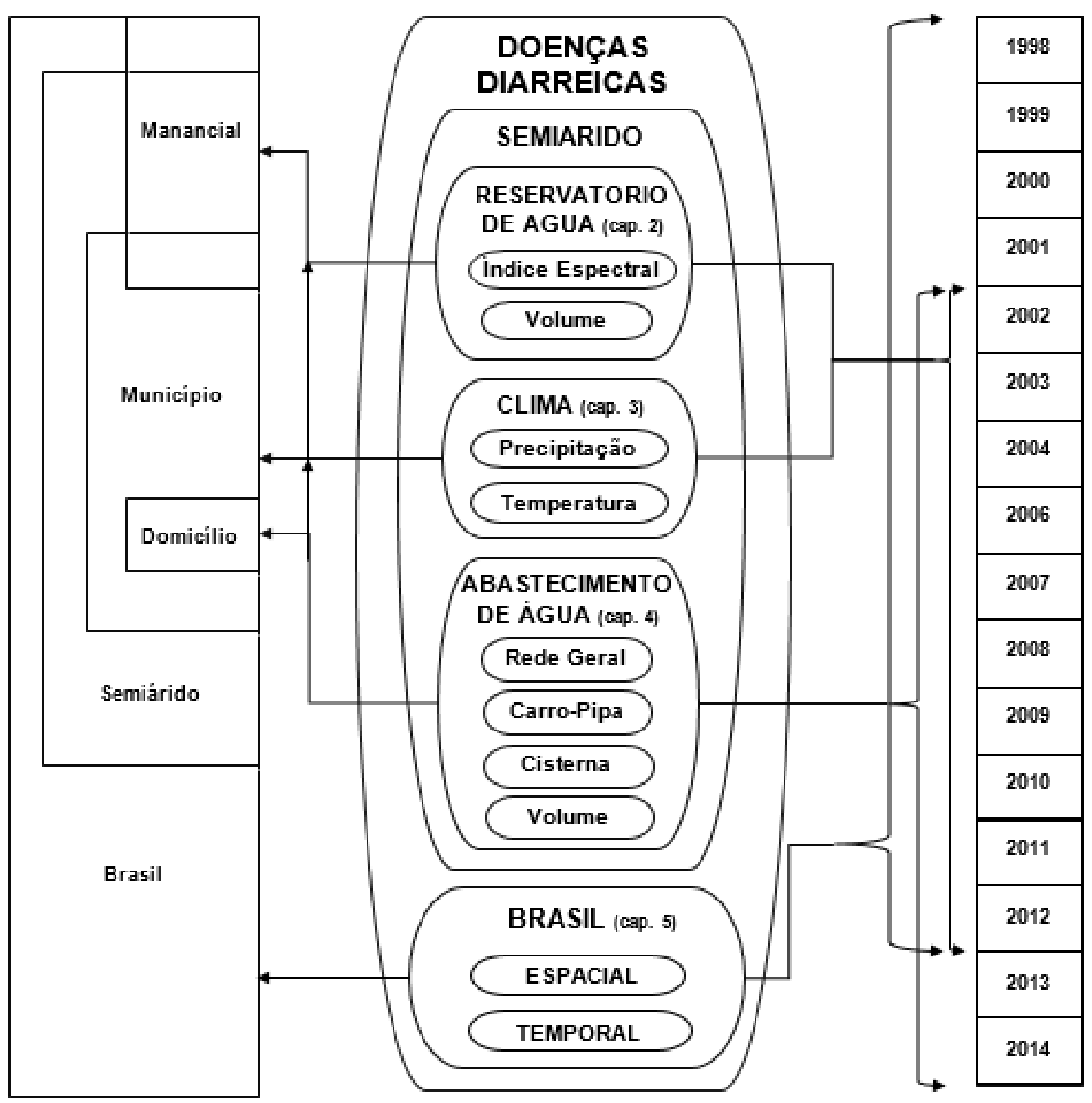

Figura 1.9: Estrutura da tese.

O Capítulo 2 efetua as análises tendo em vista questões ligadas a qualidade e disponibilidade de água de mananciais de abastecimento humano e às doenças diarreicas na população abastecida por esses mananciais; o Capítulo 3 analisa o comportamento da ocorrência das doenças diarreicas em relação ao comportamento do regime de chuvas intra e interanual; o Capítulo 4 analisa as doenças diarreicas a partir das taxas de incidência nos municípios e tendo em vista características particulares do abastecimento de água na região, consideradas de grande relevância para o entendimento dos padrões espaciais de ocorrência da doença. Os capítulos 2 a 4 estudam o problema de pesquisa apenas em um recorte espacial do semiárido brasileiro. 
O Capítulo 5 trata dos padrões espaço-temporais das internações motivadas por diarreias e gastroenterites infecciosas em um contexto nacional, envolvendo todos os municípios do país. O período do ano de maior ocorrência foi associado aos diferentes tipos climáticos, sendo destacados os padrões apresentados pelas capitais brasileiras.

Por fim, o Capítulo 6 apresenta conclusões obtidas a partir da discussão dos resultados e recomendações para estudos futuros.

\section{REFERÊNCIAS BIBLIOGRÁFICAS}

AGÊNCIA NACIONAL DE ÁGUAS (ANA). Resolução nº 687, de 03 de dezembro de 2004. Brasília: ANA, 2004. Disponível em: http://arquivos.ana.gov.br/resolucoes/2004/6872004.pdf. Acesso em: 20 abr. 2013.

Resolução n. ${ }^{\circ}$ 411, de 22 de setembro de 2005. Brasília: ANA, 2005. Disponível em: http://arquivos.ana.gov.br/projetos/pisf/Resolucao_n411_2005.pdf. Acesso em: 20 abr. 2013.

. Atlas Brasil: Abastecimento Urbano de Água. Brasília: ANA, 2011. Disponível em: http://atlas.ana.gov.br/Atlas/forms/Home.aspx. Acesso em: 20 abr. 2013.

Portal de Metadados Geoespaciais: Espelhos d'Água. Brasília: ANA, 2013a.

Disponível em: http://metadados.ana.gov.br/geonetwork/srv/pt/ main.home?uuid=7d054e5a8cc9-403c-9f1a-085fd933610c. Acesso em: 15 out. 2013.

Mapa de Áreas Aflorantes dos Aquíferos e Sistemas Aquíferos do Brasil. Escala 1:1.000.000. Brasília: ANA, 2013b.

Conjuntura dos Recursos Hídricos no Brasil: Informe 2014. Brasília: ANA, 2015. Disponível em: http://conjuntura.ana.gov.br/. Acesso em: 15 maio 2015.

ANDREAZZI, M. A. R.; BARCELLOS, C.; HACON, S. Velhos indicadores para novos problemas: a relação entre saneamento e saúde. Revista Panamericana de Salud Publica, v. 22, n. 3, p. 211-217, 2007.

BARCELLOS, C.; BASTOS, F. I. Geoprocessamento, ambiente e saúde: uma união possível? Cadernos de Saúde Pública. v. 12, n. 3, p. 389-397, 1996.

COMPANHIA DE PESQUISA DE RECURSOS MINERAIS (CPRM). Sistema de Informações de Águas Subterrâneas - SIAGAS. 2013. Disponível em: http://siagasweb. cprm.gov.br/layout/. Acesso em: 30 set. 2013. 
CONSELHO NACIONAL DE RECURSOS HÍDRICOS (CNRH). Resolução CNRH no 32, de 15 de outubro de 2003. Brasília: CNRH, 2003. Disponível em: http://www.cnrh.gov.br/ index.php?option=com_content\&view=article\&id=14. Acesso em: 07 jan. 2014.

CZERESNIA, D.; RIBEIRO, A. M. O conceito de espaço em epidemiologia: uma interpretação histórica e epistemológica. Cadernos de Saúde Pública, v.16, n.3, p. 595-605, 2000 .

ESCOREL, S.; GIOVANELLA, L.; MENDONCA, M. H. M.; SENNA, M. C. M. O Programa de Saúde da Família e a construção de um novo modelo para a atenção básica no Brasil. Revista Panamericana de Salud Publica, v. 21, n. 2-3, p. 164-176, 2007.

FERREIRA, A. L. A.; EDUARDO, A. R. B.; DANTAS, ANA C. C. L. Geografias e topografias médicas: os primeiros estudos ambientais da cidade concreta. Investigaciones Geográficas - Boletín del Instituto de Geografía, UNAM. n. 52, p. 83-98, 2003.

LIMA-COSTA, M. F.; BARRETO, S. M. Tipos de estudos epidemiológicos: conceitos básicos e aplicações na área do envelhecimento. Epidemiologia e Serviços de Saúde, Brasília, v. 12, n. 4, p. 189-201, 2003.

LINHARES, A. C.; JUSTINO, M. C. Rotavirus vaccination in Brazil: effectiveness and health impact seven years post-introduction. Expert Review of Vaccines, v. 13, n. 1, p. 43 57, 2014.

MINISTÉRIO DAS CIDADES (MCid). SISTEMA NACIONAL DE INFORMAÇÕES SOBRE SANEAMENTO (SNIS). Diagnóstico dos Serviços de Água e Esgotos, referente ao ano de 2013. Brasília: Ministério das Cidades, 2014. 181p.

MINISTÉRIO DA INTEGRAÇÃO NACIONAL (MI). Projeto de Integração do Rio São Francisco com Bacias Hidrográficas do Nordeste Setentrional: Relatório de Impacto Ambiental. Brasília: MI, 2004. Disponível em: http://www.mi.gov.br/documents/10157/ 3675235/RIMA.pdf/c7f4834d-2ca8-4baf-9bbd-21 cacb64ca2f. Acesso em: 02 mar. 2013.

Nova Delimitação do Semi-Árido Brasileiro. Brasília: MI, 2005. Disponível em: http://www.mi.gov.br/c/document_library/get_file?uuid=0aa2b9b5-aa4d-4b55-a6e182faf0762763\&groupId =24915. Acesso em: 02 mar. 2013.

MINISTÉRIO DA SAÚDE (MS). DEPARTAMENTO DE INFORMÁTICA DO SISTEMA ÚNICO DE SAÚDE (DATASUS). Informações de Saúde (TABNET). Brasília: MS, 2015. Disponível em: http://www2.datasus.gov.br/DATASUS/index.php. Acesso em: 15 mar. 2015.

MONTGOMERY, M. A.; ELIMELECH, M. Water and sanitation in developing countries: including health in the equation. Environmental Science \& Technology, v. 41, 17-24, 2007. 
PFAFSTETTER, O. Classificação de Bacias Hidrográficas - Metodologia de Codificação. Rio de Janeiro: DNOS, 1989. 19p.

PRÜSS, A.; KAY, D.; FEWTRELL, L.; BARTRAM, J. Estimating the burden of disease from water, sanitation, and hygiene at a global level. Environmental Health Perspectives, v. 110, n.5, p. 537-542, 2002.

PRÜSS-ÜSTÜN, A.; BOS, R.; GORE, F.; BARTRAM, J. Safer Water, Better Health: Costs, Benefits and Sustainability of Interventions to Protect and Promote Health. Genebra: WHO; 2008. 60p.

ROSSIN, A. C. Desinfecção. In: COMPANHIA DE TECNOLOGIA DE SANEAMENTO AMBIENTAL (CETESB). Técnica de abastecimento e tratamento de água. São Paulo: CETESB, p. 883-930, 1976.

SASTRY, N; BURGARD, S. The prevalence of diarrheal disease among Brazilian children: trends and differentials from 1986 to 1996. Social Science and Medicine, v. 60, p. 923-935, 2005 .

SORRE, M. Les Fondements da la Géographie Humaine. In: Tome Premier: Les Fondements Biologiques. Librairie Armand Colin, 1951.

SNOW, J. On the Mode of Communication of Cholera. London: John Churchill, 1855. 76p. In: Hygeia, v. 3, n. 6, p. 1-11, 2008.

SUERTEGARAY, D. M. A. Geografia Física (?), Geografia Ambiental (?) ou Geografia e Ambiente (?). In: MENDONÇA, F.; KOZEL, S. Elementos de Epistemologia da Geografia Contemporânea. Curitiba: Ed. UFPR, p. 111-119, 2002.

TAYLOR, L. H.; LATHAM, S. M.; WOOLHOUSE, M. E. Risk factors for human disease emergence. Philosophical Transactions of the Royal Society London: Biological Sciences, v. 356, n. 1411, p. 983-989, 2001.

WORLD HEALTH ORGANIZATION (WHO). Global Health Risks: Mortality and burden of disease attributable to selected major risks. Genebra: WHO, 2009. Disponível em: http://www.who.int/healthinfo/global_burden_disease/GlobalHealthRisks_report_full. pdf?ua=1\&ua=1. Acesso em: 25 out. 2015. 


\section{ANÁLISE TEMPORAL DA QUALIDADE DA ÁGUA DE RESERVATÓRIOS DE ABASTECIMENTO HUMANO POR SENSORIAMENTO REMOTO E DA OCORRÊNCIA DE DOENÇA DIARREICA AGUDA EM UM RECORTE ESPACIAL DO SEMIÁRIDO BRASILEIRO ENTRE 2002 E 2012}

RESUMO: O semiárido brasileiro constitui uma região caracterizada pela baixa disponibilidade hídrica e pela utilização massiva de açudes como fonte de água para o abastecimento humano e demais usos. Esta pesquisa utilizou uma metodologia de análise de séries temporais de imagens do sensor remoto MODIS para monitoramento da resposta espectral da água dos açudes Armando Ribeiro Gonçalves (ARG), Epitácio Pessoa e Gargalheiras (MDG) e de séries da ocorrência de doenças diarreicas agudas (DDA), de 2002 a 2012, em 41 municípios dos estados do Rio Grande do Norte e da Paraíba abastecidos pelos açudes citados. Os resultados obtidos apontaram que a maior ocorrência da DDA nesses municípios em cada ano da série temporal não esteve associada ao período de maior influência da clorofila-a, um indicador do nível de eutrofização da água, e/ou de queda no volume de água dos açudes, mas sim, ao período de maior influência do material inorgânico em suspensão na resposta espectral da água, associado aos períodos chuvosos. Foi observada uma maior associação da dinâmica de ocorrência da DDA com a dinâmica climática local, sendo que outras variáveis como o regime sazonal de chuvas parecem ter maior influência para explicar os padrões temporais de ocorrência das doenças. A metodologia adotada de processamento das imagens, por sua vez, se mostrou adequada para aplicação em reservatórios de grande tamanho, a exemplo do açude ARG, impedindo o registro das variações sazonais na resposta espectral da água em açudes menores como o MDG, observadas as limitações inerentes à resolução espacial das imagens.

Palavras-chave: açude, monitoramento, eutrofização, diarreia, sensoriamento remoto, semiárido. 


\subsection{INTRODUÇÃO}

Um amplo espectro de processos naturais e antrópicos afeta as características físicas, químicas e biológicas da água. A contaminação por excesso de nutrientes, geralmente associada a nitrogênio e fósforo, que conduz à eutrofização, tornou-se um dos problemas mais difundidos no mundo em termos de qualidade da água (CARR; NEARY, 2008; UNWWAP, 2009). Há ainda a contaminação da água por organismos patogênicos: bactérias, protozoários e vírus, que representa uma das principais ameaças à saúde humana.

Dentre as consequências da eutrofização estão a produção de toxinas por cianobactérias, o aumento da presença de bactérias patogênicas e da probabilidade de ocorrência de doenças de veiculação hídrica (TUNDISI et al., 2006). A eutrofização de reservatórios no semiárido foi analisada por autores como Bouvy et al. (2000), em Pernambuco e Figueiredo et al. (2007), no Ceará, envolvendo estudos comparativos com recortes espaciais e temáticos abrangentes. Outros estudos que atestaram a eutrofização na RHANO foram conduzidos nos açudes: Soledade (PB) (BARBOSA et al., 2006), Carangueja (AL) (ALMEIDA et al., 2008), Cedro (CE) (PEREIRA, 2008), Bodocongó (PB) (CARVALHO et al., 2008), Cruzeta (RN) (FREITAS, 2008), Armando Ribeiro Gonçalves (RN) (MOSCA, 2008) e Epitácio Pessoa (PB) (ARAÚJO JÚNIOR, 2010). Os autores encontraram resultados preocupantes e convergentes, uma vez que os referidos reservatórios são fontes de abastecimento humano.

Quanto ao registro de graves danos à saúde devido a eutrofização de reservatórios, Teixeira et al. (1993) identificaram associação entre a floração de cianobactérias no reservatório da usina hidrelétrica (UHE) Itaparica (BA) e a morte de 88 pessoas, dentre duzentas intoxicadas, em 1988. Jochimsen et al. (1998), por sua vez, concluíram que devido à contaminação da água do açude Tabocas (PE) por cianobactérias em 1996, 69 pacientes faleceram após tratamento em uma clínica de hemodiálise na cidade de Caruaru. Esse caso corresponde ao mais grave incidente de contaminação da água e ocorrência de danos à saúde pública registrado na história do Brasil, com elevado número de mortes devido à ingestão de cianobactérias.

O monitoramento da qualidade da água está integrado à densa rede hidrometeorológica existente no Brasil, coordenada pela ANA e da qual participam instituições públicas e privadas. Os custos de implantação e operação dessas estações são elevados, pois demandam a adoção 
de sistemas automáticos ou coletas de campo e análises laboratoriais*. Complementarmente, dados de sensoriamento remoto podem ser utilizados no monitoramento dos sistemas aquáticos, permitindo cobrir grandes áreas de superfície com alta repetitividade, baixo custo e rápido acesso a informações. Os estudos de qualidade da água por sensoriamento remoto apresentam basicamente dois enfoques: (a) um voltado à turbidez, associado ao material inorgânico em suspensão (VILLAR, 2013), e (b) outro à eutrofização, associado à concentração de pigmentos tais como a clorofila-a (Chla), importante indicador do estado trófico de reservatórios (VENTURA, 2013).

Séries temporais de sensoriamento remoto permitem identificar áreas prioritárias para ações de gestão em bacias hidrográficas e suprir lacunas na coleta, armazenagem, consistência e compartilhamento dos dados obtidos através do monitoramento convencional. O Moderateresolution Imaging Spectroradiometer (MODIS) ${ }^{\dagger}$, com imagens diárias e composições de oito dias das melhores tomadas de dados, a partir de um controle de qualidade, consiste em uma importante fonte para estudos.

Nesse sentido, o objetivo da pesquisa é efetuar uma análise dos padrões temporais de concentração de Chla e turbidez de reservatórios de abastecimento urbano de água através de metodologias baseadas em sensoriamento remoto; identificar o alcance e os limites da aplicação dessas metodologias de análise e; associar os dados obtidos com a ocorrência de episódios de doença diarreica aguda na população abastecida por esses reservatórios.

\footnotetext{
* De acordo com a Resolução Conjunta ANA/Agência Nacional de Energia Elétrica (ANEEL) nº 03/2010 (ANA; ANEEL, 2010), os agentes operadores do sistema elétrico são obrigados a instalar e manter uma rede telemétrica de estações limnométricas e sedimentométricas nos respectivos barramentos e, de qualidade de água, em número de uma a três estações, conforme a área de drenagem referencial, em um ponto do reservatório a ser definido. O dado deverá ser adquirido quatro vezes ao ano, para demanda bioquímica de oxigênio, fósforo total, nitrogênio total, Chla, transparência, pH e temperatura. A obrigação não se estende aos reservatórios em que não há aproveitamento hidrelétrico, porém, a Resolução ANA nº 903/2013 (ANA, 2013) criou a Rede Nacional de Monitoramento da Qualidade das Águas Superficiais (RNQA). Os pontos de monitoramento que compõem a RNQA estão distribuídos pelas doze Regiões Hidrográficas do Brasil, em cursos e corpos d'água, conforme metodologia e critérios pré-definidos e padronizados. A gestão da RNQA será efetuada considerando a divisão político-administrativa do Brasil, tendo sido estabelecidas quatro regiões, para cada uma das quais foi definida uma densidade mínima de pontos e de frequência de monitoramento. No total a rede será composta por 4.488 pontos amostrais de monitoramento de 17 parâmetros mínimos de qualidade da água. A RNQA deverá estar em operação em todas as Unidades da Federação até 2020.

$\dagger^{\dagger}$ As imagens MODIS possuem resolução radiométrica de 12 bits em 36 bandas espectrais, com resolução espacial de $250 \mathrm{~m}$, $500 \mathrm{~m}$ ou $1 \mathrm{~km}$, no intervalo de $0,4 \mu \mathrm{m}$ a $14,4 \mu \mathrm{m}$. A resolução temporal é de um ou dois dias dependendo da latitude. As imagens cobrem uma faixa de 1.200 por $1.200 \mathrm{~km}$. O MODIS foi concebido pelo programa internacional Earth Observing System (EOS) liderado pela National Aeronautics and Space Administration (NASA) para o estudo dos processos de mudanças globais (JUSTICE et al., 1998). A primeira plataforma do programa, denominada Terra, foi lançada em 1999 e passa pelo Equador em órbita descendente às 10h 30min e, a segunda plataforma, a Aqua, lançada em 2002, em órbita ascendente às 13h $30 \mathrm{~min}$.
} 


\subsection{MATERIAL E MÉTODOS}

\subsection{1 Área de estudo}

A delimitação dos reservatórios e municípios de estudo na área da RHANO foi efetuada a partir da análise dos sistemas de abastecimento de água da região. Foram adotados os seguintes critérios: municípios cujas áreas urbanas dependem exclusivamente de água proveniente de um único reservatório; reservatórios que alimentam sistemas integrados de abastecimento de água; reservatórios com área do espelho d'água superior a cem hectares e reservatórios localizados nas bacias hidrográficas que receberão aporte do PISF. Foram selecionados 24 municípios dos Estados do Rio Grande do Norte e 17 da Paraíba, com abastecimento de água de três mananciais distintos: os açudes Engenheiro Armando Ribeiro Gonçalves (ARG) e Marechal Dutra (ou Gargalheiras) (MDG) no Rio Grande do Norte e Epitácio Pessoa (ou Boqueirão) (EPB) na Paraíba (Figura 2.1). A população total dos municípios corresponde a 195.942 habitantes no Rio Grande do Norte e 592.808 habitantes na Paraíba (IBGE, 2010).

$\mathrm{O}$ açude ARG corresponde ao terceiro maior reservatório de abastecimento da RHANO e ao maior do Estado do Rio Grande do Norte (Figura 2.2A). Ele barra o Rio Piranhas/Açu e possui uma área superficial de $181,75 \mathrm{~km}^{2}$ abastecendo vinte municípios através de três sistemas integrados de adução de água e isoladamente os municípios de Itajá e São Rafael.

O açude EPB é o segundo maior reservatório do Estado da Paraíba, barrando as águas dos rios Taperoá e Paraíba, com área superficial de 43,57 km² (Figura 2.2B). O reservatório está localizado na região dos Cariris Velhos, correspondente à área de menor pluviosidade do Brasil, com média anual inferior a 500 mm (SOUZA; SUERTEGARAY, 2005). O reservatório abastece 17 municípios da Paraíba através de dois sistemas integrados, dentre eles a capital regional de Campina Grande.

O terceiro e menor dentre os reservatórios de estudo é o MDG (Figura 2.2C), que barra o Rio Acauã, afluente do Rio Seridó que, por sua vez, é afluente do Rio Piranhas. Sua área superficial é de $7,62 \mathrm{~km}^{2}$ e abastece através de um sistema integrado as cidades de Acari e Currais Novos. 

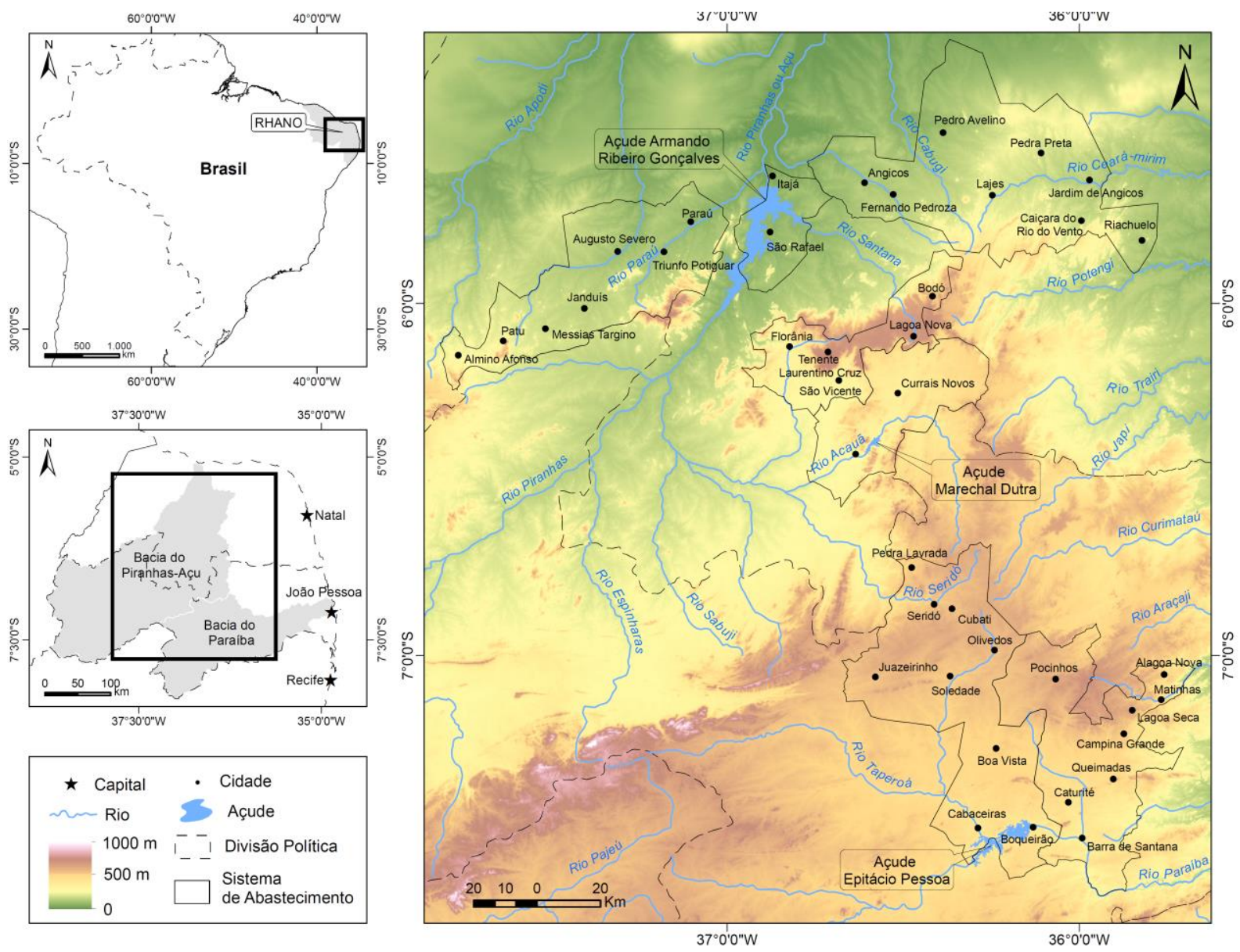

Figura 2.1: Localização do recorte espacial de estudo.

Fonte: Elaborado pelo autor a partir de imagem Shuttle Radar Topography Mission (SRTM) e de ANA (2011).

\subsubsection{Imagens MODIS}

A metodologia da pesquisa baseou-se na extração de informações a partir de imagens do sensor MODIS aplicando um modelo linear de mistura espectral. O modelo de mistura espectral permite decompor em cada pixel a contribuição da água, do fitoplâncton e das partículas inorgânicas em suspensão, extraindo essas informações das chamadas imagensfração (SHIMABUKURO; SMITH, 1991). Partindo de assinaturas espectrais de água com presença de fitoplâncton, água com alta concentração de partículas inorgânicas e água com baixa turbidez, é possível decompor a reflectância de pixels não-puros em frações da contribuição de cada tipo de água (NOVO et al., 2007). 

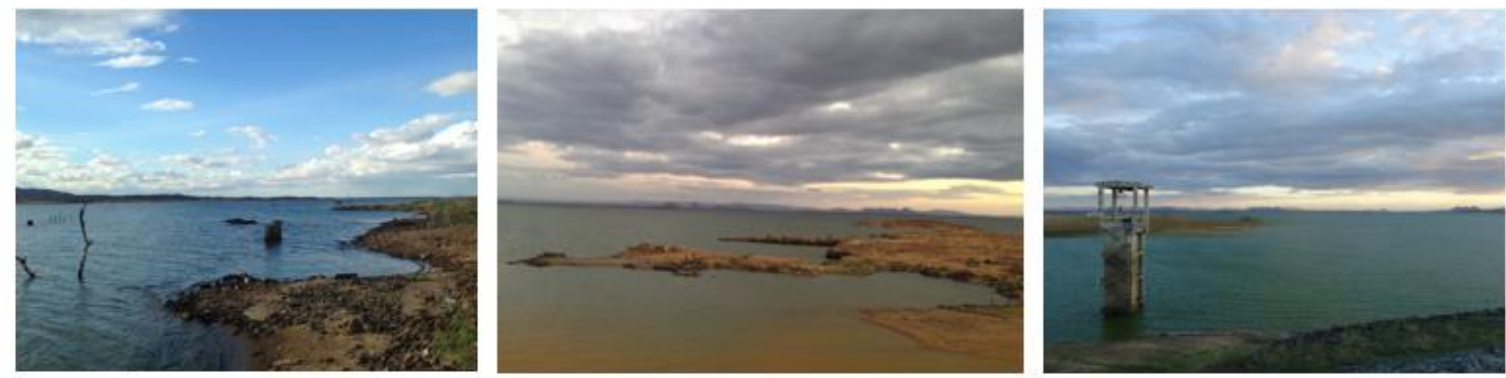

A
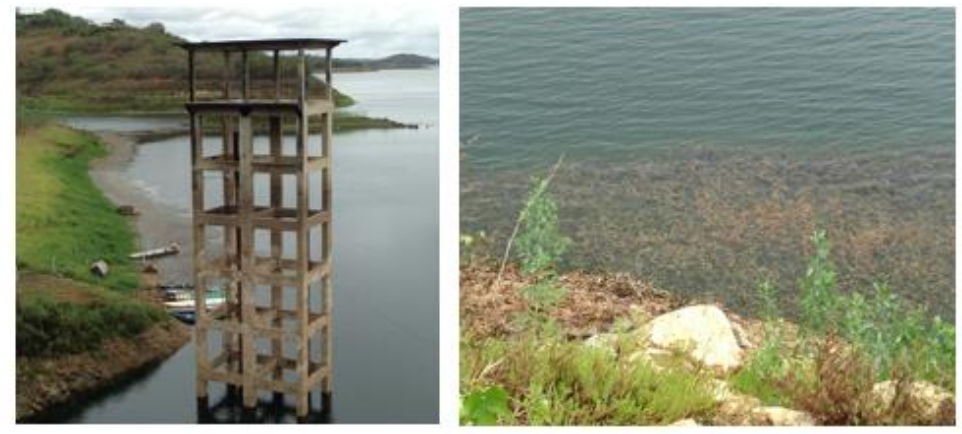

B
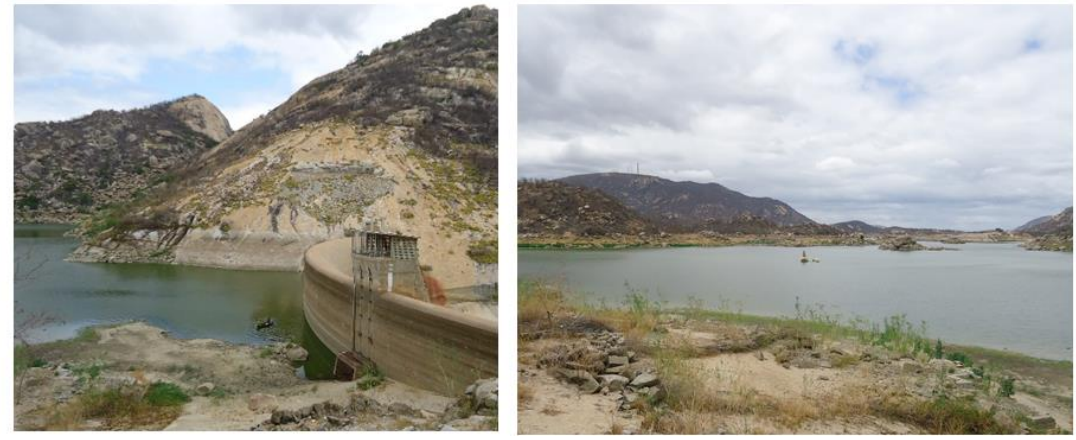

C
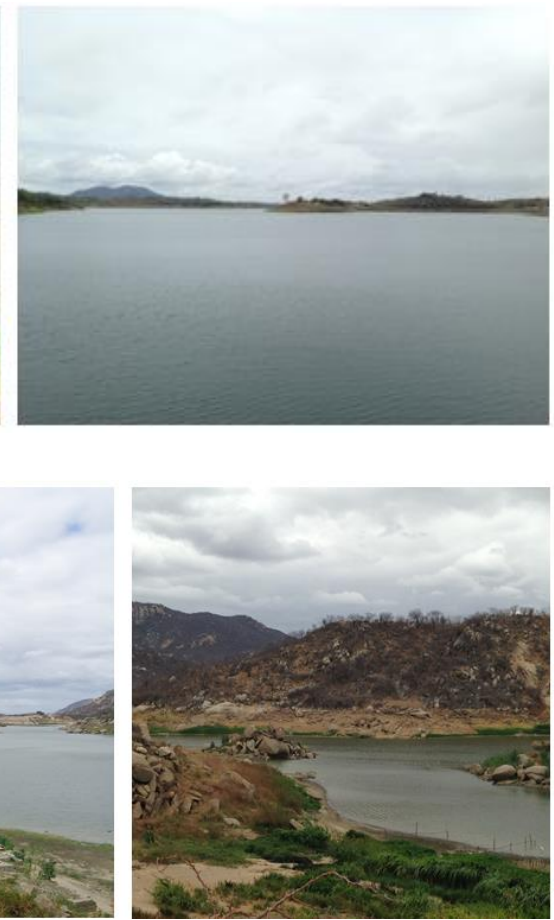

Figura 2.2: Açudes ARG em São Rafael e Itajá (RN) (A), EPB em Boqueirão (PB) (B) e MDG em Acari (RN) (C).

Fonte: Fotos do autor em 06 e 07 out. 2014.

As partículas em suspensão (orgânicas vivas, detritos orgânicos, partículas inorgânicas), componentes em solução (ácidos húmicos e fúlvicos) e organismos vivos (fitoplâncton) são componentes que alteram o comportamento espectral da água (NOVO et al., 2007). De um modo geral, a reflectância da água limpa diminui com o aumento dos comprimentos de onda. As águas com altas concentrações de pigmentos tendem a apresentar cor verde, visto que o pico de energia refletida ocorre nessa região (MENESES; MADEIRA NETTO, 2001). Por outro lado, a fração inorgânica é a maior responsável pelo aumento da reflectância da água devido ao seu maior índice de refração. Com uma maior concentração de sedimentos em suspensão na água há um deslocamento do máximo de reflectância da água em direção a comprimentos de onda mais longos, como os da região do vermelho. 
Foi efetuado o processamento digital de uma série temporal de imagens MODIS dos produtos MOD09 e MYD09 (composições de oito dias), obtidos a partir de processamento dos dados de reflectância aparente corrigida para os efeitos da atmosfera, com 500 metros de resolução espacial, da cena $H 14$ V09, na qual estão localizados os reservatórios de estudo. Foram utilizadas 986 imagens obtidas pelo sensor MODIS de 2002 a 2012.

As imagens foram obtidas através do aplicativo GetModis, desenvolvido pelo Programa The Environmental Research Observatory: Geodynamical, hydrological and biogeochemical control of erosion/alteration and material transport in the Amazon basin (ORE-HYBAM). A análise de séries temporais dos corpos hídricos utilizou o programa MODIS Reflectance Retrieval over Rivers (Mod3R) desenvolvido em linguagem de programação JAVA pelo Institut de Recherche pour le Développement (IRD) (MARTINEZ et al., 2009)*.

Segundo a documentação técnica do Projeto Hidrosat (IRD; ANA, 2013), após ter sido delimitada uma zona de interesse (máscara) na área do espelho d'água, a detecção de endmembers é realizada pelo $M O D 3 R$ em quatro etapas: (1) seleção dos pixels de boa qualidade segundo as informações de metadados encontradas na banda de qualidade dos produtos MOD/MYD09A1; (2) extração dos pixels localizados na zona de interesse definida. Somente os pixels localizados dentro da máscara são processados; (3) segmentação e classificação dos pixels em grupos homogêneos a partir do algoritmo K-means; e (4) aplicação de modelo linear de mistura espectral.

Caso houver mais de uma área de interesse em cada reservatório é recomendando que se criem tantas máscaras quantas forem as áreas de interesse. No caso específico do açude ARG, para verificar a maior influência da entrada de água no reservatório também foi definida uma máscara na área localizada mais a montante do reservatório, onde provavelmente há maior alteração na composição da água ao longo do tempo devido à presença do material inorgânico em suspensão que aflui para o reservatório.

Os parâmetros de ajuste empregados no aplicativo $M o d 3 R$ foram:

a) Número de loops igual a duzentos, que corresponde ao número de vezes em que o aplicativo segmenta a imagem, agrupando os pixels em clusters homogêneos;

\footnotetext{
* Os aplicativos GetModis e Mod3R podem ser obtidos em http://www.ore-hybam.org/index.php/fre/Logiciels.
} 
b) Número percentual de pixels sem nuvens necessário para que a imagem seja processada igual a cinco, permitindo o processamento de imagens com até 95\% de nuvens;

c) Valor igual a cem como critério na seleção dos agrupamentos de pixels (determinando desta forma $50 \%$ de peso para o critério espacial e $50 \%$ para o espectral) e;

d) Definição do número máximo de quinze clusters a serem gerados pelo aplicativo, fator que deve variar em função do número de pixels da imagem (no intervalo recomendado de seis a vinte e cinco agrupamentos, sendo o menor para imagens de pequenas áreas, inferiores a dez mil hectares, e o maior para áreas superiores a um milhão de hectares).

O aplicativo Mod3R gera quatro produtos: (1) arquivo gráfico para cada imagem processada mostrando os pixels utilizados no processamento (os pixels selecionados como membros finais são demarcados em azul, enquanto os demais adquirem cor vermelha); (2) planilha com informações dos pixels de boa qualidade selecionados na máscara; (3) planilha com informações dos clusters gerados contendo a reflectância média de cada cluster para as bandas do vermelho e do infravermelho próximo e o número de pixels do cluster e os valores de resíduo (quanto menor o resíduo, mais próximo será o comportamento do cluster ao comportamento da água pura); e (4) planilha de dados e resultados, que compreende uma classificação do nível de qualidade das imagens: "0" significa ausência de dados; "1" dados de qualidade ótima; " 2 " dados de qualidade média e; "3" dados de qualidade ruim.

Comumente, os dados de qualidade ruim estão associados à reflexão da luz solar pelo espelho d'água, causando o processo de "sunglint". Os dados de qualidade "3" são descartados automaticamente. Os dados de qualidade " 2 " correspondem a dados que foram adquiridos em condições adversas (ângulo de incidência acima de 45 graus ou forte cobertura de nuvens) e demandam observação particular, pois podem corresponder a valores discrepantes daqueles derivados de imagens disponíveis de datas próximas (outliers isolados de ruído) e sua utilização deve ser avaliada em função desses resultados.

O procedimento padrão para o cálculo dos índices de reflectância é efetuado a partir da fusão dos relatórios de imagens processadas do Terra (MOD) e Aqua (MYD) e a execução de uma rotina de processamento em Microsoft@Excel. Para a visualização podem ser selecionados apenas dados do nível de qualidade 1 e, caso for de interesse, também do nível 2. 
Neste trabalho, a concentração de Chla foi estimada por um índice espectral que corresponde à razão entre a reflectância apresentada nas bandas espectrais do verde e do vermelho (MARTINEZ et al., 2011) (Equação 2.1):

$$
\mathrm{IE}=\mathrm{R}_{\text {verde }}-\mathrm{R}_{\text {vermelho }}
$$

A Figura 2.3 apresenta um exemplo de reflectância medida em campo para amostras de águas eutrofizadas e carregadas de sedimentos no açude ARG, bem como o intervalo espectral correspondente às bandas utilizadas no índice espectral.

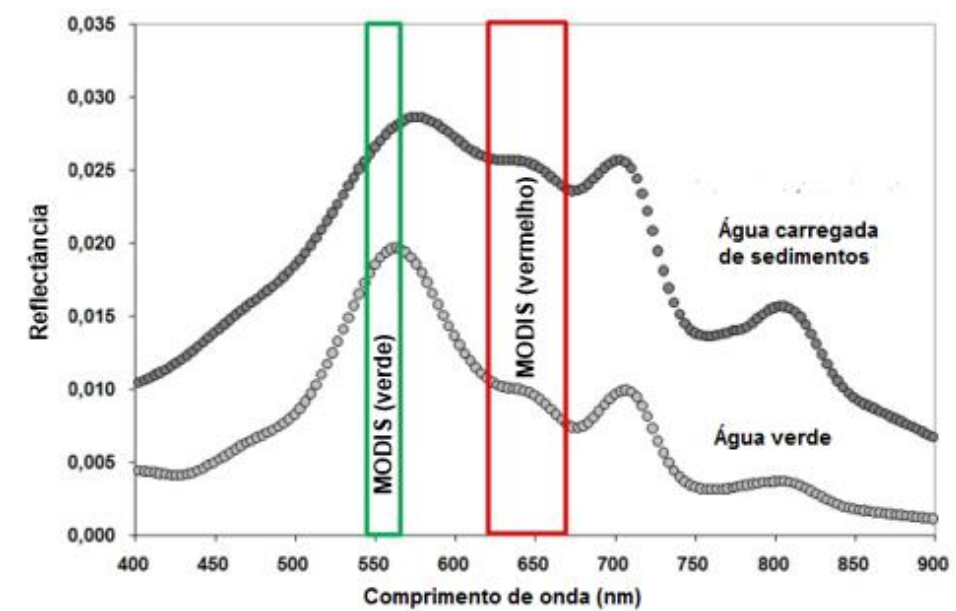

Figura 2.3: Reflectância de sensoriamento remoto medida por espectroradiômetro no açude ARG (Nov. 2008).

Fonte: Martinez et al. (2011).

As referências para a calibração dos resultados obtidos com o $M O D 3 R$ correspondem a dados oriundos de cinco campanhas de campo para coleta de dados realizadas no reservatório ARG, em novembro de 2008, dezembro de 2010, junho de 2011, novembro de 2011 e abril de 2012, em diversos pontos amostrais, pelo Programa de Hidrologia Espacial*.

\subsubsection{Dados Fluviométricos, Pluviométricos e de Doença Diarreica Aguda}

\footnotetext{
* O Programa visa desenvolver metodologias para calibração dos dados de satélites e geração de dados complementares aos adquiridos pelas estações da rede hidrometeorológica nacional, coordenada pela ANA, atuando em diferentes regiões do país, com enfoques direcionados ao estudo de fenômenos regionalizados. No Nordeste do Brasil participam do Programa o IRD, a ANA e a Universidade Federal do Rio Grande do Norte (UFRN).
} 
Os códigos das estações fluviométricas localizadas nos reservatórios de estudo foram utilizados para a indexação dos reservatórios no $\operatorname{Mod} 3 R$. Os dados de volume (absoluto e em percentual) e de nível (m) dos reservatórios foram obtidos do Departamento Nacional de Obras Contra as Secas (DNOCS) e da ANA. Conforme a classificação adotada pelo DNOCS (Tabela 2.1), os açudes ARG, EPB e MDG possuem tamanho macro, grande e médio, respectivamente, permitindo avaliar a metodologia adotada em reservatórios de diferentes dimensões.

Tabela 2.1: Informações de referência dos reservatórios de estudo.

\begin{tabular}{|c|c|c|c|}
\hline Reservatório & $\begin{array}{c}\text { Engenheiro } \\
\text { Armando Ribeiro } \\
\text { Gonçalves (ARG) } \\
\end{array}$ & $\begin{array}{c}\text { Epitácio Pessoa } \\
\text { (Boqueirão) (EPB) }\end{array}$ & $\begin{array}{c}\begin{array}{c}\text { Marechal Dutra } \\
\text { (Gargalheiras) } \\
\text { (MDG) }\end{array} \\
\end{array}$ \\
\hline Classificação (DNOCS) & $\operatorname{Macro}\left(>=550 \mathrm{hm}^{3}\right)$ & $\begin{array}{l}\text { Grande } \\
\left(>75 \mathrm{hm}^{3} \mathrm{e}<550 \mathrm{hm}^{3}\right)\end{array}$ & $\begin{array}{l}\text { Médio } \\
\left(>7 \mathrm{hm}^{3} \mathrm{e}<75 \mathrm{hm}^{3}\right)\end{array}$ \\
\hline $\begin{array}{l}\text { Estação Fluviométrica } \\
\text { (ANA) }\end{array}$ & Oiticica II & Açude Boqueirão & Açude Gargalheiras \\
\hline $\begin{array}{l}\text { Código da Estação } \\
\text { (DNAEE) }\end{array}$ & 37690000 & 38855100 & 37521000 \\
\hline $\begin{array}{l}\text { Coordenadas Geográficas } \\
\text { (Barragem) }\end{array}$ & $\begin{array}{l}05^{\circ} 40^{\prime} 10^{\prime \prime} \mathrm{S} \mathrm{e} \\
36^{\circ} 53^{\prime} 10^{\prime \prime} \mathrm{W}\end{array}$ & $\begin{array}{l}07^{\circ} 29^{\prime} 15^{\prime \prime} \mathrm{S} \mathrm{e} \\
36^{\circ} 08^{\prime} 20^{\prime \prime} \mathrm{W}\end{array}$ & $\begin{array}{l}06^{\circ} 25^{\prime} 30^{\prime \prime} \mathrm{S} \mathrm{e} \\
36^{\circ} 36^{\prime} 10^{\prime \prime} \mathrm{W}\end{array}$ \\
\hline $\begin{array}{l}\text { Ano de Conclusão da } \\
\text { Obra (DNOCS) }\end{array}$ & 1983 & 1956 & 1959 \\
\hline Domínio das Águas & Federal & Federal (Obra da União) & Federal \\
\hline $\begin{array}{l}\text { Área do Espelho d'Água } \\
\left(\mathrm{km}^{2}\right)\end{array}$ & 181,75 & 43,57 & 7,62 \\
\hline Volume $\left(\mathrm{hm}^{3}\right)$ & 2.400 & 411,69 & 44,42 \\
\hline Cota do Vertedouro (m) & 55 & 378 & 299 \\
\hline Área de Drenagem $\left(\mathbf{k m}^{2}\right)$ & 37.000 & 12.400 & 2.120 \\
\hline $\begin{array}{l}\text { Municípios Abastecidos } \\
\text { (2011) }\end{array}$ & 22 & 17 & 2 \\
\hline $\begin{array}{l}\text { População Abastecida } \\
\text { (2010) }\end{array}$ & 142.255 & 592.808 & 53.687 \\
\hline $\begin{array}{l}\text { Volume de Água para } \\
\text { Abastecimento Urbano } \\
(\mathrm{l} / \mathrm{s})\end{array}$ & 543,02 & 1.235 & 74 \\
\hline
\end{tabular}

Fonte: Elaborado pelo autor a partir de dados de ANA (2011; 2015a; 2015b), DNOCS (2015) e IBGE (2010).

Os dados de precipitação pluviométrica para cinco postos pluviométricos no Rio Grande do Norte e dois na Paraíba foram obtidos por totalização diária, em milímetros, a partir dos bancos de dados dos órgãos estaduais de monitoramento, a saber a Empresa de Pesquisa Agropecuária do Rio Grande do Norte (EMPARN) e a Agência Executiva de Gestão das Águas da Paraíba (AESA). 
Os dados de ocorrência de DDA sobre toda a população foram obtidos por semana epidemiológica. No Estado do Rio Grande do Norte foram obtidos dados de 22 municípios abastecidos pelo açude ARG e os dois (Acari e Currais Novos) abastecidos pelo MDG, no período de janeiro de 2002 a dezembro de 2012, organizados pela Secretaria de Estado da Saúde Pública do Rio Grande do Norte (SESAP). No Estado da Paraíba foram obtidos dados da Secretaria de Estado da Saúde da Paraíba (SES) para 17 municípios de janeiro de 2006 a dezembro de 2012. Em ambos os estados os dados foram disponibilizados após visitas técnicas às secretarias de saúde.

\subsection{RESULTADOS}

\subsection{1 Índice Espectral}

A Figura 2.4 apresenta a série temporal do índice espectral para o açude ARG. A série histórica mostrou uma tendência de queda do índice espectral no início de cada ano, com posterior retomada de valores elevados. Isto provavelmente se deve a influência do material inorgânico em suspensão e outros componentes opticamente ativos da água na reflectância apresentada após os períodos chuvosos (vide Figura 2.7A). A alteração da composição da água em virtude da afluência de grande quantidade de água para o reservatório nos períodos de maior volume de chuvas é mais perceptível na área de entrada do reservatório, denominada ARG montante (Figura 2.4B).

Observam-se diferenças nos valores mínimos e máximos calculados pelo índice espectral para os açudes ARG (Figura 2.4) e EPB (Figura 2.5), podendo ser verificada influência maior da turbidez da água (valores máximos negativos) em 2004 e 2008. Este fato está associado a questões intrínsecas ao uso do solo na bacia hidrográfica e a intensidade de chuvas, mas também ao tamanho do açude EPB, que, por ser menor, pressupõe maior mistura das águas com o aumento da vazão provocado pelas chuvas bem como menor tempo de residência da água. Ademais, diferentemente do ARG, este reservatório está localizado no alto curso da bacia do Rio Paraíba, drenando uma área de $12.400 \mathrm{~km}^{2}$, enquanto o ARG encontrase no baixo curso do Rio Piranhas/Açu e drena uma área três vezes maior, equivalente a 37 mil $\mathrm{km}^{2}$ (ANA, 2015b). 


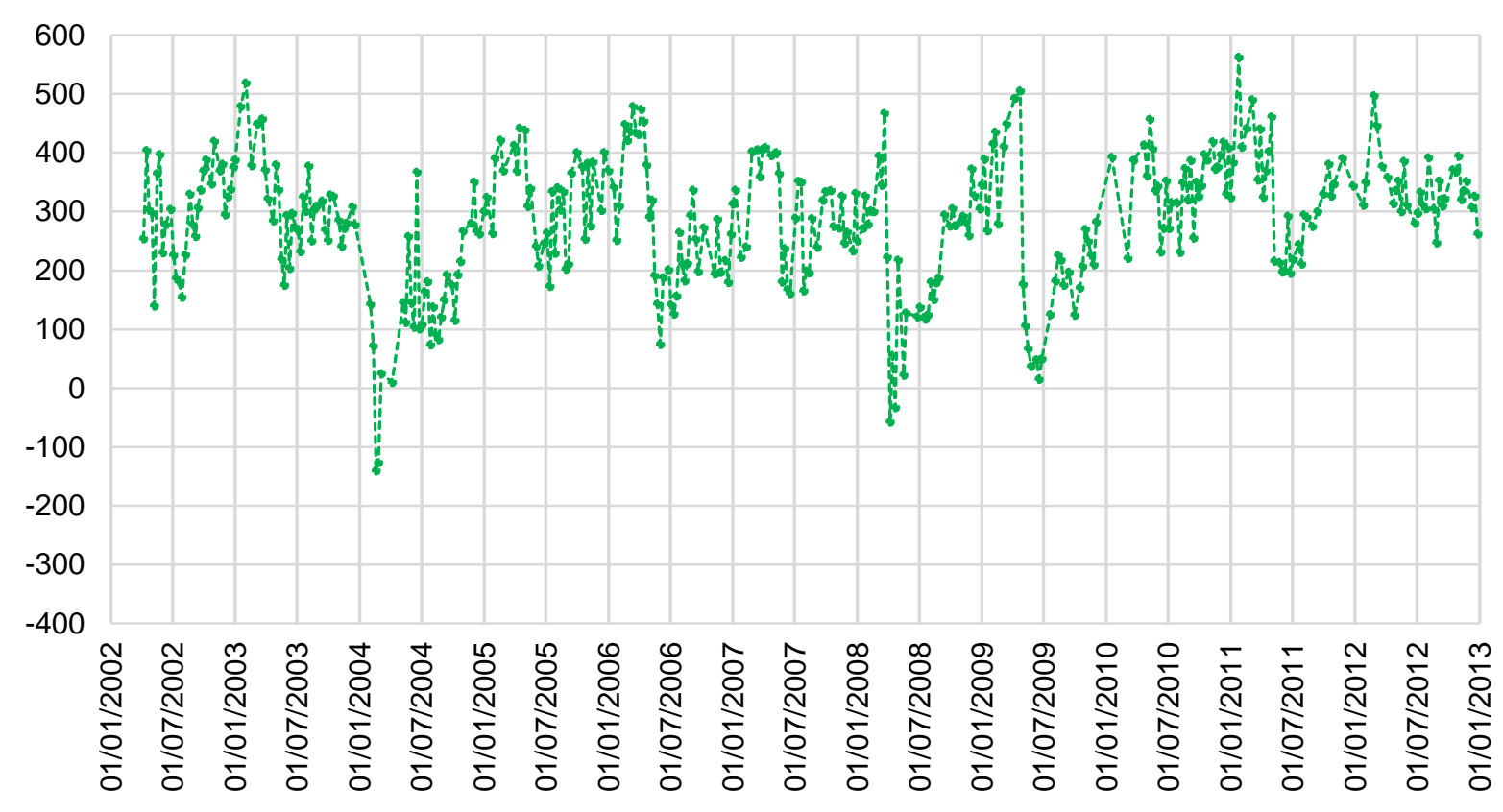

A

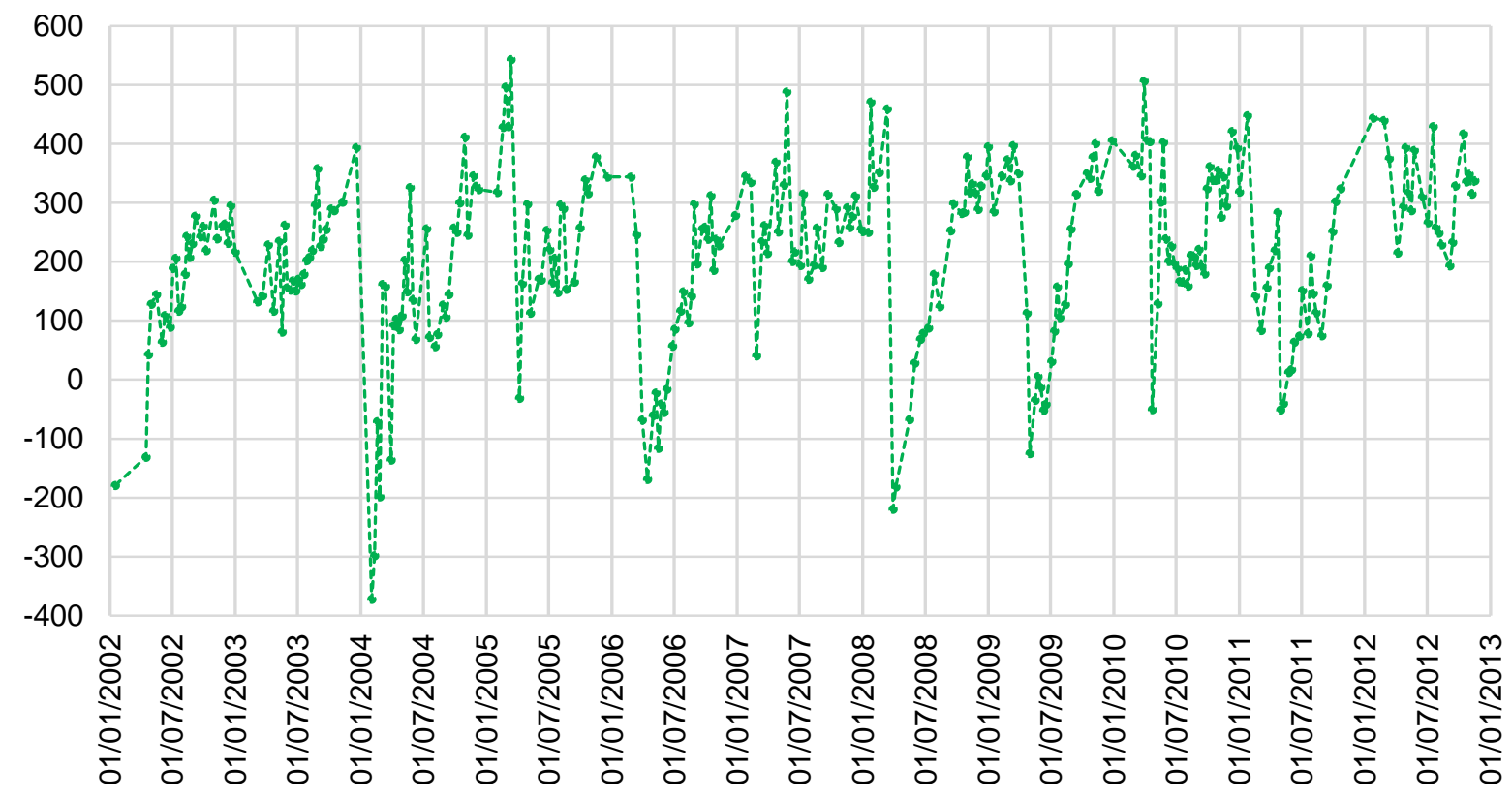

B

Figura 2.4: Índice espectral do açude ARG jusante (A) e montante (B) (2002-2012). Nota: Valores multiplicados por $10^{3}$. Somente dados de nível de qualidade 1.

Fonte: Elaborado pelo autor. 


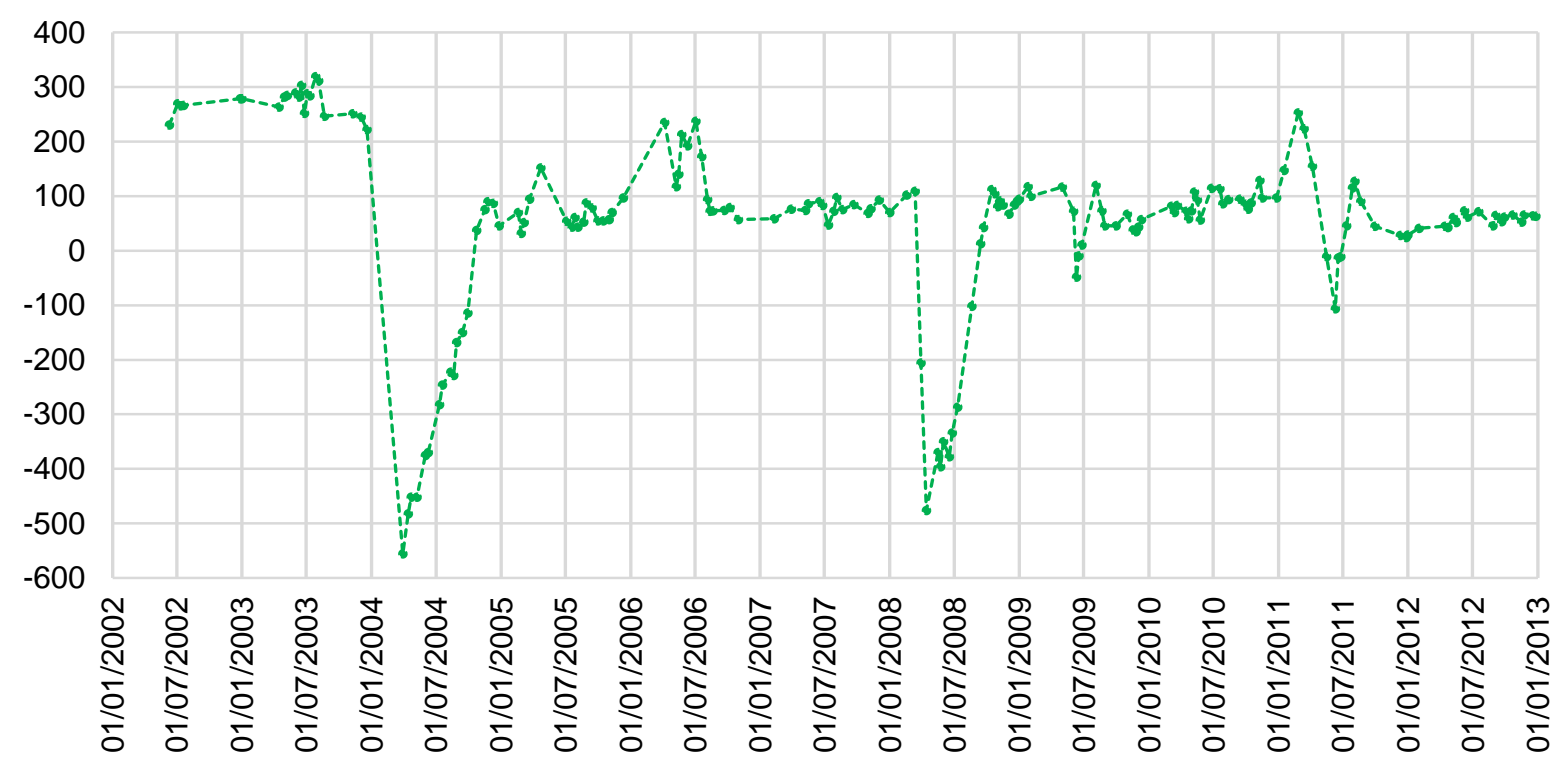

Figura 2.5: Índice espectral do açude EPB (2002-2012).

Nota: Valores multiplicados por $10^{3}$. Dados de nível de qualidade 1 e 2.

Fonte: Elaborado pelo autor.

A análise das imagens MODIS permitiu observar que a obtenção dos dados da reflectância dos reservatórios é dificultada pela baixa resolução espacial. Observou-se uma relação diretamente proporcional entre o tamanho do reservatório (e consequentemente, da máscara extraída, o que depende também da forma do reservatório, dada pela relação entre comprimento e largura) (Figura 2.6) e a quantidade de imagens consideradas como de boa qualidade pela rotina de processamento.

A partir da máscara no açude ARG (jusante), 72\% das imagens foram classificadas como de nível 1, ao passo que 59\% no ARG (montante), 32\% no EPB e apenas 15\% no MDG. A observação inversa também procede, sendo que os dados de qualidade ruim (nível 3) corresponderam a 55\% para o MDG, 29\% do EPB, 20\% do ARG (montante) e apenas 9\% do açude ARG (jusante) (Tabela 2.2). A ausência de dados (nível 0) afetou com maior intensidade o açude EPB, não havendo imagens de boa qualidade tanto do Terra, cuja órbita cruza o Equador aproximadamente $10 \mathrm{~h} 30 \mathrm{~min}$, como do Aqua, com passagem às $13 \mathrm{~h} 30 \mathrm{~min}$ aproximadamente, em $36 \%$ do tempo. 

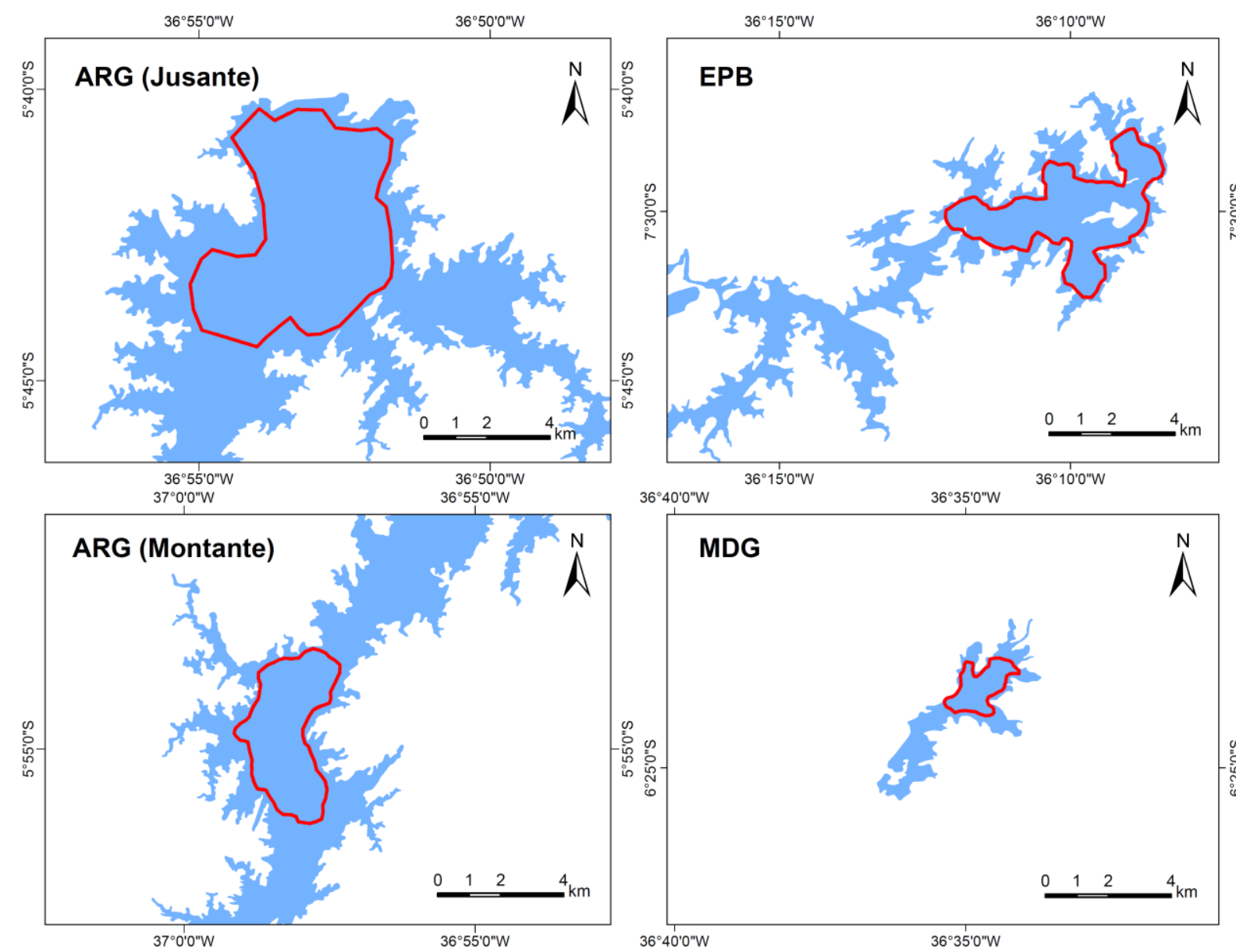

Figura 2.6: Máscara definida para os reservatórios de estudo.

Fonte: Elaborado pelo autor.

Tabela 2.2: Classificação de qualidade das imagens MODIS processadas pelo MOD3R.

\begin{tabular}{|c|c|c|c|c|c|c|c|c|c|c|c|c|c|c|c|c|c|}
\hline & \multicolumn{4}{|c|}{ ARG (Jusante) } & \multicolumn{4}{|c|}{ ARG (Montante) } & \multicolumn{4}{|c|}{ EPB } & \multicolumn{4}{|c|}{ MDG } & \\
\hline & $\mathbf{0}$ & 1 & 2 & 3 & $\mathbf{0}$ & 1 & 2 & 3 & 0 & 1 & 2 & 3 & 0 & 1 & 2 & 3 & \\
\hline 2002 & 5 & 30 & 8 & 2 & 5 & 26 & 5 & 9 & 23 & 5 & - & 17 & 18 & - & - & 27 & 45 \\
\hline 2003 & 1 & 36 & 7 & 2 & 5 & 27 & 3 & 11 & 13 & 14 & 2 & 17 & 22 & - & - & 24 & 46 \\
\hline 2004 & 2 & 32 & 9 & 3 & 4 & 31 & 7 & 4 & 15 & 16 & 2 & 13 & 13 & 11 & 1 & 21 & 46 \\
\hline 2005 & 6 & 33 & 5 & 2 & 7 & 25 & 4 & 10 & 15 & 16 & 1 & 14 & 13 & 5 & - & 28 & 46 \\
\hline 2006 & - & 38 & 7 & 1 & 3 & 26 & 5 & 12 & 18 & 10 & 3 & 15 & 17 & 7 & - & 22 & 46 \\
\hline 2007 & - & 34 & 4 & 8 & 3 & 26 & 5 & 12 & 18 & 13 & 1 & 14 & 7 & 2 & - & 37 & 46 \\
\hline 2008 & 1 & 35 & 5 & 5 & 4 & 26 & 5 & 11 & 15 & 22 & - & 9 & 14 & 11 & - & 21 & 46 \\
\hline 2009 & 3 & 31 & 3 & 9 & 6 & 28 & 5 & 7 & 16 & 17 & - & 13 & 16 & 15 & - & 15 & 46 \\
\hline 2010 & - & 33 & 10 & 3 & 4 & 35 & 1 & 6 & 14 & 18 & 4 & 10 & 11 & 9 & - & 26 & 46 \\
\hline 2011 & 1 & 31 & 11 & 3 & 4 & 24 & 11 & 7 & 19 & 13 & 2 & 12 & 13 & 9 & - & 24 & 46 \\
\hline 2012 & 2 & 32 & 7 & 5 & 3 & 23 & 6 & 14 & 15 & 17 & 1 & 13 & 5 & 9 & - & 32 & 46 \\
\hline Total & 21 & 365 & 76 & 43 & 48 & 297 & 57 & 103 & 181 & 161 & 16 & 147 & 149 & 78 & 1 & 277 & $\overline{505}$ \\
\hline
\end{tabular}

O reduzido número de imagens classificadas como de qualidade 1 ou 2 para o açude MDG, correspondente a apenas $16 \%$, impediu uma visualização adequada da série temporal de 
estimação da reflectância da água desse reservatório. Os resultados obtidos destacam a limitação do tamanho do espelho d'água para o emprego da metodologia. Consequentemente, há vários períodos em que nenhum ou quase nenhum pixel da imagem é selecionado, gerando baixa qualidade dos dados, que acabam sendo descartados.

O açude MDG apresenta pequena dimensão para a utilização das imagens MODIS, de baixa resolução espacial. Ademais, diferentemente do ARG e EPG, a borda deste açude é repleta de rochas graníticas da Serras de Acauã, da Lagoa, do Minador e do Pai Pedro (NASCIMENTO; FERREIRA, 2012), que ocasionam maior mistura espectral (Figura 2.2C). Os períodos de baixo volume do reservatório (vide Figura 2.8C) também dificultam o emprego da metodologia, pois ocasionam redução da superfície coberta pelo espelho d'água. Nessa condição, a máscara utilizada passa a não ser representativa. No entanto, ela não pode ser muito pequena, pois se retorna à mesma limitação da resolução espacial das imagens MODIS. O impacto do volume de água é maior nos anos de 2002 e 2003 nos açudes MDG e EPB (Tabela 2.2), quando os reservatórios apresentavam os níveis mais baixos da série histórica.

\subsubsection{Precipitação}

A análise de dados pluviométricos registrados por três estações próximas ao açude ARG, uma a montante do reservatório, na cidade de Jucurutu, outra na porção central do mesmo, em São Rafael, e uma terceira a jusante da barragem, em Açu (Figura 2.7A), permitiu estabelecer uma relação direta com os índices espectrais, notadamente em relação aos anos chuvosos de 2004, 2006 e 2008, com destaque para os índices pluviométricos registrados na estação de Jucurutu, entrada do reservatório. A relação tende a ser inversa, ou seja, o aumento na precipitação leva a redução nos valores do índice espectral. Em 2004 pode ser observada que chuvas intensas ocorreram sobre toda a área. No caso do açude EPB, as estações pluviométricas localizadas a montante do reservatório, na cidade de Cabaceiras, e a jusante da barragem, em Boqueirão, registraram as fortes chuvas ocorridas em 2004 e 2008 na região (Figura 2.7B). Uma análise detalhada do comportamento das chuvas em toda a área das bacias hidrográficas foge do escopo desse estudo, podendo vir a ser realizada em estudos futuros. 


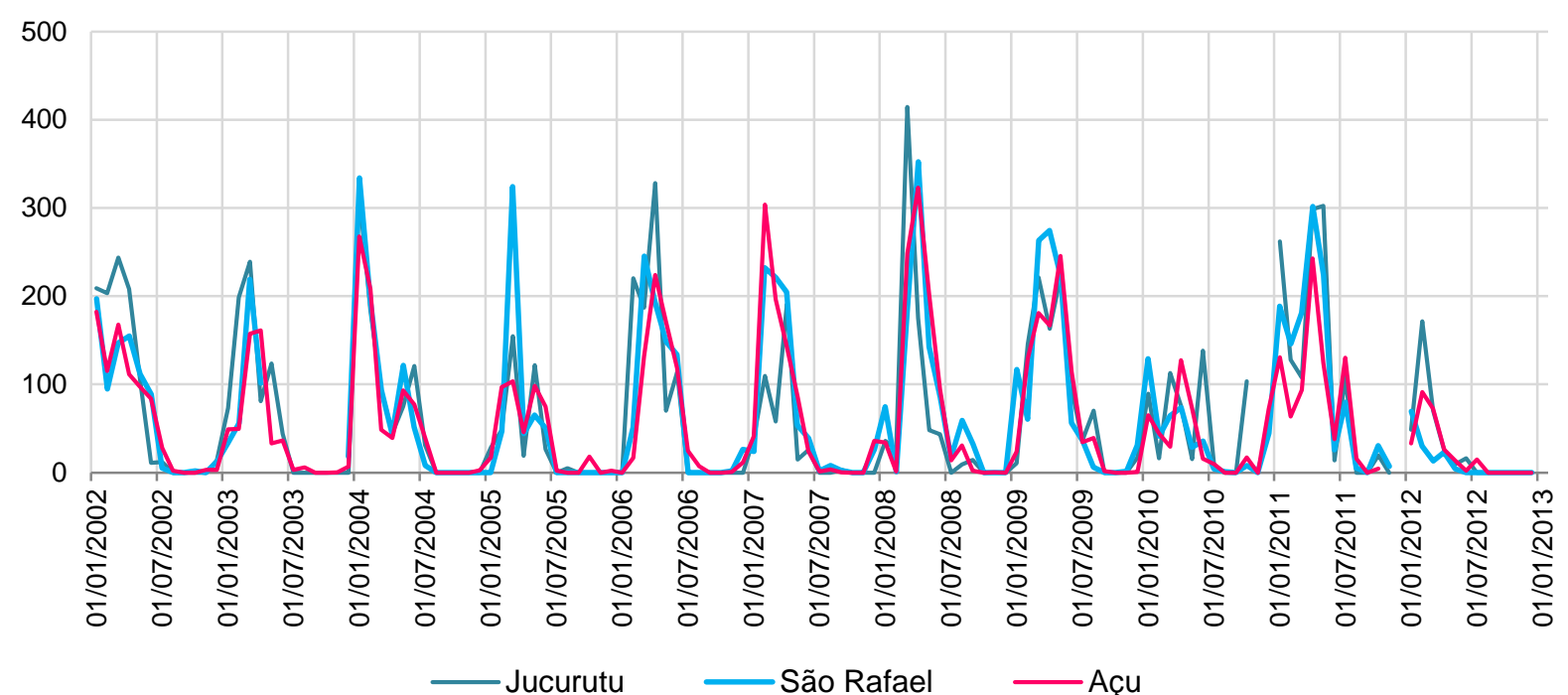

A

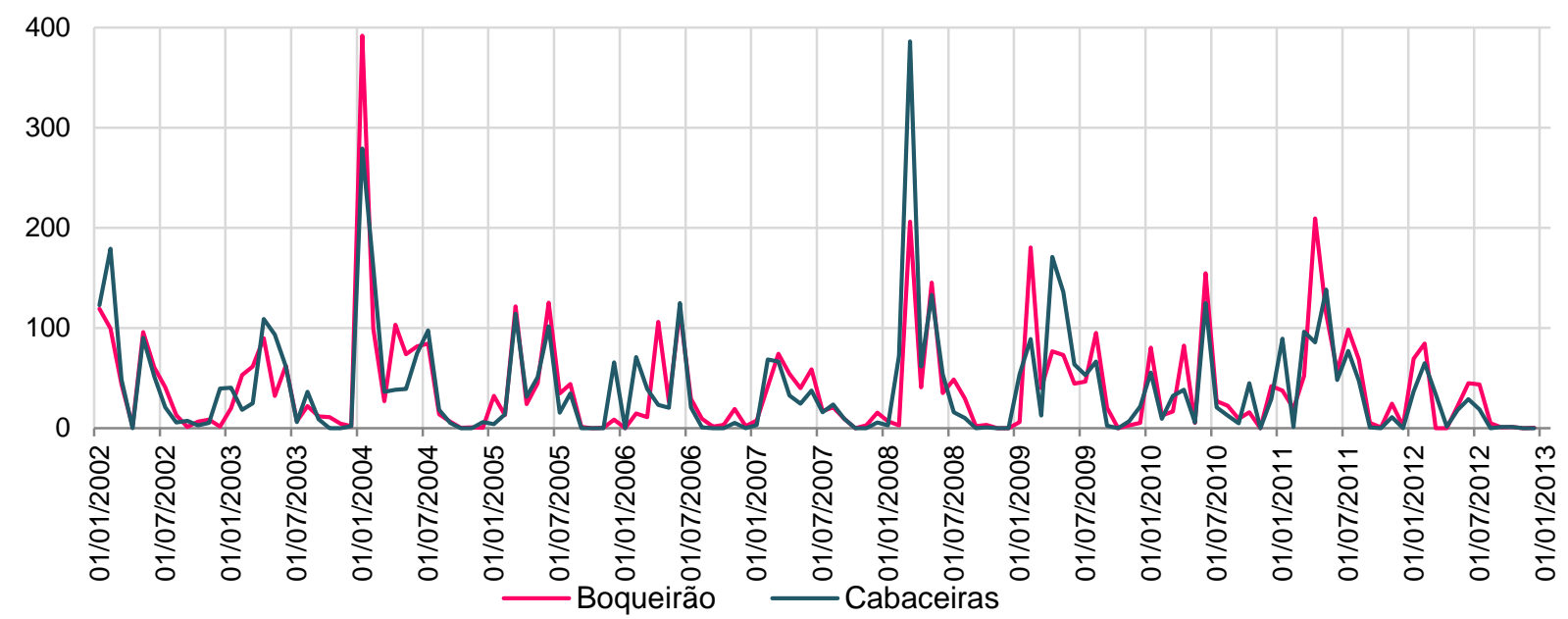

B

Figura 2.7: Precipitação mensal $(\mathrm{mm})$ registrada em estações próximas aos açudes ARG (A) e EPB (B) (2002-2012).

Fonte: Elaborado pelo autor a partir de dados da EMPARN e AESA (dados não publicados).

\subsubsection{Volume de Água}

Observa-se nitidamente uma relação inversamente proporcional entre os valores do índice espectral estimado pelo $M O D 3 R$ (Figuras 2.4 e 2.5) e a evolução do volume de água dos reservatórios (Figura 2.8 A e B) ao longo da série temporal de estudo, havendo redução nos valores do índice em períodos de aumento do volume de água armazenado (aporte de água para o reservatório). 


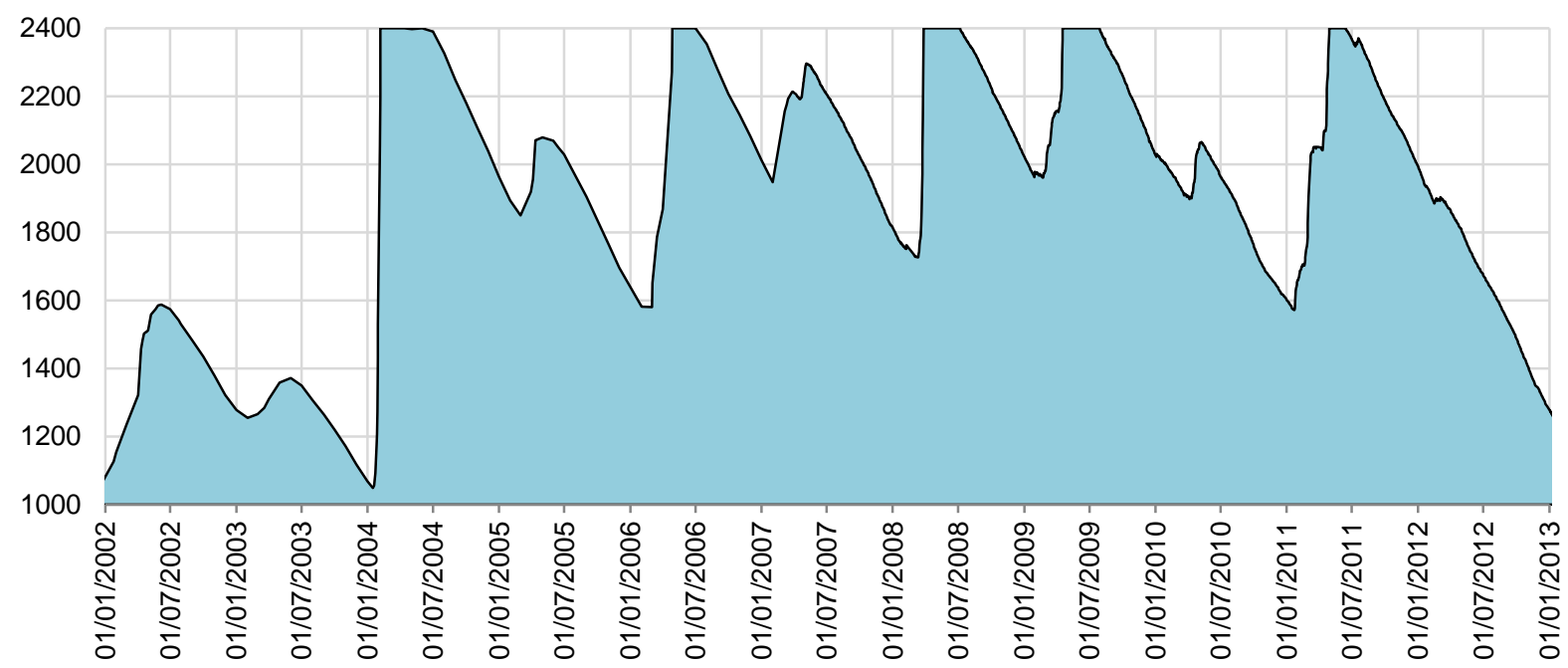

A

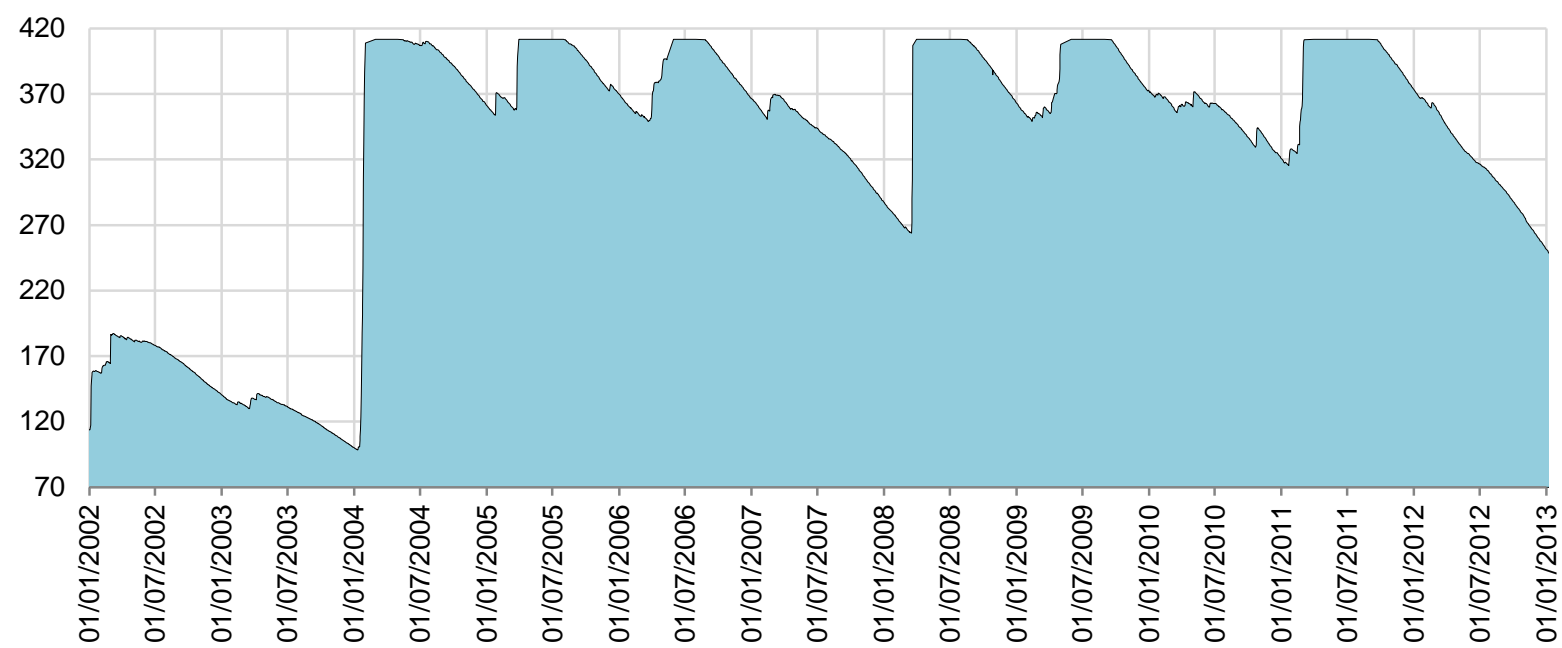

B

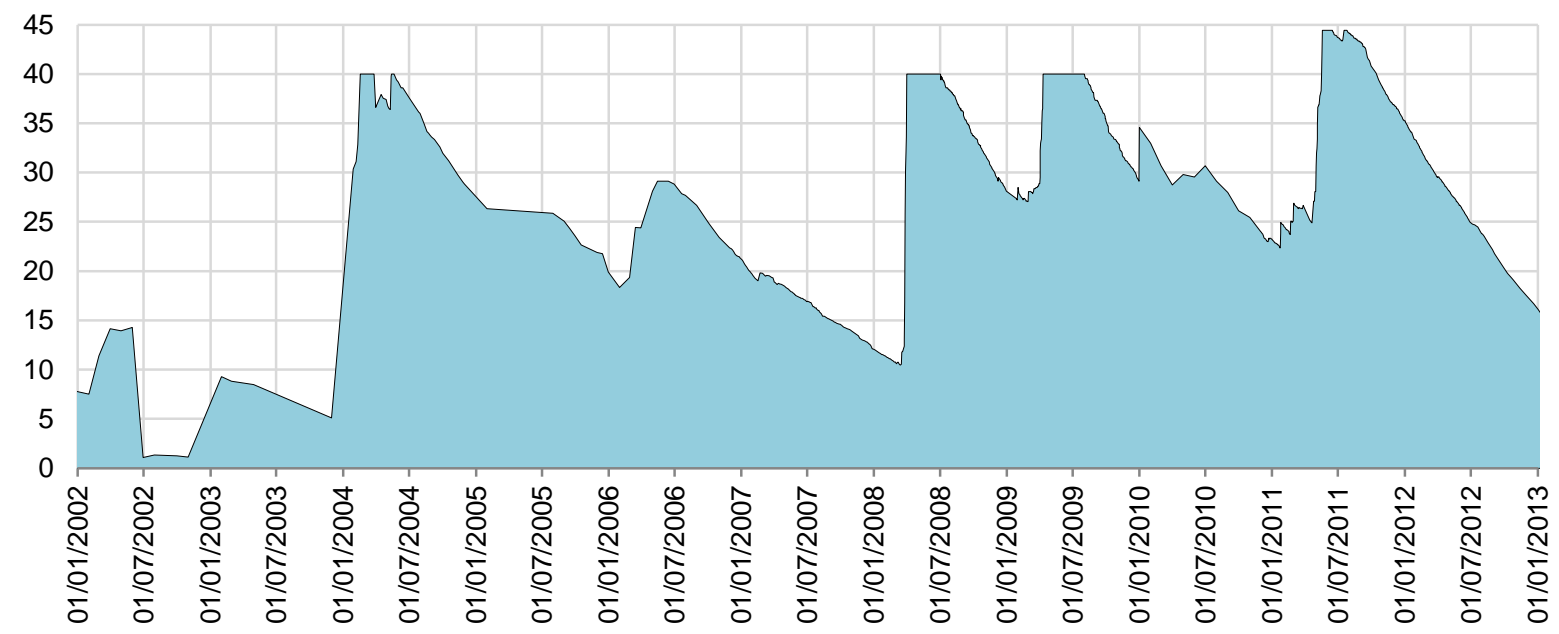

\section{C}

Figura 2.8: Série histórica volumétrica $\left(\mathrm{hm}^{3}\right)$ dos açudes ARG (A), EPB (B) e MDG (C) (20022012).

Nota: A capacidade máxima dos reservatórios é de $2.400 \mathrm{hm}^{3}$ (A), 411,69 hm³ (B) e 44,42 hm³ (após 2010) (C). Fonte: Elaborado pelo autor a partir de dados do DNOCS organizados pela ANA. 


\subsubsection{Doença Diarreica Aguda}

A Figura 2.9A apresenta a evolução do total de casos de DDA registrados por semana epidemiológica nos 22 municípios abastecidos pelo açude ARG. A diminuição nos valores do índice espectral (Figura 2.4) foi verificada em períodos de aumento no registro de casos de DDA, como em 2004, 2006, 2008 e 2009. Nos anos em que houve pequena variação no índice, como em 2005, 2007 e 2010 não foram observados picos tão elevados de incidência da DDA.

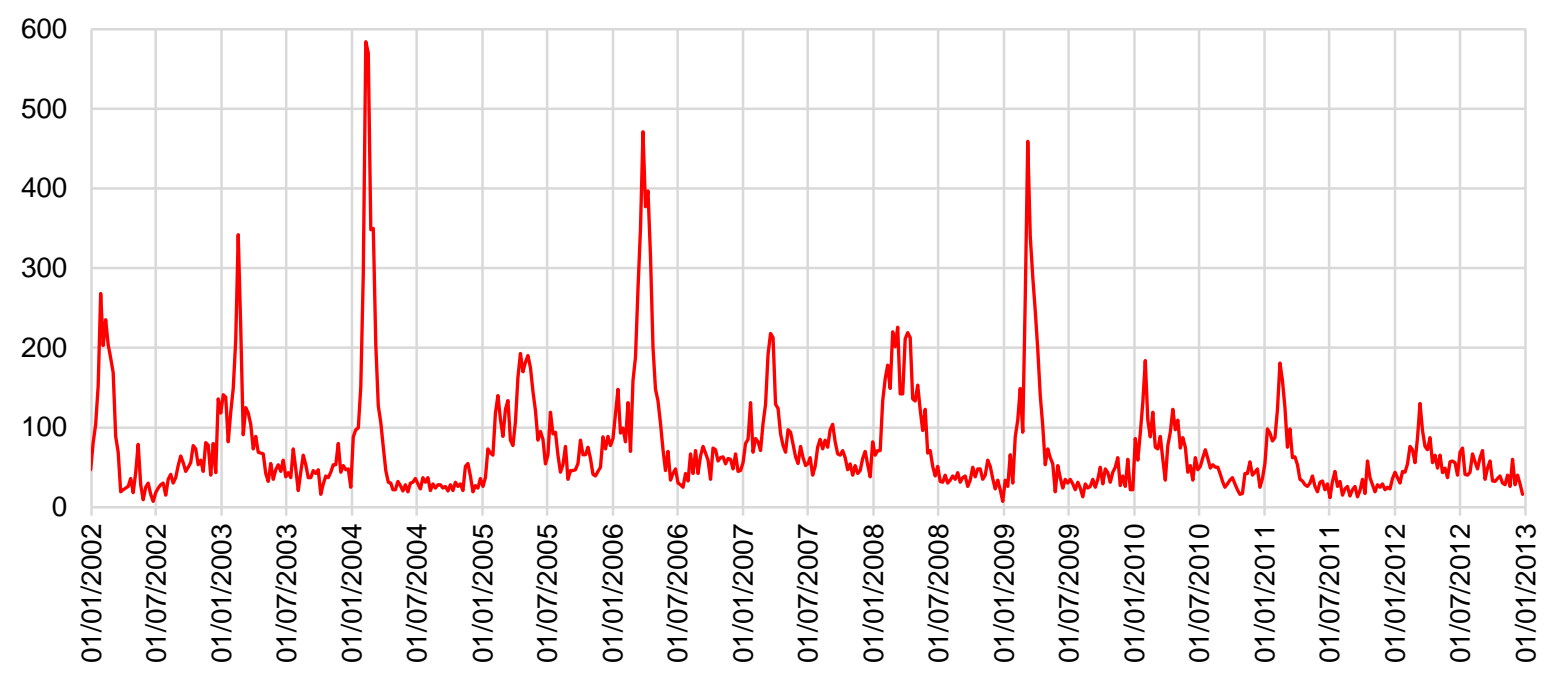

A

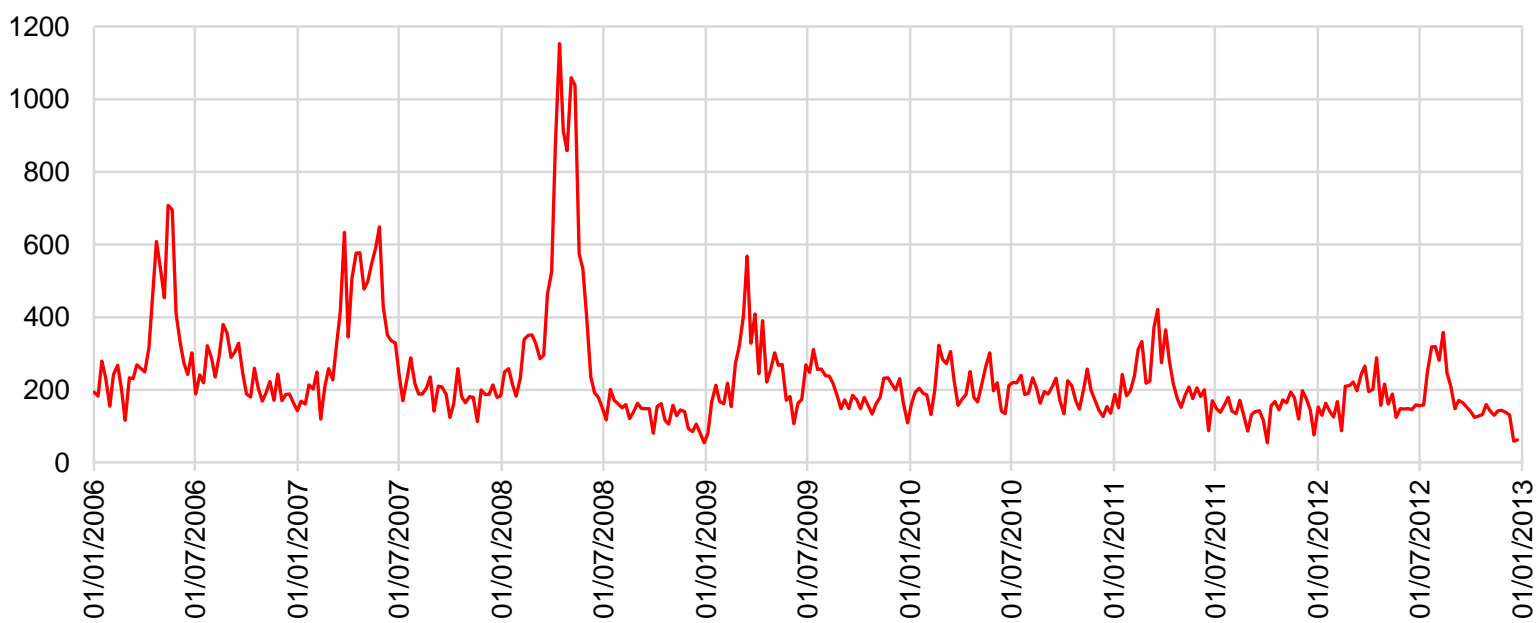

B

Figura 2.9: Casos de DDA nos 22 municípios abastecidos pelo açude ARG (2002-2012) (A) e 17 municípios abastecidos pelo açude EPB (2006-2012) (B).

Nota: O registro ostensivo e sistemático da DDA nos municípios paraibanos começou em 2006.

Fonte: Elaborado pelo autor a partir de dados da SESAP e SES (dados não publicados). 
Análise semelhante pode ser efetuada observando-se a evolução do total de casos de DDA por semana epidemiológica nos 17 municípios paraibanos abastecidos pelo açude EPB, notadamente no ano de 2008, embora a série de dados disponíveis restrinja-se ao período entre 2006 e 2012 (Figura 2.9B) e a quantidade de imagens MODIS de boa qualidade seja menor.

As maiores ocorrências de DDA na área abastecida pelo açude ARG foram observadas no período chuvoso, com destaque para os anos de 2004, 2006 e 2009, anos esses em que foram registradas chuvas intensas, tendo sido notificados cerca de quinhentos casos de DDA em uma única semana epidemiológica em cada ano citado (Figura 2.9A). Por essa razão, observou-se que não é o período do aumento das concentrações de Chla na água que está associado ao período de maior ocorrência de DDA, mas, sim, o período de maior concentração de sedimentos em suspensão na água, associado à lavagem da bacia hidrográfica no período chuvoso que, por sua vez, contribui para ocasionar a queda da participação da Chla na resposta espectral da água.

Os valores de DDA aumentam no período de chuvas e, em geral, logo após as chuvas (Figura 2.7). Em decorrência disso os dados resultantes do processamento das imagens $M O D 3 R$ foram utilizados também para avaliar a presença da turbidez da água. O comportamento é inverso, ou seja, a reflectância da água pura tende a ser nula e, quando há alguma resposta espectral, ela tende a ser resultado da contribuição das frações de vegetação ou de solo presentes na água. Por essa razão, o índice espectral apresentado na Equação 2.1 foi invertido para a subtração da reflectância estimada na banda verde em relação à banda vermelha.

A análise da relação entre os índices espectrais das imagens MODIS e a ocorrência de DDA na população abastecida foi efetuada para o açude ARG no período de 2002 a 2012. Este período compreendeu 576 semanas epidemiológicas. Para a mesma série houve 437 imagens MODIS classificadas como de qualidade 1 ou 2 para a área do açude ARG à jusante e 352 para a área à montante, perfazendo 76 e $61 \%$ de observações, respectivamente, em relação ao quantitativo de observações de DDA. Os dados de qualidade 2, considerada duvidosa, foram incluídos na análise para aumentar a quantidade de observações. No entanto, um procedimento prévio de consistência foi empregado sobre os dados de nível 2, visando detectar outliers de ruído. O procedimento suprimiu valores com diferença de mais de 200 pontos entre os índices de imagens consecutivas (data anterior e posterior), os quais ocorreram em 4 casos para o açude ARG jusante e 2 casos na área a montante.

Casos de DDA começaram a ser registrados por semana epidemiológica a partir de 2006 nos municípios abastecidos pelo açude EPB havendo, portanto, disponibilidade de dados para 
365 observações até 2012. No entanto, nesse mesmo período, apenas 119 imagens MODIS foram classificadas como de qualidade 1 ou 2, o que representa $33 \%$ de observações em relação aos dados de DDA. Por essa razão a análise restringiu-se ao açude ARG. No entanto, o impacto das chuvas de 2008 (Figura 2.7B) sobre a resposta espectral do açude EPB (Figura 2.5) e sobre os casos de DDA (Figura 2.9B) foi notório, não tendo sido verificado nos demais anos.

A Figura 2.10 apresenta a evolução das séries temporais do índice espectral extraído das imagens MODIS do açude ARG e da ocorrência da DDA na população abastecida por esse açude* . Observa-se que as águas dos reservatórios demandam mais tempo para estabilização de sua resposta espectral, ou seja, o aumento dos valores do índice espectral ocorre subitamente, provocado pela entrada de material inorgânico em suspensão e outros componentes da água em virtude da maior vazão de água introduzida pelas chuvas e consequente aumento no volume de água armazenado. Este fenômeno geralmente ocorre nos primeiros meses de cada ano e os valores dos índices reduzem paulatinamente ao longo do segundo semestre. Comportamento sazonal diferenciado é apresentado pelas séries de DDA que, também apresentam um pico nos primeiros meses do ano, com um crescimento muito rápido do número dos casos, mas, diferentemente da resposta espectral da água, logo são reduzidos, permanecendo inferiores a cem casos durante o segundo semestre de todos os anos da série. Isto permite concluir que o impacto é intenso e marcante sobre a ocorrência da DDA, no entanto o retorno à condição de estabilidade de ocorrência da doença ocorre rapidamente.

Outro fator que pode ser observado, apesar das diferenças existentes entre o número de observações disponíveis, diz respeito à rugosidade das séries temporais dos índices espectrais, que é maior na área do açude ARG a jusante (Figura 2.10A). Isto pode derivar de condições da superfície da água que afetam os registros detectados pelo sensor remoto como a influência do vento. $\mathrm{O}$ vento tende a exercer maior influência sobre águas mais abertas como as da área delimitada na porção mais a jusante do açude ARG.

\footnotetext{
* Os dados não foram apresentados segundo uma nuvem de pontos, pois o interesse foi observar o comportamento dos fenômenos em cada ano da série temporal, bem como a amplitude dos valores apresentados em cada série.
} 


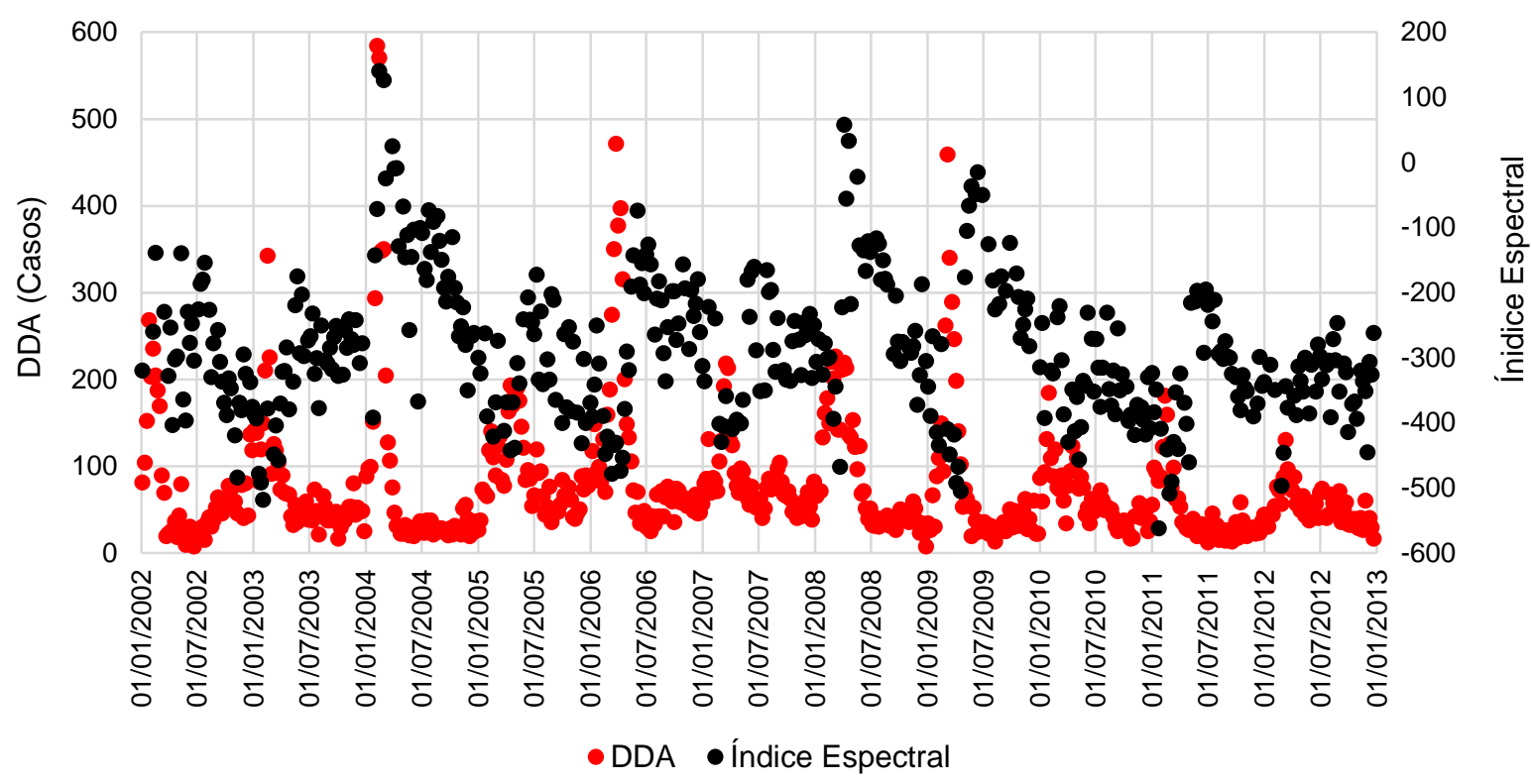

A

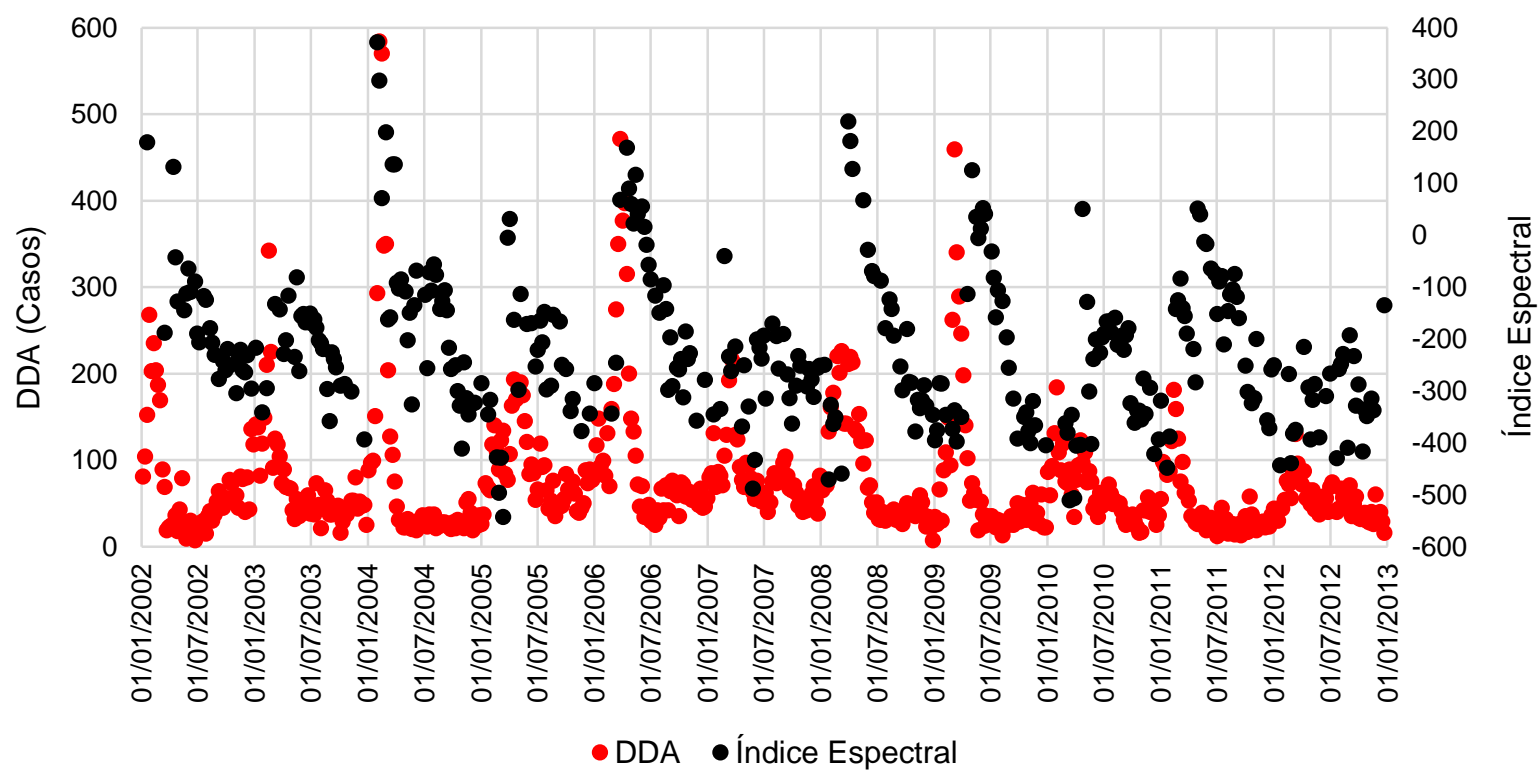

B

Figura 2.10: Séries temporais de DDA na área abastecida pelo açude ARG e índices espectrais das imagens MODIS para o açude ARG jusante (A) e montante (B) (2002-2012).

Fonte: Elaborado pelo autor a partir de dados MODIS e da SESAP (dados não publicados).

A amplitude das escalas de valores do índice espectral entre as áreas do açude ARG a jusante e a montante também permitem inferir sobre características da qualidade das águas, associadas ao fluxo de entrada, que tendem a ser mais turvas a montante e mais eutrofizadas a jusante. Um total de $51 \%$ das observações da área a jusante apresentou valores do índice espectral inferiores a -300 enquanto na área a montante o percentual foi de apenas $30 \%$. Uma maior permanência no tempo de valores mais baixos do índice é representativa de águas com 
uma maior resposta espectral da banda do verde, enquanto que o inverso é válido para a mesma observação em relação a banda do vermelho. Tal fenômeno já foi atestado pelo estudo de Martinez et al. (2011), que encontrou uma relação entre o nível dos reservatórios estudados no semiárido e os índices de eutrofização, definidos a partir de uma álgebra de bandas espectrais e da correlação entre os dados de satélite e medidas da concentração de Chla efetuadas em campo. A maior concentração de nutrientes causada por florações de cianobactérias foi verificada no açude ARG, comparada à dos açudes Banabuiú, Castanhão e Orós (CE), e a permanência no estado eutrófico ou hipereutrófico em mais de 84\% do tempo de 2000 a 2009.

Os índices do açude ARG também podem ser comparados ao açude EPB, onde grande parte das observações correspondeu a registros próximos a 100 (Figura 2.5), ou -100, caso o índice também fosse invertido como na Figura 2.10. Essa associação torna clara a influência da precipitação na bacia hidrográfica para a alteração da composição da água do açude e, consequentemente, de sua resposta espectral nas imagens de satélite, o que pode ser facilmente observado a partir da série temporal do volume de água dos reservatórios (Figura 2.8A e B).

\subsection{DISCUSSÃO}

Os reservatórios diferem dos rios e de outros sistemas aquáticos superficiais em vários aspectos, notadamente no tempo de retenção da água e micro-organismos. Excesso de nutrientes (nitrogênio e fósforo), temperatura, volume de água armazenada, área do espelho d'água e profundidade dos reservatórios afetam sua capacidade de diluição dos poluentes e resiliência (WLVARC, 2007; QUEVEDO; PAGANINI, 2011). O desafio que se impõe é o melhor aproveitamento e a melhoria da qualidade da água armazenada, com a introdução de rotinas de operação mais racionais, melhoria técnica dos processos produtivos dos usuários, principalmente irrigantes e concessionárias de abastecimento, e emprego de práticas sustentáveis de uso da terra e destinação de efluentes (SALATI et al., 2006).

O monitoramento da qualidade da água requer a disponibilidade de dados com alta resolução temporal. Uma maior resolução radiométrica aumenta a capacidade de detecção de mudanças sutis na reflectância, o que é fundamental tendo em vista a pouca radiação eletromagnética refletida pelos corpos d'água. Entretanto, a baixa resolução espacial dificulta o estudo devido à mistura da resposta espectral de diferentes alvos em um mesmo pixel. Silva 
(2004) comparou o desempenho de imagens MODIS em relação às imagens do sensor Thematic Mapper (TM)/Landsat 5 na análise do comportamento espaço-temporal de comunidades de macrófitas em lagos da planície amazônica e observou que as imagens MODIS tiveram bom desempenho na estimativa da área ocupada por macrófitas, porém, somente em escala regional. Por essa razão, as estratégias de monitoramento da qualidade da água a partir de sensoriamento remoto ainda não se aplicam a reservatórios de pequena dimensão, a exemplo do açude MDG, estando sua limitação associada à baixa resolução espacial dos sistemas sensores orbitais de alta resolução temporal em operação na atualidade.

A água acumulada nos reservatórios é submetida à intensa evaporação, o que, juntamente com as escassas precipitações e a alta insolação, concentra os sais e os compostos de fósforo e nitrogênio, acelerando a eutrofização. Investir na coleta e tratamento de esgoto e na diminuição da entrada de nutrientes nos corpos d'água é a melhor saída para a melhoria da qualidade da água armazenada em reservatórios, pois segundo Sperling e Chernicharo (2000), as tecnologias de tratamento de esgotos empregadas no Brasil são eficientes somente no que diz respeito à demanda bioquímica de oxigênio, demanda química de oxigênio e sólidos em suspensão, não produzindo um efluente compatível com os padrões de qualidade exigidos pela legislação ambiental no que se refere à concentração de amônia, coliformes fecais, nitrogênio e, principalmente, fósforo.

Alguns estudos efetuaram coleta de dados in loco para analisar a dinâmica temporal das concentrações de Chla nos açudes. Martinez et al. (2011) apontaram uma dinâmica temporal de aumento nas concentrações de Chla no açude ARG nos períodos de vazante e redução nos de enchente. Guimarães et al. (2005) observaram que as concentrações de nutrientes em pontos de coleta amostral no açude EPB foram fortemente influenciadas pelo regime de chuvas na região, apresentando as maiores concentrações nas estações chuvosas. A turbulência ocasionada pelas chuvas e o impacto de sedimentos e nutrientes pode ser apenas temporário, dependendo do estado de eutrofização do reservatório. Os sedimentos decantam e a sua influência na resposta espectral da água diminui. Há estudos que evidenciam diminuição da biomassa fitoplanctônica em reservatórios no período chuvoso e outros evidenciam aumento ou alterações pouco significativas (GUIMARÃES et al, 2005; NOVO et al., 2007; COSTA et al., 2009). Por essa razão, Ventura (2013) conclui que as alterações provavelmente derivam da combinação de diversos fatores, como o volume e a intensidade das chuvas, dimensões do açude e uso e ocupação do solo na bacia hidrográfica. 
A eutrofização ocorre em inúmeros reservatórios, dificultando a definição de áreas prioritárias de intervenção para a melhoria da qualidade da água de abastecimento no Brasil. No entanto, parece haver maior relação entre a turbidez da água e a DDA que a Chla, sendo este elemento o mais importante a ser considerado quando do estudo das doenças diarreicas. Além dos baixos índices de coleta e tratamento de esgoto, fontes de poluição difusa ou pontual, associadas às características da ocupação humana na região, constituem um grande problema do semiárido. Em muitos casos não há corpo receptor e a disposição do esgoto é efetuada no leito seco dos cursos d'água, concentrando a contaminação por coliformes fecais. Cursos d'água com regime intermitente, como é o caso da área de estudo, impedem a diluição dos efluentes, e as primeiras chuvas de cada ano efetuam uma lavagem de todo o solo carreando os contaminantes através de seus leitos. Desse modo, a precipitação corresponde a um elemento de impacto importante para a explicação da dinâmica sazonal de ocorrência da DDA na região.

Destaca-se que um dos sistemas de abastecimento que extrai água do açude ARG, o da Serra de Santana, que abastece os municípios de Bodó, Florânia, Lagoa Nova, São Vicente e Tenente Laurentino Cruz, cujo ponto de captação localiza-se na área definida como montante do reservatório, efetua apenas filtração direta ascendente como forma de tratamento da água. Já os sistemas isolados que atendem os municípios de São Rafael e Itajá, cujas áreas urbanas localizam-se próximo ao reservatório (Figura 2.1) não discriminam o tipo de filtração empregada (ANA, 2011). A filtração direta ascendente é, de forma geral, aplicável para águas que apresentam poucas variações de qualidade, observados parâmetros como cor e turbidez da água bruta, concentração de algas e suas espécies, matéria orgânica e coliformes totais. A presença de algas pode causar sérios transtornos ao sistema, comprometendo a qualidade da água produzida (DI BERNARDO, 2003). O método pode não ser efetivo no sentido de remoção dos sólidos em suspensão quando há alterações bruscas na qualidade da água bruta, tornandose ineficaz na potabilização de águas com contínuos índices elevados de turbidez (TEIXEIRA, 2004), o que pode ocorrer devido à influência das chuvas sobre a qualidade da água do açude ARG aqui discutida (Figura 2.4B).

As bacias do Piranhas/Açu e do Paraíba receberão aporte de água do PISF. Segundo o Relatório de Impacto Ambiental (RIMA) do Projeto (MI, 2004), a oferta constante de água de boa qualidade contribuirá para a redução do número de internações hospitalares na região beneficiada. Com a oferta adicional de água oriunda do Projeto, estima-se que haverá uma redução de aproximadamente 14 mil internações provocadas por doenças de veiculação hídrica 
no ano de 2025, quando o Projeto estaria operando plenamente, na área das bacias hidrográficas receptoras, enquanto as estimativas do RIMA apontam um total de $53 \mathrm{mil}$, no mesmo ano, numa eventual ausência de implantação do Projeto.

O próprio RIMA do PISF admite que, com o enchimento dos reservatórios de abastecimento, suas águas ficarão sujeitas a uma baixa circulação, o que pode ocasionar processos de eutrofização dos mesmos. $\mathrm{O}$ incremento da disponibilidade, transporte e circulação hídrica trazido pelo Programa, sem os devidos cuidados com a qualidade das águas e sem o monitoramento constante dos reservatórios, pode conduzir a uma elevação nos índices de doenças de veiculação hídrica. Para evitar esse problema, o relatório aponta que deverão ser tomados diversos cuidados para evitar a proliferação de doenças e também que, por ter um potencial de riscos à saúde da população, a implantação do PISF demanda medidas cuidadosas por parte do empreendedor e das instâncias públicas de saúde (MI, 2004).

Apesar das ferramentas de sensoriamento remoto contribuírem para os estudos da qualidade da água de reservatórios, há necessidade de um grande volume de dados auxiliares e trabalho de campo para possibilitar o entendimento de toda a dinâmica envolvida. Também é de fundamental importância envolver as condições climáticas nos estudos, notadamente o regime de chuvas local, pois a variável sazonalidade se mostra relevante na compreensão das respostas espectrais dos reservatórios e da ocorrência de doenças diarreicas.

Ademais, cumpre ressaltar que, quanto ao abastecimento de água, os dados demonstram que, embora os municípios sejam abastecidos por água transportada pelas adutoras ou a partir de pontos de captação diretamente dos reservatórios na área de estudo, há municípios em que uma parcela considerável da população não é abastecida pela rede geral, que utiliza a água proveniente dos sistemas adutores. Isto porque as redes gerais abastecem somente as áreas urbanas, havendo ainda grandes deficiências em vários municípios (Figura 2.11A) e, em alguns casos, algumas comunidades rurais. Inclusive há municípios com percentual considerável de domicílios localizados na zona rural que recorrem a outras formas de abastecimento de água (Figura 2.11B). Os dados do Censo Demográfico do Instituto Brasileiro de Geografia e Estatística (IBGE) também demonstraram que em 2010 havia forte presença de carros-pipa ou água da chuva (em geral armazenada em cisternas) como fonte de abastecimento de água. Dessa forma é importante considerar as características espaciais das diferentes fontes de abastecimento de água e a disponibilidade de seus serviços à população ao longo do tempo. 

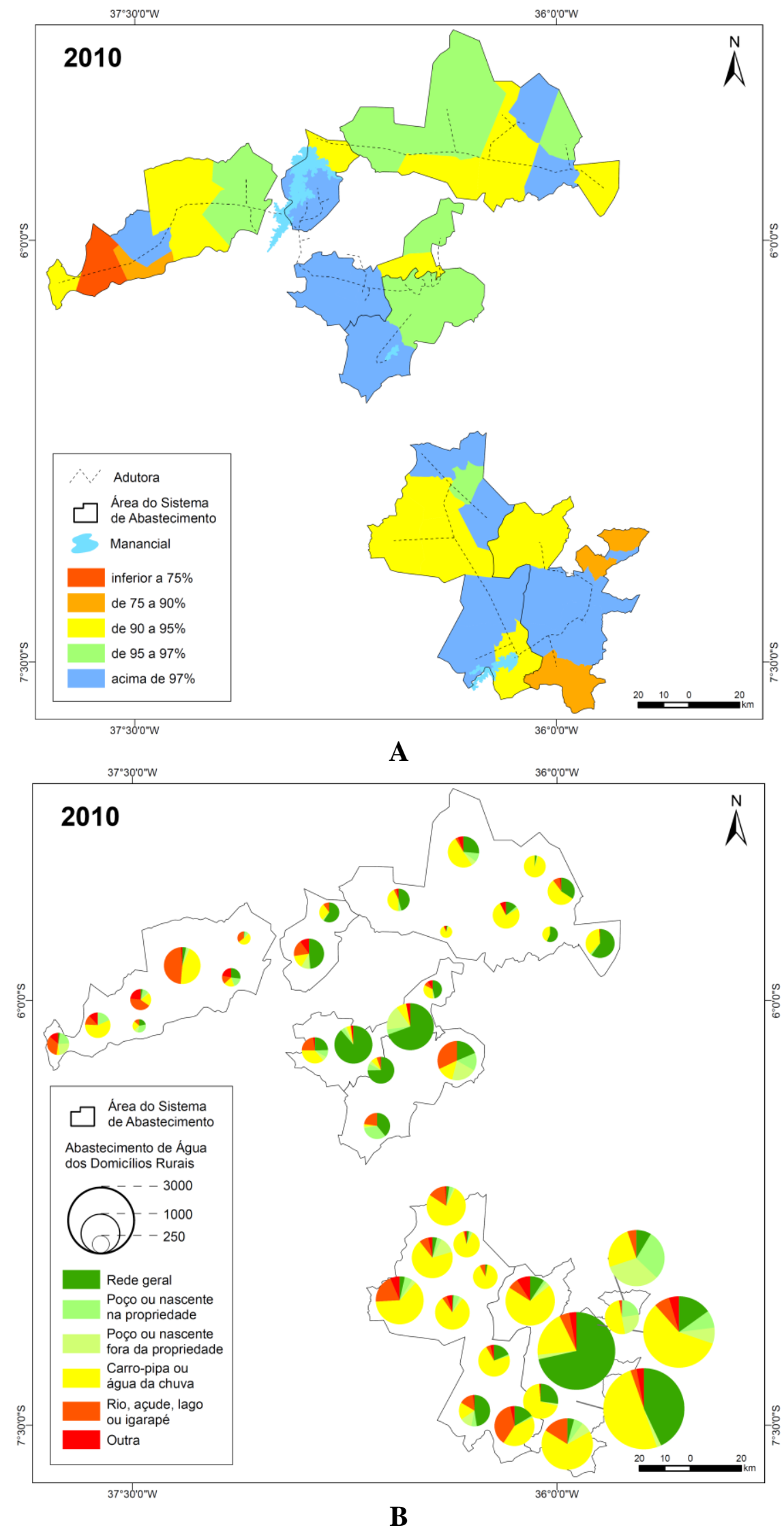

Figura 2.11: Atendimento da população urbana pela rede geral de abastecimento de água (A) e modalidades de atendimento de água dos domicílios rurais (B) (2010).

Fonte: Elaborado pelo autor a partir de dados do IBGE (2010). 


\subsection{CONSIDERAÇÕES FINAIS}

Apesar de não ser calibrado, pois para tanto é imprescindível a realização de pesquisa de campo em período concomitante à coleta de dados pelo sensor remoto, o índice espectral apresentado correspondente à diferença entre a reflectância estimada entre as bandas das faixas espectrais do verde e do vermelho mostrou-se eficiente para a análise da evolução da resposta espectral da água ao longo da série temporal de estudo. A metodologia adotada se mostrou viável para aplicação em reservatórios de grande porte, ao menos assim definidos segundo a classificação de tamanho definida pelo DNOCS, sendo que o tamanho do reservatório constitui uma limitação ao emprego da metodologia de monitoramento, o que é natural dada a resolução espacial das imagens de sensoriamento remoto utilizadas.

Estudos futuros podem vir a efetuar campanhas de campo para calibrar os resultados obtidos com dados de Unidades Nefelométricas de Turbidez (NTU), bem como poderão utilizar dados de qualidade de água do Sistema de Informação de Vigilância da Qualidade da Água para Consumo Humano (SISAGUA) da SVS e da RNQA. Também poderão ser utilizados dados de monitoramento in loco de parâmetros de qualidade da água dos açudes, coletados pelos órgãos ambientais estuduais, a saber o Instituto de Gestão das Águas do Estado do Rio Grande do Norte (IGARN) e a Superintendência de Administração do Meio Ambiente do Estado da Paraíba (SUDEMA). Ventura (2013), por exemplo, utilizou o MOD3R para estimar a concentração de Chla no açude ARG e caracterizar a evolução do estado trófico do reservatório. Seu estudo compreendeu campanhas de campo para a calibração dos resultados e permitiu desenvolver uma equação para a estimação da Chla a partir de séries temporais de dados MODIS. Estudos futuros também poderão analisar em detalhe características particulares das bacias hidrográficas, adotando esta escala espacial para a pesquisa, e dos próprios reservatórios e entorno, considerados os seus usos múltiplos, com destaque para a irrigação e piscicultura.

A análise integrada dos dados de sensoriamento remoto com os dados de saúde permitiu concluir que os períodos de maior indicativo da influência da Chla sobre a resposta espectral da água dos reservatórios não foram associados aos períodos de maior ocorrência da DDA nos municípios de estudo, mas sim os períodos de maior influência do material inorgânico em suspensão, associados aos períodos chuvosos. 
Dessa forma, a hipótese de que uma maior concentração de Chla na água levaria a maior ocorrência de DDA foi refutada. Os resultados obtidos com a pesquisa apontaram para uma maior associação da DDA com a dinâmica climática local, sendo que outras variáveis como o regime das chuvas parecem ter maior influência para explicar os padrões temporais de ocorrência da DDA.

A queda no volume de água dos reservatórios se mostrou um bom indicador para a constatação da situação de seca. Tendo em vista o fato de que o abastecimento da população pela rede geral de água não é universalizado, características particulares das diferentes fontes de abastecimento de água bem como de suas disponibilidades ao longo do tempo emergem como questões de relevância para o entendimento do processo saúde-doença em relação à DDA.

\section{REFERÊNCIAS BIBLIOGRÁFICAS}

AGÊNCIA NACIONAL DE ÁGUAS (ANA). AGÊNCIA NACIONAL DE ENERGIA ELÉTRICA (ANEEL). Resolução Conjunta ANA/ANEEL n. ${ }^{\circ}$ 03, de 10 de agosto de 2010. Brasília: ANA, 2010. Disponível em: http://arquivos.ana.gov.br/resolucoes/2010/3-2010.pdf. Acesso em: 20 abr. 2011.

AGÊNCIA NACIONAL DE ÁGUAS (ANA). Atlas Brasil: Abastecimento Urbano de Água. Brasília: ANA, 2011. Disponível em: http://atlas.ana.gov.br/Atlas/forms/Home.aspx. Acesso em: 02 mar. 2013.

Resolução n. ${ }^{0}$ 903, de 22 de julho de 2013. Brasília: ANA, 2013. Disponível em: http://arquivos.ana.gov.br/resolucoes/2013/903-2013.pdf. Acesso em: 20 abr. 2011.

Conjuntura dos Recursos Hídricos no Brasil: Informe 2014. Brasília: ANA, 2015a. Disponível em: http://conjuntura.ana.gov.br/. Acesso em: 15 maio 2015.

Hidroweb: Sistema de Informações Hidrológicas. Brasília: ANA, 2015 b.

Disponível em: http://hidroweb.ana.gov.br/. Acesso em: 15 mar. 2015.

ALMEIDA, J. C.; VIEIRA, L. L. A.; BARROS, T. T.; COSTA, V. C.; PEDROSA, V, A. Vulnerabilidade ambiental à eutrofização: Reservatório Carangueja. In: IX SIMPÓSIO DE RECURSOS HÍDRICOS DO NORDESTE, Anais, Salvador, 2008. 
ARAÚJO JÚNIOR, R. J. Evolução temporal dos níveis tróficos do Açude Epitácio Pessoa, Semi-Árido Paraibano. 2010. 71p. Dissertação (Mestrado em Ciência e Tecnologia Ambiental) - Universidade Federal de Campina Grande (UFCG), Campina Grande, 2010.

BARBOSA, J. E. L.; ANDRADE, R. S.; LINS, R. P.; DINIZ, C. R. Diagnóstico do estado trófico e aspectos limnológicos de sistemas aquáticos da Bacia Hidrográfica do Rio Taperoá, Trópico semi-árido Brasileiro. Revista de Biologia e Ciências da Terra, Suplemento Especial, n. 1, p. 81-89, 2006.

BOUVY, M.; FALCÃO, D.; MARINHO, M.; PAGANO, M.; MOURA, A. Occurence of Cylindrospermopsis (Cyanobacteria) in 39 Brazilian tropical reservoirs during the 1998 drougth. Aquatic Microbial Ecology. v. 23, p. 13-27, 2000.

CARR, G. M.; NEARY, J. P. Water Quality for Ecosystem and Human Health, 2008. $2^{\mathrm{a}}$ ed. United Nations Environment Programme Global Environment Monitoring System. Disponível em: http://www.gemswater.org/publications/pdfs/water_quality_human_health. pdf. Acesso em: 15 mar. 2015.

CARVALHO, A. P.; MORAES NETO, J. M.; LIMA, V. L. A.; SOUSA, R, F.; SILVA, D. G. K. C. Aspectos qualitativos da água do açude de Bodocongó em Campina Grande - PB. Engenharia Ambiental: pesquisa e tecnologia, v. 5, n. 2, p. 94-109, 2008.

COSTA, I. A. S.; CUNHA, S. R. D. S.; PANOSSO, R.; ARAÚJO, M. F. F.; MELO, J. L. S.; ESKINAZI-SANT'ANNA, E. M. Dinâmica de Cianobactérias em reservatórios eutróficos do semi-árido do Rio Grande do Norte. Oecologia Brasiliensis, v. 13, n. 2, p. 382-401, 2009.

DI BERNARDO, L. (Coord.). Tratamento de água para abastecimento por filtração direta. Rio de Janeiro: PROSAB, ABES, Rima, 2003. 480p.

DEPARTAMENTO NACIONAL DE OBRAS CONTRA AS SECAS (DNOCS). Fichas Técnicas dos Reservatórios. Disponível em: http://www.dnocs.gov.br/php/canais/recursos_ hidricos/index.php. Acesso em: 15 out. 2015.

FIGUEIRÊDO, M. C. B.; TEIXEIRA, A. S.; ARAÚJO, L. F. P.; ROSA, M. F.; PAULINO, W. D.; MOTA, S.; ARAÚJO, J, C. Avaliação da vulnerabilidade ambiental de reservatórios à eutrofização. Revista de Engenharia Sanitária e Ambiental, v. 12, n. 4, p. 399-409, 2007.

FREITAS, F. R. S. Eutrofização do reservatório Cruzeta na bacia representativa do rio Seridó - RN. 2008. 48p. Dissertação (Mestrado em Engenharia Sanitária) - Universidade Federal do Rio Grande do Norte, Natal, 2008.

GUIMARÃES, A. O.; MElO, A. D.; CEBAllos, B. S. O.; GALVÃO, C. O.; RIBEIRO, M. M. R. Aspectos da gestão do açude Epitácio Pessoa (PB) e variação da qualidade de água. In: 
XXIII CONGRESSO BRASILEIRO DE ENGENHARIA SANITÁRIA E AMBIENTAL, Anais, Campo Grande, 2005.

INSTITUT DE RECHERCHE POUR LE DÉVELOPPEMENT (IRD). AGÊNCIA NACIONAL DE ÁGUAS (ANA). Sistema Hidrosat: Documentação Técnica. Brasília: 2013. Disponível em: http://hidrosat.ana.gov.br/DocTecnica.aspx. Acesso em: 15 jul. 2013.

INSTITUTO BRASILEIRO DE GEOGRAFIA E ESTATÍSTICA (IBGE). Censo

Demográfico 2010: Resultados do Universo - Características da População e dos Domicílios. Rio de Janeiro: IBGE, 2010. Disponível em: http://www.sidra.ibge.gov.br/cd/cd2010universo. asp?o=7\&i=P. Acesso em: 15 mar. 2015.

JOCHIMSEM, E. M.; AZEVEDO, S. M. F. O. Liver Failture and Death Following Exposure to Microcystin Toxins at a Hemodialysis Center in Brazil. The New England Journal of Medicine, v. 36, p. 373-378, 1998.

JUSTICE, C. O.; VERMOTE, E.; TOWNSHEND, J. R. G.; DEFRIES, R.; ROY, D. P.; HALL, D. K.; SALOMONSON, V. V.; PRIVETTE, J. L.; RIGGS, G.; STRAHLER, A.; LUCHT, W.; MYNENI, R. B.; KNYAZIKHIN, Y.; RUNNING, S. W.; NEMANI, R. R.; WAN, Z.; HUETE, A. R.; VAN LEEUWEN, W.; WOLFE, R. E.; GIGLIO, L.; MULLER, J. P.; LEWIS, P.; BARNSLEY, M. J. The Moderate Resolution Imaging Spectroradiometer (MODIS): Land Remote Sensing for Global Change Research. IEEE Transactions on Geoscience and Remote Sensing, v. 36, n. 4, p. 1228-1249, 1998.

MARTINEZ, J. M.; GUYOT, J. L., FILIZOLA, N., SONDAG, F. Increase in suspended sediment discharge of the Amazon River assessed by monitoring network and satellite data. Catena, v.79. p. 257-264, 2009.

MARTINEZ, J. M.; VENTURA, D.; VIEIRA, M. R.; ATTAYDE, J. L.; BUBEL, A. P.; COIMBRA, M. R.; OLIVEIRA, E. Satellite-based monitoring of reservoir eutrophication in the Brazil Semi-arid region. In: XV SIMPÓSIO BRASILEIRO DE SENSORIAMENTO REMOTO, Anais, Curitiba, 2011.

MENESES, P. R.; MADEIRA NETTO, J. S. Sensoriamento remoto: reflectância dos alvos naturais. Brasília: UnB/Embrapa Cerrados, 2001. 262p.

MINISTÉRIO DA INTEGRAÇÃO NACIONAL (MI). Projeto de Integração do Rio São Francisco com Bacias Hidrográficas do Nordeste Setentrional: Relatório de Impacto Ambiental. Brasília: MI, 2004. Disponível em: http://www.mi.gov.br/documents/10157/ 3675235/RIMA.pdf/c7f4834d-2ca8-4baf-9bbd-21cacb64ca2f. Acesso em: 02 mar. 2013. 
MOSCA, V. P. Eutrofização do reservatório Engenheiro Armando Ribeiro Gonçalves, no Rio Grande do Norte. 2008. 73p. Dissertação (Mestrado em Bioecologia Aquática) Universidade Federal do Rio Grande do Norte, Natal, 2008.

NASCIMENTO, M. A. L.; FERREIRA, R. V. Geoparque Seridó. In: SCHOBBENHAUS, C.; SILVA, C. R. (orgs.). Geoparques do Brasil: propostas. Rio de Janeiro: CPRM, 2012, p. 361-416.

NOVO, E. M. L. M.; BARBOSA, C.; FREITAS, R. M. Sistemas aquáticos continentais. In: RUDORFF, B. T.; SHIMABUKURO, Y. E.; CEBALLOS, J. C. (orgs.) O sensor MODIS e suas aplicações ambientais no Brasil. São José dos Campos: Parêntese, 2007, p. 265-275.

PEREIRA, M. O. Avaliação qualitativa e quantitativa de cianobactérias no açude Cedro, município de Quixadá - CE, no período de janeiro/2006 a dezembro/2007. In: XII CONGRESSO BRASILEIRO DE FICOLOGIA, Anais, Pirenópolis/GO, 2008.

QUEVEDO, C. M. G; PAGANINI, W. S. Impactos das atividades humanas sobre a dinâmica do fósforo no meio ambiente e seus reflexos na saúde pública. Ciência \& Saúde Coletiva, v. 16, n. 8, p. 3529-3539, 2011.

SALATI, E.; LEMOS, H. M.; SALATI, E. Água e o desenvolvimento sustentável. In: REBOUÇAS, A. C.; BRAGA, B.; TUNDISI, J. G. (orgs.) Águas doces no Brasil: capital ecológico, uso e conservação. $3^{\text {a }}$ ed. São Paulo: Escrituras, 2006, p. 37-62.

SHIMABUKURO, Y. E.; SMITH, J. A. The Least-Squares Mixing Models to Generate Fraction Images Derived From Remote Sensing Multispectral Data. IEEE Transactions on Geoscience and Remote Sensing, v. 29, n.1 p. 16-20, 1991.

SILVA, T. S. F. Imagens EOS-MODIS e Landsat 5 TM no estudo da dinâmica das comunidades de macrófitas na várzea amazônica. 2004. 178p. Dissertação (Mestrado em Sensoriamento Remoto) - Instituto Nacional de Pesquisas Espaciais, São José dos Campos, 2004.

SOUZA, B. I.; SUERTEGARAY, D. M. A. Contribuição ao debate sobre a transposição do Rio São Francisco e as prováveis consequências em relação a desertificação nos Cariris Velhos (PB). Terra Livre, v. 2, n. 25, p. 139-155, 2005.

SPERLING, M.; CHERNICHARO, C. A. L. A comparison between wastewater treatment processes in terms of compliance with effluent quality standards. In: XXVII CONGRESSO INTERAMERICANO DE ENGENHARIA SANITÁRIA E AMBIENTAL, Anais, Porto Alegre, 2000. 
TEIXEIRA, M. G.; COSTA, M. C.; CARVALHO, V. L.; PEREIRA, M. S.; HAGE, E. Gastroenteritis Epidemic in the Area of the Itaparica Dam, Bahia, Brazil. Bulletin of the Pan American Health Organization, v. 27, n. 3, p. 244-253, 1993.

TEIXEIRA, A. R. Aplicabilidade da filtração direta para o tratamento de águas eutrofizadas. 2004. 93p. Dissertação (Mestrado em Saneamento, Meio Ambiente e Recursos Hídricos) - Universidade Federal de Minas Gerais, Belo Horizonte, 2004.

TUNDISI, J. G.; MATSUMURA-TUNDISI, T.; ABE, D. S.; ROCHA, O.; STARLING, F. Limnologia de águas interiores: impactos, conservação e recuperação de ecossistemas aquáticos. In: REBOUÇAS, A. C.; BRAGA, B.; TUNDISI, J. G. (orgs.) Águas doces no Brasil: capital ecológico, uso e conservação. $3^{\text {a }}$ ed. São Paulo: Escrituras, 2006, p. 203-240.

UNITED NATIONS WORLD WATER ASSESSMENT PROGRAMME (UNWWAP). 2009. The World Water Development Report 3: Water in a Changing World. UNESCO: Paris. Disponível em: http://www.unesco.org/water/wwap/wwdr/wwdr3/. Acesso em: 02 mar. 2013.

VENTURA, D. L. T. Uso do Sensoriamento Remoto para Monitoramento da Concentração de Clorofila A em Açudes do Semiárido. 2013. 59p. Dissertação (Mestrado em Ecologia) - Universidade de Brasília, Brasília, 2013.

VILLAR, R. A. E. Monitoramento das dinâmicas espaciais e temporais dos fluxos sedimentares na Bacia Amazônica a partir de imagens de satélite. 2013. 226p. Tese (Doutorado em Geociências Aplicadas) - Universidade de Brasília, Brasília, 2013.

WORLD LAKE VISION ACTION REPORT COMMITTEE (WLVARC). 2007. World Lake Vision Action Report: Implementing the World Lake Vision for the Sustainable Use of Lakes and Rivers. International Lake Environment Committee: Kusatsu City, Japan.

Disponível em: http://www.ilec.or.jp/eg/wlv/action_report_Project.html. Acesso em: 15 mar. 2015. 


\section{COMPORTAMENTO INTRA E INTERANUAL DE OCORRÊNCIA DA DOENÇA DIARREICA AGUDA POR SEMANA EPIDEMIOLÓGICA NO SEMIÁRIDO BRASILEIRO ENTRE 2002 E 2012}

RESUMO: As doenças diarreicas constituem um grande problema de saúde pública no Brasil e no mundo e sua maior ou menor ocorrência está associada a uma série de variáveis ambientais. O objetivo desta pesquisa foi estudar, com o auxílio de métodos estatísticos multivariados, de que modo o regime da precipitação pode explicar a ocorrência da doença diarreica aguda (DDA) em um recorte espacial do semiárido brasileiro, observando o comportamento e as relações entre essas variáveis nas escalas temporais sazonal e interanual, entre 2002 e 2012. Foram obtidos dados de DDA por semana epidemiológica de 74 municípios dos estados do Rio Grande do Norte e da Paraíba. Os resultados apontaram que a maior ocorrência da DDA na região está associada ao período de chuvas em cada ano, notadamente com as primeiras chuvas de cada ano. Foi verificado, a partir de análise de correlação cruzada, uma defasagem de três a quatro semanas em média entre o início das chuvas anuais e o aumento nos casos registrados, com coeficientes de correlação entre as séries anuais variando de 0,35 a 0,83 . Por outro lado, os anos mais secos da série temporal apresentaram maiores taxas de DDA. Esses resultados parecem indicar a influência da precipitação na contaminação das fontes de água e circulação dos patógenos. A pesquisa concluiu pela importância de fatores como a sazonalidade e da agregação de variáveis meteorológicas na análise dos padrões de ocorrência da DDA, notadamente na região semiárida brasileira, onde os impactos de déficits hídricos e das mudanças climáticas sobre a saúde das populações parecem ser expressivos.

Palavras-chave: diarreia, semiárido, precipitação, semana epidemiológica, sazonalidade, séries temporais. 


\subsection{INTRODUÇÃO}

As doenças diarreicas infecciosas (causadas por bactérias, vírus e parasitas) e não infecciosas (provocadas por intolerâncias alimentares e doenças intestinais) continuam sendo um grande problema de saúde pública com dois bilhões de casos por ano em todo o mundo (WGO, 2012). A diarreia é um fenômeno que afeta principalmente as populações dos países em desenvolvimento (GUERRANT et al., 1990). A repetição dos casos de diarreia em crianças pode levar a desnutrição e até mesmo retardos no desenvolvimento e formação intelectual dos indivíduos (NIEHAUS et al., 2002).

As doenças diarreicas constituem um grave problema de saúde pública do Brasil. Sua incidência no país aumentou consideravelmente ao longo da década de 2000, passando de 1,058 milhões de casos no ano 2000 para 4,341 milhões de casos registrados em 2010 (MS/DATASUS, 2015), isto, desconsiderando o fato de que a doença é subnotificada em todo o país. Os maiores registros são verificados na Região Nordeste, sendo que de 2000 a 2010, $50 \%$ das 2.563.061 internações hospitalares por diarreias e gastroenterites registradas ocorreram nessa região, que possui $28 \%$ da população nacional (IBGE, 2010).

A diarreia que dura até 14 dias é considerada aguda, a que tem duração de 15 a 29 dias é denominada aguda persistente e a diarreia que se prolonga por mais de um mês é considerada diarreia crônica (MINCIS et al., 2007). A doença diarreica aguda (DDA) é uma síndrome causada por diferentes agentes etiológicos (bactérias, vírus e parasitas). O modo de transmissão ocorre por via fecal-oral (MS/SVS, 2015). Os agentes enteropatogênicos causadores de DDA mais comuns são as bactérias Escherichia coli (patogênica, toxigênica e invasiva), Shiguella, Salmonella, Campylobacter, protozoários como Giardia lamblia, Entamoeba hystolítica, Criptosporidium e os vírus Rotavírus e Adenovírus (VERONESI; FOCACCIA, 2005). Os helmintos mais comuns são Trichuris trichiura, Ancylostoma duodenale, Strongyloides stercoralis e Schistosoma mansoni (MOTTA; SILVA, 2002). Os principais patógenos causadores de diarreia estão listados na Tabela 3.1.

Estima-se que a diarreia esteja em primeiro lugar entre as doenças que são ocasionadas por fatores ambientais, e que $94 \%$ da carga das doenças diarreicas sejam atribuíveis as condições ambientais, resultando em mais de 1,7 milhões de mortes por ano, principalmente em crianças (PRÜSS-ÜSTÜN; CORVALAN, 2006). A temperatura e a precipitação são fatores relacionados a transmissão de doenças gastroinfecciosas. 
Tabela 3.1: Patógenos causadores de diarreia.

\begin{tabular}{l|l|l}
\hline \multicolumn{1}{c|}{ Bactérias } & \multicolumn{1}{c}{ Vírus } & \multicolumn{1}{c}{ Parasitas } \\
\hline Escherichia coli produtora de diarreia & Rotavírus & Protozoários \\
Campylobacter jejuni & Norovírus (calicivírus) & Cryptosporidium parvum \\
Vibrio cholerae & Adenovírus (sorotipo 40/41) & Giardia intestinalis \\
Espécie Shigella & Astrovírus & Microsporida \\
Vibrio parahaemolyticus & Citomegalovírus & Entamoeba histolytica \\
Bacteroides fragilis & & Isospora belli \\
Campylobacter coli & & Cyclospora cayetanensis \\
Campylobacter upsaliensis & & Dientamoeba fragilis \\
Salmonellae não tifoide & & Blastocystis hominis \\
Clostridium difficile & & Helmintos \\
Yersinia enterocolitica & & Strongyloides stercoralis \\
Yersinia pseudotuberculosis & & Angiostrongylus costaricensis \\
& & Schistosoma mansoni \\
& & Schistosoma japonicum \\
\hline
\end{tabular}

Fonte: Adaptado de WGO (2012).

Diversos estudos avaliaram o impacto de eventos climáticos, notadamente da precipitação, sobre episódios ou surtos de doenças de veiculação hídrica. Alguns observaram o efeito defasado no tempo considerando séries temporais diárias (DRAYNA et al.; 2010; CHEN et al., 2012; EISENBERG et al., 2013; TORNEVI et al., 2013), semanais (HASHIZUME et al., 2007; D'SOUZA et al.; 2008; NICHOLS et al.; 2009; ZHANG et al., 2010) ou mensais (CURRIERO et al., 2001; SINGH et al., 2001; ZHANG et al., 2010; CHOU et al., 2010). Alguns estudos envolveram todas as faixas etárias (HASHIZUME et al., 2007; CHOU et al., 2010), outros restringiram a análise a crianças (D'SOUZA et al., 2008; DRAYNA et al., 2010). A maior parte indicou que temperaturas elevadas e episódios de precipitação intensa apresentaram associação estatística significativa com a ocorrência de diarreia e gastroenterites. No entanto, tais pesquisas, em geral, enfocaram o impacto de eventos extremos de precipitação, não buscando compreender o impacto do cenário regular do regime de chuvas sobre a doença. Tampouco estudaram uma região de clima semiárido.

Estudos demonstraram que o comportamento da diarreia em muitas regiões tropicais é sazonal e seu pico está associado ao período mais chuvoso (CAIRNCROSS; FEACHEN, 1993) ou de maior temperatura (CHECKLEY et al., 2000). Lloyd-Evans et al. (1984) analisaram o comportamento sazonal da ocorrência de diarreia em Gâmbia e observaram que ela é mais intensa na estação chuvosa, pois as chuvas aumentam a contaminação da água por coliformes fecais. Diallo et al. (2009) destacaram o papel da chuva no aumento da concentração de patógenos como Giardia lamblia e Escherichia coli em canais de Bangcoc, Tailândia. 
Este trabalho representa um estudo inovador no Brasil ao tratar do comportamento de séries temporais de ocorrência das doenças diarreicas efetuando as análises segundo o registro desse dado por semanas epidemiológicas. O objetivo da pesquisa é estudar, com o auxílio de métodos estatísticos multivariados, de que modo o regime da precipitação pode explicar a ocorrência da DDA em um recorte espacial do semiárido brasileiro, observando o comportamento e as relações entre essas variáveis nas escalas temporais sazonal e interanual, entre 2002 e 2012.

\subsection{MATERIAL E MÉTODOS}

\subsection{1 Área de Estudo}

A área de estudo contemplou 74 municípios localizados na Região Hidrográfica do Atlântico Nordeste Oriental, uma parte da Região Nordeste do Brasil que possui a menor disponibilidade hídrica do território brasileiro e enfrenta graves problemas relacionados ao abastecimento de água (ANA, 2011). Do total de municípios, 57 pertencem ao Estado do Rio Grande do Norte (RN) e 17 ao Estado da Paraíba (PB) (Figura 3.1).

A maior parte dos municípios pertence à região semiárida brasileira (MI, 2005), onde as precipitações ocorrem num período curto e $90 \%$ se perde por evapotranspiração, em função de condições do clima, geologia e geomorfologia (SALATI et al., 2006). A região possui baixa disponibilidade hídrica devido à incerteza e irregularidade das chuvas, o baixo potencial em águas subterrâneas e a intermitência dos rios, fatores estes que se agravam em virtude de deficiências na gestão e regulação dos recursos hídricos existentes.

As áreas urbanas dos municípios da área de estudo são abastecidas exclusivamente por sistemas adutores cujas captações provém de quatro diferentes reservatórios de água, localizados em bacias hidrográficas que receberão oferta de água do PISF. A população total corresponde a 590.727 habitantes no RN e 592.808 habitantes na PB (IBGE, 2010). 

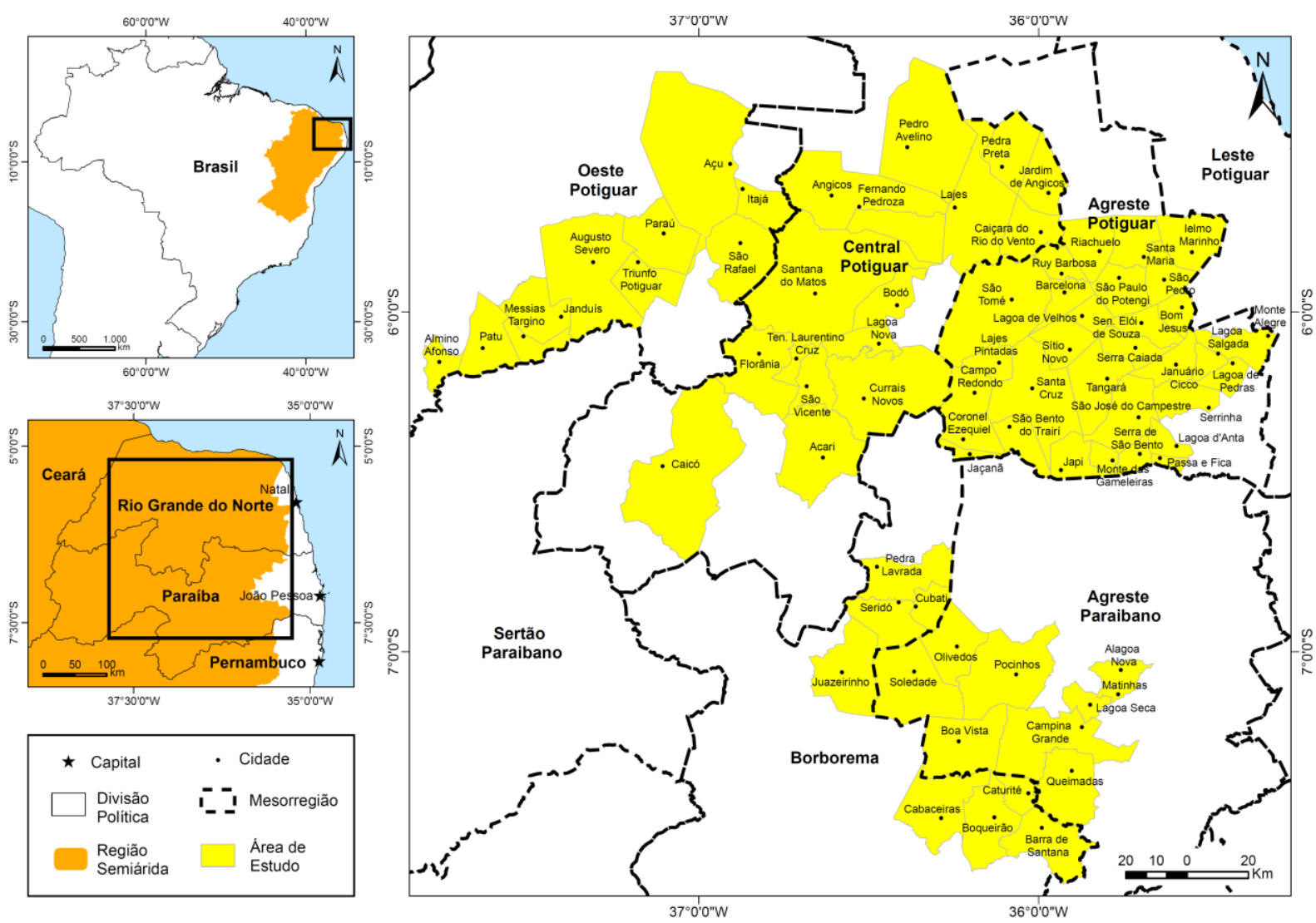

Figura 3.1: Localização da área de estudo.

Fonte: Elaborado pelo autor.

A estação chuvosa está concentrada no período de fevereiro a maio, quando a zona de baixas pressões próxima a Linha do Equador e a ZCIT atinge sua posição mais ao sul, juntamente com a zona de maior temperatura da superfície do mar (TSM). No entanto, uma série de diferenças podem ser observadas nas sub-regiões da área de estudo, sendo que em sua porção mais ocidental o período de chuvas começa tradicionalmente em dezembro e na porção oriental termina em julho. A ZCIT pode ser definida como uma grande faixa de nebulosidade formada pela confluência dos ventos alísios de nordeste e sudeste, constituindo-se no principal sistema meteorológico indutor de chuvas no Nordeste e Norte brasileiro, durante o primeiro semestre. A forma de atuação desse sistema está associada à configuração de condições atmosféricas e oceânicas apresentadas pelos oceanos Pacífico e Atlântico (PFALTZGRAFF, 2010).

Segundo Grimm et al. (1998a; 1998b), a variabilidade da precipitação no Nordeste está sujeita à forte influência das anomalias da TSM no Oceano Atlântico e à posição da ZCIT. Quando o gradiente da TSM é enfraquecido no Oceano Atlântico Norte, a zona de baixa pressão e a ZCIT são deslocadas para norte, produzindo seca no Nordeste. Os ventos alísios no Atlântico 
Norte são enfraquecidos, enquanto no Atlântico Sul são acelerados, aumentando o fluxo que cruza o Equador para o norte. Situação meteorológica inversa contribui para a ocorrência de precipitação acima da média.

\subsubsection{Séries Temporais de Ocorrência de DDA}

Em 1994, três anos após o início da epidemia de cólera no Peru, que se expandiu para o Brasil e outros países americanos, o Ministério da Saúde brasileiro (MS) implantou o programa de Monitorização de Doenças Diarreicas Agudas (MDDA) para a notificação de DDA, com o objetivo de indicar precocemente a introdução do cólera em uma determinada região (FAÇANHA; PINHEIRO, 2005). Os instrumentos de monitoramento foram aprimorados e padronizados para todo o país, gerando em 2002 o Sistema Informatizado de Vigilância Epidemiológica de Doenças Diarreicas Agudas (SIVEP-DDA). Este sistema dotou os municípios de um instrumento ágil e simplificado para a detecção de DDA, recomendação de medidas de prevenção e controle e, avaliação do impacto das ações desenvolvidas (MS/SVS, 2015). O MDDA disponibiliza dados por semana epidemiológica permitindo uma análise mais detalhada do fenômeno das diarreias agudas. No entanto, as diarreias não fazem parte do elenco de doenças de notificação compulsória do Brasil. Isso torna os números das diarreias ainda pouco conhecidos e as estatísticas pouco acuradas. Não foram identificados casos de cólera na área de estudo a partir de 2002, sendo identificados no Brasil apenas 26 casos autóctones, registrados em 2004 e 2005 no Estado de Pernambuco.

As notificações de DDA por semana epidemiológica foram obtidas sobre todas as faixas etárias, indistintamente, após visitas técnicas às secretarias de saúde dos Estados do RN e PB. A Secretaria de Estado da Saúde Pública do Rio Grande do Norte (SESAP) forneceu os dados no período de janeiro de 2002 a dezembro de 2012, enquanto a Secretaria de Estado da Saúde da Paraíba (SES) disponibilizou no período de janeiro de 2005 a dezembro de 2012. Observase que as notificações sistemáticas de DDA tiveram início em datas distintas nos dois Estados. Embora existentes, os dados de 2005 da PB não foram considerados, pois as tabelas encaminhadas pela SES apresentaram registros somente em alguns municípios, o que levou à interpretação de que o programa de MDDA ainda estava parcialmente implementado no Estado. Por convenção internacional as semanas epidemiológicas são contadas de domingo a sábado. A primeira semana de cada ano é aquela que contém o maior número de dias de janeiro e a 
última a que contém o maior número de dias de dezembro (SÃO PAULO, 2015). Desse modo, alguns anos registram uma observação a mais, perfazendo 53 semanas.

\subsubsection{Séries Temporais de Dados Meteorológicos}

Os dados de precipitação pluviométrica foram obtidos por totalização diária, em milímetros, dos órgãos estaduais de monitoramento: Empresa de Pesquisa Agropecuária do Rio Grande do Norte (EMPARN) e Agência Executiva de Gestão das Águas da Paraíba (AESA). Os dados foram registrados por uma média de 66 estações da EMPARN nos 57 municípios (variando entre 49 e 77 estações operando ao longo de cada ano de 2002 a 2012) e de 20 estações da AESA nos 17 municípios (variando entre 17 e 21 o número de estações). Os dados da EMPARN e AESA foram submetidos a procedimentos de consistência de dados, com a exclusão dos valores diários de precipitação quando acima de $100 \mathrm{~mm}$ em uma única estação da área de estudo e dos valores de estações com mais de três meses de ausência de dados em cada ano da série.

Os dados de temperatura máxima diária, em graus Celsius, foram obtidos do Banco de Dados de Estações Meteorológicas Convencionais do Instituto Nacional de Meteorologia (INMET) das estações de Areia e Campina Grande na PB, e Caicó, Cruzeta e Florânia no RN, entre 2002 e 2012 (INMET, 2015).

Os dados meteorológicos foram organizados em planilhas eletrônicas de modo análogo aos registros de DDA, ou seja, por semana epidemiológica, com totalização no caso da precipitação e valores médios no caso da temperatura.

\subsubsection{Análise de Correlação Cruzada entre as Variáveis Meteorológicas e DDA}

Considerando que os casos de DDA e as variáveis meteorológicas constituem processos estocásticos bivariados, foram calculados os coeficientes de correlação cruzada entre as séries temporais (BOX et al., 2008). O coeficiente de correlação cruzada $r_{x y}(k)$ representa a correlação entre duas séries $x$ e $y$, sendo que $x$ está defasado por $k$ observações. A função de correlação cruzada não é simétrica sobre o lag 0 , isto é, diferentes correlações serão observadas 
dependendo se o eixo $x$ for deslocado para a frente ou para trás. A correlação cruzada é demonstrada pela Equação 3.1 (BOX et al., 2008):

$$
r_{x y}(k)=\frac{c_{x y}(k)}{\sigma_{x} \sigma_{y}} \quad k=0, \pm 1, \pm 2, \ldots
$$

Onde " $r_{x y}(\mathrm{k})$ " é o coeficiente de correlação cruzada no lag $k$; $\sigma_{x}$ é o desvio padrão da série $x$ e; $\sigma_{y}$ é o desvio padrão da série $y$.

A estimativa do coeficiente de covariância cruzada no lag $k$ é dada pela Equação 3.2:

$$
c_{x y}(k)=\left\{\begin{array}{lr}
\frac{1}{n} \sum_{t=1}^{n-k}\left(x_{t}-\bar{x}\right)\left(y_{t+k}-\bar{y}\right) & k=0,1,2, \ldots \\
\frac{1}{n} \sum_{t=1}^{n+k}\left(y_{t}-\bar{y}\right)\left(x_{t-k}-\bar{x}\right) & k=0,-1,-2, \ldots
\end{array}\right.
$$

Onde $\bar{x}$ e $\bar{y}$ são as médias amostrais das séries $x_{t}$ e $y_{t}$, respectivamente.

E o erro padrão da correlação cruzada de $r_{x y}(\mathrm{k})$ é aproximadamente igual a (Equação 3.3):

$$
\operatorname{StdErr}\left(r_{x y}(k)\right)=\sqrt{\left[\frac{1}{(N-k)}\right]}
$$

Onde $N$ é o número de observações nas séries.

Foram utilizados nove lags para observar a associação entre as variáveis, que corresponde a aproximadamente dois meses antes do registro da doença (nove semanas epidemiológicas). O nível de significância adotado foi $95 \%$. Somente foram avaliadas correlações com lags positivos, ou seja, considerando defasada a precipitação em relação a DDA. A suposição contrária não foi considerada válida, pois a variável DDA não possui caráter preditivo da precipitação. A análise foi efetuada independentemente para o $\mathrm{RN}$ e $\mathrm{PB}$ bem como sobre toda a área de estudo e englobou tanto a série temporal completa quanto a observação ano a ano.

As correlações cruzadas também foram calculadas para cada município considerando a série temporal de dados disponível. Para o procedimento somente foram considerados dados de estações pluviométricas com dados disponíveis para todos os anos da série temporal, correspondentes a 37 estações, localizadas em 32 municípios. Quando houve mais de uma 
estação em um mesmo município foi calculada uma média dos dados. As correlações foram calculadas tomando como referência dados da estação pluviométrica mais próxima da sede municipal, cuja distância máxima foi de $30 \mathrm{~km}$. Para cada município, os dados referentes aos anos sem nenhum caso registrado de DDA foram excluídos da respectiva série temporal. As análises estatísticas foram efetuadas no software StatSoft@ Statistica 12.*

\subsubsection{Análise do Padrão Intra e Interanual de Ocorrência da DDA}

Partindo dos resultados obtidos com a análise de correlação cruzada, a ocorrência da DDA na área de estudo foi analisada tomando como referência o comportamento apresentado nas escalas intra e interanual. A análise intranual considerou os padrões apresentados por semana epidemiológica em cada ano da série temporal e observou as anomalias de precipitação registradas na região e em algumas de suas sub-regiões.

A análise interanual considerou as taxas anuais de DDA na área de estudo comparadas às médias de precipitação anual e temperatura anual. Também foi observada a ocorrência de fenômenos como a Oscilação Sul do El Niño (ENSO) que pode auxiliar no entendimento do padrão interanual de incidência da DDA em regiões tropicais, como já demonstrado para doenças de veiculação hídrica como o cólera (PASCUAL et al., 2000; RODÓ et al.; 2002) e a úlcera de Buruli (MORRIS et al., 2014).

\subsection{RESULTADOS}

\subsubsection{Doença Diarreica Aguda}

A pesquisa considerou 254.896 casos registrados de DDA na área de estudo sendo 168.801 no RN (2002-2012) e 86.095 na PB (2006-2012). O total de casos de DDA notificados por semana epidemiológica nos municípios estudados é apresentado na Figura 3.2. As séries temporais de DDA observadas não foram estacionárias, pois sua média e variância foram

\footnotetext{
* O calendário de semanas epidemiológicas e os dados utilizados para as análises estatísticas contidas neste Capítulo encontramse organizados no Anexo $B$ da tese.
} 
diferentes ao longo do tempo. Na maioria dos anos, a trajetória temporal da distribuição dos casos de DDA ao longo dos anos considerados apresentou um pico entre a $5^{\mathrm{a}}$ e a $25^{\mathrm{a}}$ semanas, ou seja, nos meses de fevereiro a junho.
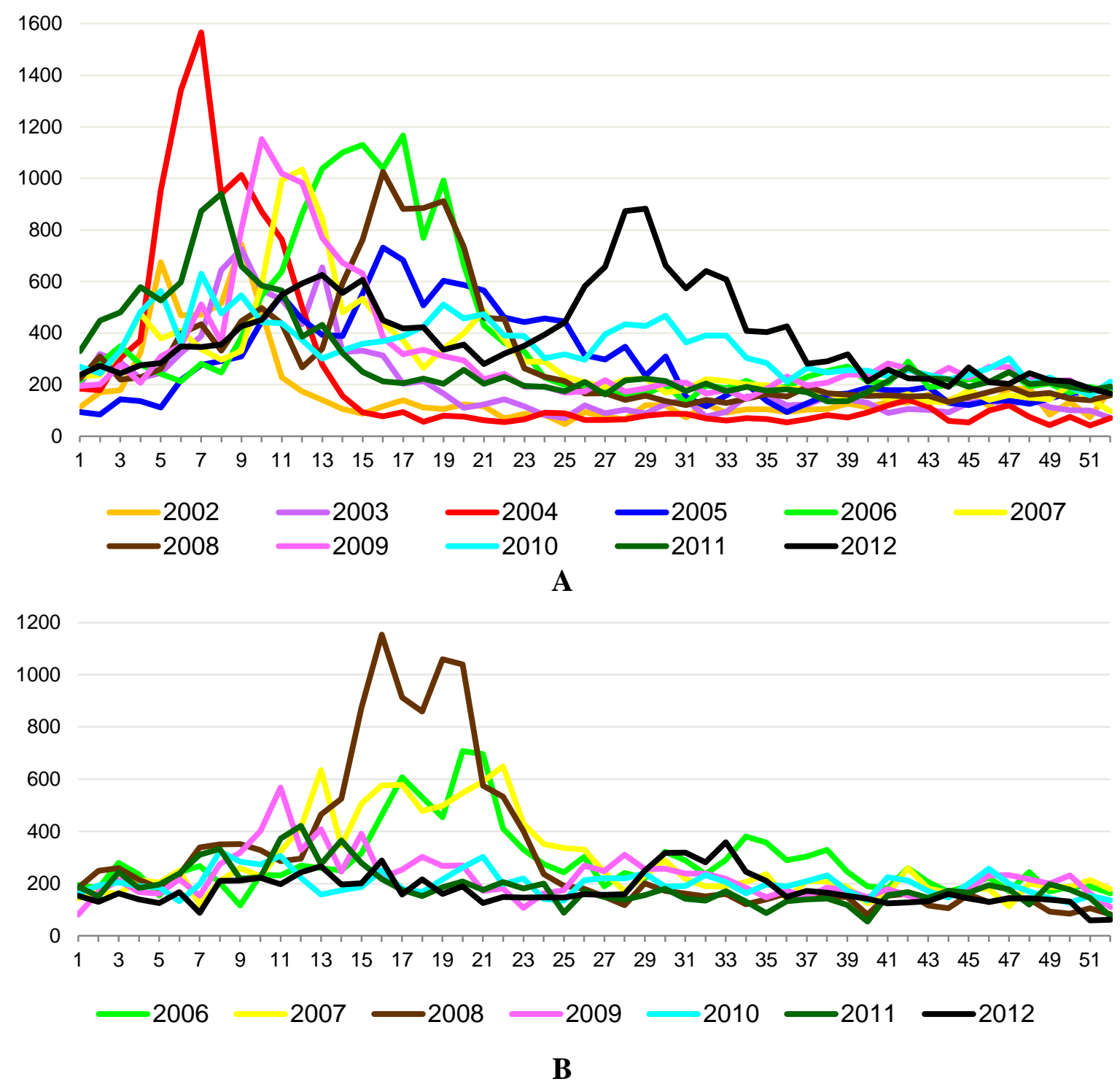

Figura 3.2: Casos de DDA por semana epidemiológica nas áreas de estudo no RN (2002-2012) (A) e PB (2006-2012) (B).

Fonte: Elaborado pelo autor a partir de dados da SESAP e SES (dados não publicados).

\subsubsection{Precipitação}


A distribuição da precipitação, calculada nos mesmos intervalos das semanas epidemiológicas, é apresentada na Figura 3.3 para as áreas de estudo no RN (A) e PB (B). A precipitação concentrou-se entre janeiro e abril no RN e março a junho na PB.

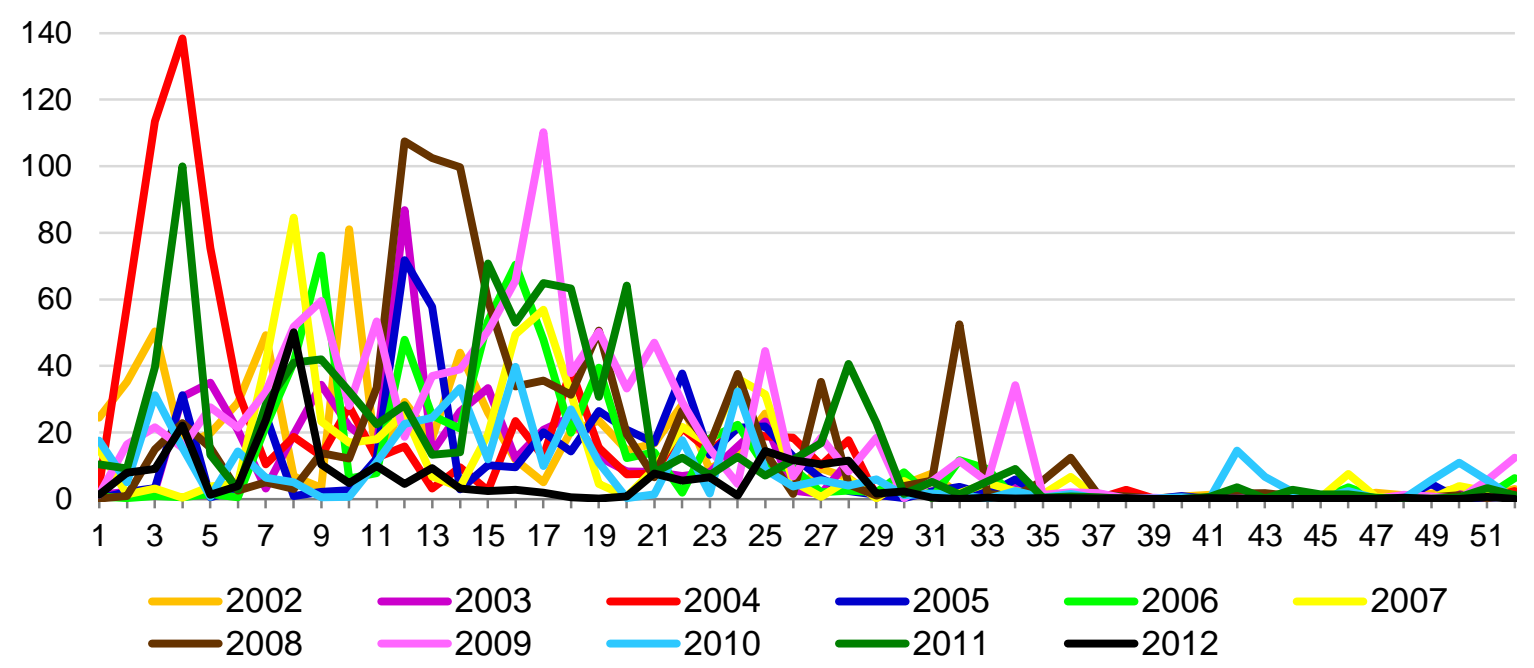

A

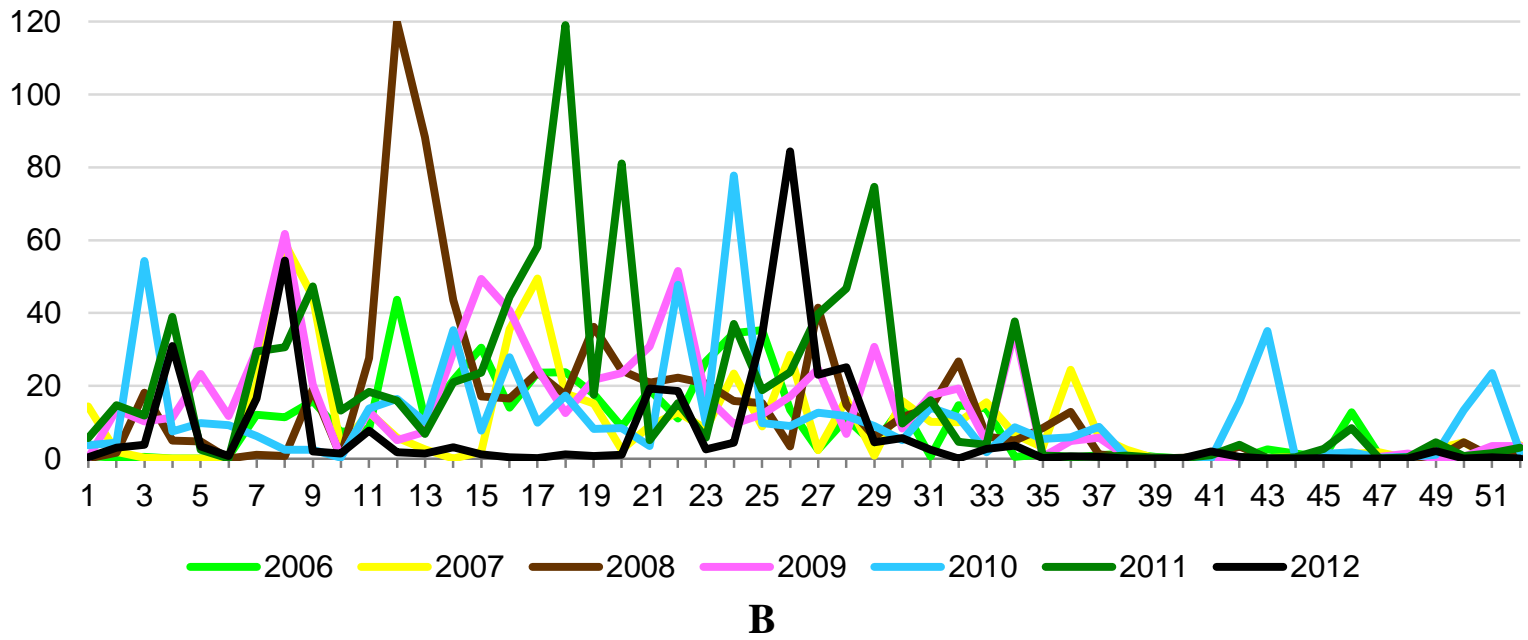

Figura 3.3: Precipitação acumulada $(\mathrm{mm})$ por semana epidemiológica: valor médio para a área de estudo no RN (2002-2012) (A) e PB (2006-2012) (B).

Fonte: Elaborado pelo autor a partir de dados da EMPARN e AESA.

\subsubsection{Temperatura}

A observação das temperaturas máximas do ar na área de estudo, cujas séries temporais são apresentadas na Figura 3.4, permitiu concluir que os meses mais quentes foram os do verão, com uma ligeira queda das temperaturas máximas nos meses de inverno. Entretanto, a variação da temperatura máxima ao longo de um mesmo ano na região foi pequena, oscilando em torno 
de $6^{\circ} \mathrm{C}$, dadas as características do clima tropical da região. O primeiro semestre do ano correspondeu ao período em que a temperatura máxima apresentou maior oscilação, chegando a corresponder a menos de $27^{\circ} \mathrm{C}$, como nos períodos chuvosos de 2007 e 2008 . A variação da temperatura ao longo da série temporal foi sazonal e esteve diretamente relacionada à ocorrência de precipitação (Figura 3.3), ou seja, quando houve precipitação as temperaturas máximas foram menores e vice-versa. Períodos secos durante a estação chuvosa estiveram associados às maiores temperaturas e às principais anomalias observadas nas médias das temperaturas máximas na área de estudo, como observado em março de 2005 e 2010 e abril e maio de 2012.

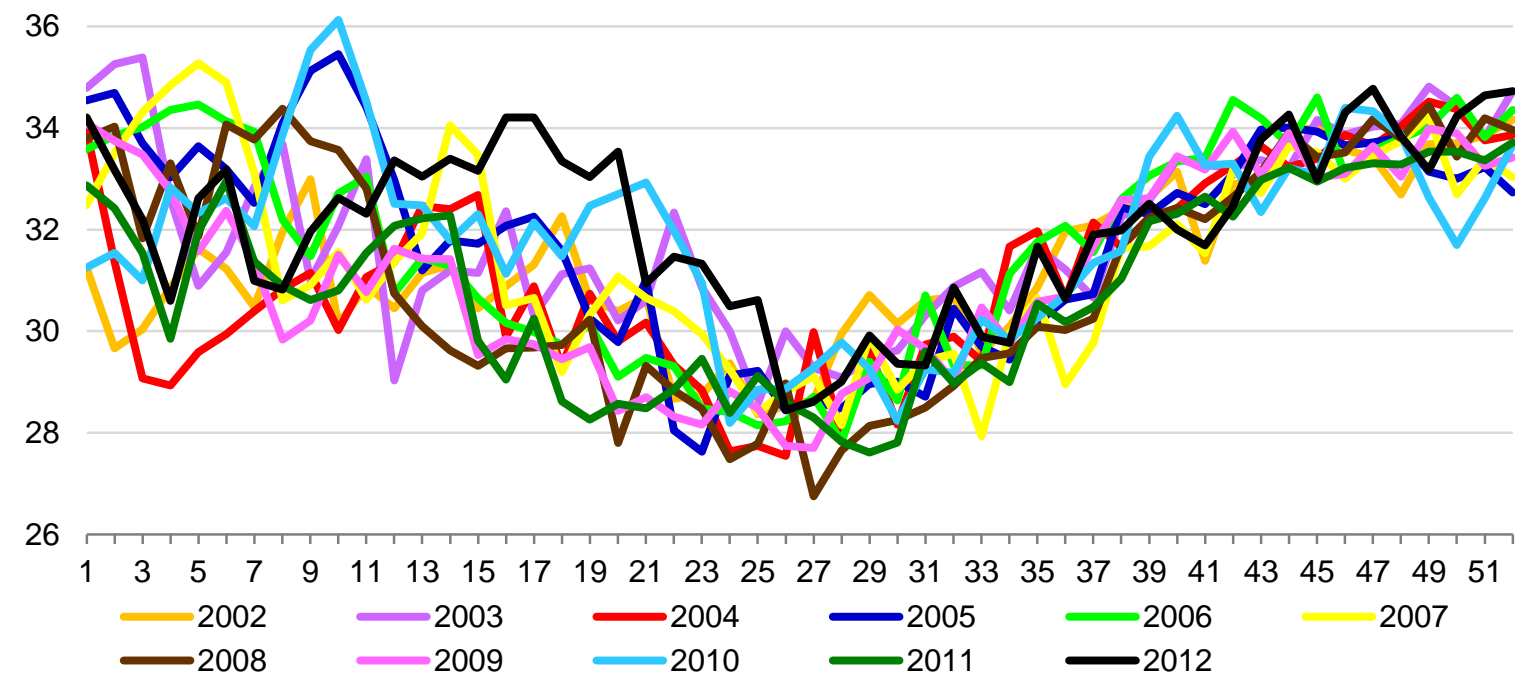

Figura 3.4: Temperatura máxima diária do $\operatorname{ar}\left({ }^{\circ} \mathrm{C}\right)$ : média por semana epidemiológica na área de estudo (2002-2012).

Nota: Média calculada a partir de dados das cinco estações do INMET com dados disponíveis. Fonte: Elaborado pelo autor a partir de dados do INMET (2015).

\subsubsection{Correlação Cruzada}

Analisando as Figuras 3.2 e 3.3 comparativamente, pode ser observado um lapso temporal em cada ano considerado, entre a ocorrência do evento de precipitação e o aumento no número de casos de DDA. A intensidade do número de casos também foi proporcional à intensidade da precipitação, ou seja, episódios de chuva intensa, ou concentrada em curtos períodos de tempo, ocasionaram picos de incidência da DDA, como observado nos anos de 
2004, 2007, 2008 e 2011. Por outro lado, a distribuição regular das chuvas ao longo do ano resulta em uma distribuição similar dos casos de DDA sem grandes variações.

Em 2004, quando as chuvas foram mal distribuídas, ocorrendo de forma intensa somente em janeiro, os casos de DDA registrados nos demais meses do ano no RN foram os menores dentre todos os anos observados. Em 2010, a distribuição das chuvas foi mais regular ao longo do ano e, comportamento semelhante foi apresentado pelos casos de DDA, inclusive com destaque para aqueles registrados no mês de julho na área de estudo no $\mathrm{RN}$, julho este que apresentou os maiores índices pluviométricos em relação aos demais anos. No ano de 2012, de índices pluviométricos extremamente baixos, o considerável número de casos apresentados em julho também foi atípico, em ambos os estados (RN e PB), porém ocorreram após as chuvas de junho, evento pluviométrico mais intenso do ano.

A Tabela 3.2 lista os maiores coeficientes de correlação cruzada entre as variáveis DDA e precipitação e os seus respectivos lags, considerando os dados do RN e PB. Os resultados também foram apresentados segundo um somatório dos casos de DDA em ambos os estados e valores médios de precipitação, para averiguar o impacto da agregação dos dados sobre os resultados. No entanto, a análise para toda a área de estudo é limitada ao período de 2006 a 2012, devido à indisponibilidade de dados entre 2002 e 2005 para os municípios paraibanos.

Tabela 3.2: Dados da correlação cruzada entre as variáveis DDA e precipitação para os municípios estudados do RN, PB e somatório entre eles.

\begin{tabular}{|c|c|c|c|c|c|c|c|c|c|c|c|c|}
\hline & $\stackrel{ }{\mathcal{్}}$ & 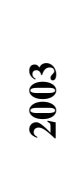 & ঠ્తి & ஜ̊ & రి & $\hat{\delta}$ & $\stackrel{\infty}{\stackrel{\overbrace{}}{8}}$ & $\stackrel{\hat{\theta}}{\hat{\mathrm{N}}}$ & $\stackrel{\theta}{\vec{\theta}}$ & $\overline{\widehat{N}}$ & $\underset{\widehat{N}}{\mathbb{N}}$ & 递 \\
\hline \multicolumn{13}{|c|}{ Rio Grande do Norte } \\
\hline $\operatorname{Lag} *$ & 2 & 1 & 3 & 4 & 0 & 4 & 3 & 1 & 4 & 4 & 5 & 3 \\
\hline$r_{x y}$ & 0,44 & 0,62 & 0,83 & 0,63 & 0,70 & 0,68 & 0,76 & 0,46 & 0,56 & 0,35 & 0,46 & 0,53 \\
\hline StdErr & 0,14 & 0,14 & 0,14 & 0,14 & 0,14 & 0,14 & 0,14 & 0,14 & 0,14 & 0,14 & 0,15 & 0,04 \\
\hline \multicolumn{13}{|c|}{ Paraíba } \\
\hline Lag & & & & & 5 & 5 & 4 & 3 & 5 & 4 & 5 & 4 \\
\hline$r_{x y}$ & & & & & 0,54 & 0,46 & 0,64 & 0,38 & 0,39 & $0,21 * *$ & 0,62 & 0,39 \\
\hline StdErr & & & & & 0,15 & 0,15 & 0,14 & 0,14 & 0,15 & 0,14 & 0,15 & 0,05 \\
\hline \multicolumn{13}{|c|}{ Somatório } \\
\hline Lag & & & & & 1 & 4 & 3 & 2 & 3 & 4 & 5 & 4 \\
\hline & & & & & 0,71 & 0,71 & 0,76 & 0,46 & 0,55 & 0,37 & 0,56 & 0,55 \\
\hline StdErr & & & & & 0,14 & 0,14 & 0,14 & 0,14 & 0,15 & 0,14 & 0,15 & 0,05 \\
\hline
\end{tabular}

*Intervalo de tempo de correlação máxima (Lag), Correlação máxima entre os diferentes intervalos de tempo $\left(r_{x y}\right)$, Erro padrão $($ StdErr).

**Não significante (valor-p maior que 0,05 ). 
A correlação foi estatisticamente significativa (nível de significância de 95\%) em todos os anos, exceto para a PB em 2011. Os menores valores foram observados nos anos de 2011 e 2009. O ano de 2009 foi considerado atípico, com elevados índices de precipitação, que perduraram por vários meses, assim como 2011, que apresentou a menor correlação estatisticamente significativa entre os anos da série.

O lag com maior ocorrências de melhor ajuste foi o 4, seguido do 3 e 5, o que indica, em geral, três a cinco semanas de defasagem entre os eventos. O maior coeficiente de correlação foi para o ano de 2004 na área de estudo no RN, 0,83, seguido de 2008, com valor de 0,76 , anos estes em que foram observados períodos de chuvas intensas e de grande número de casos de DDA. O efeito das precipitações intensas foi observado em lags mais curtos, a exemplo de 2004 e 2008. A ausência de lag (valor 0) ou lags mais longos (maior que 4) foram observados em anos cujas precipitações foram mais bem distribuídas, como em 2006, 2007 e 2012.

Em 2006 para a área de estudo completa, os coeficientes foram muito próximos, sendo de 0,71, 0,70, 0,69 e 0,68 para os lags de 1 a 4, respectivamente, todos com erro de 0,14, enquanto que o lag 5, por sua vez, apresentou 0,61 de correlação e 0,15 de erro padrão.

Os resultados obtidos para toda a série temporal foram considerados significativos e apontaram os lags de 3 e 4 semanas, para $\mathrm{RN}$ e $\mathrm{PB}$, respectivamente, como os de maior correlação. Considerando a área de estudo completa o valor da maior correlação cruzada para a série temporal completa foi superior ao valor da séries de cada estado, e correspondeu a 0,55 no lag 4. Correlações iguais ou maiores também foram observadas em cada ano para a série completa, exceto em 2010 e 2012.

Não foram encontradas correlações positivas significativas $(95 \%$ de intervalo de confiança) e tampouco com $r_{x y}$ acima de 0,35 para a associação da DDA com a temperatura até a quinta semana de lag nas áreas de estudo no RN, PB ou na área de estudo completa. Um dos fatores que pode contribuir para a ausência de resultados significativos é o fato de que a temperatura apresenta pequena variação ao longo do ano na área de estudo, por se tratar de uma área de clima tropical semiárido e, seus valores médios são elevados, de $28^{\circ} \mathrm{C}$ a $35^{\circ} \mathrm{C}$ aproximadamente.

$\mathrm{Na}$ análise das correlações cruzadas por município, os lags com maior número de ocorrências foram 4, 3 e 2, respectivamente, com 20, 17 e 11 casos (Figura 3.5), totalizando 64,9\% dos casos. Este número variou entre as sub-regiões na área de estudo, chegando a 81,2\% nos municípios da mesorregião Central Potiguar (RN) e $80 \%$ na mesorregião Oeste Potiguar 
(RN). Na Paraíba, cujos lags encontrados foram maiores ou iguais aos observados no RN em todos os anos, 76,5\% dos municípios apresentaram as maiores correlações nos lags 5, 4 ou 3.

Lags acima de 5 semanas foram apresentados por apenas três municípios e em oito casos não foram encontradas correlações significativas até a nona semana epidemiológica. Destes, seis não apresentaram a série temporal completa, ou seja, em um ou mais anos não houve registro de casos de DDA, o que levou à exclusão dos dados referentes a esses períodos das respectivas séries temporais. Outros seis municípios também apresentaram séries incompletas, porém as correlações calculadas foram consideradas significativas.

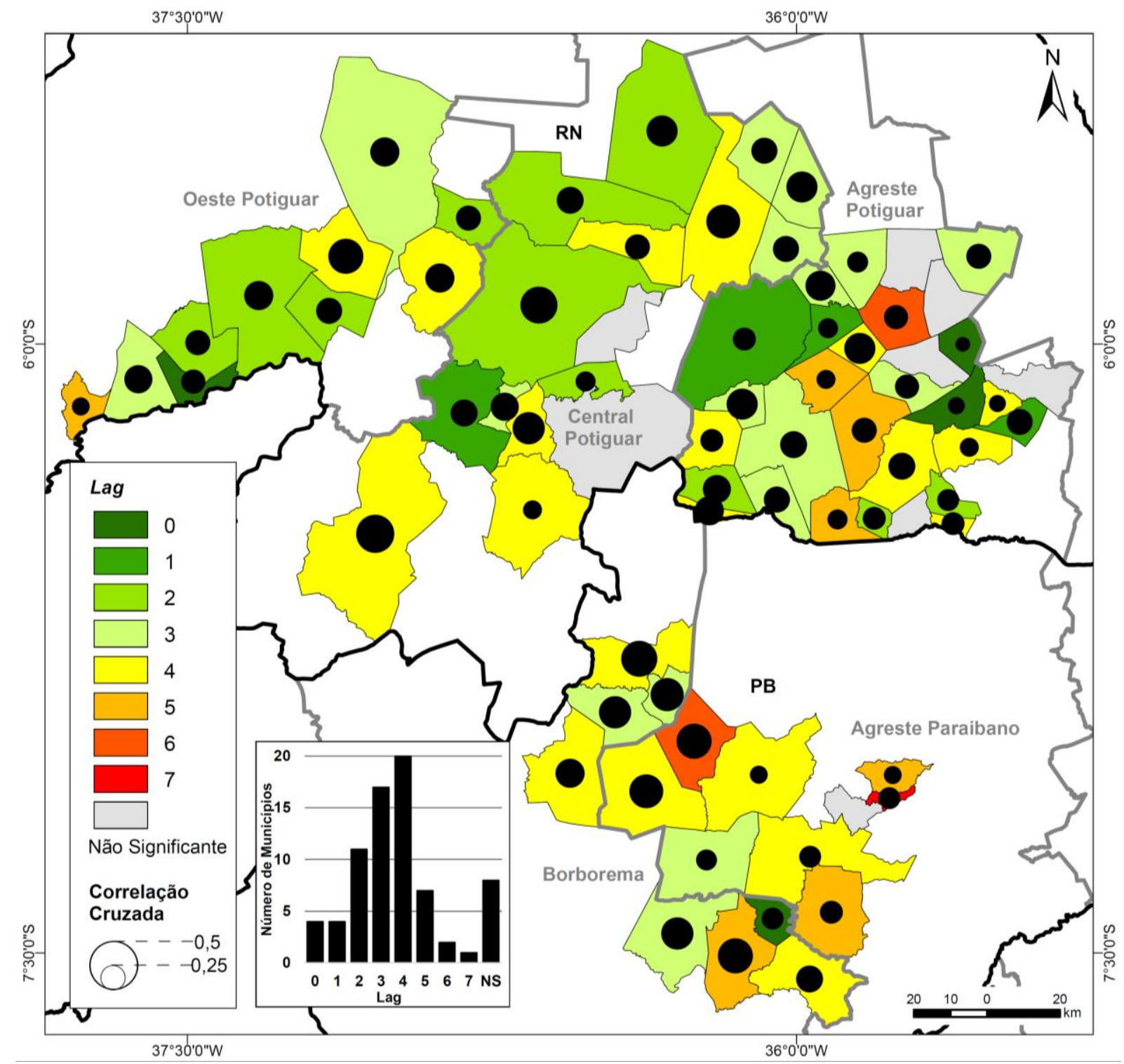

Figura 3.5: Análise de correlação cruzada entre as variáveis DDA e precipitação para os municípios da área de estudo no RN (2002-2012) e PB (2006-2012).

Fonte: Elaborado pelo autor a partir de dados da SESAP, SES, EMPARN e AESA. 


\subsubsection{Padrão Intranual de Ocorrência da DDA e Distribuição da Precipitação}

O comportamento intranual detalhado das séries temporais de ocorrência da DDA e da precipitação por semana epidemiológica entre 2002 e 2012 na área de estudo é apresentado na Figura 3.6. Os dados correspondem aos registros para a área de estudo no RN até 2005 e para o somatório dos registros de DDA no RN e PB a partir de 2006. Uma discussão referente ao comportamento das séries, com ênfase nas anomalias de precipitação registradas na região, é apresentada a seguir. $\mathrm{O}$ uso de dados de precipitação de diversas estações na área de estudo permitiu analisar os efeitos de eventos extremos de precipitação em determinados municípios sobre o conjunto dos dados.

Os totais pluviométricos registrados entre a $2^{\mathrm{a}}$ e $5^{\mathrm{a}}$ semanas epidemiológicas de 2004 foram superiores a $300 \mathrm{~mm}$ em todos os municípios da área de estudo no $\mathrm{RN}$, segundo estações com dados válidos nessas semanas (seis municípios sem dados válidos), exceto em Currais Novos $(231 \mathrm{~mm})$. Segundo o Centro de Previsão do Tempo e Estudos Climáticos (CPTEC) vinculado ao Instituto Nacional de Pesquisas Espaciais (INPE) (INPE/CPTEC, 2015), as chuvas intensas que ocorreram em janeiro de 2004 em todo o Nordeste do Brasil foram devidas ao deslocamento de frentes frias para o Norte, à atuação da zona de convergência intertropical (ZCIT) que se apresentou ao sul de sua posição normal e à presença de Vórtices Ciclônicos em Altos Níveis (VCAN) sobre o Oceano Atlântico. Este último sistema, que normalmente inibe a ocorrência de chuvas, costuma posicionar-se sobre o Nordeste. Em algumas localidades os máximos de precipitação excederam em mais de $300 \mathrm{~mm}$ a média climatológica do mês, o que corrobora os dados aqui apresentados.

Em 2006, quando o comportamento das séries ao longo do ano se assimilaram, um lag menor entre as séries foi observado no cálculo da correlação cruzada, notadamente pelo pico da DDA registrado na $17^{\mathrm{a}}$ semana. 

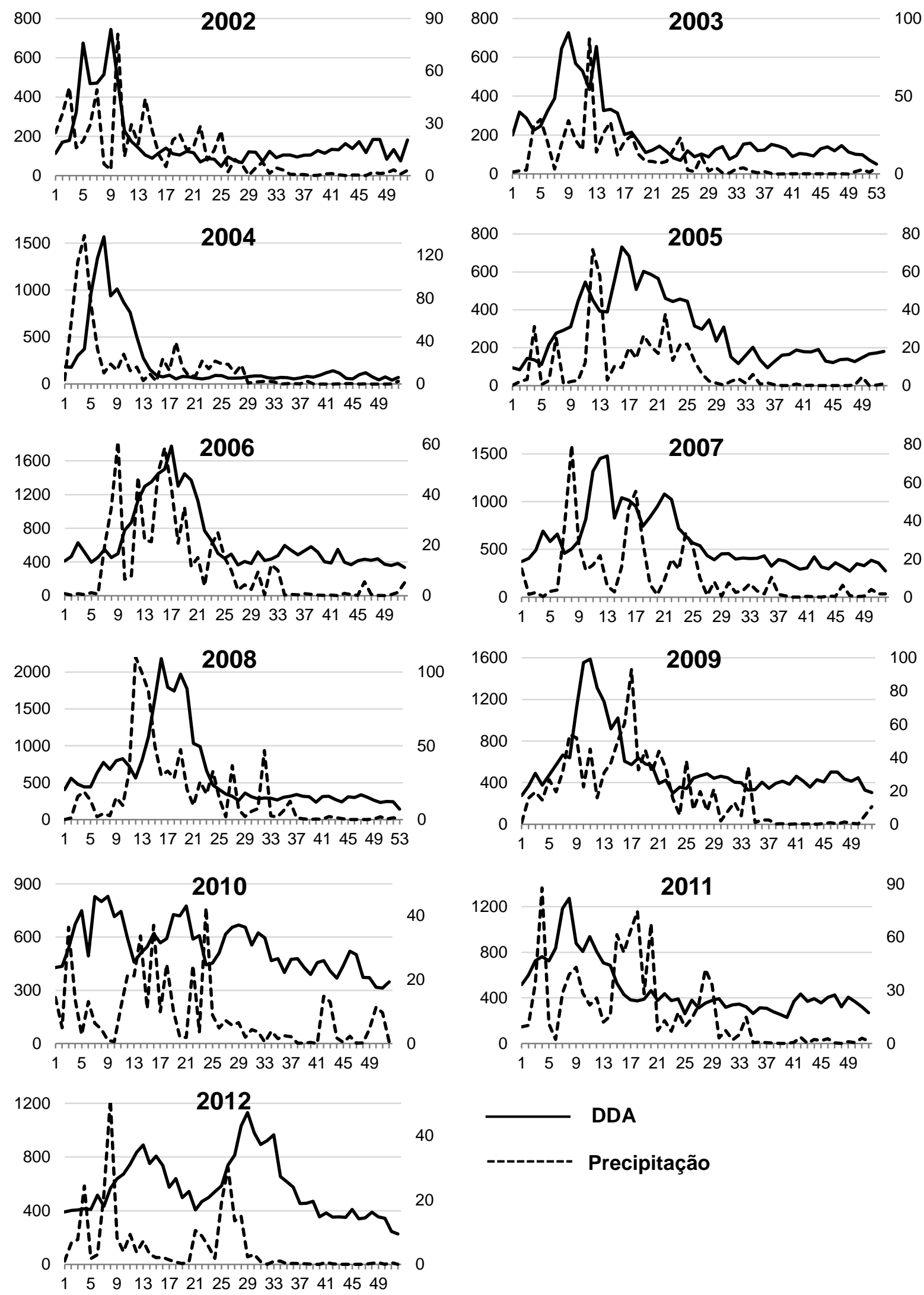

Figura 3.6: Total de casos de DDA e precipitação acumulada média (mm) por semana epidemiológica na área de estudo no RN (2002-2005) e somatório (RN e PB) (2006-2012). Nota: Valor médio de precipitação segundo as estações da área de estudo.

Fonte: Elaborado pelo autor a partir de dados da SESAP, SES, EMPARN e AESA. 
Nos dias 07 e 08 de agosto de 2008 ocorreram fortes chuvas de mais de $150 \mathrm{~mm}$, o que contribuiu para os resultados apresentados na $32^{\mathrm{a}}$ semana. Entretanto, esta anomalia de precipitação foi observada somente em oito municípios do leste da região agreste potiguar, mais próximos do Litoral, a saber Barcelona, Bom Jesus, Lagoa Salgada, Monte Alegre, Ruy Barbosa, Santa Maria, São Paulo do Potengi e São Pedro (Figura 3.1). Segundo o INPE/CPTEC (2015), a propagação de Distúrbios Ondulatórios de Leste (DOL) e os ventos de sudeste mais intensos neste período do ano causaram chuvas acentuadas na costa leste do Nordeste do Brasil, em especial no RN e PB, destacando-se os totais acumulados entre os dias 07 e 08 nas cidades de Ceará Mirim/RN (146 mm) e João Pessoa/PB (132 mm), menores ainda que aqueles registradas nos oito municípios citados da área de estudo.

O comportamento de 2009 apresentou uma situação inversa ao dos demais anos, como se a DDA estivesse defasada em relação à precipitação. As fortes chuvas ocorridas na $17^{\mathrm{a}}$ semana epidemiológica de 2009 e os baixos valores de casos de DDA observados nesse mesmo período podem auxiliar a explicar o comportamento do coeficiente de correlação cruzada para 2009. Talvez o impacto destas chuvas sobre a DDA não seja maior em razão destas, embora fortes, não terem sido as primeiras chuvas do ano. Nos últimos dias de abril de 2009 houve um evento intenso de precipitação que atingiu apenas alguns municípios da faixa central do $\mathrm{RN}$, partindo de Caiçara do Rio do Vento a Acari e passando pelos municípios de Santana do Matos, Bodó e Cerro Corá. Este evento ocasionou totais pluviométricos semanais acima de $150 \mathrm{~mm}$ em Acari, Bodó, Caiçara do Rio do Vento, Fernando Pedroza, Florânia, Jardim de Angicos, Lajes, Patu, Pedra Preta, Pedro Avelino e Triunfo Potiguar na $17^{\mathrm{a}}$ semana, evidenciando um comportamento das chuvas de Nordeste a Sudeste. O fenômeno não atingiu os municípios da PB. Segundo o INPE/CPTEC (2015), o mês de abril de 2009 foi marcado pelo excesso de chuva na maior parte das Regiões Norte e Nordeste. Os maiores totais acumulados no mês, superiores a $600 \mathrm{~mm}$, ocorreram entre o extremo norte do Pará e a faixa litorânea do Ceará, ou seja, a oeste da área de estudo. O posicionamento da ZCIT ao sul de sua posição normal e a formação de linhas de instabilidade ao longo da costa foram os sistemas que mais favoreceram a ocorrência de chuvas.

Em 2010, a distribuição das chuvas foi mais regular ao longo do ano e, comportamento semelhante foi apresentado pelos casos de DDA. Os totais máximos de chuva em uma única semana epidemiológica ao longo do ano foram pouco superiores a $40 \mathrm{~mm}$ ( $24^{\mathrm{a}}$ semana), o que não foi registrado em nenhum outro ano da série temporal estudada. $\mathrm{O}$ mesmo ocorreu com a 
DDA, tendo sido notificados pouco mais de 800 casos na $7^{\text {a }}$ e $9^{a}$ semanas, totais inferiores aos dos outros anos em que houve dados para todos os municípios (de 2006 a 2012).

Os totais pluviométricos registrados entre a $15^{\mathrm{a}}$ e $20^{\mathrm{a}}$ semanas epidemiológicas de 2011 superaram 400 mm em Alagoa Nova, Campina Grande e Lagoa Seca na PB e em Acari, Bodó, Campo Redondo, Coronel Ezequiel, Florânia, Jacanã, Lagoa Nova, São Rafael e São Vicente, além de Monte Alegre, no RN, o que também evidencia, assim como em 2009, um comportamento das chuvas de Nordeste a Sudeste. Estas chuvas foram associadas principalmente à atuação da ZCIT, que voltou a se posicionar ao sul da sua climatologia e ao aquecimento anômalo das águas superficiais do Atlântico Tropical, que favoreceu o desenvolvimento de DOL, principalmente durante a segunda quinzena de abril. Os acumulados diários de chuva que ocorreram no final da segunda quinzena, superiores a $100 \mathrm{~mm}$, causaram transtornos à população do leste do Nordeste (INPE/CPTEC, 2015).

No ano de 2012, o mais seco da série temporal de estudo, foi observada ausência de episódios intensos de chuva e de picos de DDA, verificado de forma mais intensa em julho após as chuvas efêmeras ocorridas no fim de junho na região. A partir da $25^{\mathrm{a}}$ até a $28^{\mathrm{a}}$ semana foram registrados os maiores totais de chuva do ano. Os totais pluviométricos da $8^{\mathrm{a}}$ semana foram mais elevados, porém concentrados apenas em duas semanas $\left(7^{\mathrm{a}}\right.$ e $\left.8^{\mathrm{a}}\right)$.

Os gráficos da Figura 3.7 apresentam o comportamento para os municípios de cada Unidade da Federação, podendo ser vistas diferenças somente nesta análise generalista, que agregou um conjunto de municípios localizados em uma área de mesmo tipo climático. Somente Alagoa Nova e Matinhas na PB não encontram-se inseridas na região semiárida (MI, 2005).

\subsubsection{Padrão Interanual de Ocorrência da DDA e Distribuição da Precipitação}

$\mathrm{Na}$ análise do padrão interanual da precipitação foi observado que totais anuais de precipitação acima da média e taxas de DDA abaixo da média foram registrados em 2002, 2004, 2009 e 2011 (Figura 3.8A). Por outro lado, precipitação abaixo da média e DDA acima da média foi observada em 2005, 2006, 2007 e 2012. Em 2008, ano de acréscimo da precipitação, foi observado um comportamento descendente da taxa de DDA. Assim, em geral, as notificações de DDA aumentam no período mais chuvoso (escala intranual) e em anos com precipitações abaixo da média (escala interanual). 


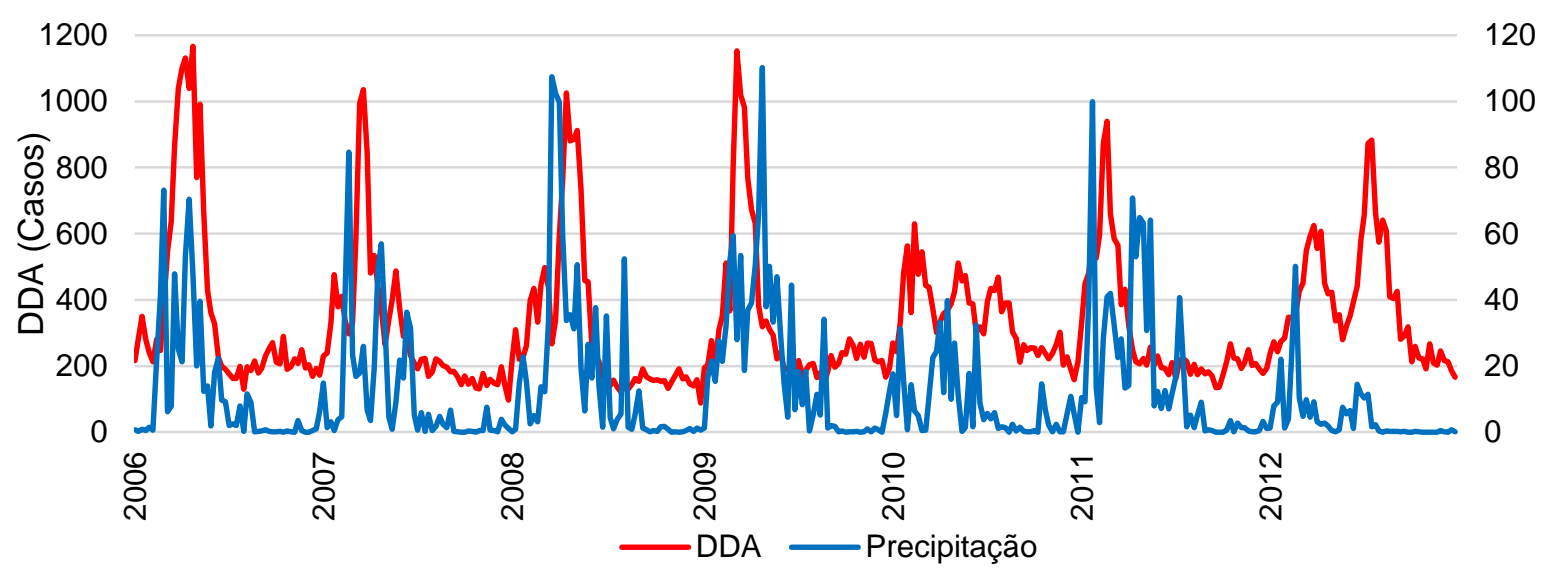

A

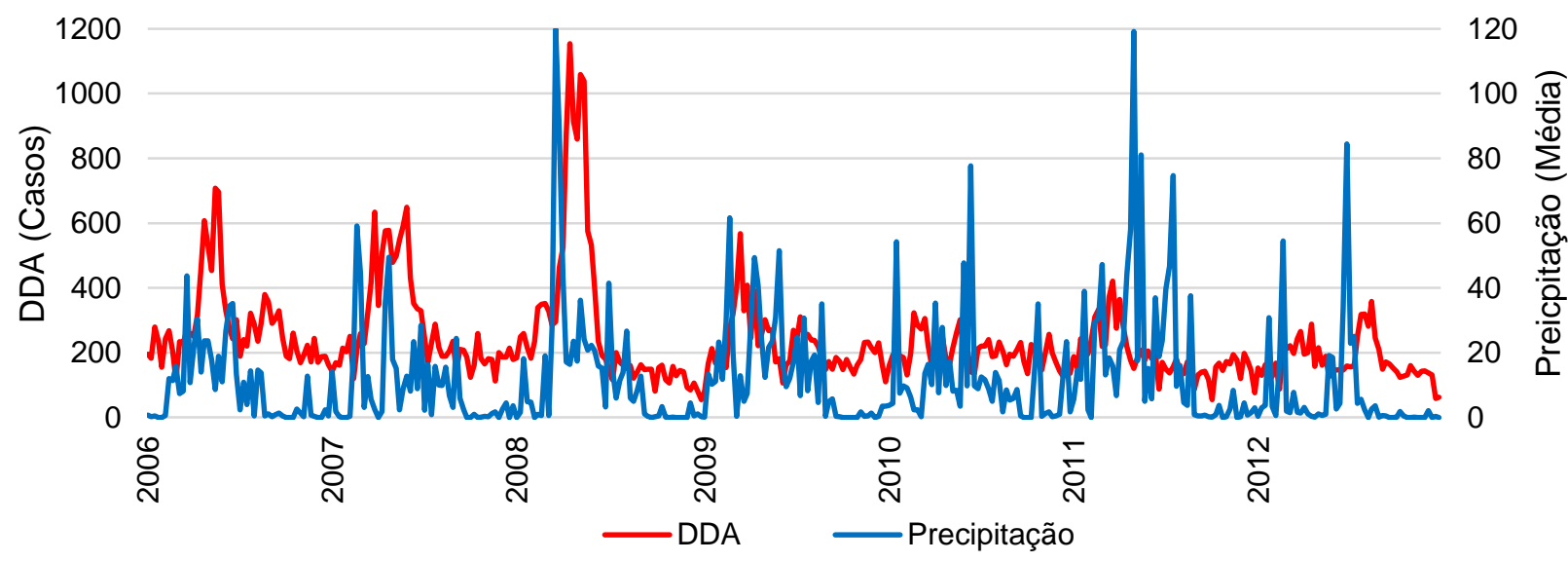

B

Figura 3.7: Série temporal dos casos de DDA e precipitação acumulada por semana epidemiológica nas áreas de estudo no RN (A) e PB (B) (2006-2012).

Nota: Valor médio de precipitação segundo as estações de cada área de estudo.

Fonte: Elaborado pelo autor a partir de dados da SESAP, SES, EMPARN e AESA.

Observa-se que a relação entre a temperatura e a precipitação é inversamente proporcional, ou seja, em anos mais chuvosos a temperatura média é menor e vice-versa (Figura 3.8B). O coeficiente de correlação entre as séries temporais foi de -0,93. Exceto em 2007, todos os demais anos com precipitação abaixo da média tiveram temperatura acima da média e viceversa.

A precipitação anual na região pode ser parcialmente explicada pelos fenômenos El Niño e La Niña em sua oscilação sul, cujos períodos de ocorrência ao longo da série temporal desse estudo e intensidade de acordo com a escala proposta pelo Índice Oceânico Niño (ONI) (NOAA, 2015) para cada ano, considerando o ano hidrológico de outubro a setembro, são apresentados na Tabela 3.3. Os anos 2003, 2005, 2007 e 2010 tiveram registro de El Niño e precipitação abaixo da média. Precipitação esteve acima da média em 2008 e 2011, anos com 
La Niña. Os eventos foram considerados moderados em 2003 e 2010 (El Niño) e 2008 (La Niña). Nestes três anos não foi observada associação inversa entre a precipitação e as taxas de DDA.

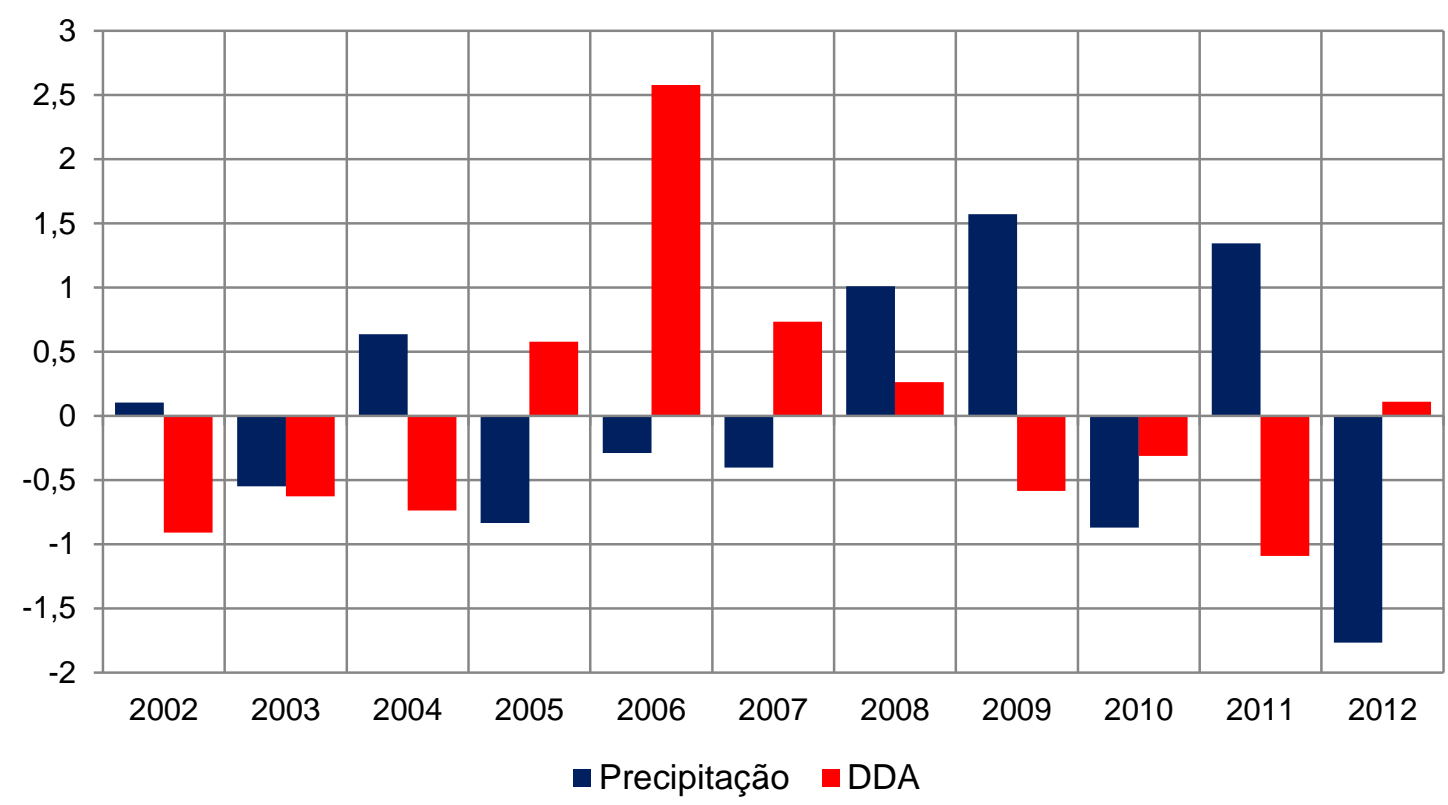

A

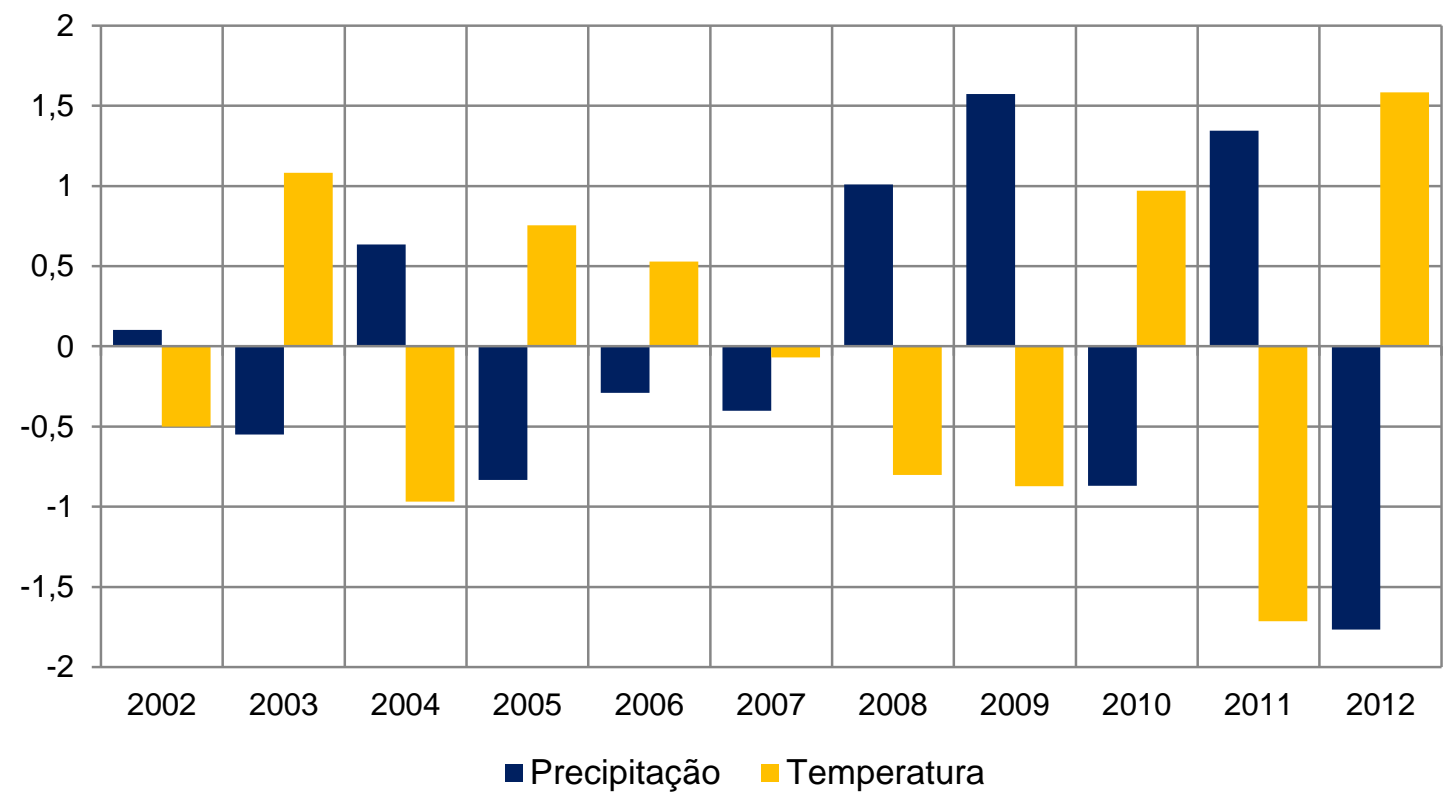

B

Figura 3.8: Comparação de dados normalizados da precipitação anual e taxa anual de DDA (A) e da precipitação anual e temperatura anual (B) na área de estudo no RN (2002-2005) e completa (2006-2012).

Nota: Média igual a 0 e desvio padrão igual a 1. Casos de DDA por cem mil habitantes. Em cada ano, foram excluídos do cálculo da média de DDA os municípios sem dados.

Fonte: Elaborado pelo autor a partir de dados da SESAP, SES, EMPARN e AESA e INMET. 
Tabela 3.3: Ocorrência dos fenômenos El Niño e La Ninã segundo o ONI (2002-2012).

\begin{tabular}{c|c}
\hline El Niño & La Niña \\
\hline $2002-2003$ & $2007-2008$ \\
$2004-2005$ & $2010-2011$ \\
$2006-2007$ & \\
$2009-2010$ & \\
\hline
\end{tabular}

Fraco $(0,5$ a 0,9 anomalia de TSM $)$
Moderado $(1,0$ a 1,4$)$
Forte $(1,5$ a 1,9$)$

Fonte: NOAA (2015).

\subsection{DISCUSSÃO}

As chuvas podem carrear contaminantes para as fontes de abastecimento de água, o que leva a ocorrência de casos de doenças diarreicas em período posterior a ocorrência das chuvas. Os patógenos podem advir do esgoto humano e também de fezes de animais. Somente $38,24 \%$ do esgoto urbano é coletado em média na área de estudo (IBGE, 2010). Fatores como a limpeza pública e a coleta de resíduos sólidos também condicionam o grau de impacto que as chuvas causam sobre a contaminação do ambiente. Até mesmo o lazer em açudes menores próximos às cidades ou residências pode contribuir à ocorrência das doenças devido a circulação dos patógenos. A maior parte dos cursos d'água na região semiárida apresenta regime intermitente, sendo as primeiras chuvas do ano responsáveis pela retomada do fluxo de água em seus leitos e consequente lavagem da bacia hidrográfica.

O impacto maior sobre a DDA é ocasionado pelas primeiras chuvas em cada ano. Fortes chuvas também aumentam os surtos de diarreia devido à contaminação dos sistemas de distribuição de água (AULD et al., 2004) incluindo água subterrânea (AMARAL et al., 2003; LEMOS et al., 2009). Façanha e Pinheiro (2005) estudaram o fenômeno da diarreia aguda no município de Fortaleza, Ceará, entre 1994 e 2001 e concluíram que fevereiro e março são os meses que apresentam as maiores taxas de incidência. Estes também são os meses de maior precipitação. Os episódios de DDA afetam todas as faixas etárias, porém de modo inversamente proporcional a faixa etária, ou seja, quanto menor a idade, maior a taxa de DDA. Nascimento et al. (2013) utilizaram dados da SESAP em um estudo descritivo da ocorrência da DDA em doze municípios do RN nos anos de 2009 e 2010. O pico da ocorrência foi verificado entre fevereiro e abril e 42,2 \% dos casos foram registrados em pacientes com até dez anos de idade. Guerrant et al. (1983) estudaram diarreias infecciosas em crianças do Nordeste do Brasil e observaram que as infecções por rotavírus estão comumente associadas com diarreia de inverno 
enquanto que a maioria das diarreias bacterianas predomina nos períodos quentes e chuvosos, sendo a Escherichia coli o patógeno mais comum. Melli e Waldman (2009) apontaram que as infecções bacterianas determinadas pela Escherichia coli patogênica assumem no verão maior importância em comunidades sem saneamento, em virtude de as águas das chuvas aumentarem a contaminação ambiental.

Se na área urbana há a contaminação dos reservatórios e da rede geral de abastecimento, as áreas rurais utilizam outras formas de abastecimento de água e são mais vulneráveis à contaminação após as primeiras chuvas. Isto porque as redes gerais abastecem somente as áreas urbanas e, em alguns casos, algumas comunidades rurais na área de estudo, distribuindo a água potável trazida pelas adutoras. Carros-pipa ou água da chuva (em geral armazenada em cisternas) estão fortemente presentes como forma de abastecimento de água (IBGE, 2010). As chuvas podem levar detritos dos telhados das edificações para dentro das cisternas da população rural, caso as devidas barreiras sanitárias não sejam aplicadas. A coleta de esgoto, por sua vez, atinge somente as áreas urbanas e está implantada em apenas alguns municípios.

$\mathrm{O}$ advento dos sintomas da diarreia não ocorre imediatamente após a infecção. Em alguns casos, há um período de uma ou mais semanas de incubação após a contaminação para o aparecimento dos sintomas. Este período é em média de um a três dias para diarreias causadas por vírus, de uma semana no caso de diarreias bacterianas e de até quatro semanas no caso de parasitas. Infecções bacterianas e diarreias causadas por parasitas tendem a se prolongar por mais tempo (MS/SVS, 2010).

Diversos são os fatores que favorecem as infecções, os quais podem estar ligados, entre outros, ao tipo climático, tipo de patógeno, condições de saneamento básico, estado imune do hospedeiro e faixa etária. Drayna et al. (2010) e Tornevi et al. (2013) encontraram defasagem de apenas alguns dias entre a precipitação e doenças gastrointestinais em seus estudos nos Estados Unidos e na Suécia, respectivamente, demonstrando um padrão de infecções tipicamente viral. No presente estudo, realizado no semiárido brasileiro, os resultados apontaram para um lag maior, o que parece estar associado a um padrão de infecções tipicamente bacteriano. Os lags encontrados concordam com o estudo de Nichols et al. (2009) (Suécia) que identificou associação de uma semana entre eventos de precipitação intensa e surtos de doenças de veiculação hídrica e de três semanas quando houve baixos índices de precipitação; e de Hashizume et al. (2007) (Bangladesh), no qual o efeito das precipitações intensas foi observado em lags mais curtos (menor número de semanas), enquanto que as 
precipitações mais bem distribuídas conduziram a lags mais longos, ou à ausência de lag. Reyburn et al. (2011) também utilizaram correlação cruzada para analisar a relação entre casos de cólera em Zanzibar (Tanzânia) e a precipitação, sendo o maior coeficiente, calculado para os lags de zero a cinco meses, obtido para o lag de um mês e correspondendo a 0,24 (95\% de confiança).

No Brasil, poucos são os trabalhos que analisam este tema. Os estudos de Andrade et al. (2009) e Portela et al. (2013) observaram a relação entre séries de dados de ocorrência de diarreia e de precipitação. O primeiro estudo encontrou correlação cruzada positiva entre a precipitação e as hospitalizações por diarreia em crianças menores de um ano de idade analisando dados mensais entre 1992 e 2001 em sete municípios do RN, que são considerados polos regionais de saúde. Também foi analisado o efeito da infraestrutura pública de saúde como o saneamento e o suprimento de água, assim como condições de renda da população e alfabetização, tendo sido encontrada correlação com as variáveis pobreza e inflação. Já Portela et al. (2013) não encontraram correlação linear simples entre as séries temporais mensais de diarreia e precipitação no município de Campina Grande/PB analisando dados de 2006 a 2008.

Para Bandyopadhyay et al. (2012), assim como as enchentes, secas que causam escassez de água também contribuem para a ocorrência de DDA. Em sua pesquisa na África Subsaariana os autores também incluíram os efeitos de um lag de um mês no tempo que, contudo, mostrou pouco efeito. Segundo os autores é necessário haver um ajuste refinado entre os dados climáticos e os registros de doenças, para obtenção de melhores resultados. Uma análise em escala espacial de detalhe também é fator importante. A metodologia empregada neste trabalho, cuja análise foi efetuada por município e por semana epidemiológica, possibilitou tal ajuste.

A hipotése de que há associação defasada no tempo entre as variáveis climáticas e os casos de DDA pode ser utilizada em estudos de modelagem da defasagem distribuída para predição da DDA. Os modelos de defasagem distribuída constituem uma técnica especializada em examinar as relações entre variáveis que envolvem algum atraso, ou seja, partem do princípio que a dependência de uma variável resposta $Y$ em relação a uma variável explicativa $X$ não é instantânea (ALMON, 1965). Souza et al. (2007) utilizaram um modelo de defasagem distribuída para explicar o comportamento estatístico da incidência do dengue usando pluviometria na $\mathrm{PB}$, no entanto o modelo não atendeu aos critérios de validade estatística e também superestimou a incidência. Já nesta pesquisa, em relação à DDA, a análise de correlação cruzada com a precipitação considerando-se os dados disponíveis apontou que há 
validade estatística. Desse modo, a aplicação de modelagem em estudos futuros pode gerar resultados válidos, e que sejam relevantes para o direcionamento de políticas públicas.

Os anos mais secos na série temporal de estudo apresentaram, em geral, maior taxa de casos de DDA e, vice-versa. Baixos índices de precipitação podem dificultar a diluição dos efluentes e ocasionar cortes no sistema de distribuição de água ou falta de água nas cisternas de uso da população rural, além de alterar as características de qualidade da água dos reservatórios de abastecimento. Os períodos de seca também contribuem para a ingestão e/ou usos da água de fontes alternativas de abastecimento, e utilização de águas brutas sem qualquer tratamento, dada a indisponibilidade de água das fontes convencionais.

Os eventos de El Niño e La Niña parecem ter influência na relação entre os totais de precipitação anuais e as taxas anuais de DDA. Há evidências de que ocorrem anomalias de TSM no Atlântico tropical durante o outono dos anos seguintes a El Niño e La Niña, principalmente ao Norte da Linha do Equador (ENFIELD; MAYER, 1997). Estas anomalias podem favorecer a ocorrência de uma estação chuvosa deficiente no Nordeste do Brasil após o El Niño, pois enfraquecem os alísios de nordeste no Atlântico Norte e fortalecem os de sudeste no Atlântico Sul, e com chuva acima do normal após La Niña (ALVES et al., 1997), como foi identificada na série temporal desse estudo (2002-2012).

Os dados utilizados não permitiram a definição dos patógenos causadores da DDA, por se tratar de um estudo ecológico. Herrador et al. (2015) ressaltam que, como os eventos não ocorrem simultaneamente, usar o mesmo lag temporal para todos os casos não é o mais adequado dada a variação nos períodos de incubação da doença devido aos diferentes patógenos.

As anomalias de precipitação observadas na área e no período de estudo, que dificultam o entendimento das correlações encontradas entre a precipitação e a DDA, fogem ao contexto climatológico normal e ocorreram apenas em alguns municípios, trazendo outliers para a análise estatística dos dados que, todavia, devem ser preservados. Uma filtragem na série temporal de dados, como o agrupamento mensal, poderia eliminar a flutuação dos dados, que pode ser fruto de variáveis aleatórias. Como os dados são apresentados por semana epidemiológica, o que é uma resolução fina, há também muito ruído. Porém, a agregação de dados reduz a variação e suaviza as relações existentes entre as variáveis. O ruído é importante para a análise da pesquisa, pois é evidenciado de modo mais intenso sobretudo nos dados de precipitação e representa os eventos anômalos de chuvas intensas registradas. 
Quando eventos anômalos de precipitações intensas foram registrados em apenas alguns municípios da área de estudo não foi observado impacto sobre os casos de DDA, mesmo nesses municípios. As diferenças detalhadas no comportamento pluviométrico entre as sub-regiões da pesquisa podem ser importantes para a explicação da DDA nessas sub-regiões, no entanto fogem ao escopo deste trabalho. Ademais, a existência de registros falhos no programa de MDDA e a subnotificação são problemas que ocorrem e devem ser considerados. Pereira e Cabral (2008) apontam que a ausência da notificação pode ocorrer por falta de registro ou pela decisão da população de ministrar tratamentos caseiros para as doenças. O Ministério da Saúde também afirma que somente são monitorados os casos atendidos em algumas unidades de saúde representativas para atendimento de DDA nos municípios, cujo número pode ser de apenas uma (MS/SVS, 2010). A definição das unidades de saúde sentinelas é feita pela vigilância epidemiológica das secretarias municipais da saúde (MS/SVS, 2015). No entanto, como a subnotificação em geral ocorre em todos os municípios, consequentemente, no aspecto temporal, as trajetórias mantém-se semelhantes.

\subsection{CONSIDERAÇÕES FINAIS}

Os resultados obtidos permitem auxiliar no entendimento dos padrões temporais de ocorrência da DDA na região semiárida brasileira. Em uma análise intranual, episódios de DDA são registrados após as chuvas e seu comportamento, na maioria dos anos, é similar ao da precipitação, com uma defasagem média de três a cinco semanas entre os eventos. Dessa forma, é recomendado maior cuidado por parte da população e vigilância mais intensa dos órgãos de saúde e vigilância da qualidade da água nesses períodos e, no sentido de reduzir a magnitude do problema, maior intervenção das políticas públicas de expansão do saneamento básico na região.

A presença ou não da chuva ao longo do ano constitui um fator que explica o padrão de ocorrência da doença diarreica. Em uma análise interanual anos mais secos tendem a apresentar taxas mais altas de DDA, ao passo que anos mais chuvosos, taxas mais baixas. Entretanto este não é o único fator e outras variáveis, como aquelas relacionadas ao abastecimento de água, podem auxiliar à investigação. 
Em resumo, observa-se que o clima é um dos fatores relevantes para o entendimento da dinâmica de ocorrência da DDA, assim como de outras doenças cujo comportamento já foi amplamente estudado pela comunidade científica, como o dengue, a malária, entre outras. Dessa forma, o estudo pode auxiliar os sistemas de saúde pública na prevenção da doença e no preparo para o atendimento e tratamento dos casos, principalmente em um período onde se observam cada vez mais anomalias climáticas e, os prognósticos ligados às mudanças do clima apontam para grandes impactos sobre a saúde das populações.

Não foi verificada influência da temperatura sobre as taxas de DDA, sendo que o comportamento dessa variável está associado diretamente ao da precipitação na área de estudo. Embora o clima seja relevante, outras variáveis e peculiaridades regionais são relevantes no entendimento da ocorrência da DDA na área de estudo e demandam estudos adicionais, notadamente desagregando os dados por subconjuntos de municípios. A análise de correlação cruzada poderá ser efetuada utilizando outros indicadores, como por exemplo o volume de água dos reservatórios de abastecimento humano.

Em pesquisas complementares a esta, a associação entre os dados da DDA e a precipitação também poderá ser analisada em outras áreas de estudo, com comportamentos climáticos semelhantes ou distintos do recorte espacial escolhido na região semiárida do Brasil. No entanto, para realizar tal estudo se faz necessário acesso completo aos bancos de dados de estações pluviométricas no território nacional, assim como acesso completo aos dados de DDA através do SIVEP-DDA e/ou secretarias estaduais de saúde. Por meio do SIVEP-DDA os casos podem ser desagregados por unidade de saúde e faixa etária. Desse modo a influência da precipitação pode ser analisada sobre a faixa etária, além da análise da ocorrência do fenômeno em escala intramunicipal. Sugere-se, portanto, que as autoridades públicas no âmbito do Ministério da Saúde facilitem o acesso a estes dados, pois embora sejam gestoras do sistema, sempre quando contatadas informaram que o pedido de coleta deveria ser feito aos órgãos que alimentam o sistema em cada um dos Estados.

\section{REFERÊNCIAS BIBLIOGRÁFICAS}

AGÊNCIA NACIONAL DE ÁGUAS (ANA). Atlas Brasil: Abastecimento Urbano de Água. Brasília: ANA, 2011. Disponível em: http://atlas.ana.gov.br/Atlas/forms/Home.aspx. Acesso em: 20 abr. 2013. 
ALMON, S. The distributed lag between capital appropriations and expenditures. Econometrica, v. 33, p. 178-96. 1965.

ALVES, J. M. B.; SOUZA, E. B.; REPELLI, C. A.; VITORINO, M. I.; FERREIRA, N. S. Episódios de La Niña na bacia do Oceano Pacífico Equatorial e a distribuição sazonal e intrasazonal das chuvas no setor norte do Nordeste brasileiro. Revista Brasileira de Meteorologia, v. 12, n. 1, p. 77-82, 1997.

AMARAL, L. A.; NADER FILHO, A.; ROSSI JÚNIOR, O. D.; FERREIRA, F. L.; BARROS, L. S. Drinking water in rural farms as a risk factor to human health. Revista de Saúde Pública, v. 37, n.4, p. 510-514, 2003.

ANDRADE, I. G.; QUEIROZ, J. W.; CABRAL, A. P.; LIEBERMAN, J. A.; JERONIMO, S. $M$. Improved sanitation and income are associated with decreased rates of hospitalization for diarrhoea in Brazilian infants. Transactions of the Royal Society of Tropical Medicine and Hygiene. v. 103, p. 506-511, 2009.

AULD, H.; MACLVER, D.; KLAASSEN, J. Heavy rainfall and waterborne disease outbreaks: the Walkerton example. Journal of Toxicology and Environmental Health A, v. 67, p. 1879-87, 2004.

BANDYOPADHYAY, S.; KANJI, S.; WANG, L. The impact of rainfall and temperature variation on diarrheal prevalence in Sub-Saharan Africa. Applied Geography, v. 33, p. 63 $72,2012$.

BOX, G. E. P.; JENKINS, G. M.; REINSEL, G. C. Time series analysis: forecasting and control. $4^{a}$ ed. New Jersey: John Wiley \& Sons, 2008. p. 474-480.

CAIRNCROSS, S.; FEACHEN, R. G. Environmental Health Engineering in the Tropics: An Introductory Text. $2^{a}$ ed. Chichester: Wiley, 1993, 324p.

CHECKLEY, W.; EPSTEIN, L. D.; GILMAN, R. H.; FIGUEROA, D.; CAMA, R. I.; PATZ, J. A.; BLACK, R. E. Effect of El Nino and ambient temperature on hospital admissions for diarrhoeal diseases in Peruvian children. Lancet, v. 355, n. 9202, p. 442-450, 2000.

CHEN, M. J.; LIN, C. Y.; WU, Y. T.; WU, P. C.; LUNG, S. C.; SU, H. J. Effects of extreme precipitation to the distribution of infectious diseases in Taiwan, 1994-2008. Plos One, v. 7 , n. 6, e $34651,2012$.

CHOU, W. C.; WU, J. L.; WANG, Y.C.; HUANG, H.; SUNG, F. C.; CHUANG, C. Y. Modeling the impact of climate variability on diarrhea associated diseases in Taiwan (19962007). Science of the Total Environment. v. 409, n. 1, p. 43-51, 2010. 
CURRIERO, F. C.; PATZ, J. A.; ROSE, J. B.; LELE, S. The association between extreme precipitation and waterborne disease outbreaks in the United States, 1948-1994. American Journal of Public Health, v. 91, n. 8, p. 1194-1199, 2001.

DIALLO, M. B. C.; ANCENO, A. J.; TAWATSUPA, B.; TRIPATHI, N. K.; WANGSUPHACHART, V.; SHIPIN, O. V. GIS-based analysis of the fate of waste-related pathogens Cryptosporidium parvum, Giardia lamblia and Escherichia coli in a tropical canal network. Journal of Water and Health, v. 7, n. 1, p. 133-143, 2009.

DRAYNA, P.; MCLELLAN, S. L.; SIMPSON, P.; LI, S. H.; GORELICK, M. H. Association between rainfall and pediatric emergency department visits for acute gastrointestinal illness. Environmental Health Perspectives, v. 118, n. 10, p. 1439-1443, 2010.

D’SOUZA, R. M.; HALL, G.; BECKER, N. G. Climatic factors associated with hospitalizations for rotavirus diarrhoea in children under 5 years of age. Epidemiology and Infection, v. 136, p. 56-64, 2008.

EISENBERG, M. C.; KUJBIDA, G.; TUITE, A. R.; FISMAN, D. N.; TIEN, J. H. Examining rainfall and cholera dynamics in Haiti using statistical and dynamic modeling approaches. Epidemics, v. 5, n. 4, p. 197-207, 2013.

ENFIELD, D. B.; MAYER, D. A. Tropical Atlantic sea surface temperature variability and its relation to El Niño-Southern Oscillation. Journal of Geophysical Research, v. 102, n. C1, p. 929-945, 1997.

FAÇANHA, M. C.; PINHEIRO, A. C. Comportamento das doenças diarréicas agudas em serviços de saúde de Fortaleza, Ceará, Brasil, entre 1996 e 2001. Cadernos de Saúde Pública, v. 21, n. 1, p. 49-54, 2005.

GUERRANT, R. L.; KIRCHHOFF, L. V.; SHIELDS, D. S.; NATIONS, M. K.; LESLIE, J.; SOUZA, M. A.; ARAUJO, J. G.; CORREIA, L. L.; SAUER, K. T.; MCCLELLAND, K. E.; TROWBRIDGE, F. L.; HUGHES, J. M. Prospective study of diarrheal illness in Northeastern Brazil: patterns of disease, nutritional impact, etiologies and risk factors. Journal of Infectious Diseases, v. 148, n. 6, p. 986-997, 1983.

; HUGHES, J. M.; LIMA, N. L. ; CRANE, J. Diarrhea in developed and developing countries: magnitude, special setting and etiologies. Reviews of Infectious Diseases, v. 12, sup. 1, p. 41-50, 1990.

GRIMM, A. M.; FERRAZ, S. E. T.; CARDOSO, A. O. Influência de El Niño sobre a chuva no Nordeste Brasileiro. In: X Congresso Brasileiro de Meteorologia e VII Congresso da FLISMET, Anais, Brasília, 1998a. 
Influência de La Niña sobre a chuva no Nordeste Brasileiro. In: X Congresso Brasileiro de Meteorologia e VII Congresso da FLISMET, Anais, Brasília, 1998b.

HASHIZUME, M. B.; ARMSTRONG, S.; HAJAT, Y.; WAGATSUMA, A. S.; FARUQUE, A. S. G.; HAYASHI, T.; SACK, D. A. Association between climate variability and hospital visits for non-cholera diarrhoea in Bangladesh: effects and vulnerable groups. International Journal of Epidemiology, v. 36, n. 5, p. 1030-1037, 2007.

HERRADOR, B. R. G. ; BLASIO, B. F.; MACDONALD, E.; NICHOLS, G.; SUDRE, B.; VOLD, L.; SEMENZA, J. C.; NYGARD, K. Analytical studies assessing the association between extreme precipitation or temperature and drinking water-related waterborne infections: a review. Environmental Health, v. 14, n. 1, 14 :29, 2015.

INSTITUTO BRASILEIRO DE GEOGRAFIA E ESTATÍSTICA (IBGE). Censo Demográfico 2010: Resultados do Universo - Características da População e dos Domicílios. Rio de Janeiro: IBGE, 2010. Disponível em: http://www.sidra.ibge.gov.br/cd/cd2010universo. asp?o=7\&i=P. Acesso em: 15 mar. 2015.

INSTITUTO NACIONAL DE METEOROLOGIA (INMET). BDMEP - Banco de Dados Meteorológicos para Ensino e Pesquisa. Brasília: INMET, 2015. Disponível em: http://www.inmet.gov.br/projetos/rede/pesquisa/. Acesso em: 15 mar. 2015.

INSTITUTO NACIONAL DE PESQUISAS ESPACIAIS (INPE). CENTRO DE PREVISÃO DO TEMPO E ESTUDOS CLIMÁTICOS (CPTEC). Infoclima. Cachoeira Paulista: INPE/CPTEC, 2015. Disponível em: http://infoclima.cptec.inpe.br/. Acesso em: 15 mar. 2015 .

LEMOS, E. C. L.; CAVALCANTI, I. N.; SABADIA, J. A. B.; GOMES, M. C. R.; MEDEIROS, F. W.; SANTOS, D. M. Qualidade das águas subterrâneas e doenças de veiculação hídrica na porção sudoeste do município de Fortaleza, Ceará, Brasil. Revista de Geologia, v. 22, n. 2, p. 151-165, 2009.

LLOYD-EVANS, N.; PICKERING, H. A.; GOH, S. G.; ROWLAND, M. G; Food and water hygiene and diarrhoea in young Gambian children: a limited case control study. Transactions of the Royal Society of Tropical Medicine and Hygiene, v. 78, p. 209-211, 1984.

MELLI, L. C. F. L.; WALDMAN, E. A. Temporal trends and inequality in under-5 mortality from diarrhea. Jornal de Pediatria, v. 85, n. 1, p. 21-27, 2009.

MINCIS, M.; MINCIS, R.; CALICHMAN, S. Como diagnosticar e tratar a diarréia aguda. Revista Brasileira de Medicina, v. 64, n. 10, p. 450-460, 2007. 
MINISTÉRIO DA INTEGRAÇÃO NACIONAL (MI). Nova Delimitação do Semi-Árido Brasileiro. Brasília: MI, 2005. Disponível em: http://www.mi.gov.br/c/document_library/ get_file?uuid=0aa2b9b5-aa4d-4b55-a6e1-82faf0762763\&groupId =24915. Acesso em: 02 mar. 2013.

MINISTÉRIO DA SAÚDE (MS). DEPARTAMENTO DE INFORMÁTICA DO SISTEMA ÚNICO DE SAÚDE (DATASUS). Informações de Saúde (TABNET). Brasília: MS, 2015. Disponível em: http://www2.datasus.gov.br/DATASUS/index.php. Acesso em: 15 mar. 2015.

MINISTÉRIO DA SAÚDE (MS). SECRETARIA DE VIGILÂNCIA EM SAÚDE (SVS). Capacitação em monitorização das doenças diarréicas agudas - MDDA: manual do monitor. Brasília: MS, 2010. Disponível em: http://bvsms.saude.gov.br/bvs/publicacoes/ capacitacao_monitoramento_diarreicas_monitor.pdf. Acesso em: 15 mar. 2015.

Doença Diarreica Aguda (DDA). Brasília: MS, 2015. Disponível em: http://portalsaude. saude.gov.br/index.php/o-ministerio/principal/secretarias/svs/doencadiarreica-aguda-dda. Acesso em: 15 mar. 2015.

MORRIS, A.; GOZLAN, R. E.; HASSANI, H.; ANDREOU, D.; COUPPIÉ, P.; GUÉGAN, J. F. Complex temporal climate signals drive the emergence of human waterborne disease.

Emerging Microbes \& Infections, v. 3, e56, 2014.

MOTTA, M. E. F. A.; SILVA, G. A. P. Diarreia por parasitas. Revista Brasileira de Saúde Materna Infantil, v. 2, n. 2, p. 117-127, 2002.

NASCIMENTO, V. S. F.; ARAÚJO, M. F. F.; NASCIMENTO, E. D.; SODRÉ NETO, L. Epidemiologia de doenças diarreicas de veiculação hídrica em uma região semiárida brasileira. Conscientiae Saúde, v. 12, n. 3, p. 353-361, 2013.

NICHOLS, G.; LANE, C.; ASGARI, N.; VERLANDER, N. Q.; CHARLETT, A. Rainfall of drinking water related disease and in England and Wales. Journal of Water and Health, v. 7, n. 1, p. 1-8, 2009.

NIEHAUS, M. D.; MOORE, S. R.; PATRICK, P. D.; DERR, L.; LORNTZ, B.; LIMA, A. A.; GUERRANT, R. L. Early childhood diarrhea is associated with diminished cognitive function 4 to 7 years later in children in a northeast Brazilian shantytown. American Journal of Tropical Medicine and Hygiene, v. 66, n. 5, p. 590-593, 2002.

NATIONAL OCEANIC AND ATMOSPHERIC ADMINISTRATION (NOAA). Historical EI Nino/La Nina episodes (1950-present): Cold \& Warm Episodes by Season (ERSSTv4). College Park: NOAA/National Weather Service/Climate Prediction Center, 2015. Disponível em: http://www.cpc.ncep.noaa.gov/products/analysis_monitoring/ensostuff/ensoyears.shtml. Acesso em: 15 out. 2015. 
PASCUAL, M.; RODÓ, X.; ELLNER, S. P.; COLWELL, R. R.; BOUMA, M. J. Cholera dynamics and El Niño-southern oscillation. Science, v. 289, p. 1766-1769, 2000.

PEREIRA, I. V.; CABRAL, I. E. Diarréia aguda em crianças menores de um ano: subsídios para o delineamento do cuidar. Escola Anna Nery Revista de Enfermagem, v. 12, n. 2, p. 224-229, 2008.

PFALTZGRAFF, P. A. S. Geodiversidade do Estado do Rio Grande do Norte. Recife: CPRM, 2010. 227p.

PORTELA, L.A.; LEITE, V.D.; PEREIRA, C.F.; ROCHA, E.M.F.M. Comportamento das doenças diarréicas nas mudanças sazonais no município de Campina Grande - PB. Hygeia, v. 9, n. 17, p. 116-128, 2013.

PRÜSS-ÜSTÜN, A.; CORVALÁN, C. Preventing disease through healthy environments. Towards an estimate of the environmental burden of disease. Genebra: World Health Organization (WHO), 2006. 106p.

REYBURN, R.; KIM, D. R.; EMCH, M.; KHATIB, A.; SEIDLEIN, L.; ALI, M. Climate Variability and the Outbreaks of Cholera in Zanzibar, East Africa: A Time Series Analysis. American Journal of Tropical Medicine and Hygiene, v. 84, n. 6, p. 862-869, 2011.

RODÓ, X.; PASCUAL, M.; FUCHS, G.; FARUQUE, A. S. G. ENSO and cholera: A nonstrationary link related to climate change? Proceedings of the National Academy of Sciences, v. 99, n. 20, p. 12901-12906, 2002.

SALATI, E.; LEMOS, H. M.; SALATI, E. Água e o desenvolvimento sustentável. In: REBOUÇAS, A. C.; BRAGA, B.; TUNDISI, J. G. (orgs.) Águas doces no Brasil: capital ecológico, uso e conservação. $3^{\text {a }}$ ed. São Paulo: Escrituras, 2006, p. 37-62.

SÃO PAULO. GOVERNO DO ESTADO. SECRETARIA DE ESTADO DA SAÚDE DE SÃO PAULO. Semanas Epidemiológicas: publicações DOE. São Paulo: Centro de Vigilância Epidemiológica, 2015. Disponível em: http://www.cve.saude.sp.gov.br/htm/ cve_se03.htm. Acesso em 15 mar. 2013.

SINGH, R.; HALES, S.; WET, N.; RAJ, R.; HEARNDEN, M.; WEINSTEIN, P. The influence of climate variation and change on diarrheal disease in the Pacific Islands. Environmental Health Perspectives, v. 109, n. 2, p. 155-159, 2001.

SOUZA, I. C. A.; VIANNA, R. P. T.; MORAES, R. M. Modelagem da incidência do dengue na Paraíba, Brasil, por modelos de defasagem distribuída. Cadernos de Saúde Pública, Rio de Janeiro, v. 23, n. 11, p. 2623-2630, 2007. 
TORNEVI, A.; AXELSSON, G.; FORSBERG, B. Association between Precipitation Upstream of a Drinking Water Utility and Nurse Advice Calls Relating to Acute Gastrointestinal Illnesses. Plos One, v. 8, n. 7, e69918, 2013.

VERONESI, R.; FOCACCIA, R. Tratado de Infectologia. $3^{\text {a }}$ ed. São Paulo: Atheneu, 2005. 2169p.

WORLD GASTROENTEROLOGY ORGANISATION (WGO). Diarreia aguda em adultos e crianças: uma perspectiva mundial. Milwaukee: WGO, 2012. 25p.

ZHANG, Y.; BI, P.; HILLER, J. E. Climate variations and Salmonella infection in Australian subtropical and tropical regions. Science of the Total Environment, v. 408, p. 524-530, 2010. 


\section{PADRÕES ESPAÇO-TEMPORAIS DAS CONDIÇÕES DE ABASTECIMENTO DE ÁGUA E DA INCIDÊNCIA DA DOENÇA DIARREICA AGUDA EM UM RECORTE ESPACIAL DO SEMIÁRIDO BRASILEIRO DE 2002 A 2014}

RESUMO: Esta pesquisa analisou condições de abastecimento de água em 71 municípios do semiárido brasileiro, cujas fontes principais de água correspondem a quatro diferentes mananciais, os açudes Armando Ribeiro Gonçalves, Gargalheiras e a Lagoa do Bonfim, localizados no estado do Rio Grande do Norte e, o açude Boqueirão, na Paraíba, e dos padrões anuais de incidência da doença diarreica aguda (DDA) nesses municípios, no período de 2002 a 2014. Foi analisada a relação de indicadores associados as diferentes fontes de abastecimento de água verificadas na área de estudo com as taxas de DDA observadas, como o percentual de atendimento da rede geral, o número de cisternas construídas e a quantidade de carros-pipa em operação. Foi verificado que municípios localizados nas extremidades das redes de adução dos sistemas de abastecimento de água possuem menores índices de cobertura da rede geral e, por sua vez, demandam maior aporte de carros-pipa. Alguns desses municípios também foram os que apresentaram as taxas mais altas de DDA. No Rio Grande do Norte, as maiores taxas foram observadas na área abastecida pela Lagoa do Bonfim e na Paraíba, nos municípios atendidos pelo Sistema Adutor do Cariri. Ao longo da série temporal de estudo as maiores taxas de DDA foram observadas em 2013, notadamente a partir de abril desse ano e na área abastecida pela Lagoa do Bonfim, após implantação de um rodízio no fornecimento de água a esses municípios. A existência de um manancial de água de boa qualidade parece não ser a variável que contribui para a ocorrência de menores taxas da doença, mas sim, características físicas e operacionais dos sistemas adutores de abastecimento e a disponibilidade contínua de água à população, em quantidade adequada, ao longo do tempo, principalmente em períodos de escassez hídrica como o ocorrido de 2012 a 2014. A pesquisa concluiu que indicadores ligados ao abastecimento de água são importantes na análise dos padrões espaço-temporais de ocorrência das doenças diarreicas, em especial na região semiárida onde as infraestruturas de abastecimento de água são complexas e os impactos de períodos de escassez hídrica sobre a saúde das populações parecem ser expressivos.

Palavras-chave: abastecimento de água, açude, adutora, carro-pipa, diarreia, semiárido. 


\subsection{INTRODUÇÃO}

O acesso à água e saneamento é uma meta básica de garantia da sustentabilidade ambiental classificada como um dos Objetivos de Desenvolvimento do Milênio (PNUD, 2012). O problema da falta de água de boa qualidade tende a crescer devido à maior poluição dos sistemas ambientais e as mudanças climáticas. Segundo Vaz (1999), 40\% das mortes de crianças por doença diarreica aguda (DDA) estão relacionadas com a falta de água própria para consumo. Cheng et al. (2012) estudaram como o acesso a água potável e ao saneamento contribuem para o decréscimo da mortalidade por diarreia em crianças de 193 países do mundo e concluíram que o aumento do acesso à agua potável tem associação estatística significativa com esses decréscimos. Porém os autores colocam questões importantes, como: o acesso a uma água potável significa acesso a água de boa qualidade?

A relação entre as doenças de veiculação hídrica e o saneamento básico é amplamente conhecida e documentada na literatura, desde o clássico trabalho de John Snow em Londres (1855). Teixeira e Pungirum (2005) estudaram a associação entre a cobertura dos sistemas de abastecimento de água e indicadores epidemiológicos em crianças de 44 países da América Latina e Caribe, encontrando uma correlação inversamente proporcional entre a taxa de mortalidade infantil e a cobertura do abastecimento de água. Guimarães et al. (2013) encontraram uma relação inversamente proporcional entre a cobertura de saneamento e a taxa de internação por DDA nas Unidades da Federação entre 1996 e 2009. Queiroz et al. (2009) analisaram a correlação entre a ocorrência de DDA e a qualidade da água para consumo humano em Vitória, Espírito Santo, monitorada pela prefeitura e pela companhia de abastecimento estadual. Os resultados encontraram associações significativas entre a diarreia e os parâmetros de turbidez e coliformes, totais e termotolerantes.

Cada dólar investido em acesso a água e saneamento tem um retorno econômico de três a quatro dólares, conforme a região, segundo uma análise custo-benefício feita pela OMS (EVANS et al., 2004). Portanto, a universalização do saneamento representa um grande ganho para a saúde. O custo da universalização dos serviços de esgoto no Brasil seria de 313,2 bilhões de reais a preços de 2013 (TRATA BRASIL; CEBDS, 2014). A expansão do saneamento de 4,1\% ao ano no início da década de 2010 perdeu velocidade em relação à década de 2000 (4,6\% ao ano), o que distancia ainda mais o país das metas de universalização dos serviços de 
saneamento básico. A universalização causaria uma economia anual de 27,3 milhões de reais pelo SUS em gastos de internação por infecções gastrointestinais, redução de $23 \%$ no número total de dias de afastamento dos trabalhadores por diarreia e redução de $6,8 \%$ no atraso escolar dos estudantes (TRATA BRASIL; CEBDS, 2014).

No Brasil, o suprimento de água tratada é deficitário, a infraestrutura sanitária é precária e as práticas de higiene não são amplamente adotadas pela população, o que aumenta o risco de transmissão de doenças (VASCONCELOS et al., 2006; ZEILHOFER et al., 2007). Dentre as diversas intervenções para redução de doenças, as mais efetivas são referentes à qualidade de água (FEWTRELL et al. 2005) ou quantidade de água, pois a frequência de lavagem das mãos é menor quando a água é escassa (BANDYOPADHYAY et al., 2012).

No período 1986-1996, a região Nordeste do Brasil não teve redução significativa de morbidade por diarreia, em contraposição com o restante do país (SASTRY; BURGARD, 2005). O risco de uma criança ter diarreia manteve-se o mesmo, apesar das intervenções de suprimento de água e saneamento. Enquanto o risco de contrair diarreia foi 33\% mais baixo em 1996 para o restante do Brasil, no Nordeste foi $72 \%$ mais alto.

Tendo em vista as considerações aqui efetuadas, o objetivo desta pesquisa é analisar o comportamento da distribuição espaço-temporal das taxas de incidência da DDA em uma área abastecida por quatro mananciais do semiárido brasileiro e sua relação com as diferentes fontes de abastecimento de água da população e sistemas de distribuição, bem como a disponibilidade de água ao longo do tempo. A definição da fonte de abastecimento de água de um determinado território e da população sob risco torna-se fundamental. Conhecer a estrutura e a dinâmica espacial permite o planejamento de ações de controle e alocação de recursos. Também auxilia a tomada de decisão para a definição das regiões mais críticas, tendo em vista a dificuldade de remediar o problema em todos os sistemas em que é verificado (QUEVEDO; PAGANINI, 2011). Nesta pesquisa, são utilizadas técnicas de geoprocessamento para a análise espacial dos fatores de agravos à saúde e das populações expostas ao risco (BARCELLOS; BASTOS, 1996).

\subsection{MATERIAL E MÉTODOS}

\subsection{1 Área de Estudo}


Neste estudo são analisados os municípios cuja água provém de quatro mananciais de abastecimento de água do semiárido: açude Armando Ribeiro Gonçalves (ARG), açude Epitácio Pessoa (ou Boqueirão) (EPB), açude Marechal Dutra (ou Gargalheiras) (MDG) e Lagoa do Bonfim (LDB). Esses mananciais se subdividem em sete sistemas integrados e dois sistemas isolados de abastecimento, atendendo a 71 municípios, sendo 54 no Estado do Rio Grande do Norte e 17 no Estado da Paraíba (Figura 4.1). Tais municípios foram selecionados, pois a água proveniente desses açudes corresponde a única fonte de abastecimento urbano, segundo dados do Atlas Brasil de Abastecimento Urbano de Água (ANA, 2011).

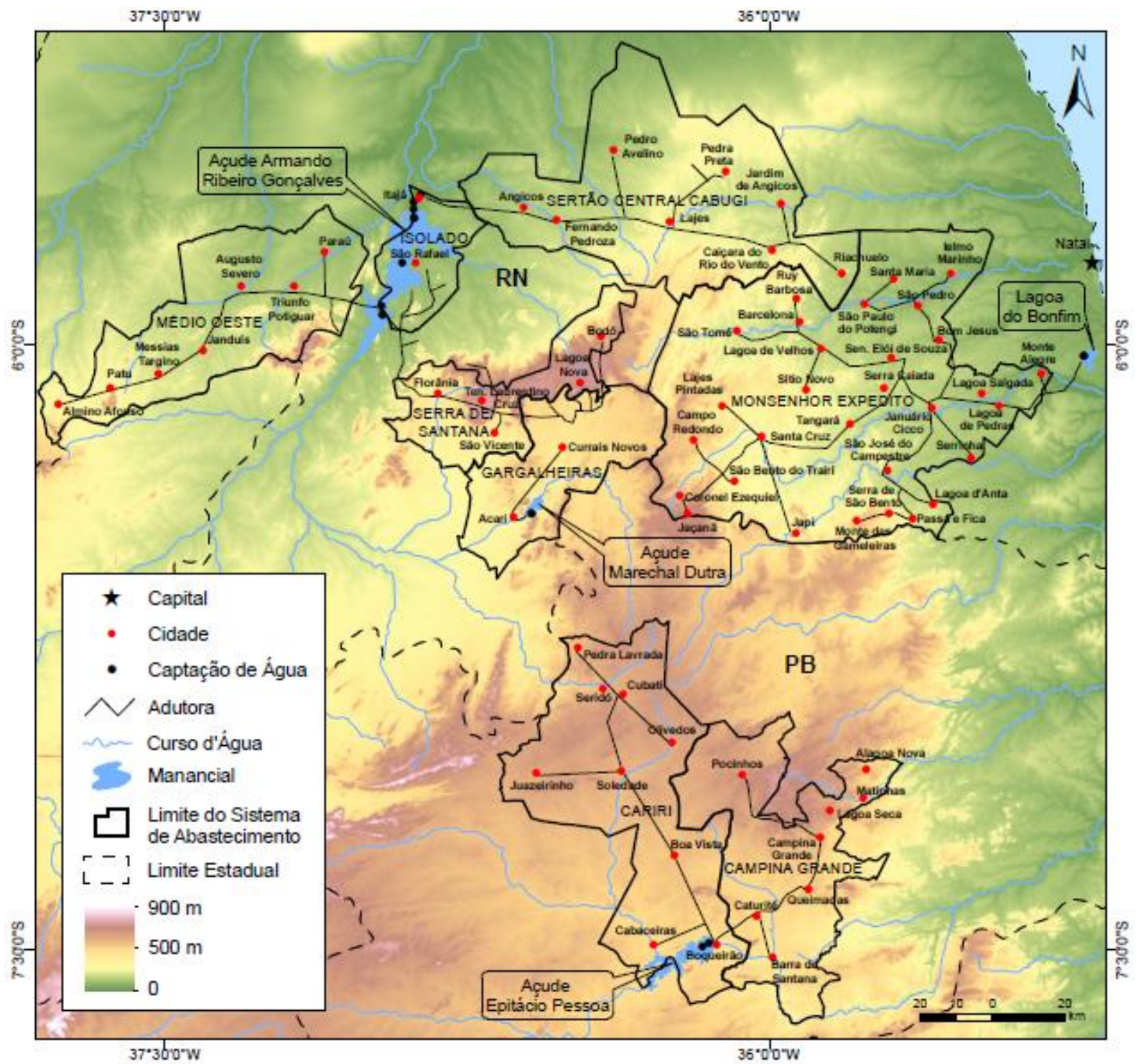

Figura 4.1: Localização da área de estudo.

Fonte: Elaborado pelo autor a partir de imagem SRTM e dados de ANA (2011). 
O açude ARG corresponde ao terceiro maior reservatório de abastecimento da Região Nordeste e ao maior do Estado do Rio Grande do Norte. Ele barra o Rio Piranhas/Açu, que receberá água do Eixo Norte do PISF. O açude possui uma área superficial de $181,75 \mathrm{~km}^{2} \mathrm{e}$ constitui fonte de água para os sistemas integrados Médio Oeste, Serra de Santana e Sertão Central Cabugi e para os sistemas isolados que abastecem as cidades de Itajá e São Rafael, totalizando aproximadamente 155 mil habitantes.

O açude EPB é o segundo maior reservatório do Estado da Paraíba, barrando as águas dos rios Taperoá e Paraíba, com área superficial de 43,57 km². O Rio Paraíba receberá água do Eixo Leste do PISF. O açude EPB abastece, através dos sistemas integrados Cariri e Campina Grande, aproximadamente 600 mil habitantes.

O terceiro e menor dentre os açudes estudados é o MDG, que barra o Rio Acauã, afluente do Rio Seridó que, por sua vez, é afluente do Rio Piranhas. Sua área superficial é de 7,62 km² e abastece, através de um sistema integrado, aproximadamente 55 mil habitantes das cidades de Acari e Currais Novos.

A LDB é um reservatório de água de origem natural, localizado na Zona da Mata potiguar, área da Formação Geológica Barreiras, que abastece, a partir de captação em poços e captação flutuante, aproximadamente 275 mil habitantes em trinta cidades do Agreste potiguar através da Adutora Monsenhor Expedito. A área abastecida pela Lagoa do Bonfim foi incluída na pesquisa como área de controle. A hipótese é de que, tendo em vista ser a LDB um manancial de água de boa qualidade, localizado na região da Zona da Mata, a região por ela abastecida deve apresentar menor incidência da DDA. O estudo de Duarte et al. (1999) classificou a LDB como sendo oligotrófica, aplicando o Índice de Estado Trófico Modificado (IET $\mathrm{M}$ ), que é adequado para a determinação do estado trófico de lagos em regiões de clima tropical.

Somente o Sistema Integrado Serra de Santana e os sistemas isolados que abastecem as cidades de Itajá e São Rafael não possuem estação de tratamento de água (ETA) convencional, dispondo apenas de sistemas de filtração de água. A Tabela 4.1 apresenta algumas características dos sistemas integrados de abastecimento de água da área de estudo."

\footnotetext{
* Os esquemas detalhados dos sistemas de abastecimento de água da área de estudo constam do Anexo A da tese.
} 
Tabela 4.1: Características dos sistemas integrados de abastecimento de água da área de estudo.

\begin{tabular}{c|c|c|c|c}
\hline Sistema Adutor & Início da Operação & $\begin{array}{c}\text { Extensão } \\
(\mathbf{k m})\end{array}$ & $\begin{array}{c}\text { Tipo de } \\
\text { Tratamento }\end{array}$ & $\begin{array}{c}\text { Vazão } \\
(\mathbf{l} / \mathbf{s})\end{array}$ \\
\hline Arnobio Abreu (Médio Oeste) & Ago/2000 & 153,35 & ETA Convencional & 78,9 \\
\hline $\begin{array}{c}\text { Sertão Central Cabugi } \\
\text { Aristófanes Fernandes (Serra } \\
\text { de Santana) }\end{array}$ & Set/1997 & 204,9 & ETA Convencional & 145 \\
\hline $\begin{array}{c}\text { Gargalheiras (Acari-Currais } \\
\text { Novos) }\end{array}$ & $\begin{array}{c}1965 \text { (ampliado em } \\
\text { Mai/2005) }\end{array}$ & 27,88 & ETA Convencional & 75 \\
\hline Monsenhor Expedito & Set/1998 & 437,92 & ETA Convencional & $452,5^{*}$ \\
\hline Gravatá (Campina Grande) & $\begin{array}{c}\text { 2008 para Lagoa Seca, } \\
\text { Matinhas e Alagoa } \\
\text { Nova) }\end{array}$ & 152 & ETA Convencional & 1100 \\
\hline Cariri & 2003 & 153,26 & ETA Convencional & 115 \\
\hline
\end{tabular}

Nota: *A captação total do sistema é de até 527 1/s, sendo 304 1/s da captação superficial e 187 1/s da captação subterrânea.

Fonte: Elaborado pelo autor a partir de dados de ANA (2011), CAERN e CAGEPA (dados não publicados).

A população residente e o percentual de população urbana nos municípios da área de estudo são apresentados na Figura 4.2. Quanto à população residente, Campina Grande constitui o grande centro regional, com quase 400 mil habitantes. Os demais municípios com população superior a 25 mil habitantes são Queimadas e Lagoa Seca, na Paraíba, vizinhos a Campina Grande e, Currais Novos e Santa Cruz, dois centros regionais de menor porte no Rio Grande do Norte. A taxa de urbanização varia consideravelmente na região havendo diversos municípios com valores inferiores a $50 \%$.

\subsubsection{Dados dos Sistemas de Abastecimento de Água}

Foram utilizados dados dos sistemas de abastecimento de água dos municípios, provenientes das seguintes fontes: índice de atendimento de água do Sistema Nacional de Informações sobre Saneamento (SNIS) do Ministério das Cidades (MCid/SNIS, 2014); formas de abastecimento de água dos domicílios do Censo Demográfico (IBGE, 2000; 2010); quantitativo de carros-pipa em operação obtidos do Ministério da Integração Nacional (MI) e; número de cisternas construídas por município proveniente do Ministério de Desenvolvimento Social e Combate à Fome (MDS)*

\footnotetext{
* Os dados referentes a carros-pipa e cisternas não estão publicados e foram disponibilizados à pesquisa após demandas aos órgãos gestores desses dados no Governo Federal.
} 


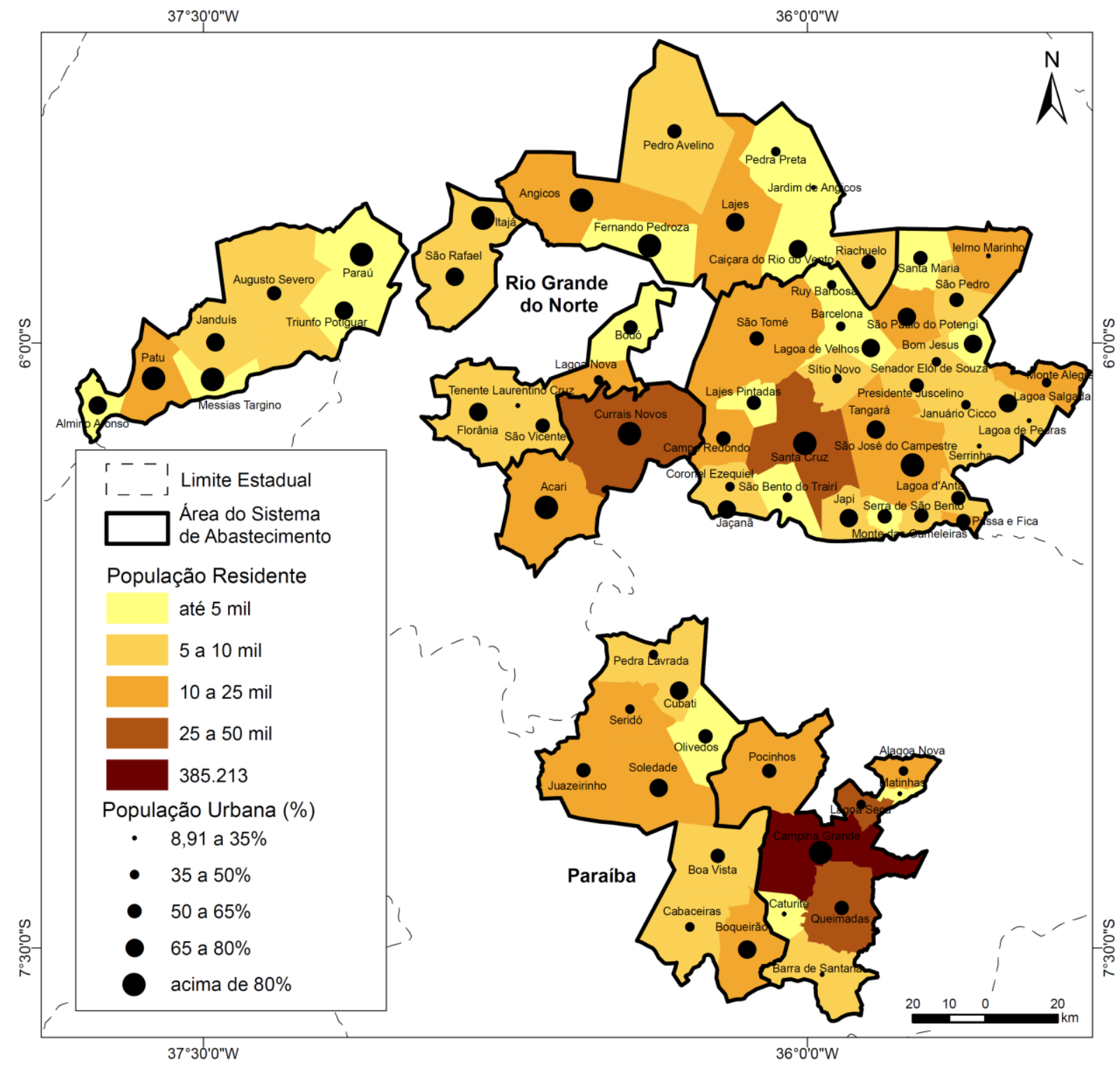

Figura 4.2: População residente e população urbana (\%) nos municípios da área de estudo (2010).

Fonte: Elaborado pelo autor a partir de dados do IBGE (2010).

A cisterna é uma caixa d'água enterrada ou semienterrada, que atende principalmente as populações difusas existentes no semiárido, recebendo água proveniente de telhados das residências e/ou de carros-pipa. Cada cisterna tem capacidade para armazenar 16 mil litros de água, volume suficiente para abastecer uma família de até seis pessoas, no período de estiagem que pode chegar a oito meses, desde que as águas sejam coletadas e utilizadas de maneira adequada (ASA BRASIL, 2015).

Os dados relativos aos índices de abastecimento total e urbano de água disponibilizados pelo SNIS no período 2002-2013 consideram percentuais por município enquanto os dados de 
tipo de abastecimento de água dos Censos Demográficos do IBGE de 2000 e 2010 consideram valores totais segundo a situação do domicílio (urbano ou rural)* . Taxas de carros-pipa em operação foram calculadas a partir dos registros mensais de 2013 e 2014 e taxas de cisternas construídas em cada município foram calculadas considerando os somatórios disponibilizados para os períodos de 2003 a 2010 e 2011 a 2014 pelo MDS e os totais de população do Censo (IBGE, 2010) e estimativas (IBGE, 2015).

O SNIS é um sistema de informações declaratório para os prestadores de serviço de saneamento básico e obrigatório para a solicitação de financiamento de obras de infraestrutura. As informações repassadas pelos prestadores são compiladas pelo Ministério das Cidades, segundo formulários padrão. Todos os municípios da área de estudo são atendidos pelas Companhias Estaduais de Água e Esgotos exceto Santa Cruz que é atendido por um Serviço Autônomo de Água e Esgoto (SAAE) e Passa e Fica que é atendido pela Prefeitura Municipal. Em 2013, o SNIS apurou informações sobre abastecimento de água em 5.035 municípios, com uma representatividade de $90,4 \%$ em relação ao total de municípios do país.

A execução do programa Operação Carro-Pipa, incluindo seleção, contratação, fiscalização e pagamento dos pipeiros, é de responsabilidade do Comando de Operações Terrestres do Exército Brasileiro (COTER). A construção ostensiva de cisternas foi iniciada pelo Programa Um Milhão de Cisternas Rurais (P1MC), implantado em 2002. O P1MC é uma das ações do Programa de Formação e Mobilização Social para a Convivência com o Semiárido da Articulação no Semiárido Brasileiro (ASA), que busca a convivência sustentável com o ecossistema do semiárido através do fortalecimento da sociedade civil, da mobilização, envolvimento e capacitação das famílias, com uma proposta de educação processual. A partir de 2011 o programa foi incluído no Plano Brasil Sem Miséria, a partir do Programa Água para Todos. Os municípios que recebem as cisternas são definidos em diagnóstico feito a partir do Cadastro Único de programas sociais do Governo Federal, considerando informações sobre a existência de domicílios rurais sem acesso à água em seu território. Municípios do semiárido com moradores em situação de extrema pobreza sem acesso à água têm inserção automática no programa (BRASIL, 2015).

\footnotetext{
* Embora a Pesquisa Nacional de Saneamento Básico (PNSB) (IBGE, 2008) forneça dados municipais sobre: tipo de captação, tratamento de água, rede coletora e tratamento de esgoto, optou-se por utilizar os dados do IBGE oriundos do Censo Demográfico, pois apresentam valores quantitativos referentes aos dados censitários por domicílios. Encontra-se em elaboração pela ANA o Atlas de Despoluição de Bacias Hidrográficas, cujos dados, ao serem concluídos, consistirão em material de grande importância para este tipo de análise.
} 


\subsubsection{Dados de Notificações de Doenças Diarreicas Agudas}

O presente estudo utilizou os dados de notificações de DDA referentes à semana epidemiológica para todos os 71 municípios abastecidos pelos quatro reservatórios. Os dados do Rio Grande do Norte foram produzidos pela Secretaria de Estado de Saúde Pública do Rio Grande do Norte (SESAP) para o período de janeiro de 2002 a dezembro de 2014. Enquanto os dados do Estado da Paraíba foram organizados pela Secretaria de Estado da Saúde (SES) para o período de janeiro de 2006 a dezembro de 2012. Tais dados foram disponibilizados após visitas técnicas às secretarias de saúde. Para efeito de comparação entre os municípios as notificações da DDA foram analisadas considerando-se os valores relativos de incidência por semana epidemiológica $(T x)$, correspondentes ao número de casos por cem mil habitantes, calculados a partir da Equação 4.1:

$$
\text { Tx }=(\text { Número de Casos / População Residente }) * 100.000
$$

Os dados de população residente por munícipio são provenientes do Censo Demográfico de 2010 do Instituto Brasileiro de Geografia e Estatística (IBGE), assim como as projeções populacionais calculadas para os anos de 2002 a 2009 e 2011 a 2014 (IBGE, 2010; 2015). As taxas foram calculadas por semana epidemiológica e foram gerados valores médios anuais.

\subsubsection{Análise Situação dos Sistemas de Abastecimento e Taxas de DDA}

Para a apresentação dos resultados foram elaborados mapas temáticos com índices de cobertura e taxas de atendimento das diferentes formas de abastecimento de água, bem como das taxas anuais de DDA por município e da taxa média observada ao longo da série temporal de dados disponível. Os intervalos das classes seguiram o método de determinação por quantis. As operações e análises espaciais em sistema de informações geográficas (SIG) foram efetuadas no software ESRI® ArcGIS 10.2.2. Para facilitar as consultas por município foi criado um banco de dados em ArcGIS Geodatabase contendo os dados vetoriais referentes a delimitação dos munícipios, sistemas de abastecimento e redes adutoras e os dados tabulares desses sistemas e de DDA. 
Os resultados concernentes às taxas de DDA verificadas em 2013 foram selecionados para uma análise detalhada, pois corresponderam aos maiores valores verificados ao longo da série temporal de estudo. Tal análise envolveu os seguintes dados: volume de água disponível ou cota dos reservatórios de abastecimento dos municípios mais afetados (LDB e MDG), obtido do DNOCS, da ANA (2015a) e da Secretaria do Meio Ambiente e dos Recursos Hídricos do Estado do Rio Grande do Norte (SEMARH); totais pluviométricos mensais de seis estações da EMPARN; volume de água mensal disponível para consumo da população abastecida pelo açude MDG, da Companhia de Águas e Esgotos do Rio Grande do Norte (CAERN)* e; informações operacionais dos sistemas adutores da CAERN veiculadas no sítio eletrônico da instituição ${ }^{\dagger}$.

Em subsídio às análises dos dados e resultados foi efetuado trabalho de campo na área de estudo nos meses de outubro de 2014 e agosto de 2015 e visita técnica às sedes da CAERN e da Companhia de Água e Esgotos da Paraíba (CAGEPA) em setembro de 2015.

\subsection{RESULTADOS}

\subsubsection{Análise Espaço-Temporal da Situação de Abastecimento de Água}

Durante a década de 2000, a região urbana dos municípios estudados teve um incremento e mudanças das categorias das coberturas de abastecimento de água contidas nos dados do Censo Demográfico (Figura 4.3). Esse aumento deve-se em parte à implantação da estrutura de conexão à rede de abastecimento oriunda da Adutora Monsenhor Expedito, como também de outras adutoras. No entanto, as áreas urbanas ainda apresentam uma porcentagem de domicílios abastecidos a partir de poços, nascentes, águas pluviais, carro-pipa (situação esta que se agrava nos períodos de seca) e até mesmo captação direta de cursos d'água ou açudes localizados próximo aos perímetros urbanos.

\footnotetext{
* A CAERN forneceu os dados de volume de água produzido mensal somente para os municípios abastecidos pelo açude MDG. Segundo a companhia, os dados foram calculados a partir de estimativas e medidores proporcionais de 2010 a 2012 e por instrumentos de macromedição em 2013 e 2014, o que confere aos dados maior precisão a partir de janeiro de 2013. A CAERN informou ainda que não há macromedição do volume de água distribuído para cada município atendido pela Adutora Monsenhor Expedito, mas somente estimativas. Segundo a CAGEPA, os dados de volume de água produzido para os municípios abastecidos pelo açude EPB eram fruto de estimativas até dezembro de 2013, sendo que medidores de vazão ultrasônicos nas captações de seus dois sistemas adutores foram instalados em janeiro de 2014.
}

$\dagger$ http://www.caern.rn.gov.br/. 

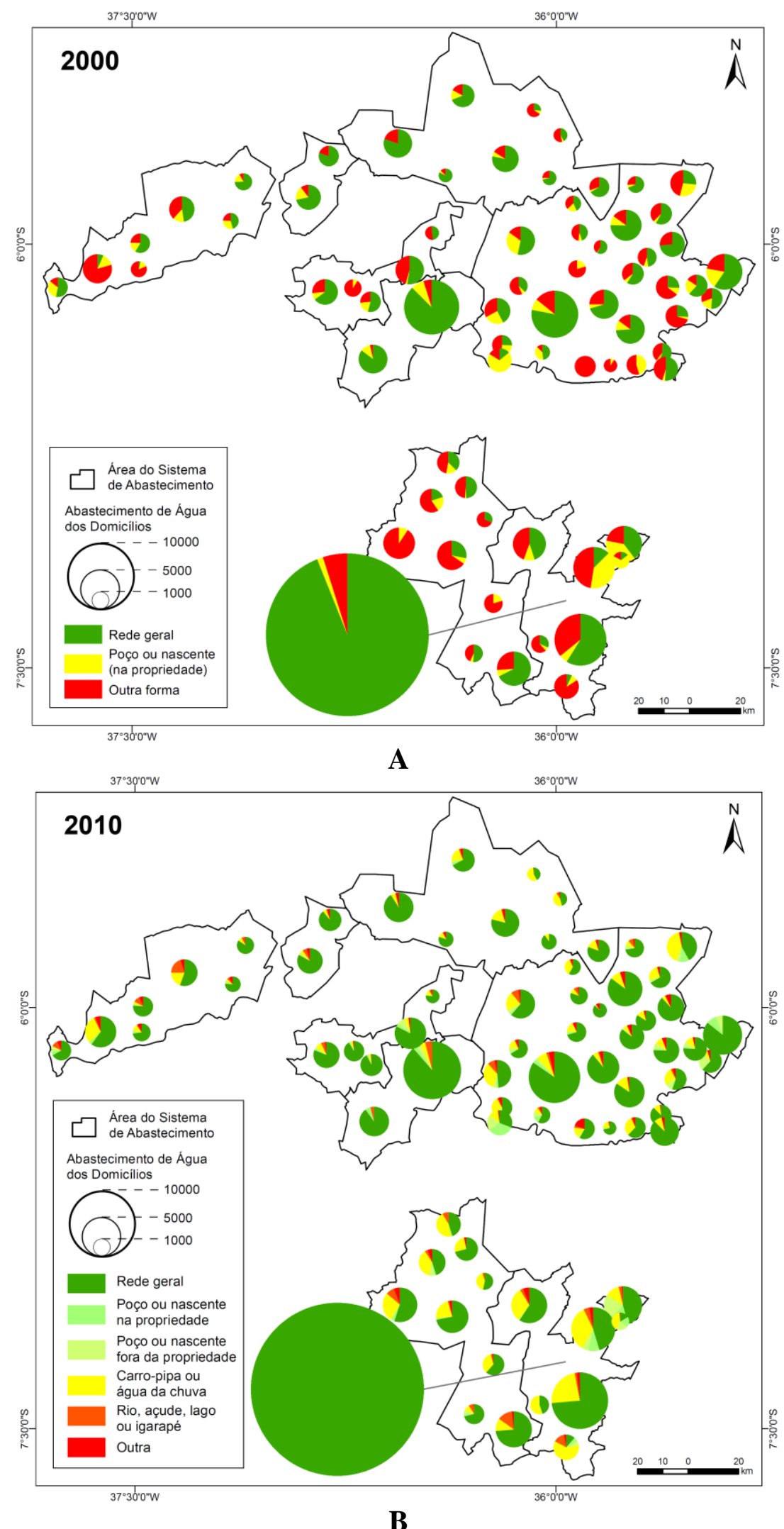

Figura 4.3: Total de domicílios segundo categorias de abastecimento de água em 2000 (A) e 2010 (B).

Fonte: Elaborado pelo autor a partir de dados do $\operatorname{IBGE}(2000,2010)$. 
Em contraposição, as áreas rurais apresentam um cenário distinto das áreas urbanas. Embora os municípios estudados sejam diretamente abastecidos pelas adutoras ou pontos de captação dos quatro reservatórios, a rede geral de distribuição não atinge a população rural. A rede geral abastece prioritariamente as áreas urbanas e, em alguns casos, são estendidas a algumas comunidades rurais. Portanto, a zona rural possui um percentual elevado de domicílios que recorrem a outras formas de abastecimento de água (Figura 4.4B).

Além disso, a dificuldade de abastecimento aumenta nos municípios mais distantes dos mananciais ou localizados no final das redes de adução, que também são aqueles que se localizam em áreas mais elevadas (Figura 4.1), como demonstra a distribuição espacial do índice SNIS de atendimento municipal de água (Figura 4.5) e do atendimento urbano de água (Figura 4.4A). Esses municípios acabam por demandar um maior aporte de água de carros-pipa para abastecimento tanto das áreas urbanas quanto das cisternas, principalmente na época de seca prolongada (Figuras 4.6 e 4.7).

No ano de 2014, o atendimento por carro pipa foi intensificado, devido ao agravamento da situação de seca (Figura 4.6B). As maiores taxas de carros-pipa em operação no Rio Grande do Norte foram apresentadas por Bodó, Coronel Ezequiel, Lajes Pintadas, Japi, Pedra Preta, Ruy Barbosa e Monte das Gameleiras, localizados no final das redes de adução. No Rio Grande do Norte, os municípios abastecidos pelo Sistema Integrado Médio Oeste foram os que apresentaram melhor situação, com menos utilização de carros-pipa. Proporcionalmente, os municípios paraibanos apresentaram maior número de domicílios abastecidos por carros-pipa ou água da chuva, notadamente os domicílios rurais dos municípios atendidos pelo Sistema Adutor do Cariri. Os municípios de Cubati, Pedra Lavrada, Olivedos e São Vicente do Seridó apresentaram em 2013 e 2014 as maiores taxas de utilização de carros-pipa na Paraíba, o que denota possíveis problemas na distribuição de água oriunda de seu sistema de abastecimento. 

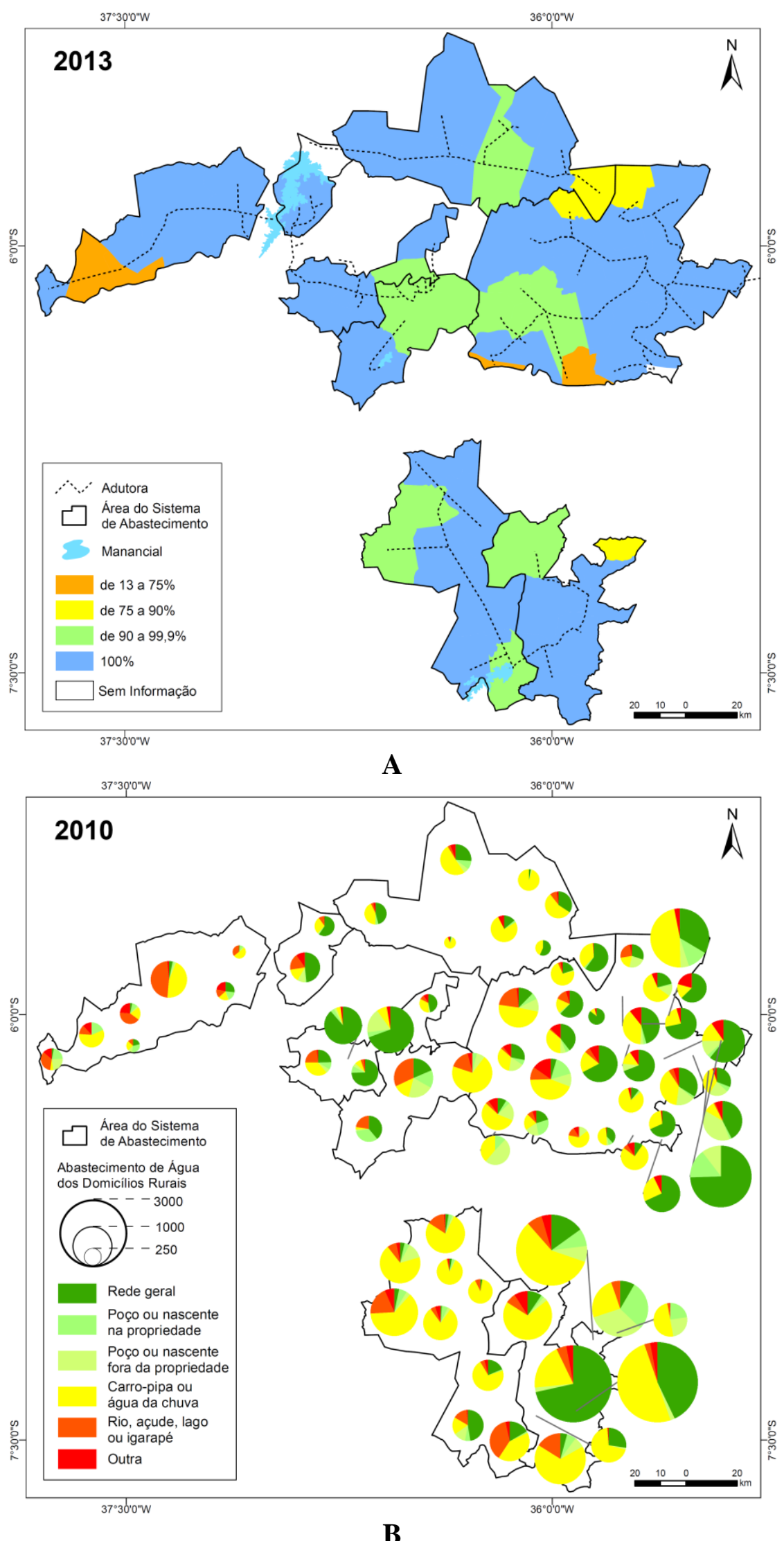

Figura 4.4: Índice de atendimento urbano de água (2013) (A) e total de domicílios rurais segundo categorias de abastecimento de água (2010) (B).

Fonte: Elaborado pelo autor a partir de dados do MCid/SNIS (2014) e IBGE (2010). 


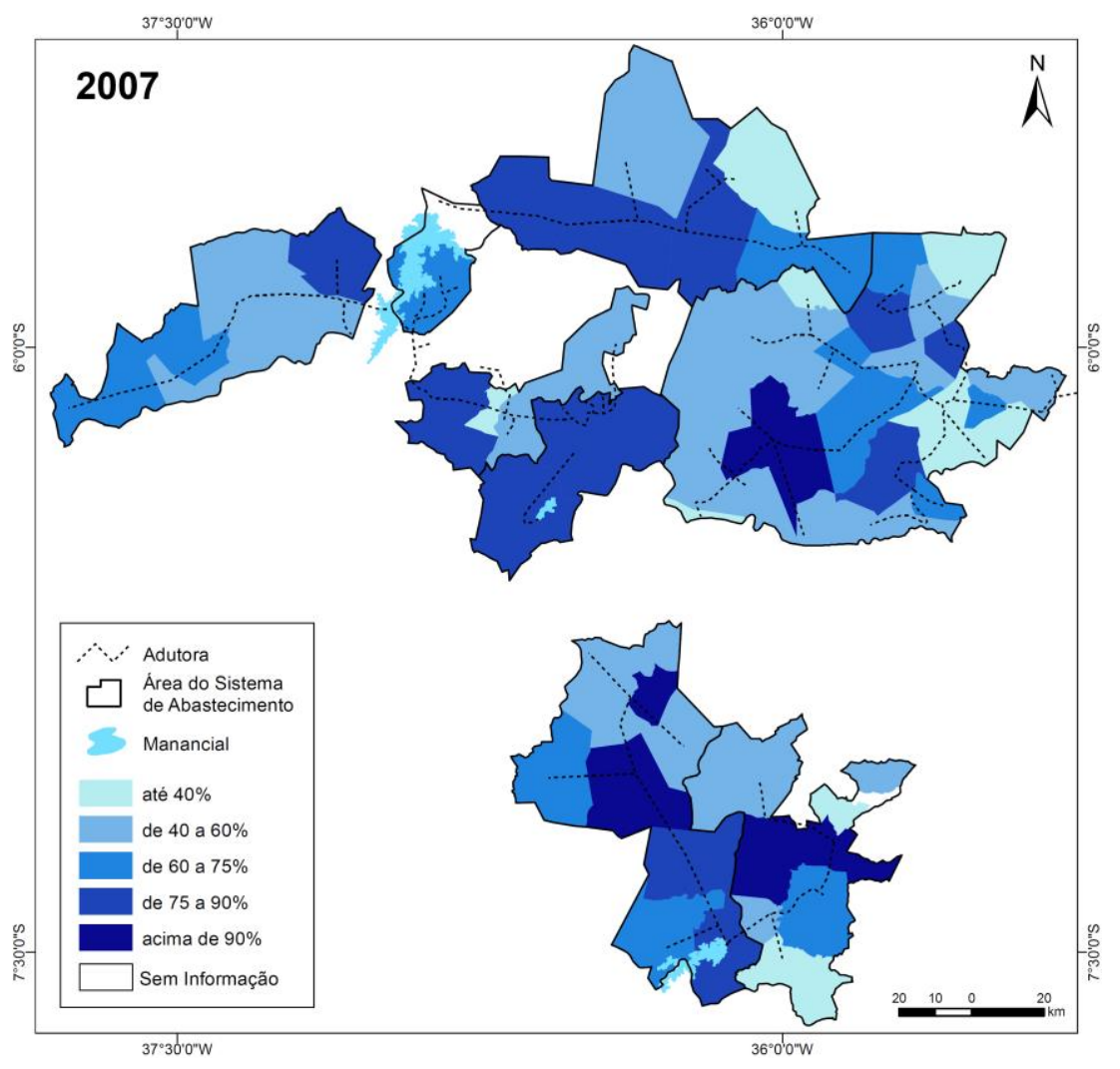

A

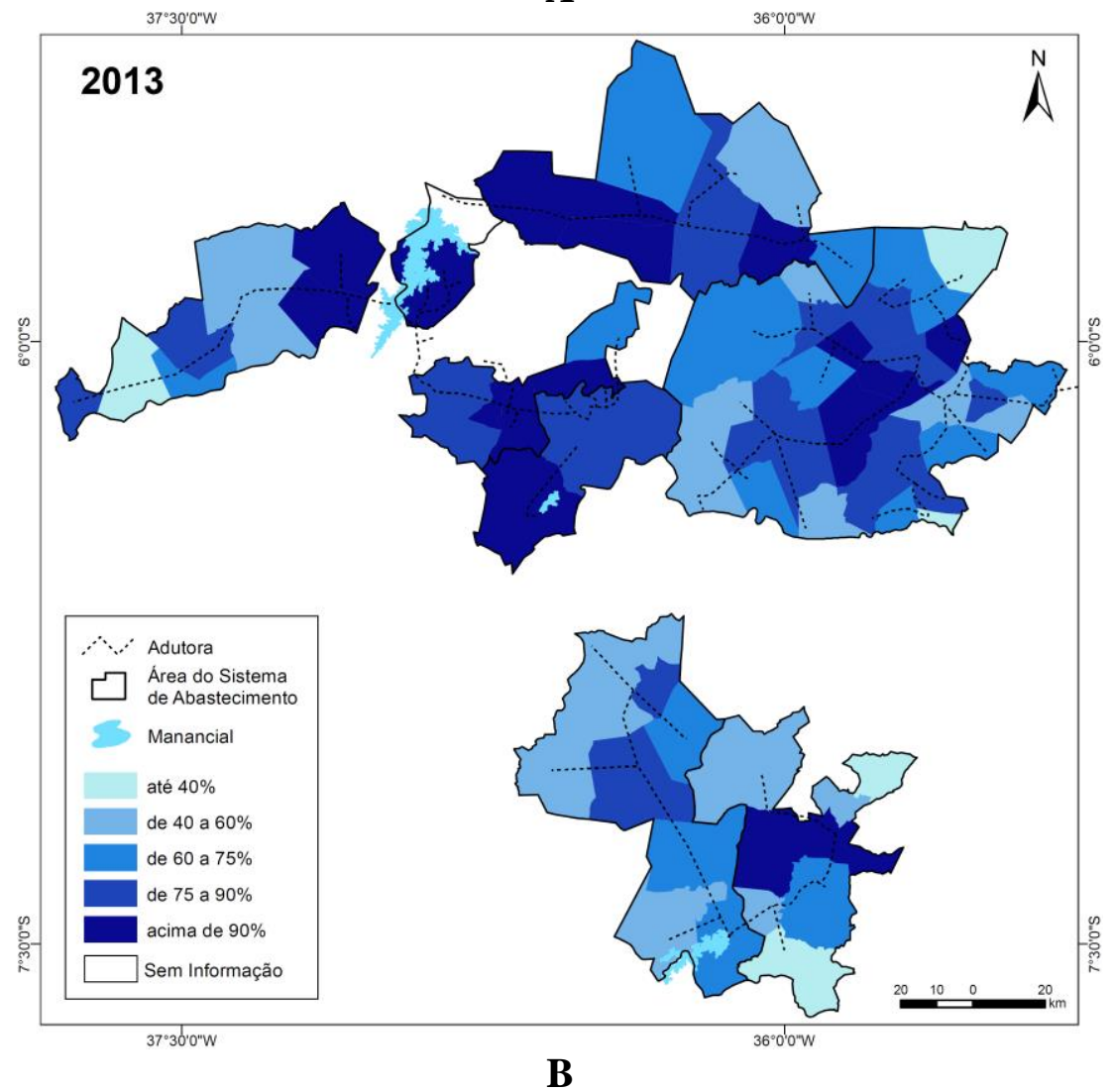

Figura 4.5: Índice de atendimento total de água por município em 2007 (A) e 2013 (B).

Nota: O SNIS possui dados desde 2002, no entanto há dados somente a partir de 2007 para todos os municípios da área de estudo, exceto Itajá, no Rio Grande do Norte e Matinhas, na Paraíba.

Fonte: Elaborado pelo autor a partir de dados do MCid/SNIS (2014). 

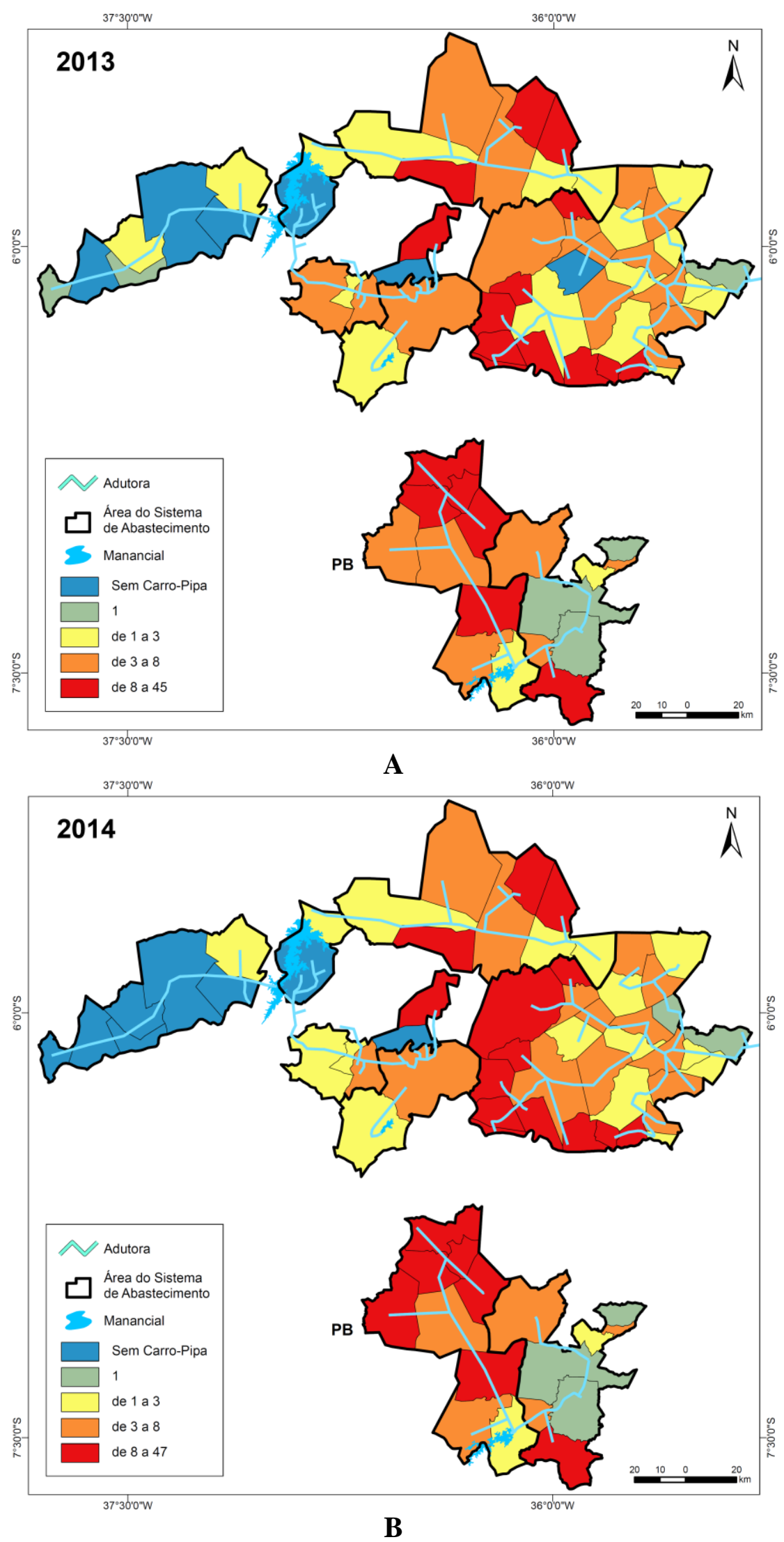

Figura 4.6: Média de carros-pipa em operação em 2013 (A) e 2014 (B) por mil habitantes.

Nota: Valores calculados a partir do quantitativo mensal de carros-pipa em operação. Dados disponíveis a partir de 2013.

Fonte: Elaborado pelo autor a partir de dados do MI (dados não publicados). 


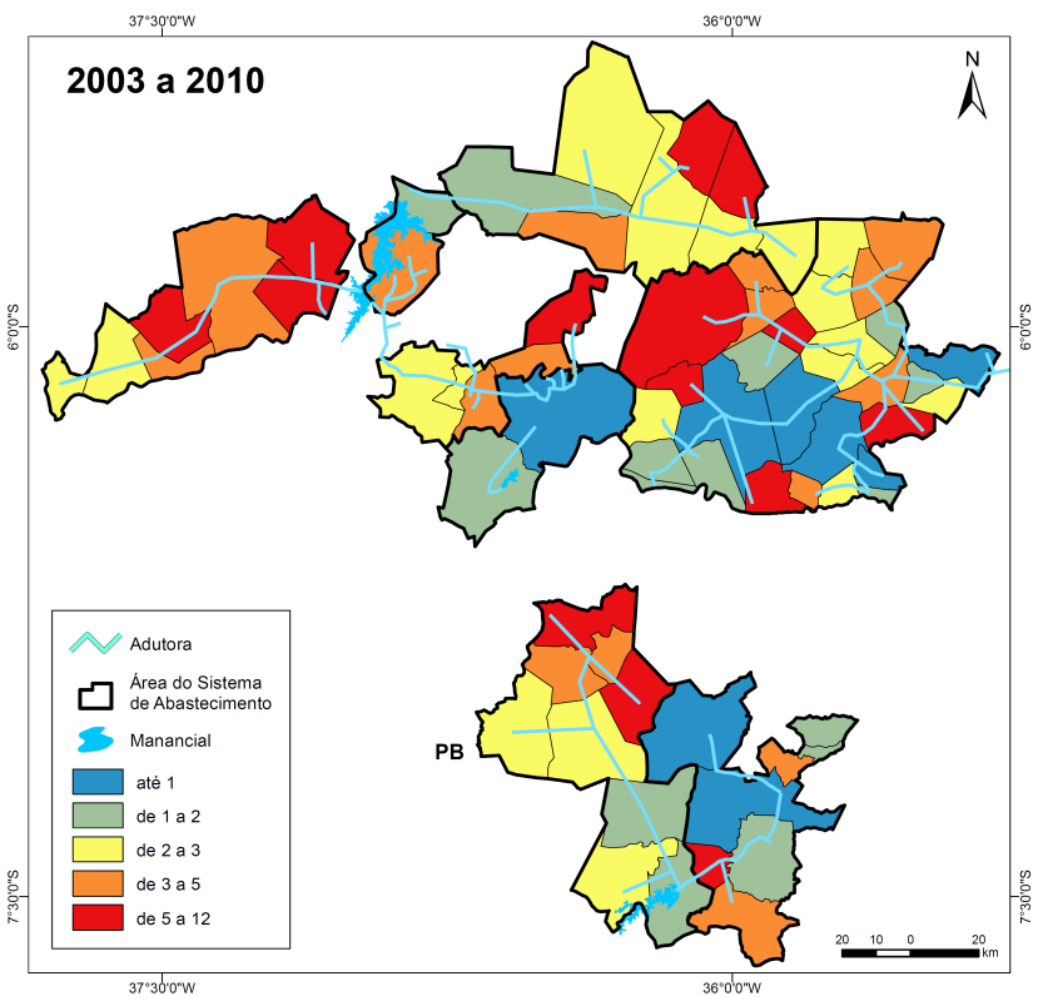

A

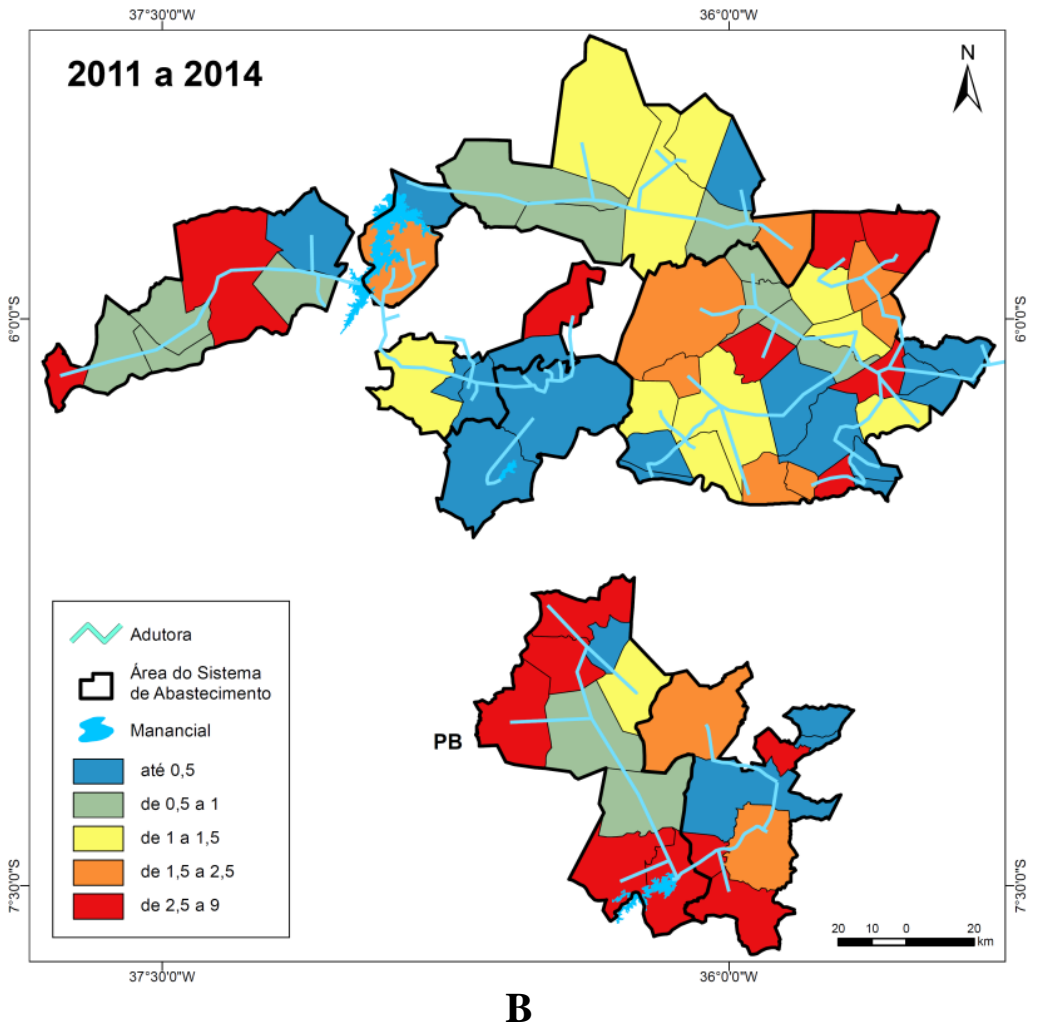

Figura 4.7: Número de cisternas construídas entre 2003 a 2010 (A) e 2011 a 2014 (B) por cada cem habitantes.

Nota: A legenda da taxa de 2011 a 2014 corresponde à metade dos valores de 2003 a 2010, pois o período corresponde à metade (quatro e oito anos). A referência de população para o cálculo da taxa foi 2010 e 2014. Fonte: Elaborado pelo autor a partir de dados do MDS (dados não publicados). 
A Figura 4.7 evidencia a distribuição espacial das cisternas, considerando os dados do MDS referentes aos totais dos períodos: (a) 2003-2010 (P1MC) e (b) 2011-2014 (Programa Água Para Todos do Governo Federal). Os mapas evidenciam que a construção de cisternas tem sido direcionada para municípios em áreas extremas da rede de adução de água e em municípios com grande quantitativo de população rural (Figura 4.2).

A utilização da cisterna em ambientes rural substitui a tradicional necessidade de recorrer aos açudes ou demais corpos d'água localizados por vezes distantes de suas residências. A qualidade da água da chuva é melhor, entretanto, a ausência de chuvas em um ou mais anos leva ao esgotamento da cisterna como fonte de abastecimento familiar, o que pode levar à dependência do carro-pipa, cuja água em geral é sem tratamento e de qualidade duvidosa, aumentando a exposição da população a doenças de veiculação hídrica.

\subsubsection{Análise Espaço-Temporal das Taxas de DDA}

O conjunto de mapas das taxas anuais de DDA é apresentado na Figura 4.8. O Estado da Paraíba apresenta dados disponíveis somente entre 2006 e 2012. As maiores taxas ocorreram entre 2006 e 2007 e em 2013. Os limites sobrepostos aos mapas correspondem aos diferentes sistemas de abastecimento de água da região, numerados de 1 a 8 .

No período 2002-2009, os municípios da região Sertão Central Cabugi (2), abastecidos pela adutora que capta águas no Canal do Pataxó (canal artificial que leva água do açude ARG ao Rio Pataxó), apresentaram altas taxas de DDA.

Também foram observadas altas taxas de DDA em municípios dispersos na área de estudo, a exemplo de Messias Targino, abastecido pelo sistema adutor Médio Oeste (1). O município, apesar de possuir a quarta maior taxa de população urbana de toda a área de estudo, menor apenas que Angicos, Currais Novos e Campina Grande, apresenta baixo índice de atendimento urbano de água (Figura 4.4A).

Os municípios abastecidos pela Adutora Monsenhor Expedito da região Agreste Potiguar (6) aumentaram as taxas de DDA a partir de 2010, que se tornaram agravadas no período 2012-2013. Em 2013, 60\% dos municípios tiveram taxas superiores a cem casos. Os 
municípios abastecidos por essa adutora, cujo manancial é a LDB, não apresentaram as menores taxas de DDA como era esperado, mas as maiores taxas, em especial no período 2012-2014.

\section{Rio Grande do Norte}
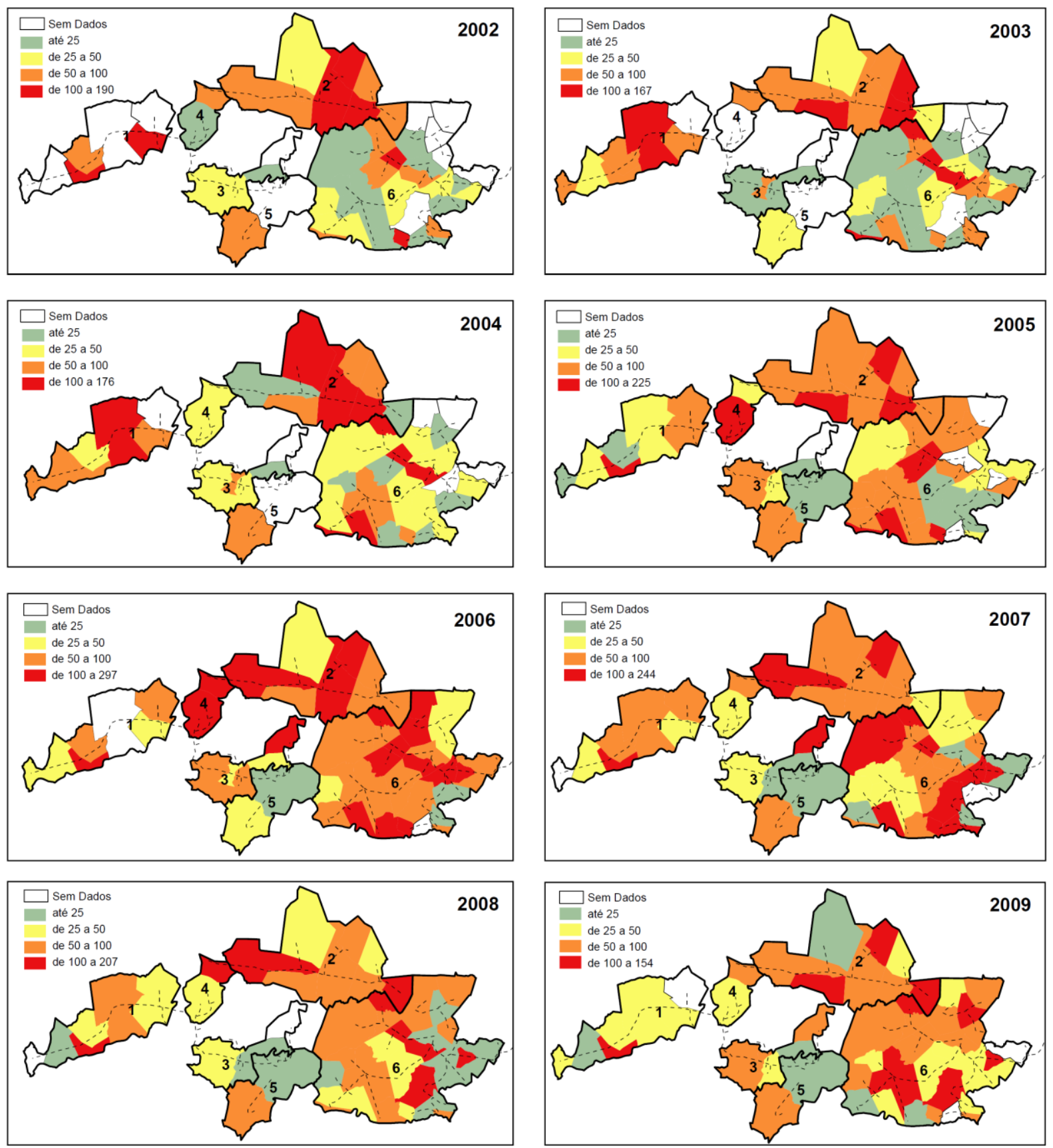

Figura 4.8: Incidência (casos por cem mil habitantes) da DDA por município nas áreas de estudo no Rio Grande do Norte (2002-2014) e Paraíba (2006-2012) (continua). 

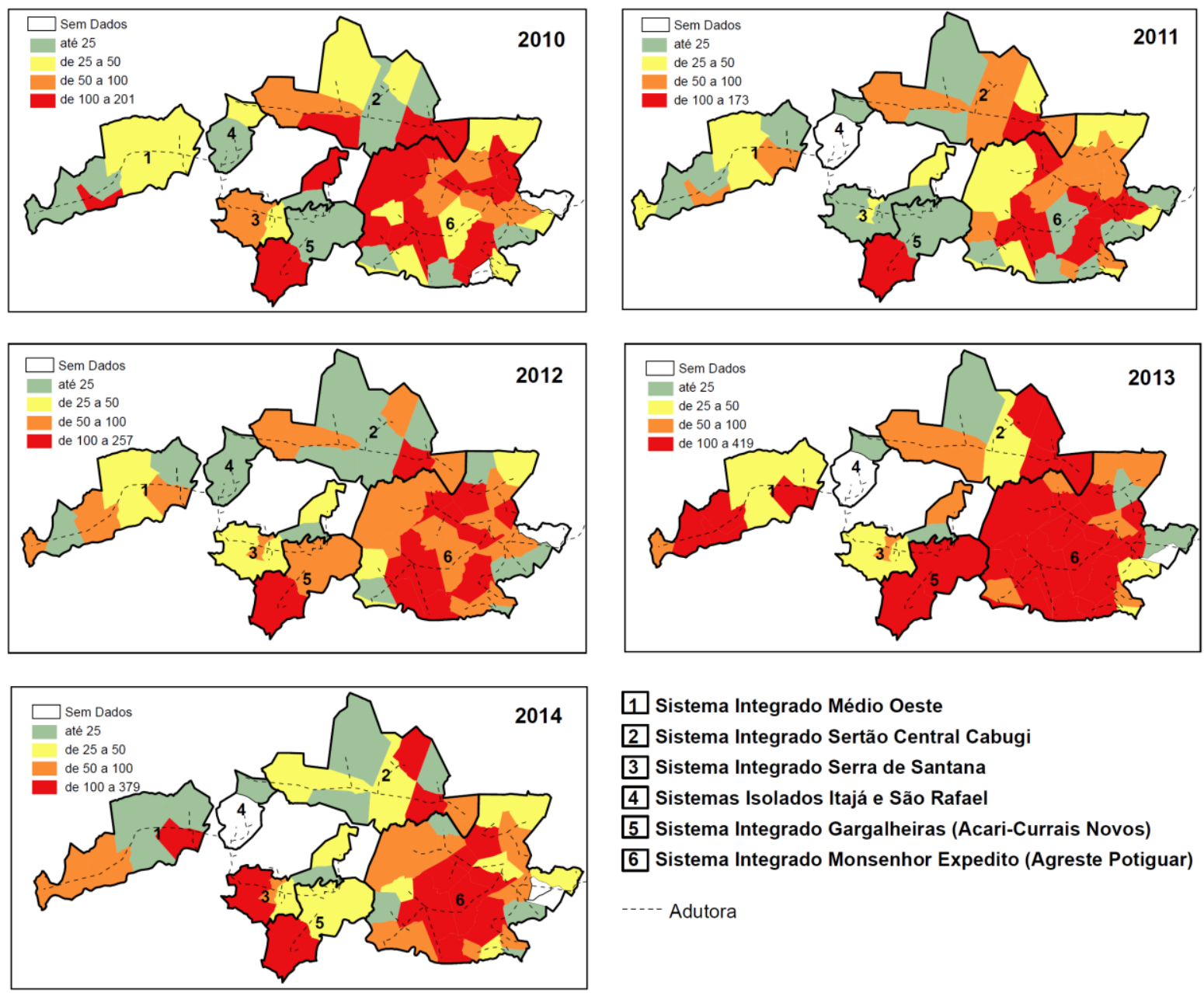

2 Sistema Integrado Sertão Central Cabugi

3 Sistema Integrado Serra de Santana

4 Sistemas Isolados Itajá e São Rafael

5 Sistema Integrado Gargalheiras (Acari-Currais Novos)

6 Sistema Integrado Monsenhor Expedito (Agreste Potiguar)

----- Adutora

Paraíba
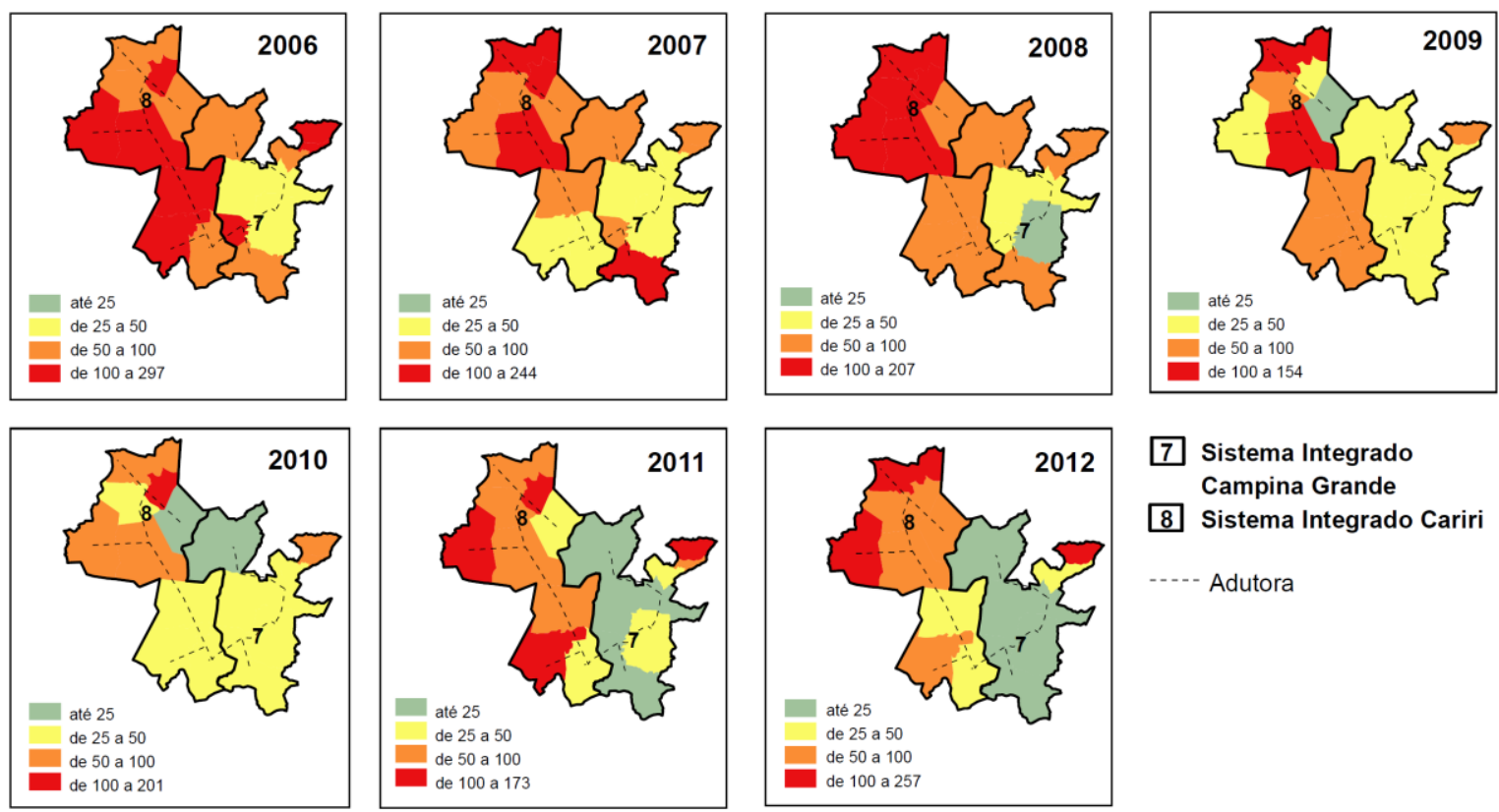

\section{Sistema Integrado \\ Campina Grande \\ 8 Sistema Integrado Cariri}

-.- Adutora

Figura 4.8: Incidência (casos por cem mil habitantes) da DDA por município nas áreas de estudo no Rio Grande do Norte (2002-2014) e Paraíba (2006-2012).

Fonte: Elaborado pelo autor a partir de dados da SESAP e SES (dados não publicados). 
Na Paraíba, as maiores taxas em todos os anos da série temporal foram apresentadas por municípios abastecidos pelo Sistema Adutor do Cariri (8), com destaque para os municípios localizados nas extremidades do sistema, como Cubati, Pedra Lavrada e Juazeirinho. Este sistema, segundo informações obtidas com a CAGEPA, é penalizado constantemente com cortes e a captação é considerada aquém da demanda existente, embora tenha englobado o abastecimento de mais uma cidade, Sossego, em 2015.

O ano de 2013 apresentou um comportamento epidêmico excepcional, principalmente para os municípios abastecidos pelo açude MDG (5) e para a área abastecida pela Adutora Monsenhor Expedito (6).

A Figura 4.9 apresenta o mapa de taxa média de DDA da série temporal. Dentre os dez municípios com as maiores taxas, somente quatro possuem mais de cinco mil habitantes: Soledade, Acari, Cubati e Santa Cruz. Soledade e Cubati também apresentam altas taxas de operação de carros-pipa (Figura 4.6), embora contenham $75 \%$ e $70 \%$ de população urbana, respectivamente, entre as maiores da área de estudo na Paraíba, inferiores apenas a Campina Grande (95\%) e no caso de Cubati a Boqueirão (71\%).

A alta taxa de Monte das Gameleiras em 2013 contribuiu para que este município apresentasse a maior taxa média de DDA na área de estudo, com 132 casos por cem mil habitantes (Figura 4.10). Monte das Gameleiras, apesar de apresentar a maior taxa média de DDA, possui a menor população absoluta dentre os municípios da área de estudo, de apenas 2.261 habitantes (IBGE, 2010), e número elevado de carros-pipa em operação.

Santa Cruz, polo regional do Agreste potiguar, apresentou taxas elevadas e crescentes ao longo da série temporal, a nona maior dentre todos os municípios. Estas taxas destacam-se, pois, este município possui uma população de 36 mil habitantes, a segunda maior da área de estudo no Rio Grande do Norte. No município de Santa Cruz está localizado o Hospital Universitário Ana Bezerra (HUAB), vinculado à UFRN, que constitui um centro de referência de saúde regional, o que pode introduzir um viés nas altas taxas de DDA do município.

Os municípios de Itajá, São Rafael (4) e da região da Serra de Santana (3), que correspondem aqueles que não possuem ETA em seus sistemas de abastecimento de água, não apresentaram maiores taxas de incidência em relação aos demais. 


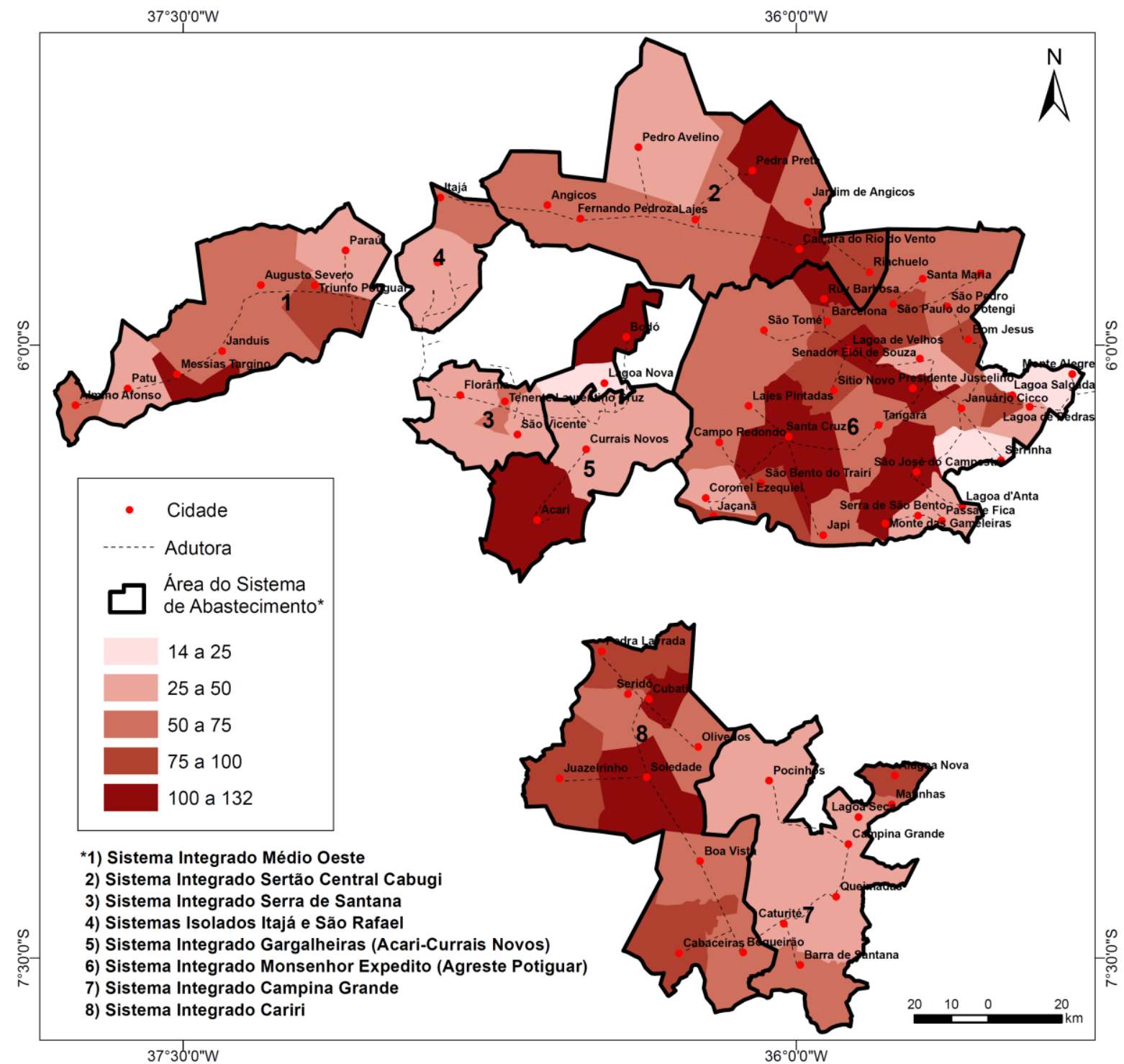

Figura 4.9: Taxa média de DDA por município (2002-2014).

Nota: Foram excluídos do cálculo da média os municípios sem dados em cada ano, a exemplo dos municípios paraibanos entre 2002 e 2005 e em 2013 e 2014.

Fonte: Elaborado pelo autor a partir de dados da SESAP e SES (dados não publicados).

As menores taxas foram apresentadas pelos municípios de Lagoa Nova, Serrinha e Monte Alegre, seguidos por Campina Grande, Queimadas e Currais Novos, os três municípios de maior população da área de estudo. Enquanto Lagoa Nova apresentou as menores taxas de DDA e não possuiu carro-pipa em operação em 2013 e 2014, seu município vizinho, Bodó apresentou as maiores taxas de DDA da Serra de Santana (3), assim como a maior taxa de carros-pipa em operação. Bodó, assim como Caiçara do Rio do Vento e Pedra Preta, estão localizados nas extremidades de sistemas adutores e apresentaram as maiores taxas dentre os municípios cuja fonte de água para abastecimento provém do açude ARG. 

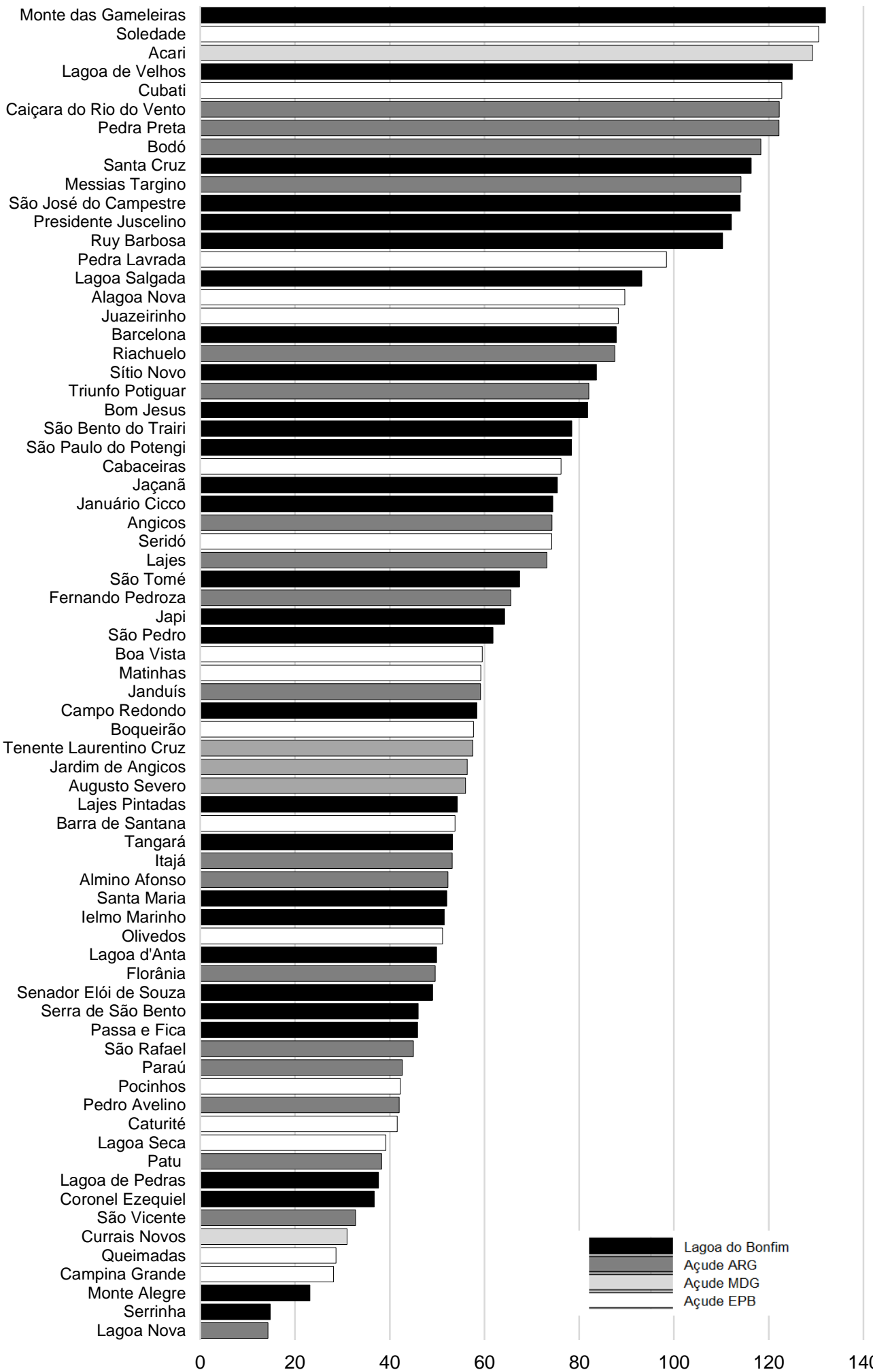

Figura 4.10: Municípios da área de estudo em ordem decrescente segundo a taxa média de DDA (2002-2014) e manancial de abastecimento de água.

Nota: Foram excluídos do cálculo da média os municípios sem dados em cada ano, a exemplo dos municípios paraibanos entre 2002 e 2005 e em 2013 e 2014.

Fonte: Elaborado pelo autor a partir de dados da SESAP e SES (dados não publicados). 


\subsubsection{Estudo de Caso: Epidemia de DDA em 2013}

Desde abril de 2012 o Nordeste brasileiro vem enfrentando uma seca excepcional (Figura 4.11). O ano de 2012 foi crítico em termos climáticos, sendo que uma análise de probabilidade de ocorrência de seca igual a que foi registrada nesse ano, tendo em vista a série histórica de dados existente, indicou um período maior que cem anos para sua repetição em boa parte do semiárido, o que denota o caráter extremo da anomalia de baixas precipitações observadas (ANA, 2015b). Consequentemente, os reservatórios e estoques de água foram sendo descarregados acentuadamente, e de 2012 a 2014 não houve chuva capaz de amenizar esse processo ou promover qualquer recarga nos açudes, estratégicos para a população da região.

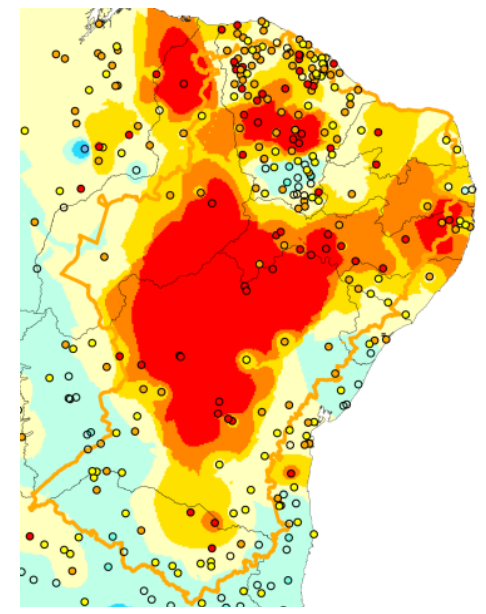

2012
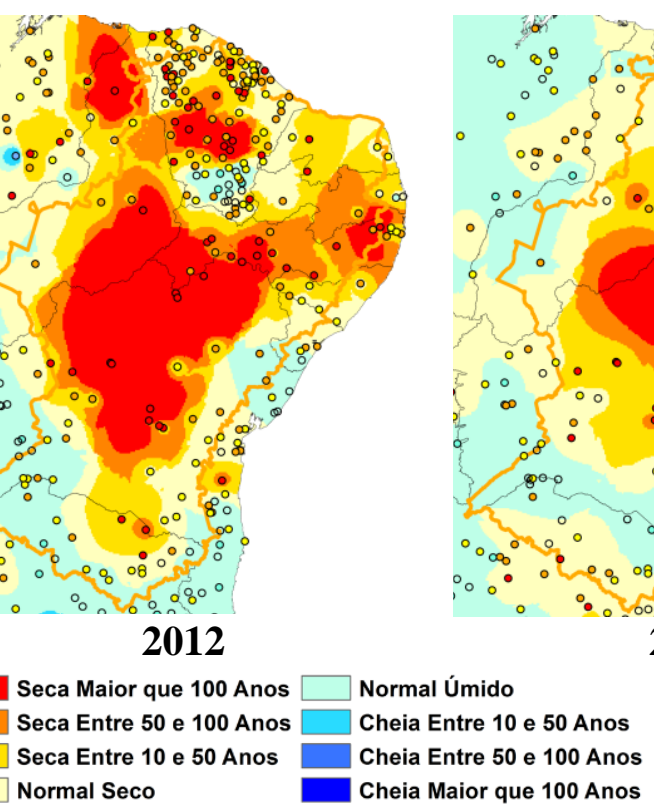

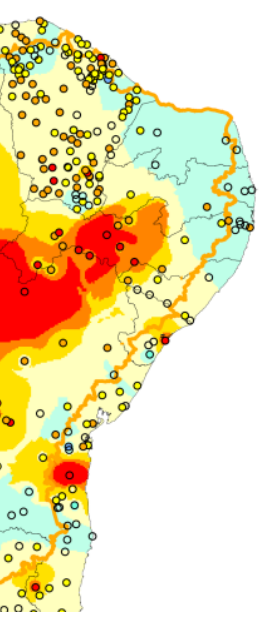

2013

Figura 4.11: Comportamento da precipitação no semiárido brasileiro em relação à probabilidade de ocorrência (2012-2014).

Fonte: Adaptado de ANA (2015b).

O regime de precipitação no Nordeste é fortemente influenciado pela ZCIT. Sem a influência da ZCIT o semiárido brasileiro seria totalmente árido. No entanto, quando as águas ficam mais frias ao sul da Linha do Equador, a ZCIT é empurrada para o Norte, o que provoca déficit de chuva no semiárido, e vice-versa. A ZCIT alcança seu ponto mais ao sul por volta da segunda quinzena de março (INPE/CPTEC, 2015). Por essa razão, tradicionalmente se não há chuva até esse período, dificilmente haverá posteriormente. Essa situação já é de conhecimento da população local, que associa o fenômeno à data comemorativa a São José, em 19 de março. 
Dentre os quatro reservatórios de abastecimento da área de estudo, o açude MDG é o que apresentou a situação mais preocupante, com apenas 14\% da capacidade no final de 2013 (Figura 4.12B). No entanto a LDB apresentou a situação mais grave. Em 25 de março de 2013 a CAERN implantou um rodízio no abastecimento de água em 16 municípios abastecidos pela Adutora Monsenhor Expedito em virtude do abaixamento do nível da lagoa a uma cota inferior a 39 m (Figura 4.12A), que permaneceu em vigor ao menos até o final de 2014.

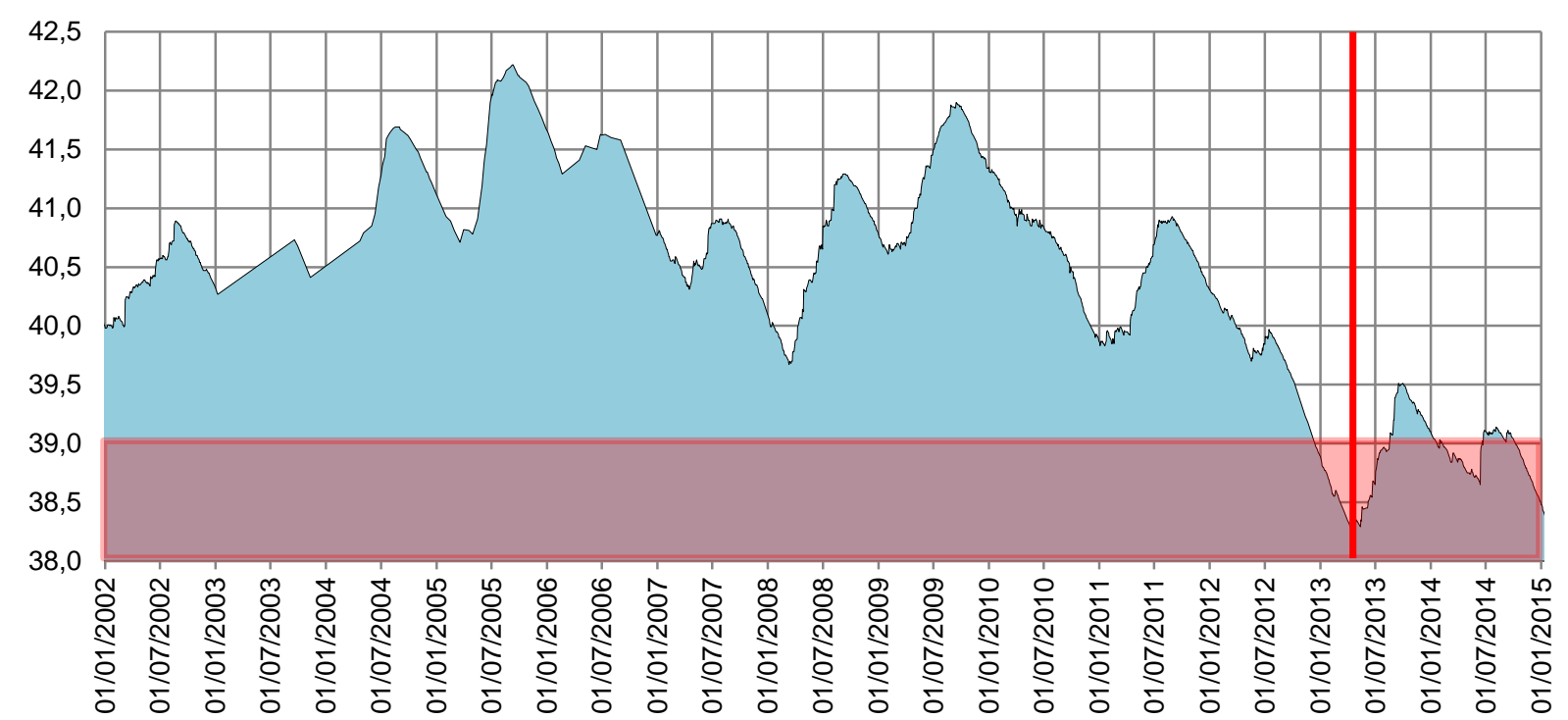

A

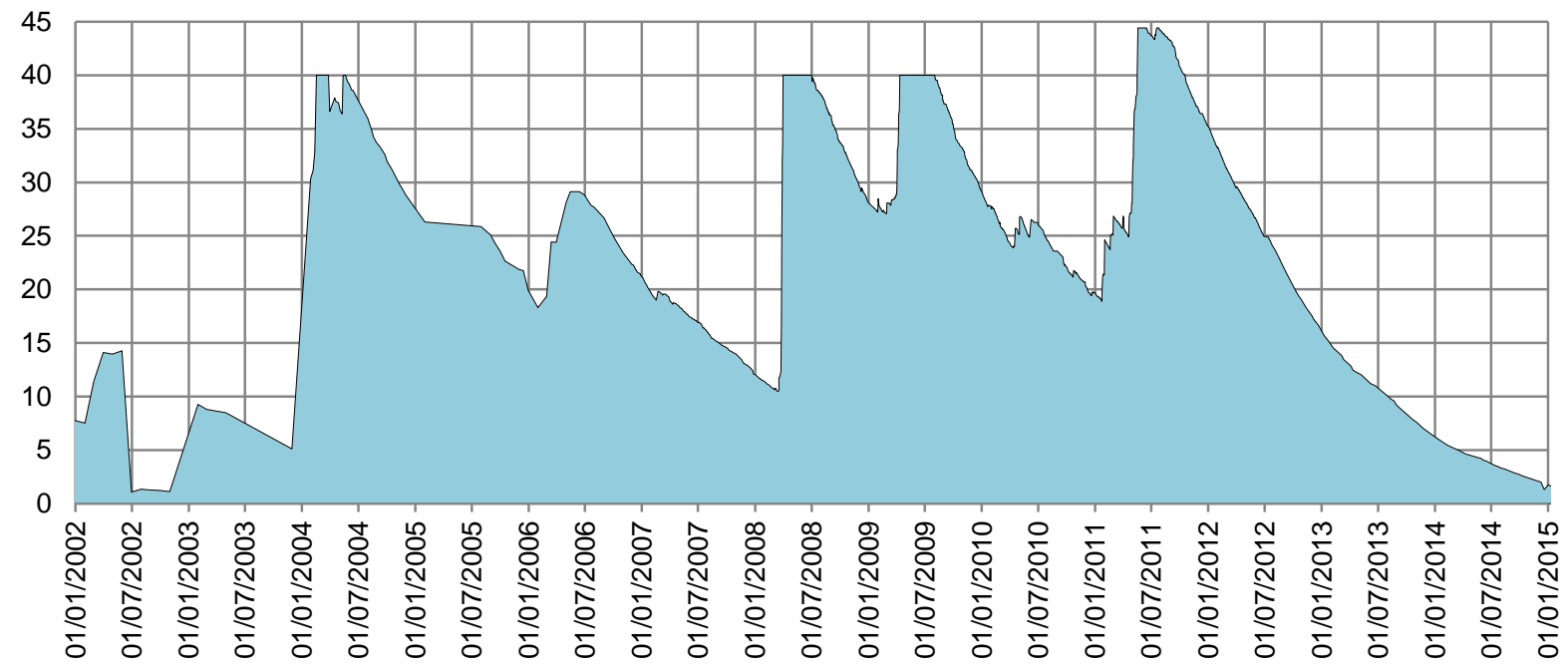

B

Figura 4.12: Série histórica de nível (m) da LDB (A) e volume (hm³) do açude MDG (B) (20022014).

Nota: Não há informações de nível para o açude MDG em toda a série. Curva cota-área-volume atualizada em 2010 , alterando a capacidade do açude para $44,42 \mathrm{hm}^{3}$.

Fonte: Elaborado pelo autor a partir de dados da SEMARH (dados não publicados) (A) e ANA (2015a) (B). 
Segundo notícias veiculadas na mídia pela CAERN, o rodízio foi adotado para evitar a falta de água nos municípios localizados no fim dos ramos da adutora, e foram estes 14 os municípios excluídos do rodízio*. Os municípios localizados nas extremidades da Adutora Monsenhor Expedito apresentam altas taxas de carros-pipa em operação (Figura 4.6), o que indica haver problemas de abastecimento de água pela rede geral. Além de haver o rodízio, informações orais obtidas durante visita técnica à CAERN confirmaram a existência de manobras operacionais no sistema de adução de água desde sua implantação em 1998.

O ano de 2013 foi um ano atípico e epidêmico para a DDA, com uma taxa média superior a 118 casos por cem mil habitantes na área de estudo. A implantação de um rodízio no abastecimento de água parece ter contribuído para o grande número de casos de DDA observados nos municípios abastecidos pela LDB, como mostra o mapa das taxas de DDA (Figura 4.8) e gráfico dos casos de DDA no RN em 2013, com um grande acréscimo a partir do início do mês de maio, um mês após o início do rodízio (Figura 4.13B). No ano de 2014, o número de casos de DDA na área de estudo se manteve estável. No entanto, os municípios que apresentaram as maiores taxas de DDA foram justamente aqueles localizados no centro da área abastecida pela LDB, ou seja, que enfrentaram o rodízio implantado em 2013 (Figura 4.8).

A área abastecida pela LDB concentrou as altas taxas de DDA em 2013 após a implantação do rodízio, o que pode ter sido motivado, provavelmente, pela necessidade de a população recorrer a outras formas de abastecimento de água diferentes da rede geral convencional. Em 2013, a taxa dos casos de DDA por cem mil habitantes na área abastecida pela LDB foi de 7.125 ao passo que no restante da área de estudo no RN foi de 5.465. Entre a $19^{\mathrm{a}}$ e a $27^{\mathrm{a}}$ semanas epidemiológicas, que concentraram os casos de DDA de 2013, a taxa na área da LDB foi maior que o dobro da área restante, 4.657 contra 1.758.

\footnotetext{
* Fonte: http://g1.globo.com/rn/rio-grande-do-norte/noticia/2013/03/estiagem-provoca-rodizio-de-fornecimento-de-agua-emcidades-do-rn.html.
} 

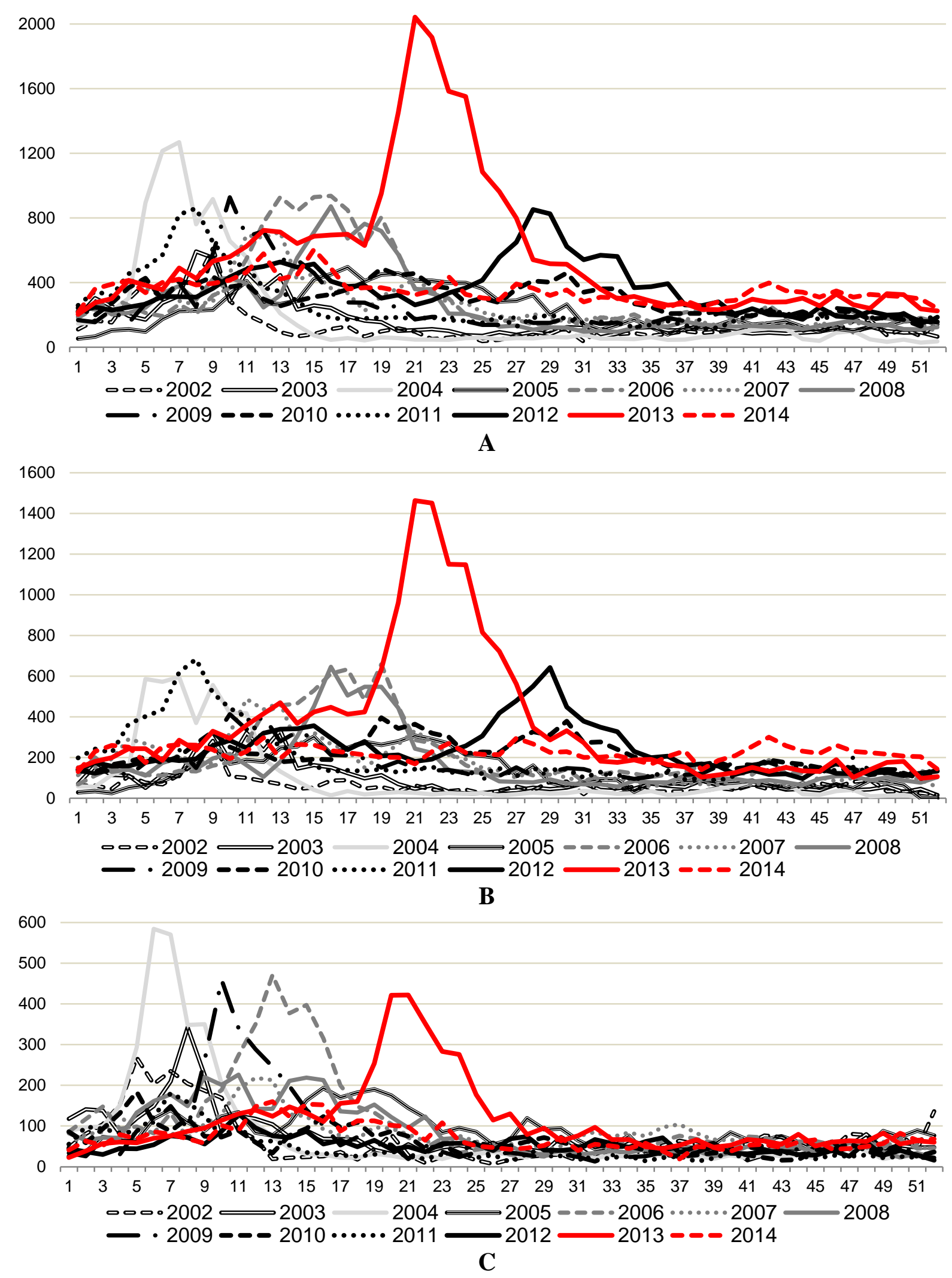

Figura 4.13: Casos de DDA por semana epidemiológica em toda a área de estudo no RN (A) e nas áreas abastecidas pela LDB (B) e açudes ARG (C) e MDG (D) (2002-2014) (continua). 


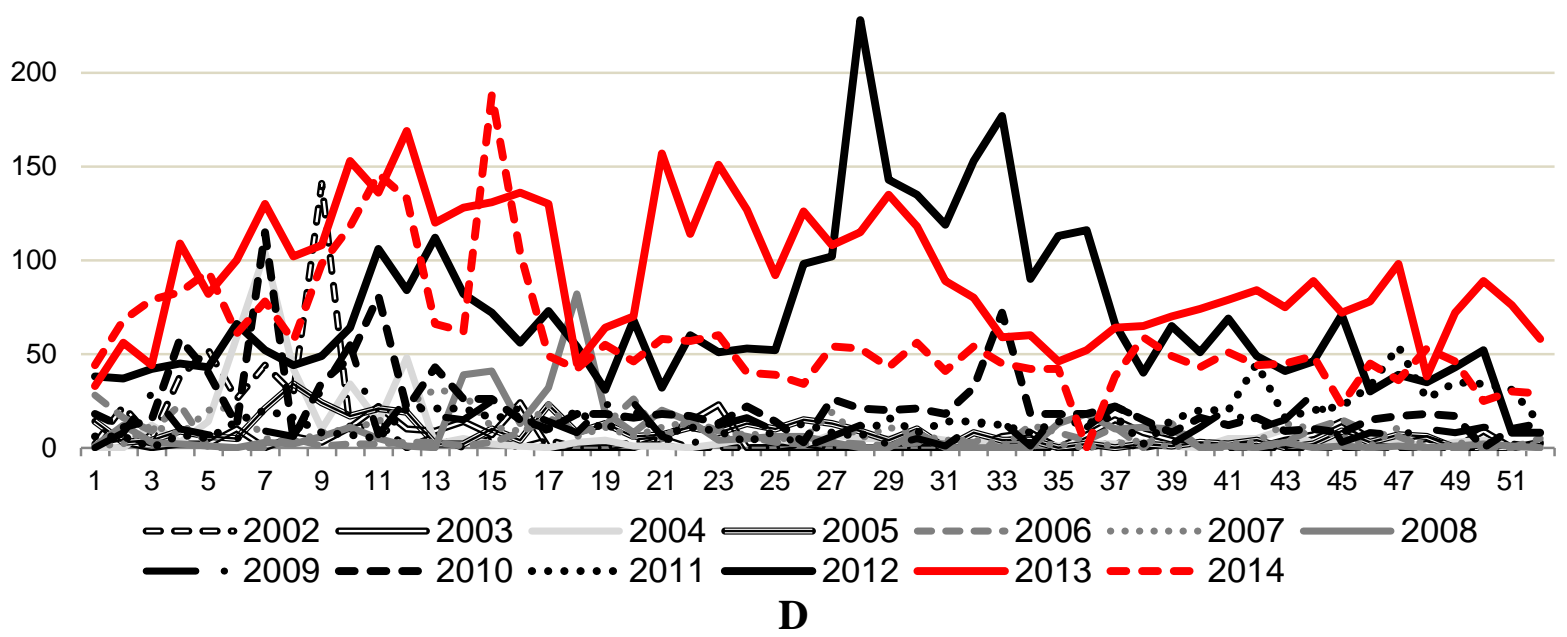

Figura 4.13: Casos de DDA por semana epidemiológica em toda a área de estudo no RN (A) e nas áreas abastecidas pela LDB (B) e açudes ARG (C) e MDG (D) (2002-2014).

Fonte: Elaborado pelo autor a partir de dados da SESAP (dados não publicados).

No entanto, a distribuição da precipitação ao longo de 2013 também deve ser considerada, haja vista os resultados obtidos no Capítulo 3, que associou o comportamento sazonal da DDA com o da precipitação. Observa-se que os totais mensais de precipitação em 2013 apresentam variação considerável ao longo da área de estudo (Figura 4.14). Na estação de Sítio Novo, localizada na área abastecida pela LDB, um quantitativo mensal de chuvas superior a $15 \mathrm{~mm}$ só veio a ser registrado no mês de abril. Já na área abastecida pelo açude ARG, que também apresentou um aumento no número de casos a partir da $19^{\mathrm{a}}$ semana epidemiológica (Figura 4.13C), os totais pluviométricos foram maiores, sendo registrados valores de 270 e 250 mm nas estações de Janduís e São Rafael, respectivamente, nesse mesmo mês.

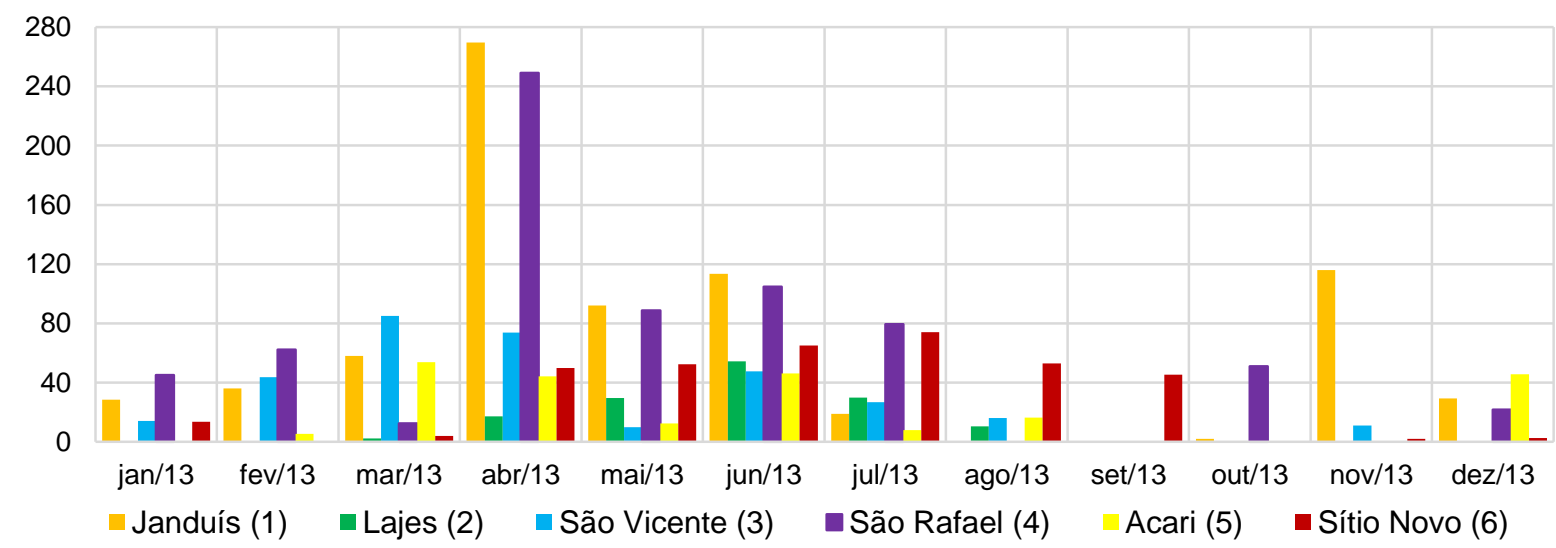

Figura 4.14: Precipitação acumulada mensal (mm) em estações selecionadas na área de estudo (2013).

Nota: Foi selecionada a estação pluviométrica em operação mais próxima do centroide da área de cada sistema de abastecimento de água.

Fonte: Elaborado pelo autor a partir de dados da EMPARN. 
O município de Acari apresentou no período 2012-2014 as maiores taxas de DDA da área de estudo. Acari é abastecida, juntamente com Currais Novos, pelo açude MDG. Segundo informações orais fornecidas por técnicos da CAERN, em situações normais aproximadamente metade da cidade de Currais Novos é abastecida pelo açude Dourado, localizado na área central da cidade, o que contradiz as informações apresentadas em ANA (2011) de que o abastecimento provém apenas do açude MDG. No entanto, os baixos níveis do açude MDG (Figura 4.12B) e o esgotamento do açude Dourado em maio de 2013, segundo os dados de volume de água produzido repassados pela CAERN, levou a cidade de Currais Novos a depender totalmente do açude MDG. Após maio de 2013, somente houve bombeamento de água a partir do açude Dourado entre agosto e outubro de 2014. A situação de escassez hídrica esteve associada ao aumento na ocorrência de DDA em Currais Novos, o maior município da área de estudo no Rio Grande do Norte, que apresentou taxas altas de DDA somente em 2012 e maiores ainda em 2013 (Figura 4.8), como também para os recordes registrados em 2012, 2013 e 2014 em Acari. Um número alto de casos foi observado nesses municípios em praticamente todas as semanas epidemiológicas desses anos, como mostra a Figura 4.13D. A taxa de DDA de Acari foi de 257 em 2012, a maior taxa dentre os municípios da área de estudo, 326 em 2013, a segunda maior taxa, superada apenas por Monte das Gameleiras (419) e 379 em 2014, novamente a maior taxa registrada (Figura 4.15).

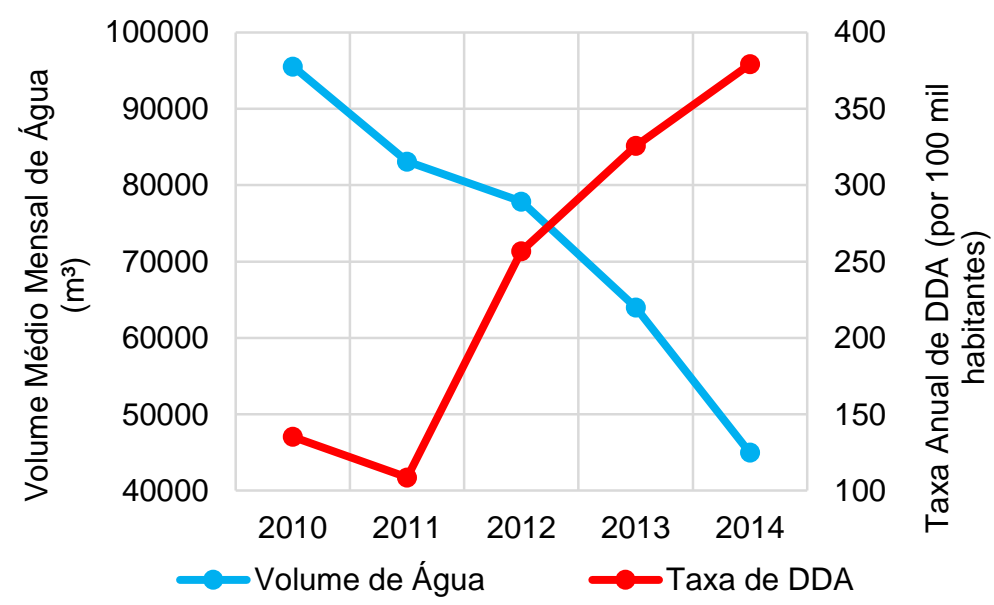

Figura 4.15: Volume de água produzido e taxa de DDA do município de Acari (2010-2014). Fonte: Elaborado pelo autor a partir de dados da CAERN e SESAP (dados não publicados). 
O volume de água mensal disponível para consumo, bombeado a partir dos sistemas da CAERN nos açudes MDG e Dourado para abastecimento de Acari e Currais Novos, entre 2010 e 2014, que corresponde ao período de dados disponível, e o total de casos de DDA registrados em cada mês nesses municípios, produto das somas dos casos registrados por semana epidemiológica, é apresentado na Figura 4.16.

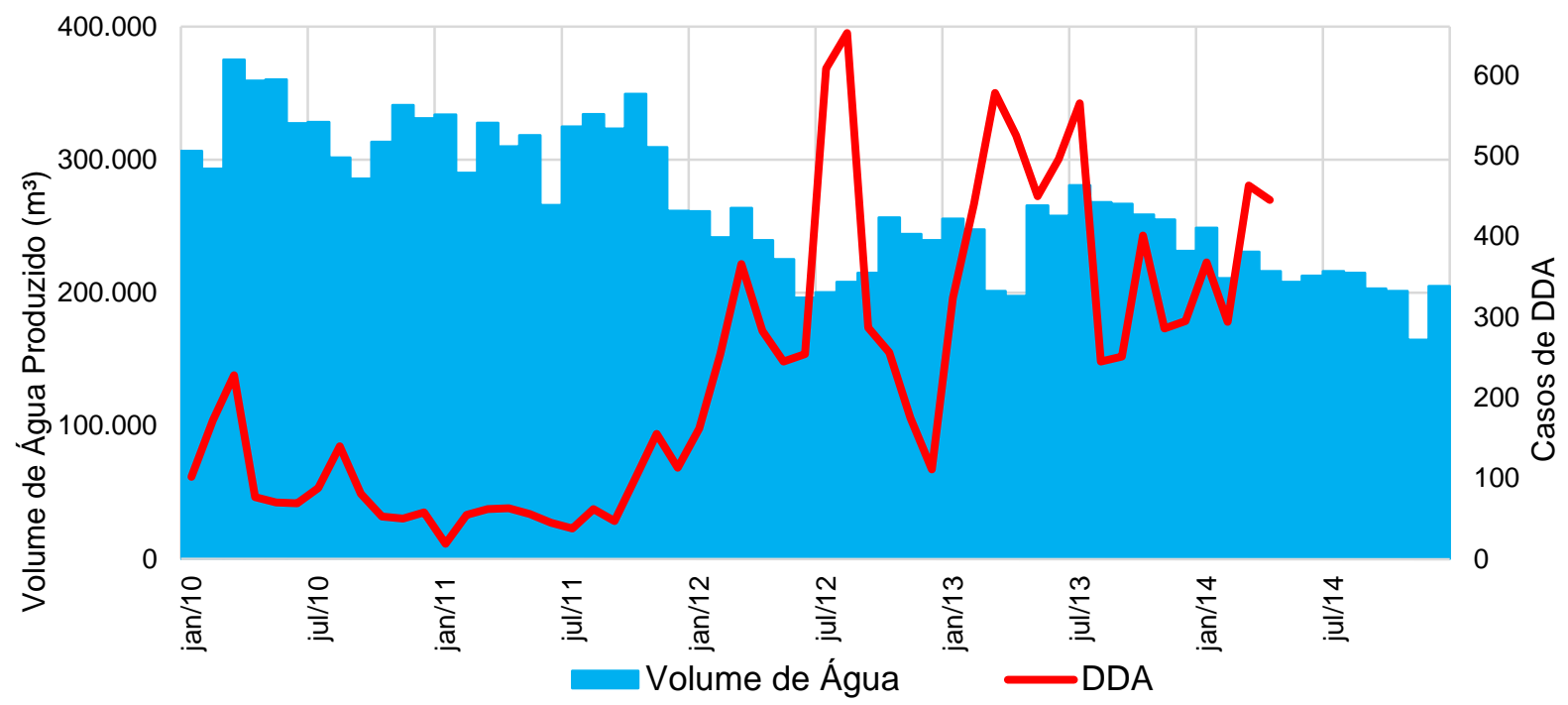

Figura 4.16: Volume de água $\left(\mathrm{m}^{3}\right)$ produzido pelos açudes MDG e Dourado e casos de DDA: valores mensais para os municípios de Acari e Currais Novos (2010-2014).

Nota: As semanas epidemiológicas foram associadas ao mês no qual ocorreu o maior número de dias. Dados de DDA não disponíveis para o município de Currais Novos a partir de maio de 2014.

Fonte: Elaborado pelo autor a partir de dados da CAERN e SESAP (dados não publicados).

O coeficiente de correlação observado entre as referidas séries temporais de janeiro de 2010 a abril de 2014 foi de $-0,72$, ou seja, a relação entre as variáveis foi inversamente proporcional. Os períodos de aumento nos casos de DDA estiveram relacionados com períodos de queda na quantidade de água captada, que impactam consequentemente a sua distribuição, com destaque para a queda acentuada no volume de água a partir do fim de 2011 e a grande elevação no número de casos registrados de DDA, fenômeno este que se repetiu novamente no início de 2013.

Comparando o volume mensal de água disponibilizado para Acari e para Currais Novos, observamos que em 2012 o valor médio foi de $77.842 \mathrm{~m}^{3}$ e $154.804 \mathrm{~m}^{3}$, respectivamente, enquanto que em 2014 este valor reduziu-se para $44.972 \mathrm{~m}^{3} \mathrm{em}$ Acari (somente $58 \%$ do volume anterior) e aumentou para $166.163 \mathrm{~m}^{3} \mathrm{em}$ Currais Novos. Desse modo, a penalização da redução no volume de água recaiu totalmente sobre Acari, sendo o aumento nos casos registrados de 
DDA uma de suas consequências (Figura 4.15). Além disso, a redução no volume de água distribuído na rede geral não foi acompanhada por um aumento no uso de carros-pipa para abastecimento em 2014 em relação ao ano anterior (Figura 4.6).

\subsection{DISCUSSÃO}

Barcellos et al. (1998) observaram que, no caso do município do Rio de Janeiro, aproximadamente $95 \%$ dos domicílios eram abastecidos por água da rede geral, mas ainda havia abastecimento por poços e nascentes, aumentando a possibilidade de contaminação. Por conta da conhecida heterogeneidade na ocupação do solo urbano e a topografia acidentada da cidade, os problemas associados com o abastecimento de água concentraram-se em áreas e grupos socioespaciais específicos. Nesse sentido, a inter-relação entre dados ambientais e sanitários foi importante para a avaliação da exposição de grupos populacionais a fatores de risco.

A presença do cloro na água tratada em adutoras de grande extensão reduz-se ao longo do sistema, o que pode estar associado à ocorrência de maiores taxas de DDA em municípios localizados no final das redes de adução. É necessário que toda a água distribuída apresente cloro residual, utilizado para a desinfecção, ao longo dos pontos de consumo, visando a garantia da qualidade da água até o último consumidor (RICHTER, 2009). Em adutoras de grande extensão, como é o caso da região de estudo, a presença de cloro residual na água recebida por municípios localizados nas extremidades da rede pode ser ínfima ou nula, devido às características do sistema de distribuição e reservação, comprometendo a qualidade da água. O ideal seria o emprego de práticas de recloração da água ao longo da rede de adução, possibilitando destruir pequenas concentrações de micro-organismos que possam ter penetrado no sistema, além de monitoramento constante da presença do cloro residual na rede de distribuição. A água também pode sofrer algum tipo de contaminação ao longo do percurso, seja por um elemento externo ou até mesmo pela falta de manutenção da estrutura. Possíveis conexões ilegais à rede também favorecem a entrada de contaminantes.

Ceballos et al. (1998) estudando a região rural nos arredores de Campina Grande, evidenciaram elevada contaminação fecal das águas de pequenos barreiros, olhos d'água e açudes, intermitentes ou não, usados para abastecimento humano sem tratamento prévio e usos domésticos em geral. Em alguns municípios da área de estudo, esta forma de abastecimento 
ainda persiste, havendo diversos casos de municípios que dispõem de açudes marginais menores nas áreas urbanas. Na área rural, o ideal é que as políticas de construção de cisternas fossem acompanhadas da implantação de fossas sépticas, ou seja, as soluções devem considerar água e esgoto de maneira integrada.

Joventino et al. (2010) encontraram uma associação inversamente proporcional entre a construção das cisternas do P1MC e o comportamento das diarreias em crianças menores de cinco anos no município de Canindé, Ceará e, a partir daí, inferiram que realmente houve uma melhoria na qualidade da água consumida pelas famílias, visto que, antes da construção das cisternas, ingeriam água proveniente, em sua maioria, de cacimbões e de açudes, a qual era escura/barrenta, salobra e com pedras.

A água da chuva nas áreas rurais do semiárido brasileiro é de excelente qualidade (XAVIER, 2010). No entanto, a adoção de múltiplas barreiras sanitárias ao longo do sistema é fundamental para fornecer água segura para o consumo humano. É de fundamental importância o desvio das águas das primeiras chuvas, que efetuam a lavagem dos telhados e calhas, e o manejo adequado da retirada de água da cisterna (ANDRADE NETO, 2004; SOUZA et al., 2011). O estudo de Tavares (2009) concluiu que as cisternas que armazenam somente água da chuva apresentam melhor qualidade de água que aquelas que recebem água de carro-pipa. No entanto, as variáveis microbiológicas indicaram contaminação fecal acima dos padrões de potabilidade nas cisternas, independentemente da origem da água, sendo o manejo do sistema elemento vital para a qualidade da água, que pode ser aprimorado a partir de educação ambiental ostensiva.

A distribuição de água por carro-pipa desvirtua os objetivos do programa de construção de cisternas, que pressupõe o manejo correto da água e evita o seu uso indiscriminado, além de introduzir água cuja qualidade pode não ser confiável e é inferior àquela proveniente da chuva. A coleta de água em pequenos açudes ou olhos d'água (fontes tradicionais de suprimento da população rural), de semelhante modo facilita a contaminação da cisterna.

Alguns municípios com grande quantitativo de domicílios rurais têm recebido as maiores contribuições do programa de construção de cisternas. O programa também tem alcançado aqueles municípios localizados nas bordas dos sistemas de abastecimento que, por sua vez, também são aqueles que mais demandam a operação de carros-pipa. Desse modo, apesar das características distintas do abastecimento de água por cisterna e por carro-pipa, observa-se que as modalidades são complementares, e a existência de mais cisternas não inibe 
o crescimento da operação de carros-pipa, haja vista a situação de seca severa observada a partir de 2012 na área de estudo. Para muitos municípios do semiárido, em períodos de seca severa, com a redução drástica do nível dos reservatórios, a única alternativa de abastecimento passa a ser o emprego de carros-pipa para entrega de água a população, tanto urbana como rural. Conforme o noticiário da mídia em geral*, este problema tem sido grave na região, conduzindo a episódios de ocorrência de doenças de veiculação hídrica e denúncias de coleta de água por carros-pipa em mananciais sem qualquer potabilidade para o consumo humano.

Conflitos existentes em relação ao uso da água da LDB parecem contribuir para os problemas verificados no abastecimento de água da Adutora Monsenhor Expedito e, consequentemente, altas taxas de DDA nessa região. A Adutora entrou em operação em 1998, inicialmente com previsão de atendimento de 23 sedes municipais e 45 comunidades rurais. No entanto, desde então, contínuas solicitações de interligação de outras comunidades rurais, além de novas sedes municipais, foram sendo atendidas, devido ao fato de não possuírem outra fonte adequada de abastecimento. Em 2013 o sistema abastecia trinta cidades e 271 comunidades rurais (RIO GRANDE DO NORTE, 2013).

Conforme Pereira et al. (2004), o projeto inicial do Sistema Adutor pretendia explotar água somente da LDB, porém, a partir do ano 2000, temendo o rebaixamento do nível do manancial e do sistema lacustre que compreende ainda outras cinco lagoas, o sistema passou a funcionar como um sistema misto, havendo a retirada de águas de um aquífero semiconfinado a partir de uma bateria de sete poços subterrâneos, instalados ao longo das margens da lagoa. O sistema misto foi implantado após determinação da cota 39 metros como o limite mínimo do espelho d'água da lagoa pelos Ministérios Públicos Estadual e Federal.

Pereira et al. (2004) já consideravam provável o agravamento do nível da LDB a partir do funcionamento desta bateria de poços, o que prejudicaria a sustentabilidade da adutora em períodos de escassez de precipitação, fato este que ocorreu com a implantação do rodízio de abastecimento no fim de março de 2013, após observação do menor registro histórico do volume de água da Lagoa (Figura 4.12A), conforme a série de dados disponíveis. Problemas de

\footnotetext{
* Conforme textos publicados na Internet em: http://g1.globo.com/al/alagoas/noticia/2013/07/sobe-para-48-o-numero-demortes-por-diarreia-em-alagoas.html; http:/g1.globo.com/pe/caruaru-regiao/noticia/2013/08/com-surto-de-diarreia-caruarufaz-pente-fino-em-caminhoes-pipa.html; http://g1.globo.com/pe/caruaru-regiao/noticia/2013/09/com-surto-de-hepatitemanari-no-pe-nao-adere-ao-mais-medicos.html; http://g1.globo.com/pe/petrolina-regiao/noticia/2013/11/com-secareservatorios-ficam-vazios-no-sertao-de-pernambuco.html; http://g1.globo.com/rn/rio-grande-do-norte/noticia/2013/12/secaobriga-moradores-do-rn-gastar-bolsa-familia-com-agua-potavel.html e; http://g1.globo.com/fantastico/noticia/2013/12/vitimas-da-seca-recebem-agua-contaminada-em-caminhoes-pipa.html.
} 
infraestrutura como o subdimensionamento da adutora podem ter levado as dificuldades no abastecimento e a sua descontinuidade parece ter agravado a situação.

Os problemas apresentados pela adutora são recorrentes e em virtude disso foram perfurados em 2012 um total de doze novos poços na área próxima ao Riacho Boacica, a sudeste do sistema lacuste formado por seis lagoas - do qual a do Bonfim é a maior delas - e a jusante no sentido hidrológico, constituindo um novo sistema de captação de água visando o atendimento da demanda da Adutora. Segundo informações orais coletadas em visita técnica à CAERN, essa nova bateria de poços, em complemento ao sistema de poços já existente, visa restringir a captação de água à fonte subterrânea, eliminar a captação flutuante existente na LDB e evitar o abaixamento de seu nível. No entanto, este sistema ainda não está operante. Além disso, há um projeto de expansão da cobertura da adutora para atender outros onze municípios do extremo sudeste potiguar.

Lee e Schwab (2005) argumentam que os principais problemas enfrentados pelos sistemas de abastecimento de água nos países em desenvolvimento derivam principalmente da vulnerabilidade e intermitência desses sistemas, mais do que de sua cobertura propriamente dita. A interrupção dos sistemas e intermitência do abastecimento e até mesmo a redução da pressão facilita o crescimento de micro-organismos, introdução de patógenos e contaminação da água, podendo levar a aumento nos casos de DDA. Falta de manutenção, baixa pressão dos sistemas, perdas excessivas e a existência de conexões ilegais ao longo da rede de adução e distribuição são deficiências mencionadas pelos autores que também são relatadas pelas companhias de abastecimento que operam na área de estudo. Quando o abastecimento é intermitente, a retomada pode levar à contaminação e a rupturas na própria estrutura hidráulica. O fator mais relevante, portanto, passa a ser a existência de "água na torneira” ou de fácil acesso, ainda que sua qualidade seja duvidosa. A diminuição das taxas de DDA depende da efetiva implantação de soluções apropriadas para esses problemas.

Outro problema citado por Andreazzi et al. (2007) é a forte dependência dos municípios dos sistemas de abastecimento não havendo, em geral, quaisquer fontes alternativas viáveis de utilização para abastecimento de água, o que se verifica na área de estudo, com baixa segurança hídrica.

Em 2015 a situação do abastecimento de água na área de estudo permanece crítica e o nível dos reservatórios continua baixando, sendo que o Governo do Estado do Rio Grande do Norte decretou em 27 de março estado de calamidade pública em 153 dos 167 municípios 
potiguares em função da seca. Há inclusive racionamento em municípios abastecidos pelo açude ARG, como é o caso daqueles atendidos pelo sistema integrado Serra de Santana. Devido ao rebaixamento do nível do açude não está sendo possível bombear água a partir do local de captação sendo que providências estão sendo tomadas para captar água a jusante do ponto atual. Além disso, o florescimento de algas em certos períodos do ano, dada a eutrofização do açude ARG já atestada na bibliografia (MARTINEZ et al., 2011) representa, segundo Richter (2009), um dos mais sérios problemas à operação de uma estação de filtragem direta, como é o caso do sistema citado, conduzindo à redução no tempo de operação e o aumento no consumo de água para lavagem dos filtros. Outros problemas como ligações clandestinas e manejo inadequado da água do Canal de Pataxó, que conduz água do açude ARG à adutora Sertão Central Cabugi, são recorrentes na região*

Enquanto o sistema do PISF não entra em operação, a grave seca que o semiárido vem enfrentando nos últimos anos tem obrigado os órgãos gestores de recursos hídricos a tomarem medidas mais drásticas, como aquela efetuada pela Resolução Conjunta ANA/IGARN/AESA $n^{0}$ 640/2015 (ANA, 2015c), que interrompeu em julho de 2015 todas as captações de águas superficiais para as finalidades de irrigação e aquicultura no Rio Piranhas/Açu a montante do açude ARG, partindo da prioridade estabelecida pela Lei nº 9.433/1999 (BRASIL, 1999), que corresponde ao abastecimento humano e animal em caso de escassez, um dos fundamentos da Política Nacional de Recursos Hídricos.

$\mathrm{Na}$ Paraíba, as águas armazenadas pelo açude EPB são insuficientes para os seus diversos usos e isto tem como uma das consequências o estrangulamento do desenvolvimento socioeconômico da cidade de Campina Grande, um dos maiores centros urbanos do interior do Nordeste. Segundo informações orais coletadas em visita técnica à CAGEPA, não houve racionamento no abastecimento a partir do açude EPB entre 2006 e 2012, tendo sido implantado em 1999 e posteriormente somente em 6 de dezembro de 2014. A partir de 31 de outubro de 2015, as cidades abastecidas pelo açude EPB passaram a contar com água apenas três dias e meio na semana. No entanto, de modo semelhante às obras em curso no Rio Grande do Norte, a CAGEPA está implantando um novo sistema de adução de água a partir do açude EPB para abastecimento de três municípios localizados ao sul do açude, e uma quarta adutora para o atendimento do Sistema Integrado Campina Grande, o que pode sobrecarregar ainda mais o já fragilizado manancial de água.

\footnotetext{
* No Apêndice $B$ da tese encontram-se fotografias associadas aos problemas de abastecimento de água citados na área de estudo.
} 


\subsection{CONSIDERAÇÕES FINAIS}

A área abastecida pela Adutora Monsenhor Expedito não apresentou menores taxas de DDA, refutando a hipótese de que esta área, cujo manancial, a Lagoa do Bonfim, de melhor qualidade de água e introduzido na pesquisa como área de controle, apresentaria menores taxas de ocorrência de DDA. Isto reforça a conclusão de que a dinâmica da DDA está mais fortemente associada a deficiências e vulnerabilidades ligadas às infraestruturas de abastecimento de água, que contribuem inclusive ao entendimento de situações epidêmicas, além das questões ligadas ao regime sazonal da precipitação. Outras variáveis, de cunho socioeconômico, associadas a questões de renda e infraestruturas, poderão ser integradas à análise em estudos complementares.

A mera existência do elemento conexão da residência à rede geral de abastecimento não significa garantia de disponibilidade contínua de água ao longo do tempo. Tampouco representa água de boa qualidade ao longo de todo o sistema, cujas redes chegam a percorrer mais de 400 km em um único sistema, como é o caso da Adutora Monsenhor Expedito.

Alguns municípios com grande número de carros-pipa em operação e baixos índices de atendimento da rede geral de abastecimento de água apresentaram taxas altas de DDA. A influência da presença de ETA não foi observada, mas deficiências nos processos de tratamento da água para consumo humano podem facilitar a ocorrência de DDA. Por essa razão, políticas públicas dos órgãos federais, estaduais, municipais devem ser direcionadas para a melhoria dos sistemas de tratamento existentes e da qualidade da água distribuída pelas operadoras dos serviços de saneamento básico. Outras características operacionais do abastecimento de água, como a implantação de um rodízio, se mostraram relevantes na análise temporal e espacial do comportamento da doença. Por essa razão, é importante haver disponibilidade contínua de água e na quantidade adequada ao longo do tempo. Os dados relativos à ocorrência da DDA nas áreas abastecidas pela Lagoa do Bonfim e pelo açude MDG auxiliam nesse entendimento.

Espera-se que o PISF venha a melhorar o aporte de água para os reservatórios de abastecimento estudados nesta pesquisa, e que os devidos cuidados com a qualidade da água, já comprometida nos reservatórios de captação na bacia do Rio São Francisco, sejam tomados. Faz-se necessário aguardar o término das obras e a entrada efetiva em operação para verificar 
as alterações que ocorrerão nos sistemas hídricos locais. Haja vista que o problema da DDA não se restringe à área que receberá a intervenção do programa e, considerando os resultados aqui apresentados, que apontam para a existência de múltiplos fatores atuando sobre os padrões espaço-temporais de ocorrência das doenças diarreicas.

Observa-se, de modo geral, a necessidade de maior regulação dos serviços de abastecimento de água prestados à população, tanto dos serviços contínuos da rede geral, sejam eles prestados por companhias estaduais, prefeituras municipais ou serviços autônomos, como dos serviços esporádicos, a exemplo da prestação dos serviços de carro-pipa que, consequentemente, demanda maior controle, gestão e fiscalização. No entanto, este tipo de abastecimento de água não pode adquirir um caráter permanente, o que é observado em algumas áreas do semiárido, fruto da insegurança hídrica do abastecimento de água da região. Ademais, é necessária uma melhor gestão da operação dos carros-pipa, principalmente aquela de caráter emergencial, para evitar o atendimento de pipeiros oportunistas e a distribuição de água pelas prefeituras municipais com interesse político-eleitoral.

Apesar das geotecnologias contribuírem a esta pesquisa, bem ressaltam Vasconcelos et al. (2006) que há a necessidade de um grande volume de dados auxiliares e trabalho de campo para possibilitar o entendimento de toda a dinâmica envolvida. Estudos observacionais auxiliam na compreensão do fenômeno, pois fatores intraurbanos podem constituir peças-chave.

Os processos e problemas sociais e ambientais geralmente transcendem os limites do território utilizado como limite para a coleta e organização dos dados ambientais e de saúde. O foco do problema pode estar localizado em uma pequena parcela do território, no entanto os dados serão referenciados a toda a unidade espacial de análise adotada (PEITER et al., 2006). Zeilhofer et al. (2007), por exemplo, verificaram problemas de qualidade da água em um distrito urbano de classe média baixa do município de Cuiabá, Mato Grosso, associados à ocorrência de gastroenterites. O estudo identificou que os problemas de qualidade da água não eram causados basicamente pela infraestrutura pública, como argumentado pela população entrevistada, mas no interior das edificações e residências, em conexões e caixas d'água. Esse tipo de análise foi relevante, pois contemplou a dimensão intraurbana na pesquisa e incluiu dados como a altitude e distância das residências e escolas em relação à caixa d'água, e a localização da ETA e da rede de esgotos. O ideal seria dispor de dados de ocorrência da diarreia conforme a situação do domicílio de moradia, urbana ou rural, para averiguar os impactos das diferentes fontes de abastecimento. Uma sugestão para o refinamento da coleta de dados da 
DDA, que até então não é feita segundo essa categorização. Estudos complementares também poderão ser efetuados envolvendo observação detalhada das soluções de esgoto locais, de semelhante modo à análise efetuada com as fontes de água.

É necessário também a definição de indicadores de seca relevantes, tendo em vista que não corresponde simplesmente à redução da precipitação. A utilização de dados como o volume de água disponibilizado à população, nível de água dos reservatórios de abastecimento e taxas de operação de carros-pipa, adotadas neste estudo, parecem ser alternativas viáveis. Até mesmo porque esta definição corresponde a uma lacuna na bibliografia. Moors et al. (2013) não encontraram estudos que quantificassem os efeitos das secas ou períodos secos prolongados sobre a incidência de diarreia explicitamente.

Embora possam não ser as melhores alternativas, o avanço da construção de cisternas e a adoção da Operação Carro-Pipa permitiram que episódios de seca severa no Nordeste não fossem mais episódios de miséria, êxodo ou morte, como era até então o flagelo de seca em toda a história do Brasil. Certamente benefícios sociais como o Bolsa Família e o Bolsa Estiagem também contribuíram para isso. Houve, sem dúvida, uma mudança de paradigma, que permitiu à população conviver com o fenômeno da seca. No entanto, estas podem ainda não ser as melhores soluções e outras alternativas devem ser encontradas. Estudos recentes indicam que novas matrizes energéticas, tais como a eólica, para o litoral, e a solar, para o sertão, representam novas oportunidades de desenvolvimento e renda para a região.

\section{REFERÊNCIAS BIBLIOGRÁFICAS}

AGÊNCIA NACIONAL DE ÁGUAS (ANA). Atlas Brasil: Abastecimento Urbano de Água. Brasília: ANA, 2011. Disponível em: http://atlas.ana.gov.br/Atlas/forms/Home.aspx. Acesso em: 20 abr. 2013.

SAR: Sistema de Acompanhamento de Reservatórios. Brasília: ANA, 2015a.

Disponível em: http://sar.ana.gov.br/. Acesso em: 30 set. 2015.

Conjuntura dos Recursos Hídricos no Brasil: Informe 2014. Encarte Especial sobre a Crise Hídrica. Brasília: ANA, 2015b. Disponível em: http://conjuntura.ana.gov.br/ docs/crisehidrica.pdf. Acesso em: 17 out. 2015. 
Resolução Conjunta ANA, IGARN-RN e AESA-PB n. ${ }^{\circ}$ 640, de 18 de junho de 2015. Brasília: ANA, 2015c. Disponível em: http://arquivos.ana.gov.br/resolucoes/2015/6402015.pdf. Acesso em: 24 jun. 2015.

ANDRADE NETO, C.O. Proteção Sanitária das Cisternas Rurais. In: XI Simpósio LusoBrasileiro de Engenharia Sanitária e Ambiental, Anais, Natal, 2004.

ANDREAZZI, M. A. R.; BARCELLOS, C.; HACON, S. Velhos indicadores para novos problemas: a relação entre saneamento e saúde. Revista Panamericana de Salud Publica, v. 22, n. 3, p. 211-217, 2007.

ASA BRASIL. ARTICULAÇÃO NO SEMIÁRIDO BRASILEIRO. Programa Um Milhão de Cisternas Rurais. Disponível em: http://www.asabrasil.org.br/acoes/p1mc. Acesso em: 15 out. 2015.

BANDYOPADHYAY, S.; KANJI, S.; WANG, L. The impact of rainfall and temperature variation on diarrheal prevalence in Sub-Saharan Africa. Applied Geography, v. 33, p. 63$72,2012$.

BARCELLOS, C.; BASTOS, F. I. Geoprocessamento, ambiente e saúde: uma união possível? Cadernos de Saúde Pública, v. 12, n. 3, p. 389-397, 1996.

; COUTINHO, K.; PINA, M. F.; MAGALHÃES, M. M. A. F.; PAOLA, J. C. M. D.; SANTOS, S. M. Inter-relacionamento de dados ambientais e de saúde: análise de risco à saúde aplicada ao abastecimento de água no Rio de Janeiro utilizando Sistemas de Informações Geográficas. Cadernos de Saúde Pública, v. 14, n. 3, p. 597-605, 1998.

BRASIL. GOVERNO FEDERAL. Lei n. 9.433, de 8 de janeiro de 1997. Disponível em: http://www.planalto.gov.br/ccivil_03/LEIS/L9433.htm. Acesso em: 15 mar. 2015.

Observatório da Seca: Construção de Cisternas. Disponível em:

http://www.brasil.gov.br/observatoriodaseca/construcao-cisternas.html. Acesso em: 15 mar. 2015 .

CEBALLOS, B. S. O.; KONIG, A.; OLIVERA, J. F. Dam reservoir eutrophication: a simplified technique for a fast diagnosis of environmental degradation. Water Research, v. 32, n. 11, p. 3477-3483, 1998.

CHENG, J. J.; SCHUSTER-WALLACE, C. J.; WATT, S.; NEWBOLD, B. K.; MENTE, A. An ecological quantification of the relationships between water, sanitation and infant, child, and maternal mortality. Environmental Health, v. 11, n. 4, p. 2-8, 2012. 
DUARTE, M. A. C.; CEBALLOS, B. S. O.; MELO, H. N. S.; KÖNIG, A. Comportamento dos Índices do Estado Trófico de Carlson (IET) e Modificado (IET $\mathrm{M}$ ) em três lagoas naturais no Nordeste do Brasil. In: $20^{\circ}$ Congresso Brasileiro de Engenharia Sanitária e Ambiental, Anais, Rio de Janeiro, 1999.

EVANS, B.; HUTTON, G.; HALLER, L. Closing the Sanitation Gap - the Case for Better Public Funding of Sanitation and Hygiene. Background paper for the OECD Round Table on Sustainable Development meeting on water and sanitation, Paris, 2004.

FEWTRELL, L.; KAUFMANN, R.; KAY, D.; ENANORIA, W.; HALLER, L.; COLFORD, $\mathrm{J}$. Water, sanitation, and hygiene interventions to reduce diarrhoea in less developed countries: a systematic review and meta-analysis. Lancet Infectious Diseases, v. 5, p. 42-52, 2005.

GUIMARÃES, R. M.; ASMUS, C. I. R. F.; OLIVEIRA JÚNIOR, S. A.; MAZOTO, M. L. Acesso ao saneamento básico e internação por doença diarreica aguda: um estudo da vulnerabilidade infantil. Revista Salud Ambiental, v. 13, n. 1, p. 22-29, 2013.

INSTITUTO BRASILEIRO DE GEOGRAFIA E ESTATÍSTICA (IBGE). Censo

Demográfico 2000: Características da População e dos Domicílios: Resultados do universo. Rio de Janeiro: IBGE, 2000. Disponível em: http://www.sidra.ibge.gov.br/cd/ cd2000ru.asp?o=24\&i=P. Acesso em: 15 mar. 2015.

Pesquisa Nacional de Saneamento Básico. Rio de Janeiro: IBGE, 2008. Disponível em: http://www.ibge.gov.br/home/estatistica/populacao/condicaodevida/pnsb/defaultquest_ 2008.shtm. Acesso em: 15 mar. 2015.

Censo Demográfico 2010: Resultados do Universo - Características da População e dos Domicílios. Rio de Janeiro: IBGE, 2010. Disponível em: http://www.sidra.ibge.gov.br/ $\mathrm{cd} / \mathrm{cd} 2010$ universo.asp?o=7\&i=P. Acesso em: 15 mar. 2015.

Estimativas de População: Estimativas populacionais para os municípios brasileiros em 01.07.2013. Rio de Janeiro: IBGE, 2015. Disponível em: http://www.ibge.gov. br/home/estatistica/populacao/estimativa2013/default.shtm. Acesso em: 15 mar. 2015.

INSTITUTO NACIONAL DE PESQUISAS ESPACIAIS (INPE). CENTRO DE PREVISÃO DO TEMPO E ESTUDOS CLIMÁTICOS (CPTEC). Infoclima. Cachoeira Paulista: INPE/CPTEC, 2015. Disponível em: http://infoclima.cptec.inpe.br/. Acesso em: 15 mar. 2015.

INSTITUTO TRATA BRASIL (TRATA BRASIL). CONSELHO EMPRESARIAL BRASILEIRO PARA O DESENVOLVIMENTO SUSTENTÁVEL (CEBDS). Benefícios econômicos da expansão do saneamento brasileiro: qualidade de vida, produtividade, 
educação e valorização ambiental. São Paulo: Trata Brasil, 2014. 24p. Disponível em: http://www.tratabrasil.org.br/ beneficios-economicos-da-expansao-do-saneamento-brasileiro. Acesso em: 15 mar. 2015.

JOVENTINO, E. S.; SILVA, S. F.; ROGERIO, R. F.; FREITAS, G. L.; XIMENES, L. B.; MOURA, E. R. F. Comportamento da diarreia infantil antes e após o consumo de água pluvial em município do semiárido brasileiro. Texto Contexto Enfermagem, v. 19, n. 4, p. 691-699, 2010.

LEE, E. J.; SCHWAB, K. J. Deficiencies in drinking water distribution systems in developing countries. Journal of Water and Health, v. 3, n. 2, p. 109-127, 2005.

MARTINEZ, J. M.; VENTURA, D.; VIEIRA, M. R.; ATTAYDE, J. L.; BUBEL, A. P.; COIMBRA, M. R.; OLIVEIRA, E. Satellite-based monitoring of reservoir eutrophication in the Brazil Semi-arid region. In: XV SIMPÓSIO BRASILEIRO DE SENSORIAMENTO REMOTO, Anais, Curitiba, 2011.

MINISTÉRIO DAS CIDADES (MCid). SISTEMA NACIONAL DE INFORMAÇÕES SOBRE SANEAMENTO (SNIS). Diagnóstico dos Serviços de Água e Esgotos, referente ao ano de 2013. Brasília: Ministério das Cidades, 2014. 181p.

MOORS, E.; SINGH, T.; SIDERIUS, C.; BALAKRISHNAN, S.; MISHRA, A. Climate change and waterborne diarrhoea in northern India: Impacts and adaptation strategies. Science of the Total Environment, 2013. Disponível em: http://dx.doi.org/10.1016/j.scitotenv.2013. 07.021 .

PEITER, P. C; BARCELLOS, C.; ROJAS, L. B. I.; GONDIM, G. M. M. Espaço Geográfíco e Epidemiologia. In: SANTOS, S. M; BARCELLOS, C. (orgs.). Abordagens espaciais na Saúde Pública. Brasília: Ministério da Saúde/FIOCRUZ, 2006. p. 11-43.

PEREIRA, R.; SILVA JÚNIOR, G. C.; GUIMARÃES JÚNIOR, J. A. Funcionamento Hidrodinâmico do Aqüífero Semiconfinado da Região do Bonfim - RN - Brasil: Uma Interação com o Aqüífero Livre e a Lagoa do Bonfim. Revista Brasileira de Recursos Hídricos, v. 9, n. 2, p. 75-84, 2004.

PROGRAMA DAS NAÇÕES UNIDAS PARA O DESENVOLVIMENTO (PNUD). ODM: Objetivos de Desenvolvimento do Milênio. Brasília: PNUD, 2012. Disponível em: http://www.pnud.org.br/ODM.aspx. Acesso em: 15 mar. 2015.

QUEIROZ, J. T. M.; HELLER, L.; SILVA, S. R. Análise da correlação de ocorrência da doença diarreica aguda com a qualidade da água para consumo humano no município de Vitória-ES. Saúde e Sociedade, v. 18, n. 3, p. 479-489, 2009. 
QUEVEDO, C. M. G; PAGANINI, W. S. Impactos das atividades humanas sobre a dinâmica do fósforo no meio ambiente e seus reflexos na saúde pública. Ciência \& Saúde Coletiva, v. 16, n. 8, p. 3529-3539, 2011.

RICHTER, C. A. Água: Métodos e Tecnologia de Tratamento. São Paulo: Edgard Blucher, 2009. 340p.

RIO GRANDE DO NORTE. GOVERNO DO ESTADO. Adutora Monsenhor Expedito. Disponível em: http://www.semiarido.rn.gov.br/adutora_mons_exp.php. Acesso em: 25 nov. 2013.

SASTRY, N; BURGARD, S. The prevalence of diarrheal disease among Brazilian children: trends and differentials from 1986 to 1996. Social Science and Medicine, v. 60, p. 923-935, 2005.

SOUZA, S. H. B.; MONTENEGRO, S. M. G. L.; SANTOS, S. M.; PESSOA, S. G. S.; NÓBREGA, R. L. B. Avaliação da Qualidade da Água e da Eficácia de Barreiras Sanitárias em Sistemas para Aproveitamento de Águas de Chuva. Revista Brasileira de Recursos Hídricos, v. 16, n. 3, p. 81-93, 2011.

TAVARES, A.C. Aspectos físicos, químicos e microbiológicos da água armazenada em cisternas de comunidades rurais no Semi-Árido Paraibano. 165p. Dissertação (Mestrado em Desenvolvimento e Meio Ambiente) - Universidade Federal da Paraíba e Universidade Estadual da Paraíba, Campina Grande, 2009.

TEIXEIRA, J.C.; PUNGIRUM, M. Análise da associação entre saneamento e saúde nos países da América Latina e do Caribe, empregando dados secundários do banco de dados da Organização Pan-Americana de Saúde - OPAS. Revista Brasileira de Epidemiologia, v. 8, n. 4, p. 365-376, 2005.

VASCONCELOS, C. H.; NOVO, E. M. L. M.; DONALISIO, M. R. Uso do sensoriamento remoto para estudar a influência de alterações ambientais na distribuição da malária na Amazônia brasileira. Cadernos de Saúde Pública, v. 22, n. 3, p. 517-526, 2006.

VAZ, F. A. C. Diarréia: fatores de risco associados ao óbito em crianças. Revista da Associação Médica Brasileira, v. 45, n. 1, p. 1, 1999.

XAVIER, R. P. Influência de barreiras sanitárias na qualidade da água de chuva armazenada em cisternas no semiárido paraibano. 114p. Dissertação (Mestrado em Recursos Hídricos e Saneamento) - Universidade Federal de Campina Grande, Campina Grande, 2010. 
ZEILHOFER, P.; ZEILHOFER, L. V. A. C.; HARDOIM, E. L.; LIMA, ZORAIDY M.;

OLIVEIRA, C. S. GIS applications for mapping and spatial modeling of urban-use water quality: a case study in District of Cuiabá, Mato Grosso, Brazil. Cadernos de Saúde Pública, v. 23, n. 4, p. 875-884, 2007. 


\section{ESTUDO DOS PADRÕES ESPAÇO-TEMPORAIS DAS INTERNAÇÕES POR DIARREIA E GASTROENTERITE NO BRASIL ENTRE 1998 E 2012}

RESUMO: As diarreias e gastroenterites constituem um grande problema de saúde pública no Brasil e no mundo e a sua dinâmica sazonal de ocorrência está associada a fatores ligados ao clima. Esta pesquisa estudou o comportamento temporal das internações hospitalares motivadas por doenças diarreicas e gastroenterites de origem infecciosa presumível (DGOIP) nos municípios brasileiros, registradas mensalmente de 1998 a 2012, com o auxílio de técnicas de análise espacial, bem como do comportamento das variáveis precipitação e temperatura. Os resultados dos totais trimestrais de internações por DGOIP permitiram observar que há padrões mais definidos de predominância das internações em um determinado período do ano em regiões onde há presença de duas estações do ano bem características, uma chuvosa e outra seca, sendo que nas demais regiões, a exemplo do Sul do país, não há um comportamento único predominante. $\mathrm{O}$ padrão temporal ligado a estação chuvosa foi verificado principalmente nas regiões Norte e Nordeste enquanto o padrão associado ao período da estação seca, no CentroOeste e Sudeste, o que supõe uma variação na etiologia predominante da infecção, de acordo com a literatura, se bacteriana ou viral. A pesquisa concluiu que fatores como a sazonalidade e a agregação de variáveis meteorológicas são relevantes na análise dos padrões de ocorrência da DGOIP, devendo ser realizados estudos de observação contínua das internações a fim de detectar alterações nos padrões sazonais de predominância dos casos das doenças, notadamente tendo em vista a ampla cobertura da vacinação infantil para o rotavírus no Brasil.

Palavras-chave: diarreia, gastroenterite, clima, precipitação, temperatura, análise espacial. 


\subsection{INTRODUÇÃO}

Segundo a OMS (WHO, 2008) as diarreias representam a segunda causa de morte nos países de baixa renda, superada apenas pelas infecções do trato respiratório inferior, e a quinta causa considerando os países do mundo inteiro, superada por doenças cardíacas, vasculares e pulmonares. Dados da mesma instituição estimam que $88 \%$ de todos os casos de diarreia no mundo podem ser atribuídos à água, saneamento e higiene (WHO, 2002).

Dados organizados pela OMS traçaram um panorama dos anos de vida ajustados pelas doenças ou incapacidade (Disability-adjusted life years [DALY]) para diversas doenças no mundo, entre elas as doenças diarreicas (Figura 5.1) (WHO, 2008). Estes indicadores foram concebidos pela OMS para avaliar o impacto de uma doença sobre as populações, no sentido de medir o tempo de vida perdido, seja com morte prematura, seja com doença debilitante, pela população global ou regional, conforme a escala de interesse (CAMARGO, 2008). Uma unidade DALY é igual a um ano de vida. Embora os países com maiores taxas se encontrem na África e no Sudeste Asiático, o Brasil ainda não apresenta condições semelhantes aquelas apresentadas pelos países desenvolvidos.

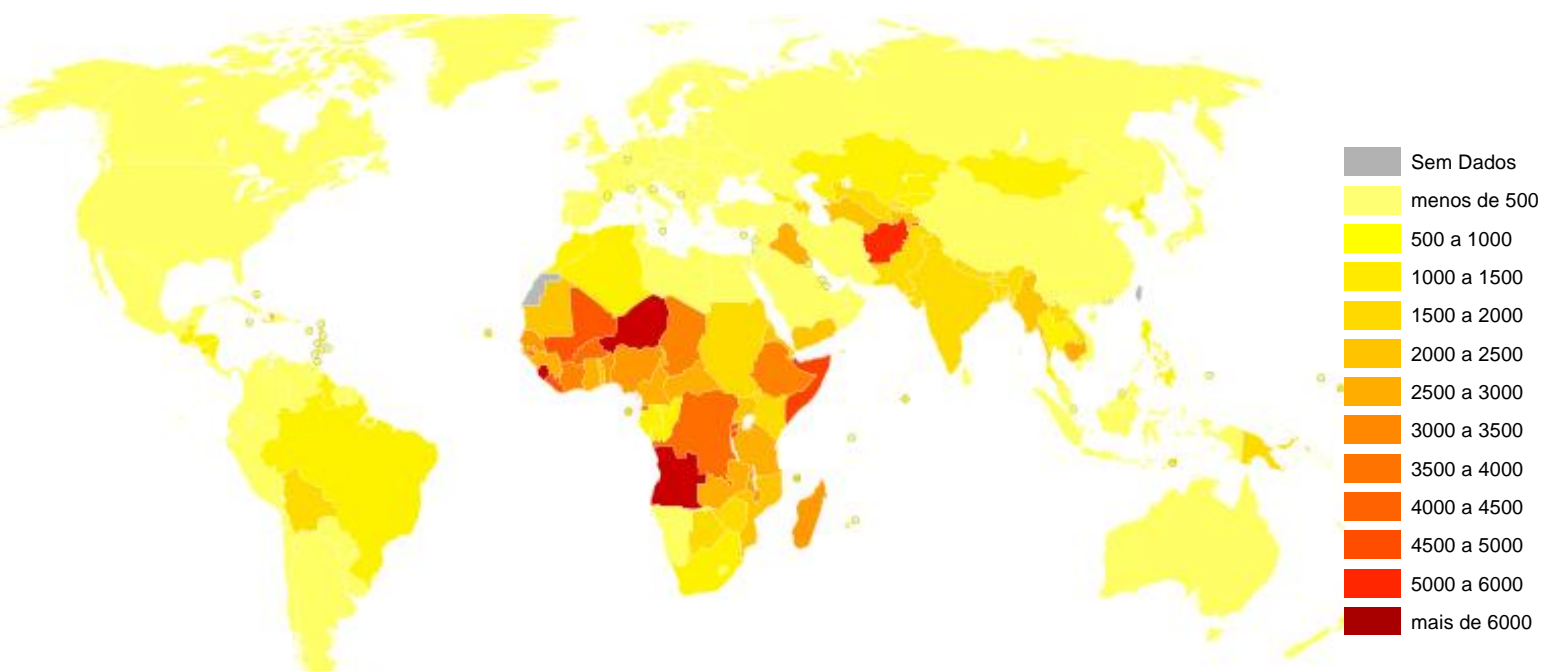

Figura 5.1: Taxas de anos de vida ajustados por doenças diarreicas por país por cem mil habitantes (2004).

Fonte: Adaptado de Wikipedia Creative Commons e WHO (2008). 
Grupos populacionais de características socioeconômicas semelhantes podem ter perfis epidemiológicos distintos por habitarem regiões diferentes (BARCELLOS; BASTOS, 1996). Determinadas condições ambientais exercem impacto sobre a saúde humana e favorecem a ocorrência de determinadas doenças em certos lugares, dentre elas destacamos as condições ligadas ao clima. Condições meteorológicas adversas podem causar efeitos sobre a fisiologia humana, que ultrapassam a capacidade de adaptação dos indivíduos. Esses efeitos são conhecidos como respostas meteoro-patológicas (LECHA, 2013).

Herrador et al. (2015) observaram que na literatura, alguns estudos apresentaram associação entre o aumento na precipitação ou na temperatura e o aumento nos casos de doenças de veiculação hídrica. Outros não encontram, o que ressalta a complexa relação existente entre essas variáveis. Por essa razão, sugerem que as pesquisas enfoquem questões como a sazonalidade. O sucesso das intervenções de saúde passa pela compreensão dos padrões sazonais das doenças diarreicas (ARDKAEW; TONGKUMCHUM, 2009).

Existem campos do conhecimento como a Biometeorologia Humana (TROMP, 1963) que busca estudar os períodos de maior incidência de uma doença na escala intranual e, a partir daí, sugerir estratégias de prevenção ou de diminuição de seus impactos. Esses períodos podem ter comportamento sazonal, repetindo-se em uma mesma época em todos os anos, ou um comportamento esporádico, associado a determinadas anomalias como as de extrema precipitação, seca, baixa umidade relativa do ar, mudanças súbitas na pressão atmosférica, ondas de calor ou de frio.

No Brasil, apesar do reduzido número de estudos, pois a maioria estuda apenas um local e/ou ano específico, segundo Sastry e Burgard (2005) o pico dos episódios de diarreia encontrase entre janeiro e fevereiro e em outubro; os primeiros meses constituem períodos de chuvas e verão, em boa parte do país, enquanto outubro em muitas áreas representa o final do período seco.

Nessa linha de pesquisa, o objetivo desse capítulo é estudar o comportamento temporal das internações por doenças diarreicas e gastroenterites infecciosas no país, tanto interanual como intranual, com o auxílio de técnicas de análise espacial. A análise da relação entre a DDA e o comportamento da precipitação pluviométrica em um recorte espacial do semiárido brasileiro apresentada no Capítulo 3 indicou que existe uma significativa associação espacial entre essas variáveis, motivando a realização de um estudo ecológico no contexto nacional, 
levando em conta os diferentes tipos climáticos existentes no país, e os principais grupos de patógenos causadores de diarreias e gastroenterites.

\subsection{MATERIAL E MÉTODOS}

\subsubsection{Dados de Internações por Diarreia e Gastroenterite de Origem Infecciosa Presumível}

Para análise da distribuição dos casos de diarreia por município do Brasil foram utilizados dados do Sistema de Informações Hospitalares (SIH), vinculado ao DATASUS (MS, 2015), registrados nas Autorizações de Internação Hospitalar (AIH). Os registros mensais de internações estão disponíveis no SIH a partir de 1992, utilizando a Nona Classificação Internacional de Doenças (CID-9) e, a partir de 1998, utilizando a Décima Classificação Internacional de Doenças (CID-10). Em virtude das diferenças existentes entre as propostas de classificação de doenças, optou-se por restringir à análise apenas aos casos classificados segundo a CID-10. Foram selecionados os registros cuja causa atribuída pelo médico responsável foi Diarreia e gastroenterite de origem infecciosa presumível (DGOIP) - cujo código corresponde a A09 - mensalmente de 1998 a 2012, segundo o município de residência, totalizando 180 observações para cada município.

Os dados do SIH apresentam a deficiência de estarem restritos somente às internações pagas em instituições conveniadas ao SUS, ou seja, hospitais públicos federais, estaduais e municipais, estando excluídos, por tanto, das análises, as internações ocorridas em hospitais particulares, ou nos hospitais públicos quando custeadas diretamente pelo paciente ou terceiros ou cobertas por planos de saúde. Estima-se que o SIH/SUS reúna informações sobre 60 a $70 \%$ das internações hospitalares no país, variando de acordo com a região (OPAS, 2008).

Taxas anuais de internação por cem mil habitantes foram calculadas a partir de dados de população residente por munícipio, obtidos dos Censos Demográficos de 2000 e 2010 do IBGE, assim como as projeções populacionais calculadas pelo órgão para os anos de 1998, 1999, 2001 a 2009, 2011 e 2012 (IBGE, 2000; 2010; 2015). O cálculo das taxas foi efetuado de forma independente para cada ano considerando a população correspondente. 
Para a análise da distribuição espacial das taxas de internações no país foi empregada análise de autocorrelação espacial. Segundo Anselin (1992), a forma como os dados se distribuem no espaço é um importante indicador da interação espacial, revelada nas medidas de autocorrelação espacial. Em outras palavras, a análise exploratória permite mostrar como os valores das áreas estão arranjados no espaço, e estimar a magnitude dessa dependência espacial.

O Índice de Moran foi utilizado como medida de autocorrelação espacial. O índice é um coeficiente que mede a relação do desvio padronizado de uma variável $Z$ numa área $i$ com o desvio padronizado das áreas vizinhas para a mesma variável $Z$. Considerando que este índice gera um único valor, como medida da associação espacial em todo o conjunto dos dados utilizados, foram calculados indicadores locais de autocorrelação espacial para evidenciar agrupamentos de valores semelhantes (clusters) ou discrepantes (outliers). Para tanto foram calculados Índices Locais de Associação Espacial, conhecidos como LISA, utilizando o método do inverso da distância. Os processamentos foram efetuados com os dados projetados para Albers. Anselin (1995) aponta que existe uma proporcionalidade direta entre o valor da autocorrelação global e os valores das autocorrelações locais, pois o LISA permite a decomposição dos indicadores globais em contribuições individuais, indicando porções territoriais de não estacionariedade e identificando aglomerados significativos de valores semelhantes em torno de determinadas localizações.

A significância do LISA é avaliada utilizando-se hipótese de normalidade. Determinada a significância estatística, com o cálculo do valor- $p$, são gerados mapas indicando as regiões que apresentaram correlação local significativamente diferente do restante dos municípios, com significância de 95\%. Para a análise da autocorrelação espacial os municípios sem registros de internações no SIH na série temporal adotada, que corresponderam a 37 casos, foram excluídos da análise.

A preparação e análise exploratória dos dados tabulares assim como a geração de saídas gráficas foram efetuadas no software Microsoft ${ }^{\circledR}$ Excel 2010. Os totais absolutos (número de casos) foram utilizados para análise da distribuição temporal das internações. Os valores foram somados segundo os meses do ano em que foram registrados de 1998 a 2012. Em seguida, através de operações algébricas empregadas nos dados tabulares em SIG foi definido, para cada município, o mês do ano de maior quantitativo de internações, considerando os registros efetuados nos quinze anos da série temporal. Em suma, o procedimento buscou encontrar a moda entre os valores de internações registrados mensalmente ao longo da série histórica em cada município. 
Durante a inspeção visual dos resultados dessa etapa, foi observada a existência de agrupamentos de valores elevados de internações em meses vizinhos. Por essa razão, optou-se por gerar somatórios móveis trimestrais do número de internações para observar o impacto do efeito desse contexto temporal na análise dos dados. A definição do trimestre de máxima internação foi elaborada segundo os critérios definidos na matriz de decisão apresentada na Tabela 5.1. Quando a soma em dois ou mais trimestres foi coincidente, foram observados os valores dos trimestres vizinhos.

Os 37 municípios sem registros de internações, em todos os casos com população inferior a dez mil habitantes (IBGE, 2010), foram excluídos da análise. Em 310 municípios, distribuídos por todas as Unidades da Federação, exceto Amapá e Distrito Federal, a soma dos registros trimestrais resultou em valores iguais para trimestres não coincidentes. Nesses casos, foram observados os valores dos trimestres vizinhos aos trimestres de maior registro. Ao final do processo restaram 55 casos, no universo de 5.564 municípios, em que não pôde ser definido (ND) o trimestre de maior número de internações. Todos os 55 municípios possuem população inferior a quinze mil habitantes, sendo em 43 deles inferior a cinco mil habitantes (IBGE, 2010). Tais municípios também foram excluídos da análise. Este procedimento excluiu uma série de municípios cujos valores eram muito baixos, reduzindo a flutuação aleatória.

Tabela 5.1: Matriz de decisão elaborada para seleção do trimestre de maior número de internações por DGOIP (trimestre modal).

\begin{tabular}{c|ccccccccccccc|c}
\hline Exemplo & JFM* & FMA & MAM & AMJ & MJJ JJA JAS ASO SON & OND & NDJ & DJF & Resultado \\
\hline A & 0 & 0 & 0 & 0 & 0 & 0 & 0 & 0 & 0 & 0 & 0 & 0 & SR*** \\
B & 1 & 0 & 0 & 0 & 0 & 0 & 0 & 0 & 0 & 0 & 0 & 0 & JFM \\
C & 1 & 1 & 1 & 0 & 0 & 0 & 0 & 0 & 0 & 0 & 0 & 0 & FMA \\
D & 1 & 1 & 0 & 1 & 0 & 0 & 0 & 0 & 0 & 0 & 0 & 0 & FMA \\
E*** & 0 & 2 & 1 & 2 & 1 & 0 & 0 & 0 & 0 & 0 & 0 & 0 & AMJ \\
F & 1 & 0 & 1 & 0 & 0 & 0 & 0 & 0 & 0 & 0 & 0 & 0 & ND $* * * *$ \\
\hline
\end{tabular}

Notas: *JFM: Janeiro-Fevereiro-Março; FMA: Fevereiro-Março-Abril; MAM: Março-Abril-Maio; AMJ: AbrilMaio-Junho; MJJ: Maio-Junho-Julho; JJA: Junho-Julho-Agosto; JAS: Julho-Agosto-Setembro; ASO: Agosto-Setembro-Outubro; SON: Setembro-Outubro-Novembro; OND: Outubro-Novembro-Dezembro; NDJ: Novembro-Dezembro-Janeiro e DJF: Dezembro-Janeiro-Fevereiro.

**SR: Sem Registros. Município sem registro de internações.

*** O mês de dezembro (12) foi considerado vizinho de janeiro (1).

****ND: Não Definido. Casos em que a observação dos trimestres vizinhos não permitiu a definição da moda.

Fonte: Elaborado pelo autor. 


\subsubsection{Dados de Precipitação}

Os dados de internações foram associados a dados de precipitação pluviométrica com o objetivo de verificar a associação do padrão de distribuição temporal da DGOIP com os diferentes tipos climáticos do país. Os dados foram obtidos das normais climatológicas construídas para o Atlas Pluviométrico do Brasil, elaborado pela Companhia de Pesquisa de Recursos Minerais (CPRM) utilizando dados do período de 1977 a 2006 de 2.568 estações pluviométricas distribuídas pelo território brasileiro, operadas por órgãos federais e estaduais (CPRM, 2012). A CPRM identificou, para cada estação, o mês mais chuvoso e o mês mais seco, segundo a média das observações da série histórica.

Os dados de estação pluviométrica foram interpolados a partir do método de delimitação de áreas por equidistância (alocação euclidiana). Este método gera um dado de área, em formato matricial. O dado matricial foi convertido para vetorial (polígonos) e foi aplicada uma suavização do contorno dos polígonos com $1 \mathrm{~km}$ de tolerância. De modo análogo aos dados de DGOIP, os dados de precipitação também foram analisados tendo em vista os totais trimestrais registrados, a partir de uma média dos registros da série temporal. As operações e análises espaciais em SIG foram efetuadas no software ESRI® ArcGIS 10.2.2.

Como há grande variabilidade da precipitação ao longo do país preferiu-se utilizar uma série temporal distinta (trinta anos) e não coincidente em sua totalidade com a série de dados de internações (quinze anos, de 1998 a 2012), pois o objetivo deste trabalho foi caracterizar os padrões temporais de ocorrência da doença, no sentido de identificar agrupamentos espaciais cuja distribuição sazonal da precipitação e temperatura pode auxiliar no seu entendimento.

Análise e discussão detalhada dos padrões temporais das internações foi efetuada para as 27 capitais brasileiras, a partir de análises de correlação linear simples entre as séries temporais*. Dados das normais climatológicas do INMET (2015) foram utilizados para a elaboração de climogramas das capitais, contendo os totais trimestrais de precipitação e as médias trimestrais de temperatura observadas entre 1961 e 1990. Os climogramas não foram elaborados a partir dos dados da CPRM para que pudessem ser utilizados dados das mesmas

\footnotetext{
* A escolha de análise dos resultados segundo as capitais brasileiras foi efetuada após análise exploratória dos padrões observados em sete áreas de estudo selecionadas em diferentes regiões do país, contida no Apêndice $C$ da tese. As áreas correspondem a: 1) Estado do Ceará; 2) Estado de São Paulo; 3) Estado de Roraima e extremo Noroeste do Amazonas; 4) Porção leste da Região Nordeste; 5) Região do Planalto Central; 6) Região do Baixo Amazonas e; 7) Região Metropolitana de Belo Horizonte. Para a apresentação dos resultados foram utilizados ainda dados concernentes a delimitação dos biomas brasileiros, ao traçado de redes de adução de sistemas de abastecimento urbano de água e das tipologias de tratamento de água empregadas pelas companhias de abastecimento.
} 
estações para as variáveis precipitação e temperatura, sendo que os dados da CPRM compreendem apenas a precipitação.

\subsection{RESULTADOS}

\subsubsection{Distribuição Espacial das Internações por DGOIP no Brasil}

No período de 1998 a 2012 foram registradas 3.412.084 internações por DGOIP no Brasil. Desse montante, $47 \%$ do total incidiram sobre crianças com idade inferior a cinco anos e 51\% ocorreram na Região Nordeste (Figura 5.2). Nesse montante há grande contribuição dos casos ocorridos em municípios da região semiárida (Figura 5.3). O mês do ano com maior número de registros foi fevereiro, com 319.507 casos, ao passo que o menor foi junho, com 252.550 registros.

Os percentuais de internações por faixa etária variam pouco conforme a região, havendo diferenças superiores a $6 \%$ somente nas internações de pessoas entre um e quatro anos de idade ou com sessenta anos ou mais nas regiões Norte e Nordeste do país, o que pode ser fruto da própria composição etária de cada região. Os maiores valores percentuais em crianças com até um ano de idade foram observados nas regiões Sudeste e Norte do país (20\%), entre um e cinco anos de idade nas regiões Norte (35\%) e Centro-Oeste (34\%), na população adulta (entre vinte e 59 anos de idade) nas regiões Nordeste (25\%) e Sul (24\%) e, também na região Nordeste na população com sessenta anos ou mais (17\%). Observa-se redução mais acentuada no número de internações nas regiões Nordeste e Sudeste do país, principalmente após 2006.

A taxa média de internações por DGOIP sobre todas as faixas etárias da população em cada município no período de 1998 a 2012, calculada a partir da taxa registrada em cada ano, é apresentada no mapa temático coroplético da Figura 5.3 e no mapa de autocorrelação espacial. O segundo mapa, conhecido como Moran Map ou Lisa Map, mostra municípios com vizinhos de valores semelhantes estatisticamente significativos, categorizados como Alto-Alto e BaixoBaixo, ou municípios cujos vizinhos apresentam valores estatisticamente diferentes, classificados como Alto-Baixo e Baixo-Alto (Figura 5.3B). O nível de significância adotado foi de 95\%. O índice global de Moran obtido para este dado foi de 0,154 com z-score de 133 ( $p$ valor $=0,00$ ). Tendo em vista que o valor encontrado foi maior que zero, indicou evidência de 
autocorrelação espacial positiva, isto é, que as áreas tendem a ser similares entre si quanto a variável utilizada.
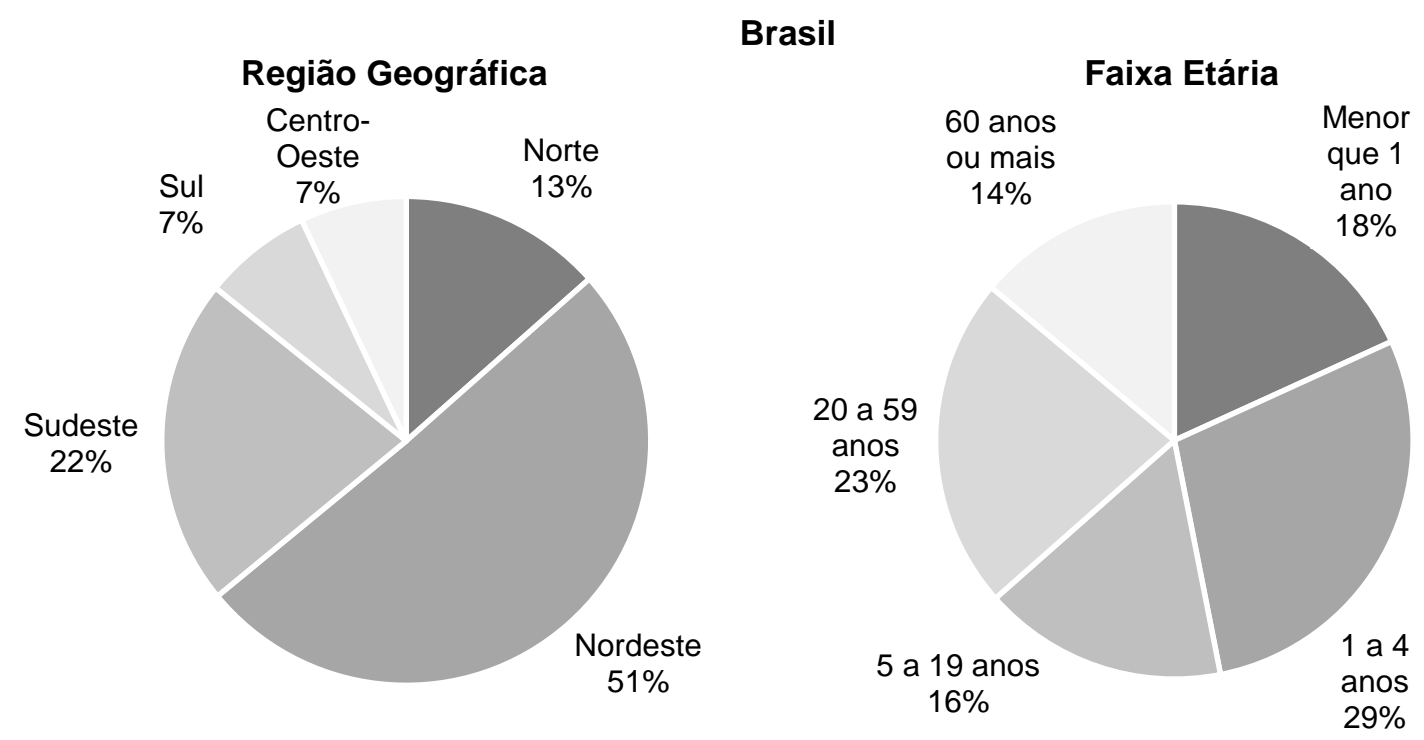

Faixa Etária por Região Geográfica

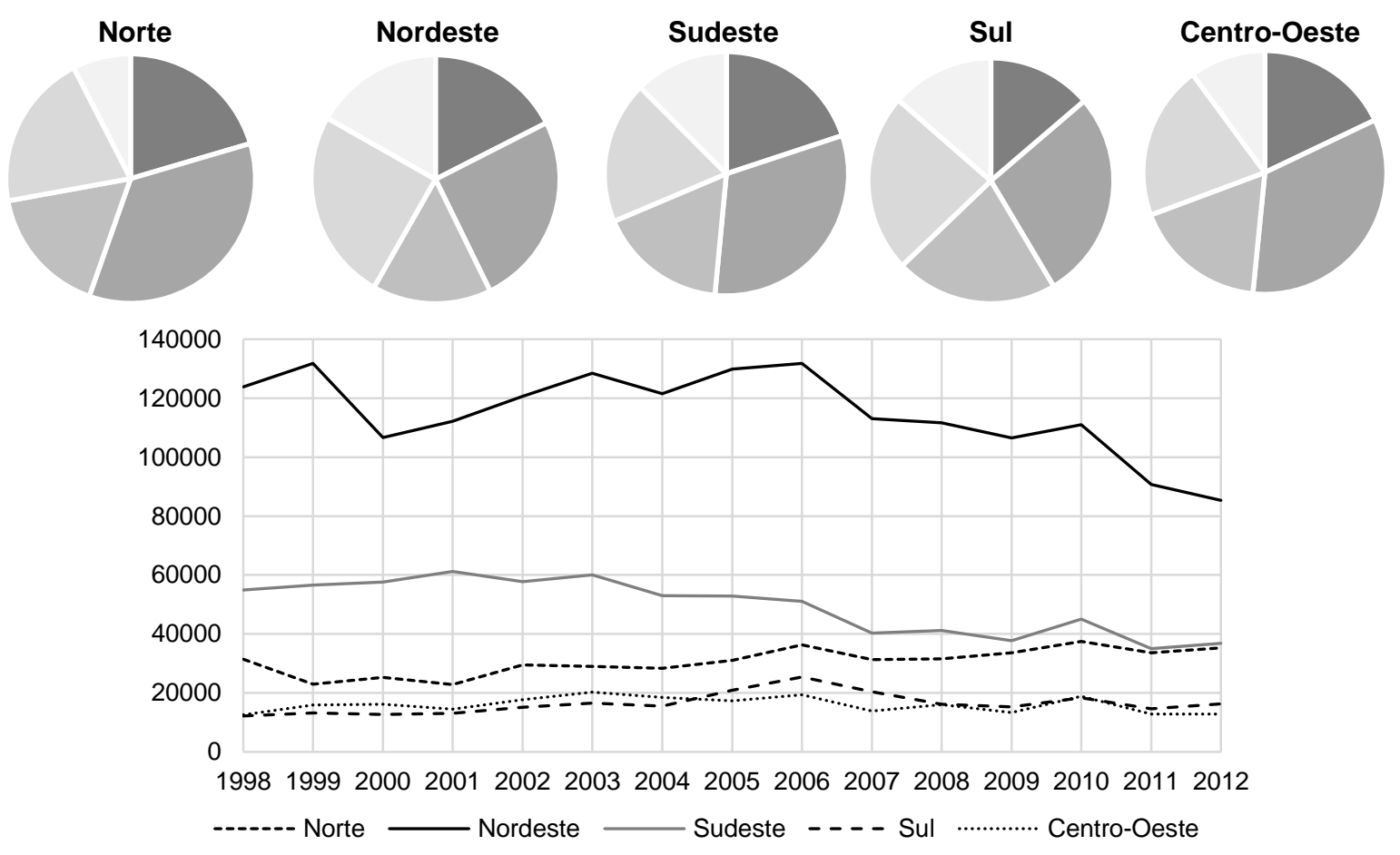

Figura 5.2: Distribuição regional, etária e anual das internações por DGOIP no Brasil (19982012).

Fonte: Elaborado pelo autor a partir de dados do SIH (MS, 2015). 
Pode ser observado um agrupamento de municípios com valores baixos do indicador na região Centro-Sul do país, notadamente nas áreas mais próximas ao litoral do Rio Grande do Sul ao Rio de Janeiro, nos vales litorâneos dos estados do Sul do Brasil, assim como na metade leste do Estado de São Paulo e na região central de Minas Gerais. Agrupamentos menos expressivos foram observados na região central de Tocantins e nos municípios da recente fronteira agrícola de Mato-Grosso (Alto Teles-Pires).

Agrupamentos de altas taxas são observados no interior de Rondônia, em praticamente toda a extensão do semiárido, região central do Piauí e baixo vale do Tocantins no Pará, havendo agrupamentos isolados na região do Alto Araguaia em Goiás, Sudeste do Pará e Nordeste de Roraima.

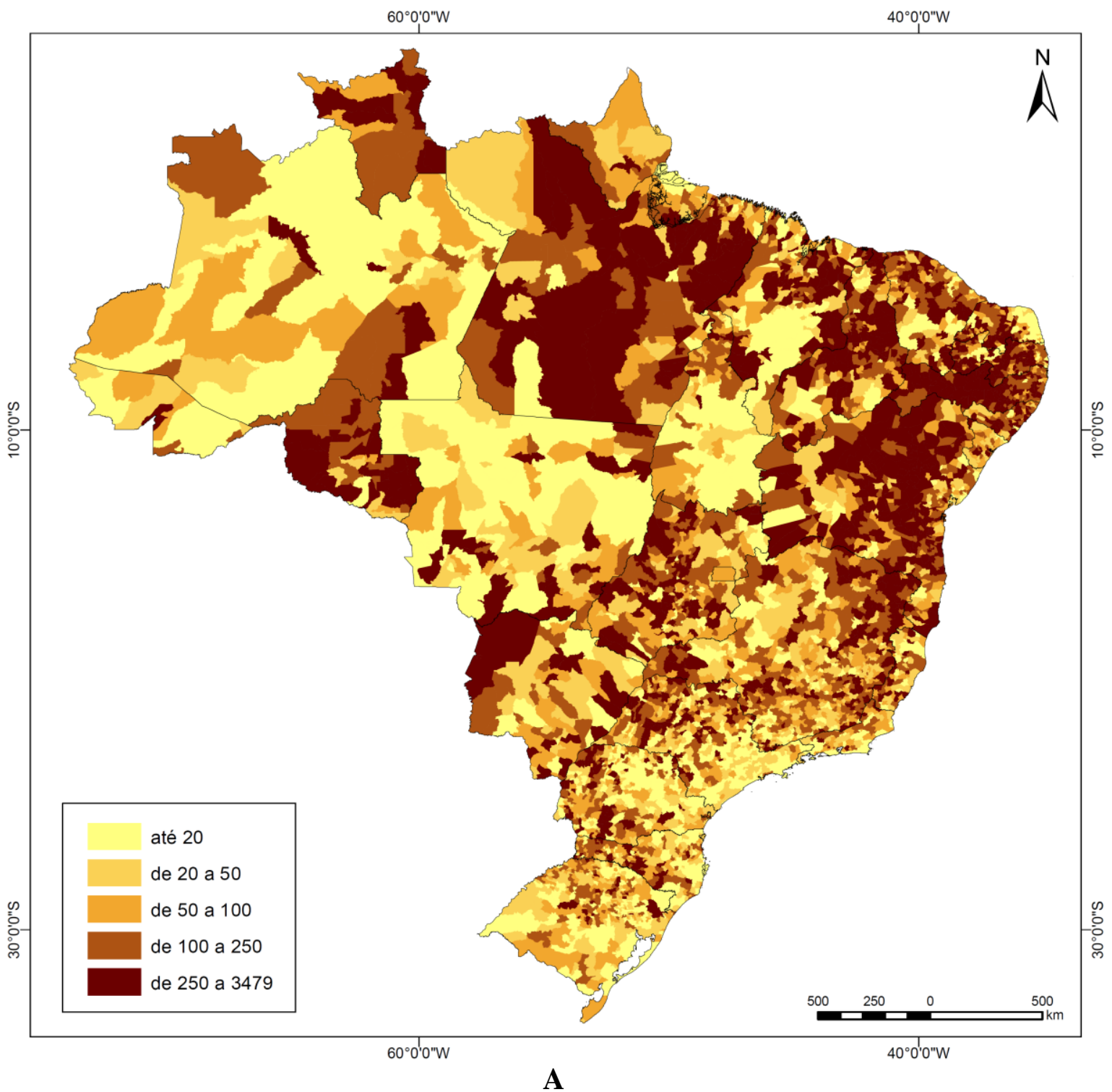

Figura 5.3: Taxa média de internações por DGOIP por município (A) e mapa de autocorrelação espacial da taxa de internações (B) (1998-2012) (continua). 


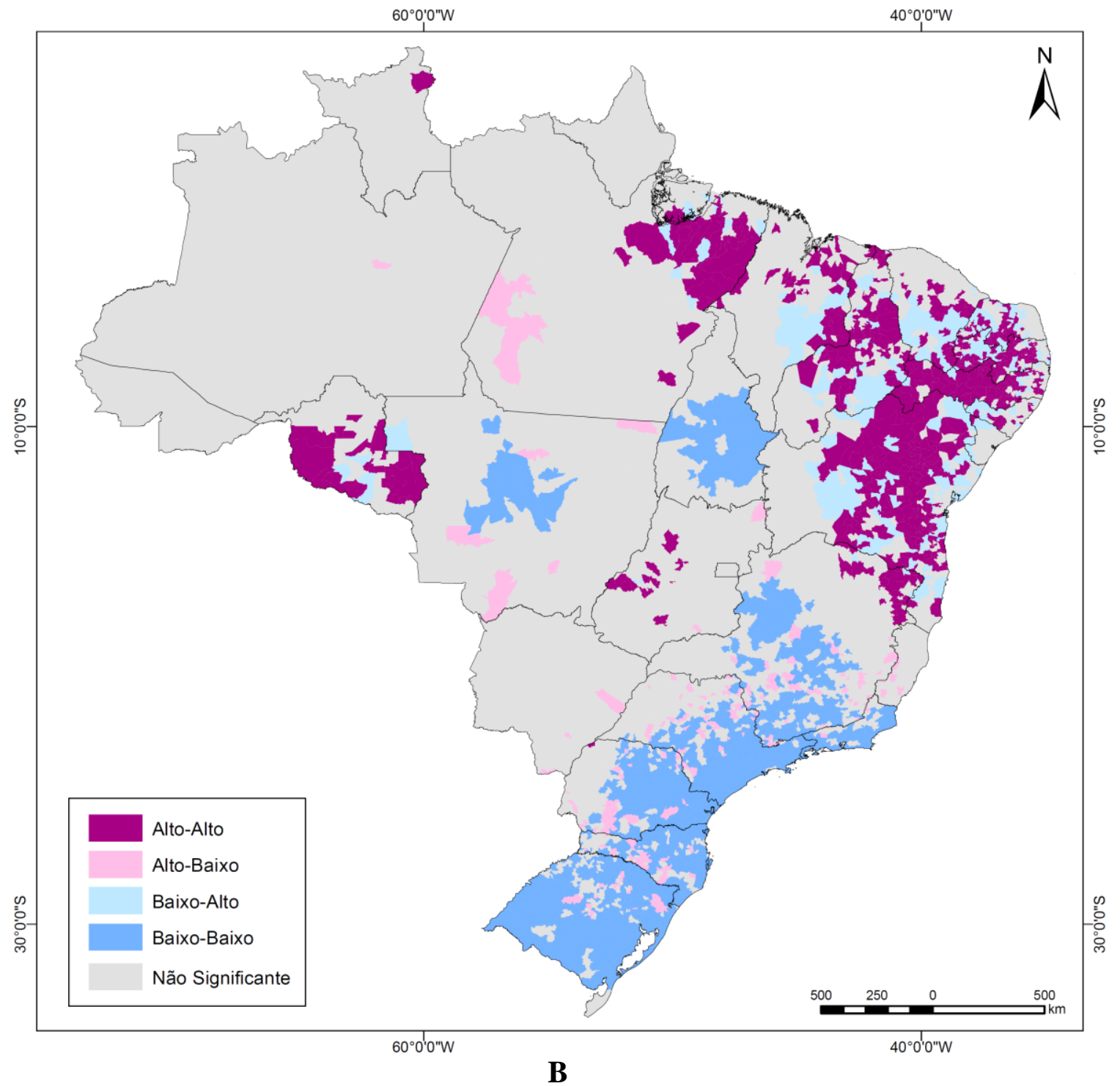

Figura 5.3: Taxa média de internações por DGOIP por município (A) e mapa de autocorrelação espacial da taxa de internações (B) (1998-2012).

Fonte: Elaborado pelo autor a partir de dados do SIH (MS, 2015).

\subsubsection{Distribuição Temporal das Internações por DGOIP no Brasil}

O trimestre de maior número absoluto de internações por DGOIP por município do Brasil, segundo a residência do paciente, é apresentado na Figura 5.4. Os dados são apresentados segundo a localização das cidades, pois as diferenças na área territorial dos municípios, principalmente na região amazônica, dificultam a identificação dos padrões espaciais objetivo desse estudo.

Dentre os 5.564 municípios do país e no período de 1998 a 2012, 37 municípios não tiveram qualquer registro de internações e em 55 municípios, também com poucos registros, 
não foi possível definir o trimestre de maior número de internações, mesmo observados os valores dos trimestres vizinhos. 489 municípios tiveram menos de dez registros. Um total de internações acima de cinco mil casos foi registrado apenas em 101 municípios. O maior número de internações ocorreu em São Paulo, com 38.862 casos, seguido de Maceió, com apenas trezentos casos a menos.

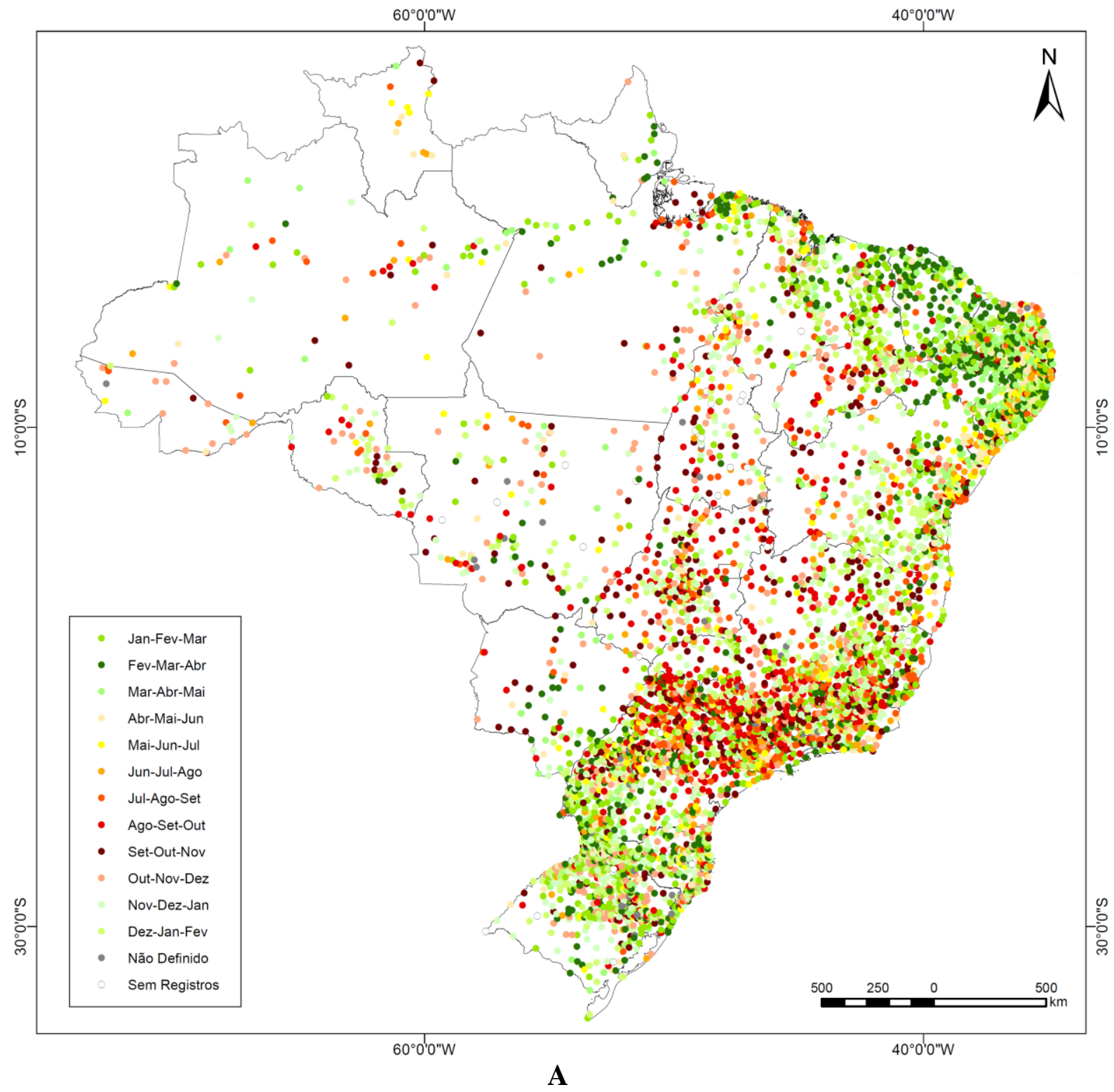

Figura 5.4: Trimestre de maior número de internações por DGOIP por município (1998-2012): mapa temático pontual qualitativo (A) e coleção de mapas (B) (continua). 

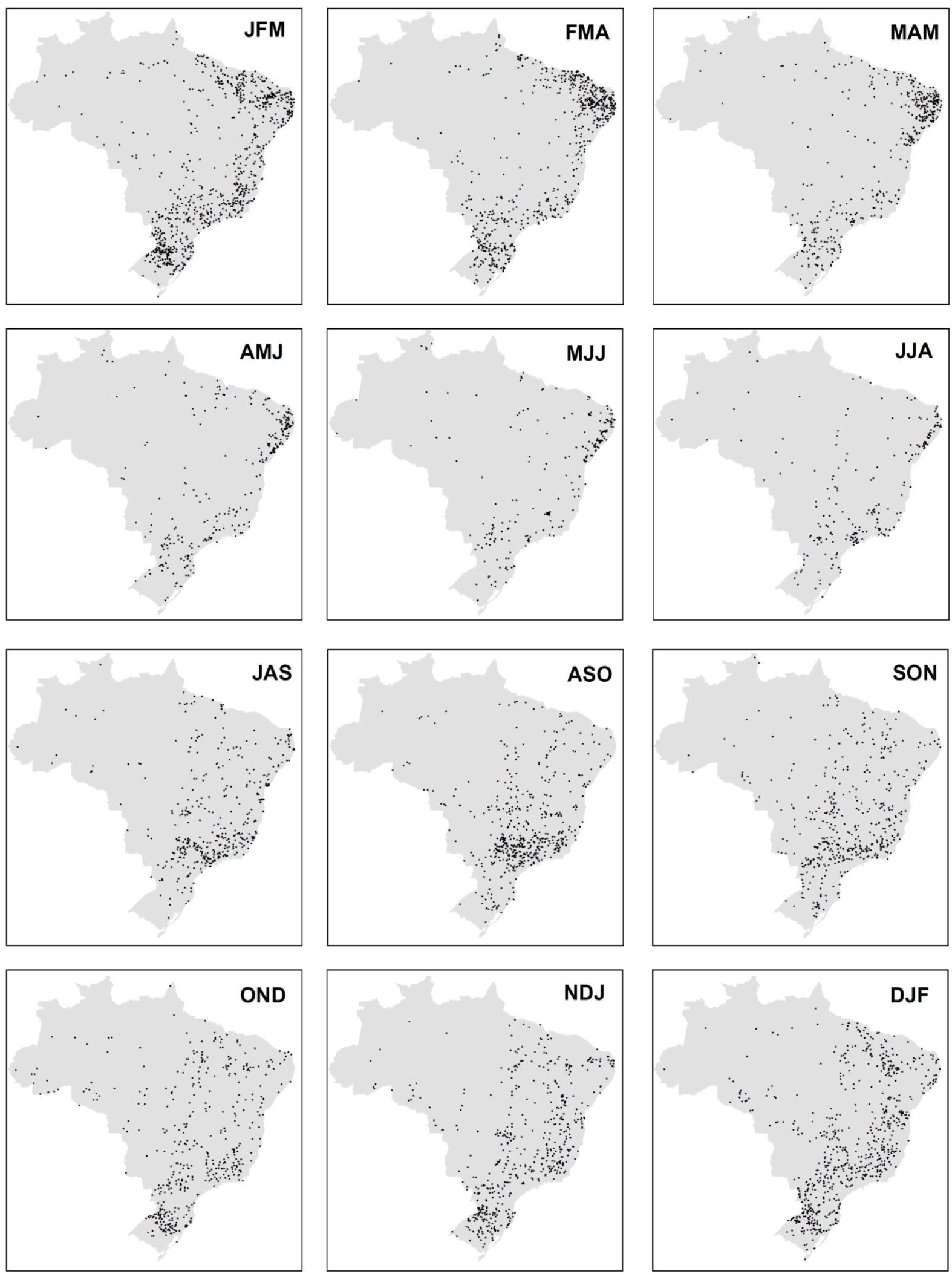

B

Figura 5.4: Trimestre de maior número de internações por DGOIP por município (1998-2012): mapa temático pontual qualitativo (A) e coleção de mapas (B).

Fonte: Elaborado pelo autor a partir de dados do SIH (MS, 2015). 
Foram observados padrões espaciais de períodos de maior número de internações bem definidos ao longo do território brasileiro. Pode ser observada a existência de agrupamentos expressivos de municípios em trimestres distintos*.

De JFM a JJA (primeiro semestre) observa-se um período de transição que começa no Nordeste do Pará, evolui em direção ao Norte da Região Nordeste, com pico em FMA. A partir de AMJ a concentração passa a localizar-se no Agreste nordestino, aproximando-se cada vez mais da Zona da Mata, terminando no Leste da Região Nordeste, entre Natal e Salvador.

Na região central do Brasil, por sua vez, a concentração inicia-se em JAS e vai até JFM (segundo semestre) com um agrupamento expressivo de municípios do Estado de São Paulo nos trimestres de JAS e ASO.

Na Região Sul do país agrupamentos significativos podem ser observados de OND a JFM, sendo visíveis com maior intensidade no Norte/Noroeste do Rio Grande do Sul e Oeste de Santa Catarina.

Na região Norte os maiores agrupamentos podem ser observados no primeiro trimestre do ano (JFM a MAM) para os municípios situados na calha dos rios Amazonas e Solimões e, no último trimestre do ano (OND a DJF) para os municípios do Acre e Rondônia. Em Roraima os agrupamentos são observados no segundo trimestre do ano (AMJ a JJA).

\subsubsection{Distribuição Temporal da Precipitação Pluviométrica no Brasil}

Quanto ao trimestre de maior índice de precipitação pluviométrica no Brasil também é possível observar a existência de padrões espaciais definidos ao longo do território (Figura 5.5). Conforme CPRM (2012) não há qualquer estação pluviométrica no país que tenha como mês mais chuvoso agosto ou como trimestre mais chuvoso ASO.

Nos municípios do noroeste do Amazonas e de Roraima o período de maior precipitação corresponde a AMJ e MJJ. O mesmo comportamento pode ser observado na cidade de Oiapoque, extremo Norte do Amapá. Esta diferença climática em relação ao restante da

\footnotetext{
* Não foi utilizada medida de autocorrelação espacial porque ela se aplica a variáveis quantitativas e, embora cada trimestre possa ser associado a um valor quantitativo, isto é, de 1 a 12, é importante considerar que o valor 12 está mais próximo do 1 que do 10, ou seja, dezembro é vizinho de janeiro. Acredita-se que tal proposta poderá ser executada adotando-se recursos matemáticos para associar os meses a graus (0 a 360) permitindo estabelecer que dezembro (12) é vizinho de janeiro (1).
} 
Amazônia decorre de sua localização geográfica no país, pertencente ao Hemisfério Norte, entre outros fatores.

Já na Região Nordeste o período de maior precipitação corresponde aos primeiros trimestres do ano, exceto na região da Zona da Mata e parte do Agreste, cujo pico de precipitação ocorre entre maio e julho. Já na faixa que cobre praticamente todo o Estado da Bahia, Norte de Minas Gerais e avança até o Espírito Santo e Norte do Rio de Janeiro, o pico da chuva ocorre no trimestre de NDJ.

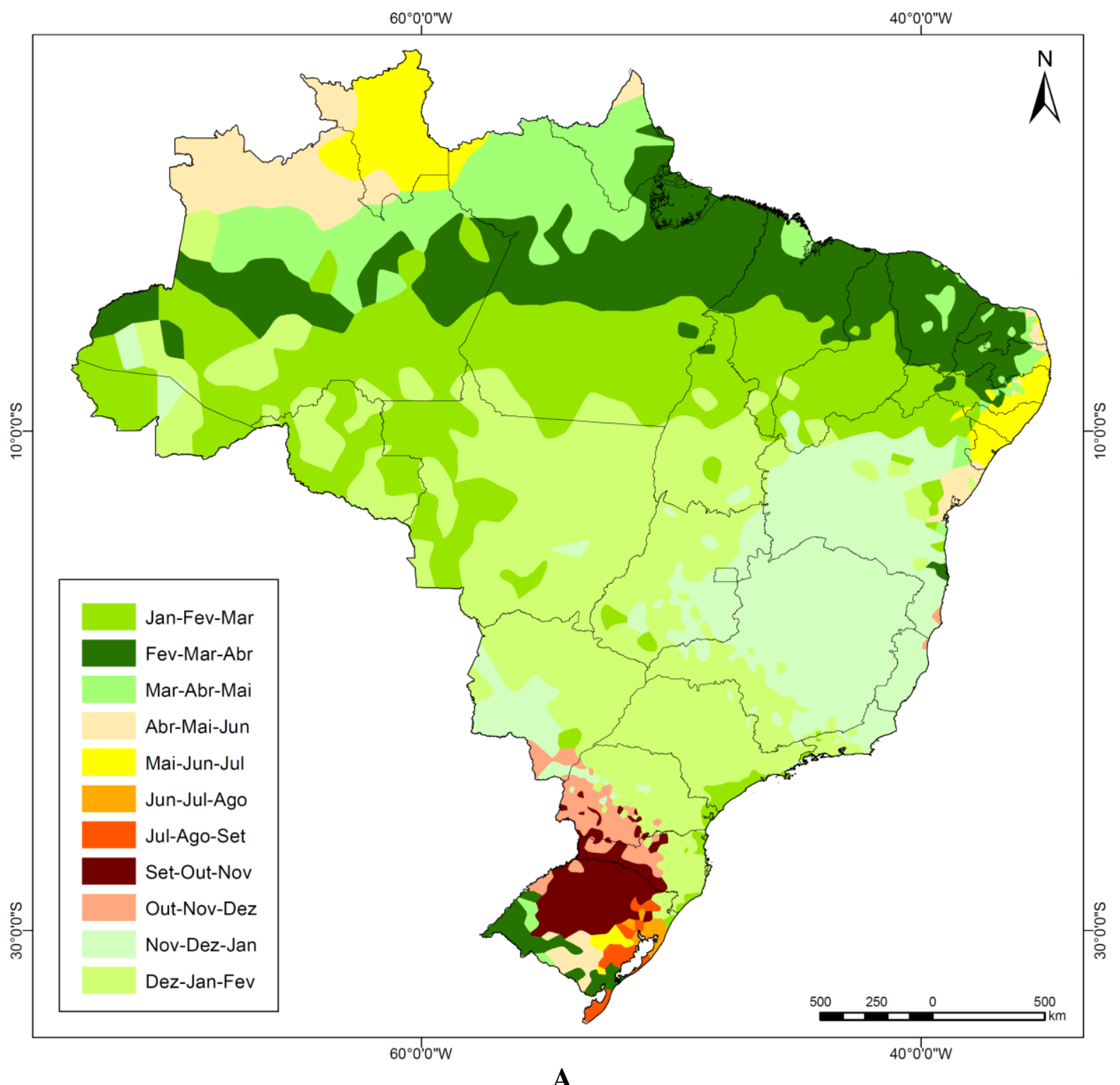

Figura 5.5: Trimestre de maior (A) e menor (B) precipitação média no Brasil (1977-2006) (continua). 


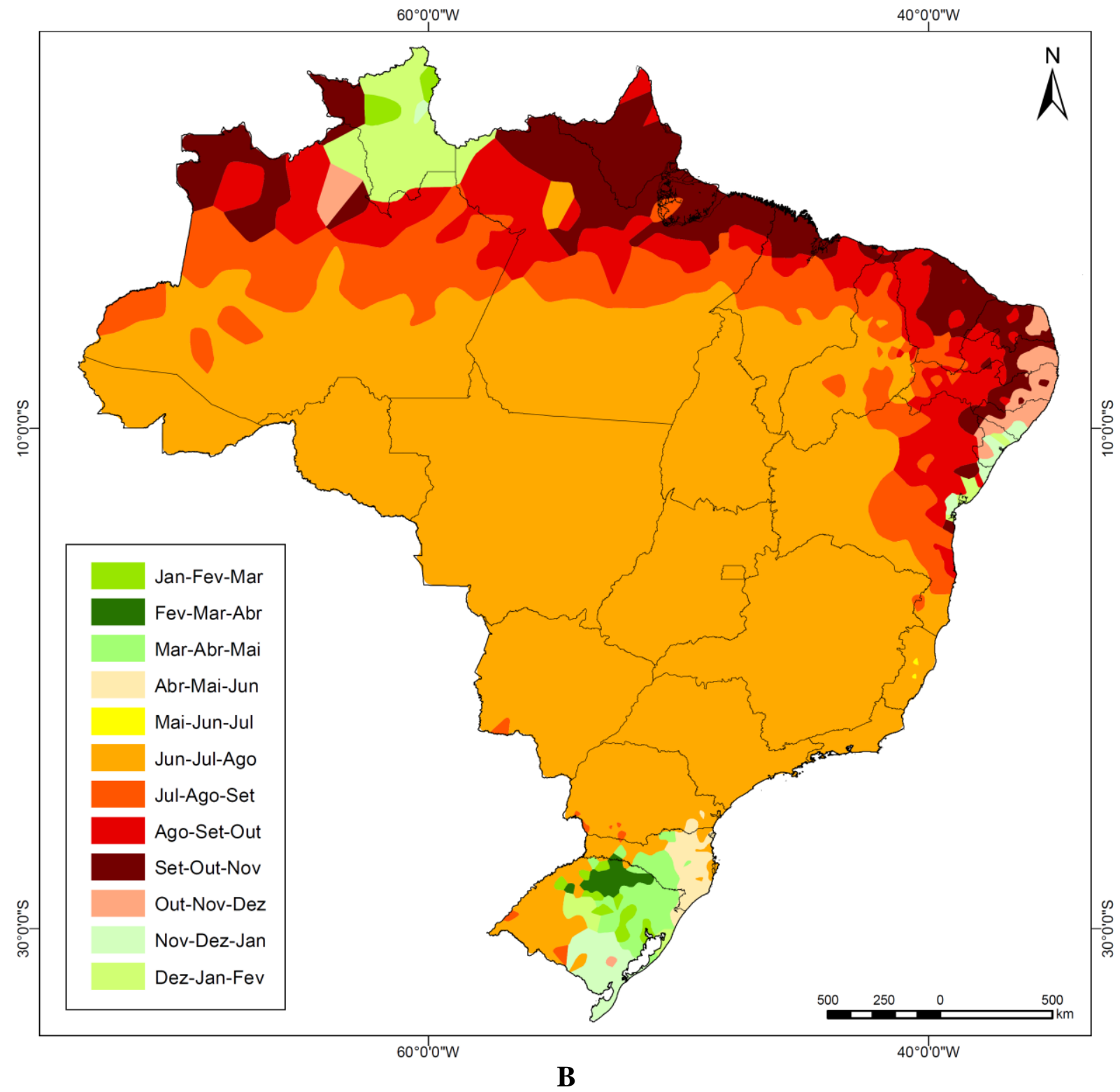

Figura 5.5: Trimestre de maior (A) e menor (B) precipitação média no Brasil (1977-2006). Fonte: Elaborado pelo autor a partir de dados de CPRM (2012).

Em praticamente toda a região Centro-Oeste do país o pico da precipitação ocorre em DJF enquanto no Norte do país observa-se três faixas de latitudes homogêneas entre JFM e MAM, de Sul para Norte, a partir da latitude $10^{\circ} \mathrm{S}$, aproximadamente. SON e OND são os trimestres de maior precipitação nas Regiões Norte/Noroeste do Rio Grande do Sul, Oeste de Santa Catarina e Sudoeste do Paraná.

Quanto ao período mais seco, grande parte do país apresenta o trimestre JJA como o mais seco do ano, havendo diferenças no leste de Santa Catarina e Rio Grande do Sul, onde o período mais seco varia de FMA a AMJ, leste da Região Nordeste, onde também há uma transição entre os trimestres de JAS a NDJ, sendo o trimestre mais seco praticamente meio ano 
após o mais chuvoso, começando em JAS no Sertão e terminando em OND na Zona da Mata e NDJ entre Maceió e Salvador e, nas latitudes menores que $5^{\circ} \mathrm{S}$.

Nas menores latitudes da Região Norte observa-se a mesma faixa de transição em relação ao período mais seco, porém restrita a JAS e SON, havendo também um comportamento distinto no Estado de Roraima, com o período seco concentrando-se em DJF ou até mesmo em JFM, segundo dados de algumas estações desse Estado.

A coleção de mapas da Figura 5.6 apresenta os totais de precipitação registrados em cada trimestre do ano. 

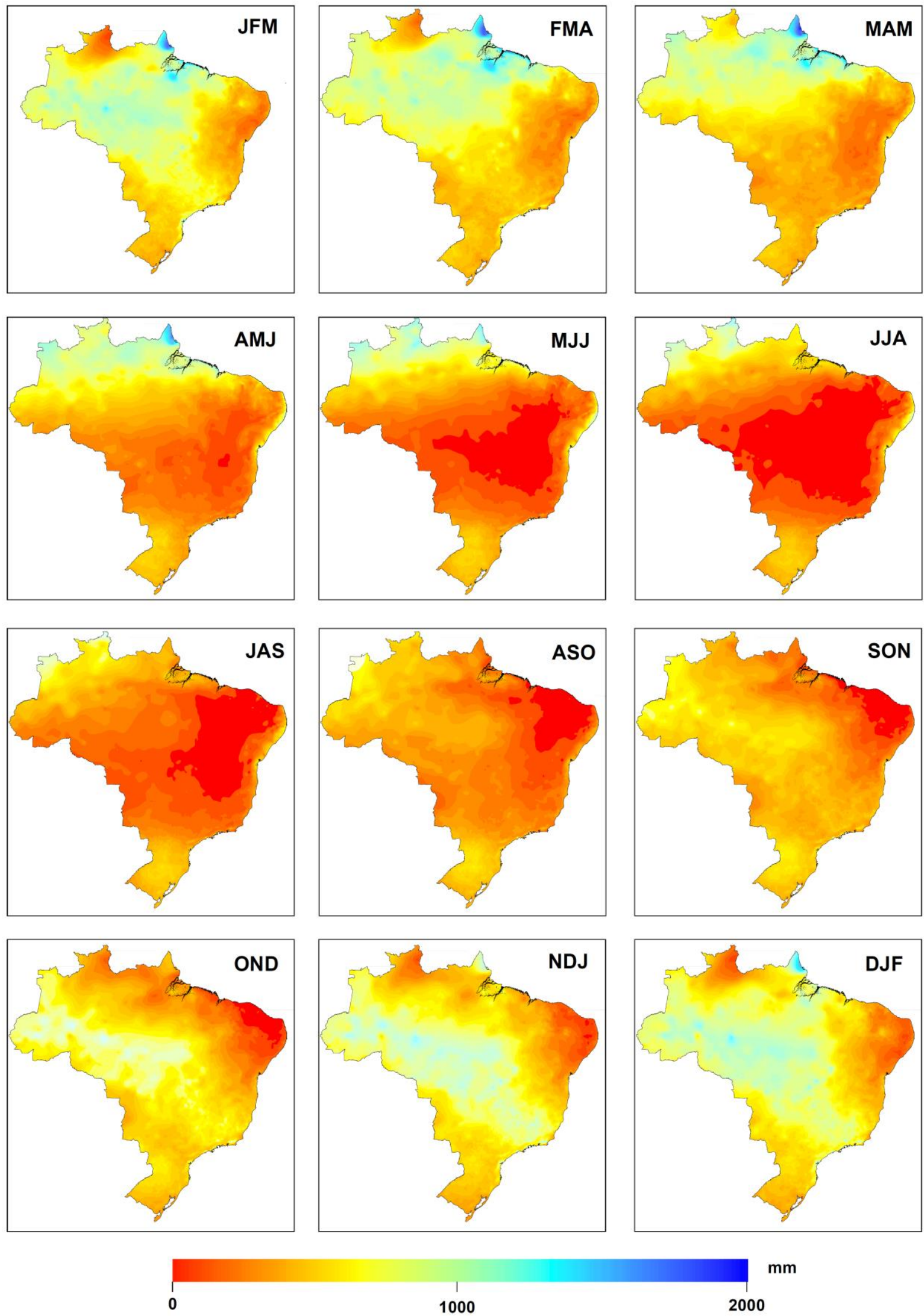

Figura 5.6: Totais trimestrais pluviométricos no Brasil (1977-2006).

Fonte: Elaborado pelo autor a partir de CPRM (2012). 


\subsubsection{Padrões das Internações por DGOIP e da Precipitação e Temperatura nas Capitais Brasileiras}

Analisando o mapa de distribuição trimestral de internações por DGOIP nas capitais brasileiras (Figura 5.7) é possível observar que o comportamento intranual se assemelha para as capitais de regime climático semelhante (Figura 5.8) e, consequentemente, proximidade quanto a sua localização geográfica.

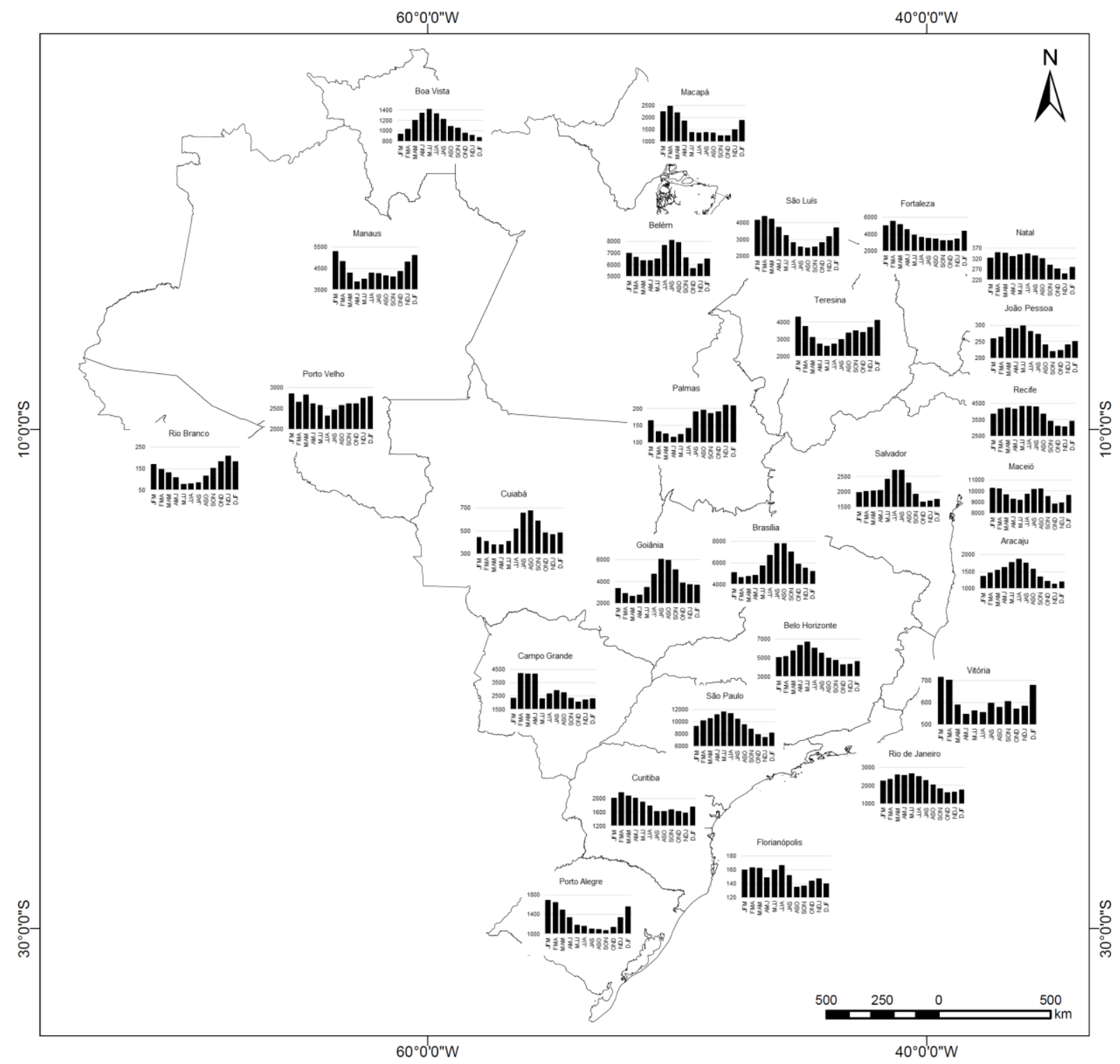

Figura 5.7: Totais trimestrais de internações por DGOIP nas capitais brasileiras (1998-2012). Nota: Os eixos verticais dos histogramas foram ajustados conforme o intervalo de valores de cada capital. Fonte: Elaborado pelo autor a partir de dados do SIH (MS, 2015). 
Essas semelhanças são nítidas quando se observam os histogramas de Recife, João Pessoa e Natal, por exemplo, assim como São Luís e Fortaleza, Salvador e Aracaju, na Região Nordeste; Belo Horizonte, Rio de Janeiro e São Paulo no Sudeste e; Brasília, Goiânia e Cuiabá, no Centro-Oeste. Os coeficientes de correlação encontrados entre os registros trimestrais de internações da série temporal são apresentados na Tabela 5.2.

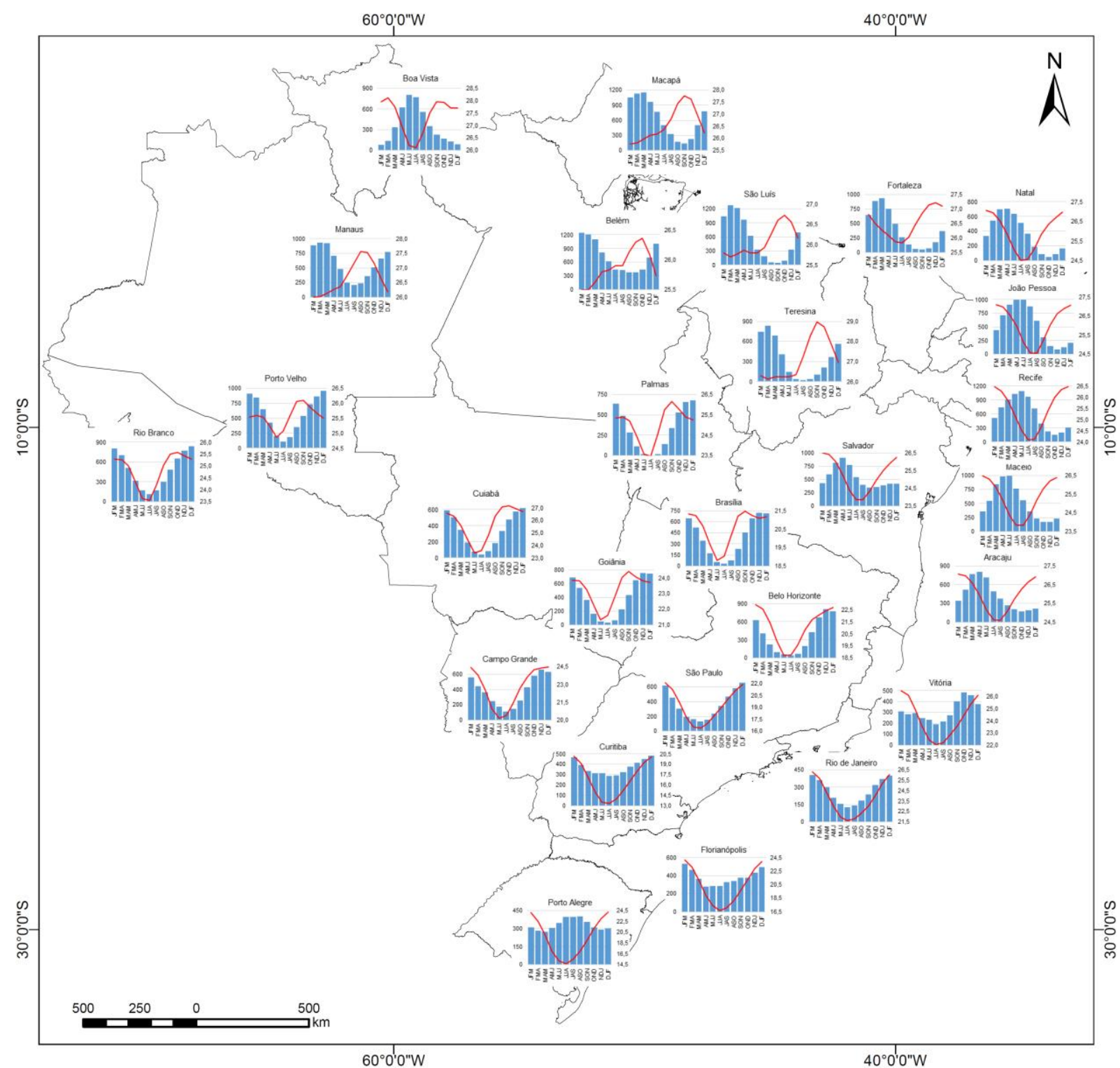

Figura 5.8: Climogramas trimestrais das capitais brasileiras (1961-1990).

Nota: As curvas de amplitude térmica estão ajustadas segundo os intervalos de cada capital. Fonte: Elaborado pelo autor a partir de dados do INMET (2015). 
Tabela 5.2: Matriz de correlação linear de Pearson ( $r$ ) entre os totais trimestrais de internações por DGOIP nas capitais brasileiras (1998-2012).

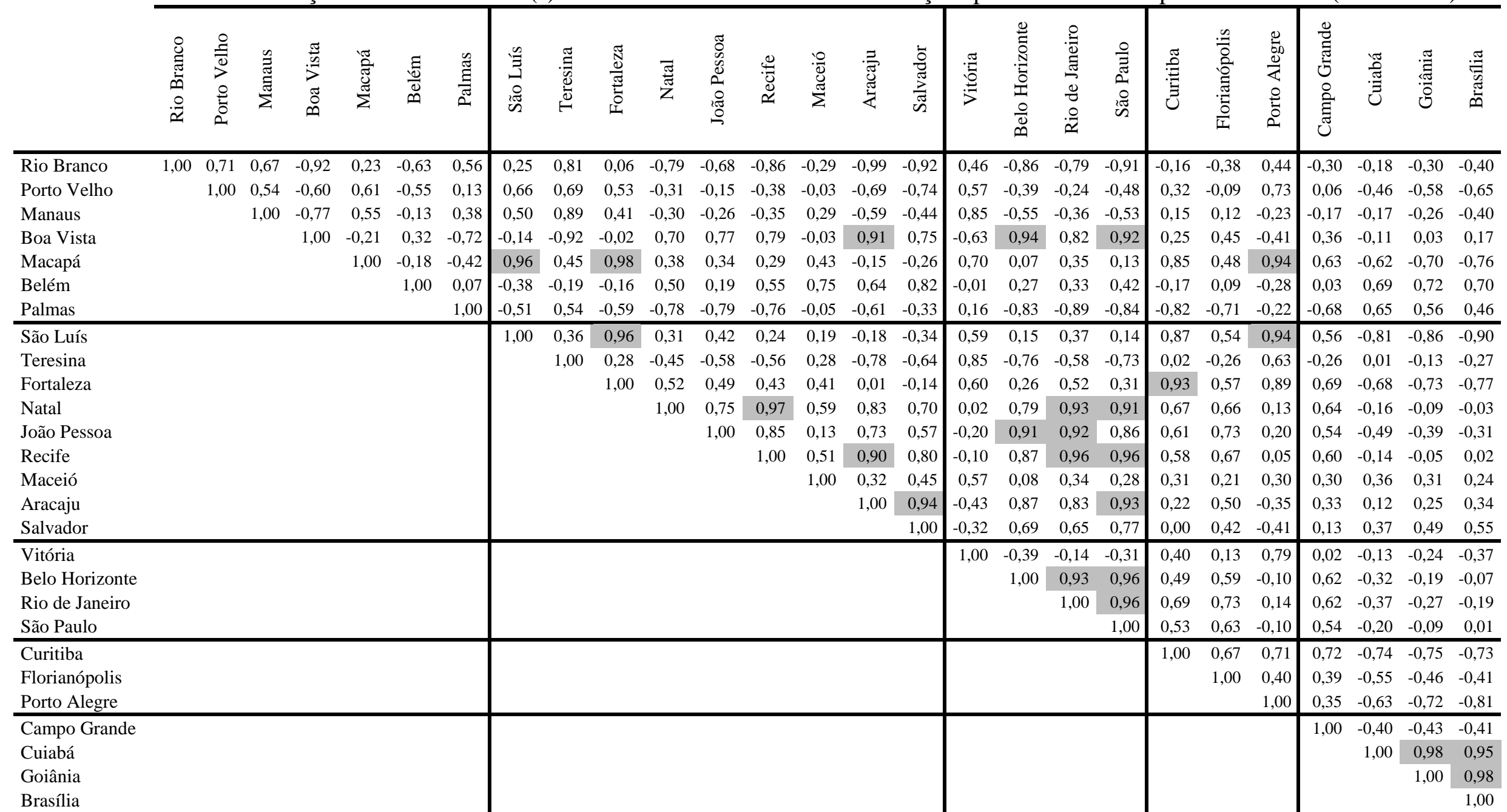

Nota: Valores de $r$ maiores ou iguais a 0,90 entre as séries estão realçados na tabela.

Fonte: Elaborado pelo autor a partir de dados do SIH (MS, 2015). 
Por outro lado, capitais com regime climático distinto das demais capitais de mesma região geográfica apresentam comportamento intranual diferenciado, como ocorre com Boa Vista, na Região Norte e, Vitória, no Sudeste. O histograma de Boa Vista apresenta distribuição equivalente com a distribuição da precipitação ao longo do ano. Vitória, por sua vez, apresenta chuvas bem distribuídas ao longo de todo o ano, com uma predominância daquelas que ocorrem no último trimestre.

A correspondência entre os histogramas das internações por DGOIP e a precipitação é notória nas regiões Norte e Nordeste do país, não sendo verificada nas demais regiões. Os coeficientes de correlação entre as séries trimestrais são apresentados na Tabela 5.3. Em todas as capitais dessas regiões, exceto Belém, foram encontradas correlações positivas entre as duas variáveis. Já no Sudeste, Sul e Centro-Oeste, o comportamento é inverso e as correlações encontradas são negativas, exceto em Vitória, sendo que o período de maior número de internações tende a ser o de menor precipitação. Observa-se, ao mesmo tempo, que valores altos de correlação são observados entre as séries temporais de Boa Vista, Natal, João Pessoa, Recife, e as de Belo Horizonte, Rio de Janeiro e São Paulo, na Tabela 5.2. Entretanto, enquanto nos primeiros a correlação é positiva com a precipitação, nos últimos ela é negativa. Em relação a temperatura, dois terços das capitais apresentaram correlação negativa, ou seja, os meses mais frios tendem a apresentar maior registro de internações. O comportamento das internações por rotavírus, discutido adiante, pode auxiliar a explicar tal comportamento.

Tabela 5.3: Coeficientes de correlação linear de Pearson $(r)$ entre as séries trimestrais de internações por DGOIP (1998-2012) e de totais trimestrais de precipitação (A) e médias trimestrais de temperatura (B) (1961-1990).

\begin{tabular}{|c|c|c|c|c|c|c|c|}
\hline & \multirow{2}{*}{\multicolumn{2}{|c|}{$\begin{array}{ll}\mathbf{A} & \mathbf{B} \\
\end{array}$}} & & \\
\hline & & & & & & $\mathbf{A}$ & B \\
\hline \multirow{7}{*}{ NORTE } & Rio Branco & 0,94 & 0,89 & \multirow{4}{*}{ SUDESTE } & Vitória & 0,13 & 0,78 \\
\hline & Porto Velho & 0,84 & 0,23 & & Belo Horizonte & $-0,86$ & $-0,81$ \\
\hline & Manaus & 0,57 & $-0,48$ & & Rio de Janeiro & $-0,48$ & $-0,37$ \\
\hline & Boa Vista & 0,96 & $-0,83$ & & São Paulo & $-0,80$ & $-0,71$ \\
\hline & Belém & $-0,31$ & $-0,12$ & \multirow{3}{*}{ SUL } & Curitiba & $-0,05$ & 0,16 \\
\hline & Macapá & 0,91 & $-0,80$ & & Florianópolis & $-0,07$ & $-0,05$ \\
\hline & Palmas & 0,48 & 0,56 & & Porto Alegre & $-0,74$ & 0,74 \\
\hline \multirow{9}{*}{ NORDESTE } & São Luís & 0,98 & $-0,58$ & \multirow{4}{*}{ CENTRO-OESTE } & Campo Grande & $-0,30$ & $-0,27$ \\
\hline & Teresina & 0,58 & 0,18 & & Cuiabá & $-0,31$ & 0,16 \\
\hline & Fortaleza & 0,95 & $-0,13$ & & Goiânia & $-0,36$ & 0,12 \\
\hline & Natal & 0,85 & $-0,38$ & & Brasília & $-0,45$ & $-0,08$ \\
\hline & João Pessoa & 0,95 & $-0,35$ & & & & \\
\hline & Recife & 0,92 & $-0,59$ & & & & \\
\hline & Maceió & 0,04 & $-0,12$ & & & & \\
\hline & Aracaju & 0,65 & $-0,77$ & & & & \\
\hline & Salvador & 0,15 & $-0,81$ & & & & \\
\hline
\end{tabular}

Fonte: Elaborado pelo autor a partir de dados do SIH (MS, 2015) e INMET (2015). 
Embora FMA a AMJ concentre os casos de internações em Campo Grande, também pode ser observada uma tendência de aumento nos meses mais secos. O mês de abril na cidade possui um total de 2.761 internações, quase o triplo de segundo mês de maior número de registros, que é agosto, com 1.050 casos. No período de análise (1998-2012), 18\% de todos os casos de internações em Campo Grande foram registrados em abril do ano 2000.

Embora a amplitude térmica ao longo do ano seja menor no Norte e Nordeste e maior no Sul do país, a influência dos meses mais frios não é observada nas capitais mais frias do país, sendo encontradas correlações positivas com a temperatura em Curitiba e Porto Alegre. Também não pode ser considerada a influência de meses mais secos ou mais chuvosos, pois, a região Sul do país não possui estação seca bem definida. O trimestre de maior número de casos esteve entre JFM e MAM em nove anos da série temporal em Porto Alegre e oito anos em Curitiba (Tabela 5.4).

O trimestre de maior número de internações em Rio Branco é NDJ ao passo que em Manaus e Porto Velho é JFM e em Macapá é FMA. Esta evolução segue o mesmo padrão latitudinal de evolução do pico de precipitação (Figura 5.5A). Em Manaus o trimestre esteve entre DJF e FMA em nove anos dos quinze da série temporal. Em Macapá, em nove anos o trimestre foi FMA, outros três anos em MAM e dois anos em JFM (Tabela 5.4). Belém possui um comportamento diferenciado, que será discutido adiante sendo que entre 1998 e 2012 somente em seis anos o mês de maior registro não foi agosto ou setembro, sendo que em cinco destes anos foi janeiro, fevereiro ou março.

As capitais com menor população não apresentam comportamento tão bem definido. Um dos fatores que contribuiu para isso é o reduzido número de internações registradas, como ocorre em Rio Branco, Palmas e Florianópolis em diversos anos da série temporal (Tabela 5.4). Rio Branco, Florianópolis e Palmas correspondem as capitais com o menor número de internações, correspondente a 546, 605 e 662, respectivamente.

Em algumas capitais observa-se que há uma mudança nos padrões temporais após 2006, principalmente nas regiões Sudeste e Centro-Oeste do país. Em São Paulo, município mais populoso do país, entre nove anos consecutivos, de 1998 a 2006, o trimestre de maior número de internações alternou entre AMJ e JJA. A partir de 2007 os trimestres sempre foram outros. 
Tabela 5.4: Trimestre (comportamento interanual) de maior número de internações por DGOIP nas capitais brasileiras (1998-2012).

\begin{tabular}{|c|c|c|c|c|c|c|c|c|c|c|c|c|c|c|c|}
\hline & $\stackrel{\infty}{\sigma}$ & ڤે & $\stackrel{\text { }}{8}$ & हి & 용 & ஜ̊̊ి & ষ্ণ & ஜ̊ & ஜ̊ & 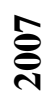 & ஜ્ণ & & 룽 & $\overline{\bar{\theta}}$ & $\frac{N}{\tilde{)}}$ \\
\hline \multicolumn{16}{|l|}{ Rio Branco } \\
\hline \multicolumn{16}{|l|}{ Porto Velho } \\
\hline \multicolumn{16}{|l|}{ Manaus } \\
\hline \multicolumn{16}{|l|}{ Boa Vista } \\
\hline \multicolumn{16}{|l|}{ Macapá } \\
\hline \multicolumn{16}{|l|}{ Belém } \\
\hline \multicolumn{16}{|l|}{ Palmas } \\
\hline \multicolumn{16}{|l|}{ São Luís } \\
\hline \multicolumn{16}{|l|}{ Teresina } \\
\hline \multicolumn{16}{|l|}{ Fortaleza } \\
\hline \multicolumn{16}{|l|}{ Natal } \\
\hline \multicolumn{16}{|l|}{ João Pessoa } \\
\hline \multicolumn{16}{|l|}{ Recife } \\
\hline \multicolumn{16}{|l|}{ Maceió } \\
\hline \multicolumn{16}{|l|}{ Aracaju } \\
\hline \multicolumn{16}{|l|}{ Salvador } \\
\hline \multicolumn{16}{|l|}{ Vitória } \\
\hline \multirow{2}{*}{\multicolumn{16}{|c|}{$\begin{array}{l}\text { Belo Horizonte } \\
\text { Rio de Janeiro }\end{array}$}} \\
\hline & & & & & & & & & & & & & & & \\
\hline \multicolumn{16}{|l|}{ São Paulo } \\
\hline \multicolumn{16}{|l|}{$\begin{array}{l}\text { Curitiba } \\
\text { Florianópolis }\end{array}$} \\
\hline Florianópolis & & & & & & & & & & & & & & & \\
\hline \multicolumn{16}{|l|}{ Porto Alegre } \\
\hline \multicolumn{16}{|l|}{ Campo Grande } \\
\hline \multicolumn{16}{|l|}{ Cuiabá } \\
\hline \multicolumn{16}{|l|}{ Goiânia } \\
\hline Brasília & & & & & & & & & & & & & & & \\
\hline & & $\sum_{\text {王 }}$ & $\sum_{i}^{\mathbb{S}}$ & $\sum$ & $\sum$ & $\Xi$ & 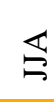 & 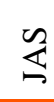 & $\begin{array}{l}0 \\
\approx\end{array}$ & Z & 文 & $\overrightarrow{\mathrm{z}}$ & 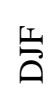 & $\stackrel{*}{\stackrel{*}{\sim}}$ & \\
\hline
\end{tabular}

Nota: *Foram consideradas como sem registros (SR) as capitais com número inferior a 12 internações em cada ano.

Fonte: Elaborado pelo autor a partir de dados do SIH (MS, 2015).

\subsection{DISCUSSÃO}

Já é notório saber na bibliografia especializada que as regiões Norte e Nordeste do Brasil apresentam taxas mais altas de diarreia e gastroenterites em relação as demais (BÜHLER et al., 2014; OLIVEIRA; LATORRE, 2010; MENDES et al., 2013). O objetivo deste artigo não é esgotar e repetir o assunto. Como ressalta Bühler et al. (2014) ainda persiste a polarização epidemiológica, geográfica e social no país, polarização esta que aponta a persistência de 
doenças infecciosas e parasitárias em determinadas regiões. Há agrupamentos de municípios com padrões de saúde próximos aos dos países desenvolvidos e agrupamentos com índices de morbidade comparados aos dos países mais pobres do globo. No entanto, uma série de políticas públicas direcionadas a essas regiões vem contribuindo no sentido de reduzir as desigualdades socioespaciais existentes no território brasileiro.

Foram observados padrões espaciais de períodos de maior número de internações bem definidos ao longo do território brasileiro, em sua maioria associados à variação na distribuição espaço-temporal da precipitação. Comparando as Figuras 5.4 e 5.5 é possível observar uma associação considerável entre os trimestres de maior internação e de maior precipitação em algumas regiões do país, principalmente no Norte e Nordeste, onde há maior fragilidade da infraestrutura de saneamento básico, tanto no que diz respeito à água como no esgoto. Observase que há padrões mais definidos do comportamento da DGOIP em regiões onde há presença de duas estações do ano bem definidas (uma chuvosa e outra seca), sendo que nas regiões com chuvas mais bem distribuídas, a exemplo do Sul do país, não há um comportamento único predominante.

Estes padrões, em parte, podem estar associados ao padrão de infecções por rotavírus. Jagai et al. (2012) realizaram uma análise multivariada buscando identificar padrões sazonais das infecções por rotavírus e sua relação com a precipitação, a temperatura e índice de vegetação (Normalized Diference Vegetation Index [NDVI]) no sul da Ásia. As maiores taxas de infecções foram observadas nos meses mais frios, mais secos e que apresentaram menor índice de vegetação. As maiores associações foram verificadas com a temperatura. Segundo os autores, em climas tropicais onde a variação da temperatura é menor, os padrões das infecções podem ser diferenciados.

Considerando a possibilidade de transmissão pessoa-pessoa do rotavírus por via respiratória, observa-se forte influência da sazonalidade também no comportamento das diarreias provocadas por este patógeno, porém com padrão diferente daquele que ocorre com bactérias e parasitas, cuja forma de transmissão é exclusivamente fecal-oral e sua redução pode ser obtida com melhorias nas condições de saneamento e higiene (PARASHAR et al., 2006).

Ao revisar a literatura da epidemiologia do rotavírus no Brasil, Linhares (2000) observou que a frequência da diarreia em termos de atendimentos ambulatoriais e internações hospitalares associadas a este microrganismo variou de $12 \%$ a $42 \%$. Ocorrendo estimativas distintas entre as regiões brasileiras, com predominância na região Sul (42\%), seguida da região 
Norte (36,5\%), Nordeste (25\%), Centro-Oeste (24\%) e Sudeste (22\%). A faixa etária mais acometida foi a de seis meses a dois anos de idade, com dois terços dos casos. Já Sartori et al. (2008) efetuaram uma revisão bibliográfica de estudos publicados no Brasil de detecção de rotavírus em crianças nos quais encontraram frequências variando entre 15 e $37 \%$ dos casos.

Conforme Linhares (2000) um terço das diarreias e gastroenterites de origem infecciosa em crianças menores de um ano pode ser atribuída ao rotavírus e os estados do Centro-Sul do país apresentam um padrão sazonal com maior ocorrência nos meses mais secos de maio a setembro, o que não se verifica no Nordeste e Norte do país.

Silva et al. (2010) analisaram o comportamento sazonal da mortalidade por diarreia em crianças menores de cinco anos em Manaus entre 1996 e 2002 e observaram correspondências entre as médias de mortalidade e de precipitação na cidade, sendo o pico registrado nos meses mais chuvosos de janeiro a março. Dias et al. (2010) observaram uma maior concentração dos casos de diarreia no Estado do Pará, entre 2000 e 2004, nos meses de janeiro a março, que, no Estado do Pará, correspondem ao período chuvoso. Em contraponto ao estudo de Dias et al. (2010), Linhares (2000) destacou que, na região Norte do país, o período de julho a setembro exibe maior número de diarreias infantis por rotavírus, correspondendo aos meses em que se registra menor precipitação pluviométrica, embora a influência da sazonalidade não seja tão marcante como a observada nas demais regiões do país. Estes fatores parecem auxiliar no entendimento do padrão apresentado pela cidade de Belém.

O estudo de Teixeira et al. (1991) demonstrou que, no Distrito Federal, entre 1986 e 1990, os mais altos índices de infecção por rotavírus ocorreram sempre entre maio e setembro, período de pluviosidade praticamente nula. Já o estudo de Cardoso et al. (2003) compreendeu o período de 1986 a 2000 e, demonstrou que em Goiânia, as maiores taxas foram observadas no período de abril a agosto. Por outro lado, apesar desta relação não estar bem estabelecida na literatura, a diminuição na umidade do ar parece estar associada ao aumento na ocorrência de doenças diarreicas, até porque sugere-se a existência de um caminho adicional à transmissão do rotavírus correspondente à via respiratória (MOORS et al., 2013). Desta forma, o período de seca, na região do Planalto Central, com taxas de umidade relativa do ar extremamente baixas, pode facilitar a transmissão desse patógeno.

Kale et al. (2004) estudando as internações e óbitos por diarreia em menores de cinco anos no município do Rio de Janeiro entre 1995 e 1998 já observaram que o pico ocorria em maio e junho, caracterizando um padrão de etiologia viral da diarreia. Outro estudo, o de Rosa 
e Silva et al. (2001), realizado em Juiz de Fora, detectou rotavírus em crianças de até cinco anos entre março e setembro de 1998, sendo o pico de incidência verificado em junho (33,3\%), que corresponde ao mês mais seco e frio na região.

Melli e Waldman (2009) estudaram os padrões temporais de mortalidade por diarreia em crianças menores que cinco anos em Osasco, São Paulo, entre 1980 e 2000 e observaram um deslocamento da sazonalidade dos óbitos do verão para o outono, a partir dos anos da década de 1990, o que pode ser atribuído à ampliação do saneamento básico. Segundo os autores, o mesmo deve-se, de um lado, ao aumento relativo das infecções por vírus, especialmente o rotavírus, e de outro, à diminuição das infecções bacterianas, principalmente as determinadas pela Escherichia coli, que assumem no verão maior importância em comunidades sem saneamento, em virtude das águas das chuvas aumentarem a contaminação ambiental.

Porto Alegre possui um comportamento diferenciado, pois, embora a bibliografia aponte que o período de maior infecção por rotavírus seja o de inverno (BITTENCOURT et al., 2000), o período de maior número de internações por DGOIP foi o período de verão (Figura 5.7). No entanto, cumpre ressaltar que esta capital apresentou os menores casos percentuais em crianças com idade inferior a cinco anos entre todas as capitais brasileiras, de apenas $36 \%$.

Em março de 2006 o Brasil introduziu no calendário de vacinação infantil a vacina contra rotavírus, devendo ser aplicada em crianças entre dois e seis meses de idade (CARMO, 2006). A alteração nos períodos de maior número de internações por DGOIP após 2006 (Tabela 5.4), verificada principalmente nas regiões Sudeste e Centro-Oeste, pode ser devida, entre outros fatores, à introdução da vacinação contra o rotavírus. Entretanto, cumpre destacar que, segundo Linhares (2000), estas são as regiões do Brasil com as menores estimativas de internações por diarreia associadas ao rotavírus.

Estudo de Linhares e Justino (2014) aponta que a cobertura da vacinação contra o rotavírus no Brasil alcançou em 2011 uma média de 87,1\%, variando de 72\% no Norte a 93\% no Sudeste do país. Tem sido demonstrada uma efetividade da vacina em 76 a $85 \%$ dos casos nas regiões Norte e Nordeste. Embora nem todas as crianças completem o ciclo de vacinação que compreende duas doses, tem sido verificada uma redução nas taxas de internação e de mortes por gastroenterites de até $48 \%$ e $54 \%$, respectivamente, em crianças com idade inferior a um ano (LINHARES; JUSTINO, 2014). Por essa razão, sugere-se a realização de estudos de observação contínua das internações por DGOIP a fim de detectar alterações nos padrões 
sazonais de predominância dos casos das doenças, notadamente nos estados do Centro-Sul do país, que também são aqueles com a maior cobertura de vacinação contra o rotavírus.

Fatores como o abastecimento de água e a coleta de esgoto parecem ser importantes ao compararmos o padrão de ocorrência das internações por diarreia nas diferentes regiões do país, sugerindo que as áreas com maiores coberturas de saneamento básico podem apresentar comportamentos dissociados com o comportamento da precipitação, o que corrobora os resultados obtidos com esta pesquisa no sentido de distinguir os padrões observados nas diferentes regiões geográficas. No entanto, a dinâmica de ocorrência da diarreia não é simples, pois há diversos patógenos envolvidos e sua influência sobre os indivíduos também é distinta conforme a faixa etária. Embora a maior parte da literatura existente trate da diarreia em crianças com idade inferior a cinco anos, esta amostra representa apenas $47 \%$ dos casos trabalhados nesta pesquisa de tese e, certamente outras interações homem-patógeno se manifestam em indivíduos das demais faixas etárias incluídas indistintamente neste estudo.

A Portaria $\mathrm{n}^{\circ} 2.914$ do Ministério da Saúde que trata da potabilidade da água para consumo humano (MS, 2011) não exige a realização de análises de vírus ou protozoários na água tratada, sendo utilizados apenas indicadores bacterianos. Tais indicadores são válidos, porém insuficientes para determinar a qualidade microbiológica da água, já que microorganismos resistentes ao cloro podem não estar sendo detectados*

Patógenos como vírus são de difícil detecção e possuem grande resistência aos métodos de desinfecção se comparados às bactérias, por essa razão, seu monitoramento é raro e não há consenso acerca de métodos de remoção e tratamento, mesmo em países desenvolvidos (REYNOLDS et al., 2008). Por outro lado, as tecnologias de tratamento da água potável empregadas atualmente são inadequadas para eliminar cistos de alguns tipos de protozoários transmitidos pela água (GAJADHAR; ALLEN, 2004). No Brasil, a análise de Cryptosporidium e Giardia só é obrigatória nos mananciais.

\subsection{CONSIDERAÇÕES FINAIS}

\footnotetext{
* Segundo informações fornecidas pela Companhia de Saneamento de Minas Gerais (COPASA), geralmente o cloro adicionado à água tratada é suficiente para matar as bactérias e o número de registros de coliformes totais, Escherichia coli e bactérias heterotróficas - parâmetros da Portaria $n^{\circ} 2.914$ - é muito pequeno. Os picos de coliformes totais ocorrem nos períodos chuvosos devido a infiltrações na rede. Já para o indicador de contaminação fecal, Escherichia coli, nem sempre ocorre o mesmo padrão.
} 
Adotando-se uma escala de análise baseada no tempo, observado o comportamento de todos os municípios do país como unidades espaciais de análise, este estudo observou que há relação temporal (intranual) entre o período do ano de maior registro de internações por DGOIP e o comportamento do clima, notadamente o da precipitação, ao longo do território brasileiro. Foi verificada a presença de dois padrões majoritários, em áreas com a presença de duas estações do ano bem definidas. Os agrupamentos espaciais de municípios cujos períodos de maior número de internações por DGOIP ao longo do ano se assemelham ocorrem em áreas de comportamento climático semelhante, sendo possível observar comportamentos distintos entre as regiões do pais, associados predominantemente ao período da estação chuvosa no Norte/Nordeste e à estação seca nas regiões Sudeste/Centro-Oeste do país, o que supõe uma variação na etiologia predominante da infecção, se bacteriana ou viral. Os padrões observados podem ser utilizados em subsídio técnico às políticas públicas das áreas de saúde e saneamento.

Em boa parte do Norte e Nordeste do Brasil, de clima equatorial, a variação da temperatura é menor ao longo do ano e os meses mais chuvosos são também os mais frios. Já no Sul, de clima subtropical, além da questão da precipitação, os meses mais frios podem ocasionar uma maior ocorrência de doenças diarreicas devido as infecções por rotavírus, devendo este fenômeno ser considerado nas análises. Tal tipo de infecções também parece explicar o comportamento das internações na região do Planalto Central do Brasil. No entanto, este tipo de estudo pode ser efetuado por pesquisas epidemiológicas que utilizam coortes e, consequentemente, uma metodologia diferente da adotada nesse trabalho, cujo foco correspondeu a um estudo ecológico e uma análise geográfica dos resultados, não podendo ser definidos os patógenos responsáveis pelas internações registradas mas, somente, efetuar inferências e observações empíricas.

Quanto às limitações desta pesquisa, ressalta-se que pode haver uma defasagem entre o mês de atendimento e o mês de ocorrência da doença mas, como todos os dados foram utilizados considerando a mesma variável e o objetivo foi analisar o problema de pesquisa segundo uma série temporal, e não apenas um período isolado, bem como o comportamento da variável para todos os municípios, o efeito dessa possível defesagem tende a ser reduzido. Convém destacar ainda que os dados utilizados se referem ao mês de processamento das $\mathrm{AIH}$, correspondendo, em quase todas as situações, ao mês da alta do paciente internado, sendo importante considerar uma defasagem entre a causa da internação e o registro propriamente dito no DATASUS (MS, 2015). As informações utilizadas correspondem ao registro do local de residência, o que 
também pode introduzir um viés na análise, pois pacientes podem recorrer a hospitais de maior complexidade ou referência localizados em municípios pólo e informar residência nestes.

É importante ressaltar também que os dados da CPRM foram compilados utilizando uma série temporal de trinta anos, maior, portanto, que a utilizada para a variável internações, correspondente a quinze anos, o que pode resultar em uma variabilidade da precipitação máxima mensal nesse período. Ademais, os períodos considerados não foram coincidentes.

Em estudos futuros, os dados poderão ser desagregados por faixa etária, observando o comportamento apresentado pelos diferentes grupos da população. Além disso, os padrões de distribuição espaço-temporal aqui identificados poderão ser analisados em escalas de maior detalhe, buscando encontrar fatores associados a ocorrência das diarreias e gastroenterites infecciosas nos contextos espaciais regionais e locais.

\section{REFERÊNCIAS BIBLIOGRÁFICAS}

ANSELIN, L. Spatial Data Analysis with GIS: An Introduction to Application in the Social Sciences. Technical Report 92-10, 1992.

Local Indicators of Spacial Association - LISA. Geographical Analysis. v. 27, p. 93-115, 1995.

ARDKAEW, J.; TONGKUMCHUM, P. Statistical Modelling of Childhood Diarrhea in Northeastern Thailand. Southeast Asian Journal of Tropical Medicine and Public Health, v. 40, n.4, p. $807-815,2009$.

BARCELLOS, C.; BASTOS, F. I. Geoprocessamento, ambiente e saúde: uma união possível? Cadernos de Saúde Pública. v. 12, n. 3, p. 389-397, 1996.

BITTENCOURT, J. A.; ARBO, E.; MALYSZ, A. S.; ORAVEC, R.; DIAS, C. Seasonal and age distribution of rotavirus infection in Porto Alegre-Brazil. Brazilian Journal of Infectious Diseases, v. 4, n. 6, p. 279-283, 2000.

BÜHLER, H. F.; IGNOTTI, E.; NEVES, S. M. A. S.; HACON, S. S. Análise espacial de indicadores integrados de saúde e ambiente para morbimortalidade por diarreia infantil no Brasil, 2010. Cadernos de Saúde Pública, Rio de Janeiro, v. 30, n. 9, p. 1921-1934, 2014.

CAMARGO, E. P. Tropical diseases. Estudos Avançados, v. 22, n. 64, p. 95-110, 2008. 
CARDOSO, D. D. P.; SOARES, C. M. A.; DIAS E SOUZA, M. B. L.; AZEVEDO, M. S. P.; MARTINS, R. M. B.; QUEIROZ, D. A. O.; BRITO, W. M. E. D.; MUNFORD, V.; RÁCZ, M. L. Epidemiological features of rotavirus infection in Goiania, Goias, Brazil, from 1986 to 2000. Memórias do Instituto Oswaldo Cruz, v. 98, n. 1, p. 25-29, 2003.

CARMO, E. H. Doença diarréica por rotavírus: magnitude, introdução da vacina e desafios para a vigilância epidemiológica. Cadernos de Saúde Pública, v. 22, n. 11, p. 2266, 2006.

COMPANHIA DE PESQUISA DE RECURSOS MINERAIS (CPRM). Atlas Pluviométrico do Brasil. Rio de Janeiro: CPRM, 2012. Disponível em: http://www.cprm.gov.br/publique/ cgi/cgilua.exe/sys/start.htm?infoid=1351\&sid=9. Acesso em: 07 jan. 2014.

DIAS, D. M.; SILVA, A. P.; HELFER, A. M.; MACIEL, A. M. T. R.; LOUREIRO, E. C. B.; SOUZA, C. O. S. Morbimortalidade por gastroenterites no Estado do Pará, Brasil. Revista Pan-Amazônica de Saúde, v. 1, n. 1, p. 53-60, 2010.

GAJADHAR, A. A.; ALLEN, J. R. Factors contributing to the public health and economic importance of waterborne zoonotic parasites. Veterinary Parasitology, v. 126, p. 3-14, 2004.

HERRADOR, B. R. G. ; BLASIO, B. F.; MACDONALD, E.; NICHOLS, G.; SUDRE, B.; VOLD, L.; SEMENZA, J. C.; NYGARD, K. Analytical studies assessing the association between extreme precipitation or temperature and drinking water-related waterborne infections: a review. Environmental Health, v. 14, n. 1, 14 :29, 2015.

KALE, P. L.; FERNANDES, C.; NOBRE, F. F. Padrão temporal das internações e óbitos por diarréia em crianças, 1995 a 1998, Rio de Janeiro. Revista de Saúde Pública, v. 38, n. 1, p. 30-37, 2004.

INSTITUTO BRASILEIRO DE GEOGRAFIA E ESTATÍSTICA (IBGE). Censo

Demográfico 2000: Características da População e dos Domicílios: Resultados do universo. Rio de Janeiro: IBGE, 2000. Disponível em: http://www.sidra.ibge.gov.br/cd/ cd2000ru.asp?o=24\&i=P. Acesso em: 15 mar. 2015.

Censo Demográfico 2010: Resultados do Universo - Características da População e dos Domicílios. Rio de Janeiro: IBGE, 2010. Disponível em: http://www.sidra.ibge.gov.br/ cd/cd2010universo.asp?o=7\&i=P. Acesso em: 15 mar. 2015.

Estimativas de População: Estimativas populacionais para os municípios brasileiros em 01.07.2013. Rio de Janeiro: IBGE, 2015. Disponível em: http://www.ibge.gov. br/home/estatistica/populacao/estimativa2013/default.shtm. Acesso em: 15 mar. 2015. 
INSTITUTO NACIONAL DE METEOROLOGIA (INMET). Normais Climatológicas do Brasil 1961-1990. Brasília: INMET, 2015. Disponível em: http://www.inmet.gov.br/portal/ index.php?r=clima/normaisclimatologicas. Acesso em: 15 mar. 2015.

JAGAI, J. S.; SARKAR, R.; CASTRONOVO, D.; KATTULA, D.; MCENTEE, J.; WARD, H.; KANG, G.; NAUMOVA, E. N. Seasonality of rotavirus in South Asia: a meta-analysis approach assessing associations with temperature, precipitation, and vegetation index. PLoS One, v. 7, n.5, e38168, 2008.

LECHA, L. B. Elementos Básicos de la Biometeorología Humana. Curso de Posgrado. Havana: Escuela Latinoamericana de Medicina (ELAM), 2013.

LINHARES, A. C. Epidemiologia das infecções por Rotavírus no Brasil e os desafios para o seu controle. Cadernos de Saúde Pública, v. 16, n. 3, p. 629-646, 2000.

LINHARES, A. C.; JUSTINO, M. C. Rotavirus vaccination in Brazil: effectiveness and health impact seven years post-introduction. Expert Review of Vaccines, v. 13, n. 1, p. 43 57, 2014.

MELLI, L. C. F. L.; WALDMAN, E. A. Temporal trends and inequality in under-5 mortality from diarrhea. Jornal de Pediatria, v. 85, n. 1, p. 21-27, 2009.

MENDES, P. S. A.; RIBEIRO JÚNIOR, H. C.; MENDES, C. M. C. Temporal trends of overall mortality and hospital morbidity due to diarrheal disease in Brazilian children younger than 5 years from 2000 to 2010. Jornal de Pediatria, v. 89, n. 3, p.315-325, 2013.

MINISTÉRIO DA SAÚDE (MS). Portaria n. ${ }^{\circ}$ 2.914, de 12 de dezembro de 2011. Brasília: MS, 2011. Disponível em: http://bvsms.saude.gov.br/bvs/saudelegis/gm/2011/ prt2914_12_12_2011.html. Acesso em: 11 out. 2015.

Informações de Saúde (TABNET). Brasília: MS/DATASUS, 2015. Disponível em: http://www2.datasus.gov.br/DATASUS/index.php. Acesso em: 15 mar. 2015.

MOORS, E.; SINGH, T.; SIDERIUS, C.; BALAKRISHNAN, S.; MISHRA, A. Climate change and waterborne diarrhoea in northern India: Impacts and adaptation strategies. Science of the Total Environment, 2013. Disponível em: http://dx.doi.org/10.1016/j.scitotenv.2013. 07.021

OLIVEIRA, T. C. R.; LATORRE, M. R. D. O. Tendências da internação e da mortalidade infantil por diarréia: Brasil, 1995 a 2005. Revista de Saúde Pública, v. 44, n. 1, p. 102-111, 2010. 
ORGANIZAÇÃO PAN-AMERICANA DE SAÚDE (OPAS). REDE INTERAGENCIAL DE INFORMAÇÃO PARA A SAÚDE (RIPSA). Indicadores básicos para a saúde no Brasil: conceitos e aplicações. $2^{\mathrm{a}}$ ed. Brasília: OPAS, 2008. 349p.

PARASHAR, U. D.; GIBSON, C. J.; BRESEE, J. S.; GLASS, R. I. Rotavirus and severe childhood diarrhoea. Emerging Infectious Diseases, v. 12, n. 2, p. 304-306, 2006.

REYNOLDS, K. A.; MENA, K. D.; GERBA, C. P. Risk of waterborne illness via drinking water in the United States. Reviews of Environmental Contamination and Toxicology, v. 192, p. 117-158, 2008.

ROSA E SILVA, M. L.; NAVECA, F. G.; CARVALHO, I. P. Epidemiological aspects of rotavirus infections in Minas Gerais, Brazil. Brazilian Journal of Infectious Diseases, v. 5, n. 4, p. 215-222, 2001.

SARTORI, A. M. C.; VALENTIM, J.; SOARES, P. C.; NOVAES, H. M. Rotavirus morbidity and mortality in children in Brazil. Revista Panamericana de Salud Publica, v. 23, n.2, p. 92-100, 2008.

SASTRY, N; BURGARD, S. The prevalence of diarrheal disease among Brazilian children: trends and differentials from 1986 to 1996. Social Science and Medicine, v. 60, p. 923-935, 2005 .

SILVA, D. X.; BARCELLOS, C.; BACURI, R. Vulnerabilidade e efeitos das mudanças climáticas na saúde pública em Manaus. Rio de Janeiro: FIOCRUZ, 2010. 85p. Disponível em: http://www.climasaude.icict.fiocruz.br/docs/vulnerabilidade_manaus_relat_final2_x_edit. pdf. Acesso em: 15 mar. 2015.

TEIXEIRA, J. M. S.; FIGUEIREDO, R. B., SANTOS, H. M. P.; FERREIRA, M. N. R.; CÂMARA, G. N. N. L. Aspectos epidemiológicos das infecções por rotavírus no Distrito Federal, Brasil. Revista da Sociedade Brasileira de Medicina Tropical, v. 24, n. 4, p. 223 230, 1991.

TROMP, S. W. Human Biometeorology. International Journal of Biometerology, v. 7, n. 2, p. 145-158, 1963.

WORLD HEALTH ORGANIZATION (WHO). World Health Report 2002: Reducing risks, promoting healthy life. Genebra: WHO, 2002. Disponível em:

http://www.who.int/whr/2002. Acesso em: 15 mar. 2015.

The global burden of disease: 2004 update. Genebra: WHO, 2008. 148p.

Disponível em: http://www.who.int/healthinfo/global_burden_disease/GBD_report_2004 update_full.pdf. Acesso em: 15 mar. 2015. 


\section{CONCLUSÕES}

Os resultados da pesquisa de tese auxiliam a identificar em que medida variáveis ligadas ao comportamento sazonal da qualidade da água dos reservatórios de abastecimento e do regime de chuvas e, também características dos sistemas de abastecimento de água, estão associadas aos padrões de ocorrência das doenças diarreicas. Para tanto foram utilizados diferentes métodos de análise espacial e análise estatística em diferentes conjuntos de dados, com recortes espaciais e séries temporais distintas.

Em relação a "Análise Temporal da Resposta Espectral da Água de Reservatórios de Abastecimento Humano e da Ocorrência de Doença Diarreica Aguda em um Recorte Espacial do Semiárido Brasileiro entre 2002 e 2012" foi observado que o monitoramento da variação sazonal de características da qualidade da água dos reservatórios, por meio da utilização de imagens do sensor remoto MODIS, se aplica àqueles de maior dimensão, como no caso do açude Armando Ribeiro Gonçalves. Os períodos de maior influência do material inorgânico em suspensão na água estiveram associados aos períodos de maior ocorrência de DDA na população abastecida por esse reservatório.

Considerando que é o período de chuvas que retoma o fluxo d'água nos rios intermitentes do semiárido e altera as características da água dos açudes, a análise da sazonalidade da precipitação demonstrou ser relevante no entendimento dos padrões de ocorrência da doença, e este tema foi abordado no estudo do "Comportamento Intra e Interanual da Ocorrência da Doença Diarreica Aguda por Semana Epidemiológica em um Recorte Espacial do Semiárido Brasileiro entre 2002 e 2012". Foi verificado que o regime climático na área de estudo, notadamente do padrão temporal de ocorrência da precipitação pluviométrica, corresponde a um elemento indutor da contaminação ambiental e circulação de patógenos que favorecem a ocorrência das diarreias agudas. O regime regular de chuvas, assim como as anomalias de precipitação registradas, auxilia a compreender a dinâmica da ocorrência da DDA na área de estudo, sendo que ocorre, em geral, um período de três a quatro semanas de defasagem entre o aumento da precipitação e o aumento nos registros de notificação da doença.

Foi confirmada a existência de uma complexa dinâmica de infraestruturas para abastecimento de água das populações urbanas e rurais na área de estudo na análise dos 


\section{"Padrões Espaço-Temporais das Condições de Abastecimento de Água em um Recorte}

Espacial do Semiárido Brasileiro de 2002 a 2014”. Maior incidência de DDA e uma maior operação de sistemas baseados em carro-pipa parece estar associada a deficiências dos sistemas adutores da região e à necessidade de complementação da quantidade de água fornecida, principalmente em períodos de escassez hídrica, como aquele verificado na área de estudo entre 2012 e 2014. Nesse período, as áreas abastecidas pela Lagoa do Bonfim e pelo açude Gargalheiras foram aquelas que apresentaram as maiores taxas de DDA e, por essa razão, outras variáveis indicaram associação com o comportamento da doença, como a implantação de rodízio no abastecimento e a redução no volume de água distribuído à população. A pesquisa concluiu que indicadores ligados ao abastecimento de água são importantes na análise dos padrões de ocorrência das doenças diarreicas, em especial na região semiárida onde as infraestruturas de abastecimento de água são complexas e os impactos tanto dos períodos de chuva como de seca sobre a saúde das populações parecem ser expressivos.

\section{Por fim, o "Estudo dos Padrões Espaço-Temporais das Internações por Diarreia e}

Gastroenterite no Brasil entre 1998 e 2012", envolveu a totalidade de municípios do Brasil e analisou séries trimestrais dos totais de internações por diarreias e gastroenterites e da precipitação. Foram encontrados padrões temporais mais definidos de predominância das internações em regiões onde há presença marcante de duas estações do ano, uma chuvosa e outra seca. O padrão ligado a estação chuvosa foi verificado principalmente nos municípios das regiões Norte e Nordeste do país e, à estação seca, no Centro-Oeste e Sudeste. Em outras regiões, como no Sul do país, onde a distribuição da precipitação ao longo do ano é mais homogênea, não foi observado um comportamento único predominante. Conforme a literatura, estes padrões estão associados à predominância de diferentes patógenos causadores das doenças, que tendem a ser bactérias nos períodos chuvosos e vírus nos períodos secos e frios.

A observação das condições ambientais da área estudo de caso da tese selecionada na região semiárida do Brasil seguiu um esquema das interações entre o homem e o ambiente que favorecem a proliferação dos patógenos que induzem à doença diarreica, representado na Figura 6.1. A ilustração sintetiza o método de observação, incluindo o trabalho de campo, a partir do qual foram buscadas respostas para as questões de pesquisa que se apresentaram ao longo do desenvolvimento da tese, no caminho do entendimento da dinâmica espaço-temporal de ocorrência das doenças diarreicas e de sua relação com as variáveis ambientais que foram selecionadas. 


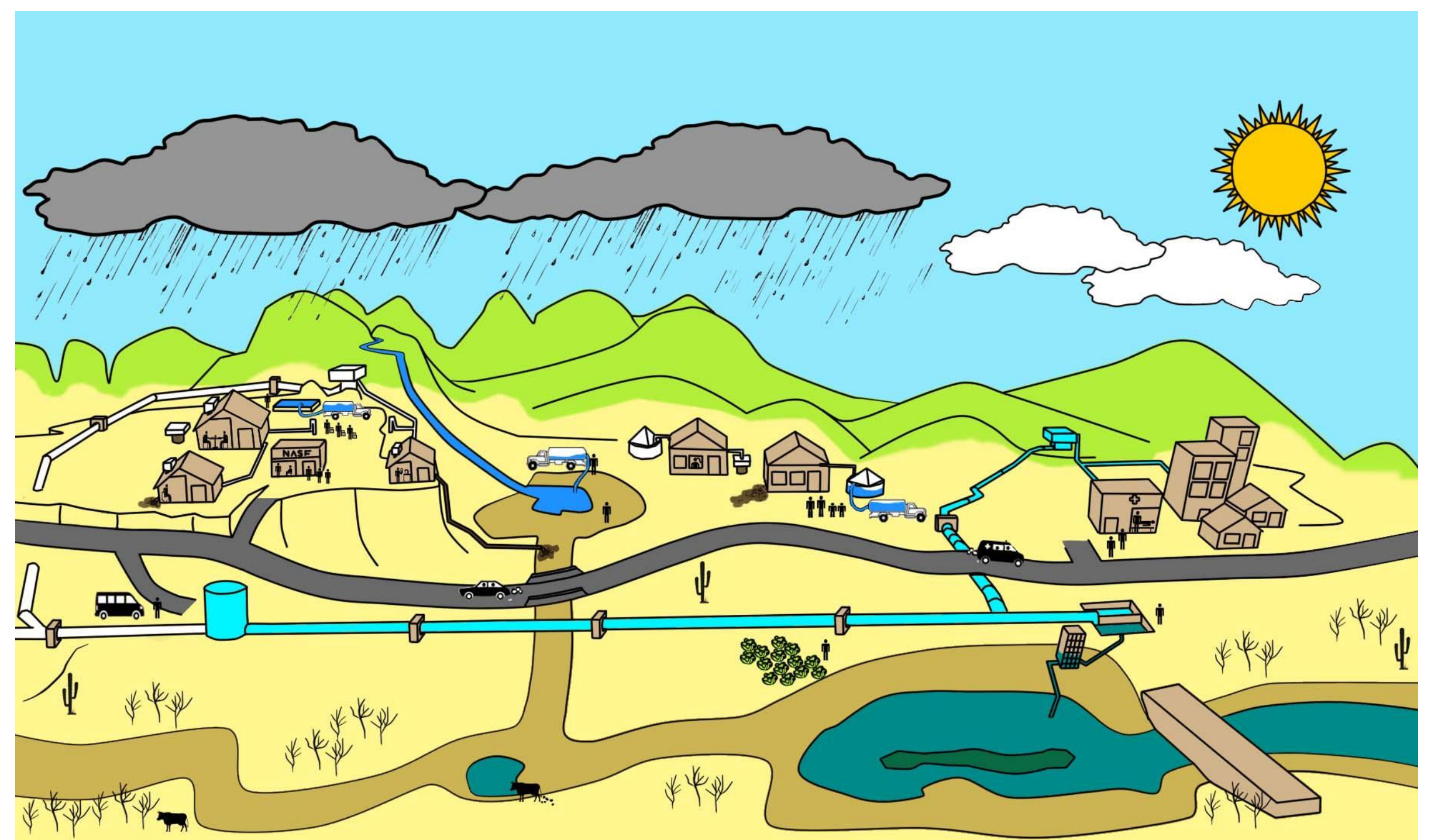

Figura 6.1: Esquema das condições ambientais observadas na área de estudo no semiárido brasileiro. Fonte: Elaborado pelo autor. 
Este esquema pode ser adaptado para outros contextos espaciais, observadas as características geográficas da região e as condições ambientais envolvidas com o problema de pesquisa. No semiárido brasileiro, a chuva constitui-se no elemento indutor da alteração nas condições ambientais e de saúde existentes, haja vista a influência que parece haver sobre a ocorrência da DDA e a ausência de mecanismos de controle das fontes poluidoras. Essa alteração ocorre, com maior ou menor intensidade e por mais ou menos tempo, todos os anos, conforme a intensidade e duração das chuvas. No entanto, a chuva não deve ser entendida como vilã, mas sim a poluição ambiental existente e deficiências no abastecimento de água e, principalmente, no esgotamento sanitário, entre outros fatores, não analisados nesta tese, como o armazenamento e uso da água para consumo humano, bem como o uso e ocupação da terra na região.

Em relação às questões de saúde, as demandas da população em geral incidem inicialmente sobre unidades de assistência à saúde de menor complexidade, disponíveis em todos os centros urbanos, para o atendimento dos casos de DDA. Este tipo de caso foi incluído na análise da pesquisa de tese no semiárido, assim como os casos de natureza mais grave, em uma escala nacional, que demandam internações em leitos hospitalares que muitas vezes estão disponíveis apenas em maiores centros urbanos.

Apesar de não serem objeto de investigação desta tese, fatores já documentados na literatura como hábitos de higiene da população e questões comportamentais são de fundamental relevância para o entendimento dos mecanismos que desencadeiam as doenças cuja cadeia de transmissão é a fecal-oral, como a doença diarreica. O homem interage com os recursos hídricos através de outros usos além do abastecimento, como: o próprio lazer, notadamente em ambientes lênticos da região como os açudes, dado o caráter intermitente da maioria dos cursos d'água; a agricultura, comercial ou de subsistência, que demanda grande aporte de água para irrigação e; a pecuária, pois animais de sangue quente também integram a cadeia de transmissão potencial de alguns patógenos e dependem do recurso hídrico para dessedentação. O próprio esgotamento sanitário das residências e demais edifícios constitui outro uso: pode haver conexão a uma rede geral de coleta ou, simplesmente a uma fossa séptica, ou ainda qualquer ligação residencial que permita ao esgoto afluir diretamente na sarjeta e/ou na rede de escoamento pluvial e dali para valas a céu aberto ou diretamente sobre o curso d’água. 
Cumpre ressaltar que esta pesquisa buscou associar as doenças diarreicas com questões ligadas à água, porém são diversos e complexos os fatores que conduzem ao seu aparecimento. Quando, na análise do contexto nacional, restringiu a pesquisa às internações hospitalares por diarreia, o fez devido às dificuldades de obtenção de dados de DDA em nível municipal no país. Além disso, a pesquisa envolveu uma série de dados não publicados, e o seu arranjo foi sendo definido em função da disponibilidade desses dados após solicitação aos órgãos responsáveis. Ademais, não buscou uma abordagem determinista e, tampouco alarmista, associando a água ou a chuva como causa mater da diarreia, mas sim considerou uma dinâmica ambiental e de infraestruturas que permitiu analisar os padrões espaço-temporais de ocorrência da doença. Para tanto, a partir dos diferentes métodos empregados de análise exploratória dos dados, levantou hipóteses cuja validade procurou ser verificada ou não, a partir de uma concepção de saúde ambiental que buscou compreender uma série de interações entre o homem, os patógenos e as condições ambientais.

A pesquisa pode auxiliar no direcionamento dos recursos e na maior articulação intersetorial para a eficácia das políticas públicas. Os resultados não excluem o papel da seca na dinâmica das doenças diarreicas, porém ressaltam que há necessidade de adoção de processos de gestão diferenciados para o período da seca e para o período da chuva, tanto das áreas de saneamento como da saúde. A partir deste estudo podem ser propostas metodologias de análise para auxiliar a tomada de decisão por parte da população e de órgãos gestores, considerando as estratégias de monitoramento e os dados disponíveis, em relação a problemática envolvida com a ocorrência da DDA. Embora ela possa ser minimizada em comparação com outras doenças tidas como de maior relevância, é um grave problema de saúde pública do Brasil e de todo o mundo.

Na agenda de recursos hídricos, por exemplo, estudos de planejamento em curso como o Programa Nacional de Segurança Hídrica, o Atlas de Despoluição de Bacias Hidrográficas e a atualização do Atlas de Abastecimento Urbano de Água, conduzidos pela ANA, podem vir a utilizar resultados desta pesquisa em apoio à tomada de decisão, notadamente em subsídio a melhoria nas condições de abastecimento de água e esgotamento sanitário do semiárido.

Em trabalhos futuros, as relações entre as características do abastecimento de água e a ocorrência da DDA poderão ser analisados em outros contextos espaciais, da mesma forma que a inclusão de um estudo detalhado do abastecimento de água pode auxiliar no entendimento 
dos padrões espaço-temporais de ocorrência de outras doenças, a exemplo das doenças associadas a vetores, como dengue, chicungunha e, mais recentemente, zica.

Considerando os resultados obtidos nesta tese e a luz de situações extremas vivenciadas nos últimos anos no país ligadas a questões do clima e do abastecimento de água, não há dúvida de que os reflexos sobre a saúde podem vir a ser expressivos. Desse modo, iniciativas devem ser tomadas para fins de adaptação das populações visando a mitigação dos potenciais efeitos de eventos climáticos extremos e dos déficits hídricos, notadamente nos campos da saúde pública e da gestão e regulação dos recursos hídricos. 


\section{REFERÊNCIAS}

AGÊNCIA NACIONAL DE ÁGUAS (ANA). Resolução no 687, de 03 de dezembro de 2004. Brasília: ANA, 2004. Disponível em: http://arquivos.ana.gov.br/resolucoes/2004/6872004.pdf. Acesso em: 20 abr. 2013.

Resolução n. ${ }^{\circ}$ 411, de 22 de setembro de 2005. Brasília: ANA, 2005. Disponível em: http://arquivos.ana.gov.br/projetos/pisf/Resolucao_n411_2005.pdf. Acesso em: 20 abr. 2013.

. Atlas Brasil: Abastecimento Urbano de Água. Brasília: ANA, 2011. Disponível em: http://atlas.ana.gov.br/Atlas/forms/Home.aspx. Acesso em: 20 abr. 2013.

Portal de Metadados Geoespaciais: Espelhos d'Água. Brasília: ANA, 2013.

Disponível em: http://metadados.ana.gov.br/geonetwork/srv/pt/ main.home?uuid=7d054e5a8cc9-403c-9f1a-085fd933610c. Acesso em: 15 out. 2013.

Mapa de Áreas Aflorantes dos Aquíferos e Sistemas Aquíferos do Brasil. Escala 1:1.000.000. Brasília: ANA, 2013.

Resolução n. ${ }^{\circ}$ 903, de 22 de julho de 2013. Brasília: ANA, 2013. Disponível em: http://arquivos.ana.gov.br/resolucoes/2013/903-2013.pdf. Acesso em: 20 abr. 2013.

Conjuntura dos Recursos Hídricos no Brasil: Informe 2014. Brasília: ANA, 2015. Disponível em: http://conjuntura.ana.gov.br/. Acesso em: 15 maio 2015.

SAR: Sistema de Acompanhamento de Reservatórios. Brasília: ANA, 2015. Disponível em: http://sar.ana.gov.br/. Acesso em: 30 set. 2015.

Resolução Conjunta ANA, IGARN-RN e AESA-PB n. ${ }^{\circ}$ 640, de 18 de junho de 2015. Brasília: ANA, 2015. Disponível em: http://arquivos.ana.gov.br/resolucoes/2015/6402015.pdf. Acesso em: 24 jun. 2015.

Hidroweb: Sistema de Informações Hidrológicas. Brasília: ANA, 2015.

Disponível em: http://hidroweb.ana.gov.br/. Acesso em: 15 mar. 2015.

Conjuntura dos Recursos Hídricos no Brasil: Informe 2014. Encarte Especial sobre a Crise Hídrica. Brasília: ANA, 2015. Disponível em: http://conjuntura.ana.gov.br/ docs/crisehidrica.pdf. Acesso em: 17 out. 2015. 


\section{AGÊNCIA NACIONAL DE ÁGUAS (ANA). AGÊNCIA NACIONAL DE ENERGIA}

ELÉTRICA (ANEEL). Resolução Conjunta ANA/ANEEL n..$^{0}$ 03, de 10 de agosto de 2010.

Brasília: ANA, 2010. Disponível em: http://arquivos.ana.gov.br/resolucoes/2010/3-2010.pdf.

Acesso em: 20 abr. 2013.

ALMEIDA, J. C.; VIEIRA, L. L. A.; BARROS, T. T.; COSTA, V. C.; PEDROSA, V, A. Vulnerabilidade ambiental à eutrofização: Reservatório Carangueja. In: IX SIMPÓSIO DE RECURSOS HÍDRICOS DO NORDESTE, Anais, Salvador, 2008.

ALMON, S. The distributed lag between capital appropriations and expenditures.

Econometrica, v. 33, p. 178-96. 1965.

ALVES, J. M. B.; SOUZA, E. B.; REPELLI, C. A.; VITORINO, M. I.; FERREIRA, N. S. Episódios de La Niña na bacia do Oceano Pacífico Equatorial e a distribuição sazonal e intrasazonal das chuvas no setor norte do Nordeste brasileiro. Revista Brasileira de Meteorologia, v. 12, n. 1, p. 77-82, 1997.

AMARAL, L. A.; NADER FILHO, A.; ROSSI JÚNIOR, O. D.; FERREIRA, F. L.;

BARROS, L. S. Drinking water in rural farms as a risk factor to human health. Revista de Saúde Pública, v. 37, n.4, p. 510-514, 2003.

ANDRADE NETO, C.O. Proteção Sanitária das Cisternas Rurais. In: XI Simpósio LusoBrasileiro de Engenharia Sanitária e Ambiental, Anais, Natal, 2004.

ANDRADE, I. G.; QUEIROZ, J. W.; CABRAL, A. P.; LIEBERMAN, J. A.; JERONIMO, S. M. Improved sanitation and income are associated with decreased rates of hospitalization for diarrhoea in Brazilian infants. Transactions of the Royal Society of Tropical Medicine and Hygiene. v. 103, p. 506-511, 2009.

ANDREAZZI, M. A. R.; BARCELLOS, C.; HACON, S. Velhos indicadores para novos problemas: a relação entre saneamento e saúde. Revista Panamericana de Salud Publica, v. 22, n. 3, p. 211-217, 2007.

ANSELIN, L. Spatial Data Analysis with GIS: An Introduction to Application in the Social Sciences. Technical Report 92-10, 1992.

Local Indicators of Spacial Association - LISA. Geographical Analysis. 27, p. 93 $115,1995$.

ARAÚJO JÚNIOR, R. J. Evolução temporal dos níveis tróficos do Açude Epitácio Pessoa, Semi-Árido Paraibano. 2010. 71p. Dissertação (Mestrado em Ciência e Tecnologia Ambiental) - Universidade Federal de Campina Grande (UFCG), Campina Grande, 2010. 
ARDKAEW, J.; TONGKUMCHUM, P. Statistical Modelling of Childhood Diarrhea in Northeastern Thailand. Southeast Asian Journal of Tropical Medicine and Public Health, v. 40, n.4, p. 807-815, 2009.

ASA BRASIL. ARTICULAÇÃO NO SEMIÁRIDO BRASILEIRO. Programa Um Milhão de Cisternas Rurais. Disponível em: http://www.asabrasil.org.br/acoes/p1mc. Acesso em: 15 out. 2015.

AULD, H.; MACLVER, D.; KLAASSEN, J. Heavy rainfall and waterborne disease outbreaks: the Walkerton example. Journal of Toxicology and Environmental Health A v.67, p. 1879-87, 2004.

BANDYOPADHYAY, S.; KANJI, S.; WANG, L. The impact of rainfall and temperature variation on diarrheal prevalence in Sub-Saharan Africa. Applied Geography, v. 33, p. 63$72,2012$.

BARCELLOS, C.; BASTOS, F. I. Geoprocessamento, ambiente e saúde: uma união possível? Cadernos de Saúde Pública. v. 12, n. 3, p. 389-397, 1996.

.; COUTINHO, K.; PINA, M. F.; MAGALHÃES, M. M. A. F.; PAOLA, J. C. M. D.; SANTOS, S. M. Inter-relacionamento de dados ambientais e de saúde: análise de risco à saúde aplicada ao abastecimento de água no Rio de Janeiro utilizando Sistemas de Informações Geográficas. Cadernos de Saúde Pública, v. 14, n. 3, p. 597-605, 1998.

BARBOSA, J. E. L.; ANDRADE, R. S.; LINS, R. P.; DINIZ, C. R. Diagnóstico do estado trófico e aspectos limnológicos de sistemas aquáticos da Bacia Hidrográfica do Rio Taperoá, Trópico semi-árido Brasileiro. Revista de Biologia e Ciências da Terra, Suplemento Especial, n. 1, p. 81-89, 2006.

BITTENCOURT, J. A.; ARBO, E.; MALYSZ, A. S.; ORAVEC, R.; DIAS, C. Seasonal and age distribution of rotavirus infection in Porto Alegre-Brazil. Brazilian Journal of Infectious Diseases, v. 4, n. 6, p. 279-283, 2000.

BOUVY, M.; FALCÃO, D.; MARINHO, M.; PAGANO, M.; MOURA, A. Occurence of Cylindrospermopsis (Cyanobacteria) in 39 Brazilian tropical reservoirs during the 1998 drougth. Aquatic Microbial Ecology. v. 23, p. 13-27, 2000.

BOX, G. E. P.; JENKINS, G. M.; REINSEL, G. C. Time series analysis: forecasting and control. $4^{\text {a }}$ ed. New Jersey: John Wiley \& Sons, 2008. p. 474-480. 
BRASIL. GOVERNO FEDERAL. Lei n. 9.433, de 8 de janeiro de 1997. Disponível em: http://www.planalto.gov.br/ccivil_03/LEIS/L9433.htm. Acesso em: 15 mar. 2015.

Observatório da Seca: Construção de Cisternas. Disponível em:

http://www.brasil.gov.br/observatoriodaseca/construcao-cisternas.html. Acesso em: 15 mar. 2015.

BÜHLER, H. F.; IGNOTTI, E.; NEVES, S. M. A. S.; HACON, S. S. Análise espacial de indicadores integrados de saúde e ambiente para morbimortalidade por diarreia infantil no Brasil, 2010. Cadernos de Saúde Pública, Rio de Janeiro, v. 30, n. 9, p. 1921-1934, 2014.

CAIRNCROSS, S.; FEACHEN, R. G. Environmental Health Engineering in the Tropics: An Introductory Text. $2^{a}$ ed. Chichester: Wiley, 1993, 324p.

CAMARGO, E. P. Tropical diseases. Estudos Avançados, v. 22, n. 64, p. 95-110, 2008.

CARDOSO, D. D. P.; SOARES, C. M. A.; DIAS E SOUZA, M. B. L.; AZEVEDO, M. S. P.; MARTINS, R. M. B.; QUEIROZ, D. A. O.; BRITO, W. M. E. D.; MUNFORD, V.; RÁCZ, M. L. Epidemiological features of rotavirus infection in Goiania, Goias, Brazil, from 1986 to 2000. Memórias do Instituto Oswaldo Cruz, v. 98, n. 1, p. 25-29, 2003.

CARMO, E. H. Doença diarréica por rotavírus: magnitude, introdução da vacina e desafios para a vigilância epidemiológica. Cadernos de Saúde Pública, v. 22, n. 11, p. 2266, 2006.

CARR, G. M.; NEARY, J. P. Water Quality for Ecosystem and Human Health, 2008. 2a ed. United Nations Environment Programme Global Environment Monitoring System.

Disponível em: http://www.gemswater.org/publications/pdfs/water_quality_human_health. pdf. Acesso em: 20 abr. 2013.

CARVALHO, A. P.; MORAES NETO, J. M.; LIMA, V. L. A.; SOUSA, R, F.; SILVA, D. G. K. C. Aspectos qualitativos da água do açude de Bodocongó em Campina Grande - PB. Engenharia Ambiental: pesquisa e tecnologia, v. 5, n. 2, p. 94-109, 2008.

CEBALlOS, B. S. O.; KONIG, A.; OLIVERA, J. F. Dam reservoir eutrophication: a simplified technique for a fast diagnosis of environmental degradation. Water Research, v. 32, n. 11, p. 3477-3483, 1998.

CHECKLEY, W.; EPSTEIN, L. D.; GILMAN, R. H.; FIGUEROA, D.; CAMA, R. I.; PATZ, J. A.; BLACK, R. E. Effect of El Nino and ambient temperature on hospital admissions for diarrhoeal diseases in Peruvian children. Lancet, v. 355, n. 9202, p. 442-450, 2000. 
CHEN, M. J.; LIN, C. Y.; WU, Y. T.; WU, P. C.; LUNG, S. C.; SU, H. J. Effects of extreme precipitation to the distribution of infectious diseases in Taiwan, 1994-2008. Plos One, v. 7, n. $6, \mathrm{e} 34651,2012$.

CHENG, J. J.; SCHUSTER-WALLACE, C. J.; WATT, S.; NEWBOLD, B. K.; MENTE, A. An ecological quantification of the relationships between water, sanitation and infant, child, and maternal mortality. Environmental Health, v. 11, n. 4, p. 2-8, 2012.

CHOU, W. C.; WU, J. L.; WANG, Y.C.; HUANG, H.; SUNG, F. C.; CHUANG, C. Y. Modeling the impact of climate variability on diarrhea associated diseases in Taiwan (19962007). Science of the Total Environment. v. 409, n. 1, p. 43-51, 2010.

COMPANHIA DE PESQUISA DE RECURSOS MINERAIS (CPRM). Atlas Pluviométrico do Brasil. Rio de Janeiro: CPRM, 2012. Disponível em: http://www.cprm.gov.br/publique/ cgi/cgilua.exe/sys/start.htm?infoid=1351\&sid=9. Acesso em: 07 jan. 2014.

Sistema de Informações de Águas Subterrâneas - SIAGAS. 2013. Disponível em: http://siagasweb. cprm.gov.br/layout/. Acesso em: 30 set. 2013.

CONSELHO NACIONAL DE RECURSOS HÍDRICOS (CNRH). Resolução CNRH no 32, de 15 de outubro de 2003. Brasília: CNRH, 2003. Disponível em: http://www.cnrh.gov.br/ index.php?option=com_content\&view=article\&id=14. Acesso em: 07 jan. 2014.

COSTA, I. A. S.; CUNHA, S. R. D. S.; PANOSSO, R.; ARAÚJO, M. F. F.; MELO, J. L. S.; ESKINAZI-SANT'ANNA, E. M. Dinâmica de Cianobactérias em reservatórios eutróficos do semi-árido do Rio Grande do Norte. Oecologia Brasiliensis, v. 13, n. 2, p. 382-401, 2009.

CURRIERO, F. C.; PATZ, J. A.; ROSE, J. B.; LELE, S. The association between extreme precipitation and waterborne disease outbreaks in the United States, 1948-1994. American Journal of Public Health, v. 91, n. 8, p. 1194-1199, 2001.

CZERESNIA, D.; RIBEIRO, A. M. O conceito de espaço em epidemiologia: uma interpretação histórica e epistemológica. Cadernos de Saúde Pública, v.16, n.3, p. 595-605, 2000 .

DEPARTAMENTO NACIONAL DE OBRAS CONTRA AS SECAS (DNOCS). Fichas Técnicas dos Reservatórios. Disponível em: http://www.dnocs.gov.br/php/canais/recursos_ hidricos/index.php. Acesso em: 15 out. 2015.

DIALLO, M. B. C.; ANCENO, A. J.; TAWATSUPA, B.; TRIPATHI, N. K.; WANGSUPHACHART, V.; SHIPIN, O. V. GIS-based analysis of the fate of waste-related 
pathogens Cryptosporidium parvum, Giardia lamblia and Escherichia coli in a tropical canal network. Journal of Water and Health, v. 7, n. 1, p. 133-143, 2009.

DIAS, D. M.; SILVA, A. P.; HELFER, A. M.; MACIEL, A. M. T. R.; LOUREIRO, E. C. B.; SOUZA, C. O. S. Morbimortalidade por gastroenterites no Estado do Pará, Brasil. Revista Pan-Amazônica de Saúde, v. 1, n. 1, p. 53-60, 2010.

DI BERNARDO, L. (Coord.). Tratamento de água para abastecimento por filtração direta. Rio de Janeiro: PROSAB, ABES, Rima, 2003. 480p.

DRAYNA, P.; MCLELLAN, S. L.; SIMPSON, P.; LI, S. H.; GORELICK, M. H. Association between rainfall and pediatric emergency department visits for acute gastrointestinal illness. Environmental Health Perspectives, v. 118, n. 10, p. 1439-1443, 2010.

D’SOUZA, R. M.; HALL, G.; BECKER, N. G. Climatic factors associated with hospitalizations for rotavirus diarrhoea in children under 5 years of age. Epidemiology and Infection, v. 136, p. 56-64, 2008.

DUARTE, M. A. C.; CEBALlOS, B. S. O.; MELO, H. N. S.; KÖNIG, A. Comportamento dos Índices do Estado Trófico de Carlson (IET) e Modificado (IET $\mathrm{M}$ ) em três lagoas naturais no Nordeste do Brasil. In: $20^{\circ}$ Congresso Brasileiro de Engenharia Sanitária e Ambiental, Anais, Rio de Janeiro, 1999.

EISENBERG, M. C.; KUJBIDA, G.; TUITE, A. R.; FISMAN, D. N.; TIEN, J. H. Examining rainfall and cholera dynamics in Haiti using statistical and dynamic modeling approaches. Epidemics, v. 5, n. 4, p. 197-207, 2013.

ENFIELD, D. B.; MAYER, D. A. Tropical Atlantic sea surface temperature variability and its relation to El Niño-Southern Oscillation. Journal of Geophysical Research, v. 102, n. C1, p. 929-945, 1997.

ESCOREL, S.; GIOVANELLA, L.; MENDONCA, M. H. M.; SENNA, M. C. M. O Programa de Saúde da Família e a construção de um novo modelo para a atenção básica no Brasil. Revista Panamericana de Salud Publica, v. 21, n. 2-3, p. 164-176, 2007.

EVAnS, B.; HUTTON, G.; HALlER, L. Closing the Sanitation Gap - the Case for Better Public Funding of Sanitation and Hygiene. Background paper for the OECD Round Table on Sustainable Development meeting on water and sanitation, Paris, 2004.

FAÇANHA, M. C.; PINHEIRO, A. C. Comportamento das doenças diarréicas agudas em serviços de saúde de Fortaleza, Ceará, Brasil, entre 1996 e 2001. Cadernos de Saúde Pública, v. 21, n. 1, p. 49-54, 2005. 
FERREIRA, A. L. A.; EDUARDO, A. R. B.; DANTAS, ANA C. C. L. Geografias e topografias médicas: os primeiros estudos ambientais da cidade concreta. Investigaciones Geográficas - Boletín del Instituto de Geografía, UNAM. n. 52, p. 83-98, 2003.

FEWTRELL, L.; KAUFMANN, R.; KAY, D.; ENANORIA, W.; HALLER, L.; COLFORD, $\mathrm{J}$. Water, sanitation, and hygiene interventions to reduce diarrhoea in less developed countries: a systematic review and meta-analysis. Lancet Infectious Diseases, v. 5, p. 42-52, 2005.

FIGUEIRÊDO, M. C. B.; TEIXEIRA, A. S.; ARAÚJO, L. F. P.; ROSA, M. F.; PAULINO, W. D.; MOTA, S.; ARAÚJO, J, C. Avaliação da vulnerabilidade ambiental de reservatórios à eutrofização. Revista de Engenharia Sanitária e Ambiental, v. 12, n. 4, p. 399-409, 2007.

FREITAS, F. R. S. Eutrofização do reservatório Cruzeta na bacia representativa do rio Seridó - RN. 2008. 48p. Dissertação (Mestrado em Engenharia Sanitária) - Universidade Federal do Rio Grande do Norte, Natal, 2008.

GAJADHAR, A. A. ; ALLEN, J. R. Factors contributing to the public health and economic importance of waterborne zoonotic parasites. Veterinary Parasitology, v. 126, p. 3-14, 2004.

GUERRANT, R. L. ; KIRCHHOFF, L. V. ; SHIELDS, D. S. ; NATIONS, M. K. ; LESLIE, J. ; SOUZA, M. A. ; ARAUJO, J. G. ; CORREIA, L. L. ; SAUER, K. T. ; MCCLELLAND, K. E.; TROWBRIDGE, F. L.; HUGHES, J. M. Prospective study of diarrheal illness in Northeastern Brazil: patterns of disease, nutritional impact, etiologies and risk factors. Journal of Infectious Diseases, v. 148, n. 6, p. 986-997, 1983.

; HUGHES, J. M.; LIMA, N. L. ; CRANE, J. Diarrhea in developed and developing countries: magnitude, special setting and etiologies. Reviews of Infectious Diseases, v. 12, sup. 1, p. 41-50, 1990.

GUIMARÃES, A. O.; MELO, A. D.; CEBALlOS, B. S. O.; GALVÃO, C. O.; RIBEIRO, M. M. R. Aspectos da gestão do açude Epitácio Pessoa (PB) e variação da qualidade de água. In: XXIII CONGRESSO BRASILEIRO DE ENGENHARIA SANITÁRIA E AMBIENTAL, Anais, Campo Grande, 2005.

GUIMARÃES, R. M.; ASMUS, C. I. R. F.; OLIVEIRA JÚNIOR, S. A.; MAZOTO, M. L. Acesso ao saneamento básico e internação por doença diarreica aguda: um estudo da vulnerabilidade infantil. Revista Salud Ambiental, v. 13, n. 1, p. 22-29, 2013. 
GRIMM, A. M.; FERRAZ, S. E. T.; CARDOSO, A. O. Influência de El Niño sobre a chuva no Nordeste Brasileiro. In: X Congresso Brasileiro de Meteorologia e VII Congresso da FLISMET, Anais, Brasília, 1998a.

Influência de La Niña sobre a chuva no Nordeste Brasileiro. In: X Congresso Brasileiro de Meteorologia e VII Congresso da FLISMET, Anais, Brasília, 1998b.

HASHIZUME, M. B.; ARMSTRONG, S.; HAJAT, Y.; WAGATSUMA, A. S.; FARUQUE, A. S. G.; HAYASHI, T.; SACK, D. A. Association between climate variability and hospital visits for non-cholera diarrhoea in Bangladesh: effects and vulnerable groups. International Journal of Epidemiology, v. 36, n. 5, p. 1030-1037, 2007.

HERRADOR, B. R. G. ; BLASIO, B. F.; MACDONALD, E.; NICHOLS, G.; SUDRE, B.; VOLD, L.; SEMENZA, J. C.; NYGARD, K. Analytical studies assessing the association between extreme precipitation or temperature and drinking water-related waterborne infections: a review. Environmental Health, v. 14, n. 1, 14 :29, 2015.

\section{INSTITUTO BRASILEIRO DE GEOGRAFIA E ESTATÍSTICA (IBGE). Censo}

Demográfico 2000: Características da População e dos Domicílios: Resultados do universo. Rio de Janeiro: IBGE, 2000. Disponível em: http://www.sidra.ibge.gov.br/cd/ cd2000ru.asp?o=24\&i=P. Acesso em: 15 mar. 2015.

Pesquisa Nacional de Saneamento Básico. Rio de Janeiro: IBGE, 2008. Disponível em: http://www.ibge.gov.br/home/estatistica/populacao/condicaodevida/pnsb/ defaultquest_2008.shtm. Acesso em: 15 mar. 2015.

Censo Demográfico 2010: Resultados do Universo - Características da População e dos Domicílios. Rio de Janeiro: IBGE, 2010. Disponível em: http://www.sidra.ibge.gov.br/ cd/cd2010universo.asp?o=7\&i=P. Acesso em: 15 mar. 2015.

Estimativas de População: Estimativas populacionais para os municípios brasileiros em 01.07.2013. Rio de Janeiro: IBGE, 2015. Disponível em: http://www.ibge.gov. br/home/estatistica/populacao/estimativa2013/default.shtm. Acesso em: 15 mar. 2015.

INSTITUTO NACIONAL DE METEOROLOGIA (INMET). Normais Climatológicas do Brasil 1961-1990. Brasília: INMET, 2015. Disponível em: http://www.inmet.gov.br/portal/ index.php?r=clima/normaisclimatologicas. Acesso em: 15 mar. 2015.

BDMEP - Banco de Dados Meteorológicos para Ensino e Pesquisa. Brasília: INMET, 2015. Disponível em: http://www.inmet.gov.br/projetos/rede/pesquisa/. Acesso em: 15 mar. 2015. 
INSTITUTO NACIONAL DE PESQUISAS ESPACIAIS (INPE). CENTRO DE PREVISÃO DO TEMPO E ESTUDOS CLIMÁTICOS (CPTEC). Infoclima. Cachoeira Paulista:

INPE/CPTEC, 2015. Disponível em: http://infoclima.cptec.inpe.br/. Acesso em: 15 mar. 2015.

INSTITUTO TRATA BRASIL (TRATA BRASIL). CONSELHO EMPRESARIAL BRASILEIRO PARA O DESENVOLVIMENTO SUSTENTÁVEL (CEBDS). Benefícios econômicos da expansão do saneamento brasileiro: qualidade de vida, produtividade, educação e valorização ambiental. São Paulo: Trata Brasil, 2014. 24p. Disponível em: http://www.tratabrasil.org.br/ beneficios-economicos-da-expansao-do-saneamento-brasileiro. Acesso em: 15 mar. 2015.

INSTITUT DE RECHERCHE POUR LE DÉVELOPPEMENT (IRD). AGÊNCIA NACIONAL DE ÁGUAS (ANA). Sistema Hidrosat: Documentação Técnica. Brasília: 2013. Disponível em: http://hidrosat.ana.gov.br/DocTecnica.aspx. Acesso em: 15 jul. 2013.

JAGAI, J. S.; SARKAR, R.; CASTRONOVO, D.; KATTULA, D.; MCENTEE, J.; WARD, H.; KANG, G.; NAUMOVA, E. N. Seasonality of rotavirus in South Asia: a meta-analysis approach assessing associations with temperature, precipitation, and vegetation index. PLoS One, v. 7, n.5, e38168, 2008.

JOCHIMSEM, E. M.; AZEVEDO, S. M. F. O. Liver Failture and Death Following Exposure to Microcystin Toxins at a Hemodialysis Center in Brazil. The New England Journal of Medicine, v. 36, p. 373-378, 1998.

JOVENTINO, E. S.; SILVA, S. F.; ROGERIO, R. F.; FREITAS, G. L.; XIMENES, L. B.; MOURA, E. R. F. Comportamento da diarreia infantil antes e após o consumo de água pluvial em município do semiárido brasileiro. Texto Contexto Enfermagem, v. 19, n. 4, p. 691-699, 2010 .

JUSTICE, C. O.; VERMOTE, E.; TOWNSHEND, J. R. G.; DEFRIES, R.; ROY, D. P.; HALL, D. K.; SALOMONSON, V. V.; PRIVETTE, J. L.; RIGGS, G.; STRAHLER, A.; LUCHT, W.; MYNENI, R. B.; KNYAZIKHIN, Y.; RUNNING, S. W.; NEMANI, R. R.; WAN, Z.; HUETE, A. R.; VAN LEEUWEN, W.; WOLFE, R. E.; GIGLIO, L.; MULLER, J. P.; LEWIS, P.; BARNSLEY, M. J. The Moderate Resolution Imaging Spectroradiometer (MODIS): Land Remote Sensing for Global Change Research. IEEE Transactions on Geoscience and Remote Sensing, v. 36, n. 4, p. 1228-1249, 1998.

KALE, P. L.; FERNANDES, C.; NOBRE, F. F. Padrão temporal das internações e óbitos por diarréia em crianças, 1995 a 1998, Rio de Janeiro. Revista de Saúde Pública, v. 38, n. 1, p. 30-37, 2004. 
LECHA, L. B. Elementos Básicos de la Biometeorología Humana. Curso de Posgrado. Havana: Escuela Latinoamericana de Medicina (ELAM), 2013.

LEE, E. J.; SCHWAB, K. J. Deficiencies in drinking water distribution systems in developing countries. Journal of Water and Health, v. 3, n. 2, p. 109-127, 2005.

LEMOS, E. C. L.; CAVALCANTI, I. N.; SABADIA, J. A. B.; GOMES, M. C. R.; MEDEIROS, F. W.; SANTOS, D. M. Qualidade das águas subterrâneas e doenças de veiculação hídrica na porção sudoeste do município de Fortaleza, Ceará, Brasil. Revista de Geologia, v. 22, n. 2, p. 151-165, 2009.

LIMA-COSTA, M. F.; BARRETO, S. M. Tipos de estudos epidemiológicos: conceitos básicos e aplicações na área do envelhecimento. Epidemiologia e Serviços de Saúde, Brasília, v. 12, n. 4, p. 189-201, 2003.

LINHARES, A. C. Epidemiologia das infecções por Rotavírus no Brasil e os desafios para o seu controle. Cadernos de Saúde Pública, v. 16, n. 3, p. 629-646, 2000.

LINHARES, A. C.; JUSTINO, M. C. Rotavirus vaccination in Brazil: effectiveness and health impact seven years post-introduction. Expert Review of Vaccines, v. 13, n. 1, p. 43 57, 2014.

LLOYD-EVANS, N.; PICKERING, H. A.; GOH, S. G.; ROWLAND, M. G; Food and water hygiene and diarrhoea in young Gambian children: a limited case control study. Transactions of the Royal Society of Tropical Medicine and Hygiene, v. 78, p. 209-211, 1984.

MARTINEZ, J. M.; GUYOT, J. L., FILIZOLA, N., SONDAG, F. Increase in suspended sediment discharge of the Amazon River assessed by monitoring network and satellite data. Catena, v.79. p. 257-264, 2009.

.; VENTURA, D.; VIEIRA, M. R.; ATTAYDE, J. L.; BUBEL, A. P.; COIMBRA, M. R.; OLIVEIRA, E. Satellite-based monitoring of reservoir eutrophication in the Brazil Semi-arid region. In: XV SIMPÓSIO BRASILEIRO DE SENSORIAMENTO REMOTO, Anais, Curitiba, 2011.

MELLI, L. C. F. L.; WALDMAN, E. A. Temporal trends and inequality in under-5 mortality from diarrhea. Jornal de Pediatria, v. 85, n. 1, p. 21-27, 2009.

MENDES, P. S. A.; RIBEIRO JÚNIOR, H. C.; MENDES, C. M. C. Temporal trends of overall mortality and hospital morbidity due to diarrheal disease in Brazilian children younger than 5 years from 2000 to 2010. Jornal de Pediatria, v. 89, n. 3, p.315-325, 2013. 
MENESES, P. R.; MADEIRA NETTO, J. S. Sensoriamento remoto: reflectância dos alvos naturais. Brasília: UnB/Embrapa Cerrados, 2001. 262p.

MINCIS, M.; MINCIS, R.; CALICHMAN, S. Como diagnosticar e tratar a diarréia aguda. Revista Brasileira de Medicina, v. 64, n. 10, p. 450-460, 2007.

MINISTÉRIO DAS CIDADES (MCid). SISTEMA NACIONAL DE INFORMAÇÕES SOBRE SANEAMENTO (SNIS). Diagnóstico dos Serviços de Água e Esgotos, referente ao ano de 2013. Brasília: Ministério das Cidades, 2014. 181p.

MINISTÉRIO DA INTEGRAÇÃO NACIONAL (MI). Projeto de Integração do Rio São Francisco com Bacias Hidrográficas do Nordeste Setentrional: Relatório de Impacto Ambiental. Brasília: MI, 2004. Disponível em: http://www.mi.gov.br/documents/10157/ 3675235/RIMA.pdf/c7f4834d-2ca8-4baf-9bbd-21 cacb64ca2f. Acesso em: 02 mar. 2013.

Nova Delimitação do Semi-Árido Brasileiro. Brasília: MI, 2005. Disponível em: http://www.mi.gov.br/c/document_library/get_file?uuid=0aa2b9b5-aa4d-4b55-a6e182faf0762763\&groupId =24915. Acesso em: 02 mar. 2013.

MINISTÉRIO DA SAÚDE (MS). SECRETARIA DE VIGILÂNCIA EM SAÚDE (SVS). Capacitação em monitorização das doenças diarréicas agudas - MDDA: manual do monitor. Brasília: MS, 2010. Disponível em: http://bvsms.saude.gov.br/bvs/publicacoes/ capacitacao_monitoramento_diarreicas_monitor.pdf. Acesso em: 15 mar. 2015.

Portaria n. ${ }^{\circ}$ 2.914, de 12 de dezembro de 2011. Brasília: MS, 2011. Disponível em: http://bvsms.saude.gov.br/bvs/saudelegis/gm/2011/prt2914_12_12_2011.html. Acesso em: 11 out. 2015 .

Doença Diarreica Aguda (DDA). Brasília: MS, 2015. Disponível em:

http://portalsaude.saude.gov.br/index.php/o-ministerio/principal/secretarias/svs/doencadiarreica-aguda-dda. Acesso em: 15 mar. 2015.

Informações de Saúde (TABNET). Brasília: MS/DATASUS, 2015. Disponível em: http://www2.datasus.gov.br/DATASUS/index.php. Acesso em: 15 mar. 2015.

MONTGOMERY, M. A.; ELIMELECH, M. Water and sanitation in developing countries: including health in the equation. Environmental Science \& Technology, v. 41, 17-24, 2007.

MOORS, E.; SINGH, T.; SIDERIUS, C.; BALAKRISHNAN, S.; MISHRA, A. Climate change and waterborne diarrhoea in northern India: Impacts and adaptation strategies. Science of the Total Environment, 2013. Disponível em: http://dx.doi.org/10.1016/j.scitotenv.2013. 07.021 . 
MORRIS, A.; GOZLAN, R. E.; HASSANI, H.; ANDREOU, D.; COUPPIÉ, P.; GUÉGAN, J. F. Complex temporal climate signals drive the emergence of human waterborne disease.

Emerging Microbes \& Infections, v. 3, e56, 2014.

MOSCA, V. P. Eutrofização do reservatório Engenheiro Armando Ribeiro Gonçalves, no Rio Grande do Norte. 2008. 73p. Dissertação (Mestrado em Bioecologia Aquática) Universidade Federal do Rio Grande do Norte, Natal, 2008.

MOTTA, M. E. F. A.; SILVA, G. A. P. Diarreia por parasitas. Revista Brasileira de Saúde Materna Infantil, v. 2, n. 2, p. 117-127, 2002.

NASCIMENTO, M. A. L.; FERREIRA, R. V. Geoparque Seridó. In: SCHOBBENHAUS, C.; SILVA, C. R. (orgs.). Geoparques do Brasil: propostas. Rio de Janeiro: CPRM, 2012, p. 361-416.

NASCIMENTO, V. S. F.; ARAÚJO, M. F. F.; NASCIMENTO, E. D.; SODRÉ NETO, L. Epidemiologia de doenças diarreicas de veiculação hídrica em uma região semiárida brasileira. Conscientiae Saúde, v. 12, n. 3, p. 353-361, 2013.

NATIONAL OCEANIC AND ATMOSPHERIC ADMINISTRATION (NOAA). Historical EI Nino/La Nina episodes (1950-present): Cold \& Warm Episodes by Season (ERSSTv4). College Park: NOAA/National Weather Service/Climate Prediction Center, 2015. Disponível em: http://www.cpc.ncep.noaa.gov/products/analysis_monitoring/ensostuff/ensoyears.shtml. Acesso em: 15 out. 2015.

NICHOLS, G.; LANE, C.; ASGARI, N.; VERLANDER, N. Q.; CHARLETT, A. Rainfall of drinking water related disease and in England and Wales. Journal of Water and Health, v. 7, n. 1, p. 1-8, 2009.

NIEHAUS, M. D.; MOORE, S. R.; PATRICK, P. D.; DERR, L.; LORNTZ, B.; LIMA, A. A.; GUERRANT, R. L. Early childhood diarrhea is associated with diminished cognitive function 4 to 7 years later in children in a northeast Brazilian shantytown. American Journal of Tropical Medicine and Hygiene, v. 66, n. 5, p. 590-593, 2002.

NOVO, E. M. L. M. Sensoriamento Remoto: princípios e aplicações. São Paulo: Edgard Blücher, 1998. 308p.

.; BARBOSA, C.; FREITAS, R. M. Sistemas aquáticos continentais. In: RUDORFF, B. T.; SHIMABUKURO, Y. E.; CEBALLOS, J. C. (orgs.) O sensor MODIS e suas aplicações ambientais no Brasil. São José dos Campos: Parêntese, 2007, p. 265-275. 
OLIVEIRA, T. C. R.; LATORRE, M. R. D. O. Tendências da internação e da mortalidade infantil por diarréia: Brasil, 1995 a 2005. Revista de Saúde Pública, v. 44, n. 1, p. 102-111, 2010.

ORGANIZAÇÃO PAN-AMERICANA DE SAÚDE [OPAS]. REDE INTERAGENCIAL DE INFORMAÇÃO PARA A SAÚDE [RIPSA]. Indicadores básicos para a saúde no Brasil: conceitos e aplicações. $2^{\mathrm{a}}$ ed. Brasília: OPAS, 2008. 349p.

PARASHAR, U. D.; GIBSON, C. J.; BRESEE, J. S.; GLASS, R. I. Rotavirus and severe childhood diarrhoea. Emerging Infectious Diseases, v. 12, n. 2, p. 304-306, 2006.

PASCUAL, M.; RODÓ, X.; ELLNER, S. P.; COLWELL, R. R.; BOUMA, M. J. Cholera dynamics and El Niño-southern oscillation. Science, v. 289, p. 1766-1769, 2000.

PEITER, P. C; BARCELLOS, C.; ROJAS, L. B. I.; GONDIM, G. M. M. Espaço Geográfico e Epidemiologia. In: SANTOS, S. M; BARCELLOS, C. (orgs.). Abordagens espaciais na Saúde Pública. Brasília: Ministério da Saúde/FIOCRUZ, 2006. p. 11-43.

PEREIRA, R.; SILVA JÚNIOR, G. C.; GUIMARÃES JÚNIOR, J. A. Funcionamento Hidrodinâmico do Aqüífero Semiconfinado da Região do Bonfim - RN - Brasil: Uma Interação com o Aqüífero Livre e a Lagoa do Bonfim. Revista Brasileira de Recursos Hídricos, v. 9, n. 2, p. 75-84, 2004.

PEREIRA, M. O. Avaliação qualitativa e quantitativa de cianobactérias no açude Cedro, município de Quixadá - CE, no período de janeiro/2006 a dezembro/2007. In: XII CONGRESSO BRASILEIRO DE FICOLOGIA, Anais, Pirenópolis/GO, 2008.

PEREIRA, I. V.; CABRAL, I. E. Diarréia aguda em crianças menores de um ano: subsídios para o delineamento do cuidar. Escola Anna Nery Revista de Enfermagem, v. 12, n. 2, p. 224-229, 2008.

PFAFSTETTER, O. Classificação de Bacias Hidrográficas - Metodologia de Codificação. Rio de Janeiro: DNOS, 1989. 19p.

PFALTZGRAFF, P. A. S. Geodiversidade do Estado do Rio Grande do Norte. Recife: CPRM, 2010. 227p.

PORTELA, L.A.; LEITE, V.D.; PEREIRA, C.F.; ROCHA, E.M.F.M. Comportamento das doenças diarréicas nas mudanças sazonais no município de Campina Grande - PB. Hygeia, v. 9, n. 17, p. 116-128, 2013. 
PROGRAMA DAS NAÇÕES UNIDAS PARA O DESENVOLVIMENTO (PNUD). ODM: Objetivos de Desenvolvimento do Milênio. Brasília: PNUD, 2012. Disponível em: http://www.pnud.org.br/ODM.aspx. Acesso em: 15 mar. 2015.

PRÜSS, A.; KAY, D.; FEWTRELL, L.; BARTRAM, J. Estimating the burden of disease from water, sanitation, and hygiene at a global level. Environmental Health Perspectives, v. 110, n.5, p. 537-542, 2002.

PRÜSS-ÜSTÜN, A.; CORVALÁN, C. Preventing disease through healthy environments. Towards an estimate of the environmental burden of disease. Genebra: World Health Organization (WHO), 2006. 106p.

.; BOS, R.; GORE, F.; BARTRAM, J. Safer Water, Better Health: Costs, Benefits and Sustainability of Interventions to Protect and Promote Health. Genebra: WHO; 2008. 60p.

QUEIROZ, J. T. M.; HELLER, L.; SILVA, S. R. Análise da correlação de ocorrência da doença diarreica aguda com a qualidade da água para consumo humano no município de Vitória-ES. Saúde e Sociedade, v. 18, n. 3, p. 479-489, 2009.

QUEVEDO, C. M. G; PAGANINI, W. S. Impactos das atividades humanas sobre a dinâmica do fósforo no meio ambiente e seus reflexos na saúde pública. Ciência \& Saúde Coletiva, v. 16, n. 8, p. 3529-3539, 2011.

REYBURN, R.; KIM, D. R.; EMCH, M.; KHATIB, A.; SEIDLEIN, L.; ALI, M. Climate Variability and the Outbreaks of Cholera in Zanzibar, East Africa: A Time Series Analysis. American Journal of Tropical Medicine and Hygiene, v. 84, n. 6, p. 862-869, 2011.

REYNOLDS, K. A.; MENA, K. D.; GERBA, C. P. Risk of waterborne illness via drinking water in the United States. Reviews of Environmental Contamination and Toxicology, v. 192, p. 117-158, 2008.

RICHTER, C. A. Água: Métodos e Tecnologia de Tratamento. São Paulo: Edgard Blucher, 2009. 340p.

RIO GRANDE DO NORTE. GOVERNO DO ESTADO. Adutora Monsenhor Expedito. Disponível em: http://www.semiarido.rn.gov.br/adutora_mons_exp.php. Acesso em: 25 nov. 2013.

RODÓ, X.; PASCUAL, M.; FUCHS, G.; FARUQUE, A. S. G. ENSO and cholera: A nonstrationary link related to climate change? Proceedings of the National Academy of Sciences, v. 99, n. 20, p. 12901-12906, 2002. 
ROSA E SILVA, M. L.; NAVECA, F. G.; CARVALHO, I. P. Epidemiological aspects of rotavirus infections in Minas Gerais, Brazil. Brazilian Journal of Infectious Diseases, v. 5, n. 4, p.215-222, 2001.

ROSSIN, A. C. Desinfecção. In: COMPANHIA DE TECNOLOGIA DE SANEAMENTO AMBIENTAL (CETESB). Técnica de abastecimento e tratamento de água. São Paulo: CETESB, p. 883-930, 1976.

SALATI, E.; LEMOS, H. M.; SALATI, E. Água e o desenvolvimento sustentável. In: REBOUÇAS, A. C.; BRAGA, B.; TUNDISI, J. G. (orgs.) Águas doces no Brasil: capital ecológico, uso e conservação. $3^{\text {a }}$ ed. São Paulo: Escrituras, 2006, p. 37-62.

SÃO PAULO. GOVERNO DO ESTADO. SECRETARIA DE ESTADO DA SAÚDE DE SÃO PAULO. Semanas Epidemiológicas: publicações DOE. São Paulo: Centro de Vigilância Epidemiológica, 2015. Disponível em: http://www.cve.saude.sp.gov.br/htm/ cve_se03.htm. Acesso em 15 mar. 2013.

SARTORI, A. M. C.; VALENTIM, J.; SOARES, P. C.; NOVAES, H. M. Rotavirus morbidity and mortality in children in Brazil. Revista Panamericana de Salud Publica, v. 23, n.2, p. 92-100, 2008.

SASTRY, N; BURGARD, S. The prevalence of diarrheal disease among Brazilian children: trends and differentials from 1986 to 1996. Social Science and Medicine, v. 60, p. 923-935, 2005.

SHIMABUKURO, Y. E.; SMITH, J. A. The Least-Squares Mixing Models to Generate Fraction Images Derived From Remote Sensing Multispectral Data. IEEE Transactions on Geoscience and Remote Sensing, v. 29, n.1 p. 16-20, 1991.

SILVA, T. S. F. Imagens EOS-MODIS e Landsat 5 TM no estudo da dinâmica das comunidades de macrófitas na várzea amazônica. 2004. 178p. Dissertação (Mestrado em Sensoriamento Remoto) - Instituto Nacional de Pesquisas Espaciais, São José dos Campos, 2004.

SILVA, D. X.; BARCELLOS, C.; BACURI, R. Vulnerabilidade e efeitos das mudanças climáticas na saúde pública em Manaus. Rio de Janeiro: FIOCRUZ, 2010. 85p. Disponível em: http://www.climasaude.icict.fiocruz.br/docs/vulnerabilidade_manaus_relat_final2_x_edit. pdf. Acesso em: 15 mar. 2015.

SINGH, R.; HALES, S.; WET, N.; RAJ, R.; HEARNDEN, M.; WEINSTEIN, P. The influence of climate variation and change on diarrheal disease in the Pacific Islands. Environmental Health Perspectives, v. 109, n. 2, p. 155-159, 2001. 
SORRE, M. Les Fondements da la Géographie Humaine. In: Tome Premier: Les Fondements Biologiques. Librairie Armand Colin, 1951.

SOUZA, B. I.; SUERTEGARAY, D. M. A. Contribuição ao debate sobre a transposição do Rio São Francisco e as prováveis consequências em relação a desertificação nos Cariris Velhos (PB). Terra Livre, v. 2, n. 25, p. 139-155, 2005.

SOUZA, I. C. A.; VIANNA, R. P. T.; MORAES, R. M. Modelagem da incidência do dengue na Paraíba, Brasil, por modelos de defasagem distribuída. Cadernos de Saúde Pública, Rio de Janeiro, v. 23, n. 11, p. 2623-2630, 2007.

SOUZA, S. H. B.; MONTENEGRO, S. M. G. L.; SANTOS, S. M.; PESSOA, S. G. S.; NÓBREGA, R. L. B. Avaliação da Qualidade da Água e da Eficácia de Barreiras Sanitárias em Sistemas para Aproveitamento de Águas de Chuva. Revista Brasileira de Recursos Hídricos, v. 16, n. 3, p. 81-93, 2011.

SNOW, J. On the Mode of Communication of Cholera. London: John Churchill, 1855. 76p. In: Hygeia, v. 3, n. 6, p. 1-11, 2008.

SPERLING, M.; CHERNICHARO, C. A. L. A comparison between wastewater treatment processes in terms of compliance with effluent quality standards. In: XXVII CONGRESSO INTERAMERICANO DE ENGENHARIA SANITÁRIA E AMBIENTAL, Anais, Porto Alegre, 2000.

SUERTEGARAY, D. M. A. Geografia Física (?), Geografia Ambiental (?) ou Geografia e Ambiente (?). In: MENDONÇA, F.; KOZEL, S. Elementos de Epistemologia da Geografia Contemporânea. Curitiba: Ed. UFPR, p. 111-119, 2002.

TAVARES, A.C. Aspectos físicos, químicos e microbiológicos da água armazenada em cisternas de comunidades rurais no Semi-Árido Paraibano. 165p. Dissertação (Mestrado em Desenvolvimento e Meio Ambiente) - Universidade Federal da Paraíba e Universidade Estadual da Paraíba, Campina Grande, 2009.

TAYLOR, L. H.; LATHAM, S. M.; WOOLHOUSE, M. E. Risk factors for human disease emergence. Philosophical Transactions of the Royal Society London: Biological Sciences, v. 356, n. 1411, p. 983-989, 2001.

TEIXEIRA, A. R. Aplicabilidade da filtração direta para o tratamento de águas eutrofizadas. 2004. 93p. Dissertação (Mestrado em Saneamento, Meio Ambiente e Recursos Hídricos) - Universidade Federal de Minas Gerais, Belo Horizonte, 2004. 
TEIXEIRA, J. M. S.; FIGUEIREDO, R. B., SANTOS, H. M. P.; FERREIRA, M. N. R.; CÂMARA, G. N. N. L. Aspectos epidemiológicos das infecções por rotavírus no Distrito Federal, Brasil. Revista da Sociedade Brasileira de Medicina Tropical, v. 24, n. 4, p. 223230, 1991.

TEIXEIRA, M. G.; COSTA, M. C.; CARVALHO, V. L.; PEREIRA, M. S.; HAGE, E. Gastroenteritis Epidemic in the Area of the Itaparica Dam, Bahia, Brazil. Bulletin of the Pan American Health Organization, v. 27, n. 3, p. 244-253, 1993.

TEIXEIRA, J.C.; PUNGIRUM, M. Análise da associação entre saneamento e saúde nos países da América Latina e do Caribe, empregando dados secundários do banco de dados da Organização Pan-Americana de Saúde - OPAS. Revista Brasileira de Epidemiologia, v. 8, n. 4, p. 365-376, 2005.

TORNEVI, A.; AXELSSON, G.; FORSBERG, B. Association between Precipitation Upstream of a Drinking Water Utility and Nurse Advice Calls Relating to Acute Gastrointestinal Illnesses. Plos One, v. 8, n. 7, e69918, 2013.

TROMP, S. W. Human Biometeorology. International Journal of Biometerology, v. 7, n. 2, p. $145-158,1963$.

TUNDISI, J. G.; MATSUMURA-TUNDISI, T.; ABE, D. S.; ROCHA, O.; STARLING, F. Limnologia de águas interiores: impactos, conservação e recuperação de ecossistemas aquáticos. In: REBOUÇAS, A. C.; BRAGA, B.; TUNDISI, J. G. (orgs) Águas doces no Brasil: capital ecológico, uso e conservação. $3^{\text {a }}$ ed. São Paulo: Escrituras, 2006, p. 203-240.

UNITED NATIONS WORLD WATER ASSESSMENT PROGRAMME (UNWWAP). 2009. The World Water Development Report 3: Water in a Changing World. UNESCO: Paris. Disponível em: http://www.unesco.org/water/wwap/wwdr/wwdr3/. Acesso em: 02 mar. 2013.

VASCONCELOS, C. H.; NOVO, E. M. L. M.; DONALISIO, M. R. Uso do sensoriamento remoto para estudar a influência de alterações ambientais na distribuição da malária na Amazônia brasileira. Cadernos de Saúde Pública, v. 22, n. 3, p. 517-526, 2006.

VAZ, F. A. C. Diarréia: fatores de risco associados ao óbito em crianças. Revista da Associação Médica Brasileira, v. 45, n. 1, p. 1, 1999.

VENTURA, D. L. T. Uso do Sensoriamento Remoto para Monitoramento da Concentração de Clorofila A em Açudes do Semiárido. 2013. 59p. Dissertação (Mestrado em Ecologia) - Universidade de Brasília, Brasília, 2013. 
VERONESI, R.; FOCACCIA, R. Tratado de Infectologia. $3^{\text {a }}$ ed. São Paulo: Atheneu, 2005. 2169p.

VILLAR, R. A. E. Monitoramento das dinâmicas espaciais e temporais dos fluxos sedimentares na Bacia Amazônica a partir de imagens de satélite. 2013. 226p. Tese (Doutorado em Geociências Aplicadas) - Universidade de Brasília, Brasília, 2013.

WORLD GASTROENTEROLOGY ORGANISATION (WGO). Diarreia aguda em adultos e crianças: uma perspectiva mundial. Milwaukee: WGO, 2012. 25p.

WORLD HEALTH ORGANIZATION (WHO). World Health Report 2002: Reducing risks, promoting healthy life. Genebra: WHO, 2002. Disponível em: http://www.who.int/whr/2002. Acesso em: 15 mar. 2015.

The global burden of disease: 2004 update. Genebra: WHO, 2008. 148p.

Disponível em: http://www.who.int/healthinfo/global_burden_disease/GBD_report_2004 update_full.pdf. Acesso em: 15 mar. 2015.

Global Health Risks: Mortality and burden of disease attributable to selected

major risks. Genebra: WHO, 2009. Disponível em: http://www.who.int/healthinfo/global_ burden_disease/GlobalHealthRisks_report_full.pdf?ua=1\&ua=1. Acesso em: 25 out. 2015.

WORLD LAKE VISION ACTION REPORT COMMITTEE (WLVARC). 2007. World Lake Vision Action Report: Implementing the World Lake Vision for the Sustainable Use of Lakes and Rivers. International Lake Environment Committee: Kusatsu City, Japan.

Disponível em: http://www.ilec.or.jp /eg/wlv/action_report_Project.html. Acesso em: 20 abr. 2013.

XAVIER, R. P. Influência de barreiras sanitárias na qualidade da água de chuva armazenada em cisternas no semiárido paraibano. 114P. Dissertação (Mestrado em Recursos Hídricos e Saneamento) - Universidade Federal de Campina Grande, Campina Grande, 2010.

ZEILHOFER, P.; ZEILHOFER, L. V. A. C.; HARDOIM, E. L.; LIMA, ZORAIDY M.; OLIVEIRA, C. S. GIS applications for mapping and spatial modeling of urban-use water quality: a case study in District of Cuiabá, Mato Grosso, Brazil. Cadernos de Saúde Pública, v. 23, n. 4, p. 875-884, 2007.

ZHANG, Y.; BI, P.; HILLER, J. E. Climate variations and Salmonella infection in Australian subtropical and tropical regions. Science of the Total Environment, v. 408, p. $524-530$, 2010 . 


\section{APÊNDICE A}

\section{Comparação entre a Precipitação estimada por satélite e a Precipitação medida por pluviômetros}

Nesta pesquisa de tese, a metodologia inicial adotada para associação entre os dados de DDA e a precipitação utilizava dados do Sistema de Informações Ambientais (SISAM) alimentado pelo CPTEC/INPE, correspondentes aos índices de precipitação acumulada. Segundo notas de referência do SISAM ${ }^{1}$, a precipitação acumulada é calculada a partir da taxa de precipitação instantânea, estimada a partir de imagens do satélite Geostationary Operational Environmental Satellite (GOES), utilizando uma relação entre a temperatura do topo da nuvem e a chuva na superfície. O método que calcula essa taxa é chamado de hidroestimador e os dados apresentam $4 \mathrm{~km}$ de resolução espacial. As taxas são acumuladas das $12 \mathrm{~h} 00$ min do dia anterior às 12 h 00 min do dia corrente, considerando o Universal Time Coordinated (UTC), padronização para o registro de dados meteorológicos.

Os dados do SISAM também foram obtidos por totalização diária (em mm), para cada um dos municípios da área de estudo a partir da página do sistema na internet (MS; MCT, 2013), e organizados em planilhas eletrônicas segundo os intervalos correspondentes às semanas epidemiológicas.

No entanto, não foram encontradas referências na literatura sobre a utilização dos dados e não puderam ser obtidas séries temporais completas para o período de estudo, havendo disponibilidade de dados somente a partir de 2004 e grande ausência de dados em 2012. Estes fatores contribuíram para a decisão de coletar e utilizar dados de estações meteorológicas de solo na tese.

Porém, houve interesse em verificar a confiabilidade dos dados de precipitação acumulada do SISAM. Para tanto, as estimativas de precipitação obtidas pelo método hidroestimador (SISAM) foram comparadas a dados coletados por estações pluviométricas

\footnotetext{
${ }^{1}$ Fonte: MINISTÉRIO DA SAÚDE (MS). MINISTÉRIO DA CIÊNCIA E TECNOLOGIA (MCT). Sistema de Informações Ambientais (SISAM). Brasília: 2013. Disponível em: http://sisam.cptec.inpe.br/sisam/. Acesso em: 15 mar. 2013.
} 
convencionais localizadas na área de estudo, operadas pela EMPARN e AESA. Os dados provenientes dos órgãos de monitoramento estaduais possuem as vantagens de apresentar alta densidade espacial e estar disponíveis para todo o período de análise, de 2002 a 2012.

Os dados são apresentados nas Figuras A-1 e A-2 para o intervalo de 2004 a 2011 pois este corresponde ao intervalo de dados disponível no SISAM.

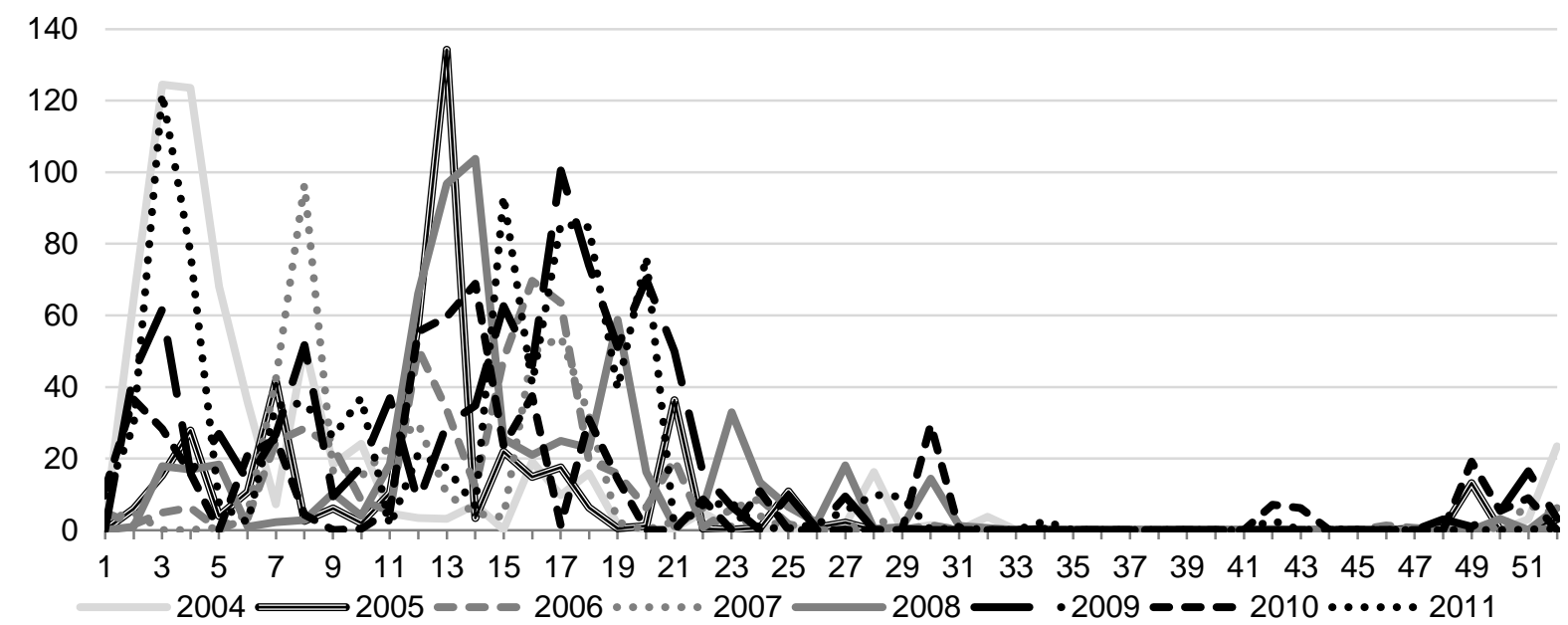

A

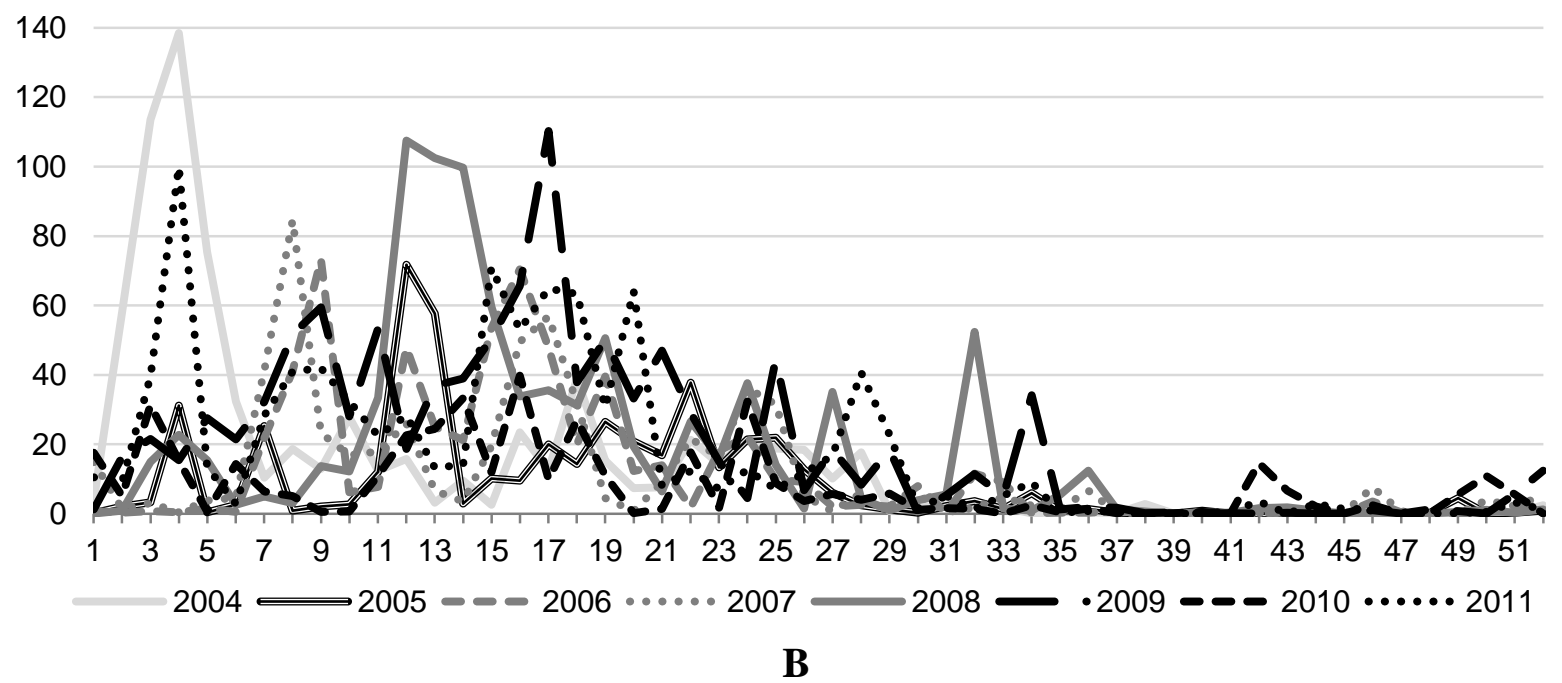

Figura A-1: Precipitação acumulada (mm) por semana epidemiológica (2004-2011): valor médio para os municípios na área de estudo no RN segundo dados de satélite (A) e de solo (B). Fonte: Elaborado pelo autor a partir de dados do SISAM e EMPARN. 


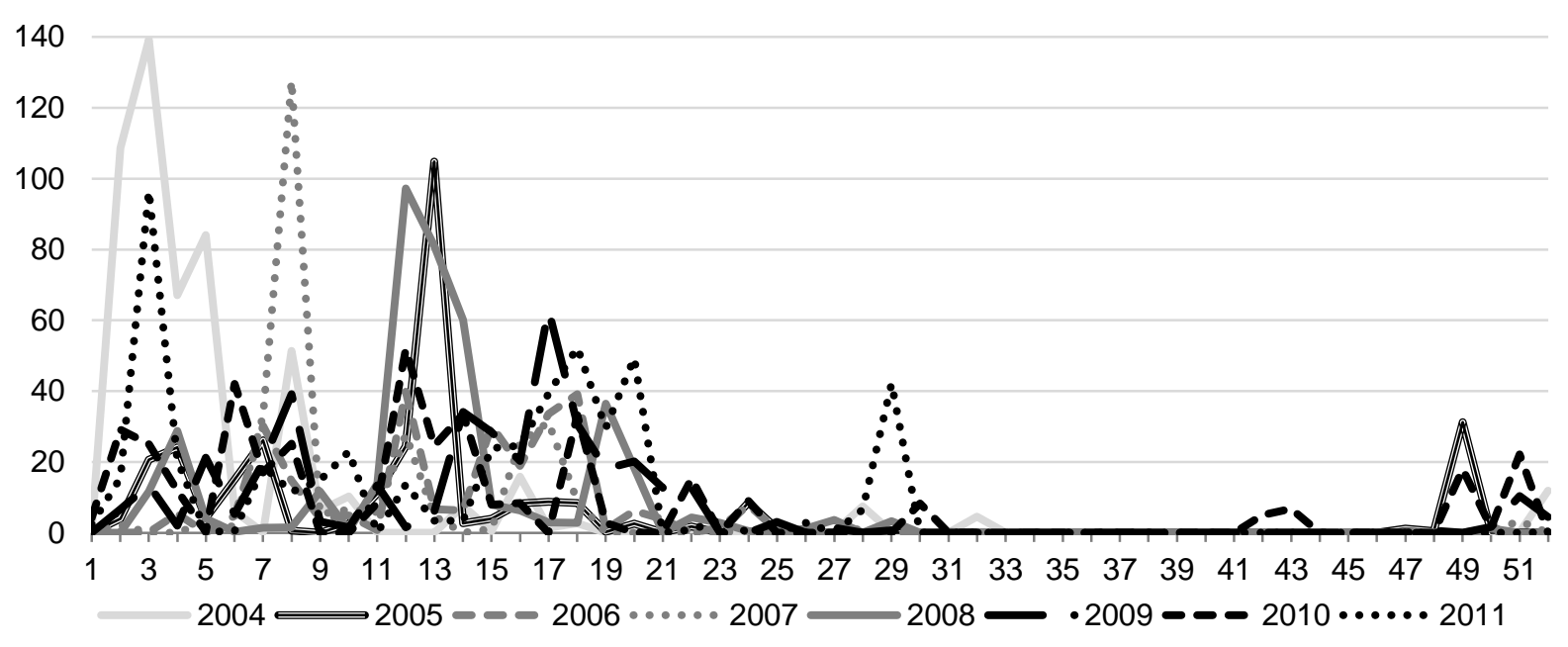

A

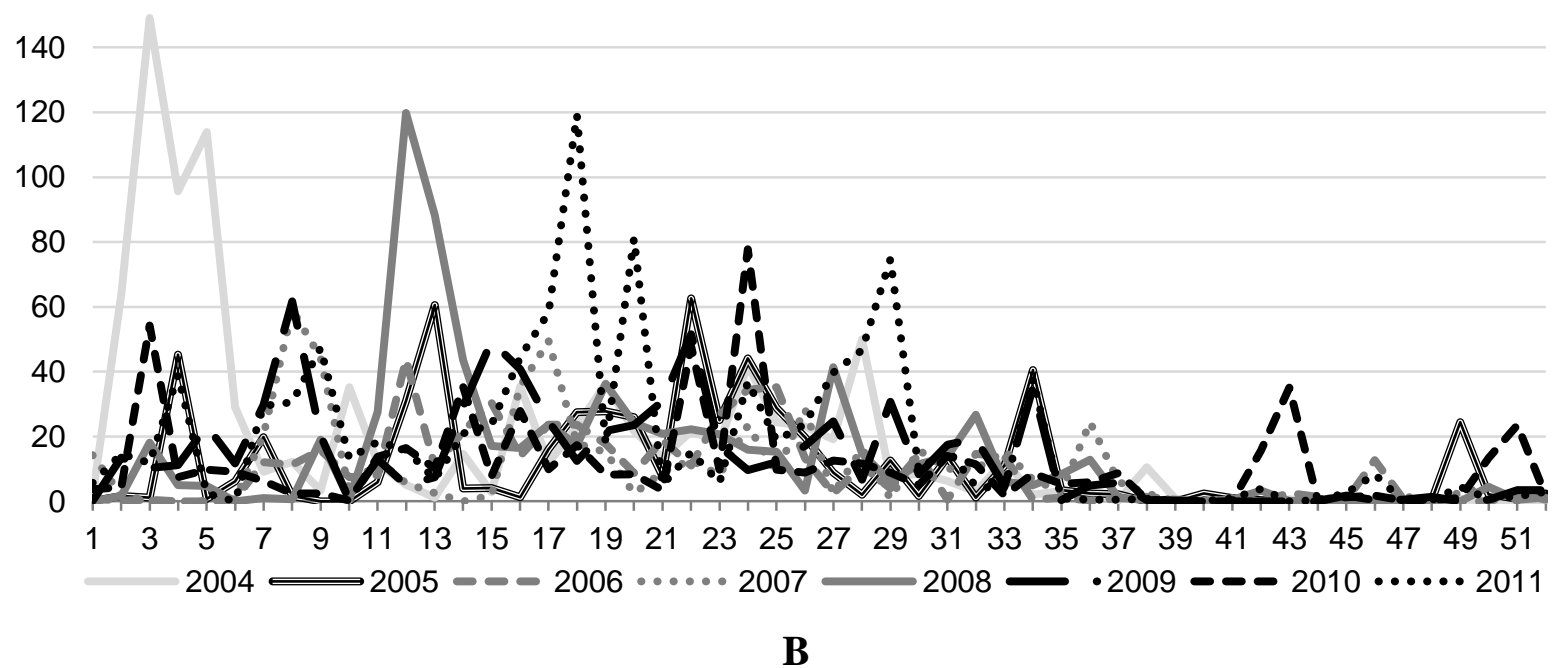

Figura A-2: Precipitação acumulada (mm) por semana epidemiológica (2004-2011): valor médio para os municípios na área de estudo na PB segundo dados de satélite (A) e de solo (B). Fonte: Elaborado pelo autor a partir de dados do SISAM e AESA.

O coeficiente de correlação linear simples encontrado entre as séries de dados no RN média da precipitação acumulada por semana epidemiológica considerando dados de 57 municípios do SISAM e dados de uma média de 72 estações por ano da EMPARN (quantitativo anual variável entre 62 e 77 estações) - foi de 0,845 .

O coeficiente de correlação encontrado entre as séries de dados na PB - média da precipitação acumulada por semana epidemiológica considerando dados de 17 municípios do SISAM e dados de uma média de 20 estações por ano da AESA (variando entre 17 e 21 estações) - foi de 0,695 , um pouco abaixo do valor obtido para a área de estudo no Rio Grande do Norte. 
Entretanto, os resultados evidenciam uma boa qualidade e acurácia dos dados de precipitação estimada por satélite. Caso analisarmos os anos de modo independente, 2004, 2007 e 2008 foram os que apresentam os maiores coeficientes de correlação linear nas duas áreas de estudo (Figura A-3).

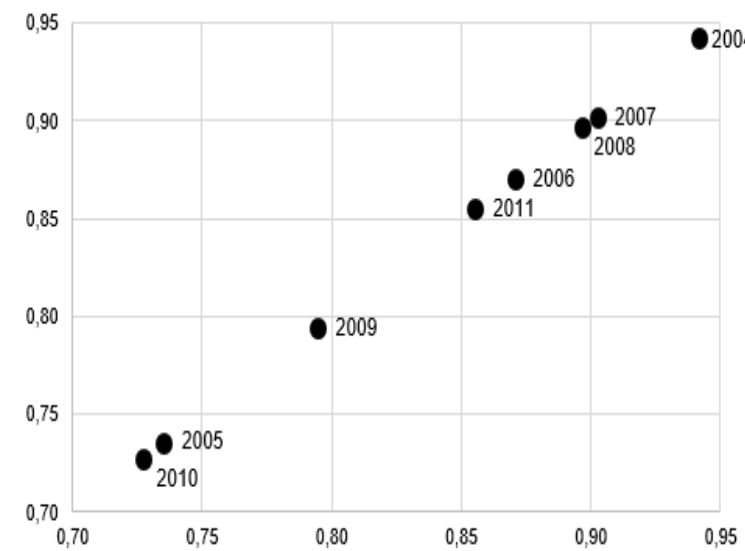

A

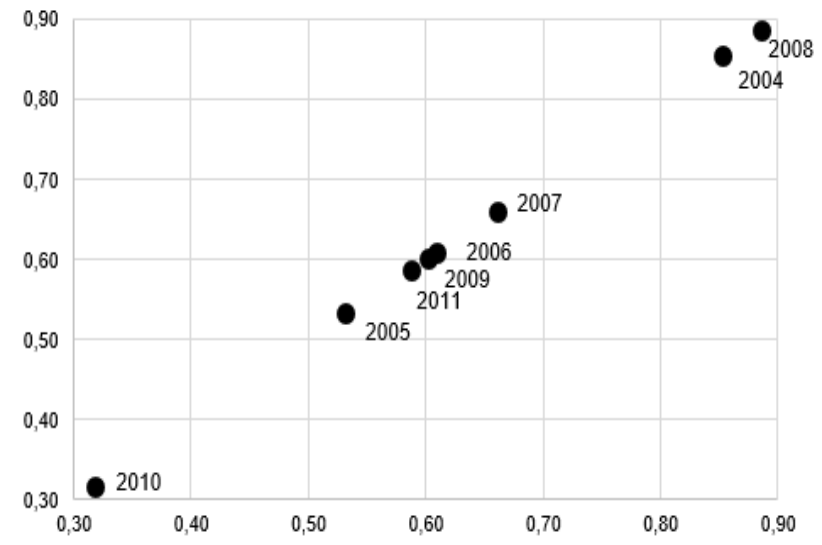

B

Figura A-3: Correlação anual entre os dados de precipitação estimados pelo SISAM e dados de estações pluviométricas da EMPARN (A) e da AESA (B), organizados por semana epidemiológica.

Fonte: Elaborado pelo autor a partir de dados do SISAM, EMPARN e AESA. 


\section{APÊNDICE B}

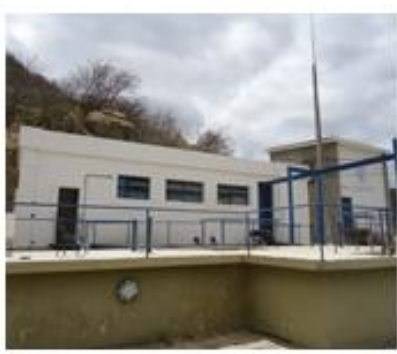

A

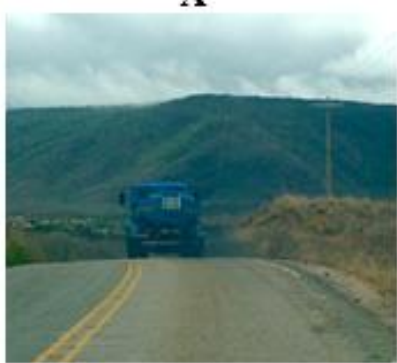

D

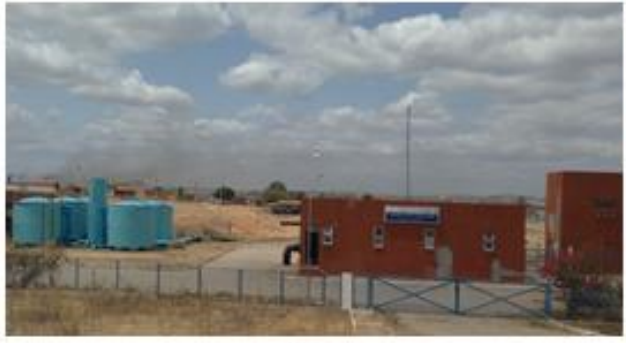

B

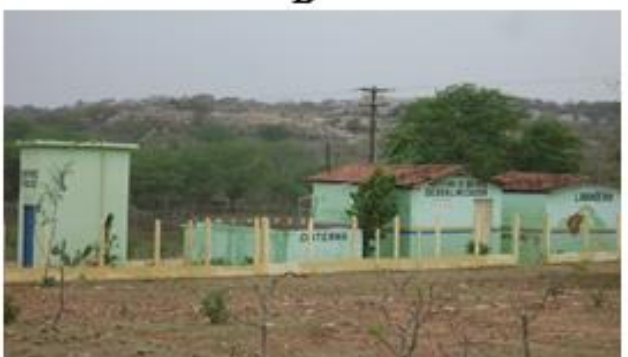

$\mathbf{E}$

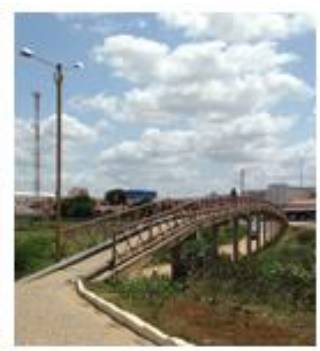

C

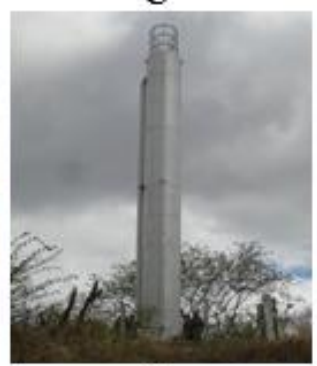

F

Figura B-1: Infraestruturas de abastecimento de água na área de estudo: ETA Acari-Currais Novos em Acari (A), ETA da Adutora Sertão Central Cabugi em Itajá (B), tubulação da Adutora Monsenhor Expedito em São Paulo do Potengi (C), carro-pipa em operação em Currais Novos (D), estrutura de oferta de água a comunidade rural em Boa Vista (E) e estação elevatória do Sistema Integrado Serra de Santana em Florânia (F).

Fonte: Fotos do autor em 06, 07 e 08 out. 2014.

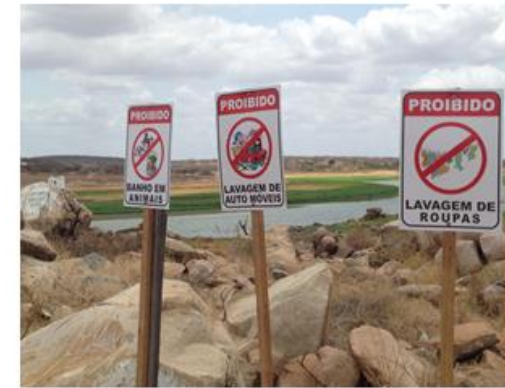

$\mathbf{A}$

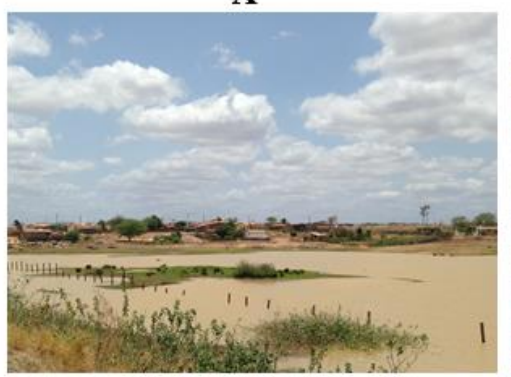

D

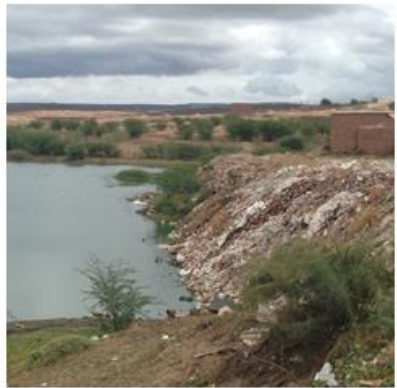

B

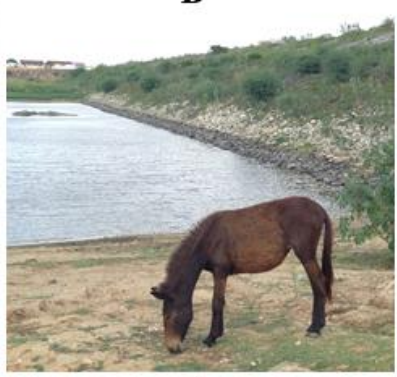

$\mathbf{E}$

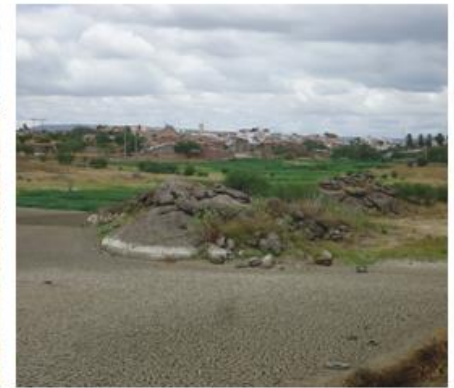

C

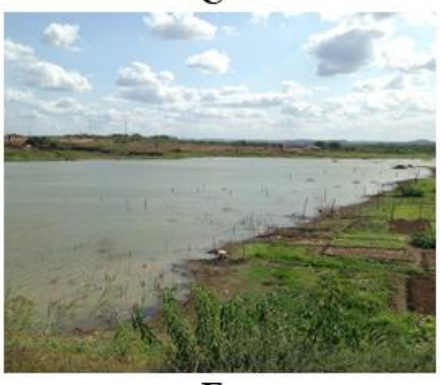

$\mathbf{F}$

Figura B-2: Açudes nas áreas urbanas dos municípios de Angicos (A), Currais Novos (B e C), Fernando Pedroza (D) e Santa Cruz (E e F).

Fonte: Fotos do autor em 06, 07 e 08 out. 2014. 


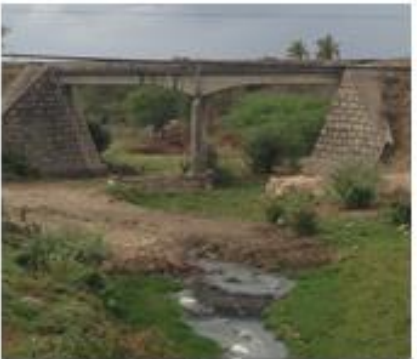

A

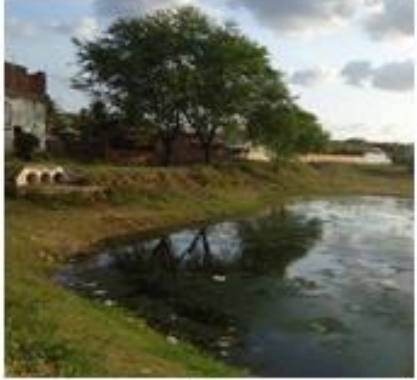

D

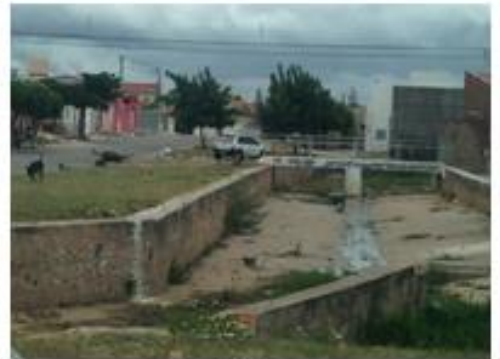

B

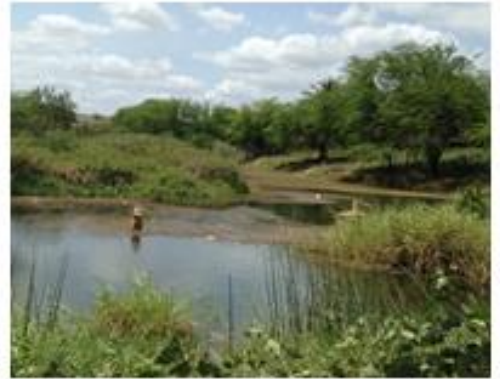

$\mathbf{E}$

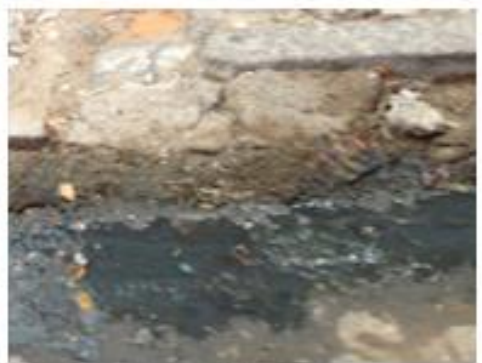

C

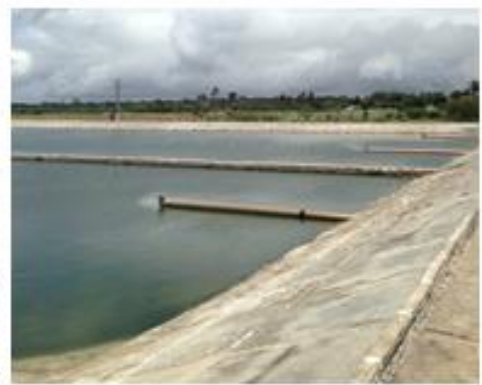

$\mathbf{F}$

Figura B-3: Situações de esgotamento sanitário em áreas urbanas da área de estudo: córrego em Soledade (A), vala canalizada em Currais Novos (B), esgoto em via pública de Angicos (C), açude em Passa e Fica (D), Rio Potengi em São Paulo do Potengi (E) e estação de tratamento de esgotos em Lagoa Nova (F).

Fonte: Fotos do autor em 06, 07 e 08 out. 2014.

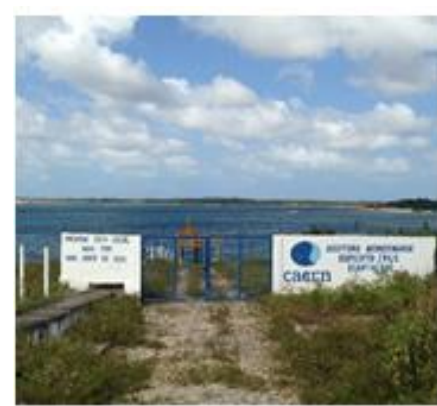

A

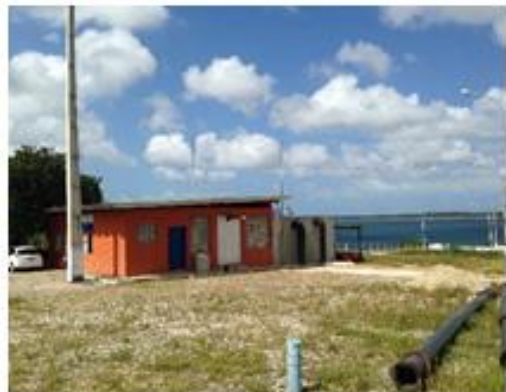

B

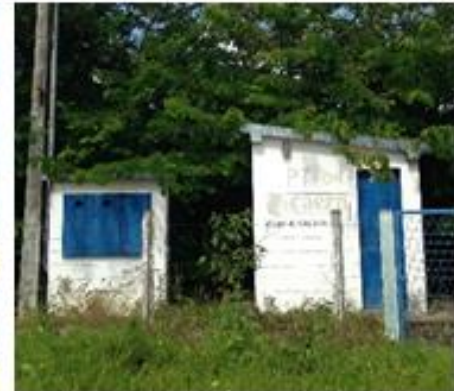

C

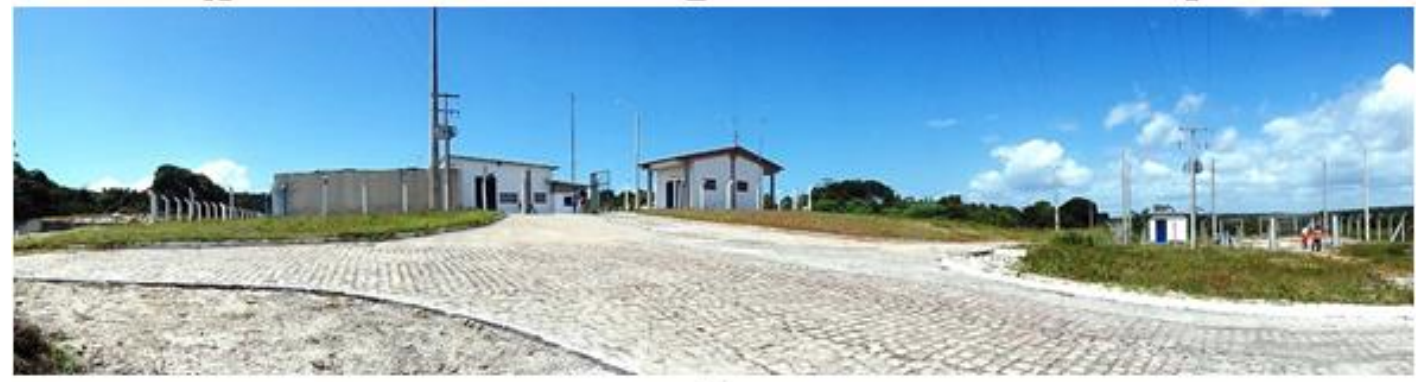

D

Figura B-4: Captações da Adutora Monsenhor Expedito: Captação flutuante na Lagoa do Bonfim (A), estação de bombeamento da adutora (B), poço do sistema complementar de captação da adutora (C) e novo sistema de poços de captação (D).

Fonte: Fotos do autor em 30 ago. 2015 (A, B e C) e foto da CAERN em dez. 2014 (D). 


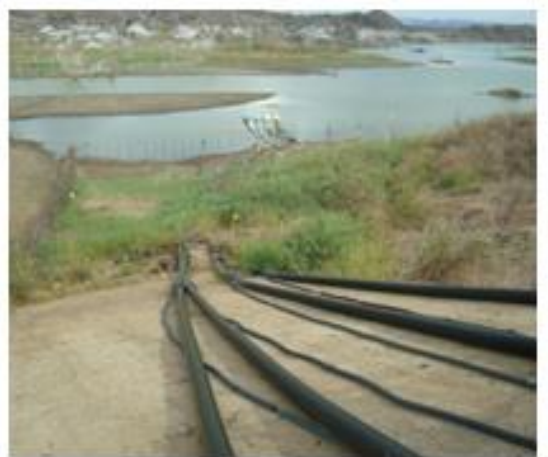

A

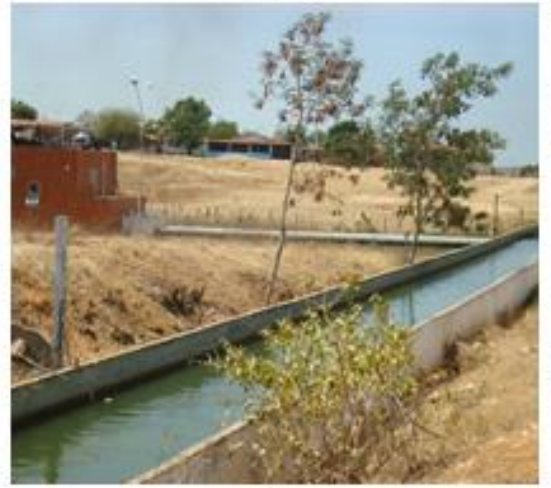

D

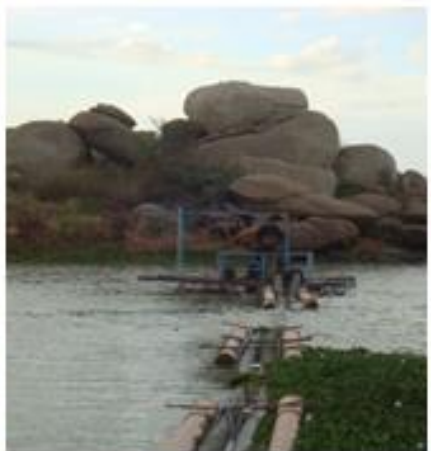

B

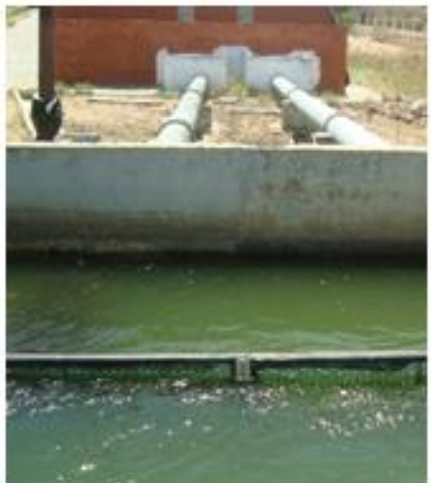

$\mathbf{E}$

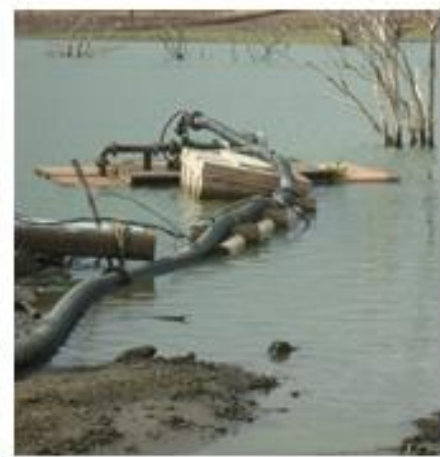

C

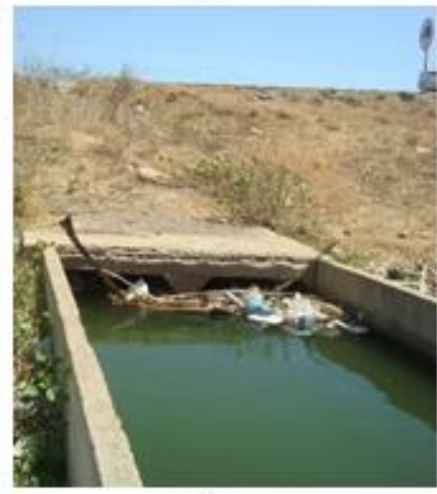

$\mathbf{F}$

Figura B-5: Captações para abastecimento urbano de água no açude ARG: Sistema Integrado Médio Oeste (A), Sistema Integrado Serra de Santana (B), Sistema Isolado São Rafael (C) e Sistema Integrado Sertão Central Cabugi (Canal de Pataxó) (D, E e F).

Fonte: Fotos da CAERN em dez. 2014.

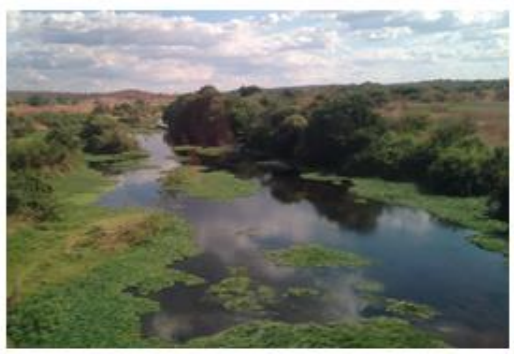

A

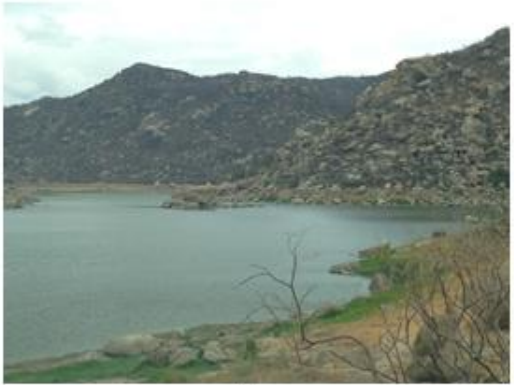

D

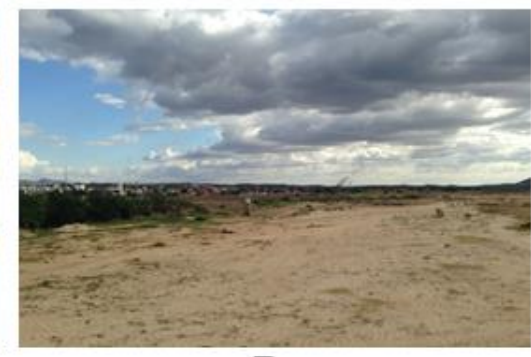

B

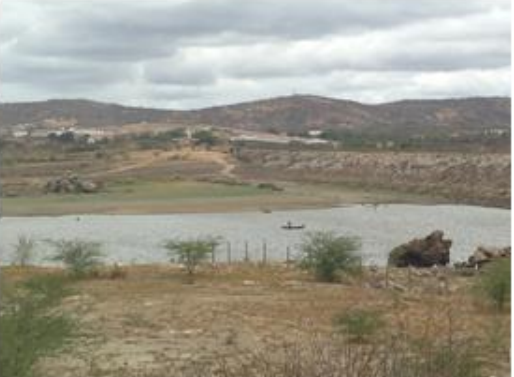

$\mathbf{E}$

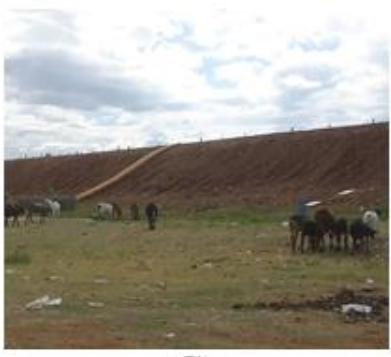

C

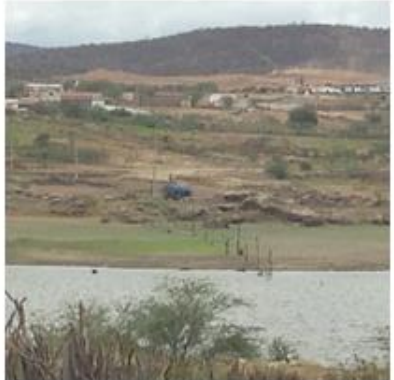

$\mathbf{F}$

Figura B-6: Leito do Rio Piranhas em Pombal (PB) (A) e Jucurutu (RN) (B), dique para proteção a inundação em Jucurutu (C), açude MDG em Acari (D) e açude Dourado em Currais Novos (RN) (E) em cuja margem há carro-pipa retirando água (F).

Fonte: Fotos do autor em 05 e 07 out. 2014. 


\section{APÊNDICE C}

\section{Áreas de Estudo Complementar}

A Figura C-1 apresenta o padrão temporal das internações por DGOIP nos 177 municípios brasileiros com mais de 150 mil habitantes ${ }^{2}$. Tal padrão obedece, em geral, ao padrão observado na capital do país mais próxima.

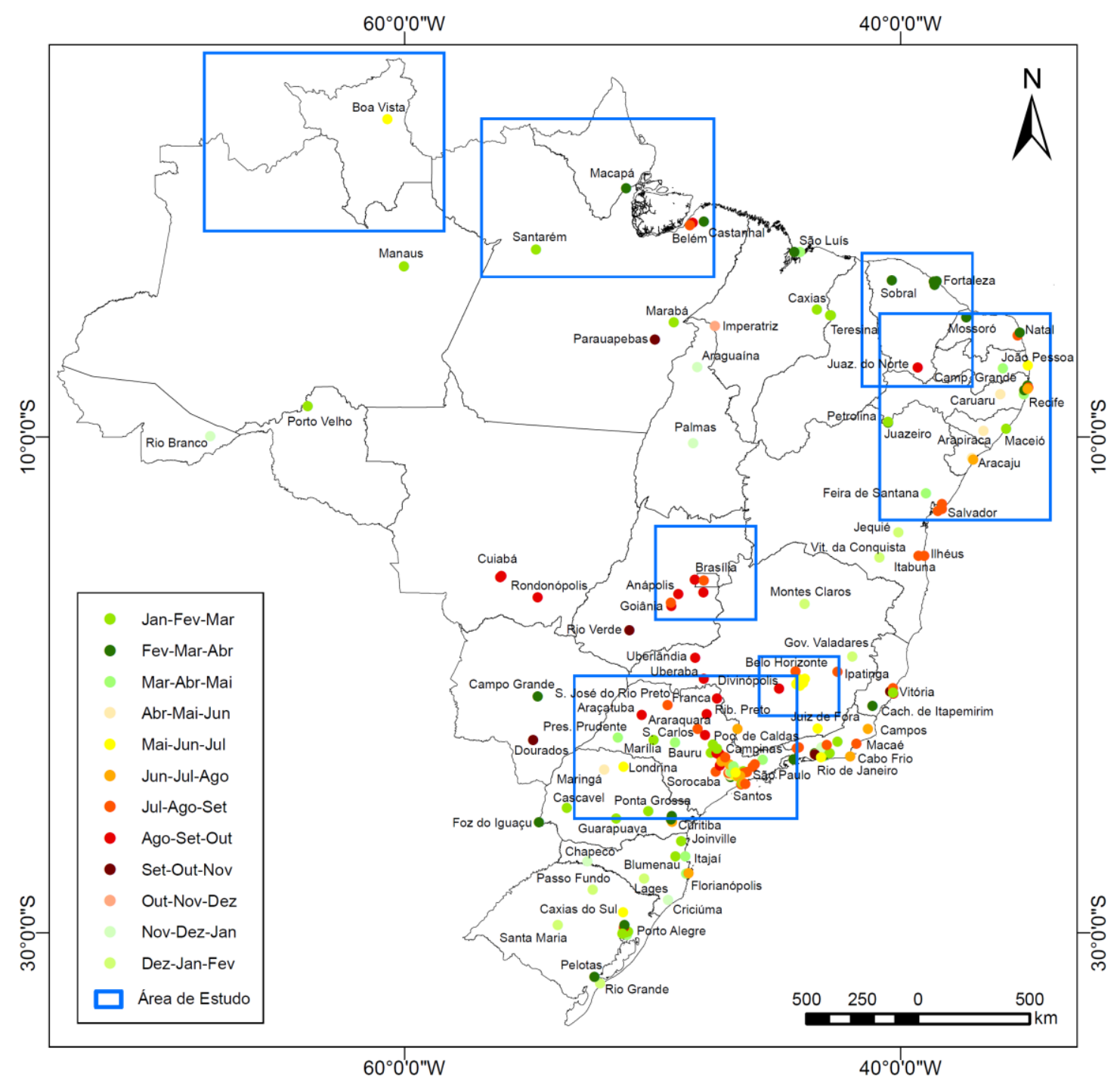

Figura C-1: Trimestre de maior número de internações por DGOIP nos municípios brasileiros com mais de 150 mil habitantes (1998-2012) e áreas selecionadas para estudo complementar. Fonte: Elaborado pelo autor a partir de dados do SIH.

\footnotetext{
${ }^{2}$ Fonte: INSTITUTO BRASILEIRO DE GEOGRAFIA E ESTATÍSTICA (IBGE). Censo Demográfico 2010: Resultados do Universo - Características da População e dos Domicílios. Rio de Janeiro: IBGE, 2010. Disponível em: http://www.sidra. ibge.gov.br/cd/cd2010universo.asp?o=7\&i=P. Acesso em: 15 mar. 2015.
} 
A análise exploratória dos padrões temporais das internações por DGOIP em alguns recortes espaciais selecionados ao longo do território nacional (Figura C-1) foi utilizada em subsídio ao estudo dos padrões apresentados pelas capitais brasileiras cujos resultados são apresentados no Capítulo 5 da tese. A análise complementar de cada um dos sete estudos de caso é apresentada a seguir.

Os Estados do Ceará e de São Paulo apresentam um comportamento praticamente invariável tanto do trimestre de maior como de menor precipitação pluviométrica ao longo de seu território (vide Figura 5.5). Ambos também apresentam padrões bem definidos quanto as internações por DGOIP, como detalhado na Figura C-2.

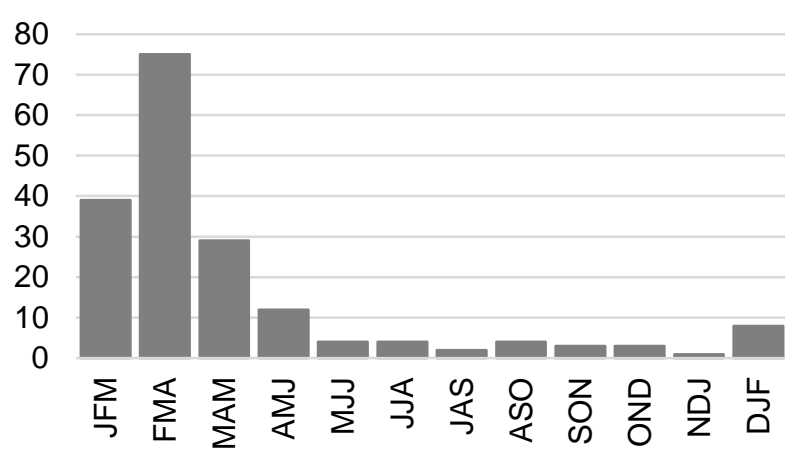

A

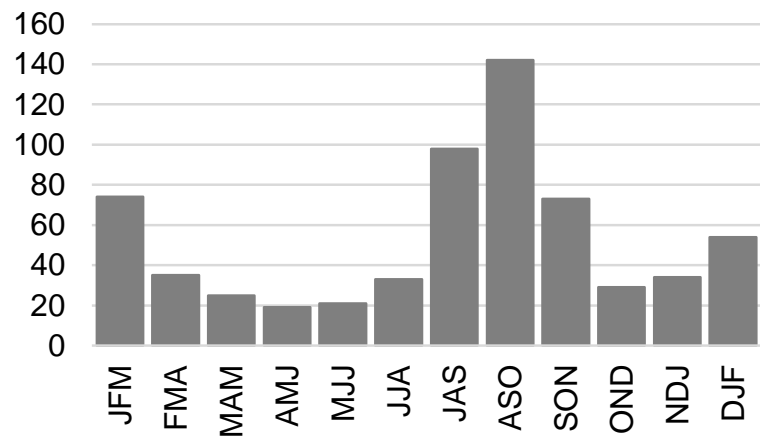

B

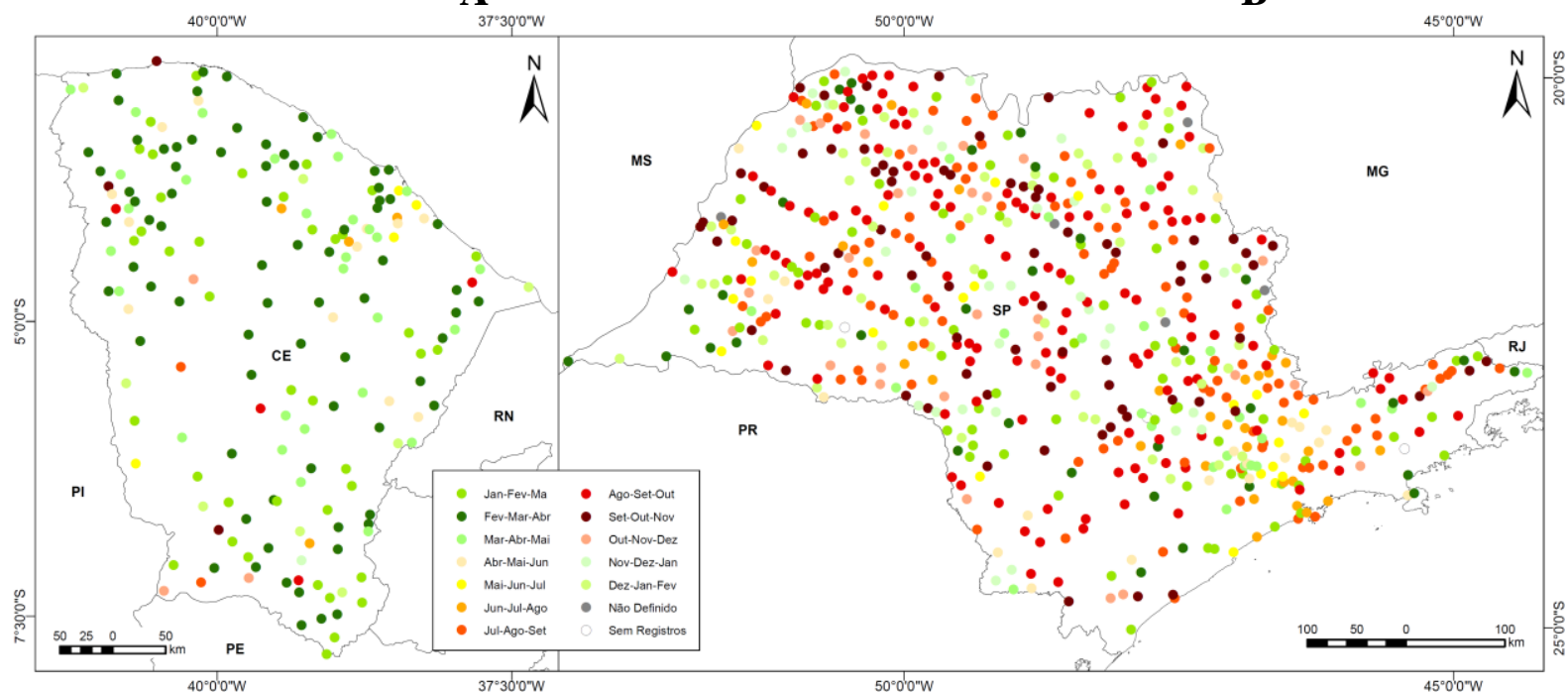

Figura C-2: Distribuição dos municípios segundo o trimestre de maior número de internações por DGOIP nos Estados do Ceará (A) e São Paulo (B) (1998-2012).

Fonte: Elaborado pelo autor a partir de dados do $\mathrm{SIH}^{3}$.

\footnotetext{
${ }^{3}$ Fonte: MINISTÉRIO DA SAÚDE (MS). Informações de Saúde (TABNET). Brasília: MS/DATASUS, 2015. Disponível em: http://www2.datasus.gov.br/DATASUS/index.php. Acesso em: 15 mar. 2015.
} 
Ceará: Em 78\% dos municípios do Ceará, o período de maior número de internações por DGOIP ocorre entre JFM e MAM. O pico da chuva no estado é o trimestre de FMA e o comportamento da precipitação é homogêneo em todo o estado sendo que apenas alguns municípios ao longo do litoral não estão inseridos na região semiárida.

Dentre os municípios do Estado com mais de 150 mil habitantes, o maior número de internações também é registrado em FMA em Fortaleza, Caucaia e Maracanaú, na Região Metropolitana, assim como em Sobral, no interior.

Jijoca de Jericoacoara é o único município litorâneo do Estado com comportamento diferenciado, sendo que o trimestre de maior número de internações nesse município é SON, considerado período de alta temporada ${ }^{4}$, devido ao regime dos ventos alísios que atraem os turistas à prática de esportes náuticos, principalmente de origem internacional.

Destaca-se ainda que nas maiores cidades dos Estados vizinhos ao Ceará, como São Luís no Maranhão, Mossoró e Natal no Rio Grande do Norte, o maior número de internações também é em FMA. Em Teresina, capital do Piauí e Timon e Caxias no Maranhão é JFM.

São Paulo: No Estado de São Paulo, 49\% dos 645 municípios tem como trimestre de maior número de registro de internações o período de JAS (98 municípios) a SON (73 municípios), sendo o pico em ASO com 142 municípios. No entanto, essa concentração é mais expressiva em toda a região Noroeste do Estado (Figura C-2), sendo que nenhum dos 19 municípios da Região Metropolitana de São Paulo com mais de 150 mil habitantes apresentam ASO como o trimestre de maior quantitativo e apenas Itapevi, Ferraz de Vasconcelos, Suzano e Mogi das Cruzes apresentam JAS.

O comportamento difere do interior, pois dentre os demais municípios do Estado com mais de 150 mil habitantes (28 casos), 17 possuem como trimestre de maior registro JAS ou ASO. Indaiatuba, Jundiaí e Santos apresentam JJA. Piracicaba, Rio Claro e Limeira, assim como São Vicente, apresentam JFM. Bauru, Marília e Presidente Prudente, apesar de apresentarem comportamento distinto, tem nos trimestres de JAS (Bauru e Marília) e ASO (em Presidente Prudente) o segundo maior registro de casos.

\footnotetext{
${ }^{4}$ Fonte: http://oglobo.globo.com/boa-viagem/a-alta-da-baixa-temporada-de-jericoacoara-2803440.
} 
Roraima: No Estado de Roraima o comportamento é diferente daquele apresentado por outras regiões da Amazônia, assim como difere o regime climático da região (Figura C-3). Os trimestres com mais internações por DGOIP vão de AMJ a JJA, exceto em quatro municípios do Norte do Estado: Amajari, Pacaraima, Normandia e Uiramutã. O período de maior precipitação é o trimestre MJJ, que coincide com o período de maior número de internações em Boa Vista, Alto Alegre, Bonfim e Cantá. Em todos os demais municípios de Roraima, exceto em Caroebe e Uiramutã, o trimestre MJJ é o segundo com mais internações. No trimestre JJA, os maiores totais de chuva do país ainda ocorrem sobre o extremo norte do Amazonas e norte de Roraima, associados principalmente à atuação da ZCIT e à formação de Linhas de Instabilidade ${ }^{5}$.

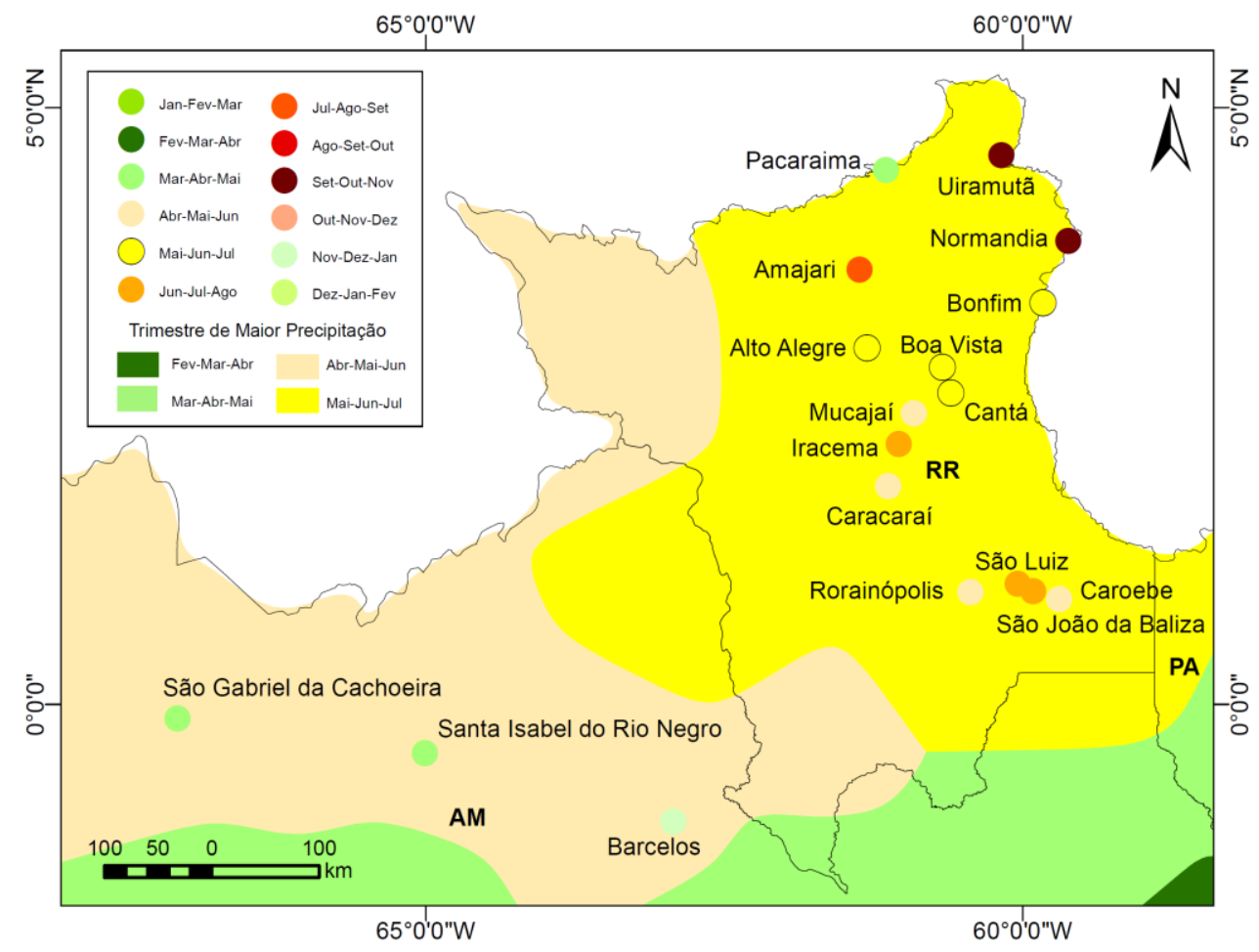

Figura C-3: Trimestre de maior número de internações por DGOIP (1998-2012) e de maior precipitação (1977-2006) nos municípios do Estado de Roraima e Noroeste do Amazonas. Fonte: Elaborado pelo autor a partir de dados do SIH e CPRM ${ }^{6}$.

\footnotetext{
${ }^{5}$ Fonte: INSTITUTO NACIONAL DE PESQUISAS ESPACIAIS (INPE). CENTRO DE PREVISÃO DO TEMPO E ESTUDOS CLIMÁTICOS (CPTEC). Infoclima. Cachoeira Paulista: INPE/CPTEC, 2015. Disponível em: http://infoclima.cptec.inpe.br/. Acesso em: 15 mar. 2015.

${ }^{6}$ Fonte: COMPANHIA DE PESQUISA DE RECURSOS MINERAIS (CPRM). Atlas Pluviométrico do Brasil. Rio de Janeiro: CPRM, 2012. Disponível em: http://www.cprm.gov.br/publique/cgi/cgilua.exe/sys/start.htm?infoid=1351\&sid=9. Acesso em: 07 jan. 2014.
} 
Em São Gabriel da Cachoeira e Santa Isabel do Rio Negro, onde o trimestre mais chuvoso é AMJ, o trimestre de maior número de internações é MAM. Em São Gabriel da Cachoeira, MJJ também é o segundo trimestre de maior número, o que não ocorre em Santa Isabel do Rio Negro e Barcelos. No entanto estes dois municípios possuem os menores registros da região, de apenas 12 e 17 casos ao longo da série histórica.

Leste da Região Nordeste: O comportamento intranual dos trimestres de maior número de internações por DGOIP na porção leste da região Nordeste do país varia conforme a região fitogeográfica, a saber o Sertão, o Agreste e a Zona da Mata. Enquanto na maior parte dos municípios do Sertão o trimestre é de JFM a MAM, na região do Agreste e notadamente na área de transição entre a faixa litorânea úmida e a região semiárida, os trimestres variam de AMJ a JAS, sendo poucos os municípios do Sertão que possuem esse comportamento (Figura C-4).

O comportamento interanual do trimestre de maior número de internações por DGOIP nas capitais da região permite observar tal diferença e transição (vide Tabela 5.4). Enquanto no extremo Norte da região o maior quantitativo de internações em geral encontra-se no início do ano: em São Luís em doze anos o trimestre de maior registro foi entre DJF e MAM, em Teresina em oito anos o trimestre foi JFM e em Fortaleza em onze anos foi entre JFM e MAM, no outro extremo o pico das internações encontra-se no meio do ano: em onze anos o trimestre foi entre MJJ e JAS em Salvador e entre MJJ e ASO em Aracaju. Já em Recife e Maceió o comportamento apresentou uma tendência bimodal sendo que em sete anos no Recife o trimestre esteve entre MJJ e JAS e em seis anos em FMA ou MAM, ao passo que em Maceió em seis anos foi JAS ou ASO e em sete anos foi JFM ou FMA. Em Natal e João Pessoa o comportamento também não foi bem definido havendo alternância ao longo da série temporal entre trimestres do início e do meio do ano.

Destaca-se que Maceió e Recife ocupam o segundo e terceiro lugar no país em número de internações por DGOIP entre 1998 e 2012 se a Recife forem somados os registros de internações de Jaboatão dos Guararapes, município vizinho a capital cuja população é de quase setecentos mil habitantes. Isoladamente Recife ocupa a $15^{\mathrm{a}}$ posição, superada no Nordeste por Parnaíba (14 $)$, Fortaleza (11 $\left.1^{\mathrm{a}}\right)$, Jaboatão $\left(9^{\mathrm{a}}\right)$ e, Campina Grande ( $7^{\mathrm{a}}$ posição). 


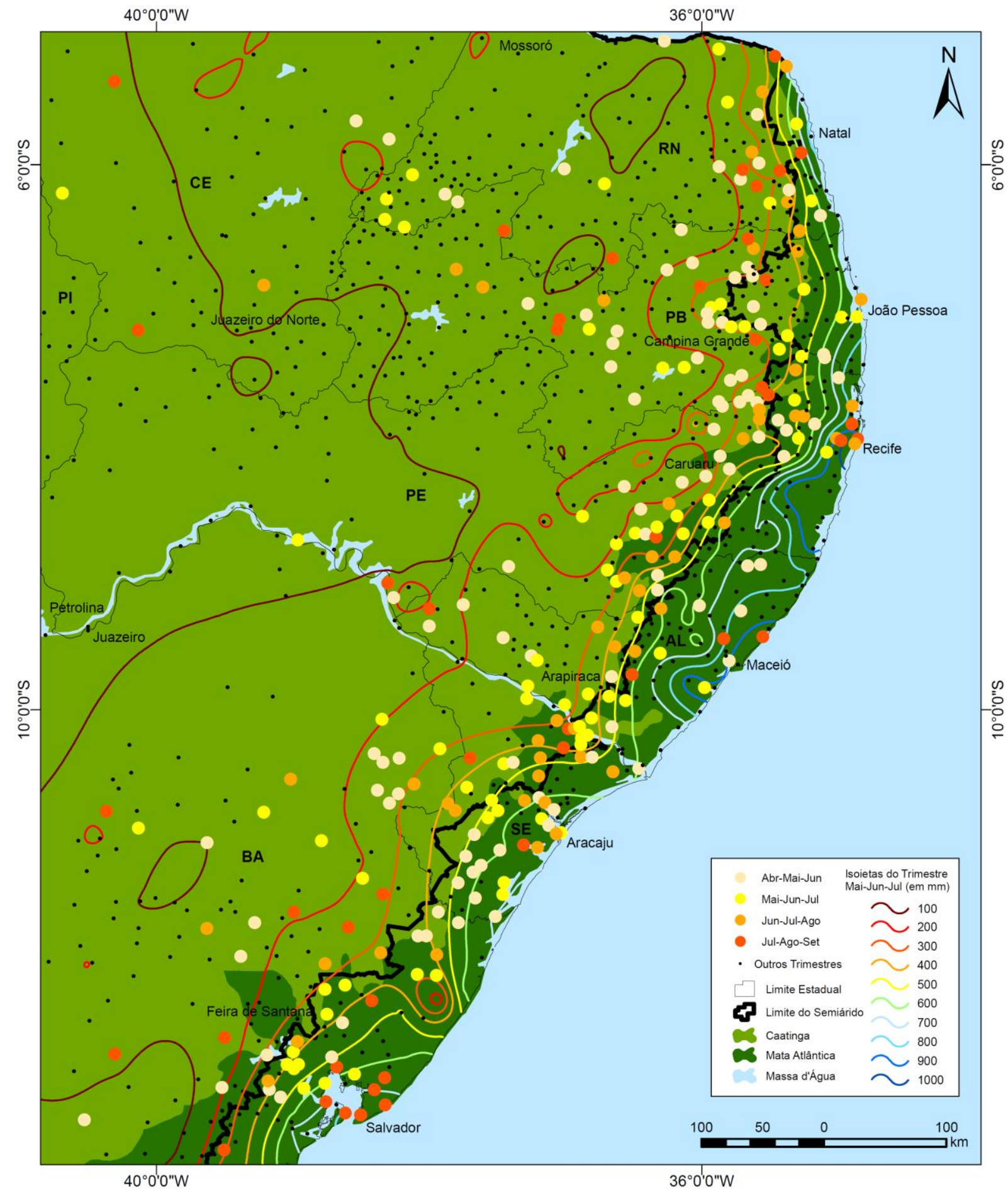

Figura C-4: Trimestre de maior número de internações por DGOIP no leste da Região Nordeste do Brasil (1998-2012).

Fonte: Elaborado pelo autor a partir de dados do SIH, $\mathrm{IBGE}^{7}, \mathrm{MI}^{8}$ e CPRM.

\footnotetext{
${ }^{7}$ Fonte: INSTITUTO BRASILEIRO DE GEOGRAFIA E ESTATÍ́STICA (IBGE). Mapa de Biomas do Brasil - Escala 1:5000000. Rio de Janeiro: IBGE, 2004. Disponível em: http://www.visualizador.inde.gov.br/. Acesso em: 15 mar. 2015.

${ }^{8}$ Fonte: MINISTÉRIO DA INTEGRAÇÃO NACIONAL (MI). Nova Delimitação do Semi-Árido Brasileiro. Brasília: MI, 2005. Disponível em: http://www.mi.gov.br/c/document_library/get_file?uuid=0aa2b9b5-aa4d-4b55-a6e1-82faf0762763\& groupId=24915. Acesso em: 02 mar. 2013.
} 
As delimitações do semiárido e do bioma Mata Atlântica, representadas na Figura C-4, auxiliam na observação da faixa de transição no comportamento das diarreias e gastroenterites na região. A atual delimitação do semiárido brasileiro não considera apenas a precipitação pluviométrica média anual inferior a $800 \mathrm{~mm}$ como indicador para a inclusão de um município em seu polígono, mas considera também o índice de aridez de até 0,5 calculado pelo balanço hídrico que relaciona as precipitações e a evapotranspiração potencial, no período entre 1961 e 1990 e, o risco de seca maior que 60\%, tomando por base o período entre 1970 e 1990.

Enquanto os municípios do Brejo Paraibano, apesar de estarem incluídos no bioma caatinga, não fazem parte do semiárido, os municípios do Brejo Pernambucano fazem parte do semiárido apesar de estarem no bioma Mata Atlântica. A mesma situação em Pernambuco ocorre com a área mais alta do Planalto da Borborema - planalto este que se estende em um sentido Norte-Sul do Rio Grande do Norte a Alagoas - localizada na região do maciço de Garanhuns.

Nas capitais regionais do Agreste, enquanto em Campina Grande e Feira de Santana o trimestre de maior número de internações por DGOIP ainda é MAM, em Caruaru e Arapiraca é AMJ. No litoral, em João Pessoa é MJJ, em Recife e Aracaju é JJA e em Salvador, Camaçari, Simões Filho, Lauro de Freitas, São Francisco do Conde e Vera Cruz é JAS. Até mesmo os maiores municípios do litoral sul da Bahia apresentam o mesmo comportamento dos municípios metropolitanos tendo Ilhéus, Itabuna e Porto Seguro o pico também em JAS.

Grandes municípios das regiões metropolitanas de João Pessoa, Recife e Aracaju também possuem como trimestres de maior quantitativo de AMJ a JAS. É o caso de Cabedelo e Santa Rita na Paraíba, Olinda, Abreu e Lima, Camaragibe e São Lourenço da Mata em Pernambuco e, São Cristóvao, Laranjeiras, Nossa Senhora do Socorro e Barra dos Coqueiros em Sergipe.

Maceió possui um comportamento distinto das demais capitais do eixo João PessoaSalvador, que estão na área do pico da precipitação em MJJ, pois, apresenta como trimestre de maior número de internações JFM. No entanto esta é a única, dentre as capitais do Nordeste, que possui um comportamento bimodal, havendo grande número de casos entre JJA e ASO (vide Figura 5.7). Convém destacar também que este município é o segundo do Brasil com maior número de casos, que soma quase 39 mil. 
As isoietas correspondentes ao total médio de precipitação no trimestre MJJ entre 1977 e 2006 auxiliam na caracterização do comportamento climático dessa região (Figura C-4). A mesma faixa de transição do Sertão à Zona da Mata é observada com a precipitação. No trimestre MJJ a costa leste do Nordeste se encontra no período mais chuvoso do ano, com totais acumulados de precipitação que podem exceder $700 \mathrm{~mm}$ entre o litoral do Rio Grande do Norte e Alagoas. O principal sistema meteorológico responsável pelas chuvas mais intensas no leste da Região Nordeste são os Distúrbios Ondulatórios de Leste (DOL). Estes distúrbios meteorológicos atuam principalmente favorecendo a convecção proveniente do oceano sobre a porção tropical leste da América do $\mathrm{Sul}^{9}$. Estudos indicam que os DOL são o principal sistema causador de precipitação nessa área no período de outono/inverno ${ }^{10}$.

Planalto Central: A Figura C-5 apresenta o comportamento dos municípios da região do Planalto Central do Brasil, notadamente daqueles que compõem a Região Metropolitana de Goiânia e a Região Integrada de Desenvolvimento do Distrito Federal e Entorno (RIDE). Em 15 dos 23 municípios da RIDE o período de maior registro de internações por DGOIP corresponde aos trimestres de JAS ou ASO. Em Brasília e Goiânia é JAS, sendo o mês de setembro o de maior quantitativo.

Em dez anos da série temporal (1998 a 2012) o trimestre de maior número de internações foi JJA, JAS ou ASO em Brasília, enquanto em Goiânia em onze anos foi JAS ou ASO (vide Tabela 5.4). Em Cuiabá os trimestres foram JAS, ASO ou SON em dez anos da série.

Os municipios de Formosa, Santo Antônio do Descoberto, Corumbá de Goiás e Cidade Ocidental possuem um comportamento distinto, sendo o pico das internações em trimestres que se seguem ao trimestre de maior precipitação na região da RIDE, que é NDJ. Porém estes municípios também apresentam uma elevação no número de casos no período de julho a setembro.

\footnotetext{
${ }^{9}$ Fonte: CAVALCANTI, I. F. A.; FERREIRA, M.; ASSUNÇÃO, F. S. D.; GERTRUDES, A.; SILVA, J. Tempo e Clima no Brasil. São Paulo: Oficina de Textos, 2009. 464p.

${ }^{10}$ Fonte: ALVES, K. M. A. S.; CAVALCANTI, L. C. S.; NÓBREGA, R. S. Eventos extremos e risco de inundação: uma análise do comportamento evolutivo dos Distúrbios Ondulatórios de Leste em junho de 2010 sobre a bacia do rio Una Pernambuco. GeoTextos, v. 9, n. 2, p. 173-189, 2013.
} 


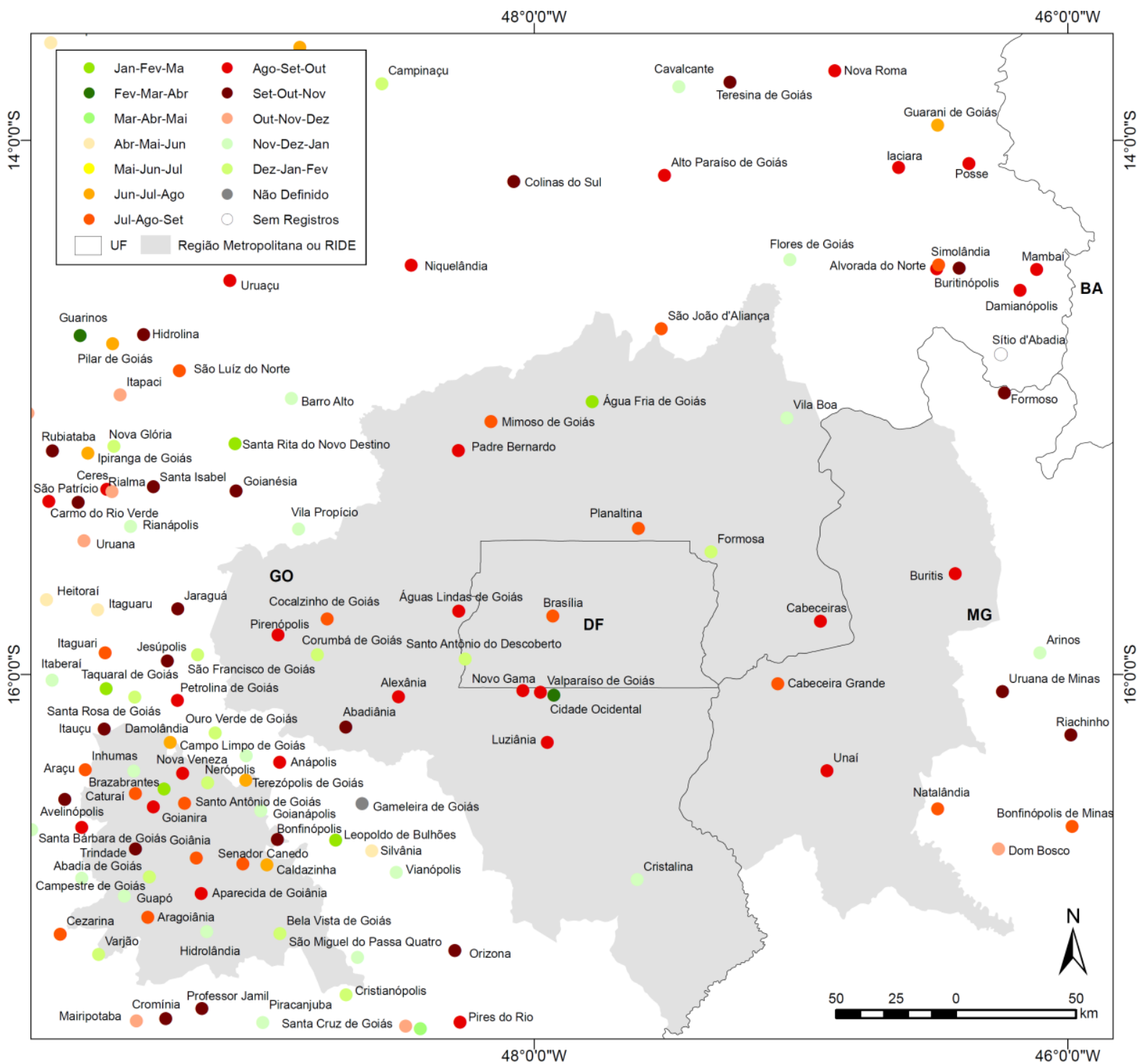

Figura C-5: Trimestre de maior número de internações por DGOIP nos municípios da RIDE, Região Metropolitana de Goiânia e arredores (1998-2012).

Fonte: Elaborado pelo autor a partir de dados do SIH.

Um maior número de internações por DGOIP nos trimestres de JAS ou ASO também é o comportamento da maioria dos municípios da região do Planalto Central do Brasil - os quais possuem estação seca bem definida durante o inverno - assim como dos municípios goianos e mato-grossenses do vale do Rio Araguaia. O período coincide com o período do início das chuvas na região e término da estação seca. Em geral esse também é o período mais quente do ano. Ao Norte de Brasília, o trimestre de maior registro em Posse, Iaciara, Padre Bernardo, Alto Paraíso de Goiás, Pirenópolis, Ceres, Niquelândia, Uruaçu, Minaçu, Porangatu e até mesmo Gurupi no Sul do Tocantins é ASO. Aparecida de Goiânia e Anápolis também é ASO, assim como Alexânia, Águas Lindas de Goiás, Luziânia, Novo Gama, Valparaíso de Goiás e Unaí. 
Em Rondonópolis, Várzea Grande e Cuiabá, Sul do Estado de Mato Grosso, o trimestre também é ASO. Assim como em Uberaba e Uberlândia, no Triângulo Mineiro, e Araçatuba, Franca, e Ribeirão Preto no Norte de São Paulo e até mesmo Divinópolis em Minas Gerais, já próximo a Belo Horizonte. No Sul de Goiás em Jataí e Pires do Rio também é ASO enquanto em Itumbiara, Catalão e Rio Verde o trimestre é SON. Em Caldas Novas, o maior destino turístico da região, o trimestre é JFM, entretanto, com o registro de uma internação a menos, o trimestre de ASO é o segundo com maior quantitativo.

Baixo Amazonas: Os municípios da região do Baixo Amazonas no Pará e Amapá, assim como das regiões de Altamira (baixo curso do Rio Xingu) e de Castanhal (Nordeste do Pará) no Estado do Pará, incluídos na Figura C-6, apresentam o maior quantitativo de internações nos trimestres de JFM a MAM, com exceção apenas dos municípios de Curuá, Gurupá e Pedra Branca do Amapari, nos quais o trimestre é DJF, e Serra do Navio e Vitória do Xingu, nos quais é AMJ. O município de Mazagão apresenta um comportamento diferenciado, no entanto o total de internações registradas em FMA é o segundo maior e a diferença é de apenas dois registros a menos que o trimestre OND.

Nos maiores municípios da região Norte, exceto Belém, também predomina o trimestre JFM, como em Santarém, Itaituba, Marabá e também Manaus (AM) e Porto Velho (RO). Em Macapá e Santana o trimestre é FMA. Esse fenômeno pode ser associado com a dinâmica climática, sendo este o período de maior ocorrência das chuvas, por influência da ZCIT.

A região do Marajó apresenta um comportamento diferenciado no que se refere ao trimestre de maior número de internações por DGOIP em relação aos municípios do baixo curso do Rio Amazonas, Amapá e Nordeste do Pará, incluídos na Figura C-6. Apesar de estarem localizados em uma área de regime climático semelhante, todos os municípios da região do Marajó, exceto Afuá, Muaná, Salvaterra e Oeiras do Pará - que, todavia, tampouco apresentam pico em JFM ou FMA, porém em MAM no caso de Afuá e NDJ em Muaná e Salvaterra apresentam o pico de JAS a SON. Oeiras do Pará apresenta AMJ, porém a diferença para ASO é de apenas três casos, 484 ante 481. 


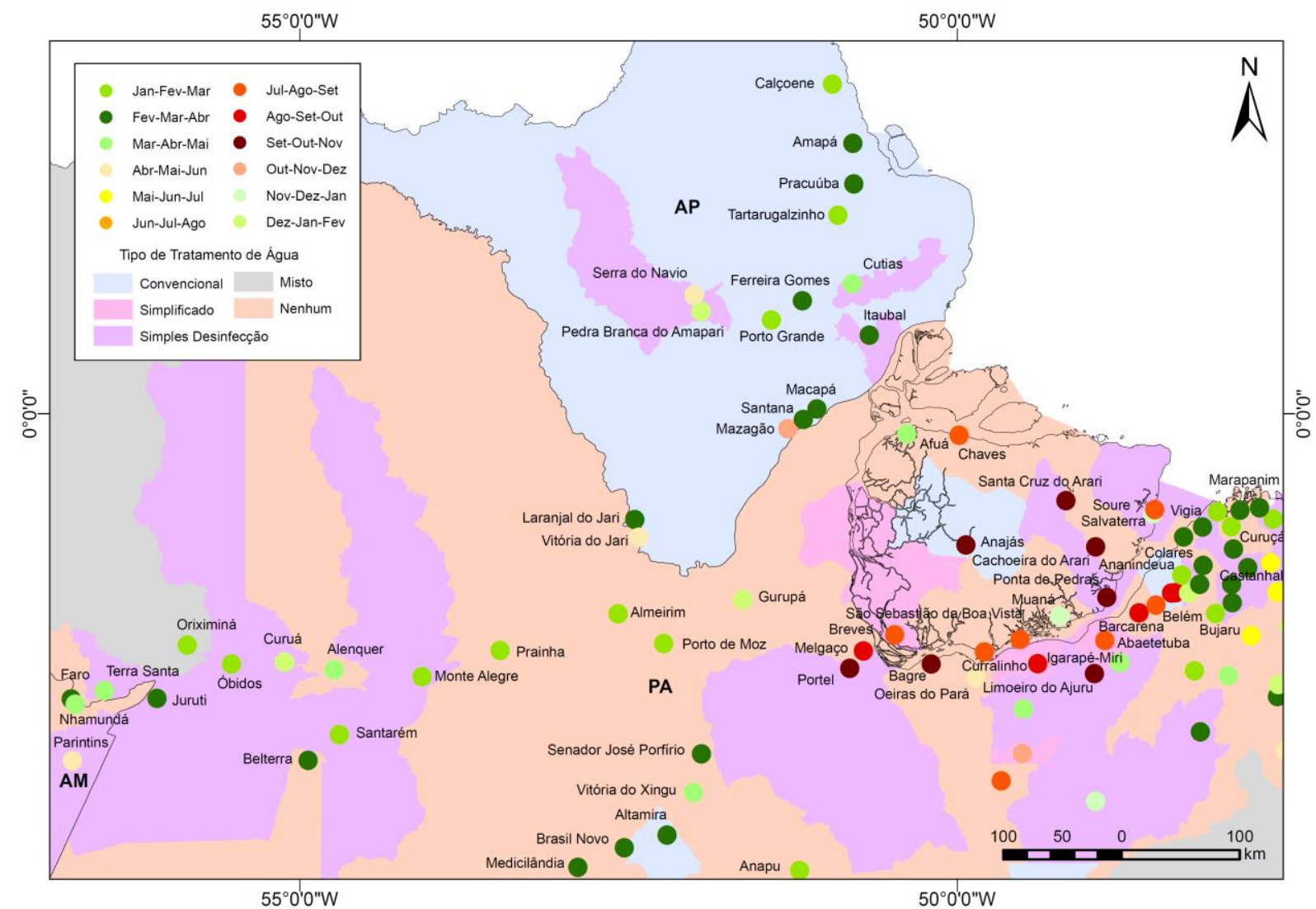

Figura C-6: Trimestre de maior número de internações por DGOIP e tipo de tratamento de água de abastecimento urbano por município da região do Baixo Amazonas (1998-2012).

Fonte: Elaborado pelo autor a partir de dados do SIH e ANA ${ }^{11}$.

A capital Belém e os municípios vizinhos de Ananindeua e Marituba apresentam o mesmo comportamento que a Região do Marajó, assim como os municípios vizinhos de Barcarena e Abaetetuba, sendo o trimestre de maior número de internações JAS ou ASO. Entre 1998 e 2012 somente em seis anos o mês de maior registro em Belém não foi agosto ou setembro, sendo que em cinco destes anos foi janeiro, fevereiro ou março.

Na região do Marajó o período de julho a setembro é um período em que o nível das águas dos rios e igarapés baixa e com isso as fontes de água podem se tornar mais contaminadas, além do excesso de turbidez. Este também é um período de redução nos índices pluviométricos. Em estudo realizado pela ANA (2011), dentre todos os municípios da mesorregião do Marajó apenas o município de Santa Cruz do Arari informou não possuir problemas de tratamento da água. E de todos os municípios do Baixo Amazonas atendidos pela Companhia de Saneamento

\footnotetext{
${ }^{11}$ Fonte: AGÊNCIA NACIONAL DE ÁGUAS (ANA). Atlas Brasil: Abastecimento Urbano de Água. Brasília: ANA, 2011. Disponível em: http://atlas.ana.gov.br/Atlas/forms/Home.aspx. Acesso em: 20 abr. 2013.
} 
do Pará (COSANPA), somente em Abaetetuba e Benevides, além de Santa Cruz do Arari, foi informado não haver problemas de tratamento da água.

Toda a região é caracterizada pela existência de sistemas isolados de abastecimento de água, exceto para o sistema que atende Belém, Ananindeua e Marituba (BAM). No entanto, nessa região uma grande parte da população é ribeirinha e não é atendida pela rede geral. De todas as cidades paraenses representadas na Figura C-6, somente Afuá, Anajás e Bagre possuem mananciais superficiais. O sistema BAM é misto, assim como os sistemas que atendem Belterra, Melgaço e Oriximiná. Os demais dependem de poços subterrâneos. Todos os municípios no Amapá possuem algum tipo de tratamento de água. Já no Pará apenas o sistema BAM possui ETA convencional, assim como os sistemas que atendem Altamira e Anajás. Os demais municípios possuem formas menos exigentes de tratamento, com destaque para trinta municípios da região do Baixo Amazonas que não possuem qualquer tipo de tratamento. Dentre as soluções sugeridas pela ANA para o abastecimento de água da região do Marajó, destaca-se a substituição dos poços rasos por poços profundos e a implantação de estações de tratamento de água.

Região Metropolitana de Belo Horizonte: Em Minas Gerais, dos 853 municípios do Estado, apenas 21 apresentam o trimestre MJJ como o de maior número de internações. No entanto, chama a atenção que desses 21 , onze estão localizados na Região Metropolitana de Belo Horizonte (RMBH), e nove são abastecidos por água dos sistemas integrados de abastecimento dessa região (Figura C-7). Outros seis municípios da RMBH possuem o trimestre JJA como o de maior número de internações sendo que, somados aos onze de MJJ, correspondem a metade dos 34 municípios. Em Sarzedo, Mário Campos, Raposos e São Joaquim de Bicas o trimestre MJJ é o segundo com maior número de casos, assim como em Pedro Leopoldo, Confins, São José da Lapa, Vespasiano, Jaboticatubas, Esmeralda e Florestal.

O comportamento em Belo Horizonte foi semelhante na maioria dos anos, sendo que em dez anos o mês de maior registro foi maio, junho ou julho, ou seja, no período do meio do ano. Em outros quatro anos foi setembro. Um total de $77 \%$ dos casos de internações ocorreram na faixa etária de crianças menores de cinco anos. A hipótese mais plausível para as infecções diarreicas serem mais frequentes nos meses de estiagem/frio em algumas regiões está relacionado a infecções virais. $\mathrm{O}$ fato de ser mais pronunciado em uma Região Metropolitana provavelmente está relacionado ao adensamento populacional e maior risco de propagação de 
infecções virais transmitidas também pelo contato pessoa a pessoa, como ocorre com o rotavírus, norovírus, adenovírus entre outros.

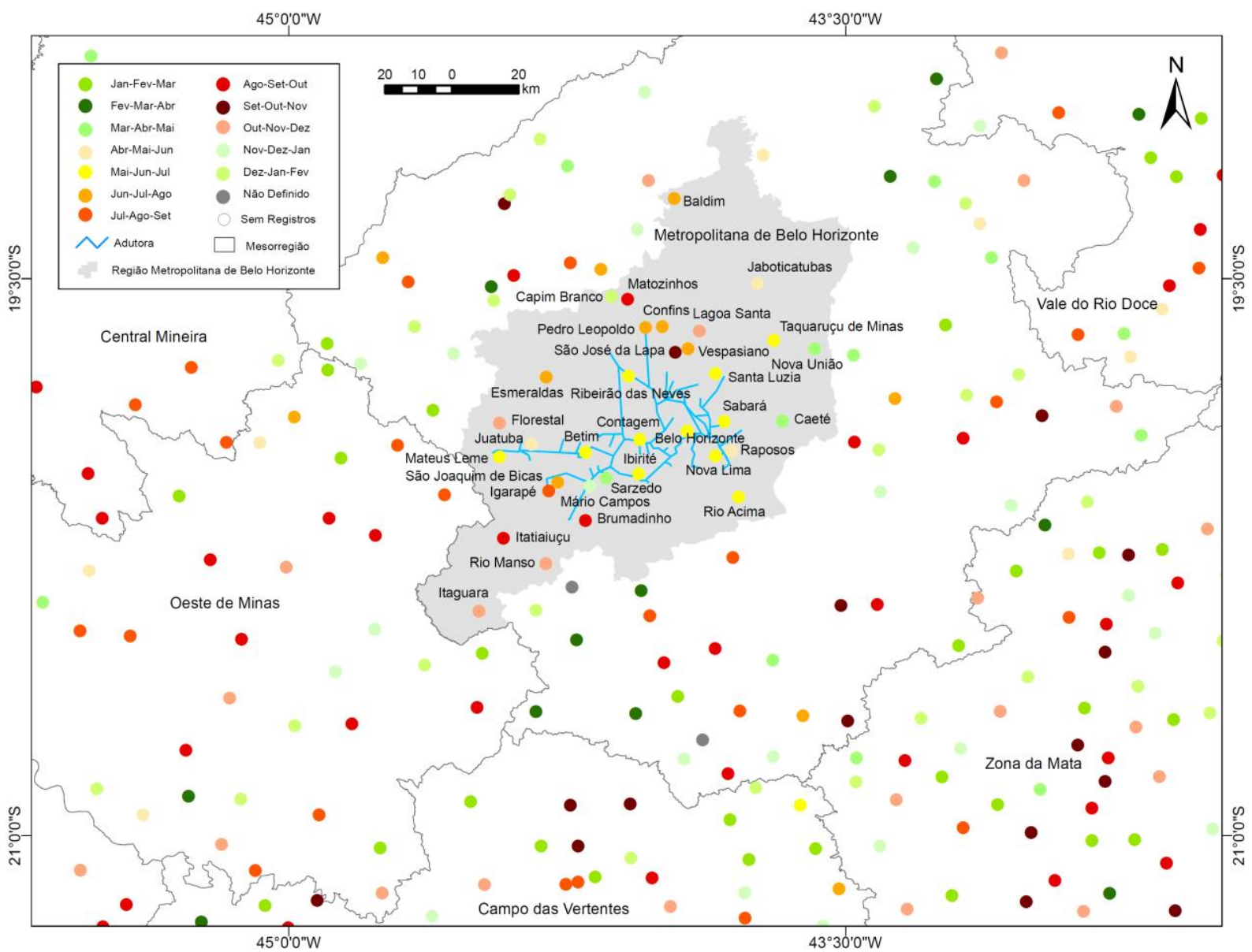

Figura C-7: Trimestre de maior número de internações por DGOIP na Região Metropolitana de Belo Horizonte e arredores (1998-2012).

Fonte: Elaborado pelo autor a partir de dados do SIH e ANA.

Os municípios de Belo Horizonte, Contagem, Ibirité, Ribeirão das Neves, Vespasiano, Betim e Santa Luzia, estão, nessa ordem, entre os dez municípios com maiores densidades demográficas do Estado (IBGE, 2010), sendo que em Belo Horizonte o valor é superior a sete mil habitantes por $\mathrm{km}^{2}$. A RMBH é também a terceira maior região metropolitana do país, atrás apenas de São Paulo e Rio de Janeiro, com população aproximada de 5,5 milhões de habitantes (IBGE, 2010). Os municípios de Juiz de Fora, Rio de Janeiro e São Paulo também apresentam maior número de internações em MJJ. 
Os sete sistemas integrados de abastecimento de água da RMBH são complexos e podem auxiliar na explicação desse padrão, pois observa-se na Figura C-7 que os municípios cujo pico é em MJJ são abastecidos por adutoras que distribuem a água proveniente destes sistemas produtores. No entanto, haja vista o grande número possível de causas para as diarreias e gastroenterites, não há como se fazer uma associação precisa entre a qualidade da água distribuída e a ocorrência das doenças, principalmente porque há diferentes fontes de abastecimento de água, os patógenos são diversificados e poucos são os estudos já realizados no Brasil que comprovam o agente etiológico das ocorrências ${ }^{12}$.

Por fim, além das sete áreas selecionadas, outras poderiam ser estudadas, como os municípios do Pantanal Mato-Grossense, onde o maior registro de internações por DGOIP ocorre entre JAS e OND (vide Figura 5.4), ou do Sudeste da Bahia e Nordeste de Minas Gerais, onde tanto em Jequié como Vitória da Conquista, Montes Claros e Governador Valadares, os maiores municípios da região, que estão na área onde o pico da chuva é em NDJ, o pico das internações ocorre em DJF (Figura C-1).

\footnotetext{
${ }^{12}$ Segundo informações fornecidas pela COPASA, as análises exigidas pelo Ministério da Saúde são integralmente cumpridas na rede de abastecimento da RMBH e não demonstram qualquer nível de contaminação preocupante.
} 


\section{ANEXO A}

\section{Sistemas de Abastecimento de Água ${ }^{13}$}

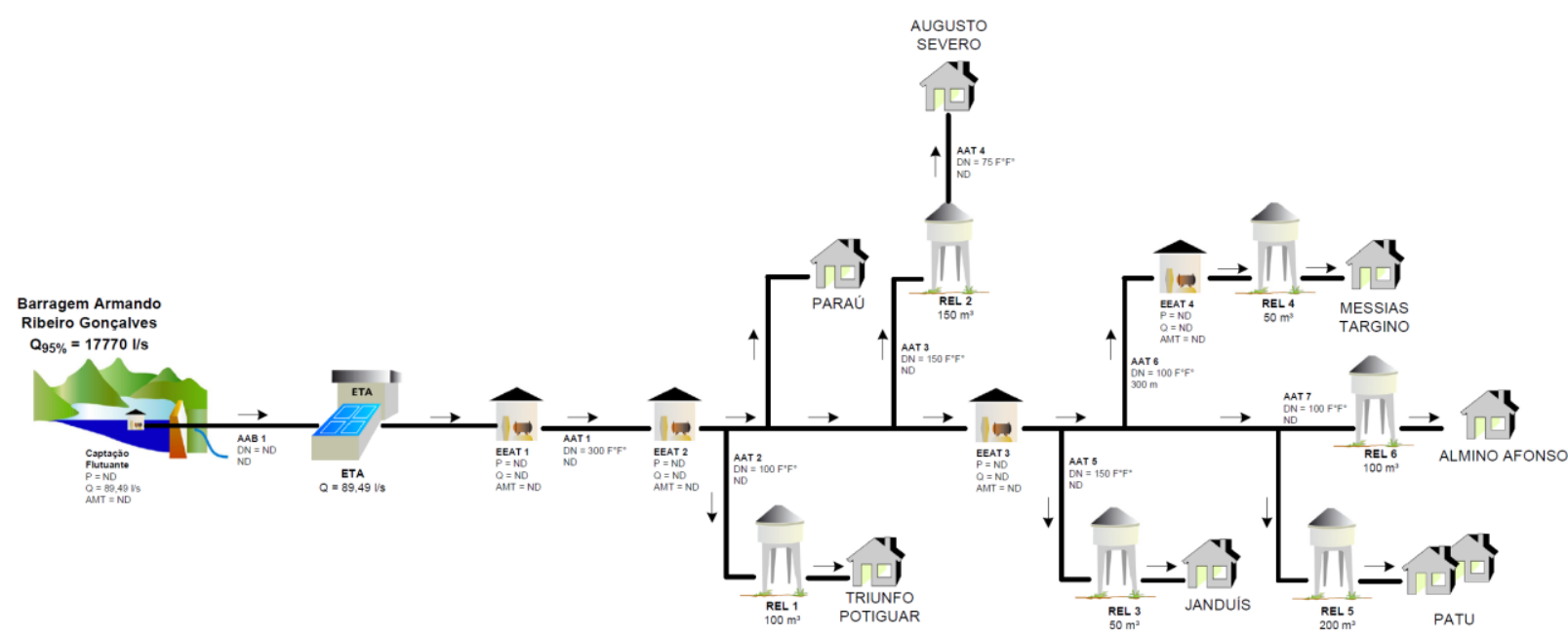

1) Sistema Integrado Médio Oeste

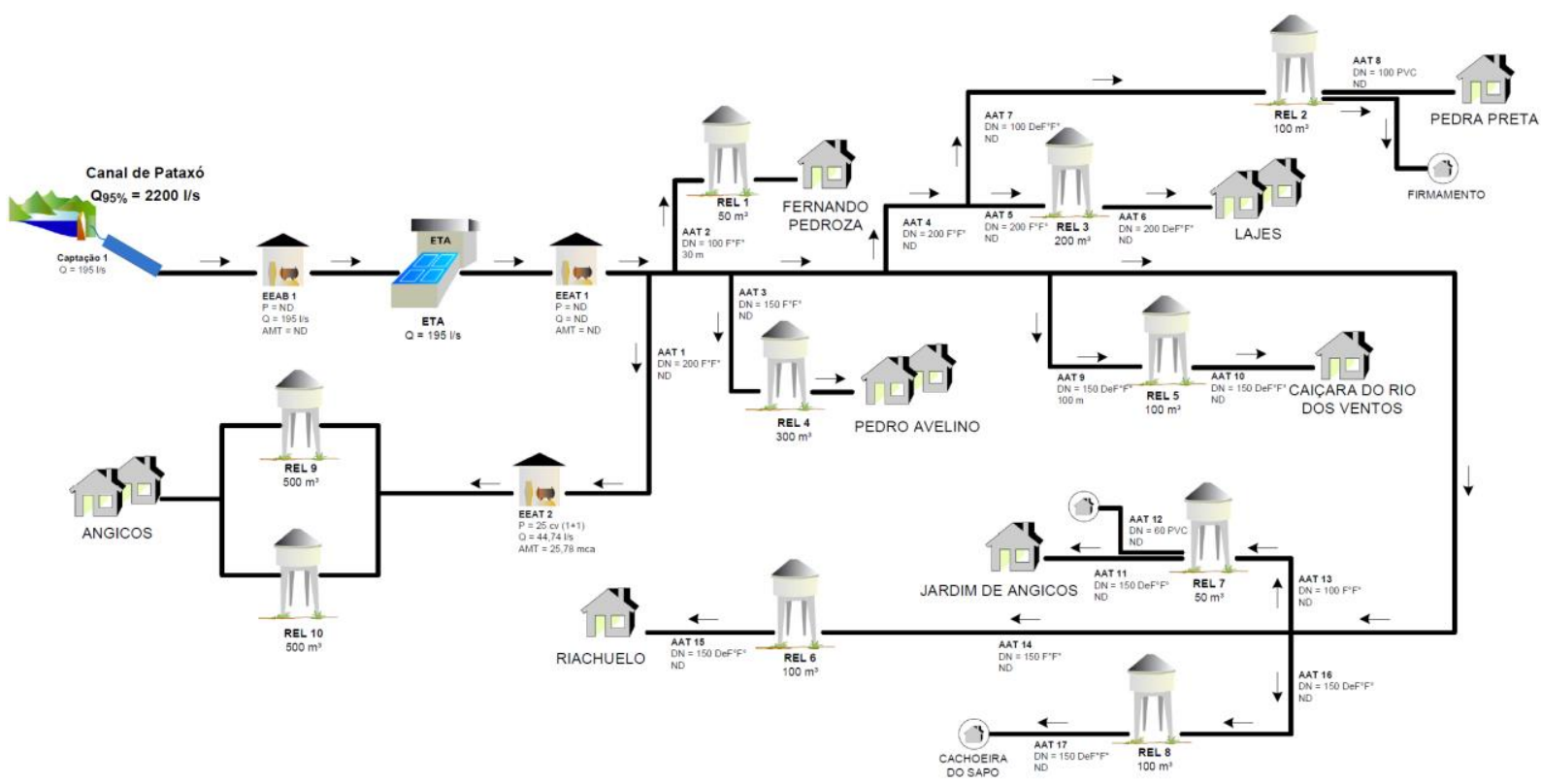

2) Sistema Integrado Sertão Central Cabugi

${ }^{13}$ Fonte: AGÊNCIA NACIONAL DE ÁGUAS (ANA). Atlas Brasil: Abastecimento Urbano de Água. Brasília: ANA, 2011. Disponível em: http://atlas.ana.gov.br/Atlas/forms/Home.aspx. Acesso em: 20 abr. 2013. 


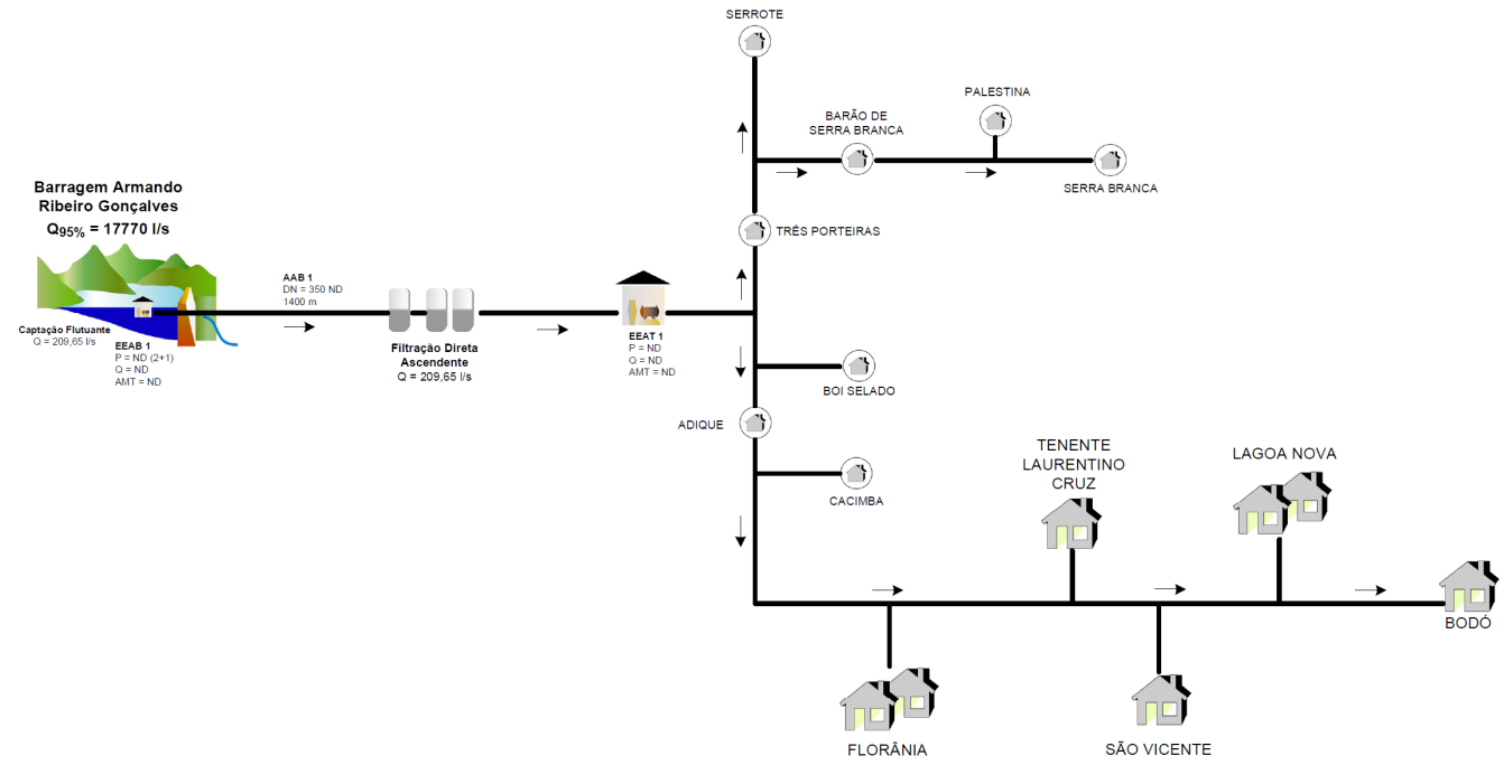

3) Sistema Integrado Serra de Santana

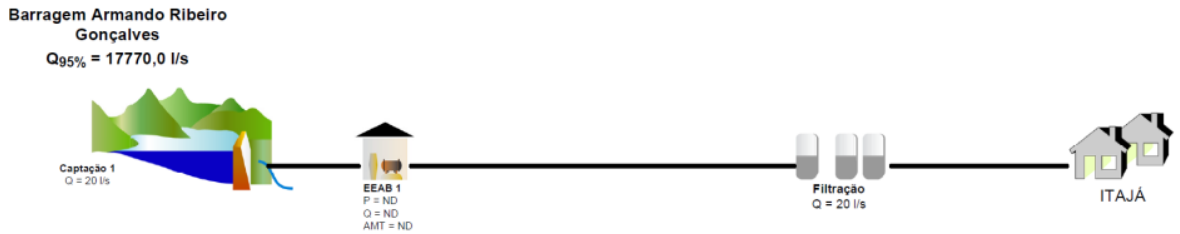

Barragem Armando

Ribeiro Gonçalves

$Q_{95 \%}=17770 \mathrm{l} / \mathrm{s}$

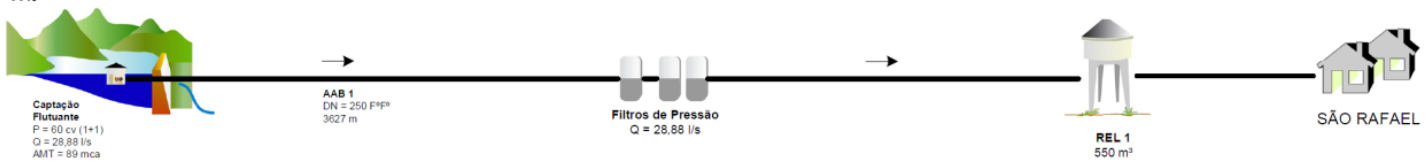

4) Sistemas Isolados Itajá e São Rafael 


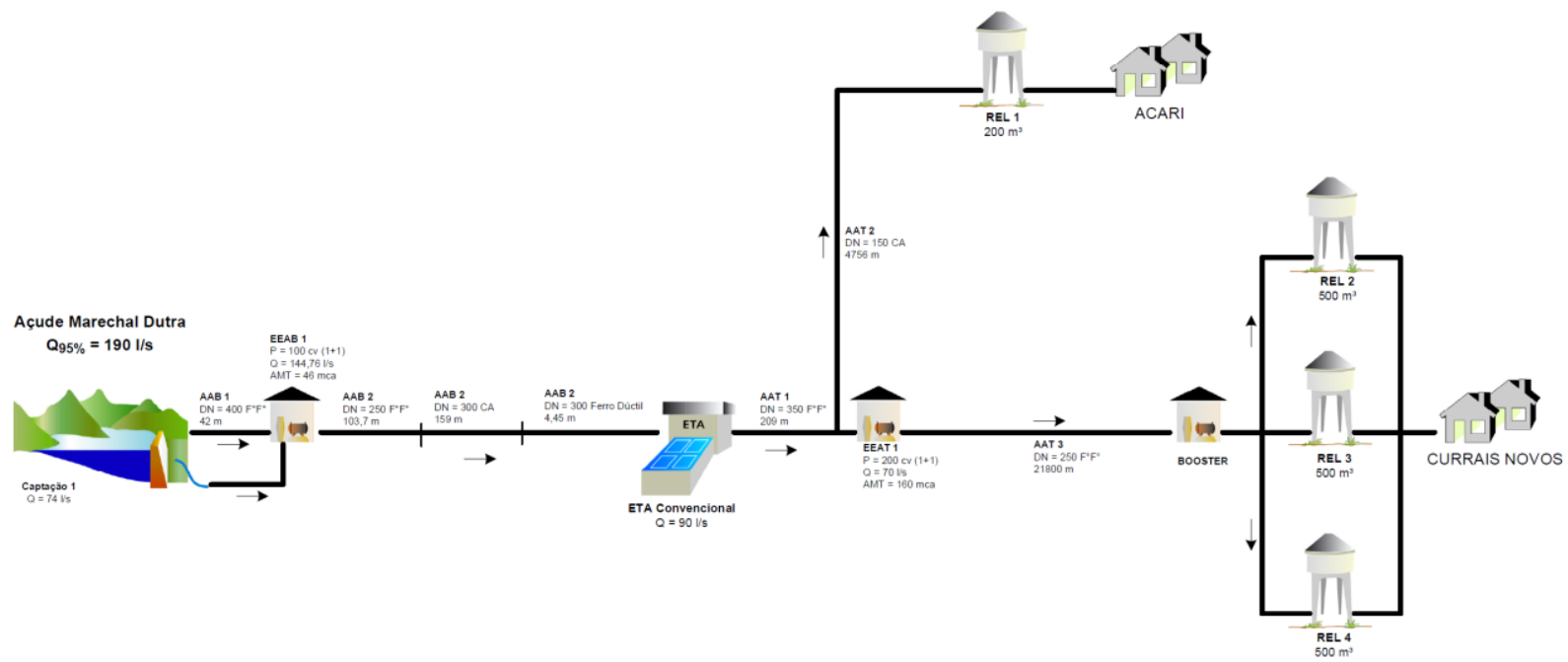

5) Sistema Integrado Gargalheiras (Acari-Currais Novos)

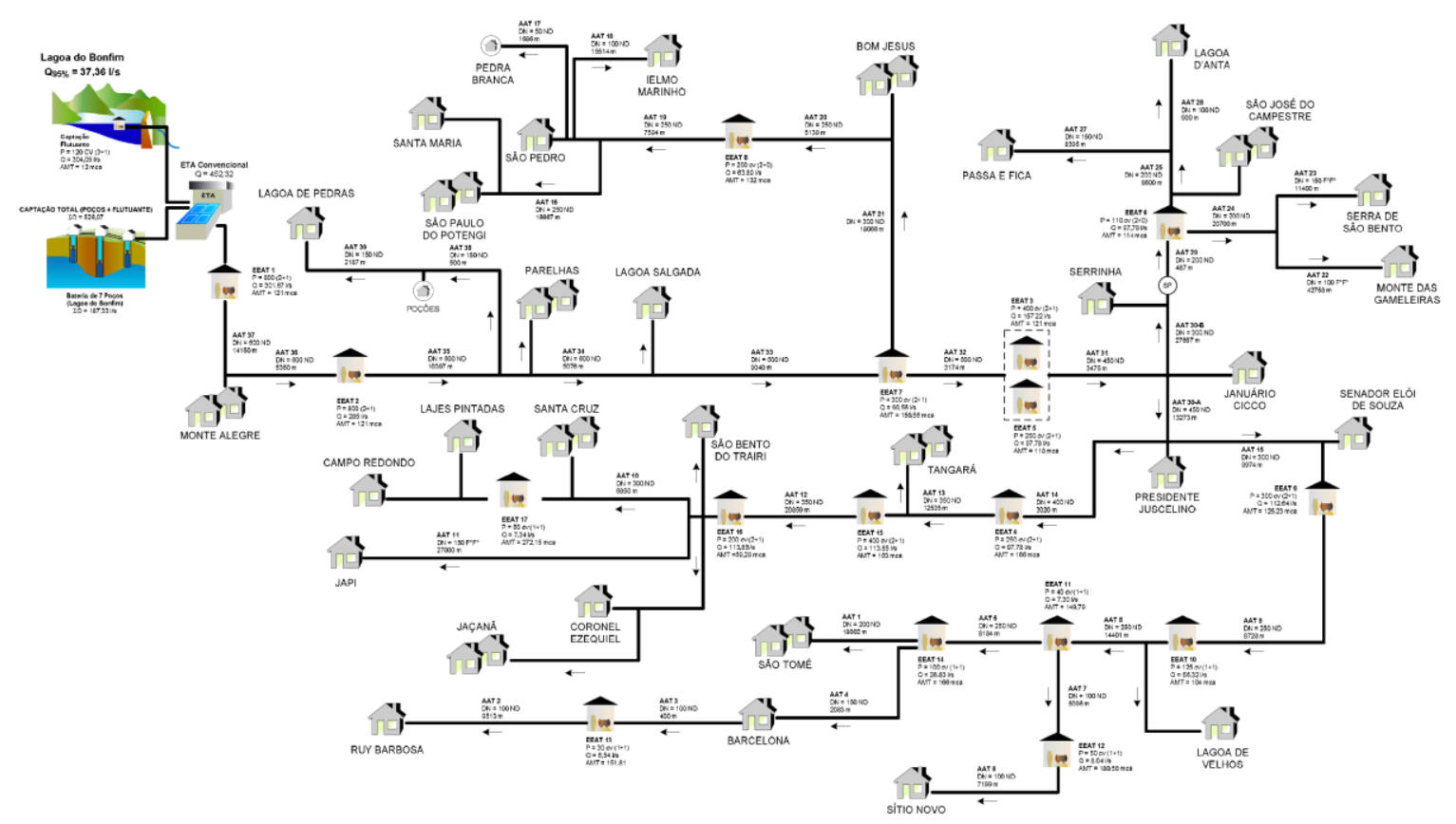

6) Sistema Integrado Monsenhor Expedito 


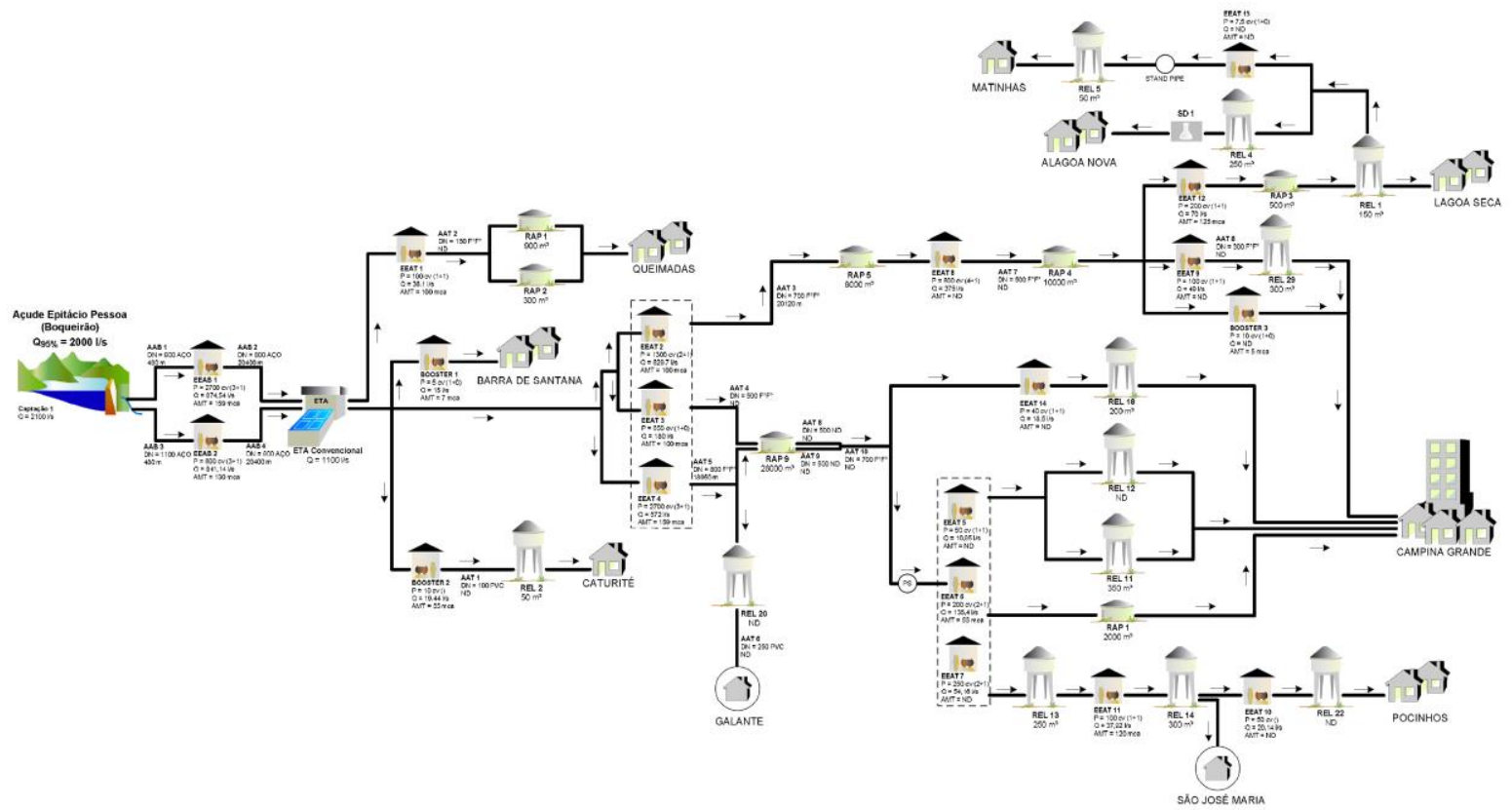

7) Sistema Integrado Campina Grande

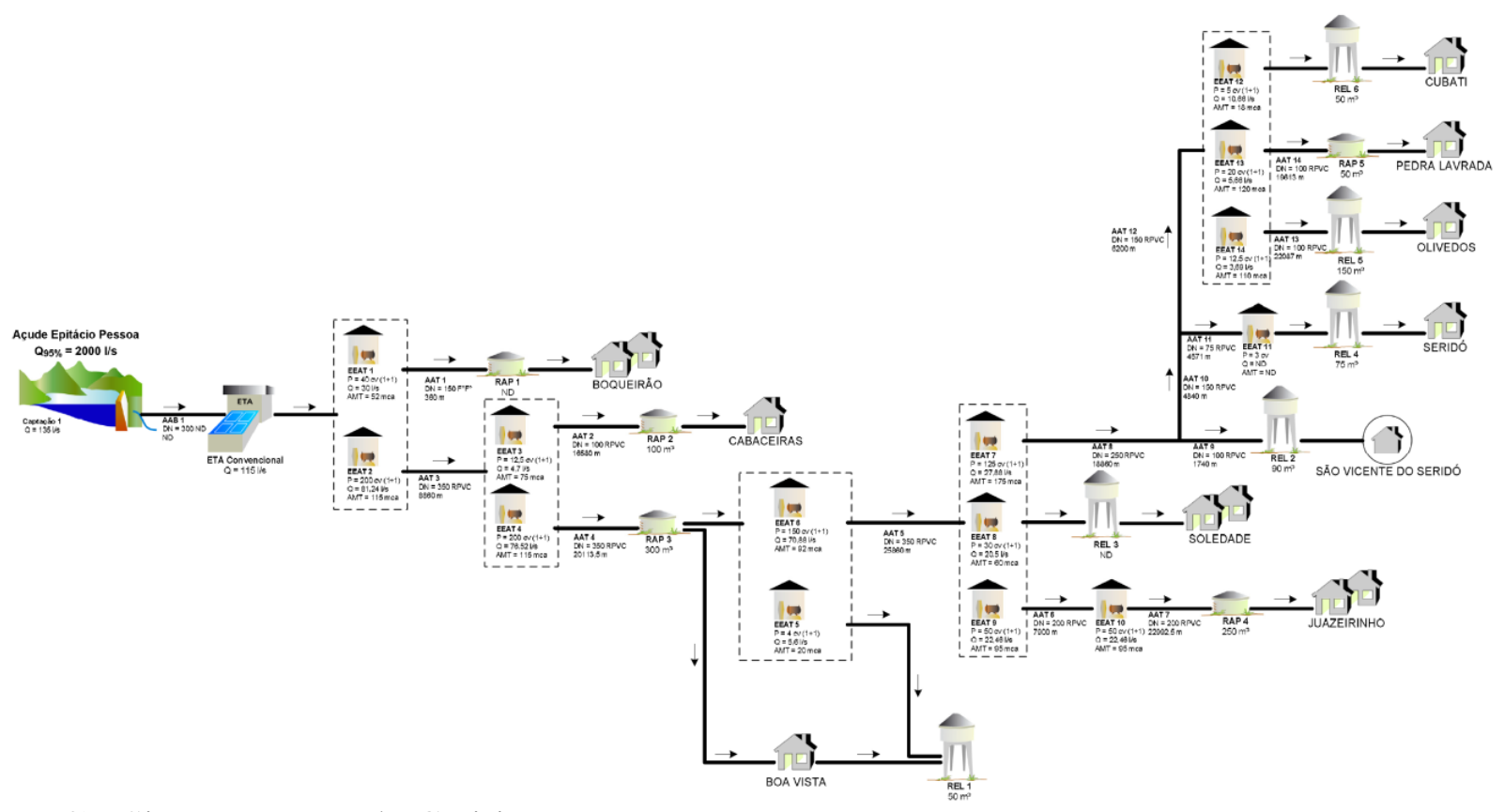

8) Sistema Integrado Cariri 


\section{ANEXO B}

\section{Calendário de Semanas Epidemiológicas}

\begin{tabular}{|c|c|c|c|c|c|c|c|c|c|c|c|c|c|c|c|c|c|c|c|c|}
\hline \multicolumn{3}{|c|}{2002} & \multicolumn{3}{|c|}{2003} & \multicolumn{3}{|c|}{2004} & \multicolumn{3}{|c|}{2005} & \multicolumn{3}{|c|}{2006} & \multicolumn{3}{|c|}{2007} & \multicolumn{3}{|c|}{2008} \\
\hline s1 & $30 / 12 / 01$ & $5 / 01 / 02$ & s1 & $29 / 12 / 02$ & 4/01/03 & s1 & $04 / 01 / 04$ & $0 / 01 / 04$ & s1 & $2 / 01 / 05$ & $8 / 01 / 05$ & s1 & $01 / 01 / 06$ & $07 / 01 / 06$ & s1 & $31 / 12 / 06$ & $06 / 01 / 07$ & s1 & $30 / 12 / 07$ & $05 / 01 / 08$ \\
\hline s2 & 06/01/02 & $2 / 01 / 02$ & s2 & $5 / 01 / 03$ & $1 / 01 / 03$ & s2 & & & s2 & & & s2 & & & s2 & & & s2 & & \\
\hline s3 & $13 / 01 / 02$ & & s3 & $12 / 01 / 03$ & & s3 & & & s3 & & & s3 & & & s3 & & & s3 & & \\
\hline s4 & 20/01/02 & $26 / 01 / 02$ & s4 & 19/01/03 & $25 / 01 / 03$ & s4 & $25 / 01 / 04$ & $31 / 01 / 04$ & s4 & 23/01/05 & 29/01/05 & s4 & $22 / 01 / 06$ & $28 / 01 / 06$ & s4 & $21 / 01 / 07$ & & s4 & $01 / 08$ & \\
\hline s5 & $27 / 01 / 02$ & $02 / 0$ & s5 & $26 / 01 / 03$ & $01 / 02 / 03$ & s5 & $01 / 02 / 04$ & $07 / 0$ & s5 & $30 / 01 / 05$ & 05 & s5 & 29/01/06 & $04 / 0$ & s5 & $28 / 01 / 07$ & & s5 & /08 & \\
\hline s6 & 03/02/02 & $09 / 0$ & s6 & $02 / 02 / 03$ & $08 / 0$ & s6 & 08/02/04 & $14 / 0$ & s6 & & & co & & & s6 & & & s6 & & \\
\hline s7 & $10 / 02 / 02$ & $16 / 02 / 02$ & s7 & 09/02/03 & $15 / 02 / 03$ & s7 & $15 / 02 / 04$ & $21 / C$ & s7 & $13 / 02 / 05$ & & s7 & $12 / 02 / 06$ & & s7 & & & s7 & 2/08 & \\
\hline s8 & $17 / 0$ & $23 / 0$ & s8 & $16 / 02 / 03$ & $22 / 0$ & s8 & $22 / 02 / 04$ & $28 /($ & s8 & & & & & & s8 & & & s8 & & \\
\hline s9 & $24 / 0$ & $02 / 0$ & s9 & $23 / 0$ & $01 /$ & s9 & $29 /$ & $06 /($ & s9 & & & & & & s9 & & & s9 & & \\
\hline s10 & $03 / 0$ & $09 / 0$ & s10 & 02/03/03 & $08 /$ & s10 & 07/03/04 & & s10 & $06 / 03$ & & s10 & 03/06 & & s10 & & & s10 & 08 & \\
\hline & & & & & & & & & & & & & & & & & & & & \\
\hline s12 & $17 / 0$ & $23 / C$ & & $16 / c$ & & s12 & & & & & & & & & s12 & & & s12 & & \\
\hline s13 & $24 / 0$ & $30 / 0$ & & $23 / 0$ & $29 /$ & s13 & $28 /($ & 03/ & 13 & $27 /$ & & & /06 & & s13 & & & s13 & $/ 08$ & \\
\hline s14 & $31 / 0$ & $06 / C$ & & $30 / 0$ & & s14 & & & & & & & & & s14 & & & & & \\
\hline s15 & $07 / 0$ & & & $06 / 0$ & & s15 & & & & & & & & & s15 & & & s15 & & \\
\hline s16 & $14 / C$ & $20 / 0$ & & $13 /$ & & s16 & $18 /$ & & & & & & $16 /$ & & & & & s16 & & \\
\hline s17 & $21 / 0$ & $27 / 0$ & s17 & $20 / 04 / 03$ & $26 /$ & s17 & $25 / 04 / 04$ & $01 /$ & 17 & $24 / C$ & & & 106 & & s17 & & /07 & s17 & /08 & \\
\hline s18 & $28 / 0$ & $04 / 0$ & & $27 / 04 / 03$ & 03/ & s18 & $02 /($ & & 18 & & & & & & s18 & & & s18 & & \\
\hline s19 & $05 / 05 / 02$ & & & $04 / 0$ & & s19 & & & & & & & & & & & & s19 & & \\
\hline s20 & $12 / 05 / 02$ & $18 / 05$ & s20 & $11 / 05 / 03$ & $17 / 05 / 03$ & s20 & $16 / 05 / 04$ & $22 / 0$ & s20 & $15 / 05 / 05$ & & s20 & $14 / 05 / 06$ & & s20 & $5 / 07$ & $5 / 07$ & s20 & /08 & $/ 08$ \\
\hline s21 & 19/05/02 & $25 / 0$ & s21 & $18 / 05 / 03$ & 24/05/03 & s21 & $23 / 05 / 04$ & $29 / C$ & s21 & $22 / 05 / 05$ & & s21 & /05/06 & & s21 & & /07 & s21 & /08 & \\
\hline s22 & $26 / 05 / 02$ & 01/06/02 & s22 & $25 / 05 / 03$ & $31 / 06 / 03$ & s22 & & 05/06/04 & s22 & & & s22 & & & s22 & & & s22 & & \\
\hline s23 & 02/06/02 & 08/06/02 & s23 & 01/06/03 & 07/06/03 & s23 & 06/06/04 & $12 / 06 / 04$ & s23 & 05/06/05 & $11 / 06 / 05$ & s23 & 04/06/06 & $10 / 06 / 06$ & s23 & 03/06/07 & 09/06/07 & s23 & 01/06/08 & 07/06/08 \\
\hline s24 & 09/06/02 & $15 / 06 / 02$ & s24 & 08/06/03 & $14 / 06 / 03$ & s24 & $13 / 06 / 04$ & $19 / 06 / 04$ & s24 & $12 / 06 / 05$ & $18 / 06 / 05$ & s24 & $11 / 06 / 06$ & $17 / 06 / 06$ & s24 & $10 / 06 / 07$ & $16 / 06 / 07$ & s24 & 08/06/08 & $14 / 06 / 08$ \\
\hline s25 & $16 / 06 / 02$ & $22 / 06 / 02$ & s25 & $15 / 06 / 03$ & $21 / 06 / 03$ & s25 & $20 / 06 / 04$ & $26 / 06 / 04$ & s25 & $19 / 06 / 05$ & $25 / 06 / 05$ & s25 & $18 / 06 / 06$ & $24 / 06 / 06$ & s25 & $17 / 06 / 07$ & $23 / 06 / 07$ & $s 25$ & $15 / 06 / 08$ & $21 / 06 / 08$ \\
\hline
\end{tabular}




\begin{tabular}{|c|c|c|c|c|c|c|c|c|c|c|c|c|c|c|c|c|c|c|c|c|}
\hline \multicolumn{3}{|c|}{2002} & \multicolumn{3}{|c|}{2003} & \multicolumn{3}{|c|}{2004} & \multicolumn{3}{|c|}{2005} & \multicolumn{3}{|c|}{2006} & \multicolumn{3}{|c|}{2007} & \multicolumn{3}{|c|}{2008} \\
\hline s26 & $23 / 06 / 02$ & $29 / 06 / 02$ & s26 & $22 / 06 / 03$ & $28 / 06 / 03$ & s26 & $27 / 06 / 04$ & $03 / 07 / 04$ & 26 & $26 / 06 / 05$ & $02 / 07 / 05$ & s26 & $25 / 06 / 06$ & 01/07/06 & $s 26$ & $24 / 06 / 07$ & $30 / 06 / 07$ & s26 & $22 / 06 / 08$ & $28 / 06 / 08$ \\
\hline s27 & $30 / 06 / 02$ & 06/07/02 & s27 & 29/06/03 & 05/07/03 & s27 & $04 / 07 / 04$ & $10 / 07 / 04$ & 27 & 03/07/05 & & s27 & 2/07/06 & 3/07/06 & s27 & 1/07/07 & & s27 & 29/06/08 & \\
\hline s28 & 07/07/02 & 3/07/02 & 28 & / $/ 07 / 03$ & 2/07/03 & s28 & 7/04 & & 28 & /07/05 & & 28 & & & s28 & & & s28 & & \\
\hline s29 & $4 / 07 / 02$ & 20/07/02 & 29 & & & 29 & & & 29 & & & & & & s29 & 7/07 & 21/07/07 & s29 & 7/08 & \\
\hline s30 & $21 / 07 / 02$ & 27/07/02 & 30 & 20/07/03 & 26/07/03 & s30 & $25 / 07 / 04$ & $31 / 07 / 04$ & 30 & 24/07/05 & 0/07/05 & 30 & 23/07/06 & 29/07/06 & s30 & $22 / 07 / 07$ & 28/07/07 & s30 & 20/07/08 & /08 \\
\hline s31 & $28 / 07 / 02$ & 03/08/02 & & $27 / 07 / 03$ & $02 / 0$ & 31 & $01 /$ & $07 / C$ & 31 & $31 / 07 / 05$ & 05 & & 06 & /06 & s31 & $29 / 07 / 07$ & & s31 & $7 / 08$ & \\
\hline s32 & $04 / 08 / 02$ & $10 / 08 / 02$ & 32 & 03/08/03 & $09 / 0$ & 32 & $/ 04$ & & 32 & 07/08/05 & & & & & s32 & $8 / 07$ & & s32 & 3/08 & \\
\hline s33 & $11 / 08 / 02$ & $17 / 08 / 02$ & 33 & $10 / 08 / 03$ & $16 / 08 / 03$ & s33 & $08 / 04$ & $21 /($ & 33 & $14 / 08 / 05$ & & s33 & $13 / 08 / 06$ & /06 & s33 & 08/07 & /07 & s33 & $08 / 08$ & \\
\hline s34 & $18 / 0$ & $24 / 0$ & & $17 / 0$ & & & & & & & & & & & & & & s34 & & \\
\hline s35 & $25 / 08 / 02$ & $31 / 0$ & 35 & $24 / 08 / 03$ & $30 / 0$ & s35 & $8 / 04$ & $04 /($ & 35 & $28 / 08 / 05$ & & & /06 & & s35 & $8 / 07$ & & s35 & $8 / 08$ & \\
\hline s36 & $01 / 09 / 02$ & $07 / 0$ & 36 & $31 / 08 / 03$ & $06 / 0$ & s36 & $/ 04$ & $11 /$ & 36 & 04/09/05 & & 36 & $03 / 0 \varsigma$ & /06 & s36 & 02/09/07 & /07 & s36 & $31 / 08 / 08$ & \\
\hline s37 & $08 / 09$ & $14 / 0$ & 37 & 07/09/03 & & & & & 37 & & & & & & s37 & /07 & & s37 & /08 & \\
\hline s38 & $15 / 09 / 02$ & $21 / 0$ & 38 & $14 / 09 / 03$ & $20 / 0$ & s38 & $9 / 04$ & $25 /($ & 38 & $18 / 09 / 05$ & & 38 & & & s38 & $9 / 07$ & & s38 & $/ 08$ & \\
\hline s39 & $22 / 09 / 02$ & $28 / 0$ & 39 & $21 / 09 / 03$ & $27 / C$ & s39 & $26 /($ & $02 /$ & 39 & $25 / C$ & & & 06 & & s39 & $9 / 07$ & & s39 & $/ 08$ & \\
\hline s40 & $29 / 09 / 02$ & $05 / 1$ & 40 & $28 / 09 / 03$ & $04 /$ & $s 40$ & /04 & & 40 & $02 /$ & & & & & s40 & /07 & & s40 & $/ 08$ & \\
\hline s41 & 06/10/02 & $12 / 10$ & & 05/10/03 & & s41 & & & & & & & & & s41 & & & s41 & & \\
\hline s42 & $13 / 1$ & $19 / 1$ & & $12 / 1$ & $18 /$ & s42 & $17 /$ & 23/ & 42 & $16 /$ & & & & & s42 & /07 & & s42 & & \\
\hline s43 & $20 / 10 / 02$ & $26 / 10$ & 43 & $19 / 10 / 03$ & $25 / 1$ & s43 & $24 / 10 / 04$ & $30 /$ & 43 & 10/05 & & & & & s43 & /07 & & s43 & /08 & \\
\hline s44 & 27/10/02 & $02 / 1$ & & 26/10/03 & & s44 & & & & & & & & & s44 & & & s44 & & \\
\hline s45 & $03 / 11 / 02$ & $09 / 1$ & 40 & $02 /$ & & s45 & & & 45 & & & & & & s45 & & & s45 & /08 & \\
\hline s46 & $10 / 11 / 02$ & $16 / 1$ & 46 & $09 / 11 / 03$ & $15 / 1$ & s46 & $1 / 1 / 04$ & $20 /$ & 46 & $11 / 05$ & & 46 & & & s46 & & & s46 & /08 & \\
\hline s47 & 17/11/02 & $23 / 1$ & & & & s47 & & & & & & & & & s47 & & & s47 & & \\
\hline s48 & $24 / 11 / 02$ & $30 / 1$ & 48 & $23 / 11 / 03$ & & s48 & $28 /$ & 04/ & 48 & $27 /$ & & & & 02/ & s48 & /07 & & s48 & & \\
\hline s49 & $01 / 12 / 02$ & 07/12/02 & 49 & $30 / 11 / 03$ & 06/12/03 & s49 & $05 / 12 / 04$ & $11 /$ & s49 & $04 / 12 / 05$ & $2 / 05$ & s49 & $12 / 06$ & $/ 06$ & s49 & $12 / 07$ & $2 / 07$ & s49 & $30 / 11 / 08$ & $2 / 08$ \\
\hline s50 & 08/12/02 & $14 / 12 / 02$ & 50 & 07/12/03 & & s50 & $12 / 12 / 04$ & & s50 & $11 / 12 / 05$ & & & & & s50 & & & s50 & 07/12/08 & \\
\hline s51 & 15/12/02 & $21 / 12 / 02$ & s51 & $14 / 12 / 03$ & 20/12/03 & s51 & $19 / 12 / 04$ & $25 / 12 / 04$ & 51 & $18 / 12 / 05$ & 24/12/05 & 51 & $17 / 12 / 06$ & 2/06 & s51 & $16 / 12 / 07$ & 22/12/07 & s51 & $14 / 12 / 08$ & $20 / 12$ \\
\hline s52 & $22 / 12 / 02$ & 28/12/02 & s52 & $21 / 12 / 03$ & 27/12/03 & s52 & 26/12/04 & 01/01/05 & s52 & $25 / 12 / 05$ & $31 / 12 / 05$ & s52 & 24/12/06 & $30 / 12 / 06$ & s52 & 23/12/07 & 29/12/07 & s52 & $21 / 12 / 08$ & $27 / 12 / 08$ \\
\hline & & & s53 & 28/12/03 & 03/01/04 & & & & & & & & & & & & & s53 & $28 / 12 / 08$ & 03/01/09 \\
\hline
\end{tabular}




\begin{tabular}{|c|c|c|c|c|c|c|c|c|c|c|c|c|c|c|c|c|c|}
\hline \multicolumn{3}{|c|}{2009} & \multicolumn{3}{|c|}{2010} & \multicolumn{3}{|c|}{2011} & \multicolumn{3}{|c|}{2012} & \multicolumn{3}{|c|}{2013} & \multicolumn{3}{|c|}{2014} \\
\hline s1 & $04 / 01 / 09$ & $10 / 01 / 09$ & s1 & $03 / 01 / 10$ & $09 / 01 / 10$ & $\mathrm{~s} 1$ & $02 / 01 / 11$ & $08 / 01 / 11$ & s1 & $01 / 01 / 12$ & $07 / 01 / 12$ & s1 & $30 / 12 / 12$ & $05 / 01 / 13$ & s1 & $29 / 12 / 13$ & $04 / 01 / 14$ \\
\hline s2 & $11 / 01 / 09$ & $17 / 01 / 09$ & s2 & $10 / 01 / 10$ & $16 / 01 / 10$ & s2 & $09 / 01 / 11$ & $15 / 01 / 11$ & s2 & $08 / 01 / 12$ & $14 / 01 / 12$ & s2 & $06 / 01 / 13$ & $12 / 01 / 13$ & s2 & $05 / 01 / 14$ & $11 / 01 / 14$ \\
\hline s3 & $18 / 01 / 09$ & $24 / 01 / 09$ & s3 & $17 / 01 / 10$ & $23 / 01 / 10$ & s3 & $16 / 01 / 11$ & $22 / 01 / 11$ & s3 & $15 / 01 / 12$ & $21 / 01 / 12$ & s3 & $13 / 01 / 13$ & $19 / 01 / 13$ & s3 & $12 / 01 / 14$ & $18 / 01 / 14$ \\
\hline s4 & $25 / 01 / 09$ & $31 / 01 / 09$ & s4 & $24 / 01 / 10$ & $30 / 01 / 10$ & s4 & $23 / 01 / 11$ & $29 / 01 / 11$ & s4 & $22 / 01 / 12$ & $28 / 01 / 12$ & s4 & $20 / 01 / 13$ & $26 / 01 / 13$ & s4 & $19 / 01 / 14$ & $25 / 01 / 14$ \\
\hline s5 & 01/02/09 & 07/02/09 & s5 & $31 / 01 / 10$ & $06 / 02 / 10$ & s5 & $30 / 01 / 11$ & $05 / 02 / 11$ & s5 & $29 / 01 / 12$ & $04 / 02 / 12$ & s5 & $27 / 01 / 13$ & $02 / 02 / 13$ & s5 & $26 / 01 / 14$ & $01 / 02 / 14$ \\
\hline s6 & 08/02/09 & $14 / 02 / 09$ & s6 & $07 / 02 / 10$ & $13 / 02 / 10$ & s6 & $06 / 02 / 11$ & $12 / 02 / 11$ & s6 & $05 / 02 / 12$ & $11 / 02 / 12$ & s6 & $03 / 02 / 13$ & $09 / 02 / 13$ & s6 & $02 / 02 / 14$ & $08 / 02 / 14$ \\
\hline s7 & $15 / 02 / 09$ & $21 / 02 / 09$ & s7 & $14 / 02 / 10$ & $20 / 02 / 10$ & s7 & $13 / 02 / 11$ & $19 / 02 / 11$ & s7 & $12 / 02 / 12$ & $18 / 02 / 12$ & s7 & $10 / 02 / 13$ & $16 / 02 / 13$ & s7 & $09 / 02 / 14$ & $15 / 02 / 14$ \\
\hline s8 & $22 / 02 / 09$ & $28 / 02 / 09$ & s8 & $21 / 02 / 10$ & $27 / 02 / 10$ & s8 & $20 / 02 / 11$ & $26 / 02 / 11$ & s8 & $19 / 02 / 12$ & $25 / 02 / 12$ & s8 & $17 / 02 / 13$ & $23 / 02 / 13$ & s8 & $16 / 02 / 14$ & $22 / 02 / 14$ \\
\hline s9 & $01 / 03 / 09$ & $07 / 03 / 09$ & s9 & $28 / 02 / 10$ & $06 / 03 / 10$ & s9 & $27 / 02 / 11$ & $05 / 03 / 11$ & s9 & $26 / 02 / 12$ & $03 / 03 / 12$ & s9 & $24 / 02 / 13$ & $02 / 03 / 13$ & s9 & $23 / 02 / 14$ & $01 / 0$ \\
\hline s10 & 08/03/09 & $14 / 03 / 09$ & $s 10$ & $07 / 03 / 10$ & $13 / 03 / 10$ & s10 & $06 / 03 / 11$ & $12 / 03 / 11$ & s10 & 04/03/12 & $10 / 03 / 12$ & $s 10$ & 03/03/13 & 09/03/13 & s10 & $02 / 03 / 14$ & $08 / 03 / 14$ \\
\hline s11 & 15/03/09 & $21 / 03 / 09$ & s11 & $14 / 03 / 10$ & $20 / 03 / 10$ & s11 & $13 / 03 / 11$ & $19 / 03 / 11$ & s11 & $11 / 03 / 12$ & & s11 & & $16 / 03 / 13$ & s11 & $3 / 14$ & \\
\hline s12 & $22 / 03 / 09$ & $28 / 03 / 09$ & s12 & $21 / 03 / 10$ & $27 / 03 / 10$ & s12 & $20 / 03 / 11$ & $26 / 03 / 11$ & s12 & $18 / 03 / 12$ & $24 / 03 / 12$ & s12 & $17 / 03 / 13$ & $23 / 03 / 13$ & s12 & $16 / 03 / 14$ & $22 / C$ \\
\hline s13 & $29 / 03 / 09$ & $04 / 04 / 09$ & s13 & $28 / 03 / 10$ & $03 / 04 / 10$ & s13 & $27 / 03 / 11$ & $02 / 04 / 11$ & s13 & $25 / 03 / 12$ & $31 / 03 / 12$ & s13 & $24 / 03 / 13$ & $30 / 03 / 13$ & s13 & $3 / 14$ & $29 /$ \\
\hline s14 & 05/04/09 & $11 / 04 / 09$ & s14 & $04 / 04 / 10$ & $10 / 04 / 10$ & s14 & $03 / 04 / 11$ & $09 / 04 / 11$ & s14 & $01 / 04 / 12$ & $07 / 04 / 12$ & s14 & $31 / 03 / 13$ & $06 / 04 / 13$ & s14 & $30 / 03 / 14$ & \\
\hline s15 & $12 / 04 / 09$ & $18 / 04 / 09$ & s15 & $11 / 04 / 10$ & $17 / 04 / 10$ & s15 & $10 / 04 / 11$ & $16 / 04 / 11$ & s15 & $08 / 04 / 12$ & $14 / 04 / 12$ & s15 & $07 / 04 / 13$ & $13 / 04 / 13$ & s15 & $06 / 04 / 14$ & $12 / 04 / 14$ \\
\hline s16 & $19 / 04 / 09$ & $25 / 04 / 09$ & s16 & $18 / 04 / 10$ & $24 / 04 / 10$ & s16 & $17 / 04 / 11$ & $23 / 04 / 11$ & s16 & $15 / 04 / 12$ & $21 / 04 / 12$ & s16 & $14 / 04 / 13$ & $20 / 04 / 13$ & s16 & $13 / 04 / 14$ & $19 / 04 / 14$ \\
\hline s17 & $26 / 04 / 09$ & $02 / 05 / 09$ & s17 & $25 / 04 / 10$ & $01 / 05 / 10$ & s17 & $24 / 04 / 11$ & $30 / 04 / 11$ & s17 & $22 / 04 / 12$ & $28 / 04 / 12$ & s17 & $21 / 04 / 13$ & $27 / 04 / 13$ & s17 & $20 / 04 / 14$ & $04 / 14$ \\
\hline s18 & 03/05/09 & 09/05/09 & s18 & $02 / 05 / 10$ & $08 / 05 / 10$ & s18 & $01 / 05 / 11$ & $07 / 05 / 11$ & s18 & $29 / 04 / 12$ & $05 / 05 / 12$ & s18 & $28 / 04 / 13$ & $04 / 05 / 13$ & s18 & $27 / 04 / 14$ & $03 /$ \\
\hline s19 & $10 / 05 / 09$ & $16 / 05 / 09$ & s19 & $09 / 05 / 10$ & $15 / 05 / 10$ & s19 & $08 / 05 / 11$ & $14 / 0$ & s19 & $06 / 05 / 12$ & $12 / \mathrm{C}$ & s19 & $05 / 05 / 13$ & $11 / 05 / 13$ & s19 & $04 / 05 / 14$ & $10 / 0$ \\
\hline s2o & $17 / 05 / 09$ & $23 / 05 / 09$ & s20 & $16 / 05 / 10$ & $22 / 05 / 10$ & $s 20$ & $15 / 05 / 11$ & $21 / 05 / 11$ & s20 & $13 / 05 / 12$ & $19 / 05 / 12$ & s20 & $12 / 05 / 13$ & $18 / 05 / 13$ & s20 & $5 / 14$ & $17 / 05 / 14$ \\
\hline s21 & $24 / 05 / 09$ & $30 / 05 / 09$ & s21 & $23 / 05 / 10$ & $29 / 05 / 10$ & s21 & $22 / 05 / 11$ & $28 / 05 / 11$ & s21 & $20 / 05 / 12$ & $26 / 05 / 12$ & s21 & $5 / 13$ & $/ 13$ & s21 & $5 / 14$ & \\
\hline s22 & $31 / 05 / 09$ & 06/06/09 & s22 & $30 / 05 / 10$ & 05/06/10 & s22 & $29 / 05 / 11$ & $04 / 06 / 11$ & s22 & $27 / 05 / 12$ & $6 / 12$ & s22 & $5 / 13$ & $/ 13$ & s22 & $5 / 14$ & \\
\hline s23 & 07/06/09 & $13 / 06 / 09$ & s23 & $06 / 06 / 10$ & $12 / 06 / 10$ & $s 23$ & 05/06/11 & $11 / 06 / 11$ & s23 & $03 / 06 / 12$ & $09 / 06 / 12$ & s23 & $02 / 06 / 13$ & $08 / 06 / 13$ & $s 23$ & $01 / 06 / 14$ & $07 / 06 / 14$ \\
\hline s24 & $14 / 06 / 09$ & 20/06/09 & s24 & $13 / 06 / 10$ & $19 / 06 / 10$ & s24 & $12 / 06 / 11$ & $18 / 06 / 11$ & s24 & $10 / 06 / 12$ & $6 / 12$ & s24 & $6 / 13$ & $6 / 13$ & s24 & $/ 14$ & \\
\hline s25 & $21 / 06 / 09$ & $27 / 06 / 09$ & s25 & $20 / 06 / 10$ & & s25 & & & s25 & $6 / 12$ & & s25 & $16 / C$ & $22 /($ & s25 & b/14 & \\
\hline s26 & $28 / 06 / 09$ & $04 / 07 / 09$ & s26 & $27 / 06 / 10$ & $03 / 07 / 10$ & $s 26$ & $26 / 06 / 11$ & $02 / 07 / 11$ & s26 & $24 / 06 / 12$ & $30 / 06 / 12$ & s26 & $23 / 06 / 13$ & $29 / 06 / 13$ & $s 26$ & $22 / 06 / 14$ & $28 / 06 / 14$ \\
\hline s27 & 05/07/09 & $11 / 07 / 09$ & s27 & $04 / 07 / 10$ & $10 / 07 / 10$ & s27 & $03 / 07 / 11$ & $09 / 07 / 11$ & s27 & $01 / 07 / 12$ & $07 / 07 / 12$ & s27 & $30 / 06 / 13$ & $06 / 07 / 13$ & s27 & $29 / 06 / 14$ & $05 / 07 / 14$ \\
\hline s28 & $12 / 07 / 09$ & $18 / 07 / 09$ & $s 28$ & $11 / 07 / 10$ & $17 / 07 / 10$ & s28 & $10 / 07 / 11$ & $16 / 07 / 11$ & s28 & 08/07/12 & $14 / 07 / 12$ & s28 & $07 / 07 / 13$ & $13 / 07 / 13$ & $s 28$ & $06 / 07 / 14$ & $12 / 07 / 14$ \\
\hline s29 & 19/07/09 & $25 / 07 / 09$ & s29 & $18 / 07 / 10$ & $24 / 07 / 10$ & $\mathbf{s} 29$ & $17 / 07 / 11$ & $23 / 07 / 11$ & s29 & $15 / 07 / 12$ & $21 / 07 / 12$ & s29 & $14 / 07 / 13$ & $20 / 07 / 13$ & $s 29$ & $13 / 07 / 14$ & $19 / 07 / 14$ \\
\hline s30 & $26 / 07 / 09$ & $01 / 08 / 09$ & s30 & $25 / 07 / 10$ & $31 / 07 / 10$ & s30 & $24 / 07 / 11$ & $30 / 07 / 11$ & s30 & $22 / 07 / 12$ & $28 / 07 / 12$ & s30 & $21 / 07 / 13$ & $27 / 07 / 13$ & s30 & $20 / 07 / 14$ & $26 / 07 / 14$ \\
\hline s31 & 02/08/09 & 08/08/09 & s31 & $01 / 08 / 10$ & 07/08/10 & s31 & $31 / 07 / 11$ & $06 / 08 / 11$ & s31 & $29 / 07 / 12$ & $04 / 08 / 12$ & s31 & $28 / 07 / 13$ & $03 / 08 / 13$ & s31 & $27 / 07 / 14$ & $02 / 08 / 14$ \\
\hline s32 & 09/08/09 & $15 / 08 / 09$ & s32 & 08/08/10 & $14 / 08 / 10$ & s32 & $07 / 08 / 11$ & $13 / 08 / 11$ & s32 & $05 / 08 / 12$ & $11 / 08 / 12$ & s32 & $04 / 08 / 13$ & $10 / 08 / 13$ & s32 & $03 / 08 / 14$ & $09 / 08 / 14$ \\
\hline s33 & $16 / 08 / 09$ & $22 / 08 / 09$ & s33 & $15 / 08 / 10$ & $21 / 08 / 10$ & s33 & $14 / 08 / 11$ & $20 / 08 / 11$ & s33 & $12 / 08 / 12$ & $18 / 08 / 12$ & s33 & $11 / 08 / 13$ & $17 / 08 / 13$ & s33 & $10 / 08 / 14$ & $16 / 08 / 14$ \\
\hline s34 & 23/08/09 & 29/08/09 & s34 & $22 / 08 / 10$ & $28 / 08 / 10$ & s34 & $21 / 08 / 11$ & $27 / 08 / 11$ & s34 & $19 / 08 / 12$ & $25 / 08 / 12$ & s34 & $18 / 08 / 13$ & $24 / 08 / 13$ & s34 & $17 / 08 / 14$ & $23 / 08 / 14$ \\
\hline
\end{tabular}


$\begin{array}{lllllllllllllllllllll}\text { s35 } & 30 / 08 / 09 & 05 / 09 / 09 & \mathbf{s} 35 & 29 / 08 / 10 & 04 / 09 / 10 & \mathbf{s} 35 & 28 / 08 / 11 & 03 / 09 / 11 & \mathbf{s} 35 & 26 / 08 / 12 & 01 / 09 / 12 & \mathbf{s 3 5} & 25 / 08 / 13 & 31 / 08 / 13 & \mathbf{s} 35 & 24 / 08 / 14 & 30 / 08 / 14\end{array}$ $\begin{array}{lllllllllllllllllllllll}\text { s36 } & 06 / 09 / 09 & 12 / 09 / 09 & \mathbf{s} 36 & 05 / 09 / 10 & 11 / 09 / 10 & \mathbf{s} 36 & 04 / 09 / 11 & 10 / 09 / 11 & \mathbf{s} 36 & 02 / 09 / 12 & 08 / 09 / 12 & \mathbf{s} 36 & 01 / 09 / 13 & 07 / 09 / 13 & \mathbf{s} 36 & 31 / 08 / 14 & 06 / 09 / 14\end{array}$ $\begin{array}{lllllllllllllllllllll}\text { s37 } & 13 / 09 / 09 & 19 / 09 / 09 & \mathbf{s} 37 & 12 / 09 / 10 & 18 / 09 / 10 & \mathbf{s} 37 & 11 / 09 / 11 & 17 / 09 / 11 & \mathbf{s} 37 & 09 / 09 / 12 & 15 / 09 / 12 & \mathbf{s} 37 & 08 / 09 / 13 & 14 / 09 / 13 & \mathbf{s} 37 & 07 / 09 / 14 & 13 / 09 / 14\end{array}$ $\begin{array}{llllllllllllllllllllll}\text { s38 } & 20 / 09 / 09 & 26 / 09 / 09 & \mathbf{s} 38 & 19 / 09 / 10 & 25 / 09 / 10 & \mathbf{s} 38 & 18 / 09 / 11 & 24 / 09 / 11 & \mathbf{s} 38 & 16 / 09 / 12 & 22 / 09 / 12 & \mathbf{s} 38 & 15 / 09 / 13 & 21 / 09 / 13 & \mathbf{s} 38 & 14 / 09 / 14 & 20 / 09 / 14\end{array}$ $\begin{array}{lllllllllllllllllllllllll}\text { s39 } & 27 / 09 / 09 & 03 / 10 / 09 & \text { s39 } & 26 / 09 / 10 & 02 / 10 / 10 & \text { s39 } & 25 / 09 / 11 & 01 / 10 / 11 & \text { s39 } & 23 / 09 / 12 & 29 / 09 / 12 & s 39 & 22 / 09 / 13 & 28 / 09 / 13 & s 39 & 21 / 09 / 14 & 27 / 09 / 14\end{array}$ $\begin{array}{llllllllllllllllllllll}\mathbf{s} 40 & 04 / 10 / 09 & 10 / 10 / 09 & \mathbf{s} 40 & 03 / 10 / 10 & 09 / 10 / 10 & \mathbf{s 4 0} & 02 / 10 / 11 & 08 / 10 / 11 & \mathbf{s} 40 & 30 / 09 / 12 & 06 / 10 / 12 & \mathbf{s} 40 & 29 / 09 / 13 & 05 / 10 / 13 & \mathbf{s} 40 & 28 / 09 / 14 & 04 / 10 / 14\end{array}$

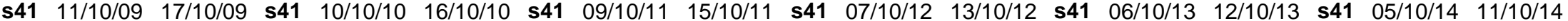
$\begin{array}{llllllllllllllllllllllll}s 42 & 18 / 10 / 09 & 24 / 10 / 09 & s 42 & 17 / 10 / 10 & 23 / 10 / 10 & s 42 & 16 / 10 / 11 & 22 / 10 / 11 & s 42 & 14 / 10 / 12 & 20 / 10 / 12 & s 42 & 13 / 10 / 13 & 19 / 10 / 13 & s 42 & 12 / 10 / 14 & 18 / 10 / 14\end{array}$ $\begin{array}{llllllllllllllllllllll}s 43 & 25 / 10 / 09 & 31 / 10 / 09 & s 43 & 24 / 10 / 10 & 30 / 10 / 10 & \mathbf{s} 43 & 23 / 10 / 11 & 29 / 10 / 11 & \mathbf{s} 43 & 21 / 10 / 12 & 27 / 10 / 12 & \mathbf{s} 43 & 20 / 10 / 13 & 26 / 10 / 13 & \mathbf{s} 43 & 19 / 10 / 14 & 25 / 10 / 14\end{array}$

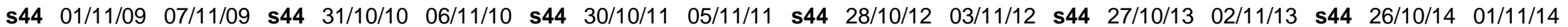
$\begin{array}{llllllllllllllllllll}s 45 & 08 / 11 / 09 & 14 / 11 / 09 & s 45 & 07 / 11 / 10 & 13 / 11 / 10 & s 45 & 06 / 11 / 11 & 12 / 11 / 11 & s 45 & 04 / 11 / 12 & 10 / 11 / 12 & s 45 & 03 / 11 / 13 & 09 / 11 / 13 & s 45 & 02 / 11 / 14 & 08 / 11 / 14\end{array}$

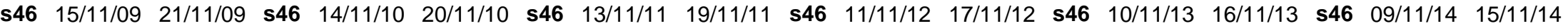
$\begin{array}{lllllllllllllllllll}s 47 & 22 / 11 / 09 & 28 / 11 / 09 & s 47 & 21 / 11 / 10 & 27 / 11 / 10 & s 47 & 20 / 11 / 11 & 26 / 11 / 11 & s 47 & 18 / 11 / 12 & 24 / 11 / 12 & s 47 & 17 / 11 / 13 & 23 / 11 / 13 & s 47 & 16 / 11 / 14 & 22 / 11 / 14\end{array}$ $\begin{array}{llllllllllllllllllll}\mathbf{s} 48 & 29 / 11 / 09 & 05 / 12 / 09 & \mathbf{s} 48 & 28 / 11 / 10 & 04 / 12 / 10 & \mathbf{s} 48 & 27 / 11 / 11 & 03 / 12 / 11 & \mathbf{s} 48 & 25 / 11 / 12 & 01 / 12 / 12 & \mathbf{s} 48 & 24 / 11 / 13 & 30 / 11 / 13 & \mathbf{s} 48 & 23 / 11 / 14 & 29 / 11 / 14\end{array}$ $\begin{array}{llllllllllllllllllll}\mathbf{s} 49 & 06 / 12 / 09 & 12 / 12 / 09 & \mathbf{s} 49 & 05 / 12 / 10 & 11 / 12 / 10 & \mathbf{s} 49 & 04 / 12 / 11 & 10 / 12 / 11 & \mathbf{s} 49 & 02 / 12 / 12 & 08 / 12 / 12 & \mathbf{s} 49 & 01 / 12 / 13 & 07 / 12 / 13 & \mathbf{s} 49 & 30 / 11 / 14 & 06 / 12 / 14\end{array}$ $\begin{array}{llllllllllllllllll}\mathbf{s} 50 & 13 / 12 / 09 & 19 / 12 / 09 & \mathbf{s} 50 & 12 / 12 / 10 & 18 / 12 / 10 & \mathbf{s} 50 & 11 / 12 / 11 & 17 / 12 / 11 & \mathbf{s} 50 & 09 / 12 / 12 & 15 / 12 / 12 & \mathbf{s} 50 & 08 / 12 / 13 & 14 / 12 / 13 & \mathbf{s} 50 & 07 / 12 / 14 & 13 / 12 / 14\end{array}$ $\begin{array}{lllllllllllllllllllll}s 51 & 20 / 12 / 09 & 26 / 12 / 09 & s 51 & 19 / 12 / 10 & 25 / 12 / 10 & s 51 & 18 / 12 / 11 & 24 / 12 / 11 & s 51 & 16 / 12 / 12 & 22 / 12 / 12 & s 51 & 15 / 12 / 13 & 21 / 12 / 13 & s 51 & 14 / 12 / 14 & 20 / 12 / 14\end{array}$

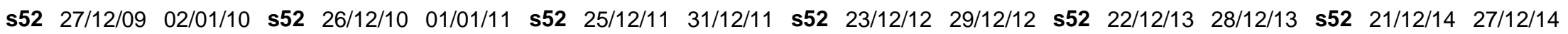
s53 28/12/14 03/01/15 


\section{Casos de Doença Diarreica Aguda}

\begin{tabular}{|c|c|c|c|c|c|c|c|c|c|c|c|c|c|c|c|c|c|c|c|c|c|c|c|c|c|c|c|c|}
\hline 2002 & Município & s1 & s2 & s3 & s4 & s5 & s6 & s7 & s8 & s9 & s10 & s11 & s12 & s13 & s14 & s15 & s16 & s17 & $s 18$ & s19 & s20 & s21 & s22 & $s 23$ & s24 & $s 25$ & $s 26$ & s27 \\
\hline & Acari & 2 & 22 & 5 & 38 & 52 & 26 & 44 & 29 & 141 & 10 & 13 & 0 & 6 & 0 & 5 & 0 & 4 & 0 & 0 & 3 & 5 & 0 & 0 & 0 & 0 & 2 & 0 \\
\hline & Açu & - & - & - & - & 83 & 39 & 43 & 21 & 10 & 14 & 10 & 5 & 16 & 3 & 2 & 3 & 1 & 3 & 5 & 6 & 9 & 3 & 3 & 5 & 8 & - & 1 \\
\hline & Almino Afonso & 0 & 0 & 0 & 0 & 0 & 0 & 0 & 0 & 0 & 0 & 0 & 0 & 0 & 0 & 0 & 0 & 0 & 0 & 0 & 0 & 0 & 0 & 0 & 0 & 0 & 0 & 0 \\
\hline & Angicos & 5 & 7 & 19 & 51 & 53 & 46 & 50 & 24 & 6 & 0 & 0 & 0 & 0 & 0 & 0 & 0 & 0 & 0 & 0 & 0 & 0 & 0 & 0 & 0 & 0 & 0 & 0 \\
\hline & Augusto Severo & 0 & 0 & 0 & 0 & 0 & 0 & 0 & 0 & 0 & 0 & 0 & 0 & 0 & 0 & 0 & 0 & 0 & 0 & 0 & 0 & 0 & 0 & 0 & 0 & 0 & 0 & 0 \\
\hline & Barcelona & 0 & 0 & 0 & 13 & 0 & 0 & 0 & 0 & 58 & 33 & 0 & 0 & 0 & 0 & 0 & 0 & 5 & 0 & 0 & 0 & 5 & 0 & 0 & 0 & 0 & 4 & 0 \\
\hline & Bodó & 0 & 0 & 0 & 0 & 0 & 0 & 0 & 0 & 0 & 0 & 0 & 0 & 0 & 0 & 0 & 0 & 0 & 0 & 0 & 0 & 0 & 0 & 0 & 0 & 0 & 0 & 0 \\
\hline & Bom Jesus & 0 & 0 & 0 & 0 & 0 & 0 & 0 & 0 & 0 & 0 & 0 & 0 & 0 & 0 & 0 & 0 & 0 & 0 & 0 & 0 & 0 & 0 & 0 & 0 & 0 & 0 & 0 \\
\hline & Caiçara do Rio do Vento & - & 2 & 14 & 15 & 13 & 3 & 27 & 4 & - & 7 & 9 & 10 & 4 & 1 & - & 2 & 7 & 1 & 1 & 1 & 5 & - & - & 5 & 3 & 2 & - \\
\hline & Caicó & 1 & 2 & 25 & 26 & 192 & 128 & 22 & 81 & 93 & 184 & 12 & 17 & 21 & 34 & 5 & 1 & 3 & 43 & 2 & 1 & 11 & 10 & 24 & 6 & 1 & 48 & - \\
\hline & Campo Redondo & 0 & 12 & 6 & 10 & 12 & 8 & 0 & 13 & 8 & 15 & 7 & 4 & 2 & 0 & 1 & 5 & 2 & 4 & 2 & 1 & 12 & 5 & 0 & 2 & 0 & 3 & 3 \\
\hline & Coronel Ezequiel & 0 & 0 & 0 & 0 & 18 & 0 & 11 & 25 & 21 & 0 & 0 & 0 & 7 & 1 & 5 & 0 & 0 & 0 & 0 & 0 & 1 & 2 & 5 & 2 & 0 & - & 2 \\
\hline & Currais Novos & 0 & 0 & 0 & 0 & 0 & 0 & 0 & 0 & 0 & 0 & 0 & 0 & 0 & 0 & 0 & 0 & 0 & 0 & 0 & 0 & 0 & 0 & 0 & 0 & 0 & 0 & 0 \\
\hline & Fernando Pedroza & 0 & 0 & 0 & 0 & 0 & 0 & 0 & 0 & 0 & 0 & 0 & 0 & 0 & 0 & 0 & 0 & 0 & 0 & 0 & 0 & 0 & 0 & 0 & 0 & 0 & 0 & 0 \\
\hline & Florânia & 3 & 8 & 4 & 18 & 18 & 7 & 7 & 9 & 11 & 5 & - & - & - & - & 2 & 6 & 1 & 0 & 0 & 0 & - & - & 1 & - & - & - & 3 \\
\hline & Ielmo Marinho & - & - & - & - & - & - & - & - & - & - & - & - & - & - & - & - & - & - & - & - & - & - & - & - & - & - & - \\
\hline & Itajá & 5 & 4 & 7 & 8 & 24 & 25 & 20 & 18 & 23 & 10 & 5 & 5 & - & 1 & 2 & 2 & 3 & 1 & 0 & 0 & 4 & 1 & 2 & 2 & 2 & 1 & 0 \\
\hline & Jaçanã & 0 & 0 & 0 & 0 & - & 0 & 27 & 15 & 56 & 0 & 0 & 21 & 2 & 0 & 13 & 10 & 5 & 2 & 5 & 5 & 7 & 7 & 4 & 11 & 6 & 6 & 4 \\
\hline & Janduís & 0 & 0 & 0 & 0 & 0 & 0 & 6 & 3 & 9 & 4 & - & 6 & 1 & 2 & 1 & - & 1 & - & 0 & 2 & 2 & - & - & 1 & 1 & 1 & - \\
\hline & Januário Cicco & 3 & 5 & 12 & 26 & 0 & 8 & 0 & 5 & 13 & 3 & 13 & 4 & 0 & 0 & 0 & 9 & 3 & 2 & 3 & 2 & 6 & 3 & - & 1 & 0 & - & - \\
\hline & Japi & 0 & 2 & 0 & 0 & 0 & 3 & 0 & 0 & 3 & 0 & 0 & 0 & 0 & 0 & 0 & 0 & 2 & 0 & 0 & 0 & - & 0 & 0 & 0 & 0 & - & 0 \\
\hline & Jardim de Angicos & 8 & 13 & 3 & 1 & 8 & 5 & 8 & 8 & 7 & 4 & 11 & 6 & 4 & 4 & 2 & - & 4 & - & - & - & - & - & 2 & - & 1 & - & 1 \\
\hline & Lagoa d'Anta & - & 6 & 8 & - & - & 0 & - & 0 & 0 & 0 & 7 & 10 & 13 & - & 0 & 7 & 2 & 1 & 3 & 1 & 0 & 2 & 3 & 4 & 3 & 3 & 0 \\
\hline & Lagoa de Pedras & - & 0 & 0 & 0 & 0 & 0 & 0 & 12 & 9 & 9 & 8 & 9 & 2 & 3 & 9 & 5 & 7 & 5 & 10 & 7 & 0 & 2 & 2 & 2 & - & 2 & 4 \\
\hline & Lagoa de Velhos & 5 & 7 & 6 & 10 & 8 & 19 & 0 & 16 & 11 & 5 & 10 & 7 & 0 & 0 & 0 & 2 & 1 & - & 1 & 0 & 2 & 1 & 1 & 3 & 0 & 2 & 6 \\
\hline & Lagoa Nova & 10 & 10 & 14 & 5 & 11 & 9 & 7 & 4 & 3 & 0 & 2 & 2 & 0 & 0 & 1 & 0 & 0 & 0 & 0 & 0 & 0 & 0 & 0 & 2 & 2 & 0 & 0 \\
\hline & Lagoa Salgada & 0 & 0 & 0 & 0 & 12 & 0 & 0 & 0 & 0 & 0 & 0 & 0 & 0 & 0 & 0 & 0 & 0 & 0 & 0 & 0 & 0 & 0 & 0 & 0 & 0 & 0 & 0 \\
\hline & Lajes & - & 11 & 2 & 4 & 5 & 12 & 73 & 55 & 54 & 33 & 35 & 15 & - & - & - & - & 9 & 1 & 3 & 4 & 2 & - & - & 3 & 1 & - & 2 \\
\hline & Lajes Pintadas & 0 & 0 & 0 & 0 & 0 & 0 & 8 & 0 & 0 & 0 & 0 & 0 & 0 & 0 & 0 & 0 & 0 & 0 & 0 & 0 & 0 & 0 & 0 & 0 & 0 & 0 & 0 \\
\hline & Messias Targino & 10 & 17 & 28 & 0 & 16 & 6 & 12 & 8 & 6 & 0 & 7 & 0 & 0 & 2 & 4 & 4 & 4 & 5 & 2 & 0 & 6 & - & 3 & 1 & - & 2 & 3 \\
\hline & Monte Alegre & 0 & 0 & 0 & 0 & 0 & 0 & 0 & 0 & 0 & 0 & 0 & 0 & 0 & 0 & 0 & 0 & 0 & 0 & 0 & 0 & 0 & 0 & 0 & 0 & 0 & 0 & 0 \\
\hline & Monte das Gameleiras & 11 & 7 & 0 & 11 & 2 & - & 5 & 13 & 12 & 5 & 11 & 11 & 4 & 3 & 5 & 0 & 3 & 0 & 4 & 0 & 4 & 0 & 4 & 0 & 3 & 6 & 2 \\
\hline & & & & & & & & & & & & & & & & & & & & & & & & & & & 214 & \\
\hline
\end{tabular}




\begin{tabular}{|c|c|c|c|c|c|c|c|c|c|c|c|c|c|c|c|c|c|c|c|c|c|c|c|c|c|c|c|}
\hline 2002 & Município & s1 & s2 & s3 & s4 & s5 & s6 & s7 s & s8 $s 9$ & $\mathrm{~s} 10$ & $s 11$ & s12 & $s 13$ & $s 14$ & s15 & $s 16$ & $s 17$ & s18 & $s 19$ & $s 20$ & $s 21$ & s22 & $s 23$ & s24 & $\mathbf{s} 25$ & s26 & $s 27$ \\
\hline & Paraú & 0 & 0 & 0 & 0 & 0 & 0 & 0 & $\begin{array}{ll}0 & 0\end{array}$ & 0 & 0 & 0 & 0 & 0 & 0 & 0 & 0 & 0 & 0 & 0 & 0 & 0 & 0 & 0 & 0 & 0 & 0 \\
\hline & Passa e Fica & 12 & 4 & 0 & 8 & 0 & 0 & 0 & 0 & 0 & 0 & 0 & 0 & 0 & 0 & 0 & 0 & 0 & 0 & 0 & 0 & 0 & 0 & 0 & 0 & 0 & 0 \\
\hline & Patu & 0 & 0 & 0 & 0 & 0 & 0 & 0 & 0 & 0 & 0 & 0 & 0 & 0 & 0 & 0 & 0 & 0 & 0 & 0 & 0 & 0 & 0 & 0 & 0 & 0 & 0 \\
\hline & Pedra Preta & 2 & 1 & 2 & 8 & 4 & 4 & 10 & 32 & 0 & 3 & 6 & - & 3 & 5 & 5 & 1 & 3 & 29 & 72 & 3 & - & 2 & 3 & 1 & - & - \\
\hline & Pedro Avelino & - & 1 & 0 & 8 & 22 & 16 & - & 11 & 6 & 6 & 7 & 2 & 4 & 5 & 4 & - & 4 & 1 & - & 1 & 1 & 2 & 1 & - & - & 1 \\
\hline & Presidente Juscelino & 0 & 0 & 0 & 0 & 0 & 0 & 0 & 0 & 0 & 0 & 0 & 0 & 0 & 0 & 4 & 10 & 7 & 14 & 4 & 8 & 16 & 9 & 6 & 0 & 8 & 28 \\
\hline & Riachuelo & 1 & 1 & 3 & 5 & 0 & 6 & - & 15 & 17 & 4 & 7 & 2 & - & - & - & 3 & - & 4 & - & 5 & - & - & 3 & 0 & 1 & 2 \\
\hline & Ruy Barbosa & 0 & 0 & 0 & 0 & 0 & 0 & 0 & 56 & 0 & 10 & 6 & 0 & 0 & 0 & 0 & 0 & 0 & 5 & 0 & 0 & 0 & 0 & 0 & 0 & 0 & 0 \\
\hline & Santa Cruz & 12 & 13 & 8 & 6 & 11 & 15 & 47 & 17 & 13 & 14 & 0 & 13 & 7 & 10 & 10 & 37 & 9 & 0 & 5 & 3 & 3 & 5 & 6 & 4 & 2 & 0 \\
\hline & Santa Maria & 0 & 0 & 0 & 0 & 0 & 0 & 0 & 0 & 0 & 0 & 0 & 0 & 0 & 0 & 0 & 0 & 0 & 0 & 0 & 0 & 0 & 0 & 0 & 0 & 0 & 0 \\
\hline & Santana do Matos & - & 3 & - & - & 4 & 6 & 13 & 33 & - & 4 & - & 10 & - & 0 & - & 7 & - & - & - & - & 5 & - & - & - & - & 1 \\
\hline & São Bento do Trairi & 0 & 0 & 0 & 1 & 2 & 0 & 0 & 10 & 0 & 0 & 3 & 3 & 0 & 0 & 2 & 1 & - & 0 & - & - & - & - & - & 0 & - & 6 \\
\hline & São José do Campestre & 0 & 0 & 0 & 0 & 0 & 0 & 0 & 0 & 0 & 0 & 0 & 0 & 0 & 0 & 0 & 0 & 0 & 0 & 0 & 0 & 0 & 0 & 0 & 0 & 0 & 0 \\
\hline & São Paulo do Potengi & 0 & 0 & 0 & 0 & 0 & 0 & 0 & 0 & 0 & 0 & 0 & 6 & 6 & 4 & 4 & 0 & 6 & 0 & 0 & 0 & 0 & 0 & 0 & 0 & - & 0 \\
\hline & São Pedro & 0 & 0 & 0 & 0 & 0 & 0 & 0 & 0 & 0 & 0 & 0 & 0 & 0 & 0 & 0 & 0 & 0 & 0 & 0 & 0 & 0 & 0 & 0 & 0 & 0 & 0 \\
\hline & São Rafael & 0 & 0 & 0 & 0 & 0 & 0 & 0 & 0 & 0 & 0 & 0 & 0 & 0 & 0 & 0 & 0 & 0 & 0 & 0 & 0 & 0 & 10 & 6 & 5 & - & 5 \\
\hline & São Tomé & 0 & 0 & 0 & 0 & 0 & 0 & 0 & 0 & 3 & 7 & 3 & 4 & 0 & 2 & 15 & 1 & 0 & 2 & 5 & 7 & - & - & - & - & 1 & - \\
\hline & São Vicente & 0 & 0 & 0 & 8 & 14 & 19 & 5 & 0 & 0 & 0 & 0 & 0 & 0 & 0 & 0 & 0 & 0 & 0 & 0 & 0 & 0 & 0 & 0 & 0 & 0 & 0 \\
\hline & Senador Elói de Souza & 0 & 0 & 0 & 0 & 0 & 0 & 0 & 0 & 7 & 0 & 5 & 8 & 0 & 3 & 4 & 2 & 3 & 0 & 2 & 1 & 1 & 2 & 1 & 1 & 0 & 1 \\
\hline & Serra de São Bento & 0 & 0 & 0 & 0 & 0 & 0 & 0 & 0 & 0 & 0 & 0 & 0 & 0 & 0 & 0 & 0 & 0 & 0 & 0 & 0 & 0 & 0 & 0 & 0 & 0 & 0 \\
\hline & Serrinha & 1 & - & - & 1 & - & 1 & 3 & - & - & 1 & - & - & - & - & 1 & - & 0 & 0 & 2 & - & 0 & - & - & 0 & - & 0 \\
\hline & Sítio Novo & 0 & 0 & 0 & 22 & 11 & 13 & 13 & 11 & 5 & 0 & 0 & 5 & 1 & 0 & 2 & 4 & 0 & - & - & - & - & - & - & 3 & 0 & - \\
\hline & Tangará & 18 & 6 & 5 & 0 & 0 & 0 & 0 & 39 & 9 & 12 & 0 & 0 & 25 & 0 & 6 & 4 & 8 & 6 & 0 & 7 & 0 & 0 & 4 & 2 & 0 & 0 \\
\hline & Tenente Laurentino Cruz & - & - & - & - & - & 23 & - & 0 & 59 & - & - & - & - & - & - & - & - & 0 & - & 0 & 0 & - & 0 & 0 & 0 & - \\
\hline & Triunfo Potiguar & 3 & 6 & 8 & 21 & 80 & 22 & 10 & 10 & 24 & 7 & 5 & 6 & 5 & 2 & 3 & 3 & 3 & 3 & - & - & 7 & 3 & 3 & - & - & 1 \\
\hline 2002 & Município & $s 28$ & $s 2 c$ & & 530 & s31 & s32 & s33 & 3 s34 & s35 & s36 & s37 & s38 & s39 & $s 40$ & s41 & s42 & $s 43$ & s44 & s45 & $s 46$ & s47 & $s 48$ & s49 & s50 & s51 & $s 52$ \\
\hline & Acari & 0 & 0 & & 0 & 0 & 0 & 0 & 0 & 0 & 0 & 3 & 0 & 3 & 0 & 0 & 0 & 0 & 0 & 0 & 0 & 0 & 0 & 0 & 0 & 2 & 0 \\
\hline & Açu & 2 & 6 & & 4 & 10 & 4 & 8 & 14 & 8 & 1 & 0 & 6 & 4 & 3 & 4 & 4 & 3 & - & 14 & 17 & 13 & 7 & 8 & 18 & 5 & 1 \\
\hline & Almino Afonso & 0 & 0 & & 0 & 0 & 0 & 0 & 0 & 0 & 0 & 0 & 2 & 0 & 0 & 0 & 0 & 0 & 0 & - & - & - & 0 & - & - & - & 0 \\
\hline & Angicos & 0 & 1 & & 0 & 1 & 6 & 6 & 4 & 3 & 1 & 12 & 2 & 0 & 7 & 0 & 9 & 0 & 11 & 7 & 2 & 2 & 13 & 0 & 14 & 7 & 76 \\
\hline & Augusto Severo & 0 & 0 & & 0 & 0 & 0 & 0 & 0 & 0 & 0 & 0 & 0 & 0 & 0 & 0 & 0 & 0 & 0 & 0 & 0 & 0 & 0 & 0 & 0 & 0 & 0 \\
\hline & Barcelona & 0 & 0 & & 6 & 0 & 0 & 0 & 6 & 0 & 0 & 0 & 0 & 0 & 8 & 0 & 0 & 5 & 0 & 0 & 0 & 4 & 0 & 0 & 0 & 0 & 0 \\
\hline & Bodó & 0 & 0 & & 0 & 0 & 0 & 0 & 0 & 0 & 0 & 0 & 0 & 0 & 0 & 0 & 0 & 0 & 0 & 0 & 0 & 0 & 0 & 0 & 0 & 0 & 0 \\
\hline & Bom Jesus & 0 & 0 & & 0 & 0 & 0 & 0 & 0 & 0 & 0 & 0 & 0 & 0 & 0 & 0 & 0 & 0 & 0 & 0 & 0 & 0 & 0 & 0 & 0 & 0 & 0 \\
\hline & Caiçara do Rio do Vento & 1 & - & & - & 2 & 2 & - & 2 & - & 11 & 7 & 7 & 3 & 1 & 4 & 5 & 2 & 5 & 6 & 4 & 8 & 1 & 1 & 0 & 0 & 0 \\
\hline & Caicó & 1 & 4 & & - & 24 & 4 & 2 & 3 & 23 & 9 & 3 & 10 & 26 & 19 & 7 & 4 & 13 & 28 & 26 & 0 & 9 & 0 & 0 & 0 & $\begin{array}{c}0 \\
215\end{array}$ & 17 \\
\hline
\end{tabular}




\begin{tabular}{|c|c|c|c|c|c|c|c|c|c|c|c|c|c|c|c|c|c|c|c|c|c|c|c|c|c|c|}
\hline 2002 & Município & $s 28$ & s29 & s30 & s31 & s32 & s33 & s34 & s35 & s36 & s37 & s38 & s39 & s40 & s41 & s42 & s43 & s44 & s45 & s46 & s47 & s48 & s49 & s50 & s51 & s52 \\
\hline & Campo Redondo & 0 & 4 & 1 & 2 & 1 & 0 & 2 & 1 & - & - & - & - & - & - & - & 1 & 2 & 2 & - & 11 & 17 & 0 & 0 & 0 & 0 \\
\hline & Coronel Ezequiel & 0 & 0 & 0 & 0 & - & 0 & 1 & - & - & 1 & 2 & 2 & 0 & 0 & - & - & - & - & - & 0 & 3 & 0 & 0 & 0 & 0 \\
\hline & Currais Novos & 0 & 0 & 0 & 0 & 0 & 0 & 0 & 0 & 0 & 0 & 0 & 0 & 0 & 0 & 0 & 0 & 0 & 0 & 0 & 0 & 0 & 0 & 0 & 0 & 0 \\
\hline & Fernando Pedroza & 0 & 3 & 2 & 0 & 9 & 3 & 5 & 2 & 0 & 3 & 0 & 2 & 0 & - & 8 & 3 & 0 & 4 & 0 & 0 & 0 & 9 & 5 & - & 11 \\
\hline & Florânia & 0 & - & - & 1 & 0 & - & 1 & - & 4 & 4 & - & - & - & 9 & - & - & - & 0 & 0 & 2 & 8 & 6 & 5 & 5 & 3 \\
\hline & Ielmo Marinho & - & - & - & - & - & - & - & - & - & - & - & - & - & - & - & - & - & - & - & - & - & - & - & - & - \\
\hline & Itajá & 4 & 1 & 2 & 1 & 1 & 5 & 3 & 1 & 1 & 0 & 1 & 2 & 2 & 1 & 5 & 4 & 4 & 3 & 2 & 3 & 1 & 3 & 4 & 8 & 8 \\
\hline & Jaçanã & 6 & 3 & 0 & 2 & 4 & 6 & 3 & 1 & - & 6 & 2 & 2 & 3 & - & 4 & 1 & 3 & 4 & 0 & 10 & 14 & 5 & 0 & 0 & 0 \\
\hline & Janduís & 1 & 2 & - & 1 & 2 & 3 & 4 & 4 & 3 & - & 7 & 11 & 3 & 5 & - & 4 & 15 & 9 & 0 & 31 & 15 & 6 & 0 & 0 & 3 \\
\hline & Januário Cicco & - & - & - & - & 15 & - & 8 & 3 & 3 & 7 & - & 5 & 4 & 8 & 2 & 2 & 2 & 3 & 2 & 2 & 3 & 0 & 0 & 0 & 0 \\
\hline & Japi & 0 & 0 & - & 0 & 0 & 0 & 0 & 0 & 0 & 0 & 0 & 2 & 0 & 0 & 0 & 0 & 7 & 0 & 9 & 4 & 0 & 0 & 0 & 0 & 0 \\
\hline & Jardim de Angicos & 1 & - & - & - & - & - & - & 1 & 2 & 1 & 0 & 0 & - & 2 & 1 & 4 & - & - & 1 & - & - & - & - & 1 & - \\
\hline & Lagoa d'Anta & 2 & 3 & 5 & 1 & 0 & 0 & 2 & 0 & 3 & 0 & 0 & 3 & 0 & 20 & 11 & 0 & 7 & 6 & 0 & 5 & 7 & 4 & 11 & 0 & 0 \\
\hline & Lagoa de Pedras & 0 & 1 & 2 & 1 & 4 & 1 & 0 & 2 & 0 & 0 & 3 & 0 & 0 & 5 & 2 & 3 & 3 & 2 & 0 & 2 & 1 & 1 & 7 & 3 & 0 \\
\hline & Lagoa de Velhos & 3 & 14 & 6 & 3 & 4 & 5 & 4 & 4 & 4 & 3 & - & 2 & 6 & 6 & 1 & 7 & 2 & 2 & 1 & 3 & 4 & 0 & 0 & 0 & 0 \\
\hline & Lagoa Nova & 0 & 0 & 0 & 0 & 0 & 0 & 0 & 4 & 0 & 0 & 2 & 2 & 2 & 4 & 2 & 3 & 0 & 0 & 4 & 2 & 8 & 2 & 8 & 1 & 22 \\
\hline & Lagoa Salgada & 0 & 0 & 0 & 0 & 0 & 0 & 0 & 0 & 0 & 0 & 0 & 0 & 0 & 0 & 0 & 0 & 0 & 0 & 0 & 0 & 0 & 0 & 0 & 0 & 0 \\
\hline & Lajes & - & 3 & 1 & - & 5 & 4 & 6 & 7 & 18 & 23 & 28 & 6 & 17 & 10 & 19 & 26 & 8 & 11 & 10 & 13 & 5 & 2 & 7 & 7 & 7 \\
\hline & Lajes Pintadas & 0 & 0 & 0 & 0 & 0 & 0 & 0 & 0 & 0 & 0 & 0 & 0 & 0 & 0 & 0 & 0 & 0 & 0 & 0 & 0 & 0 & 0 & 0 & 0 & 0 \\
\hline & Messias Targino & 8 & 7 & 9 & 5 & 2 & 3 & - & 1 & 2 & 0 & 3 & 2 & 2 & 2 & - & 8 & 2 & 3 & 3 & 1 & - & 2 & 0 & 4 & 0 \\
\hline & Monte Alegre & 0 & 0 & 0 & 0 & 0 & 0 & 0 & 0 & 0 & 0 & 0 & 0 & 0 & 0 & 0 & 0 & 0 & 0 & 0 & 0 & 0 & 0 & 0 & 0 & 0 \\
\hline & Monte das Gameleiras & 5 & 0 & 3 & 0 & 0 & 0 & 7 & 4 & 7 & 7 & 0 & 8 & 0 & 0 & 4 & 0 & 2 & 5 & 0 & 4 & 0 & 4 & 9 & 17 & 11 \\
\hline & Paraú & 0 & 0 & 0 & 0 & 0 & 0 & 0 & 0 & 0 & 0 & 0 & 0 & 0 & 0 & 0 & 0 & 0 & 0 & 0 & 0 & 0 & 0 & 0 & 0 & 0 \\
\hline & Passa e Fica & 0 & 0 & 0 & 0 & 0 & 0 & 0 & 0 & 0 & 0 & 0 & 0 & 2 & 1 & 1 & 12 & 2 & 3 & 2 & 7 & 0 & 4 & 1 & 4 & 4 \\
\hline & Patu & 0 & 0 & 0 & 0 & 0 & 0 & 0 & 0 & 0 & 0 & 0 & 0 & 0 & 0 & 0 & 0 & 0 & 0 & 0 & 0 & 0 & 0 & 0 & 0 & 0 \\
\hline & Pedra Preta & - & - & 1 & - & 2 & 1 & 1 & - & 2 & 2 & - & - & 9 & 2 & 3 & 1 & 2 & 5 & 5 & 3 & 3 & 0 & 26 & 1 & 2 \\
\hline & Pedro Avelino & - & 1 & 2 & 0 & 1 & 1 & 1 & 3 & 1 & - & - & - & 1 & 1 & 3 & 3 & 1 & 3 & 7 & 7 & 4 & 1 & 6 & 5 & - \\
\hline & Presidente Juscelino & 17 & 32 & 20 & 1 & 0 & 14 & 0 & 6 & 6 & 0 & 10 & 4 & 4 & 6 & 11 & 17 & 13 & 13 & 11 & 10 & 0 & 0 & 0 & 0 & 0 \\
\hline & Riachuelo & 2 & 4 & 6 & - & - & 6 & - & 3 & - & 3 & - & 2 & - & 1 & 5 & 3 & - & 3 & 3 & - & 5 & - & 5 & - & - \\
\hline & Ruy Barbosa & 0 & 2 & 2 & 6 & 0 & 4 & 5 & - & 1 & 5 & 1 & 1 & 5 & 5 & 1 & 3 & 4 & 2 & 0 & 4 & 9 & 3 & 0 & 0 & 0 \\
\hline & Santa Cruz & 1 & 9 & 2 & 0 & 13 & 3 & 9 & 7 & 7 & 0 & 6 & 8 & 3 & 3 & 3 & 8 & 0 & 9 & 16 & 0 & 0 & 0 & 0 & 0 & 0 \\
\hline & Santa Maria & 0 & 0 & 0 & 0 & 0 & 0 & 0 & 0 & 0 & 0 & 0 & 0 & 0 & 0 & 0 & 0 & 0 & 0 & 0 & 0 & 0 & 0 & 0 & 0 & 0 \\
\hline & Santana do Matos & - & 3 & 4 & 3 & 1 & - & - & 3 & - & - & - & - & 1 & 1 & 3 & 3 & 9 & 0 & - & 1 & 10 & 2 & 1 & 0 & 12 \\
\hline & São Bento do Trairi & - & 3 & 7 & 4 & 4 & 7 & 3 & 1 & 1 & 1 & - & 1 & - & 1 & 1 & - & 1 & 3 & 5 & 0 & 3 & 4 & 0 & 0 & 0 \\
\hline & São José do Campestre & 0 & 0 & 0 & 0 & 0 & 0 & 0 & 3 & 0 & 0 & 0 & 0 & 0 & 0 & 0 & 0 & 0 & 0 & 0 & 2 & 0 & 0 & 0 & 0 & 0 \\
\hline & São Paulo do Potengi & 0 & 0 & 0 & 0 & 0 & 0 & 0 & 0 & 0 & 0 & 0 & 0 & 0 & 0 & 0 & 0 & 0 & 0 & 0 & 0 & 0 & 0 & 0 & 0 & 0 \\
\hline & São Pedro & 0 & 0 & 0 & 0 & 0 & 0 & 0 & 0 & 0 & 0 & 0 & 0 & 0 & 0 & 0 & 0 & 0 & 0 & 0 & 0 & 0 & 0 & 0 & 0 & 0 \\
\hline
\end{tabular}




\begin{tabular}{|c|c|c|c|c|c|c|c|c|c|c|c|c|c|c|c|c|c|c|c|c|c|c|c|c|c|c|}
\hline 2002 & Município & s28 & $\mathbf{s 2 9}$ & s30 & s31 & s32 & s33 & s34 & s35 & s36 & s37 & s38 & s39 & $s 40$ & s41 & s42 & $s 43$ & s44 & s45 & $s 46$ & s47 & $s 48$ & s49 & s50 & s51 & s52 \\
\hline & São Rafael & 4 & 4 & 5 & 1 & 4 & 8 & 2 & 4 & 4 & 6 & 2 & - & 0 & 0 & 0 & 0 & 0 & 0 & 0 & 0 & 0 & 0 & 0 & 0 & 0 \\
\hline & São Tomé & 4 & 4 & - & - & - & - & - & - & - & - & - & 3 & - & - & 2 & - & - & 9 & 3 & 4 & - & 4 & 0 & 0 & 0 \\
\hline & São Vicente & 0 & 0 & 0 & 0 & 0 & 0 & 0 & 0 & 0 & 0 & 0 & 10 & 0 & 10 & 14 & 8 & 0 & 0 & 0 & 6 & 7 & 6 & 0 & 0 & 0 \\
\hline & Senador Elói de Souza & 0 & 0 & 0 & 0 & 0 & 0 & 0 & 1 & 0 & 0 & 0 & 0 & 0 & 0 & 0 & 0 & 0 & 2 & 0 & 1 & 1 & 1 & 0 & 0 & 0 \\
\hline & Serra de São Bento & 0 & 0 & 0 & 0 & 0 & 0 & 0 & 0 & 0 & 3 & 3 & 4 & 5 & 10 & 0 & 2 & 0 & 0 & 6 & 1 & 0 & 3 & 5 & 0 & 0 \\
\hline & Serrinha & 0 & 0 & 4 & 0 & 0 & 0 & 0 & 0 & 0 & 0 & 0 & 1 & 0 & 0 & 0 & 0 & 0 & 0 & 0 & 0 & 0 & 0 & 0 & 0 & 0 \\
\hline & Sítio Novo & 0 & - & - & - & - & - & 7 & - & - & 0 & 2 & - & - & - & - & 2 & - & 2 & 0 & 6 & 1 & 0 & 0 & 0 & 0 \\
\hline & Tangará & 0 & 5 & 23 & 0 & 35 & 0 & 0 & 0 & 0 & 0 & 4 & 3 & 0 & 0 & 0 & 7 & 0 & 7 & 0 & 0 & 26 & 0 & 0 & 0 & 0 \\
\hline & Tenente Laurentino Cruz & - & - & - & - & - & - & - & - & - & - & - & - & 3 & - & - & - & - & - & 0 & 0 & 0 & 0 & 0 & 0 & 0 \\
\hline & Triunfo Potiguar & 3 & 2 & 2 & 3 & 1 & 1 & 1 & 4 & 3 & 3 & 2 & 5 & 3 & 5 & 3 & 4 & 5 & 5 & 4 & 3 & 8 & 2 & - & 4 & 4 \\
\hline
\end{tabular}

Município

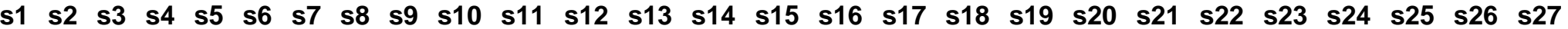

Aca

Açu

Almino Afonso

Angicos

Augusto Severo

Barcelona

Bodó

Bom Jesus

Caiçara do Rio do Vento

Caicó

Campo Redondo

Coronel Ezequiel

Currais Novos

Fernando Pedroza

Florânia

lelmo Marinho

Itajá

Jaçanã

Janduís

Januário Cicco

Japi

Jardim de Angicos

Lagoa d'Anta

Lagoa de Pedras

$\begin{array}{ccccccccccc}0 & 3 & - & 2 & 2 & 10 & - & 6 & 3 & 11 & 22 \\ 10 & 11 & 18 & 10 & 26 & 19 & 25 & 21 & 51 & 46 & 35\end{array}$

$\begin{array}{cc}\mathbf{s} 13 & \mathbf{s} 14 \\ 9 & 14\end{array}$

s16 s17

\section{s18}

10

s21 5

$\begin{array}{cccccc}\mathbf{s} 22 & \mathbf{s} 23 & \mathbf{s} 24 & \mathbf{s} 25 & \mathbf{s 2 6} & \mathbf{s 2 7} \\ 14 & 23 & 0 & 0 & 0 & 0\end{array}$

$\begin{array}{llllllllllllllllllllllllllll}10 & 11 & 18 & 10 & 26 & 19 & 25 & 21 & 51 & 46 & 35 & 17 & 57 & 10 & 8 & 7 & 3 & 5 & 10 & 7 & 7 & 7 & 1 & 3\end{array}$
$\begin{array}{cccccccccc}- & - & 23 & 17 & 50 & 50 & 7 & 4 & 4 & 2 \\ 7 & 11 & 6 & 5 & 12 & - & 20 & 36 & 27 & 12\end{array}$ $8 \begin{array}{cccccccccc}8 & 7 & 0 & 0 & 0 & 0 & 0 & 0 & 0 & 0\end{array}$

$\begin{array}{llllllllll}0 & 0 & 0 & 0 & 0 & 0 & 0 & 0 & 0 & 0\end{array}$

$\begin{array}{llllllllll}0 & 0 & 0 & 0 & 0 & 0 & 0 & 0 & 0 & 0\end{array}$

$\begin{array}{llllllllll}2 & 2 & 1 & 5 & 12 & 9 & 10 & 27 & 12 & 12\end{array}$

Lagoa de Velhos

$\begin{array}{cccccccccccc}- & - & 9 & 4 & 26 & 24 & 38 & 21 & 93 & 235 & 26 & 41 \\ 5 & 9 & 10 & - & - & 2 & 1 & 4 & 7 & 2 & 4 & 3\end{array}$

$\begin{array}{llllllllll}12 & 10 & 6 & 4 & - & - & - & 0 & -\end{array}$

$\begin{array}{llllllllll}0 & 0 & 0 & 0 & 0 & 0 & 0 & 0 & 0 & 0\end{array}$

$\begin{array}{llllllllll}8 & 31 & 5 & 0 & 0 & 0 & 8 & 4 & 10 & 0\end{array}$

$\begin{array}{ccccccccccccc}4 & - & 7 & 1 & - & 6 & 2 & 14 & 15 & 6 & 5 & 4 & 2\end{array}$

$\begin{array}{lllllllllllll}20 & 20 & 11 & 5 & 3 & 6 & 6 & 10 & 6 & 9 & 7 & 7 & 3\end{array}$

$\begin{array}{llllllllll}0 & 17 & 14 & 18 & 4 & - & 3 & 8 & 26 & 43\end{array}$

$\begin{array}{llllllllll}3 & 8 & 7 & 2 & 12 & 7 & 8 & 13 & 13 & 2\end{array}$

$\begin{array}{lllllllll}5 & 2 & 2 & 7 & 6 & 3 & 3 & 14 & 12\end{array}$

$\begin{array}{llllllllll}0 & 7 & 0 & 0 & 0 & 0 & 0 & 2 & 0 & 6\end{array}$

$\begin{array}{llllllllll}8 & 7 & 7 & 4 & 7 & 7 & 42 & 25 & 10 & 6\end{array}$

$\begin{array}{cccccccccc}- & 49 & 10 & 7 & 7 & 13 & 17 & 16 & 3 & 5 \\ 4 & 4 & 5 & 7 & 1 & 9 & 5 & 15 & 14 & 10\end{array}$

$\begin{array}{lllllllllll}3 & 5 & 6 & 1 & 0 & 3 & 0 & 13 & 22 & 21 & 14\end{array}$

$\begin{array}{ccccccc}- & 1 & 4 & 0 & 26 & 19 & 23\end{array}$

$\begin{array}{llll}0 & 23 & 12 & 6 \\ 0 & 90 & 0 & 0\end{array}$

$\begin{array}{cccc}0 & 0 & 0 & 0 \\ 16 & 16 & 4 & 7\end{array}$

$\begin{array}{llll}128 & 80 & 57 & 62\end{array}$

Lagoa de Velhos 


\begin{tabular}{|c|c|c|c|c|c|c|c|c|c|c|c|c|c|c|c|c|c|c|c|c|c|c|c|c|c|c|c|c|}
\hline 2003 & Município & s1 & s2 & s3 & s4 & s5 & s6 & s7 & s8 & s9 & $s 10$ & s11 & $\mathbf{s} 12$ & $s 13$ & s14 & $s 15$ & s16 & $\mathbf{s} 17$ & s18 & $s 19$ & s20 & s21 & s22 & s23 & $s 24$ & s25 & $s 26$ & s27 \\
\hline & Lagoa Nova & 6 & 5 & 1 & 3 & 1 & 4 & 6 & 0 & 0 & 0 & 0 & 14 & 1 & 0 & 0 & 0 & 8 & 0 & 0 & 0 & 2 & 2 & 9 & 5 & 1 & 9 & 7 \\
\hline & Lagoa Salgada & 0 & 0 & 0 & 0 & 0 & 0 & 0 & 0 & 0 & 0 & 0 & 0 & 0 & 6 & 18 & 10 & 14 & 9 & 8 & 7 & 4 & 4 & 0 & 0 & 0 & 0 & 0 \\
\hline & Lajes & 22 & 17 & 29 & 16 & 0 & 29 & 61 & 61 & 42 & 26 & 23 & 6 & 2 & 12 & 12 & 3 & 4 & 3 & 9 & 3 & 3 & 7 & - & - & - & - & - \\
\hline & Lajes Pintadas & - & - & 1 & 11 & 11 & 1 & 3 & 2 & 5 & - & 3 & - & - & 1 & 1 & 1 & 3 & 1 & 5 & 2 & 2 & - & 1 & 1 & - & 2 & - \\
\hline & Messias Targino & 1 & 2 & 4 & 5 & 6 & 11 & 18 & 12 & 3 & 6 & 3 & 6 & 0 & 0 & 0 & 2 & 0 & 2 & 2 & 0 & 0 & 0 & 0 & 0 & 0 & - & 1 \\
\hline & Monte Alegre & 0 & 0 & 0 & 0 & 0 & 0 & 0 & 0 & 0 & 0 & 0 & 0 & - & 2 & - & - & 5 & 6 & - & - & 0 & 0 & 0 & 0 & 0 & 0 & 0 \\
\hline & Monte das Gameleiras & 4 & 2 & - & 4 & 5 & 3 & 2 & 7 & 0 & 7 & 5 & - & 7 & 5 & 0 & 4 & 2 & 4 & - & 4 & 0 & 2 & 0 & 4 & 0 & 3 & 0 \\
\hline & Paraú & 0 & 0 & 0 & 0 & 0 & 0 & 0 & 0 & 0 & 0 & 0 & 0 & 0 & 0 & 0 & 0 & 0 & 0 & 0 & 0 & 0 & 0 & 0 & 0 & 0 & 0 & 0 \\
\hline & Passa e Fica & 10 & 10 & 23 & 20 & 9 & 4 & 8 & 40 & 28 & 3 & 39 & 4 & 14 & 15 & 0 & 17 & - & 9 & 1 & 0 & 4 & 2 & 0 & 2 & 2 & 2 & 2 \\
\hline & Patu & 0 & 0 & 0 & 0 & 0 & 0 & 0 & 0 & 0 & 0 & 0 & 0 & 0 & 0 & 0 & 0 & 0 & 0 & 0 & 0 & 0 & 0 & 0 & 6 & 6 & 12 & 3 \\
\hline & Pedra Preta & - & 3 & 7 & 2 & 5 & 3 & 6 & 39 & 29 & 0 & 6 & 5 & 5 & 5 & 1 & 1 & - & - & 1 & - & 1 & 3 & 2 & 2 & - & 2 & - \\
\hline & Pedro Avelino & 7 & 10 & 13 & 7 & 2 & 7 & 3 & 13 & 4 & 2 & 5 & 7 & 4 & 4 & 3 & 4 & 2 & 3 & - & 3 & 5 & 5 & 1 & 4 & 5 & 4 & 1 \\
\hline & Presidente Juscelino & 11 & 20 & 27 & 6 & 6 & 3 & 20 & 27 & 46 & 35 & 51 & 3 & 72 & 0 & 48 & 46 & 34 & 15 & 25 & 0 & 0 & 1 & 0 & 0 & 0 & 5 & 6 \\
\hline & Riachuelo & 3 & - & - & 2 & - & 3 & 7 & 28 & 20 & 0 & 3 & 5 & 10 & 2 & 2 & 3 & 5 & - & 4 & - & 3 & - & - & - & - & - & 1 \\
\hline & Ruy Barbosa & 0 & 0 & 0 & 0 & 0 & 10 & 0 & 34 & 76 & 19 & 37 & 9 & 21 & 13 & 3 & 0 & 0 & 0 & 0 & 4 & 6 & 0 & 0 & 3 & 4 & 2 & 1 \\
\hline & Santa Cruz & - & - & 0 & 0 & 0 & - & 19 & 16 & 0 & 6 & 14 & 11 & 14 & 17 & 7 & 19 & 9 & 15 & 20 & 6 & 5 & 6 & 6 & 3 & - & 4 & 4 \\
\hline & Santa Maria & 0 & 0 & 0 & 0 & 0 & 0 & 0 & 0 & 0 & 0 & 0 & 0 & 0 & 0 & 0 & 0 & 0 & 0 & 0 & 0 & 0 & 0 & 0 & 0 & 0 & 0 & 0 \\
\hline & Santana do Matos & 3 & 5 & 8 & 17 & 23 & 6 & 7 & 10 & 29 & - & 2 & 12 & 24 & 4 & 9 & - & 9 & - & 1 & 2 & - & 12 & - & - & - & 9 & - \\
\hline & São Bento do Trairi & 8 & 6 & 3 & 3 & 0 & - & 4 & 7 & 2 & 6 & 9 & 4 & 3 & 1 & 0 & - & 1 & 0 & 7 & 2 & 2 & 6 & 2 & - & 0 & 2 & 1 \\
\hline & São José do Campestre & 0 & 0 & 0 & 0 & 0 & 0 & 0 & 0 & 0 & 0 & 0 & 0 & 0 & 0 & 3 & 0 & 0 & 0 & 0 & 0 & 0 & 0 & 0 & 0 & 0 & 0 & 0 \\
\hline & São Paulo do Potengi & - & 0 & 2 & 1 & - & 14 & 4 & 11 & 10 & 4 & 12 & 3 & 1 & - & 2 & - & 2 & 1 & 0 & - & - & 5 & 4 & 0 & 0 & 1 & - \\
\hline & São Pedro & 0 & 0 & 0 & 0 & 0 & 0 & 0 & 0 & 0 & 0 & 0 & 0 & 0 & 0 & 0 & 0 & 0 & 0 & 0 & 0 & 0 & 0 & 0 & 0 & 0 & 0 & 0 \\
\hline & São Rafael & 0 & 0 & 0 & 0 & 0 & 0 & 0 & 0 & 0 & 0 & 0 & 0 & 0 & 0 & 0 & 0 & 0 & 0 & 0 & 0 & 0 & 0 & 0 & 0 & 0 & 0 & 0 \\
\hline & São Tomé & - & 6 & - & 15 & - & 8 & 13 & 6 & 32 & - & 19 & - & 2 & 4 & 1 & - & 1 & - & - & 10 & 0 & - & 4 & 0 & 0 & 0 & - \\
\hline & São Vicente & 14 & 0 & 0 & 0 & 0 & 0 & 0 & 21 & 17 & 0 & 0 & 0 & 0 & 0 & 0 & 0 & 0 & 0 & 0 & 0 & 0 & 0 & 5 & 1 & 1 & 0 & 1 \\
\hline & Senador Elói de Souza & 0 & 0 & 3 & 5 & - & 2 & 6 & 13 & 0 & 3 & 0 & 0 & 0 & 0 & 0 & 0 & 2 & 5 & 0 & 5 & 2 & 0 & 0 & 0 & 0 & 3 & 2 \\
\hline & Serra de São Bento & 0 & 0 & 0 & 0 & 0 & 0 & 0 & 1 & 0 & 6 & 5 & 2 & 0 & 0 & 0 & 0 & 0 & 0 & 0 & 0 & 0 & 1 & 0 & 0 & 0 & 0 & 0 \\
\hline & Serrinha & - & - & - & - & - & - & - & 2 & - & 2 & 6 & 4 & 2 & 1 & - & 3 & - & - & 1 & - & - & 5 & 3 & - & 3 & - & - \\
\hline & Sítio Novo & - & 5 & 2 & 1 & 1 & - & 0 & 6 & 2 & - & 1 & 3 & 5 & - & 3 & 3 & 5 & - & 4 & 1 & 1 & 2 & 0 & - & - & - & - \\
\hline & Tangará & 0 & 0 & 0 & 0 & 0 & 40 & 0 & 0 & 40 & 0 & 0 & 70 & 0 & 0 & 0 & 0 & 0 & 0 & 15 & 0 & 0 & 0 & 0 & 0 & 0 & 0 & 10 \\
\hline & Tenente Laurentino Cruz & - & - & - & - & - & - & 2 & 5 & - & - & - & - & 5 & 4 & 6 & 8 & 7 & 11 & 4 & 6 & 5 & 4 & 5 & 6 & 8 & 4 & 7 \\
\hline & Triunfo Potiguar & 2 & 3 & 5 & 2 & 2 & 3 & 3 & 21 & 6 & 1 & 6 & 4 & 8 & 4 & 5 & 3 & 1 & 2 & 1 & 2 & 1 & - & - & 2 & - & 1 & - \\
\hline
\end{tabular}

\begin{tabular}{|c|c|c|c|c|c|c|c|c|c|c|c|c|c|c|c|c|c|c|c|c|c|c|c|c|c|c|c|}
\hline 2003 & Município & $s 28$ & $\mathbf{s 2 9}$ & s30 & s31 & s32 & s33 & s34 & s35 & s36 & s37 & s38 & s39 & $s 40$ & s41 & $s 42$ & s43 & s44 & s45 & $s 46$ & s47 & $s 48$ & $s 49$ & s50 & s51 & s52 & s53 \\
\hline & Acari & 0 & 0 & 0 & 0 & 0 & 6 & 8 & 0 & 7 & 15 & 8 & 4 & 1 & 3 & 0 & 4 & 7 & 14 & 5 & 2 & 5 & 0 & 9 & 0 & 3 & 0 \\
\hline & Açu & 7 & 5 & - & - & 5 & 11 & 12 & 3 & 8 & 6 & 6 & 2 & 3 & 5 & 3 & 5 & - & 6 & 8 & 8 & - & 5 & 7 & 7 & 2 & 0 \\
\hline
\end{tabular}




\begin{tabular}{|c|c|c|c|c|c|c|c|c|c|c|c|c|c|c|c|c|c|c|c|c|c|c|c|c|c|}
\hline \multirow{2}{*}{$\begin{array}{l}\text { Almino Afonso } \\
\text { Angicos }\end{array}$} & 1 & 2 & 8 & 1 & 0 & 5 & 0 & 4 & 1 & 0 & 3 & - & 2 & 1 & 4 & 1 & 13 & 1 & 2 & 3 & 1 & 3 & 2 & 3 & 4 \\
\hline & 2 & 3 & 7 & 16 & 2 & - & 8 & 9 & 0 & 1 & 4 & 4 & 4 & - & - & - & - & 4 & 4 & 0 & 7 & 0 & 0 & 0 & 0 \\
\hline Augusto Severo & 4 & 2 & 4 & 7 & 7 & 9 & 9 & 2 & 6 & 9 & 6 & 4 & 7 & 2 & 7 & 10 & 6 & 8 & 8 & 7 & 24 & 8 & 11 & 19 & 7 \\
\hline Barcelona & 0 & 0 & 0 & 15 & 0 & 0 & 0 & 15 & 0 & 0 & 0 & 0 & 0 & 0 & 0 & 0 & 0 & 0 & 9 & 0 & 0 & 0 & 0 & 0 & 0 \\
\hline Bodó & 0 & 0 & 0 & 0 & 0 & 0 & 0 & 0 & 0 & 0 & 0 & 0 & 0 & 0 & 0 & 0 & 0 & 0 & 0 & 0 & 0 & 0 & 0 & 0 & 0 \\
\hline Bom Jesus & 0 & 0 & 0 & 4 & 7 & 7 & 2 & 2 & 5 & 4 & 9 & 1 & 0 & 9 & 2 & 5 & 12 & 6 & 0 & 0 & 13 & 3 & 8 & 8 & 0 \\
\hline Caiçara do Rio do Vento & 4 & 4 & - & - & 1 & 6 & 1 & 1 & - & 1 & 1 & 3 & - & - & 3 & - & 1 & - & 0 & 0 & 12 & 0 & 7 & - & - \\
\hline Caicó & - & - & - & 21 & 9 & - & 22 & 24 & 7 & 9 & 6 & 32 & 30 & 0 & 12 & 12 & 3 & 27 & 5 & 17 & 18 & 6 & 4 & 0 & 0 \\
\hline Campo Redondo & 6 & 2 & - & - & 3 & 3 & 18 & 3 & 3 & 2 & 13 & 1 & 1 & 1 & 7 & 0 & 0 & 1 & 9 & - & 0 & - & 0 & - & 0 \\
\hline Coronel Ezequiel & 0 & 0 & 0 & 0 & 0 & 0 & 0 & 0 & 6 & 2 & 4 & 0 & 3 & 1 & 1 & 0 & 0 & 3 & 1 & 0 & 0 & 0 & 0 & 0 & 0 \\
\hline Currais Novos & 0 & 0 & 0 & 0 & 0 & 0 & 0 & 0 & 0 & 0 & 0 & 0 & 0 & 0 & 0 & 0 & 0 & 0 & 0 & 0 & 0 & 0 & 0 & 0 & 0 \\
\hline Fernando Pedroza & 5 & 2 & - & - & - & - & 1 & 2 & - & - & - & 4 & 5 & - & 0 & 1 & 3 & 0 & 0 & - & 1 & - & 3 & 9 & 9 \\
\hline Florânia & - & 2 & 1 & 1 & 1 & 2 & 3 & 2 & - & - & - & 1 & - & - & - & 1 & - & 1 & - & 0 & 1 & 1 & 3 & 1 & 0 \\
\hline Ielmo Marinho & - & - & - & - & - & - & - & - & - & - & - & - & - & - & - & - & - & - & - & - & - & - & - & - & - \\
\hline Itajá & 2 & 0 & 11 & 1 & 1 & 2 & 0 & 9 & 3 & 2 & 2 & 0 & 1 & 0 & 4 & 1 & 0 & 2 & 7 & 6 & 0 & 4 & 5 & 2 & 14 \\
\hline Jaçanã & - & 2 & 6 & 13 & 2 & 2 & 2 & 14 & 8 & 8 & 18 & 17 & 13 & 6 & 12 & 4 & 4 & 3 & 4 & 5 & 7 & 1 & - & 1 & 0 \\
\hline Janduís & - & - & 1 & 1 & 3 & 3 & 2 & 3 & - & 3 & 1 & - & 1 & 1 & 1 & 2 & 1 & 2 & 1 & - & - & 1 & 1 & 1 & 3 \\
\hline Januário Cicco & - & - & - & - & 0 & 0 & 0 & 0 & 0 & 0 & 0 & 0 & 0 & 0 & 0 & 0 & 0 & 0 & 0 & 0 & 0 & 0 & 0 & 0 & 0 \\
\hline Japi & 2 & 8 & 0 & 0 & 3 & 0 & 0 & 0 & 0 & 0 & 0 & 0 & 2 & 8 & 0 & 0 & 0 & 3 & 0 & 0 & 0 & 0 & 0 & 0 & 0 \\
\hline Jardim de Angicos & 0 & 2 & 1 & 2 & - & - & - & - & - & 1 & 3 & 7 & 1 & - & - & - & - & 2 & 4 & 2 & 3 & 0 & - & - & - \\
\hline Lagoa d'Anta & - & - & - & 4 & - & - & 6 & 8 & 0 & 0 & 0 & 0 & 0 & 0 & 0 & 0 & 0 & 0 & 0 & 0 & 0 & 20 & 0 & 0 & 0 \\
\hline Lagoa de Pedras & 6 & 3 & 4 & 1 & 6 & 4 & 2 & 2 & 10 & 6 & 0 & 0 & 4 & 3 & 0 & 0 & 0 & 2 & 0 & 0 & 0 & 0 & 1 & 0 & 0 \\
\hline Lagoa de Velhos & 0 & 7 & 12 & - & 0 & - & - & 0 & - & 0 & 0 & 2 & - & - & 1 & 2 & - & 0 & - & 1 & 2 & 9 & 2 & 0 & 0 \\
\hline Lagoa Nova & 0 & 0 & 0 & 0 & 0 & 0 & 9 & 0 & 5 & 0 & 0 & 0 & 0 & 0 & 0 & 0 & 1 & 1 & 2 & 7 & 0 & 0 & 0 & 0 & 0 \\
\hline Lagoa Salgada & 0 & 0 & 0 & 0 & 0 & 0 & 0 & 0 & 4 & 1 & 4 & 9 & 0 & 16 & 9 & 3 & 0 & 1 & 1 & 4 & 0 & 0 & 0 & 0 & 0 \\
\hline Lajes & - & - & - & 1 & - & - & 3 & 1 & 4 & 5 & 7 & 5 & 0 & 1 & 1 & 6 & 2 & 12 & 7 & 11 & 9 & 6 & 7 & 2 & 3 \\
\hline Lajes Pintadas & 1 & 1 & 1 & - & 2 & 2 & 0 & - & 3 & - & - & 1 & - & 1 & - & - & - & 1 & - & - & - & - & - & - & 0 \\
\hline Messias Targino & 1 & 0 & 0 & 0 & 0 & 2 & 1 & 1 & 1 & 2 & 2 & - & 2 & - & - & 1 & - & 0 & 4 & 0 & 0 & 6 & 0 & 3 & 2 \\
\hline Monte Alegre & 0 & 0 & 0 & 0 & 0 & 0 & 0 & 0 & 0 & 0 & 0 & 0 & 0 & 0 & 0 & 0 & 0 & 0 & 0 & 0 & 0 & 0 & 0 & 0 & 0 \\
\hline Monte das Gameleiras & 0 & 0 & 4 & 2 & 4 & 0 & 0 & 1 & 0 & 0 & 0 & 0 & 0 & 0 & 0 & 0 & 0 & 0 & 0 & 0 & 0 & 0 & 0 & 0 & 0 \\
\hline Paraú & 0 & 0 & 0 & 0 & 0 & 0 & 0 & 0 & 0 & 0 & 0 & 0 & 0 & 0 & 0 & 0 & 0 & 0 & 0 & 0 & 0 & 0 & 0 & 0 & 0 \\
\hline Passa e Fica & 9 & 4 & 3 & - & 2 & 2 & - & - & 0 & 2 & 0 & 2 & 2 & 1 & 3 & 2 & 2 & 2 & 3 & 8 & 5 & 11 & 9 & 3 & 0 \\
\hline Patu & 11 & 6 & 25 & 9 & 1 & 6 & 24 & 10 & 16 & 0 & 9 & 6 & 13 & 5 & 3 & 11 & 2 & 1 & 4 & 7 & 8 & 2 & 2 & 3 & 2 \\
\hline Pedra Preta & - & 1 & - & 1 & 0 & - & - & - & - & 1 & - & 1 & 6 & - & - & 1 & - & - & 1 & 1 & 4 & 1 & 1 & - & 1 \\
\hline Pedro Avelino & 1 & - & 5 & 2 & 1 & 3 & 2 & 1 & - & 1 & 1 & - & 1 & - & 3 & 1 & 2 & 6 & 2 & 1 & 2 & 2 & 4 & 4 & 3 \\
\hline Presidente Juscelino & 4 & 1 & 3 & 5 & 4 & 4 & 0 & 0 & - & 2 & 1 & 2 & 2 & 5 & 13 & 11 & 6 & 4 & 17 & 3 & 2 & 2 & 2 & 3 & 4 \\
\hline Riachuelo & 3 & - & 4 & 1 & - & - & - & - & - & - & - & - & - & - & - & - & - & - & 0 & 1 & - & 0 & 1 & - & - \\
\hline Ruy Barbosa & 7 & 2 & 2 & 1 & 1 & 2 & 2 & 2 & 0 & 3 & 5 & 1 & 4 & 3 & 2 & 2 & 3 & 3 & 3 & 4 & 4 & 2 & 6 & 12 & 9 \\
\hline
\end{tabular}


Santa Cruz

Santa Maria

Santana do Matos

São Bento do Trair

São José do Campestre

São Paulo do Potengi

São Pedro

São Rafael

São Tomé

São Vicente

Senador Elói de Souza

Serra de São Bento

Serrinha

Sítio Novo

Tangará

Tenente Laurentino Cruz

Triunfo Potiguar

$\begin{array}{llllllllllllllllllllllllllllllllll}s 1 & s 2 & s 3 & s 4 & s 5 & s 6 & s 7 & s 8 & s 9 & s 10 & s 11 & s 12 & s 13 & s 14 & s 15 & s 16 & s 17 & s 18 & s 19 & s 20 & s 21 & s 22 & s 23 & s 24 & s 25 & s 26 & s 27\end{array}$

Acar

Açu

Almino Afonso

Angicos

Augusto Severo

Barcelona

Bodó

Bom Jesus

Caiçara do Rio do Vento

$\begin{array}{lllllllllllll}0 & 0 & 12 & 3 & 14 & 37 & 104 & 42 & 10 & 34 & 14 & 48 & 2\end{array}$

$\begin{array}{ll}4 & 12 \\ 0 & \\ - \\ 2 \\ 0 \\ 1 \\ 0 \\ 0 \\ - \\ - \\ 2 \\ 6 \\ 0 \\ 2 \\ 0 \\ 3 \\ 4\end{array}$

Caicó

Campo Redondo

Coronel Ezequie

$\begin{array}{ccccccccccccc}30 & 13 & 21 & 22 & 0 & 0 & 0 & 0 & 0 & 61 & 19 & 15 & 35 \\ 8 & 4 & 2 & 4 & 4 & 4 & 0 & 6 & 7 & 5 & 3 & 5 & 8\end{array}$

$\begin{array}{lllllllll}8 & 4 & 2 & 4 & 4 & 4 & 0 & 6 & 7\end{array}$

$\begin{array}{cccccccc}0 & 0 & 0 & 0 & 0 & 18 & 73 & 4 \\ 8 & 16 & 20 & 25 & 32 & 87 & 79 & 49\end{array}$

Fernando Pedroz

Florânia

Ielmo Marinho

Itajá

Jaçanã

Janduís

$\begin{array}{llllllllll}0 & 0 & 0 & 0 & 0 & 0 & 0 & 0 & 0 & 0\end{array}$

$\begin{array}{lllllllll}1 & 2 & 21 & 5 & 22 & 22 & 48 & 4 & 0\end{array}$

$\begin{array}{lllllllll}1 & 21 & 5 & 22 & 22 & 48 & 4 & 0 & 10\end{array}$

$\begin{array}{llllllllll}22 & 22 & 47 & 203 & 177 & 98 & 140 & 177 & 124 & 31\end{array}$

$\begin{array}{lllllllllllll}2 & 1 & 4 & 2 & 19 & 27 & 28 & 15 & 16 & 12 & 11 & 8 & 0\end{array}$

$\begin{array}{lllllllllllll}0 & 0 & 0 & 0 & 0 & 22 & 0 & 0 & 0 & 0 & 0 & 0 & 0\end{array}$

$\begin{array}{lllllllllllll}4 & 3 & 3 & 4 & 1 & 18 & 6 & 8 & 10 & 6 & 0 & 3 & 12\end{array}$

$\begin{array}{lllllllllll}0 & 23 & 3 & 9 & 16 & 15 & 3 & 0 & 3 & 2 & 2\end{array}$

$\begin{array}{llllllllll}28 & 9 & 13 & 2 & 11 & 17 & 25 & 3 & 2 & 3\end{array}$

$\begin{array}{lllllllllllll}1 & 2 & 0 & 20 & 35 & 60 & 56 & 75 & 50 & 35 & 16 & 0 & 4\end{array}$ 


\begin{tabular}{|c|c|c|c|c|c|c|c|c|c|c|c|c|c|c|c|c|c|c|c|c|c|c|c|c|c|c|c|c|}
\hline 2004 & Município & s1 & s2 & s3 & s4 & s5 & s6 & s7 & s8 & s9 & s10 & s11 & s12 & $s 13$ & s14 & s15 & s16 & s17 & $s 18$ & $\mathbf{s 1 9}$ & s20 & s21 & s22 & s23 & s24 & s25 & $s 26$ & s27 \\
\hline & Januário Cicco & 0 & 0 & 0 & 0 & 0 & 0 & 0 & 0 & 4 & 0 & 0 & 0 & 0 & 0 & 0 & 0 & 0 & 0 & 0 & 0 & 0 & 0 & 0 & 0 & 0 & 0 & 0 \\
\hline & Japi & 0 & 0 & 2 & 0 & 0 & 5 & 18 & 18 & 3 & 5 & 5 & 9 & 0 & 0 & 0 & 0 & 4 & 0 & 0 & 0 & 0 & 0 & 0 & 0 & 0 & 0 & 0 \\
\hline & Jardim de Angicos & 0 & 3 & 0 & 6 & 5 & 16 & 19 & 10 & 3 & 0 & 0 & 0 & 0 & 0 & 0 & 0 & 0 & 0 & 4 & 0 & 0 & 0 & 0 & 0 & 0 & 0 & 0 \\
\hline & Lagoa d'Anta & 0 & 5 & 6 & 1 & 15 & 25 & 8 & 0 & 10 & 34 & 11 & 4 & 0 & 1 & 2 & 0 & 3 & 1 & 0 & 1 & 3 & 0 & 3 & 0 & 0 & 0 & 2 \\
\hline & Lagoa de Pedras & 3 & 1 & 4 & 7 & 5 & 11 & 0 & 7 & 12 & 17 & 13 & 5 & 4 & 4 & 2 & 1 & 3 & 0 & 0 & 5 & 0 & 0 & 0 & 0 & 1 & 0 & 2 \\
\hline & Lagoa de Velhos & 6 & 1 & 4 & 2 & 14 & 6 & 29 & 29 & 20 & 6 & 6 & 9 & 6 & 0 & 2 & 0 & 5 & 5 & 0 & 1 & 2 & 0 & 0 & 5 & 2 & 0 & 6 \\
\hline & Lagoa Nova & 0 & 0 & 0 & 1 & 2 & 2 & 0 & 0 & 5 & 7 & 8 & 0 & 0 & 0 & 0 & 2 & 0 & 0 & 0 & 0 & 0 & 0 & 0 & 2 & 0 & 0 & 1 \\
\hline & Lagoa Salgada & 0 & 1 & 0 & 1 & 10 & 16 & 10 & 33 & 12 & 2 & 3 & 6 & 8 & 5 & 1 & 1 & 1 & 3 & 1 & 6 & 0 & 3 & 4 & 3 & 2 & 1 & 0 \\
\hline & Lajes & 10 & 7 & 15 & 37 & 73 & 179 & 160 & 128 & 125 & 47 & 29 & 8 & 3 & 11 & 5 & 7 & 4 & 0 & 0 & 3 & 0 & 0 & 0 & 0 & 0 & 0 & 6 \\
\hline & Lajes Pintadas & 0 & 0 & 0 & 0 & 10 & 14 & 18 & 5 & 4 & 3 & 0 & 1 & 0 & 0 & 0 & 0 & 0 & 0 & 0 & 0 & 0 & 0 & 0 & 0 & 0 & 0 & 0 \\
\hline & Messias Targino & 0 & 3 & 3 & 9 & 19 & 37 & 16 & 12 & 12 & 3 & 3 & 3 & 3 & 3 & 0 & 0 & 0 & 0 & 0 & 0 & 0 & 0 & 0 & 0 & 0 & 1 & 1 \\
\hline & Monte Alegre & 0 & 0 & 0 & 0 & 0 & 0 & 0 & 0 & 0 & 0 & 0 & 0 & 0 & 0 & 0 & 0 & 0 & 0 & 0 & 0 & 0 & 0 & 0 & 0 & 0 & 0 & 0 \\
\hline & Monte das Gameleiras & 0 & 0 & 2 & 9 & 13 & 24 & 0 & 15 & 0 & 2 & 5 & 0 & 0 & 0 & 0 & 0 & 4 & 0 & 0 & 4 & 0 & 0 & 4 & 0 & 0 & 2 & 0 \\
\hline & Paraú & 0 & 0 & 0 & 0 & 0 & 0 & 0 & 0 & 0 & 0 & 0 & 0 & 0 & 0 & 0 & 0 & 0 & 0 & 0 & 0 & 0 & 0 & 0 & 0 & 0 & 0 & 0 \\
\hline & Passa e Fica & 0 & 9 & 3 & 14 & 0 & 0 & 11 & 33 & 6 & 8 & 15 & 18 & 9 & 0 & 0 & 0 & 1 & 0 & 0 & 0 & 0 & 3 & 0 & 0 & 0 & 0 & 0 \\
\hline & Patu & 5 & 4 & 8 & 8 & 29 & 24 & 43 & 47 & 33 & 8 & 8 & 9 & 5 & 6 & 0 & 0 & 0 & 3 & 0 & 0 & 0 & 5 & 0 & 0 & 0 & 5 & 0 \\
\hline & Pedra Preta & 0 & 0 & 0 & 1 & 1 & 27 & 16 & 3 & 6 & 2 & 2 & 0 & 1 & 3 & 1 & 0 & 2 & 2 & 0 & 0 & 0 & 1 & 3 & 0 & 1 & 3 & 1 \\
\hline & Pedro Avelino & 5 & 4 & 7 & 15 & 56 & 46 & 37 & 14 & 10 & 6 & 7 & 5 & 4 & 4 & 0 & 1 & 1 & 2 & 0 & 2 & 0 & 1 & 2 & 3 & 2 & 5 & 5 \\
\hline & Presidente Juscelino & 8 & 7 & 12 & 13 & 20 & 7 & 105 & 0 & 23 & 17 & 9 & 7 & 0 & 4 & 11 & 0 & 0 & 1 & 9 & 0 & 3 & 3 & 7 & 2 & 8 & 4 & 5 \\
\hline & Riachuelo & 0 & 0 & 0 & 0 & 4 & 0 & 2 & 0 & 9 & 0 & 0 & 0 & 0 & 0 & 0 & 0 & 0 & 0 & 0 & 0 & 0 & 0 & 0 & 0 & 0 & 0 & 0 \\
\hline & Ruy Barbosa & 20 & 7 & 11 & 10 & 72 & 22 & 40 & 14 & 22 & 23 & 0 & 0 & 4 & 1 & 4 & 0 & 2 & 1 & 0 & 4 & 4 & 0 & 0 & 0 & 0 & 1 & 1 \\
\hline & Santa Cruz & 4 & 4 & 13 & 26 & 273 & 173 & 76 & 19 & 50 & 29 & 171 & 65 & 36 & 58 & 5 & 6 & 3 & 3 & 5 & 3 & 3 & 2 & 4 & 2 & 4 & 0 & 0 \\
\hline & Santa Maria & 0 & 0 & 0 & 0 & 0 & 0 & 0 & 0 & 0 & 0 & 0 & 0 & 0 & 0 & 0 & 0 & 0 & 0 & 0 & 0 & 0 & 0 & 0 & 0 & 0 & 0 & 0 \\
\hline & Santana do Matos & 9 & 13 & 36 & 25 & 40 & 80 & 95 & 3 & 0 & 13 & 10 & 15 & 3 & 0 & 6 & 0 & 15 & 0 & 0 & 0 & 6 & 0 & 0 & 0 & 12 & 0 & 0 \\
\hline & São Bento do Trairi & 8 & 3 & 2 & 11 & 29 & 52 & 22 & 6 & 13 & 2 & 3 & 3 & 2 & 1 & 0 & 1 & 0 & 0 & 4 & 0 & 0 & 0 & 0 & 0 & 0 & 0 & 0 \\
\hline & São José do Campestre & 0 & 0 & 0 & 0 & 0 & 0 & 37 & 76 & 66 & 40 & 16 & 15 & 0 & 0 & 0 & 0 & 0 & 0 & 0 & 0 & 0 & 0 & 0 & 0 & 0 & 0 & 0 \\
\hline & São Paulo do Potengi & 0 & 0 & 4 & 1 & 7 & 15 & 26 & 3 & 55 & 81 & 55 & 17 & 2 & 0 & 1 & 0 & 1 & 0 & 0 & 1 & 0 & 0 & 0 & 0 & 0 & 0 & 1 \\
\hline & São Pedro & 0 & 0 & 0 & 0 & 0 & 0 & 0 & 0 & 19 & 21 & 20 & 0 & 0 & 0 & 0 & 0 & 0 & 0 & 0 & 0 & 0 & 0 & 0 & 0 & 0 & 0 & 0 \\
\hline & São Rafael & 0 & 0 & 0 & 0 & 9 & 7 & 13 & 3 & 20 & 20 & 11 & 11 & 4 & 6 & 3 & 3 & 0 & 0 & 3 & 9 & 4 & 0 & 0 & 4 & 4 & 6 & 3 \\
\hline & São Tomé & 1 & 8 & 13 & 8 & 18 & 27 & 40 & 0 & 5 & 6 & 17 & 5 & 0 & 3 & 0 & 0 & 0 & 0 & 0 & 0 & 0 & 0 & 0 & 0 & 0 & 0 & 0 \\
\hline & São Vicente & 0 & 0 & 0 & 0 & 0 & 0 & 0 & 12 & 12 & 23 & 9 & 5 & 0 & 0 & 0 & 0 & 0 & 0 & 0 & 0 & 0 & 0 & 0 & 0 & 0 & 0 & 0 \\
\hline & Senador Elói de Souza & 0 & 2 & 4 & 0 & 11 & 1 & 9 & 6 & 21 & 9 & 8 & 8 & 0 & 0 & 1 & 0 & 0 & 1 & 1 & 0 & 0 & 0 & 0 & 2 & 0 & 0 & 0 \\
\hline & Serra de São Bento & 0 & 3 & 0 & 0 & 0 & 0 & 0 & 6 & 3 & 0 & 13 & 0 & 0 & 0 & 0 & 0 & 0 & 0 & 0 & 0 & 0 & 5 & 0 & 0 & 3 & 0 & 0 \\
\hline & Serrinha & 0 & 0 & 0 & 2 & 5 & 6 & 4 & 6 & 1 & 3 & 0 & 2 & 4 & 0 & 0 & 1 & 0 & 0 & 0 & 0 & 0 & 2 & 0 & 0 & 0 & 0 & 1 \\
\hline & Sítio Novo & 1 & 0 & 3 & 2 & 8 & 10 & 3 & 0 & 0 & 0 & 4 & 7 & 0 & 2 & 0 & 0 & 0 & 0 & 2 & 1 & 0 & 0 & 0 & 2 & 0 & 0 & 0 \\
\hline & Tangará & 0 & 0 & 6 & 0 & 0 & 44 & 0 & 0 & 115 & 38 & 0 & 0 & 0 & 0 & 0 & 0 & 0 & 0 & 0 & 0 & 0 & 0 & 0 & 0 & 0 & 0 & 0 \\
\hline & Tenente Laurentino Cruz & 1 & 4 & 4 & 6 & 11 & 18 & 10 & 16 & 7 & 8 & 5 & 9 & 5 & 0 & 2 & 3 & 4 & 2 & 0 & 0 & 0 & 0 & 0 & 0 & 0 & 0 & 0 \\
\hline
\end{tabular}




\begin{tabular}{|c|c|c|c|c|c|c|c|c|c|c|c|c|c|c|c|c|c|c|c|c|c|c|c|c|c|c|}
\hline 2004 & Município & s1 & s2 s3 & 3 s4 & s5 & s6 & s7 & s8 & s10 & $0 \mathrm{s1}$ & $1 \mathrm{~s} 12$ & $2 s 13$ & $3 \mathrm{~s} 1$ & $4 \mathrm{~s} 15$ & $5 \mathrm{~s} 16$ & $6 \mathrm{~s} 1 \mathrm{~T}$ & $7 \mathrm{~s} 18$ & $8 \mathrm{~s} 1 \mathrm{~s}$ & $9 \mathrm{s2C}$ & 0 s2 & $1 \mathrm{~s} 22$ & $2 s 23$ & 3 s24 & $4 \quad s 25$ & $5 \mathrm{s2}$ & $6 \quad s 27$ \\
\hline & Triunfo Potiguar & 3 & 43 & 2 & 2 & 19 & 9 & 5 & 6 & 7 & 4 & 4 & 2 & 2 & 0 & 0 & 4 & 2 & 0 & 2 & 2 & 1 & 1 & 3 & 3 & 3 \\
\hline 2004 & Município & s28 & $s 29$ & s30 & s31 & s32 & s33 & 3 s34 & s35 & s36 & s37 & s38 & s39 & s40 & s41 & $s 42$ & s43 & s44 & s45 & s46 & $s 47$ & s48 & s49 & $s 50$ & s51 & $s 52$ \\
\hline & Acari & 5 & 5 & 6 & 4 & 3 & 4 & 3 & 1 & 2 & 2 & 3 & 1 & 0 & 5 & 5 & 10 & 2 & 3 & 5 & 4 & 0 & 3 & 4 & 0 & 0 \\
\hline & Açu & 6 & 1 & 2 & 2 & 5 & 2 & 4 & 1 & 3 & 3 & 3 & 0 & 4 & 1 & 3 & 0 & 8 & 5 & 0 & 4 & 3 & 2 & 2 & 4 & 2 \\
\hline & Almino Afonso & 0 & 4 & 0 & 2 & 2 & 0 & 1 & 0 & 4 & 2 & 2 & 2 & 4 & 2 & 3 & 0 & 6 & 0 & 5 & 3 & 3 & 1 & 2 & 3 & 2 \\
\hline & Angicos & 0 & 0 & 0 & 0 & 0 & 0 & 0 & 0 & 0 & 0 & 0 & 0 & 0 & 0 & 0 & 0 & 0 & 0 & 0 & 0 & 0 & 0 & 0 & 0 & 0 \\
\hline & Augusto Severo & 6 & 5 & 5 & 6 & 4 & 3 & 2 & 3 & 3 & 4 & 1 & 2 & 6 & 4 & 4 & 6 & 2 & 3 & 5 & 4 & 5 & 8 & 10 & 6 & 8 \\
\hline & Barcelona & 0 & 0 & 0 & 0 & 0 & 0 & 0 & 0 & 0 & 0 & 0 & 3 & 0 & 0 & 0 & 0 & 0 & 0 & 0 & 4 & 0 & 0 & 0 & 0 & 0 \\
\hline & Bodó & 0 & 0 & 0 & 0 & 0 & 0 & 0 & 0 & 0 & 0 & 0 & 0 & 0 & 0 & 0 & 0 & 0 & 0 & 0 & 0 & 0 & 0 & 0 & 0 & 0 \\
\hline & Bom Jesus & 0 & 0 & 0 & 0 & 0 & 0 & 0 & 0 & 0 & 0 & 0 & 0 & 0 & 0 & 0 & 0 & 0 & 0 & 0 & 0 & 0 & 0 & 0 & 0 & 0 \\
\hline & Caiçara do Rio do Vento & 0 & 1 & 0 & 0 & 1 & 1 & 0 & 0 & 0 & 0 & 1 & 0 & 0 & 2 & 0 & 0 & 0 & 0 & 0 & 0 & 0 & 0 & 0 & 0 & 0 \\
\hline & Caicó & 4 & 14 & 19 & 5 & 11 & 5 & 10 & 3 & 5 & 15 & 17 & 4 & 2 & 11 & 17 & 1 & 0 & 8 & 7 & 10 & 19 & 5 & 25 & 10 & 30 \\
\hline & Campo Redondo & 0 & 3 & 0 & 5 & 4 & 2 & 0 & 0 & 1 & 1 & 0 & 0 & 0 & 6 & 5 & 5 & 0 & 1 & 1 & 1 & 0 & 0 & 0 & 0 & 0 \\
\hline & Coronel Ezequiel & 0 & 0 & 0 & 1 & 0 & 0 & 0 & 0 & 0 & 0 & 0 & 0 & 0 & 0 & 0 & 0 & 0 & 0 & 4 & 1 & 2 & 0 & 0 & 0 & 0 \\
\hline & Currais Novos & 0 & 0 & 0 & 0 & 0 & 0 & 0 & 0 & 0 & 0 & 0 & 0 & 0 & 0 & 0 & 0 & 0 & 0 & 0 & 0 & 0 & 0 & 0 & 0 & 0 \\
\hline & Fernando Pedroza & 0 & 0 & 6 & 0 & 0 & 2 & 0 & 0 & 0 & 0 & 0 & 0 & 1 & 1 & 0 & 2 & 0 & 0 & 0 & 2 & 0 & 0 & 0 & 0 & 3 \\
\hline & Florânia & 2 & 3 & 3 & 2 & 1 & 2 & 1 & 1 & 3 & 0 & 2 & 2 & 3 & 2 & 0 & 3 & 3 & 7 & 4 & 18 & 6 & 3 & 0 & 2 & 0 \\
\hline & lelmo Marinho & - & - & - & - & - & - & - & - & - & - & - & - & - & - & - & - & - & - & - & - & - & - & - & - & - \\
\hline & Itajá & 0 & 0 & 0 & 2 & 2 & 1 & 0 & 0 & 2 & 0 & 4 & 0 & 0 & 1 & 1 & 2 & 2 & 2 & 4 & 1 & 2 & 2 & 1 & 1 & 1 \\
\hline & Jaçanã & 10 & 0 & 2 & 8 & 1 & 8 & 0 & 3 & 6 & 5 & 8 & 0 & 10 & 9 & 9 & 14 & 3 & 6 & 9 & 5 & 1 & 3 & 1 & 0 & 0 \\
\hline & Janduís & 0 & 0 & 0 & 0 & 0 & 0 & 1 & 2 & 0 & 0 & 1 & 0 & 1 & 2 & 4 & 1 & 2 & 2 & 1 & 2 & 1 & 0 & 1 & 1 & 0 \\
\hline & Januário Cicco & 0 & 0 & 0 & 0 & 0 & 0 & 0 & 0 & 0 & 0 & 0 & 0 & 0 & 0 & 0 & 0 & 0 & 0 & 0 & 0 & 0 & 0 & 0 & 0 & 0 \\
\hline & Japi & 0 & 0 & 0 & 0 & 3 & 0 & 0 & 0 & 0 & 0 & 0 & 0 & 6 & 0 & 0 & 0 & 0 & 0 & 4 & 0 & 0 & 0 & 0 & 0 & 0 \\
\hline & Jardim de Angicos & 0 & 0 & 0 & 0 & 0 & 4 & 1 & 1 & 2 & 2 & 3 & 0 & 0 & 0 & 0 & 0 & 3 & 0 & 0 & 0 & 0 & 0 & 0 & 0 & 0 \\
\hline & Lagoa d'Anta & 0 & 0 & 0 & 0 & 0 & 2 & 0 & 0 & 0 & 0 & 0 & 8 & 0 & 4 & 0 & 0 & 0 & 0 & 0 & 0 & 0 & 0 & 0 & 0 & 0 \\
\hline & Lagoa de Pedras & 5 & 0 & 3 & 0 & 0 & 1 & 2 & 3 & 1 & 1 & 2 & 0 & 4 & 2 & 0 & 1 & 0 & 0 & 0 & 0 & 0 & 0 & 0 & 0 & 0 \\
\hline & Lagoa de Velhos & 3 & 2 & 0 & 1 & 0 & 0 & 0 & 0 & 0 & 0 & 3 & 0 & 0 & 1 & 0 & 2 & 0 & 1 & 0 & 4 & 1 & 0 & 0 & 0 & 0 \\
\hline & Lagoa Nova & 0 & 0 & 0 & 0 & 0 & 0 & 0 & 0 & 0 & 0 & 0 & 0 & 0 & 0 & 0 & 0 & 0 & 0 & 0 & 0 & 0 & 0 & 0 & 0 & 0 \\
\hline & Lagoa Salgada & 0 & 0 & 0 & 1 & 2 & 0 & 4 & 3 & 2 & 0 & 0 & 0 & 0 & 11 & 13 & 0 & 0 & 0 & 0 & 0 & 0 & 0 & 0 & 0 & 0 \\
\hline & Lajes & 0 & 3 & 1 & 3 & 0 & 0 & 0 & 0 & 0 & 0 & 0 & 0 & 3 & 0 & 0 & 1 & 4 & 0 & 7 & 2 & 2 & 1 & 2 & 0 & 3 \\
\hline & Lajes Pintadas & 0 & 0 & 0 & 0 & 0 & 0 & 0 & 0 & 0 & 0 & 0 & 0 & 0 & 0 & 0 & 0 & 0 & 0 & 0 & 0 & 0 & 0 & 0 & 0 & 0 \\
\hline & Messias Targino & 4 & 2 & 0 & 2 & 1 & 0 & 1 & 3 & 0 & 1 & 1 & 1 & 2 & 1 & 1 & 1 & 0 & 1 & 1 & 0 & 0 & 0 & 0 & 0 & 0 \\
\hline & Monte Alegre & 0 & 0 & 0 & 0 & 0 & 0 & 0 & 0 & 0 & 0 & 0 & 0 & 0 & 0 & 0 & 0 & 0 & 0 & 0 & 0 & 0 & 0 & 0 & 0 & 0 \\
\hline & Monte das Gameleiras & 0 & 1 & 0 & 0 & 0 & 0 & 2 & 0 & 0 & 0 & 0 & 0 & 0 & 0 & 3 & 2 & 3 & 0 & 1 & 1 & 0 & 0 & 0 & 0 & 0 \\
\hline & Paraú & 0 & 0 & 0 & 0 & 0 & 0 & 0 & 0 & 0 & 0 & 0 & 0 & 0 & 0 & 0 & 0 & 0 & 0 & 0 & 0 & 0 & 0 & 0 & 0 & 0 \\
\hline & Passa e Fica & 0 & 0 & 2 & 0 & 0 & 0 & 2 & 1 & 0 & 0 & 2 & 1 & 0 & 0 & 0 & 0 & 0 & 0 & 0 & 0 & 0 & 0 & 0 & $\begin{array}{c}0 \\
222\end{array}$ & 0 \\
\hline
\end{tabular}




\begin{tabular}{|c|c|c|c|c|c|c|c|c|c|c|c|c|c|c|c|c|c|c|c|c|c|c|c|c|c|c|}
\hline 2004 & Município & s28 & $\mathbf{s 2 9}$ & s30 & s31 & s32 & s33 & s34 & s35 & s36 & s37 & s38 & s39 & $s 40$ & s41 & s42 & s43 & s44 & s45 & s46 & s47 & s48 & $s 49$ & s50 & s51 & s52 \\
\hline & Patu & 0 & 6 & 1 & 4 & 5 & 3 & 8 & 3 & 2 & 7 & 0 & 0 & 0 & 0 & 0 & 0 & 0 & 0 & 0 & 0 & 0 & 0 & 0 & 0 & 0 \\
\hline & Pedra Preta & 2 & 0 & 0 & 2 & 0 & 0 & 0 & 0 & 1 & 0 & 2 & 1 & 1 & 0 & 3 & 2 & 2 & 1 & 1 & 5 & 1 & 1 & 2 & 1 & 0 \\
\hline & Pedro Avelino & 5 & 4 & 4 & 8 & 4 & 5 & 5 & 6 & 7 & 4 & 4 & 3 & 0 & 3 & 4 & 3 & 3 & 3 & 5 & 4 & 4 & 3 & 7 & 4 & 3 \\
\hline & Presidente Juscelino & 3 & 6 & 7 & 5 & 4 & 0 & 12 & 12 & 0 & 0 & 9 & 20 & 28 & 46 & 38 & 28 & 8 & 0 & 8 & 10 & 0 & 5 & 10 & 0 & 0 \\
\hline & Riachuelo & 0 & 0 & 3 & 2 & 0 & 3 & 1 & 3 & 0 & 0 & 0 & 0 & 0 & 0 & 1 & 0 & 0 & 2 & 0 & 0 & 0 & 0 & 0 & 0 & 0 \\
\hline & Ruy Barbosa & 5 & 1 & 6 & 3 & 4 & 4 & 0 & 0 & 0 & 0 & 0 & 0 & 2 & 3 & 2 & 3 & 1 & 1 & 2 & 3 & 0 & 0 & 0 & 0 & 0 \\
\hline & Santa Cruz & 0 & 0 & 4 & 6 & 7 & 4 & 0 & 2 & 5 & 6 & 6 & 1 & 4 & 0 & 4 & 6 & 3 & 5 & 5 & 0 & 0 & 0 & 3 & 4 & 0 \\
\hline & Santa Maria & 0 & 0 & 0 & 0 & 0 & 0 & 0 & 0 & 0 & 0 & 0 & 0 & 0 & 0 & 0 & 0 & 0 & 0 & 0 & 0 & 0 & 0 & 0 & 0 & 0 \\
\hline & Santana do Matos & 0 & 0 & 4 & 2 & 0 & 0 & 5 & 0 & 0 & 1 & 0 & 0 & 0 & 0 & 5 & 0 & 0 & 1 & 1 & 6 & 5 & 2 & 1 & 0 & 2 \\
\hline & São Bento do Trairi & 0 & 0 & 0 & 0 & 0 & 0 & 1 & 0 & 0 & 0 & 0 & 0 & 0 & 0 & 0 & 2 & 0 & 0 & 0 & 4 & 3 & 4 & 2 & 0 & 0 \\
\hline & São José do Campestre & 0 & 0 & 0 & 0 & 0 & 0 & 0 & 0 & 0 & 0 & 0 & 0 & 0 & 0 & 0 & 0 & 0 & 0 & 0 & 0 & 0 & 0 & 0 & 0 & 0 \\
\hline & São Paulo do Potengi & 0 & 0 & 0 & 0 & 0 & 0 & 0 & 0 & 0 & 0 & 0 & 0 & 0 & 0 & 0 & 0 & 0 & 0 & 0 & 0 & 0 & 0 & 0 & 0 & 0 \\
\hline & São Pedro & 0 & 0 & 0 & 0 & 0 & 0 & 0 & 0 & 0 & 0 & 0 & 0 & 0 & 0 & 0 & 0 & 0 & 0 & 0 & 0 & 0 & 0 & 0 & 0 & 0 \\
\hline & São Rafael & 2 & 1 & 6 & 1 & 1 & 5 & 0 & 2 & 0 & 1 & 3 & 0 & 0 & 2 & 6 & 1 & 0 & 0 & 3 & 4 & 0 & 0 & 0 & 4 & 11 \\
\hline & São Tomé & 0 & 0 & 0 & 0 & 2 & 0 & 0 & 7 & 0 & 5 & 3 & 11 & 0 & 0 & 0 & 6 & 0 & 1 & 0 & 7 & 2 & 0 & 0 & 0 & 0 \\
\hline & São Vicente & 0 & 0 & 0 & 0 & 0 & 0 & 0 & 3 & 3 & 0 & 0 & 5 & 5 & 1 & 0 & 0 & 0 & 0 & 0 & 2 & 15 & 0 & 0 & 0 & 0 \\
\hline & Senador Elói de Souza & 1 & 3 & 0 & 0 & 0 & 0 & 0 & 3 & 1 & 0 & 0 & 1 & 5 & 0 & 6 & 4 & 2 & 1 & 1 & 1 & 0 & 0 & 0 & 0 & 0 \\
\hline & Serra de São Bento & 0 & 0 & 0 & 5 & 0 & 0 & 0 & 0 & 0 & 3 & 0 & 2 & 0 & 0 & 0 & 5 & 0 & 0 & 0 & 0 & 0 & 0 & 0 & 0 & 0 \\
\hline & Serrinha & 0 & 6 & 0 & 1 & 0 & 0 & 1 & 0 & 0 & 0 & 0 & 0 & 0 & 0 & 0 & 0 & 0 & 0 & 0 & 0 & 0 & 0 & 0 & 0 & 0 \\
\hline & Sítio Novo & 0 & 0 & 0 & 0 & 2 & 0 & 0 & 0 & 0 & 0 & 0 & 0 & 0 & 0 & 0 & 0 & 0 & 0 & 0 & 0 & 0 & 0 & 0 & 0 & 0 \\
\hline & Tangará & 0 & 0 & 0 & 0 & 0 & 0 & 0 & 0 & 0 & 0 & 0 & 0 & 0 & 0 & 0 & 0 & 0 & 0 & 0 & 0 & 0 & 0 & 0 & 0 & 0 \\
\hline & Tenente Laurentino Cruz & 0 & 3 & 2 & 0 & 0 & 0 & 0 & 0 & 0 & 0 & 0 & 0 & 0 & 0 & 1 & 2 & 0 & 0 & 15 & 6 & 0 & 0 & 0 & 0 & 0 \\
\hline & Triunfo Potiguar & 2 & 5 & 0 & 3 & 0 & 0 & 3 & 1 & 1 & 3 & 2 & 4 & 2 & 0 & 3 & 2 & 2 & 0 & 0 & 2 & 0 & 0 & 2 & 2 & 5 \\
\hline
\end{tabular}

Município

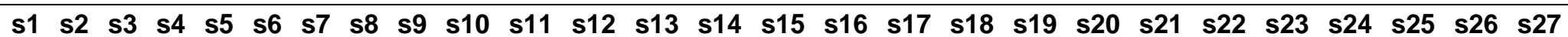
Acari Açu $\begin{array}{lllllllllllllll}14 & 3 & 4 & 9 & 6 & 5 & 21 & 34 & 24 & 17 & 21 & 11 & 2 & 2 & 10\end{array}$

$4 \mathbf{s}$

\begin{tabular}{cccccccccc}
8 & $\mathbf{s 1 9}$ & $\mathbf{s 2 0}$ & $\mathbf{s 2 1}$ & $\mathbf{s 2 2}$ & $\mathbf{s 2 3}$ & $\mathbf{s 2 4}$ & $\mathbf{s 2 5}$ & $\mathbf{s 2 6}$ & $\mathbf{s 2 7}$ \\
\hline & 7 & 6 & 7 & 11 & 8 & 13 & 10 & 10 & 9 \\
20 & 38 & 15 & 10 & 6 & 15 & 20 & 8 & 3
\end{tabular}

Almino Afonso $\begin{array}{cccccccccc}13 & 11 & 9 & 2 & 9 & 40 & 29 & 22 & 54 & 57 \\ - & 2 & 2 & 1 & 5 & 4 & - & 2 & 3 & -\end{array}$

Angicos

Augusto Severo Barcelona Bodó

Bom Jesus

Caiçara do Rio do Vento Caicó $\begin{array}{lllllllll}0 & 0 & 0 & 0 & 0 & 0 & 0 & 0 & 0\end{array}$

Campo Redondo Coronel Ezequiel 


\begin{tabular}{|c|c|c|c|c|c|c|c|c|c|c|c|c|c|c|c|c|c|c|c|c|c|c|c|c|c|c|c|c|}
\hline 2005 & Município & s1 & s2 & s3 & s4 & s5 & s6 & s7 & s8 & s9 & s10 & s11 & s12 & s13 & s14 & s15 & s16 & s17 & $s 18$ & s19 & s20 & s21 & s22 & s23 & s24 & s25 & $s 26$ & s27 \\
\hline & Currais Novos & 0 & 0 & 0 & 0 & 0 & 0 & 0 & 0 & 0 & 0 & 0 & 8 & 0 & 0 & 0 & 0 & 5 & 0 & 6 & 0 & 0 & 0 & 0 & 0 & 0 & 5 & 4 \\
\hline & Fernando Pedroza & - & - & 12 & 3 & 1 & 4 & 5 & 5 & 8 & 14 & - & 2 & 1 & 6 & 15 & 22 & 4 & 4 & 3 & 10 & 6 & 3 & 3 & 0 & 0 & 0 & 0 \\
\hline & Florânia & 3 & - & 3 & 3 & 2 & - & 3 & 11 & 22 & 8 & 13 & 4 & 2 & 7 & 5 & 8 & 6 & 1 & 6 & 9 & 3 & 1 & 7 & 5 & 2 & 3 & 8 \\
\hline & Ielmo Marinho & - & - & - & - & - & - & - & - & - & - & - & - & - & - & - & - & - & - & - & - & - & - & - & - & - & - & - \\
\hline & Itajá & 0 & 0 & 0 & 0 & 0 & 0 & 0 & 0 & 0 & 0 & 0 & 0 & 0 & 1 & 14 & 20 & 19 & 12 & 11 & 5 & 2 & 2 & 1 & 2 & 1 & - & 1 \\
\hline & Jaçanã & 1 & 2 & 7 & 4 & 2 & 15 & 13 & 10 & 9 & 10 & 9 & 9 & 7 & 10 & 9 & 7 & 11 & 17 & 13 & 15 & 15 & 35 & 52 & 29 & 26 & 28 & 24 \\
\hline & Janduís & 0 & 0 & 0 & 0 & 0 & 0 & 0 & 0 & 0 & 0 & 0 & 0 & 0 & 0 & 0 & 0 & 0 & 0 & 0 & 0 & 0 & 0 & 0 & 0 & 0 & 0 & 0 \\
\hline & Januário Cicco & 0 & 0 & 0 & 0 & 0 & 0 & 0 & 0 & 0 & 0 & 0 & 0 & 0 & 4 & 14 & 0 & 0 & 0 & 0 & 21 & 21 & 13 & 0 & 4 & 10 & 0 & 0 \\
\hline & Japi & 0 & 0 & 0 & 0 & 2 & 0 & 0 & 0 & 3 & 0 & 13 & 4 & 11 & 3 & 4 & 6 & 6 & 7 & 5 & 2 & 2 & 0 & 0 & 2 & 3 & 0 & 0 \\
\hline & Jardim de Angicos & - & 1 & 2 & 1 & 2 & 7 & 15 & 11 & 0 & 3 & 0 & 1 & 1 & 2 & - & 8 & 3 & 3 & 4 & 3 & 1 & - & 8 & 7 & 13 & 5 & 3 \\
\hline & Lagoa d'Anta & - & 1 & 1 & 3 & 1 & - & 0 & - & - & - & - & - & 0 & - & - & - & - & 3 & 1 & 3 & 7 & - & - & - & - & - & 8 \\
\hline & Lagoa de Pedras & 2 & 1 & 1 & 2 & 1 & 2 & - & - & 4 & - & 7 & 5 & 3 & 19 & 11 & 4 & 5 & 5 & 10 & 11 & 6 & 10 & 15 & 12 & 8 & 2 & 7 \\
\hline & Lagoa de Velhos & - & 1 & 1 & 1 & 10 & 19 & 7 & - & 5 & - & 2 & 1 & 3 & 3 & 11 & 14 & 12 & 5 & 0 & 6 & 6 & 6 & 10 & 10 & 3 & 13 & - \\
\hline & Lagoa Nova & 0 & 0 & 8 & 0 & 0 & 0 & 0 & 0 & 0 & 0 & 0 & 0 & 0 & 0 & 0 & 0 & 0 & 0 & 0 & 11 & 0 & 0 & 0 & 3 & 0 & 0 & 0 \\
\hline & Lagoa Salgada & 0 & 5 & 0 & 0 & 0 & 0 & 0 & 0 & 0 & 0 & 0 & 0 & 0 & 0 & 0 & 0 & 0 & 0 & 0 & 0 & 0 & 0 & 0 & 0 & 0 & 0 & 0 \\
\hline & Lajes & - & 2 & 6 & 4 & - & - & 4 & 12 & 2 & 17 & 9 & 6 & 19 & 4 & 11 & 8 & 19 & 15 & - & 13 & 7 & - & - & - & - & - & - \\
\hline & Lajes Pintadas & - & 2 & 4 & - & - & - & 4 & 9 & 5 & 12 & - & 2 & 2 & 3 & 7 & 15 & 3 & 2 & 6 & 8 & 5 & 9 & 10 & 6 & 2 & 1 & 7 \\
\hline & Messias Targino & 9 & 15 & 15 & 12 & 9 & 10 & 6 & 2 & 1 & 8 & 14 & 15 & 5 & 4 & 18 & 15 & 13 & 22 & 14 & 11 & 18 & 20 & 13 & 8 & 5 & - & 12 \\
\hline & Monte Alegre & 7 & 4 & 1 & 2 & - & - & - & 2 & - & 4 & 12 & 7 & 20 & 22 & 8 & 23 & 26 & 36 & 13 & 12 & 26 & 8 & 35 & 16 & 0 & 0 & 0 \\
\hline & Monte das Gameleiras & - & 2 & 3 & 6 & 6 & 8 & 22 & 16 & 7 & 3 & 4 & - & 6 & 10 & 11 & 6 & 6 & 6 & 8 & 12 & 12 & 7 & 0 & 12 & 5 & 10 & 10 \\
\hline & Paraú & - & - & - & 0 & - & 7 & 11 & 18 & 10 & 17 & 6 & 7 & 4 & 6 & 16 & 10 & 12 & 24 & 23 & 10 & 3 & 2 & - & - & 0 & 0 & - \\
\hline & Passa e Fica & - & - & - & - & - & - & - & - & 1 & - & - & 3 & 7 & 12 & 15 & 11 & 4 & 2 & 12 & 15 & 21 & 5 & 6 & - & - & 2 & 5 \\
\hline & Patu & - & - & - & 2 & - & - & 1 & 4 & 1 & - & 15 & 12 & 10 & 24 & 4 & 10 & 14 & 6 & 16 & 3 & 11 & 26 & 5 & 6 & 6 & 0 & 0 \\
\hline & Pedra Preta & 3 & 1 & 1 & - & 2 & - & 13 & 9 & 3 & 7 & 7 & 1 & 8 & 5 & 12 & 7 & 3 & 22 & 2 & 8 & 11 & 1 & 8 & 11 & 9 & 8 & - \\
\hline & Pedro Avelino & 5 & 7 & 11 & 23 & 21 & 34 & 24 & - & - & - & - & - & - & - & 0 & - & 0 & 6 & 4 & 2 & - & 5 & - & - & 0 & 3 & 6 \\
\hline & Presidente Juscelino & 2 & - & 2 & 2 & - & 3 & 1 & 2 & 6 & 15 & 47 & 11 & 3 & 9 & 13 & 6 & 4 & 6 & 7 & 2 & 3 & 2 & - & 4 & 1 & 1 & 2 \\
\hline & Riachuelo & 2 & 1 & - & 2 & 1 & 4 & 2 & 6 & 2 & 9 & 14 & 7 & 4 & 1 & 1 & 3 & 3 & 9 & 7 & 11 & 27 & 17 & 4 & 10 & 13 & 8 & 2 \\
\hline & Ruy Barbosa & - & 2 & 1 & 4 & 2 & 3 & 2 & 7 & 4 & 10 & 0 & 2 & 2 & 2 & 7 & 3 & 0 & 8 & 7 & 0 & 3 & 2 & 3 & 11 & 9 & 5 & 7 \\
\hline & Santa Cruz & 1 & 3 & 6 & 8 & 1 & 1 & 3 & 19 & 44 & 59 & 97 & 57 & 60 & 30 & 39 & 18 & 53 & 28 & 56 & 50 & 43 & 62 & 78 & 51 & 67 & 31 & 18 \\
\hline & Santa Maria & 0 & 0 & 0 & 0 & 0 & 0 & 0 & 0 & 0 & 0 & 0 & 0 & 0 & 0 & 0 & 0 & 0 & 0 & 1 & 0 & 0 & 0 & 0 & 0 & 0 & 0 & 0 \\
\hline & Santana do Matos & 4 & 4 & 4 & 12 & 4 & - & - & 9 & - & 11 & 5 & 4 & 14 & 13 & 4 & 9 & 40 & 7 & 11 & 7 & 10 & 3 & 5 & - & 2 & 14 & 0 \\
\hline & São Bento do Trairi & - & - & - & 0 & - & - & 6 & 4 & 9 & 10 & 17 & 5 & 3 & 4 & 3 & 9 & - & - & - & 9 & 2 & 6 & 5 & 10 & 4 & 7 & 9 \\
\hline & São José do Campestre & 0 & 0 & 0 & 0 & 0 & 0 & 0 & 0 & 0 & 0 & 0 & 0 & 0 & 0 & 0 & 22 & 0 & 0 & 0 & 0 & 7 & 0 & 22 & 7 & 21 & 6 & 9 \\
\hline & São Paulo do Potengi & 0 & - & - & 1 & - & - & - & 1 & 4 & 2 & 18 & 18 & - & 0 & 17 & 21 & 26 & 7 & 45 & 26 & 24 & 50 & 17 & 49 & 43 & 31 & 33 \\
\hline & São Pedro & 0 & 0 & 0 & 0 & 0 & 0 & 0 & 0 & 9 & 14 & 5 & 4 & 12 & 15 & 25 & 25 & 18 & 28 & 23 & - & 7 & 6 & 5 & 5 & 6 & 6 & 7 \\
\hline & São Rafael & 0 & 2 & 0 & 0 & 0 & 2 & 1 & 1 & - & 12 & 24 & 9 & 8 & 27 & 41 & 38 & 31 & 28 & 27 & 25 & 30 & 3 & 10 & 13 & 4 & - & 4 \\
\hline & São Tomé & 0 & 0 & 0 & 0 & 0 & 0 & 0 & 0 & 0 & 0 & 4 & 14 & 0 & 10 & 22 & 0 & 49 & 12 & 0 & 7 & 0 & 0 & 0 & 0 & 0 & 6 & 17 \\
\hline
\end{tabular}




\begin{tabular}{|c|c|c|c|c|c|c|c|c|c|c|c|c|c|c|c|c|c|c|c|c|c|c|c|c|c|c|}
\hline 2005 & Município & s1 & s2 s? & s3 s4 & s5 & $\mathrm{s} 6 \mathrm{~s}$ & s7 s8 & s9 & $s 10$ & s11 & s12 & s13 & $s 14$ & s15 & s16 & s17 & s18 & s19 & s20 & s21 & s22 & s23 & s24 & s25 & s26 & s27 \\
\hline & São Vicente & 0 & 0 & $\begin{array}{ll}0 & 0\end{array}$ & 0 & 02 & 218 & 0 & 6 & 10 & 10 & 0 & 6 & 2 & $\mathrm{~N}$ & - & 0 & 9 & 2 & 1 & 2 & 4 & - & 9 & 4 & 2 \\
\hline & Senador Elói de Souza & 0 & 0 & 0 & 0 & 0 & 0 & 0 & 0 & 0 & 0 & 0 & 0 & 0 & 0 & 0 & 0 & 0 & 0 & 0 & 0 & 0 & 0 & 0 & 0 & 0 \\
\hline & Serra de São Bento & 0 & 0 & 0 & 0 & 0 & 0 & 0 & 0 & 0 & 0 & 0 & 0 & 0 & 0 & 0 & 0 & 0 & 0 & 0 & 0 & 0 & 0 & 0 & 0 & 0 \\
\hline & Serrinha & 0 & 0 & 0 & 0 & 0 & 0 & 0 & 0 & 0 & 0 & 0 & 0 & 0 & 0 & 0 & 0 & 0 & 0 & 0 & 0 & 0 & 0 & 0 & 0 & 0 \\
\hline & Sítio Novo & - & 3 & 1 & - & 1 & 4 & 4 & 4 & 2 & 6 & 5 & 4 & 4 & 6 & 27 & 3 & 6 & 28 & 31 & 20 & 21 & 17 & 24 & 26 & 18 \\
\hline & Tangará & 0 & 0 & 0 & 0 & 0 & 0 & - & 28 & - & 7 & 20 & - & 5 & 39 & 7 & 16 & 0 & 0 & 5 & 0 & 5 & 0 & 0 & 0 & 0 \\
\hline & Tenente Laurentino Cruz & - & 3 & 2 & - & 14 & 2 & 10 & 2 & - & 5 & 7 & 4 & 4 & 5 & 6 & 2 & 17 & 6 & 9 & 13 & 2 & 7 & 6 & 8 & 6 \\
\hline & Triunfo Potiguar & 3 & - & 5 & 12 & 7 & 13 & 7 & 5 & 11 & 2 & 4 & 7 & 1 & 8 & 7 & 1 & 8 & - & 3 & 1 & 1 & 1 & - & 1 & 2 \\
\hline 2005 & Município & s28 & $s 29$ & 9 s30 & s31 & s32 & s33 & s34 & s35 & s36 & s37 & s38 & s39 & $s 40$ & s41 & s42 & s43 & s44 & s45 & s46 & s47 & s48 & s49 & s50 & s51 & s52 \\
\hline & Acari & 9 & 4 & 10 & 0 & 8 & 4 & 2 & - & 2 & - & 2 & 1 & 1 & 2 & 4 & - & 2 & 9 & 3 & 6 & 6 & - & - & - & - \\
\hline & Açu & 6 & 10 & 15 & 4 & 5 & 8 & 4 & 3 & 11 & 3 & - & 3 & 1 & 7 & 6 & 3 & 3 & 6 & 6 & 7 & 1 & 3 & 0 & 0 & 5 \\
\hline & Almino Afonso & - & - & 0 & - & - & - & - & - & - & - & - & - & - & 0 & - & 0 & 0 & - & 0 & 0 & - & 0 & 0 & 0 & 0 \\
\hline & Angicos & 1 & 3 & 13 & 10 & 1 & 3 & 10 & 0 & - & 8 & 15 & 9 & 7 & 16 & 13 & 13 & 11 & 11 & 18 & 9 & 22 & 32 & 17 & 43 & 20 \\
\hline & Augusto Severo & 0 & 0 & 5 & 7 & 2 & 0 & 1 & 0 & 0 & 4 & 0 & 3 & 4 & 0 & 0 & 0 & 8 & 4 & 0 & 4 & 1 & 0 & 0 & 0 & 0 \\
\hline & Barcelona & 13 & 11 & 6 & 0 & 3 & 6 & 2 & 0 & 4 & 4 & 1 & 1 & 2 & 3 & 6 & 3 & 1 & 1 & 0 & 0 & 0 & 0 & 0 & 0 & 0 \\
\hline & Bodó & 0 & 0 & 0 & 0 & 0 & 0 & 0 & 0 & 0 & 0 & 0 & 0 & 0 & 0 & 0 & 0 & 0 & 0 & 0 & 0 & 0 & 0 & 0 & 0 & 0 \\
\hline & Bom Jesus & 20 & 11 & 7 & 3 & 4 & 6 & 5 & 2 & 3 & 6 & 4 & - & 4 & 2 & 1 & - & - & - & - & - & - & 0 & 2 & 4 & 6 \\
\hline & Caiçara do Rio do Vento & 3 & 3 & 3 & - & - & 1 & 2 & 0 & 0 & - & - & - & - & - & 1 & - & - & - & - & 2 & 1 & 1 & - & 1 & 2 \\
\hline & Caicó & 15 & 21 & 21 & 5 & 3 & 14 & 26 & 8 & 3 & 6 & 42 & 18 & 14 & 30 & 24 & 26 & - & 3 & 12 & 16 & 1 & 7 & 7 & 3 & 32 \\
\hline & Campo Redondo & 13 & 16 & 0 & 9 & 9 & 9 & 10 & 12 & 8 & 11 & 10 & 12 & 16 & 15 & 17 & 19 & 13 & 14 & 11 & 11 & 8 & 7 & 11 & 0 & 0 \\
\hline & Coronel Ezequiel & 4 & 2 & 5 & 3 & - & 1 & 6 & 3 & 2 & 4 & 4 & 6 & 4 & 8 & 6 & - & 6 & 6 & - & - & - & 2 & 4 & 6 & 1 \\
\hline & Currais Novos & 0 & 0 & 0 & 0 & 0 & 0 & 2 & 0 & 0 & 0 & 0 & 0 & 2 & 0 & 0 & 0 & 0 & 0 & 0 & 1 & 0 & 0 & 0 & 0 & 2 \\
\hline & Fernando Pedroza & 0 & 0 & 1 & 0 & 0 & 0 & 0 & 0 & 0 & 0 & 0 & 0 & 0 & 0 & 0 & 0 & 6 & 0 & 0 & 0 & 0 & 0 & 0 & 0 & 18 \\
\hline & Florânia & 3 & 2 & 2 & 8 & 1 & 3 & 3 & 2 & 4 & 3 & 2 & 11 & 5 & - & 0 & 14 & 12 & 11 & 7 & 3 & 8 & 11 & 9 & 11 & 14 \\
\hline & Ielmo Marinho & - & - & - & - & - & - & - & - & - & - & - & - & - & - & - & - & - & - & - & - & - & - & - & - & - \\
\hline & Itajá & - & 3 & - & 3 & - & 1 & 1 & 0 & 7 & 3 & - & 3 & 3 & 4 & 8 & 8 & 0 & 0 & 0 & 0 & 0 & 0 & 0 & 0 & 0 \\
\hline & Jaçanã & 3 & 8 & - & 2 & 3 & 3 & 1 & 3 & 2 & 5 & 7 & 5 & 5 & 1 & 5 & - & - & - & 4 & 1 & 2 & 3 & 3 & 0 & 2 \\
\hline & Janduís & 0 & 0 & 0 & 0 & 0 & 0 & 0 & 0 & 0 & 0 & 0 & 0 & 10 & 0 & 0 & 0 & 7 & 2 & 4 & 6 & 7 & 4 & 6 & 5 & 3 \\
\hline & Januário Cicco & 9 & 6 & 8 & 2 & 4 & 6 & 0 & 0 & 0 & 0 & 0 & 3 & 6 & 7 & - & 1 & 2 & - & 3 & 5 & 0 & - & 2 & 2 & 7 \\
\hline & Japi & 2 & 0 & 3 & 0 & 0 & 3 & 4 & 4 & 0 & 4 & 6 & 5 & 7 & 5 & 11 & 0 & 5 & 5 & 0 & 0 & 6 & 4 & 16 & 11 & 0 \\
\hline & Jardim de Angicos & 3 & - & - & 1 & - & - & - & - & - & - & - & 1 & 2 & 2 & - & 1 & - & 1 & 1 & 1 & - & - & - & 2 & 2 \\
\hline & Lagoa d'Anta & 3 & - & 2 & - & 2 & 2 & - & - & - & - & - & - & - & - & - & 0 & 0 & 0 & 0 & 0 & 0 & 0 & 0 & 0 & 0 \\
\hline & Lagoa de Pedras & 14 & 8 & 6 & 2 & - & 2 & 4 & - & - & - & 2 & 4 & - & - & 1 & 1 & 1 & 0 & 4 & 7 & 1 & 1 & - & 5 & 0 \\
\hline & Lagoa de Velhos & 2 & 2 & 4 & 3 & 2 & - & - & - & - & - & - & - & - & - & 1 & - & - & - & - & - & 3 & - & - & 3 & - \\
\hline & Lagoa Nova & 0 & 5 & 0 & 0 & - & 9 & - & - & - & - & 4 & - & - & - & 3 & - & - & - & - & - & - & 3 & 11 & 1 & 0 \\
\hline & Lagoa Salgada & 0 & 0 & 0 & 0 & 0 & 0 & 0 & 0 & 0 & 0 & 0 & 0 & 0 & 0 & 0 & 0 & 0 & - & 0 & 0 & 0 & 0 & 0 & $\begin{array}{c}0 \\
225\end{array}$ & 0 \\
\hline
\end{tabular}




\begin{tabular}{|c|c|c|c|c|c|c|c|c|c|c|c|c|c|c|c|c|c|c|c|c|c|c|c|c|c|c|}
\hline 2005 & Município & s28 & $\mathbf{s 2 9}$ & s30 & s31 & s32 & s33 & s34 & s35 & s36 & s37 & s38 & s39 & $s 40$ & s41 & s42 & s43 & s44 & s45 & $s 46$ & $s 47$ & $s 48$ & s49 & $s 50$ & $s 51$ & s52 \\
\hline & Lajes & 48 & 33 & 30 & 9 & 9 & 12 & 6 & - & 8 & 7 & - & - & 8 & - & 3 & 0 & 5 & - & - & 3 & - & - & 5 & 3 & - \\
\hline & Lajes Pintadas & 0 & 2 & - & - & - & - & 1 & 1 & - & - & - & 1 & 3 & 1 & - & - & - & - & 1 & - & - & - & - & - & 1 \\
\hline & Messias Targino & 11 & 5 & 10 & 4 & 8 & 6 & 9 & 10 & 15 & 7 & 13 & 9 & 6 & 19 & 7 & 8 & 1 & - & - & 1 & - & 6 & 3 & 5 & 1 \\
\hline & Monte Alegre & 0 & 0 & 0 & 0 & 0 & 0 & 0 & 0 & 0 & 0 & 0 & 0 & 0 & 0 & 0 & 0 & 0 & 0 & 0 & 0 & 0 & 0 & 0 & 0 & 0 \\
\hline & Monte das Gameleiras & 3 & 9 & 1 & 6 & - & 9 & 5 & - & - & - & - & 6 & 5 & - & - & 4 & 6 & - & 1 & 4 & 2 & 0 & 4 & 4 & 2 \\
\hline & Paraú & - & - & - & - & - & - & - & 0 & - & - & - & - & - & 0 & - & - & 0 & 0 & 0 & 0 & - & - & - & 0 & - \\
\hline & Passa e Fica & 12 & 3 & 12 & 2 & 5 & - & - & 2 & - & 5 & - & - & - & 1 & 2 & 1 & 1 & 0 & - & 2 & 0 & 1 & 1 & 1 & 1 \\
\hline & Patu & 9 & 0 & 1 & - & 3 & 6 & 3 & 12 & - & 5 & 1 & 8 & 6 & 5 & - & 11 & 3 & - & - & 3 & 3 & 3 & - & 4 & 5 \\
\hline & Pedra Preta & 18 & 21 & 10 & 6 & 7 & 5 & 4 & 2 & 2 & 5 & 2 & 3 & 6 & 5 & 5 & 4 & 3 & 2 & 1 & 3 & - & 5 & 3 & 1 & - \\
\hline & Pedro Avelino & 3 & 2 & 0 & 1 & 2 & - & 2 & 1 & - & 1 & 5 & - & 3 & 1 & - & - & - & - & - & - & 3 & - & 7 & - & - \\
\hline & Presidente Juscelino & 2 & 2 & 2 & 2 & 0 & 2 & 5 & 1 & 3 & 2 & 3 & 2 & 2 & 6 & 5 & 3 & 5 & 4 & 4 & 3 & 3 & - & 3 & 0 & 11 \\
\hline & Riachuelo & 6 & - & 1 & 1 & 5 & - & - & 2 & 1 & - & - & 1 & 6 & - & 9 & 8 & 2 & 4 & 1 & - & - & 2 & 1 & 4 & 2 \\
\hline & Ruy Barbosa & 4 & 0 & 0 & 0 & 1 & 1 & 2 & 1 & 0 & 0 & 3 & 2 & 1 & 1 & 4 & 1 & 2 & 2 & 0 & 0 & 0 & 0 & 0 & 0 & 0 \\
\hline & Santa Cruz & 19 & 16 & 17 & 8 & 9 & 9 & 8 & 1 & 0 & 4 & 7 & 3 & 10 & 11 & 11 & 10 & 12 & 11 & 17 & 3 & 24 & 20 & 18 & 13 & 12 \\
\hline & Santa Maria & 0 & 0 & 37 & 12 & 0 & 0 & 0 & 40 & 0 & 0 & 0 & 25 & 0 & 0 & 0 & 35 & 0 & 0 & 0 & 0 & 0 & 0 & 19 & 5 & 10 \\
\hline & Santana do Matos & 2 & - & 9 & - & - & - & - & - & - & - & 2 & 6 & 1 & 2 & - & - & - & 14 & 4 & 13 & 1 & 1 & - & - & - \\
\hline & São Bento do Trairi & 4 & 2 & - & 4 & 1 & 1 & - & 3 & 8 & 3 & - & - & 3 & - & 1 & 2 & 3 & 2 & 1 & 2 & 6 & 4 & - & 1 & 4 \\
\hline & São José do Campestre & 0 & 0 & 0 & 4 & 0 & 0 & 17 & 6 & - & 3 & - & 7 & - & 2 & 0 & - & - & 0 & 0 & 3 & 0 & - & - & 2 & 0 \\
\hline & São Paulo do Potengi & 33 & 0 & 21 & 0 & 0 & 9 & 16 & 6 & 0 & 14 & 8 & 0 & 8 & 9 & 4 & 0 & 5 & 3 & 19 & 3 & 5 & - & 0 & 8 & 0 \\
\hline & São Pedro & 6 & 6 & 6 & 5 & 5 & 5 & 6 & 5 & 1 & 3 & 1 & - & 1 & - & 1 & 1 & - & - & 3 & 5 & 6 & 6 & 2 & 4 & 5 \\
\hline & São Rafael & 8 & 3 & 6 & 6 & 4 & 2 & 32 & 0 & 0 & 0 & 0 & 0 & 15 & 11 & 10 & 3 & 0 & 0 & 0 & 0 & 0 & 16 & 9 & - & - \\
\hline & São Tomé & 9 & 0 & 8 & 0 & 6 & 0 & 0 & 0 & 0 & 0 & 12 & 0 & 4 & 0 & 0 & 5 & 0 & 0 & 0 & 0 & 0 & 0 & 0 & 7 & 0 \\
\hline & São Vicente & - & 1 & - & - & - & 2 & - & 1 & 6 & 0 & 2 & 2 & - & - & 3 & - & 2 & 4 & - & - & 3 & 5 & 2 & 9 & 10 \\
\hline & Senador Elói de Souza & 0 & 0 & 4 & 0 & 0 & 0 & 0 & 0 & 0 & 0 & 0 & 0 & 0 & 0 & 0 & 0 & 0 & 0 & 0 & 0 & 0 & 0 & 0 & 0 & 0 \\
\hline & Serra de São Bento & 0 & 0 & 0 & 0 & 0 & 0 & 0 & 0 & 0 & 0 & 0 & 0 & 0 & 0 & 0 & 0 & 0 & 0 & 0 & 0 & 0 & 0 & 0 & 0 & 0 \\
\hline & Serrinha & 0 & 0 & 0 & 0 & 0 & 0 & 0 & 0 & 1 & 5 & - & - & 2 & - & - & - & 0 & - & 1 & - & - & - & - & 2 & 2 \\
\hline & Sítio Novo & 21 & 4 & 11 & 10 & 2 & 5 & 0 & 0 & - & 0 & - & 0 & 2 & - & 2 & - & 1 & - & 4 & 2 & 1 & - & 2 & 2 & - \\
\hline & Tangará & 0 & 0 & 0 & 0 & 0 & 0 & 0 & 0 & 0 & - & 0 & 0 & 0 & 0 & 0 & 0 & 0 & 0 & 0 & 0 & 0 & 0 & 0 & 0 & 0 \\
\hline & Tenente Laurentino Cruz & 3 & 10 & 11 & 7 & 0 & 2 & 3 & 4 & 2 & 1 & 3 & 5 & 2 & 1 & 3 & 1 & 1 & 2 & 0 & 1 & 2 & - & - & - & - \\
\hline & Triunfo Potiguar & 3 & 1 & 1 & 2 & 2 & 1 & - & 1 & 1 & 2 & - & - & 1 & 2 & 1 & 4 & 0 & 0 & 7 & 9 & 0 & 0 & 0 & 0 & 0 \\
\hline
\end{tabular}

2006

Município

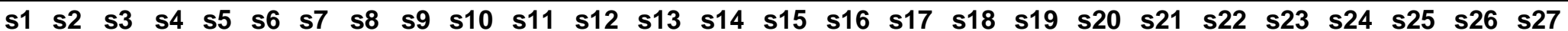

Acari

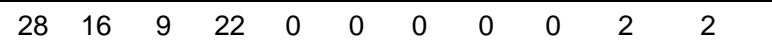

Açu

$\begin{array}{lllllllllllllllll}18 & 17 & 9 & 14 & 14 & 16 & 6 & 16 & 18 & 23 & 37 & 37 & 21 & 76 & 64 & 36 & 26\end{array}$

Almino Afonso

$\begin{array}{lllllllllllllllll}0 & 0 & 0 & 0 & 0 & 4 & 0 & 1 & 1 & 3 & 4 & 10 & 24 & 13 & 12 & 10 & 12\end{array}$

Angicos

$\begin{array}{llllllllllllllll}13 & 27 & 21 & 25 & 28 & 13 & 21 & 20 & 36 & 13 & 22 & 37 & 36 & 22 & 15 & 25\end{array}$ 


\begin{tabular}{|c|c|c|c|c|c|c|c|c|c|c|c|c|c|c|c|c|c|c|c|c|c|c|c|c|c|c|c|c|}
\hline 2006 & Município & s1 & s2 & s3 & s4 & s5 & s6 & s7 & s8 & s9 & s10 & $s 11$ & $s 12$ & $s 13$ & s14 & s15 & s16 & s17 & s18 & s19 & s20 & s21 & s22 & s23 & s24 & s25 & s26 & s27 \\
\hline & Augusto Severo & - & - & - & - & - & - & - & - & - & - & - & - & - & - & - & - & - & - & - & - & - & - & - & - & - & - & - \\
\hline & Barcelona & 5 & 0 & 7 & 4 & 3 & 3 & 2 & 2 & 5 & 2 & 4 & 5 & 6 & 8 & 9 & 12 & 5 & 25 & 17 & 2 & 0 & 3 & 4 & 0 & 2 & 0 & 1 \\
\hline & Bodó & 8 & 5 & 5 & 2 & 11 & 6 & 5 & 2 & 2 & 7 & 11 & 9 & 10 & 11 & 11 & 12 & 11 & 7 & 8 & 8 & 8 & 7 & 6 & 9 & 7 & 7 & 5 \\
\hline & Bom Jesus & 0 & 12 & 0 & 2 & 0 & 2 & 0 & 0 & 0 & 0 & 0 & 4 & 1 & 8 & 6 & 8 & 7 & 0 & 13 & 9 & 13 & 3 & 6 & 0 & 0 & 0 & 0 \\
\hline & Caiçara do Rio do Vento & 0 & 0 & 1 & 2 & 0 & 1 & 2 & 0 & 1 & 11 & 5 & 13 & 9 & 9 & 6 & 7 & 1 & 2 & 2 & 1 & 3 & 1 & 2 & 0 & 2 & 0 & 0 \\
\hline & Caicó & 16 & 14 & 35 & 0 & 14 & 3 & 7 & 19 & 46 & 151 & 44 & 41 & 45 & 138 & 112 & 52 & 226 & 113 & 174 & 63 & 58 & 22 & 14 & 21 & 24 & 24 & 3 \\
\hline & Campo Redondo & 3 & 2 & 1 & 2 & 2 & 1 & 2 & 3 & 1 & 7 & 13 & 11 & 8 & 6 & 6 & 7 & 9 & 6 & 6 & 5 & 8 & 9 & 3 & 3 & 3 & 3 & 4 \\
\hline & Coronel Ezequiel & 5 & 4 & 6 & 0 & 2 & 0 & 0 & 0 & 2 & 0 & 0 & 2 & 7 & 20 & 0 & 26 & 28 & 9 & 4 & 3 & 5 & 0 & 2 & 0 & 0 & 1 & 0 \\
\hline & Currais Novos & 0 & 0 & 0 & 1 & 0 & 0 & 0 & 5 & 1 & 0 & 0 & 0 & 0 & 0 & 0 & 0 & 0 & 0 & 2 & 15 & 0 & 10 & 3 & 1 & 1 & 0 & 0 \\
\hline & Fernando Pedroza & 3 & 0 & 5 & 7 & 3 & 0 & - & - & - & - & - & 0 & 16 & 3 & 2 & 2 & 15 & 4 & 2 & 2 & 1 & 0 & 0 & 2 & 1 & 0 & 0 \\
\hline & Florânia & 5 & 7 & 8 & 3 & 0 & 4 & 3 & 1 & 3 & 8 & 9 & 17 & 45 & 29 & 12 & 24 & 13 & 11 & 6 & 10 & 6 & 0 & 2 & 0 & 2 & 2 & 0 \\
\hline & lelmo Marinho & 7 & 10 & 2 & 13 & 2 & 2 & 5 & 1 & 0 & 3 & 3 & 0 & 8 & 16 & 3 & 6 & 16 & 7 & 22 & 10 & 12 & 4 & 11 & 6 & 3 & 4 & 11 \\
\hline & Itajá & 13 & 3 & 2 & 2 & 2 & 2 & 3 & 0 & 1 & 8 & 15 & 13 & 5 & 79 & 78 & 43 & 8 & 17 & 9 & 11 & 6 & 0 & 7 & 1 & 1 & 1 & 4 \\
\hline & Jaçanã & 2 & 0 & 2 & 1 & 5 & 0 & 2 & 1 & 0 & 3 & 2 & 10 & 10 & 7 & 9 & 30 & 11 & 15 & 11 & 12 & 21 & 11 & 5 & 3 & 0 & 0 & 4 \\
\hline & Janduís & 11 & 10 & 11 & 10 & 9 & 0 & 21 & 6 & 6 & 4 & 9 & 3 & 3 & 5 & 2 & 4 & 4 & 2 & 4 & 2 & 4 & 2 & 3 & 3 & 3 & 2 & 1 \\
\hline & Januário Cicco & 0 & 1 & 3 & 7 & 10 & 6 & 8 & 10 & 10 & 4 & 7 & 8 & 32 & 26 & 38 & 18 & 17 & 8 & 29 & 32 & 17 & 17 & 18 & 18 & 9 & 14 & 11 \\
\hline & Japi & 6 & 4 & 11 & 3 & 10 & 8 & 5 & 7 & 8 & 10 & 4 & 3 & 9 & 7 & 4 & 11 & 10 & 12 & 18 & 15 & 7 & 5 & 5 & 6 & 5 & 5 & 5 \\
\hline & Jardim de Angicos & 0 & 2 & 1 & 2 & 1 & 0 & 1 & 0 & 2 & 1 & 4 & 6 & 4 & 1 & 5 & 1 & 0 & 2 & 7 & 0 & 1 & 1 & 3 & 0 & 0 & 1 & 0 \\
\hline & Lagoa d'Anta & 0 & 1 & 2 & 6 & 0 & 0 & 0 & 0 & 2 & 0 & 0 & 0 & 4 & 3 & 1 & 0 & 6 & 3 & 4 & 1 & 5 & 3 & 0 & 3 & 1 & 0 & 0 \\
\hline & Lagoa de Pedras & 2 & 1 & 4 & 2 & 2 & 4 & 9 & 0 & 1 & 4 & 10 & 6 & 5 & 4 & 13 & 16 & 19 & 22 & 5 & 6 & 7 & 7 & 6 & 7 & 6 & 0 & 0 \\
\hline & Lagoa de Velhos & 0 & 2 & 9 & 2 & 10 & 2 & 1 & 1 & 1 & 3 & 6 & 13 & 13 & 30 & 20 & 9 & 16 & 10 & 12 & 5 & 1 & 4 & 3 & 6 & 1 & 1 & 2 \\
\hline & Lagoa Nova & 5 & 14 & 28 & 4 & 2 & 15 & 28 & 0 & 0 & 31 & 18 & 12 & 10 & 13 & 36 & 32 & 5 & 30 & 13 & 0 & 0 & 0 & 0 & 0 & 0 & 0 & 0 \\
\hline & Lagoa Salgada & - & - & - & - & - & - & - & - & 14 & 12 & 22 & 22 & 33 & 33 & 43 & 44 & 43 & 52 & 65 & - & 24 & 16 & 8 & 21 & 7 & 14 & 13 \\
\hline & Lajes & 0 & 4 & 2 & 3 & 6 & 2 & 10 & 7 & 74 & 33 & 20 & 47 & 134 & 17 & 83 & 11 & 23 & 7 & 8 & 6 & 11 & 1 & 4 & 3 & 4 & 12 & 6 \\
\hline & Lajes Pintadas & 2 & 1 & 0 & 1 & 0 & 2 & 2 & 2 & 1 & 0 & 0 & 13 & 4 & 20 & 23 & 23 & 9 & 20 & 17 & 18 & 8 & 7 & 2 & 0 & 2 & 0 & 1 \\
\hline & Messias Targino & 2 & 3 & 10 & 7 & 12 & 14 & 4 & 4 & 7 & 10 & 39 & 49 & 25 & 9 & 3 & 4 & 7 & 6 & 1 & 4 & 1 & 4 & 3 & 1 & 3 & 2 & 1 \\
\hline & Monte Alegre & 6 & 9 & 10 & 11 & 4 & 6 & 2 & 7 & 1 & 17 & 17 & 24 & 20 & 13 & 12 & 18 & 30 & 26 & 22 & 28 & 19 & 19 & 13 & 3 & 15 & 8 & 12 \\
\hline & Monte das Gameleiras & 2 & 0 & 0 & 0 & 4 & 0 & 2 & 3 & 0 & 7 & 5 & 0 & 15 & 19 & 23 & 4 & 24 & 10 & 5 & 6 & 0 & 9 & 4 & 0 & 0 & 10 & 5 \\
\hline & Paraú & 2 & 4 & 8 & 0 & 1 & 2 & 6 & 1 & 0 & 1 & 17 & 15 & 27 & 15 & 4 & 5 & 2 & 5 & 1 & 10 & 4 & 1 & 1 & 0 & 2 & 1 & 0 \\
\hline & Passa e Fica & 0 & 3 & 8 & 3 & 2 & 11 & 8 & 13 & 2 & 2 & 21 & 14 & 18 & 0 & 0 & 0 & 2 & 10 & 27 & 15 & 14 & 12 & 13 & 12 & 2 & 1 & 8 \\
\hline & Patu & 5 & 2 & 13 & 3 & 6 & 1 & 6 & 7 & 7 & 2 & 0 & 0 & 2 & 22 & 23 & 31 & 12 & 12 & 21 & 0 & 0 & 11 & 0 & 0 & 1 & 3 & 0 \\
\hline & Pedra Preta & 4 & 10 & 3 & 0 & 3 & 7 & 9 & 1 & 3 & 9 & 17 & 14 & 15 & 18 & 17 & 30 & 27 & 6 & 8 & 7 & 0 & 0 & 3 & - & - & - & 0 \\
\hline & Pedro Avelino & 0 & 0 & 4 & 3 & 4 & 0 & 2 & 0 & 0 & 8 & 0 & 9 & 11 & 8 & 4 & 0 & 0 & 0 & 2 & 2 & 3 & 3 & 0 & 0 & 2 & 0 & 1 \\
\hline & Presidente Juscelino & 3 & 32 & 5 & 11 & 4 & 4 & 3 & 8 & 5 & 10 & 12 & 25 & 31 & 28 & 12 & 10 & 16 & 9 & 15 & 33 & 0 & 2 & 14 & 12 & 15 & 1 & 8 \\
\hline & Riachuelo & 3 & 1 & 3 & 5 & 6 & 2 & 3 & 6 & 3 & 5 & 10 & 22 & 21 & 4 & 16 & 5 & 8 & 17 & 11 & 8 & 3 & 8 & 8 & 5 & 6 & 7 & 2 \\
\hline & Ruy Barbosa & 3 & 1 & 1 & 8 & 10 & 2 & 7 & 5 & 3 & 11 & 9 & 24 & 19 & 29 & 17 & 18 & 4 & 9 & 5 & 2 & 5 & 1 & 2 & 9 & 0 & 1 & 4 \\
\hline & Santa Cruz & 4 & 2 & 23 & 4 & 15 & 9 & 6 & 18 & 33 & 5 & 11 & 30 & 38 & 36 & 113 & 178 & 142 & 117 & 196 & 127 & 49 & 70 & 61 & 23 & 21 & 23 & 16 \\
\hline
\end{tabular}




\begin{tabular}{|c|c|c|c|c|c|c|c|c|c|c|c|c|c|c|c|c|c|c|c|c|c|c|c|c|c|c|c|c|}
\hline 2006 & Município & s1 & s2 & s3 & s4 & s5 & s6 & s7 & s8 & s9 & s10 & s11 & s12 & s13 & s14 & s15 & s16 & s17 & s18 & s19 & s20 & s21 & s22 & s23 & s24 & s25 & s26 & s27 \\
\hline & Santa Maria & 1 & 3 & 5 & 4 & 4 & 6 & 8 & 4 & 0 & 14 & 16 & 37 & 14 & 0 & 0 & 2 & 17 & 17 & 5 & 5 & 10 & 5 & 2 & 3 & 2 & 1 & 1 \\
\hline & Santana do Matos & 1 & 8 & 1 & 6 & 1 & 1 & 3 & 6 & 0 & 6 & 10 & 15 & 44 & 44 & 26 & 15 & 66 & 12 & 4 & 9 & 4 & 6 & 2 & 3 & 0 & 5 & 0 \\
\hline & São Bento do Trairi & 0 & 0 & 6 & 4 & 3 & 2 & 2 & 7 & 25 & 7 & 11 & 13 & 24 & 20 & 13 & 21 & 10 & 11 & 8 & 18 & 9 & 3 & 3 & 2 & 1 & 0 & 2 \\
\hline & São José do Campestre & 0 & 0 & 2 & 22 & 4 & 8 & 18 & 3 & 24 & 1 & 4 & 23 & 25 & 2 & 4 & 5 & 16 & 5 & 37 & 10 & 6 & 1 & 11 & 7 & 6 & 6 & 5 \\
\hline & São Paulo do Potengi & 6 & 3 & 20 & 16 & 0 & 8 & 12 & 12 & 7 & 28 & 48 & 65 & 65 & 77 & 87 & 58 & 28 & 20 & 36 & 24 & 19 & 10 & 11 & 1 & 7 & 8 & 10 \\
\hline & São Pedro & 4 & 3 & 5 & 3 & 4 & 0 & 5 & 5 & 1 & 7 & 12 & 10 & 4 & 4 & 3 & 3 & 4 & 4 & 2 & 2 & 5 & 0 & 2 & 2 & 3 & 1 & 1 \\
\hline & São Rafael & 7 & 6 & 19 & 9 & 2 & 4 & 4 & 5 & 0 & 11 & 33 & 45 & 33 & 64 & 42 & 55 & 39 & 3 & 10 & 18 & 10 & 0 & 6 & 3 & 7 & 0 & 2 \\
\hline & São Tomé & 0 & 7 & 2 & 0 & 0 & 3 & 1 & 3 & 0 & 4 & 15 & 33 & 13 & 11 & 24 & 6 & 18 & 4 & 7 & 9 & 3 & 14 & 3 & 6 & 0 & 0 & 0 \\
\hline & São Vicente & 3 & 14 & 3 & 6 & 1 & 1 & 0 & 3 & 6 & 9 & 23 & 9 & 17 & 23 & 12 & 6 & 6 & 7 & 3 & 2 & 0 & 0 & 15 & 0 & 0 & 3 & 2 \\
\hline & Senador Elói de Souza & 0 & 5 & 3 & 6 & 3 & 1 & 7 & 7 & 4 & 5 & 11 & 7 & 8 & 15 & 7 & 11 & 15 & 10 & 15 & 14 & 7 & 0 & 6 & 2 & 6 & 5 & 6 \\
\hline & Serra de São Bento & - & - & - & - & - & - & - & - & - & - & - & - & - & - & - & - & - & - & - & - & - & - & - & - & - & - & - \\
\hline & Serrinha & 0 & 1 & 0 & 0 & 2 & 4 & 4 & 0 & 2 & 1 & 1 & 2 & 0 & 0 & - & 0 & 12 & 0 & 0 & 0 & 0 & 12 & 1 & 0 & 5 & 0 & 0 \\
\hline & Sítio Novo & 0 & 2 & 0 & 2 & 4 & 4 & 3 & 1 & 0 & 3 & 2 & 3 & 15 & 13 & 0 & 15 & 39 & 12 & 36 & 13 & 5 & 8 & 0 & 0 & 1 & 0 & 0 \\
\hline & Tangará & 6 & 1 & 11 & 6 & 5 & 13 & 10 & 8 & 8 & 5 & 5 & 11 & 6 & 10 & 39 & 54 & 60 & 28 & 19 & 25 & 7 & 15 & 4 & 7 & 6 & 3 & 7 \\
\hline & Tenente Laurentino Cruz & 0 & 2 & 1 & 0 & 2 & 4 & 3 & 6 & 7 & 12 & 14 & 12 & 15 & 6 & 7 & 4 & 3 & 2 & 0 & 0 & 1 & 0 & 1 & 0 & 0 & 0 & 0 \\
\hline & Triunfo Potiguar & 2 & 3 & 0 & 0 & 0 & 0 & 0 & 0 & 0 & 2 & 4 & 8 & 9 & 6 & 7 & 4 & 4 & 1 & 2 & 0 & 0 & 0 & 0 & 0 & 1 & 0 & 0 \\
\hline & Alagoa Nova & 10 & 8 & 11 & 2 & 12 & 7 & 9 & 9 & 34 & 25 & 14 & 23 & 29 & 12 & 24 & 16 & 17 & 28 & 59 & 62 & 53 & 29 & 34 & 23 & 29 & 16 & 12 \\
\hline & Barra de Santana & 0 & 0 & 0 & 3 & 0 & 6 & 4 & 1 & 0 & 4 & 1 & 2 & 9 & 1 & 3 & 4 & 16 & 26 & 15 & 21 & 44 & 44 & 11 & 13 & 18 & 4 & 5 \\
\hline & Boa Vista & 1 & 11 & 6 & 2 & 6 & 4 & 2 & 4 & 2 & 1 & 3 & 3 & 2 & 3 & 13 & 15 & 11 & 17 & 12 & 16 & 7 & 8 & - & 6 & 8 & 3 & - \\
\hline & Boqueirão & 16 & 5 & 10 & 12 & 11 & 8 & 10 & - & 4 & 11 & 5 & 11 & 7 & 13 & 11 & 18 & 13 & 31 & 42 & 32 & 49 & 1 & 45 & 45 & 28 & 3 & 15 \\
\hline & Cabaceiras & 2 & 3 & 3 & 2 & 1 & 7 & 0 & - & 5 & 5 & 10 & 4 & 7 & 20 & 12 & 4 & 10 & 13 & 7 & 7 & 10 & 6 & - & 7 & 6 & 6 & 12 \\
\hline & Campina Grande & 96 & 82 & 138 & 92 & 59 & 94 & 88 & 111 & 19 & 91 & 82 & 96 & 103 & 56 & 110 & 151 & 248 & 226 & 94 & 284 & 251 & 158 & 127 & 85 & 95 & 143 & 93 \\
\hline & Caturité & 0 & 0 & 5 & 7 & 5 & 3 & 4 & - & 1 & 7 & 5 & 1 & 4 & 2 & 6 & 11 & 10 & 5 & 20 & 13 & 38 & 23 & 3 & 12 & 6 & 2 & 0 \\
\hline & Cubati & 9 & 5 & 12 & 8 & 17 & 7 & 13 & 4 & 7 & 9 & 16 & 0 & 0 & 3 & 3 & 12 & 14 & 6 & 12 & 35 & 17 & 13 & 15 & 0 & 8 & 7 & 0 \\
\hline & Juazeirinho & 23 & 35 & 35 & 40 & 16 & 6 & 29 & 9 & 9 & 14 & 26 & 10 & 22 & 27 & 2 & 40 & 86 & - & 5 & 16 & 11 & 10 & 22 & 7 & 10 & 12 & 10 \\
\hline & Lagoa Seca & 6 & 8 & 17 & 12 & 3 & 12 & 23 & 20 & 7 & 14 & 18 & 22 & 20 & 6 & 19 & 23 & 24 & 17 & 25 & 30 & 32 & 20 & 14 & 3 & 8 & 17 & 9 \\
\hline & Matinhas & 3 & 0 & 0 & 0 & 1 & 2 & 2 & 0 & 0 & 3 & 0 & 7 & 4 & 5 & 4 & 15 & 7 & 7 & 13 & 19 & 21 & 14 & 14 & 10 & 2 & 0 & 4 \\
\hline & Olivedos & 1 & 0 & 0 & 1 & 5 & 6 & - & 0 & 0 & 1 & 0 & 0 & 0 & 4 & 2 & 0 & 5 & 9 & 10 & 5 & 9 & 3 & 1 & 3 & 2 & 1 & 0 \\
\hline & Pedra Lavrada & 9 & 2 & 6 & 4 & 7 & 5 & 3 & 0 & 1 & 1 & 7 & 12 & 22 & 18 & 12 & 23 & 17 & 16 & 8 & 8 & 9 & 7 & 2 & 2 & 2 & 4 & 1 \\
\hline & Pocinhos & 0 & 0 & 10 & 11 & 4 & 5 & 12 & - & 5 & - & 10 & 4 & 12 & 12 & 16 & 31 & 25 & 7 & 36 & 10 & 28 & 6 & - & 14 & 0 & 28 & 9 \\
\hline & Queimadas & 0 & 7 & 4 & 12 & 1 & 1 & 15 & 10 & 0 & 5 & 6 & 14 & 11 & 12 & 8 & 5 & 45 & 58 & 32 & 72 & 69 & 52 & 19 & 16 & 6 & 32 & - \\
\hline & Seridó/São Vicente do Seridó & - & - & 10 & 20 & - & 28 & 9 & 12 & 9 & 12 & 0 & 11 & 7 & - & 8 & 13 & - & - & 4 & 4 & 18 & - & 2 & 4 & 5 & 14 & 5 \\
\hline & Soledade & 19 & 17 & 12 & 7 & 7 & 42 & 45 & 24 & 13 & 31 & 28 & 49 & - & 56 & 63 & 82 & 60 & 65 & 60 & 74 & 30 & 17 & 21 & 24 & 10 & 10 & 14 \\
\hline
\end{tabular}

$\begin{array}{llllllllllllllllllllllllll}s 28 & s 29 & s 30 & s 31 & s 32 & s 33 & s 34 & s 35 & s 36 & s 37 & s 38 & s 39 & s 40 & s 41 & s 42 & s 43 & s 44 & s 45 & s 46 & s 47 & s 48 & s 49 & s 50 & s 51 & s 52\end{array}$

Acari

$\begin{array}{lllllllllllllllllllllllllll}2 & 1 & 3 & 2 & 3 & 0 & 9 & 8 & 4 & 7 & 0 & 11 & 0 & 0 & 1 & 3 & 6 & 14 & 7 & 6 & 0 & 0 & 0 & 0 & 1\end{array}$ 


\begin{tabular}{|c|c|c|c|c|c|c|c|c|c|c|c|c|c|c|c|c|c|c|c|c|c|c|c|c|c|c|}
\hline 2006 & Município & $s 28$ & $\mathbf{s 2 9}$ & s30 & s31 & s32 & s33 & s34 & s35 & s36 & s37 & s38 & s39 & $s 40$ & s41 & s42 & s43 & s44 & s45 & s46 & s47 & s48 & s49 & s50 & s51 & s52 \\
\hline & Almino Afonso & 0 & 0 & 0 & 0 & 0 & 0 & 0 & 0 & 0 & 0 & 0 & 0 & 0 & 0 & 0 & 0 & 0 & 0 & 0 & 0 & 0 & 0 & 0 & 0 & 0 \\
\hline & Angicos & 0 & 0 & 3 & 0 & 21 & 10 & 17 & 17 & 33 & 28 & 18 & 0 & 9 & 26 & 10 & 0 & 11 & 6 & 7 & 7 & 0 & 10 & 10 & 2 & 4 \\
\hline & Augusto Severo & - & - & - & - & - & - & - & - & - & - & - & - & - & - & - & - & - & - & - & - & - & - & - & - & - \\
\hline & Barcelona & 1 & 0 & 4 & 3 & 2 & 1 & 2 & 1 & 3 & 3 & 4 & 2 & 2 & 1 & 4 & 3 & 1 & 4 & 4 & 7 & 4 & 15 & 0 & 0 & 10 \\
\hline & Bodó & 4 & 5 & 7 & 7 & 7 & 7 & 7 & 6 & 7 & 8 & 8 & 6 & 3 & 12 & 13 & 13 & 14 & 14 & 12 & 10 & 13 & 11 & 10 & 12 & 12 \\
\hline & Bom Jesus & 4 & 6 & 1 & 0 & 0 & 0 & 0 & 0 & 0 & 0 & 0 & 0 & 0 & 0 & 26 & 12 & 11 & 5 & 0 & 4 & 1 & 6 & 0 & 0 & 0 \\
\hline & Caiçara do Rio do Vento & 0 & 1 & 1 & 3 & 2 & 2 & 1 & 1 & 1 & 0 & 0 & 2 & 0 & 0 & 1 & 2 & 1 & 1 & 3 & 0 & 2 & 3 & 3 & 0 & 2 \\
\hline & Caicó & 17 & 20 & 11 & 6 & 8 & 8 & 7 & 22 & 4 & 8 & 16 & 39 & 41 & 14 & 23 & 6 & 0 & 6 & 8 & 14 & 14 & 16 & 0 & 5 & 10 \\
\hline & Campo Redondo & 2 & 1 & 5 & 2 & 2 & 2 & 2 & 4 & 1 & 3 & 4 & 3 & 2 & 4 & 1 & 1 & 1 & 0 & 0 & 1 & 1 & 0 & 2 & 0 & 0 \\
\hline & Coronel Ezequiel & 1 & 0 & 0 & 0 & 0 & 0 & 0 & 0 & 0 & 0 & 2 & 8 & 0 & 0 & 0 & 0 & 0 & 0 & 0 & 0 & 6 & 0 & 0 & 0 & 0 \\
\hline & Currais Novos & 0 & 0 & 0 & 0 & 0 & 0 & 3 & 0 & 0 & 4 & 0 & 2 & 0 & 0 & 0 & 0 & 4 & 1 & 1 & 0 & 0 & 0 & 0 & 0 & 4 \\
\hline & Fernando Pedroza & 0 & 0 & 1 & 0 & 0 & - & - & - & - & 0 & 0 & 5 & 2 & 0 & 1 & 5 & 2 & 0 & 2 & 2 & 6 & - & - & - & - \\
\hline & Florânia & 3 & 2 & 1 & 3 & 3 & 1 & 1 & 0 & 1 & 3 & 2 & 2 & 2 & 2 & 0 & 5 & 6 & 2 & 1 & 2 & 6 & 2 & 5 & 3 & 3 \\
\hline & Ielmo Marinho & 6 & 10 & 11 & 5 & 2 & 5 & 5 & 0 & 2 & 5 & 2 & 10 & 6 & 0 & 3 & 1 & 0 & 0 & 4 & 1 & 0 & 3 & 0 & 5 & 0 \\
\hline & Itajá & 2 & 0 & 1 & 4 & 2 & 0 & 1 & 0 & 3 & 3 & 3 & 0 & 2 & 8 & 2 & 2 & 0 & 10 & 0 & 2 & 0 & 5 & 4 & 7 & 3 \\
\hline & Jaçanã & 3 & 4 & 6 & 5 & 6 & 8 & 6 & 3 & 5 & 4 & 9 & 5 & 5 & 1 & 5 & 4 & 5 & 5 & 2 & 0 & 2 & 0 & 4 & 0 & 2 \\
\hline & Janduís & 3 & 0 & 2 & 1 & 2 & 1 & 2 & 5 & 1 & 3 & 4 & 2 & 1 & 1 & 1 & 2 & 1 & 4 & 1 & 1 & 1 & 1 & 3 & 2 & 1 \\
\hline & Januário Cicco & 6 & 7 & 13 & 10 & 11 & 7 & 6 & 6 & 3 & 2 & 2 & 5 & 2 & 3 & 3 & 5 & 8 & 11 & 11 & 13 & 10 & 8 & 5 & 4 & 3 \\
\hline & Japi & 4 & 7 & 3 & 3 & 5 & 5 & 6 & 7 & 2 & 5 & 4 & 3 & 21 & 10 & 24 & 6 & 7 & 15 & 17 & 12 & 3 & 14 & 5 & 4 & 3 \\
\hline & Jardim de Angicos & 0 & 1 & 0 & 2 & 1 & 2 & 0 & 2 & 0 & 0 & 0 & 5 & 0 & 2 & 2 & 1 & 1 & 0 & 0 & 1 & 4 & 0 & 4 & 4 & 2 \\
\hline & Lagoa d'Anta & 0 & 1 & 3 & 0 & 1 & 0 & 1 & 0 & 1 & 0 & 0 & 1 & 0 & 0 & 0 & 0 & 0 & 0 & 0 & 7 & 0 & 0 & 0 & 0 & 0 \\
\hline & Lagoa de Pedras & 0 & 0 & 0 & 3 & 1 & 5 & 1 & 4 & 2 & 6 & 2 & 1 & 5 & 2 & 4 & 2 & - & 3 & 2 & 2 & 6 & 0 & 1 & 3 & 3 \\
\hline & Lagoa de Velhos & 3 & 0 & 0 & 0 & 2 & 0 & 0 & 0 & 2 & 1 & 6 & 2 & 3 & 2 & 0 & 0 & 1 & 1 & 0 & 6 & 4 & 0 & 0 & 0 & 1 \\
\hline & Lagoa Nova & 0 & 0 & 0 & 0 & 0 & 3 & 4 & 0 & 0 & 4 & 5 & 0 & 0 & 0 & 6 & 0 & 0 & 0 & 7 & 11 & 0 & 0 & 1 & 0 & 0 \\
\hline & Lagoa Salgada & 9 & 6 & 8 & 10 & 7 & 13 & 12 & 7 & 9 & 8 & 9 & 20 & 4 & 13 & 12 & 21 & 12 & 13 & 25 & 21 & 19 & 16 & 8 & 18 & 15 \\
\hline & Lajes & 4 & 4 & 8 & 5 & 8 & 2 & 6 & 6 & 6 & 7 & 6 & 5 & 4 & 8 & 6 & 6 & 8 & 8 & 9 & 6 & 9 & 6 & 5 & 7 & 7 \\
\hline & Lajes Pintadas & 3 & 1 & 0 & 2 & 1 & 2 & 1 & 1 & 0 & 1 & 1 & 0 & 2 & 2 & 0 & 5 & 0 & 2 & 2 & 5 & 1 & 1 & 0 & 3 & 1 \\
\hline & Messias Targino & 5 & 1 & 3 & 0 & 1 & 0 & 9 & 2 & 2 & 3 & 4 & 2 & 1 & 4 & - & 1 & 2 & 1 & 2 & 2 & - & 1 & 0 & 0 & 1 \\
\hline & Monte Alegre & 18 & 10 & 23 & 10 & 9 & 5 & 7 & 3 & 1 & 8 & 28 & 9 & 1 & 1 & 6 & 5 & 5 & 6 & 4 & 11 & 11 & 3 & 7 & 11 & 0 \\
\hline & Monte das Gameleiras & 0 & 5 & 0 & 0 & 3 & 4 & 0 & 0 & 0 & 0 & 5 & 3 & 0 & 5 & 8 & 0 & 0 & 0 & 4 & 6 & 0 & 0 & 2 & 11 & 0 \\
\hline & Paraú & 1 & 0 & 0 & 1 & 2 & 2 & 4 & 1 & 0 & 0 & 1 & 0 & 1 & 0 & 1 & 0 & 0 & 1 & 1 & 2 & 2 & 1 & 3 & 0 & 0 \\
\hline & Passa e Fica & 3 & 11 & 7 & 3 & 7 & 13 & 12 & 8 & 5 & 2 & 11 & - & 10 & 3 & 1 & 1 & 6 & 4 & 5 & 1 & 9 & 11 & 15 & 5 & 7 \\
\hline & Patu & 0 & 0 & 0 & 0 & 0 & 0 & 0 & 0 & 0 & 0 & 0 & 0 & - & - & - & - & - & - & - & - & - & - & - & - & - \\
\hline & Pedra Preta & 1 & 0 & 0 & 0 & 2 & 2 & 4 & 0 & 3 & 3 & 2 & 1 & 4 & 7 & 5 & 6 & 6 & 2 & 4 & 1 & 9 & 5 & 7 & 1 & 1 \\
\hline & Pedro Avelino & 2 & 3 & 3 & 0 & 2 & 2 & 1 & 2 & 1 & 0 & 0 & 2 & 2 & 0 & 3 & 3 & 5 & 7 & 0 & 3 & 1 & 0 & 0 & 2 & 2 \\
\hline & Presidente Juscelino & 6 & 6 & 7 & 0 & 0 & 0 & 0 & 2 & 5 & 7 & 6 & 0 & 0 & 0 & 1 & 0 & 6 & 6 & 2 & 2 & 5 & 4 & 5 & 6 & 2 \\
\hline & Riachuelo & 1 & 3 & 4 & 1 & 7 & 2 & 0 & 0 & 3 & 1 & 2 & 1 & 0 & 2 & 0 & 1 & 3 & 1 & 1 & 0 & 2 & 0 & 2 & 0 & 0 \\
\hline
\end{tabular}




\begin{tabular}{|c|c|c|c|c|c|c|c|c|c|c|c|c|c|c|c|c|c|c|c|c|c|c|c|c|c|c|}
\hline 2006 & Município & s28 & s29 & s30 & s31 & s32 & s33 & s34 & s35 & s36 & s37 & s38 & s39 & s40 & s41 & s42 & $s 43$ & s44 & s45 & s46 & s47 & $s 48$ & $s 49$ & s50 & s51 & s52 \\
\hline & Ruy Barbosa & 4 & 5 & 0 & 1 & 5 & 2 & 1 & 2 & 6 & 1 & 6 & 3 & 5 & 1 & 2 & 3 & 11 & 23 & 3 & 8 & 4 & 9 & 0 & 3 & 0 \\
\hline & Santa Cruz & 12 & 4 & 8 & 4 & 13 & 13 & 10 & 5 & 9 & 13 & 8 & 13 & 13 & 30 & 24 & 24 & 7 & 12 & 13 & 5 & 7 & 15 & 7 & 1 & 11 \\
\hline & Santa Maria & 2 & 0 & 0 & 1 & 1 & 7 & 6 & 8 & 3 & 4 & 3 & 2 & 6 & 3 & 3 & 3 & 2 & 3 & 1 & 2 & 1 & 1 & 1 & 0 & 2 \\
\hline & Santana do Matos & 0 & 0 & 0 & 0 & 0 & 0 & 2 & 0 & 4 & 1 & 3 & 1 & 6 & 0 & 5 & 3 & 2 & 1 & 2 & 8 & 1 & 3 & 1 & 1 & 7 \\
\hline & São Bento do Trairi & 0 & 2 & 2 & 0 & 2 & 1 & 0 & 0 & 0 & 0 & 3 & 0 & 0 & 0 & 0 & 1 & 0 & 1 & 0 & 1 & 0 & 1 & 0 & 0 & 0 \\
\hline & São José do Campestre & 10 & 3 & 10 & 8 & 11 & 7 & 7 & 0 & 2 & 7 & 0 & 4 & 2 & 1 & 1 & 4 & 18 & 5 & 7 & 9 & 11 & 5 & 9 & 43 & 11 \\
\hline & São Paulo do Potengi & 8 & 11 & 19 & 6 & 11 & 11 & 19 & 28 & 25 & 24 & 17 & 17 & 6 & 11 & 9 & 2 & 1 & 1 & 3 & 9 & 0 & 6 & 19 & 4 & 13 \\
\hline & São Pedro & 0 & 2 & 0 & 1 & 2 & 1 & 1 & 0 & 2 & 1 & 1 & 3 & 1 & 0 & 3 & 2 & 1 & 2 & 1 & 0 & 2 & 1 & 2 & 7 & 7 \\
\hline & São Rafael & 1 & 2 & 0 & 4 & 6 & 5 & 11 & 0 & 3 & 12 & 13 & 21 & 0 & 2 & 6 & 2 & 0 & 3 & 2 & 3 & 2 & 3 & 7 & 2 & 5 \\
\hline & São Tomé & 1 & 2 & 0 & 1 & 0 & 8 & 4 & 0 & 11 & 5 & 6 & 10 & 6 & 1 & 6 & 1 & 9 & 3 & 10 & 12 & 5 & 4 & 2 & 3 & 0 \\
\hline & São Vicente & 1 & 0 & 3 & 1 & 0 & 0 & 0 & 0 & 0 & 0 & 0 & 4 & 2 & 0 & 1 & 3 & 1 & 3 & 0 & 5 & 0 & 0 & 0 & 0 & 0 \\
\hline & Senador Elói de Souza & 2 & 0 & 0 & 1 & 0 & 4 & 5 & 1 & 2 & 5 & 1 & 7 & 1 & 0 & 3 & 4 & 5 & 2 & 2 & 3 & 3 & 2 & 0 & 0 & 0 \\
\hline & Serra de São Bento & - & - & - & - & - & - & - & - & - & - & - & - & - & - & - & - & - & - & - & - & - & - & - & - & - \\
\hline & Serrinha & 1 & 6 & 5 & - & 0 & 1 & 0 & 0 & 0 & 0 & 0 & 0 & 0 & 1 & 5 & 0 & 0 & 1 & 0 & 0 & 0 & 0 & 0 & 0 & 0 \\
\hline & Sítio Novo & 3 & 0 & 3 & 2 & 5 & 3 & 0 & 3 & 4 & 0 & 4 & 2 & 0 & 3 & 4 & 2 & 1 & 0 & 5 & 0 & 0 & 2 & 0 & 2 & 5 \\
\hline & Tangará & 0 & 6 & 4 & 0 & 6 & 5 & 6 & 11 & 10 & 14 & 17 & 25 & 23 & 17 & 29 & 8 & 6 & 4 & 5 & 4 & 2 & 3 & 1 & 3 & 4 \\
\hline & Tenente Laurentino Cruz & 0 & 1 & 3 & 0 & 1 & 0 & 3 & 0 & 0 & 0 & 0 & 0 & 0 & 0 & 2 & 2 & 0 & 0 & 0 & 2 & 2 & 0 & 3 & 3 & 3 \\
\hline & Triunfo Potiguar & 0 & 2 & 2 & 1 & 0 & 1 & 0 & 0 & 0 & 1 & 0 & 1 & 2 & 0 & 12 & 4 & 1 & 0 & 2 & 1 & 1 & 0 & 0 & 0 & 0 \\
\hline & Alagoa Nova & 20 & 11 & 16 & 15 & 10 & 12 & 10 & 18 & 14 & 12 & 8 & 17 & 22 & 15 & 23 & 18 & 14 & 5 & 15 & 17 & 19 & 16 & 22 & 18 & 26 \\
\hline & Barra de Santana & 11 & 2 & 23 & 0 & 0 & 5 & 7 & 6 & 4 & 0 & 2 & 2 & 0 & 2 & 3 & 8 & 6 & 0 & 4 & 1 & 2 & 9 & 4 & 7 & 0 \\
\hline & Boa Vista & 9 & 8 & 4 & 8 & 2 & 6 & 9 & 8 & 6 & 3 & 4 & 4 & 5 & - & 2 & 4 & 7 & 32 & 8 & 2 & 10 & - & 2 & 0 & 4 \\
\hline & Boqueirão & 36 & 7 & 46 & 22 & 7 & 24 & 11 & 0 & 7 & 0 & 12 & 5 & 1 & 0 & 13 & 0 & 3 & 1 & 5 & 4 & 5 & - & 0 & 10 & 1 \\
\hline & Cabaceiras & - & 10 & 2 & 2 & - & 2 & 0 & 6 & 0 & 6 & 0 & 2 & - & 3 & 1 & - & - & 5 & 6 & 2 & 1 & 3 & 5 & 2 & 0 \\
\hline & Campina Grande & 91 & 119 & 135 & 147 & 140 & 154 & 194 & 173 & 119 & 148 & 158 & 135 & 102 & 91 & 83 & 89 & 77 & 98 & 135 & 91 & 116 & 82 & 99 & 121 & 84 \\
\hline & Caturité & 3 & 1 & 3 & 1 & 2 & 2 & 7 & 5 & 1 & 3 & 0 & 6 & 1 & 0 & 1 & 0 & 2 & 1 & 0 & 0 & 3 & 0 & 0 & 0 & 0 \\
\hline & Cubati & 1 & 1 & 13 & 7 & 0 & 0 & 11 & 0 & 0 & 11 & 11 & 6 & 6 & 12 & 24 & 13 & 6 & 2 & 10 & 3 & 11 & 6 & 3 & 5 & 4 \\
\hline & Juazeirinho & 8 & 11 & 15 & 12 & 5 & 16 & 15 & 27 & 8 & 25 & 26 & 19 & 28 & 24 & 27 & 30 & 14 & 10 & 10 & 5 & 16 & 16 & 18 & 0 & 13 \\
\hline & Lagoa Seca & 14 & 8 & 13 & 8 & 11 & 17 & 17 & 13 & 24 & 11 & 20 & 12 & 12 & 17 & 10 & 5 & 2 & 10 & 6 & 9 & 15 & 13 & 4 & 8 & 10 \\
\hline & Matinhas & 4 & 3 & 3 & 25 & 12 & 1 & 5 & 11 & 3 & 0 & 1 & 1 & 3 & 2 & 5 & 1 & - & 1 & 0 & 0 & 1 & 3 & 0 & 4 & 0 \\
\hline & Olivedos & 0 & 5 & 4 & 4 & 1 & 1 & 1 & 1 & 1 & 3 & 1 & 1 & 0 & 0 & 4 & 4 & 1 & 1 & 1 & 1 & 0 & 1 & 0 & 1 & 1 \\
\hline & Pedra Lavrada & 1 & 2 & 1 & 1 & 0 & 4 & 4 & 4 & 2 & 6 & 6 & 4 & 2 & 5 & 3 & 6 & 2 & 2 & 2 & 0 & 3 & 4 & 3 & 3 & 3 \\
\hline & Pocinhos & 14 & 8 & 3 & 7 & 8 & 5 & 25 & 11 & 22 & 19 & 32 & 23 & 4 & 10 & 10 & 0 & 6 & 0 & 0 & 7 & 6 & 0 & 0 & 7 & 2 \\
\hline & Queimadas & 18 & 6 & 13 & 4 & 6 & 1 & 16 & 12 & 5 & 7 & 0 & 0 & 3 & 0 & 0 & 8 & 5 & 2 & 0 & 0 & 11 & 0 & 0 & 0 & 6 \\
\hline & Seridó/São Vicente do Seridó & 1 & 0 & - & 0 & 5 & - & 4 & 7 & 22 & 14 & 11 & - & - & - & 22 & 7 & 6 & - & 8 & 9 & 8 & 6 & 4 & - & 0 \\
\hline & Soledade & 10 & 18 & 28 & 25 & 27 & 41 & 44 & 55 & 52 & 36 & 37 & 9 & - & - & 29 & 13 & 18 & 22 & 13 & 20 & 17 & 11 & 24 & 3 & 9 \\
\hline
\end{tabular}




\begin{tabular}{|c|c|c|c|c|c|c|c|c|c|c|c|c|c|c|c|c|c|c|c|c|c|c|c|c|c|c|c|c|}
\hline 2007 & Município & s1 & s2 & s3 & s4 & s5 & s6 & s7 & s8 & s9 & $\mathrm{s} 10$ & s11 & s12 & s13 & s14 & s15 & s16 & s17 & s18 & $s 19$ & s20 & s21 & $s 22$ & s23 & s24 & s25 & s26 & s27 \\
\hline & Acari & 1 & 2 & 10 & 6 & 14 & 17 & 3 & 3 & 6 & 7 & 11 & 22 & 25 & 14 & 11 & 7 & 22 & 3 & 11 & 6 & 8 & 9 & 0 & 8 & 5 & 0 & 14 \\
\hline & Açu & 12 & 1 & 15 & 7 & 0 & 25 & 13 & 12 & 2 & 21 & 31 & 23 & 8 & 16 & - & 24 & 6 & 5 & 7 & 1 & 2 & 0 & 4 & 4 & 2 & 1 & 8 \\
\hline & Almino Afonso & 0 & 0 & 0 & 0 & 0 & 0 & 0 & 0 & 0 & 0 & 0 & 0 & 0 & 0 & 0 & 0 & 0 & 0 & 0 & 0 & 0 & 0 & 0 & 0 & 0 & 0 & 0 \\
\hline & Angicos & 13 & 27 & 21 & 25 & 28 & 13 & 21 & 20 & 36 & 13 & 22 & 37 & 36 & 22 & 15 & 25 & - & 7 & 15 & 14 & 10 & 7 & 6 & 7 & 0 & 7 & 6 \\
\hline & Augusto Severo & 8 & 6 & 8 & 9 & 8 & 9 & 7 & 8 & 7 & 8 & 9 & 6 & 6 & 7 & 9 & 6 & 7 & 7 & 9 & 5 & 6 & 8 & 8 & 9 & 7 & 7 & - \\
\hline & Barcelona & 9 & 2 & 7 & 0 & 5 & 7 & 6 & 2 & 5 & 12 & 3 & 8 & 6 & 3 & 3 & 3 & 0 & 3 & 4 & 5 & 5 & 4 & 0 & 4 & 3 & 3 & 0 \\
\hline & Bodó & 8 & 6 & 6 & 4 & 5 & 5 & 7 & 5 & 6 & 7 & 4 & 7 & 9 & 7 & 5 & 6 & 7 & 6 & 8 & 8 & 9 & 10 & 8 & 8 & 7 & 9 & 8 \\
\hline & Bom Jesus & 9 & 12 & 13 & 13 & 8 & 22 & 27 & 15 & 19 & 44 & 9 & 14 & 2 & 6 & 8 & 7 & 0 & 5 & 1 & 11 & 21 & 15 & 23 & 26 & 13 & 11 & 5 \\
\hline & Caiçara do Rio do Vento & 1 & 0 & 1 & 2 & 3 & 1 & 2 & 3 & 6 & 7 & 5 & 5 & 5 & 6 & - & - & - & - & 1 & 2 & 2 & 2 & 1 & 3 & 1 & 2 & 1 \\
\hline & Caicó & 10 & 4 & 18 & 40 & 14 & 40 & 36 & 20 & 41 & 100 & 256 & 317 & 106 & 34 & 69 & 40 & 27 & 29 & 15 & 31 & 62 & 19 & 13 & 9 & 13 & 12 & 7 \\
\hline & Campo Redondo & 0 & 0 & 1 & 0 & 0 & 0 & 9 & 1 & 7 & 8 & 14 & 4 & 2 & 2 & 7 & 7 & 2 & 5 & 3 & 7 & 4 & 13 & 14 & 10 & 0 & 0 & 4 \\
\hline & Coronel Ezequiel & 1 & 1 & 0 & 0 & 1 & 1 & 0 & 0 & 1 & 4 & 5 & 2 & 0 & 4 & 8 & 0 & 6 & 0 & 1 & 1 & 3 & 2 & 1 & 3 & 0 & 2 & 0 \\
\hline & Currais Novos & 0 & 0 & 2 & 1 & 6 & 5 & 2 & 0 & 2 & 3 & 3 & 1 & 6 & 15 & 0 & 2 & 1 & 3 & 0 & 0 & 3 & 5 & 4 & 0 & 0 & 5 & 5 \\
\hline & Fernando Pedroza & - & - & - & - & 11 & - & - & - & 8 & 16 & - & - & 6 & - & - & - & 3 & - & - & - & - & 0 & - & - & - & 0 & - \\
\hline & Florânia & 2 & 4 & 5 & 25 & 2 & 7 & 1 & 4 & 2 & 5 & 10 & 17 & 10 & 8 & 6 & 1 & 8 & 3 & 4 & 5 & 1 & 3 & 0 & 10 & 5 & 2 & 1 \\
\hline & Ielmo Marinho & 0 & 2 & 5 & 11 & 10 & 13 & 0 & 0 & 3 & 5 & 6 & 9 & 25 & 3 & 4 & 8 & 1 & 4 & 0 & 0 & 5 & 8 & 0 & 4 & 23 & 6 & 3 \\
\hline & Itajá & 7 & 4 & 7 & 6 & 1 & 14 & 7 & 2 & 1 & 7 & 13 & 34 & 10 & 20 & 23 & 14 & 2 & 8 & 7 & 7 & 8 & 2 & 3 & 4 & 0 & 1 & 9 \\
\hline & Jaçanã & 2 & 2 & 3 & 4 & 5 & 18 & 6 & 9 & 4 & 5 & 10 & 10 & 7 & 12 & 25 & 19 & 10 & 6 & 8 & 7 & 3 & 7 & 11 & 6 & 7 & 6 & 9 \\
\hline & Janduís & 2 & 2 & 2 & 3 & 0 & 1 & 2 & 3 & 3 & 1 & 1 & 0 & 1 & 6 & 1 & 1 & 5 & 2 & 7 & 7 & 1 & 4 & 2 & 5 & 2 & 1 & 4 \\
\hline & Januário Cicco & 2 & 2 & 7 & 13 & 19 & 39 & 41 & 41 & 21 & 20 & 23 & 24 & 25 & 21 & 18 & 15 & 12 & 10 & 12 & 9 & 9 & 13 & 5 & 2 & 0 & 7 & 4 \\
\hline & Japi & 10 & 3 & 5 & 8 & 8 & - & 2 & 7 & 3 & 11 & 9 & 17 & 21 & 5 & 12 & 10 & 10 & 11 & 8 & 15 & 11 & 6 & 7 & 12 & 4 & 4 & 5 \\
\hline & Jardim de Angicos & 0 & 0 & 1 & 1 & 0 & 6 & 3 & 2 & 0 & 2 & 4 & 2 & 0 & 1 & 2 & 1 & 1 & 1 & 0 & 1 & 0 & 7 & 0 & 0 & 1 & 3 & 3 \\
\hline & Lagoa d'Anta & 3 & 0 & 0 & 0 & 0 & 0 & 0 & 2 & - & 0 & 1 & 0 & 5 & 1 & 0 & 4 & 2 & 0 & 0 & 2 & 4 & 0 & 0 & - & - & 0 & 0 \\
\hline & Lagoa de Pedras & 2 & 3 & 5 & 6 & 5 & - & 5 & 3 & 1 & 3 & 2 & 1 & 1 & 2 & 2 & 1 & 2 & 3 & 2 & 1 & 0 & 2 & 1 & 3 & 2 & 2 & 1 \\
\hline & Lagoa de Velhos & 7 & 3 & 3 & 2 & 6 & 1 & 4 & 0 & 1 & 1 & 0 & 2 & 4 & 3 & 0 & 4 & 6 & 4 & 5 & 7 & 20 & 6 & 8 & 7 & 5 & 3 & 7 \\
\hline & Lagoa Nova & 0 & 0 & 2 & 0 & 0 & 0 & 2 & 2 & 0 & 1 & 10 & 2 & 0 & 3 & 3 & 0 & 0 & 0 & 9 & 9 & 0 & 0 & 0 & 3 & 0 & 0 & 2 \\
\hline & Lagoa Salgada & 18 & 22 & 30 & 42 & 36 & 18 & 23 & 17 & 21 & 17 & 18 & 26 & 16 & 20 & 22 & 17 & 19 & - & - & 24 & 16 & 18 & 12 & 11 & 12 & 16 & 11 \\
\hline & Lajes & 2 & 3 & 3 & 9 & 3 & 9 & 5 & 5 & 7 & 10 & 6 & 9 & 8 & 5 & 5 & 10 & 7 & 10 & 9 & 7 & 7 & 6 & 7 & 8 & 5 & 8 & 8 \\
\hline & Lajes Pintadas & 0 & 2 & 2 & 1 & 4 & 1 & 1 & 1 & 3 & 2 & 4 & 6 & 3 & 8 & 3 & 4 & 2 & 1 & 4 & 3 & 3 & 3 & 3 & 5 & 5 & 3 & 1 \\
\hline & Messias Targino & 3 & 8 & 7 & 0 & 1 & 2 & 4 & 6 & 5 & 6 & 12 & 11 & 29 & 13 & 21 & 4 & 6 & 3 & 4 & 7 & 0 & 7 & 1 & 0 & 4 & 3 & 1 \\
\hline & Monte Alegre & 3 & 21 & 35 & 29 & 6 & 1 & 16 & 8 & 0 & 0 & 3 & 10 & 9 & 1 & 11 & 2 & 17 & 5 & 20 & 7 & 10 & 4 & 2 & 13 & 5 & 9 & 5 \\
\hline & Monte das Gameleiras & 0 & 0 & 0 & 8 & 9 & 20 & 0 & 3 & 0 & 6 & 6 & 8 & 26 & 4 & 0 & 0 & 5 & 6 & 6 & 0 & 0 & 10 & 4 & 0 & 0 & 4 & 0 \\
\hline & Paraú & 0 & 6 & 3 & 7 & 2 & 2 & 1 & 3 & 8 & 8 & 9 & 11 & 11 & 7 & 13 & 8 & 3 & 2 & 4 & 1 & 1 & 0 & 2 & 2 & 3 & 0 & 1 \\
\hline & Passa e Fica & 11 & 13 & 26 & 34 & 22 & 12 & 9 & 3 & 12 & 17 & - & - & 57 & 37 & 41 & 34 & 23 & 17 & 19 & 24 & 34 & 26 & 18 & 17 & 11 & 6 & - \\
\hline & Patu & 2 & 0 & 0 & 0 & 2 & 0 & 1 & 2 & 0 & 1 & 43 & 26 & 30 & 8 & 2 & 0 & 4 & 4 & 1 & 1 & 2 & 1 & 0 & 0 & 5 & 0 & 5 \\
\hline & Pedra Preta & 1 & 1 & 1 & 1 & 1 & 2 & 2 & 6 & 3 & 4 & 5 & 9 & 6 & 2 & 7 & 6 & 5 & 3 & 6 & 3 & 6 & 2 & 7 & 4 & 6 & 3 & 0 \\
\hline & Pedro Avelino & - & - & - & 21 & 0 & 12 & 6 & 0 & 6 & 7 & 6 & 9 & 7 & 4 & - & 4 & 4 & - & 10 & 5 & 9 & 3 & 3 & 4 & $\begin{array}{l}10 \\
231\end{array}$ & - & 4 \\
\hline
\end{tabular}




\begin{tabular}{|c|c|c|c|c|c|c|c|c|c|c|c|c|c|c|c|c|c|c|c|c|c|c|c|c|c|c|c|c|}
\hline 2007 & Município & s1 & s2 & s3 & s4 & s5 & s6 & s7 & s8 & s9 & s10 & s11 & s12 & $s 13$ & s14 & s15 & s16 & s17 & $s 18$ & $\mathbf{s 1 9}$ & s20 & s21 & s22 & s23 & s24 & s25 & $s 26$ & s27 \\
\hline & Presidente Juscelino & 2 & 2 & 1 & 13 & 4 & 4 & 12 & 4 & 2 & 11 & 30 & 40 & 29 & 33 & 8 & 6 & 6 & 2 & 1 & 5 & 12 & 7 & 6 & 1 & 4 & 0 & - \\
\hline & Riachuelo & 3 & 1 & 3 & 3 & 0 & 1 & 2 & 0 & 3 & 1 & 1 & 2 & 4 & 7 & 2 & 0 & 0 & 1 & 0 & 2 & 5 & 0 & 1 & 4 & 0 & 1 & 2 \\
\hline & Ruy Barbosa & 4 & 2 & 3 & 1 & 0 & 0 & 2 & 0 & 2 & 4 & 9 & 3 & 4 & 0 & 11 & 5 & 11 & 6 & 2 & 7 & 13 & 4 & 3 & 1 & 0 & 7 & 0 \\
\hline & Santa Cruz & 5 & 2 & 11 & 10 & 10 & 11 & 3 & 14 & 3 & 29 & 79 & 63 & 47 & 12 & 18 & 17 & 25 & 9 & 10 & 13 & 4 & 7 & 7 & 6 & 14 & 3 & 9 \\
\hline & Santa Maria & 1 & 2 & 3 & 5 & 5 & 1 & 1 & 2 & 1 & 1 & 1 & 3 & 2 & 4 & 2 & 3 & 1 & 1 & 2 & 2 & 5 & 3 & 3 & 2 & 2 & 1 & 6 \\
\hline & Santana do Matos & 0 & 2 & 7 & 0 & 8 & 2 & 2 & 2 & 5 & 7 & 14 & 18 & 16 & 16 & 8 & 8 & 5 & 6 & 3 & 2 & 2 & 5 & 2 & 0 & 2 & 4 & 2 \\
\hline & São Bento do Trairi & 0 & 0 & 2 & 0 & 5 & 14 & 9 & 0 & 4 & 17 & 25 & 11 & 14 & 9 & 10 & 2 & 5 & 1 & 8 & 3 & 8 & 6 & 3 & 2 & 1 & 0 & 0 \\
\hline & São José do Campestre & 26 & 20 & 6 & 36 & 13 & 11 & 1 & 26 & 20 & 22 & 87 & 67 & 62 & 23 & 23 & 23 & 28 & 10 & 16 & 26 & 27 & 35 & 12 & 12 & 11 & 5 & 2 \\
\hline & São Paulo do Potengi & 3 & 3 & 10 & 5 & 30 & 8 & 5 & 9 & 12 & 14 & 17 & 17 & 7 & 5 & 3 & 13 & 0 & 8 & 16 & - & 19 & 31 & 21 & 16 & 5 & 5 & 8 \\
\hline & São Pedro & 9 & 12 & 2 & 0 & 2 & 3 & 2 & 0 & 1 & 2 & 0 & 2 & 0 & 1 & 2 & 2 & 1 & 1 & 2 & 3 & 2 & 1 & 3 & 2 & 0 & 1 & 1 \\
\hline & São Rafael & 1 & 8 & 10 & 13 & 2 & 0 & 0 & 0 & 0 & 9 & 9 & 6 & 0 & 0 & 5 & 4 & 13 & 0 & 3 & 6 & 6 & 0 & 3 & 2 & 6 & 3 & 0 \\
\hline & São Tomé & 9 & 12 & 3 & 35 & 23 & 9 & 7 & 10 & 9 & 30 & 13 & 9 & 6 & 9 & 28 & 18 & 13 & 15 & 16 & 34 & 49 & 17 & 26 & 9 & 15 & 21 & 16 \\
\hline & São Vicente & 3 & 3 & 3 & 0 & 0 & 2 & 5 & 0 & 3 & 3 & 4 & 12 & 14 & 3 & 4 & 2 & 0 & 8 & 0 & 0 & 0 & 0 & 0 & 0 & 0 & 0 & 0 \\
\hline & Senador Elói de Souza & 4 & 7 & 4 & 2 & 5 & 3 & - & 1 & 0 & 7 & 2 & - & - & - & 3 & - & - & - & 4 & 5 & 4 & - & - & - & - & - & - \\
\hline & Serra de São Bento & - & - & - & - & - & - & - & - & - & 14 & 69 & 44 & 53 & 14 & 37 & 21 & 21 & 8 & 13 & 11 & 13 & 1 & 10 & 9 & - & - & - \\
\hline & Serrinha & - & - & 0 & 0 & 2 & 0 & 4 & 0 & 0 & 0 & 0 & 0 & 0 & 0 & 0 & 0 & 0 & 0 & 0 & 0 & 0 & 0 & 0 & 0 & 0 & 0 & 0 \\
\hline & Sítio Novo & 6 & 0 & 0 & 3 & 11 & 4 & 0 & 6 & 5 & 9 & 13 & 6 & 12 & 3 & 2 & 0 & 0 & 0 & 3 & 0 & 8 & 10 & 3 & 3 & 4 & 5 & 0 \\
\hline & Tangará & 5 & - & 6 & 10 & 14 & 14 & 5 & 5 & 10 & 5 & 29 & 30 & 25 & 12 & 11 & 20 & 7 & 9 & 21 & 33 & 20 & 13 & 6 & 6 & 2 & 5 & 3 \\
\hline & Tenente Laurentino Cruz & 0 & 0 & 2 & 0 & 0 & 0 & 4 & 0 & 1 & 13 & 11 & 11 & 15 & 0 & 0 & 0 & 0 & 3 & 0 & 4 & 4 & 0 & 3 & 0 & 0 & 2 & 0 \\
\hline & Triunfo Potiguar & 0 & 1 & 0 & 2 & 0 & 0 & - & - & - & 0 & 8 & 2 & 6 & 0 & 1 & 0 & 2 & 1 & 0 & 0 & 2 & 1 & 0 & 3 & 0 & 0 & 0 \\
\hline & Alagoa Nova & 0 & 14 & 15 & 13 & 15 & 11 & 33 & 11 & 26 & 9 & 18 & 23 & 14 & 31 & 22 & 18 & 27 & 32 & 37 & 50 & 35 & 25 & 36 & 22 & 13 & 19 & 22 \\
\hline & Barra de Santana & 1 & 10 & 3 & 5 & 6 & 4 & 0 & 42 & 14 & 6 & 0 & 23 & 41 & 21 & 27 & 42 & 43 & 20 & 34 & 15 & 23 & 4 & 0 & 12 & 3 & 16 & 5 \\
\hline & Boa Vista & 3 & 5 & 3 & 7 & 4 & 6 & 3 & 1 & 2 & 4 & 7 & 3 & 10 & 10 & 2 & 3 & 5 & 2 & 3 & 5 & 1 & 3 & 1 & 4 & 5 & 4 & 1 \\
\hline & Boqueirão & - & 6 & 10 & 10 & 8 & 4 & 0 & 4 & 13 & 0 & 12 & 9 & 26 & 16 & 29 & 3 & 4 & 39 & 0 & 17 & 3 & 28 & 0 & 5 & 20 & 14 & 7 \\
\hline & Cabaceiras & - & 0 & - & 1 & 2 & - & - & - & 2 & 3 & 9 & 6 & 15 & 2 & 2 & - & 2 & 9 & 2 & - & 2 & 4 & 7 & 3 & 6 & 3 & 4 \\
\hline & Campina Grande & 86 & 84 & 98 & 116 & 118 & 154 & 48 & 101 & 136 & 123 & 147 & 160 & 201 & 152 & 239 & 291 & 287 & 274 & 251 & 286 & 324 & 317 & 259 & 181 & 162 & 141 & 146 \\
\hline & Caturité & 0 & 0 & 3 & 3 & 2 & 2 & 4 & 1 & 5 & 1 & 4 & 2 & 6 & 2 & 12 & 17 & 23 & 9 & 9 & 6 & 5 & 8 & 1 & 9 & 0 & 1 & 0 \\
\hline & Cubati & 7 & 8 & 3 & 11 & 0 & 5 & 2 & 3 & 10 & 11 & 5 & 31 & 45 & 5 & 30 & 17 & 12 & 6 & 12 & 32 & 19 & 22 & 20 & 8 & 16 & 5 & 2 \\
\hline & Juazeirinho & 8 & 7 & 2 & - & 14 & 12 & 5 & 13 & 11 & 17 & 27 & 33 & 72 & 39 & 56 & - & 25 & 14 & 12 & 8 & 3 & 44 & 17 & 7 & 10 & 4 & 5 \\
\hline & Lagoa Seca & 21 & 9 & 10 & 8 & 9 & 10 & 7 & 4 & 0 & 8 & 8 & 5 & 12 & 3 & 34 & 32 & 24 & 21 & 40 & 22 & 28 & 27 & 7 & 3 & 13 & 7 & 8 \\
\hline & Matinhas & 0 & 0 & 2 & 0 & 0 & 1 & 2 & 1 & 1 & 1 & 2 & 6 & 3 & 0 & 7 & 10 & 3 & 3 & 9 & 6 & 9 & 1 & 3 & 5 & 2 & 2 & 1 \\
\hline & Olivedos & 0 & 1 & 0 & 2 & 0 & 1 & 0 & 1 & 2 & 5 & 5 & 7 & 9 & 1 & 3 & 7 & - & 3 & 6 & 3 & 6 & 3 & 1 & 3 & 1 & 0 & 3 \\
\hline & Pedra Lavrada & 1 & 8 & 2 & 3 & 1 & 3 & 0 & 5 & 3 & 8 & 15 & 7 & 31 & 24 & 19 & 21 & 17 & 1 & 15 & 19 & 26 & 14 & 11 & 7 & 11 & 9 & 6 \\
\hline & Pocinhos & 2 & - & - & 9 & 1 & 6 & - & 0 & 7 & 6 & 5 & 25 & 64 & 0 & 19 & 20 & 28 & 7 & 14 & 27 & 20 & 34 & 13 & 12 & 32 & 0 & 2 \\
\hline & Queimadas & 12 & 0 & 0 & 1 & 12 & 4 & 0 & 0 & 10 & 0 & 0 & 0 & 16 & 0 & 5 & 17 & 54 & 15 & 10 & 6 & 19 & 85 & 22 & 48 & 17 & 75 & 14 \\
\hline & Seridó/São Vicente do Seridó & 0 & 8 & 2 & 13 & 11 & 13 & 13 & 4 & 1 & 1 & 1 & 7 & 10 & 19 & 0 & 27 & 3 & 10 & 25 & 11 & 39 & 5 & 14 & 5 & 3 & 8 & 0 \\
\hline & Soledade & 2 & 9 & 8 & 12 & - & 14 & 3 & 18 & 16 & 25 & 59 & 69 & 59 & 21 & - & 51 & 21 & 13 & 19 & 34 & 29 & 25 & 18 & 18 & 22 & 22 & 18 \\
\hline
\end{tabular}




\begin{tabular}{|c|c|c|c|c|c|c|c|c|c|c|c|c|c|c|c|c|c|c|c|c|c|c|c|c|c|c|}
\hline 2007 & Município & s28 & $s 29$ & s30 & s31 & s32 & s33 & s34 & s35 & s36 & s37 & s38 & s39 & $s 40$ & s41 & s42 & $s 43$ & s44 & s45 & s46 & s47 & $s 48$ & $s 49$ & $s 50$ & s51 & s52 \\
\hline & Acari & 3 & 10 & 5 & 3 & 3 & 1 & 1 & 2 & 0 & 1 & 2 & 0 & 2 & 0 & 0 & 12 & 3 & 4 & 1 & - & 0 & 0 & 4 & 0 & 1 \\
\hline & Açu & 7 & 18 & 9 & 4 & 21 & 36 & 23 & 59 & 6 & 3 & 5 & 5 & 8 & 7 & 4 & 1 & 0 & 20 & 1 & 5 & 7 & 10 & 9 & 1 & 0 \\
\hline & Almino Afonso & 0 & 0 & 0 & 0 & 0 & 0 & 0 & 0 & 0 & 0 & 0 & 0 & 0 & 0 & 0 & 0 & 3 & 0 & 0 & 0 & 0 & 0 & 0 & 0 & 0 \\
\hline & Angicos & 0 & 0 & 3 & 0 & 21 & 10 & 17 & 17 & 33 & 28 & 18 & 0 & 9 & 26 & 10 & 0 & 11 & 6 & 7 & 7 & 0 & 10 & 10 & 2 & 4 \\
\hline & Augusto Severo & 7 & 9 & 7 & 8 & 7 & 7 & 8 & 8 & 7 & 9 & 7 & 6 & 6 & 8 & 5 & 6 & - & 5 & 7 & 7 & 8 & 8 & 7 & 6 & 7 \\
\hline & Barcelona & 2 & 6 & 2 & 0 & 0 & 2 & 2 & 1 & 1 & 2 & 5 & 5 & 3 & 0 & 2 & 0 & 0 & 2 & 2 & 3 & 3 & 3 & 0 & 0 & 0 \\
\hline & Bodó & 10 & 9 & 9 & 10 & 8 & 10 & 9 & 8 & 9 & 9 & 10 & 8 & 10 & 9 & 10 & 10 & 10 & 10 & - & - & - & - & - & - & - \\
\hline & Bom Jesus & 7 & 1 & 5 & 5 & 3 & 11 & 6 & 2 & 3 & 6 & 2 & 1 & 1 & 6 & 9 & 2 & 3 & - & 6 & 10 & 9 & 14 & 9 & 4 & 11 \\
\hline & Caiçara do Rio do Vento & 2 & 1 & 0 & 5 & 2 & 1 & 2 & 0 & 1 & 1 & 1 & 1 & 1 & 1 & 2 & 1 & 2 & 1 & 0 & 2 & 2 & 2 & 1 & 1 & 2 \\
\hline & Caicó & 7 & 19 & 1 & 7 & 11 & 9 & 7 & 5 & 7 & 2 & 8 & 4 & 0 & 2 & 7 & 7 & 5 & 6 & 1 & 2 & 2 & 2 & 4 & 0 & 2 \\
\hline & Campo Redondo & 0 & 0 & 0 & 3 & 0 & 0 & 0 & 0 & 0 & 0 & 0 & 2 & 0 & 1 & 0 & 1 & 0 & 0 & 1 & 0 & 1 & 3 & - & - & - \\
\hline & Coronel Ezequiel & 0 & 0 & 0 & 2 & 0 & 1 & 2 & - & 0 & 1 & 0 & 1 & 1 & - & 2 & - & 1 & 0 & 1 & 0 & 4 & 1 & 0 & - & - \\
\hline & Currais Novos & 2 & 1 & 2 & 1 & 1 & 1 & 0 & 0 & 0 & 1 & 2 & 0 & 1 & 2 & 3 & 1 & 7 & 2 & 0 & 11 & 0 & 2 & 0 & 0 & 1 \\
\hline & Fernando Pedroza & - & 0 & - & 2 & 1 & 2 & 1 & 2 & 3 & 2 & 0 & 2 & 0 & 0 & 9 & 6 & 0 & 1 & 1 & 0 & 0 & 0 & 0 & 0 & - \\
\hline & Florânia & 0 & 1 & 1 & 2 & 6 & 1 & 5 & 5 & 0 & 3 & 2 & 1 & - & 1 & 4 & 1 & 3 & 1 & 8 & 4 & - & 3 & 11 & 2 & 1 \\
\hline & lelmo Marinho & 3 & 4 & 13 & 1 & 14 & 15 & 13 & 7 & 0 & 9 & 6 & 0 & 4 & 7 & 0 & 3 & 4 & 2 & 3 & 1 & 5 & 6 & 11 & 14 & 4 \\
\hline & Itajá & 18 & 7 & 9 & 11 & 3 & 3 & 3 & 0 & - & - & - & - & - & - & - & - & - & - & - & - & - & - & - & - & - \\
\hline & Jaçanã & 1 & 2 & 5 & 7 & 6 & 5 & 2 & 2 & 6 & 4 & 3 & 2 & 1 & 4 & 6 & 4 & 3 & 3 & 0 & 6 & 4 & 0 & 3 & 3 & 4 \\
\hline & Janduís & 3 & 1 & 9 & 18 & 17 & 12 & 2 & 2 & 1 & 2 & 2 & - & - & 3 & 2 & 2 & 0 & 2 & 1 & 1 & 0 & 1 & 1 & 0 & 0 \\
\hline & Januário Cicco & 7 & 6 & 8 & 5 & 9 & 7 & 6 & 3 & 5 & 4 & 8 & 0 & 8 & 0 & 0 & 7 & 2 & 12 & 5 & 7 & 0 & 0 & 0 & 3 & 0 \\
\hline & Japi & 4 & 15 & 5 & 5 & 0 & 0 & 1 & 5 & 1 & 2 & 0 & 4 & 6 & 4 & 5 & 0 & - & 7 & 10 & 2 & 4 & 2 & 3 & 4 & 4 \\
\hline & Jardim de Angicos & 1 & 0 & 2 & 8 & 4 & 1 & 2 & 1 & 0 & 1 & 6 & 1 & 0 & 0 & 1 & 0 & 0 & 0 & 3 & 4 & 4 & - & 1 & 2 & 0 \\
\hline & Lagoa d'Anta & 2 & 0 & 2 & 0 & 0 & 1 & 0 & 2 & 2 & 0 & 0 & 0 & 0 & 4 & 0 & 1 & 0 & 0 & 2 & 0 & 0 & 2 & 0 & 0 & 0 \\
\hline & Lagoa de Pedras & 1 & 1 & 1 & 2 & 0 & 2 & 1 & - & 0 & 0 & 1 & 1 & 0 & 0 & 3 & 0 & 2 & 1 & 1 & 0 & 1 & 1 & 0 & 2 & 2 \\
\hline & Lagoa de Velhos & 6 & 2 & 0 & 5 & 1 & 1 & 1 & 0 & - & 1 & 2 & 3 & 0 & 0 & 3 & 3 & 3 & 4 & 1 & - & 6 & 1 & 3 & 0 & 3 \\
\hline & Lagoa Nova & 6 & 0 & 0 & 0 & 1 & 0 & 0 & 0 & 0 & 0 & 0 & 0 & 0 & 0 & 0 & 0 & 0 & 0 & 0 & 0 & 7 & 0 & 1 & 1 & 0 \\
\hline & Lagoa Salgada & 10 & 12 & 12 & 11 & 2 & 10 & 13 & 3 & 9 & 6 & 6 & 4 & 3 & 3 & 3 & 4 & 0 & 7 & 13 & 7 & 7 & 4 & 8 & 10 & 8 \\
\hline & Lajes & 4 & - & - & 2 & 5 & 5 & 12 & 17 & 25 & 20 & 7 & 9 & 7 & 5 & 10 & 13 & 8 & - & 6 & 7 & 9 & 9 & 8 & 13 & 11 \\
\hline & Lajes Pintadas & 0 & 1 & 0 & 0 & 0 & 2 & 0 & 2 & 2 & - & 1 & 1 & 0 & 1 & 0 & 0 & 1 & 0 & 0 & 1 & 0 & 0 & 0 & 0 & 0 \\
\hline & Messias Targino & 4 & 3 & 2 & - & - & 6 & 5 & - & 5 & 5 & 6 & 3 & 3 & 2 & 0 & 1 & 5 & 3 & 3 & 1 & 4 & 3 & 0 & 12 & 2 \\
\hline & Monte Alegre & 14 & 2 & - & - & - & - & - & - & - & - & - & - & - & - & - & - & - & - & - & - & - & - & - & - & - \\
\hline & Monte das Gameleiras & 4 & 0 & 0 & 0 & 0 & 0 & 0 & 0 & 0 & 0 & 0 & 6 & 0 & 0 & 0 & 0 & 0 & 0 & 0 & 0 & 3 & - & 0 & 0 & - \\
\hline & Paraú & 1 & 2 & 0 & 0 & 0 & 2 & 1 & 3 & 1 & 3 & 3 & 2 & 1 & 3 & 1 & 0 & 2 & 2 & 4 & 2 & 4 & 4 & 1 & 2 & 0 \\
\hline & Passa e Fica & 19 & 21 & 6 & 7 & 11 & 3 & 5 & 2 & 5 & 6 & 4 & 6 & 8 & 9 & 3 & 5 & 3 & 2 & 4 & 7 & 6 & 0 & 11 & 0 & 0 \\
\hline & Patu & 0 & 0 & 0 & 0 & 0 & 0 & 0 & 0 & 0 & 0 & 0 & 0 & 0 & 0 & 0 & 0 & 2 & 0 & 0 & 0 & 0 & 0 & 3 & 1 & 2 \\
\hline & Pedra Preta & 2 & - & 2 & 2 & 3 & 5 & 6 & 3 & 4 & 10 & 11 & 13 & 13 & - & - & - & - & - & - & 1 & - & 1 & 5 & - & - \\
\hline
\end{tabular}




\begin{tabular}{|c|c|c|c|c|c|c|c|c|c|c|c|c|c|c|c|c|c|c|c|c|c|c|c|c|c|c|}
\hline 2007 & Município & $\mathbf{s 2 8}$ & $\mathbf{s 2 9}$ & s30 & s31 & s32 & s33 & s34 & s35 & s36 & s37 & s38 & s39 & $s 40$ & s41 & $\mathrm{s} 42$ & $s 43$ & $s 44$ & $s 45$ & $s 46$ & $s 47$ & $s 48$ & $s 49$ & $s 50$ & s51 & s52 \\
\hline & Pedro Avelino & 2 & 6 & 5 & 4 & 4 & 4 & 8 & 5 & 4 & 8 & 4 & 10 & 7 & 5 & 4 & 2 & 5 & 4 & 4 & - & 6 & 4 & 4 & - & 4 \\
\hline & Presidente Juscelino & 0 & 7 & 6 & 3 & 4 & 4 & 0 & 2 & 4 & 4 & 0 & 8 & 14 & 6 & 4 & 10 & 11 & 5 & 5 & 8 & 4 & 1 & 6 & 2 & 0 \\
\hline & Riachuelo & 1 & 1 & 1 & - & 2 & 2 & 0 & 1 & 0 & 0 & 1 & 3 & 5 & 3 & 2 & 4 & 1 & 5 & 6 & 5 & 1 & 15 & 13 & 7 & 2 \\
\hline & Ruy Barbosa & 8 & 8 & 7 & 4 & 0 & 3 & 3 & 2 & 6 & 3 & 5 & 8 & 5 & 3 & 8 & 2 & 1 & 1 & 1 & 9 & 7 & 7 & 9 & 14 & - \\
\hline & Santa Cruz & 6 & 5 & 2 & 3 & 4 & 3 & 3 & 3 & 12 & 2 & 7 & 4 & 1 & 1 & 1 & - & 4 & 7 & 3 & 7 & 4 & 2 & 3 & 4 & 11 \\
\hline & Santa Maria & 0 & 1 & 1 & 1 & 7 & 2 & 3 & 1 & 4 & 1 & 0 & 0 & 0 & 0 & 3 & 2 & 0 & 0 & 4 & 3 & 2 & 3 & 4 & - & - \\
\hline & Santana do Matos & 2 & 1 & 4 & 2 & 2 & 0 & 0 & 1 & 1 & 0 & 0 & 2 & 0 & 0 & 3 & 0 & 3 & 3 & 4 & 1 & 0 & 0 & 0 & 0 & 1 \\
\hline & São Bento do Trairi & 1 & 3 & 1 & 1 & 2 & 1 & 0 & 0 & 1 & 3 & 1 & 1 & 1 & 1 & 2 & 2 & 0 & 2 & 0 & 0 & 0 & 4 & 0 & 6 & - \\
\hline & São José do Campestre & 6 & 9 & 6 & 1 & 6 & - & 5 & 8 & - & 6 & 5 & 4 & 8 & 2 & 7 & 4 & 4 & 6 & 3 & 7 & 2 & 3 & 4 & - & - \\
\hline & São Paulo do Potengi & - & - & 0 & 5 & 3 & 3 & 6 & - & 4 & - & 0 & - & 0 & 0 & 3 & 7 & 2 & 19 & 8 & 9 & 5 & 6 & 14 & - & - \\
\hline & São Pedro & 3 & 1 & 0 & 0 & 2 & 3 & 1 & 0 & 1 & 2 & 2 & 0 & 0 & 2 & 1 & - & - & 3 & 1 & 3 & 0 & 1 & 0 & - & 3 \\
\hline & São Rafael & 0 & 0 & 0 & 3 & 0 & 0 & 0 & 0 & 0 & 0 & 0 & 0 & 2 & 4 & 1 & 0 & 0 & 0 & 0 & 0 & 0 & 0 & 0 & 0 & 0 \\
\hline & São Tomé & 12 & 18 & 7 & 8 & 11 & 6 & 5 & 6 & 2 & 5 & 5 & 0 & 14 & 7 & 3 & 9 & 13 & 6 & 7 & 4 & 9 & 4 & 11 & 10 & 4 \\
\hline & São Vicente & 0 & 0 & 0 & 0 & 0 & 0 & 0 & 0 & 0 & 0 & 0 & 3 & 0 & 0 & 0 & 0 & 0 & - & 0 & 0 & 0 & 0 & 0 & 1 & 2 \\
\hline & Senador Elói de Souza & - & - & - & - & - & - & - & - & - & - & - & - & - & - & - & - & - & - & - & - & - & - & - & - & - \\
\hline & Serra de São Bento & 10 & 0 & - & - & 3 & 2 & - & - & - & - & - & - & - & - & - & - & - & - & - & - & - & - & - & - & - \\
\hline & Serrinha & 0 & 0 & 0 & 0 & 0 & 0 & 0 & 0 & 0 & 0 & 0 & - & 0 & 0 & 0 & 0 & 0 & 0 & 0 & 0 & 0 & 0 & 0 & - & - \\
\hline & Sítio Novo & 3 & 3 & 6 & 4 & 0 & 3 & 1 & 1 & 3 & 2 & 5 & 4 & 15 & - & 11 & - & 2 & 7 & 1 & - & 3 & 0 & 12 & 14 & - \\
\hline & Tangará & 8 & 6 & 2 & 6 & 10 & 4 & 7 & 3 & 1 & 4 & 1 & 1 & 1 & 2 & 5 & 0 & 0 & 7 & 0 & 5 & 5 & 0 & 0 & 0 & 0 \\
\hline & Tenente Laurentino Cruz & 0 & 0 & 1 & 0 & 0 & 2 & 3 & 0 & 0 & 0 & 3 & 3 & 1 & 0 & 0 & 1 & 0 & 0 & 0 & 1 & 0 & 0 & 4 & 2 & 1 \\
\hline & Triunfo Potiguar & 1 & 0 & 0 & 0 & 1 & 0 & 0 & 3 & 4 & 3 & 1 & 2 & 0 & 1 & 1 & 0 & 2 & 0 & 2 & 0 & 1 & 1 & 0 & 1 & 0 \\
\hline & Alagoa Nova & 19 & 10 & 17 & 15 & 6 & 7 & 5 & - & 5 & 5 & 10 & 7 & 6 & 3 & 6 & 8 & 8 & 6 & 11 & 14 & 8 & 6 & 9 & 5 & 20 \\
\hline & Barra de Santana & 6 & 4 & 0 & 6 & 1 & 3 & 2 & 2 & 0 & 2 & 3 & 2 & 0 & 3 & 7 & 7 & 3 & 3 & 2 & 4 & 1 & 1 & 1 & 4 & 2 \\
\hline & Boa Vista & 6 & 3 & 2 & 2 & 2 & 4 & - & 2 & 2 & 6 & 3 & 4 & 2 & 0 & 6 & - & 2 & 4 & 2 & 2 & 3 & 2 & 3 & 1 & 3 \\
\hline & Boqueirão & 0 & 0 & 3 & 8 & - & 9 & 0 & 11 & 2 & 0 & 8 & 0 & 4 & 4 & 0 & 6 & 0 & 4 & 2 & 0 & 3 & 13 & 3 & - & 0 \\
\hline & Cabaceiras & 3 & - & - & 3 & 0 & 2 & 1 & 0 & - & - & 3 & 3 & - & 2 & - & - & - & 0 & - & - & - & 0 & 0 & 0 & - \\
\hline & Campina Grande & 51 & 90 & 152 & 101 & 106 & 76 & 117 & 124 & 81 & 85 & 90 & 112 & 37 & 90 & 102 & 99 & 103 & 120 & 113 & 62 & 126 & 117 & 142 & 138 & 119 \\
\hline & Caturité & 0 & 1 & 1 & 0 & 1 & 1 & 1 & 3 & 2 & 1 & 3 & 2 & 1 & 0 & 4 & 0 & 1 & 2 & 2 & 4 & 2 & 0 & 1 & 0 & 0 \\
\hline & Cubati & 1 & 2 & 0 & 8 & 16 & 0 & 8 & 0 & 0 & 5 & 14 & 3 & 0 & 1 & 7 & 5 & - & - & - & - & - & - & - & 16 & 1 \\
\hline & Juazeirinho & 9 & 7 & 15 & 6 & 0 & 10 & 5 & 7 & 3 & 10 & 12 & 5 & 4 & 13 & 18 & 12 & 6 & 8 & 14 & - & 21 & 4 & - & - & 9 \\
\hline & Lagoa Seca & 5 & 4 & 7 & 16 & 4 & 1 & 12 & 10 & 15 & 9 & 5 & 5 & 20 & 7 & 6 & 7 & 1 & 0 & 2 & 2 & 0 & 9 & 0 & 4 & 12 \\
\hline & Matinhas & 1 & 0 & 0 & 0 & 0 & 1 & 0 & 3 & 0 & 0 & 0 & 0 & 2 & 0 & 3 & 0 & 0 & 0 & 0 & 1 & 0 & 6 & 3 & 2 & 0 \\
\hline & Olivedos & 1 & 6 & 3 & 0 & 0 & 1 & 3 & 0 & 0 & 3 & 6 & 1 & 2 & 0 & 0 & 1 & - & 2 & 1 & 1 & 1 & 1 & 0 & 0 & 1 \\
\hline & Pedra Lavrada & 5 & 4 & 3 & 2 & 4 & 10 & 6 & 0 & 7 & 4 & 4 & 5 & 6 & 5 & 1 & 1 & 5 & 5 & 1 & 2 & 2 & 1 & 2 & 1 & 0 \\
\hline & Pocinhos & 9 & 7 & 18 & 0 & 4 & 2 & 6 & 15 & 0 & 21 & 14 & - & 22 & 13 & 28 & 13 & 15 & 9 & 11 & 9 & 15 & 7 & 6 & 12 & 2 \\
\hline & Queimadas & 18 & 30 & 30 & 13 & 10 & 15 & 18 & 22 & 3 & 8 & 12 & 9 & 0 & 8 & 44 & 8 & 3 & 8 & 4 & 5 & 4 & 10 & 4 & 19 & 0 \\
\hline & Seridó/São Vicente do Seridó & 20 & 39 & 17 & 17 & 9 & 20 & 0 & 21 & 17 & 36 & 8 & 9 & 7 & 4 & 8 & 6 & 4 & - & - & - & - & - & - & - & - \\
\hline
\end{tabular}




\begin{tabular}{|c|c|c|c|c|c|c|c|c|c|c|c|c|c|c|c|c|c|c|c|c|c|c|c|c|c|c|c|c|}
\hline \multirow[t]{2}{*}{2007} & Município & \multirow{2}{*}{$\frac{\mathbf{s 2 8}}{16}$} & \multirow{2}{*}{$\frac{\mathbf{s 2 9}}{23}$} & \multirow{2}{*}{$\frac{\text { s30 }}{20}$} & \multirow{2}{*}{$\frac{\mathbf{s} 31}{20}$} & \multicolumn{2}{|c|}{ s32 } & s33 & s34 & \multirow{2}{*}{$\frac{\mathbf{s} 35}{16}$} & \multirow{2}{*}{$\begin{array}{c}\text { s36 } \\
5\end{array}$} & \multirow{2}{*}{$\begin{array}{c}\mathbf{s} 37 \\
16\end{array}$} & \multirow{2}{*}{$\begin{array}{c}\mathbf{s} 38 \\
13\end{array}$} & \multirow{2}{*}{$\begin{array}{c}\text { s39 } \\
20\end{array}$} & \multirow{2}{*}{$\begin{array}{c}\mathbf{s 4 0} \\
11\end{array}$} & \multirow{2}{*}{$\begin{array}{c}\mathbf{s 4 1} \\
8\end{array}$} & \multirow{2}{*}{$\begin{array}{c}\mathbf{s 4 2} \\
19\end{array}$} & $s 43$ & s44 & s45 & s46 & s47 & s48 & s49 & s50 & s51 & s52 & \\
\hline & Soledade & & & & & 26 & & 27 & 22 & & & & & & & & & 9 & 14 & 11 & 14 & 7 & 14 & 10 & 13 & 12 & 10 & \\
\hline 2008 & Município & s1 & s2 & s3 & s4 & s5 & s6 & s7 & s8 & s9 & s10 & s11 & s12 & s13 & $s 14$ & s15 & s16 & s17 & $s 18$ & $s 19$ & s20 & s21 & s22 & s23 & s24 & s25 & s26 & s27 \\
\hline & Acari & 0 & 9 & 1 & 0 & 1 & 0 & 3 & 2 & 6 & 5 & 5 & - & - & 37 & 38 & 7 & 32 & 78 & 19 & 4 & 11 & 13 & 4 & 5 & 6 & 6 & 3 \\
\hline & Açu & 21 & 28 & 9 & 7 & 8 & 38 & 36 & 10 & 2 & 34 & 15 & 5 & 0 & 18 & 18 & 105 & 167 & 106 & 181 & 125 & 91 & 88 & 55 & 25 & 28 & 32 & 24 \\
\hline & Almino Afonso & 0 & 0 & 0 & 0 & 0 & 0 & 2 & 1 & 0 & 0 & 0 & 0 & 0 & 0 & 0 & 0 & 0 & 0 & 0 & 0 & 0 & 0 & 0 & 0 & 0 & 0 & 0 \\
\hline & Angicos & 0 & 5 & 9 & 10 & 8 & 34 & 34 & 38 & 56 & 45 & 70 & 16 & 17 & 66 & 50 & 28 & 22 & 25 & 56 & 31 & 22 & 33 & 13 & 14 & 5 & 6 & 0 \\
\hline & Augusto Severo & 8 & 8 & 7 & 9 & 8 & 8 & 6 & 8 & 9 & 7 & 9 & 7 & 6 & 45 & 5 & 9 & 6 & 7 & 9 & 6 & 8 & 7 & 8 & 7 & 7 & 9 & 8 \\
\hline & Barcelona & 3 & 5 & 0 & 2 & 0 & 6 & 1 & 0 & 5 & 7 & 7 & 0 & 9 & 10 & 21 & 14 & 16 & 14 & 10 & 12 & 0 & 1 & 5 & 3 & 0 & 0 & 0 \\
\hline & Bodó & - & - & - & - & - & - & - & - & - & - & - & - & - & - & - & - & - & - & - & - & - & - & - & - & - & - & - \\
\hline & Bom Jesus & 10 & 4 & 5 & 2 & 0 & 0 & 8 & 12 & 25 & 9 & 5 & 8 & 11 & 14 & 0 & 5 & 15 & 19 & 21 & 22 & 14 & 19 & 6 & 15 & - & - & 0 \\
\hline & Caiçara do Rio do Vento & 4 & 2 & 5 & 2 & 3 & 4 & 5 & 0 & 8 & 6 & 7 & 6 & 2 & 0 & 3 & 5 & 7 & 3 & 6 & 5 & 1 & 10 & 10 & 5 & 6 & 3 & 3 \\
\hline & Caicó & 5 & 5 & 8 & 6 & 3 & 18 & 9 & 16 & 23 & 20 & 28 & 7 & 17 & 16 & 13 & 23 & 30 & 11 & 12 & 14 & 7 & 8 & 0 & 0 & 3 & 4 & 8 \\
\hline & Campo Redondo & 0 & 0 & 0 & 3 & 2 & 0 & 2 & 1 & 0 & 0 & 0 & 0 & 0 & 1 & 4 & 6 & 4 & 3 & 0 & 5 & 2 & 8 & 0 & 2 & 1 & 0 & 2 \\
\hline & Coronel Ezequiel & 0 & 0 & - & 0 & 2 & 3 & 4 & 3 & 1 & 3 & 3 & 2 & 3 & 25 & 26 & 12 & 3 & 3 & 3 & 7 & 2 & 0 & - & 0 & - & 3 & 0 \\
\hline & Currais Novos & 1 & 3 & 2 & 2 & 0 & 0 & 0 & 0 & 0 & 6 & 0 & 1 & 0 & 2 & 3 & 6 & 0 & 4 & 0 & 4 & 9 & 1 & 0 & - & 0 & 0 & 0 \\
\hline & Fernando Pedroza & 3 & 2 & 3 & 0 & 3 & 17 & 25 & 7 & 9 & 0 & 0 & 0 & 0 & 0 & 0 & 0 & 0 & 0 & 0 & 0 & 0 & 0 & 0 & 0 & 0 & 0 & 0 \\
\hline & Florânia & 4 & 6 & 3 & 2 & 0 & 1 & 2 & 3 & 13 & 8 & 13 & 8 & 12 & 11 & 14 & 10 & 9 & 9 & 4 & 11 & 1 & 9 & 1 & 4 & 0 & 3 & 0 \\
\hline & Ielmo Marinho & 2 & 22 & 17 & 11 & 6 & 6 & 9 & 10 & 8 & 25 & 16 & 12 & 20 & 33 & 15 & 34 & 45 & 24 & 38 & 34 & 27 & 27 & 10 & 5 & 14 & 1 & 7 \\
\hline & Itajá & - & - & - & - & 59 & - & 46 & 18 & 22 & 25 & 32 & 24 & 19 & 20 & - & 25 & 13 & 15 & 9 & 11 & 11 & 8 & 5 & 6 & 3 & 4 & 6 \\
\hline & Jaçanã & 7 & 1 & 2 & 0 & 3 & 9 & 13 & 8 & 7 & 13 & 11 & 10 & 11 & - & 2 & 10 & 2 & 6 & 8 & 8 & 4 & 8 & 3 & 5 & 6 & 3 & 3 \\
\hline & Janduís & 3 & 5 & 2 & 3 & 6 & 4 & 2 & 4 & 18 & 17 & 2 & 3 & 3 & - & 0 & 1 & 1 & 0 & 2 & 2 & 0 & 0 & 0 & - & 0 & 0 & 0 \\
\hline & Januário Cicco & 0 & 0 & 0 & 5 & 4 & 1 & 7 & 8 & 6 & 6 & 7 & 4 & 5 & 7 & 3 & 0 & 2 & 4 & 0 & - & 0 & 2 & 4 & 5 & 8 & - & 0 \\
\hline & Japi & 4 & 3 & 6 & 3 & 4 & 5 & 5 & 2 & 2 & 5 & - & - & - & - & 9 & 25 & 11 & 10 & 6 & 7 & 7 & 5 & 8 & 12 & 18 & 3 & 6 \\
\hline & Jardim de Angicos & 0 & 0 & 0 & 0 & 0 & 3 & 4 & 4 & 3 & 0 & 3 & 1 & 4 & 3 & 1 & 5 & 2 & 4 & 1 & 0 & 1 & 0 & 0 & 0 & 0 & 0 & 8 \\
\hline & Lagoa d'Anta & 0 & 2 & 0 & 0 & 0 & 0 & 5 & 0 & 0 & 0 & 2 & 0 & 1 & 1 & 3 & 8 & 0 & 1 & 2 & 12 & 0 & 0 & 0 & 0 & 0 & 0 & 0 \\
\hline & Lagoa de Pedras & 0 & 1 & 0 & 1 & 2 & 1 & 4 & 2 & 1 & 2 & 5 & 2 & 0 & 3 & 6 & 4 & 3 & 2 & 3 & 2 & 0 & 6 & 0 & 2 & 3 & 0 & 1 \\
\hline & Lagoa de Velhos & 2 & 7 & 5 & 10 & 0 & 1 & 7 & 4 & 6 & 11 & 1 & 3 & 0 & 14 & 12 & 15 & 15 & 24 & 25 & 9 & 10 & 8 & 0 & 7 & 6 & 1 & 0 \\
\hline & Lagoa Nova & 0 & 3 & 4 & 0 & 0 & 3 & 13 & 10 & 0 & 18 & 17 & 14 & 2 & 7 & - & - & 0 & 0 & 2 & 1 & 1 & 0 & 0 & 3 & - & - & 0 \\
\hline & Lagoa Salgada & 13 & 17 & 17 & 28 & 20 & 12 & 17 & 15 & 9 & 12 & 11 & 6 & 9 & 24 & 21 & 27 & 30 & 24 & 38 & 33 & 18 & 15 & 17 & 7 & 10 & 9 & 10 \\
\hline & Lajes & 11 & 11 & 19 & 8 & 17 & 20 & 14 & 16 & 22 & 14 & 11 & 4 & 20 & 5 & 25 & 28 & 27 & 15 & 5 & 3 & 2 & 4 & 5 & 0 & 3 & 0 & 2 \\
\hline & Lajes Pintadas & 2 & 1 & 1 & 2 & 1 & 0 & 2 & 4 & 3 & 4 & 1 & 0 & 3 & 6 & 8 & 16 & 21 & 22 & 22 & 3 & 3 & 2 & 1 & 5 & 1 & 1 & 1 \\
\hline & Messias Targino & 29 & 10 & 1 & 6 & 1 & 1 & 0 & 12 & 33 & 14 & 16 & 9 & 10 & 4 & 13 & 2 & 3 & 2 & 3 & 0 & 3 & 3 & 0 & 4 & 2 & 0 & 2 \\
\hline & Monte Alegre & 0 & 0 & 1 & 5 & 5 & 1 & 0 & 3 & 0 & 4 & 11 & 0 & 4 & 3 & 27 & 5 & 1 & 2 & 16 & - & - & - & - & - & - & - & - \\
\hline & Monte das Gameleiras & 0 & 12 & 0 & 0 & 0 & 0 & 8 & 0 & 0 & 3 & 7 & - & - & 0 & 0 & 21 & 0 & 0 & 0 & 0 & 0 & 0 & 0 & 0 & 0 & 3 & 0 \\
\hline & Paraú & 1 & 2 & 2 & 0 & 4 & 7 & 9 & 8 & 12 & 10 & 8 & 5 & 2 & 2 & 2 & 3 & 2 & 6 & 5 & 3 & 6 & 1 & 0 & - & - & - & - \\
\hline & Passa e Fica & 0 & 3 & 1 & 1 & 1 & 14 & 6 & 4 & 13 & 13 & - & - & 12 & 9 & 21 & 21 & 11 & 18 & 14 & 12 & 9 & 13 & 8 & 5 & $\begin{array}{r}2 \\
235\end{array}$ & 4 & 2 \\
\hline
\end{tabular}




\begin{tabular}{|c|c|c|c|c|c|c|c|c|c|c|c|c|c|c|c|c|c|c|c|c|c|c|c|c|c|c|c|c|}
\hline 2008 & Município & s1 & s2 & s3 & s4 & s5 & s6 & s7 & s8 & s9 & $s 10$ & s11 & $\mathrm{s} 12$ & s13 & s14 & s15 & s16 & s17 & s18 & s19 & s20 & s21 & s22 & s23 & s24 & $s 25$ & $s 26$ & $s 27$ \\
\hline & Patu & 1 & 0 & 0 & 0 & 0 & 16 & 0 & 0 & 1 & 3 & 2 & 0 & 2 & 0 & 0 & 0 & 0 & 0 & 0 & 0 & 0 & 0 & 0 & 3 & 0 & 0 & 0 \\
\hline & Pedra Preta & 0 & - & 0 & 0 & 0 & 16 & 0 & 0 & 0 & 0 & 9 & 10 & 0 & 4 & 18 & 11 & 7 & 14 & 0 & 12 & 5 & 5 & 0 & 0 & 0 & 7 & 8 \\
\hline & Pedro Avelino & 0 & 2 & 3 & 3 & 3 & 3 & 4 & 3 & 4 & 3 & 3 & 6 & 4 & 10 & 18 & 3 & 8 & 3 & 8 & 3 & 3 & 4 & 6 & 3 & 6 & 2 & 1 \\
\hline & Presidente Juscelino & 2 & 12 & 4 & 2 & 4 & 6 & 5 & 3 & 16 & 6 & 13 & 7 & 6 & 39 & 15 & 24 & 33 & 9 & 13 & 41 & 31 & 12 & 6 & 8 & 4 & 7 & 3 \\
\hline & Riachuelo & 14 & 6 & 3 & 15 & 12 & 19 & 9 & 11 & 7 & 15 & 7 & 13 & 9 & 9 & 35 & 52 & 17 & 13 & 27 & 19 & 29 & 31 & 12 & 12 & 13 & 5 & 6 \\
\hline & Ruy Barbosa & 3 & 3 & 1 & 0 & 1 & 14 & 8 & 2 & 18 & 17 & 9 & 9 & 18 & 16 & 17 & 32 & 28 & 24 & 16 & 13 & 0 & 0 & 0 & 0 & 0 & 0 & 0 \\
\hline & Santa Cruz & 14 & 12 & 27 & 21 & 5 & 42 & 31 & 37 & 33 & 20 & 11 & 12 & 15 & 40 & 79 & 161 & 56 & 103 & 157 & 79 & 41 & 32 & 25 & 30 & 39 & 15 & 29 \\
\hline & Santa Maria & 3 & 6 & 3 & 5 & 7 & 6 & 7 & 4 & 3 & 8 & 7 & 6 & 4 & 12 & 16 & 8 & 4 & 3 & 8 & 13 & - & - & - & - & 2 & 3 & 2 \\
\hline & Santana do Matos & 1 & - & 0 & 2 & 5 & 8 & 10 & 11 & - & 14 & 1 & 8 & 2 & 7 & 20 & 26 & 11 & 5 & 0 & 22 & 2 & 0 & 0 & 0 & 2 & 2 & 1 \\
\hline & São Bento do Trairi & 5 & 3 & 3 & 0 & 2 & 0 & 4 & 0 & 2 & 7 & 8 & - & - & 5 & - & - & 6 & - & 6 & 0 & 0 & - & - & - & - & - & - \\
\hline & São José do Campestre & 6 & 5 & 2 & 5 & 6 & 3 & 16 & 3 & 2 & 9 & 6 & 2 & 7 & 11 & 47 & 67 & 67 & 80 & 50 & 32 & 37 & 17 & 8 & 5 & 3 & 17 & 4 \\
\hline & São Paulo do Potengi & 13 & 12 & 13 & 7 & 13 & 30 & 9 & 3 & 14 & 14 & - & 0 & 13 & - & 40 & 39 & 42 & 62 & 41 & 38 & 1 & 10 & 10 & 4 & 0 & 0 & 0 \\
\hline & São Pedro & 8 & 5 & 6 & 5 & 1 & 2 & 0 & 0 & 2 & 2 & 3 & 5 & 8 & - & - & - & - & - & 1 & 2 & - & 2 & 0 & 2 & 1 & 3 & 0 \\
\hline & São Rafael & 0 & 0 & 3 & - & - & - & - & - & - & 9 & 4 & 5 & 5 & 0 & 11 & 11 & 0 & 9 & 12 & 9 & 3 & 0 & 5 & 8 & 4 & 0 & 5 \\
\hline & São Tomé & 5 & 13 & 7 & 12 & 15 & 7 & 8 & 9 & 6 & 11 & 10 & 11 & 16 & 20 & 46 & 57 & 62 & 65 & 36 & 34 & 14 & 19 & 12 & 6 & 3 & 3 & 4 \\
\hline & São Vicente & - & - & - & - & - & - & - & - & - & - & - & - & 11 & 18 & 10 & 5 & 7 & 0 & - & 0 & 0 & 0 & 0 & 0 & 0 & 0 & 0 \\
\hline & Senador Elói de Souza & 0 & 1 & 1 & 0 & 1 & 2 & 4 & 2 & 2 & - & - & - & - & - & - & - & - & - & - & - & - & - & - & - & - & - & - \\
\hline & Serra de São Bento & 1 & 0 & 0 & 0 & 0 & 0 & 3 & 0 & 0 & 0 & 0 & 0 & 0 & 0 & 0 & 3 & 2 & 3 & - & 7 & 5 & - & 3 & - & 1 & 0 & 0 \\
\hline & Serrinha & 0 & 0 & 0 & 0 & 0 & 1 & 0 & 0 & 0 & 0 & 0 & 0 & 0 & 0 & 0 & 0 & 0 & 0 & 0 & 12 & 3 & - & - & - & 0 & 0 & 0 \\
\hline & Sítio Novo & 2 & 18 & 5 & 5 & 2 & 1 & 0 & 5 & 1 & 4 & 5 & 0 & 3 & 1 & 4 & 4 & 11 & 6 & 7 & 0 & 3 & 5 & 2 & 1 & 2 & 3 & 5 \\
\hline & Tangará & 8 & 32 & 2 & 5 & 4 & 0 & 5 & 0 & 10 & 2 & 3 & 5 & 0 & 9 & 9 & 28 & 15 & 17 & 6 & 6 & 12 & 11 & 8 & 1 & 0 & 3 & 1 \\
\hline & Tenente Laurentino Cruz & 4 & 1 & 7 & 13 & 9 & 5 & 3 & 6 & 3 & 5 & 3 & 5 & 5 & 4 & 8 & 6 & 4 & 5 & 4 & 6 & - & 2 & 3 & 1 & 2 & 0 & 0 \\
\hline & Triunfo Potiguar & 0 & 2 & 0 & 0 & 0 & 0 & 0 & 0 & 0 & 2 & 10 & 6 & 9 & 3 & 6 & 9 & 1 & 3 & 0 & 0 & 0 & 6 & 0 & 1 & 0 & 0 & 2 \\
\hline & Alagoa Nova & 7 & 12 & 6 & 10 & 3 & 12 & 8 & 11 & 21 & 7 & 7 & 7 & 23 & 12 & 22 & 22 & 39 & 60 & 55 & 105 & 45 & 53 & 22 & 25 & 13 & 29 & 11 \\
\hline & Barra de Santana & 6 & 5 & 5 & 6 & 1 & 1 & 2 & - & 6 & - & 3 & 6 & 1 & 24 & 17 & 20 & 20 & 24 & 12 & 12 & 18 & 5 & 6 & 2 & 5 & 4 & 0 \\
\hline & Boa Vista & 4 & 2 & 1 & 3 & 1 & 4 & 3 & 1 & 4 & 2 & 2 & 5 & - & 5 & 9 & 8 & - & 7 & 16 & 3 & 5 & - & 5 & 2 & 6 & 4 & 1 \\
\hline & Boqueirão & 0 & 2 & 9 & 0 & - & 1 & 15 & 14 & 9 & 6 & 4 & 8 & 26 & 18 & 48 & 41 & 112 & 79 & 54 & 61 & 20 & 15 & 22 & 12 & 17 & 5 & 9 \\
\hline & Cabaceiras & 0 & 0 & 1 & 0 & 3 & 4 & 5 & 2 & 0 & 7 & 0 & 0 & 11 & 8 & 38 & 9 & 20 & 20 & 21 & 15 & 8 & 0 & 4 & 6 & 0 & 4 & 1 \\
\hline & Campina Grande & 130 & 155 & 123 & 127 & 110 & 159 & 238 & 197 & 210 & 195 & 113 & 152 & 191 & 198 & 291 & 373 & 212 & 249 & 486 & 477 & 298 & 289 & 209 & 130 & 91 & 96 & 92 \\
\hline & Caturité & 0 & 1 & 1 & 0 & 0 & 0 & 5 & 3 & 5 & 3 & 3 & 12 & 1 & 3 & 11 & 19 & 3 & 0 & 2 & 2 & 3 & 1 & 3 & 0 & 0 & 0 & 1 \\
\hline & Cubati & 4 & 4 & 0 & 0 & 1 & 2 & 12 & 16 & 12 & 8 & 29 & 14 & 18 & 38 & 61 & 79 & 16 & 43 & 16 & 0 & 7 & 20 & 12 & 6 & 3 & 6 & 5 \\
\hline & Juazeirinho & 9 & 13 & 30 & 4 & 6 & 17 & 6 & 10 & 16 & 20 & 23 & 4 & 38 & 21 & 0 & 206 & 53 & 59 & 16 & 43 & 19 & 9 & 4 & 3 & 14 & 8 & 8 \\
\hline & Lagoa Seca & 5 & 11 & 9 & 4 & 0 & 0 & 5 & 5 & 4 & 0 & 19 & 3 & 16 & 15 & 15 & 36 & 70 & 59 & 87 & 86 & 82 & 47 & 42 & 10 & 5 & 5 & 0 \\
\hline & Matinhas & 1 & 4 & 1 & 3 & 0 & 0 & 1 & 4 & 1 & 3 & 1 & 0 & 0 & 1 & 2 & 1 & 10 & 3 & 22 & 24 & 5 & 2 & 1 & 6 & 3 & 0 & 1 \\
\hline & Olivedos & 0 & 1 & 0 & 1 & 1 & 0 & 0 & 6 & 7 & 1 & 1 & 0 & 1 & 1 & 7 & 9 & 27 & 17 & 30 & 14 & 2 & 7 & 2 & 2 & 1 & - & 1 \\
\hline & Pedra Lavrada & 0 & 4 & 2 & 4 & 2 & 4 & 2 & 7 & 4 & 11 & 11 & 7 & 21 & 53 & 52 & 68 & 56 & 34 & 40 & 24 & 11 & 11 & 9 & 2 & 2 & 2 & 1 \\
\hline & Pocinhos & - & 6 & 27 & 18 & 21 & 5 & 19 & 34 & 21 & 21 & 17 & 29 & 10 & 11 & 18 & 68 & 20 & 24 & 25 & 62 & - & 15 & 12 & 0 & 4 & 4 & 0 \\
\hline
\end{tabular}


Queimadas

Seridó/São Vicente do Seridó

$\begin{array}{cccccccccc}0 & 13 & 6 & 0 & 3 & 0 & 11 & 4 & 0 \\ 0 & 23 & 12 & 10 & 8 & 5 & 14 & 9 & 26\end{array}$

Soledade

$\begin{array}{llllllll}18 & 16 & 8 & 17 & 24 & 14 & 13 & 15\end{array}$

\begin{tabular}{|c|c|c|c|c|c|c|c|c|c|c|c|c|c|c|c|c|c|c|c|c|c|c|c|c|c|c|c|}
\hline 2008 & Município & s28 & $s 29$ & s30 & s31 & s32 & s33 & s34 & s35 & s36 & s37 & s38 & s39 & $s 40$ & s41 & $s 42$ & s43 & s44 & s45 & $s 46$ & s47 & $s 48$ & s49 & s50 & $s 51$ & s52 & s53 \\
\hline & Acari & 0 & - & 8 & 0 & 0 & 0 & 0 & 3 & 0 & 0 & 0 & 0 & 0 & 1 & 0 & 3 & 0 & 0 & 0 & 0 & 0 & 0 & 0 & 0 & 0 & - \\
\hline & Açu & 29 & 29 & 11 & 23 & 38 & 29 & 24 & 28 & 25 & 28 & 23 & 24 & 28 & 25 & 24 & 23 & 18 & 21 & 19 & 22 & 23 & 29 & 34 & 29 & 34 & 18 \\
\hline & Almino Afonso & 0 & 0 & 0 & 0 & 0 & 0 & 0 & 0 & 0 & 0 & 0 & 0 & 0 & 0 & 0 & 0 & 0 & 0 & 0 & 0 & 0 & 0 & 0 & 0 & 0 & - \\
\hline & Angicos & 3 & 0 & 5 & 3 & 7 & 3 & 0 & 8 & 0 & 0 & 9 & 7 & 12 & 15 & 10 & 8 & 5 & 4 & 6 & 19 & 19 & - & - & - & - & - \\
\hline & Augusto Severo & 7 & 8 & 7 & 8 & 7 & 8 & 9 & 8 & 9 & 10 & 7 & 7 & 9 & 6 & 8 & 9 & 10 & 8 & 7 & 7 & 10 & 8 & 8 & 8 & 7 & - \\
\hline & Barcelona & 2 & 1 & 0 & 0 & 0 & 0 & 0 & 0 & 0 & 0 & 0 & 0 & 0 & 0 & 0 & 0 & 0 & 0 & 0 & 3 & 0 & 2 & 2 & 0 & 0 & - \\
\hline & Bodó & - & - & - & 1 & - & - & - & - & - & - & - & - & - & - & - & - & - & - & - & - & - & - & - & - & - & - \\
\hline & Bom Jesus & 3 & 4 & 4 & 3 & 3 & 0 & 5 & 1 & 3 & 3 & 0 & 4 & 0 & 0 & 0 & 5 & 0 & 11 & 0 & 5 & 0 & 0 & 0 & 0 & - & - \\
\hline & Caiçara do Rio do Vento & - & 2 & 0 & 0 & 1 & - & 0 & 3 & 5 & 1 & 0 & 0 & 4 & 5 & 1 & - & - & 2 & 2 & - & 1 & 2 & 1 & - & - & - \\
\hline & Caicó & 3 & 5 & 4 & 1 & 0 & 5 & 1 & 2 & - & 4 & 4 & 4 & 0 & 1 & 4 & 0 & 2 & 0 & 4 & 1 & 0 & 0 & 0 & 0 & 0 & - \\
\hline & Campo Redondo & 2 & 2 & 1 & 1 & 2 & 2 & 2 & 3 & 2 & 2 & 2 & 2 & 1 & 2 & 2 & 1 & 1 & 1 & 2 & 1 & 2 & 2 & 1 & 1 & 1 & 1 \\
\hline & Coronel Ezequiel & 1 & 0 & 0 & 0 & 0 & 0 & 0 & 3 & 2 & - & 2 & 0 & 1 & 1 & 0 & - & 1 & 1 & 0 & 3 & 0 & 2 & 1 & - & - & - \\
\hline & Currais Novos & 0 & 0 & 0 & 0 & 0 & 0 & 0 & 10 & 18 & 10 & 11 & 10 & 0 & 0 & - & 0 & - & 1 & 0 & 1 & 0 & 1 & 2 & 1 & 0 & - \\
\hline & Fernando Pedroza & 0 & 0 & 0 & 0 & 2 & 0 & 0 & 2 & 0 & 3 & 0 & 0 & 0 & 0 & 2 & 0 & 0 & 2 & 5 & 3 & 0 & 0 & 0 & 0 & 0 & - \\
\hline & Florânia & 1 & 3 & 0 & 0 & 3 & 3 & 1 & 1 & 1 & 2 & 0 & 0 & 1 & 0 & 0 & 4 & 2 & 0 & 0 & 3 & 0 & 3 & 5 & 6 & 2 & 0 \\
\hline & lelmo Marinho & 3 & 9 & 3 & 7 & 0 & 7 & 4 & 5 & 1 & 7 & - & 2 & 1 & 6 & 8 & 0 & 3 & 3 & 7 & 9 & 10 & 6 & 9 & - & 8 & 1 \\
\hline & Itajá & 5 & 6 & 11 & 0 & 0 & 3 & 1 & 3 & 0 & 6 & 0 & 1 & - & 9 & 1 & 6 & 0 & 1 & 3 & 2 & 6 & 4 & 0 & 7 & 5 & 1 \\
\hline & Jaçanã & 1 & 3 & 4 & 4 & 1 & 5 & 6 & 2 & 0 & 1 & 4 & 6 & 1 & 10 & 7 & 7 & 2 & 5 & 3 & 1 & 4 & 1 & 3 & 1 & 1 & - \\
\hline & Janduís & 0 & 0 & 0 & 0 & 0 & 0 & 5 & 0 & 0 & 3 & 0 & 0 & 0 & 0 & 0 & 0 & 0 & 0 & 0 & 1 & 0 & 0 & 0 & 0 & 0 & - \\
\hline & Januário Cicco & 0 & 0 & 3 & 1 & 0 & 0 & 0 & 1 & 2 & 5 & 6 & 2 & 0 & 0 & 0 & 0 & 0 & 2 & 1 & 0 & 0 & 0 & 0 & 0 & - & - \\
\hline & Japi & 1 & 2 & 2 & 1 & 0 & 2 & 1 & 0 & 1 & 3 & 4 & 0 & 0 & 1 & 0 & 0 & 0 & 0 & 0 & - & - & - & - & - & 0 & 1 \\
\hline & Jardim de Angicos & 0 & 0 & 0 & - & 0 & 0 & 0 & 0 & 0 & 0 & 0 & 0 & 0 & 0 & - & 0 & 4 & 0 & 1 & 1 & 0 & 0 & 0 & - & 1 & 0 \\
\hline & Lagoa d'Anta & 0 & 0 & 0 & 0 & 0 & 0 & 0 & 0 & 0 & 0 & 0 & 0 & 0 & 0 & 0 & 0 & 0 & 0 & 3 & 0 & 0 & 0 & 0 & 0 & 0 & - \\
\hline & Lagoa de Pedras & 1 & 4 & 2 & 1 & 2 & 1 & 1 & 2 & 3 & 3 & 1 & 1 & 2 & 2 & 2 & 2 & 0 & 0 & 1 & 3 & 1 & 0 & 1 & 2 & 0 & - \\
\hline & Lagoa de Velhos & 3 & 3 & 4 & 1 & 1 & 2 & 3 & 2 & 1 & 1 & 2 & - & 1 & 0 & 2 & 2 & 0 & 0 & 0 & 2 & 3 & 0 & 0 & - & - & - \\
\hline & Lagoa Nova & 0 & 0 & 0 & 0 & 0 & 0 & 0 & 0 & 0 & 0 & 2 & 0 & 0 & 0 & 3 & 4 & 0 & 0 & 0 & 0 & 0 & 0 & 1 & 0 & 0 & 0 \\
\hline & Lagoa Salgada & 4 & 6 & 8 & 5 & 4 & 11 & 5 & 10 & 21 & 8 & 6 & 16 & 16 & 8 & 8 & 11 & 8 & 11 & 10 & 7 & 8 & 10 & 5 & 2 & 10 & 7 \\
\hline & Lajes & 3 & 0 & 1 & 6 & 6 & 5 & 6 & - & - & - & - & - & - & - & - & - & - & - & - & - & - & - & - & - & - & - \\
\hline & Lajes Pintadas & 1 & 0 & 1 & 0 & 1 & 1 & 2 & 0 & 0 & 0 & 3 & 0 & 0 & 2 & 0 & 0 & 1 & 1 & 0 & 2 & 0 & - & 1 & 0 & 0 & - \\
\hline & Messias Targino & 3 & 0 & 2 & 0 & 2 & 10 & 1 & 10 & - & 4 & 2 & 0 & 3 & 1 & 1 & 0 & 6 & 0 & 1 & 4 & 3 & 1 & 4 & 3 & 4 & - \\
\hline & Monte Alegre & - & - & - & - & - & - & - & - & - & - & - & - & - & - & - & - & - & - & - & - & - & - & - & - & - & - \\
\hline & Monte das Gameleiras & 1 & 0 & 0 & 0 & 0 & 0 & 0 & 0 & 0 & 0 & 0 & 0 & 0 & 0 & 0 & 0 & 0 & 0 & 0 & 0 & 0 & 0 & - & - & - & - \\
\hline
\end{tabular}




\begin{tabular}{|c|c|c|c|c|c|c|c|c|c|c|c|c|c|c|c|c|c|c|c|c|c|c|c|c|c|c|c|}
\hline 2008 & Município & $\mathbf{s 2 8}$ & $\mathbf{s} 29$ & s30 & s31 & s32 & s33 & s34 & s35 & s36 & s37 & s38 & s39 & $s 40$ & s41 & $s 42$ & s43 & s44 & $s 45$ & $s 46$ & $s 47$ & $s 48$ & $s 49$ & s50 & s51 & s52 & s53 \\
\hline & Paraú & - & - & - & - & - & - & - & - & - & - & - & - & - & - & - & - & - & - & - & - & - & - & - & - & - & - \\
\hline & Passa e Fica & 2 & 2 & 0 & 4 & 2 & 5 & 3 & 3 & 3 & 3 & 3 & 5 & 6 & 3 & 2 & 2 & 5 & 3 & 2 & 5 & 2 & 4 & 2 & 3 & 3 & 3 \\
\hline & Patu & 0 & 0 & 0 & 0 & 0 & 0 & 0 & 0 & 0 & 0 & 0 & 0 & 0 & 0 & 0 & 0 & 0 & 0 & 0 & 0 & 0 & 0 & 0 & 0 & - & - \\
\hline & Pedra Preta & 3 & 2 & 0 & 0 & 0 & 0 & 0 & 2 & - & 0 & 0 & 2 & 0 & 6 & 0 & 3 & 0 & 0 & - & - & 0 & - & - & - & - & - \\
\hline & Pedro Avelino & 0 & 0 & 4 & 2 & 1 & 0 & 2 & 1 & 2 & 0 & 0 & 2 & 0 & 1 & 2 & 1 & 0 & 0 & 0 & 0 & 0 & 0 & 0 & - & - & - \\
\hline & Presidente Juscelino & 11 & 7 & 4 & 3 & 4 & 0 & 9 & 4 & 3 & 26 & 24 & 20 & 17 & 17 & 11 & 5 & 2 & 0 & 9 & 5 & 6 & 5 & 5 & 5 & 3 & - \\
\hline & Riachuelo & 5 & 8 & 10 & 8 & 4 & 7 & 6 & 5 & 10 & 6 & 19 & 5 & 5 & 5 & 10 & 13 & 21 & 13 & 13 & 13 & 9 & 13 & 2 & 7 & 3 & 6 \\
\hline & Ruy Barbosa & 2 & 1 & 0 & 0 & 0 & - & 0 & 0 & 0 & 0 & 0 & 0 & - & - & 0 & 0 & 0 & 0 & 0 & 1 & 4 & 3 & - & 0 & 0 & 6 \\
\hline & Santa Cruz & 20 & 24 & 14 & 13 & 31 & 8 & 15 & 24 & 23 & 32 & 14 & 13 & 33 & 25 & 23 & 22 & 22 & 14 & 22 & 38 & 22 & 24 & 35 & 34 & 61 & 44 \\
\hline & Santa Maria & 3 & 1 & 4 & 3 & 4 & 3 & 1 & 1 & 2 & 1 & 0 & 1 & 1 & 1 & 2 & 1 & 5 & 1 & 3 & 6 & - & - & - & - & - & - \\
\hline & Santana do Matos & 0 & 0 & 0 & 0 & 1 & 0 & 0 & - & 2 & 1 & - & - & 0 & - & 0 & 4 & 0 & 0 & 0 & 0 & 0 & 0 & 0 & 0 & 0 & 0 \\
\hline & São Bento do Trairi & - & - & - & - & - & - & - & - & - & 0 & 0 & 2 & 0 & 0 & 0 & - & - & - & - & - & - & - & - & - & - & - \\
\hline & São José do Campestre & 3 & 8 & 4 & 13 & 9 & 5 & 6 & 11 & 7 & 10 & 8 & 11 & 7 & 3 & 15 & 13 & 12 & 24 & 30 & 16 & 15 & 15 & 11 & 19 & 13 & - \\
\hline & São Paulo do Potengi & 0 & 3 & 0 & 3 & 0 & 0 & 13 & 2 & 0 & 0 & 6 & 7 & 0 & 0 & 0 & 0 & 1 & 8 & 11 & - & 4 & 23 & 3 & 0 & - & - \\
\hline & São Pedro & 2 & 3 & 4 & 1 & 2 & 3 & 2 & 0 & 0 & 3 & 2 & - & 1 & 0 & 2 & 3 & 0 & - & - & - & - & - & - & - & - & - \\
\hline & São Rafael & 0 & 0 & 0 & 0 & 0 & 0 & 3 & 0 & 0 & 0 & 0 & 0 & 0 & 0 & 0 & 0 & 0 & 0 & 0 & 5 & 0 & 0 & 0 & 0 & 0 & - \\
\hline & São Tomé & 5 & 4 & 5 & 2 & 0 & 0 & 3 & 3 & 2 & 1 & 0 & 0 & 2 & 0 & 3 & 2 & 1 & 3 & 3 & 1 & 5 & 3 & 6 & 3 & 1 & - \\
\hline & São Vicente & 0 & 0 & 0 & 0 & - & 0 & 0 & - & 0 & 0 & 0 & - & 0 & 0 & 0 & 0 & 0 & 0 & 0 & 0 & 0 & 0 & 0 & 0 & 0 & 0 \\
\hline & Serrinha & 0 & 0 & 0 & 0 & 0 & 0 & 2 & 0 & 0 & 0 & 0 & 0 & 0 & - & 0 & 0 & 0 & 0 & 0 & - & - & - & - & - & - & 0 \\
\hline & Sítio Novo & 4 & 4 & 4 & 1 & 2 & 1 & 1 & & 0 & 1 & 1 & 0 & 3 & 0 & 0 & 2 & 0 & 0 & 1 & 0 & 1 & 0 & 0 & 2 & 0 & - \\
\hline & Tangará & 2 & 1 & 2 & 0 & 0 & 0 & 1 & 0 & 2 & 1 & 2 & 5 & 1 & 0 & 1 & 0 & 0 & 6 & 0 & 0 & 0 & 2 & 2 & 4 & 2 & - \\
\hline & Tenente Laurentino Cruz & 1 & 2 & 0 & 2 & 1 & 0 & 1 & 0 & 2 & 1 & 0 & 0 & 0 & - & 0 & 0 & 0 & 3 & 2 & 0 & 3 & 3 & 2 & 0 & 0 & 0 \\
\hline & Triunfo Potiguar & 1 & 0 & 0 & 0 & 0 & 0 & 0 & 0 & 2 & 1 & 0 & 2 & 0 & 2 & 0 & 0 & 0 & 2 & 0 & 1 & 0 & 2 & 0 & 3 & 0 & - \\
\hline & Alagoa Nova & 16 & 22 & 12 & 13 & 13 & 10 & 10 & 5 & 3 & 12 & 7 & 4 & 4 & 11 & 11 & 11 & 5 & 5 & 3 & 3 & 17 & 9 & 18 & 7 & 11 & 1 \\
\hline & Barra de Santana & 0 & 4 & 4 & 0 & 3 & 6 & 5 & 2 & 0 & 0 & 3 & 1 & 3 & 0 & 5 & 3 & 0 & 3 & 1 & 2 & 2 & 1 & 1 & 2 & 2 & 2 \\
\hline & Boa Vista & 4 & 2 & 3 & 2 & 2 & 1 & 3 & 3 & 1 & 2 & 2 & 1 & 3 & 4 & 2 & 3 & 2 & 2 & 4 & 2 & 3 & 1 & 3 & 2 & 2 & 2 \\
\hline & Boqueirão & 11 & 6 & 5 & 3 & 7 & 2 & 6 & 10 & 4 & 4 & 2 & 3 & 4 & 6 & 6 & 8 & 8 & 6 & 6 & 2 & 0 & 4 & 1 & - & - & 1 \\
\hline & Cabaceiras & 0 & 0 & 0 & 2 & 0 & 0 & 1 & 0 & 2 & 0 & 2 & 1 & 0 & 0 & 0 & 1 & 1 & 3 & 5 & 3 & 1 & 0 & 0 & 0 & 0 & 0 \\
\hline & Campina Grande & 57 & 101 & 86 & 107 & 85 & 101 & 50 & 69 & 105 & 75 & 76 & 100 & 39 & 95 & 84 & 54 & 58 & 73 & 54 & 76 & 71 & 42 & 28 & 57 & 48 & 34 \\
\hline & Caturité & 0 & 2 & 0 & 0 & 0 & 2 & 0 & 0 & 0 & 0 & 1 & 2 & 0 & 0 & 0 & 0 & 2 & 0 & - & 2 & 0 & 0 & 0 & 0 & 0 & 0 \\
\hline & Cubati & 0 & 6 & 16 & 8 & 7 & 6 & 8 & 4 & 4 & 14 & 9 & 0 & 0 & 13 & 7 & 1 & 6 & 4 & 5 & 6 & 10 & 6 & 7 & 7 & 1 & 2 \\
\hline & Juazeirinho & 5 & 11 & 10 & 4 & 4 & 7 & 6 & 13 & 13 & 10 & 14 & 6 & 5 & 12 & 18 & 10 & 12 & 12 & 17 & 11 & 4 & 6 & 0 & - & 0 & 0 \\
\hline & Lagoa Seca & 0 & 6 & 3 & 0 & 2 & 0 & 2 & 2 & 0 & 0 & 0 & 2 & 0 & 0 & 1 & 0 & 2 & 4 & 0 & 2 & 2 & 0 & 7 & 9 & 0 & 0 \\
\hline & Matinhas & 1 & 2 & 0 & 1 & 4 & 0 & 2 & 1 & 0 & 0 & 3 & 0 & 0 & 0 & 0 & 0 & 2 & 1 & 0 & 0 & 3 & 0 & 2 & 0 & 0 & 0 \\
\hline & Olivedos & 1 & 1 & 2 & 0 & 0 & 0 & 0 & 2 & 0 & 0 & 0 & 1 & 0 & 1 & 0 & 2 & 0 & 0 & 0 & 2 & 1 & 0 & 0 & - & 1 & 0 \\
\hline
\end{tabular}




\begin{tabular}{|c|c|c|c|c|c|c|c|c|c|c|c|c|c|c|c|c|c|c|c|c|c|c|c|c|c|c|c|}
\hline 2008 & Município & s28 & s29 & s30 & s31 & s32 & s33 & s34 & s35 & s36 & s37 & s38 & s39 & $\mathbf{s} 40$ & s41 & $s 42$ & s43 & $s 44$ & $s 45$ & $s 46$ & s47 & $s 48$ & $s 49$ & s50 & s51 & s52 & s53 \\
\hline & Pedra Lavrada & 2 & 1 & 1 & 1 & 2 & 2 & 0 & 0 & 5 & 2 & 6 & 2 & 4 & 2 & 2 & 1 & 2 & 2 & 10 & 3 & 3 & 3 & 2 & 3 & 2 & 4 \\
\hline & Pocinhos & 8 & 14 & 14 & 8 & 8 & 4 & 9 & 8 & 8 & 16 & 16 & 13 & 13 & 8 & 20 & 9 & 0 & 13 & 6 & 13 & 10 & 10 & 5 & 7 & 2 & 0 \\
\hline & Queimadas & 0 & 10 & 0 & 0 & 0 & 4 & 0 & 0 & 0 & - & 0 & 1 & 0 & 0 & - & 0 & 0 & 0 & 0 & 0 & 0 & 0 & 0 & 0 & 8 & 0 \\
\hline & Seridó/São Vicente do Seridó & 6 & 8 & 3 & 5 & 4 & 6 & 8 & 8 & 4 & 0 & 0 & 0 & 0 & 0 & 0 & 0 & 2 & 2 & 5 & 6 & 0 & 5 & 2 & 0 & 0 & 0 \\
\hline & Soledade & 6 & 5 & 13 & 8 & 10 & 9 & 11 & 13 & 14 & 13 & 8 & 12 & 6 & 2 & 6 & 13 & 4 & 28 & 13 & 12 & 14 & 6 & 9 & 12 & 5 & 9 \\
\hline
\end{tabular}

\begin{tabular}{|c|c|c|c|c|c|c|c|c|c|c|c|c|c|c|c|c|c|c|c|c|c|c|c|c|c|c|c|c|}
\hline 2009 & Município & s1 & s2 & s3 & s4 & s5 & s6 & s7 & s8 & s9 & $s 10$ & s11 & s12 & s13 & s14 & $\mathrm{s} 15$ & $s 16$ & $\mathrm{~s} 17$ & $s 18$ & $s 19$ & $\mathbf{s 2 0}$ & s21 & $s 22$ & s23 & s24 & $s 25$ & s26 & s27 \\
\hline & Acari & 0 & 0 & 0 & 0 & 0 & 0 & 0 & 0 & 0 & 0 & 7 & 18 & 14 & 15 & 19 & 17 & 13 & 8 & 16 & 24 & 6 & 1 & 12 & 16 & 9 & 0 & 6 \\
\hline & Açu & 26 & 37 & 38 & 41 & 30 & 41 & 76 & 106 & 162 & 131 & 135 & 149 & 158 & 102 & 80 & 45 & 33 & 59 & 38 & 34 & 38 & 53 & 0 & 26 & 26 & 33 & 18 \\
\hline & Almino Afonso & 0 & 0 & 0 & 0 & 0 & 0 & 0 & 0 & 2 & 13 & 0 & 38 & 11 & 37 & 8 & 6 & 0 & 0 & 0 & 0 & 0 & 0 & 0 & 0 & 0 & 0 & 0 \\
\hline & Angicos & 0 & 0 & 32 & - & - & 3 & 21 & - & 40 & 177 & 92 & 26 & 27 & 15 & 3 & 10 & - & 13 & - & - & - & - & - & - & 3 & - & - \\
\hline & Augusto Severo & 3 & 1 & 2 & 0 & 5 & 7 & 7 & 2 & 9 & 11 & 13 & 10 & 12 & 10 & 0 & 3 & 1 & 2 & 2 & 5 & 2 & 3 & 3 & 2 & 1 & 2 & 2 \\
\hline & Barcelona & 0 & 0 & 1 & 2 & 3 & 1 & 2 & 1 & 1 & 5 & 5 & 7 & 6 & 6 & 3 & 6 & 2 & 0 & 3 & 3 & 2 & 0 & 3 & 2 & 0 & 3 & 0 \\
\hline & Bodó & 3 & 0 & 5 & 0 & 0 & 6 & 2 & 7 & 0 & 2 & 5 & 7 & 7 & 3 & 0 & 9 & 3 & 0 & 7 & 0 & 0 & 0 & 0 & 0 & 11 & 0 & 0 \\
\hline & Bom Jesus & 5 & 12 & 8 & 0 & 11 & 4 & 2 & 0 & 12 & 19 & 18 & 20 & 5 & 10 & 16 & 2 & 3 & 5 & 4 & 10 & 6 & 7 & 2 & 0 & 6 & 5 & 18 \\
\hline & Caiçara do Rio do Vento & 1 & 1 & 1 & 3 & 5 & 3 & 4 & 5 & 16 & 0 & 15 & 5 & 2 & 1 & 0 & 2 & 0 & 1 & 0 & 1 & 2 & 8 & 3 & 0 & 1 & 3 & 4 \\
\hline & Caicó & 1 & 8 & 5 & 15 & 9 & 2 & 33 & 4 & 48 & 47 & 172 & 108 & 62 & 27 & 72 & 0 & 8 & 0 & 37 & 2 & 3 & 1 & 3 & 5 & 5 & 2 & 7 \\
\hline & Campo Redondo & 6 & 0 & 0 & 0 & 0 & 2 & 6 & 0 & 8 & 31 & 20 & 19 & 9 & 34 & 29 & 8 & 11 & 8 & 1 & 28 & 3 & 11 & 8 & 6 & 0 & 8 & 6 \\
\hline & Coronel Ezequiel & 0 & 0 & 0 & 1 & 1 & 2 & 2 & 2 & 2 & 0 & 3 & 0 & 1 & 0 & 1 & 1 & 0 & 0 & 1 & 0 & 0 & 0 & 0 & 0 & 0 & 1 & 0 \\
\hline & Currais Novos & 0 & 8 & 29 & 10 & 7 & 5 & 9 & 6 & 31 & 55 & 0 & 8 & 3 & 0 & 6 & 3 & 1 & 0 & 7 & 0 & 0 & 0 & 0 & 0 & 0 & 0 & 0 \\
\hline & Fernando Pedroza & 1 & 0 & 0 & 5 & 6 & 2 & 8 & 0 & 6 & 6 & 4 & 0 & 22 & 11 & 5 & 9 & 12 & 0 & 3 & 6 & 0 & 7 & 2 & 0 & 0 & 0 & 5 \\
\hline & Florânia & 1 & 0 & 3 & 0 & 2 & 8 & 1 & 16 & 20 & 25 & 11 & 6 & 8 & 2 & 1 & 1 & 6 & 9 & 7 & 8 & 1 & 8 & 0 & 0 & 1 & 3 & 4 \\
\hline & Ielmo Marinho & 3 & 7 & 12 & 0 & 9 & 18 & 7 & 4 & 14 & 10 & 13 & 10 & 18 & 3 & 11 & 9 & 14 & 8 & 10 & 10 & 7 & 13 & 6 & 4 & 8 & 5 & 5 \\
\hline & Itajá & 6 & 2 & 0 & 2 & 5 & 17 & 14 & - & 36 & 51 & 34 & 36 & 22 & 13 & 6 & 9 & 6 & 2 & 0 & - & 1 & 1 & 0 & - & 1 & 1 & 2 \\
\hline & Jaçanã & 3 & 0 & 3 & 0 & 1 & 2 & 5 & 3 & 8 & 4 & 11 & 5 & 1 & 5 & 1 & 3 & 1 & 5 & 1 & 3 & 1 & 3 & 0 & 2 & 0 & 1 & 0 \\
\hline & Janduís & 0 & 0 & - & 0 & 0 & 0 & 0 & 4 & 11 & 26 & 23 & 9 & 0 & 7 & 7 & 0 & 0 & 0 & 2 & 0 & 0 & 0 & 0 & 0 & 0 & 0 & 0 \\
\hline & Januário Cicco & 1 & 6 & 9 & 3 & 0 & 2 & 0 & 2 & 3 & 10 & 3 & 6 & 0 & 4 & 6 & 3 & 5 & 5 & 7 & 3 & 4 & 0 & 4 & 0 & 2 & 0 & 1 \\
\hline & Japi & 0 & 0 & 0 & 0 & 1 & 7 & 1 & 1 & 4 & 5 & 0 & 2 & 0 & 0 & 4 & 0 & 0 & 0 & 2 & 1 & 1 & 1 & 1 & 0 & 0 & 1 & 0 \\
\hline & Jardim de Angicos & 0 & 2 & 2 & 2 & 1 & 1 & 0 & 0 & 0 & 3 & 6 & 3 & 3 & 1 & 2 & 1 & 2 & 1 & 2 & 1 & 0 & 1 & 0 & 1 & 0 & 0 & 0 \\
\hline & Lagoa d'Anta & & 3 & 0 & 1 & 0 & 0 & 5 & 2 & 3 & 16 & 13 & 12 & 2 & 9 & 0 & 4 & 8 & 3 & 0 & 0 & 0 & 0 & 5 & 3 & 0 & - & 4 \\
\hline & Lagoa de Pedras & 2 & 2 & 1 & 2 & 2 & 2 & 3 & 2 & 2 & 3 & 3 & 3 & 4 & 5 & 4 & 4 & 1 & 2 & 0 & 2 & 4 & 3 & 1 & 2 & 2 & 3 & 1 \\
\hline & Lagoa de Velhos & 0 & 5 & 1 & 6 & 6 & 2 & 3 & 3 & 0 & 2 & 4 & 8 & 12 & 7 & 4 & 3 & 6 & 1 & 0 & 1 & 3 & 0 & 4 & 0 & 1 & 4 & 0 \\
\hline & Lagoa Nova & 0 & 0 & 0 & 2 & 5 & 10 & 14 & 2 & 4 & 1 & 1 & 1 & 0 & 0 & 3 & 0 & 0 & 0 & 0 & 0 & 0 & 0 & 1 & 1 & 1 & 4 & 3 \\
\hline & Lagoa Salgada & 5 & 12 & 8 & 8 & 16 & 16 & 30 & 21 & 13 & 15 & 12 & 17 & 22 & 17 & 18 & 8 & 10 & 8 & 6 & 7 & 5 & 11 & 8 & 4 & 15 & 4 & 12 \\
\hline & Lajes & 0 & 0 & 0 & 0 & 22 & 20 & 23 & 18 & 30 & 26 & 24 & 23 & 23 & 21 & 4 & 5 & 3 & 2 & 0 & 8 & 1 & 8 & 7 & 5 & 3 & 5 & 2 \\
\hline & Lajes Pintadas & 1 & 2 & 1 & 3 & 1 & 3 & 3 & 1 & 3 & 1 & 4 & 12 & 3 & 4 & 6 & 4 & 1 & 3 & 2 & 2 & 2 & 2 & 1 & 2 & 0 & 1 & 1 \\
\hline & Messias Targino & 0 & 3 & 6 & - & 5 & 4 & 0 & 3 & 9 & 6 & 10 & 30 & 21 & 9 & 13 & 7 & 5 & 6 & 3 & 2 & 4 & 2 & 4 & 2 & $\begin{array}{r}2 \\
239\end{array}$ & 5 & 3 \\
\hline
\end{tabular}


Monte Alegre

$\begin{array}{lllllllllllll}- & - & - & - & - & - & - & - & - & - & - & -\end{array}$

Paraú

Passa e Fica

Patu

Pedra Preta

Pedro Avelino

Presidente Juscelino

Riachuelo

Ruy Barbosa

Santa Cruz

Santa Maria

Santana do Matos

São Bento do Trairi

São José do Campestre

São Paulo do Potengi

São Pedro

São Rafael

São Tomé

São Vicente

Senador Elói de Souza

Serra de São Bento

Serrinha

Sítio Novo

Tangará

Tenente Laurentino Cruz

Triunfo Potiguar

Alagoa Nova

Barra de Santana

Boa Vista

Boqueirão

Cabaceiras

Campina Grande

Caturité

Cubati

Juazeirinho

$\begin{array}{ccccccccccc}4 & 4 & 7 & 7 & 7 & 4 & 6 & 6 & 6 & 15 & 5\end{array}$

$\begin{array}{ccccccccccc}0 & 0 & 4 & 0 & 2 & 1 & 2 & 0 & 3 & 14 & 13 \\ 1 & 1 & 0 & 0 & 2 & 4 & 3 & 8 & 8 & 10 & 7\end{array}$

$\begin{array}{lllllllllll}2 & 0 & 0 & 0 & 2 & 2 & 5 & 5 & 1 & 3 & 10\end{array}$

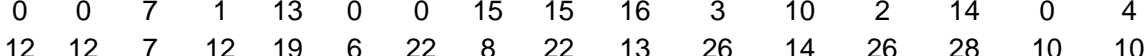

$\begin{array}{llllllllllllll}1 & 6 & 0 & 2 & 7 & 0 & 9 & 3 & 16 & 28 & 24 & 19 & 0 & 0\end{array}$

$\begin{array}{lllllllllll}53 & 40 & 52 & 38 & 48 & 72 & 89 & 38 & 60 & 83 & 48\end{array}$

$\begin{array}{llllllllllll}0 & 0 & 0 & 1 & 0 & 3 & 5 & 0 & 1 & 4 & 7\end{array}$

$\begin{array}{cccccccccccccccc}0 & 0 & 1 & 0 & 2 & 6 & 6 & 7 & 14 & 48 & 27 & 8 & 7 & 5 & 19\end{array}$

$\begin{array}{llllllllllll}0 & 0 & 3 & 1 & 0 & 3 & 5 & 2 & 5 & 5 & 4 & 1\end{array}$

$\begin{array}{llllllllll}19 & 9 & 13 & 12 & 11 & 14 & 14 & 9 & 34 & 34\end{array}$

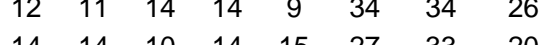

$\begin{array}{lllllllllll}4 & 4 & 3 & 0 & 1 & 8 & 8 & 5 & 23 & 40 & 13\end{array}$

$\begin{array}{lllllllll}0 & 3 & 0 & 3 & 9 & 6 & 10 & 0 & 13\end{array}$

Lagoa Seca

$\begin{array}{lllllllllll}0 & 0 & 0 & 0 & 0 & 1 & 0 & 0 & 8 & 14 & 16\end{array}$

$\begin{array}{lllllllllllll}0 & 0 & 1 & 3 & 0 & 0 & 2 & 0 & 3 & 6 & 7 & 2 & 15\end{array}$

$\begin{array}{ccccccccccccccc}4 & 0 & 0 & 0 & 0 & 0 & 5 & 7 & 19 & 10 & 23 & 21 & 4 & 29 & 28 \\ 0 & 0 & 1 & 2 & 3 & 0 & 4 & 4 & 5 & 25 & 15 & 28 & 6 & 4 & 13\end{array}$

$\begin{array}{lllllllll}0 & 0 & 1 & 2 & 3 & 0 & 4 & 4 & 5 \\ 0 & 0 & - & 2 & 2 & 2 & 4 & 4 & 15\end{array}$

$\begin{array}{lllllllllll}20 & 8 & 30 & 12 & 16 & 9 & 9 & 23 & 20 & 28 & 54\end{array}$

$\begin{array}{ccccccccccccccc}20 & 8 & 30 & 12 & 16 & 9 & 9 & 23 & 20 & 28 & 54 & 24 & 28 & 16 & 29 \\ 3 & 1 & 0 & 0 & 0 & 0 & 0 & 6 & 5 & 20 & 17 & 4 & 2 & 6 & 8 \\ 1 & 2 & 2 & 2 & 2 & 3 & 2 & 6 & 7 & 7 & 9 & 5 & 10 & 8 & 3\end{array}$

$\begin{array}{ccccccccccccc}4 & 1 & 2 & 6 & 8 & 7 & 5 & 6 & 24 & 34 & 35 & 34 & 36\end{array}$

$\begin{array}{llllllllllll}0 & 0 & 0 & 4 & 1 & 1 & 0 & 13 & 24 & 18 & 16 & 19\end{array}$

$\begin{array}{lllllllllllllll}34 & 89 & 117 & 102 & 78 & 123 & 42 & 143 & 135 & 180 & 222 & 122 & 165 & 126 & 181\end{array}$

$\begin{array}{lllllllllll}0 & 2 & 0 & 0 & 0 & 1 & 1 & 0 & 12\end{array}$

4

3

2

2

$\begin{array}{ccccccccccccccc}0 & 2 & 0 & 0 & 0 & 1 & 1 & 0 & 12 & 0 & 4 & 4 & 10 & 0 & 7 \\ 1 & 5 & 1 & 0 & 2 & 1 & 3 & 6 & 4 & 6 & 5 & 2 & 5 & 1 & 3 \\ 0 & 10 & 13 & 9 & 10 & 1 & 17 & 10 & 10 & 12 & 29 & 3 & 0 & 4 & 8 \\ 0 & 7 & 3 & 8 & 0 & 5 & 3 & 0 & 3 & 22 & 24 & 10 & 26 & 24 & 30\end{array}$

$\begin{array}{ccccccccccccccc}0 & 2 & 0 & 0 & 0 & 1 & 1 & 0 & 12 & 0 & 4 & 4 & 10 & 0 & 7 \\ 1 & 5 & 1 & 0 & 2 & 1 & 3 & 6 & 4 & 6 & 5 & 2 & 5 & 1 & 3 \\ 0 & 10 & 13 & 9 & 10 & 1 & 17 & 10 & 10 & 12 & 29 & 3 & 0 & 4 & 8 \\ 0 & 7 & 3 & 8 & 0 & 5 & 3 & 0 & 3 & 22 & 24 & 10 & 26 & 24 & 30\end{array}$

$\begin{array}{ccccccccccccccc}0 & 2 & 0 & 0 & 0 & 1 & 1 & 0 & 12 & 0 & 4 & 4 & 10 & 0 & 7 \\ 1 & 5 & 1 & 0 & 2 & 1 & 3 & 6 & 4 & 6 & 5 & 2 & 5 & 1 & 3 \\ 0 & 10 & 13 & 9 & 10 & 1 & 17 & 10 & 10 & 12 & 29 & 3 & 0 & 4 & 8 \\ 0 & 7 & 3 & 8 & 0 & 5 & 3 & 0 & 3 & 22 & 24 & 10 & 26 & 24 & 30\end{array}$ 


\begin{tabular}{|c|c|c|c|c|c|c|c|c|c|c|c|c|c|c|c|c|c|c|c|c|c|c|c|c|c|c|c|}
\hline \multirow[t]{8}{*}{2009} & Município & s1 & s2 & s3 & s4 s & s6 & s7 & s8 & s9 & $s 10 s$ & $\mathrm{~s} 11 \mathrm{~s}$ & $s 12 s$ & $\mathrm{~s} 13 \mathrm{~s}$ & s14 & $s 15 s$ & $\mathrm{~s} 16 \mathrm{~s}$ & s17s & $s 18 s$ & $s 19 s$ & $s 20 s$ & s21 & s22 & s23 & s24 & $s 25$ & s26 & s2 \\
\hline & Matinhas & 0 & 0 & 0 & 1 & 1 & 0 & 1 & 4 & 0 & 1 & 3 & 2 & 2 & 1 & 2 & 2 & 2 & 0 & 0 & 3 & 4 & 0 & 0 & 0 & 2 & \\
\hline & Olivedos & 0 & 0 & 0 & 0 & 1 & 0 & 0 & 1 & 0 & 0 & 3 & 2 & 0 & 0 & 4 & 1 & 6 & 1 & 0 & 2 & 0 & 0 & 2 & 1 & 1 & \\
\hline & Pedra Lavrada & 5 & 0 & 4 & 5 & 2 & 1 & 3 & 1 & 23 & 14 & 21 & 12 & 19 & 5 & 7 & 6 & 5 & 5 & 3 & 3 & 4 & 1 & 0 & 3 & 5 & \\
\hline & Pocinhos & - & 10 & 6 & 10 & 11 & 12 & 12 & 7 & 9 & 33 & 4 & 24 & 0 & 34 & 11 & 10 & 13 & 13 & 19 & 4 & 7 & 0 & 11 & 18 & 6 & \\
\hline & Queimadas & 2 & 19 & 18 & 7 & 37 & 23 & 5 & 28 & 26 & 55 & 23 & 50 & 8 & 58 & 13 & 6 & 20 & 15 & 58 & 9 & 25 & 5 & 6 & 0 & 4 & \\
\hline & Seridó/São Vicente do Seridó & 0 & 0 & 6 & 0 & 5 & 14 & 33 & 25 & 0 & 9 & 9 & 9 & 10 & 8 & 4 & 2 & 4 & 0 & 0 & 0 & 0 & 0 & 0 & 6 & 6 & \\
\hline & Soledade & 11 & 13 & 11 & 2 & 10 & 22 & 7 & 9 & 17 & 41 & 39 & 23 & 13 & 9 & 6 & 13 & 6 & 22 & 19 & 17 & 9 & 0 & 22 & 14 & 24 & \\
\hline \multirow[t]{29}{*}{2009} & Município & s28 & $\mathbf{s 2 9}$ & s30 & s31 & s32 & s33 & s34 & s35 & 5 s36 & s37 & s38 & 3539 & $s 40$ & $s 41$ & $s 42$ & $\mathrm{~s} 43$ & 3 s44 & $4 \mathrm{~s} 45$ & $\mathrm{~s} 46$ & $\mathrm{~s} 47$ & $7 \mathrm{~s} 4 \varepsilon$ & 3549 & $9 \mathrm{~s} 50$ & $\begin{array}{ll}0 & s 51 \\
\end{array}$ & $1 s 52$ & \\
\hline & Acari & 8 & 1 & 2 & 1 & 11 & 13 & 1 & 19 & 11 & 20 & 15 & 2 & 11 & 21 & 10 & 15 & 6 & 3 & 8 & 6 & 10 & 7 & 11 & 10 & 7 & \\
\hline & Açu & 20 & 20 & 18 & 40 & 18 & 20 & 25 & 31 & 47 & 27 & 30 & 28 & 25 & 36 & 32 & 27 & 42 & 36 & 23 & 21 & 34 & 34 & 6 & 17 & 21 & \\
\hline & Almino Afonso & 0 & 0 & 0 & 0 & 0 & 0 & 0 & 0 & 0 & 0 & 0 & 0 & 0 & 0 & 0 & 0 & 0 & 0 & 0 & 0 & 0 & 0 & 0 & 0 & 0 & \\
\hline & Angicos & - & - & 2 & 0 & 0 & 0 & 5 & 0 & 0 & 0 & 0 & 9 & 1 & 1 & 1 & 1 & - & - & - & - & 2 & - & - & - & - & \\
\hline & Augusto Severo & 2 & 1 & 1 & 2 & 2 & 2 & 1 & 1 & 3 & 1 & 5 & 0 & 3 & 1 & 2 & 4 & 2 & 1 & 0 & 7 & 4 & 1 & 3 & 3 & 0 & \\
\hline & Barcelona & 2 & 6 & 1 & 0 & 2 & 2 & 2 & 2 & 2 & 1 & 3 & 1 & 2 & 0 & 2 & 1 & 3 & 0 & 0 & 1 & 1 & 1 & 2 & 1 & 1 & \\
\hline & Bodó & 5 & 0 & 0 & 3 & 0 & 3 & 0 & 1 & 0 & 4 & 0 & 0 & 0 & 4 & 3 & 0 & 0 & 0 & 10 & 0 & 0 & 8 & 13 & 0 & 0 & \\
\hline & Bom Jesus & 8 & 11 & 6 & 7 & 6 & 5 & 4 & 0 & 3 & 6 & 8 & 8 & 4 & 8 & 5 & 15 & 10 & 9 & 12 & 11 & 14 & 3 & 4 & 9 & 3 & \\
\hline & Caiçara do Rio do Vento & 1 & 3 & 2 & 2 & 1 & 2 & 0 & 0 & 2 & 1 & 1 & 2 & 2 & 0 & 7 & 1 & 3 & 5 & 0 & 0 & 0 & 0 & 0 & 0 & 0 & \\
\hline & Caicó & 3 & 15 & 0 & 0 & 1 & 4 & 0 & 2 & 3 & 8 & 8 & 2 & 0 & 14 & 1 & 3 & 1 & 3 & 5 & 14 & 0 & 0 & 0 & 0 & 6 & \\
\hline & Campo Redondo & 4 & 18 & 18 & 19 & 14 & 6 & 6 & 11 & 7 & 12 & 8 & 9 & 8 & 6 & 9 & 17 & 18 & 7 & 6 & 6 & 9 & 9 & 23 & 12 & 37 & \\
\hline & Coronel Ezequiel & 0 & 1 & 3 & 0 & 0 & 1 & 1 & 0 & 1 & 0 & 0 & 1 & 0 & 0 & 0 & 0 & 1 & 1 & 0 & 1 & 0 & 0 & 0 & 0 & 0 & \\
\hline & Currais Novos & 4 & 0 & 3 & 0 & 1 & 1 & 0 & 0 & 0 & 2 & 0 & 0 & 0 & 0 & 0 & 0 & 23 & 0 & 0 & 1 & 0 & 1 & 0 & 0 & 1 & \\
\hline & Fernando Pedroza & 3 & 2 & 4 & 6 & 0 & 2 & 0 & 6 & 4 & 3 & 3 & 1 & 0 & 0 & 0 & 0 & 0 & 2 & 1 & 2 & 5 & 0 & 0 & 0 & 0 & \\
\hline & Florânia & 2 & 1 & 1 & 0 & 0 & 5 & 0 & 3 & 6 & 3 & 5 & 12 & 4 & 4 & 10 & 14 & 15 & 12 & 14 & 3 & 7 & 1 & 0 & 0 & 11 & \\
\hline & Ielmo Marinho & 3 & 7 & 6 & 4 & 2 & 6 & 4 & 6 & 5 & 5 & 0 & 11 & 5 & 9 & 17 & 4 & 3 & 10 & 3 & 8 & 5 & 7 & 12 & 8 & 5 & \\
\hline & Itajá & 0 & - & 0 & 0 & 0 & 0 & 3 & 3 & 1 & 6 & 0 & 3 & 0 & 15 & 1 & 2 & 7 & 2 & 0 & 0 & 0 & 7 & 9 & 6 & 0 & \\
\hline & Jaçanã & 0 & 1 & 0 & 1 & 0 & 0 & 0 & 0 & 0 & 2 & 0 & 0 & 2 & 4 & 1 & 3 & 1 & 0 & 1 & 1 & 0 & 1 & 1 & 0 & 1 & \\
\hline & Janduís & 0 & 0 & 0 & 0 & 0 & 0 & 0 & 0 & 0 & 0 & 0 & 0 & 0 & 0 & 0 & 0 & 0 & 0 & 0 & 0 & 0 & 0 & 0 & 0 & 0 & \\
\hline & Januário Cicco & 0 & 0 & 0 & 0 & 0 & 2 & 4 & 1 & 7 & 5 & 0 & 0 & 1 & 0 & 0 & 2 & 0 & 0 & 0 & 0 & 0 & 0 & 0 & 0 & 2 & \\
\hline & Japi & 2 & 1 & 3 & 0 & 2 & 0 & 2 & 0 & 0 & 1 & 0 & 2 & 1 & 2 & 0 & 0 & 0 & 2 & 2 & 3 & 1 & 2 & 0 & 1 & 2 & \\
\hline & Jardim de Angicos & 1 & 0 & 0 & 2 & 1 & 0 & 1 & 0 & 2 & 0 & 2 & 0 & 0 & 1 & 0 & 1 & 2 & 0 & 0 & 0 & 0 & 0 & 1 & 0 & 0 & \\
\hline & Lagoa d'Anta & 4 & 3 & 2 & 3 & 2 & 1 & 2 & 2 & - & 0 & 2 & 3 & 2 & 2 & 0 & 0 & 3 & 2 & 7 & 6 & 6 & 5 & 1 & 0 & 0 & \\
\hline & Lagoa de Pedras & 2 & 2 & 25 & 3 & 2 & 0 & 3 & 1 & 2 & 1 & 1 & 1 & 2 & 0 & 3 & 0 & 0 & 4 & 2 & 1 & 1 & 2 & 1 & 3 & 2 & \\
\hline & Lagoa de Velhos & 1 & 1 & 1 & 4 & 4 & 3 & 3 & 3 & 1 & 1 & 1 & 2 & 5 & 2 & 3 & 0 & 2 & 1 & 4 & 3 & 0 & 2 & 2 & 1 & 1 & \\
\hline & Lagoa Nova & 0 & 0 & 0 & 0 & 0 & 0 & 0 & 0 & 0 & 0 & 0 & 0 & 0 & 0 & 0 & 0 & 0 & 0 & 3 & 0 & 2 & 0 & 0 & 0 & 0 & \\
\hline & Lagoa Salgada & 7 & 9 & 5 & 7 & 3 & 4 & - & 3 & 10 & 2 & 4 & 5 & 3 & 4 & 3 & 7 & 4 & - & - & - & - & - & - & - & - & \\
\hline & Lajes & 0 & 3 & 6 & 2 & 1 & 7 & 1 & 1 & 5 & 0 & 0 & 0 & 4 & 2 & 1 & 0 & 0 & 3 & 0 & 0 & 1 & 0 & 0 & 0 & 0 & \\
\hline
\end{tabular}




\begin{tabular}{|c|c|c|c|c|c|c|c|c|c|c|c|c|c|c|c|c|c|c|c|c|c|c|c|c|c|c|}
\hline 2009 & Município & $\mathbf{s 2 8}$ & $\mathbf{s 2 9}$ & s30 & s31 & s32 & s33 & s34 & s35 & s36 & s37 & s38 & s39 & $s 40$ & s41 & s42 & $s 43$ & s44 & $s 45$ & $s 46$ & $s 47$ & s48 & s49 & s50 & $s 51$ & s52 \\
\hline & Lajes Pintadas & 0 & 0 & 2 & 1 & 1 & 0 & 1 & 1 & 3 & 0 & 1 & 2 & 0 & 0 & 1 & 0 & 0 & 0 & 4 & 3 & 2 & 0 & 2 & 0 & 0 \\
\hline & Messias Targino & 3 & 0 & 1 & 4 & 0 & 0 & 3 & 3 & 6 & 1 & 4 & 0 & 1 & 5 & 4 & - & 1 & 4 & 1 & 0 & 0 & 2 & 5 & 2 & 7 \\
\hline & Monte Alegre & - & - & - & - & - & - & - & - & - & - & - & - & - & 3 & - & - & - & - & - & - & - & - & - & - & - \\
\hline & Monte das Gameleiras & 0 & 1 & 0 & 0 & 1 & 0 & 3 & 1 & 1 & 1 & 0 & 0 & 1 & 1 & 2 & 0 & 1 & 0 & 1 & 0 & 0 & 0 & 1 & 0 & 2 \\
\hline & Paraú & - & - & - & - & - & - & - & - & - & - & - & - & - & - & - & - & - & - & - & - & - & - & - & - & - \\
\hline & Passa e Fica & 3 & 3 & 3 & 1 & 1 & 12 & 2 & 4 & 5 & 10 & 10 & 4 & 3 & 7 & 7 & 3 & 8 & 6 & 9 & 8 & 7 & 7 & 6 & 4 & 6 \\
\hline & Patu & 0 & 0 & 3 & 0 & 0 & 0 & 2 & 0 & 0 & 1 & 1 & 2 & 0 & 2 & 1 & 0 & 0 & 1 & 0 & 0 & 0 & 0 & 0 & 2 & 0 \\
\hline & Pedra Preta & 3 & 2 & 3 & 2 & 3 & 0 & 3 & 2 & 2 & 1 & 3 & 2 & 2 & 5 & 0 & 0 & 1 & 0 & 2 & 0 & 3 & 4 & 9 & 0 & 0 \\
\hline & Pedro Avelino & 0 & - & 0 & 0 & 0 & 0 & 0 & 0 & 0 & 0 & 2 & 0 & 0 & 0 & 0 & 0 & 0 & 0 & 0 & 0 & 0 & 0 & 3 & - & - \\
\hline & Presidente Juscelino & 2 & 2 & 0 & 0 & 3 & 0 & 0 & 0 & 0 & 0 & 0 & 0 & 0 & 5 & 6 & 2 & 4 & 3 & 3 & 6 & 2 & 3 & 6 & 0 & 0 \\
\hline & Riachuelo & 9 & 8 & 8 & 0 & 5 & 6 & 2 & 2 & 2 & 4 & 7 & 9 & 10 & 7 & 10 & 7 & 5 & 11 & 21 & 10 & 11 & 3 & 11 & 5 & 3 \\
\hline & Ruy Barbosa & 4 & 8 & 5 & 4 & 0 & 5 & 4 & 5 & 4 & 8 & 2 & 6 & 2 & 6 & 5 & 4 & 7 & 5 & 3 & 0 & 3 & 0 & 0 & 4 & 0 \\
\hline & Santa Cruz & 25 & 19 & 36 & 48 & 38 & 48 & 28 & 20 & 47 & 26 & 37 & 58 & 73 & 43 & 41 & 25 & 38 & 28 & 34 & 59 & 39 & 29 & 47 & 32 & 43 \\
\hline & Santa Maria & 0 & 0 & 1 & 0 & 1 & 0 & 1 & 0 & 0 & 2 & 0 & 1 & 0 & 0 & 6 & 3 & 2 & 0 & 4 & 5 & 0 & 4 & 0 & 0 & 0 \\
\hline & Santana do Matos & 0 & 0 & 3 & 0 & 2 & 4 & 0 & 0 & 0 & 0 & 0 & 1 & 1 & 0 & 0 & 1 & 1 & 6 & 0 & 0 & 0 & 2 & 0 & 0 & 0 \\
\hline & São Bento do Trairi & 5 & 1 & 0 & 2 & 0 & 0 & 0 & 0 & 0 & 0 & 0 & 1 & 7 & 2 & 4 & 2 & 2 & 0 & 0 & 2 & 1 & 0 & 2 & 0 & 0 \\
\hline & São José do Campestre & 7 & 12 & 6 & 11 & 8 & 4 & 3 & 9 & 6 & 3 & 9 & 3 & 8 & 18 & 20 & 20 & 20 & 29 & 44 & 49 & 22 & 38 & 10 & 11 & 15 \\
\hline & São Paulo do Potengi & 7 & 3 & 9 & 9 & 11 & 1 & 6 & 10 & 8 & 0 & 2 & 1 & 4 & 3 & 13 & 12 & 2 & 3 & 11 & 4 & 3 & 13 & 3 & 16 & 0 \\
\hline & São Pedro & 12 & 11 & 12 & 10 & 7 & 4 & 7 & 10 & 11 & 14 & 11 & 19 & 11 & 11 & 8 & 12 & 12 & 8 & 13 & 14 & 10 & 11 & 15 & 10 & 11 \\
\hline & São Rafael & - & - & - & - & - & - & - & - & - & - & - & - & - & - & - & - & - & - & - & - & - & - & - & - & - \\
\hline & São Tomé & 1 & 2 & 0 & 1 & 2 & 1 & 2 & 0 & 4 & 0 & 1 & 1 & 5 & 8 & 5 & 0 & 0 & 3 & 1 & 0 & 0 & 0 & 2 & 4 & 0 \\
\hline & São Vicente & 0 & 2 & 0 & 1 & 0 & 2 & 1 & 3 & 1 & 0 & 0 & 5 & 2 & 1 & 0 & 1 & 0 & 0 & 2 & 0 & 2 & 0 & 2 & 1 & 1 \\
\hline & Senador Elói de Souza & 5 & 1 & 0 & 2 & 4 & 2 & 0 & 5 & 4 & 5 & 7 & 0 & 2 & 4 & 2 & 3 & 0 & 3 & 4 & 5 & 7 & 5 & 0 & 1 & 6 \\
\hline & Serra de São Bento & - & - & - & - & - & - & - & - & - & - & - & - & - & - & - & - & - & - & - & - & - & - & - & - & - \\
\hline & Serrinha & 1 & 3 & 0 & 1 & 1 & 1 & 2 & 7 & 1 & 0 & 1 & 0 & 0 & 3 & 6 & 0 & 0 & - & 0 & 3 & 0 & 1 & 0 & 0 & 0 \\
\hline & Sítio Novo & 0 & 2 & 0 & 1 & 0 & 1 & 0 & 4 & 2 & 5 & 9 & 16 & 10 & 8 & 7 & 8 & 5 & 5 & 3 & 0 & 0 & 0 & 0 & 0 & 0 \\
\hline & Tangará & 4 & 0 & 3 & 4 & 4 & 0 & 5 & 1 & 2 & 4 & 3 & 2 & 9 & 4 & 0 & 3 & 3 & 0 & 0 & 0 & 2 & 0 & 0 & 0 & 0 \\
\hline & Tenente Laurentino Cruz & 0 & 0 & 0 & 0 & 0 & 0 & 2 & 1 & 1 & 0 & 2 & 5 & 0 & 0 & 3 & 0 & 8 & 9 & 8 & 5 & 2 & 0 & 4 & 3 & 0 \\
\hline & Triunfo Potiguar & 0 & 0 & 0 & 0 & 0 & 0 & 0 & 0 & 0 & 0 & 0 & 0 & 0 & 0 & 0 & 0 & 0 & 0 & 0 & 0 & 0 & 0 & 0 & 0 & 0 \\
\hline & Alagoa Nova & 11 & 13 & 12 & 7 & - & 8 & 10 & 7 & 9 & 12 & 11 & 7 & 7 & 16 & 6 & 7 & 17 & 23 & 17 & 25 & 39 & 13 & 17 & 21 & 13 \\
\hline & Barra de Santana & 0 & 9 & 3 & 13 & 0 & 0 & 2 & 6 & 0 & 1 & 2 & 3 & 4 & 3 & 3 & 1 & 0 & 2 & 2 & 2 & 0 & 0 & 0 & 4 & 0 \\
\hline & Boa Vista & 2 & 2 & 3 & 1 & 2 & 1 & 2 & 1 & 0 & 4 & 1 & 2 & 1 & 2 & 1 & 2 & 1 & 2 & 1 & 2 & 1 & 1 & 2 & 4 & 3 \\
\hline & Boqueirão & 5 & 8 & 12 & 13 & 4 & 6 & 5 & 10 & 2 & 1 & 9 & 0 & 3 & 2 & 11 & 2 & 4 & 12 & 4 & 6 & 16 & 19 & 21 & 4 & 8 \\
\hline & Cabaceiras & 1 & 1 & 0 & 0 & 1 & 1 & 0 & 0 & 7 & 0 & 0 & 0 & 0 & 1 & 0 & 0 & 0 & 0 & 0 & 0 & 0 & 0 & 0 & 0 & 0 \\
\hline & Campina Grande & 225 & 171 & 154 & 149 & 144 & 130 & 91 & 80 & 100 & 60 & 68 & 71 & 66 & 88 & 90 & 77 & 119 & 111 & 137 & 143 & 117 & 115 & 115 & 77 & 57 \\
\hline & Caturité & 1 & 1 & 0 & 0 & 0 & 2 & 2 & 0 & 0 & 1 & 2 & 0 & 0 & 0 & 0 & 0 & 0 & 0 & 0 & 0 & 0 & 0 & 0 & 0 & 0 \\
\hline & Cubati & 1 & 3 & 2 & 1 & 2 & 1 & 2 & 1 & 2 & 3 & 3 & 1 & 2 & 2 & 4 & 5 & 3 & 2 & 4 & 6 & 2 & 2 & 8 & 18 & 8 \\
\hline
\end{tabular}




\begin{tabular}{|c|c|c|c|c|c|c|c|c|c|c|c|c|c|c|c|c|c|c|c|c|c|c|c|c|c|c|c|c|}
\hline \multirow{10}{*}{2009} & Município & $s 28$ & s29 & \multicolumn{2}{|c|}{ s30 } & s31 & s32 & s33 & s34 & 4 s3 & $35 \mathrm{~s} 3$ & $\mathrm{~s} 36 \mathrm{~s}$ & s37 s & s38 s & s39 s & $\mathrm{s} 40 \mathrm{~s}$ & s41 s & s42s & s43 s & s44 s & s45s & $s 46$ & s47 & $s 48$ & s49 & s50 & s51 & $s 52$ \\
\hline & Juazeirinho & 9 & 5 & 10 & & 5 & 17 & 12 & 23 & $3 \quad-$ & -1 & 12 & 9 & 0 & 8 & 7 & - & 5 & - & - & - & 3 & 0 & - & 1 & - & 12 & 0 \\
\hline & Lagoa Seca & 2 & 2 & 11 & & 6 & 6 & 9 & 6 & 2 & 2 & 4 & 2 & 13 & 6 & 6 & 10 & 4 & 6 & 0 & 0 & 0 & 7 & 9 & 12 & 9 & 7 & 7 \\
\hline & Matinhas & 1 & 0 & 0 & 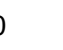 & 6 & 3 & 3 & 5 & 5 & 5 & 0 & 2 & 1 & 1 & 2 & 0 & 1 & 1 & 3 & 1 & 0 & 0 & 1 & 1 & - & - & 0 \\
\hline & Olivedos & 0 & 0 & 0 & 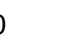 & 0 & 0 & 0 & 0 & 0 & 0 & 1 & 1 & 2 & 0 & 0 & 0 & 3 & 2 & 0 & 0 & 0 & 0 & 0 & 0 & 0 & 0 & 0 \\
\hline & Pedra Lavrada & 1 & 0 & 3 & & 1 & 4 & 1 & 2 & 3 & 3 & 3 & 15 & 60 & 46 & 18 & 12 & 6 & 9 & 2 & 6 & 3 & 2 & 8 & 17 & 8 & 7 & 7 \\
\hline & Pocinhos & 17 & 0 & 2 & & 3 & 4 & 4 & 4 & 3 & 3 & 8 & 5 & 4 & 11 & 2 & 3 & 6 & 5 & 6 & 9 & 12 & 5 & 0 & - & 0 & 0 & 0 \\
\hline & Queimadas & 11 & 28 & 11 & & 13 & 20 & 17 & 6 & 3 & 3 & 4 & 13 & 1 & 3 & 4 & 25 & 1 & 1 & 0 & 3 & 34 & 24 & 18 & 12 & 24 & 6 & 0 \\
\hline & Seridó/São Vicente do Seridó & 12 & 3 & 9 & 9 & 10 & 9 & 9 & 7 & 15 & 15 & 9 & 8 & 0 & 0 & 0 & 0 & 0 & 0 & 0 & 0 & 0 & 0 & 0 & 0 & 12 & 0 & 0 \\
\hline & Soledade & 12 & 10 & 25 & 5 & 11 & 22 & 15 & 17 & 12 & 12 & 12 & 12 & 8 & 14 & 26 & 15 & 14 & 16 & 6 & 8 & 15 & 11 & 5 & 7 & 15 & 2 & 7 \\
\hline 2010 & Município & s1 & s2 & s3 & s4 & s5 & s6 & s7 & s8 & s9 & s10 & s11 & $1 \mathrm{~s} 12$ & $2 \mathrm{s13}$ & 314 & $\mathbf{s 1 5}$ & 516 & $6 \quad s 17$ & $7 \mathrm{~s} 18$ & $8 \quad s 19$ & $9 s 20$ & s21 & $1 \mathrm{~s} 22$ & $2 s 23$ & 3 s24 & $4 \mathrm{~s} 25$ & $25 s 26$ & $6 \mathrm{~s} 27$ \\
\hline & Acari & 10 & 11 & 15 & 12 & 12 & 12 & 22 & 5 & 22 & 38 & 13 & 15 & 42 & 26 & 26 & 15 & 10 & 18 & 18 & 16 & 18 & 11 & 13 & 17 & 11 & 13 & 9 \\
\hline & Açu & 22 & 38 & 43 & 57 & 49 & 53 & 61 & 38 & 38 & 51 & 46 & 27 & 33 & 30 & 34 & 36 & 26 & 24 & 12 & 4 & 0 & 11 & 21 & 11 & 13 & 19 & 27 \\
\hline & Almino Afonso & 0 & 0 & 0 & 0 & - & 0 & 0 & 0 & 0 & - & 0 & 0 & 0 & 0 & 0 & 0 & 0 & 0 & 0 & 0 & 0 & 0 & 0 & 2 & 0 & 0 & 0 \\
\hline & Angicos & 7 & 0 & 18 & 27 & 42 & 37 & 3 & 20 & 12 & 15 & 9 & 7 & 3 & 6 & 6 & 6 & 15 & 21 & 7 & 2 & 13 & 0 & 2 & 0 & 13 & 5 & 5 \\
\hline & Augusto Severo & 2 & 3 & 1 & 5 & 4 & 5 & 5 & 2 & 2 & 3 & 5 & 5 & 1 & 1 & 3 & 2 & 1 & 2 & 6 & 10 & 3 & 3 & 2 & 6 & 5 & 1 & 1 \\
\hline & Barcelona & 1 & 0 & 2 & 1 & 1 & 6 & 1 & 9 & 4 & 7 & 4 & 3 & 5 & 3 & 0 & 5 & 8 & 4 & 7 & 8 & 5 & 8 & 6 & 2 & 3 & 3 & 3 \\
\hline & Bodó & 12 & 0 & 6 & 9 & 14 & 7 & 12 & 0 & 3 & 4 & 0 & 3 & 0 & 2 & 0 & 0 & 5 & 0 & 0 & 4 & 2 & 0 & 2 & 2 & 5 & 1 & 6 \\
\hline & Bom Jesus & 10 & 18 & 12 & 13 & 12 & 14 & 9 & 12 & 23 & 15 & 15 & 35 & 14 & 13 & 10 & 10 & 10 & 18 & 36 & 57 & 65 & 46 & 48 & 29 & 36 & 24 & 34 \\
\hline & Caiçara do Rio do Vento & 5 & 2 & 0 & 0 & 0 & 0 & 0 & 0 & 0 & 0 & 6 & 3 & 3 & 7 & 7 & 18 & 12 & 20 & 4 & 5 & 14 & 9 & - & - & 9 & 6 & 2 \\
\hline & Caicó & 2 & 3 & 10 & 40 & 44 & 0 & 142 & 35 & 60 & 17 & 0 & 49 & 13 & 13 & 12 & 0 & 3 & 0 & 8 & 5 & 18 & 0 & 0 & 11 & 0 & 3 & 7 \\
\hline & Campo Redondo & 28 & - & 17 & 26 & 19 & - & - & 24 & 35 & 29 & 19 & 13 & 13 & - & - & - & 12 & 15 & 13 & 15 & 9 & 16 & 13 & 14 & 14 & 18 & 19 \\
\hline & Coronel Ezequiel & 0 & 1 & 1 & 2 & 2 & 0 & 1 & 0 & 3 & 2 & 1 & 1 & 1 & 0 & 1 & 1 & 1 & 0 & 3 & 0 & 0 & 0 & 0 & 0 & 0 & 0 & 1 \\
\hline & Currais Novos & 8 & 0 & 0 & 46 & 28 & 0 & 93 & 0 & 13 & 10 & 68 & 6 & 1 & 0 & 0 & 0 & 0 & 0 & 0 & 0 & 0 & 6 & 0 & 5 & 3 & 0 & 17 \\
\hline & Fernando Pedroza & 10 & 8 & 5 & 18 & 9 & 5 & 5 & 17 & 4 & 3 & 0 & 2 & - & 3 & 6 & 3 & 9 & 12 & 8 & 8 & 4 & 0 & 0 & 0 & 0 & - & 0 \\
\hline & Florânia & 6 & 6 & 6 & 8 & 15 & 9 & 3 & 0 & 15 & - & 1 & 4 & 7 & 9 & 17 & 8 & 9 & 12 & 1 & 2 & 2 & 6 & 4 & 0 & 7 & 0 & 3 \\
\hline & Ielmo Marinho & 6 & 5 & 7 & 0 & 6 & 1 & 2 & 0 & 2 & 7 & 6 & 10 & 2 & 3 & 5 & 5 & 5 & 3 & 0 & 3 & 3 & 7 & 5 & 5 & 5 & 6 & 7 \\
\hline & Itajá & 4 & 4 & 7 & 1 & 15 & 14 & 8 & 24 & 0 & 0 & 6 & 0 & 0 & 0 & 0 & 0 & 0 & 0 & 5 & 0 & 0 & 0 & 0 & 0 & 0 & 1 & 2 \\
\hline & Jaçanã & 3 & 1 & 5 & 0 & 2 & 0 & 0 & 0 & 0 & 1 & 0 & 0 & 0 & 2 & 2 & 3 & 3 & 4 & 1 & 6 & 1 & 4 & 6 & 1 & 3 & 1 & 7 \\
\hline & Janduís & 3 & 2 & 8 & 7 & 0 & 0 & 0 & 0 & 0 & 5 & 0 & 0 & 0 & 0 & 0 & 0 & 0 & 0 & 0 & 0 & 0 & 0 & 0 & 0 & 0 & 4 & 0 \\
\hline & Januário Cicco & 1 & 1 & 1 & 0 & 1 & 0 & 1 & 1 & 2 & 1 & 0 & 1 & 6 & 7 & 12 & 15 & 12 & 10 & 15 & 6 & 10 & 14 & 12 & 10 & 10 & 9 & 7 \\
\hline & Japi & 1 & 0 & 2 & 0 & 0 & 0 & 1 & 0 & 0 & 1 & 0 & 0 & 0 & 0 & 1 & 0 & 0 & 2 & 0 & 0 & 1 & 0 & 0 & 1 & 1 & 0 & 0 \\
\hline & Jardim de Angicos & 0 & 0 & 0 & 0 & 0 & 2 & 0 & 0 & 0 & 4 & 1 & 0 & 0 & 2 & 0 & 0 & 1 & 2 & 0 & 0 & 2 & 0 & 0 & 2 & 0 & 0 & 1 \\
\hline & Lagoa d'Anta & 0 & 4 & 2 & 3 & 4 & 10 & 3 & 5 & 12 & 2 & 0 & 3 & 0 & 2 & 2 & 3 & 4 & 4 & 3 & 4 & 3 & 3 & 4 & 2 & 4 & 3 & 3 \\
\hline & Lagoa de Pedras & 3 & 0 & 1 & 3 & 2 & 4 & 4 & 2 & 4 & 5 & 1 & 4 & 1 & 1 & 2 & 0 & 2 & 1 & 2 & 1 & 2 & 0 & 2 & 2 & 2 & 1 & 4 \\
\hline & Lagoa de Velhos & 2 & 3 & 4 & 2 & 7 & 10 & 10 & 0 & 9 & 8 & 0 & 2 & 2 & 2 & 5 & 2 & 3 & - & 15 & 15 & 8 & 5 & 0 & 5 & 3 & 7 & 3 \\
\hline & Lagoa Nova & 2 & 0 & 2 & 0 & 2 & 2 & 0 & 6 & 0 & 2 & 5 & 1 & 0 & 0 & 1 & 0 & 0 & 0 & 0 & 5 & 0 & 3 & 8 & 3 & $\begin{array}{c}0 \\
243\end{array}$ & 3 & 2 \\
\hline
\end{tabular}




\begin{tabular}{|c|c|c|c|c|c|c|c|c|c|c|c|c|c|c|c|c|c|c|c|c|c|c|c|c|c|c|c|c|}
\hline 2010 & Município & s1 & s2 & s3 & s4 & s5 & s6 & s7 & s8 & s9 & s10 & s11 & s12 & s13 & $s 14$ & $\mathbf{s} 15$ & $s 16$ & $s 17$ & s18 & $\mathbf{s} 19$ & s20 & s21 & $\mathrm{s} 22$ & s23 & s24 & $s 25$ & $s 26$ & s27 \\
\hline & Lagoa Salgada & - & - & - & - & - & - & - & - & 21 & 15 & 8 & 8 & 5 & 13 & 6 & 11 & 10 & 6 & 10 & 11 & 7 & 7 & 13 & 8 & 5 & 3 & 9 \\
\hline & Lajes & 0 & 1 & 0 & 2 & 2 & 3 & 0 & 8 & 6 & 7 & 18 & 9 & 1 & 11 & 0 & 9 & 0 & 0 & 3 & 0 & 0 & 0 & 0 & 3 & 2 & 2 & 5 \\
\hline & Lajes Pintadas & 1 & 0 & 2 & 0 & 0 & 0 & 2 & 6 & 3 & 4 & 5 & 2 & 0 & 0 & 0 & 1 & 1 & 1 & 4 & 2 & 1 & 4 & 3 & 1 & 0 & 0 & 1 \\
\hline & Messias Targino & 6 & 11 & 12 & 23 & 18 & 6 & 17 & 9 & 6 & 8 & 10 & 3 & 6 & 3 & 5 & 7 & 10 & 6 & 0 & 10 & 11 & 0 & 5 & - & 0 & 3 & 2 \\
\hline & Monte Alegre & - & - & - & - & - & - & - & - & - & - & - & - & - & - & - & - & - & - & - & - & - & - & - & - & - & - & - \\
\hline & Monte das Gameleiras & 0 & 1 & 5 & 5 & 2 & 3 & 3 & 4 & 2 & 2 & 7 & 1 & 1 & 1 & 4 & 2 & 4 & 5 & 3 & 5 & 3 & 0 & 1 & 2 & 0 & 0 & 2 \\
\hline & Paraú & 0 & 1 & 3 & 1 & 9 & 4 & 1 & 0 & 1 & 5 & 0 & 0 & 2 & 1 & 0 & 1 & 0 & 2 & - & 0 & 0 & - & 0 & 0 & 0 & 1 & 3 \\
\hline & Passa e Fica & 6 & 5 & 4 & 3 & 6 & 4 & 9 & 7 & 4 & 6 & 5 & 4 & 3 & 3 & 3 & 3 & 3 & 3 & 3 & 7 & 7 & 6 & 0 & 0 & 0 & 5 & 5 \\
\hline & Patu & 0 & 3 & 3 & 7 & 9 & 3 & 23 & 6 & 6 & 1 & 3 & 3 & 0 & 6 & 5 & 4 & 0 & 0 & 5 & 3 & 1 & 3 & 1 & 2 & 3 & 0 & 3 \\
\hline & Pedra Preta & 0 & 3 & 0 & 3 & 0 & 0 & 0 & 3 & 0 & 0 & 0 & 2 & 0 & 2 & 5 & 4 & 0 & 0 & 3 & 4 & 0 & 0 & 1 & 2 & 5 & 4 & 1 \\
\hline & Pedro Avelino & 0 & 0 & 0 & 0 & 0 & 0 & 0 & 0 & 3 & 2 & 8 & 7 & 3 & 0 & 12 & 37 & 11 & 6 & 0 & 1 & 1 & 0 & 2 & 0 & 0 & 0 & 1 \\
\hline & Presidente Juscelino & 0 & 0 & 0 & 1 & 1 & 1 & 5 & 0 & 5 & 6 & 0 & 0 & 13 & 2 & 5 & 8 & 9 & 18 & 26 & 1 & 8 & 6 & 9 & 2 & 6 & 7 & 22 \\
\hline & Riachuelo & 17 & 8 & 12 & 9 & 12 & 9 & 4 & 15 & 10 & 9 & 9 & 5 & 1 & 13 & 13 & 7 & 20 & 23 & 21 & 27 & 22 & 17 & 21 & 11 & 12 & 12 & 6 \\
\hline & Ruy Barbosa & 8 & 2 & 1 & 4 & 8 & 7 & 21 & 21 & 6 & 2 & 4 & 0 & 4 & 4 & 7 & 0 & 17 & 6 & 2 & 0 & 5 & 7 & 6 & 11 & 2 & 6 & 2 \\
\hline & Santa Cruz & 34 & 48 & 40 & 46 & 65 & 60 & 60 & 83 & 82 & 61 & 43 & 54 & 37 & 39 & 51 & 57 & 48 & 60 & 82 & 61 & 73 & 71 & 74 & 56 & 78 & 54 & 72 \\
\hline & Santa Maria & 0 & 3 & 5 & 4 & 4 & 4 & 6 & 3 & 3 & 3 & 3 & 3 & 2 & 1 & 1 & 3 & 1 & 1 & 3 & 0 & 0 & 2 & 1 & 1 & 1 & 3 & 3 \\
\hline & Santana do Matos & 2 & 4 & 7 & 17 & 43 & 15 & 19 & 12 & 12 & 2 & 4 & 0 & 0 & 3 & 2 & 5 & 2 & 1 & 4 & 2 & 0 & 0 & 1 & 5 & 2 & 0 & 1 \\
\hline & São Bento do Trairi & 0 & 0 & 0 & - & 2 & 0 & 1 & 5 & 7 & 2 & 1 & 0 & 2 & 3 & 1 & - & 4 & 2 & 0 & 2 & 3 & 3 & - & 1 & 2 & 0 & 1 \\
\hline & São José do Campestre & 16 & 8 & 24 & 15 & 20 & 9 & 14 & 21 & 31 & 28 & 39 & 27 & 23 & 39 & 25 & 20 & 14 & 27 & 63 & - & 45 & 29 & 29 & 24 & 16 & 28 & - \\
\hline & São Paulo do Potengi & - & 4 & 10 & 8 & 6 & - & 18 & 25 & 22 & 19 & 26 & 15 & 16 & 5 & 16 & 16 & 25 & 20 & 28 & 10 & 16 & 15 & 14 & 6 & 5 & 12 & 6 \\
\hline & São Pedro & 15 & 16 & 15 & 19 & 11 & 15 & 16 & 4 & 7 & 5 & 4 & 9 & 5 & 7 & 9 & 8 & 6 & 16 & 9 & 13 & 13 & 12 & 15 & 12 & 7 & 4 & 21 \\
\hline & São Rafael & - & - & - & - & - & - & - & - & - & - & 0 & 0 & - & 6 & 11 & 13 & 0 & 0 & 7 & - & - & - & - & - & - & - & - \\
\hline & São Tomé & 0 & 0 & 0 & 0 & 8 & 8 & 12 & 18 & 21 & 6 & 17 & 8 & 10 & 13 & 10 & 0 & 16 & 30 & - & 31 & 18 & 6 & 8 & 11 & 10 & 14 & 18 \\
\hline & São Vicente & 6 & 3 & 5 & 4 & 16 & 0 & 4 & 3 & 3 & 0 & 3 & 1 & 2 & 2 & 2 & 0 & 0 & 1 & 2 & 3 & - & 0 & 0 & 0 & 0 & 5 & 5 \\
\hline & Senador Elói de Souza & 2 & 5 & 3 & 0 & 12 & 10 & 6 & 10 & 10 & 6 & 3 & 5 & 6 & 10 & 7 & 10 & 6 & 8 & 40 & 42 & 35 & 6 & 3 & 9 & 5 & 8 & 7 \\
\hline & Serra de São Bento & - & - & - & - & - & - & - & - & - & - & - & - & - & - & - & - & - & - & - & - & - & - & - & - & - & - & - \\
\hline & Serrinha & 1 & 1 & 0 & 2 & 0 & 0 & 0 & 2 & 1 & 1 & 1 & 1 & 1 & 1 & 1 & 0 & 0 & 2 & 1 & 12 & 0 & 11 & 0 & 0 & 1 & 2 & 0 \\
\hline & Sítio Novo & 1 & 2 & 1 & 22 & 1 & 7 & 0 & 6 & 4 & 7 & 5 & 4 & 5 & 8 & 5 & 5 & 8 & 5 & 5 & 14 & 14 & 16 & 10 & - & - & - & 3 \\
\hline & Tangará & 0 & 0 & 0 & 0 & 1 & 0 & 0 & 0 & 3 & 1 & 1 & 3 & 1 & 2 & 0 & 1 & 18 & 2 & 21 & 17 & 8 & 15 & 19 & 4 & 8 & 7 & 24 \\
\hline & Tenente Laurentino Cruz & 3 & 0 & 5 & 7 & 14 & 2 & 3 & 4 & 4 & 2 & 0 & 3 & 3 & 1 & 0 & 2 & 4 & 2 & 2 & 3 & 0 & 3 & 4 & 1 & 1 & 2 & 2 \\
\hline & Triunfo Potiguar & 3 & 4 & 0 & 0 & 3 & 1 & 0 & 2 & 0 & 3 & 5 & 2 & 2 & 2 & 1 & 2 & 0 & - & - & - & - & - & - & - & - & - & 1 \\
\hline & Alagoa Nova & - & 12 & 17 & 22 & 10 & 7 & 15 & 29 & 20 & 9 & 21 & 13 & 6 & 8 & 11 & 7 & 20 & 9 & 14 & 15 & 10 & 23 & 14 & 22 & 28 & 16 & 11 \\
\hline & Barra de Santana & 0 & 0 & 0 & 0 & 0 & 0 & 11 & 10 & 8 & 9 & 4 & 10 & 3 & 1 & 2 & 4 & 5 & 0 & 9 & 12 & 8 & 7 & 4 & 0 & 3 & 1 & 4 \\
\hline & Boa Vista & 2 & 4 & 3 & 2 & 2 & 3 & 1 & 2 & 1 & 2 & 1 & 2 & 4 & 2 & 4 & 2 & 3 & 2 & 3 & 1 & 1 & 2 & 2 & 1 & 2 & 1 & 5 \\
\hline & Boqueirão & 7 & 5 & 9 & 5 & 5 & 7 & 2 & 6 & 9 & 4 & 18 & 7 & 9 & 6 & 2 & 2 & - & 5 & 0 & 2 & 10 & 5 & 8 & 6 & 2 & 9 & 0 \\
\hline & Cabaceiras & 0 & 15 & 0 & 0 & 0 & 0 & 0 & 7 & 0 & 0 & 4 & 0 & 0 & 0 & 0 & 0 & 0 & - & 0 & 0 & 0 & 0 & 3 & 0 & - & 0 & 0 \\
\hline & Campina Grande & 129 & 103 & 67 & 109 & 90 & 36 & 101 & 162 & 158 & 117 & 130 & 105 & 92 & 89 & 102 & 118 & 96 & 86 & 107 & 120 & 130 & 87 & 107 & 47 & 71 & 125 & 131 \\
\hline
\end{tabular}




\begin{tabular}{|c|c|c|c|c|c|c|c|c|c|c|c|c|c|c|c|c|c|c|c|c|c|c|c|c|c|c|c|c|}
\hline 2010 & Município & s1 & s2 & s3 & s4 & s5 & s6 & s7 & s8 & s9 & s10 & s11 & $s 12$ & s13 & s14 & $s 15$ & s16 & $\mathrm{s} 17$ & s18 & s19 & s20 & s21 & s22 & s23 & s24 & $s 25$ & $s 26$ & $s 27$ \\
\hline & Caturité & 0 & 0 & 3 & 0 & 4 & 0 & 0 & 0 & 1 & 4 & 2 & 2 & 0 & 1 & 0 & 0 & 0 & 6 & 4 & 3 & 9 & 3 & 5 & 0 & 0 & 0 & 2 \\
\hline & Cubati & 5 & 5 & 8 & 8 & 15 & 28 & 28 & 15 & 8 & 23 & 17 & 17 & 4 & 4 & 3 & 33 & 12 & 5 & 17 & 14 & 6 & 5 & 15 & 11 & 8 & 6 & 5 \\
\hline & Juazeirinho & 0 & 4 & 5 & 5 & 10 & 1 & 1 & 6 & 13 & 9 & 3 & 7 & 2 & 13 & 9 & 13 & 11 & 7 & 13 & 21 & 17 & 3 & 4 & 3 & 5 & 11 & 10 \\
\hline & Lagoa Seca & 5 & 2 & 2 & 3 & 11 & 6 & 5 & 7 & 5 & 28 & 13 & 13 & 11 & 11 & 6 & 7 & 9 & 7 & 2 & 8 & 6 & 10 & 9 & 5 & 0 & 11 & 9 \\
\hline & Matinhas & 0 & 0 & 0 & 0 & 4 & 0 & 0 & 3 & 2 & 4 & 0 & 1 & 3 & 2 & 2 & 3 & 2 & 4 & 2 & 4 & 3 & 6 & 4 & 2 & 2 & 5 & 4 \\
\hline & Olivedos & 0 & 0 & 0 & 0 & 0 & 0 & 0 & 0 & 0 & 0 & 0 & 2 & 0 & 0 & 0 & 0 & 0 & 0 & 3 & 2 & 2 & 1 & 0 & 0 & 4 & 1 & 1 \\
\hline & Pedra Lavrada & 2 & 11 & 16 & 8 & 10 & 3 & 4 & 10 & 2 & 7 & 5 & 5 & 1 & 6 & 4 & 2 & 2 & 4 & 0 & 4 & 7 & 2 & 6 & 1 & 2 & 0 & 11 \\
\hline & Pocinhos & 0 & 2 & 1 & 0 & 0 & - & 1 & 4 & 0 & 4 & 3 & 2 & 0 & 5 & 0 & 18 & 3 & 0 & 2 & 8 & 2 & 0 & 1 & 3 & 0 & 0 & 0 \\
\hline & Queimadas & 7 & 20 & 64 & 15 & 15 & 23 & 15 & 36 & 24 & 30 & 64 & 20 & 9 & 16 & 16 & 23 & 6 & 8 & 29 & 25 & 64 & 8 & 19 & 24 & 2 & 7 & 19 \\
\hline & Seridó/São Vicente do Seridó & 0 & 0 & 0 & 0 & 2 & 0 & 0 & 0 & 9 & 0 & 8 & 0 & 0 & 0 & 8 & 8 & 0 & 18 & 0 & 12 & 17 & 17 & 13 & 5 & 0 & 4 & 0 \\
\hline & Soledade & 3 & 10 & 10 & 14 & 8 & 18 & 14 & 26 & 24 & 23 & 13 & 16 & 14 & 11 & 18 & 11 & 11 & 6 & 11 & 11 & 10 & 19 & 6 & 12 & 6 & 16 & 9 \\
\hline
\end{tabular}

\begin{tabular}{|c|c|c|c|c|c|c|c|c|c|c|c|c|c|c|c|c|c|c|c|c|c|c|c|c|c|c|}
\hline 2010 & Município & s28 & $\mathbf{s} 29$ & s30 & s31 & s32 & s33 & s34 & s35 & s36 & s37 & s38 & s39 & $s 40$ & s41 & $s 42$ & $s 43$ & s44 & $s 45$ & s46 & $s 47$ & $s 48$ & s49 & $\mathrm{s} 50$ & s51 & s52 \\
\hline & Acari & 10 & 20 & 17 & 17 & 10 & 8 & 14 & 16 & 18 & 22 & 15 & 8 & 16 & 12 & 16 & 9 & 10 & 8 & 15 & 17 & 18 & 17 & 0 & 10 & 13 \\
\hline & Açu & 15 & 17 & - & 19 & 27 & 21 & 11 & 31 & - & 30 & 21 & 24 & 33 & 23 & 29 & 26 & 16 & 23 & 30 & 55 & 30 & 28 & 16 & - & - \\
\hline & Almino Afonso & 1 & 1 & 0 & 1 & 2 & 1 & 1 & 1 & 0 & 0 & 0 & 2 & 1 & 1 & 1 & 1 & 1 & 1 & 0 & 1 & 1 & 2 & 0 & 1 & 1 \\
\hline & Angicos & 5 & 5 & 10 & 9 & 3 & 0 & 10 & 8 & 4 & 2 & 2 & 1 & 6 & 1 & 0 & 1 & 3 & 9 & 3 & 1 & 6 & 1 & 6 & 7 & 4 \\
\hline & Augusto Severo & 2 & 4 & - & 2 & 1 & 2 & 0 & 1 & - & - & - & - & 1 & 2 & 3 & 0 & 2 & 3 & 1 & 0 & 0 & 4 & 2 & 3 & 8 \\
\hline & Barcelona & 4 & 4 & 5 & 4 & 6 & 8 & 1 & 3 & 5 & 4 & 6 & 3 & 1 & 2 & 1 & 4 & 0 & 1 & 3 & 3 & 3 & 0 & 2 & 1 & 3 \\
\hline & Bodó & 3 & 7 & 4 & 2 & 2 & 3 & 4 & 0 & 2 & 2 & 0 & 0 & 2 & 3 & 1 & 0 & 1 & 1 & 0 & 2 & 0 & 5 & 3 & 3 & 1 \\
\hline & Bom Jesus & 24 & 30 & 19 & 23 & 22 & 22 & 18 & 14 & 10 & 9 & 20 & 15 & 13 & 7 & 10 & 9 & 7 & 8 & 15 & 11 & 9 & 8 & 5 & 9 & 12 \\
\hline & Caiçara do Rio do Vento & 6 & 9 & 12 & 3 & 4 & 12 & 4 & 5 & 2 & 2 & 4 & 3 & 9 & 0 & 1 & 0 & 0 & - & 6 & 4 & 2 & 4 & 4 & 2 & 0 \\
\hline & Caicó & 9 & 5 & 7 & 0 & 0 & 3 & 20 & 0 & 0 & 24 & 16 & 10 & 21 & 15 & 0 & 11 & 11 & 13 & 7 & 26 & 1 & 11 & 0 & 27 & 24 \\
\hline & Campo Redondo & 17 & 15 & 23 & 14 & 12 & 11 & 20 & 14 & - & - & 14 & 10 & 7 & 12 & 15 & 14 & 13 & 10 & 10 & 14 & 14 & 13 & 10 & 0 & 0 \\
\hline & Coronel Ezequiel & 1 & 0 & 0 & 1 & 0 & 0 & 0 & 0 & 2 & 1 & 0 & 1 & 0 & 1 & 0 & 0 & 0 & 0 & 0 & 0 & 0 & 0 & 0 & 0 & 0 \\
\hline & Currais Novos & 11 & 0 & 4 & 1 & 22 & 64 & 4 & 2 & 0 & 0 & 0 & 0 & 0 & 0 & 0 & 0 & 0 & 0 & 0 & 0 & 0 & 0 & 0 & 0 & 0 \\
\hline & Fernando Pedroza & 0 & 4 & 2 & 0 & 0 & 0 & 0 & 0 & 0 & 0 & 0 & 0 & 0 & 0 & 0 & 0 & 0 & 0 & 1 & 1 & 1 & 1 & 0 & 0 & 0 \\
\hline & Florânia & 4 & 4 & 2 & 4 & 1 & 2 & 7 & 8 & 1 & 2 & 2 & 4 & 3 & 5 & 0 & 4 & 2 & 4 & 7 & 15 & 1 & 3 & 0 & 0 & 7 \\
\hline & Ielmo Marinho & 2 & 4 & 4 & 3 & 3 & 5 & 4 & 6 & 2 & 1 & 3 & 3 & 3 & 1 & 5 & 6 & 1 & 0 & 5 & 4 & 4 & 6 & 0 & 3 & 0 \\
\hline & Itajá & 3 & 7 & 0 & 0 & - & 0 & - & 0 & 3 & - & - & - & - & - & - & - & - & - & - & - & - & - & - & - & - \\
\hline & Jaçanã & 2 & 2 & 4 & 5 & 3 & 3 & 3 & 4 & 1 & 1 & 2 & 2 & 0 & 1 & 3 & 4 & 1 & 1 & 4 & 3 & 4 & - & 1 & 1 & 1 \\
\hline & Janduís & 0 & 0 & 0 & 3 & 0 & 1 & 0 & 0 & 1 & 0 & 0 & 1 & - & 1 & 0 & 0 & 0 & 3 & 0 & 0 & 0 & 0 & 0 & 0 & 0 \\
\hline & Januário Cicco & 3 & 7 & 5 & 7 & 7 & 2 & 10 & 5 & 6 & 15 & 6 & 0 & 8 & 0 & 12 & 9 & 1 & 0 & 0 & 2 & 0 & 3 & 0 & 0 & 9 \\
\hline & Japi & 0 & 2 & 2 & 2 & 2 & 1 & 0 & 3 & 1 & 2 & 1 & 0 & 1 & 0 & 0 & 0 & 0 & 0 & 0 & 7 & 0 & 4 & - & 1 & - \\
\hline & Jardim de Angicos & 0 & 0 & 1 & 0 & 0 & 2 & 0 & 0 & 1 & 2 & 0 & 0 & 2 & 1 & 0 & 0 & 1 & 2 & 0 & 0 & 0 & 0 & 0 & 0 & 0 \\
\hline & Lagoa d'Anta & 3 & 6 & 4 & 3 & 6 & - & 3 & 0 & 0 & 4 & - & 2 & 5 & 0 & 0 & 1 & 2 & 1 & 0 & 2 & 2 & 0 & 2 & 2 & 0 \\
\hline & Lagoa de Pedras & 3 & 4 & 3 & 3 & 4 & 2 & 2 & 4 & 4 & 4 & 3 & 0 & 0 & 3 & 3 & 0 & 5 & 2 & 1 & 1 & 1 & 2 & 1 & 1 & 0 \\
\hline
\end{tabular}




\begin{tabular}{|c|c|c|c|c|c|c|c|c|c|c|c|c|c|c|c|c|c|c|c|c|c|c|c|c|c|c|}
\hline 2010 & Município & $\mathbf{s 2 8}$ & $\mathbf{s 2 9}$ & s30 & s31 & s32 & s33 & s34 & s35 & s36 & s37 & s38 & s39 & $s 40$ & s41 & s42 & $s 43$ & s44 & $s 45$ & s46 & s47 & s48 & s49 & s50 & $s 51$ & s52 \\
\hline & Lagoa de Velhos & 4 & 4 & 6 & 3 & 2 & 0 & 1 & 0 & 1 & 1 & 0 & 1 & 2 & 2 & 0 & 0 & 1 & 0 & 4 & 0 & 2 & 0 & 0 & 1 & 1 \\
\hline & Lagoa Nova & 0 & 1 & 2 & 1 & 1 & 2 & 0 & 0 & 0 & 0 & 0 & 6 & 0 & 0 & 4 & 0 & 0 & 0 & 4 & 0 & 0 & 0 & 20 & 0 & 0 \\
\hline & Lagoa Salgada & 11 & 10 & 4 & 5 & 4 & 3 & 7 & 3 & 8 & 4 & 1 & 1 & 0 & 5 & 2 & 3 & 5 & 2 & 3 & 2 & 0 & 0 & 5 & 4 & - \\
\hline & Lajes & 1 & 4 & 2 & 2 & 2 & 4 & 1 & 0 & 0 & 0 & 1 & 0 & 0 & 2 & 4 & 0 & 0 & 3 & 0 & 2 & 0 & 0 & 0 & 0 & 0 \\
\hline & Lajes Pintadas & 4 & 2 & 4 & 1 & 3 & 2 & 3 & 0 & 0 & 1 & 2 & 0 & 1 & 3 & 1 & 0 & 1 & 0 & 0 & 0 & 0 & 2 & 0 & 1 & 1 \\
\hline & Messias Targino & 4 & 5 & 3 & - & 11 & 1 & 5 & 1 & 2 & 0 & 0 & 2 & 0 & 4 & 1 & 0 & 0 & 1 & 5 & 2 & 15 & 4 & 2 & 2 & 6 \\
\hline & Monte Alegre & - & - & - & - & - & - & - & - & - & - & - & - & - & - & - & - & - & - & - & - & - & - & - & - & - \\
\hline & Monte das Gameleiras & 1 & 2 & 1 & 2 & 0 & 0 & 5 & 1 & 1 & 3 & 0 & 1 & 3 & 1 & 3 & 3 & 2 & 0 & 4 & 3 & 1 & 5 & 5 & 1 & 3 \\
\hline & Paraú & 2 & 0 & 0 & 1 & 1 & 2 & 0 & 0 & 0 & 0 & 3 & 0 & 0 & 0 & 0 & 0 & 3 & 2 & 3 & 6 & 5 & 3 & 0 & 0 & 1 \\
\hline & Passa e Fica & 5 & 4 & 4 & 3 & 0 & 0 & 0 & 6 & 3 & 3 & 0 & 3 & 3 & 0 & 3 & 1 & 1 & 4 & 3 & 2 & - & - & - & - & - \\
\hline & Patu & 1 & 3 & 1 & 0 & 4 & 1 & 2 & 0 & 1 & 0 & 1 & 3 & 1 & 0 & 1 & 3 & 0 & 5 & 0 & 0 & 2 & 0 & 2 & 3 & 0 \\
\hline & Pedra Preta & 2 & 0 & 0 & 0 & 3 & 3 & 0 & 2 & 3 & 1 & 0 & 0 & 0 & 0 & 0 & 0 & 0 & 0 & 0 & 0 & 0 & 0 & 0 & 0 & 0 \\
\hline & Pedro Avelino & 1 & 0 & 0 & 0 & 1 & 1 & 1 & 4 & 0 & 1 & 4 & 0 & 1 & 0 & 0 & 0 & 0 & 1 & 0 & 3 & 4 & - & 1 & 2 & 0 \\
\hline & Presidente Juscelino & 7 & 8 & 43 & 22 & 13 & 20 & 21 & 3 & 10 & 8 & 0 & 0 & 2 & 10 & 0 & 4 & 1 & 0 & 6 & 2 & 6 & 0 & 3 & 0 & 0 \\
\hline & Riachuelo & 19 & 14 & 8 & 12 & 10 & 10 & 10 & 7 & 5 & 7 & 7 & 9 & 3 & 7 & - & 6 & 4 & 2 & 2 & 5 & 3 & 7 & 7 & 2 & 5 \\
\hline & Ruy Barbosa & 2 & 3 & 7 & 4 & 7 & 8 & 3 & 0 & 3 & 1 & & 9 & 5 & 6 & 9 & 6 & 0 & 3 & 3 & 1 & 2 & 0 & 3 & - & - \\
\hline & Santa Cruz & 115 & 75 & 91 & 84 & 94 & 69 & 57 & 74 & 59 & 47 & 51 & 63 & 50 & 44 & 70 & 90 & 76 & 81 & 72 & 61 & 49 & 50 & 57 & 58 & 69 \\
\hline & Santa Maria & 4 & 5 & 3 & 2 & 0 & 1 & 0 & 0 & 0 & 4 & 2 & 2 & 0 & - & - & - & - & - & - & - & - & - & - & - & 3 \\
\hline & Santana do Matos & 1 & 4 & 1 & 5 & 3 & 4 & 3 & 3 & 4 & 2 & 1 & 2 & 2 & 0 & 1 & 2 & 1 & 2 & 2 & 3 & 0 & 3 & 3 & 2 & 2 \\
\hline & São Bento do Trairi & 0 & 2 & 1 & 3 & 0 & 2 & 1 & 2 & 0 & 1 & 2 & 0 & 0 & 0 & 2 & 0 & 4 & 3 & 2 & 2 & 2 & - & - & - & - \\
\hline & São José do Campestre & 30 & 30 & 33 & - & 30 & 32 & 15 & 17 & 10 & 20 & 22 & 25 & 15 & 27 & 21 & - & 24 & 18 & 16 & 15 & 8 & 13 & 6 & 6 & 7 \\
\hline & São Paulo do Potengi & 15 & 16 & 13 & 25 & 0 & 9 & 10 & 3 & 5 & 10 & 2 & 1 & 5 & 0 & 5 & 4 & 8 & 1 & 4 & - & - & 0 & 8 & 0 & 7 \\
\hline & São Pedro & 12 & 6 & 6 & 3 & 3 & 3 & 2 & 7 & 11 & 1 & 3 & 6 & 6 & 2 & 3 & 1 & 3 & 8 & 4 & 4 & 3 & 6 & 3 & 3 & 5 \\
\hline & São Rafael & - & - & - & - & - & - & - & - & - & - & - & - & - & - & - & - & - & - & - & - & - & - & - & - & - \\
\hline & São Tomé & 28 & 26 & 46 & 41 & 34 & 25 & 13 & 11 & 3 & 4 & 4 & 10 & 10 & 7 & 7 & 7 & 6 & 4 & 4 & 1 & 2 & 6 & 9 & 3 & 13 \\
\hline & São Vicente & 2 & 2 & 8 & 4 & 0 & 0 & 0 & 0 & 1 & 0 & 0 & 2 & 1 & 0 & 0 & 0 & 0 & - & 0 & 3 & 0 & 0 & 0 & 0 & 0 \\
\hline & Senador Elói de Souza & 5 & 7 & 5 & 6 & 4 & 6 & 2 & 3 & 2 & 0 & 4 & 6 & 3 & 2 & 4 & 2 & 3 & - & 2 & 2 & 2 & 6 & 3 & 0 & 3 \\
\hline & Serra de São Bento & - & - & - & - & - & - & - & - & - & - & - & - & - & - & - & - & - & - & - & - & - & - & - & - & - \\
\hline & Serrinha & 0 & 0 & 17 & 2 & 0 & 4 & 0 & 0 & 0 & 0 & 1 & 4 & 0 & 0 & 0 & 0 & 1 & 0 & 0 & 2 & 0 & 0 & 0 & 0 & 0 \\
\hline & Sítio Novo & 4 & 21 & 20 & 1 & 1 & 1 & 1 & 1 & 2 & 7 & 0 & 0 & 2 & 12 & 7 & 4 & - & 3 & 0 & - & - & - & - & - & - \\
\hline & Tangará & 21 & 15 & 5 & 1 & 16 & 1 & 0 & 6 & 9 & 6 & 16 & 10 & 0 & 5 & 2 & 2 & 0 & 0 & 3 & 0 & 0 & 1 & 0 & 0 & 0 \\
\hline & Tenente Laurentino Cruz & 2 & 0 & 4 & 3 & 2 & 3 & 1 & 3 & 2 & 6 & 3 & 1 & 7 & 1 & 6 & 1 & 0 & 4 & 6 & 10 & 0 & 8 & 0 & 0 & 3 \\
\hline & Triunfo Potiguar & 4 & 2 & 2 & 2 & 5 & - & 4 & 1 & 3 & 0 & 2 & 0 & 0 & 1 & 0 & - & - & 1 & 4 & 2 & 0 & 2 & 1 & 0 & 0 \\
\hline & Alagoa Nova & 26 & 7 & 14 & 7 & 27 & 14 & 22 & 24 & 23 & 22 & 13 & 3 & 11 & 21 & 12 & 17 & 17 & 7 & 25 & 15 & - & 18 & 5 & 21 & 23 \\
\hline & Barra de Santana & 3 & 0 & 4 & 2 & 4 & 1 & 0 & 0 & 0 & 0 & 2 & 0 & 0 & 0 & 0 & 1 & 3 & 0 & 7 & 0 & 6 & 3 & 0 & 3 & 0 \\
\hline & Boa Vista & 2 & 1 & 2 & 1 & 3 & 2 & 3 & 2 & 1 & 2 & 3 & 2 & 1 & 2 & 2 & 3 & 2 & 3 & 2 & 3 & 3 & 2 & 5 & 2 & 2 \\
\hline & Boqueirão & 15 & 5 & 5 & 10 & 12 & 22 & 15 & 8 & 16 & 22 & 27 & 21 & 17 & 9 & 2 & 2 & 2 & 4 & 5 & 2 & 8 & 7 & 7 & 2 & 5 \\
\hline
\end{tabular}




\begin{tabular}{|c|c|c|c|c|c|c|c|c|c|c|c|c|c|c|c|c|c|c|c|c|c|c|c|c|c|c|c|c|}
\hline \multirow[t]{14}{*}{2010} & \multirow{2}{*}{$\begin{array}{l}\text { Municipio } \\
\text { Cabaceiras }\end{array}$} & s28 & $s 2 S$ & & $30 s$ & s31 & s32 & s33 & s34 & s35 & $5 \mathrm{~s} 36$ & s37 & 7 s38 & 8 s39 & s40 & $\begin{array}{ll}0 & s 41 \\
\end{array}$ & $1 \mathrm{~s} 42$ & $2 s 43$ & 3 s44 & $4 s 45$ & 5 s46 & $\begin{array}{ll}6 & s 47 \\
\end{array}$ & 7 s48 & 8 s49 & 9 s50 & s51 & \multicolumn{2}{|c|}{ s52 } \\
\hline & & 0 & 0 & & 0 & 0 & 0 & 0 & 0 & 0 & 0 & 0 & 2 & 0 & 0 & 0 & 5 & 0 & 6 & 7 & 5 & 4 & 7 & 0 & 4 & 0 & \multicolumn{2}{|c|}{0} \\
\hline & Campina Grande & 117 & 129 & & 01 & 99 & 128 & 102 & 92 & 108 & 89 & 114 & 110 & 93 & 71 & 103 & 118 & 60 & 40 & 114 & $4 \quad 123$ & 105 & 86 & 83 & 82 & 74 & \multicolumn{2}{|c|}{57} \\
\hline & Caturité & 0 & 1 & & 0 & 3 & 2 & 1 & 4 & 1 & 1 & 0 & 0 & 0 & 1 & 0 & 0 & 0 & 0 & 0 & 0 & 0 & 0 & 0 & 0 & 0 & \multicolumn{2}{|l|}{-} \\
\hline & Cubati & 6 & 5 & & 6 & 15 & 14 & 6 & 3 & 6 & 10 & 15 & 12 & 7 & 15 & 31 & 29 & 32 & 27 & 22 & 20 & 10 & 5 & 5 & 5 & 15 & \multicolumn{2}{|l|}{17} \\
\hline & Juazeirinho & 16 & 23 & & 13 & 11 & 5 & 3 & 7 & 21 & 11 & 1 & 15 & 10 & 2 & 17 & 7 & 10 & 17 & 5 & 26 & 35 & 17 & 9 & 7 & 27 & \multicolumn{2}{|l|}{9} \\
\hline & Lagoa Seca & 9 & 7 & & 2 & 3 & 5 & 4 & 4 & 0 & 5 & 9 & 4 & 9 & 4 & 11 & 10 & 6 & 6 & 9 & 16 & 4 & 9 & 9 & 0 & 5 & \multicolumn{2}{|l|}{12} \\
\hline & Matinhas & 2 & 0 & & 2 & 1 & 4 & 3 & 4 & 2 & 1 & 5 & 2 & 3 & 2 & 3 & 2 & 2 & 1 & 1 & 4 & 2 & 4 & 2 & 0 & 3 & \multicolumn{2}{|l|}{1} \\
\hline & Olivedos & 1 & 3 & & 1 & 0 & 3 & 3 & 1 & 1 & 0 & 1 & 2 & 2 & 0 & 3 & 1 & - & 1 & 2 & - & 2 & - & 0 & 1 & 1 & \multicolumn{2}{|l|}{0} \\
\hline & Pedra Lavrada & 3 & 12 & & 3 & 6 & 2 & 5 & 2 & 0 & 3 & 2 & 5 & 3 & 1 & 3 & 1 & 9 & 13 & 13 & 6 & 10 & 7 & 4 & 2 & 1 & \multicolumn{2}{|l|}{4} \\
\hline & Pocinhos & 2 & 3 & & 0 & 0 & - & 3 & 0 & 3 & 2 & 0 & 2 & 3 & 0 & 0 & 0 & 0 & 0 & 0 & 0 & 0 & 0 & 0 & 0 & 0 & \multicolumn{2}{|l|}{0} \\
\hline & Queimadas & - & 19 & & 7 & 22 & 17 & 25 & 2 & 13 & 13 & 11 & 19 & 9 & 3 & 14 & 20 & 18 & 4 & 6 & 7 & 7 & 1 & 2 & 2 & 0 & \multicolumn{2}{|l|}{0} \\
\hline & Seridó/São Vicente do Seridó & 0 & 11 & & 0 & 4 & 0 & 0 & - & 0 & 3 & 0 & - & - & - & - & - & - & - & - & - & - & - & - & - & - & \\
\hline & Soledade & 18 & 14 & & 8 & 7 & 7 & 12 & 4 & 7 & 11 & 5 & 14 & 8 & 7 & 8 & 3 & 11 & 8 & 7 & 11 & - & 17 & - & 7 & 0 & \multicolumn{2}{|l|}{6} \\
\hline 2011 & Município & s1 & s2 & s3 & s4 & s5 & $s 6$ & s7 & s8 & s9 s & s10 & s11 & s12 & s13s & s14 & s15 & s16 & $\mathrm{s} 17$ & s18 & s19 & s20 & s21 & s22 & s23 & s24 & s25 & $s 26$ & s27 \\
\hline & Acari & 6 & 6 & 0 & 7 & 5 & 14 & 20 & 16 & 8 & 7 & 5 & 21 & 21 & 21 & 16 & 17 & 9 & 20 & 9 & 20 & 7 & 11 & 9 & 3 & 8 & 13 & 8 \\
\hline & Açu & 51 & 72 & 127 & 80 & - & - & - & - & - & - & - & - & - & 16 & 15 & 20 & 21 & 15 & 14 & 18 & 12 & 31 & 17 & 10 & 16 & 14 & 15 \\
\hline & Almino Afonso & 1 & 0 & 2 & 2 & 1 & 1 & 1 & 2 & 2 & 2 & 2 & 3 & 3 & 3 & 3 & 3 & 3 & 3 & 3 & 3 & 2 & 0 & 4 & 3 & 0 & 5 & 0 \\
\hline & Angicos & 2 & 17 & 16 & 5 & 1 & 16 & 37 & 32 & 3 & 7 & 9 & 16 & 3 & 11 & 1 & 6 & 3 & 4 & 3 & 5 & 7 & 1 & 11 & 10 & 8 & 4 & 4 \\
\hline & Augusto Severo & 2 & 3 & 5 & 6 & 0 & 5 & 8 & 9 & 6 & 5 & 9 & 3 & 7 & 4 & 2 & 1 & 2 & 0 & 2 & 5 & 1 & 1 & 2 & 1 & 1 & 2 & 2 \\
\hline & Barcelona & 0 & 9 & 3 & 9 & 22 & 15 & 19 & 14 & 12 & 3 & 5 & 5 & 3 & 1 & 2 & 0 & 1 & 3 & 2 & 1 & 4 & 4 & 0 & 4 & 1 & 2 & 0 \\
\hline & Bodó & 1 & 3 & 3 & 2 & 3 & 2 & 2 & 2 & 6 & 0 & 1 & 2 & 0 & 0 & 0 & 0 & 2 & 2 & 1 & 1 & 0 & 1 & 2 & 0 & 0 & 0 & 1 \\
\hline & Bom Jesus & 4 & 7 & 27 & 37 & - & 26 & - & 19 & 28 & 25 & 19 & 15 & 10 & 2 & 6 & 7 & 6 & 7 & 3 & 11 & 5 & 12 & 8 & 8 & 9 & 12 & 1 \\
\hline & Caiçara do Rio do Vento & 9 & 6 & 19 & 16 & 22 & 21 & 7 & 9 & 10 & 12 & 5 & 0 & 0 & 5 & 6 & 7 & 2 & 0 & 3 & 4 & 3 & 3 & 2 & 5 & 0 & 0 & 0 \\
\hline & Caicó & 14 & 30 & 31 & 38 & 30 & 22 & 47 & 74 & 5 & 54 & 60 & 16 & 82 & 8 & 22 & 4 & 8 & 21 & 3 & 46 & 8 & 11 & 4 & 11 & 4 & 4 & 17 \\
\hline & Campo Redondo & 0 & 0 & 0 & 0 & 12 & 1 & 45 & 40 & 18 & 23 & 19 & 4 & 16 & 13 & 5 & 0 & 12 & 8 & 8 & 11 & 10 & 0 & 13 & 0 & 12 & 12 & 21 \\
\hline & Coronel Ezequiel & 0 & 1 & 1 & 1 & 1 & 1 & 1 & 3 & 1 & 4 & 0 & 0 & 0 & 0 & 0 & 2 & 0 & 0 & 0 & 0 & 0 & 0 & 1 & 1 & 0 & 0 & 0 \\
\hline & Currais Novos & 0 & 0 & 0 & 0 & 0 & 0 & 0 & 0 & 0 & 0 & 0 & 0 & 0 & 0 & 0 & 0 & 0 & 0 & 0 & 0 & 0 & 0 & 0 & 0 & 1 & 0 & 0 \\
\hline & Fernando Pedroza & 1 & 3 & - & 0 & 3 & 2 & 2 & 3 & 0 & 0 & 1 & 2 & 1 & 0 & 0 & 0 & 0 & 0 & 0 & 0 & 0 & 0 & 0 & 0 & 0 & 0 & 0 \\
\hline & Florânia & 0 & 0 & 5 & 5 & 5 & 12 & 14 & 6 & 22 & 11 & 8 & 4 & 3 & 1 & 0 & 0 & 0 & 1 & 1 & 1 & 0 & 0 & 0 & 1 & 1 & 1 & 0 \\
\hline & lelmo Marinho & 7 & 2 & 3 & 12 & 13 & 10 & 27 & 26 & 6 & 7 & 0 & 7 & 8 & 4 & 5 & 6 & 1 & 3 & 2 & 3 & 8 & 14 & 5 & 7 & 3 & 4 & 1 \\
\hline & Itajá & 4 & 11 & 0 & 0 & 0 & 1 & 1 & 0 & 1 & 0 & 0 & 0 & 0 & 0 & 0 & - & 0 & 0 & 0 & 0 & 0 & 0 & 0 & 0 & 0 & 0 & 0 \\
\hline & Jaçanã & 0 & 0 & 0 & 4 & 0 & 4 & 11 & 6 & 7 & 7 & 4 & 15 & 15 & 9 & 5 & 0 & 5 & 2 & 2 & 0 & 0 & 0 & 2 & 3 & 1 & 4 & 0 \\
\hline & Janduís & 0 & 0 & 0 & 0 & 0 & 0 & 0 & 0 & 0 & 0 & 0 & 0 & 0 & 0 & 0 & 0 & 0 & 0 & 0 & 0 & 0 & 0 & 0 & 0 & 0 & 0 & 0 \\
\hline & Januário Cicco & 3 & 8 & 8 & 25 & 21 & 19 & 28 & 47 & 35 & 19 & 16 & 9 & 6 & 7 & 11 & 5 & 3 & 12 & 8 & 8 & 8 & 6 & 3 & 8 & 3 & 7 & 1 \\
\hline & Japi & 0 & 0 & 0 & 3 & 0 & 0 & 0 & 0 & 13 & 0 & 0 & 5 & 0 & 0 & 10 & 0 & 3 & 0 & 0 & 0 & 0 & 0 & 0 & 0 & 0 & 0 & 0 \\
\hline & Jardim de Angicos & - & 7 & 6 & 2 & 7 & 6 & 11 & 4 & 3 & 3 & 2 & 1 & 0 & 0 & 0 & 0 & 0 & 0 & 0 & 0 & 0 & 0 & 0 & 0 & 0 & 0 & 0 \\
\hline
\end{tabular}




\begin{tabular}{|c|c|c|c|c|c|c|c|c|c|c|c|c|c|c|c|c|c|c|c|c|c|c|c|c|c|c|c|c|}
\hline 2011 & Município & s1 & s2 & s3 & s4 & s5 & s6 & s7 & s8 & s9 & s10 & s11 & s12 & $s 13$ & s14 & s15 & s16 & s17 & $s 18$ & s19 & s20 & s21 & s22 & s23 & s24 & s25 & $s 26$ & s27 \\
\hline & Lagoa d'Anta & 0 & 0 & 3 & 3 & 6 & 15 & 16 & 15 & 17 & 22 & 10 & 10 & 12 & 17 & 11 & 5 & 3 & 3 & 3 & 3 & 0 & 4 & 2 & 2 & 0 & 0 & 2 \\
\hline & Lagoa de Pedras & 3 & 4 & 7 & 7 & 7 & 4 & 5 & 4 & 5 & 5 & 2 & 2 & 4 & 3 & 1 & 2 & 4 & 2 & 2 & 2 & 3 & 2 & 4 & 4 & 0 & 4 & 3 \\
\hline & Lagoa de Velhos & 0 & 5 & 4 & 4 & 4 & 5 & 9 & 4 & 7 & 5 & 1 & 1 & 2 & 2 & 0 & 2 & 0 & 0 & 1 & 3 & 5 & 1 & 2 & 2 & 3 & 5 & 1 \\
\hline & Lagoa Nova & 2 & 1 & 3 & 0 & 0 & 0 & 2 & 0 & 0 & 0 & 0 & 2 & 6 & 0 & 1 & 0 & 0 & 0 & 7 & 1 & 0 & 0 & 2 & 2 & 2 & 0 & 0 \\
\hline & Lagoa Salgada & 9 & 15 & 13 & 28 & 40 & 40 & 25 & 38 & 23 & 12 & 15 & 16 & 6 & 16 & 12 & 6 & 9 & 0 & 12 & 0 & 0 & 2 & 5 & 6 & 12 & 3 & - \\
\hline & Lajes & 15 & 17 & 0 & 0 & 18 & 3 & 22 & 43 & 28 & 8 & 22 & 4 & 15 & 6 & 9 & 7 & 5 & 5 & 3 & 13 & 5 & 2 & 0 & 0 & 3 & 8 & 1 \\
\hline & Lajes Pintadas & 1 & 2 & 1 & 1 & 2 & 2 & 2 & 2 & 5 & 5 & 2 & 2 & 0 & 4 & 1 & 0 & 1 & 0 & 2 & 1 & 2 & 0 & 1 & 1 & 0 & 0 & 0 \\
\hline & Messias Targino & 5 & 0 & 5 & 8 & 1 & 7 & 13 & 16 & 12 & 3 & 8 & 0 & 4 & 4 & 3 & 3 & - & 0 & 2 & 0 & 0 & 0 & 0 & 1 & 5 & - & 0 \\
\hline & Monte Alegre & - & - & 2 & 25 & 25 & - & 22 & 45 & - & - & - & - & - & - & - & - & - & - & - & - & - & - & - & - & - & - & - \\
\hline & Monte das Gameleiras & 0 & 4 & 2 & 3 & 2 & 7 & 3 & 5 & 2 & 6 & 3 & 0 & 2 & 3 & 2 & 0 & 0 & 1 & 0 & 1 & 6 & 2 & 1 & 1 & 0 & 0 & 3 \\
\hline & Paraú & - & 0 & 0 & 0 & 0 & 0 & 0 & 3 & 4 & 0 & 2 & 2 & 2 & 2 & 0 & 0 & 4 & 0 & 2 & 0 & 2 & 3 & 0 & 0 & 0 & 2 & 1 \\
\hline & Passa e Fica & 7 & 5 & 6 & 9 & 6 & 9 & 12 & 9 & 13 & 8 & 6 & 8 & 9 & 5 & 7 & 5 & 4 & 5 & 3 & 3 & 3 & 1 & 3 & 1 & 2 & 0 & 0 \\
\hline & Patu & 4 & 0 & 0 & 6 & 0 & 3 & 5 & 0 & 0 & 0 & 2 & 0 & 0 & 0 & 2 & 0 & 0 & 2 & 0 & 0 & 0 & 0 & 0 & 0 & 0 & 0 & 0 \\
\hline & Pedra Preta & 0 & 3 & 6 & 2 & 0 & 4 & 10 & 7 & 4 & 7 & 7 & 0 & 2 & 1 & 2 & 0 & 2 & 0 & 0 & 0 & 5 & 0 & 0 & 4 & 0 & 0 & 0 \\
\hline & Pedro Avelino & 4 & 14 & 15 & 14 & 1 & 9 & 8 & 2 & 6 & 0 & 0 & 1 & 0 & 0 & 0 & 0 & 1 & 0 & 0 & 0 & 0 & 0 & 0 & 0 & 0 & 0 & 0 \\
\hline & Presidente Juscelino & 10 & 11 & 15 & 18 & 20 & 10 & 39 & 54 & 65 & 34 & 26 & 29 & 21 & 24 & 20 & 14 & 7 & 8 & 14 & 14 & 5 & 22 & 6 & 1 & 5 & 6 & 9 \\
\hline & Riachuelo & 0 & 3 & 2 & 10 & 6 & 13 & 16 & 17 & 16 & 6 & 13 & 7 & 10 & 10 & 3 & 5 & 4 & 7 & 2 & 5 & 1 & 6 & 2 & 5 & 0 & 6 & 3 \\
\hline & Ruy Barbosa & 0 & 0 & 0 & 13 & 11 & 24 & 16 & 14 & 22 & 6 & 14 & 6 & 7 & 4 & 4 & 4 & 6 & 3 & 9 & 5 & 3 & 5 & 3 & 3 & 1 & 1 & 11 \\
\hline & Santa Cruz & 92 & 107 & 75 & 105 & 132 & 138 & 192 & 167 & 140 & 171 & 133 & 87 & 68 & 51 & 31 & 40 & 31 & 46 & 44 & 33 & 40 & 42 & 39 & 42 & 33 & 55 & 41 \\
\hline & Santa Maria & 0 & 0 & 0 & 0 & 12 & 11 & 12 & 6 & 6 & 7 & 0 & 0 & 0 & 0 & 0 & 0 & 0 & 0 & 0 & 0 & 0 & 0 & 0 & 0 & 0 & 0 & 0 \\
\hline & Santana do Matos & 6 & 1 & 6 & 5 & 3 & 4 & 6 & 7 & 5 & 6 & 4 & 1 & 5 & 11 & 2 & 7 & 4 & 8 & 4 & 8 & 7 & 4 & 7 & 8 & 3 & 4 & 2 \\
\hline & São Bento do Trairi & 0 & 0 & 2 & 0 & 2 & 8 & 0 & 3 & 1 & 4 & 5 & 2 & 1 & 0 & 0 & 0 & 1 & 1 & 3 & 1 & 5 & 2 & 2 & 4 & 6 & 0 & 2 \\
\hline & São José do Campestre & 20 & 14 & 13 & 11 & 12 & 17 & 44 & 77 & 41 & 30 & 30 & 24 & 15 & 13 & 14 & 12 & 3 & 11 & 7 & 6 & 15 & 16 & 8 & 7 & 20 & 9 & - \\
\hline & São Paulo do Potengi & 3 & 8 & 6 & 15 & 14 & 17 & 24 & 30 & 13 & 0 & 34 & 8 & 14 & 6 & 2 & 7 & 3 & 2 & 2 & 0 & 5 & 0 & 4 & 5 & 0 & 6 & 2 \\
\hline & São Pedro & 9 & 15 & 16 & 10 & 12 & 15 & 22 & 13 & 7 & 5 & 6 & 10 & 13 & 10 & 2 & 2 & 6 & 4 & 2 & 6 & 5 & 3 & 6 & 5 & 5 & 4 & 1 \\
\hline & São Rafael & - & - & - & - & - & - & - & - & - & - & - & - & - & - & - & - & - & - & - & - & - & - & - & - & - & - & - \\
\hline & São Tomé & 17 & 4 & 10 & 7 & 4 & 6 & 17 & 2 & 12 & 12 & 26 & 2 & 8 & 12 & 3 & 4 & 5 & 2 & 2 & 1 & 4 & 12 & 2 & 8 & 1 & 2 & 5 \\
\hline & São Vicente & 0 & 6 & 2 & 0 & 5 & 5 & 9 & 4 & 0 & 4 & 3 & 4 & 0 & 0 & 0 & 0 & 0 & 0 & 0 & 0 & 0 & 0 & 0 & 0 & 0 & 0 & 0 \\
\hline & Senador Elói de Souza & 6 & 7 & 3 & 8 & 6 & 6 & 7 & 3 & 3 & 5 & 3 & 4 & 2 & 4 & 2 & 0 & 3 & 2 & 4 & 0 & 4 & 1 & 4 & 0 & 3 & 2 & 2 \\
\hline & Serra de São Bento & 1 & 7 & 0 & 2 & 3 & 2 & 0 & 1 & 3 & 0 & 1 & 0 & 0 & 1 & 1 & 2 & 17 & 3 & 2 & 8 & - & - & - & - & - & - & - \\
\hline & Serrinha & 0 & 4 & 1 & 3 & 7 & 0 & 2 & 27 & 2 & 4 & 8 & 2 & 1 & 0 & 0 & 0 & 0 & 0 & 1 & 0 & 0 & 1 & 0 & 0 & 0 & 3 & 0 \\
\hline & Sítio Novo & 2 & 2 & 3 & 1 & 0 & 6 & 0 & 5 & 5 & 0 & 5 & 13 & 18 & 2 & 2 & 7 & 2 & 5 & 5 & 3 & 3 & 2 & 3 & 4 & 0 & 0 & 2 \\
\hline & Tangará & 4 & 1 & 0 & 1 & 6 & 17 & 19 & 5 & 5 & 13 & 5 & - & - & 0 & 0 & 0 & 0 & 0 & 0 & 2 & 0 & 0 & 0 & 0 & 0 & 5 & 0 \\
\hline & Tenente Laurentino Cruz & 0 & 0 & 4 & 5 & 12 & 11 & 5 & 0 & 2 & 2 & 4 & 8 & 6 & 5 & 0 & 0 & 0 & 2 & 0 & 1 & 0 & 2 & 5 & 0 & 0 & 0 & 0 \\
\hline & Triunfo Potiguar & 5 & 4 & 0 & 0 & 2 & 1 & 8 & - & - & 5 & 0 & 3 & 1 & 1 & 3 & 1 & 0 & 0 & 1 & 0 & 0 & 0 & 1 & 1 & 2 & 1 & 0 \\
\hline & Alagoa Nova & 25 & - & 15 & 18 & 26 & 38 & 37 & 15 & 25 & 43 & 42 & 55 & 35 & 52 & 24 & 27 & 22 & 27 & 20 & 18 & 27 & 17 & 11 & 13 & 25 & 11 & 9 \\
\hline & Barra de Santana & 1 & 1 & 0 & 4 & 1 & 1 & 3 & 3 & 3 & 0 & 5 & 7 & 5 & 7 & 7 & 0 & 1 & 0 & 0 & 2 & 1 & 3 & 1 & 1 & 0 & 1 & 1 \\
\hline
\end{tabular}




\begin{tabular}{|c|c|c|c|c|c|c|c|c|c|c|c|c|c|c|c|c|c|c|c|c|c|c|c|c|c|c|c|c|}
\hline 2011 & Município & s1 & s2 & s3 & s4 & s5 & s6 & s7 & s8 & s9 & $s 10$ & s11 & s12 & s13 & s14 & s15 & s16 & s17 & s18 & s19 & s20 & s21 & s22 & s23 & s24 & s25 & s26 & s27 \\
\hline & Boa Vista & 3 & 4 & 5 & 5 & 3 & 3 & 2 & 9 & 6 & 12 & 6 & 4 & 2 & 10 & 5 & 4 & 3 & 3 & 4 & 6 & 3 & 6 & 3 & 0 & 5 & 4 & 3 \\
\hline & Boqueirão & 9 & 14 & 9 & 4 & 6 & 11 & 10 & 3 & 12 & 9 & 12 & 1 & 3 & 2 & 2 & 1 & 3 & 3 & 6 & 4 & 7 & 16 & 21 & 23 & 8 & 5 & 16 \\
\hline & Cabaceiras & 0 & 0 & 0 & 0 & 0 & 0 & 6 & 14 & 0 & 7 & 9 & 10 & 11 & 13 & 8 & 9 & 5 & 3 & 15 & 11 & 17 & 6 & 11 & 9 & 9 & 6 & 7 \\
\hline & Campina Grande & 32 & 37 & 55 & 54 & 93 & 109 & 80 & 126 & 86 & 52 & 125 & 202 & 104 & 144 & 74 & 83 & 61 & 48 & 88 & 86 & 72 & 94 & 86 & 86 & - & 85 & 71 \\
\hline & Caturité & 0 & 0 & 0 & 0 & 0 & 0 & 1 & 1 & 1 & 1 & 0 & 1 & 0 & 0 & 1 & 2 & 3 & 1 & 2 & 2 & 0 & 0 & 2 & 1 & 0 & 0 & 0 \\
\hline & Cubati & 11 & 13 & 7 & 17 & 9 & 12 & 17 & 21 & 8 & 5 & 28 & 16 & 17 & 24 & 17 & 20 & 16 & 7 & 11 & 5 & 7 & 8 & 7 & 7 & 3 & 5 & 2 \\
\hline & Juazeirinho & 4 & 30 & 42 & 31 & 19 & 10 & 18 & 10 & 3 & 22 & 40 & 36 & 25 & 40 & 26 & 27 & 11 & 24 & 12 & 41 & 13 & 18 & 9 & 24 & 11 & 28 & 10 \\
\hline & Lagoa Seca & 8 & 15 & 7 & 2 & 8 & 9 & 8 & 16 & 9 & 6 & 10 & 9 & 6 & 20 & 13 & 10 & 6 & 6 & 8 & 6 & 6 & 7 & 5 & 6 & 4 & 4 & 7 \\
\hline & Matinhas & 2 & 3 & 1 & 2 & 0 & 0 & 0 & 0 & 0 & 5 & 2 & 4 & 3 & 4 & 1 & 1 & 2 & 2 & 1 & 3 & 2 & 1 & 2 & 0 & 2 & 1 & 2 \\
\hline & Olivedos & 1 & 2 & 2 & 2 & 0 & 0 & 1 & 3 & 7 & 4 & 9 & 7 & 4 & 5 & 5 & 3 & 3 & 2 & 0 & 2 & 4 & 5 & 1 & 0 & 1 & 2 & 1 \\
\hline & Pedra Lavrada & 5 & 5 & 3 & 2 & 6 & 5 & 8 & 6 & 8 & 11 & 10 & 15 & 11 & 8 & 3 & 7 & 7 & 1 & 4 & 4 & 5 & 3 & 2 & 3 & 4 & 2 & 5 \\
\hline & Pocinhos & 0 & 0 & 1 & 0 & 0 & 0 & 6 & 3 & 0 & 0 & 2 & 0 & 0 & 0 & 1 & 1 & 8 & 0 & 0 & 0 & 0 & 0 & 0 & 0 & 1 & 1 & 0 \\
\hline & Queimadas & 0 & 4 & 35 & 7 & 13 & 28 & 64 & 32 & 26 & 24 & 29 & 27 & 26 & 26 & 40 & 16 & 1 & 8 & 6 & 11 & 8 & 13 & 16 & 12 & 3 & 5 & 6 \\
\hline & Seridó/São Vicente do Seridó & 73 & 0 & 22 & 18 & 0 & 4 & 27 & 42 & 19 & 0 & 14 & 0 & 0 & 0 & 25 & 5 & 21 & 0 & 0 & 0 & 0 & 0 & 0 & 0 & 0 & 0 & 0 \\
\hline & Soledade & 14 & 23 & 39 & 18 & 13 & 8 & 23 & 29 & 6 & 23 & 29 & 27 & 23 & 10 & 27 & 2 & 3 & 17 & 9 & 7 & 4 & 9 & 5 & 15 & 12 & 10 & 9 \\
\hline
\end{tabular}

\begin{tabular}{|c|c|c|c|c|c|c|c|c|c|c|c|c|c|c|c|c|c|c|c|c|c|c|c|c|c|c|}
\hline 2011 & Município & s28 & s29 & s30 & s31 & s32 & s33 & s34 & s35 & s36 & s37 & s38 & s39 & $s 40$ & s41 & s42 & s43 & s44 & $s 45$ & $s 46$ & s47 & $s 48$ & $s 49$ & $s 50$ & s51 & s52 \\
\hline & Acari & 6 & 16 & 8 & 12 & 14 & 12 & 7 & 14 & 13 & 14 & 2 & 12 & 20 & 20 & 10 & 16 & 17 & 21 & 11 & 14 & 4 & 10 & 15 & 15 & 13 \\
\hline & Açu & 25 & 7 & 21 & 22 & 28 & 17 & 16 & 15 & 19 & 16 & 8 & 6 & 3 & 11 & 17 & 10 & 14 & 16 & 0 & 15 & 11 & 15 & 6 & - & - \\
\hline & Almino Afonso & 3 & 4 & 3 & 2 & 4 & 3 & 2 & 4 & - & - & - & - & 4 & - & 4 & 3 & 3 & - & 2 & 2 & 2 & 3 & 3 & 3 & 3 \\
\hline & Angicos & 6 & 10 & 2 & 3 & 2 & 0 & 9 & 1 & 1 & 4 & 4 & 6 & 7 & 2 & 4 & 2 & 3 & 5 & 1 & 5 & 1 & 1 & 3 & 1 & 0 \\
\hline & Augusto Severo & 0 & 1 & 1 & 2 & 2 & 1 & 3 & 0 & 2 & 1 & 3 & 2 & 2 & 1 & 0 & 3 & 2 & 2 & 3 & 1 & 0 & 1 & 1 & 2 & 2 \\
\hline & Barcelona & 3 & 4 & 3 & 6 & 6 & 3 & 0 & 1 & 0 & 3 & 3 & 3 & 1 & 0 & 2 & 0 & 1 & 5 & 3 & 2 & 2 & 3 & 3 & 0 & 6 \\
\hline & Bodó & 1 & 0 & 0 & 1 & 0 & 1 & 1 & 3 & 0 & 0 & 1 & 0 & 0 & 0 & 0 & 2 & 0 & 0 & 1 & 0 & 0 & 0 & 0 & 2 & 0 \\
\hline & Bom Jesus & 16 & 1 & 2 & 1 & 9 & 7 & 2 & 13 & 6 & 7 & 8 & 3 & 8 & 6 & 10 & 8 & 10 & 7 & 2 & 8 & 6 & 11 & 8 & 7 & 7 \\
\hline & Caiçara do Rio do Vento & 4 & 5 & 3 & 3 & 2 & 2 & 1 & 2 & 4 & 0 & 0 & 2 & 1 & 3 & 6 & 2 & 6 & 1 & 4 & 1 & 1 & 1 & 3 & 0 & 4 \\
\hline & Caicó & 9 & 12 & 13 & 4 & 14 & 5 & 46 & 17 & 0 & 13 & 8 & 4 & 2 & 0 & 9 & 5 & 4 & 1 & 10 & 2 & 8 & 1 & 6 & 2 & 2 \\
\hline & Campo Redondo & 0 & 7 & 12 & 0 & 7 & 0 & 6 & 7 & 12 & 0 & 0 & 0 & 8 & 9 & 4 & 0 & 13 & 0 & 12 & 8 & 8 & 12 & 11 & 0 & 0 \\
\hline & Coronel Ezequiel & 0 & 0 & 0 & 0 & 1 & 1 & - & 1 & 0 & 0 & 0 & 0 & 0 & 0 & - & 0 & 0 & 0 & 0 & 0 & 0 & - & - & 0 & - \\
\hline & Currais Novos & - & 0 & 0 & 2 & 0 & 0 & 1 & 0 & 0 & 3 & 0 & 3 & 0 & 0 & 35 & 0 & 3 & 1 & 22 & 40 & 22 & 25 & 19 & 16 & - \\
\hline & Fernando Pedroza & 0 & 0 & 0 & 0 & 0 & 0 & 0 & 0 & 0 & 0 & 0 & 1 & 0 & 0 & 0 & 0 & 0 & 0 & 0 & 0 & 0 & 0 & 0 & 6 & 0 \\
\hline & Florânia & 3 & 0 & 0 & 0 & 0 & 0 & 1 & 0 & 1 & 0 & 0 & 0 & 0 & 0 & 4 & 0 & 0 & 0 & 0 & 0 & 0 & 0 & 0 & 0 & 1 \\
\hline & lelmo Marinho & 2 & 3 & 3 & 1 & 2 & 2 & 2 & 1 & 3 & 5 & 6 & 0 & 2 & 6 & 3 & 4 & 6 & 5 & 5 & 6 & 4 & 0 & 8 & 6 & 8 \\
\hline & Itajá & 1 & 0 & 0 & 0 & 0 & 0 & 0 & 0 & 0 & 0 & 0 & 0 & 0 & 0 & 0 & - & - & - & - & - & - & - & - & - & - \\
\hline & Jaçanã & 0 & 2 & 0 & 0 & 2 & 3 & 0 & 3 & 0 & 0 & 0 & 0 & 0 & 0 & 0 & 0 & 0 & 0 & 0 & 2 & 2 & 0 & 1 & - & 0 \\
\hline & Janduís & 4 & 0 & 0 & 0 & 0 & 0 & 0 & 0 & 0 & 3 & 0 & 0 & 0 & 0 & 3 & 3 & 1 & 0 & 6 & 4 & 12 & 0 & 0 & 0 & 15 \\
\hline & Januário Cicco & 12 & 6 & 10 & 2 & 8 & 6 & 7 & 4 & 8 & 5 & 3 & 6 & 9 & 10 & 4 & 9 & 5 & 4 & 6 & 4 & 2 & 3 & 2 & 5 & 5 \\
\hline
\end{tabular}




\begin{tabular}{|c|c|c|c|c|c|c|c|c|c|c|c|c|c|c|c|c|c|c|c|c|c|c|c|c|c|c|}
\hline 2011 & Município & s28 & s29 & s30 & s31 & s32 & s33 & s34 & s35 & s36 & s37 & s38 & s39 & $s 40$ & s41 & s42 & s43 & s44 & s45 & s46 & s47 & $s 48$ & $s 49$ & s50 & $s 51$ & s52 \\
\hline & Japi & 0 & 0 & 0 & 4 & 0 & 0 & 0 & 4 & 0 & 4 & 0 & 0 & 2 & 2 & 0 & 0 & 0 & 0 & 0 & 0 & 0 & 0 & 0 & 0 & 0 \\
\hline & Jardim de Angicos & 0 & 0 & 0 & 0 & 0 & 0 & 0 & 0 & 0 & 0 & 0 & 0 & 0 & 0 & 0 & 0 & 0 & 0 & 0 & 0 & 0 & 0 & 0 & 0 & 0 \\
\hline & Lagoa d'Anta & 5 & 2 & 0 & 0 & 2 & 6 & 4 & 3 & 4 & 0 & 0 & - & 0 & 0 & 2 & 14 & 8 & - & 5 & 4 & 1 & 5 & 3 & 3 & 3 \\
\hline & Lagoa de Pedras & - & - & - & - & 1 & 3 & 2 & 3 & 3 & 0 & 0 & 1 & 1 & 2 & 4 & 2 & 0 & 4 & 1 & 4 & 4 & 2 & 0 & 0 & 2 \\
\hline & Lagoa de Velhos & 1 & 3 & 3 & 4 & 0 & 1 & 0 & 0 & 0 & 0 & 0 & 1 & 0 & 0 & 0 & 0 & 0 & 3 & 1 & 2 & 0 & 0 & 0 & 1 & 0 \\
\hline & Lagoa Nova & 0 & 0 & 0 & 0 & 0 & 3 & 0 & 0 & 0 & 8 & 3 & 0 & 2 & 0 & 0 & 3 & 0 & 0 & 0 & 0 & 0 & 4 & 0 & 0 & 0 \\
\hline & Lagoa Salgada & 8 & 7 & 5 & 6 & 4 & 3 & 0 & 4 & 1 & 0 & 0 & 0 & 0 & 3 & 9 & 7 & 3 & 2 & 2 & 5 & 4 & 5 & 2 & 4 & 7 \\
\hline & Lajes & 0 & 0 & 6 & 11 & 0 & 4 & 2 & 0 & 2 & 3 & 0 & 3 & 11 & 5 & 29 & 2 & 4 & 3 & 2 & 0 & 0 & 0 & 0 & 0 & 0 \\
\hline & Lajes Pintadas & 3 & 2 & 1 & 1 & 2 & 1 & 0 & 1 & 1 & 2 & 3 & 2 & 1 & 2 & 1 & 1 & 2 & 4 & 1 & 1 & 2 & 2 & - & 2 & 1 \\
\hline & Messias Targino & 0 & - & 1 & 0 & 0 & 0 & 0 & 1 & 2 & 0 & 1 & 0 & 1 & 1 & 0 & 0 & 0 & 1 & 6 & - & 0 & 4 & 0 & 0 & 7 \\
\hline & Monte Alegre & - & - & - & - & - & - & - & - & - & - & - & - & - & - & - & - & - & - & - & - & - & - & - & - & - \\
\hline & Monte das Gameleiras & 1 & 1 & 1 & 1 & 3 & 3 & 0 & 1 & 4 & 2 & 2 & 0 & 6 & 2 & 0 & 1 & 0 & 1 & 2 & 1 & 1 & 1 & 2 & 0 & 0 \\
\hline & Paraú & 0 & 0 & 2 & 0 & 2 & 0 & 0 & 0 & 0 & 0 & 0 & - & 0 & 0 & 0 & 0 & 0 & 0 & 0 & 0 & 2 & 1 & 0 & 3 & 0 \\
\hline & Passa e Fica & 1 & 2 & 0 & 0 & 3 & 2 & 0 & 2 & 2 & 0 & 3 & 0 & 5 & 2 & 0 & 2 & 4 & 0 & 2 & 3 & 3 & 2 & 0 & 3 & 4 \\
\hline & Patu & 0 & 0 & 0 & 0 & 0 & 0 & 2 & 1 & 0 & 0 & 0 & 0 & 0 & 0 & 0 & 1 & 0 & 0 & 0 & 1 & 0 & 0 & 0 & 0 & 0 \\
\hline & Pedra Preta & 0 & 3 & 0 & 0 & 0 & 0 & 0 & 0 & 0 & 3 & 0 & 2 & 0 & 1 & 3 & 0 & 0 & 4 & 0 & 5 & 0 & 0 & 1 & 2 & 0 \\
\hline & Pedro Avelino & 0 & 2 & 0 & 0 & 0 & 0 & 1 & 0 & 0 & 0 & 0 & 0 & 0 & 0 & 1 & 0 & 0 & 0 & 0 & 0 & 0 & 1 & 0 & 1 & 0 \\
\hline & Presidente Juscelino & 1 & 0 & 4 & 6 & 8 & 16 & 13 & 11 & 10 & 8 & 6 & 3 & 4 & 3 & 4 & 8 & 3 & 21 & 5 & 7 & 10 & 5 & 0 & 11 & 13 \\
\hline & Riachuelo & 7 & 14 & 7 & 5 & 1 & 7 & 3 & 1 & 1 & 4 & 1 & 4 & 2 & 4 & 0 & 14 & 4 & 3 & 3 & 1 & 7 & 4 & 9 & 2 & 4 \\
\hline & Ruy Barbosa & 6 & 0 & 2 & 0 & 3 & 1 & 0 & 1 & 0 & 0 & 4 & 5 & 3 & 2 & 4 & 0 & 4 & 1 & 1 & 2 & 0 & 1 & 1 & 0 & 0 \\
\hline & Santa Cruz & 51 & 67 & 53 & 38 & 45 & 35 & 46 & 32 & 40 & 27 & 38 & 29 & 38 & 46 & 40 & 49 & 46 & 35 & 45 & 43 & 45 & 47 & 46 & 44 & 54 \\
\hline & Santa Maria & 0 & 0 & 0 & 0 & 0 & 0 & 0 & 0 & 0 & 0 & 2 & 0 & 0 & 1 & 4 & 0 & 0 & 0 & 2 & 4 & 3 & 2 & 4 & 6 & - \\
\hline & Santana do Matos & 0 & 4 & 4 & 2 & 6 & 3 & 4 & 5 & 1 & 6 & 7 & 4 & 3 & 5 & 5 & 5 & 2 & 3 & 2 & 1 & 2 & 3 & 2 & 2 & 2 \\
\hline & São Bento do Trairi & 1 & 1 & 0 & 5 & 1 & 1 & 0 & 2 & 4 & 1 & 0 & 1 & 3 & 1 & - & 5 & 3 & 2 & 2 & 0 & 1 & 0 & 2 & - & 1 \\
\hline & São José do Campestre & 11 & 7 & 8 & 12 & 6 & 6 & - & - & 9 & 10 & - & 12 & 7 & 6 & 8 & 12 & 12 & 12 & 11 & 10 & 7 & - & 5 & 10 & 7 \\
\hline & São Paulo do Potengi & 4 & 6 & 4 & 5 & 2 & 2 & 3 & 9 & 11 & 8 & 8 & 13 & 7 & 16 & 15 & 17 & 24 & 10 & 16 & 22 & 11 & 14 & 13 & 13 & 10 \\
\hline & São Pedro & 8 & 8 & 5 & 5 & 3 & 6 & 2 & 2 & 2 & 2 & 1 & 4 & 2 & 4 & 2 & 2 & 3 & 3 & 4 & 3 & 5 & 4 & 4 & 3 & 5 \\
\hline & São Rafael & - & - & - & - & - & - & - & - & - & - & - & - & - & - & - & - & - & - & - & - & - & - & - & - & - \\
\hline & São Tomé & 2 & 7 & 5 & 1 & 0 & 3 & 0 & 2 & 3 & 2 & 4 & 1 & 0 & 0 & 0 & 0 & 0 & 5 & 0 & 4 & 0 & 7 & 0 & 0 & 3 \\
\hline & São Vicente & 0 & 0 & 0 & 0 & 0 & 0 & 0 & 0 & 0 & 0 & 0 & 0 & 0 & 0 & 0 & 0 & 0 & 0 & 0 & 0 & 0 & 0 & 0 & 0 & 0 \\
\hline & Senador Elói de Souza & 4 & 2 & 5 & 2 & 3 & 3 & 0 & 2 & 2 & 4 & 2 & 0 & 3 & 10 & 8 & 8 & 6 & 7 & 8 & 4 & 4 & 6 & 3 & 2 & 4 \\
\hline & Serra de São Bento & - & - & - & - & - & - & - & - & - & - & - & - & - & - & - & - & - & - & - & - & - & - & - & - & - \\
\hline & Serrinha & 0 & 0 & 3 & 0 & 4 & 0 & 0 & 0 & 0 & 0 & 0 & 0 & 0 & 2 & 2 & 1 & 0 & 0 & 0 & 0 & 0 & 0 & 0 & - & - \\
\hline & Sítio Novo & 2 & 1 & 8 & 1 & 3 & 0 & 4 & 2 & 2 & 2 & 4 & 2 & 0 & 0 & 1 & 1 & 0 & 0 & 1 & 3 & 1 & 0 & 0 & 0 & 0 \\
\hline & Tangará & 2 & 0 & 5 & - & - & - & - & - & - & - & - & - & - & 26 & 6 & - & 0 & 0 & 0 & 0 & 0 & 0 & 0 & 0 & - \\
\hline & Tenente Laurentino Cruz & 0 & 6 & 0 & 2 & 0 & 0 & 0 & 0 & 3 & 0 & 0 & 0 & 0 & 0 & 0 & 1 & 1 & 0 & 0 & 0 & 0 & 0 & 0 & 0 & 0 \\
\hline & Triunfo Potiguar & 3 & 0 & 1 & 3 & 2 & 2 & 1 & 1 & 6 & 0 & 0 & 1 & 5 & - & 4 & 1 & 4 & - & - & 5 & 4 & 2 & 5 & 1 & 0 \\
\hline
\end{tabular}




\begin{tabular}{|c|c|c|c|c|c|c|c|c|c|c|c|c|c|c|c|c|c|c|c|c|c|c|c|c|c|c|}
\hline 2011 & Município & s28 & s29 & s30 & s31 & s32 & s33 & s34 & s35 & s36 & s37 & s38 & s39 & $s 40$ & s41 & s42 & s43 & s44 & s45 & s46 & s47 & $s 48$ & s49 & s50 & s51 & s52 \\
\hline & Alagoa Nova & 8 & 17 & 12 & 18 & - & 32 & 17 & 11 & - & 15 & 10 & 13 & 5 & 17 & 12 & 6 & 13 & 9 & 24 & 23 & 9 & 15 & 33 & 22 & 14 \\
\hline & Barra de Santana & 1 & 2 & 0 & 3 & 0 & 7 & 0 & 5 & 0 & 3 & 10 & 0 & 0 & 0 & 2 & 0 & 0 & 1 & 0 & 0 & 0 & 0 & 0 & 0 & 0 \\
\hline & Boa Vista & 5 & 3 & 6 & 2 & 4 & 3 & 2 & 4 & 3 & 2 & 3 & 4 & 2 & 3 & 2 & 3 & 2 & 2 & 4 & 2 & 3 & 2 & 2 & 3 & 2 \\
\hline & Boqueirão & 4 & 0 & 4 & 14 & 6 & 6 & 10 & 0 & 4 & 1 & 20 & 5 & 4 & 12 & 0 & 4 & 2 & 13 & 0 & 13 & 4 & 10 & 8 & 10 & 3 \\
\hline & Cabaceiras & 4 & 6 & 13 & 10 & 15 & 14 & 11 & 12 & 9 & 5 & 3 & 3 & 4 & 6 & 7 & 8 & 8 & 11 & 7 & 17 & 5 & 10 & 7 & 7 & 5 \\
\hline & Campina Grande & 58 & 79 & 83 & 37 & 73 & 39 & 44 & - & 55 & 61 & 41 & 51 & 3 & 55 & 94 & 71 & 85 & 80 & 91 & 66 & 53 & 100 & 81 & 64 & 5 \\
\hline & Caturité & 2 & 0 & 0 & 0 & 0 & 0 & 0 & 0 & 0 & 0 & 0 & 0 & 1 & 0 & 0 & 0 & 0 & 0 & 0 & 0 & 0 & 0 & 0 & 0 & 0 \\
\hline & Cubati & 0 & 2 & 6 & 9 & 11 & 8 & 4 & 6 & 6 & 13 & 6 & 8 & 4 & 3 & 12 & 9 & 5 & 4 & 2 & 3 & 4 & 4 & 3 & 3 & 4 \\
\hline & Juazeirinho & 31 & 16 & 22 & 18 & 11 & 16 & 17 & 22 & 26 & 9 & 25 & 10 & 1 & 32 & 7 & 27 & 12 & 17 & 8 & 21 & 14 & 19 & 17 & 15 & 11 \\
\hline & Lagoa Seca & 4 & 5 & 3 & 0 & 2 & 12 & 6 & 8 & 5 & 8 & 5 & 6 & 0 & 6 & 8 & 0 & 6 & 10 & 8 & 6 & 9 & 19 & 8 & 9 & 8 \\
\hline & Matinhas & 2 & 2 & 3 & 3 & 1 & 3 & 4 & 2 & 3 & 4 & 5 & 2 & 4 & 1 & 3 & 2 & 3 & 1 & 1 & 1 & 3 & 4 & 2 & 1 & 7 \\
\hline & Olivedos & 0 & 0 & 2 & 1 & 0 & 1 & 0 & 0 & 1 & 1 & 0 & 0 & 0 & 1 & 0 & 1 & 2 & 0 & 2 & 1 & 0 & 1 & 1 & 0 & 1 \\
\hline & Pedra Lavrada & 5 & 6 & 8 & 6 & 3 & 7 & 5 & 9 & 6 & 5 & 6 & 0 & 2 & 2 & 4 & 2 & 5 & 1 & 4 & 2 & 0 & 3 & 1 & 4 & 2 \\
\hline & Pocinhos & 0 & 0 & 1 & 0 & 0 & 0 & 0 & 0 & 0 & 0 & 0 & 0 & 0 & 0 & 0 & 5 & 0 & 5 & 0 & 2 & 0 & 0 & 0 & 0 & 1 \\
\hline & Queimadas & 3 & 11 & 6 & 1 & 3 & 2 & 1 & 0 & 2 & 2 & 1 & 5 & 9 & 4 & 1 & 4 & 5 & 3 & 10 & 5 & 8 & 3 & 3 & 2 & 0 \\
\hline & Seridó/São Vicente do Seridó & - & 0 & 0 & 9 & 5 & 0 & 8 & 2 & 7 & 4 & 8 & 7 & 7 & 8 & - & - & 18 & 3 & 21 & - & 6 & - & - & 3 & 12 \\
\hline & Soledade & 11 & 7 & 11 & 11 & 1 & 21 & 2 & 6 & 5 & 7 & 0 & 4 & 9 & 6 & 16 & 3 & 7 & 5 & 12 & 16 & 2 & 8 & 11 & 2 & 1 \\
\hline
\end{tabular}

Município

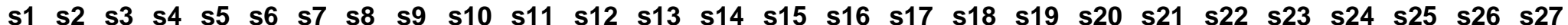
Acari Açu Angicos

Augusto Severo

Barcelona

Bodó

Bom Jesus

$\begin{array}{llllllllllccc}13 & 11 & 13 & 10 & 1 & 2 & 2 & 5 & 7 & 26 & 15 & 31 & 28\end{array}$

$\begin{array}{lllllllllllllll}11 & 14 & 8 & 21 & 8 & 16 & 18 & 23 & 25 & 0 & 44 & 28 & 27 & 41 & 30\end{array}$

$\begin{array}{lllllllllll}3 & 4 & 5 & 3 & 4 & 2 & 5 & 3 & 1 & 3 & 4\end{array}$

$\begin{array}{cccccccccc}4 & 4 & 6 & 10 & 6 & 14 & 28 & 20 & 16 & 12\end{array}$

$2 \begin{array}{cccccccccc}4 & 4 & 6 & 1 & 3 & 4 & 1 & 1 & 2 & 2\end{array}$

$\begin{array}{lllllllllll}1 & 8 & 6 & 6 & 4 & 4 & 0 & 6 & 2 & 4 & 3\end{array}$

Caiçara do Rio do Vento

Caicó

Campo Redondo

Coronel Ezequiel

Currais Novos

$\begin{array}{lllllllll}1 & 7 & 0 & 1 & 1 & 2 & 1 & 0 & 0\end{array}$

Fernando Pedroza

Florânia

$\begin{array}{llllllllll}15 & 11 & 6 & 8 & 8 & 5 & 14 & 7 & 15 & 7\end{array}$

$\begin{array}{ccccccccc}6 & 2 & 1 & 2 & 0 & 2 & 3 & 4 & 1 \\ 2 & 4 & 3 & 4 & 6 & 14 & 6 & 1 & 15\end{array}$

lelmo Marinho

$\begin{array}{ccccccccc}2 & 4 & 3 & 4 & 6 & 14 & 6 & 1 & 15 \\ 0 & 0 & 0 & 0 & 14 & 20 & 0 & 8 & 8\end{array}$

Itajá

Jaçanã

$\begin{array}{ccccccccc}25 & 26 & 29 & 35 & 42 & 64 & 50 & 39 & 42\end{array}$

$\begin{array}{lllllllll}0 & 0 & 1 & 1 & 0 & 0 & 0 & 0 & 0 \\ 5 & 0 & 2 & 3 & 6 & 3 & 0 & 8 & 9\end{array}$

$\begin{array}{lllllllll}0 & 9 & 2 & 5 & 7 & 2 & 5 & 3 & 4 \\ 0 & 0 & 0 & 0 & 0 & 0 & 0 & 0 & 0\end{array}$ 


\begin{tabular}{|c|c|c|c|c|c|c|c|c|c|c|c|c|c|c|c|c|c|c|c|c|c|c|c|c|c|c|c|c|}
\hline 2012 & Município & s1 & s2 & s3 & s4 & s5 & s6 & s7 & s8 & s9 & s10 & s11 & $s 12$ & $s 13$ & s14 & s15 & s16 & s17 & s18 & s19 & s20 & s21 & s22 & s23 & s24 & s25 & $s 26$ & s27 \\
\hline & Janduís & 7 & 0 & 0 & 2 & 8 & 0 & 7 & 0 & 5 & 10 & 5 & 15 & 26 & 5 & 10 & 5 & 0 & 4 & 6 & 5 & 2 & 0 & 4 & 0 & 4 & 0 & 0 \\
\hline & Januário Cicco & 3 & 8 & 2 & 5 & 0 & 12 & 7 & 9 & 14 & 16 & 6 & 5 & 10 & 0 & 8 & 6 & 10 & 6 & 9 & 6 & 9 & 8 & 8 & 11 & 31 & 36 & 15 \\
\hline & Japi & 0 & 0 & 0 & 0 & 5 & 6 & 4 & 10 & 3 & 8 & 12 & 18 & 7 & 5 & 12 & 2 & 13 & 11 & 2 & 6 & 2 & 4 & 2 & 11 & 10 & 25 & 20 \\
\hline & Jardim de Angicos & 0 & 0 & 0 & 0 & 4 & 3 & 0 & 0 & 0 & 0 & 0 & 0 & 0 & 0 & 0 & 0 & 0 & 0 & 0 & 0 & 0 & 0 & 0 & 0 & 0 & 0 & 0 \\
\hline & Lagoa d'Anta & 4 & 7 & 3 & 4 & - & 3 & 6 & 9 & 5 & 7 & - & - & 9 & 17 & 9 & 7 & 7 & 0 & 1 & 4 & 11 & 4 & - & 2 & - & 1 & 4 \\
\hline & Lagoa de Pedras & 4 & 3 & 2 & 2 & 1 & - & - & - & - & - & - & - & - & - & - & - & - & - & - & - & - & - & - & - & - & - & - \\
\hline & Lagoa de Velhos & 2 & 1 & 0 & 0 & 1 & 0 & 0 & 0 & 6 & 5 & 4 & 10 & 8 & 8 & 4 & 3 & 1 & 3 & 3 & 0 & 1 & 5 & 14 & 19 & 20 & 20 & 22 \\
\hline & Lagoa Nova & 1 & 3 & 1 & 0 & 0 & 0 & 0 & 1 & 0 & 4 & 5 & 0 & 0 & 0 & 0 & 0 & 0 & 0 & 0 & 0 & 0 & 0 & 0 & 5 & 0 & 0 & 2 \\
\hline & Lagoa Salgada & 8 & 7 & 17 & 2 & 16 & 7 & 11 & 9 & 1 & 5 & 4 & 4 & 2 & - & 3 & 4 & 7 & 6 & 8 & 4 & 10 & 4 & 6 & 2 & 4 & 21 & 18 \\
\hline & Lajes & 0 & 0 & 0 & 0 & 0 & 4 & 5 & 6 & 3 & 3 & 7 & 13 & 1 & 0 & 0 & 0 & 0 & 0 & 0 & 0 & 0 & 0 & 0 & 0 & 0 & 0 & 0 \\
\hline & Lajes Pintadas & 1 & 1 & 1 & 1 & 2 & 2 & 2 & 2 & 3 & 2 & 3 & 3 & 3 & 3 & 2 & 3 & 3 & 3 & 3 & 2 & 3 & 4 & 2 & 3 & 5 & 6 & 8 \\
\hline & Messias Targino & 3 & 1 & 0 & 1 & 2 & 3 & 3 & 6 & 3 & 6 & 4 & 9 & 3 & 8 & 8 & 10 & 5 & 2 & 6 & 2 & 2 & 3 & 0 & 3 & 2 & 2 & 4 \\
\hline & Monte Alegre & - & - & - & - & - & - & - & - & - & - & - & - & - & - & - & - & - & - & - & - & - & - & - & - & - & - & - \\
\hline & Monte das Gameleiras & 0 & 2 & 0 & 0 & 0 & 2 & 2 & 0 & 2 & 0 & 4 & 7 & 6 & 2 & 1 & 2 & 1 & 1 & 2 & 0 & 1 & 4 & 1 & 2 & 0 & 1 & 0 \\
\hline & Paraú & 0 & 0 & 0 & 0 & 0 & 0 & 0 & 0 & 0 & 2 & 3 & 2 & 0 & 0 & 0 & 0 & 0 & 0 & 0 & 0 & 0 & 0 & 0 & 0 & 0 & 1 & 1 \\
\hline & Passa e Fica & 4 & 5 & 0 & 2 & 4 & 0 & 4 & 0 & 2 & 2 & 3 & 3 & 7 & 4 & 4 & 4 & 4 & 2 & 0 & 0 & 2 & 0 & 3 & 3 & 3 & 5 & 2 \\
\hline & Patu & 0 & 0 & 0 & 1 & 0 & 0 & 0 & 0 & 0 & 2 & 0 & 0 & 0 & 0 & 2 & 0 & 0 & 0 & 0 & 0 & 0 & 0 & 0 & 0 & 0 & 1 & 0 \\
\hline & Pedra Preta & 0 & 0 & 2 & 0 & 0 & 1 & 2 & 0 & 0 & 2 & 0 & 3 & 3 & 0 & 3 & 0 & 0 & 1 & 4 & 2 & 3 & 2 & 4 & 7 & 5 & 4 & 1 \\
\hline & Pedro Avelino & 0 & 0 & 0 & 4 & 2 & 0 & 0 & 0 & 2 & 3 & 1 & 2 & 0 & 0 & 0 & 0 & 0 & 1 & 0 & 0 & 0 & 0 & 0 & 0 & 3 & 0 & 0 \\
\hline & Presidente Juscelino & 9 & 12 & 18 & 35 & 17 & 11 & 14 & 6 & 27 & 12 & 20 & 10 & 31 & 38 & 19 & 14 & 10 & 9 & 10 & 9 & 4 & 5 & 6 & 9 & 6 & 19 & 31 \\
\hline & Riachuelo & 0 & 0 & 0 & 0 & 5 & 8 & 7 & 7 & 1 & 4 & 7 & 7 & 3 & 4 & 7 & 7 & 10 & 6 & 11 & 2 & 1 & 5 & 4 & 8 & 15 & 11 & 17 \\
\hline & Ruy Barbosa & 0 & 0 & 11 & 1 & 6 & 5 & 7 & 1 & 2 & 4 & 8 & 7 & 0 & 0 & 16 & 6 & 0 & 15 & 5 & 0 & 0 & 2 & 3 & 1 & 10 & 12 & 8 \\
\hline & Santa Cruz & 42 & 46 & 49 & 33 & 47 & 48 & 42 & 41 & 64 & 76 & 73 & 107 & 86 & 97 & 112 & 100 & 80 & 86 & 61 & 60 & 48 & 51 & 64 & 84 & 116 & 155 & 189 \\
\hline & Santa Maria & - & 0 & 1 & 2 & 4 & - & - & 4 & 3 & - & 6 & - & 5 & 0 & 4 & 0 & 0 & 9 & 0 & 0 & 0 & 2 & 2 & 0 & 0 & 0 & 7 \\
\hline & Santana do Matos & 3 & 7 & 3 & 2 & 4 & 4 & 10 & 22 & 22 & 9 & 20 & 24 & 13 & 10 & 15 & 8 & 13 & 11 & 10 & 7 & 5 & 14 & 5 & 4 & 8 & 9 & 4 \\
\hline & São Bento do Trairi & 1 & 2 & 2 & 2 & 3 & 4 & 1 & 2 & 3 & 12 & 7 & 3 & 13 & 7 & 7 & 7 & 5 & 4 & 1 & 10 & 1 & 4 & 8 & 7 & 8 & 11 & 7 \\
\hline & São José do Campestre & 12 & 7 & 8 & 5 & 6 & 8 & 7 & 9 & 6 & 9 & 10 & 13 & 22 & 21 & 17 & 17 & 11 & 9 & 6 & 10 & 7 & 11 & 15 & 12 & 9 & 16 & 19 \\
\hline & São Paulo do Potengi & 20 & 31 & 14 & 25 & 25 & 26 & 26 & 31 & 39 & 28 & 19 & 44 & 41 & 33 & 36 & 27 & 25 & 46 & 20 & 33 & 22 & 19 & 22 & 35 & 26 & - & 45 \\
\hline & São Pedro & 6 & 4 & 4 & 3 & 2 & 3 & 4 & 1 & 5 & 8 & 1 & 6 & 4 & 8 & 9 & 6 & 5 & 4 & 6 & 6 & 2 & 8 & 6 & 4 & - & 7 & 6 \\
\hline & São Rafael & 0 & 3 & 1 & 0 & 0 & 0 & 0 & 0 & 0 & 2 & 0 & 0 & 0 & 0 & 0 & 0 & 0 & 0 & 0 & 0 & 0 & 0 & 0 & 0 & 0 & - & 0 \\
\hline & São Tomé & 3 & 0 & 2 & 1 & 1 & 1 & 16 & 3 & 10 & 22 & 21 & 19 & 20 & 8 & 22 & 13 & 6 & 11 & 6 & 7 & 8 & 4 & 3 & 1 & 1 & 7 & 1 \\
\hline & São Vicente & 0 & 0 & 0 & 0 & 0 & 0 & 0 & 0 & 0 & 0 & 13 & 0 & 0 & 0 & 11 & 0 & 7 & 11 & 0 & 3 & 7 & 0 & 3 & 0 & 3 & 3 & 4 \\
\hline & Senador Elói de Souza & 2 & 0 & 3 & 5 & 3 & 2 & 2 & 5 & 4 & 6 & 7 & 8 & 6 & 5 & 8 & 5 & 3 & 5 & 3 & 6 & 2 & 2 & 4 & 5 & 7 & 4 & 5 \\
\hline & Serra de São Bento & 0 & 2 & 4 & 4 & 2 & 12 & 4 & 15 & 20 & 14 & 13 & 7 & 16 & 9 & 4 & 4 & 3 & 4 & 12 & 6 & 2 & 3 & 1 & 2 & 5 & 0 & 0 \\
\hline & Serrinha & 0 & 0 & 0 & 0 & 0 & 0 & 0 & 0 & 1 & 1 & 0 & 0 & 3 & 1 & 2 & 5 & 3 & 0 & 2 & 5 & 1 & 3 & 1 & 0 & 1 & 9 & 1 \\
\hline & Sítio Novo & 2 & 6 & 1 & 4 & 0 & 0 & 1 & 7 & 5 & 4 & 0 & 3 & 6 & 8 & 8 & 2 & 0 & 0 & 2 & 6 & 1 & 2 & 7 & 9 & 2 & 13 & 7 \\
\hline & Tangará & 0 & 1 & 0 & 0 & 0 & 0 & 0 & 0 & 0 & 10 & 2 & 17 & 16 & 18 & 12 & 23 & 21 & 13 & 12 & 5 & 8 & 6 & 10 & 8 & 0 & 20 & 23 \\
\hline
\end{tabular}




\begin{tabular}{|c|c|c|c|c|c|c|c|c|c|c|c|c|c|c|c|c|c|c|c|c|c|c|c|c|c|c|c|c|}
\hline 2012 & Município & s1 & s2 & s3 & s4 & s5 & s6 & s7 & s8 & s9 & s10 & s11 & s12 & s13 & s14 & s15 & s16 & s17 & s18 & s19 & s20 & s21 & s22 & s23 & s24 & s25 & s26 & s27 \\
\hline & Tenente Laurentino Cruz & 11 & 9 & 5 & 12 & 2 & 3 & 8 & 9 & 7 & 8 & 4 & 2 & 9 & 5 & 3 & 4 & 4 & 3 & 3 & 1 & 1 & 0 & 0 & 4 & 0 & 5 & 2 \\
\hline & Triunfo Potiguar & 1 & 3 & 4 & 4 & 1 & 5 & 6 & 7 & 6 & 5 & 7 & 5 & 5 & 8 & 7 & 6 & 7 & 5 & 9 & 6 & 8 & 6 & 5 & 6 & 6 & 1 & 7 \\
\hline & Alagoa Nova & 16 & 15 & 12 & 8 & 16 & 24 & 13 & 30 & 19 & 29 & 26 & 24 & 28 & 21 & 20 & 22 & 19 & 26 & - & - & 15 & 22 & 26 & 21 & 12 & 20 & 18 \\
\hline & Barra de Santana & 0 & 2 & 2 & 0 & 1 & 0 & 0 & 2 & 0 & 0 & 0 & 0 & 3 & 3 & 5 & 4 & 1 & 9 & 0 & 0 & 5 & 2 & 1 & 3 & 4 & 3 & 2 \\
\hline & Boa Vista & 2 & 2 & 3 & 1 & 3 & 2 & 5 & 3 & 4 & 3 & 3 & 5 & 2 & 3 & 3 & 4 & 3 & 2 & 4 & 3 & 2 & 4 & 3 & 3 & 2 & 3 & 3 \\
\hline & Boqueirão & 15 & 0 & 14 & 13 & 6 & 0 & 2 & 19 & 9 & 8 & 10 & 8 & 15 & 3 & 0 & 17 & 0 & 19 & 1 & 2 & 1 & 14 & 2 & 20 & 10 & 1 & 22 \\
\hline & Cabaceiras & 5 & 4 & 0 & 7 & 7 & 10 & 7 & 9 & 13 & 12 & 10 & 7 & 4 & 9 & 11 & 14 & 13 & 12 & 4 & 3 & 3 & 0 & 0 & 1 & 2 & 3 & 1 \\
\hline & Campina Grande & 72 & 55 & 72 & 69 & 46 & 80 & 4 & 93 & 115 & 61 & 54 & 80 & 87 & 85 & 75 & 105 & 36 & 74 & 75 & 87 & 41 & 65 & 65 & 33 & 64 & 79 & 48 \\
\hline & Caturité & 0 & 0 & 0 & 1 & 0 & 0 & 0 & 0 & 1 & 2 & 0 & 3 & 0 & 0 & 0 & 0 & 0 & 0 & 0 & 0 & 0 & 0 & 0 & 0 & 2 & 0 & 0 \\
\hline & Cubati & 3 & 4 & 1 & 0 & 0 & 3 & 4 & 5 & 2 & 7 & 6 & 9 & 8 & 8 & 4 & 4 & 6 & 4 & 4 & 3 & 3 & 2 & 4 & 2 & 1 & 3 & 5 \\
\hline & Juazeirinho & 18 & 26 & 16 & 21 & 11 & 15 & 20 & 5 & 15 & 44 & 27 & 43 & 33 & 27 & 36 & 41 & 20 & 15 & 19 & 16 & 3 & 11 & 10 & 14 & 8 & 6 & 22 \\
\hline & Lagoa Seca & 8 & 12 & 8 & 6 & 5 & 11 & 2 & 8 & 12 & 22 & 11 & 19 & 20 & 11 & 18 & 20 & 21 & 6 & 8 & 10 & 13 & 9 & 9 & 16 & 0 & 8 & 8 \\
\hline & Matinhas & 2 & 2 & 1 & 2 & 3 & 2 & 6 & 0 & 0 & 3 & 5 & 2 & 1 & 2 & 4 & 3 & 3 & 1 & 2 & 3 & 2 & 3 & 0 & 2 & 2 & 3 & 5 \\
\hline & Olivedos & 1 & 0 & 1 & 1 & 1 & 0 & 0 & 1 & 2 & 1 & 1 & 1 & 1 & 0 & 4 & 5 & 3 & 0 & 1 & 1 & 1 & 0 & 0 & 1 & 1 & 0 & 5 \\
\hline & Pedra Lavrada & 3 & 3 & 4 & 3 & 5 & 1 & 5 & 4 & 3 & 9 & 13 & 8 & 14 & 10 & 7 & 11 & 8 & 10 & 2 & 6 & 3 & 2 & 3 & 8 & 7 & 5 & 7 \\
\hline & Pocinhos & 0 & 0 & 0 & 1 & 2 & 1 & 0 & 0 & 2 & 1 & 0 & 3 & 5 & 0 & 3 & 0 & 8 & 0 & 1 & 0 & 0 & 0 & 0 & 0 & 0 & 3 & 0 \\
\hline & Queimadas & 0 & 0 & 9 & 0 & 4 & 2 & 3 & 0 & 0 & 3 & 5 & 9 & 1 & 0 & 0 & 17 & 4 & 3 & 2 & 20 & 6 & 0 & 2 & 1 & 10 & 2 & 0 \\
\hline & Seridó/São Vicente do Seridó & 6 & 0 & 16 & 4 & 4 & 4 & 8 & 7 & 3 & 0 & 14 & 10 & 7 & 0 & 0 & 5 & 8 & 21 & 26 & 17 & 15 & 6 & 6 & 8 & 11 & 9 & 3 \\
\hline & Soledade & 2 & 5 & 4 & 3 & 12 & 13 & 9 & 25 & 12 & 17 & 13 & 12 & 37 & 14 & 11 & 16 & 5 & 14 & 12 & 18 & 12 & 9 & 16 & 15 & 10 & 11 & 8 \\
\hline
\end{tabular}

\begin{tabular}{|c|c|c|c|c|c|c|c|c|c|c|c|c|c|c|c|c|c|c|c|c|c|c|c|c|c|c|}
\hline 2012 & Município & s28 & $s 29$ & s30 & s31 & s32 & s33 & s34 & s35 & s36 & s37 & s38 & s39 & $s 40$ & s41 & $\mathrm{s} 42$ & $s 43$ & s44 & $s 45$ & $s 46$ & $s 47$ & $s 48$ & $s 49$ & $s 50$ & s51 & s52 \\
\hline & Acari & 151 & 96 & 111 & 41 & 70 & 73 & 7 & 43 & 58 & 9 & 25 & 41 & 19 & 12 & 15 & 18 & 13 & 23 & 10 & 10 & 15 & 17 & 9 & 8 & 8 \\
\hline & Açu & 10 & 0 & 20 & 18 & 29 & 29 & 23 & 19 & 26 & 8 & 16 & 13 & 6 & 12 & 19 & 10 & 15 & 15 & 10 & 13 & 18 & 16 & 9 & 21 & 7 \\
\hline & Almino Afonso & 5 & 1 & 4 & 3 & 1 & 1 & 8 & 4 & 3 & 1 & 3 & 1 & 3 & 3 & 1 & 4 & 2 & 2 & 2 & 2 & 3 & 3 & 4 & 3 & 1 \\
\hline & Angicos & 13 & 7 & 0 & 5 & 8 & 16 & 11 & 11 & 3 & 3 & 8 & 4 & 3 & 4 & 0 & 8 & 5 & 3 & 0 & 0 & 0 & 0 & 2 & 0 & 0 \\
\hline & Augusto Severo & 6 & 2 & 5 & 4 & 2 & 2 & 0 & 4 & 5 & 4 & 3 & 3 & 4 & 2 & 1 & 1 & 0 & 3 & 3 & 2 & 4 & 3 & 2 & 3 & 2 \\
\hline & Barcelona & 9 & 14 & 6 & 10 & 10 & 7 & 6 & 8 & 4 & 7 & 2 & 1 & 2 & 2 & 4 & 3 & 3 & 4 & 0 & 0 & 3 & 2 & 3 & 0 & 0 \\
\hline & Bodó & 0 & 2 & 0 & 0 & 1 & 0 & 1 & 1 & 0 & 1 & 1 & 0 & 0 & 1 & 1 & 1 & 0 & 0 & 0 & 2 & 2 & 0 & 0 & 2 & 0 \\
\hline & Bom Jesus & 26 & 21 & 22 & - & 8 & 13 & - & 3 & 2 & 7 & 7 & 9 & 11 & 11 & 5 & 9 & 4 & 4 & 7 & 5 & 6 & 6 & 7 & 14 & 6 \\
\hline & Caiçara do Rio do Vento & 18 & 4 & 0 & 0 & 20 & 12 & 6 & 7 & 6 & 6 & 4 & 4 & 8 & 4 & 4 & 1 & 2 & 8 & 8 & 3 & 20 & 4 & 5 & 3 & 1 \\
\hline & Caicó & 6 & 41 & 3 & 0 & 32 & 3 & 4 & 3 & 0 & 3 & 10 & 14 & 2 & 0 & - & 13 & 0 & 2 & 0 & 2 & 0 & 0 & 0 & - & - \\
\hline & Campo Redondo & - & - & - & - & - & - & - & - & - & - & - & - & - & - & - & - & - & - & - & - & - & - & - & - & - \\
\hline & Coronel Ezequiel & 0 & 0 & 0 & 0 & 1 & 0 & 0 & 1 & 0 & 0 & 0 & 0 & 0 & - & 0 & 0 & 0 & 0 & 1 & 0 & 0 & 0 & 0 & - & - \\
\hline & Currais Novos & 77 & 47 & 24 & 78 & 83 & 104 & 83 & 70 & 58 & 57 & 15 & 24 & 32 & 57 & 34 & 23 & 33 & 48 & 20 & 29 & 20 & 26 & 43 & - & - \\
\hline & Fernando Pedroza & 0 & 0 & 0 & 0 & 0 & 0 & 0 & 0 & 0 & 0 & 0 & 0 & 0 & 0 & 0 & 0 & 0 & 0 & 0 & 0 & 0 & 0 & 0 & 0 & 0 \\
\hline & Florânia & 2 & 3 & 0 & 2 & 1 & 1 & 4 & 2 & 11 & 2 & 0 & 2 & 1 & 0 & 0 & 0 & 2 & 0 & 0 & 0 & 6 & 2 & 8 & 5 & 4 \\
\hline & Ielmo Marinho & 4 & 1 & 8 & 7 & 10 & 11 & 3 & 5 & 5 & 4 & 7 & 4 & 6 & 6 & 5 & 4 & 5 & 11 & 7 & 3 & 5 & 6 & 8 & 4 & 10 \\
\hline
\end{tabular}




\begin{tabular}{|c|c|c|c|c|c|c|c|c|c|c|c|c|c|c|c|c|c|c|c|c|c|c|c|c|c|c|}
\hline 2012 & Município & s28 & $s 29$ & s30 & s31 & s32 & s33 & s34 & s35 & s36 & s37 & s38 & s39 & $s 40$ & s41 & $s 42$ & s43 & s44 & s45 & $s 46$ & s47 & $s 48$ & $s 49$ & $\mathrm{s50}$ & $s 51$ & s52 \\
\hline & Itajá & 0 & 0 & 0 & 0 & 0 & 0 & 0 & 0 & 0 & 0 & 0 & 0 & 0 & 0 & 0 & 0 & 0 & 0 & 0 & 0 & 0 & 0 & 0 & 0 & 0 \\
\hline & Jaçanã & 4 & 9 & 7 & 2 & 3 & 1 & 2 & 6 & 3 & 1 & 3 & 5 & 1 & 5 & 8 & 0 & 0 & 2 & 0 & 0 & 0 & 0 & 0 & 0 & 0 \\
\hline & Janduís & 0 & 0 & 5 & 0 & 6 & 0 & 0 & 0 & 0 & 0 & 1 & 0 & 0 & 0 & 0 & 0 & 0 & 0 & 0 & 0 & 0 & 0 & 0 & 0 & 0 \\
\hline & Januário Cicco & 16 & 17 & 13 & 8 & 11 & 8 & 23 & 12 & 12 & 1 & 4 & 9 & 7 & 2 & 5 & 4 & 3 & 4 & 4 & 5 & 6 & 0 & 4 & 2 & 0 \\
\hline & Japi & 19 & 22 & 18 & 7 & 11 & 9 & 5 & 6 & 6 & 7 & 7 & 3 & 4 & 6 & 3 & 2 & 2 & 7 & 2 & 3 & 4 & 0 & 4 & 6 & 5 \\
\hline & Jardim de Angicos & 0 & 0 & 0 & 0 & 0 & 0 & 0 & 0 & 0 & 0 & 0 & 0 & 0 & 0 & 0 & 0 & 0 & 0 & 0 & 0 & 0 & 0 & 0 & 0 & 0 \\
\hline & Lagoa d'Anta & 12 & 12 & 14 & 1 & 12 & 2 & 10 & 5 & 6 & 1 & 4 & - & 3 & 1 & 3 & 6 & 2 & 4 & 6 & 1 & 4 & 5 & 3 & 0 & 1 \\
\hline & Lagoa de Pedras & - & - & - & - & - & - & - & - & - & - & - & - & - & - & - & - & - & - & - & - & - & - & - & - & - \\
\hline & Lagoa de Velhos & 14 & 14 & 7 & 2 & 4 & 8 & 4 & 2 & 4 & 3 & 4 & 2 & 3 & 0 & 3 & 4 & 0 & 0 & 3 & 0 & 5 & 2 & 0 & 0 & 0 \\
\hline & Lagoa Nova & 5 & 1 & 0 & 0 & 0 & 0 & 0 & 0 & 0 & 0 & 0 & 0 & 0 & 0 & - & - & 0 & 0 & 0 & 0 & 0 & 0 & 0 & 0 & - \\
\hline & Lagoa Salgada & 0 & 20 & 0 & 17 & 9 & 18 & 10 & 5 & 4 & 9 & 12 & 7 & 7 & 1 & 5 & 1 & 1 & 0 & 0 & 4 & 2 & 0 & 0 & - & - \\
\hline & Lajes & 0 & 0 & 0 & 0 & 0 & 0 & 1 & 11 & 1 & 5 & 0 & 1 & 0 & 0 & 1 & 0 & 3 & 0 & 3 & 0 & 0 & 0 & 0 & 1 & 0 \\
\hline & Lajes Pintadas & 8 & 7 & 3 & 2 & 3 & 5 & 6 & 5 & 5 & 4 & 4 & 4 & 3 & 3 & 2 & 5 & 2 & 4 & 2 & 2 & 2 & 3 & 1 & 2 & 4 \\
\hline & Messias Targino & 0 & 4 & 0 & 7 & 0 & 0 & 3 & 0 & 2 & 0 & 0 & 8 & 4 & 1 & 3 & 8 & 5 & 2 & 8 & - & 7 & 4 & 10 & 6 & 8 \\
\hline & Monte Alegre & - & - & - & - & - & - & - & - & - & - & - & - & - & - & - & - & - & - & - & - & - & - & - & - & - \\
\hline & Monte das Gameleiras & 7 & 13 & 9 & 9 & 2 & 3 & 2 & 5 & 4 & 7 & 3 & 7 & 0 & 0 & 0 & 0 & 0 & 0 & 0 & 0 & 0 & 0 & 0 & 0 & 0 \\
\hline & Paraú & 0 & 0 & 2 & 0 & 0 & 0 & 0 & - & 0 & 0 & 0 & 0 & 0 & 0 & 0 & 0 & 0 & 0 & 0 & 0 & 0 & 0 & 0 & 0 & 0 \\
\hline & Passa e Fica & 4 & 4 & 0 & 0 & 3 & 4 & 3 & 0 & 2 & 0 & 0 & 4 & 2 & 3 & 0 & 3 & 3 & 4 & 2 & 0 & 0 & 1 & 4 & 5 & 4 \\
\hline & Patu & 0 & 0 & 4 & 4 & 8 & 6 & - & 10 & 9 & - & 4 & 6 & 6 & 7 & 0 & 0 & - & 7 & 7 & - & 5 & 6 & 3 & 3 & 0 \\
\hline & Pedra Preta & 5 & 4 & 2 & 2 & 1 & 0 & 3 & 2 & 0 & 0 & 3 & 2 & 0 & 0 & 4 & 4 & 0 & 0 & 5 & 5 & 3 & 0 & 4 & 0 & - \\
\hline & Pedro Avelino & 0 & 1 & 7 & 5 & 0 & 0 & 0 & 0 & 12 & 0 & 10 & 11 & 0 & 0 & 11 & 2 & 0 & 0 & 0 & 0 & 0 & 0 & 0 & 0 & 0 \\
\hline & Presidente Juscelino & 0 & 53 & 0 & 51 & 15 & 19 & 7 & 19 & 11 & 0 & 7 & 9 & 8 & 6 & 6 & 9 & 1 & 2 & 6 & 10 & 3 & 5 & 8 & 8 & 4 \\
\hline & Riachuelo & 17 & 9 & 5 & 2 & 4 & 5 & 3 & 4 & 8 & 8 & 4 & 8 & 2 & 6 & 4 & 4 & 5 & 3 & 3 & 6 & 9 & 5 & 1 & 0 & 0 \\
\hline & Ruy Barbosa & 2 & 3 & 6 & 2 & 0 & 3 & 3 & 1 & 3 & 1 & 0 & 0 & 1 & 0 & 3 & 2 & 1 & 0 & 0 & 0 & 0 & 0 & 0 & 0 & 0 \\
\hline & Santa Cruz & 260 & 255 & 216 & 156 & 173 & 123 & 90 & 70 & 72 & 63 & 45 & 51 & 39 & 41 & 44 & 52 & 40 & 66 & 50 & 62 & 53 & 62 & 46 & 58 & 91 \\
\hline & Santa Maria & 1 & 1 & 2 & 0 & 0 & 0 & 0 & 0 & 0 & 0 & 0 & 0 & 0 & 0 & 0 & 0 & 0 & 0 & 0 & 0 & 0 & 0 & 0 & 0 & - \\
\hline & Santana do Matos & 5 & 16 & 16 & 15 & 11 & 15 & 14 & 8 & 7 & 8 & 8 & 11 & 4 & 8 & 3 & - & 4 & 4 & 7 & 3 & 5 & 3 & 1 & 5 & 2 \\
\hline & São Bento do Trairi & 13 & 31 & 20 & 11 & 9 & 3 & 4 & 2 & 0 & 0 & 0 & 2 & 2 & 1 & 1 & 0 & 0 & 0 & 1 & 0 & 3 & 3 & 1 & 8 & 3 \\
\hline & São José do Campestre & 37 & 51 & 28 & 37 & 24 & 23 & 24 & - & 30 & 8 & 18 & 11 & 5 & 9 & - & 8 & 10 & 15 & 9 & 7 & 15 & 9 & 10 & 14 & - \\
\hline & São Paulo do Potengi & 58 & 36 & 0 & 0 & 0 & 31 & 0 & 0 & 12 & 12 & 18 & 8 & 0 & 13 & 10 & 0 & 10 & 11 & 14 & 10 & 9 & 9 & 7 & 0 & 0 \\
\hline & São Pedro & 8 & 5 & 4 & 2 & 4 & 0 & 0 & 2 & 3 & 3 & 3 & 5 & - & 9 & 3 & 2 & 2 & 4 & 3 & 6 & 3 & 4 & 3 & 2 & 5 \\
\hline & São Rafael & 0 & 0 & 0 & 0 & 0 & 0 & 0 & 0 & 0 & 0 & 0 & 0 & 0 & 0 & 0 & 0 & 0 & 0 & 0 & 0 & 0 & 0 & 0 & 0 & 0 \\
\hline & São Tomé & 11 & 14 & 22 & 11 & 2 & 4 & 0 & 4 & 0 & 0 & 0 & 0 & 0 & 0 & 0 & 0 & 0 & 0 & 0 & 0 & 0 & 0 & 0 & - & - \\
\hline & São Vicente & 0 & 0 & 0 & 10 & 13 & 9 & 7 & 5 & 9 & 0 & 6 & 7 & 0 & 3 & 5 & 5 & 4 & 0 & 0 & 5 & 0 & 0 & 0 & 0 & 0 \\
\hline & Senador Elói de Souza & 5 & 4 & 4 & 4 & 5 & 6 & 2 & 6 & 4 & 3 & 6 & 4 & 5 & 6 & 4 & 2 & 5 & 5 & 5 & 2 & 4 & 5 & 2 & 0 & 0 \\
\hline & Serra de São Bento & 2 & 10 & 8 & 8 & 1 & 10 & 4 & - & - & - & - & - & - & - & - & - & - & - & - & - & - & - & - & - & - \\
\hline & Serrinha & 0 & 1 & 3 & 0 & 0 & 0 & 1 & 1 & 3 & 0 & 1 & 0 & 0 & 0 & 0 & 0 & 0 & 0 & 0 & 0 & 0 & 0 & - & - & - \\
\hline
\end{tabular}




\begin{tabular}{|c|c|c|c|c|c|c|c|c|c|c|c|c|c|c|c|c|c|c|c|c|c|c|c|c|c|c|c|c|}
\hline \multirow[t]{22}{*}{2012} & \multicolumn{2}{|l|}{ Município } & $\mathbf{s} 28$ & $\mathbf{s 2 9}$ & s30 & & $31 s$ & s32 & s33 & s34 & s35 & s36 & s37 & s38 & $3 \quad 539$ & $s 40$ & $s 41$ & s42 & $2 \mathrm{~s} 43$ & s44 & s45 & $s 46$ & s47 & $s 48$ & $s 49$ & $s 50$ & s51 & s52 \\
\hline & \multicolumn{2}{|l|}{ Sítio Novo } & 17 & 12 & 11 & & 8 & 21 & 16 & 6 & 18 & 5 & 9 & 3 & 3 & 3 & 3 & 3 & 3 & 0 & 0 & 0 & 0 & 0 & 0 & 0 & 0 & 0 \\
\hline & \multicolumn{2}{|l|}{ Tangará } & 13 & 12 & 17 & & 23 & 8 & - & 15 & 13 & 6 & 11 & 10 & 9 & 5 & 10 & 0 & 0 & 2 & 0 & 0 & 0 & 0 & 5 & 0 & 0 & - \\
\hline & \multicolumn{2}{|l|}{ Tenente Laurentino Cruz } & 3 & 1 & 5 & & 0 & 2 & 5 & 0 & 0 & 1 & 4 & 1 & 0 & 0 & 0 & 0 & 0 & 0 & 0 & 0 & - & 0 & - & - & 2 & 0 \\
\hline & \multicolumn{2}{|l|}{ Triunfo Potiguar } & - & 2 & 1 & & 0 & 0 & 0 & 1 & 1 & 1 & 1 & 1 & 1 & 2 & 1 & 1 & 1 & 2 & - & 1 & 1 & 1 & 1 & 1 & 1 & - \\
\hline & \multicolumn{2}{|l|}{ Alagoa Nova } & 9 & 21 & 33 & & 29 & 14 & 23 & 25 & 24 & 27 & 32 & 20 & 17 & 15 & 33 & 29 & 23 & 30 & 9 & 20 & 19 & 27 & 23 & 30 & 3 & 21 \\
\hline & \multicolumn{2}{|l|}{ Barra de Santana } & 0 & 0 & 5 & & 6 & 5 & 13 & 8 & 0 & 4 & 3 & 0 & 0 & 3 & 0 & 0 & 0 & 2 & 0 & 0 & 3 & 1 & 0 & 0 & 0 & - \\
\hline & \multicolumn{2}{|l|}{ Boa Vista } & 2 & 3 & 3 & & 2 & 5 & 3 & 4 & 3 & 2 & 3 & 4 & 3 & 3 & 2 & 3 & 3 & 2 & 3 & 4 & 2 & 3 & 4 & 2 & 1 & 2 \\
\hline & \multicolumn{2}{|l|}{ Boqueirão } & 10 & 29 & 2 & & 25 & 12 & 17 & 10 & 15 & 2 & 4 & 5 & 9 & 0 & 0 & 7 & 2 & 3 & 3 & 3 & 2 & 0 & 2 & 0 & 0 & 0 \\
\hline & \multicolumn{2}{|l|}{ Cabaceiras } & 9 & 5 & 3 & & 1 & 3 & 5 & 0 & 3 & 3 & 0 & 0 & 4 & 0 & 3 & 0 & 3 & 1 & 1 & 1 & 0 & 2 & 0 & 0 & 0 & - \\
\hline & \multicolumn{2}{|l|}{ Campina Grande } & 56 & 45 & 73 & & 53 & 75 & 117 & 81 & 86 & 49 & 49 & 76 & 64 & 50 & 52 & 48 & 73 & 80 & 69 & 53 & 56 & 57 & 58 & 57 & 31 & 27 \\
\hline & \multicolumn{2}{|l|}{ Caturité } & 6 & 1 & 0 & & 0 & 8 & 2 & 3 & 0 & 0 & 4 & 0 & 4 & 2 & 0 & 1 & 0 & 0 & 3 & 0 & 0 & 0 & 0 & 0 & 0 & 0 \\
\hline & \multicolumn{2}{|l|}{ Cubati } & 5 & 4 & 5 & & 10 & 10 & 13 & 13 & 13 & 13 & 11 & 6 & 1 & 6 & 3 & 4 & 2 & 4 & 5 & 4 & 3 & 7 & 6 & 4 & 8 & 7 \\
\hline & \multicolumn{2}{|l|}{ Juazeirinho } & 4 & 43 & 60 & & 69 & 33 & 38 & 18 & 19 & 12 & 20 & 18 & 15 & 20 & 6 & 12 & 9 & 6 & 2 & 8 & 11 & 11 & 9 & 10 & - & 0 \\
\hline & \multicolumn{2}{|l|}{ Lagoa Seca } & 11 & 18 & 17 & & 20 & 17 & 10 & 13 & 10 & 14 & 12 & 12 & 4 & 9 & 0 & 5 & 0 & 9 & 22 & 14 & 17 & 12 & 11 & 10 & 8 & 0 \\
\hline & Matinhas & & 3 & 1 & 3 & & 3 & 6 & 3 & 1 & 2 & 3 & 3 & 2 & 1 & 2 & 2 & 1 & 3 & 2 & 2 & 1 & 0 & 0 & 0 & 0 & 0 & 0 \\
\hline & Olivedos & & 5 & 10 & 8 & & 9 & 6 & 2 & 2 & 1 & 1 & 4 & 3 & 5 & 3 & 1 & 2 & 1 & 1 & 2 & 0 & 0 & 0 & 0 & 0 & 0 & 0 \\
\hline & Pedra Lavrada & & 10 & 31 & 68 & & 32 & 12 & 20 & 11 & 5 & 3 & 9 & 2 & 4 & 9 & 2 & 6 & 5 & 14 & 16 & 9 & 13 & 13 & 6 & 4 & 2 & 5 \\
\hline & Pocinhos & & 0 & 2 & 1 & & 0 & 2 & 2 & 10 & 1 & 0 & 4 & 0 & 6 & 0 & 0 & 5 & 0 & 0 & 0 & 0 & 2 & 0 & 0 & 2 & 0 & 0 \\
\hline & Queimadas & & 8 & 17 & 6 & & 14 & 28 & 42 & 32 & 13 & 1 & 1 & 10 & 3 & 2 & 0 & 1 & 0 & 0 & 2 & 0 & 2 & 0 & 0 & 3 & 0 & 0 \\
\hline & Seridó/São Vicente do Ser & & 10 & 2 & 21 & & 28 & 29 & 35 & 6 & 9 & 6 & 0 & 0 & 5 & 7 & 9 & 0 & 0 & 0 & 0 & 8 & 7 & 6 & 5 & 0 & 0 & 0 \\
\hline & Soledade & & 11 & 17 & 10 & & 18 & 17 & 13 & 9 & 7 & 9 & 13 & 7 & 8 & 11 & 11 & 4 & 8 & 6 & 4 & 5 & 6 & 5 & 14 & 9 & 6 & - \\
\hline 2013 & Município & s1 & s2 & s3 & s4 & s5 & s6 & s7 & s8 & s9 & s10 & s11 & s12 & $s 13$ & s14 & s15 & s16 & s17 & s18 & s19 & s20 & $s 21$ & s22 & $s 23$ & s24 & $s 25$ & $s 26$ & s27 \\
\hline & Acari & 15 & 27 & 14 & 18 & 18 & 20 & 28 & 26 & 23 & 54 & 68 & 47 & 39 & 48 & 49 & 21 & 20 & 45 & 64 & 70 & 44 & 31 & 59 & 49 & 37 & 63 & 55 \\
\hline & Açu & 17 & 18 & 72 & 52 & 64 & 43 & 81 & 121 & 74 & 171 & 234 & 195 & 167 & 227 & 141 & 83 & 61 & 47 & 81 & 98 & 115 & 120 & 124 & 162 & 63 & 39 & 41 \\
\hline & Almino Afonso & 3 & 2 & 4 & 2 & 4 & 4 & 3 & - & 0 & 4 & 4 & 4 & 2 & 4 & 2 & 2 & 3 & 4 & 7 & 2 & 3 & 4 & 3 & 4 & 2 & 4 & 4 \\
\hline & Angicos & 0 & 0 & 5 & 6 & - & 17 & 15 & 12 & 16 & 12 & 8 & 3 & 15 & 21 & 4 & 5 & 26 & 18 & 43 & 47 & 29 & 22 & 15 & 13 & 2 & 3 & 5 \\
\hline & Augusto Severo & 2 & 3 & 2 & 5 & 5 & 2 & 3 & 3 & 9 & 5 & 8 & 10 & 6 & 5 & 4 & 6 & 8 & 8 & 6 & 4 & 5 & 5 & 4 & 3 & 2 & 2 & 1 \\
\hline & Barcelona & 0 & 5 & 3 & 4 & 9 & 2 & 6 & 4 & 9 & 5 & 13 & 15 & 7 & 3 & 7 & 6 & 10 & 13 & 25 & 24 & 30 & 39 & 26 & 49 & 28 & 12 & 13 \\
\hline & Bodó & 0 & 1 & 0 & 1 & 0 & 1 & 0 & 5 & 4 & 0 & 0 & 2 & 3 & 3 & 6 & 8 & 8 & 18 & 6 & 11 & 6 & 0 & 9 & 1 & 0 & 0 & 1 \\
\hline & Bom Jesus & 6 & 7 & 8 & 4 & 7 & 9 & 18 & 4 & 6 & 19 & 7 & 50 & 42 & 25 & 21 & 22 & 23 & 19 & 19 & 25 & 15 & 25 & 18 & 25 & 31 & 28 & 20 \\
\hline & Caiçara do Rio do Vento & 5 & 2 & 11 & 8 & 2 & 2 & 4 & 5 & 1 & 3 & 11 & 10 & 4 & 0 & 7 & 7 & 6 & 5 & 9 & 20 & 24 & 38 & 19 & 28 & 18 & 14 & 16 \\
\hline & Caicó & 2 & 1 & 0 & 0 & 0 & 9 & 0 & 0 & 0 & 5 & 5 & 15 & 5 & 5 & 20 & 7 & 22 & 23 & 21 & 58 & 93 & 20 & 30 & 51 & 13 & 17 & 5 \\
\hline & Campo Redondo & 0 & 0 & 0 & 0 & 0 & 0 & 0 & 1 & 8 & 8 & 14 & 0 & 20 & 18 & 33 & 29 & 18 & 27 & 32 & 47 & 78 & 135 & 0 & 68 & 36 & 25 & 12 \\
\hline & Coronel Ezequiel & 0 & 0 & 0 & 0 & 0 & 0 & 1 & 0 & 5 & - & 0 & 8 & 1 & 1 & 1 & 5 & 0 & 6 & 6 & 19 & 25 & 51 & 24 & 24 & 16 & 7 & 7 \\
\hline & Currais Novos & 18 & 29 & 30 & 91 & 64 & 80 & 102 & 76 & 85 & 99 & 68 & 122 & 81 & 80 & 82 & 115 & 110 & - & - & - & 113 & 83 & 92 & 78 & 55 & 63 & 53 \\
\hline & Fernando Pedroza & 0 & 0 & 0 & 0 & 0 & 0 & 0 & 0 & 0 & 0 & 0 & 0 & 0 & 0 & 0 & 0 & 0 & 0 & 0 & 31 & 31 & 22 & 0 & 0 & 0 & $\begin{array}{r}0 \\
255\end{array}$ & 0 \\
\hline
\end{tabular}




\begin{tabular}{|c|c|c|c|c|c|c|c|c|c|c|c|c|c|c|c|c|c|c|c|c|c|c|c|c|c|c|c|c|}
\hline 2013 & Município & s1 & s2 & s3 & s4 & s5 & s6 & s7 & s8 & s9 & s10 & s11 & s12 & $s 13$ & s14 & s15 & s16 & s17 & s18 & s19 & s20 & $s 21$ & s22 & s23 & s24 & s25 & $s 26$ & s27 \\
\hline & Florânia & 2 & 2 & 4 & 3 & 8 & 13 & 6 & 1 & 5 & 4 & 0 & 3 & 2 & 1 & 3 & 6 & 0 & 1 & 3 & 6 & 20 & 35 & 12 & 15 & 3 & 4 & 2 \\
\hline & lelmo Marinho & 0 & 0 & 3 & 1 & 3 & 6 & 3 & 10 & 2 & 1 & 11 & 10 & 8 & 2 & 9 & 6 & 5 & 7 & 9 & 9 & 10 & 9 & 14 & 38 & 62 & 2 & 28 \\
\hline & Itajá & 0 & 1 & 0 & 0 & 2 & 1 & 0 & 0 & 3 & 4 & 2 & 3 & 1 & 0 & 0 & 0 & 2 & 0 & 4 & 6 & 10 & 5 & - & - & - & - & - \\
\hline & Jaçanã & 0 & 4 & 0 & 0 & 6 & 4 & 7 & 12 & 4 & 2 & 12 & - & 2 & 8 & 13 & 26 & 36 & 27 & 60 & 65 & 62 & 81 & 48 & 50 & 34 & 12 & 14 \\
\hline & Janduís & 0 & 3 & 14 & 5 & 13 & 0 & 18 & 21 & 19 & 18 & 15 & 17 & 15 & 32 & 29 & 21 & 18 & 15 & 20 & 28 & 26 & 21 & 20 & 26 & 21 & 22 & 15 \\
\hline & Januário Cicco & 3 & 6 & 5 & 10 & 13 & 11 & 10 & 9 & 21 & 21 & 25 & 26 & 15 & 15 & 17 & 23 & 13 & 20 & 27 & 26 & 48 & 30 & 38 & 33 & 28 & 54 & 27 \\
\hline & Japi & 3 & 3 & 8 & 7 & 3 & 2 & 5 & 5 & 6 & 7 & 6 & 6 & 9 & 8 & 10 & 11 & 6 & 1 & 9 & 6 & 7 & 59 & 38 & 23 & 19 & 25 & 14 \\
\hline & Jardim de Angicos & 0 & 0 & 0 & 0 & 0 & 0 & 0 & 0 & 0 & 0 & 6 & 10 & 4 & 13 & 10 & 4 & 9 & 3 & 8 & 16 & 15 & 15 & 6 & 11 & 7 & 1 & 0 \\
\hline & Lagoa d'Anta & 3 & 9 & 12 & 15 & 7 & 2 & 4 & 6 & 7 & 2 & 10 & 3 & 10 & 5 & 5 & 3 & 2 & 1 & 5 & 28 & 33 & 9 & 16 & 8 & 9 & 3 & 4 \\
\hline & Lagoa de Pedras & - & - & - & - & - & - & - & - & - & - & - & - & - & - & - & - & - & - & - & - & - & - & - & - & - & - & - \\
\hline & Lagoa de Velhos & 0 & 1 & 0 & 2 & 3 & 0 & 6 & 0 & 6 & 7 & 14 & 0 & 2 & 8 & 5 & 4 & 2 & 7 & 13 & 18 & 24 & 18 & 9 & 9 & 7 & 2 & 1 \\
\hline & Lagoa Nova & 0 & 0 & 0 & 0 & 0 & 0 & 0 & 0 & 0 & 0 & 0 & 0 & 0 & 0 & 0 & 0 & 0 & - & - & 18 & 40 & 58 & 15 & 5 & 20 & 0 & 0 \\
\hline & Lagoa Salgada & 0 & 0 & 0 & 0 & 0 & 0 & 0 & 0 & 0 & 0 & 0 & 0 & 8 & 0 & 0 & 0 & 0 & 0 & 0 & 5 & 8 & 7 & 4 & 0 & 0 & 0 & 0 \\
\hline & Lajes & 0 & 0 & 0 & 0 & 0 & 3 & 7 & 0 & 0 & 3 & 4 & 9 & 3 & 8 & 0 & 0 & 4 & 4 & 5 & 2 & 43 & 2 & 7 & 14 & 10 & 21 & 27 \\
\hline & Lajes Pintadas & 1 & 1 & 2 & 1 & 1 & 1 & 4 & 4 & 7 & 5 & 7 & 2 & 2 & 2 & 8 & 2 & 3 & 5 & 3 & 14 & 18 & 33 & 26 & 74 & 36 & 48 & 44 \\
\hline & Messias Targino & 7 & 7 & 0 & 7 & 4 & 10 & 8 & 7 & 9 & 7 & 14 & 6 & 22 & 6 & 7 & 5 & 12 & 7 & 34 & 23 & 14 & 12 & 7 & 8 & 9 & 8 & 2 \\
\hline & Monte Alegre & 0 & 0 & 1 & 1 & 2 & 5 & 2 & 3 & 15 & 4 & 0 & 0 & 3 & 12 & 0 & 2 & 0 & 7 & 7 & 9 & 2 & 11 & 7 & 24 & 11 & 15 & 10 \\
\hline & Monte das Gameleiras & 0 & 0 & 0 & 0 & 3 & 0 & 0 & 7 & 7 & 5 & 4 & 11 & 4 & 5 & 4 & 15 & 31 & 11 & 9 & 16 & 20 & 27 & 32 & 15 & 19 & 18 & 33 \\
\hline & Paraú & - & 0 & 0 & 0 & 0 & 0 & 0 & 4 & 0 & 0 & 0 & 0 & 6 & 4 & 1 & 0 & 1 & 8 & 2 & 15 & 14 & 16 & - & 0 & 0 & 1 & 0 \\
\hline & Passa e Fica & 4 & 3 & 5 & 3 & 0 & 2 & 0 & 3 & 2 & 4 & 0 & 0 & 5 & 7 & 9 & 2 & 3 & 0 & 2 & 5 & 4 & 6 & 7 & 5 & 2 & 3 & 0 \\
\hline & Patu & 0 & 0 & 0 & 0 & 0 & 0 & 0 & 0 & 0 & 0 & 0 & 0 & 0 & 0 & 0 & 0 & 0 & 33 & 36 & 57 & 47 & 42 & 37 & 47 & 17 & 12 & 13 \\
\hline & Pedra Preta & 0 & 0 & 0 & 0 & 0 & 0 & 0 & 9 & 7 & 15 & 11 & 6 & 10 & 1 & 1 & 2 & 13 & 3 & 23 & 71 & - & - & 25 & 18 & 12 & 11 & 9 \\
\hline & Pedro Avelino & 0 & 0 & 0 & 3 & 0 & 0 & 0 & 0 & 4 & 2 & 0 & 3 & 4 & 6 & 5 & 6 & 5 & 4 & 10 & 5 & 6 & 0 & 1 & 0 & 3 & 2 & 3 \\
\hline & Presidente Juscelino & 9 & 9 & 5 & 17 & 15 & 20 & 14 & 17 & 47 & 9 & 36 & 27 & 16 & 28 & 23 & 19 & 15 & 23 & 46 & 67 & 35 & 53 & 31 & 39 & 30 & 26 & 18 \\
\hline & Riachuelo & 0 & 2 & 0 & 6 & 4 & 4 & - & 8 & 8 & 16 & 13 & 7 & 8 & 10 & 14 & 11 & 15 & 7 & 15 & 40 & 48 & 44 & 77 & 73 & 34 & - & 30 \\
\hline & Ruy Barbosa & 0 & 8 & 3 & 2 & 0 & 0 & 0 & 0 & 0 & 0 & 0 & 0 & 0 & 1 & 0 & 0 & 0 & 1 & 1 & 0 & 20 & 30 & 4 & 23 & 0 & 8 & 0 \\
\hline & Santa Cruz & 64 & 78 & 101 & 81 & 104 & 75 & 108 & 73 & 100 & 87 & 133 & 115 & 123 & 77 & 96 & 113 & 87 & 94 & 101 & 162 & 286 & 295 & 281 & 262 & 162 & 161 & 120 \\
\hline & Santa Maria & 0 & 0 & 2 & 1 & 2 & 3 & 2 & 5 & 3 & 10 & 0 & 1 & 17 & 7 & 3 & 3 & 1 & 5 & 6 & - & 7 & 9 & 17 & 6 & 12 & 5 & 5 \\
\hline & Santana do Matos & 13 & 7 & 21 & 18 & 19 & 18 & 42 & 35 & 32 & 103 & 108 & 86 & 60 & 90 & 64 & 64 & 51 & 34 & 29 & 39 & 41 & 35 & 10 & 13 & 11 & 11 & 5 \\
\hline & São Bento do Trairi & 3 & 1 & 0 & 5 & 0 & 2 & 4 & 2 & 5 & 1 & 1 & 3 & 10 & 4 & 0 & 5 & 0 & 3 & 16 & 0 & 27 & 17 & 20 & 6 & 0 & 19 & 13 \\
\hline & São José do Campestre & 14 & 8 & 13 & 41 & 43 & 17 & 42 & 16 & 8 & 43 & 11 & 33 & 29 & 34 & 20 & 28 & 40 & 20 & 22 & 53 & 86 & 87 & 41 & 69 & 48 & 44 & 39 \\
\hline & São Paulo do Potengi & 20 & 22 & 17 & 15 & 9 & 19 & 14 & 17 & 30 & 19 & 30 & 49 & 53 & 51 & 70 & 58 & 43 & 53 & 82 & 204 & 245 & 163 & 100 & 103 & 74 & 104 & 50 \\
\hline & São Pedro & 13 & 10 & 9 & 13 & - & - & - & - & - & - & - & - & - & - & - & - & - & - & - & - & - & - & - & - & - & - & - \\
\hline & São Rafael & - & - & - & - & - & - & - & - & - & - & - & - & - & - & - & - & - & - & - & - & - & - & - & - & - & - & - \\
\hline & São Tomé & 0 & 2 & 0 & 0 & 0 & 0 & 18 & 13 & 7 & 6 & 6 & 19 & 17 & 22 & 34 & 35 & 48 & 39 & 81 & 100 & 163 & 70 & 118 & 73 & 17 & 42 & 18 \\
\hline & São Vicente & 3 & 3 & 3 & 4 & 0 & 0 & 3 & 0 & 0 & 0 & 0 & 3 & 0 & 2 & 3 & 0 & 4 & 0 & 5 & 5 & 5 & 4 & 2 & 4 & 4 & 0 & 0 \\
\hline & Senador Elói de Souza & 0 & 0 & 2 & 4 & 4 & 0 & 0 & 2 & 5 & 3 & - & 8 & 4 & 9 & 10 & 3 & 0 & 7 & 2 & 8 & 9 & 5 & 11 & 6 & 8 & 11 & 9 \\
\hline
\end{tabular}




\begin{tabular}{|c|c|c|c|c|c|c|c|c|c|c|c|c|c|c|c|c|c|c|c|c|c|c|c|c|c|c|c|c|}
\hline 2013 & Município & s1 & s2 & s3 & s4 & s5 & s6 & s7 & $\mathbf{s} 8$ & s9 & $s 10$ & s11 & s12 & s13 & s14 & s15 & $s 16$ & s17 & s18 & $s 19$ & s20 & s21 & s22 & s23 & s24 & s25 & s26 & s27 \\
\hline & Serra de São Bento & 1 & 1 & 0 & 0 & 5 & 3 & 4 & 0 & 0 & 6 & 0 & 0 & 10 & 3 & 9 & 7 & - & 11 & 8 & 6 & 78 & 45 & 45 & 44 & 22 & 0 & 11 \\
\hline & Serrinha & 0 & 0 & 0 & 0 & 0 & 0 & 0 & 0 & 0 & 0 & 0 & 3 & 15 & 0 & 1 & 0 & 0 & 0 & 0 & 0 & 3 & 16 & 15 & 17 & 0 & 7 & 9 \\
\hline & Sítio Novo & 0 & 0 & 0 & 3 & 2 & 1 & 0 & 3 & 2 & 4 & 7 & 3 & 5 & 6 & 5 & 11 & 8 & 17 & 15 & 24 & 48 & 51 & 79 & 18 & 10 & 3 & 7 \\
\hline & Tangará & 3 & 2 & 0 & 13 & 2 & 2 & 13 & 20 & 17 & 15 & 12 & 23 & 32 & 6 & 10 & 9 & 19 & 0 & 26 & 21 & 72 & 70 & 81 & 37 & 94 & 38 & 35 \\
\hline & Tenente Laurentino Cruz & 0 & 10 & 5 & 6 & 6 & 6 & 4 & 7 & 7 & 2 & 18 & 24 & 10 & 16 & 17 & 9 & 14 & 16 & 9 & 0 & 19 & 1 & 14 & 2 & 4 & 2 & 1 \\
\hline & Triunfo Potiguar & 1 & 3 & 9 & 5 & 11 & 7 & 5 & 5 & 3 & 19 & 16 & 19 & 9 & 15 & 19 & 19 & 8 & 6 & 9 & 14 & 17 & 6 & 10 & 4 & 9 & 8 & 1 \\
\hline
\end{tabular}

\begin{tabular}{|c|c|c|c|c|c|c|c|c|c|c|c|c|c|c|c|c|c|c|c|c|c|c|c|c|c|c|}
\hline 2013 & Município & s28 & $s 29$ & s30 & s31 & s32 & s33 & s34 & s35 & s36 & s37 & s38 & s39 & $s 40$ & s41 & s42 & s43 & s44 & s45 & $s 46$ & s47 & $s 48$ & s49 & s50 & s51 & s52 \\
\hline & Acari & 54 & 78 & 52 & 39 & 22 & 23 & 28 & 19 & 32 & 22 & 36 & 50 & 23 & 39 & 38 & 28 & 31 & 20 & 30 & 32 & 38 & 29 & 43 & 33 & 32 \\
\hline & Açu & 38 & 43 & 50 & 64 & 72 & 75 & 69 & 89 & 72 & 48 & 56 & 40 & 54 & 40 & 51 & 53 & 51 & 55 & 56 & 50 & 39 & 49 & 56 & 36 & 11 \\
\hline & Almino Afonso & 2 & 3 & 3 & 2 & 4 & 1 & 2 & 5 & 3 & 6 & 4 & 1 & 6 & 6 & 11 & 8 & 9 & 6 & 9 & 7 & 7 & 3 & - & 2 & 6 \\
\hline & Angicos & 1 & 3 & 5 & 4 & 9 & 2 & 4 & 2 & 2 & 4 & 5 & 6 & 7 & 4 & 1 & 3 & 2 & 5 & 2 & 0 & 8 & 3 & 0 & 2 & 0 \\
\hline & Augusto Severo & 2 & 1 & 2 & 2 & 3 & 1 & 3 & - & 2 & 3 & 2 & 0 & 1 & 2 & 1 & 3 & 2 & 1 & 2 & 3 & 2 & 2 & 2 & 3 & 2 \\
\hline & Barcelona & 3 & 6 & 7 & 4 & 6 & 2 & 6 & 1 & 3 & 1 & 1 & 0 & 1 & 3 & 6 & 2 & 9 & 1 & 1 & 2 & 12 & 0 & 5 & 1 & 1 \\
\hline & Bodó & 0 & 0 & 0 & 0 & 0 & 1 & 0 & 0 & 0 & 0 & 0 & 0 & 0 & 0 & 0 & 0 & 0 & 0 & 0 & 4 & 0 & 1 & 1 & 1 & 1 \\
\hline & Bom Jesus & 10 & 9 & 11 & 8 & 11 & 5 & 7 & 8 & 6 & 12 & 5 & 2 & 2 & 2 & 5 & 6 & 7 & 3 & 1 & 5 & 7 & 4 & 8 & 4 & 6 \\
\hline & Caiçara do Rio do Vento & 5 & 13 & 1 & 7 & 9 & 2 & 4 & 7 & 0 & 3 & 5 & 8 & 6 & 6 & 5 & 3 & 1 & 2 & 1 & 3 & 2 & 2 & 0 & 0 & 1 \\
\hline & Caicó & 13 & 11 & 5 & 9 & 2 & 22 & 5 & 6 & 1 & 8 & 4 & 4 & 1 & 0 & 5 & 0 & 3 & 3 & 7 & 3 & 5 & 4 & 5 & 5 & 1 \\
\hline & Campo Redondo & 0 & 0 & 1 & 0 & 0 & 0 & 9 & 0 & 2 & 6 & 8 & 0 & 9 & 10 & 12 & 0 & 10 & 9 & 12 & 11 & 0 & 10 & 9 & 0 & 0 \\
\hline & Coronel Ezequiel & 4 & 2 & 0 & 2 & 0 & 0 & - & 0 & 0 & 0 & 0 & 0 & - & 0 & 0 & - & - & - & 0 & 0 & 2 & 3 & 0 & - & - \\
\hline & Currais Novos & 61 & 57 & 66 & 50 & 58 & 36 & 32 & 27 & 20 & 42 & 29 & 20 & 51 & 40 & 46 & 47 & 58 & 52 & 48 & 66 & - & 43 & 46 & 43 & 26 \\
\hline & Fernando Pedroza & 2 & 0 & 0 & 1 & 1 & 0 & 0 & 0 & 0 & 0 & 1 & 0 & 0 & 0 & 0 & 0 & 0 & 0 & 0 & 0 & 0 & 0 & 0 & 0 & 0 \\
\hline & Florânia & 4 & 2 & 0 & 4 & 3 & 2 & 6 & 2 & - & 3 & 0 & 3 & 1 & 3 & 0 & 3 & 1 & 2 & 4 & 3 & 1 & 4 & 3 & 1 & 0 \\
\hline & Ielmo Marinho & 2 & 7 & 8 & 4 & 5 & 6 & 4 & 6 & 1 & 4 & 1 & 1 & 7 & 1 & 3 & 3 & 4 & 0 & 1 & 2 & 2 & 3 & 4 & 2 & 4 \\
\hline & Itajá & - & - & - & - & - & - & - & - & - & - & - & - & - & - & - & - & - & - & - & - & - & - & - & - & - \\
\hline & Jaçanã & 7 & 5 & 3 & 3 & 6 & 3 & 5 & 4 & 11 & 5 & 3 & 3 & 2 & 7 & 2 & 11 & 2 & 5 & 3 & 5 & 1 & 10 & 0 & 2 & 2 \\
\hline & Janduís & 12 & 12 & 9 & 11 & 12 & 4 & 3 & 2 & 3 & 5 & 6 & 5 & 4 & 5 & 6 & 6 & 2 & 1 & 4 & 3 & 0 & 1 & 3 & 3 & 6 \\
\hline & Januário Cicco & 17 & 9 & 20 & 10 & 11 & 11 & 7 & 5 & 3 & 10 & 2 & 7 & 7 & 3 & 1 & 16 & 1 & 11 & 10 & 5 & 11 & 5 & 7 & 4 & 7 \\
\hline & Japi & 9 & 21 & 11 & 6 & 8 & 8 & 9 & 6 & 11 & 3 & 5 & 2 & 7 & 11 & 13 & 3 & 2 & 5 & 7 & 2 & 3 & 4 & 9 & 4 & 3 \\
\hline & Jardim de Angicos & 4 & 0 & 0 & 0 & 2 & 0 & 0 & 0 & 2 & 0 & 4 & 0 & 1 & 2 & 4 & 1 & 1 & 1 & 0 & 3 & 0 & 0 & 0 & 0 & 1 \\
\hline & Lagoa d'Anta & 5 & 3 & 5 & 3 & 2 & 1 & 2 & 4 & 4 & 2 & 3 & 14 & 5 & 5 & 5 & 5 & 4 & 8 & 5 & - & 4 & 2 & 2 & 3 & 3 \\
\hline & Lagoa de Pedras & - & - & - & - & - & - & - & - & - & - & - & - & - & - & - & - & - & - & - & - & - & - & - & - & - \\
\hline & Lagoa de Velhos & 4 & 0 & 0 & 6 & 6 & 3 & 0 & 0 & 0 & 0 & 0 & 0 & 0 & 4 & 1 & 2 & 0 & 0 & 1 & 3 & 1 & 0 & 0 & 0 & 0 \\
\hline & Lagoa Nova & 0 & 0 & 2 & 0 & 0 & 0 & 0 & 1 & 0 & 0 & 0 & 0 & 3 & 0 & 0 & 0 & 1 & 0 & 0 & 0 & 4 & 0 & 0 & 0 & 0 \\
\hline & Lagoa Salgada & 0 & 0 & 0 & 0 & 0 & 0 & 0 & 0 & 0 & 3 & 0 & 0 & - & - & - & - & - & - & - & - & - & - & - & - & - \\
\hline & Lajes & 26 & 14 & 2 & 6 & 1 & 0 & 2 & 0 & 0 & 2 & 4 & 0 & 0 & 1 & 1 & 0 & 3 & 0 & 0 & 0 & 0 & 0 & 4 & 7 & 0 \\
\hline & Lajes Pintadas & 10 & 11 & 12 & 7 & 3 & 3 & 2 & 1 & 5 & 1 & 1 & 3 & 0 & 1 & 3 & 2 & 2 & 0 & 2 & 1 & 1 & 1 & 4 & $\begin{array}{r}1 \\
257\end{array}$ & 1 \\
\hline
\end{tabular}




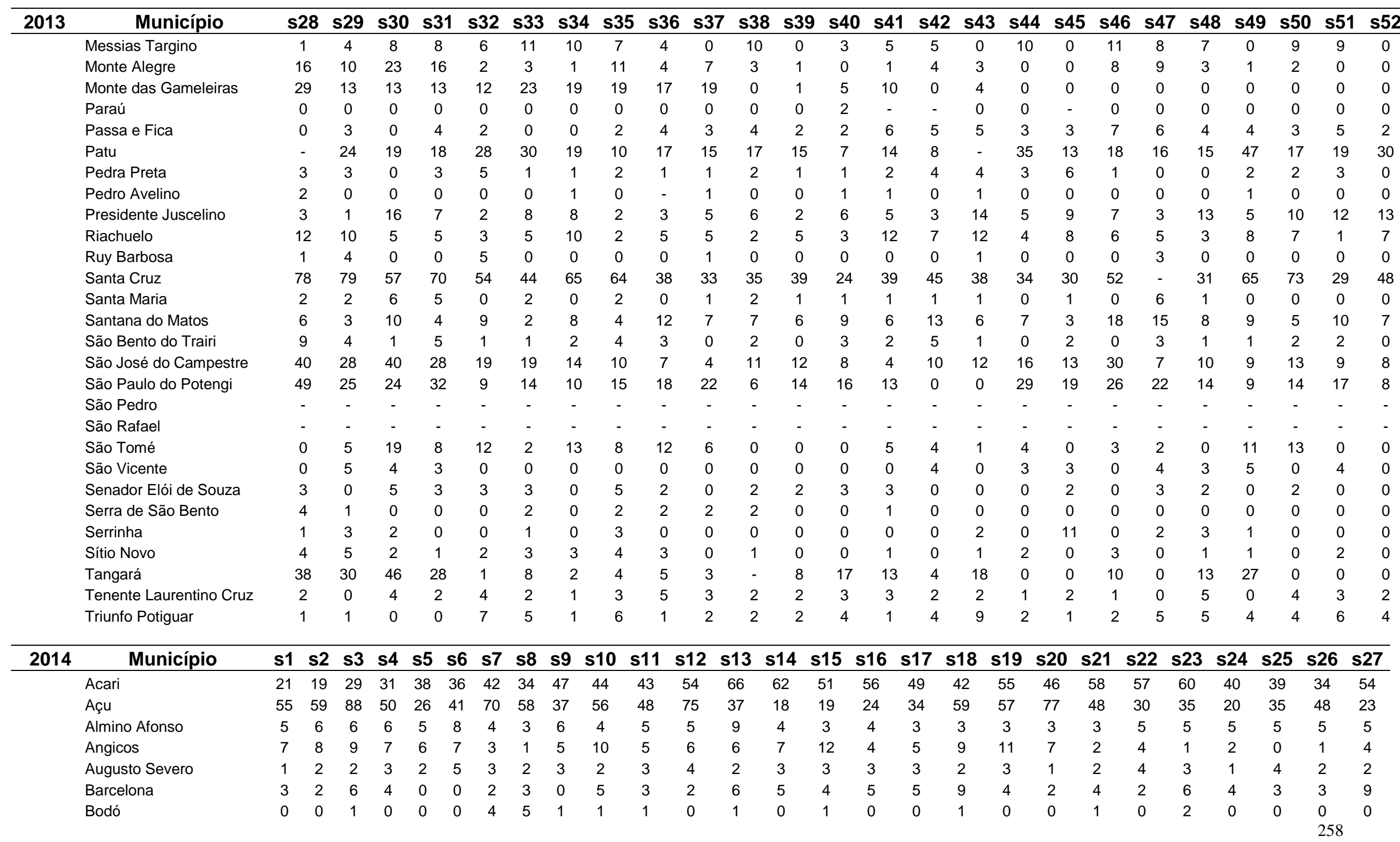




\begin{tabular}{|c|c|c|c|c|c|c|c|c|c|c|c|c|c|c|c|c|c|c|c|c|c|c|c|c|c|c|c|c|}
\hline 2014 & Município & s1 & s2 & s3 & s4 & s5 & s6 & s7 & s8 & s9 & $s 10$ & s11 & s12 & $s 13$ & s14 & s15 & s16 & s17 & s18 & s19 & s20 & s21 & s22 & s23 & s24 & s25 & s26 & s27 \\
\hline & Bom Jesus & 0 & 2 & 5 & 4 & 2 & 7 & 2 & 8 & 22 & 6 & 3 & 14 & 3 & 11 & 11 & - & 7 & 5 & 10 & 3 & 5 & 4 & 7 & 9 & 3 & 6 & - \\
\hline & Caiçara do Rio do Vento & 3 & 2 & 0 & 4 & 1 & 0 & 2 & 5 & 8 & 4 & 1 & 8 & 6 & 4 & 4 & 2 & 10 & 7 & 5 & 9 & 1 & 5 & 4 & 4 & 4 & 5 & 0 \\
\hline & Caicó & 0 & 2 & 2 & 1 & 7 & 7 & 16 & 3 & 3 & 0 & 3 & 10 & 8 & 1 & 21 & 1 & 2 & 10 & 10 & 10 & 12 & 42 & 29 & 29 & 23 & 18 & 0 \\
\hline & Campo Redondo & 9 & 11 & 0 & 18 & 0 & 0 & - & 0 & 0 & 0 & 0 & 5 & 25 & 26 & 0 & 0 & 0 & 0 & 6 & - & 5 & 10 & 18 & 18 & 0 & 0 & 12 \\
\hline & Coronel Ezequiel & 0 & 0 & 3 & - & - & 2 & 2 & 0 & 0 & 0 & 0 & 0 & 0 & 0 & 0 & 0 & 0 & 0 & 0 & 0 & - & 0 & 0 & 0 & 1 & 2 & 0 \\
\hline & Currais Novos & 23 & 49 & 50 & 52 & 56 & 25 & 36 & 23 & 51 & 74 & 103 & 79 & - & - & 137 & 48 & - & - & - & - & - & - & - & - & - & - & - \\
\hline & Fernando Pedroza & 0 & 0 & 1 & 4 & 0 & 0 & 0 & 0 & 0 & 0 & 0 & 0 & 0 & 0 & 0 & 0 & 0 & 0 & 0 & 0 & 0 & 0 & 0 & 0 & 0 & 0 & 0 \\
\hline & Florânia & 0 & 0 & 5 & 7 & 7 & 7 & 10 & 15 & 6 & 22 & 21 & 46 & 59 & 15 & 25 & 34 & 4 & 19 & 5 & 2 & 3 & 7 & 11 & 3 & 6 & 3 & 8 \\
\hline & Ielmo Marinho & 0 & 0 & 3 & 0 & 2 & 1 & 3 & 2 & 0 & 2 & 0 & 0 & 0 & 0 & 4 & 2 & 0 & 2 & 2 & 2 & 3 & 0 & 4 & 3 & 4 & 0 & 7 \\
\hline & Itajá & 0 & 0 & 2 & 0 & 2 & 2 & 1 & 1 & 2 & 4 & 1 & 4 & 1 & 0 & 0 & 0 & 2 & 1 & 4 & 6 & 13 & 3 & 16 & 6 & 0 & 3 & 0 \\
\hline & Jaçanã & 2 & 6 & 1 & 7 & 6 & 6 & 9 & 10 & 6 & 5 & 6 & 9 & 14 & 3 & 17 & - & - & 7 & 20 & 5 & 9 & 9 & 6 & 2 & 10 & - & 14 \\
\hline & Janduís & 4 & 4 & 5 & 10 & 3 & 6 & 3 & 8 & 0 & 1 & 8 & 10 & 3 & 12 & 6 & 2 & 3 & 11 & 13 & 8 & 11 & 6 & 10 & 8 & 4 & 6 & 6 \\
\hline & Januário Cicco & 7 & 7 & 6 & 5 & 7 & 12 & 6 & 12 & 3 & 5 & 11 & 7 & 11 & 8 & 11 & 10 & 19 & 16 & 7 & 5 & 4 & 6 & 5 & 4 & 4 & 5 & 6 \\
\hline & Japi & 2 & 8 & 6 & 8 & 11 & 6 & 8 & 4 & 3 & 5 & 11 & 8 & 7 & 7 & 6 & 3 & 6 & 4 & 2 & 6 & 1 & 2 & 3 & 4 & 5 & 3 & 7 \\
\hline & Jardim de Angicos & 0 & 0 & 0 & 0 & 0 & 0 & 6 & 3 & 0 & 0 & 0 & 0 & 0 & 0 & 8 & 0 & 0 & 0 & 0 & 0 & 0 & 0 & 0 & 0 & 0 & 0 & 0 \\
\hline & Lagoa d'Anta & 2 & 18 & 18 & 22 & 7 & 3 & 8 & 6 & 8 & 11 & 14 & 5 & 6 & 14 & 4 & 0 & 5 & 5 & 3 & 5 & 7 & 4 & 2 & 6 & 2 & 3 & 2 \\
\hline & Lagoa de Pedras & - & - & - & - & - & - & - & - & - & - & - & - & - & - & - & - & - & - & - & - & - & - & - & - & - & - & - \\
\hline & Lagoa de Velhos & 1 & 0 & 2 & 1 & 2 & 3 & 0 & 9 & 11 & 13 & 11 & 2 & 4 & 3 & 1 & 8 & 5 & 2 & 8 & 0 & 2 & 0 & 2 & 1 & 5 & 1 & 2 \\
\hline & Lagoa Nova & 0 & 0 & 0 & 0 & 0 & 3 & 0 & 0 & 0 & 0 & 0 & 0 & 0 & 0 & 0 & 0 & 0 & 0 & 5 & 3 & 1 & 0 & 21 & 2 & 0 & 3 & 0 \\
\hline & Lagoa Salgada & - & - & - & - & - & - & - & - & - & - & - & - & - & - & - & - & - & - & - & - & - & - & - & - & - & - & - \\
\hline & Lajes & 3 & 0 & 0 & 2 & 0 & 12 & - & - & 0 & 8 & 13 & 14 & 22 & 9 & - & 13 & 0 & 13 & 2 & 1 & 12 & 4 & 0 & 2 & 5 & 1 & 0 \\
\hline & Lajes Pintadas & 3 & 5 & 4 & 2 & 1 & 3 & 3 & 3 & 5 & 6 & 7 & 4 & 4 & 2 & 5 & 5 & 2 & 3 & 0 & 1 & 0 & 0 & 5 & 3 & 3 & 3 & 5 \\
\hline & Messias Targino & 10 & 11 & 0 & 14 & 4 & 0 & 5 & 8 & 0 & 7 & 4 & 2 & 0 & 0 & 6 & 5 & 0 & 0 & 13 & 11 & 3 & 3 & 2 & 3 & 4 & 0 & 1 \\
\hline & Monte Alegre & 0 & 5 & 2 & 6 & 8 & 2 & 6 & 8 & 7 & 3 & 2 & 3 & 6 & - & 4 & 7 & 16 & 6 & 6 & 2 & 2 & 5 & 6 & 3 & 12 & 4 & 3 \\
\hline & Monte das Gameleiras & 0 & 3 & 4 & 0 & 0 & 4 & 10 & 0 & 1 & 2 & 0 & 2 & 0 & 0 & 0 & 10 & 0 & 3 & 0 & 4 & 2 & 0 & 0 & 2 & 1 & 1 & 4 \\
\hline & Paraú & 0 & 0 & 0 & 1 & 8 & 0 & 1 & 3 & 0 & 0 & 0 & 0 & 0 & 0 & 2 & 0 & 0 & 0 & 0 & 0 & 0 & 0 & 0 & 0 & 0 & 0 & 0 \\
\hline & Passa e Fica & 3 & 4 & 3 & 4 & 6 & 6 & 4 & 5 & 5 & 4 & 2 & 3 & 4 & 4 & 4 & 5 & 3 & 4 & 0 & 2 & 3 & 0 & 1 & 2 & 0 & 0 & 4 \\
\hline & Patu & 5 & 6 & 6 & - & 2 & 11 & 10 & 6 & 5 & - & 6 & 7 & 6 & 16 & 28 & 37 & 22 & 24 & 17 & 17 & 15 & 8 & 7 & 6 & 9 & 6 & 6 \\
\hline & Pedra Preta & 1 & 0 & - & 5 & 1 & 3 & 4 & - & 8 & 7 & 1 & 7 & 5 & 13 & 14 & 7 & - & 5 & 6 & 4 & 2 & 0 & 2 & 4 & 2 & 4 & 2 \\
\hline & Pedro Avelino & 0 & 1 & 0 & 1 & 1 & 0 & 0 & 0 & 0 & 0 & 0 & 0 & 1 & 3 & 1 & 0 & 2 & 2 & 0 & 2 & 3 & 2 & 0 & 0 & 0 & 0 & 0 \\
\hline & Presidente Juscelino & 14 & 14 & 11 & 14 & 19 & 17 & 14 & 9 & 11 & 13 & 11 & 16 & 14 & 16 & 16 & 15 & 10 & 13 & 12 & 11 & 9 & 11 & 8 & 13 & 11 & 15 & 17 \\
\hline & Riachuelo & 1 & 9 & 6 & 4 & 12 & 11 & 13 & 4 & 4 & 19 & 5 & 13 & 15 & 5 & 6 & 9 & 11 & 4 & 4 & 7 & 5 & 4 & 5 & 3 & 3 & 3 & 3 \\
\hline & Ruy Barbosa & 0 & 0 & 0 & 0 & 3 & 0 & 2 & 0 & 0 & 0 & 0 & 9 & 6 & 0 & 0 & 4 & - & 4 & 0 & - & 0 & 0 & 0 & - & 0 & - & - \\
\hline & Santa Cruz & 52 & 51 & 70 & 67 & 56 & 59 & 76 & 92 & 68 & 77 & 67 & 91 & 27 & 80 & 76 & 65 & 66 & 34 & 65 & 59 & 56 & 80 & 100 & 85 & 67 & 75 & 102 \\
\hline & Santa Maria & 1 & 1 & 0 & 1 & 0 & 1 & 1 & 6 & 2 & 0 & 3 & 0 & 2 & 6 & 7 & 7 & 10 & 4 & 5 & 2 & 2 & 1 & 1 & 4 & 0 & 0 & 2 \\
\hline & Santana do Matos & 9 & 12 & 21 & 20 & 16 & 13 & 12 & 12 & 32 & 14 & 11 & 38 & 34 & 48 & 30 & 28 & 16 & 18 & 18 & 9 & 16 & 12 & 19 & 5 & 7 & 20 & 5 \\
\hline & São Bento do Trairi & 3 & 4 & 3 & 1 & 0 & 7 & 3 & 2 & 0 & 0 & 2 & 5 & 2 & 1 & 3 & 2 & 5 & 2 & 5 & 3 & 1 & 2 & 2 & 2 & 3 & 3 & 3 \\
\hline
\end{tabular}




\begin{tabular}{|c|c|c|c|c|c|c|c|c|c|c|c|c|c|c|c|c|c|c|c|c|c|c|c|c|c|c|c|c|c|}
\hline \multirow[t]{14}{*}{2014} & Município & s1 & s2 & s3 & s4 & $\mathrm{s} 5 \mathrm{~s}$ & $36 \mathrm{~s} 7$ & s8 & s9 s & s10s & s11 & s12 & s13 & s14 & s15 & $s 16$ & s17 & s18 & s19 & $\mathbf{s 2 0}$ & s21 & s2 & & $23 \mathrm{~s}$ & $s 24 s$ & $s 25$ & s26 & \multicolumn{2}{|l|}{ s27 } \\
\hline & São José do Campestre & 11 & 39 & 56 & 36 & 146 & $60 \quad 54$ & 28 & 35 & 4 & 17 & 51 & 6 & 13 & 29 & 33 & 10 & 26 & 5 & 28 & 29 & 16 & & 15 & & 28 & 19 & \multicolumn{2}{|l|}{19} \\
\hline & São Paulo do Potengi & 11 & 22 & 14 & 15 & 16 & 20 & 13 & 23 & 22 & 19 & 27 & 27 & 25 & 25 & 16 & 22 & 10 & 10 & 0 & 0 & 15 & & 13 & 14 & 14 & 16 & \multicolumn{2}{|l|}{17} \\
\hline & São Pedro & 6 & 7 & 6 & 8 & 11 & 5 & 5 & 6 & 4 & 6 & 5 & 6 & 7 & 7 & 3 & 4 & 3 & - & 5 & - & - & & 7 & 10 & 6 & 4 & \multicolumn{2}{|l|}{2} \\
\hline & São Rafael & 0 & 0 & 0 & 0 & 0 & 0 & 0 & 0 & 0 & 0 & 0 & 0 & 0 & 0 & 0 & 0 & 0 & 0 & 0 & 0 & 0 & & 0 & 0 & 0 & 0 & \multicolumn{2}{|l|}{0} \\
\hline & São Tomé & 0 & 4 & - & 1 & 1 & 2 & 3 & 3 & 1 & 0 & 0 & 0 & 0 & 0 & 0 & 6 & 7 & 8 & 17 & 9 & 16 & & 14 & 9 & 7 & 11 & \multicolumn{2}{|l|}{15} \\
\hline & São Vicente & 0 & 4 & 0 & 0 & 4 & 4 & 0 & 5 & 0 & 0 & 4 & 9 & 10 & 0 & 7 & 8 & 6 & 0 & 4 & 0 & 0 & & 0 & 5 & 0 & 1 & \multicolumn{2}{|l|}{1} \\
\hline & Senador Elói de Souza & 0 & 0 & 0 & 0 & 0 & 3 & 0 & 5 & 1 & 4 & 4 & 3 & 1 & 0 & 0 & 2 & 2 & 0 & 0 & 2 & 1 & & 0 & 8 & 0 & 10 & \multicolumn{2}{|l|}{4} \\
\hline & Serra de São Bento & 0 & 0 & 0 & 0 & 0 & 1 & 0 & 4 & 3 & 5 & 5 & 0 & 5 & 0 & 0 & 0 & 4 & 0 & 1 & 0 & 3 & & 2 & 0 & 0 & 3 & \multicolumn{2}{|l|}{6} \\
\hline & Serrinha & 0 & 0 & 0 & 0 & 0 & 0 & 1 & 2 & 2 & 0 & 0 & 1 & 1 & 1 & 0 & 0 & 1 & 1 & 4 & 1 & 1 & & 2 & 0 & 0 & 0 & \multicolumn{2}{|l|}{0} \\
\hline & Sítio Novo & 0 & 0 & 0 & 1 & 2 & 4 & 14 & 8 & 0 & 5 & 1 & 11 & 8 & 11 & 13 & 8 & 13 & 15 & 18 & 12 & 8 & 1 & 18 & 7 & 8 & 12 & \multicolumn{2}{|l|}{16} \\
\hline & Tangará & 0 & 17 & 36 & 26 & 0 & 15 & 17 & - & - & 20 & 19 & - & 18 & 16 & 20 & 12 & 24 & 7 & 15 & - & 32 & 2 & 22 & 10 & 18 & 15 & \multicolumn{2}{|l|}{17} \\
\hline & Tenente Laurentino Cruz & 0 & 3 & 6 & 1 & 4 & 4 & 1 & 2 & 3 & 8 & 12 & 8 & 16 & 24 & 22 & 8 & 5 & 10 & 9 & 11 & 7 & $\epsilon$ & 6 & 3 & 4 & 2 & \multicolumn{2}{|l|}{2} \\
\hline & Triunfo Potiguar & 1 & 7 & 3 & 10 & 7 & 3 & 4 & 3 & 10 & 7 & 6 & 7 & 6 & 11 & 3 & 7 & 1 & 12 & 8 & 10 & 3 & & 13 & 6 & 1 & 2 & \multicolumn{2}{|l|}{3} \\
\hline 2014 & Município & $\mathbf{s}$ & 28 & $\mathbf{s 2 9}$ & s30 & s31 & s32 & s33 & s34 & 4 s35 & 536 & 6 s37 & $7 \mathrm{~s} 38$ & $8 \mathrm{~s} 3 \mathrm{~s}$ & $9 \mathrm{s4}$ & $0 \mathrm{~s} 4$ & $1 \mathrm{s4}$ & $2 \mathrm{~s} 4$ & $3 \mathrm{s4}$ & 4 s4 & & $46 s$ & 347 & s48 & $s 49$ & 550 & $0 \mathrm{s51}$ & \multicolumn{2}{|c|}{1 s52 s53 } \\
\hline & Acari & & 53 & 43 & 56 & 41 & 54 & 45 & 42 & 42 & & 38 & 59 & 49 & 43 & 351 & 44 & $4 \quad 45$ & $5 \quad 49$ & 92 & & 5 & 36 & 53 & 46 & 25 & 30 & 29 & 32 \\
\hline & Açu & & 33 & 24 & 19 & 24 & 23 & 24 & 22 & 24 & 3 & 18 & 24 & 18 & 16 & 35 & 15 & $1 \varepsilon$ & 9 & 15 & & 6 & 37 & 31 & 33 & 31 & 52 & 19 & 12 \\
\hline & Almino Afonso & & 4 & 5 & 5 & 4 & 4 & 5 & 5 & 5 & 6 & 3 & 4 & 4 & 4 & 3 & 6 & 4 & 5 & 5 & & 6 & 5 & 4 & 6 & 5 & 4 & 3 & 5 \\
\hline & Angicos & & 4 & 3 & 4 & 0 & 0 & 1 & 0 & 4 & 0 & 0 & 0 & 1 & 3 & 0 & 0 & 4 & 2 & 1 & & 3 & 1 & 0 & 3 & 0 & 0 & 0 & 1 \\
\hline & Augusto Severo & & 2 & 1 & 2 & 3 & 3 & 2 & 3 & 2 & - & - & - & - & 2 & 2 & 3 & 1 & 3 & 3 & & 1 & 2 & 3 & - & 2 & 2 & 2 & 3 \\
\hline & Barcelona & & 6 & 3 & 5 & 1 & 0 & 0 & 0 & 4 & 2 & 11 & 3 & 7 & 2 & 1 & 3 & 3 & 2 & 10 & & 6 & 2 & 4 & 6 & 3 & 1 & 2 & 0 \\
\hline & Bodó & & 2 & 0 & 3 & 0 & 0 & 0 & 0 & 0 & 2 & 0 & 0 & 0 & 3 & 1 & 0 & 0 & 2 & 0 & & 3 & 1 & 0 & 1 & 1 & 1 & 2 & 1 \\
\hline & Bom Jesus & & 7 & 10 & 3 & - & 12 & 3 & 3 & 5 & 5 & 4 & 3 & - & 3 & 10 & - & - & 8 & 6 & & 6 & 4 & 5 & 3 & 3 & 10 & 4 & 7 \\
\hline & Caiçara do Rio do Vento & & 3 & 5 & 4 & 3 & 10 & 4 & 4 & 8 & 7 & 5 & 8 & 5 & 2 & 4 & 1 & 3 & 6 & 3 & & 4 & 0 & 3 & 2 & 3 & 2 & 0 & 0 \\
\hline & Caicó & 1 & 9 & 15 & 17 & 21 & 14 & 19 & 14 & 8 & 11 & 16 & 10 & 0 & 11 & 20 & 11 & $1 \varepsilon$ & 15 & 17 & & 2 & 19 & 22 & 25 & 16 & 18 & 14 & 25 \\
\hline & Campo Redondo & & 7 & 0 & 6 & 6 & 11 & 12 & 10 & 0 & 12 & 11 & 0 & 7 & - & 20 & - & 0 & 15 & 4 & & 6 & 7 & 9 & 11 & 0 & 20 & 0 & 13 \\
\hline & Coronel Ezequiel & & 0 & 1 & 0 & 0 & - & - & - & - & - & - & - & - & - & 0 & 1 & - & - & - & & - & - & - & - & - & 0 & - & 5 \\
\hline & Currais Novos & & - & - & - & - & - & - & - & - & - & - & - & - & - & - & - & - & - & - & & - & - & - & - & - & - & - & - \\
\hline & Fernando Pedroza & & 0 & 0 & 2 & 0 & 0 & 2 & 0 & 2 & 0 & 0 & 0 & 0 & 0 & 0 & 0 & 0 & 0 & 0 & & 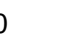 & - & 0 & 0 & 0 & 0 & 0 & - \\
\hline & Florânia & & 1 & 0 & 5 & 8 & 4 & 10 & 5 & 5 & 5 & 0 & 5 & 11 & 5 & 9 & 3 & 0 & 11 & 14 & & 2 & 8 & 8 & 7 & 16 & 7 & 2 & 2 \\
\hline & Ielmo Marinho & & 8 & 5 & 1 & 5 & 3 & 3 & 1 & 0 & 4 & 6 & 9 & 6 & 8 & 6 & 10 & 11 & 9 & 9 & & 9 & 7 & 4 & 1 & 17 & 3 & 3 & 8 \\
\hline & Itajá & & 1 & 5 & 1 & 0 & 0 & 0 & 0 & 0 & 0 & 0 & 2 & 0 & 0 & 0 & 0 & 0 & 0 & 0 & & 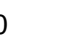 & 0 & 0 & 0 & 0 & 0 & 0 & 0 \\
\hline & Jaçanã & & 0 & 4 & 13 & 2 & 6 & 2 & 1 & 2 & 6 & 2 & 2 & 1 & 2 & 1 & 4 & - & - & 6 & & - & 1 & 1 & 1 & - & - & - & - \\
\hline & Janduís & & 7 & 4 & 2 & 5 & 3 & 1 & 8 & 3 & 1 & 2 & 6 & 6 & 6 & 3 & 5 & 4 & 2 & 6 & & 5 & 6 & 5 & 5 & 6 & 4 & 0 & 4 \\
\hline & Januário Cicco & & 2 & 5 & 10 & 11 & 9 & 3 & 6 & 9 & 5 & 8 & 6 & 7 & 7 & 8 & 17 & 5 & 14 & 6 & & 2 & 18 & 14 & 6 & 11 & 9 & 15 & 18 \\
\hline & Japi & & 9 & 6 & 6 & 7 & 5 & 6 & 3 & 2 & 2 & 4 & 3 & 5 & 2 & 7 & 10 & 17 & 17 & 12 & & 1 & 7 & 6 & 2 & 9 & 3 & 11 & 5 \\
\hline & Jardim de Angicos & & 0 & 0 & 0 & 1 & 2 & 0 & 3 & 0 & 0 & 0 & 0 & 0 & 0 & 0 & 0 & 2 & 2 & 5 & & 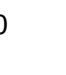 & 0 & 0 & 0 & 0 & $\begin{array}{r}0 \\
260\end{array}$ & 0 & 0 \\
\hline
\end{tabular}




\begin{tabular}{|c|c|c|c|c|c|c|c|c|c|c|c|c|c|c|c|c|c|c|c|c|c|c|c|c|c|c|c|}
\hline 2014 & Município & s28 & $s 29$ & s30 & s31 & s32 & s33 & s34 & s35 & s36 & s37 & s38 & s39 & s40 & s41 & s42 & s43 & s44 & s45 & $s 46$ & s47 & s48 & $s 49$ & s50 & s51 & s52 & s53 \\
\hline & Lagoa d'Anta & 3 & 2 & 5 & 3 & 4 & 3 & 2 & 3 & 4 & 4 & 2 & 3 & 2 & 5 & 2 & 1 & 6 & 6 & 3 & 10 & 1 & 0 & 0 & 2 & 1 & 0 \\
\hline & Lagoa de Pedras & - & - & - & - & - & - & - & - & - & - & - & - & - & - & - & - & - & - & - & - & - & - & - & - & - & - \\
\hline & Lagoa de Velhos & 3 & 4 & 0 & 2 & 3 & 5 & 2 & 1 & 6 & 4 & 3 & 5 & 6 & 1 & 3 & 2 & 3 & 3 & 1 & 1 & 2 & 2 & 0 & 0 & 0 & 4 \\
\hline & Lagoa Nova & 0 & 0 & 0 & 2 & 0 & 0 & 0 & 0 & 0 & 0 & 4 & 0 & 0 & 1 & 0 & 0 & 0 & 0 & 0 & - & 3 & 0 & 0 & 0 & 1 & 0 \\
\hline & Lagoa Salgada & - & - & - & - & - & - & - & - & - & - & - & - & - & - & - & - & - & - & - & - & - & - & - & - & - & - \\
\hline & Lajes & 0 & 0 & 6 & 0 & 1 & 5 & 0 & 11 & 0 & 0 & 0 & 0 & 1 & 2 & 2 & 0 & 0 & 0 & 0 & 0 & 0 & 0 & - & 6 & 0 & - \\
\hline & Lajes Pintadas & 3 & 5 & 1 & 2 & 2 & 1 & 0 & - & 5 & - & 1 & 2 & 2 & 3 & 2 & 1 & 0 & 0 & 2 & 0 & 1 & 2 & 1 & 1 & - & 2 \\
\hline & Messias Targino & 0 & 3 & 4 & - & 10 & 2 & - & 4 & 1 & - & 6 & 5 & - & 4 & 4 & 7 & 2 & 3 & 3 & 4 & 5 & 3 & 12 & 7 & 8 & 9 \\
\hline & Monte Alegre & 14 & 24 & 12 & 23 & 20 & 14 & 16 & 28 & 10 & 13 & 23 & 3 & 35 & 5 & 14 & 11 & 2 & 6 & 7 & 0 & 4 & 4 & 2 & 9 & 0 & 5 \\
\hline & Monte das Gameleiras & 0 & 0 & 3 & 1 & 0 & 2 & 1 & 3 & 2 & 0 & 2 & 0 & 0 & 0 & 3 & 3 & 0 & 0 & 1 & 0 & 0 & 0 & 6 & 0 & 1 & 0 \\
\hline & Paraú & 0 & 0 & 0 & 0 & 0 & 0 & 0 & 0 & 0 & 0 & 0 & 0 & 0 & 0 & 0 & 0 & 0 & 0 & 0 & 0 & 0 & 0 & 0 & 0 & 0 & 0 \\
\hline & Passa e Fica & 4 & 2 & 0 & 1 & 0 & 2 & 0 & 3 & 3 & 4 & 1 & 0 & 5 & 2 & 3 & 3 & 0 & 3 & 4 & 5 & 4 & 3 & 4 & 6 & 3 & 1 \\
\hline & Patu & 1 & 4 & 16 & 3 & 1 & 14 & 9 & 8 & 8 & 2 & 4 & 7 & - & 12 & 12 & 15 & 12 & 12 & 5 & 3 & 6 & 6 & 17 & 12 & 27 & 16 \\
\hline & Pedra Preta & 3 & 0 & 2 & 0 & 1 & 2 & 3 & 4 & 2 & 2 & 1 & 1 & 1 & 1 & 0 & 0 & 5 & 4 & 2 & 1 & 5 & 2 & 2 & 2 & 3 & 3 \\
\hline & Pedro Avelino & 0 & 0 & 0 & 0 & 1 & 0 & 0 & 0 & 0 & 0 & 0 & 0 & 2 & 0 & 0 & 1 & 0 & 0 & 0 & 0 & 0 & 4 & 0 & 0 & 0 & 0 \\
\hline & Presidente Juscelino & 9 & 16 & 20 & 6 & 13 & 18 & 13 & 14 & 12 & 10 & 10 & 10 & 11 & 9 & 11 & 15 & 20 & - & 27 & 18 & 17 & - & 9 & 15 & 10 & 11 \\
\hline & Riachuelo & 7 & 13 & 7 & 1 & 7 & 2 & 1 & 0 & 3 & 3 & 3 & 3 & 4 & 5 & 7 & 2 & 4 & 2 & 6 & 6 & 4 & 12 & 16 & 16 & 18 & 16 \\
\hline & Ruy Barbosa & - & - & - & - & - & - & - & - & - & - & - & - & - & - & - & - & - & - & - & - & - & - & - & - & - & - \\
\hline & Santa Cruz & 74 & 56 & 54 & 60 & 42 & 49 & 52 & 39 & 47 & 34 & 18 & 72 & 48 & 53 & 61 & 68 & 56 & 66 & 59 & 38 & 57 & 53 & 27 & 39 & 40 & 37 \\
\hline & Santa Maria & 1 & 0 & 0 & 0 & 1 & 0 & 0 & 0 & 0 & 0 & 0 & 0 & 0 & 0 & 0 & 0 & 2 & 0 & 0 & 0 & 0 & 0 & 0 & 0 & 0 & 0 \\
\hline & Santana do Matos & 7 & 6 & 11 & 1 & 6 & 6 & 2 & 14 & 4 & 9 & 7 & 7 & 6 & 3 & 4 & 1 & 5 & 2 & 1 & 8 & 14 & 19 & 15 & 9 & 16 & 11 \\
\hline & São Bento do Trairi & 5 & 1 & 1 & 0 & 6 & 4 & 3 & 0 & 1 & 2 & 0 & 1 & 0 & 0 & 2 & 5 & 13 & 12 & 6 & 4 & 3 & 4 & 2 & 0 & 0 & 0 \\
\hline & São José do Campestre & 12 & 12 & 33 & 6 & 10 & 16 & 11 & 19 & 15 & 11 & 13 & 14 & 8 & 17 & 55 & 15 & 14 & 14 & 11 & 22 & 13 & 29 & 26 & 26 & 22 & 19 \\
\hline & São Paulo do Potengi & 14 & 15 & 17 & 21 & 16 & 9 & 15 & 9 & 14 & 18 & 16 & 21 & 29 & 34 & 33 & 24 & 17 & 15 & 26 & 21 & 20 & 34 & 27 & 26 & 22 & 23 \\
\hline & São Pedro & 2 & 3 & 3 & 4 & 5 & 5 & 3 & 7 & 12 & 10 & 4 & 4 & 6 & 5 & 6 & - & - & - & - & 9 & - & - & - & - & - & - \\
\hline & São Rafael & 0 & 0 & 0 & 0 & 0 & 0 & 0 & 0 & 0 & 0 & 0 & 0 & 0 & 0 & 0 & 0 & 0 & - & - & - & - & - & - & - & - & - \\
\hline & São Tomé & 17 & 10 & 7 & 3 & 5 & - & 5 & 3 & 5 & 7 & - & 2 & - & - & - & 8 & 7 & 8 & 14 & 19 & 13 & 21 & 19 & 9 & - & 14 \\
\hline & São Vicente & 5 & 4 & 3 & 1 & 2 & 0 & 0 & 0 & 0 & 0 & 0 & 0 & 4 & 3 & 3 & 2 & 0 & 3 & 0 & 3 & 3 & 3 & 0 & 0 & 0 & 0 \\
\hline & Senador Elói de Souza & 4 & 3 & 0 & 3 & 0 & 0 & 8 & 4 & 0 & 0 & 0 & 0 & 0 & 3 & 0 & 7 & 0 & 3 & 0 & 2 & 0 & 0 & 0 & 0 & 0 & 4 \\
\hline & Serra de São Bento & 0 & 0 & 2 & 0 & 0 & 1 & 1 & 0 & 0 & 1 & 6 & 5 & 11 & 11 & 7 & 4 & 0 & 0 & 0 & 0 & 5 & 0 & 0 & 0 & 0 & 5 \\
\hline & Serrinha & 0 & 1 & 0 & 1 & 0 & 0 & 0 & 0 & 0 & 4 & 0 & 0 & 0 & 0 & 4 & 0 & 1 & 2 & 0 & 3 & 1 & 1 & 0 & 0 & 0 & 0 \\
\hline & Sítio Novo & 21 & 11 & 4 & 15 & 9 & 0 & 2 & 4 & 8 & 5 & 3 & 5 & 15 & 5 & 8 & 6 & 8 & 3 & 3 & 6 & 5 & 10 & 10 & 4 & 5 & - \\
\hline & Tangará & 12 & 26 & 22 & 17 & 19 & 51 & 30 & 8 & 25 & 59 & 12 & 6 & 7 & 48 & 40 & 49 & 17 & 26 & 36 & 25 & 34 & 23 & 30 & 21 & 4 & 17 \\
\hline & Tenente Laurentino Cruz & 3 & 1 & 2 & 4 & 2 & - & 2 & - & 0 & 0 & 5 & 1 & 0 & 1 & 2 & 0 & 0 & 0 & 1 & 0 & 1 & 0 & 0 & 0 & 2 & 1 \\
\hline & Triunfo Potiguar & 3 & 4 & 3 & 5 & 4 & 1 & 2 & 2 & 4 & 2 & 2 & 3 & 1 & 2 & 7 & 2 & 5 & 5 & 2 & 5 & 0 & 3 & 2 & 2 & 0 & 0 \\
\hline
\end{tabular}




\section{Precipitação Acumulada (mm)}

\begin{tabular}{|c|c|c|c|c|c|c|c|c|c|c|c|c|c|c|c|c|c|c|c|c|c|}
\hline 2002 & Estação & s1 & s2 & s3 & s4 & s5 & s6 & s7 & s8 & s9 & $s 10$ & s11 & s12 & $s 13$ & s14 & s15 & s16 & s17 & s18 & $\mathbf{s} 19$ & s20 \\
\hline & Acari (Açude Gargalheiras) & 99,9 & 29,7 & 39,9 & 27 & 23,3 & 49,3 & 104,3 & 14,6 & 0 & 159,3 & 7,8 & 56,7 & 7,8 & 39,3 & 22,4 & 7,2 & 0 & 24,8 & 17,3 & 17,3 \\
\hline & Assu (Particular) & 15,8 & 21,9 & 119,6 & 17,2 & 7,6 & 28,6 & 81,6 & 4,1 & 1 & 59,6 & 22,8 & 78,9 & 5 & 61,4 & 13,9 & 18,4 & 18,2 & 14,9 & 17,8 & 41,5 \\
\hline & Assu (Volta) & 8 & 34 & 65 & 16 & 2 & 12 & 68,3 & 52 & 0 & 65 & 0 & 0 & 18 & 44 & 26,4 & 8 & 25 & 3 & 25 & 14 \\
\hline & Afonso Bezerra (EMATER) & 39 & 75 & 60 & 55 & 0 & 60 & 128 & 25 & 10 & 87 & 32 & 15 & 30 & 93 & 60 & 30 & 0 & 18 & 7 & 0 \\
\hline & Afonso Bezerra (Assentamento Santa Maria) & 2,5 & 72,3 & 38,7 & 16,5 & 0 & 42,6 & 60,7 & 0 & 0 & 65,3 & 42,8 & 32,2 & 0 & 11,2 & 0 & 0 & 0 & 0 & 32,2 & 1,5 \\
\hline & Angicos (Prefeitura) & 10 & 0 & 36 & 5 & 28 & 28 & 4 & 0 & 3 & 135,8 & 0,4 & 88,2 & 27,9 & 15,7 & 61,1 & 23 & 0 & 34 & 28,4 & 3,9 \\
\hline & Campo Grande (Particular) & 48,6 & 54,1 & 106,3 & 6,8 & 24 & 59,6 & 82,7 & 22,3 & 0 & 76,1 & 2 & 27,7 & 15 & 60,1 & 51,3 & 17,8 & 2,1 & 12,9 & 0 & 84 \\
\hline & Campo Grande (Açude Morcego - Extinto) & 16 & 80 & 41 & 12 & 21 & 35 & 37 & 4 & 8 & 0 & 0 & 0 & 0 & 0 & 0 & 0 & 0 & 0 & 0 & 0 \\
\hline & Campo Grande (Particular 2) & 64 & 88 & 129,9 & 33,2 & 24,3 & 82,6 & 115,1 & 9 & 0 & 109,7 & 6,7 & 29 & 21,1 & 88 & 27,4 & 29,3 & 40 & 25 & 41,3 & 83 \\
\hline & Barcelona (Particular) & 0 & 44,5 & 14 & 9,5 & 2 & 31 & 3 & 0 & 4 & 80,5 & 10 & 29 & 2 & 48,5 & 8 & 2,5 & 10,5 & 18 & 43 & 0 \\
\hline & Bom Jesus (Particular) & 79,8 & 28,4 & 38 & 2 & 28,4 & 119,1 & 0 & 0 & 0 & 74,8 & 18,8 & 9,3 & 36,8 & 15 & 17 & 10 & 4 & 16,2 & 40 & 0,6 \\
\hline & Caiçara do Rio do Vento (Particular) & 0 & 6,5 & 43 & 0 & 14,7 & 22 & 2 & 0 & 0 & 72,9 & 2,5 & 19,9 & 14 & 7,1 & 3 & 0 & 0 & 17 & 30 & 0 \\
\hline & Caicó (Batalhão) & 38,4 & 21,8 & 102,2 & 39,3 & 33,5 & 29 & 86,5 & 7 & 7 & 142,5 & 4,5 & 88,5 & 42 & 140,5 & 37,5 & 13 & 0 & 21,5 & 30 & 31,5 \\
\hline & Caicó (Açude Mundo Novo - EMPARN) & 47,4 & 49 & 101,7 & 0 & 41,8 & 35 & 101,4 & 10,5 & 0 & 82,2 & 0 & 60,8 & 42,1 & 58,2 & 45,7 & 23 & 0 & 14 & 23,4 & 31,5 \\
\hline & Caicó (Palma) & 63,4 & 31,4 & 78 & 14,6 & 23,8 & 26,4 & 85,6 & 0 & 0 & 109,6 & 2 & 43 & 21,6 & 95 & 33,8 & 28,8 & 0 & 9,6 & 13,6 & 36,2 \\
\hline & Caicó (Açude Itans) & 33,2 & 15,6 & 113,6 & 33,4 & 31,5 & 7,9 & 41,2 & 1,8 & 25,1 & 118,2 & 0,8 & 62,4 & 46,1 & 129,3 & 30,1 & 11,1 & 15 & 15,1 & 15,7 & 17,9 \\
\hline & Campo Redondo (Polícia Rodoviária) & 35 & 35,1 & 22,1 & 0 & 15,6 & 0 & 0 & 0 & 0 & 40,2 & 17,6 & 38,1 & 3,2 & 23,7 & 35,8 & 0 & 0 & 31,5 & 9,5 & 0 \\
\hline & Cerro Corá (EMATER) & 0 & 0 & 28,5 & 0 & 8 & 4 & 28 & 2 & 0 & 157,7 & 42 & 10,4 & 50 & 2 & 69 & 0 & 0 & 6 & 11 & 0 \\
\hline & Coronel Ezequiel (Particular) & 0 & 20 & 11 & 4 & 35 & 11 & 88,2 & 0 & 0 & 92,5 & 4 & 25,8 & 0 & 4 & 26,2 & 0 & 0 & 9 & 20,6 & 19 \\
\hline & Cruzeta (Base Física da EMPARN) & 84,1 & 6,2 & 73,7 & 5,7 & 38,1 & 10,9 & 121,3 & 1,6 & 0 & 138,6 & 6,8 & 33,6 & 8,6 & 47,4 & 70,3 & 9,9 & 0,3 & 2,1 & 33,8 & 80,1 \\
\hline & Currais Novos (CERCEL) & 10 & 7 & 107 & 2 & 24 & 43 & 59 & 6 & 0 & 107 & 8 & 20 & 0 & 50 & 38 & 25 & 0 & 0 & 11 & 11 \\
\hline & Currais Novos (Açude Tororó) & 14,7 & 19,2 & 67,4 & 0 & 40,6 & 0 & 106,7 & 0 & 0 & 80 & 0 & 36,4 & 0 & 70,8 & 0 & 20,6 & 0 & 5 & 2 & 49,4 \\
\hline & Janduís (EMATER) & 74,5 & 36 & 91,5 & 64 & 60 & 8 & 213 & 32 & 0 & 126 & 7 & 47 & 4 & 71 & 63,5 & 14 & 2 & 26 & 11,5 & 61 \\
\hline & Boa Saúde (EMATER) & 4,7 & 29,3 & 0 & 6,9 & 13 & 15 & 1,5 & 0 & 0 & 73,5 & 0 & 25 & 0 & 53,8 & 11,5 & 3 & 15,5 & 23,5 & 38,5 & 0 \\
\hline & Lagoa d'Anta (Prefeitura) & 65 & 55,9 & 15,4 & 2,3 & 10 & 8,1 & 1,2 & 0 & 0,6 & 33,2 & 5,8 & 35,9 & 54 & 10,8 & 2,3 & 13,1 & 11,3 & 53,8 & 50,9 & 0 \\
\hline & Lagoa Nova (EMATER/Sítio Humaitá) & 22,6 & 0 & 27,6 & 0 & 4 & 49,6 & 72,2 & 12 & 0 & 163,4 & 21,2 & 20,4 & 8 & 27,6 & 12,8 & 0 & 0 & 16 & 10 & 0 \\
\hline & Lagoa Salgada (Delegacia) & 1,9 & 32,1 & 37 & 3,4 & 13 & 31,3 & 27,5 & 0 & 0 & 118,8 & 0 & 21,1 & 80,5 & 12,2 & 4,9 & 7,6 & 3,4 & 20,5 & 32,8 & 0 \\
\hline & Monte Alegre (EMATER) & 14 & 50 & 23 & 13 & 46 & 43 & 7 & 5 & 1 & 104,6 & 17 & 30 & 6 & 58,4 & 35 & 9 & 10 & 21 & 36 & 0 \\
\hline & Paraú (Prefeitura) & 34,6 & 96,5 & 41,8 & 42 & 16,2 & 61,2 & 16,8 & 26,2 & 0 & 58,2 & 0 & 0 & 0 & 0 & 0 & 0 & 0 & 0 & 0 & 0 \\
\hline & Patu (Particular) & 96 & 47 & 108 & 41 & 46 & 6 & 120 & 20 & 4 & 128 & 0 & 43 & 40 & 55 & 90 & 60 & 48 & 52 & 63 & 58 \\
\hline & Santa Maria (Sindicato dos Trabalhadores Rurais) & 45 & 27 & 8 & 0 & 29 & 40 & 0 & 0 & 0 & 122 & 8,6 & 11 & 27 & 87 & 0 & 0 & 0 & 25 & 50 & 0 \\
\hline & Pedra Preta (EMATER) & 0 & 2 & 8,4 & 71,6 & 10,3 & 16 & 11 & 0 & 0 & 87 & 5,2 & 43,2 & 8,2 & 33 & 3,4 & 1,2 & 0 & 13,2 & 33,4 & 2,2 \\
\hline
\end{tabular}




\begin{tabular}{|c|c|c|c|c|c|c|c|c|c|c|c|c|c|c|c|c|c|c|c|c|c|}
\hline 2002 & Estação & s1 & s2 & s3 & s4 & s5 & s6 & s7 & s8 & s9 & s10 & s11 & s12 & s13 & s14 & s15 & s16 & s17 & s18 & s19 & s20 \\
\hline & Pedro Avelino (Particular) & 6 & 26,4 & 45,8 & 23,3 & 19 & 35,6 & 60,2 & 0 & 0 & 51,9 & 61,4 & 15,2 & 13,4 & 43,6 & 42,5 & 40 & 1 & 30,5 & 13 & 0 \\
\hline & Pedro Avelino (Base Física da EMPARN) & 0 & 63,2 & 108,1 & 1,2 & 22,7 & 38 & 3,5 & 0 & 0 & 64,8 & 9,5 & 44,9 & 18 & 53,7 & 64 & 5,1 & 9,1 & 82,5 & 17,1 & 4,6 \\
\hline & Pedro Avelino (Assentamento Feijão) & 4 & 31,4 & 30,5 & 0 & 11,2 & 11 & 2 & 0 & 15 & 26,5 & 57,7 & 38 & 9 & 52,2 & 56,5 & 19,2 & 0 & 20,2 & 15,2 & 0 \\
\hline & Pedro Avelino (Assentamento Nova Conquista) & 0 & 54 & 41 & 20 & 12 & 50 & 42 & 0 & 0 & 78 & 0 & 40 & 0 & 100 & 70 & 30 & 0 & 100 & 20 & 0 \\
\hline & Riachuelo (EMATER) & 49,5 & 44 & 0 & 8,5 & 14 & 9 & 4,5 & 0 & 0 & 41 & 1 & 56 & 58 & 58 & 8 & 0 & 0 & 18 & 40 & 5 \\
\hline & Santa Cruz (EMATER) & 5,5 & 58 & 20,7 & 0 & 27 & 9,9 & 0 & 0 & 0 & 44 & 2 & 16 & 37,5 & 0 & 0 & 1 & 0 & 30,5 & 12 & 0 \\
\hline & Santana do Matos (EMATER) & 0 & 25 & 90,8 & 14,2 & 34 & 15,7 & 75 & 7,5 & 18,6 & 99,3 & 14,6 & 15,1 & 0 & 72 & 37 & 19 & 17 & 11 & 0 & 26,2 \\
\hline & Santana do Matos (Barão de Serra Branca) & 17,3 & 8,3 & 48,7 & 9 & 26,5 & 10,7 & 65,7 & 17,7 & 18,8 & 65,1 & 16,7 & 68,4 & 19 & 102,5 & 45,1 & 20 & 9,7 & 30 & 0 & 22,5 \\
\hline & Santana do Matos (São José da Passagem) & 0 & 28,2 & 41 & 7,5 & 5 & 28,4 & 30,1 & 7,6 & 20,6 & 182,6 & 37,6 & 4,2 & 0 & 6,5 & 64,4 & 7,2 & 9,2 & 11,2 & 25 & 0 \\
\hline & São José do Campestre (EMATER) & 50 & 0 & 32 & 11 & 10 & 16 & 8 & 0 & 0 & 44,5 & 7 & 23 & 8 & 23 & 5 & 0 & 0 & 30 & 37 & 0 \\
\hline & São José do Campestre (Açude Japi II) & 0 & 0 & 16 & 15 & 30 & 0 & 35 & 0 & 20 & 0 & 10 & 0 & 36 & 0 & 10,5 & 0 & 0 & 0 & 0 & 0 \\
\hline & São Paulo do Potengi (EMATER) & 3,6 & 95,1 & 8,8 & 0 & 20 & 25,4 & 5,5 & 0 & 0 & 76,8 & 4 & 21,5 & 8,6 & 67,5 & 9,4 & 0,3 & 0,6 & 11,3 & 67,6 & 0,4 \\
\hline & São Rafael (EMATER) & 0 & 61 & 73 & 22,4 & 40,8 & 29,6 & 50 & 0 & 15 & 72 & 6 & 39 & 30 & 51 & 34,4 & 29 & 0 & 63,6 & 15,5 & 39 \\
\hline & São Tomé (EMATER) & 0 & 0 & 0 & 0 & 0 & 0 & 0 & 0 & 0 & 95,8 & 24 & 4,7 & 14,8 & 2,2 & 12 & 0 & 0 & 11 & 43 & 0 \\
\hline & São Vicente (EMATER - Ex Particular) & 31 & 30 & 34 & 50 & 15 & 42 & 108 & 30 & 3 & 90 & 10 & 50 & 21 & 129 & 4 & 54 & 0 & 0 & 22 & 18 \\
\hline & Senador Eloi de Souza (EMATER) & 0 & 0 & 0 & 0 & 0 & 0 & 0 & 0 & 0 & 67,1 & 2,9 & 8,6 & 13,6 & 15,1 & 9,1 & 1,8 & 0 & 22,4 & 18,7 & 0 \\
\hline & Serra de São Bento (EMATER) & 15,5 & 15,1 & 29,8 & 17,5 & 3,1 & 18,6 & 9,4 & 0 & 0 & 65 & 5,5 & 14,5 & 34,8 & 2,1 & 0 & 4,4 & 6,7 & 20,8 & 64,2 & 0 \\
\hline & Tangará (EMATER) & 2 & 75 & 40 & 0,5 & 26 & 34 & 5 & 0 & 2 & 29 & 5,5 & 0 & 12 & 22 & 0 & 6 & 10 & 10 & 27 & 0 \\
\hline & Tangará (Açude Trairi) & 6,9 & 40,5 & 34,8 & 5,9 & 0 & 26,3 & 0 & 0 & 0 & 31 & 4,1 & 8,7 & 12,8 & 17,6 & 0 & 3,6 & 0 & 26,8 & 24,5 & 0 \\
\hline & Tenente Laurentino Cruz (EMATER) & 37 & 0 & 67,1 & 57 & 12,2 & 93,8 & 171 & 9 & 0 & 0 & 0 & 0 & 0 & 0 & 0 & 0 & 0 & 7 & 8,3 & 20,3 \\
\hline & Triunfo Potiguar (Chá Cacimbas/Serra J. Vale) & 0 & 96 & 112 & 34 & 8 & 25 & 57 & 30 & 0 & 0 & 0 & 0 & 0 & 0 & 0 & 0 & 0 & 0 & 0 & 0 \\
\hline
\end{tabular}

Gargalheiras

$\begin{array}{llllllllllllllllllll}s 21 & s 22 & s 23 & s 24 & s 25 & s 26 & s 27 & s 28 & s 29 & s 30 & s 31 & s 32 & s 33 & s 34 & s 35 & s 36 & s 37 & s 38 & s 39 & s 40\end{array}$

Assu (Particular)

Assu (Volta)

Afonso Bezerra (EMATER)

Afonso Bezerra (Assentamento Santa Maria)

Angicos (Prefeitura)

Campo Grande (Particular)

Campo Grande (Açude Morcego - Extinto)

Campo Grande (Particular 2)

Barcelona (Particular)

Bom Jesus (Particular)

Caiçara do Rio do Vento (Particular)

Caicó (Batalhão)

$\begin{array}{ccccccccc}155,6 & 27,6 & 3,7 & 17,5 & 6,7 & 0 & 0 & 0 & 0 \\ 13,9 & 22,7 & 1,5 & 51,5 & 17,8 & 0 & 15 & 7,1 & 0 \\ 35 & 117 & 0 & 9 & 15 & 0 & 0 & 0 & 0 \\ 30 & 33 & 0 & 16 & 0 & 0 & 0 & 0 & 0 \\ 2,5 & 42 & 0 & 33,7 & 2,5 & 42 & 0 & 0 & 0 \\ 35,5 & 26,4 & 0 & 0 & 17,3 & 0 & 8,8 & 0 & 0 \\ 18,5 & 13 & 11,5 & 0 & 8,5 & 8,4 & 2,3 & 5,6 & 0 \\ 32 & 0 & 0 & 0 & 0 & 0 & 0 & 0 & 0 \\ 25,6 & 16,1 & 26 & 4,7 & 12,6 & 0 & 4 & 10 & 0 \\ 0 & 14 & 20 & 22 & 28,5 & 0 & 11,5 & 10 & 0 \\ 3 & 33,4 & 12,6 & 43,8 & 31 & 7,6 & 25 & 8,9 & 0 \\ 0 & 6 & 0 & 12 & 65 & 0 & 9 & 1,5 & 2 \\ 33,5 & 32 & 1,5 & 0 & 0 & 0 & 0 & 0 & 0\end{array}$

$\begin{array}{cccc}0 & 0 & 0 & 0 \\ 3,8 & 2 & 0 & 2,1 \\ 0 & 0 & 0 & 0 \\ 0 & 0 & 0 & 0 \\ 0 & 0 & 0 & 0 \\ 0 & 0 & 0 & 0 \\ 0 & 0 & 0 & 0 \\ 0 & 0 & 0 & 0 \\ 0 & 0 & 0 & 7,4 \\ 14 & 13 & 6 & 5 \\ 18,6 & 15,8 & 16,8 & 0 \\ 0 & 4 & 0 & 0 \\ 0 & 0 & 0 & 0\end{array}$

$\begin{array}{ccccccc}34 & \text { s35 } & \text { s36 } & \text { s37 } & \text { s38 } & \text { s39 } & \text { s40 } \\ 0 & 0 & 0 & 0 & 0 & 0 & 0 \\ 0 & 0 & 0 & 0 & 0 & 0 & 0 \\ 0 & 0 & 0 & 0 & 0 & 0 & 0 \\ 0 & 0 & 0 & 0 & 0 & 0 & 0 \\ 0 & 0 & 0 & 0 & 0 & 0 & 0 \\ 0 & 0 & 0 & 0 & 0 & 0 & 0 \\ 0 & 0 & 0 & 0 & 0 & 0 & 0 \\ 0 & 0 & 0 & 0 & 0 & 0 & 0 \\ 0 & 0 & 0 & 0 & 0 & 0 & 4,3 \\ 4 & 0 & 0 & 0 & 0 & 0 & 0 \\ 0 & 33,8 & 6 & 11,4 & 0,8 & 9,8 & 0 \\ 0 & 0 & 0 & 0 & 0 & 0 & 0 \\ 0 & 0 & 0 & 0 & 0 & 0 & 0\end{array}$




\begin{tabular}{|c|c|c|c|c|c|c|c|c|c|c|c|c|c|c|c|c|c|c|c|c|c|}
\hline 2002 & Estação & s21 & s22 & s23 & s24 & s25 & s26 & $\mathbf{s 2 7}$ & $\mathbf{s} 28$ & $\mathbf{s 2 9}$ & s30 & s31 & s32 & s33 & s34 & s35 & s36 & s37 & s38 & s39 & s40 \\
\hline & Caicó (Açude Mundo Novo - EMPARN) & 19 & 0 & 0 & 0 & 0 & 0 & 0 & 0 & 0 & 0 & 0 & 0 & 0 & 0 & 0 & 0 & 0 & 0 & 0 & 18 \\
\hline & Caicó (Palma) & 13 & 4,4 & 3 & 0 & 0 & 0 & 0 & 0 & 0 & 0 & 0 & 0 & 0 & 0 & 0 & 0 & 0 & 0 & 0 & 0 \\
\hline & Caicó (Açude Itans) & 26,1 & 12,4 & 1,5 & 0 & 0 & 0 & 0 & 0 & 0 & 0 & 0 & 0 & 0 & 0 & 0 & 0 & 0 & 0 & 0 & 0 \\
\hline & Campo Redondo (Polícia Rodoviária) & 55 & 44,5 & 5,3 & 28,6 & 51 & 0 & 5,3 & 5,5 & 0 & 16,7 & 11,4 & 0 & 0 & 13,6 & 0 & 0 & 0 & 0 & 0 & 0 \\
\hline & Cerro Corá (EMATER) & 17 & 96 & 8 & 0 & 59 & 0 & 0 & 0 & 0 & 0 & 9,5 & 0 & 10 & 0 & 0 & 0 & 0 & 0 & 0 & 0 \\
\hline & Coronel Ezequiel (Particular) & 18,8 & 104 & 16 & 12,2 & 24 & 0 & 11 & 7,5 & 0 & 9 & 0 & 0 & 0 & 0 & 0 & 0 & 0 & 0 & 0 & 0 \\
\hline & Cruzeta (Base Física da EMPARN) & 14,1 & 0,9 & 22,6 & 3 & 2,4 & 0 & 1,6 & 1,9 & 0 & 0 & 0,7 & 0 & 0 & 0,2 & 0 & 0 & 0 & 0 & 0 & 0 \\
\hline & Currais Novos (CERCEL) & 10 & 32 & 2 & 0 & 0 & 0 & 0 & 2 & 0 & 0 & 0 & 0 & 0 & 0 & 0 & 0 & 0 & 0 & 0 & 0 \\
\hline & Currais Novos (Açude Tororó) & 0 & 34 & 11 & 10 & 15,7 & 7,4 & 6 & 8,2 & 0 & 0 & 0 & 0 & 0 & 0 & 0 & 0 & 0 & 0 & 0 & 0 \\
\hline & Janduís (EMATER) & 5 & 2 & 2 & 0 & 13 & 0 & 1 & 12 & 0 & 8 & 0 & 0 & 0 & 0 & 0 & 0 & 0 & 0 & 0 & 0 \\
\hline & Boa Saúde (EMATER) & 3,5 & 35,3 & 9,3 & 43,5 & 44 & 0 & 20 & 39 & 0 & 0 & 29,5 & 10 & 9 & 23,5 & 0 & 0 & 0 & 0 & 0 & 0 \\
\hline & Lagoa d'Anta (Prefeitura) & 6 & 39,1 & 52,2 & 6,8 & 58,9 & 6 & 31,3 & 14,9 & 0 & 27,7 & 21 & 0 & 12,2 & 13,3 & 1,3 & 2,5 & 6,8 & 2,1 & 0 & 0 \\
\hline & Lagoa Nova (EMATER/Sítio Humaitá) & 19,9 & 36,8 & 11,6 & 37,6 & 41 & 0 & 25,4 & 0 & 0 & 0 & 0 & 7 & 3 & 6 & 0 & 0 & 0 & 0 & 0 & 0 \\
\hline & Lagoa Salgada (Delegacia) & 6,7 & 28,5 & 13 & 33,6 & 114,7 & 8 & 40,2 & 35 & 0 & 15,6 & 55 & 6,4 & 10 & 31 & 0 & 0 & 0 & 0 & 0 & 0 \\
\hline & Monte Alegre (EMATER) & 0 & 56 & 25 & 7,8 & 139 & 9 & 21 & 39 & 1 & 7 & 59 & 3 & 55 & 35 & 0 & 0 & 0 & 0 & 0 & 0 \\
\hline & Paraú (Prefeitura) & 0 & 0 & 0 & 0 & 0 & 0 & 0 & 0 & 0 & 0 & 0 & 0 & 0 & 0 & 0 & 0 & 0 & 0 & 0 & 0 \\
\hline & Patu (Particular) & 2 & 3 & 18 & 2 & 8 & 0 & 2 & 0 & 0 & 11 & 0 & 0 & 0 & 0 & 0 & 20 & 0 & 0 & 0 & 0 \\
\hline & Santa Maria (Sindicato dos Trabalhadores Rurais) & 0 & 0 & 0 & 50 & 60 & 10 & 33 & 22 & 0 & 0 & 20 & 0 & 0 & 0 & 0 & 0 & 0 & 0 & 0 & 0 \\
\hline & Pedra Preta (EMATER) & 1 & 22,6 & 16,4 & 6,4 & 23,8 & 2,2 & 0 & 15,2 & 0 & 10,2 & 7,4 & 0 & 0 & 0 & 0 & 0 & 0 & 0 & 0 & 0 \\
\hline & Pedro Avelino (Particular) & 0 & 19,6 & 4,6 & 1,8 & 11,2 & 0 & 4,1 & 3 & 0 & 0 & 4,2 & 0 & 0 & 0 & 0 & 0 & 0 & 0 & 0 & 0 \\
\hline & Pedro Avelino (Base Física da EMPARN) & 0,2 & 36,2 & 1,1 & 27,3 & 11,8 & 0 & 5,3 & 5 & 0 & 0 & 0 & 0 & 0 & 0 & 0 & 0 & 0 & 0 & 0 & 0 \\
\hline & Pedro Avelino (Assentamento Feijão) & 13 & 10,2 & 0 & 2 & 9,2 & 0 & 0 & 0 & 0 & 0 & 0 & 0 & 0 & 0 & 0 & 0 & 0 & 0 & 0 & 0 \\
\hline & Pedro Avelino (Assentamento Nova Conquista) & 0 & 20 & 0 & 0 & 15 & 0 & 0 & 0 & 0 & 0 & 0,4 & 0 & 0 & 0 & 0 & 0 & 0 & 0 & 0 & 0 \\
\hline & Riachuelo (EMATER) & 5,5 & 9 & 9,5 & 51,5 & 38 & 0 & 21,5 & 16,5 & 0 & 4 & 35 & 3 & 21,5 & 10 & 0 & 0 & 0 & 0 & 0 & 0 \\
\hline & Santa Cruz (EMATER) & 0 & 74,5 & 35 & 72,5 & 26 & 0 & 0 & 0 & 0 & 0 & 17 & 0 & 6,5 & 0 & 0 & 0 & 0 & 0 & 0 & 0 \\
\hline & Santana do Matos (EMATER) & 20,5 & 13,8 & 0 & 0 & 30 & 0 & 0 & 0 & 0 & 0 & 0 & 0 & 0 & 0 & 0 & 0 & 0 & 0 & 0 & 0 \\
\hline & Santana do Matos (Barão de Serra Branca) & 49,5 & 13,7 & 8,3 & 0 & 12,3 & 3 & 8,3 & 0 & 0 & 0 & 0 & 0 & 0 & 0 & 0 & 0 & 0 & 0 & 0 & 18,9 \\
\hline & Santana do Matos (São José da Passagem) & 34 & 16,4 & 0 & 16,2 & 0 & 0 & 0 & 0 & 0 & 0 & 0 & 0 & 0 & 0 & 0 & 0 & 0 & 0 & 0 & 0 \\
\hline & São José do Campestre (EMATER) & 0 & 23 & 24 & 25 & 54 & 0 & 37 & 7 & 0 & 25 & 20 & 0 & 20 & 0 & 0 & 0 & 0 & 0 & 0 & 0 \\
\hline & São José do Campestre (Açude Japi II) & 0 & 30,5 & 0 & 0 & 0 & 0 & 22,5 & 0 & 0 & 0 & 0 & 0 & 0 & 0 & 0 & 0 & 0 & 0 & 0 & 0 \\
\hline & São Paulo do Potengi (EMATER) & 10,9 & 9,4 & 12,6 & 4,8 & 52,3 & 0 & 9,9 & 7,6 & 0 & 13,4 & 22,2 & 14,8 & 7,4 & 15,2 & 0 & 0 & 0 & 0 & 0 & 0 \\
\hline & São Rafael (EMATER) & 14,2 & 29 & 12,5 & 26,8 & 40,2 & 0 & 1,8 & 3,6 & 0 & 0 & 0 & 0 & 0 & 0 & 0 & 0 & 0 & 0 & 0 & 2 \\
\hline & São Tomé (EMATER) & 29 & 93 & 15 & 0 & 32 & 11 & 12,5 & 0 & 0 & 0 & 6,5 & 0 & 0 & 0 & 0 & 0 & 0 & 0 & 0 & 0 \\
\hline & São Vicente (EMATER - Ex Particular) & 69 & 30 & 0 & 20 & 8 & 0 & 28 & 0 & 0 & 0 & 0 & 0 & 0 & 0 & 0 & 0 & 0 & 0 & 0 & 0 \\
\hline & Senador Eloi de Souza (EMATER) & 0,9 & 0 & 10,4 & 28,9 & 34 & 0 & 12,2 & 14,7 & 0 & 13,9 & 13,5 & 0 & 0 & 0 & 0 & 0 & 0 & 0 & 0 & 0 \\
\hline & Serra de São Bento (EMATER) & 0 & 40 & 29,8 & 16,8 & 43,5 & 0 & 18,4 & 9,9 & 0 & 23 & 22,6 & 0 & 43,3 & 5,5 & 1,5 & 0 & 0 & 0 & 0 & 0 \\
\hline
\end{tabular}




\begin{tabular}{|c|c|c|c|c|c|c|c|c|c|c|c|c|c|c|c|c|c|c|c|c|c|c|}
\hline \multirow[t]{5}{*}{2002} & Estação & s21 & s2 & $22 s 2$ & 352 & \multicolumn{2}{|c|}{ s25 } & s26 & s27 & s28 & s29 & s30 & s31 & s32 & s33 & s34 & s35 & s36 & s37 & s38 & s39 & s40 \\
\hline & Tangará (EMATER) & 4 & 35 & $5 \quad 0$ & 4 & 4 & 38 & 0,5 & 0 & 0 & 0 & 0 & 0 & 0 & 0 & 0 & 0 & 0 & 0 & 0 & 0 & 0 \\
\hline & Tangará (Açude Trairi) & 3,5 & 20 , & ,3 & 0 & 3 & 1,7 & 0 & 13,4 & 8 & 0 & 12 & 18,2 & 0 & 6,7 & 8,7 & 0 & 0 & 0 & 0 & 0 & 0 \\
\hline & Tenente Laurentino Cruz (EMATER) & 29,2 & 42 , & 2,8 & 13 & 3,5 & 3,3 & 0 & 9,1 & 0 & 0 & 0 & 0 & 0 & 0 & 0 & 0 & 0 & 0 & 0 & 0 & 0 \\
\hline & Triunfo Potiguar (Chá Cacimbas/Serra J. Vale) & 0 & 0 & 0 & c & 0 & 0 & 0 & 8 & 15 & 8 & 0 & 0 & 0 & 15 & 0 & 0 & 0 & 15 & 0 & 0 & 0 \\
\hline 2002 & Estação & s41 & s42 & s43 & s44 & s45 & s46 & s47 & s4 & $8 \mathrm{~s} 4$ & $9 \mathrm{~s} 50$ & s51 & $1 \mathrm{~s} 5$ & & & & & & & & & \\
\hline & Acari (Açude Gargalheiras) & 0 & 0 & 0 & 0 & 0 & 0 & 15,6 & 67,6 & 0 & 0 & 0 & 21,6 & & & & & & & & & \\
\hline & Assu (Particular) & 0 & 0 & 0 & 0 & 0 & 0 & 3 & 0 & 0 & 3 & 0 & 0 & & & & & & & & & \\
\hline & Assu (Volta) & 0 & 0 & 0 & 0 & 0 & 0 & 0 & 0 & 0 & 0 & 0 & 0 & & & & & & & & & \\
\hline & Afonso Bezerra (EMATER) & 0 & 0 & 0 & 0 & 0 & 0 & 0 & 0 & 0 & 0 & 0 & 0 & & & & & & & & & \\
\hline & Afonso Bezerra (Assentamento Santa Maria) & 0 & 0 & 0 & 0 & 0 & 0 & 0 & 0 & 0 & 0 & 0 & 0 & & & & & & & & & \\
\hline & Angicos (Prefeitura) & 0 & 0 & 0 & 0 & 0 & 0 & 0 & 0 & 0 & 42 & 0 & 0 & & & & & & & & & \\
\hline & Campo Grande (Particular) & 0 & 0 & 0 & 0 & 0 & 0 & 0 & 0 & 0 & 0 & 0 & 0 & & & & & & & & & \\
\hline & Campo Grande (Açude Morcego - Extinto) & 0 & 0 & 0 & 0 & 0 & 0 & 0 & 0 & 0 & 0 & 0 & 0 & & & & & & & & & \\
\hline & Campo Grande (Particular 2) & 0 & 0 & 0 & 0 & 0 & 0 & 3,8 & 8 & 0 & 3,1 & 0 & 4 & & & & & & & & & \\
\hline & Barcelona (Particular) & 11,5 & 0 & 0 & 0 & 0 & 0 & 0 & 0 & 0 & 0 & 0 & 0 & & & & & & & & & \\
\hline & Bom Jesus (Particular) & 2 & 21,6 & 0 & 18,4 & 0 & 0 & 0 & 0 & 0 & 0 & 0 & 0 & & & & & & & & & \\
\hline & Caiçara do Rio do Vento (Particular) & 0 & 0 & 0 & 0 & 0 & 0 & 0 & 0 & 0 & 0 & 0 & 0 & & & & & & & & & \\
\hline & Caicó (Batalhão) & 0 & 0 & 0 & 0 & 0 & 0 & 0 & 0 & 0 & 0 & 0 & 8 & & & & & & & & & \\
\hline & Caicó (Açude Mundo Novo - EMPARN) & 0 & 0 & 0 & 0 & 0 & 0 & 0 & 0 & 0 & 0 & 0 & 0 & & & & & & & & & \\
\hline & Caicó (Palma) & 0 & 0 & 0 & 0 & 3 & 0 & 2 & 0 & 0 & 5 & 0 & 0 & & & & & & & & & \\
\hline & Caicó (Açude Itans) & 0 & 0 & 0 & 0 & 0 & 0 & 0 & 0 & 0 & 0 & 0 & 0 & & & & & & & & & \\
\hline & Campo Redondo (Polícia Rodoviária) & 0 & 0 & 0 & 0 & 0 & 0 & 0 & 15 & 0 & 14,4 & 0 & 0 & & & & & & & & & \\
\hline & Cerro Corá (EMATER) & 0 & 0 & 0 & 0 & 0 & 0 & 1,2 & 0,3 & 0 & 0 & 0 & 0 & & & & & & & & & \\
\hline & Coronel Ezequiel (Particular) & 16 & 0 & 0 & 0 & 0 & 0 & 3 & 2 & 0 & 2,6 & 0 & 0 & & & & & & & & & \\
\hline & Cruzeta (Base Física da EMPARN) & 0 & 0 & 0 & 0 & 0 & 0 & 1 & 0 & 0,2 & 38,2 & 0 & 0 & & & & & & & & & \\
\hline & Currais Novos (CERCEL) & 0 & 0 & 0 & 0 & 0 & 0 & 0 & 0 & 0 & 0 & 0 & 0 & & & & & & & & & \\
\hline & Currais Novos (Açude Tororó) & 0 & 0 & 0 & 0 & 0 & 0 & 10 & 0 & 0 & 0 & 0 & 0 & & & & & & & & & \\
\hline & Janduís (EMATER) & 0 & 0 & 0 & 0 & 0 & 0 & 4 & 2 & 0 & 0 & 0 & 49 & & & & & & & & & \\
\hline & Boa Saúde (EMATER) & 0 & 0 & 0 & 0 & 0 & 2,5 & 8,5 & 1 & 0 & 0 & 0 & 41 & & & & & & & & & \\
\hline & Lagoa d'Anta (Prefeitura) & 10,2 & 0 & 1,1 & 0 & 5,4 & 0,5 & 7,4 & 8,6 & 0 & 0,5 & 6,3 & 1,3 & & & & & & & & & \\
\hline & Lagoa Nova (EMATER/Sítio Humaitá) & 0 & 0 & 0 & 0 & 0 & 0 & 0 & 0 & 0 & 0 & 0 & 0 & & & & & & & & & \\
\hline & Lagoa Salgada (Delegacia) & 0 & 0 & 0 & 0 & 0 & 0 & 0 & 0 & 0 & 0 & 0 & 0 & & & & & & & & & \\
\hline & Monte Alegre (EMATER) & 0 & 0 & 0 & 0 & 0 & 0 & 0 & 0 & 0 & 0 & 0 & 0 & & & & & & & & & \\
\hline & Paraú (Prefeitura) & 0 & 0 & 0 & 0 & 0 & 0 & 0 & 0 & 0 & 0 & 0 & 0 & & & & & & & & & \\
\hline & Patu (Particular) & 0 & 0 & 0 & 0 & 6 & 0 & 0 & 5 & 0 & 0 & 0 & 5 & & & & & & & & & \\
\hline
\end{tabular}




\begin{tabular}{|c|c|c|c|c|c|c|c|c|c|c|c|c|c|c|c|c|c|c|c|c|c|}
\hline 2002 & Estação & s41 & s4 & & s43 & s44s & s45 & $s 46$ & s47 & s48 s & s49 & s50 s & s51 s52 & & & & & & & & \\
\hline & Santa Maria (Sindicato dos Trabalhadores Rurais) & 0 & 0 & & 0 & 0 & 0 & 0 & 0 & 0 & 0 & 0 & $0 \quad 0$ & & & & & & & & \\
\hline & Pedra Preta (EMATER) & 0 & 0 & & 0 & 0 & 0 & 0 & 0 & 0 & 6,2 & 14,2 & 0 & & & & & & & & \\
\hline & Pedro Avelino (Particular) & 0 & 0 & & 0 & 0 & 0 & 0 & 0 & 0 & 0 & 0 & 0 & & & & & & & & \\
\hline & Pedro Avelino (Base Física da EMPARN) & 0 & 0 & & 0 & 0 & 0 & 0 & 0 & 0 & 25 & 0 & 0 & & & & & & & & \\
\hline & Pedro Avelino (Assentamento Feijão) & 0 & 0 & & 0 & 0 & 0 & 0 & 0 & 0 & 0 & 0 & 0 & & & & & & & & \\
\hline & Pedro Avelino (Assentamento Nova Conquista) & 0 & 0 & & 0 & 0 & 0 & 0 & 0 & 0 & 25 & 0 & 0 & & & & & & & & \\
\hline & Riachuelo (EMATER) & 0 & 0 & & 0 & 0 & 0 & 0 & 0 & 8 & 0 & 0 & 0 & & & & & & & & \\
\hline & Santa Cruz (EMATER) & 0 & 0 & & 0 & 0 & 0 & 0 & 0 & 0 & 0 & 0 & 0 & & & & & & & & \\
\hline & Santana do Matos (EMATER) & 0 & 0 & & 0 & 0 & 0 & 0 & 0 & 0 & 0 & 10 & 18 & & & & & & & & \\
\hline & Santana do Matos (Barão de Serra Branca) & 0 & 0 & & 0 & 0 & 0 & 0 & 0 & 0 & 0 & 15,8 & 8,5 & & & & & & & & \\
\hline & Santana do Matos (São José da Passagem) & 0 & 0 & & 0 & 0 & 0 & 0 & 0 & 0 & 0 & 0 & 0 & & & & & & & & \\
\hline & São José do Campestre (EMATER) & 12 & 0 & & 0 & 0 & 0 & 0 & 16 & 0 & 0 & 0 & 0 & & & & & & & & \\
\hline & São José do Campestre (Açude Japi II) & 5,2 & 0 & & 0 & 0 & 0 & 0 & 0 & 0 & 0 & 0 & 0 & & & & & & & & \\
\hline & São Paulo do Potengi (EMATER) & 0 & 0 & & 0 & 0 & 0 & 0 & 0 & 0 & 23,2 & 0 & 0 & & & & & & & & \\
\hline & São Rafael (EMATER) & 0 & 0 & & 0 & 0 & 0 & 0 & 0 & 0 & 0 & 12,6 & 0 & & & & & & & & \\
\hline & São Tomé (EMATER) & 0 & 0 & & 0 & 0 & 0 & 0 & 4,2 & 0 & 0 & 0 & 0 & & & & & & & & \\
\hline & São Vicente (EMATER - Ex Particular) & 0 & 0 & & 0 & 0 & 0 & 0 & 0 & 0 & 0 & 0 & 0 & & & & & & & & \\
\hline & Senador Eloi de Souza (EMATER) & 0 & 0 & & 0 & 0 & 0 & 0 & 0 & 0 & 0 & 0 & 0 & & & & & & & & \\
\hline & Serra de São Bento (EMATER) & 0 & 0 & & 0 & 0 & 0 & 0 & 20,7 & 0 & 4,4 & 10 & 0 & & & & & & & & \\
\hline & Tangará (EMATER) & 0 & 0 & & 0 & 0 & 0 & 0 & 0 & 0 & 0 & 0 & 0 & & & & & & & & \\
\hline & Tangará (Açude Trairi) & 7 & 0 & & 0 & 0 & 0 & 0 & 0 & 5,8 & 0 & 0 & 0 & & & & & & & & \\
\hline & Tenente Laurentino Cruz (EMATER) & 0 & 0 & & 0 & 0 & 0 & 0 & 0 & 0 & 0 & 0 & 0 & & & & & & & & \\
\hline & Triunfo Potiguar (Chá Cacimbas/Serra J. Vale) & 0 & 0 & & 0 & 0 & 0 & 0 & 0 & 0 & 0 & 0 & 30 & & & & & & & & \\
\hline 2003 & Estação & s1 & s2 & s3 & s4 & s5 & s6 & s7 & s8 & s9 & s10 & s11 & s12 & s13 & s14 & s15 & s16 & s17 & s18 & s19 & s20 \\
\hline & Acari (Açude Gargalheiras) & 0 & 0 & 9,8 & 36,3 & 13,2 & 12,7 & 3,5 & 7,9 & 64,6 & 0 & 0 & 131,5 & 34 & 5,2 & 12,6 & 12,3 & 12,5 & 63 & 16 & 0 \\
\hline & Assu (Particular) & 0 & 0 & 0 & 28,3 & 322,8 & 31,5 & 0 & 1,3 & 14,7 & 40,5 & 8,9 & 66,7 & 1,4 & 72,6 & 67,1 & 16,7 & 38,5 & 15,6 & 12,1 & 8,9 \\
\hline & Assu (Volta) & 0 & 0 & 0 & 34 & 52 & 0 & 3 & 5 & 13 & 11 & 35 & 65 & 0 & 58 & 22 & 10 & 42 & 0 & 13 & 0 \\
\hline & Afonso Bezerra (EMATER) & 0 & 0 & 0 & 10 & 70 & 10 & 8 & 0 & 0 & 8 & 15 & 130 & 8 & 82 & 50 & 20 & 0 & 0 & 40 & 0 \\
\hline & Afonso Bezerra (Assentamento Santa Maria) & 0 & 0 & 0 & 46,4 & 31,3 & 0 & 0 & 0 & 0 & 56,7 & 38,8 & 44,6 & 61,1 & 8,3 & 32,2 & 17,7 & 3 & 0 & 19,9 & 11,2 \\
\hline & Almino Afonso (Particular - Ex Sítio Milagres) & 0 & 0 & 0 & 63,5 & 54,7 & 18,3 & 0 & 62,2 & 117,1 & 70,1 & 21,7 & 34,4 & 112,9 & 34,6 & 56,5 & 81,7 & 31,4 & 76,3 & 13,3 & 10,3 \\
\hline & Angicos (Prefeitura) & 0 & 0 & 0 & 0 & 67,4 & 6 & 0 & 0 & 22,9 & 16 & 0 & 87 & 0 & 33,9 & 27,1 & 0 & 69,3 & 6,6 & 34,8 & 12,2 \\
\hline & Campo Grande (Particular) & 0 & 0 & 0 & 15,4 & $4 \quad 48,3$ & 0 & 0 & 71,2 & 95,8 & 7,3 & 110,1 & ,1 101,8 & 1,2 & 36,9 & 17,2 & 0 & 36,6 & 31,4 & 28,6 & 0 \\
\hline & Campo Grande (Particular 2) & 0 & 0 & 0 & 26,5 & 561 & 0 & 0 & 79,3 & 83,8 & 16,7 & $7 \quad 138,2$ & ,2 111,7 & 6,3 & 30,6 & 31,8 & 3 & 31,5 & 39,3 & 26,5 & 22,8 \\
\hline & Barcelona (Particular) & 0 & 0 & 0 & 28 & 64 & 45 & 0 & 1 & 22 & 33 & 1 & 106 & 2 & 1 & 31 & 2 & 22 & 14 & 12 & 0 \\
\hline & Bom Jesus (Particular) & 0 & 0 & 0 & 3 & 34,2 & 45,8 & 0 & 2 & 83 & 32,8 & 23,8 & 142 & 8 & 40 & 2 & 0 & 19,2 & 32 & 0,8 & 3,6 \\
\hline
\end{tabular}




\begin{tabular}{|c|c|c|c|c|c|c|c|c|c|c|c|c|c|c|c|c|c|c|c|c|c|}
\hline 2003 & Estação & s1 & s2 & s3 & s4 & s5 & s6 & s7 & s8 & s9 & s10 & s11 & s12 & s13 & s14 & s15 & s16 & s17 & s18 & s19 & s20 \\
\hline & Caiçara do Rio do Vento (Particular) & 0 & 0 & 30 & 42 & 59 & 13,5 & 0 & 0 & 58 & 37 & 0 & 17,9 & 0 & 18,5 & 51,5 & 0 & 16 & 14,2 & 0 & 3 \\
\hline & Caicó (Batalhão) & 22,5 & 0 & 0 & 0 & 5 & 53,5 & 24,5 & 50 & 17,5 & 12,5 & 10 & 106,9 & 6 & 20 & 43,6 & 40 & 82,5 & 46 & 10 & 0 \\
\hline & Caicó (Açude Mundo Novo - EMPARN) & 0 & 0 & 0 & 51 & 26,5 & 31,5 & 30,1 & 1,2 & 25,5 & 18,6 & 2,8 & 109,3 & 13,6 & 14,6 & 45,5 & 35 & 16 & 30,6 & 14,2 & 0 \\
\hline & Caicó (Palma) & 0 & 0 & 8 & 47 & 42,2 & 1,8 & 12 & 9 & 2,6 & 35,2 & 13 & 195,6 & 52,2 & 33,6 & 22,6 & 73 & 1,6 & 36,2 & 9 & 0 \\
\hline & Caicó (Açude Itans) & 0 & 0 & 0 & 38,5 & 11,3 & 8,8 & 15,9 & 18,1 & 11,3 & 37,3 & 22,8 & 87,3 & 4,1 & 24,9 & 29,9 & 30,7 & 14,3 & 10 & 11,2 & 0 \\
\hline & Campo Redondo (Polícia Rodoviária) & 0 & 0 & 0 & 96,3 & 51,4 & 39,4 & 0 & 0 & 0 & 13,1 & 0 & 65,6 & 30,2 & 1,3 & 18,5 & 0 & 18,2 & 13,2 & 13,4 & 4,5 \\
\hline & Cerro Corá (Sítio Recanto - Extinto) & 0 & 0 & 0 & 0 & 0 & 27,9 & 0 & 0 & 5,5 & 7,2 & 1,2 & 63 & 2,8 & 26,5 & 36,6 & 38,2 & 19,5 & 0 & 10 & 0 \\
\hline & Coronel Ezequiel (Particular) & 0 & 0 & 0 & 63 & 89 & 39 & 0 & 0 & 22,1 & 33 & 0 & 93,9 & 16 & 34 & 10 & 4,9 & 28 & 11,4 & 0 & 13 \\
\hline & Cruzeta (Base Física da EMPARN) & 0 & 0 & 0 & 29,5 & 40,3 & 6,9 & 6,3 & 11,2 & 18,6 & 20,6 & 0 & 74,1 & 10,8 & 10,6 & 87,5 & 0 & 21,1 & 46,8 & 54,6 & 0,3 \\
\hline & Currais Novos (CERCEL) & 0 & 0 & 0 & 63 & 11 & 30 & 0 & 0 & 0 & 0 & 0 & 55 & 0 & 0 & 96 & 3 & 26 & 0 & 9,2 & 2 \\
\hline & Currais Novos (Açude Tororó) & 0 & 0 & 0 & 22,4 & 11,6 & 26,4 & 0 & 0 & 0 & 0 & 0 & 64,8 & 0 & 0 & 19,4 & 40 & 0 & 0 & 0 & 0 \\
\hline & Janduís (EMATER) & 0 & 0 & 0 & 37 & 46 & 24 & 0 & 45 & 66 & 54 & 57 & 83 & 15 & 58 & 50 & 0 & 8 & 116 & 20 & 62 \\
\hline & Boa Saúde (EMATER) & 0 & 68 & 0 & 42 & 19 & 11 & 14,5 & 55 & 0 & 0 & 0 & 68,5 & 24,5 & 12 & 7,7 & 0 & 23 & 34 & 1,5 & 4 \\
\hline & Japi (Particular) & 16,8 & 10,4 & 6,2 & 0 & 0 & 0 & 0 & 0 & 0 & 39,8 & 2,2 & 0 & 12,8 & 0 & 0 & 0 & 0 & 0 & 6,4 & 0 \\
\hline & Lagoa d'Anta (Prefeitura) & 0 & 0 & 0 & 14 & 67,1 & 54,8 & 0 & 27 & 142,2 & 42,1 & 25,2 & 102,7 & 29,8 & 21 & 17,6 & 3,7 & 45 & 43,5 & 5,9 & 15,8 \\
\hline & Lagoa Nova (EMATER/Sítio Humaitá) & 0 & 10 & 7 & 23 & 69 & 12,5 & 0 & 0 & 0 & 0 & 0 & 101 & 3 & 20,5 & 37,5 & 0 & 14 & 27,5 & 1 & 0 \\
\hline & Lagoa Salgada (Delegacia) & 0 & 0 & 0 & 23,9 & 31,2 & 58,4 & 0 & 38 & 87,5 & 8 & 24,7 & 115,6 & 31,5 & 12,2 & 0 & 0 & 17,1 & 25,3 & 6,8 & 11,6 \\
\hline & Monte Alegre (EMATER) & 0 & 0 & 0 & 20 & 37 & 59 & 3 & 17 & 87 & 31 & 21 & 151 & 27 & 17 & 20 & 4 & 22 & 31 & 5 & 35 \\
\hline & Patu (Particular) & 0 & 0 & 0 & 133 & 26 & 10 & 4 & 88 & 84 & 75 & 11 & 73 & 20 & 111 & 44 & 20 & 5 & 118 & 19 & 55 \\
\hline & Pedra Preta (EMATER) & 0 & 0 & 6,2 & 33,6 & 22,6 & 47 & 0 & 14,2 & 34,6 & 9,6 & 4,2 & 83,2 & 0 & 2,2 & 0 & 0 & 0 & 0 & 0 & 0 \\
\hline & Pedro Avelino (Particular) & 0 & 0 & 0 & 18,4 & 49,1 & 14,6 & 29 & 5,2 & 5,8 & 3,8 & 8,8 & 45 & 1,8 & 50,2 & 43,2 & 1,4 & 12,2 & 0 & 12 & 0 \\
\hline & Pedro Avelino (Base Física da EMPARN) & 0 & 0 & 0 & 18 & 1,8 & 5 & 0 & 47,6 & 50,6 & 0 & 10,1 & 110,7 & 0 & 52,8 & 40,6 & 4,1 & 33,9 & 16,1 & 30,1 & 0 \\
\hline & Pedro Avelino (Assentamento Feijão) & 0 & 0 & 0 & 15,2 & 10,3 & 11 & 0 & 9 & 0 & 4 & 6 & 40 & 0 & 25,1 & 30,2 & 0 & 8 & 0 & 15 & 0 \\
\hline & Pedro Avelino (Assentamento Nova Conquista) & 0 & 0 & 0 & 50 & 65 & 36 & 0 & 80 & 81,8 & 28 & 0 & 145 & 0 & 61,8 & 10 & 0 & 0 & 10 & 11 & 0 \\
\hline & Riachuelo (EMATER) & 0 & 0 & 0 & 33 & 36,6 & 32 & 0 & 3 & 60,5 & 36,5 & 6 & 53,5 & 0 & 16 & 19 & 0 & 12 & 32 & 5 & 22 \\
\hline & Santa Cruz (EMATER) & 0 & 0 & 0 & 41,5 & 12 & 21 & 0 & 0 & 13 & 0 & 0 & 25,5 & 11 & 0 & 4 & 0 & 10,5 & 15,5 & 2 & 11 \\
\hline & Santana do Matos (EMATER) & 0 & 0 & 39 & 17,5 & 51 & 0 & 0 & 36,5 & 0 & 0 & 0 & 106 & 0 & 19 & 85 & 0 & 0 & 28 & 6 & 35 \\
\hline & Santana do Matos (Barão de Serra Branca) & 0 & 0 & 0 & 32,7 & 48,8 & 0 & 0 & 3,7 & 16,8 & 15,9 & 0 & 127,6 & 0 & 56,5 & 76 & 25,7 & 9,7 & 32,3 & 45,7 & 16,7 \\
\hline & São José do Campestre (EMATER) & 0 & 4 & 0 & 0 & 45 & 11 & 0 & 0 & 110 & 63 & 0 & 113 & 0 & 23 & 0 & 0 & 31 & 23 & 0 & 0 \\
\hline & São José do Campestre (Açude Japi II) & 0 & 0 & 0 & 8,4 & 64,9 & 0 & 0 & 0 & 0 & 0 & 14 & 40,2 & 0 & 18 & 28 & 15 & 0 & 0 & 0 & 30 \\
\hline & São Paulo do Potengi (EMATER) & 0 & 0 & 0 & 11,4 & 19,7 & 32,2 & 0 & 0 & 28,2 & 4,8 & 16,2 & 89 & 12,4 & 1,4 & 10 & 0 & 5,9 & 37,2 & 5,4 & 1,6 \\
\hline & São Rafael (EMATER) & 0 & 0 & 0 & 4,4 & 33,3 & 22,4 & 2,4 & 2 & 24,6 & 31,4 & 32,2 & 105,2 & 41 & 25,4 & 51,4 & 9,4 & 24,4 & 0 & 0 & 0 \\
\hline & São Tomé (EMATER) & 0 & 0 & 0 & 0 & 25 & 43 & 0 & 0 & 27 & 13 & 3 & 52 & 10 & 0 & 27,5 & 0 & 7 & 10,5 & 0 & 9 \\
\hline & São Vicente (EMATER - Ex Particular) & 0 & 10 & 0 & 0 & 14 & 6 & 0 & 5,6 & 0 & 0 & 0 & 152 & 0 & 45 & 45 & 35 & 21 & 60 & 15 & 0 \\
\hline & Senador Eloi de Souza (EMATER) & 0 & 0 & 0 & 0 & 0 & 0 & 0 & 0 & 0 & 42,3 & 27,7 & 0 & 13,8 & 23,5 & 9,1 & 1,8 & 0 & 22,4 & 18,7 & 0 \\
\hline & Tangará (Açude Trairi) & 0 & 0 & 0 & 36,6 & 16 & 49,7 & 0 & 0 & 46,7 & 43,6 & 17,1 & 81,5 & 13,5 & 4 & 12,1 & 0 & 63 & 24,9 & 0 & 0 \\
\hline
\end{tabular}




\begin{tabular}{|c|c|c|c|c|c|c|c|c|c|c|c|c|c|c|c|c|c|c|c|c|c|}
\hline 2003 & Estação & s1 & s2 & s3 & s4 & s5 & s6 & s7 & s8 & s9 & s10 & s11 & s12 & s13 & s14 & s15 & s16 & s17 & s18 & s19 & s20 \\
\hline & Tenente Laurentino Cruz (EMA & 0 & 0 & 0 & 49 & 28 & 4 & 0 & 136 & 25 & 0 & 0 & 94 & 0 & 16,4 & 74,6 & 4 & 15 & 0 & 0 & 0 \\
\hline & Triunfo Potiguar (Chá Cacimbas/Serra J. & 20 & 0 & 15 & 100 & 0 & 2 & 0 & 18 & 11 & 15 & 25 & 140 & 50 & 13 & 80 & 45 & 85 & 18 & 40 & 5 \\
\hline
\end{tabular}
$\begin{array}{llllllllllllllllllll}s 21 & s 22 & s 23 & s 24 & s 25 & s 26 & s 27 & s 28 & s 29 & s 30 & s 31 & s 32 & s 33 & s 34 & s 35 & s 36 & s 37 & s 38 & s 39 & s 40\end{array}$

Acari (Açude Gargalheiras)

Assu (Particular)

Assu (Volta)

Afonso Bezerra (EMATER)

Afonso Bezerra (Assentamento Santa Maria)

Almino Afonso (Particular - Ex Sítio Milagres)

Angicos (Prefeitura)

Campo Grande (Particular)

Campo Grande (Particular 2)

Barcelona (Particular)

Bom Jesus (Particular)

Caiçara do Rio do Vento (Particular)

Caicó (Batalhão)

Caicó (Açude Mundo Novo - EMPARN)

Caicó (Palma)

Caicó (Açude Itans)

Campo Redondo (Polícia Rodoviária)

Cerro Corá (Sítio Recanto - Extinto)

Coronel Ezequiel (Particular)

Cruzeta (Base Física da EMPARN)

Currais Novos (CERCEL)

Currais Novos (Açude Tororó)

Janduís (EMATER)

Boa Saúde (EMATER)

Japi (Particular)

Lagoa d'Anta (Prefeitura)

Lagoa Nova (EMATER/Sítio Humaitá)

Lagoa Salgada (Delegacia)

Monte Alegre (EMATER)

Patu (Particular)

Pedra Preta (EMATER)

Pedro Avelino (Particular)

\begin{tabular}{|c|c|c|c|c|c|c|c|c|c|c|c|c|c|c|c|c|c|c|}
\hline 0 & 0 & 0 & 0 & 83,2 & 0 & 0 & 0 & 0 & 0 & 0 & 0 & 0 & 0 & 0 & 0 & 0 & 0 & 0 \\
\hline 2,5 & 0,1 & 17,7 & 2,1 & 16,4 & 0 & 0 & 3,3 & 0 & 0 & 0,1 & 0 & 0 & 5,9 & 0 & 0 & 0 & 0 & 0 \\
\hline 6 & 0 & 6 & 12 & 20 & 42 & 0 & 0 & 0 & 0 & 0 & 0 & 0 & 0 & 0 & 0 & 0 & 0 & 0 \\
\hline 22 & 0 & 0 & 12 & 0 & 0 & 0 & 0 & 0 & 0 & 0 & 0 & 0 & 0 & 0 & 0 & 0 & 0 & 0 \\
\hline 13,2 & 0 & 16,6 & 27,9 & 2,1 & 0 & 0 & 0 & 0 & 0 & 0 & 0 & 0 & 0 & 0 & 0 & 0 & 0 & 0 \\
\hline 0 & 45,5 & 3,1 & 6,3 & 3 & 0 & 0 & 0 & 0 & 0 & 0 & 0 & 0 & 3,1 & 0 & 0 & 0 & 0 & \\
\hline 2,8 & 10,4 & 0 & 4,6 & 1,6 & 0 & 0 & 0 & 0 & 0 & 0 & 0 & 0 & 0 & 0 & 0 & 0 & 0 & \\
\hline 0 & 42,3 & 36,9 & 0 & 22,9 & 0 & 0 & 0 & 0 & 0 & 0 & 0 & 0 & 0 & 0 & 0 & 2,3 & 0 & 0 \\
\hline 0 & 26 & 38,6 & 10 & 29,8 & 0 & 0 & 0 & 0 & 0 & 0 & 0 & 0 & 0 & 0 & 0 & 10 & 0 & 0 \\
\hline 46 & 0 & 4 & 39 & 34 & 10 & 4 & 14 & 4 & 7 & 0 & 0 & 11 & 0 & 0 & 0 & 4,5 & 0 & 0 \\
\hline 18 & 0 & 19,2 & 81,8 & 39 & 8,8 & 1,6 & 37,8 & 9,4 & 20,4 & 0 & 2,6 & 9 & 5 & 4,2 & 0 & 6,2 & 7 & 0 \\
\hline 13,5 & 0 & 2,7 & 11,6 & 16 & 0 & 0 & 0 & 0 & 4 & 0 & 0 & 0 & 0 & 0 & 0 & 0 & 0 & 0 \\
\hline 0 & 0 & 5 & 0 & 22,5 & 0 & 0 & 11 & 0 & 0 & 0 & 0 & 0 & 0 & 9,5 & 0 & 0 & 0 & 0 \\
\hline 0 & 0 & 3,5 & 0 & 40,2 & 0 & 0 & 11,2 & 0 & 0 & 0 & 0 & 0 & 0 & 0 & 0 & 0 & 0 & \\
\hline 0 & 4 & 0 & 0 & 0,5 & 0 & 0 & 9,2 & 0 & 0 & 0 & 0 & 1 & 11 & 0 & 0 & 0 & 0 & 0 \\
\hline 0 & 0 & 1,5 & 0 & 6,4 & 0 & 0 & 10,4 & 0 & 0 & 0 & 0 & 1 & 1,4 & 0 & 0 & 0,8 & 0 & 0 \\
\hline 8,3 & 0 & 7,5 & 31,4 & 23,1 & 4,9 & 0 & 28,4 & 8,9 & 4,7 & 0 & 0 & 28 & 2,5 & 3,5 & 0 & 1,7 & 0 & 0 \\
\hline 6 & 0 & 10 & 15 & 12,5 & 0 & 1,2 & 8,2 & 1,4 & 0 & 0,8 & 0 & 0 & 6,2 & 0 & 0 & 2,1 & 0 & 0 \\
\hline 0 & 12 & 23 & 40 & 2 & 0 & 0 & 23 & 0 & 0 & 0 & 0 & 0 & 11 & 0 & 0 & 0 & 0 & 0 \\
\hline 0 & 0 & 0,8 & 0,8 & 63,4 & 0 & 0 & 8,4 & 0 & 0 & 0 & 0 & 0 & 10,1 & 5,7 & 0 & 0 & 0 & 0 \\
\hline 3,5 & 0 & 5 & 2 & 4,5 & 0 & 0 & 5 & 3,6 & 0 & 0 & 0 & 10,2 & 3,4 & 0 & 0 & 0,3 & 0 & 0 \\
\hline 0 & 0 & 0 & 55 & 0 & 0 & 0 & 0 & 0 & 0 & 0 & 0 & 0 & 0 & 0 & 0 & 0 & 0 & 0 \\
\hline 0 & 29 & 0 & 5,5 & 17 & 0 & 0 & 0 & 0 & 0 & 0 & 0 & 0 & 4,5 & 6,8 & 0 & 0 & 0 & 0 \\
\hline 16,2 & 3 & 35 & 11 & 56 & 5,5 & 2,4 & 64,7 & 0 & 15,5 & 5,3 & 0 & 0 & 15 & 3,6 & 0 & 2,5 & 0 & 0 \\
\hline 0 & 21,2 & 4,4 & 0 & 27,4 & 0 & 0 & 8,4 & 12,4 & 8,2 & 0 & 0 & 0 & 0 & 0 & 0 & 0 & 0 & 0 \\
\hline 14,3 & 2,8 & 36,2 & 28,7 & 54,2 & 7,3 & 4,2 & 45,9 & 0 & 23,6 & 1,2 & 2,8 & 4,8 & 9,6 & 24,2 & 1,9 & 8,8 & 0 & 0 \\
\hline 9 & 0 & 16 & 35 & 37 & 0 & 0 & 8 & 0 & 0 & 0 & 0 & 0 & 12 & 0 & 0 & 0 & 0 & 0 \\
\hline 14,5 & 8,1 & 18,3 & 92,5 & 43,9 & 7,9 & 10,6 & 33,2 & 12,5 & 19 & 5,7 & 4 & 1,5 & 18,6 & 7,9 & 0 & 8,9 & 3,5 & 0 \\
\hline 30 & 4 & 27 & 54 & 63 & 2 & 5 & 59 & 23 & 30 & 9 & 2 & 12 & 13 & 12 & 0 & 15 & 2 & 2 \\
\hline 0 & 105 & 3 & 4 & 11 & 0 & 0 & 12 & 0 & 0 & 0 & 0 & 0 & 0 & 3,2 & 0 & 0 & 0 & 0 \\
\hline 0 & 0 & 0 & 0 & 0 & 0 & 0 & 0 & 0 & 0 & 0 & 0 & 0 & 0 & 0 & 0 & 0 & 0 & 0 \\
\hline 14,4 & 0 & 1 & 3,2 & 18,6 & 0 & 0 & 0 & 0 & 0 & 0 & 0 & 0 & 0 & 0 & 0 & 0 & 0 & 0 \\
\hline
\end{tabular}




\begin{tabular}{|c|c|c|c|c|c|c|c|c|c|c|c|c|c|c|c|c|c|c|c|c|c|}
\hline \multirow[t]{18}{*}{2003} & Estação & s21 & s22 & s23 & s24 & s25 & $s 26$ & s27 & $\mathbf{s} 28$ & $\mathbf{s} 29$ & s30 & s31 & s32 & s33 & s34 & s35 & s36 & s37 & s38 & $\mathbf{s 3 9}$ & s40 \\
\hline & Pedro Avelino (Base Física da EMPARN) & 0 & 0 & 10 & 12,5 & 0 & 0 & 0 & 0 & 0 & 0 & 0 & 0 & 0 & 0 & 0 & 0 & 0 & 0 & 0 & 0 \\
\hline & Pedro Avelino (Assentamento Feijão) & 9 & 0 & 0 & 0 & 0 & 0 & 0 & 0 & 0 & 0 & 0 & 0 & 0 & 0 & 0 & 0 & 0 & 0 & 0 & 0 \\
\hline & Pedro Avelino (Assentamento Nova Conquista) & 0 & 0 & 0 & 0 & 12,8 & 0 & 0 & 0 & 0 & 0 & 0 & 0 & 0 & 0 & 0 & 0 & 0 & 0 & 0 & 0 \\
\hline & Riachuelo (EMATER) & 24 & 0 & 5,5 & 19 & 18,5 & 0 & 2 & 28,5 & 2 & 7 & 4,5 & 0 & 6 & 2 & 0 & 0 & 0 & 0 & 0 & 0 \\
\hline & Santa Cruz (EMATER) & 3 & 0 & 0 & 31,5 & 27,5 & 0 & 2,5 & 0,8 & 15,5 & 9,5 & 0 & 0 & 21,5 & 0 & 0 & 0 & 0 & 0 & 0 & 0 \\
\hline & Santana do Matos (EMATER) & 0 & 0 & 0 & 6,5 & 15 & 0 & 13 & 0 & 0 & 0 & 0 & 15 & 8 & 0 & 0 & 0 & 0 & 0 & 0 & 0 \\
\hline & Santana do Matos (Barão de Serra Branca) & 5,7 & 2,8 & 0 & 13,7 & 26,1 & 0 & 8,7 & 11,9 & 0 & 0 & 0 & 0 & 5,7 & 1,5 & 0 & 5,7 & 0 & 0 & 0 & 0 \\
\hline & São José do Campestre (EMATER) & 18 & 0 & 18,5 & 16 & 48 & 6 & 0 & 41 & 0 & 7,5 & 0 & 1 & 18 & 14 & 0 & 0 & 6 & 0 & 0 & 0 \\
\hline & São José do Campestre (Açude Japi II) & 2,5 & 0 & 0 & 36 & 20 & 25 & 0 & 15,9 & 0 & 0 & 0 & 0 & 0 & 0 & 0 & 0 & 0 & 0 & 0 & 0 \\
\hline & São Paulo do Potengi (EMATER) & 15 & 2 & 6 & 0 & 0 & 0 & 0 & 0 & 0 & 0 & 0 & 0 & 0 & 0 & 0 & 0 & 0 & 0 & 0 & 0 \\
\hline & São Rafael (EMATER) & 0 & 0 & 0 & 0 & 0 & 0 & 0 & 0 & 0 & 0 & 0 & 0 & 0 & 0 & 0 & 0 & 0 & 0 & 0 & 0 \\
\hline & São Tomé (EMATER) & 0 & 0 & 0 & 14,5 & 36,5 & 0 & 0 & 0 & 0 & 9,5 & 0 & 0 & 16,2 & 1,2 & 0 & 28,7 & 4 & 0 & 0 & 4 \\
\hline & São Vicente (EMATER - Ex Particular) & 0 & 0 & 0 & 10 & 47 & 0 & 0 & 0 & 0 & 0 & 0 & 0 & 10 & 0 & 0 & 0 & 0 & 0 & 0 & 0 \\
\hline & Senador Eloi de Souza (EMATER) & 0,9 & 0 & 1,5 & 12,8 & 59 & 0 & 12,2 & 14,7 & 0 & 13,9 & 13,5 & 0 & 0 & 0 & 0 & 0 & 0 & 0 & 0 & 0 \\
\hline & Tangará (Açude Trairi) & 15,7 & 0 & 10,6 & 7,7 & 34,6 & 5,7 & 0 & 21,8 & 0 & 8,4 & 0 & 0 & 0 & 28,7 & 7,6 & 0 & 0 & 0 & 0 & 0 \\
\hline & Tenente Laurentino Cruz (EMATER) & 0 & 0 & 0 & 0 & 0 & 0 & 0 & 0 & 0 & 0 & 0 & 0 & 0 & 0 & 0 & 0 & 0 & 0 & 0 & 0 \\
\hline & Triunfo Potiguar (Chá Cacimbas/Serra J. Vale) & 65 & 20 & 0 & 10 & 28 & 0 & 8 & 15 & 0 & 20 & 0 & 0 & 0 & 10 & 0 & 0 & 0 & 0 & 0 & 0 \\
\hline \multirow[t]{18}{*}{2003} & Estação & s41 & s42 & s43 & s44 & s45 & s46 & s47 & s48 & s49 & s50 & s51 & s52 & s53 & & & & & & & \\
\hline & Acari (Açude Gargalheiras) & 0 & 0 & 0 & 0 & 0 & 0 & 0 & 0 & 0 & 0 & 13,5 & 0 & 0 & & & & & & & \\
\hline & Assu (Particular) & 0 & 0 & 0 & 0 & 0 & 0,5 & 0 & 0 & 0 & 0,6 & 6,4 & 0 & 10,3 & & & & & & & \\
\hline & Assu (Volta) & 0 & 0 & 0 & 0 & 0 & 0 & 0 & 0 & 0 & 0 & 0 & 0 & 0 & & & & & & & \\
\hline & Afonso Bezerra (EMATER) & 0 & 0 & 0 & 0 & 0 & 0 & 0 & 0 & 0 & 0 & 0 & 0 & 0 & & & & & & & \\
\hline & Afonso Bezerra (Assentamento Santa Maria) & 0 & 0 & 0 & 0 & 0 & 0 & 0 & 0 & 0 & 0 & 0 & 0 & 0 & & & & & & & \\
\hline & Almino Afonso (Particular - Ex Sítio Milagres) & 0 & 0 & 0 & 0 & 0 & 0 & 0 & 0 & 0 & 0 & 0 & 0 & 0 & & & & & & & \\
\hline & Angicos (Prefeitura) & 0 & 0 & 0 & 0 & 0 & 0 & 0 & 0 & 0 & 0 & 0 & 0 & 0 & & & & & & & \\
\hline & Campo Grande (Particular) & 0 & 0 & 0 & 0 & 0 & 0 & 0 & 0 & 0 & 0 & 0 & 0 & 48 & & & & & & & \\
\hline & Campo Grande (Particular 2) & 0 & 0 & 0 & 0 & 0 & 0 & 0 & 0 & 0 & 6 & 0 & 0 & 0 & & & & & & & \\
\hline & Barcelona (Particular) & 0 & 0 & 0 & 0 & 0 & 0 & 0 & 0 & 0 & 0 & 0 & 0 & 12 & & & & & & & \\
\hline & Bom Jesus (Particular) & 0 & 0 & 0 & 6 & 0 & 0 & 0 & 0 & 0 & 0 & 0 & 0 & 1,6 & & & & & & & \\
\hline & Caiçara do Rio do Vento (Particular) & 0 & 0 & 0 & 0 & 0 & 0 & 0 & 0 & 0 & 0 & 10 & 0 & 0 & & & & & & & \\
\hline & Caicó (Batalhão) & 0 & 0 & 0 & 0 & 0 & 0 & 0 & 0 & 0 & 0 & 4,5 & 0 & 0 & & & & & & & \\
\hline & Caicó (Açude Mundo Novo - EMPARN) & 0 & 0 & 0 & 0 & 0 & 0 & 0 & 0 & 0 & 0 & 13,5 & 0 & 0 & & & & & & & \\
\hline & Caicó (Palma) & 0 & 0 & 0 & 0 & 4,4 & 0 & 0 & 0 & 0 & 0 & 0 & 0 & 0 & & & & & & & \\
\hline & Caicó (Açude Itans) & 0 & 0 & 0 & 0 & 0 & 0 & 0 & 0 & 0 & 0 & 0 & 0 & 0 & & & & & & & \\
\hline & Campo Redondo (Polícia Rodoviária) & 0 & 0 & 0 & 0 & 0 & 0 & 2,5 & 0 & 0 & 0 & 0 & 0 & 15,1 & & & & & & & \\
\hline
\end{tabular}




\begin{tabular}{|c|c|c|c|c|c|c|c|c|c|c|c|c|c|c|c|c|c|c|c|c|c|c|c|}
\hline 2003 & Estação & s41 & s42 & s43 & s44 & s45 & s46 & s47 & s48 & s49 & s50 & s51 & $\mathrm{s} 52$ & $s 53$ & & & & & & & & & \\
\hline & Cerro Corá (Sítio Recanto - Extinto) & 0 & 0 & 0 & 0 & 0 & 0 & 0 & 0 & 0 & 0 & 0 & 0 & 0 & & & & & & & & & \\
\hline & Coronel Ezequiel (Particular) & 0 & 0 & 0 & 0 & 0 & 0 & 0 & 0 & 0 & 0 & 0 & 0 & 0 & & & & & & & & & \\
\hline & Cruzeta (Base Física da EMPARN) & 0 & 0 & 0 & 0 & 0 & 0 & 0 & 0 & 0 & 0,1 & 0 & 0 & 5 & & & & & & & & & \\
\hline & Currais Novos (CERCEL) & 0 & 0 & 0 & 0 & 0 & 0 & 0 & 0 & 0 & 0 & 1,4 & 0 & 0 & & & & & & & & & \\
\hline & Currais Novos (Açude Tororó) & 0 & 0 & 0 & 0 & 0 & 0 & 0 & 0 & 0 & 0 & 0 & 0 & 0 & & & & & & & & & \\
\hline & Janduís (EMATER) & 0 & 0 & 0 & 0 & 0 & 0 & 0 & 0 & 0 & 0 & 0 & 2 & 24 & & & & & & & & & \\
\hline & Boa Saúde (EMATER) & 0 & 0 & 0 & 0 & 0 & 0 & 0 & 0 & 0 & 0 & 0 & 0 & 0 & & & & & & & & & \\
\hline & Japi (Particular) & 0 & 0 & 0 & 0 & 0 & 0 & 0 & 0 & 0 & 0 & 0 & 0 & 0 & & & & & & & & & \\
\hline & Lagoa d'Anta (Prefeitura) & 0 & 5,8 & 2,7 & 0 & 0 & 0 & 0 & 0 & 0 & 0 & 4,8 & 0 & 13 & & & & & & & & & \\
\hline & Lagoa Nova (EMATER/Sítio Humaitá) & 0 & 0 & 0 & 0 & 0 & 0 & 0 & 0 & 0 & 0 & 0 & 0 & 0 & & & & & & & & & \\
\hline & Lagoa Salgada (Delegacia) & 0 & 0 & 0 & 0 & 0 & 0 & 0 & 0 & 0 & 0,8 & 0 & 13 & 0 & & & & & & & & & \\
\hline & Monte Alegre (EMATER) & 5 & 0 & 5 & 1 & 3 & 3 & 0 & 3 & 0 & 0 & 34 & 2 & 4 & & & & & & & & & \\
\hline & Patu (Particular) & 0 & 0 & 0 & 0 & 0 & 0 & 0 & 0 & 0 & 0 & 0 & 0 & 0 & & & & & & & & & \\
\hline & Pedra Preta (EMATER) & 0 & 0 & 0 & 0 & 0 & 0 & 0 & 0 & 0 & 0 & 0 & 0 & 0 & & & & & & & & & \\
\hline & Pedro Avelino (Particular) & 0 & 0 & 0 & 0 & 0 & 0 & 0 & 0 & 0 & 0 & 0 & 4,2 & 1,4 & & & & & & & & & \\
\hline & Pedro Avelino (Base Física da EMPARN) & 0 & 0 & 0 & 0 & 0 & 0 & 0 & 0 & 0 & 0 & 0 & 4,2 & 1,4 & & & & & & & & & \\
\hline & Pedro Avelino (Assentamento Feijão) & 0 & 0 & 0 & 0 & 0 & 0 & 0 & 0 & 0 & 0 & 0 & 0 & 0 & & & & & & & & & \\
\hline & Pedro Avelino (Assentamento Nova Conquista) & 0 & 0 & 0 & 0 & 0 & 0 & 0 & 0 & 0 & 0 & 0 & 0 & 0 & & & & & & & & & \\
\hline & Riachuelo (EMATER) & 0 & 0 & 2 & 0 & 0 & 0 & 0 & 0 & 0 & 0 & 0 & 3 & 3 & & & & & & & & & \\
\hline & Santa Cruz (EMATER) & 0 & 0 & 0 & 0 & 0 & 0 & 0 & 0 & 0 & 0 & 0,5 & 0 & 11 & & & & & & & & & \\
\hline & Santana do Matos (EMATER) & 0 & 0 & 0 & 0 & 0 & 0 & 0 & 0 & 0 & 10 & 20 & 0 & 0 & & & & & & & & & \\
\hline & Santana do Matos (Barão de Serra Branca) & 0 & 0 & 0 & 0 & 0 & 0 & 0 & 0 & 0 & 2,7 & 28 & 0 & 0 & & & & & & & & & \\
\hline & São José do Campestre (EMATER) & 0 & 0 & 0 & 0 & 0 & 0 & 0 & 0 & 0 & 0 & 0 & 0 & 0 & & & & & & & & & \\
\hline & São José do Campestre (Açude Japi II) & 0 & 0 & 0 & 0 & 0 & 0 & 0 & 0 & 0 & 0 & 0 & 0 & 0 & & & & & & & & & \\
\hline & São Paulo do Potengi (EMATER) & 0 & 0 & 0 & 0 & 0 & 0 & 0 & 0 & 0 & 0,9 & 0,7 & 4,5 & 1 & & & & & & & & & \\
\hline & São Rafael (EMATER) & 0 & 0 & 0 & 0 & 0 & 0 & 0 & 0 & 0 & 15,4 & 0 & 1,6 & 2,6 & & & & & & & & & \\
\hline & São Tomé (EMATER) & 0 & 0 & 0 & 0 & 0 & 0 & 0 & 0 & 0 & 0 & 0 & 0 & 0 & & & & & & & & & \\
\hline & São Vicente (EMATER - Ex Particular) & 0 & 0 & 0 & 0 & 0 & 0 & 0 & 0 & 0 & 31 & 0 & 0 & 0 & & & & & & & & & \\
\hline & Senador Eloi de Souza (EMATER) & 0 & 0 & 0 & 0 & 0 & 0 & 0 & 0 & 0 & 0 & 0 & 0 & 0 & & & & & & & & & \\
\hline & Tangará (Açude Trairi) & 0 & 0 & 0 & 0 & 0 & 0 & 0 & 0 & 0 & 5,9 & 0 & 0 & 14 & & & & & & & & & \\
\hline & Tenente Laurentino Cruz (EMATER) & 0 & 0 & 0 & 0 & 0 & 0 & 0 & 0 & 0 & 0 & 0 & 0 & 0 & & & & & & & & & \\
\hline & Triunfo Potiguar (Chá Cacimbas/Serra J. Vale) & 0 & 0 & 0 & 0 & 0 & 0 & 0 & 0 & 0 & 0 & 0 & 15 & 30 & & & & & & & & & \\
\hline 2004 & Estação & & s1 & s2 & s3 & s4 & s & 5 & s6 & s7 & s8 & s9 & s10 & s11 & s12 & s13 & s14 & s15 & s16 & $\mathbf{s 1 7}$ & s18 & s19 & s20 \\
\hline & Acari (Particular) & & 0 & 126 & 123,8 & 146,5 & & 33 & 30 & 3,6 & 33 & 2,4 & 2,6 & 6,6 & 8,2 & 0 & 15 & 0,8 & 6,3 & 58,6 & 26,1 & 101,7 & 7,8 \\
\hline & Acari (Açude Gargalheiras) & & 0 & 153,1 & 182,6 & 176,9 & 54 & 4,5 & 30 & 0 & 38,5 & 13,5 & 18 & 9 & 12,4 & 12,5 & 0 & 0 & 5,6 & 83 & 30,2 & 5,5 & 18,1 \\
\hline
\end{tabular}




\begin{tabular}{|c|c|c|c|c|c|c|c|c|c|c|c|c|c|c|c|c|c|c|c|c|c|}
\hline 2004 & Estação & s1 & s2 & s3 & s4 & s5 & $s 6$ & s7 & s8 & s9 & s10 & s11 & s12 & $s 13$ & s14 & s15 & s16 & s17 & s18 & s19 & s20 \\
\hline & Assu (Particular) & 22,8 & 78,8 & 52,6 & 17,6 & 28,6 & 81,6 & 4,1 & 1 & 42,9 & 39,5 & 57,3 & 25,4 & 2,6 & 67 & 9,3 & 16 & 19 & 31,8 & 0,1 & 42,8 \\
\hline & Assu (Volta) & 0 & 32 & 123 & 209 & 55 & 53 & 0 & 67 & 0 & 3 & 10 & 11 & 5 & 0 & 0 & 0 & 0 & 0 & 0 & 0 \\
\hline & Afonso Bezerra (EMATER) & 0 & 53 & 121 & 192 & 47 & 22 & 18 & 32 & 18 & 20 & 0 & 0 & 0 & 0 & 0 & 20 & 6 & 50 & 0 & 0 \\
\hline & Afonso Bezerra (Assentamento Santa Maria) & 0 & 18 & 87,8 & 206,9 & 0 & 0 & 0 & 0 & 0 & 21,7 & 0 & 12,2 & 0 & 0 & 0 & 15 & 7 & 28,1 & 5,4 & 0 \\
\hline & Almino Afonso (Particular - Ex Sítio Milagres) & 0 & 21,4 & 115 & 215,1 & 64,8 & 35,5 & 39,5 & 28,6 & 48,6 & 55,7 & 37,9 & 16,3 & 18,6 & 16,3 & 2,4 & 4,3 & 18,3 & 16,3 & 0 & 37,3 \\
\hline & Angicos (Prefeitura) & 0 & 101,8 & 61,6 & 188,5 & 133 & 11,4 & 43 & 53,2 & 9 & 7,4 & 18 & 6 & 6,2 & 0 & 0 & 38 & 0 & 24 & 22,3 & 2 \\
\hline & Campo Grande (Particular) & 51,7 & 109,3 & 6,8 & 24 & 12,4 & 129,9 & 22,3 & 0 & 76,1 & 0,8 & 28,1 & 15,8 & 18,1 & 80,2 & 21,4 & 9,5 & 4,5 & 10,5 & 0 & 84 \\
\hline & Campo Grande (Açude Morcego - Extinto) & 0 & 0 & 96 & 190 & 0 & 0 & 63 & 43 & 0 & 0 & 0 & 0 & 0 & 0 & 0 & 0 & 0 & 0 & 0 & 0 \\
\hline & Campo Grande (Particular 2) & 0 & 28 & 138,2 & 257,5 & 62,2 & 44,3 & 56,5 & 50,8 & 22 & 15 & 6,3 & 43,4 & 50 & 20,6 & 0 & 25,2 & 27,3 & 62,8 & 19,3 & 0 \\
\hline & Barcelona (Particular) & 0 & 64 & 145 & 208,5 & 96 & 53,5 & 6 & 16,5 & 24 & 22,5 & 20,5 & 12 & 11 & 12 & 0 & 30,5 & 7 & 56 & 2 & 0 \\
\hline & Bom Jesus (Particular) & 0 & 26,2 & 150,6 & 168,2 & 74,4 & 138,6 & 5,8 & 32 & 41,2 & 52 & 6,6 & 38,8 & 4,2 & 6,6 & 4 & 53,6 & 10,8 & 56 & 4 & 0 \\
\hline & Caiçara do Rio do Vento (Particular) & 0 & 48,2 & 159,3 & 201 & 54 & 38 & 18 & 10 & 0 & 65,7 & 0 & 4,2 & 0 & 5 & 0 & 7,3 & 17 & 36,1 & 0 & 0 \\
\hline & Caicó (Batalhão) & 6 & 119 & 97,3 & 194,5 & 106 & 0 & 10 & 33 & 0 & 0 & 23 & 2,5 & 0 & 0 & 26 & 13,7 & 21,6 & 9,6 & 3 & 12,5 \\
\hline & Caicó (Açude Mundo Novo - EMPARN) & 10,5 & 32,3 & 195 & 121,2 & 211,8 & 25 & 13 & 41 & 0 & 44,5 & 27,8 & 2 & 0 & 0 & 6,8 & 22,5 & 23 & 13,7 & 4 & 10 \\
\hline & Caicó (Palma) & 0 & 36 & 109,6 & 166 & 158,4 & 10,6 & 10 & 25,8 & 0 & 0 & 0 & 0 & 0 & 0 & 10,4 & 11 & 7,4 & 3,6 & 21,4 & 4 \\
\hline & Caicó (Açude Itans) & 0 & 51,2 & 169,7 & 124,3 & 148,5 & 13,2 & 7,4 & 24,1 & 0 & 26,9 & 29,4 & 2,2 & 0 & 0 & 9,6 & 21,7 & 28,3 & 6,7 & 4,8 & 6,8 \\
\hline & Caicó (EMATER) & 0 & 51,9 & 178,6 & 131,5 & 143,8 & 23,8 & 3 & 28,2 & 52,3 & 0 & 5,4 & 7,5 & 0 & 18,6 & 19,5 & 8,4 & 0 & 0 & 14 & 25,2 \\
\hline & Campo Redondo (Polícia Rodoviária) & 0 & 101 & 120,8 & 101,6 & 185 & 60,5 & 1,8 & 23,5 & 20,4 & 29,3 & 36,2 & 23,1 & 0 & 15,5 & 0 & 23,8 & 7,5 & 54,3 & 1,6 & 2,9 \\
\hline & Cerro Corá (EMATER) & 0 & 70,6 & 117,4 & 276,3 & 70,2 & 20,2 & 6 & 6,7 & 12 & 37,2 & 14,5 & 25 & 14,5 & 12,2 & 0 & 27,2 & 0 & 40,7 & 6 & 0 \\
\hline & Cerro Corá (Sítio Recanto - Extinto) & 0 & 91,5 & 102,2 & 96,7 & 102,7 & 11,8 & 11,5 & 13,2 & 2,3 & 0 & 0 & 0 & 0 & 0 & 0 & 0 & 0 & 0 & 0 & 0 \\
\hline & Coronel Ezequiel (Particular) & 0 & 128 & 100,6 & 169,3 & 74,4 & 32 & 16 & 16 & 33 & 16 & 3 & 17 & 0 & 7 & 2 & 6,5 & 3 & 70 & 9 & 10 \\
\hline & Cruzeta (Base Física da EMPARN) & 0 & 77,7 & 144,4 & 217,1 & 152 & 50,4 & 1,2 & 40,1 & 0,2 & 32,9 & 24,1 & 13,4 & 0 & 0,2 & 2,9 & 25,2 & 25 & 29,3 & 38,3 & 11,1 \\
\hline & Currais Novos (CERCEL) & 0 & 87,8 & 88,9 & 61,5 & 94 & 23 & 0 & 8 & 8 & 12 & 25 & 24 & 0 & 28 & 0 & 17 & 0 & 49 & 0 & 18,6 \\
\hline & Currais Novos (Açude Tororó) & 0 & 10 & 89 & 126 & 6 & 129,2 & 25 & 0 & 0 & 20 & 26 & 0 & 0 & 30 & 20 & 4 & 0 & 41,2 & 55,2 & 25,2 \\
\hline & Janduís (EMATER) & 0 & 16 & 150,2 & 137,8 & 81,6 & 37,2 & 29 & 2,4 & 37,6 & 81,8 & 27,8 & 0 & 0 & 11 & 10 & 10 & 7 & 27 & 2 & 8 \\
\hline & Boa Saúde (EMATER) & 0 & 66 & 152,9 & 146 & 14 & 53 & 2,5 & 20 & 1,5 & 40,5 & 16 & 28,1 & 10 & 3,5 & 0 & 87,2 & 4,7 & 87,6 & 3,2 & 2 \\
\hline & Japi (Particular) & 0 & 68,2 & 460,4 & 132,6 & 25,6 & 24,4 & 18,2 & 0 & 6,2 & 36,6 & 0 & 0 & 0 & 0 & 0 & 24,4 & 0 & 99,6 & 10,2 & 0 \\
\hline & Japi (Assentamento Barbaco - Extinto) & 11 & 89 & 139 & 130 & 81 & 0 & 0 & 32 & 0 & 0 & 0 & 0 & 0 & 0 & 0 & 0 & 0 & 0 & 0 & 0 \\
\hline & Lagoa d'Anta (Prefeitura) & 1,3 & 126,6 & 165,9 & 35 & 92,9 & 46,3 & 10 & 0 & 0 & 6 & 28,5 & 41,2 & 2 & 1,3 & 0 & 26,3 & 46,7 & 73,3 & 6,7 & 0 \\
\hline & Lagoa de Pedras (Prefeitura) & 0 & 0 & 0 & 0 & 0 & 0 & 0 & 0 & 0 & 0 & 0 & 6,1 & 0 & 5,2 & 1,4 & 80,7 & 5,3 & 104,6 & 0 & 5,3 \\
\hline & Lagoa de Velhos (Delegacia) & 0 & 0 & 0 & 0 & 0 & 0 & 0 & 0 & 0 & 0 & 0,6 & 15,2 & 0 & 16,4 & 0 & 23 & 19,5 & 56,5 & 0,3 & 0,7 \\
\hline & Lagoa Nova (EMATER/Sítio Humaitá) & 0 & 84,5 & 85,5 & 0 & 176,1 & 34 & 28 & 5 & 3 & 18 & 0 & 18 & 0 & 16 & 0 & 26 & 0 & 50 & 0 & 2 \\
\hline & Lagoa Nova (Assentamento Santana/Sítio de Dentro) & 0 & 35,1 & 71,4 & 154,5 & 25,9 & 0 & 0 & 13 & 16,3 & 0 & 0 & 19 & 0 & 0 & 0 & 20,3 & 9,2 & 35,3 & 96,7 & 0 \\
\hline & Lagoa Salgada (Delegacia) & 0 & 76 & 135,1 & 175,3 & 98,8 & 55,2 & 0 & 9 & 29,5 & 95,8 & 17,3 & 79,9 & 0 & 6 & 0 & 54,2 & 23,6 & 85,5 & 4,4 & 3,5 \\
\hline & Monte Alegre (EMATER) & 2 & 48 & 115 & 135 & 100 & 39 & 11 & 9,8 & 10,4 & 79,6 & 20 & 64 & 2 & 12 & 2,2 & 66,6 & 6,8 & 89,4 & 2 & 8,8 \\
\hline & Monte das Gameleiras (EMATER) & 0 & 0 & 13,4 & 6,6 & 0 & 0 & 0 & 0 & 0 & 0 & 0 & 20 & 0 & 22,6 & 0 & 26,7 & 18,7 & 83,2 & 0 & 15,1 \\
\hline
\end{tabular}




\begin{tabular}{|c|c|c|c|c|c|c|c|c|c|c|c|c|c|c|c|c|c|c|c|c|c|}
\hline 2004 & Estação & s1 & s2 & s3 & s4 & s5 & s6 & s7 & s8 & s9 & s10 & s11 & s12 & $\mathbf{s 1 3}$ & s14 & s15 & s16 & s17 & s18 & $\mathbf{s 1 9}$ & s20 \\
\hline & Paraú (Prefeitura) & 3,3 & 16,8 & 67,9 & 203,1 & 49,8 & 60,1 & 53,3 & 72,5 & 7 & 78,5 & 12,8 & 27,2 & 3 & 0 & 0 & 5,4 & 21,5 & 0 & 0 & 0 \\
\hline & Patu (Particular) & 0 & 43,2 & 89 & 172,8 & 85 & 13 & 30 & 27 & 56 & 76,6 & 8 & 21,4 & 0 & 29,2 & 5 & 9 & 39 & 28,6 & 9 & 37,4 \\
\hline & Santa Maria (Sindicato dos Trabalhadores Rurais) & 0 & 25 & 131,5 & 93 & 55 & 13,5 & 7,5 & 0 & 27 & 5 & 30 & 15 & 15 & 0 & 0 & 35 & 0 & 64,4 & 15 & 0 \\
\hline & Pedro Avelino (Particular) & 0 & 80,4 & 151,4 & 208,2 & 45 & 6,4 & 10 & 13,9 & 17 & 34,1 & 4 & 0 & 0 & 11,6 & 0 & 10 & 4 & 42,3 & 0 & 0 \\
\hline & Pedro Avelino (Base Física da EMPARN) & 0 & 64,6 & 115,9 & 180,4 & 97,7 & 0 & 30,1 & 23,2 & 2,1 & 86,7 & 72,4 & 30,6 & 0 & 2,5 & 0 & 0 & 20,3 & 34,4 & 5 & 0 \\
\hline & Pedro Avelino (Assentamento Feijão) & 0 & 144 & 67 & 143 & 42 & 13 & 0 & 14 & 9,3 & 2,4 & 2 & 0,4 & 0 & 4 & 0 & 14 & 12 & 40 & 0 & 0 \\
\hline & Pedro Avelino (Assentamento Nova Conquista) & 85 & 0 & 63 & 238 & 86 & 41 & 0 & 0 & 15 & 45 & 10 & 0 & 0 & 0 & 0 & 15 & 0 & 57,8 & 0 & 0 \\
\hline & Riachuelo (EMATER) & 9 & 98,5 & 123 & 138 & 49 & 19 & 5 & 14,5 & 25 & 31 & 9 & 2 & 0 & 0 & 0 & 0 & 0 & 0 & 0 & 0 \\
\hline & Santa Cruz (EMATER) & 0 & 51 & 140,5 & 95 & 88,5 & 58 & 1 & 5,2 & 11,4 & 41,9 & 1,3 & 13,3 & 0 & 29,9 & 0 & 37,4 & 0 & 41,4 & 16 & 5,7 \\
\hline & Santa Cruz (Açude Inharé) & 0 & 34,2 & 246,7 & 57,3 & 116,1 & 40 & 0 & 47,2 & 0 & 37,1 & 0 & 17,1 & 0 & 0 & 0 & 25,1 & 0 & 27,1 & 0 & 0 \\
\hline & Santana do Matos (EMATER) & 0 & 89,4 & 98,3 & 290,3 & 191,3 & 41,9 & 0 & 24,6 & 0 & 0 & 0 & 0 & 0 & 0 & 0 & 0 & 30 & 21 & 120 & 0 \\
\hline & Santana do Matos (Barão de Serra Branca) & 3 & 68 & 88,5 & 214 & 162,3 & 25,2 & 9,1 & 39,9 & 10,4 & 46,9 & 8,1 & 2,1 & 0 & 10 & 4,2 & 12,6 & 14 & 19,7 & 68 & 0 \\
\hline & Santana do Matos (São José da Passagem) & 0 & 137,6 & 51,7 & 88,1 & 12,2 & 0 & 0 & 0 & 0 & 7 & 0 & 0 & 0 & 0 & 0 & 47,3 & 0 & 0 & 0 & 0 \\
\hline & São José do Campestre (EMATER) & 0 & 110 & 311 & 199 & 54 & 100 & 0 & 7 & 0 & 63,5 & 15 & 23 & 0 & 0 & 0 & 38,5 & 12 & 74,5 & 0 & 13 \\
\hline & São José do Campestre (Açude Japi II) & 9,6 & 49,2 & 195,4 & 144 & 64 & 67,1 & 0 & 0 & 37 & 45 & 20 & 22 & 20,2 & 24,7 & 0 & 60,1 & 37,2 & 30,1 & 25,2 & 11 \\
\hline & São Paulo do Potengi (EMATER) & 0 & 43,4 & 90,4 & 175,3 & 74,9 & 23,6 & 5,7 & 7,6 & 18,2 & 59,8 & 5 & 37,8 & 0 & 4 & 0,9 & 25,6 & 19,3 & 49,1 & 1,4 & 0 \\
\hline & São Rafael (EMATER) & 21 & 33,8 & 68 & 210 & 134,6 & 1,2 & 9,4 & 51 & 2,2 & 57,2 & 16,4 & 17,4 & 0 & 17 & 0 & 12 & 14,6 & 37 & 84,6 & 0 \\
\hline & São Tomé (EMATER) & 0 & 35,4 & 110 & 147 & 114,4 & 30 & 0 & 16,4 & 0 & 16 & 9,2 & 13 & 0 & 0 & 0 & 29 & 0 & 63 & 0 & 2 \\
\hline & São Vicente (EMATER - Ex Particular) & 0 & 96 & 154,9 & 210,6 & 145,2 & 25 & 0 & 22,2 & 5,5 & 6 & 11 & 17,5 & 0 & 0 & 0 & 23 & 12 & 24 & 43 & 0 \\
\hline & Serrinha (EMATER) & 0 & 0 & 0 & 0 & 0 & 0 & 0 & 0 & 0 & 0 & 0 & 25 & 0 & 7,6 & 0,8 & 84,4 & 16,8 & 83,4 & 11 & 19,7 \\
\hline & Sítio Novo (Prefeitura) & 0 & 0 & 0 & 0 & 0 & 0 & 0 & 0 & 12 & 38 & 5 & 39,5 & 2 & 3 & 0 & 42 & 10 & 41,5 & 0 & 0 \\
\hline & Tangará (EMATER) & 0 & 0 & 0 & 0 & 0 & 0 & 0 & 0 & 0 & 0 & 0 & 0 & 0 & 0 & 0 & 0 & 0 & 0 & 0 & 0 \\
\hline & Tangará (Açude Trairi) & 0 & 46,8 & 107 & 136,4 & 93,3 & 71,6 & 0 & 16,4 & 17,5 & 47 & 3,6 & 40,1 & 0 & 7,4 & 0 & 37,4 & 0 & 49,6 & 0 & 6 \\
\hline & Tenente Laurentino Cruz (EMATER) & 0 & 11 & 0 & 0 & 0 & 0 & 0 & 0 & 0 & 0 & 0 & 0 & 0 & 10 & 0 & 32 & 8 & 40,5 & 111 & 0 \\
\hline
\end{tabular}

\begin{tabular}{|c|c|c|c|c|c|c|c|c|c|c|c|c|c|c|c|c|c|c|c|c|c|}
\hline 2004 & Estação & s21 & s22 & s23 & s24 & s25 & s26 & s27 & s28 & $\mathbf{s 2 9}$ & s30 & s31 & s32 & s33 & s34 & s35 & s36 & s37 & s38 & s39 & s40 \\
\hline & Acari (Particular) & 0 & 3,2 & 0 & 32 & 0,7 & 5,3 & 5,4 & 0 & 0 & 0 & 0 & 0 & 0 & 0 & 0 & 0 & 0 & 7 & 0 & 0 \\
\hline & Acari (Açude Gargalheiras) & 0 & 2,1 & 5,4 & 67,6 & 0 & 0 & 0 & 0 & 0 & 0 & 0 & 0 & 0 & 0 & 0 & 0 & 0 & 5,5 & 0 & 0 \\
\hline & Assu (Particular) & 22,3 & 13 & 6,5 & 64,3 & 0 & 1 & 18,8 & 2,3 & 0 & 5,8 & 0 & 0 & 2,1 & 0 & 0 & 0 & 0 & 0 & 0 & 0 \\
\hline & Assu (Volta) & 0 & 0 & 0 & 0 & 0 & 0 & 0 & 0 & 0 & 0 & 0 & 0 & 0 & 0 & 0 & 0 & 0 & 0 & 0 & 0 \\
\hline & Afonso Bezerra (EMATER) & 0 & 25 & 0 & 25 & 18 & 0 & 11 & 6 & 0 & 0 & 0 & 0 & 0 & 0 & 0 & 0 & 0 & 0 & 0 & 0 \\
\hline & Afonso Bezerra (Assentamento Santa Maria) & 6 & 39 & 3,1 & 3 & 0 & 10,1 & 0 & 0 & 0 & 0 & 0 & 0 & 0 & 0 & 0 & 0 & 0 & 0 & 0 & 0 \\
\hline & Almino Afonso (Particular - Ex Sítio Milagres) & 7,2 & 68,3 & 0 & 9,4 & 0 & 8 & 23,4 & 4,4 & 0 & 0 & 6,2 & 0 & 0 & 0 & 0 & 0 & 0 & 0 & 0 & 0 \\
\hline & Angicos (Prefeitura) & 0 & 9,6 & 0 & 16,6 & 8 & 0 & 5,4 & 4,2 & 0 & 0 & 0 & 0 & 0 & 0 & 0 & 0 & 0 & 0 & 0 & 0 \\
\hline & Campo Grande (Particular) & 18,5 & 13 & 11,5 & 8,5 & 6,3 & 4,4 & 0 & 5,6 & 0 & 0 & 0 & 0 & 0 & 0 & 0 & 0 & 0 & 0 & 0 & 0 \\
\hline & Campo Grande (Açude Morcego - Extinto) & 0 & 0 & 0 & 0 & 0 & 0 & 0 & 0 & 0 & 0 & 0 & 0 & 0 & 0 & 0 & 0 & 0 & 0 & 0 & 0 \\
\hline
\end{tabular}




\begin{tabular}{|c|c|c|c|c|c|c|c|c|c|c|c|c|c|c|c|c|c|c|c|c|c|}
\hline 2004 & Estação & s21 & s22 & s23 & s24 & $s 25$ & $s 26$ & s27 & s28 & s29 & s30 & s31 & s32 & s33 & s34 & s35 & s36 & s37 & s38 & s39 & s40 \\
\hline & Campo Grande (Particular 2) & 7,2 & 30 & 7,8 & 25,2 & 0 & 24 & 6 & 0 & 0 & 0 & 0 & 0 & 0 & 0 & 0 & 0 & 3 & 4,5 & 0 & 0 \\
\hline & Barcelona (Particular) & 3 & 17,5 & 27 & 27 & 73,5 & 26 & 12 & 39 & 0 & 4,5 & 0 & 10,5 & 1,5 & 0 & 0 & 0 & 0 & 12 & 0 & 0 \\
\hline & Bom Jesus (Particular) & 41,4 & 5,6 & 62 & 81 & 107,2 & 72 & 8,2 & 93,6 & 0 & 8,2 & 0,6 & 17,2 & 0 & 0 & 0 & 2,2 & 0 & 5,6 & 0 & 0 \\
\hline & Caiçara do Rio do Vento (Particular) & 0 & 0 & 5 & 10,6 & 14,2 & 18,4 & 0 & 26,4 & 0 & 2,6 & 0 & 0 & 0 & 0 & 0 & 0 & 0 & 0 & 0 & 0 \\
\hline & Caicó (Batalhão) & 0 & 104,7 & 0 & 15 & 0 & 8,5 & 6,6 & 0 & 0 & 0 & 0 & 0 & 0 & 0 & 0 & 0 & 0 & 0 & 0 & 0 \\
\hline & Caicó (Açude Mundo Novo - EMPARN) & 2,4 & 96,2 & 44 & 10,8 & 5,5 & 0 & 26,9 & 0 & 0 & 0 & 0 & 0 & 0 & 0 & 0 & 0 & 0 & 0 & 0 & 0 \\
\hline & Caicó (Palma) & 0 & 24 & 0 & 31,4 & 0,4 & 4,4 & 19,4 & 0,6 & 0 & 0 & 0 & 0 & 1 & 0 & 0 & 0 & 0 & 7,2 & 0 & 0 \\
\hline & Caicó (Açude Itans) & 28,3 & 18,3 & 13,4 & 3,4 & 3,2 & 7,4 & 2,8 & 1,1 & 0 & 0 & 0 & 0 & 1,3 & 0 & 0 & 0 & 0 & 0 & 0 & 0 \\
\hline & Caicó (EMATER) & 27 & 0,3 & 0,8 & 6,8 & 13,5 & 0 & 9,9 & 7,5 & 3,5 & 0 & 9,9 & 0 & 0 & 0 & 0 & 0 & 3,5 & 0 & 0 & 0 \\
\hline & Campo Redondo (Polícia Rodoviária) & 0 & 13,5 & 16,7 & 19 & 26,4 & 34,9 & 21,9 & 16,2 & 3,4 & 6,1 & 9,7 & 0 & 4,3 & 0 & 0 & 0 & 0 & 5,1 & 0 & 0 \\
\hline & Cerro Corá (EMATER) & 12 & 23,4 & 5 & 18 & 19 & 32,6 & 3,4 & 15 & 0 & 0 & 0 & 0 & 0 & 0 & 0 & 0 & 0 & 0 & 0 & 0 \\
\hline & Cerro Corá (Sítio Recanto - Extinto) & 0 & 0 & 0 & 0 & 0 & 0 & 0 & 0 & 0 & 0 & 0 & 0 & 0 & 0 & 0 & 0 & 0 & 0 & 0 & 0 \\
\hline & Coronel Ezequiel (Particular) & 2 & 8 & 4 & 12 & 24 & 0 & 32,5 & 10 & 0 & 0 & 2 & 0 & 2 & 0 & 0 & 0 & 0 & 13 & 0 & 0 \\
\hline & Cruzeta (Base Física da EMPARN) & 0 & 46,9 & 9,5 & 16,1 & 2,1 & 7 & 16 & 1,3 & 2,7 & 0,3 & 0 & 0,8 & 0,7 & 0 & 0 & 0 & 0 & 4,1 & 0 & 0 \\
\hline & Currais Novos (CERCEL) & 12,5 & 14 & 0 & 65,8 & 42,5 & 34,5 & 26,8 & 22,3 & 19,5 & 0 & 0 & 0 & 0 & 0 & 0 & 0 & 0 & 0 & 0 & 0 \\
\hline & Currais Novos (Açude Tororó) & 0 & 25,2 & 70,6 & 41 & 65,3 & 0 & 0 & 0 & 0 & 0 & 0 & 0 & 0 & 0 & 0 & 0 & 0 & 0 & 0 & 0 \\
\hline & Janduís (EMATER) & 11,4 & 50,9 & 7 & 17,5 & 0 & 0 & 91 & 0 & 0 & 0 & 0 & 0 & 0 & 0 & 0 & 0 & 0 & 0 & 0 & 0 \\
\hline & Boa Saúde (EMATER) & 19 & 18 & 0 & 0 & 0 & 0 & 0 & 0 & 0 & 0 & 0 & 0 & 0 & 0 & 0 & 0 & 0 & 0 & 0 & 0 \\
\hline & Japi (Particular) & 0 & 8,2 & 0 & 18,6 & 0 & 40 & 20,8 & 12,4 & 6,2 & 6,4 & 44,2 & 0 & 0 & 0 & 29,8 & 0 & 0 & 0 & 0 & 0 \\
\hline & Japi (Assentamento Barbaco - Extinto) & 0 & 0 & 0 & 0 & 0 & 0 & 0 & 0 & 0 & 0 & 0 & 0 & 0 & 0 & 0 & 0 & 0 & 0 & 0 & 0 \\
\hline & Lagoa d'Anta (Prefeitura) & 0 & 0 & 0 & 0 & 0 & 0 & 0 & 0 & 0 & 0 & 0 & 0 & 0 & 0 & 0 & 0 & 0 & 0 & 0 & 0 \\
\hline & Lagoa de Pedras (Prefeitura) & 24,2 & 30,1 & 36 & 67,9 & 51,7 & 68,6 & 1,7 & 140,1 & 2,9 & 21,8 & 4,2 & 18,7 & 14,5 & 0 & 0 & 2,8 & 0,8 & 18,9 & 0 & 0 \\
\hline & Lagoa de Velhos (Delegacia) & 16,3 & 2,3 & 38,3 & 27,6 & 42,1 & 27 & 15,7 & 47,9 & 0,4 & 5,1 & 1,4 & 11,9 & 1,5 & 0 & 0 & 0 & 0 & 12,4 & 0 & 0 \\
\hline & Lagoa Nova (EMATER/Sítio Humaitá) & 0 & 30 & 15 & 43 & 15,3 & 35 & 30 & 25 & 0 & 0 & 0 & 0 & 0 & 0 & 0 & 0 & 0 & 0 & 0 & 0 \\
\hline & Lagoa Nova (Assentamento Santana/Sítio de Dentro) & 0 & 39 & 12,3 & 20 & 46,1 & 0 & 0,5 & 15,5 & 0 & 0 & 0 & 0 & 0 & 0 & 0 & 0 & 0 & 0 & 0 & 0 \\
\hline & Lagoa Salgada (Delegacia) & 25,6 & 19,1 & 69,7 & 61 & 53,9 & 54 & 22,7 & 127,2 & 0 & 9 & 9,5 & 20 & 12,7 & 0 & 0 & 0 & 0 & 16 & 0 & 0 \\
\hline & Monte Alegre (EMATER) & 22,2 & 37 & 100 & 121 & 40,2 & 91 & 23,2 & 119 & 1 & 18,8 & 14 & 10,4 & 17 & 0 & 0 & 7,8 & 2 & 13,2 & 0 & 0 \\
\hline & Monte das Gameleiras (EMATER) & 10,3 & 23,6 & 12,2 & 13,2 & 11,6 & 18,1 & 21 & 16,4 & 0 & 2,7 & 9,8 & 0 & 7,5 & 0 & 0 & 0 & 0 & 8,5 & 0 & 0 \\
\hline & Paraú (Prefeitura) & 0 & 0 & 0 & 0 & 0 & 0 & 0 & 0 & 0 & 0 & 0 & 0 & 0 & 0 & 0 & 0 & 0 & 0 & 0 & 0 \\
\hline & Patu (Particular) & 19 & 22 & 13 & 9,8 & 4 & 3 & 47,2 & 0 & 0 & 0 & 0 & 0 & 10 & 0 & 0 & 0 & 0 & 0 & 0 & 0 \\
\hline & Santa Maria (Sindicato dos Trabalhadores Rurais) & 10 & 60 & 15 & 20 & 125 & 85 & 20 & 0 & 0 & 0 & 26 & 0 & 0 & 0 & 0 & 15 & 0 & 0 & 0 & 0 \\
\hline & Pedro Avelino (Particular) & 0 & 55 & 13,2 & 11,2 & 2 & 13,8 & 0 & 11 & 0 & 0 & 0 & 0 & 0 & 0 & 0 & 0 & 0 & 0 & 0 & 0 \\
\hline & Pedro Avelino (Base Física da EMPARN) & 10 & 27,3 & 0 & 8,4 & 59,5 & 82,1 & 6 & 8 & 3 & 0 & 0 & 0 & 0 & 0 & 0 & 0 & 0 & 0 & 0 & 0 \\
\hline & Pedro Avelino (Assentamento Feijão) & 0 & 39 & 0 & 18 & 9 & 10 & 0 & 0 & 0 & 0 & 0 & 0 & 0 & 0 & 0 & 0 & 0 & 0 & 0 & 0 \\
\hline & Pedro Avelino (Assentamento Nova Conquista) & 0 & 50 & 8 & 15 & 5,8 & 30 & 0 & 21 & 0 & 0 & 0 & 1 & 0 & 0 & 0 & 0 & 1 & 0 & 1 & 0 \\
\hline & Riachuelo (EMATER) & 0 & 0 & 0 & 0 & 0 & 0 & 0 & 0 & 0 & 0 & 0 & 0 & 0 & 0 & 0 & 0 & 0 & 0 & 0 & 0 \\
\hline
\end{tabular}




\begin{tabular}{|c|c|c|c|c|c|c|c|c|c|c|c|c|c|c|c|c|c|c|c|c|c|}
\hline 2004 & Estação & s21 & s22 & s23 & s24 & s25 & s26 & s27 & $\mathbf{s 2 8}$ & $\mathbf{s 2 9}$ & s30 & s31 & s32 & s33 & s34 & s35 & s36 & s37 & s38 & s39 & s40 \\
\hline & Santa Cruz (EMATER) & 0 & 15,5 & 9,7 & 4,7 & 23,4 & 14,1 & 17,1 & 14 & 0 & 0 & 0 & 0 & 1,1 & 0 & 0 & 0 & 0 & 0 & 0 & 0 \\
\hline & Santa Cruz (Açude Inharé) & 0 & 20 & 0 & 20 & 16,3 & 33,4 & 0 & 13,3 & 0 & 0 & 0 & 14,2 & 20 & 0 & 0 & 0 & 0 & 0 & 0 & 0 \\
\hline & Santana do Matos (EMATER) & 0 & 0 & 0 & 3 & 0 & 0 & 0 & 0 & 0 & 0 & 0 & 0 & 0 & 0 & 0 & 0 & 0 & 0 & 0 & 0 \\
\hline & Santana do Matos (Barão de Serra Branca) & 0 & 63 & 12,7 & 12,1 & 5 & 0 & 0 & 0 & 0 & 0 & 0 & 0 & 0 & 0 & 0 & 0 & 0 & 0 & 0 & 0 \\
\hline & Santana do Matos (São José da Passagem) & 0 & 20,9 & 2 & 3 & 2,9 & 0 & 0 & 6,2 & 0 & 0 & 0 & 0 & 0 & 0 & 0 & 0 & 0 & 0 & 0 & 0 \\
\hline & São José do Campestre (EMATER) & 0 & 9 & 21 & 25 & 39,2 & 27 & 0 & 25 & 2 & 1 & 0 & 12 & 5 & 0 & 0 & 0 & 0 & 0 & 0 & 0 \\
\hline & São José do Campestre (Açude Japi II) & 38,1 & 0 & 0 & 0 & 0 & 0 & 0 & 0 & 0 & 0 & 0 & 0 & 0 & 0 & 0 & 0 & 0 & 0 & 0 & 0 \\
\hline & São Paulo do Potengi (EMATER) & 2 & 6,8 & 39 & 21,2 & 58,1 & 81,4 & 12,4 & 56,9 & 2,2 & 1,8 & 2,3 & 7,4 & 1 & 0 & 0 & 0 & 0 & 3,6 & 0 & 0 \\
\hline & São Rafael (EMATER) & 0 & 4,3 & 32 & 5,2 & 10 & 2,4 & 3,3 & 2,2 & 0 & 0 & 0 & 0 & 0 & 0 & 0 & 0 & 0 & 0 & 0 & 0 \\
\hline & São Tomé (EMATER) & 0 & 40 & 15 & 27 & 25 & 2 & 0 & 20 & 0 & 0 & 0 & 0 & 0 & 0 & 0 & 0 & 0 & 0 & 0 & 0 \\
\hline & São Vicente (EMATER - Ex Particular) & 0 & 0 & 0 & 0 & 0 & 0 & 0 & 0 & 0 & 0 & 0 & 0 & 0 & 0 & 0 & 0 & 0 & 0 & 0 & 0 \\
\hline & Serrinha (EMATER) & 22,6 & 14,5 & 75,1 & 54,5 & 30,2 & 20,3 & 8,7 & 85,1 & 0,3 & 14,7 & 0 & 19,4 & 13,3 & 0,4 & 0 & 0 & 0 & 20 & 5,5 & 0 \\
\hline & Sítio Novo (Prefeitura) & 45 & 13,5 & 13,5 & 24 & 23 & 34 & 0 & 10 & 0 & 0 & 0 & 10 & 0 & 0 & 0 & 0 & 0 & 0 & 0 & 0 \\
\hline & Tangará (EMATER) & 0 & 0 & 0 & 0 & 15,7 & 24,3 & 2 & 32 & 1 & 6 & 3 & 2 & 5 & 0 & 0 & 0 & 0 & 13 & 0 & 0 \\
\hline & Tangará (Açude Trairi) & 5,2 & 4,2 & 27,1 & 23,1 & 23,1 & 30,5 & 7,1 & 21,7 & 0 & 2,5 & 0 & 12 & 3 & 0 & 0 & 0 & 0 & 5,4 & 0 & 0 \\
\hline & Tenente Laurentino Cruz (EMATER) & 0 & 0 & 8 & 16 & 0 & 15 & 20 & 12 & 0 & 0 & 0 & 0 & 0 & 0 & 0 & 0 & 0 & 0 & 0 & 0 \\
\hline
\end{tabular}

Acari (Particular)

Acari (Açude Gargalheiras)

Assu (Particular)

Assu (Volta)

Afonso Bezerra (EMATER)

Afonso Bezerra (Assentamento Santa Maria)

Almino Afonso (Particular - Ex Sítio Milagres)

Angicos (Prefeitura)

Campo Grande (Particular)

Campo Grande (Açude Morcego - Extinto)

Campo Grande (Particular 2)

Barcelona (Particular)

Bom Jesus (Particular)

Caiçara do Rio do Vento (Particular)

Caicó (Batalhão)

Caicó (Açude Mundo Novo - EMPARN)

Caicó (Palma)

Caicó (Açude Itans)

$\begin{array}{cccccccccccc}0 & 0 & 0 & 0 & 0 & 0 & 0 & 0 & 0 & 0 & 0 & 6 \\ 0 & 0 & 0 & 0 & 0 & 0 & 0 & 0 & 0 & 0 & 0 & 0 \\ 0 & 0 & 0 & 0 & 0 & 0 & 3 & 0 & 3 & 0 & 0 & 0 \\ 0 & 0 & 0 & 0 & 0 & 0 & 0 & 0 & 0 & 0 & 0 & 0 \\ 0 & 0 & 0 & 0 & 0 & 0 & 0 & 0 & 0 & 0 & 0 & 0 \\ 0 & 0 & 0 & 0 & 0 & 0 & 0 & 0 & 0 & 0 & 0 & 0 \\ 0 & 0 & 0 & 0 & 0 & 0 & 0 & 0 & 0 & 0 & 4,1 & 0 \\ 0 & 0 & 0 & 0 & 0 & 0 & 0 & 0 & 0 & 0 & 0 & 0 \\ 0 & 0 & 0 & 0 & 0 & 0 & 0 & 0 & 0 & 0 & 0 & 0 \\ 0 & 0 & 0 & 0 & 0 & 0 & 0 & 0 & 0 & 0 & 0 & 0 \\ 0 & 0 & 0 & 0 & 0 & 0 & 0 & 0 & 0 & 0 & 8,3 & 23 \\ 0 & 0 & 0 & 0 & 0 & 0 & 0 & 0 & 0 & 0 & 0 & 0 \\ 0 & 0 & 0 & 0 & 0 & 0 & 0 & 0 & 0 & 0 & 0 & 0 \\ 0 & 0 & 0 & 0 & 0 & 0 & 0 & 0 & 0 & 0 & 0 & 0 \\ 0 & 0 & 0 & 0 & 0 & 0 & 0 & 0 & 0 & 0 & 0 & 0 \\ 0 & 0 & 0 & 0 & 0 & 0 & 0 & 0 & 0 & 0 & 0 & 0 \\ 0 & 0 & 0 & 0 & 0 & 0 & 0 & 0 & 0 & 0 & 0 & 10,8 \\ 0 & 0 & 0 & 0 & 0 & 0 & 0 & 0 & 0 & 0 & 0 & 2,5\end{array}$




\begin{tabular}{|c|c|c|c|c|c|c|c|c|c|c|c|c|c|}
\hline 2004 & Estação & s41 & s42 & s43 & s44 & s45 & s46 & s47 & s48 & s49 & s50 & s51 & s52 \\
\hline & Caicó (EMATER) & 0 & 0 & 0 & 0 & 0 & 0 & 0 & 0 & 0 & 0 & 0 & 3,3 \\
\hline & Campo Redondo (Polícia Rodoviária) & 0 & 0 & 0 & 0 & 0 & 0 & 0 & 0 & 0 & 0 & 0 & 25 \\
\hline & Cerro Corá (EMATER) & 0 & 0 & 0 & 0 & 0 & 0 & 0 & 0 & 0 & 0 & 0 & 0 \\
\hline & Cerro Corá (Sítio Recanto - Extinto) & 0 & 0 & 0 & 0 & 0 & 0 & 0 & 0 & 0 & 0 & 0 & 0 \\
\hline & Coronel Ezequiel (Particular) & 0 & 0 & 0 & 0 & 0 & 0 & 0 & 0 & 0 & 0 & 0 & 0 \\
\hline & Cruzeta (Base Física da EMPARN) & 0 & 0 & 0 & 0 & 0,4 & 0 & 0,1 & 0 & 0 & 0 & 0 & 26 \\
\hline & Currais Novos (CERCEL) & 0 & 0 & 0 & 0 & 0 & 0 & 0 & 0 & 0 & 0 & 0 & 0 \\
\hline & Currais Novos (Açude Tororó) & 0 & 0 & 0 & 0 & 0 & 0 & 0 & 0 & 0 & 0 & 0 & 0 \\
\hline & Janduís (EMATER) & 0 & 0 & 0 & 0 & 0 & 0 & 0 & 0 & 0 & 0 & 0 & 5,4 \\
\hline & Boa Saúde (EMATER) & 0 & 0 & 0 & 0 & 0 & 0 & 0 & 0 & 0 & 0 & 0 & 0 \\
\hline & Japi (Particular) & 0 & 0 & 0 & 0 & 0 & 0 & 0 & 0 & 0 & 0 & 0 & 0 \\
\hline & Japi (Assentamento Barbaco - Extinto) & 0 & 0 & 0 & 0 & 0 & 0 & 0 & 0 & 0 & 0 & 0 & 0 \\
\hline & Lagoa d'Anta (Prefeitura) & 0 & 0 & 0 & 0 & 0 & 0 & 0 & 0 & 0 & 0 & 0 & 0 \\
\hline & Lagoa de Pedras (Prefeitura) & 0 & 3,5 & 0 & 6,8 & 2,8 & 0 & 0 & 0 & 0 & 0 & 0,4 & 0 \\
\hline & Lagoa de Velhos (Delegacia) & 0 & 0 & 8,3 & 0,3 & 0,9 & 0 & 0 & 0 & 0 & 0 & 0 & 0 \\
\hline & Lagoa Nova (EMATER/Sítio Humaitá) & 0 & 0 & 0 & 0 & 0 & 0 & 0 & 0 & 0 & 0 & 0 & 0 \\
\hline & Lagoa Nova (Assentamento Santana/Sítio de Dentro) & 0 & 0 & 0 & 0 & 0 & 0 & 0 & 0 & 0 & 0 & 0 & 2,1 \\
\hline & Lagoa Salgada (Delegacia) & 0 & 0 & 0 & 5,5 & 0 & 0 & 0 & 0 & 0 & 0 & 1 & 0 \\
\hline & Monte Alegre (EMATER) & 2 & 1 & 2,2 & 7,8 & 8,4 & 0 & 0 & 0 & 0 & 0 & 0 & 3,8 \\
\hline & Monte das Gameleiras (EMATER) & 0 & 0 & 0 & 0 & 3,7 & 0 & 0 & 0 & 0 & 0 & 0 & 7,5 \\
\hline & Paraú (Prefeitura) & 0 & 0 & 0 & 0 & 0 & 0 & 0 & 0 & 0 & 0 & 0 & 0 \\
\hline & Patu (Particular) & 0 & 0 & 0 & 0 & 4 & 0 & 0 & 0 & 0 & 0 & 0 & 0 \\
\hline & Santa Maria (Sindicato dos Trabalhadores Rurais) & 0 & 0 & 0 & 0 & 0 & 0 & 0 & 0 & 0 & 0 & 0 & 0 \\
\hline & Pedro Avelino (Particular) & 0 & 0 & 0 & 0 & 0 & 0 & 0 & 0 & 0 & 0 & 0 & 20 \\
\hline & Pedro Avelino (Base Física da EMPARN) & 0 & 0 & 0 & 0 & 0 & 0 & 0 & 0 & 0 & 0 & 0 & 0 \\
\hline & Pedro Avelino (Assentamento Feijão) & 0 & 0 & 0 & 0 & 0 & 0 & 0 & 0 & 0 & 0 & 0 & 0 \\
\hline & Pedro Avelino (Assentamento Nova Conquista) & 0 & 0 & 1 & 0 & 0 & 0 & 0 & 0 & 0 & 0 & 0 & 0 \\
\hline & Riachuelo (EMATER) & 0 & 0 & 0 & 0 & 0 & 0 & 0 & 0 & 0 & 0 & 0 & 0 \\
\hline & Santa Cruz (EMATER) & 0 & 0 & 0 & 0 & 0 & 0 & 0 & 0 & 0 & 0 & 0 & 0 \\
\hline & Santa Cruz (Açude Inharé) & 0 & 0 & 0 & 0 & 0 & 0 & 0 & 0 & 0 & 0 & 0 & 0 \\
\hline & Santana do Matos (EMATER) & 0 & 0 & 0 & 0 & 0 & 0 & 0 & 0 & 0 & 0 & 0 & 0 \\
\hline & Santana do Matos (Barão de Serra Branca) & 0 & 0 & 0 & 0 & 0 & 0 & 3,4 & 0 & 0 & 0 & 2,3 & 0 \\
\hline & Santana do Matos (São José da Passagem) & 0 & 0 & 0 & 0 & 0 & 0 & 0 & 0 & 0 & 0 & 0 & 0 \\
\hline & São José do Campestre (EMATER) & 0 & 0 & 0 & 0 & 0 & 0 & 0 & 0 & 0 & 0 & 0 & 12,3 \\
\hline & São José do Campestre (Açude Japi II) & 0 & 0 & 0 & 0 & 0 & 0 & 0 & 0 & 0 & 0 & 0 & 0 \\
\hline & São Paulo do Potengi (EMATER) & 0 & 0 & 0 & 6,7 & 0 & 0 & 0 & 0 & 0 & 0 & 0 & 0 \\
\hline
\end{tabular}




\begin{tabular}{|c|c|c|c|c|c|c|c|c|c|c|c|c|c|c|c|c|c|c|c|c|c|}
\hline 2004 & Estação & $s 41$ & s42 & s43 & s44 & s45 & $s 46$ & $s 47$ & $s 48$ & $8 s 49$ & $9 \mathrm{s5c}$ & 0 s51 & 1 s52 & & & & & & & & \\
\hline & São Rafael (EMATER) & 0 & 0 & 0 & 0 & 0 & 0 & 0 & 0 & 0 & 0 & 0 & 0 & & & & & & & & \\
\hline & São Tomé (EMATER) & 0 & 0 & 0 & 0 & 0 & 0 & 0 & 0 & 0 & 0 & 0 & 0 & & & & & & & & \\
\hline & São Vicente (EMATER - Ex Particular) & 0 & 0 & 0 & 0 & 0 & 0 & 0 & 0 & 0 & 0 & 0 & 0 & & & & & & & & \\
\hline & Serrinha (EMATER) & 0 & 0 & 0,4 & 0 & 0 & 0 & 0,8 & 0 & 0 & 0 & 0 & 0 & & & & & & & & \\
\hline & Sítio Novo (Prefeitura) & 0 & 0 & 0 & 0 & 0 & 0 & 0 & 0 & 0 & 0 & 0 & 0 & & & & & & & & \\
\hline & Tangará (EMATER) & 0 & 0 & 0 & 0,5 & 0 & 0 & 0 & 0 & 0 & 0 & 0 & 2 & & & & & & & & \\
\hline & Tangará (Açude Trairi) & 0 & 0 & 0 & 0 & 0 & 0 & 0 & 0 & 0 & 0 & 0 & 0 & & & & & & & & \\
\hline & Tenente Laurentino Cruz (EMATER) & 0 & 0 & 0 & 0 & 0 & 0 & 0 & 0 & 0 & 0 & 0 & 0 & & & & & & & & \\
\hline 2005 & Estação & s1 & s2 & s3 & s4 & s5 & s6 & s7 & s8 & s9 & $\mathbf{s 1 0}$ & s11 & $s 12$ & s13 & s14 & $\mathbf{s 1 5}$ & s16 & $s 17$ & $\mathbf{s 1 8}$ & $\mathbf{s 1 9}$ & s20 \\
\hline & Acari (Particular) & 0 & 0 & 0 & 25,4 & 0 & 2,2 & 46,3 & 0 & 0 & 0 & 5 & 61,3 & 70 & 0 & 0,8 & 13,4 & 31,7 & 7,3 & 11,9 & 0,5 \\
\hline & Acari (Açude Gargalheiras) & 0 & 0 & 8,6 & 38,6 & 0 & 0 & 31,1 & 0 & 0 & 0 & 0 & 128,1 & 66,3 & 1,2 & 7,2 & 3,8 & 35 & 9 & 11 & 0 \\
\hline & Assu (Particular) & 0 & 0 & 0,4 & 16,7 & 0,1 & 0 & 84,9 & 0 & 12 & 0 & 0 & 37,8 & 65,5 & 0 & 41,7 & 0 & 4,3 & 7 & 6,2 & 36,3 \\
\hline & Assu (EMATER/Sítio Casa Forte) & 0 & 0 & 0 & 42,6 & 0 & 0 & 83,6 & 0 & 31,1 & 0 & 0 & 27,6 & 103,7 & 0 & 35,9 & 2,1 & 23,6 & 1,8 & 1,8 & 49,6 \\
\hline & Afonso Bezerra (EMATER) & 0 & 0 & 22 & 15 & 0 & 0 & 8 & 8 & 0 & 0 & 10 & 15 & 80 & 0 & 0 & 0 & 43 & 14 & 10 & 0 \\
\hline & Almino Afonso (Particular - Ex Sítio Milagres) & 0 & 0 & 13 & 19 & 0 & 4,3 & 40,4 & 21,2 & 4,1 & 19,1 & 0 & 141,4 & 120,2 & 0 & 21,3 & 1,2 & 86,3 & 44,3 & 2,3 & 22,5 \\
\hline & Angicos (Prefeitura) & 0 & 0 & 0 & 13,1 & 0 & 0 & 26,1 & 0 & 0 & 0 & 45 & 63 & 22,5 & 0 & 6 & 11 & 101 & 24 & 0 & 10 \\
\hline & Campo Grande (Particular) & 0 & 0 & 12 & 8,4 & 0,8 & 0 & 44,8 & 0,7 & 0 & 0 & 30,7 & 202,7 & 74,3 & 0 & 21,4 & 0,9 & 34,8 & 59,3 & 2,8 & 6,4 \\
\hline & Campo Grande (Particular 2) & 0 & 0 & 12 & 10,7 & 0 & 0 & 43,9 & 4,1 & 0 & 4 & 3,5 & 214,6 & 84,3 & 7,2 & 32,3 & 0 & 37,1 & 53,2 & 0 & 8 \\
\hline & Barcelona (Particular) & 0 & 0 & 2 & 0 & 0 & 0 & 4 & 0 & 0 & 0 & 2 & 5 & 32,5 & 0 & 0 & 8,5 & 2 & 0 & 43,5 & 31 \\
\hline & Bodó (EMATER/TRF P/Delegacia) & 0 & 2,7 & 0 & 75 & 7,8 & 7 & 38,4 & 0 & 0 & 16,7 & 14,6 & 68,9 & 49 & 0 & 0 & 0 & 51,7 & 7,6 & 0 & 0 \\
\hline & Bom Jesus (Particular) & 0 & 0 & 0 & 22 & 0 & 0 & 14,8 & 0 & 0 & 0 & 28,4 & 28,6 & 37,6 & 0 & 13,6 & 23,8 & 24,4 & 2,6 & 88 & 42,9 \\
\hline & Caiçara do Rio do Vento (Particular) & 0 & 0 & 1,6 & 2,2 & 0 & 0 & 2,8 & 0 & 0 & 0 & 0 & 13 & 0 & 0 & 0 & 0 & 84,5 & 0 & 25,4 & 22 \\
\hline & Caicó (Batalhão) & 0 & 0 & 0 & 14,5 & 0 & 4 & 34 & 5,5 & 0 & 15 & 122 & 131,8 & 78,3 & 5 & 3,5 & 2 & 39,5 & 59 & 3 & 3 \\
\hline & Caicó (Açude Mundo Novo - EMPARN) & 0 & 0 & 12,5 & 6,4 & 0 & 0 & 49,1 & 0 & 0 & 0 & 96 & 112,2 & 116,7 & 2 & 2,7 & 8,6 & 2 & 68,6 & 1,6 & 7,8 \\
\hline & Caicó (Palma) & 0 & 0 & 3 & 7 & 0 & 11 & 70,8 & 0 & 0 & 0 & 10 & 70 & 113,6 & 14,2 & 4,5 & 5 & 2 & 32,4 & 5,2 & 0 \\
\hline & Caicó (Açude Itans) & 0 & 0 & 0 & 12,6 & 0 & 37,1 & 22,4 & 1,1 & 4 & 12,1 & 8,3 & 153,5 & 80,7 & 21,1 & 17,4 & 13,3 & 19 & 69,1 & 7,1 & 1,4 \\
\hline & Caicó (EMATER) & 0 & 0 & 0 & 9,4 & 0 & 16,2 & 21,3 & 0 & 4,5 & 9,7 & 18,8 & 135,8 & 89,2 & 6,4 & 9,1 & 13,5 & 18,4 & 58 & 7,7 & 3,8 \\
\hline & Campo Redondo (EMATER) & 0 & 0 & 10 & 25 & 0 & 0 & 8,2 & 0 & 0 & 0 & 0 & 49 & 62 & 0 & 4,9 & 3,7 & 63,1 & 40,6 & 53,4 & 11,8 \\
\hline & Campo Redondo (Polícia Rodoviária) & 0 & 0 & 0 & 74,3 & 0 & 0 & 5,8 & 0 & 0 & 0 & 0 & 30,2 & 54 & 0 & 0 & 4,1 & 41,9 & 2,7 & 51 & 19,1 \\
\hline & Cerro Corá (EMATER) & 0 & 0 & 9 & 35,2 & 1,2 & 0 & 13,7 & 0 & 0 & 3,3 & 1,1 & 45,2 & 52,2 & 2,4 & 8,9 & 4,1 & 56,9 & 0 & 12,4 & 14,4 \\
\hline & Coronel Ezequiel (Particular) & 0 & 0 & 0 & 67 & 2 & 0 & 18 & 0 & 0 & 0 & 5 & 36 & 79 & 0 & 10,9 & 14 & 5 & 24 & 23,5 & 23,5 \\
\hline & Cruzeta (Base Física da EMPARN) & 0 & 32,2 & 7,9 & 33,3 & 0 & 27,3 & 32,9 & 0,2 & 0 & 0 & 1,9 & 56,5 & 131,7 & 1,2 & 6,1 & 12,4 & 32,1 & 11,9 & 9,2 & 3,5 \\
\hline & Currais Novos (CERCEL) & 0 & 0 & 0 & 75,9 & 0 & 0 & 8 & 0 & 0 & 10 & 4,3 & 166,6 & 19,8 & 0 & 0 & 165 & 0 & 15 & 0 & 7 \\
\hline & Currais Novos (Açude Tororó) & 0 & 25,4 & 37,2 & 0 & 0 & 12 & 14,2 & 0 & 0 & 0 & 17 & 177 & 67 & 9 & 8,2 & 2 & 0 & 22,2 & 21,2 & 7 \\
\hline & Fernando Pedroza (EMATER) & 2 & 6 & 0 & 7 & 2 & 0 & 45,6 & 0 & 0 & 0 & 55,5 & 87,9 & 33,2 & 0 & 0 & 7,4 & 23,4 & 0 & 2,3 & 0 \\
\hline
\end{tabular}




\begin{tabular}{|c|c|c|c|c|c|c|c|c|c|c|c|c|c|c|c|c|c|c|c|c|c|}
\hline 2005 & Estação & s1 & s2 & s3 & s4 & s5 & s6 & s7 & s8 & s9 & $\mathbf{s 1 0}$ & s11 & s12 & s13 & s14 & s15 & s16 & $\mathbf{s 1 7}$ & s18 & $s 19$ & s20 \\
\hline & Florânia (INMET) & 0 & 0,1 & 0 & 57,1 & 0,2 & 2 & 55,6 & 0 & 1,2 & 0 & 12 & 87 & 60 & 0,2 & 31,2 & 0 & 15,6 & 23,8 & 4,1 & 0,5 \\
\hline & Florânia (Sítio Jucuri) & 0 & 0 & 0 & 48,7 & 0 & 6,6 & 82,3 & 0 & 0 & 4,7 & 17,5 & 96,9 & 57,2 & 0 & 23,8 & 0 & 14,8 & 24,9 & 5,5 & 0 \\
\hline & Ielmo Marinho (Prefeitura) & 0 & 0 & 0 & 9,8 & 0 & 0 & 7,5 & 0 & 6,1 & 0 & 0 & 28,3 & 25,4 & 7,1 & 22,6 & 8,3 & 6,3 & 0 & 58 & 50,3 \\
\hline & Jaçanã (EMATER) & 0 & 0,8 & 0,7 & 40 & 0,2 & 0 & 4,5 & 2,1 & 0 & 0 & 12,7 & 16 & 193,1 & 2,8 & 11,3 & 13,6 & 10,6 & 9,2 & 35,5 & 18,9 \\
\hline & Janduís (EMATER) & 0 & 0 & 4,5 & 8,5 & 0 & 0 & 45,2 & 0 & 4,2 & 2,2 & 29,7 & 13 & 121,4 & 32,8 & 45,2 & 34 & 29,4 & 31 & 13,7 & 5,7 \\
\hline & Boa Saúde (EMATER) & 1,3 & 0 & 1,3 & 43,3 & 0 & 0 & 7,3 & 4,6 & 1,4 & 0 & 9,7 & 1,6 & 88,8 & 0 & 15,4 & 10 & 16,3 & 0 & 72,7 & 42,3 \\
\hline & Japi (Particular) & 0 & 0 & 0 & 61,2 & 0 & 0 & 92,4 & 0 & 0 & 0 & 23 & 6,2 & 25,2 & 0 & 6,4 & 8,4 & 0 & 4,6 & 30 & 19 \\
\hline & Japi (EMATER) & 0 & 0 & 0 & 42,4 & 0 & 0 & 0 & 0 & 0 & 0 & 0 & 23 & 0 & 0 & 0 & 0 & 0 & 0 & 25,9 & 25,5 \\
\hline & Jardim de Angicos (EMATER) & 0 & 0 & 0 & 26 & 0 & 0 & 0 & 0 & 0 & 0 & 0 & 0 & 0 & 0 & 0 & 0 & 0 & 0 & 26,5 & 59,6 \\
\hline & Lagoa d'Anta (Prefeitura) & 0 & 0 & 0 & 55,5 & 0 & 0 & 7,6 & 0 & 0 & 0 & 2,5 & 31,2 & 49,5 & 20,6 & 6,1 & 4,4 & 7,6 & 0 & 47,4 & 35,4 \\
\hline & Lagoa de Pedras (Prefeitura) & 4,3 & 0 & 3,2 & 9,5 & 0,7 & 0 & 41,3 & 1,3 & 0 & 0,1 & 9,7 & 7,5 & 17,9 & 4,4 & 22,5 & 16,2 & 6,5 & 0 & 93,4 & 47,4 \\
\hline & Lagoa de Velhos (Delegacia) & 0,3 & 0 & 1,8 & 0,1 & 0,3 & 0 & 4,1 & 0 & 0 & 0 & 0,3 & 6,9 & 54,2 & 1 & 0 & 14,7 & 0,9 & 0 & 43,4 & 20,3 \\
\hline & Lagoa Nova (EMATER/Sítio Humaitá) & 0 & 0 & 0 & 12,5 & 0 & 4,2 & 35,5 & 0 & 0 & 0 & 54,5 & 22,5 & 39,5 & 0 & 5,2 & 0 & 0 & 0 & 4,2 & 11,2 \\
\hline & Lagoa Nova (Assentamento Santana/Sítio de Dentro) & 0 & 0 & 15,8 & 2,5 & 0 & 0 & 46,4 & 0 & 0 & 0 & 27,8 & 20,7 & 32,5 & 0 & 0 & 0 & 0 & 3,9 & 0 & 0 \\
\hline & Lagoa Salgada (Delegacia) & 5,3 & 0 & 0 & 7,6 & 3 & 0 & 14,6 & 0 & 0 & 0 & 2,7 & 2 & 28,1 & 1,6 & 14 & 14 & 34,7 & 0 & 88,8 & 55,2 \\
\hline & Lajes (Prefeitura) & 0 & 0 & 1,6 & 67,6 & 0 & 0 & 8,8 & 0 & 0 & 0 & 0 & 76,2 & 16,9 & 0 & 4,4 & 0 & 2 & 5,7 & 13,6 & 6,7 \\
\hline & Lajes Pintadas (Prefeitura) & 0 & 0 & 3,3 & 35,1 & 1,4 & 0 & 5,5 & 0 & 0 & 0 & 0 & 74,9 & 60,4 & 0 & 3,1 & 9,4 & 17,6 & 0 & 30 & 18,2 \\
\hline & Monte Alegre (EMATER) & 0 & 1,8 & 8,2 & 18,2 & 2,8 & 0,4 & 46,2 & 0 & 8,2 & 0 & 2,6 & 12 & 73,4 & 6 & 51 & 28,6 & 5,8 & 0,4 & 104,8 & 81,6 \\
\hline & Monte das Gameleiras (EMATER) & 0 & 0 & 0 & 57,2 & 0 & 2 & 7,5 & 0 & 0 & 0 & 10 & 8,2 & 41,6 & 0 & 12 & 7,6 & 2,3 & 0 & 56 & 60,1 \\
\hline & Paraú (Sindicato) & 0 & 0 & 0 & 32,2 & 0 & 0 & 34,6 & 0 & 38,7 & 0 & 0 & 161,9 & 72,8 & 37,7 & 19,8 & 0 & 0 & 40,1 & 6,7 & 0 \\
\hline & Passa e Fica (Prefeitura) & 0 & 0 & 0 & 63,8 & 0 & 0 & 8,8 & 0 & 0 & 0 & 0 & 35,8 & 49,9 & 0 & 11,6 & 8,4 & 12 & 0 & 31,1 & 21,8 \\
\hline & Patu (Particular) & 0 & 0 & 0 & 3 & 0 & 4,4 & 90 & 0 & 1,2 & 0 & 0 & 127,4 & 104,4 & 11 & 30,4 & 42,6 & 38,4 & 72,6 & 0 & 4,8 \\
\hline & Pedra Preta (EMATER) & 0 & 0 & 0 & 10 & 0 & 0 & 13,7 & 0 & 0 & 0 & 0 & 50,7 & 14,2 & 0 & 0 & 0 & 0 & 0 & 13,5 & 20,2 \\
\hline & Pedro Avelino (Particular) & 0 & 0 & 0 & 53 & 0 & 0 & 15,8 & 2 & 0 & 0 & 0 & 39 & 31,4 & 2,8 & 0 & 0 & 15,8 & 10,2 & 3,6 & 8,4 \\
\hline & Pedro Avelino (Base Física da EMPARN) & 0 & 0 & 0 & 0 & 0 & 0 & 0 & 0 & 0 & 0 & 0 & 54,7 & 47,2 & 0 & 0 & 0 & 0 & 0 & 27,7 & 12,1 \\
\hline & Pedro Avelino (Assentamento Nova Conquista) & 0 & 0 & 0 & 0,5 & 0 & 0 & 5,7 & 0 & 0 & 0 & 0 & 37,8 & 7,6 & 3,9 & 1,5 & 0 & 88,9 & 0 & 14,4 & 11,2 \\
\hline & Riachuelo (EMATER) & 0 & 0 & 0 & 7,2 & 1,5 & 0 & 5,8 & 0 & 0 & 0 & 0 & 22,4 & 16,6 & 0 & 0 & 0 & 0 & 0 & 29,2 & 64,7 \\
\hline & Rui Barbosa (EMATER) & 0 & 0 & 0,7 & 11,4 & 0 & 0 & 13 & 3 & 0 & 0 & 0 & 0,4 & 70,9 & 0 & 3 & 16,3 & 5,7 & 0 & 27,8 & 71,2 \\
\hline & Santa Cruz (EMATER) & 0 & 0 & 0,5 & 84,9 & 0 & 0 & 12,1 & 0 & 0 & 0 & 0 & 121,6 & 40,7 & 0 & 0 & 8,1 & 0,8 & 0 & 28,2 & 24,3 \\
\hline & Santa Cruz (Açude Inharé) & 0 & 0 & 0 & 70 & 0 & 0 & 25,1 & 0 & 0 & 0 & 0 & 85,1 & 35,1 & 0 & 0 & 20 & 0 & 0 & 30 & 40,2 \\
\hline & Santana do Matos (EMATER) & 0 & 17 & 29,3 & 0 & 1,9 & 17,6 & 36,4 & 0 & 0 & 71 & 15 & 149,7 & 14,9 & 0 & 0 & 0 & 0 & 13 & 0 & 0 \\
\hline & Santana do Matos (Barão de Serra Branca) & 0 & 29,5 & 0 & 77,3 & 0 & 3,8 & 0 & 0 & 0 & 4,7 & 3,3 & 121,3 & 56,4 & 0 & 10,7 & 0 & 0 & 19,9 & 0 & 4,7 \\
\hline & Santana do Matos (São José da Passagem) & 0 & 0 & 0 & 0 & 0 & 0 & 12 & 0 & 0 & 0 & 16 & 171,7 & 43,8 & 0 & 0 & 0 & 17 & 0 & 0 & 0 \\
\hline & São Bento do Trairi (Prefeitura) & 0 & 0 & 0 & 68,2 & 0 & 0 & 37,2 & 0 & 0 & 0 & 5,2 & 96,2 & 105,3 & 0 & 3 & 6,2 & 29,9 & 18 & 37,9 & 22,1 \\
\hline & São Paulo do Potengi (EMATER) & 0,6 & 0 & 0 & 107,6 & 1,6 & 0 & 5 & 1,2 & 0 & 0 & 1,3 & 0,3 & 17,4 & 0 & 3,8 & 0 & 4,1 & 0 & 61 & 42,4 \\
\hline & São Pedro (EMATER) & 0 & 0 & 0 & 32,8 & 0,7 & 0 & 8,3 & 0,9 & 0 & 0 & 56,3 & 7,7 & 34,8 & 6,6 & 12,5 & 8,2 & 8,6 & 1 & 63,7 & 75,9 \\
\hline
\end{tabular}




\begin{tabular}{|c|c|c|c|c|c|c|c|c|c|c|c|c|c|c|c|c|c|c|c|c|c|}
\hline \multirow[t]{12}{*}{2005} & Estação & s1 & s2 & s3 & s4 & s5 s6 & s7 & s8 & s9 & s10 & s11 & s12 & \multicolumn{2}{|c|}{$s 13$} & $s 14$ & s15 & s16 & s17 & s18 & s19 & $s 20$ \\
\hline & São Rafael (EMATER) & 0 & 0 & 0 & 0 & 516 & 25 & 0 & 0 & 23,4 & $4 \quad 0$ & 198 & & 2,6 & 0 & 19,8 & 02 & $24,2 \quad 4$ & 42,9 & 1,6 & $\overline{3,4}$ \\
\hline & São Tomé (EMATER) & 0 & 0 & 2 & 0 & 0 & 0 & 0 & 0 & 0 & 0 & 93 & & 32 & 0 & 0 & 9 & 0 & 0 & 9 & 12 \\
\hline & São Vicente (EMATER - Ex Particular) & 0 & 0 & 0 & 137,8 & $0, \subseteq$ & 20 & 0 & 0 & 0 & 0 & 249 & & 1,1 & 0 & 0 & 0 & 27,7 & 29,2 & 23,1 & 15,4 \\
\hline & Senador Eloi de Souza (Particular) & 0 & 0 & 0 & 15 & 0 & 5 & 4,5 & 0 & 0 & 15 & 41 & & 1,5 & 2,4 & 0 & 18,4 & 10 & 0 & 59,6 & 38,3 \\
\hline & Serrinha (EMATER) & 0 & 0 & 0 & 6,4 & 0 & 32,2 & 0 & 4,6 & 0 & 23,1 & 23,1 & & 18 & 0,3 & 3,8 & 6,2 & 34,8 & 5,6 & 63,6 & 32,5 \\
\hline & Sítio Novo (Prefeitura) & 0 & 0 & 0 & 0 & 1,5 & $1 \quad 11,5$ & 0 & 0 & 0 & 0 & 86 & & 3,5 & 0 & 0 & 9,5 & 0 & 0 & 50 & 16,5 \\
\hline & Tangará (EMATER) & 0 & 0 & 3 & 39 & 0 & $, 5 \quad 4,5$ & 0 & 0 & 0 & 0 & 23,5 & & 75 & 0 & 0 & 1,5 & 4,5 & 2,5 & 44,5 & 30 \\
\hline & Tangará (Açude Trairi) & 0 & 0 & 0 & 76,3 & 0 & 10,7 & 1,6 & 0 & 0 & 0 & 11,8 & & 4,5 & 0 & 2,7 & 4,6 & 0 & 0 & 53,6 & 25,7 \\
\hline & Tenente Laurentino Cruz (EMATER) & 0 & 37 & 0 & 73 & 0 & 22 & 0 & 0 & 0 & 19,1 & 162 & & 5,7 & 0 & 30,5 & 0 & 34,2 & 20 & 23,5 & 0 \\
\hline & Triunfo Potiguar (Prefeitura) & 0 & 0 & 11,8 & 45,9 & 0,5 & 60,9 & 3,5 & 35,2 & 0 & 0 & 189 & & 9,1 & 0 & 30,6 & 5 & 7 & 14,2 & 0 & 3,8 \\
\hline & Triunfo Potiguar (Chá Cacimbas/Serra J. Vale) & 0 & 0 & 0 & 0 & 0 & 0 & 0 & 0 & 0 & 35 & 85 & & 0 & 0 & 25 & 40 & 65 & 20 & 73 & 27 \\
\hline 2005 & Estação & s21 & s22 & s23 & s24 & $s 25$ & $s 26$ & $\mathbf{s 2 7}$ & $\mathbf{s} 28$ & $s 29$ & s30 & s31 & s32 & s33 & s34 & s35 & $s 36$ & 6 s37 & s38 & s39 & $s 40$ \\
\hline & Acari (Particular) & 17 & 29,8 & 1 & 2,2 & 12,2 & 2,6 & 0 & 0 & 0 & 0 & 0 & 0 & 0 & 4,9 & 0 & 0 & 0 & 0 & 0 & 0 \\
\hline & Acari (Açude Gargalheiras) & 0 & 25,9 & 2,3 & 2,9 & 4,1 & 7,1 & 0 & 0 & 0 & 0 & 0 & 0 & 0 & 7,1 & 0 & 0 & 0 & 0 & 0 & 0 \\
\hline & Assu (Particular) & 30,4 & 81,4 & 3,2 & 1,3 & 5,9 & 2,4 & 0,8 & 0 & 0 & 0 & 0 & 0 & 0 & 0 & 0 & 0 & 0 & 0 & 0 & 18,2 \\
\hline & Assu (EMATER/Sítio Casa Forte) & 30,7 & 92,2 & 6,3 & 4,4 & 10,7 & 5,7 & 4,5 & 0 & 0 & 0 & 0 & 0 & 0 & 0 & 0 & 0 & 0 & 0 & 0 & 5 \\
\hline & Afonso Bezerra (EMATER) & 8 & 4 & 0 & 0 & 0 & 15 & 15 & 0 & 0 & 0 & 0 & 0 & 0 & 0 & 0 & 0 & 0 & 0 & 0 & 0 \\
\hline & Almino Afonso (Particular - Ex Sítio Milagres) & 7,3 & 10,4 & 0 & 15,3 & 0 & 23,2 & 0 & 0 & 0 & 0 & 0 & 5,2 & 0 & 0 & 0 & 0 & 0 & 0 & 0 & 0 \\
\hline & Angicos (Prefeitura) & 6 & 5 & 0 & 0 & 1 & 2 & 10 & 0 & 0 & 0 & 0 & 0 & 0 & 0 & 0 & 0 & 0 & 0 & 0 & 0 \\
\hline & Campo Grande (Particular) & 21,8 & 9,4 & 8,3 & 0 & 0 & 0 & 1,5 & 6,5 & 0 & 0 & 0 & 0 & 0 & 0 & 0 & 0 & 0 & 0 & 0 & 0 \\
\hline & Campo Grande (Particular 2) & 30,1 & 9,2 & 5 & 18,3 & 7,8 & 0 & 4,3 & 0 & 0 & 0 & 0 & 0 & 0 & 0 & 0 & 0 & 0 & 0 & 0 & 0 \\
\hline & Barcelona (Particular) & 22 & 64,5 & 11 & 72 & 40 & 8 & 7,5 & 0 & 0 & 0 & 9 & 0 & 0 & 17 & 2,5 & 0 & 0 & 0 & 0 & 0 \\
\hline & Bodó (EMATER/TRF P/Delegacia) & 6,3 & 12 & 2,8 & 3 & 6,3 & 0 & 0 & 10,3 & 0 & 0 & 0 & 0 & 0 & 0 & 0 & 0 & 0 & 0 & 0 & 0 \\
\hline & Bom Jesus (Particular) & 49,7 & 107,3 & 35,4 & 27,5 & 577,2 & 49,7 & 5,2 & 6 & 17 & 0 & 0 & 1,8 & 2 & 5,7 & 3,6 & 7,8 & 0 & 0 & 0 & 5,8 \\
\hline & Caiçara do Rio do Vento (Particular) & 0 & 34,4 & 10,4 & 28 & 0 & 0 & 4,8 & 19,2 & 0 & 0 & 0 & 0 & 0 & 0 & 0 & 0 & 0 & 0 & 0 & 0 \\
\hline & Caicó (Batalhão) & 0 & 13 & 4 & 0 & 8,5 & 0 & 0 & 0 & 0 & 0 & 0 & 0 & 0 & 0 & 0 & 0 & 0 & 0 & 0 & 0 \\
\hline & Caicó (Açude Mundo Novo - EMPARN) & 0,6 & 24 & 1,6 & 0 & 0 & 0 & 2,2 & 0 & 0 & 0 & 0 & 0 & 0 & 0 & 0 & 0 & 0 & 0 & 0 & 0 \\
\hline & Caicó (Palma) & 0 & 8 & 0 & 10 & 2 & 0 & 2 & 0 & 0 & 0 & 0 & 0 & 0 & 2 & 0 & 0 & 0 & 0 & 0 & 0 \\
\hline & Caicó (Açude Itans) & 10 & 8,9 & 4,3 & 0 & 0,6 & 0,6 & 1,1 & 0 & 0 & 0 & 0 & 0 & 0 & 0 & 0 & 0 & 0 & 0 & 0 & 0 \\
\hline & Caicó (EMATER) & 5,8 & 17,7 & 5 & 0 & 4 & 0 & 0 & 0 & 0 & 0 & 0 & 0 & 0 & 0 & 0 & 0 & 0 & 0 & 0 & 0 \\
\hline & Campo Redondo (EMATER) & 21,7 & 54,5 & 19,9 & 24,5 & 10,5 & 18,2 & 12 & 2,1 & 3,2 & 0 & 0 & 0 & 0 & 0 & 0 & 0 & 0 & 0 & 0 & 0 \\
\hline & Campo Redondo (Polícia Rodoviária) & 13,5 & 48 & 28,6 & 14 & 24,8 & 25,7 & 3,4 & 0 & 0 & 0 & 4,4 & 0 & 0 & 10,3 & 0 & 0 & 0 & 0 & 0 & 0 \\
\hline & Cerro Corá (EMATER) & 10,4 & 41,4 & 8 & 6 & 30,1 & 11,2 & 9,2 & 0,6 & 0 & 0 & 0 & 0 & 0 & 14 & 3,2 & 2,2 & 0 & 0 & 0 & 0 \\
\hline & Coronel Ezequiel (Particular) & 21,6 & 26 & 13,9 & 13,5 & 31,5 & 21,2 & 3 & 0 & 0 & 0 & 0 & 0 & 0 & 19 & 0 & 0 & 0 & 0 & 0 & 0 \\
\hline & Cruzeta (Base Física da EMPARN) & 2,2 & 24,5 & 9,3 & 0 & 3,2 & 5,5 & 0,3 & 0 & 0,3 & 0 & 0 & 0 & 0 & 1,3 & 0 & 0 & 0 & 0 & 0 & 0 \\
\hline
\end{tabular}




\begin{tabular}{|c|c|c|c|c|c|c|c|c|c|c|c|c|c|c|c|c|c|c|c|c|c|}
\hline 2005 & Estação & s21 & s22 & s23 & s24 & s25 & s26 & s27 & $\mathbf{s} 28$ & s29 & s30 & s31 & s32 & s33 & s34 & s35 & s36 & s37 & s38 & s39 & s40 \\
\hline & Currais Novos (CERCEL) & 0 & 19,4 & 4,5 & 11,8 & 1,5 & 1,5 & 0 & 0 & 0 & 0 & 0 & 0 & 0 & 0 & 0 & 0 & 0 & 0 & 0 & 0 \\
\hline & Currais Novos (Açude Tororó) & 0 & 0 & 0 & 0 & 0 & 0 & 0 & 0 & 0 & 0 & 0 & 0 & 0 & 0 & 0 & 0 & 0 & 0 & 0 & 0 \\
\hline & Fernando Pedroza (EMATER) & 0 & 11,3 & 0 & 0 & 1,7 & 0 & 0 & 0 & 0 & 0 & 0 & 0 & 0 & 0 & 0 & 0 & 0 & 0 & 0 & 0 \\
\hline & Florânia (INMET) & 5,7 & 15 & 3,6 & 7,3 & 4,2 & 1,9 & 0 & 0 & 0 & 0 & 0 & 0 & 0 & 2,2 & 0 & 0 & 0,1 & 0 & 0 & 0 \\
\hline & Florânia (Sítio Jucuri) & 0 & 17,5 & 1,1 & 0 & 0 & 0 & 0 & 0 & 0 & 0 & 0 & 0 & 0 & 4,5 & 0 & 0 & 0 & 0 & 0 & 0 \\
\hline & Ielmo Marinho (Prefeitura) & 41,8 & 116 & 61,1 & 85 & 38 & 74,7 & 36 & 3,5 & 2,2 & 5,5 & 0 & 13,5 & 10,5 & 0 & 25 & 0 & 0 & 0 & 0 & 0 \\
\hline & Jaçanã (EMATER) & 18 & 40,3 & 12,6 & 32,1 & 52,3 & 15,3 & 5,3 & 0 & 0 & 0 & 5,5 & 0 & 0 & 17,5 & 0 & 0 & 0 & 0 & 0 & 0 \\
\hline & Janduís (EMATER) & 34,4 & 10,5 & 2,6 & 12 & 0 & 1,4 & 0 & 0 & 1 & 0 & 0 & 0 & 0 & 0 & 0 & 0 & 0 & 0 & 0 & 0 \\
\hline & Boa Saúde (EMATER) & 24,7 & 82 & 40,1 & 50,6 & 60,2 & 20,6 & 7,1 & 3,2 & 3,7 & 0 & 16,7 & 25,9 & 5,7 & 20,2 & 1 & 3,7 & 1,4 & 0 & 0 & 0 \\
\hline & Japi (Particular) & 0 & 41,2 & 0 & 18,6 & 60,8 & 0 & 0 & 10,8 & 2,2 & 4,2 & 0 & 0 & 17,8 & 15,8 & 0 & 0 & 0 & 0 & 0 & 0 \\
\hline & Japi (EMATER) & 5,4 & 25,6 & 1,2 & 15,4 & 32,9 & 6,5 & 0,6 & 3,2 & 1,4 & 0 & 0 & 0 & 0 & 0 & 0 & 0 & 0 & 0 & 0 & 0 \\
\hline & Jardim de Angicos (EMATER) & 6,1 & 35,3 & 23,5 & 35 & 13,5 & 28,3 & 32 & 0 & 0 & 0 & 0 & 0 & 10 & 0 & 0 & 0 & 0 & 0 & 0 & 0 \\
\hline & Lagoa d'Anta (Prefeitura) & 53,9 & 79,2 & 16,7 & 35,7 & 17,4 & 14,7 & 0 & 1,6 & 4,5 & 0 & 17,7 & 11,3 & 5,2 & 17,6 & 0 & 0 & 0 & 0 & 0 & 0 \\
\hline & Lagoa de Pedras (Prefeitura) & 36,9 & 83,6 & 31,5 & 106,5 & 54,4 & 28,5 & 26,5 & 12,2 & 9,1 & 0 & 5,5 & 30,5 & 2,9 & 14,7 & 3,3 & 3,1 & 9,8 & 0 & 0 & 4,3 \\
\hline & Lagoa de Velhos (Delegacia) & 14 & 51,2 & 23 & 56,9 & 38,3 & 6,4 & 4,2 & 3,5 & 0,5 & 0 & 7,4 & 2,7 & 2,4 & 11 & 0 & 3,5 & 0 & 0,1 & 0 & 0,3 \\
\hline & Lagoa Nova (EMATER/Sítio Humaitá) & 0 & 15,2 & 13 & 3 & 0 & 0 & 0 & 0 & 0 & 0 & 0 & 0 & 0 & 0 & 0 & 0 & 0 & 0 & 0 & 0 \\
\hline & Lagoa Nova (Assentamento Santana/Sítio de Dentro) & 27,4 & 10,4 & 0 & 0 & 0 & 0 & 0 & 0 & 0 & 0 & 0 & 0 & 7,5 & 0 & 0 & 0 & 0 & 0 & 0 & 0 \\
\hline & Lagoa Salgada (Delegacia) & 45,7 & 88,7 & 35,4 & 85,1 & 66,3 & 28,9 & 19,7 & 10,2 & 4,7 & 0 & 0 & 21,5 & 2,5 & 12 & 1 & 6,3 & 3,7 & 0 & 0 & 0 \\
\hline & Lajes (Prefeitura) & 0 & 19,8 & 2,8 & 4,4 & 15,6 & 7,7 & 5,3 & 0 & 0 & 0 & 0 & 0 & 0 & 0 & 0 & 0 & 0 & 0 & 0 & 0 \\
\hline & Lajes Pintadas (Prefeitura) & 21,1 & 54,8 & 19 & 15,5 & 38,4 & 21,6 & 4,7 & 3,4 & 2,2 & 0 & 5,3 & 0 & 0 & 24,7 & 1,9 & 6,4 & 0 & 0 & 0 & 0 \\
\hline & Monte Alegre (EMATER) & 49,6 & 136 & 60,2 & 110,2 & 65,6 & 51,4 & 41,8 & 8,8 & 3,8 & 0,2 & 8,3 & 37 & 10,8 & 14,4 & 6,6 & 20,2 & 7,2 & 0 & 0,6 & 13 \\
\hline & Monte das Gameleiras (EMATER) & 42,2 & 36,7 & 17,7 & 14,4 & 44,7 & 17,2 & 3,3 & 0 & 2,8 & 0 & 0 & 0 & 1 & 29,2 & 0 & 0 & 0 & 0 & 0 & 0 \\
\hline & Paraú (Sindicato) & 10,5 & 11,3 & 2,5 & 44,6 & 0 & 0 & 0 & 0 & 0 & 0 & 0 & 0 & 0 & 0 & 0 & 0 & 0 & 0 & 0 & 0 \\
\hline & Passa e Fica (Prefeitura) & 38,7 & 60,3 & 13,3 & 78,7 & 43,1 & 18,1 & 4,9 & 1,2 & 1,3 & 0 & 16,8 & 6,4 & 6,5 & 38,2 & 1,5 & 8,2 & 0 & 0 & 0 & 0 \\
\hline & Patu (Particular) & 31,2 & 12 & 6 & 0 & 0 & 51 & 0 & 0 & 0 & 0 & 0 & 5 & 0 & 1,2 & 0 & 0 & 0 & 0 & 0 & 0 \\
\hline & Pedra Preta (EMATER) & 5 & 38,5 & 18,1 & 27 & 8,3 & 27 & 21,8 & 0 & 0 & 0 & 0 & 0 & 0 & 0 & 0 & 0 & 0 & 0 & 0 & 0 \\
\hline & Pedro Avelino (Particular) & 0 & 3,5 & 5 & 1 & 7,4 & 8 & 5 & 0 & 0 & 0 & 0 & 0 & 0 & 0 & 0 & 2 & 0 & 0 & 0 & 0 \\
\hline & Pedro Avelino (Base Física da EMPARN) & 27,2 & 29,3 & 33,3 & 0 & 58,2 & 24 & 0 & 0 & 0 & 0 & 0 & 0 & 0 & 0 & 0 & 0 & 0 & 0 & 0 & 0 \\
\hline & Pedro Avelino (Assentamento Nova Conquista) & 22,6 & 3,5 & 0 & 0 & 0 & 0 & 0 & 0 & 0 & 0 & 0 & 0 & 0 & 0 & 0 & 0 & 0 & 0 & 0 & 0 \\
\hline & Riachuelo (EMATER) & 28,8 & 61,5 & 39,3 & 32 & 56,8 & 29,4 & 19,5 & 0 & 0 & 0 & 0 & 0 & 0 & 0 & 0 & 0 & 0 & 0 & 0 & 0 \\
\hline & Rui Barbosa (EMATER) & 22,9 & 70,7 & 22,5 & 52,7 & 33,3 & 16 & 14,9 & 7,3 & 4,3 & 0 & 10,4 & 8,2 & 0 & 1 & 0 & 1,1 & 0 & 0 & 0 & 0 \\
\hline & Santa Cruz (EMATER) & 31,9 & 38 & 18,3 & 7,4 & 58,7 & 8,6 & 3,6 & 0,6 & 2,1 & 0 & 6,2 & 0 & 0 & 9,3 & 1,5 & 3,3 & 0 & 0 & 0 & 0 \\
\hline & Santa Cruz (Açude Inharé) & 20 & 42,4 & 0 & 4,3 & 17,4 & 2,1 & 0 & 0 & 10 & 0 & 0 & 0 & 0 & 0 & 0 & 0 & 0 & 0 & 0 & 0 \\
\hline & Santana do Matos (EMATER) & 12 & 9,3 & 0 & 0 & 0 & 6 & 0 & 0 & 0 & 0 & 0,8 & 0 & 0 & 12,1 & 0 & 0 & 0 & 0 & 0 & 0 \\
\hline & Santana do Matos (Barão de Serra Branca) & 0 & 8,5 & 8,5 & 5 & 0 & 0 & 0 & 0 & 0 & 0 & 0 & 0 & 0 & 5,7 & 0 & 0 & 0 & 0 & 0 & 0 \\
\hline & Santana do Matos (São José da Passagem) & 0 & 0 & 0 & 0 & 0 & 10,2 & 0 & 0 & 0 & 0 & 0 & 0 & 0 & 0 & 0 & 0 & 0 & 0 & 0 & 0 \\
\hline
\end{tabular}




\begin{tabular}{|c|c|c|c|c|c|c|c|c|c|c|c|c|c|c|c|c|c|c|c|c|c|}
\hline 2005 & Estação & s21 & s22 & s23 & s24 & s2 & $25 s 26$ & $6 \mathrm{~s} 27$ & $\mathbf{s 2 8}$ & 28529 & $9 \mathrm{~s} 30$ & s31 & 1 s32 & s33 & s34 & s35 & s36 & s37 & s38 & s39 & s40 \\
\hline & São Bento do Trairi (Prefeitura) & 15,2 & 30,2 & 13,5 & 31 & 15 & $, 4 \quad 5,5$ & $\begin{array}{ll}5 & 11,7\end{array}$ & $22, \varepsilon$ & 83,5 & $\begin{array}{ll}5 & 12\end{array}$ & 1,5 & $\begin{array}{ll}5 & 1\end{array}$ & 0 & 13 & 0 & 0 & 0 & 0 & 0 & 0 \\
\hline & São Paulo do Potengi (EMATER) & 30,7 & 70,6 & 34,6 & 16,5 & 50 & $, 828,3$ & 20 & 0,2 & 7,2 & 0 & 1,2 & 7,2 & 0 & 3,6 & 0 & 3,8 & 0 & 0 & 0 & 5,4 \\
\hline & São Pedro (EMATER) & 13,5 & 89,9 & 59,3 & 42,4 & 39 & $, 7 \quad 30,2$ & ,2 28,8 & 0 & 2,6 & 0 & 0 & 16 & 3,2 & 8,3 & 0 & 15,9 & 0 & 0 & 0 & 6,5 \\
\hline & São Rafael (EMATER) & 13,8 & 13,6 & 0 & 36,2 & 0 & 4 & 0 & 0 & 0 & 0 & 0 & 0 & 0 & 0 & 0 & 0 & 0 & 0 & 0 & 0 \\
\hline & São Tomé (EMATER) & 10 & 49,4 & 7,4 & 32,6 & 14 & 125,1 & 2,6 & 0 & 0 & 0 & 0 & 0 & 0 & 0 & 0 & 0 & 0 & 0 & 0 & 0 \\
\hline & São Vicente (EMATER - Ex Particular) & 0 & 6 & 0 & 23,5 & 0 & 0 & 0 & 23, & 0 & 0 & 0 & 33,4 & 0 & 0 & 0 & 0 & 0 & 0 & 0 & 0 \\
\hline & Senador Eloi de Souza (Particular) & 10,4 & 72,5 & 14,5 & 30,5 & 32 & $, 512,1$ & 2,3 & 7,9 & 0 & 0 & 15,4 & $4 \quad 8,5$ & 0 & 16,8 & 1,5 & 0 & 0 & 0 & 0 & 0 \\
\hline & Serrinha (EMATER) & 78,4 & 86,3 & 44,6 & 67,2 & 38 & 323,2 & 215,5 & 5,4 & 1 & 1,6 & 21 & 22,3 & 11,6 & 25,9 & 0,5 & 7,7 & 2,7 & 0 & 1,3 & 3,2 \\
\hline & Sítio Novo (Prefeitura) & 13,5 & 47 & 24 & 12 & 67 & 720 & 4 & 0 & 0 & 0 & 2,5 & 0 & 0 & 0 & 0 & 0 & 0 & 0 & 0 & 0 \\
\hline & Tangará (EMATER) & 8 & 45 & 7 & 11 & 47 & 9 & 3 & 2 & 0 & 0 & 0 & 8,5 & 0 & 15 & 0 & 2,5 & 0 & 0 & 0 & 0 \\
\hline & Tangará (Açude Trairi) & 15 & 38,7 & 11,3 & 6,2 & 52 & 8,9 & 4,5 & 0 & 0 & 0 & 6,8 & 4,2 & 0 & 18,2 & 0 & 6,9 & 0 & 0 & 0 & 0 \\
\hline & Tenente Laurentino Cruz (EMATER) & 0 & 49,6 & 25 & 11,5 & 37 & 42 & 0 & 0 & 0 & 0 & 0 & 0 & 0 & 0 & 0 & 0 & 0 & 0 & 0 & 0 \\
\hline & Triunfo Potiguar (Prefeitura) & 32,4 & 21,6 & 7,7 & 30,6 & 4,5 & 0 & 11 & 0 & 0 & 0 & 0 & 0 & 0 & 0 & 0 & 0 & 0 & 0 & 0 & 0 \\
\hline & Triunfo Potiguar (Chá Cacimbas/Serra J. Vale) & 0 & 3,1 & 8 & 15 & 27 & 0 & 0 & 0 & 5 & 0 & 0 & 0 & 0 & 0 & 0 & 0 & 0 & 0 & 0 & 0 \\
\hline 2005 & Estação & s41 & s42 & s43 & s44 & s45 & s46 & s47 & s48 & $s 49$ & s50 & s51 & s52 & & & & & & & & \\
\hline & Acari (Particular) & 0 & 0 & 0 & 0 & 0 & 0 & 0 & 0 & 41,5 & 0 & 0 & 0 & & & & & & & & \\
\hline & Acari (Açude Gargalheiras) & 0 & 0 & 0 & 0 & 0 & 0 & 0 & 0 & 38,5 & 0 & 0 & 0 & & & & & & & & \\
\hline & Assu (Particular) & 0 & 0 & 0 & 0 & 0 & 0 & 0 & 0 & 1,4 & 0,8 & 0 & 0 & & & & & & & & \\
\hline & Assu (EMATER/Sítio Casa Forte) & 0 & 0 & 0 & 0 & 0 & 0 & 0 & 0 & 0 & 3,9 & 0 & 0,9 & & & & & & & & \\
\hline & Afonso Bezerra (EMATER) & 0 & 0 & 0 & 0 & 0 & 0 & 0 & 0 & 0 & 0 & 0 & 0 & & & & & & & & \\
\hline & Almino Afonso (Particular - Ex Sítio Milagres) & 0 & 0 & 0 & 0 & 0 & 0 & 0 & 0 & 18,1 & 0 & 0 & 0 & & & & & & & & \\
\hline & Angicos (Prefeitura) & 0 & 0 & 0 & 0 & 0 & 0 & 0 & 0 & 1 & 0 & 0 & \multirow{2}{*}{0} & & & & & & & & \\
\hline & Campo Grande (Particular) & 0 & 0 & 0 & 0 & 0 & 0 & 0 & 0 & 0 & 0 & 0 & & & & & & & & & \\
\hline & Campo Grande (Particular 2) & 0 & 0 & 0 & 0 & 0 & 0 & 0 & 0 & 0 & 0 & 0 & 0 & & & & & & & & \\
\hline & Barcelona (Particular) & 0 & 0 & 0 & 0 & 0 & 0 & 0 & 0 & 0 & 0 & 0 & 0 & & & & & & & & \\
\hline & Bodó (EMATER/TRF P/Delegacia) & 0 & 0 & 0 & 0 & 0 & 0 & 0 & 0 & 0 & 0 & 0 & 0 & & & & & & & & \\
\hline & Bom Jesus (Particular) & 0 & 0 & 0 & 0 & 0 & 0 & 0 & 0 & 0 & 0 & 0 & 0 & & & & & & & & \\
\hline & Caiçara do Rio do Vento (Particular) & 0 & 0 & 0 & 0 & 0 & 0 & 0 & 0 & 0 & 0 & 0 & \multirow{2}{*}{$\begin{array}{l}0 \\
0\end{array}$} & & & & & & & & \\
\hline & Caicó (Batalhão) & 0 & 0 & 0 & 0 & 0 & 0 & 0 & 0 & 0 & 0 & 0 & & & & & & & & & \\
\hline & Caicó (Açude Mundo Novo - EMPARN) & 0 & 0 & 0 & 0 & 0 & 0 & 0 & 0 & 5,5 & 0 & 0 & 18,5 & & & & & & & & \\
\hline & Caicó (Palma) & 0 & 0 & 0 & 0 & 0 & 0 & 0 & 0 & 0 & 0 & 0 & 0 & & & & & & & & \\
\hline & Caicó (Açude Itans) & 0 & 0 & 0 & 0 & 0 & 0 & 0 & 0 & 71,2 & 0 & 0 & 0 & & & & & & & & \\
\hline & Caicó (EMATER) & 0 & 0 & 0 & 0 & 0 & 0 & 0 & 0 & 50,5 & 0 & 0 & 0 & & & & & & & & \\
\hline & Campo Redondo (EMATER) & 0 & 0 & 0 & 0 & 0 & 0 & 0 & 0 & 0 & 0 & 0 & \multirow{2}{*}{$\begin{array}{l}0 \\
0\end{array}$} & & & & & & & & \\
\hline & Campo Redondo (Polícia Rodoviária) & 0 & 0 & 0 & 0 & 0 & 0 & 0 & 0 & 5,7 & 0 & 0 & & & & & & & & & \\
\hline
\end{tabular}




\begin{tabular}{|c|c|c|c|c|c|c|c|c|c|c|c|c|c|}
\hline 2005 & Estação & s41 & s42 & s43 & s44 & s45 & s46 & s47 & s48 & $s 49$ & s50 & s51 & s52 \\
\hline & Cerro Corá (EMATER) & 0 & 0 & 0 & 0 & 0 & 0 & 0 & 0 & 5,4 & 0 & 0 & 0 \\
\hline & Coronel Ezequiel (Particular) & 0 & 0 & 0 & 0 & 0 & 0 & 0 & 0 & 0 & 0 & 0 & 0 \\
\hline & Cruzeta (Base Física da EMPARN) & 0 & 0 & 0 & 0 & 0 & 0 & 0 & 0 & 21,4 & 0 & 0 & 0 \\
\hline & Currais Novos (CERCEL) & 0 & 0 & 0 & 0 & 0 & 0 & 0 & 13,6 & 0 & 0 & 0 & 0 \\
\hline & Currais Novos (Açude Tororó) & 0 & 0 & 0 & 0 & 0 & 0 & 0 & 0 & 0 & 0 & 0 & 0 \\
\hline & Fernando Pedroza (EMATER) & 0 & 0 & 0 & 0 & 0 & 0 & 0 & 0 & 8,4 & 0 & 0 & 0 \\
\hline & Florânia (INMET) & 0 & 0 & 0 & 0 & 0 & 0 & 0 & 0 & 3,4 & 0 & 0 & 1 \\
\hline & Florânia (Sítio Jucuri) & 0 & 0 & 0 & 0 & 0 & 0 & 0 & 0 & 0 & 0 & 0 & 0 \\
\hline & Ielmo Marinho (Prefeitura) & 0 & 0 & 0 & 0 & 0 & 0 & 0 & 0 & 0 & 0 & 0 & 2,1 \\
\hline & Jaçanã (EMATER) & 0 & 0 & 0 & 0 & 0 & 0 & 0 & 0 & 0 & 0 & 0 & 0 \\
\hline & Janduís (EMATER) & 0 & 0 & 0 & 0 & 0 & 0 & 0 & 0 & 41 & 0 & 4 & 0 \\
\hline & Boa Saúde (EMATER) & 0 & 0 & 0 & 0 & 0 & 0 & 0 & 0 & 0 & 0 & 0 & 7,9 \\
\hline & Japi (Particular) & 0 & 0 & 0 & 0 & 0 & 0 & 0 & 0 & 0 & 0 & 0 & 0 \\
\hline & Japi (EMATER) & 0 & 0 & 0 & 0 & 0 & 0 & 0 & 0 & 0 & 0 & 0 & 0 \\
\hline & Jardim de Angicos (EMATER) & 0 & 0 & 0 & 0 & 0 & 0 & 0 & 0 & 0 & 0 & 0 & 0 \\
\hline & Lagoa d'Anta (Prefeitura) & 0 & 0 & 0 & 0 & 0 & 0 & 0 & 0 & 0 & 0 & 1,2 & 1,9 \\
\hline & Lagoa de Pedras (Prefeitura) & 0 & 0 & 0 & 0 & 0 & 0 & 0 & 0 & 0 & 0 & 0 & 8,7 \\
\hline & Lagoa de Velhos (Delegacia) & 0 & 0,2 & 0 & 0 & 0 & 0 & 0 & 0,5 & 0 & 0 & 0 & 2,6 \\
\hline & Lagoa Nova (EMATER/Sítio Humaitá) & 0 & 0 & 0 & 0 & 0 & 0 & 0 & 0 & 0 & 0 & 0 & 0 \\
\hline & Lagoa Nova (Assentamento Santana/Sítio de Dentro) & 0 & 0 & 0 & 0 & 0 & 0 & 0 & 0 & 0 & 0 & 0 & 0 \\
\hline & Lagoa Salgada (Delegacia) & 0 & 0 & 0 & 0 & 0 & 0 & 0 & 0 & 0 & 0 & 0 & 8,5 \\
\hline & Lajes (Prefeitura) & 0 & 0 & 0 & 0 & 0 & 0 & 0 & 0 & 0 & 0 & 0 & 0 \\
\hline & Lajes Pintadas (Prefeitura) & 0 & 0 & 0 & 0 & 0 & 0 & 0 & 0 & 0 & 0 & 0 & 3 \\
\hline & Monte Alegre (EMATER) & 0 & 6,2 & 0 & 0 & 0 & 0 & 0 & 3 & 0,4 & 0,4 & 1 & 1,2 \\
\hline & Monte das Gameleiras (EMATER) & 0 & 0 & 0 & 0 & 0 & 0 & 0 & 0 & 0 & 0 & 0 & 0 \\
\hline & Paraú (Sindicato) & 0 & 0 & 0 & 0 & 0 & 0 & 0 & 0 & 0 & 0 & 0 & 0 \\
\hline & Passa e Fica (Prefeitura) & 0 & 0 & 0 & 0 & 0 & 0 & 0 & 0 & 0 & 0 & 0 & 0 \\
\hline & Patu (Particular) & 0 & 0 & 0 & 0 & 0 & 0 & 0 & 0 & 2 & 0 & 11 & 0 \\
\hline & Pedra Preta (EMATER) & 0 & 0 & 0 & 0 & 0 & 0 & 0 & 0 & 0 & 0 & 0 & 0 \\
\hline & Pedro Avelino (Particular) & 0 & 0 & 0 & 0 & 0 & 0 & 0 & 0 & 0 & 0 & 0 & 0 \\
\hline & Pedro Avelino (Base Física da EMPARN) & 0 & 0 & 0 & 0 & 0 & 0 & 0 & 0 & 0 & 0 & 0 & 0 \\
\hline & Pedro Avelino (Assentamento Nova Conquista) & 0 & 0 & 0 & 0 & 0 & 0 & 0 & 0 & 0 & 0 & 0 & 0 \\
\hline & Riachuelo (EMATER) & 0 & 0 & 0 & 0 & 0 & 0 & 0 & 0 & 0 & 0 & 0 & 0 \\
\hline & Rui Barbosa (EMATER) & 0 & 0 & 0 & 0 & 0 & 0 & 0 & 0 & 0 & 0 & 0 & 0 \\
\hline & Santa Cruz (EMATER) & 0 & 0 & 0 & 0 & 0 & 0 & 0 & 0 & 0 & 0 & 0 & 0 \\
\hline & Santa Cruz (Açude Inharé) & 0 & 0 & 0 & 0 & 0 & 0 & 0 & 0 & 0 & 0 & 0 & 0 \\
\hline
\end{tabular}




\begin{tabular}{|c|c|c|c|c|c|c|c|c|c|c|c|c|c|c|c|c|c|c|c|c|c|}
\hline \multirow[t]{18}{*}{2005} & Estação & s41 & s42 & s43 & $s 44$ & s45 & s46 & $6 \mathrm{s47}$ & $s 48$ & $s 49$ & s50 & s51 & s52 & & & & & & & & \\
\hline & Santana do Matos (EMATER) & 0 & 0 & 0 & 0 & 0 & 0 & 0 & 0 & 0 & 0 & 0 & 0 & & & & & & & & \\
\hline & Santana do Matos (Barão de Serra Branca) & 0 & 0 & 0 & 0 & 0 & 0 & 0 & 0 & 0 & 0 & 0 & 0 & & & & & & & & \\
\hline & Santana do Matos (São José da Passagem) & 0 & 0 & 0 & 0 & 0 & 0 & 0 & 0 & 12,3 & 0 & 0 & 0 & & & & & & & & \\
\hline & São Bento do Trairi (Prefeitura) & 0 & 0 & 0 & 0 & 0 & 0 & 0 & 0 & 0 & 0 & 0 & 0 & & & & & & & & \\
\hline & São Paulo do Potengi (EMATER) & 0 & 0 & 0,1 & 0 & 0 & 0 & 0 & 0 & 0 & 0 & 0 & 0 & & & & & & & & \\
\hline & São Pedro (EMATER) & 0 & 0 & 0 & 0 & 0 & 0 & 0 & 0 & 0 & 0 & 0 & 0 & & & & & & & & \\
\hline & São Rafael (EMATER) & 0 & 0 & 0 & 0 & 0 & 0 & 0 & 0 & 0 & 0 & 0 & 0 & & & & & & & & \\
\hline & São Tomé (EMATER) & 0 & 0 & 0 & 0 & 0 & 0 & 0 & 0 & 0 & 0 & 0 & 0 & & & & & & & & \\
\hline & São Vicente (EMATER - Ex Particular) & 0 & 0 & 0 & 0 & 0 & 0 & 0 & 0 & 0 & 0 & 0 & 0 & & & & & & & & \\
\hline & Senador Eloi de Souza (Particular) & 0 & 0 & 0 & 0 & 0 & 0 & 0 & 0 & 0 & 0 & 0 & 0 & & & & & & & & \\
\hline & Serrinha (EMATER) & 0 & 1,2 & 0 & 0 & 0 & 0 & 0 & 0 & 0 & 0 & 0 & 4,2 & & & & & & & & \\
\hline & Sítio Novo (Prefeitura) & 0 & 0 & 0 & 0 & 0 & 0 & 0 & 0 & 0 & 0 & 0 & 0 & & & & & & & & \\
\hline & Tangará (EMATER) & 0 & 0 & 0 & 0 & 0 & 0 & 0 & 0 & 0 & 0 & 0 & 1,5 & & & & & & & & \\
\hline & Tangará (Açude Trairi) & 0 & 0 & 0 & 0 & 0 & 0 & 0 & 0 & 0 & 0 & 0 & 2,3 & & & & & & & & \\
\hline & Tenente Laurentino Cruz (EMATER) & 0 & 0 & 0 & 0 & 0 & 0 & 0 & 0 & 0 & 0 & 0 & 0 & & & & & & & & \\
\hline & Triunfo Potiguar (Prefeitura) & 0 & 0 & 0 & 0 & 0 & 0 & 0 & 0 & 2,7 & 0 & 0 & 0 & & & & & & & & \\
\hline & Triunfo Potiguar (Chá Cacimbas/Serra J. Vale) & 0 & 0 & 0 & 0 & 0 & 0 & 0 & 0 & 0 & 0 & 0 & 0 & & & & & & & & \\
\hline \multirow[t]{18}{*}{2006} & Estação & s1 & s2 & s3 & s4 & s5 & s6 & s7 & s8 & s9 & $\mathbf{s 1 0}$ & s11 & s12 & s13 & s14 & s15 & s16 & s17 & s18 & $\mathbf{s 1 9}$ & s20 \\
\hline & Acari (Particular) & 0 & 0 & 0 & 0 & 0 & 0 & 34,1 & 44,2 & 15,9 & 2,5 & 14 & 2,5 & 43,2 & 29,9 & 60,2 & 24,1 & 104 & 27,7 & 28,4 & 41,1 \\
\hline & Acari (Açude Gargalheiras) & 0 & 0 & 0 & 0 & 0 & 10 & 74 & 69 & 21 & 10 & 27 & 35 & 58 & 5 & 106 & 50 & 111 & 8 & 115 & 22 \\
\hline & Assu (Particular) & 0 & 0 & 0 & 0 & 0 & 0 & 0 & 16,4 & 52,5 & 0 & 4,5 & 59,7 & 27,8 & 4,8 & 39,3 & 100 & 67,1 & 12,8 & 120,7 & 21,5 \\
\hline & Assu (EMATER/Sítio Casa Forte) & 0 & 0 & 0 & 0 & 0 & 0 & 0,6 & 45,4 & 54,4 & 9,7 & 1,8 & 65,2 & 14,1 & 3,1 & 32,2 & 81,7 & 70,9 & 5,4 & 56,6 & 18 \\
\hline & Afonso Bezerra (EMATER) & 0 & 0 & 0 & 0 & 0 & 0 & 12 & 3 & 45 & 13 & 5 & 81,5 & 123 & 48 & 31,5 & 149 & 44 & 14 & 58 & 44,5 \\
\hline & Afonso Bezerra (Assentamento Santa Maria) & 0 & 0 & 0 & 0 & 0 & 0 & 20,2 & 8,2 & 108,6 & 28,4 & 37,4 & 41,2 & 20,7 & 14,2 & 78,6 & 78 & 106,2 & 1,2 & 0 & 0 \\
\hline & Almino Afonso (Particular - Ex Sítio Milagres) & 0 & 13,1 & 2,2 & 0 & 0 & 0 & 45,7 & 29,3 & 73,5 & 2,1 & 14,3 & 124,6 & 56,3 & 55,7 & 40,4 & 65 & 67,5 & 27,6 & 185,2 & 70,2 \\
\hline & Angicos (Prefeitura) & 0 & 0 & 0 & 0 & 0 & 0 & 0 & 61 & 76 & 19,8 & 98 & 15 & 67 & 1 & 25 & 121,5 & 0 & 0 & 37,5 & 0 \\
\hline & Campo Grande (Particular) & 0 & 0 & 0 & 0 & 0 & 0 & 72,1 & 14,6 & 229,9 & 0 & 0 & 53,8 & 4,1 & 13,1 & 36,7 & 100,9 & 43,5 & 56,6 & 20,1 & 6,9 \\
\hline & Campo Grande (Particular 2) & 0 & 0 & 0 & 0 & 0 & 0 & 73,7 & 21 & 250,9 & 3,6 & 0 & 55,7 & 1,8 & 13,4 & 54,3 & 98,5 & 62,1 & 57,4 & 26,4 & 4,4 \\
\hline & Barcelona (Particular) & 0 & 0 & 0 & 0 & 0 & 0 & 0 & 53 & 101,5 & 2 & 2 & 25 & 7 & 25,5 & 49 & 37 & 24,5 & 11,5 & 0 & 1 \\
\hline & Bodó (EMATER/TRF P/Delegacia) & 0 & 0 & 0 & 0 & 0 & 0 & 58,9 & 39,3 & 154,6 & 0 & 12,8 & 47,4 & 28,7 & 34,9 & 69,1 & 74,1 & 52,4 & 0 & 52,4 & 0 \\
\hline & Bom Jesus (Particular) & 0 & 0 & 0 & 0 & 0 & 0 & 2,4 & 2,9 & 32,2 & 0 & 1 & 116,9 & 0,9 & 2 & 71,8 & 28,9 & 29,8 & 40,8 & 4,4 & 3,7 \\
\hline & Caiçara do Rio do Vento (Particular) & 0 & 0 & 0 & 0 & 0 & 0 & 0 & 52 & 56,5 & 72 & 8 & 40,4 & 22 & 6 & 37,8 & 87,8 & 4,6 & 30 & 0 & 0 \\
\hline & Caicó (Batalhão) & 0 & 0 & 0 & 0 & 0 & 0 & 87,5 & 27 & 56 & 0 & 34 & 35 & 79 & 15,5 & 83,5 & 50,5 & 185 & 36 & 72 & 44,5 \\
\hline & Caicó (Açude Mundo Novo - EMPARN) & 0 & 0 & 0 & 0 & 0 & 0 & 11 & 44,7 & 83,2 & 0 & 25,5 & 22,7 & 11 & 86,5 & 94,1 & 99,9 & 37,4 & 23,9 & 70,2 & 27,1 \\
\hline & Caicó (Palma) & 0 & 0 & 0 & 0 & 0 & 0 & 51 & 47 & 64,8 & 14 & 7,4 & 40 & 60,6 & 50 & 33,8 & 55 & 80,2 & 11,6 & 111,2 & 0 \\
\hline
\end{tabular}




\begin{tabular}{|c|c|c|c|c|c|c|c|c|c|c|c|c|c|c|c|c|c|c|c|c|c|}
\hline 2006 & Estação & s1 & s2 & s3 & s4 & s5 & s6 & s7 & s8 & s9 & s10 & s11 & s12 & s13 & s14 & s15 & s16 & s17 & $s 18$ & $\mathbf{s 1 9}$ & s20 \\
\hline & Caicó (Açude Itans) & 0 & 0 & 0 & 0 & 0 & 0 & 27,3 & 30,4 & 59,1 & 10 & 33,9 & 38,2 & 39,7 & 5 & 50,6 & 27,4 & 107 & 37,6 & 70,6 & 27,3 \\
\hline & Caicó (EMATER) & 0 & 0 & 0 & 0 & 0 & 0 & 42,6 & 12,4 & 26,5 & 0 & 29,5 & 35 & 82,8 & 39,5 & 44 & 25 & 157,5 & 84,5 & 53 & 25,5 \\
\hline & Campo Redondo (EMATER) & 0 & 0 & 0 & 0 & 0 & 0 & 2 & 19 & 108,8 & 17 & 0 & 19,3 & 34,8 & 1,8 & 94,5 & 169 & 54,5 & 5 & 53 & 9,3 \\
\hline & Campo Redondo (Polícia Rodoviária) & 0 & 0 & 0 & 0 & 0 & 0 & 8,7 & 58,5 & 92,2 & 0 & 0 & 12,3 & 4,8 & 7,7 & 150,8 & 116,2 & 57 & 0 & 60,6 & 8,5 \\
\hline & Cerro Corá (EMATER) & 0 & 0 & 0 & 0 & 0 & 0 & 56,5 & 23,4 & 172,7 & 2,3 & 0 & 19,3 & 20,6 & 6,9 & 92,7 & 79,7 & 73,1 & 2,7 & 86 & 1 \\
\hline & Coronel Ezequiel (Particular) & 0 & 0 & 8,5 & 0 & 0 & 0 & 0 & 127 & 121 & 0 & 7 & 33,3 & 8 & 16,2 & 128,5 & 38 & 77 & 0 & 9 & 9 \\
\hline & Cruzeta (Base Física da EMPARN) & 0,4 & 0 & 0,1 & 0 & 0 & 0 & 47,9 & 33,7 & 52,3 & 0 & 0 & 48,3 & 36,2 & 50 & 41,9 & 80,2 & 42,8 & 30,4 & 67 & 6,5 \\
\hline & Currais Novos (CERCEL) & 0 & 0 & 0 & 0 & 0 & 0 & 11,2 & 171,8 & 114,4 & 0 & 0 & 58,3 & 0 & 2,8 & 0 & 123,6 & 44,2 & 0 & 26,1 & 24,4 \\
\hline & Currais Novos (Açude Tororó) & 0 & 0 & 0 & 0 & 0 & 0 & 0 & 118,3 & 186,4 & 0 & 0 & 44,2 & 0 & 20 & 70,2 & 121,7 & 88,4 & 168,4 & 54,2 & 0 \\
\hline & Fernando Pedroza (EMATER) & 0 & 0 & 0 & 0 & 0 & 0 & 14,9 & 7,5 & 112,5 & 11,5 & 3,5 & 23,2 & 42,9 & 51,6 & 88,5 & 83,3 & 39,8 & 0 & 47,5 & 20 \\
\hline & Florânia (INMET) & 0 & 1 & 0 & 0 & 0 & 9,2 & 84 & 29,2 & 85 & 6,6 & 12,4 & 6,7 & 37,3 & 31,7 & 31,1 & 49,6 & 47,7 & 49,5 & 26,2 & 25,2 \\
\hline & Florânia (Sítio Jucuri) & 0 & 3 & 0 & 0 & 0 & 14 & 104 & 9,4 & 127,8 & 2 & 14,7 & 6,5 & 17,5 & 21,8 & 80,1 & 42,7 & 92,2 & 2,4 & 40,6 & 4,6 \\
\hline & lelmo Marinho (Prefeitura) & 20,2 & 0 & 0 & 0 & 0 & 0 & 0 & 60,5 & 0 & 0 & 0 & 91,2 & 9,8 & 0 & 44,7 & 60,8 & 58,9 & 35,9 & 7,5 & 0 \\
\hline & Jaçanã (EMATER) & 0 & 0 & 7,2 & 0 & 0 & 0 & 0 & 90 & 71,4 & 48 & 0 & 56,4 & 10 & 31,9 & 137,6 & 43,6 & 48,4 & 9,5 & 52,1 & 7,4 \\
\hline & Janduís (EMATER) & 0 & 0 & 0 & 1,2 & 0 & 3,4 & 70 & 34,8 & 94 & 0 & 7 & 107,2 & 32,9 & 68,3 & 37,8 & 96 & 24 & 32,8 & 76,5 & 13,6 \\
\hline & Boa Saúde (EMATER) & 0 & 0 & 0 & 0 & 0 & 0 & 2,9 & 21,8 & 35,3 & 0 & 0 & 33,1 & 2,5 & 16,1 & 16,1 & 63,9 & 32,9 & 16,4 & 26,9 & 2,6 \\
\hline & Japi (Particular) & 0 & 0 & 0 & 0 & 0 & 0 & 0 & 42,2 & 80,6 & 0 & 0 & 41,2 & 12,2 & 0 & 27,2 & 32,4 & 29,8 & 0 & 4,2 & 6,4 \\
\hline & Japi (EMATER) & 0 & 0 & 0 & 0 & 0 & 0 & 0 & 42,2 & 80,6 & 0 & 0 & 41,2 & 12,2 & 0 & 27,2 & 32,4 & 29,8 & 0 & 4,2 & 6,4 \\
\hline & Jardim de Angicos (EMATER) & 0 & 0 & 0 & 0 & 0 & 0 & 0 & 41,4 & 5 & 12 & 4,8 & 1 & 0 & 82 & 0 & 116,4 & 18,7 & 0 & 12 & 0 \\
\hline & Lagoa d'Anta (Prefeitura) & 0 & 0 & 0 & 0 & 0 & 0 & 0 & 51,8 & 3,2 & 0 & 0 & 51,5 & 8,9 & 26 & 9,9 & 53,8 & 36,3 & 6,7 & 0 & 1,4 \\
\hline & Lagoa de Pedras (Prefeitura) & 0 & 0 & 0 & 0 & 0 & 0 & 4,8 & 31,6 & 16,7 & 0 & 1 & 85,9 & 1,5 & 10,8 & 30,4 & 75,9 & 35,5 & 13,1 & 9,4 & 6,4 \\
\hline & Lagoa de Velhos (Delegacia) & 0,4 & 0,1 & 0 & 0 & 0,1 & 0 & 2,1 & 51,2 & 54,3 & 0 & 6,2 & 26,9 & 2,9 & 9 & 11,8 & 102,3 & 22,5 & 6,8 & 2,1 & 0,7 \\
\hline & Lagoa Nova (EMATER/Sítio Humaitá) & 0 & 0 & 0 & 0 & 0 & 0 & 40 & 43,2 & 5 & 0 & 8 & 14 & 6 & 33 & 124 & 32 & 33 & 0 & 56,5 & 34 \\
\hline & Lagoa Nova (Assentamento Santana/Sítio de Dentro) & 0 & 0 & 0 & 0 & 0 & 0 & 9,4 & 65,1 & 91,6 & 7,1 & 0 & 17,5 & 0 & 28,5 & 74,3 & 73,1 & 39,5 & 6,1 & 119,2 & 23,6 \\
\hline & Lagoa Salgada (Delegacia) & 0 & 0 & 0 & 0 & 0 & 0 & 0 & 17,3 & 29,5 & 0 & 0 & 49,8 & 2 & 13,7 & 22 & 33,2 & 44,7 & 31,3 & 10,5 & 17,7 \\
\hline & Lajes (Prefeitura) & 0 & 0 & 0 & 0 & 0 & 0 & 66,3 & 46,6 & 73,5 & 20,3 & 0 & 15,7 & 14,1 & 18,7 & 49,5 & 85,1 & 2,3 & 0 & 84,1 & 0 \\
\hline & Lajes Pintadas (Prefeitura) & 0 & 0 & 0 & 0 & 0 & 0 & 0 & 24,9 & 122,5 & 2,2 & 3,2 & 26,9 & 12,6 & 13,4 & 137,2 & 83,7 & 51,5 & 7,3 & 65,1 & 2,9 \\
\hline & Messias Targino (Prefeitura) & 0 & 0 & 0 & 0 & 0 & 0 & 71,6 & 0 & 63 & 0 & 0 & 118 & 30 & 54,6 & 60,1 & 80,6 & 46,1 & 15,2 & 154,7 & 0 \\
\hline & Monte Alegre (EMATER) & 2 & 1 & 0,2 & 0,6 & 0,2 & 0 & 3,5 & 35 & 12,8 & 0 & 14,8 & 119 & 11 & 14,4 & 31 & 16,6 & 66 & 32 & 24 & 13 \\
\hline & Monte das Gameleiras (EMATER) & 0 & 0 & 0 & 0 & 0 & 0 & 2,7 & 11,9 & 16,8 & 0 & 0 & 47,5 & 0 & 4,1 & 6,7 & 34,5 & 5,2 & 11 & 0 & 0 \\
\hline & Paraú (Sindicato) & 0 & 0 & 0 & 0 & 0 & 0 & 0 & 78,3 & 147,2 & 19,1 & 1,6 & 74,3 & 6,7 & 0 & 0 & 0 & 0 & 0 & 0 & 0 \\
\hline & Passa e Fica (Prefeitura) & 0 & 0 & 0 & 0 & 0 & 0 & 6,4 & 21,6 & 7,8 & 0 & 0 & 61,7 & 7,6 & 37,1 & 32,6 & 37,5 & 13,9 & 29,3 & 0 & 0 \\
\hline & Patu (Particular) & 0 & 0 & 19 & 0 & 0 & 5 & 95 & 34 & 59 & 0 & 9 & 85,6 & 75,4 & 56 & 14,6 & 165 & 48 & 41,8 & 129,4 & 41 \\
\hline & Santa Maria (Sindicato dos Trabalhadores Rurais) & 9,9 & 0,3 & 0 & 0 & 0 & 0 & 0,7 & 53 & 72 & 0 & 2,4 & 89,3 & 16,8 & 7,7 & 39,3 & 26 & 26,6 & 36,8 & 13 & 0 \\
\hline & Pedra Preta (EMATER) & 5,5 & 0 & 0 & 0 & 0 & 0 & 58 & 42 & 14 & 0 & 3,5 & 27 & 12 & 36 & 94,5 & 18,5 & 8 & 3,5 & 0 & 9 \\
\hline & Pedro Avelino (Particular) & 0 & 0 & 0 & 0 & 0 & 0 & 14,8 & 15,4 & 43,2 & 1,4 & 0 & 78,4 & 141,6 & 40,2 & 20,4 & 51,1 & 10,8 & 6,2 & 14,2 & 11,4 \\
\hline
\end{tabular}




\begin{tabular}{|c|c|c|c|c|c|c|c|c|c|c|c|c|c|c|c|c|c|c|c|c|c|}
\hline 2006 & Estação & s1 & s2 & s3 & s4 & s5 & s6 & s7 & s8 & s9 & s10 & s11 & s12 & s13 & s14 & s15 & s16 & s17 & s18 & s19 & s20 \\
\hline & Pedro Avelino (Base Física da EMPARN) & 0 & 0 & 0 & 0 & 0 & 0 & 0 & 43,1 & 142,6 & 5,1 & 15,4 & 74,7 & 21 & 54,1 & 87,4 & 135,3 & 51,4 & 16,2 & 22,8 & 53,8 \\
\hline & Pedro Avelino (Assentamento Nova Conquista) & 0 & 0 & 0 & 0 & 0 & 0 & 14,3 & 100,6 & 83,7 & 18,3 & 28,7 & 51,4 & 41,3 & 0 & 0 & 0 & 0 & 0 & 0 & 0 \\
\hline & Rui Barbosa (EMATER) & 0 & 0 & 0 & 0 & 0 & 0 & 0 & 109,8 & 81,4 & 5,4 & 0 & 43,6 & 12,7 & 4,6 & 37,6 & 75,5 & 21,5 & 74,3 & 0 & 0 \\
\hline & Santa Cruz (EMATER) & 4 & 0 & 0 & 0 & 0 & 0 & 0,2 & 21,7 & 14,4 & 0 & 0 & 31,7 & 13,5 & 9,1 & 10 & 3,7 & 47,9 & 4,3 & 12,5 & 1,3 \\
\hline & Santana do Matos (EMATER) & 0 & 0 & 0 & 0 & 0 & 0 & 5 & 35 & 120 & 2 & 3 & 11 & 0 & 19,5 & 189 & 44,3 & 68 & 0 & 84,4 & 22,8 \\
\hline & Santana do Matos (Barão de Serra Branca) & 0 & 0 & 0 & 0 & 9,8 & 0 & 0 & 85 & 79,3 & 3,4 & 22,5 & 67,9 & 82,6 & 11 & 40,9 & 103,6 & 74,2 & 0 & 80,4 & 8 \\
\hline & Santana do Matos (São José da Passagem) & 0 & 0 & 23 & 17,1 & 102,4 & 0 & 0 & 0 & 0 & 0 & 0 & 7,4 & 63,9 & 11 & 87,3 & 72,7 & 15,8 & 22,5 & 24,6 & 0 \\
\hline & São Bento do Trairi (Prefeitura) & 0 & 0 & 2,4 & 16,1 & 0 & 0 & 2,4 & 16,1 & 42,3 & 16,1 & 0 & 17,1 & 3,5 & 3,1 & 86,3 & 54,4 & 51,3 & 12,9 & 61,1 & 8 \\
\hline & São José do Campestre (EMATER) & 0 & 0 & 0 & 0 & 0 & 0 & 9,5 & 26,5 & 9,5 & 0 & 2 & 77,5 & 0 & 3,2 & 1,5 & 56 & 25,2 & 11,7 & 2 & 0 \\
\hline & São Paulo do Potengi (EMATER) & 0 & 0 & 0 & 0 & 0 & 0 & 0 & 17,6 & 49,6 & 0 & 0 & 38,3 & 5,2 & 5,7 & 31 & 41,3 & 17,6 & 31,4 & 8,5 & 0 \\
\hline & São Pedro (EMATER) & 2,5 & 0,9 & 0 & 0 & 0 & 0 & 0,2 & 30 & 53,6 & 0 & 0 & 55,7 & 11,8 & 8,4 & 9,8 & 38 & 19,4 & 54,9 & 12,3 & 0 \\
\hline & São Rafael (EMATER) & 0 & 0 & 0 & 0 & 0 & 0 & 13,4 & 24,2 & 113,5 & 5 & 0 & 81,2 & 60 & 54,4 & 0 & 111 & 27 & 0 & 5,8 & 56 \\
\hline & São Tomé (EMATER) & 0 & 0 & 0 & 0 & 0 & 0 & 0 & 14 & 11,2 & 0 & 0 & 8 & 20,3 & 12 & 68,8 & 92,5 & 20 & 11,7 & 7 & 0 \\
\hline & São Vicente (EMATER - Ex Particular) & 0 & 0 & 0 & 0 & 0 & 0 & 20,4 & 20,8 & 170,3 & 0 & 0 & 126 & 39 & 0 & 109,1 & 78,4 & 124 & 0 & 63 & 59 \\
\hline & Senador Eloi de Souza (Particular) & 0 & 0 & 0 & 0 & 0 & 0 & 0 & 40 & 65,7 & 0 & 0 & 26,3 & 0 & 11,5 & 22,3 & 46,8 & 38 & 16,7 & 6 & 0 \\
\hline & Serrinha (EMATER) & 3,7 & 0 & 0 & 0 & 0 & 0 & 0 & 47,1 & 40,7 & 0 & 0 & 57,4 & 13 & 6,2 & 28,7 & 71,2 & 35 & 31,9 & 5 & 4,8 \\
\hline & Sítio Novo (Prefeitura) & 0 & 0 & 0 & 0 & 0 & 0 & 3,5 & 26 & 53,5 & 0 & 0 & 40,5 & 11 & 23 & 11,5 & 104 & 58 & 17 & 0 & 0 \\
\hline & Tangará (EMATER) & 1,8 & 0 & 0 & 0 & 0 & 0 & 2 & 15,5 & 25 & 0 & 0 & 35,5 & 3 & 12 & 28,5 & 24 & 9,5 & 12 & 0 & 0 \\
\hline & Tangará (Açude Trairi) & 6,9 & 0 & 0 & 0 & 0 & 0 & 11,5 & 13 & 1,2 & 0 & 1,5 & 50,5 & 9,7 & 4,5 & 16 & 28,7 & 31,2 & 4,5 & 0 & 0 \\
\hline & Triunfo Potiguar (Prefeitura) & 0 & 0 & 0 & 0 & 0 & 0 & 54,4 & 63 & 126,7 & 1,3 & 30 & 44,8 & 18,2 & 5,7 & 102,5 & 204,4 & 105,7 & 40 & 71,7 & 32,7 \\
\hline & Triunfo Potiguar (Chá Cacimbas/Serra J. Vale) & 0 & 0 & 0 & 0 & 0 & 0 & 35 & 110 & 120 & 72 & 0 & 0 & 0 & 60 & 103 & 145 & 0 & 0 & 0 & 0 \\
\hline & Triunfo Potiguar (Chá Velha/Serra J. Vale) & 0 & 0 & 0 & 0 & 0 & 0 & 71,2 & 52,1 & 151,4 & 0 & 24,8 & 74,6 & 69,1 & 7,8 & 72 & 75,6 & 44,4 & 49,3 & 78 & 15,8 \\
\hline & Alagoa Nova & 0 & 0 & 0 & 0 & 0,3 & 0 & 13,9 & 17,6 & 20,2 & 0 & 7,5 & 109,9 & 19,2 & 25,6 & 97,8 & 16,2 & 50,3 & 31,4 & 13,2 & 12,8 \\
\hline & Barra de Santana & 2,3 & 0 & 0 & 0 & 0 & 0 & 6,3 & 0 & 11,5 & 0 & 35 & 27,1 & 4,6 & 30,9 & 3,4 & 14,2 & 13 & 20,7 & 0 & 7,5 \\
\hline & Barra de Santana/Bodocongó & 0 & 0 & 0 & 0 & 0 & 0 & 7 & 0 & 16 & 0 & 40,4 & 27,2 & 3,2 & 29 & 5 & 13 & 12,8 & 15,6 & 0 & 9,4 \\
\hline & Boa Vista & 0 & 0 & 0 & 0 & 0 & 0 & 0 & 22 & 10,8 & 24 & 0 & 33,2 & 0 & 3,1 & 3 & 17,8 & 5,4 & 13,8 & 5 & 0 \\
\hline & Boqueirão/Açude Boqueirão & 0 & 0 & 0 & 0 & 0 & 0 & 14,9 & 0 & 5,2 & 0 & 0,9 & 5,1 & 0 & 21,2 & 0,1 & 4,6 & 27,3 & 55,8 & 4,1 & 0 \\
\hline & Cabaceiras & 0 & 0 & 0 & 0 & 0 & 0 & 69,2 & 0 & 25,2 & 0 & 0 & 16,2 & 0 & 0 & 0 & 0 & 23,5 & 0 & 0 & 8 \\
\hline & Campina Grande/EMBRAPA & 0,6 & 0,4 & 0 & 0 & 0 & 0,4 & 7,3 & 6,8 & 0,5 & 0 & 10,8 & 83 & 2,5 & 62,6 & 46,5 & 8,1 & 24,5 & 26,9 & 34,9 & 13 \\
\hline & Campina Grande/Santa Terezinha & 4,2 & 0 & 0 & 0 & 0 & 0 & 18,2 & 19,4 & 1,5 & 0 & 1,6 & 99,5 & 19,4 & 28,1 & 36,3 & 15,2 & 19,8 & 18,7 & 3,9 & 18,9 \\
\hline & Campina Grande/São José da Mata & 0 & 0 & 0 & 0 & 0 & 0 & 0 & 0 & 4,8 & 0 & 3,2 & 48,8 & 6,1 & 24,3 & 40,7 & 1,5 & 14,3 & 12,9 & 16,9 & 14,6 \\
\hline & Caturité & 0 & 0 & 0 & 0 & 0 & 0 & 13,9 & 2,2 & 7 & 0 & 23,8 & 15,1 & 3,7 & 15,1 & 8,3 & 9,8 & 24,8 & 13,2 & 11,6 & 0 \\
\hline & Caturité/Fazenda Campo de Emas & 0 & 0 & 9,9 & 0 & 0 & 6,2 & 13 & 0 & 12,2 & 0 & 0 & 12 & 13,2 & 0 & 13 & 12 & 7,1 & 24 & 0 & 0 \\
\hline & Cubati & 0 & 0 & 0 & 0 & 0 & 0 & 0 & 27 & 33 & 25 & 0 & 88,4 & 0 & 8,2 & 30,4 & 39,6 & 30,6 & 65,4 & 31 & 4,6 \\
\hline & Lagoa Seca & 6,2 & 3,3 & 0 & 0 & 0 & 0,6 & 4,7 & 18 & 5,6 & 0 & 22,7 & 59,7 & 8,4 & 39,8 & 29,4 & 24,2 & 27,2 & 34,8 & 9,5 & 14,3 \\
\hline & Matinhas & 0 & 0 & 0 & 0 & 0 & 0 & 14,3 & 20,7 & 4,7 & 0 & 0 & 83,2 & 6 & 6,5 & 10,5 & 5 & 52 & 23 & 2,5 & 6,5 \\
\hline
\end{tabular}




\begin{tabular}{|c|c|c|c|c|c|c|c|c|c|c|c|c|c|c|c|c|c|c|c|c|c|}
\hline 2006 & Estação & s1 & s2 & s3 & s4 & s5 & s6 & s7 & s8 & s9 & s10 & s11 & s12 & s13 & s14 & s15 & s16 & s17 & s18 & s19 & s20 \\
\hline & Olivedos & 0 & 0 & 0 & 0 & 0 & 0 & 9 & 7,8 & 24,3 & 32,4 & 1,2 & 28,7 & 0 & 0 & 40,8 & 48,6 & 20,8 & 10,2 & 10,2 & 14,4 \\
\hline & Pedra Lavrada & 0 & 0 & 0 & 0 & 0 & 0 & 16,8 & 14,5 & 28,2 & 30,5 & 0 & 13,5 & 40,2 & 19 & 28,3 & 11,1 & 54,2 & 0 & 39 & 0 \\
\hline & Pocinhos & 1,1 & 0 & 0 & 0 & 0 & 0 & 16,5 & 2,2 & 6 & 15,1 & 11,2 & 39,2 & 0 & 0 & 28,1 & 1,8 & 7,4 & 18,9 & 2,8 & 7 \\
\hline & Queimadas & 0 & 0 & 0 & 0 & 0 & 0 & 9,8 & 3,2 & 0 & 0 & 0 & 45,3 & 8,6 & 42,9 & 8,3 & 7,5 & 15 & 20,4 & 20,1 & 3,8 \\
\hline & Seridó/São Vicente do Seridó & 0 & 0 & 0 & 0 & 0 & 4 & 0,1 & 40,1 & 76,9 & 14,5 & 2 & 27,8 & 60 & 55 & 99,9 & 27,2 & 31,5 & 61,3 & 126,1 & 23,7 \\
\hline & Soledade & 0 & 0 & 0 & 0 & 0 & 0 & 6,6 & 25,2 & 22,6 & 6 & 1,9 & 10,7 & 19,8 & 19,9 & 79,4 & 3 & 10,9 & 6,7 & 24,3 & 15,2 \\
\hline
\end{tabular}

Acari (Particular)

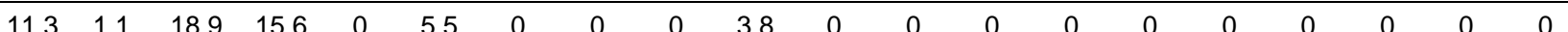

Assu (EMATER/Sítio Casa Forte)

Afonso Bezerra (EMATER)

Afonso Bezerra (Assentamento Santa Maria)

Almino Afonso (Particular - Ex Sítio Milagres)

Angicos (Prefeitura)

Campo Grande (Particular)

Campo Grande (Particular 2)

Barcelona (Particular)

Bodó (EMATER/TRF P/Delegacia)

Bom Jesus (Particular)

Caiçara do Rio do Vento (Particular)

Caicó (Batalhão)

Caicó (Açude Mundo Novo - EMPARN)

Caicó (Palma)

Caicó (Açude Itans)

Caicó (EMATER)

Campo Redondo (EMATER)

Campo Redondo (Polícia Rodoviária)

Cerro Corá (EMATER)

Coronel Ezequiel (Particular)

Cruzeta (Base Física da EMPARN)

Currais Novos (CERCEL)

Currais Novos (Açude Tororó)

Fernando Pedroza (EMATER)

Florânia (INMET)

$\begin{array}{ccccccccccccc}11,3 & 1,1 & 18,9 & 15,6 & 0 & 5,5 & 0 & 0 & 0 & 3,8 & 0 & 0 & 0 \\ 7 & 0 & 18 & 48 & 0 & 0 & 0 & 0 & 0 & 0 & 8 & 4,2 & 2,2 \\ 16,3 & 0,5 & 60 & 37,5 & 18,3 & 1,9 & 0,8 & 1,1 & 0,5 & 22,2 & 0 & 6,3 & 1,1 \\ 18,4 & 4,8 & 36,7 & 31,7 & 14,6 & 0,7 & 0 & 0 & 0 & 28,8 & 0 & 4,8 & 1,7 \\ 36,5 & 2 & 2,5 & 36 & 0 & 0 & 0 & 0 & 0 & 0 & 0 & 0 & 0 \\ 0 & 0 & 5,1 & 25,3 & 9,1 & 0 & 0 & 0 & 0 & 0 & 0 & 0 & 0 \\ 8,2 & 1,2 & 13 & 62 & 0 & 0 & 0 & 0 & 6 & 0 & 0 & 0 & 3 \\ 0 & 0 & 0 & 37,5 & 0 & 0 & 0 & 0 & 0 & 0 & 0 & 0 & 0 \\ 4,5 & 0 & 25,1 & 4,5 & 0 & 0 & 3,5 & 0 & 0 & 0 & 0 & 0 & 0 \\ 15,6 & 0 & 20,1 & 8,5 & 0 & 6,3 & 0 & 0 & 0 & 0 & 0 & 17,2 & 0 \\ 25 & 0 & 3,5 & 6 & 15 & 14 & 3,5 & 7 & 0 & 12 & 0 & 26 & 8 \\ 0 & 0 & 0 & 0 & 0 & 0 & 0 & 0 & 0 & 0 & 0 & 0 & 0 \\ 3,6 & 0 & 1 & 29,6 & 28,2 & 16,5 & 4,3 & 8,6 & 4,5 & 44,3 & 0 & 25 & 19 \\ 0 & 0 & 0 & 0 & 0 & 0 & 0 & 0 & 0 & 0 & 0 & 10,6 & 17,8 \\ 18,5 & 16 & 52,5 & 25,5 & 0 & 0 & 0 & 0 & 0 & 0 & 0 & 0 & 0 \\ 19,5 & 1,8 & 52,5 & 32 & 0 & 4,4 & 0 & 0 & 4 & 0 & 0 & 0 & 0 \\ 16 & 0 & 24 & 6,5 & 5 & 0 & 0 & 0 & 0 & 0 & 0 & 0 & 0 \\ 14 & 21,2 & 48 & 25,2 & 0 & 0 & 0 & 0 & 0 & 0 & 0 & 0 & 0 \\ 16,8 & 10,8 & 43,8 & 24 & 0 & 0 & 0 & 0 & 3,2 & 0 & 0 & 4,4 & 0 \\ 13,8 & 0 & 8,4 & 95,6 & 8 & 18 & 6,5 & 10 & 11 & 12,2 & 0 & 26,2 & 21 \\ 9,8 & 0 & 8,5 & 98 & 5 & 8,5 & 8,1 & 0,7 & 12,6 & 0 & 0 & 23,7 & 19,4 \\ 7,7 & 0 & 9,7 & 54,4 & 4 & 4,3 & 0,2 & 0 & 0 & 12,9 & 0 & 17,2 & 13 \\ 3 & 0 & 9 & 51 & 8 & 3 & 4 & 0 & 0 & 8 & 0 & 14,4 & 13,5 \\ 32,3 & 6,3 & 84,5 & 45,2 & 0,7 & 0 & 1,4 & 0,3 & 0 & 5 & 3,3 & 7,1 & 2,8 \\ 24,9 & 0 & 36,5 & 27,3 & 0 & 0 & 0 & 0 & 0 & 0 & 0 & 0 & 0 \\ 0 & 0 & 0 & 0 & 0 & 0 & 0 & 0 & 0 & 0 & 0 & 0 & 0 \\ 21 & 0 & 4,5 & 47,2 & 0 & 0 & 0 & 0 & 0 & 0 & 0 & 0 & 0 \\ 54,8 & 2,8 & 35,2 & 31,6 & 5,6 & 1 & 0 & 0 & 0 & 0 & 0 & 5,6 & 2,2\end{array}$
4 


\begin{tabular}{|c|c|c|c|c|c|c|c|c|c|c|c|c|c|c|c|c|c|c|c|c|c|}
\hline 2006 & Estação & s21 & s22 & s23 & s24 & s25 & s26 & s27 & $\mathbf{s} 28$ & $\mathbf{s 2 9}$ & s30 & s31 & s32 & s33 & s34 & s35 & s36 & s37 & s38 & s39 & s40 \\
\hline & Florânia (Sítio Jucuri) & 49,1 & 0 & 41 & 35,2 & 6 & 0 & 0 & 0 & 6 & 0 & 0 & 0 & 0 & 0 & 0 & 0 & 0 & 0 & 0 & 0 \\
\hline & lelmo Marinho (Prefeitura) & 0 & 0 & 5,3 & 4,8 & 50,6 & 65,1 & 22,2 & 19,7 & 22,2 & 0 & 0 & 32,9 & 10,2 & 0 & 0 & 0 & 2 & 0 & 0 & 6,2 \\
\hline & Jaçanã (EMATER) & 4 & 2,7 & 12,2 & 34,9 & 7,4 & 4,3 & 6,8 & 3,8 & 0 & 8,2 & 0 & 24,2 & 12,3 & 0 & 0 & 0 & 0 & 0 & 0 & 0 \\
\hline & Janduís (EMATER) & 25,2 & 14,8 & 15 & 26,6 & 0 & 6 & 0 & 0 & 0 & 5,6 & 0 & 7 & 0 & 0 & 0 & 0 & 0 & 0 & 0 & 0 \\
\hline & Boa Saúde (EMATER) & 5,6 & 0,8 & 6,3 & 23,4 & 33,4 & 20,5 & 6,3 & 7,2 & 5,3 & 25 & 1,1 & 25,5 & 23,8 & 0 & 0 & 0 & 0 & 0 & 0 & 0 \\
\hline & Japi (Particular) & 21,4 & 0 & 6,4 & 21,6 & 0 & 22,8 & 0 & 2,2 & 4,2 & 0 & 0 & 6,2 & 7 & 6,6 & 4,4 & 2,2 & 0 & 0 & 0 & 0 \\
\hline & Japi (EMATER) & 21,4 & 0 & 6,4 & 20 & 2,8 & 6,2 & 0 & 1 & 0,4 & 3,6 & 0 & 9 & 8,8 & 0 & 3 & 0 & 0,4 & 0 & 1 & 0 \\
\hline & Jardim de Angicos (EMATER) & 2,5 & 0 & 0 & 7,9 & 13,6 & 11 & 2,8 & 2 & 0,7 & 2,2 & 0 & 11 & 0 & 0 & 0 & 0 & 0 & 0 & 0 & 0 \\
\hline & Lagoa d'Anta (Prefeitura) & 21,9 & 5 & 16,2 & 17,6 & 27,7 & 25 & 11,3 & 3,2 & 6,8 & 23,8 & 0 & 28,6 & 24,7 & 0,8 & 0 & 0 & 1,1 & 0 & 0 & 0 \\
\hline & Lagoa de Pedras (Prefeitura) & 18,7 & 0,6 & 2,2 & 41,7 & 31,5 & 19,5 & 7,3 & 15,5 & 6,7 & 30,4 & 2,7 & 31 & 28,4 & 0 & 0 & 0 & 4,3 & 0 & 1,3 & 0 \\
\hline & Lagoa de Velhos (Delegacia) & 4,1 & 2,4 & 0,6 & 6,2 & 10,9 & 17,3 & 1,6 & 4,9 & 0 & 21,8 & 0 & 20,4 & 15,1 & 1 & 1,3 & 0 & 7,5 & 0 & 0 & 0 \\
\hline & Lagoa Nova (EMATER/Sítio Humaitá) & 3,9 & 0 & 8,7 & 4,2 & 5 & 3 & 0 & 0 & 0 & 0 & 0 & 0 & 0 & 0 & 0 & 0 & 0 & 0 & 0 & 0 \\
\hline & Lagoa Nova (Assentamento Santana/Sítio de Dentro) & 0 & 0 & 0 & 14,8 & 5,1 & 0 & 0 & 0 & 0 & 0 & 0 & 21,2 & 21,1 & 0 & 0 & 0 & 0 & 0 & 0 & 0 \\
\hline & Lagoa Salgada (Delegacia) & 5,2 & 0,8 & 0 & 18,7 & 35,4 & 12,2 & 6,4 & 4,8 & 3,5 & 23,3 & 0 & 20,5 & 28,1 & 0 & 0 & 0 & 0 & 0 & 0 & 0 \\
\hline & Lajes (Prefeitura) & 0 & 0 & 0 & 0 & 0 & 0 & 0 & 0 & 0 & 0 & 0 & 4 & 0 & 0 & 0 & 0 & 0 & 0 & 0 & 0 \\
\hline & Lajes Pintadas (Prefeitura) & 1,2 & 1,2 & 6,7 & 2 & 0 & 21,6 & 0 & 0 & 0 & 26 & 0 & 34,4 & 35,6 & 0 & 0 & 0 & 0 & 0 & 0 & 0 \\
\hline & Messias Targino (Prefeitura) & 42,7 & 0 & 0 & 0 & 0 & 0 & 0 & 0 & 0 & 0 & 0 & 0 & 0 & 0 & 0 & 0 & 0 & 0 & 0 & 0 \\
\hline & Monte Alegre (EMATER) & 10 & 3,4 & 4 & 27,4 & 60 & 43,6 & 8,4 & 15 & 10,8 & 44 & 0 & 58,8 & 32 & 1,8 & 0 & 2,6 & 11,4 & 0,2 & 1,8 & 0 \\
\hline & Monte das Gameleiras (EMATER) & 12 & 0 & 7,1 & 7,7 & 14,1 & 16,5 & 0 & 0 & 0 & 13 & 0 & 23 & 16,9 & 0 & 0 & 0 & 0 & 0 & 0 & 0 \\
\hline & Paraú (Sindicato) & 0 & 0 & 0 & 0 & 0 & 0 & 0 & 0 & 0 & 0 & 0 & 0 & 0 & 0 & 0 & 0 & 0 & 0 & 0 & 0 \\
\hline & Passa e Fica (Prefeitura) & 17 & 0 & 13,6 & 16,7 & 21,6 & 24,5 & 5,3 & 4,9 & 3,5 & 20,2 & 0 & 36,5 & 32 & 0 & 0 & 0 & 0 & 0 & 0 & 0 \\
\hline & Patu (Particular) & 27,2 & 8,2 & 17 & 59 & 0 & 3 & 0 & 0 & 0 & 5 & 0 & 0 & 0 & 0 & 0 & 0 & 0 & 0 & 0 & 0 \\
\hline & Santa Maria (Sindicato dos Trabalhadores Rurais) & 8,2 & 2 & 3 & 15 & 36,4 & 32,2 & 6,9 & 6,5 & 6 & 13 & 0 & 17 & 15,4 & 0 & 0 & 0 & 0 & 0 & 0 & 0 \\
\hline & Pedra Preta (EMATER) & 6,5 & 0 & 0 & 3,5 & 4,5 & 22,5 & 0 & 0 & 0 & 5 & 0 & 10,5 & 26,5 & 0 & 0 & 0 & 0 & 0 & 0 & 0 \\
\hline & Pedro Avelino (Particular) & 7,4 & 0 & 65 & 35,4 & 0 & 0 & 0 & 0 & 0 & 1 & 0 & 0 & 5,5 & 0 & 0 & 0 & 0 & 0 & 0 & 0 \\
\hline & Pedro Avelino (Base Física da EMPARN) & 48,5 & 12 & 0 & 0 & 0 & 0 & 0 & 0 & 0 & 0 & 0 & 0 & 0 & 0 & 0 & 0 & 0 & 0 & 0 & 0 \\
\hline & Pedro Avelino (Assentamento Nova Conquista) & 0 & 0 & 0 & 0 & 0 & 0 & 0 & 0 & 0 & 0 & 0 & 0 & 0 & 0 & 0 & 0 & 0 & 0 & 0 & 0 \\
\hline & Rui Barbosa (EMATER) & 2,5 & 3,9 & 0 & 0 & 16 & 32,5 & 0 & 8,8 & 0 & 6,4 & 0 & 28,7 & 16,6 & 0 & 0 & 0 & 0 & 0 & 0 & 0 \\
\hline & Santa Cruz (EMATER) & 2,4 & 0 & 4,2 & 16,4 & 9,4 & 10,3 & 4,4 & 2 & 7,9 & 19,4 & 0 & 25 & 17,3 & 0 & 0 & 15 & 12,6 & 14,7 & 0 & 0 \\
\hline & Santana do Matos (EMATER) & 6,3 & 0 & 74,5 & 62,8 & 0 & 0 & 0 & 0 & 0 & 0 & 0 & 0 & 0 & 0 & 0 & 0 & 0 & 0 & 0 & 0 \\
\hline & Santana do Matos (Barão de Serra Branca) & 19,4 & 0 & 110,7 & 21,4 & 3,3 & 0 & 2 & 0 & 0 & 12,6 & 3,5 & 2,7 & 3 & 0 & 0 & 0 & 0 & 0 & 0 & 0 \\
\hline & Santana do Matos (São José da Passagem) & 0 & 0 & 51,7 & 38,3 & 0 & 0 & 0 & 0 & 0 & 0 & 0 & 0 & 0 & 0 & 0 & 0 & 0 & 0 & 0 & 0 \\
\hline & São Bento do Trairi (Prefeitura) & 5,8 & 0 & 3,7 & 9,9 & 0 & 13 & 3,6 & 1 & 7 & 8,5 & 0 & 13,7 & 14,5 & 0 & 1,2 & 0 & 0 & 0 & 0 & 0 \\
\hline & São José do Campestre (EMATER) & 12,5 & 5,5 & 7 & 16 & 23 & 24 & 6 & 10 & 0 & 19 & 0 & 22,5 & 29,5 & 0 & 0 & 0 & 0 & 0 & 0 & 0 \\
\hline & São Paulo do Potengi (EMATER) & 0 & 0 & 0 & 12,9 & 13,9 & 28,8 & 2 & 7 & 8,4 & 18,6 & 0 & 14,5 & 16,6 & 0 & 0,4 & 0 & 2 & 0,2 & 0 & 0 \\
\hline & São Pedro (EMATER) & 5,3 & 0 & 3,4 & 8,2 & 32,1 & 33,7 & 4,6 & 7,2 & 3,5 & 9,8 & 0 & 17,8 & 13,2 & 0,7 & 0,7 & 0 & 4,8 & 0 & 0 & 0 \\
\hline
\end{tabular}




\begin{tabular}{|c|c|c|c|c|c|c|c|c|c|c|c|c|c|c|c|c|c|c|c|c|c|}
\hline 2006 & Estação & s21 & s22 & s23 & s24 & s25 & $s 26$ & s27 & s28 & $\mathbf{s 2 9}$ & s30 & s31 & s32 & s33 & s34 & s35 & s36 & s37 & s38 & s39 & s40 \\
\hline & São Rafael (EMATER) & 85 & 1,3 & 115,3 & 11,8 & 6,5 & 0 & 0 & 0 & 0 & 0 & 0 & 0 & 0 & 0 & 0 & 0 & 0 & 0 & 0 & 0 \\
\hline & São Tomé (EMATER) & 5,7 & 0 & 1,7 & 6 & 8,5 & 5 & 0 & 0 & 0 & 0 & 0 & 2 & 0,7 & 0 & 0 & 0 & 0 & 0 & 0 & 0 \\
\hline & São Vicente (EMATER - Ex Particular) & 76 & 0 & 0 & 0 & 0 & 0 & 0 & 0 & 0 & 0 & 0 & 0 & 0 & 0 & 0 & 0 & 0 & 0 & 0 & 0 \\
\hline & Senador Eloi de Souza (Particular) & 0 & 0 & 0 & 20,5 & 27 & 10 & 2 & 12,4 & 2,3 & 20,7 & 0 & 15,5 & 17 & 0 & 0 & 0 & 0 & 0 & 0 & 0 \\
\hline & Serrinha (EMATER) & 16 & 0 & 8,6 & 24,3 & 48,1 & 43,4 & 7,1 & 17,4 & 5,2 & 27,2 & 0 & 25,4 & 27,8 & 0 & 0 & 0 & 2,3 & 0 & 0,6 & 0 \\
\hline & Sítio Novo (Prefeitura) & 5 & 3 & 0 & 18 & 22 & 0 & 0 & 0 & 0 & 0 & 0 & 43 & 0 & 0 & 0 & 0 & 0 & 0 & 0 & 0 \\
\hline & Tangará (EMATER) & 0 & 0 & 0 & 0 & 20 & 18,5 & 0 & 0 & 0 & 16,5 & 0 & 21,2 & 35,5 & 0 & 0 & 0 & 1,5 & 0 & 0 & 0 \\
\hline & Tangará (Açude Trairi) & 6,2 & 0 & 3,8 & 13,3 & 12,7 & 12 & 5,1 & 6,1 & 1,7 & 18,4 & 0 & 26,1 & 14 & 0 & 4,4 & 0,6 & 1,6 & 0 & 0 & 0 \\
\hline & Triunfo Potiguar (Prefeitura) & 13,2 & 6,2 & 47,3 & 15,6 & 0 & 0 & 0 & 0 & 0 & 0 & 0 & 0 & 4,1 & 0 & 0 & 0 & 0 & 0 & 0 & 0 \\
\hline & Triunfo Potiguar (Chá Cacimbas/Serra J. Vale) & 0 & 0 & 0 & 0 & 0 & 0 & 0 & 0 & 0 & 0 & 0 & 0 & 0 & 0 & 0 & 0 & 0 & 0 & 0 & 0 \\
\hline & Triunfo Potiguar (Chá Velha/Serra J. Vale) & 28 & 0 & 74 & 26 & 0 & 0 & 0 & 0 & 0 & 0 & 0 & 0 & 0 & 0 & 0 & 0 & 0 & 0 & 0 & 0 \\
\hline & Alagoa Nova & 30,8 & 3 & 20,8 & 41 & 45 & 33,1 & 8,4 & 19 & 0 & 39,2 & 0 & 42,8 & 38,4 & 0 & 4,2 & 0,8 & 0 & 8,2 & 4,8 & 0 \\
\hline & Barra de Santana & 20,1 & 4,8 & 26,9 & 37,9 & 53,8 & 7,6 & 0 & 7,3 & 8,7 & 11,4 & 0 & 3,7 & 0,7 & 0 & 0,9 & 0,6 & 0 & 0 & 0 & 0 \\
\hline & Barra de Santana/Bodocongó & 15 & 8,7 & 23,5 & 37,3 & 52,2 & 8,9 & 0 & 6,9 & 7 & 13,1 & 0 & 4,8 & 1,6 & 0 & 0,5 & 0 & 1,6 & 0 & 0 & 0 \\
\hline & Boa Vista & 7,5 & 6,3 & 51,2 & 4,2 & 33,9 & 7,2 & 0 & 8,6 & 0 & 8 & 0 & 11,6 & 4,4 & 0 & 0 & 0 & 0 & 0 & 0 & 0 \\
\hline & Boqueirão/Açude Boqueirão & 12,2 & 7,4 & 36 & 21,3 & 52,7 & 7 & 0,7 & 5,7 & 6,9 & 16,3 & 0 & 5,9 & 3,5 & 0 & 0,8 & 0 & 0,8 & 0 & 0 & 0 \\
\hline & Cabaceiras & 11,6 & 1 & 42,4 & 9,2 & 68,2 & 5 & 0 & 6 & 6 & 8,7 & 0 & 1 & 0 & 0 & 0 & 0 & 0 & 0 & 0 & 0 \\
\hline & Campina Grande/EMBRAPA & 20,7 & 21,7 & 8,7 & 60,9 & 63 & 39,8 & 3,4 & 17,5 & 16,4 & 29,1 & 0 & 36,6 & 24 & 1,8 & 2,1 & 1,4 & 3,5 & 5,4 & 0 & 0 \\
\hline & Campina Grande/Santa Terezinha & 26,1 & 12,3 & 3,1 & 57,8 & 55,4 & 25,1 & 3,2 & 11,5 & 2,5 & 27,4 & 0 & 35,4 & 17,5 & 1,6 & 3 & 0 & 1,7 & 1,3 & 0 & 0 \\
\hline & Campina Grande/São José da Mata & 14,4 & 18,2 & 12,5 & 61,7 & 47,5 & 28,9 & 2,1 & 17,6 & 4,5 & 23,2 & 0 & 23,3 & 27,9 & 0 & 0 & 0 & 0 & 2,7 & 0 & 0 \\
\hline & Caturité & 25,3 & 19,9 & 18,7 & 52 & 25,6 & 15,3 & 0 & 12,5 & 0 & 2,6 & 0 & 12 & 3,1 & 0 & 0 & 0 & 0 & 0 & 0 & 0 \\
\hline & Caturité/Fazenda Campo de Emas & 40,6 & 12 & 6,4 & 37,2 & 38,2 & 10,8 & 0 & 7,2 & 0 & 5,2 & 0 & 0 & 0 & 0 & 0 & 0 & 0 & 0 & 0 & 0 \\
\hline & Cubati & 6,4 & 12,4 & 6,8 & 15 & 10,4 & 5,2 & 0 & 3,8 & 0 & 1,2 & 0 & 4 & 10 & 0 & 0 & 0 & 0 & 0 & 0 & 0 \\
\hline & Lagoa Seca & 24,9 & 22,3 & 26,8 & 77,1 & 38 & 25,8 & 5 & 29,3 & 9 & 38,3 & 0 & 36,4 & 39,5 & 6,3 & 5 & 1,8 & 7,9 & 9,8 & 2,4 & 0 \\
\hline & Matinhas & 16,1 & 15,2 & 11 & 67,8 & 10,6 & 10 & 13,8 & 26,9 & 3,7 & 9,2 & 11 & 24 & 45 & 0 & 6,5 & 0 & 2,7 & 0 & 3,2 & 0 \\
\hline & Olivedos & 4,1 & 12,1 & 70,6 & 10,5 & 10,5 & 7,1 & 1,7 & 6 & 1,8 & 6 & 0 & 2,6 & 13,5 & 0 & 0 & 0 & 0 & 0 & 0 & 0 \\
\hline & Pedra Lavrada & 15,5 & 6,1 & 68 & 9,2 & 7,7 & 0 & 0 & 0 & 0 & 0 & 0 & 0 & 0 & 0 & 0 & 0 & 0 & 0 & 0 & 0 \\
\hline & Pocinhos & 10,1 & 5,2 & 3,9 & 31,5 & 15,7 & 7,3 & 0,2 & 5,5 & 1 & 12,4 & 0 & 10,3 & 18 & 0,6 & 0 & 0 & 0 & 0 & 0 & 0 \\
\hline & Queimadas & 44,6 & 16,5 & 21 & 39,9 & 55,7 & 13,2 & 8,5 & 15,6 & 10,9 & 33,2 & 0 & 28,6 & 12,3 & 0 & 0 & 0 & 0 & 0 & 0 & 0 \\
\hline & Seridó/São Vicente do Seridó & 3 & 7 & 18,6 & 12,2 & 13,8 & 4,3 & 1,4 & 7,7 & 0,2 & 1 & 0 & 5,1 & 11,1 & 0 & 0 & 0 & 0 & 0 & 0 & 0 \\
\hline & Soledade & 29,7 & 7,8 & 56,7 & 4,8 & 7,2 & 5,9 & 0 & 4,4 & 0,5 & 2,1 & 0 & 4,8 & 4,2 & 0 & 0 & 0 & 0 & 0 & 0 & 0 \\
\hline
\end{tabular}

Acari (Particular)

Acari (Açude Gargalheiras)

Assu (Particular) 


\begin{tabular}{|c|c|c|c|c|c|c|c|c|c|c|c|c|c|}
\hline 2006 & Estação & s41 & s42 & s43 & s44 & s45 & s46 & s47 & $\mathbf{s 4 8}$ & $s 49$ & s50 & s51 & s52 \\
\hline & Assu (EMATER/Sítio Casa Forte) & 0 & 0 & 0 & 0 & 0 & 0 & 0 & 0 & 0 & 0 & 0 & 0 \\
\hline & Afonso Bezerra (EMATER) & 0 & 0 & 0 & 0 & 0 & 0 & 0 & 0 & 0 & 0 & 0 & 25 \\
\hline & Afonso Bezerra (Assentamento Santa Maria) & 0 & 0 & 0 & 0 & 0 & 0 & 0 & 0 & 0 & 0 & 0 & 58,2 \\
\hline & Almino Afonso (Particular - Ex Sítio Milagres) & 0 & 0 & 0 & 0 & 0 & 0 & 0 & 0 & 0 & 0 & 0 & 0 \\
\hline & Angicos (Prefeitura) & 0 & 0 & 0 & 0 & 0 & 0 & 0 & 0 & 0 & 0 & 0 & 4 \\
\hline & Campo Grande (Particular) & 0 & 0 & 0 & 0 & 0 & 0 & 0 & 0 & 0 & 0 & 1,1 & 0 \\
\hline & Campo Grande (Particular 2) & 0 & 0 & 0 & 0 & 0 & 0 & 0 & 0 & 0 & 0 & 5,3 & 3,4 \\
\hline & Barcelona (Particular) & 0 & 0 & 0 & 0 & 0 & 12 & 0 & 0 & 0 & 0 & 0 & 13 \\
\hline & Bodó (EMATER/TRF P/Delegacia) & 0 & 0 & 0 & 0 & 0 & 0 & 0 & 0 & 0 & 0 & 0 & 0 \\
\hline & Bom Jesus (Particular) & 0 & 0 & 3,2 & 0 & 0 & 3,2 & 0 & 0 & 0 & 0 & 0,8 & 22,3 \\
\hline & Caiçara do Rio do Vento (Particular) & 0 & 0 & 0 & 0 & 0 & 21 & 0 & 0 & 0 & 0 & 0 & 0 \\
\hline & Caicó (Batalhão) & 0 & 0 & 0 & 0 & 0 & 0 & 0 & 0 & 0 & 0 & 0 & 0 \\
\hline & Caicó (Açude Mundo Novo - EMPARN) & 0 & 0 & 0 & 0 & 0 & 0 & 0 & 0 & 0 & 0 & 0 & 0 \\
\hline & Caicó (Palma) & 0 & 0 & 0 & 0 & 0 & 0 & 0 & 0 & 0 & 0 & 0 & 0 \\
\hline & Caicó (Açude Itans) & 0 & 0 & 0 & 0 & 0 & 0 & 0 & 0 & 0 & 0 & 0 & 0 \\
\hline & Caicó (EMATER) & 0 & 0 & 0 & 0 & 0 & 0 & 0 & 0 & 0 & 0 & 0 & 0 \\
\hline & Campo Redondo (EMATER) & 0 & 0 & 0 & 0 & 0 & 0 & 0 & 0 & 0 & 0 & 0 & 0 \\
\hline & Campo Redondo (Polícia Rodoviária) & 0 & 0 & 0 & 0 & 0 & 0 & 0 & 0 & 0 & 0 & 0 & 0 \\
\hline & Cerro Corá (EMATER) & 0 & 0 & 0 & 0 & 0 & 0 & 0 & 0 & 0 & 0 & 0 & 0 \\
\hline & Coronel Ezequiel (Particular) & 0 & 0 & 0 & 0 & 0 & 2 & 5 & 0 & 0 & 0 & 0 & 0 \\
\hline & Cruzeta (Base Física da EMPARN) & 0 & 0 & 0 & 0 & 0 & 2,3 & 7,2 & 0 & 0 & 0 & 2,5 & 0 \\
\hline & Currais Novos (CERCEL) & 0 & 0 & 0 & 0 & 0 & 0 & 0 & 0 & 0 & 0 & 0 & 13,5 \\
\hline & Currais Novos (Açude Tororó) & 0 & 0 & 0 & 0 & 0 & 0 & 0 & 0 & 0 & 0 & 0 & 0 \\
\hline & Fernando Pedroza (EMATER) & 0 & 0 & 0 & 0 & 0 & 0 & 0 & 0 & 0 & 0 & 0 & 0 \\
\hline & Florânia (INMET) & 0 & 0 & 0 & 0 & 0 & 0,2 & 6,6 & 0 & 0 & 0 & 0 & 0,3 \\
\hline & Florânia (Sítio Jucuri) & 0 & 0 & 0 & 0 & 0 & 0 & 0 & 0 & 0 & 0 & 0 & 0 \\
\hline & Ielmo Marinho (Prefeitura) & 0 & 0 & 0 & 0 & 0 & 53,8 & 0 & 0 & 0 & 0 & 0 & 4,1 \\
\hline & Jaçanã (EMATER) & 0 & 0 & 0 & 0 & 0 & 0 & 14 & 0 & 0 & 0 & 0 & 0 \\
\hline & Janduís (EMATER) & 0 & 0 & 0 & 0 & 0 & 0 & 0 & 0 & 0 & 0 & 3,6 & 1 \\
\hline & Boa Saúde (EMATER) & 0 & 0 & 1,1 & 2,2 & 0 & 0 & 0 & 0 & 0 & 0 & 0 & 3,9 \\
\hline & Japi (Particular) & 0 & 0 & 0 & 0 & 0 & 0 & 0 & 0 & 0 & 0 & 10,6 & 9,6 \\
\hline & Japi (EMATER) & 1 & 0 & 0 & 0 & 0 & 0 & 0 & 0 & 0 & 0,3 & 8,9 & 1,9 \\
\hline & Jardim de Angicos (EMATER) & 0 & 0 & 0 & 0 & 0 & 24 & 0 & 0 & 0 & 0 & 0 & 5 \\
\hline & Lagoa d'Anta (Prefeitura) & 0 & 0 & 0 & 0 & 0 & 0 & 0 & 0 & 0 & 0 & 0 & 6,3 \\
\hline & Lagoa de Pedras (Prefeitura) & 1,3 & 0 & 1,4 & 3,3 & 0 & 5,3 & 0 & 1,6 & 0 & 0 & 2,5 & 25,8 \\
\hline & Lagoa de Velhos (Delegacia) & 0 & 0 & 0 & 0 & 0 & 15 & 0 & 0 & 0 & 0 & 0 & 0 \\
\hline
\end{tabular}




\begin{tabular}{|c|c|c|c|c|c|c|c|c|c|c|c|c|c|}
\hline 2006 & Estação & s41 & s42 & s43 & s44 & s45 & s46 & s47 & s48 & $s 49$ & s50 & s51 & s52 \\
\hline & Lagoa Nova (EMATER/Sítio Humaitá) & 0 & 0 & 0 & 0 & 0 & 0 & 0 & 0 & 0 & 0 & 0 & 45 \\
\hline & Lagoa Nova (Assentamento Santana/Sítio de Dentro) & 0 & 0 & 0 & 0 & 0 & 0 & 0 & 0 & 0 & 0 & 0 & 0 \\
\hline & Lagoa Salgada (Delegacia) & 0 & 0 & 2,1 & 0 & 0 & 2,4 & 0 & 0 & 0 & 0 & 1,2 & 28,9 \\
\hline & Lajes (Prefeitura) & 0 & 0 & 0 & 0 & 0 & 0 & 0 & 0 & 0 & 0 & 0 & 0 \\
\hline & Lajes Pintadas (Prefeitura) & 0 & 0 & 0 & 0 & 0 & 0 & 0 & 0 & 0 & 0 & 0 & 0 \\
\hline & Messias Targino (Prefeitura) & 0 & 0 & 0 & 0 & 0 & 0 & 0 & 0 & 0 & 0 & 0 & 0 \\
\hline & Monte Alegre (EMATER) & 8 & 0 & 4,2 & 4,4 & 0 & 17,6 & 0 & 0,6 & 0 & 2,8 & 18,8 & 29 \\
\hline & Monte das Gameleiras (EMATER) & 0 & 0 & 0 & 0 & 0 & 0 & 0 & 0 & 0 & 0 & 0 & 10 \\
\hline & Paraú (Sindicato) & 0 & 0 & 0 & 0 & 0 & 0 & 0 & 0 & 0 & 0 & 0 & 0 \\
\hline & Passa e Fica (Prefeitura) & 0 & 0 & 1,2 & 0 & 0 & 3,5 & 0 & 0 & 0 & 0 & 0 & 3 \\
\hline & Patu (Particular) & 0 & 0 & 0 & 0 & 0 & 7 & 0 & 0 & 0 & 0 & 4 & 0 \\
\hline & Santa Maria (Sindicato dos Trabalhadores Rurais) & 0 & 0 & 0 & 0 & 0 & 0 & 0 & 0 & 0 & 0 & 0 & 0 \\
\hline & Pedra Preta (EMATER) & 0 & 0 & 0 & 0 & 0 & 19 & 0 & 0 & 0 & 0 & 0 & 0 \\
\hline & Pedro Avelino (Particular) & 0 & 0 & 0 & 0 & 0 & 7 & 0 & 0 & 0 & 0 & 0 & 4,4 \\
\hline & Pedro Avelino (Base Física da EMPARN) & 0 & 0 & 0 & 0 & 0 & 0 & 0 & 0 & 0 & 0 & 0 & 47,6 \\
\hline & Pedro Avelino (Assentamento Nova Conquista) & 0 & 0 & 0 & 0 & 0 & 0 & 0 & 0 & 0 & 0 & 0 & 0 \\
\hline & Rui Barbosa (EMATER) & 0 & 0 & 0 & 0 & 0 & 14,7 & 0 & 0 & 0 & 0 & 0 & 0 \\
\hline & Santa Cruz (EMATER) & 0 & 0 & 1,5 & 0 & 0 & 5,7 & 0 & 0 & 0 & 0 & 0 & 0 \\
\hline & Santana do Matos (EMATER) & 0 & 0 & 0 & 0 & 0 & 0 & 0 & 0 & 0 & 0 & 0 & 0 \\
\hline & Santana do Matos (Barão de Serra Branca) & 0 & 0 & 0 & 0 & 0 & 0 & 0 & 0 & 0 & 0 & 0 & 0 \\
\hline & Santana do Matos (São José da Passagem) & 0 & 0 & 0 & 0 & 0 & 0 & 0 & 0 & 0 & 0 & 0 & 0 \\
\hline & São Bento do Trairi (Prefeitura) & 0 & 0 & 1,5 & 0 & 0 & 1,6 & 0 & 0 & 0 & 0 & 0 & 0 \\
\hline & São José do Campestre (EMATER) & 3 & 0 & 3,5 & 0 & 0 & 6 & 0 & 0 & 0 & 0 & 0 & 4 \\
\hline & São Paulo do Potengi (EMATER) & 0 & 0 & 0 & 0 & 0 & 9,2 & 0,3 & 0 & 0 & 0 & 0,9 & 1,5 \\
\hline & São Pedro (EMATER) & 2,6 & 0 & 0 & 0 & 0 & 13,3 & 0 & 0 & 0 & 0 & 1,7 & 12 \\
\hline & São Rafael (EMATER) & 0 & 0 & 0 & 0 & 0 & 2 & 0 & 0 & 0 & 0 & 0 & 19,5 \\
\hline & São Tomé (EMATER) & 0 & 0 & 0 & 0 & 0 & 0 & 0 & 0 & 0 & 0 & 0 & 0 \\
\hline & São Vicente (EMATER - Ex Particular) & 0 & 0 & 0 & 0 & 0 & 0 & 0 & 0 & 0 & 0 & 0 & 0 \\
\hline & Senador Eloi de Souza (Particular) & 0 & 0 & 0 & 0 & 0 & 0 & 0 & 0 & 0 & 0 & 0 & 0 \\
\hline & Serrinha (EMATER) & 0 & 0 & 1,8 & 0 & 0 & 6,3 & 0 & 1 & 0 & 0 & 8,1 & 12,6 \\
\hline & Sítio Novo (Prefeitura) & 0 & 0 & 0 & 0 & 0 & 0 & 0 & 0 & 0 & 0 & 0 & 0 \\
\hline & Tangará (EMATER) & 3 & 0 & 6 & 0 & 0 & 0 & 0 & 0 & 0 & 0 & 0 & 14,4 \\
\hline & Tangará (Açude Trairi) & 1,1 & 0 & 3,1 & 0 & 0 & 0 & 0 & 0 & 0 & 0 & 0 & 12,3 \\
\hline & Triunfo Potiguar (Prefeitura) & 0 & 0 & 0 & 0 & 0 & 0 & 0 & 0 & 0 & 0 & 0 & 5,1 \\
\hline & Triunfo Potiguar (Chá Cacimbas/Serra J. Vale) & 0 & 0 & 0 & 0 & 0 & 0 & 0 & 0 & 0 & 0 & 0 & 0 \\
\hline & Triunfo Potiguar (Chá Velha/Serra J. Vale) & 0 & 0 & 0 & 0 & 0 & 0 & 0 & 0 & 0 & 31 & 0 & 25,2 \\
\hline
\end{tabular}




\begin{tabular}{|c|c|c|c|c|c|c|c|c|c|c|c|c|c|c|c|c|c|c|c|c|c|}
\hline \multirow{21}{*}{2006} & Estação & s4 & & s42 & $s 43$ & s44 & $s 45$ & s46 & s47 & $s 48 s 49$ & $9 \mathrm{s50}$ & s51 & s52 & & & & & & & & \\
\hline & Alagoa Nova & 0 & & 0 & 5,8 & 3,5 & 0 & 0 & 0 & $0 \quad 0$ & 0 & 13,1 & 6,5 & & & & & & & & \\
\hline & Barra de Santana & 0 & & 0 & 2,7 & 3,8 & 0 & 11,8 & 0 & 0 & 0 & 0 & 0 & & & & & & & & \\
\hline & Barra de Santana/Bodocongó & 0 & & 0 & 2,7 & 1,5 & 0 & 13,4 & 0 & 1,5 & 0 & 1,5 & 0 & & & & & & & & \\
\hline & Boa Vista & 0 & & 0 & 0 & 0 & 0 & 15 & 0 & 0 & 0 & 0 & 0 & & & & & & & & \\
\hline & Boqueirão/Açude Boqueirão & 0 & & 0 & 3,5 & 0 & 0 & 16,4 & 0 & 3 & 0 & 0 & 2,3 & & & & & & & & \\
\hline & Cabaceiras & 0 & & 0 & 0 & 0 & 0 & 5,2 & 0 & 0 & 0 & 0 & 0 & & & & & & & & \\
\hline & Campina Grande/EMBRAPA & 0 & & 0 & 4 & 2,5 & 0 & 36,3 & 2,4 & 1,1 & 0 & 1,9 & 0 & & & & & & & & \\
\hline & Campina Grande/Santa Terezinha & 0 & & 0 & 4,1 & 1,6 & 0 & 29,1 & 1,9 & 0 & 0 & 4,5 & 0 & & & & & & & & \\
\hline & Campina Grande/São José da Mata & 0 & & 0 & 1,8 & 2,4 & 0 & 11,7 & 0 & 0 & 0 & 3,3 & 0 & & & & & & & & \\
\hline & Caturité & 0 & & 0 & 0 & 1 & 0 & 17,8 & 0 & 0 & 0 & 0 & 0 & & & & & & & & \\
\hline & Caturité/Fazenda Campo de Emas & 0 & & 0 & 0 & 0 & 6 & 12 & 3,4 & 0 & 0 & 0 & 0 & & & & & & & & \\
\hline & Cubati & 0 & & 0 & 0 & 0 & 0 & 0 & 0 & 0 & 0 & 0 & 0 & & & & & & & & \\
\hline & Lagoa Seca & 0 & & 0 & 18,4 & 6,2 & 0 & 24,8 & 2,7 & 0,7 & 0 & 15,6 & 0,7 & & & & & & & & \\
\hline & Matinhas & 0 & & 0 & 3,4 & 5,1 & 0 & 26,6 & 5,2 & 0,6 & 0,1 & 8 & 0,2 & & & & & & & & \\
\hline & Olivedos & 0 & & 0 & 0 & 0 & 0 & 5,3 & 0 & 0 & 0 & 0 & 0 & & & & & & & & \\
\hline & Pedra Lavrada & 0 & & 0 & 0 & 0 & 0 & 0 & 0 & 0 & 0 & 0 & 0 & & & & & & & & \\
\hline & Pocinhos & 0 & & 0 & 0 & 0 & 0 & 1,7 & 0 & 0 & 0 & 0 & 0 & & & & & & & & \\
\hline & Queimadas & 0 & & 0 & 5,3 & 0 & 0 & 23,2 & 0 & 0 & 0 & 0 & 0 & & & & & & & & \\
\hline & Seridó/São Vicente do Seridó & 0 & & 0 & 0 & 0 & 0 & 3,4 & 0,4 & 0 & 0 & 0,7 & 1 & & & & & & & & \\
\hline & Soledade & 0 & & 0 & 0 & 0 & 0 & 0,9 & 0 & 0 & 0 & 0 & 0 & & & & & & & & \\
\hline \multirow[t]{15}{*}{2007} & Estação & s1 & s2 & s3 & s4 & s5 & s6 & s7 & s8 & s9 & s10 & s11 & s12 & $\mathbf{s 1 3}$ & s14 & s15 & s16 & s17 & s18 & $\mathbf{s 1 9}$ & s20 \\
\hline & Acari (Particular) & 0 & 0 & 0 & 0 & 0 & 0 & 3,8 & 111,4 & 0 & 95,8 & 1,2 & 11,3 & 6,5 & 0 & 0 & 13,2 & 29,3 & 0 & 0 & 0 \\
\hline & Acari (Açude Gargalheiras) & 0 & 0 & 8 & 0 & 0 & 54 & 56 & 90 & 4,1 & 85 & 26 & 18 & 8 & 7 & 0 & 41 & 2 & 8 & 0 & 0 \\
\hline & Assu (Particular) & 43,5 & 0 & 9,2 & 0 & 0,3 & 0 & 13,1 & $282, \varsigma$ & 38,5 & 67,7 & 39,4 & 34,6 & 24,3 & 6,7 & 7,6 & 51,8 & 62 & 67,1 & 1,4 & 0 \\
\hline & Assu (EMATER/Sítio Casa Forte) & 55,8 & 0 & 1,1 & 0 & 0,8 & 0 & 4,1 & 247,6 & 53,6 & 14,3 & 53 & 14,4 & 26,8 & 10,4 & 10,2 & 43 & 39,5 & 79,5 & 0 & 0 \\
\hline & Afonso Bezerra (EMATER) & 6 & 0 & 0 & 0 & 0 & 0 & 101 & 66,5 & 47,5 & 12,5 & 24,5 & 3 & 28 & 0 & 76 & 26 & 57 & 14 & 2 & 0 \\
\hline & Afonso Bezerra (Assentamento Santa Maria) & 27,1 & 0 & 0 & 3,2 & 0 & 12,7 & 48,9 & 56,9 & 58,1 & 111,4 & 23,9 & 33,9 & 0 & 0 & 7,5 & 26 & 44,2 & 14,3 & 0 & 0 \\
\hline & Almino Afonso (Particular - Ex Sítio Milagres) & 0 & 0 & 0 & 0 & 0 & 0 & 65,5 & 176,1 & 7 & 20,8 & 84,4 & 59,2 & 19,3 & 8,7 & 0 & 63,4 & 128,2 & 99,7 & 14,4 & 0 \\
\hline & Angicos (Prefeitura) & 58,7 & 0 & 3,5 & 0 & 0 & 0 & 46,8 & 36 & 0 & 22,4 & 6 & 9,6 & 2,4 & 0 & 4,5 & 150,5 & 41 & 1,7 & 0 & 0 \\
\hline & Campo Grande (Particular) & 19,8 & 0 & 0 & 0 & 0 & 52,4 & 28 & 129,1 & 64,4 & 38,5 & 115,6 & 49,3 & 14,2 & 33,6 & 0 & 15 & 101 & 25,8 & 0 & 0 \\
\hline & Campo Grande (Particular 2) & 14,3 & 15 & 16,3 & 0 & 0 & 67,9 & 99,2 & 58,7 & 64,4 & 36,3 & 86,6 & 56 & 15,3 & 31,3 & 2,3 & 29,6 & 89,7 & 9,3 & 0 & 0 \\
\hline & Barcelona (Particular) & 14 & 0 & 2,5 & 0 & 1,5 & 0 & 2,5 & 69,5 & 0 & 0 & 4,5 & 0 & 0 & 0 & 8,5 & 40,5 & 68,5 & 32,5 & 7,5 & 3,5 \\
\hline & Bom Jesus (Particular) & 25,7 & 0,2 & 19,4 & 0 & 7 & 0 & 33,4 & 9,5 & 41,1 & 0,4 & 0 & 0 & 0,7 & 0 & 17,1 & 79,4 & 62,6 & 52,9 & 3,8 & 0 \\
\hline & Caiçara do Rio do Vento (Particular) & 5,2 & 0 & 0 & 0 & 0 & 0 & 31,8 & 52,6 & 8 & 0 & 0 & 0 & 0 & 0 & 18 & 0 & 41 & 93 & 0 & 4,5 \\
\hline & Caicó (Batalhão) & 15 & 0 & 0 & 0 & 0 & 0 & 84 & 80 & 18 & 44 & 18 & 9 & 0 & 0 & 94 & 51 & 100,5 & 0 & 0 & 0 \\
\hline
\end{tabular}




\begin{tabular}{|c|c|c|c|c|c|c|c|c|c|c|c|c|c|c|c|c|c|c|c|c|c|}
\hline 2007 & Estação & s1 & s2 & s3 & s4 & s5 & s6 & s7 & s8 & s9 & s10 & s11 & s12 & s13 & s14 & s15 & s16 & s17 & s18 & s19 & s20 \\
\hline & Caicó (Açude Mundo Novo - EMPARN) & 0 & 0 & 0 & 0 & 0 & 0 & 12 & 139,6 & 24,4 & 24,5 & 40,3 & 15 & 0 & 0 & 45,6 & 26,8 & 63,9 & 0 & 0 & 0 \\
\hline & Caicó (Palma) & 4,6 & 2 & 0 & 0 & 58 & 0 & 152,4 & 92 & 19,9 & 69 & 68 & 31,4 & 0 & 0 & 24 & 18,2 & 132,1 & 3,2 & 9,6 & 2 \\
\hline & Caicó (Açude Itans) & 23,1 & 0 & 0 & 0 & 0 & 0 & 90,3 & 282 & 22,9 & 29,3 & 8,8 & 14,2 & 0,2 & 3,1 & 50,2 & 46,6 & 111,1 & 3,9 & 3,5 & 0 \\
\hline & Caicó (EMATER) & 10,1 & 0 & 0 & 0 & 0 & 0 & 36,1 & 141 & 28,5 & 5,9 & 5,8 & 8,5 & 1 & 2 & 105 & 60,1 & 97,1 & 7,3 & 3 & 0 \\
\hline & Campo Redondo (EMATER) & 2,6 & 0 & 4,6 & 0 & 3,6 & 0 & 97,6 & 71 & 13,8 & 0 & 0 & 0 & 0 & 0 & 8,1 & 65,8 & 32,1 & 12,8 & 19,1 & 0 \\
\hline & Campo Redondo (Polícia Rodoviária) & 9,1 & 0 & 0 & 0 & 3 & 0 & 77,8 & 88 & 12,9 & 0 & 0 & 30,7 & 6,2 & 0 & 53,7 & 47,8 & 71,4 & 34,4 & 6,2 & 0 \\
\hline & Cerro Corá (EMATER) & 18,5 & 8,6 & 0,6 & 0 & 0 & 0 & 51,8 & 150,7 & 3,6 & 9,5 & 18,5 & 9,5 & 0 & 0 & 28 & 70 & 20 & 9,4 & 2,7 & 0 \\
\hline & Coronel Ezequiel (Particular) & 6,5 & 0 & 0 & 0 & 0 & 0 & 39 & 79 & 36,7 & 1 & 4,4 & 2 & 3,5 & 2 & 63 & 61 & 51,5 & 29 & 8 & 0 \\
\hline & Cruzeta (Base Física da EMPARN) & 2,1 & 0,5 & 0 & 0 & 1,7 & 0,1 & 20,1 & 93,9 & 11,4 & 20,4 & 5,7 & 73 & 0,2 & 0 & 12,2 & 56,4 & 112,8 & 23,4 & 1,3 & 0 \\
\hline & Currais Novos (CERCEL) & 0 & 0 & 0,3 & 0 & 0 & 0 & 10,8 & 65,8 & 19,9 & 0 & 0 & 112 & 0 & 0 & 11,1 & 77,5 & 11,5 & 0 & 0 & 0 \\
\hline & Fernando Pedroza (EMATER) & 30,1 & 0 & 0 & 0 & 8,3 & 7,5 & 30 & 83,7 & 12,3 & 3 & 10,7 & 32,6 & 0 & 0 & 0 & 38,7 & 55,3 & 11,3 & 0 & 0 \\
\hline & Florânia (INMET) & 12,1 & 0,5 & 0,2 & 2,3 & 0 & 4,2 & 50 & 163,7 & 26,7 & 5,6 & 46,8 & 49,5 & 0,6 & 1,6 & 3,4 & 37,3 & 58,3 & 29,6 & 2,4 & 0 \\
\hline & Florânia (Sítio Jucuri) & 13,7 & 0 & 0 & 0 & 0 & 4 & 160 & 93,6 & 22,6 & 33,3 & 51,5 & 23,6 & 1,5 & 0 & 9 & 41,4 & 78,7 & 4,7 & 0 & 0 \\
\hline & Ielmo Marinho (Prefeitura) & 30 & 10,3 & 0 & 0 & 0 & 0 & 15 & 35,4 & 0 & 0 & 0 & 0 & 0 & 0 & 48,6 & 57,6 & 84,1 & 86,2 & 10,4 & 0 \\
\hline & Itajá (EMATER) & 0 & 0 & 0 & 0 & 0 & 0 & 40 & 303 & 56 & 44 & 115 & 60 & 0 & 25 & 20 & 65 & 100,7 & 105 & 0 & 0 \\
\hline & Jaçanã (EMATER) & 4,8 & 2,8 & 1 & 0 & 0 & 0 & 44,4 & 94,9 & 44,2 & 6,9 & 0 & 35 & 0 & 0 & 37,6 & 41,3 & 44,7 & 22,7 & 13,4 & 0 \\
\hline & Janduís (EMATER) & 40 & 20 & 0 & 1 & 15,4 & 4 & 22,5 & 146 & 11 & 34,4 & 47,8 & 82,2 & 24 & 19 & 37,4 & 41,4 & 100,8 & 17 & 3 & 5 \\
\hline & Boa Saúde (EMATER) & 24,5 & 0 & 18,9 & 0 & 0 & 0 & 12,3 & 26,3 & 51,2 & 2,7 & 3,2 & 0 & 0 & 0 & 14,1 & 70,3 & 20,9 & 75 & 7,5 & 0 \\
\hline & Japi (Particular) & 2,2 & 0 & 0 & 0 & 0 & 34,2 & 72,6 & 59,4 & 10,8 & 0 & 0 & 8,4 & 0 & 0 & 14,2 & 49,2 & 25,4 & 50 & 2,2 & 6,6 \\
\hline & Japi (EMATER) & 0 & 0,8 & 0,5 & 0 & 2,4 & 0 & 24,6 & 63,2 & 12,7 & 0 & 0 & 4,4 & 0 & 0 & 13,3 & 45,3 & 22,7 & 32,8 & 0 & 0 \\
\hline & Jardim de Angicos (EMATER) & 2 & 0 & 0 & 0 & 0 & 0 & 41,9 & 64,2 & 0 & 2 & 9,3 & 0 & 0 & 0 & 22,3 & 15,5 & 16,6 & 18,9 & 0 & 0 \\
\hline & Lagoa d'Anta (Prefeitura) & 11,2 & 0 & 0 & 0 & 0 & 0 & 14,8 & 113,3 & 17,9 & 0 & 0 & 2,1 & 2 & 0 & 7,3 & 79,5 & 39 & 60 & 5,3 & 0 \\
\hline & Lagoa de Pedras (Prefeitura) & 34,2 & 0 & 12,6 & 0 & 21,5 & 0 & 12,7 & 41,8 & 6,4 & 21,8 & 0 & 0 & 0 & 0 & 19 & 15 & 15 & 82,7 & 28,7 & 6,3 \\
\hline & Lagoa de Velhos (Delegacia) & 30,1 & 0,6 & 2,6 & 0 & 7,4 & 2 & 7,4 & 9 & 16,1 & 5,9 & 0 & 44,8 & 0 & 0 & 5,2 & 29,6 & 83,5 & 50,1 & 17,1 & 1 \\
\hline & Lagoa Nova (EMATER/Sítio Humaitá) & 38,7 & 0 & 0 & 0 & 0 & 0 & 57,3 & 93,3 & 24,3 & 10,2 & 0 & 34 & 0 & 0 & 72,9 & 35,5 & 11 & 20 & 0 & 0 \\
\hline & Lagoa Salgada (Delegacia) & 27,3 & 0 & 6,3 & 0 & 25,9 & 2,3 & 8,7 & 10 & 18,8 & 0 & 3 & 0 & 2,9 & 0 & 22,7 & 53 & 8,6 & 54,5 & 17,9 & 0 \\
\hline & Lajes (Prefeitura) & 0 & 0 & 0 & 0 & 0 & 3,4 & 47,9 & 36,8 & 0 & 0 & 37 & 2 & 0 & 0 & 39,4 & 21 & 59 & 1 & 0 & 0 \\
\hline & Lajes Pintadas (Prefeitura) & 17,5 & 0 & 5,5 & 0 & 0,1 & 0 & 72,8 & 50,5 & 9,9 & 0 & 0 & 0 & 2,2 & 0 & 2,8 & 53,8 & 37,3 & 45,1 & 7,7 & 0 \\
\hline & Messias Targino (Prefeitura) & 0 & 2,3 & 0 & 0 & 1,3 & 8,2 & 125,2 & 179,6 & 18,1 & 31,4 & 45,4 & 125,2 & 32,6 & 39,7 & 44,8 & 19,6 & 80,2 & 1 & 0 & 0 \\
\hline & Monte Alegre (EMATER) & 57,6 & 1,8 & 22,4 & 1,6 & 10 & 4 & 18,6 & 32,4 & 93 & 37,8 & 0 & 0 & 2 & 0 & 43,4 & 169 & 50 & 92 & 48,6 & 8 \\
\hline & Monte das Gameleiras (EMATER) & 8,8 & 0 & 0 & 0 & 0 & 0 & 55,5 & 35,3 & 19 & 0 & 0 & 5,7 & 0 & 0 & 53,1 & 49,5 & 73,8 & 45 & 5,2 & 3 \\
\hline & Paraú (Prefeitura) & 0 & 0 & 0 & 0 & 0 & 14,8 & 54,8 & 54,3 & 34,3 & 11,4 & 37,7 & 13,2 & 0 & 13,1 & 0 & 73,5 & 21,9 & 35,3 & 0 & 0 \\
\hline & Paraú (Sindicato) & 0 & 0 & 0 & 0 & 0 & 15,8 & 33,3 & 100,6 & 17,2 & 22 & 55 & 23 & 0 & 0 & 12,7 & 78 & 36,5 & 5,3 & 0 & 0 \\
\hline & Passa e Fica (Prefeitura) & 10,8 & 2,2 & 1,2 & 0 & 3 & 0 & 11,8 & 86,4 & 54,3 & 7,9 & 0 & 0 & 3,4 & 0 & 0 & 91,1 & 36,1 & 63,9 & 13,5 & 0 \\
\hline & Patu (Particular) & 5 & 0 & 0 & 0 & 0 & 0 & 72,2 & 245,2 & 26 & 54,6 & 8 & 96 & 86 & 21 & 8 & 57 & 65,2 & 35,2 & 6 & 0 \\
\hline & Santa Maria (Sindicato dos Trabalhadores Rurais) & 0 & 24,2 & 21,6 & 0 & 0,2 & 0,2 & 0 & 0 & 9,5 & 0 & 0 & 0 & 2,3 & 0 & 17,8 & 61,9 & 64,1 & 27,5 & 2 & 0 \\
\hline
\end{tabular}




\begin{tabular}{|c|c|c|c|c|c|c|c|c|c|c|c|c|c|c|c|c|c|c|c|c|c|}
\hline 2007 & Estação & s1 & s2 & s3 & s4 & s5 & s6 & s7 & s8 & s9 & s10 & s11 & s12 & s13 & s14 & $s 15$ & s16 & s17 & s18 & s19 & s20 \\
\hline & Pedra Preta (EMATER) & 10,7 & 0 & 12,5 & 0 & 0 & 9 & 0 & 22,5 & 0 & 0 & 0 & 0 & 0 & 0 & 0 & 8,1 & 19,5 & 11,5 & 5,5 & 0 \\
\hline & Pedro Avelino (Particular) & 28 & 0 & 3,2 & 0 & 0 & 0 & 63,6 & 126 & 1 & 0 & 8 & 10 & 0 & 0 & 5,6 & 65,2 & 23,7 & 4,4 & 0 & 0 \\
\hline & Pedro Avelino (Base Física da EMPARN) & 1 & 0 & 2,5 & 0 & 13,2 & 21,5 & 43,8 & 33 & 11,9 & 24,6 & 11,2 & 31,7 & 0 & 0 & 2,3 & 18,1 & 3,1 & 57 & 0 & 0 \\
\hline & Riachuelo (EMATER) & 12 & 0 & 12 & 0 & 0 & 0 & 25 & 6 & 0 & 0 & 0 & 0 & 0 & 0 & 8,5 & 61,5 & 70 & 52,7 & 2 & 0 \\
\hline & Rui Barbosa (EMATER) & 31 & 0 & 0 & 0 & 1,9 & 12,2 & 64,1 & 27 & 4,3 & 0 & 0 & 0 & 0 & 12 & 0 & 47,6 & 29,3 & 26 & 0 & 8,8 \\
\hline & Santa Cruz (EMATER) & 5 & 1,4 & 1,6 & 0 & 18,6 & 0 & 16,5 & 87,8 & 4,2 & 0 & 2,5 & 7,3 & 12,7 & 0 & 3,9 & 80,8 & 116,5 & 29,4 & 3,7 & 0 \\
\hline & Santana do Matos (EMATER) & 0 & 0 & 0 & 26 & 0 & 0 & 56,2 & 130,1 & 5 & 33,3 & 37 & 8 & 0 & 0 & 25,7 & 10,3 & 103,1 & 5 & 0 & 0 \\
\hline & Santana do Matos (Barão de Serra Branca) & 36 & 0 & 0 & 0 & 6,2 & 8 & 43 & 0 & 11,2 & 13,5 & 63,7 & 183 & 0 & 0 & 13 & 23,5 & 89,7 & 7 & 0 & 0 \\
\hline & Santana do Matos (São José da Passagem) & 0 & 7,2 & 0 & 0 & 15,2 & 0 & 68,8 & 31,7 & 0 & 20 & 17,7 & 6,7 & 0 & 0 & 7 & 10,7 & 0 & 0 & 0 & 0 \\
\hline & São Bento do Trairi (Prefeitura) & 7 & 0 & 0 & 0 & 0 & 0 & 88,3 & 31 & 34,8 & 6,4 & 0 & 0 & 0 & 0 & 15,2 & 62,4 & 16,3 & 25,5 & 0 & 0 \\
\hline & São José do Campestre (EMATER) & 16 & 0 & 3,5 & 0 & 8,5 & 0 & 37,3 & 70,5 & 17,8 & 3,4 & 0 & 16,8 & 0 & 0 & 15,9 & 102,4 & 28,3 & 17,9 & 4,8 & 0 \\
\hline & São Paulo do Potengi (EMATER) & 31,1 & 0,3 & 10,6 & 0 & 0 & 0 & 12,7 & 13,6 & 11,8 & 0 & 0 & 0 & 0,4 & 0 & 6,8 & 64,2 & 113,8 & 55,1 & 0,8 & 0,2 \\
\hline & São Pedro (EMATER) & 33,1 & 0,9 & 13,1 & 0 & 7,4 & 0,2 & 8,5 & 40,3 & 18,8 & 0 & 5,9 & 0 & 1,7 & 0 & 6 & 57,2 & 74,2 & 50 & 6,5 & 1,2 \\
\hline & São Rafael (EMATER) & 31 & 0 & 0 & 0 & 0 & 2 & 74,9 & 150,4 & 5 & 15,2 & 16,2 & 232 & 112,2 & 7,4 & 13,9 & 43,1 & 124 & 47 & 0 & 0 \\
\hline & São Tomé (EMATER) & 18 & 0 & 0 & 0 & 11,8 & 0 & 8 & 18 & 24 & 0 & 3 & 0 & 0 & 0 & 30 & 39 & 30 & 45 & 4 & 0 \\
\hline & São Vicente (EMATER - Ex Particular) & 0 & 0 & 0 & 0 & 0 & 0 & 0 & 0 & 12,2 & 31,2 & 9,2 & 33 & 0 & 0 & 0 & 14 & 97,8 & 2,5 & 1 & 0 \\
\hline & São Vicente (EMATER - Extinto) & 0 & 0 & 0 & 0 & 0 & 0 & 0 & 0 & 24,4 & 0 & 31,2 & 31,2 & 9,4 & 0 & 0 & 14 & 97,8 & 2,5 & 1 & 0 \\
\hline & Senador Eloi de Souza (Particular) & 24,9 & 0 & 0 & 0 & 12 & 0 & 15,5 & 16,7 & 32,5 & 4,5 & 0 & 0 & 0 & 0 & 5,5 & 46,9 & 71 & 49,3 & 3 & 1 \\
\hline & Serra de São Bento (EMATER) & 19,5 & 0 & 0 & 0 & 8,3 & 0 & 4,2 & 94,7 & 33,9 & 1 & 1,3 & 2,7 & 6 & 0 & 12,4 & 84,5 & 31,3 & 81 & 3,1 & 0,7 \\
\hline & Serrinha (EMATER) & 47,3 & 0,9 & 10,6 & 0 & 0 & 0 & 33,8 & 39,5 & 99,1 & 8 & 0 & 0 & 0 & 0 & 17 & 106,6 & 24,7 & 39,4 & 32,2 & 1,3 \\
\hline & Sítio Novo (Prefeitura) & 15 & 0 & 3,5 & 0 & 0 & 0 & 38,5 & 86 & 10 & 0 & 0 & 0 & 0 & 0 & 45 & 51 & 122 & 65 & 0 & 7 \\
\hline & Tangará (EMATER) & 10 & 0 & 0 & 0 & 15 & 0 & 11,5 & 21,5 & 4 & 0 & 17 & 0 & 0 & 0 & 3,5 & 71 & 53 & 31,5 & 0 & 0 \\
\hline & Tangará (Açude Trairi) & 5,4 & 0 & 3,6 & 0 & 2,5 & 0 & 10,7 & 43,6 & 4,5 & 0 & 6,1 & 1,8 & 2,6 & 0 & 46,6 & 68,5 & 76,1 & 6,5 & 3,9 & 3,1 \\
\hline & Tenente Laurentino Cruz (EMATER) & 2,3 & 0 & 0 & 0 & 0 & 0 & 0 & 203,4 & 33,3 & 0 & 23,7 & 0 & 0 & 4 & 0 & 67 & 11 & 15 & 0 & 0 \\
\hline & Triunfo Potiguar (Prefeitura) & 1 & 0 & 2,4 & 0 & 0 & 9,5 & 67,8 & 146,2 & 67,7 & 10,6 & 21,2 & 177,8 & 45,8 & 20,6 & 0 & 43,1 & 95,5 & 22,8 & 0 & 0 \\
\hline & Triunfo Potiguar (Chá Cacimbas/Serra J. Vale) & 0 & 0 & 0 & 0 & 0 & 0 & 35 & 127 & 58 & 15 & 0 & 20 & 10 & 0 & 0 & 0 & 0 & 0 & 0 & 0 \\
\hline & Triunfo Potiguar (Chá Velha/Serra J. Vale) & 0 & 0 & 0 & 0 & 0 & 0 & 35 & 56,8 & 52 & 72 & 0 & 0 & 0 & 0 & 0 & 0 & 0 & 0 & 0 & 0 \\
\hline & Alagoa Nova & 40,3 & 5,8 & 3 & 0 & 0 & 0 & 4,8 & 34,7 & 55,8 & 6,8 & 15,5 & 6,5 & 4,8 & 0 & 8,8 & 91,4 & 6,3 & 22,9 & 25,9 & 0 \\
\hline & Barra de Santana & 8,9 & 0 & 0 & 0 & 0 & 0 & 16,1 & 111,9 & 113,1 & 7,6 & 9,3 & 1,9 & 2,6 & 0 & 0 & 13,6 & 89,3 & 9,9 & 15,3 & 8,9 \\
\hline & Barra de Santana/Bodocongó & 7,5 & 0 & 0 & 0 & 0 & 0 & 15,3 & 107,7 & 96,8 & 8 & 8,9 & 2 & 2,5 & 0 & 0 & 14 & 77,3 & 10 & 15 & 9,3 \\
\hline & Boa Vista & 35,6 & 0 & 0 & 0 & 0 & 0 & 61,2 & 34,2 & 35,9 & 1,2 & 13,2 & 0 & 0 & 0 & 0 & 42,2 & 23,6 & 6,6 & 14,8 & 0 \\
\hline & Boqueirão/Açude Boqueirão & 7,9 & 0 & 0 & 0 & 0 & 0 & 0 & 36,6 & 54,5 & 10,4 & 9,8 & 3,4 & 1,2 & 0 & 0 & 17,7 & 26,5 & 15,6 & 9,2 & 5,3 \\
\hline & Cabaceiras & 2,3 & 1 & 0 & 0 & 0 & 0 & 43,4 & 24,7 & 55,6 & 7,2 & 4,5 & 0 & 0 & 0 & 0 & 21,3 & 6,7 & 4,6 & 5,6 & 0 \\
\hline & Campina Grande/EMBRAPA & 27,6 & 4,4 & 0,4 & 0 & 0 & 0,1 & 24,8 & 44,4 & 43,6 & 5,8 & 29 & 14,4 & 3,2 & 0 & 6,8 & 57,5 & 45,1 & 34,5 & 32,6 & 2,2 \\
\hline & Campina Grande/Santa Terezinha & 18 & 3,9 & 0 & 0 & 0 & 5,9 & 25,9 & 47,4 & 47,7 & 2,9 & 34,5 & 11,2 & 3,3 & 0 & 1,6 & 61,5 & 61,8 & 31,5 & 15,5 & 2,8 \\
\hline & Campina Grande/São José da Mata & 10,4 & 2,1 & 0 & 0 & 0 & 0 & 5,2 & 29,5 & 32,9 & 0 & 16,8 & 6,4 & 3 & 0 & 0 & 46,1 & 44,3 & 13,6 & 23,3 & 0 \\
\hline
\end{tabular}




\begin{tabular}{|c|c|c|c|c|c|c|c|c|c|c|c|c|c|c|c|c|c|c|c|c|c|}
\hline 2007 & Estação & s1 & s2 & s3 & s4 & s5 & s6 & s7 & s8 & s9 & s10 & s11 & s12 & s13 & s14 & s15 & s16 & s17 & s18 & s19 & s20 \\
\hline & Caturité & 15,6 & 0,4 & 0 & 0 & 0 & 0 & 5,9 & 59 & 43,7 & 0 & 14,9 & 12,5 & 2,5 & 0 & 0 & 40,3 & 61,6 & 26,3 & & 0 \\
\hline & Caturité/Fazenda Campo de Emas & 11 & 1 & 0 & 0 & 0 & 0 & 8 & 34,2 & 32,2 & 0 & 12,6 & 30 & 6,6 & 0 & 0 & 28,4 & 83,2 & 15,8 & 2,8 & 2 \\
\hline & Cubati & 7,5 & 0 & 0 & 0 & 0 & 0 & 21,2 & 66,4 & 14 & 1,6 & 17 & 0 & 0 & 0 & 0 & 13 & 68,2 & 11,8 & 9,4 & 0 \\
\hline & Lagoa Seca & 22,7 & 9,3 & 0,8 & 0 & 0 & 0 & 7,8 & 29,7 & 35,1 & 0 & 18,4 & 12,1 & 4 & 0 & 6,4 & 57,8 & 21 & 23,4 & 29,4 & 1,6 \\
\hline & Matinhas & 21,8 & 4,9 & 1,5 & 0 & 0 & 1,2 & 11 & 47,5 & 62,9 & 3,7 & 9,8 & 9,7 & 4,8 & 0 & 13,2 & 76,9 & 56,4 & 15,6 & 30,9 & 16,1 \\
\hline & Olivedos & 2,8 & 0 & 0 & 0 & 0 & 0 & 10 & 78,4 & 6,6 & 0 & 2,9 & 1,5 & 0 & 0 & 0 & 9,1 & 77,8 & 24,2 & 6,5 & 0 \\
\hline & Pedra Lavrada & 0 & 0 & 0 & 0 & 0 & 0 & 14,3 & 136,3 & 0 & 0 & 0 & 0 & 4,7 & 0 & 0 & 29,3 & 72 & 20,6 & 5,3 & 0 \\
\hline & Pocinhos & 4,6 & 0,4 & 0 & 0 & 0 & 0,1 & 7,4 & 10,5 & 23,1 & 0 & 2,4 & 0 & 0,9 & 0 & 0 & 32 & 26,1 & 7,2 & 12 & 0 \\
\hline & Queimadas & 24,1 & 4,3 & 0 & 0 & 0 & 0 & 44,4 & 93,9 & 71 & 0 & 23,7 & 0 & 5,9 & 0 & 0 & 26,6 & 36 & 38 & 23,8 & 0 \\
\hline & Seridó/São Vicente do Seridó & 13,7 & 0 & 0 & 0 & 0 & 0 & 29,9 & 79,3 & 44,3 & 4,8 & 1,8 & 1,7 & 0 & 0 & 0 & 10,7 & 32,5 & 22,5 & 9,2 & 0 \\
\hline & Soledade & 3,7 & 0 & 0 & 0 & 0 & 0 & 51,1 & 76,5 & 19,1 & 2,4 & 8,3 & 0,4 & 0 & 0 & 0 & 20 & 72,9 & 2,9 & 1,8 & 0 \\
\hline
\end{tabular}

\begin{tabular}{|c|c|c|c|c|c|c|c|c|c|c|c|c|c|c|c|c|c|c|c|c|c|}
\hline 2007 & Estação & s21 & $s 22$ & s23 & s24 & s25 & $s 26$ & s27 & $\mathbf{s} 28$ & s29 & s30 & s31 & s32 & s33 & s34 & s35 & s36 & s37 & s38 & s39 & s40 \\
\hline & Acari (Particular) & 0 & 3,4 & 0 & 7,9 & 0 & 1,7 & 0 & 0 & 0 & 0 & 0 & 0 & 0 & 0 & 0 & 7 & 0 & 0 & 0 & 0 \\
\hline & Acari (Açude Gargalheiras) & 0 & 0 & 0 & 12 & 19 & 0 & 0 & 0 & 0 & 32 & 0 & 0 & 0 & 0 & 0 & 7 & 0 & 0 & 0 & 0 \\
\hline & Assu (Particular) & 5,5 & 27 & 9,5 & 4 & 9,7 & 0,5 & 0 & 1,1 & 0 & 0 & 0 & 3,4 & 0,2 & 0 & 0,1 & 0,2 & 0 & 0 & 0 & 0 \\
\hline & Assu (EMATER/Sítio Casa Forte) & 2,5 & 33,5 & 17,4 & 1,8 & 8,4 & 0,2 & 0 & 0 & 0 & 0 & 0 & 6,8 & 0 & 0 & 0 & 0 & 0 & 0 & 0 & 0 \\
\hline & Afonso Bezerra (EMATER) & 11 & 6 & 8 & 0 & 23 & 0 & 0 & 13 & 0 & 0 & 0 & 0 & 0 & 0 & 0 & 0 & 0 & 0 & 0 & 0 \\
\hline & Afonso Bezerra (Assentamento Santa Maria) & 7,3 & 0 & 5,1 & 19,5 & 0 & 0 & 0 & 0 & 0 & 0 & 0 & 0 & 0 & 0 & 0 & 0 & 0 & 0 & 0 & 0 \\
\hline & Almino Afonso (Particular - Ex Sítio Milagres) & 3,3 & 61,7 & 6,1 & 7 & 0 & 0 & 0 & 0 & 0 & 0 & 0 & 0 & 0 & 0 & 0 & 0 & 0 & 0 & 0 & 0 \\
\hline & Angicos (Prefeitura) & 0 & 0 & 0 & 24 & 8,5 & 0 & 0 & 0 & 0 & 0 & 0 & 0 & 0 & 0 & 0 & 0 & 0 & 0 & 0 & 0 \\
\hline & Campo Grande (Particular) & 57,2 & 3,5 & 0 & 0 & 0 & 0 & 0 & 0 & 0 & 27,6 & 0 & 0 & 0 & 0 & 0 & 0 & 0 & 0 & 0 & 0 \\
\hline & Campo Grande (Particular 2) & 55,5 & 7 & 7,5 & 1,4 & 10 & 0 & 0 & 2,2 & 0 & 26 & 0 & 0 & 0 & 0 & 0 & 0 & 0 & 0 & 0 & 0 \\
\hline & Barcelona (Particular) & 5,5 & 30 & 22 & 127 & 33 & 12,5 & 2 & 12 & 0 & 4 & 0 & 3,5 & 6 & 0 & 7 & 19 & 0 & 0 & 0 & 0 \\
\hline & Bom Jesus (Particular) & 31,5 & 88,6 & 37,8 & 122,1 & 44 & 32,8 & 2 & 14,8 & 0 & 21,2 & 1,3 & 8,5 & 10,8 & 11 & 3,9 & 22,4 & 5,6 & 0 & 0 & 0 \\
\hline & Caiçara do Rio do Vento (Particular) & 0 & 7 & 15,5 & 16,4 & 30 & 0 & 0 & 0 & 0 & 0 & 0 & 0 & 0 & 0 & 0 & 0 & 0 & 0 & 0 & 0 \\
\hline & Caicó (Batalhão) & 34 & 0 & 0 & 0 & 0 & 0 & 0 & 0 & 0 & 4,8 & 0 & 0 & 0 & 0 & 0 & 0 & 0 & 0 & 0 & 0 \\
\hline & Caicó (Açude Mundo Novo - EMPARN) & 1,5 & 29 & 0 & 19 & 2,2 & 0 & 0 & 0 & 0 & 3 & 0 & 0 & 0 & 0 & 0 & 0 & 0 & 0 & 0 & 0 \\
\hline & Caicó (Palma) & 17,6 & 5,6 & 0 & 0 & 0 & 1 & 0 & 0 & 0 & 0 & 0 & 0 & 0 & 0 & 0 & 0 & 0 & 0 & 0 & 0 \\
\hline & Caicó (Açude Itans) & 20 & 0 & 3,3 & 5,8 & 0,4 & 0 & 0 & 1,2 & 0 & 1,3 & 0,7 & 0 & 0 & 0 & 0 & 0 & 0 & 0 & 0 & 0 \\
\hline & Caicó (EMATER) & 18,5 & 0 & 0 & 6 & 0 & 0 & 0 & 0 & 0 & 0 & 0 & 0 & 0 & 0 & 0 & 0 & 0 & 12,5 & 0 & 0 \\
\hline & Campo Redondo (EMATER) & 2,5 & 4 & 15 & 64 & 54 & 8,5 & 0 & 9,8 & 0 & 5,6 & 5,8 & 3 & 25,1 & 0,5 & 0 & 7 & 0 & 0 & 0 & 0 \\
\hline & Campo Redondo (Polícia Rodoviária) & 0 & 21,2 & 14,3 & 67,9 & 58,2 & 10,9 & 0 & 10,6 & 0 & 4,4 & 6,1 & 5,4 & 16,8 & 5,8 & 0 & 28 & 0 & 0 & 0 & 0 \\
\hline & Cerro Corá (EMATER) & 10,9 & 10,7 & 3,1 & 7,7 & 10,9 & 0 & 0 & 4 & 0 & 0 & 0 & 4,2 & 0 & 0 & 0 & 0 & 0 & 0 & 0 & 0 \\
\hline & Coronel Ezequiel (Particular) & 4 & 16 & 8 & 23 & 21 & 8 & 0 & 9 & 0 & 6 & 2 & 0 & 14,5 & 0 & 0 & 19 & 0 & 0 & 0 & 0 \\
\hline & Cruzeta (Base Física da EMPARN) & 43,4 & 13,9 & 1,6 & 6,7 & 1,8 & 0,5 & 0 & 1,5 & 0 & 2,8 & 0,1 & 0,4 & 2 & 0 & 1,9 & 3,5 & 0,1 & 0 & 0 & 0 \\
\hline
\end{tabular}




\begin{tabular}{|c|c|c|c|c|c|c|c|c|c|c|c|c|c|c|c|c|c|c|c|c|c|}
\hline 2007 & Estação & s21 & s22 & s23 & s24 & $s 25$ & s26 & s27 & $\mathbf{s} 28$ & s29 & s30 & s31 & s32 & s33 & s34 & s35 & s36 & s37 & s38 & s39 & s40 \\
\hline & Currais Novos (CERCEL) & 17 & 0 & 0 & 0 & 10,3 & 1,6 & 0 & 0 & 0 & 0 & 0 & 0 & 0 & 0 & 0 & 5,2 & 0 & 0 & 0 & 0 \\
\hline & Fernando Pedroza (EMATER) & 0 & 0 & 0 & 10 & 7,5 & 0 & 0 & 0 & 0 & 0 & 0 & 0 & 0 & 0 & 0 & 0 & 0 & 0 & 0 & 0 \\
\hline & Florânia (INMET) & 1,4 & 3,9 & 0,6 & 16,2 & 5,5 & 0,8 & 0 & 0 & 0 & 0 & 0,4 & 0 & 2,6 & 0 & 1 & 6,5 & 0 & 0 & 0 & 0 \\
\hline & Florânia (Sítio Jucuri) & 0 & 9 & 0 & 13 & 5,5 & 0 & 0 & 0 & 0 & 0 & 0 & 0 & 0 & 0 & 0 & 0 & 0 & 0 & 0 & 0 \\
\hline & Ielmo Marinho (Prefeitura) & 0 & 61,7 & 0 & 66,1 & 102,6 & 6,5 & 12 & 27,4 & 0 & 53,5 & 0 & 8 & 5,8 & 5,5 & 0 & 3,5 & 0 & 0 & 0 & 0 \\
\hline & Itajá (EMATER) & 0 & 67 & 0 & 0 & 10,2 & 0 & 0 & 0 & 0 & 0 & 0 & 0 & 0 & 0 & 0 & 0 & 0 & 0 & 0 & 0 \\
\hline & Jaçanã (EMATER) & 13,2 & 15 & 15,1 & 36,7 & 24 & 7,8 & 0 & 17 & 0 & 8,5 & 4,9 & 0,5 & 19,3 & 0 & 4,2 & 25,6 & 0 & 0 & 0 & 0 \\
\hline & Janduís (EMATER) & 8 & 14,2 & 0 & 10 & 3 & 0 & 0 & 0 & 0 & 3 & 0 & 0 & 0 & 0 & 0 & 5 & 0 & 0 & 0 & 0 \\
\hline & Boa Saúde (EMATER) & 18,8 & 70,6 & 78,1 & 95,6 & 84,7 & 7,4 & 3,4 & 10,8 & 0 & 12,3 & 0 & 8,2 & 11,7 & 8,3 & 6 & 32,5 & 0 & 0 & 0 & 0 \\
\hline & Japi (Particular) & 0 & 15 & 10,2 & 54,6 & 39,6 & 0 & 0 & 2,2 & 2,2 & 0 & 0 & 2,2 & 4,2 & 0 & 0 & 4,4 & 0 & 0 & 0 & 0 \\
\hline & Japi (EMATER) & 1,8 & 6,3 & 7,8 & 43,2 & 30,2 & 0 & 0 & 1,9 & 0 & 0 & 0 & 0 & 5,6 & 0 & 0 & 0 & 0 & 0 & 0 & 0 \\
\hline & Jardim de Angicos (EMATER) & 0 & 12 & 4 & 16,5 & 32 & 6,4 & 0 & 8,5 & 0 & 0 & 0 & 0 & 0 & 10 & 0 & 0 & 0 & 0 & 0 & 0 \\
\hline & Lagoa d'Anta (Prefeitura) & 18,5 & 5,7 & 0 & 0 & 0 & 0 & 2,8 & 13,1 & 0 & 13,6 & 0 & 1,8 & 12,5 & 0,6 & 8,5 & 23,9 & 0 & 0 & 0 & 0 \\
\hline & Lagoa de Pedras (Prefeitura) & 13,4 & 93,3 & 122,4 & 132,8 & 65,7 & 9,2 & 7,9 & 11,3 & 5,2 & 18 & 0,6 & 11,6 & 17,9 & 15 & 2,4 & 22,7 & 3,2 & 0 & 0 & 0 \\
\hline & Lagoa de Velhos (Delegacia) & 3,5 & 28,7 & 31,5 & 103,5 & 71,5 & 7,6 & 0 & 10,2 & 0 & 5,2 & 2,1 & 2,9 & 7,9 & 2,7 & 2,4 & 19 & 0 & 0 & 0 & 0 \\
\hline & Lagoa Nova (EMATER/Sítio Humaitá) & 0 & 5 & 6 & 45 & 35 & 0 & 0 & 0 & 0 & 0 & 0 & 0 & 0 & 0 & 0 & 0 & 0 & 0 & 0 & 0 \\
\hline & Lagoa Salgada (Delegacia) & 15,2 & 104,5 & 71,8 & 67,7 & 46 & 14,8 & 5,5 & 14,4 & 0 & 0 & 0 & 0 & 5,5 & 0 & 0 & 8,7 & 0 & 0 & 0 & 0 \\
\hline & Lajes (Prefeitura) & 0 & 0 & 8 & 20,4 & 4,6 & 0 & 0 & 0 & 0 & 0 & 0 & 0 & 0 & 0 & 0 & 0 & 0 & 0 & 0 & 0 \\
\hline & Lajes Pintadas (Prefeitura) & 5,2 & 31,1 & 14 & 63,5 & 59,8 & 7,2 & 0 & 0 & 10 & 7,9 & 0 & 9,5 & 11,1 & 2,9 & 4,1 & 19,7 & 0 & 0 & 0 & 0 \\
\hline & Messias Targino (Prefeitura) & 0 & 18,9 & 8,2 & 0 & 9,9 & 0 & 0 & 0 & 0 & 1 & 0 & 0 & 0 & 0 & 0 & 0 & 0 & 0 & 0 & 0 \\
\hline & Monte Alegre (EMATER) & 9 & 110,8 & 56,6 & 63,6 & 90 & 44 & 1,6 & 42 & 0 & 9,8 & 3,8 & 8,4 & 15 & 14,8 & 1,2 & 18,2 & 3 & 0 & 0 & 0 \\
\hline & Monte das Gameleiras (EMATER) & 0 & 16,3 & 30,8 & 77,9 & 47,1 & 15 & 0 & 6 & 0 & 16,5 & 0 & 0 & 19,5 & 10,7 & 0 & 20,2 & 0 & 0 & 0 & 0 \\
\hline & Paraú (Prefeitura) & 0 & 28 & 0 & 0 & 0 & 1,9 & 0 & 1,5 & 0 & 4,6 & 0 & 2,2 & 0 & 0 & 0 & 0 & 0 & 0 & 0 & 0 \\
\hline & Paraú (Sindicato) & 7,6 & 9,7 & 0 & 0 & 0 & 0 & 0 & 0 & 0 & 0 & 0 & 0 & 0 & 0 & 0 & 0 & 0 & 0 & 0 & 0 \\
\hline & Passa e Fica (Prefeitura) & 3,5 & 32 & 48,7 & 118,2 & 72,2 & 4,5 & 0 & 20 & 0 & 15,5 & 0 & 3,8 & 12,8 & 7 & 0 & 17,2 & 5,7 & 0 & 0 & 0 \\
\hline & Patu (Particular) & 8 & 40,4 & 8 & 3,4 & 0 & 6 & 0 & 3 & 0 & 0 & 0 & 0 & 0 & 0 & 0 & 6 & 0 & 0 & 0 & 0 \\
\hline & Santa Maria (Sindicato dos Trabalhadores Rurais) & 33 & 43,3 & 50 & 61 & 83,9 & 16,7 & 0 & 12,3 & 2,1 & 0 & 0 & 4,8 & 13,1 & 20,6 & 1,5 & 0 & 0 & 0 & 0 & 0 \\
\hline & Pedra Preta (EMATER) & 2,5 & 8 & 2,5 & 12 & 27 & 6 & 0 & 14 & 0 & 2,5 & 0 & 0 & 2,5 & 0 & 0 & 9 & 0 & 0 & 0 & 0 \\
\hline & Pedro Avelino (Particular) & 4 & 4,2 & 0,5 & 2 & 19,6 & 0 & 0 & 11,6 & 0 & 0 & 0 & 0 & 0 & 0 & 1 & 2 & 0 & 0 & 0 & 0 \\
\hline & Pedro Avelino (Base Física da EMPARN) & 0 & 2,9 & 6,2 & 0 & 19,3 & 0 & 0 & 14,6 & 0 & 0 & 0 & 0 & 0 & 0 & 0 & 0 & 0 & 0 & 0 & 0 \\
\hline & Riachuelo (EMATER) & 14 & 30,2 & 42,5 & 24,6 & 55,2 & 9,5 & 0 & 13,1 & 0 & 4 & 0 & 0 & 9 & 10,5 & 0 & 0 & 0 & 0 & 0 & 0 \\
\hline & Rui Barbosa (EMATER) & 0 & 2 & 20,9 & 59 & 71,7 & 21,4 & 0 & 20,1 & 0 & 5,8 & 4,3 & 0 & 2,7 & 3 & 0 & 3,2 & 0 & 0 & 0 & 0 \\
\hline & Santa Cruz (EMATER) & 6,9 & 16 & 28,8 & 60,5 & 64,6 & 3,3 & 0 & 7,9 & 0 & 6,5 & 0,7 & 2,3 & 12,4 & 2,7 & 8,7 & 7,8 & 0 & 0 & 0 & 0 \\
\hline & Santana do Matos (EMATER) & 0 & 13 & 0 & 0 & 0 & 0 & 0 & 0 & 0 & 0 & 0 & 0 & 0 & 0 & 0 & 0 & 0 & 0 & 0 & 0 \\
\hline & Santana do Matos (Barão de Serra Branca) & 3,8 & 5,7 & 0 & 0 & 0 & 0 & 0 & 0 & 0 & 0 & 0 & 0 & 0 & 0 & 0 & 0 & 0 & 0 & 0 & 0 \\
\hline & Santana do Matos (São José da Passagem) & 0 & 0 & 0 & 0 & 10 & 16 & 0 & 0 & 0 & 0 & 0 & 0 & 0 & 0 & 0 & 0 & 0 & 0 & 0 & 0 \\
\hline
\end{tabular}




\begin{tabular}{|c|c|c|c|c|c|c|c|c|c|c|c|c|c|c|c|c|c|c|c|c|c|}
\hline 2007 & Estação & s21 & s22 & s23 & s24 & s25 & s26 & s27 & s28 & s29 & s30 & s31 & s32 & s33 & s34 & s35 & s36 & s37 & s38 & s39 & s40 \\
\hline & São Bento do Trairi (Prefeitura) & 0 & 6,3 & 13,4 & 39 & 35,6 & 4,8 & 0 & 0 & 0 & 4 & 0 & 0 & 6,2 & 0 & 0 & 0,3 & 0 & 0 & 0 & 0 \\
\hline & São José do Campestre (EMATER) & 31,3 & 16,5 & 45,3 & 109,5 & 89,7 & 11,9 & 0 & 12 & 0 & 9 & 2,5 & 0 & 9,8 & 3 & 2,3 & 13 & 0 & 0 & 0 & 0 \\
\hline & São Paulo do Potengi (EMATER) & 17 & 31,8 & 28,4 & 38,9 & 77,4 & 21,3 & 2,5 & 10,9 & 0 & 0 & 0 & 10,9 & 1,5 & 11,2 & 0 & 16,8 & 0,2 & 0 & 0 & 0 \\
\hline & São Pedro (EMATER) & 7,4 & 39,3 & 24,5 & 44,8 & 94,9 & 14,4 & 0 & 8,1 & 0 & 3,8 & 0 & 7 & 18,6 & 12,4 & 8 & 13,3 & 2,9 & 0 & 0 & 0 \\
\hline & São Rafael (EMATER) & 12,5 & 25 & 1 & 17 & 6,2 & 0 & 0 & 1,5 & 0 & 0,4 & 0 & 1,8 & 4,2 & 0 & 2,2 & 2,4 & 0 & 0 & 0 & 0 \\
\hline & São Tomé (EMATER) & 8 & 18 & 18 & 87 & 15 & 0 & 0 & 0 & 0 & 0 & 0 & 0 & 0 & 0 & 0 & 8 & 0 & 0 & 0 & 0 \\
\hline & São Vicente (EMATER - Ex Particular) & 0 & 0 & 3,2 & 12 & 5 & 0 & 0 & 0 & 0 & 0 & 0 & 0 & 0 & 0 & 0 & 0 & 0 & 0 & 0 & 0 \\
\hline & São Vicente (EMATER - Extinto) & 0 & 0 & 3,2 & 12 & 5 & 0 & 0 & 0 & 0 & 0 & 0 & 0 & 0 & 0 & 0 & 0 & 0 & 0 & 0 & 0 \\
\hline & Senador Eloi de Souza (Particular) & 1 & 46,7 & 29,3 & 74 & 68,6 & 18,3 & 0 & 1,5 & 0 & 0 & 1 & 4 & 7,1 & 5,3 & 0 & 27,9 & 0 & 0 & 0 & 0 \\
\hline & Serra de São Bento (EMATER) & 1,7 & 42 & 39 & 97,5 & 64,4 & 7,5 & 0 & 17,2 & 0 & 20,6 & 0 & 3,1 & 16,3 & 4,4 & 0,2 & 0 & 0 & 0 & 0 & 0 \\
\hline & Serrinha (EMATER) & 11,8 & 52,8 & 94,3 & 169,1 & 137,2 & 12,2 & 5,8 & 13,4 & 0,2 & 9,2 & 0 & 7,8 & 17,6 & 11,4 & 5 & 36 & 1 & 0 & 0 & 0 \\
\hline & Sítio Novo (Prefeitura) & 10 & 57 & 19 & 80 & 88 & 0 & 2 & 3 & 0 & 8 & 0 & 0 & 14 & 0 & 28 & 0 & 0 & 0 & 0 & 0 \\
\hline & Tangará (EMATER) & 8 & 15 & 36 & 62 & 94 & 5 & 0 & 2,5 & 0 & 15 & 0 & 0 & 2,5 & 0 & 2,5 & 9,5 & 0 & 0 & 0 & 0 \\
\hline & Tangará (Açude Trairi) & 6,4 & 20,3 & 31,3 & 88,9 & 71,7 & 7,5 & 0 & 5,3 & 0 & 5,4 & 0 & 0 & 4,8 & 4,2 & 2,3 & 13 & 0 & 0 & 0 & 0 \\
\hline & Tenente Laurentino Cruz (EMATER) & 0 & 0 & 0 & 28,1 & 0 & 0 & 0 & 0 & 0 & 0 & 0 & 0 & 0 & 0 & 0 & 0 & 0 & 0 & 0 & 0 \\
\hline & Triunfo Potiguar (Prefeitura) & 38,2 & 9,5 & 8,5 & 9 & 7 & 0 & 0 & 0 & 0 & 0 & 0 & 0 & 0 & 0 & 0 & 0 & 0 & 0 & 0 & 0 \\
\hline & Triunfo Potiguar (Chá Cacimbas/Serra J. Vale) & 0 & 0 & 21 & 0 & 20 & 10 & 0 & 20 & 0 & 15 & 0 & 0 & 0 & 0 & 0 & 0 & 0 & 0 & 0 & 0 \\
\hline & Triunfo Potiguar (Chá Velha/Serra J. Vale) & 0 & 0 & 0 & 0 & 0 & 0 & 0 & 0 & 0 & 0 & 0 & 0 & 0 & 0 & 0 & 0 & 0 & 0 & 0 & 0 \\
\hline & Alagoa Nova & 23,9 & 53,7 & 11,6 & 30,5 & 21 & 60,7 & 4,4 & 39,2 & 0 & 36,4 & 15,4 & 11 & 23,5 & 18,2 & 8 & 55,1 & 16,1 & 4,2 & 0 & 0 \\
\hline & Barra de Santana & 0 & 9,7 & 5,3 & 17,7 & 5,8 & 28,6 & 0,8 & 11,6 & 0 & 14,2 & 11,7 & 7,4 & 4,8 & 0 & 0,7 & 9,2 & 1,2 & 0 & 0 & 0 \\
\hline & Barra de Santana/Bodocongó & 0 & 15,2 & 4,2 & 17,9 & 4,1 & 31,5 & 0,5 & 8,8 & 0 & 15,8 & 11,1 & 8,2 & 2,4 & 0,4 & 0,5 & 7,5 & 1,9 & 0,5 & 0 & 0 \\
\hline & Boa Vista & 0 & 15 & 8 & 6 & 3,8 & 11,2 & 0 & 9,4 & 0 & 11,5 & 0 & 9,8 & 6 & 0 & 0 & 11,6 & 3,2 & 0 & 0 & 0 \\
\hline & Boqueirão/Açude Boqueirão & 3,4 & 21,2 & 2,5 & 22,1 & 3,1 & 26,6 & 0 & 8,7 & 0 & 8,5 & 6,4 & 8,3 & 3,7 & 0,8 & 1,5 & 7,7 & 0 & 1,6 & 0 & 0 \\
\hline & Cabaceiras & 9,3 & 9,5 & 0 & 9,3 & 4,8 & 23,5 & 0 & 6 & 0 & 10 & 11,2 & 7,9 & 4,6 & 0 & 1,1 & 6,6 & 1,8 & 0 & 0 & 0 \\
\hline & Campina Grande/EMBRAPA & 19,8 & 15 & 8,1 & 40,4 & 8,5 & 46,2 & 2,3 & 31,2 & 0,3 & 25,4 & 17,3 & 21,3 & 29,5 & 12,9 & 5,5 & 57,8 & 20,1 & 4,4 & 0 & 0 \\
\hline & Campina Grande/Santa Terezinha & 14,5 & 15,1 & 7,2 & 42,6 & 8,1 & 36,7 & 2,6 & 21,5 & 1 & 28,3 & 14,6 & 15,3 & 23,7 & 8,5 & 4,5 & 43,4 & 9,8 & 2,2 & 0 & 0 \\
\hline & Campina Grande/São José da Mata & 18,8 & 11,7 & 10,7 & 27,3 & 10 & 39,6 & 6,2 & 22,6 & 0 & 23,2 & 10,2 & 17,8 & 22,9 & 12,7 & 6,8 & 39,5 & 11,2 & 10 & 0 & 0 \\
\hline & Caturité & 19,7 & 0 & 15,8 & 27,5 & 4,9 & 35,8 & 2,6 & 16,5 & 0 & 12,6 & 10,7 & 6,9 & 0 & 7,6 & 0 & 13,6 & 0,8 & 1,3 & 0 & 0 \\
\hline & Caturité/Fazenda Campo de Emas & 3,4 & 11 & 10 & 25 & 9,4 & 21,8 & 0,8 & 14,6 & 2,4 & 12 & 0 & 0 & 0 & 0 & 0 & 0 & 0 & 0 & 0 & 0 \\
\hline & Cubati & 5 & 0 & 5,8 & 15,4 & 5,2 & 12,4 & 0 & 6,6 & 0 & 2,6 & 4,4 & 2 & 7 & 2,8 & 0 & 8,8 & 0 & 0 & 0 & 0 \\
\hline & Lagoa Seca & 20,7 & 30,3 & 15,4 & 46,6 & 19,5 & 57,3 & 5,2 & 40,8 & 1,7 & 42,8 & 23,7 & 24,1 & 58,1 & 25,9 & 11,8 & 71,8 & 23,2 & 11,7 & 0 & 0 \\
\hline & Matinhas & 10,1 & 16,4 & 27,5 & 34,7 & 25,5 & 48,8 & 14,8 & 21,2 & 11,6 & 30,9 & 16 & 14,7 & 43,3 & 22 & 8,1 & 53,8 & 16,6 & 4,3 & 0 & 0,5 \\
\hline & Olivedos & 0 & 5,2 & 6,4 & 15,6 & 6,7 & 8,7 & 0 & 9,1 & 0 & 7,5 & 7,4 & 8,7 & 9 & 2,5 & 0 & 7,3 & 0 & 4,4 & 0 & 0 \\
\hline & Pedra Lavrada & 0 & 0 & 0 & 16,7 & 0 & 0 & 0 & 0 & 0 & 0 & 0 & 0 & 0 & 0 & 0 & 0 & 0 & 0 & 0 & 0 \\
\hline & Pocinhos & 10,6 & 8,7 & 2,2 & 15,4 & 8,1 & 19,3 & 0 & 12,1 & 0 & 9,5 & 6,8 & 13,7 & 29,9 & 8,8 & 2,5 & 15,8 & 5,7 & 1,4 & 0 & 0 \\
\hline & Queimadas & 16,1 & 16,8 & 7,8 & 28,9 & 16,6 & 43,9 & 5,7 & 28,3 & 0 & 15 & 13,3 & 12,7 & 25,6 & 8,2 & 9,4 & 47,3 & 5,1 & 0 & 0 & 0 \\
\hline
\end{tabular}




\begin{tabular}{|c|c|c|c|c|c|c|c|c|c|c|c|c|c|c|c|c|c|c|c|c|c|}
\hline 2007 & Estação & s21 & s22 & $\mathbf{s} 23$ & s24 & $s 25$ & $s 26$ & $\mathbf{s 2 7}$ & $s 28$ & $s 29$ & $\mathbf{s} 30$ & s31 & s32 & s33 & s34 & s35 & s36 & s37 & s38 & s39 & $s 40$ \\
\hline & do Seridó & 1,9 & 0 & 7,1 & 20,1 & 6,7 & 9,4 & 0 & 8,1 & 0 & 5,2 & 11,2 & 3,2 & 11,2 & 1,8 & 0,8 & 11,5 & 1,1 & 1 & 0 & 0 \\
\hline
\end{tabular}

\begin{tabular}{|c|c|c|c|c|c|c|c|c|c|c|c|c|c|}
\hline 2007 & Estação & s41 & $s 42$ & s43 & s44 & s45 & s46 & s47 & s48 & $s 49$ & s50 & s51 & s52 \\
\hline & Acari (Particular) & 0 & 0 & 0 & 0 & 0 & 0 & 0 & 0 & 0 & 0 & 0 & 0 \\
\hline & Acari (Açude Gargalheiras) & 0 & 0 & 0 & 0 & 0 & 0 & 0 & 0 & 0 & 0 & 0 & 0 \\
\hline & Assu (Particular) & 0 & 0 & 0 & 0 & 0 & 0 & 0 & 0 & 0,4 & 0 & 30,7 & 4,7 \\
\hline & Assu (EMATER/Sítio Casa Forte) & 0 & 0 & 0 & 0 & 0 & 0 & 0,3 & 0 & 0 & 0 & 51,9 & 1,5 \\
\hline & Afonso Bezerra (EMATER) & 0 & 0 & 0 & 0 & 0 & 0 & 0 & 0 & 0 & 0 & 0 & 0 \\
\hline & Afonso Bezerra (Assentamento Santa Maria) & 0 & 0 & 0 & 0 & 0 & 0 & 0 & 0 & 0 & 0 & 0 & 0 \\
\hline & Almino Afonso (Particular - Ex Sítio Milagres) & 0 & 0 & 0 & 0 & 0 & 0 & 0 & 0 & 0 & 0 & 0 & 0 \\
\hline & Angicos (Prefeitura) & 0 & 0 & 0 & 0 & 0 & 0 & 0 & 0 & 0 & 0 & 0 & 0 \\
\hline & Campo Grande (Particular) & 0 & 17,3 & 0 & 0 & 0 & 0 & 0 & 0 & 0 & 0 & 0 & 0 \\
\hline & Campo Grande (Particular 2) & 0 & 0 & 0 & 0 & 0 & 0 & 0 & 0 & 0 & 4,2 & 0 & 0 \\
\hline & Barcelona (Particular) & 0 & 0 & 0 & 0 & 0 & 7 & 0 & 0 & 0 & 0 & 0 & 0 \\
\hline & Bom Jesus (Particular) & 0 & 0 & 0 & 3,6 & 0 & 0 & 0 & 0 & 0 & 0 & 0 & 0 \\
\hline & Caiçara do Rio do Vento (Particular) & 0 & 0 & 0 & 0 & 0 & 0 & 0 & 0 & 0 & 3,2 & 0 & 0 \\
\hline & Caicó (Batalhão) & 0 & 0 & 0 & 0 & 0 & 0 & 0 & 0 & 0 & 0 & 0 & 0 \\
\hline & Caicó (Açude Mundo Novo - EMPARN) & 0 & 0 & 0 & 0 & 0 & 0 & 0 & 0 & 0 & 0 & 0 & 0 \\
\hline & Caicó (Palma) & 0 & 0 & 0 & 0 & 0 & 0 & 0 & 0 & 0 & 0 & 0 & 0 \\
\hline & Caicó (Açude Itans) & 0 & 0 & 0 & 0 & 0 & 0 & 0 & 0 & 0 & 0 & 11,2 & 0 \\
\hline & Caicó (EMATER) & 0 & 0 & 0 & 0 & 0 & 0 & 0 & 0 & 0 & 0 & 0 & 0 \\
\hline & Campo Redondo (EMATER) & 0 & 0 & 0 & 0 & 0 & 15 & 0 & 0 & 0 & 0 & 9,6 & 0 \\
\hline & Campo Redondo (Polícia Rodoviária) & 0 & 0 & 0 & 0 & 0 & 0 & 0 & 0 & 0 & 0 & 0 & 0 \\
\hline & Cerro Corá (EMATER) & 0 & 0 & 0 & 0 & 0 & 0 & 0 & 0 & 0 & 0 & 0 & 0 \\
\hline & Coronel Ezequiel (Particular) & 0 & 0 & 0 & 0 & 0 & 29 & 0 & 0 & 0 & 0 & 0 & 6 \\
\hline & Cruzeta (Base Física da EMPARN) & 0 & 0 & 0 & 0 & 0 & 0 & 0 & 0 & 0,4 & 0 & 0,8 & 0 \\
\hline & Currais Novos (CERCEL) & 0 & 0 & 0 & 0 & 0 & 0 & 0 & 0 & 0 & 0 & 0 & 0 \\
\hline & Fernando Pedroza (EMATER) & 0 & 0 & 0 & 0 & 0 & 0 & 0 & 0 & 0 & 0 & 3 & 0 \\
\hline & Florânia (INMET) & 0 & 0 & 0 & 0 & 0 & 2 & 0 & 0 & 2,4 & 19,2 & 0,5 & 0 \\
\hline & Florânia (Sítio Jucuri) & 0 & 0 & 0 & 0 & 0 & 0 & 0 & 0 & 0 & 15 & 0 & 0 \\
\hline & Ielmo Marinho (Prefeitura) & 0 & 0 & 0 & 0 & 0 & 0 & 0 & 0 & 0 & 0 & 0 & 0 \\
\hline & Itajá (EMATER) & 0 & 0 & 0 & 0 & 0 & 0 & 0 & 0 & 0 & 0 & 0 & 0 \\
\hline & Jaçanã (EMATER) & 0 & 0 & 0 & 0 & 0 & 27,6 & 0 & 0 & 0 & 0 & 0 & 0 \\
\hline & Janduís (EMATER) & 0 & 0 & 0 & 8 & 0 & 0 & 0 & 0 & 1 & 0 & 1 & 0 \\
\hline & Boa Saúde (EMATER) & 0 & 0 & 0 & 0 & 1 & 7,2 & 6,9 & 0 & 0 & 0 & 0 & 0 \\
\hline
\end{tabular}




\begin{tabular}{|c|c|c|c|c|c|c|c|c|c|c|c|c|c|}
\hline 2007 & Estação & s41 & $s 42$ & s43 & s44 & $s 45$ & s46 & s47 & s48 & $s 49$ & s50 & s51 & s52 \\
\hline & Japi (Particular) & 0 & 0 & 0 & 0 & 0 & 47,4 & 0 & 0 & 0 & 0 & 0 & 0 \\
\hline & Japi (EMATER) & 0 & 0 & 0 & 0 & 0 & 42,5 & 0 & 0 & 0 & 12 & 0 & 0 \\
\hline & Jardim de Angicos (EMATER) & 0 & 0 & 0 & 0 & 0 & 0 & 0 & 0 & 0 & 0 & 0 & 0 \\
\hline & Lagoa d'Anta (Prefeitura) & 4,4 & 0 & 0 & 0 & 0 & 48,5 & 0 & 0 & 0 & 0 & 0 & 0 \\
\hline & Lagoa de Pedras (Prefeitura) & 2,5 & 0 & 2,2 & 0 & 2,5 & 13,2 & 9,4 & 0 & 0 & 1,3 & 0 & 8,4 \\
\hline & Lagoa de Velhos (Delegacia) & 0 & 0 & 0 & 0 & 0 & 3,9 & 0 & 0 & 0 & 0 & 0 & 0 \\
\hline & Lagoa Nova (EMATER/Sítio Humaitá) & 0 & 0 & 0 & 0 & 0 & 0 & 0 & 0 & 0 & 0 & 0 & 0 \\
\hline & Lagoa Salgada (Delegacia) & 0 & 0 & 1 & 0 & 5,1 & 7,5 & 5,3 & 13,2 & 0 & 0 & 0 & 0 \\
\hline & Lajes (Prefeitura) & 0 & 0 & 0 & 0 & 0 & 0 & 0 & 0 & 0 & 0 & 0 & 0 \\
\hline & Lajes Pintadas (Prefeitura) & 0 & 0 & 0 & 0 & 0 & 10,5 & 0,5 & 0 & 0 & 0 & 0 & 0 \\
\hline & Messias Targino (Prefeitura) & 0 & 0 & 0 & 0 & 0 & 0 & 0 & 0 & 0 & 0 & 0 & 0 \\
\hline & Monte Alegre (EMATER) & 6,2 & 0 & 0,2 & 0 & 4,2 & 13 & 7 & 0 & 0 & 0 & 0 & 0 \\
\hline & Monte das Gameleiras (EMATER) & 0 & 0 & 0 & 0 & 0 & 55 & 1 & 0 & 0 & 69,3 & 0 & 0 \\
\hline & Paraú (Prefeitura) & 0 & 0 & 0 & 28,2 & 0 & 0 & 0 & 0 & 0 & 0 & 0 & 0 \\
\hline & Paraú (Sindicato) & 0 & 0 & 0 & 0 & 0 & 0 & 0 & 0 & 0 & 0 & 0 & 0 \\
\hline & Passa e Fica (Prefeitura) & 0 & 0 & 0 & 0 & 0 & 33 & 0 & 0 & 0 & 14 & 15,7 & 0 \\
\hline & Patu (Particular) & 0 & 0 & 0 & 0 & 0 & 0 & 0 & 0 & 0 & 0 & 0 & 0 \\
\hline & Santa Maria (Sindicato dos Trabalhadores Rurais) & 0 & 0 & 0 & 0 & 0 & 16,6 & 0 & 0 & 0 & 0 & 0 & 0 \\
\hline & Pedra Preta (EMATER) & 0 & 0 & 0 & 0 & 0 & 30 & 0 & 0 & 0 & 0 & 0 & 0 \\
\hline & Pedro Avelino (Particular) & 0 & 0 & 0 & 0,8 & 0 & 2,5 & 0 & 0 & 2,6 & 0 & 0 & 0 \\
\hline & Pedro Avelino (Base Física da EMPARN) & 0 & 0 & 0 & 0 & 0 & 30,8 & 0 & 0 & 0 & 0 & 0 & 0 \\
\hline & Riachuelo (EMATER) & 0 & 0 & 0 & 0 & 0 & 0 & 0 & 0 & 0 & 0 & 0 & 0 \\
\hline & Rui Barbosa (EMATER) & 0 & 0 & 0 & 0 & 0 & 21 & 0 & 0 & 0 & 0 & 0 & 0 \\
\hline & Santa Cruz (EMATER) & 0 & 0 & 0 & 0 & 0 & 0 & 0 & 20,5 & 0 & 0 & 0 & 0 \\
\hline & Santana do Matos (EMATER) & 0 & 0 & 0 & 0 & 0 & 0 & 0 & 0 & 0 & 46,2 & 0 & 0 \\
\hline & Santana do Matos (Barão de Serra Branca) & 0 & 0 & 0 & 0 & 0 & 0 & 0 & 0 & 0 & 0 & 0 & 0 \\
\hline & Santana do Matos (São José da Passagem) & 0 & 0 & 0 & 0 & 0 & 0 & 0 & 0 & 0 & 0 & 0 & 0 \\
\hline & São Bento do Trairi (Prefeitura) & 0 & 0 & 0 & 0 & 0 & 24,5 & 0 & 0 & 0 & 0 & 0 & 0 \\
\hline & São José do Campestre (EMATER) & 0 & 0 & 0 & 0 & 0 & 0 & 0 & 0 & 0 & 0 & 0 & 0 \\
\hline & São Paulo do Potengi (EMATER) & 0,8 & 0 & 0,3 & 0 & 0,4 & 12 & 0,6 & 0 & 0 & 3,9 & 0 & 0 \\
\hline & São Pedro (EMATER) & 1,1 & 0 & 0 & 0 & 0 & 18,6 & 7,5 & 0 & 0 & 2,4 & 0,2 & 0 \\
\hline & São Rafael (EMATER) & 0 & 0 & 0 & 0 & 0 & 0 & 0 & 0 & 0 & 2 & 11 & 11 \\
\hline & São Tomé (EMATER) & 0 & 0 & 0 & 0 & 0 & 4 & 0 & 0 & 0 & 0 & 0 & 0 \\
\hline & São Vicente (EMATER - Ex Particular) & 0 & 0 & 0 & 0 & 0 & 0 & 0 & 0 & 0 & 0 & 0 & 13,5 \\
\hline & São Vicente (EMATER - Extinto) & 0 & 0 & 0 & 0 & 0 & 0 & 0 & 0 & 0 & 0 & 0 & 13,5 \\
\hline & Senador Eloi de Souza (Particular) & 0 & 0 & 0 & 0 & 0 & 10 & 5 & 0 & 0 & 0 & 0 & 0 \\
\hline
\end{tabular}




\begin{tabular}{|c|c|c|c|c|c|c|c|c|c|c|c|c|c|c|c|c|c|c|c|c|c|c|}
\hline 2007 & Estação & s41 & s42 & s43 & s44 & s45 & s46 & s47 & $s 48$ & 549 & s5 & & s51 s & 552 & & & & & & & & \\
\hline & Serra de São Bento (EMATER) & 0 & 0 & 0 & 0 & 0 & 0 & 0 & 0 & 0 & 0 & & 0 & 0 & & & & & & & & \\
\hline & Serrinha (EMATER) & 3,8 & 0 & 0 & 0 & 0 & 24,5 & 5,5 & 0 & 0 & 0 & & 0 & 6,6 & & & & & & & & \\
\hline & Sítio Novo (Prefeitura) & 0 & 0 & 0 & 0 & 0 & 7 & 0 & 0 & 0 & 22 & & 0 & 0 & & & & & & & & \\
\hline & Tangará (EMATER) & 2 & 0 & 0 & 0 & 0 & 3,5 & 0 & 0 & 0 & 42 & & 0 & 0 & & & & & & & & \\
\hline & Tangará (Açude Trairi) & 3,3 & 0 & 0 & 1,2 & 0 & 16,6 & 0 & 0 & 0 & 3,7 & & 0 & 0 & & & & & & & & \\
\hline & Tenente Laurentino Cruz (EMATER) & 0 & 0 & 0 & 0 & 0 & 0 & 0 & 0 & 0 & 0 & & 0 & 0 & & & & & & & & \\
\hline & Triunfo Potiguar (Prefeitura) & 0 & 0 & 0 & 0 & 0 & 0 & 0 & 0 & 0 & 8,4 & & 0 & 0 & & & & & & & & \\
\hline & Triunfo Potiguar (Chá Cacimbas/Serra J. Vale) & 0 & 0 & 0 & 0 & 0 & 0 & 0 & 0 & 0 & 0 & & 35 & 0 & & & & & & & & \\
\hline & Triunfo Potiguar (Chá Velha/Serra J. Vale) & 0 & 0 & 0 & 0 & 21 & 0 & 0 & 0 & 0 & 31 & & 0 & 25,2 & & & & & & & & \\
\hline & Alagoa Nova & 1,5 & 0 & 0 & 0 & 0 & 5 & 0 & 0 & 0 & 20 & & 0 & 1 & & & & & & & & \\
\hline & Barra de Santana & 0 & 0 & 0 & 0,7 & 0 & 0 & 2,7 & 0 & 0 & 10 & & 0 & 8,5 & & & & & & & & \\
\hline & Barra de Santana/Bodocongó & 0 & 0 & 0 & 0 & 0 & 0 & 2,5 & 0 & 0 & 9 & & 0 & 7,8 & & & & & & & & \\
\hline & Boa Vista & 0 & 0 & 0 & 0 & 0 & 0 & 1,6 & 0 & 0 & 0 & & 0 & 0 & & & & & & & & \\
\hline & Boqueirão/Açude Boqueirão & 0 & 0 & 0 & 0,3 & 0 & 0 & 2,6 & 0 & 0 & 14 , & & 0 & 1,5 & & & & & & & & \\
\hline & Cabaceiras & 0 & 0 & 0 & 0 & 0 & 0 & 0 & 0 & 0 & 4 & & 0 & 1,5 & & & & & & & & \\
\hline & Campina Grande/EMBRAPA & 1,9 & 0 & 0,5 & 1,2 & 1,2 & 0,8 & 5,8 & 0 & 2,1 & $1, \varepsilon$ & & 0 & 0 & & & & & & & & \\
\hline & Campina Grande/Santa Terezinha & 1,1 & 0 & 0,9 & 0,7 & 0,7 & 1 & 6,5 & 0 & 0 & 2, & & 0 & 12,6 & & & & & & & & \\
\hline & Campina Grande/São José da Mata & 2,4 & 0 & 0 & 0,8 & 0 & 0 & 2,9 & 0 & 0 & 1,2 & & 0 & 4,7 & & & & & & & & \\
\hline & Caturité & 0 & 0 & 0 & 0 & 0 & 0 & 3,5 & 0 & 0 & 0 & & 0 & 0 & & & & & & & & \\
\hline & Caturité/Fazenda Campo de Emas & 0 & 0 & 0 & 0 & 0 & 0 & 0 & 0 & 0 & 0 & & 0 & 0 & & & & & & & & \\
\hline & Cubati & 0 & 0 & 0 & 0 & 0 & 0 & 0 & 0 & 0 & 0 & & 0 & 0 & & & & & & & & \\
\hline & Lagoa Seca & 7,8 & 0 & 0,8 & 2,8 & 0,5 & 3,6 & 2,2 & 0 & 1,4 & 4,6 & & 0 & 10,4 & & & & & & & & \\
\hline & Matinhas & 3,2 & 0 & 0,1 & 1,9 & 0,7 & 7,7 & 0,9 & 0 & 1,7 & 11 , & & 0,7 & 15,7 & & & & & & & & \\
\hline & Olivedos & 0 & 0 & 0 & 0 & 0 & 0 & 0 & 0 & 0 & 0 & & 0 & 5,2 & & & & & & & & \\
\hline & Pedra Lavrada & 0 & 0 & 0 & 0 & 0 & 0 & 0 & 0 & 0 & 0 & & 0 & 0 & & & & & & & & \\
\hline & Pocinhos & 1,8 & 0 & 0 & 0 & 1,2 & 4,1 & 3 & 0 & 0 & 4, & & 0 & 2,3 & & & & & & & & \\
\hline & Queimadas & 0 & 0 & 0 & 0 & 0 & 0 & 0 & 0 & 47,3 & 5, & & 0 & 0 & & & & & & & & \\
\hline & Seridó/São Vicente do Seridó & 0 & 0 & 0 & 0 & 0 & 0 & 0 & 0 & 0 & 0 & & 0 & 1,7 & & & & & & & & \\
\hline & Soledade & 0 & 0 & 0 & 0 & 0 & 3,5 & 0 & 0 & 0 & 2,5 & & 0 & 0 & & & & & & & & \\
\hline 2008 & Estação & s1 & s2 & s3 & s4 & $\mathbf{s}^{5}$ & 5 & $s 6$ & s7 & s8 & s9 & s10 & $s 11$ & s12 & s13 & s14 & s15 & s16 & s17 & s18 & s19 & s20 \\
\hline & Acari (Particular) & 0 & 0 & 0 & 34,5 & 14 & 4,6 & 0 & 0 & 0 & 23,2 & 20,5 & 9,2 & 195,2 & 98,6 & 96,3 & 105,2 & 20,5 & 26,4 & 41,1 & 44,2 & 19,6 \\
\hline & Acari (Açude Gargalheiras) & 0 & 0 & 0 & 68 & 0 & 0 & 0 & 0 & 0 & 38 & 63 & 46 & 220 & 151 & 97 & 98 & 27 & 53 & 115 & 64 & 16 \\
\hline & Assu (Particular) & 0 & 0 & 3,4 & 18,3 & 12 , & 2,3 & 0 & 0 & 1,1 & 13,5 & 13,1 & 14 & 54,7 & 123,1 & 137,7 & 62,2 & 107,9 & 19,8 & 38,2 & 108,6 & 46,8 \\
\hline & Assu (EMATER/Sítio Casa Forte) & 0 & 1,1 & 15,9 & 9,4 & 6, & 9 & 0 & 0 & 0,7 & 12,1 & 6 & 32,2 & 100,8 & 78,8 & 132,3 & 65,2 & 62,9 & 8,2 & 23 & 55,2 & 55,3 \\
\hline & Afonso Bezerra (EMATER) & 0 & 0 & 0 & 0 & 44 & 14 & 0 & 0 & 0 & 18 & 2,5 & 4 & 73 & 135 & 209 & 62 & 37,5 & 12 & 12 & 72 & 18 \\
\hline
\end{tabular}




\begin{tabular}{|c|c|c|c|c|c|c|c|c|c|c|c|c|c|c|c|c|c|c|c|c|c|}
\hline 2008 & Estação & s1 & s2 & s3 & s4 & s5 & s6 & s7 & s8 & s9 & s10 & s11 & s12 & $\mathbf{s} 13$ & $s 14$ & $\mathbf{s} 15$ & s16 & s17 & s18 & $\mathbf{s 1 9}$ & s20 \\
\hline & Afonso Bezerra (Assentamento Santa Maria) & 0 & 0 & 0 & 0 & 6,1 & 0 & 7,7 & 0 & 37,1 & 0 & 30,8 & 97,5 & 148,9 & 197,1 & 105,7 & 41,6 & 36,8 & 35,1 & 68,1 & 9,7 \\
\hline & Almino Afonso (Particular - Ex Sítio Milagres) & 0 & 0 & 60,7 & 99,5 & 20,3 & 3 & 11,5 & 16,4 & 18 & 7,4 & 59,6 & 179,6 & 64 & 227 & 122,6 & 18,2 & 10,5 & 8,2 & 64,8 & 13,2 \\
\hline & Angicos (Prefeitura) & 0 & 0 & 15,8 & 13,5 & 61,7 & 0 & 0,5 & 0 & 23 & 8,6 & 17 & 68,2 & 56,3 & 104 & 45,1 & 19,7 & 4,4 & 10 & 41,8 & 7,5 \\
\hline & Campo Grande (Particular) & 0 & 0 & 1 & 80,6 & 29,7 & 15,3 & 17,3 & 7,3 & 7,5 & 3,6 & 31 & 115,8 & 47 & 112,6 & 46,6 & 47,2 & 2,3 & 15,6 & 10,2 & 13,5 \\
\hline & Campo Grande (Particular 2) & 0 & 2 & 6,5 & 83 & 22 & 16,3 & 18 & 4,2 & 12,9 & 3 & 33,9 & 132,5 & 32,3 & 103,8 & 90,7 & 4 & 13,8 & 6,5 & 61,8 & 11,2 \\
\hline & Barcelona (Particular) & 0 & 0 & 7 & 8,6 & 1 & 0 & 0 & 0 & 0 & 24,5 & 24 & 27,5 & 90,5 & 40,5 & 51 & 13,5 & 73 & 20 & 19 & 9 \\
\hline & Bodó (EMATER/TRF P/Delegacia) & 0 & 0 & 4,5 & 8 & 14,5 & 0 & 0 & 0 & 0 & 0 & 54 & 166,5 & 245 & 50,5 & 29 & 30 & 38,9 & 3,8 & 63 & 12 \\
\hline & Bom Jesus (Particular) & 0 & 7,7 & 58,3 & 10,4 & 2 & 0 & 0 & 0 & 0 & 0 & 37,6 & 34,6 & 71,4 & 108,3 & 37,3 & 22,6 & 79 & 62,8 & 69,1 & 18,3 \\
\hline & Caiçara do Rio do Vento (Particular) & 0 & 0 & 22 & 0 & 0 & 0 & 0 & 0 & 0 & 49,5 & 67,2 & 36,8 & 62,8 & 67,5 & 72 & 32,3 & 39 & 0 & 43 & 0 \\
\hline & Caicó (Batalhão) & 0 & 0 & 6 & 24 & 3 & 17 & 34 & 33,7 & 48,5 & 1,5 & 7 & 98,5 & 183 & 144 & 2 & 20 & 87 & 0 & 28 & 20 \\
\hline & Caicó (Açude Mundo Novo - EMPARN) & 0 & 0 & 6,6 & 45,5 & 8,5 & 0 & 12,1 & 11 & 84,7 & 5,9 & 10,5 & 77,6 & 136,6 & 150,4 & 48,7 & 13,5 & 26,5 & 21,1 & 30 & 2,4 \\
\hline & Caicó (Palma) & 0 & 0 & 6 & 21,2 & 40,2 & 0 & 27,2 & 15 & 12 & 18,2 & 9,6 & 98,4 & 109,4 & 207,2 & 48,4 & 94 & 45 & 33 & 69,4 & 5 \\
\hline & Caicó (Açude Itans) & 0 & 0 & 9,9 & 28,6 & 57,1 & 6,2 & 0 & 23,2 & 57 & 1,3 & 29 & 65,9 & 114 & 194,6 & 59,2 & 9,3 & 31,7 & 16,8 & 57,8 & 18,3 \\
\hline & Caicó (EMATER) & 0 & 0 & 16,5 & 16,5 & 42,8 & 7 & 25 & 21,4 & 59,8 & 1,2 & 11,8 & 69,6 & 138,7 & 213 & 55 & 17 & 8 & 44 & 47 & 20 \\
\hline & Campo Redondo (EMATER) & 0 & 2 & 2 & 15 & 0 & 0 & 1 & 0 & 6,7 & 0 & 17,6 & 181,4 & 154 & 79,6 & 31,5 & 63 & 56 & 22,7 & 39,5 & 20,8 \\
\hline & Campo Redondo (Polícia Rodoviária) & 0 & 0 & 12,8 & 19,1 & 0 & 0 & 0 & 0 & 0 & 0 & 6,9 & 153,2 & 147,7 & 81,6 & 33,4 & 45,8 & 69,5 & 23,1 & 51 & 17,1 \\
\hline & Cerro Corá (EMATER) & 0 & 0 & 12 & 75 & 3,7 & 0 & 0 & 0 & 3 & 18,7 & 85,5 & 196,4 & 184 & 91,7 & 66,5 & 4,8 & 47,8 & 33,8 & 19 & 47,2 \\
\hline & Coronel Ezequiel (Particular) & 0 & 0 & 0 & 0 & 0 & 9 & 0 & 0 & 33 & 0 & 41,1 & 243,5 & 56,7 & 107,3 & 18,2 & 13 & 38 & 6 & 101 & 26 \\
\hline & Cruzeta (Base Física da EMPARN) & 0,9 & 0 & 2,9 & 34,1 & 5,2 & 0 & 0 & 5,1 & 44,4 & 35,7 & 14,8 & 224,4 & 81,9 & 66 & 30,8 & 10,3 & 25,3 & 10,5 & 14,4 & 7,2 \\
\hline & Currais Novos (CERCEL) & 0 & 0 & 31 & 25,8 & 0 & 0 & 0 & 0 & 17,5 & 5 & 5,4 & 36,5 & 67,4 & 151,9 & 69 & 11,2 & 28,5 & 7 & 23,9 & 71,8 \\
\hline & Fernando Pedroza (EMATER) & 2,9 & 0 & 16 & 3,1 & 96 & 0 & 24,5 & 0 & 5,5 & 6,1 & 16,4 & 99,6 & 69,3 & 146,9 & 40,5 & 7,5 & 13,3 & 0 & 43,7 & 21,5 \\
\hline & Florânia (INMET) & 0 & 0 & 9 & 45,6 & 64,5 & 0 & 8,6 & 0 & 22,9 & 27,7 & 7,7 & 125,2 & 130,7 & 175,4 & 69,9 & 67,2 & 29,1 & 12,3 & 58,1 & 21,6 \\
\hline & Florânia (Sítio Jucuri) & 0 & 0 & 6,8 & 46,5 & 74,5 & 0 & 14,4 & 2,2 & 29,2 & 41,5 & 7,1 & 146,3 & 118,9 & 231,8 & 65,9 & 66,1 & 18,9 & 13,8 & 75,2 & 4,5 \\
\hline & Itajá (EMATER) & 0 & 0 & 0 & 0 & 0 & 25 & 0 & 1,5 & 23,5 & 6,3 & 36,5 & 49 & 166 & 65 & 72 & 108,5 & 94,5 & 48,2 & 0 & 0 \\
\hline & Jaçanã (EMATER) & 0 & 0 & 17,5 & 64,4 & 15,8 & 0 & 3,4 & 0 & 54,4 & 0 & 50,3 & 119,1 & 94,5 & 61,1 & 13,6 & 41 & 47 & 48 & 69,1 & 21,9 \\
\hline & Janduís (EMATER) & 0 & 0 & 16 & 63,4 & 31,6 & 0 & 27,8 & 16,4 & 89,6 & 47,4 & 30,6 & 176,4 & 62,4 & 64 & 83,2 & 14,8 & 14,6 & 48 & 42 & 2,1 \\
\hline & Boa Saúde (EMATER) & 0 & 0 & 44 & 1,4 & 0,3 & 0 & 0 & 0 & 0 & 0 & 29,6 & 79,7 & 77 & 26,4 & 43 & 15,7 & 56,4 & 35,8 & 36 & 25,7 \\
\hline & Japi (Particular) & 0 & 0 & 10,4 & 0 & 0 & 0 & 0 & 0 & 0 & 0 & 30,4 & 273,6 & 111,8 & 108,4 & 20,8 & 167,2 & 6,4 & 15,6 & 52,8 & 6,2 \\
\hline & Japi (EMATER) & 0 & 0 & 9,5 & 1 & 16,7 & 0 & 0 & 0 & 0 & 0 & 29,9 & 230,4 & 139 & 64,5 & 13,7 & 145,4 & 33 & 10,8 & 49 & 17 \\
\hline & Jardim de Angicos (EMATER) & 0 & 0 & 7 & 0 & 0 & 0 & 0 & 0 & 0 & 12 & 57,5 & 39 & 120,1 & 60,1 & 85,5 & 50 & 52 & 7 & 0 & 18,5 \\
\hline & Lagoa de Pedras (Prefeitura) & 0 & 0 & 43 & 0 & 1,2 & 0 & 2,3 & 0 & 14,8 & 0 & 44,6 & 97,5 & 86,6 & 21,2 & 61,6 & 39,1 & 41,2 & 84,5 & 70,3 & 52,8 \\
\hline & Lagoa de Velhos (Delegacia) & 0 & 0 & 6,4 & 8,6 & 14,7 & 0 & 0,5 & 0 & 0 & 0 & 41,7 & 32,2 & 96,2 & 36 & 24,3 & 28,1 & 107,9 & 27,6 & 67,7 & 12,9 \\
\hline & Lagoa Nova (Assentamento Santana/Sítio de Dentro) & 0 & 0 & 0 & 70 & 20,1 & 0 & 0 & 0 & 0 & 0 & 53 & 147,9 & 94,1 & 140,9 & 6 & 0 & 14 & 9,7 & 67,9 & 8,8 \\
\hline & Lagoa Salgada (Delegacia) & 0 & 0 & 37,8 & 0 & 0 & 0 & 0 & 0 & 0 & 1,1 & 52,5 & 82,8 & 27,5 & 19,5 & 52,3 & 12,1 & 16 & 53,6 & 100 & 47,9 \\
\hline & Lajes (Prefeitura) & 0 & 0 & 1 & 6 & 108,2 & 0 & 0 & 0 & 1,3 & 20,9 & 9,1 & 73,5 & 97,5 & 194,4 & 56,5 & 70,5 & 20,3 & 18,4 & 10 & 0,5 \\
\hline & Lajes Pintadas (Prefeitura) & 0 & 0 & 6,6 & 20,5 & 0 & 0 & 0 & 0 & 5,5 & 0 & 24,2 & 183,6 & 92,7 & 37,6 & 6,1 & 37,5 & 29,6 & 42,1 & 65,3 & 20,5 \\
\hline
\end{tabular}




\begin{tabular}{|c|c|c|c|c|c|c|c|c|c|c|c|c|c|c|c|c|c|c|c|c|c|}
\hline 2008 & Estação & s1 & s2 & s3 & s4 & s5 & s6 & s7 & s8 & s9 & s10 & s11 & s12 & $s 13$ & s14 & s15 & s16 & s17 & s18 & s19 & s20 \\
\hline & Messias Targino (Prefeitura) & 0 & 0 & 27 & 76,1 & 35,7 & 23,1 & 27 & 0,3 & 3,1 & 0 & 40,1 & 162,3 & 57,2 & 79 & 94,3 & 0 & 38,2 & 30 & 45,5 & 0 \\
\hline & Monte Alegre (EMATER) & 0 & 0 & 90 & 3,2 & 2 & 0 & 14,4 & 0 & 1 & 3 & 14 & 62,6 & 58,6 & 18 & 84,6 & 15 & 50,4 & 114 & 27 & 57,3 \\
\hline & Monte das Gameleiras (EMATER) & 0 & 0 & 17 & 27,3 & 20 & 0 & 0 & 0 & 0 & 0 & 104 & 38,2 & 104,9 & 16 & 20,4 & 0 & 45,8 & 32 & 8,9 & 20,5 \\
\hline & Paraú (Sindicato) & 0 & 4,7 & 0 & 103,8 & 0 & 0 & 11 & 1,9 & 5,1 & 9,5 & 43,8 & 92,1 & 122 & 202,2 & 24,4 & 14,3 & 7,1 & 42,2 & 41,5 & 32,2 \\
\hline & Passa e Fica (Prefeitura) & 0 & 0 & 40,2 & 7,1 & 0 & 0 & 0 & 4,2 & 6 & 0 & 99,7 & 147,1 & 79,4 & 50,1 & 58,1 & 29,6 & 43,2 & 38,7 & 50,8 & 31,1 \\
\hline & Patu (Particular) & 0 & 0 & 61 & 90 & 39 & 20,4 & 0 & 3 & 39 & 2 & 38,2 & 176,2 & 87 & 258,4 & 277 & 5,6 & 15,2 & 18 & 92 & 10 \\
\hline & Santa Maria (Sindicato dos Trabalhadores Rurais) & 0 & 0 & 27,3 & 17 & 0 & 0 & 0 & 0 & 0 & 0 & 32,2 & 35,2 & 39,9 & 32 & 73,3 & 18,3 & 35 & 66,7 & 20 & 32,9 \\
\hline & Pedra Preta (EMATER) & 0 & 0 & 3 & 0 & 0 & 0 & 0 & 0 & 7 & 37,5 & 56 & 48,5 & 38,5 & 100,5 & 61 & 27 & 24,5 & 26 & 38 & 0 \\
\hline & Pedro Avelino (Particular) & 0 & 0 & 0 & 0 & 0 & 0 & 0 & 0 & 0 & 0 & 0 & 0 & 0 & 1,2 & 0 & 0 & 0 & 1 & 26,6 & 0,8 \\
\hline & Pedro Avelino (Base Física da EMPARN) & 0 & 0 & 1,9 & 0 & 54,9 & 0 & 13 & 0 & 0 & 21,7 & 23,8 & 27,9 & 156 & 46,2 & 35,2 & 28,4 & 5,3 & 3,7 & 35,9 & 3,2 \\
\hline & Riachuelo (EMATER) & 0 & 0 & 31,8 & 0 & 0 & 0 & 0 & 0 & 0 & 0 & 50 & 40 & 34,6 & 13 & 87,5 & 49,5 & 63 & 38,9 & 51 & 6 \\
\hline & Rui Barbosa (EMATER) & 0 & 0 & 10,8 & 14,1 & 0 & 0 & 0 & 0 & 0 & 12,9 & 34,9 & 37,2 & 66,5 & 39,8 & 59,2 & 24 & 73,2 & 25,6 & 8,2 & 14 \\
\hline & Santa Cruz (EMATER) & 0 & 0 & 0 & 23,8 & 8,1 & 0 & 0 & 0 & 4,2 & 0 & 16,5 & 101,2 & 127,2 & 89,4 & 25,9 & 33 & 34,7 & 27,3 & 42,3 & 12 \\
\hline & Santana do Matos (EMATER) & 0 & 0 & 0 & 0 & 0 & 0 & 0 & 0 & 0 & 14,7 & 46,5 & 189 & 221,7 & 266,5 & 132,2 & 18 & 11 & 71 & 5 & 7 \\
\hline & Santana do Matos (Barão de Serra Branca) & 0 & 0 & 0 & 0 & 0 & 0 & 0 & 0 & 11,5 & 7 & 31 & 194,6 & 150,4 & 139,2 & 56 & 5 & 12,3 & 17 & 32,8 & 7,4 \\
\hline & Santana do Matos (São José da Passagem) & 0 & 0 & 0 & 0 & 0 & 0 & 0 & 0 & 0 & 30 & 38,9 & 47,7 & 94,5 & 66 & 77 & 38 & 27,3 & 0 & 91,2 & 80 \\
\hline & São Bento do Trairi (Prefeitura) & 0 & 0 & 8,7 & 7,3 & 20,3 & 0 & 0 & 0 & 3,8 & 0 & 22,6 & 268,8 & 106,9 & 24,5 & 41,4 & 63,1 & 54,8 & 20,3 & 72,6 & 30,3 \\
\hline & São José do Campestre (EMATER) & 0 & 0 & 11,2 & 3 & 2 & 0 & 0 & 0 & 3 & 0 & 38,1 & 65,7 & 54,6 & 19,9 & 55,6 & 3 & 22 & 30 & 42 & 42,5 \\
\hline & São Paulo do Potengi (EMATER) & 0 & 0 & 16,7 & 7,3 & 0,2 & 0 & 0 & 0 & 0 & 0,2 & 62 & 26 & 136,8 & 3 & 72 & 37,8 & 66,1 & 64,2 & 39,2 & 9 \\
\hline & São Pedro (EMATER) & 0,8 & 0 & 21,3 & 5,1 & 0 & 0 & 0,3 & 0 & 0,2 & 0,2 & 81,5 & 13 & 68,9 & 17,6 & 93 & 32,8 & 38 & 53,3 & 36,7 & 18,5 \\
\hline & São Rafael (EMATER) & 2,4 & 0 & 16 & 17,2 & 41,5 & 0,8 & 0 & 0 & 0 & 14,4 & 52,8 & 68,1 & 31,4 & 90,8 & 115,2 & 66,6 & 59 & 70,8 & 56,4 & 18,4 \\
\hline & São Tomé (EMATER) & 0 & 0 & 2 & 11,3 & 0 & 0 & 0 & 0 & 0 & 10 & 19 & 32 & 148 & 92 & 20 & 60 & 15,4 & 13 & 29 & 6 \\
\hline & São Vicente (EMATER - Ex Particular) & 0 & 0 & 7,5 & 6,6 & 11 & 0 & 0 & 0 & 9,5 & 84 & 0 & 84,7 & 112,9 & 81 & 93,2 & 25 & 21,7 & 12,5 & 88,1 & 8,7 \\
\hline & São Vicente (EMATER - Extinto) & 0 & 0 & 7,5 & 6,6 & 11 & 0 & 0 & 0 & 9,5 & 84 & 0 & 84,7 & 112,9 & 81 & 93,2 & 25 & 21,7 & 12,5 & 88,1 & 8,7 \\
\hline & Senador Eloi de Souza (Particular) & 0 & 0 & 10,5 & 4,6 & 0 & 0 & 1 & 0 & 8 & 3,5 & 33 & 50 & 24,1 & 76,5 & 46,3 & 31,4 & 67,7 & 62,4 & 47,5 & 20,3 \\
\hline & Serrinha (EMATER) & 0 & 0 & 32,5 & 1,1 & 6,7 & 0 & 0 & 0 & 0 & 1,5 & 11,3 & 174,4 & 87,4 & 28 & 41,9 & 34 & 56,2 & 28,1 & 110 & 35,9 \\
\hline & Sítio Novo (Prefeitura) & 0 & 0 & 0 & 15 & 0 & 0 & 0 & 0 & 0 & 18 & 53 & 44 & 239 & 63 & 53 & 50 & 43 & 45 & 32 & 18 \\
\hline & Tangará (EMATER) & 0 & 0 & 15 & 0 & 0 & 0 & 12 & 0 & 0 & 23 & 21,5 & 47,5 & 112,5 & 39,5 & 50,5 & 11 & 21,5 & 57 & 37 & 16,5 \\
\hline & Tangará (Açude Trairi) & 0 & 0 & 26 & 16,7 & 2,5 & 0 & 0 & 9 & 4,7 & 0 & 36 & 55,7 & 75,9 & 9,7 & 24 & 16,3 & 29,1 & 37 & 21,7 & 20,2 \\
\hline & Triunfo Potiguar (Prefeitura) & 0 & 6,7 & 0 & 41,5 & 13,7 & 28,8 & 14,4 & 0 & 4,5 & 14,1 & 30,5 & 167,2 & 69,3 & 229 & 54,8 & 20,6 & 57,1 & 62,1 & 135,8 & 9,1 \\
\hline & Triunfo Potiguar (Chá Cacimbas/Serra J. Vale) & 0 & 37 & 52 & 25 & 0 & 3 & 20 & 40 & 0 & 35 & 15 & 180 & 203 & 145 & 95 & 27 & 20 & 67 & 75 & 40 \\
\hline & Triunfo Potiguar (Chá Velha/Serra J. Vale) & 0 & 4 & 19,5 & 60,6 & 15,4 & 8,9 & 14,3 & 6,9 & 65,4 & 10 & 75,8 & 178,8 & 94,8 & 237,2 & 69,1 & 0 & 42,1 & 11,7 & 93,5 & 12 \\
\hline & Alagoa Nova & 0 & 0 & 52 & 0 & 0 & 0 & 0 & 0 & 0 & 4,4 & 16,8 & 65,6 & 68,8 & 47 & 25 & 13,2 & 57,6 & 59,3 & 45,8 & 32,5 \\
\hline & Barra de Santana & 0 & 0 & 9,1 & 0 & 3,5 & 0 & 0 & 0 & 4,3 & 0 & 30,1 & 103,1 & 17,6 & 43,5 & 7,1 & 2,4 & 9,8 & 10,1 & 36,5 & 6,8 \\
\hline & Barra de Santana/Bodocongó & 0 & 0 & 6,5 & 0 & 2,6 & 0 & 0 & 0 & 3,5 & 0 & 28,5 & 112,5 & 18,1 & 42,4 & 6,5 & 2,3 & 9,7 & 12 & 35,7 & 5 \\
\hline & Boa Vista & 0 & 0 & 0 & 0 & 14,2 & 0 & 0 & 0 & 11,6 & 0 & 24,3 & 159,4 & 46,6 & 41,8 & 4,2 & 13,8 & 4,8 & 10 & 25 & 14,2 \\
\hline
\end{tabular}




\begin{tabular}{|c|c|c|c|c|c|c|c|c|c|c|c|c|c|c|c|c|c|c|c|c|c|}
\hline 2008 & Estação & s1 & s2 & s3 & s4 & s5 & s6 & s7 & s8 & s9 & $\mathbf{s 1 0}$ & s11 & $s 12$ & s13 & s14 & s15 & s16 & $s 17$ & s18 & s19 & s20 \\
\hline & Boqueirão/Açude Boqueirão & 0 & 0 & 4,9 & 1,8 & 0,4 & 0 & 0 & 0 & 2,8 & 3,2 & 26,1 & 137,2 & 26,9 & 25 & 2,1 & 4,5 & 20,1 & 20,3 & 73,5 & 12,2 \\
\hline & Cabaceiras & 0 & 0 & 0 & 2,8 & 0 & 0 & 0 & 0 & 72,4 & 0 & 11,1 & 358,6 & 16,3 & 48,2 & 0 & 13,4 & 0 & 0 & 112 & 7 \\
\hline & Campina Grande/EMBRAPA & 0 & 3,4 & 38,5 & 5 & 7,1 & 0 & 6,8 & 2,7 & 0 & 0 & 31 & 97,9 & 94,7 & 29,1 & 51,3 & 0,5 & 16,1 & 13,4 & 40,5 & 52,1 \\
\hline & Campina Grande/INSA & 0 & 3,3 & 9,9 & 2,5 & 9,4 & 0 & 0 & 0 & 0 & 0 & 4,4 & 75,1 & 151,4 & 36,6 & 14,3 & 2,9 & 24,4 & 17,3 & 11,5 & 63,6 \\
\hline & Campina Grande/Santa Terezinha & 0 & 4,7 & 49,5 & 20,8 & 3,3 & 0 & 0 & 1,8 & 0 & 0 & 28,1 & 95,8 & 109,3 & 32,4 & 45,2 & 6,8 & 19,9 & 10,4 & 35,5 & 39,1 \\
\hline & Campina Grande/São José da Mata & 0 & 4 & 21,4 & 0 & 5,2 & 0 & 0 & 0 & 0 & 0 & 7,5 & 90,3 & 82,2 & 29,1 & 11,9 & 13,7 & 18,2 & 10,7 & 11,8 & 30,6 \\
\hline & Caturité & 0 & 0 & 8,5 & 0 & 0 & 0 & 0 & 0 & 0 & 0 & 15,6 & 180,7 & 97,1 & 22,9 & 3,7 & 3,3 & 11 & 19,5 & 16,8 & 24,4 \\
\hline & Caturité/Fazenda Campo de Emas & 0 & 0 & 0 & 8,6 & 0 & 0 & 0 & 0 & 0 & 0 & 23,5 & 136,4 & 121,2 & 34,4 & 0 & 12,2 & 0 & 20,2 & 13,2 & 3,4 \\
\hline & Cubati & 0 & 0 & 6,6 & 4 & 6,4 & 0 & 0 & 0 & 23,6 & 0 & 62,6 & 200,2 & 135 & 9,2 & 7,8 & 30,6 & 31,2 & 31 & 22,2 & 7 \\
\hline & Lagoa Seca & 0 & 11,8 & 45,2 & 4,4 & 3,8 & 0 & 4,6 & 3 & 0 & 0 & 4,1 & 73,8 & 77,7 & 45,5 & 25,4 & 25,9 & 28,9 & 33,8 & 8,2 & 47,9 \\
\hline & Matinhas & 0 & 0 & 66,4 & 13,1 & 10 & 0 & 9,8 & 6,7 & 0 & 5,1 & 32,2 & 83,7 & 75 & 39,5 & 53,9 & 15,1 & 42,6 & 13,4 & 12,4 & 35,7 \\
\hline & Olivedos & 0 & 0 & 12,9 & 5,1 & 4,9 & 0 & 0 & 0 & 25,6 & 0 & 84 & 86,5 & 159,4 & 42,3 & 23,4 & 63,9 & 57,4 & 3 & 116,4 & 20,2 \\
\hline & Pedra Lavrada & 0 & 0 & 5,8 & 8,8 & 4,3 & 0 & 0 & 0 & 36,5 & 0 & 24,5 & 125,7 & 128,7 & 106,9 & 8,8 & 40,4 & 18,3 & 28,6 & 0 & 27,1 \\
\hline & Pocinhos & 0,2 & 6,5 & 12,8 & 0,2 & 21,8 & 0 & 0 & 0 & 0 & 0 & 0 & 44,8 & 74,8 & 53 & 7,6 & 8,8 & 33,9 & 9,6 & 19,8 & 17,1 \\
\hline & Queimadas & 0 & 0 & 20,9 & 0 & 0 & 0 & 0 & 0 & 0 & 0 & 19,2 & 165,1 & 138,4 & 48,2 & 23,8 & 3,4 & 36,3 & 30,7 & 25,1 & 33,7 \\
\hline & Seridó/São Vicente do Seridó & 0 & 0 & 9,7 & 12,7 & 2,8 & 0 & 0 & 0 & 166 & 0 & 62,8 & 51,8 & 110,7 & 79 & 11,7 & 41,1 & 33,2 & 1 & 52,2 & 18,4 \\
\hline & Soledade & 0 & 0 & 0,7 & 13,8 & 0 & 0 & 0 & 0 & 54 & 0 & 42,3 & 72,5 & 104,3 & 58,1 & 25,6 & 27,5 & 21,9 & 10,9 & 46,7 & 9,5 \\
\hline
\end{tabular}

Estação

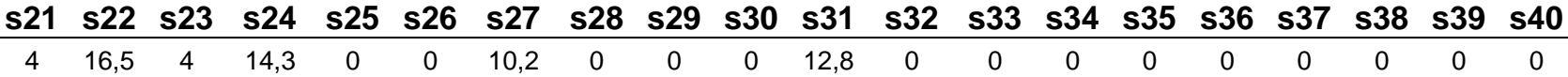

Acari (Particular)

Acari (Açude Gargalheiras)

Assu (Particular)

Assu (EMATER/Sítio Casa Forte)

Afonso Bezerra (EMATER)

Afonso Bezerra (Assentamento Santa Maria)

Almino Afonso (Particular - Ex Sítio Milagres)

Angicos (Prefeitura)

Campo Grande (Particular)

Campo Grande (Particular 2)

Barcelona (Particular)

Bodó (EMATER/TRF P/Delegacia)

Bom Jesus (Particular)

Caiçara do Rio do Vento (Particular)

Caicó (Batalhão)

Caicó (Açude Mundo Novo - EMPARN)

Caicó (Palma)

$9 \begin{array}{ccccccccccccccccccc}9 & 14 & 18 & 3 & 0 & 17 & 4 & 0 & 0 & 24 & 21 & 0 & 0 & 8 & 0 & 0 & 0 & 0 & 0\end{array}$

$18 \begin{array}{llllllllllllllllllll}14,9 & 33,1 & 43,6 & 14 & 0 & 15,3 & 2,5 & 0 & 0,1 & 0 & 16,8 & 0 & 0 & 13,8 & 2 & 0 & 0 & 0 & 0\end{array}$

$\begin{array}{lllllllllllllllllllll}22,3 & 34,2 & 35 & 41,6 & 6,5 & 0 & 26,7 & 0 & 0 & 0 & 0 & 22,9 & 0,5 & 0,1 & 15,3 & 2,4 & 0 & 0 & 0 & 0\end{array}$

$\begin{array}{lllllllllllllllllllll}0 & 30 & 35 & 45 & 0 & 0 & 20 & 0 & 0 & 0 & 0 & 15 & 0 & 0 & 0 & 0 & 0 & 0 & 0 & 0\end{array}$

$\begin{array}{llllllllllllllllllll}6,7 & 64,1 & 0 & 57 & 0 & 16 & 12,3 & 8,7 & 10,5 & 0 & 3,5 & 0 & 0 & 0 & 0 & 0 & 0 & 0 & 0 & 0\end{array}$

$\begin{array}{lllllllllllllllllllll}15 & 17,4 & 3,2 & 24,3 & 13,1 & 0 & 5,2 & 0 & 2,1 & 2 & 0 & 16,2 & 0 & 0 & 0 & 23 & 0 & 0 & 0 & 0\end{array}$

$\begin{array}{lllllllllllllllllllll}0 & 42,7 & 8,5 & 29 & 1,8 & 0 & 14,9 & 4,5 & 0 & 0 & 0 & 0 & 0 & 0 & 0 & 0 & 0 & 0 & 0 & 0\end{array}$

$\begin{array}{llllllllllllllllllll}11,4 & 3 & 32,2 & 0 & 0 & 0 & 0 & 0 & 7,6 & 0 & 0 & 0 & 0 & 0 & 0 & 4,2 & 0 & 0 & 0 & 0\end{array}$

$\begin{array}{llllllllllllllllllll}0 & 0 & 33,3 & 25 & 0 & 0 & 2,2 & 0 & 4,8 & 3 & 0 & 6,3 & 0 & 0 & 0 & 12,5 & 0 & 0 & 0 & 0\end{array}$

$\begin{array}{llllllllllllllllllll}21,5 & 34 & 7 & 45 & 31,5 & 18 & 51 & 0 & 0 & 21 & 0 & 164 & 9 & 0 & 33,5 & 30 & 0 & 0 & 0 & 0\end{array}$

$\begin{array}{llllllllllllllllllll}0 & 4 & 16,5 & 34,7 & 13,1 & 0 & 24 & 0 & 0 & 11 & 0 & 54 & 2,5 & 0 & 0 & 0 & 0 & 0 & 0 & 0\end{array}$

$\begin{array}{llllllllllllllllllll}0 & 40,6 & 26 & 89,4 & 2,7 & 2,4 & 110,6 & 8,7 & 0,3 & 9,1 & 13,4 & 184,2 & 5,6 & 6,5 & 23,9 & 0 & 2,3 & 4,5 & 4,3 & 0,6\end{array}$

$\begin{array}{lllllllllllcllllllll}0 & 46 & 3,2 & 5,8 & 0 & 0 & 56 & 0 & 0 & 0 & 0 & 75,2 & 0 & 0 & 0 & 0 & 0 & 0 & 0 & 0 \\ 0 & 7,5 & 30 & 8 & 0 & 0 & 11 & 0 & 0 & 0 & 0 & 0 & 0 & 0 & 0 & 0 & 0 & 0 & 0 & 0\end{array}$

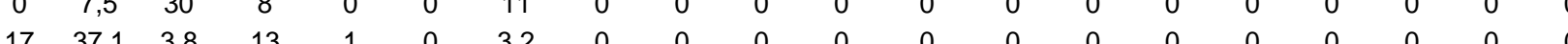

$\begin{array}{llllllllllllllllllll}0 & 41 & 5 & 10 & 0 & 0 & 0 & 0 & 0 & 0 & 0 & 0 & 0 & 0 & 0 & 0 & 0 & 0 & 0 & 0\end{array}$ 


\begin{tabular}{|c|c|c|c|c|c|c|c|c|c|c|c|c|c|c|c|c|c|c|c|c|c|}
\hline 2008 & Estação & s21 & s22 & s23 & s24 & s25 & s26 & s27 & s28 & $\mathbf{s} 29$ & s30 & s31 & s32 & s33 & s34 & s35 & s36 & s37 & s38 & s39 & s40 \\
\hline & Caicó (Açude Itans) & 8,9 & 16,1 & 3,6 & 17,6 & 2,1 & 0 & 7,2 & 0 & 0 & 0 & 0 & 0 & 0 & 0 & 0 & 0 & 0 & 0 & 0 & 0 \\
\hline & Caicó (EMATER) & 20 & 21 & 9,6 & 0 & 2 & 0 & 0 & 0 & 0 & 0 & 0 & 0 & 0 & 0 & 0 & 0 & 0 & 0 & 0 & 0 \\
\hline & Campo Redondo (EMATER) & 6,8 & 15,8 & 39,6 & 26 & 20,3 & 6 & 26 & 20,5 & 0 & 0 & 17 & 75,5 & 7,8 & 0 & 4 & 37 & 3 & 0 & 0 & 0 \\
\hline & Campo Redondo (Polícia Rodoviária) & 2,7 & 13,2 & 31,4 & 46,2 & 25,3 & 0 & 26,5 & 8,7 & 0 & 4 & 12,2 & 74,8 & 5,2 & 0 & 4,8 & 40 & 0 & 3,1 & 0 & 0 \\
\hline & Cerro Corá (EMATER) & 1,6 & 59,6 & 1,9 & 44,7 & 26,2 & 0 & 0 & 0 & 0 & 0 & 0 & 0 & 0 & 0 & 0 & 0 & 0 & 0 & 0 & 0 \\
\hline & Coronel Ezequiel (Particular) & 8 & 15 & 2 & 43,3 & 2 & 0 & 18 & 5 & 0 & 0 & 0 & 49,5 & 0 & 0 & 4 & 12 & 0 & 0 & 0 & 0 \\
\hline & Cruzeta (Base Física da EMPARN) & 5,5 & 38,6 & 17 & 17,1 & 26,9 & 0 & 13,9 & 0,5 & 0 & 0,1 & 9 & 12,9 & 0,5 & 0 & 3,5 & 12,3 & 0 & 0 & 0 & 0 \\
\hline & Currais Novos (CERCEL) & 3,8 & 30 & 9,5 & 41,8 & 14,4 & 0 & 0 & 0 & 0 & 0 & 0 & 0 & 0 & 0 & 0 & 0 & 0 & 0 & 0 & 0 \\
\hline & Fernando Pedroza (EMATER) & 0 & 19,5 & 2 & 29,4 & 0 & 0 & 18,7 & 0 & 0 & 0 & 0 & 33,7 & 0 & 0 & 0 & 0 & 0 & 0 & 0 & 0 \\
\hline & Florânia (INMET) & 4,8 & 43 & 25,1 & 38,8 & 4,7 & 0 & 0 & 0 & 0 & 0 & 0 & 7,5 & 0,2 & 0 & 0 & 15 & 0 & 0 & 0 & 0 \\
\hline & Florânia (Sítio Jucuri) & 3,6 & 59,8 & 4,2 & 37,4 & 4,5 & 0 & 4,6 & 2,9 & 0 & 9,6 & 0 & 12,3 & 0 & 0 & 0 & 0 & 5,6 & 0 & 0 & 0 \\
\hline & Itajá (EMATER) & 0 & 0 & 0 & 0 & 0 & 0 & 0 & 0 & 0 & 0 & 0 & 0 & 0 & 0 & 0 & 0 & 0 & 0 & 0 & 0 \\
\hline & Jaçanã (EMATER) & 0 & 16,7 & 7,5 & 47,3 & 11,8 & 0 & 27,6 & 3,4 & 0 & 0 & 18 & 40,4 & 0 & 0 & 4 & 13 & 0 & 0 & 0 & 0 \\
\hline & Janduís (EMATER) & 14 & 27,2 & 31 & 38 & 2 & 0 & 6,8 & 0 & 0 & 0 & 4 & 8 & 0 & 0 & 0 & 0 & 0 & 0 & 0 & 0 \\
\hline & Boa Saúde (EMATER) & 0 & 24,1 & 18,7 & 34,9 & 29,2 & 0 & 85,8 & 8,5 & 1 & 4,9 & 13,9 & 133,3 & 7,4 & 3,2 & 43,4 & 29,8 & 0 & 0 & 0 & 0 \\
\hline & Japi (Particular) & 12,6 & 35 & 8,4 & 25,6 & 6,4 & 4,4 & 35,6 & 0 & 0 & 8,4 & 0 & 72,6 & 0 & 0 & 0 & 10,2 & 0 & 0 & 0 & 0 \\
\hline & Japi (EMATER) & 0 & 23 & 0 & 25,5 & 6,5 & 0 & 35,5 & 0 & 0 & 10 & 6 & 58,6 & 0 & 0 & 0 & 6,2 & 0 & 0 & 0 & 0 \\
\hline & Jardim de Angicos (EMATER) & 9 & 46,9 & 5,5 & 78 & 12 & 0 & 89 & 4 & 0 & 14 & 0 & 0 & 0 & 0 & 0 & 0 & 0 & 0 & 0 & 0 \\
\hline & Lagoa de Pedras (Prefeitura) & 5,8 & 52,3 & 6,1 & 52,8 & 58,2 & 1,5 & 119,3 & 18,2 & 4 & 3,6 & 18,1 & 78,7 & 7,5 & 11,5 & 30,8 & 35,1 & 3,5 & 0 & 0 & 0 \\
\hline & Lagoa de Velhos (Delegacia) & 4,2 & 32 & 4,8 & 38,6 & 37,7 & 0 & 64,5 & 3,7 & 1,4 & 31,7 & 11,7 & 135,9 & 4,4 & 0,9 & 37,8 & 0 & 0 & 0 & 0 & 0 \\
\hline & Lagoa Nova (Assentamento Santana/Sítio de Dentro) & 0 & 13,7 & 13,7 & 55 & 0 & 0 & 0 & 0 & 0 & 0 & 0 & 0 & 0 & 0 & 0 & 0 & 0 & 0 & 0 & 0 \\
\hline & Lagoa Salgada (Delegacia) & 21,4 & 31,7 & 27,1 & 55,3 & 42,4 & 0 & 127,1 & 3,1 & 7,6 & 12 & 0 & 157,4 & 0,8 & 0 & 0 & 0 & 0 & 0 & 0 & 0 \\
\hline & Lajes (Prefeitura) & 0 & 12 & 12,5 & 67,5 & 6 & 0 & 32,8 & 0 & 0 & 0 & 5 & 67,5 & 0 & 0 & 0 & 0 & 0 & 0 & 0 & 0 \\
\hline & Lajes Pintadas (Prefeitura) & 5,6 & 10,6 & 57,4 & 35,8 & 33,1 & 0 & 29,1 & 6,6 & 0 & 3,5 & 13 & 84,1 & 1,2 & 0 & 0 & 39,1 & 0 & 0 & 0 & 0 \\
\hline & Messias Targino (Prefeitura) & 1,7 & 53,5 & 30 & 0 & 0 & 0 & 0 & 0 & 0 & 0 & 0 & 0 & 0 & 0 & 0 & 0 & 0 & 0 & 0 & 0 \\
\hline & Monte Alegre (EMATER) & 0 & 21 & 34,8 & 81 & 71 & 8,6 & 159,2 & 19,8 & 5,6 & 19 & 17 & 226 & 7 & 19 & 8,2 & 20 & 12,4 & 0 & 0 & 0 \\
\hline & Monte das Gameleiras (EMATER) & 2,3 & 9,8 & 5,6 & 30 & 19,5 & 9 & 57 & 0 & 0 & 8 & 10 & 99 & 3,3 & 0 & 2,2 & 28,3 & 0 & 0 & 0 & 0 \\
\hline & Paraú (Sindicato) & 0 & 37 & 60,3 & 30 & 0 & 0 & 3,5 & 0 & 0 & 0 & 0 & 7,6 & 0 & 0 & 0 & 0 & 0 & 0 & 0 & 0 \\
\hline & Passa e Fica (Prefeitura) & 1,7 & 10,4 & 32,2 & 33,1 & 35,1 & 0 & 71,2 & 16,9 & 0 & 4,8 & 9,6 & 105,1 & 0 & 0 & 4 & 60,7 & 0 & 0 & 0 & 0 \\
\hline & Patu (Particular) & 5 & 65,4 & 13,6 & 38,2 & 7 & 0 & 4 & 4 & 6,4 & 3 & 0 & 7 & 0 & 0 & 0 & 0 & 0 & 0 & 0 & 0 \\
\hline & Santa Maria (Sindicato dos Trabalhadores Rurais) & 3,1 & 19,9 & 40,3 & 115,9 & 44 & 0 & 145,8 & 3,9 & 0 & 0 & 3,2 & 153 & 0 & 0 & 0 & 0 & 0 & 0 & 0 & 0 \\
\hline & Pedra Preta (EMATER) & 0 & 48,5 & 2 & 11,5 & 12 & 0 & 12 & 0 & 0 & 5 & 0 & 48 & 0 & 0 & 3 & 8,5 & 0 & 0 & 0 & 0 \\
\hline & Pedro Avelino (Particular) & 0 & 1,8 & 33,2 & 0 & 7 & 4,4 & 20,6 & 39 & 0 & 0 & 0 & 1,4 & 5,5 & 0 & 1,5 & 46,2 & 45,8 & 40,6 & 1,6 & 28,4 \\
\hline & Pedro Avelino (Base Física da EMPARN) & 0 & 34,1 & 0 & 34,4 & 0 & 0 & 31,9 & 2,6 & 9,8 & 0 & 0 & 10,2 & 0,5 & 0 & 4,7 & 1 & 0 & 0 & 0 & 0 \\
\hline & Riachuelo (EMATER) & 0 & 39 & 13 & 84 & 30,5 & 0 & 101 & 8,4 & 0 & 6,5 & 30,6 & 123 & 0 & 0 & 20,5 & 25 & 0 & 0 & 0 & 0 \\
\hline & Rui Barbosa (EMATER) & 0 & 13,9 & 35,9 & 84,1 & 38,2 & 0 & 79,6 & 4 & 0 & 1,9 & 15,8 & 151,2 & 10,7 & 0 & 15,3 & 31,8 & 0 & 0 & 0 & 0 \\
\hline
\end{tabular}




\begin{tabular}{|c|c|c|c|c|c|c|c|c|c|c|c|c|c|c|c|c|c|c|c|c|c|}
\hline 2008 & Estação & s21 & s22 & s23 & s24 & s25 & s26 & s27 & s28 & s29 & s30 & s31 & s32 & s33 & s34 & s35 & s36 & s37 & s38 & s39 & s40 \\
\hline & Santa Cruz (EMATER) & 0 & 45,8 & 2,8 & 31 & 25,5 & 0 & 26,8 & 4,6 & 0 & 1,7 & 5,5 & 75 & 1 & 0 & 0 & 38,2 & 0 & 0 & 0 & 0 \\
\hline & Santana do Matos (EMATER) & 3 & 12 & 8 & 8 & 3 & 7 & 0 & 0 & 0 & 0 & 0 & 25 & 0 & 0 & 0 & 0 & 0 & 0 & 0 & 0 \\
\hline & Santana do Matos (Barão de Serra Branca) & 5,6 & 30 & 0 & 0 & 6 & 33,1 & 22,6 & 15,7 & 2,6 & 0 & 17,3 & 15,1 & 8,3 & 7,3 & 3,1 & 0 & 20,7 & 0 & 0 & 0 \\
\hline & Santana do Matos (São José da Passagem) & 0 & 0 & 0 & 19,9 & 0 & 0 & 7 & 0 & 0 & 0 & 0 & 33,2 & 0 & 0 & 0 & 0 & 0 & 0 & 0 & 0 \\
\hline & São Bento do Trairi (Prefeitura) & 6,1 & 5,5 & 0 & 23,8 & 14,4 & 0 & 23,5 & 2,8 & 0 & 0 & 0 & 53,5 & 0 & 0 & 0 & 23,6 & 0 & 0 & 0 & 0 \\
\hline & São José do Campestre (EMATER) & 0 & 11,5 & 11,9 & 37,6 & 20,3 & 0 & 53,2 & 3 & 2,5 & 13,4 & 0 & 81 & 0 & 0 & 13,3 & 49,3 & 0 & 0 & 0 & 0 \\
\hline & São Paulo do Potengi (EMATER) & 0 & 10,7 & 42,8 & 96,3 & 28,2 & 0 & 96 & 4,9 & 1 & 10,4 & 14,8 & 161,1 & 8,3 & 1,9 & 14,3 & 37,8 & 0 & 0 & 0 & 1,2 \\
\hline & São Pedro (EMATER) & 3,3 & 21 & 41,4 & 109 & 37 & 1,6 & 113 & 10 & 2,3 & 9,2 & 2,3 & 168,8 & 3 & 6,2 & 18,8 & 25,3 & 0 & 0 & 0 & 0,5 \\
\hline & São Rafael (EMATER) & 12,2 & 21 & 54,6 & 26,2 & 4,6 & 0 & 8,6 & 2 & 0 & 0 & 6,2 & 57,8 & 0 & 0 & 1,4 & 32,2 & 0 & 0 & 0 & 0 \\
\hline & São Tomé (EMATER) & 0 & 15 & 0 & 51 & 18 & 0 & 52 & 0 & 0 & 0 & 0 & 66 & 0 & 0 & 0 & 0 & 0 & 0 & 0 & 0 \\
\hline & São Vicente (EMATER - Ex Particular) & 16 & 12 & 14,6 & 50 & 3,5 & 0 & 8,5 & 0 & 0 & 0 & 0 & 0 & 0 & 0 & 0 & 16,6 & 0 & 0 & 0 & 0 \\
\hline & São Vicente (EMATER - Extinto) & 16 & 12 & 14,6 & 50 & 3,5 & 0 & 8,5 & 0 & 0 & 0 & 0 & 0 & 0 & 0 & 0 & 16,6 & 0 & 0 & 0 & 0 \\
\hline & Senador Eloi de Souza (Particular) & 0 & 8,3 & 10 & 36,8 & 0 & 0 & 77 & 5,3 & 0 & 3,5 & 23,3 & 0 & 0 & 0 & 0 & 0 & 0 & 0 & 0 & 0 \\
\hline & Serrinha (EMATER) & 3,5 & 16,2 & 21,2 & 59,9 & 39,2 & 0 & 86,5 & 3,6 & 3,3 & 22,5 & 15,9 & 142,5 & 10,2 & 7,1 & 32,9 & 38,2 & 2,1 & 1,7 & 0 & 0,6 \\
\hline & Sítio Novo (Prefeitura) & 0 & 32 & 14 & 50 & 20 & 0 & 55 & 0 & 0 & 12 & 15 & 125 & 0 & 0 & 15 & 0 & 0 & 0 & 0 & 0 \\
\hline & Tangará (EMATER) & 0 & 8,5 & 7 & 40 & 20,5 & 0 & 45,5 & 1 & 0 & 0 & 18 & 117 & 0 & 0 & 15 & 31,5 & 0 & 0 & 0 & 0 \\
\hline & Tangará (Açude Trairi) & 2,8 & 16,1 & 5,1 & 32,9 & 29,1 & 0 & 40,1 & 4,2 & 1,9 & 3,8 & 5,5 & 82,5 & 0 & 0 & 2,7 & 38,5 & 0 & 1,9 & 0 & 0 \\
\hline & Triunfo Potiguar (Prefeitura) & 39,1 & 34,5 & 5 & 24,6 & 0 & 0 & 8,6 & 0 & 0 & 14,9 & 13,7 & 14,3 & 0 & 0 & 0 & 14,4 & 0 & 0 & 0 & 0 \\
\hline & Triunfo Potiguar (Chá Cacimbas/Serra J. Vale) & 88 & 123 & 0 & 5 & 30 & 0 & 0 & 50 & 0 & 0 & 0 & 0 & 0 & 0 & 0 & 0 & 0 & 0 & 0 & 0 \\
\hline & Triunfo Potiguar (Chá Velha/Serra J. Vale) & 0 & 45 & 8 & 53,3 & 0 & 0 & 0 & 0 & 0 & 0 & 0 & 0 & 0 & 0 & 0 & 0 & 0 & 0 & 0 & 0 \\
\hline & Alagoa Nova & 7,9 & 29,3 & 35,4 & 54,7 & 48,2 & 5,7 & 92,5 & 41 & 7,8 & 16,8 & 24,6 & 70,7 & 8,1 & 19,7 & 36,6 & 36,5 & 4,5 & 3,4 & 0 & 1,9 \\
\hline & Barra de Santana & 25,3 & 15,6 & 16,9 & 4 & 7,7 & 1,1 & 14,4 & 2,5 & 3,2 & 7,4 & 4,1 & 9 & 5,1 & 1,5 & 7,1 & 0 & 0 & 0 & 0 & 0 \\
\hline & Barra de Santana/Bodocongó & 25,2 & 15,5 & 17,8 & 3,2 & 2,5 & 1 & 14,3 & 3,4 & 5 & 5,6 & 3,8 & 9,5 & 3,2 & 1 & 7,5 & 2,8 & 0 & 0 & 0 & 0 \\
\hline & Boa Vista & 15,8 & 5 & 22,4 & 6,6 & 8,8 & 2,6 & 32 & 16,2 & 7 & 6,6 & 3,6 & 17,8 & 6,6 & 0 & 4,2 & 0 & 0 & 0 & 0 & 2 \\
\hline & Boqueirão/Açude Boqueirão & 22,5 & 19,1 & 19,4 & 3,9 & 6,9 & 1,5 & 19,1 & 8,6 & 8,5 & 9,1 & 18,2 & 8,7 & 5,3 & 1,1 & 3,5 & 2 & 0 & 0 & 0 & 0 \\
\hline & Cabaceiras & 0 & 14 & 40,1 & 4,8 & 9,1 & 0 & 0 & 0 & 2 & 14,1 & 0 & 10,1 & 0 & 0 & 0 & 0 & 0 & 0 & 0 & 0 \\
\hline & Campina Grande/EMBRAPA & 27,1 & 34,2 & 46,3 & 21,3 & 24,8 & 3,4 & 66,8 & 21,7 & 12,3 & 16,8 & 21,4 & 51,1 & 11 & 7,8 & 10 & 31,1 & 1,9 & 0,2 & 0,1 & 0,4 \\
\hline & Campina Grande/INSA & 26,1 & 24,5 & 17,5 & 9,6 & 16 & 3,8 & 46,7 & 14,6 & 9,6 & 10,2 & 22,9 & 29,9 & 3,8 & 4,3 & 6,8 & 13,7 & 1,3 & 0 & 0 & 0,2 \\
\hline & Campina Grande/Santa Terezinha & 26,8 & 37,5 & 26,5 & 18,4 & 18,8 & 4,2 & 51,8 & 31,3 & 6,9 & 17,7 & 22,7 & 49,6 & 8 & 5,8 & 8,9 & 30,5 & 1,1 & 0 & 0 & 0,5 \\
\hline & Campina Grande/São José da Mata & 27,8 & 24,8 & 30,9 & 25 & 29,3 & 5,1 & 69,8 & 16,9 & 12,6 & 18,6 & 23,7 & 44,8 & 13,3 & 9,2 & 11,9 & 23,7 & 3,2 & 1,3 & 0 & 0 \\
\hline & Caturité & 29,1 & 13,6 & 17,4 & 5,3 & 12,5 & 3,4 & 32,7 & 12,2 & 3,7 & 8,9 & 22,3 & 18,8 & 4 & 5,1 & 5,7 & 0 & 0 & 0 & 0 & 0 \\
\hline & Caturité/Fazenda Campo de Emas & 46,8 & 10,6 & 11,8 & 8,4 & 11 & 1,6 & 32,2 & 17 & 8,6 & 5 & 15,2 & 1,8 & 6 & 3 & 11,4 & 16 & 0 & 0 & 0 & 0 \\
\hline & Cubati & 15,8 & 19 & 4,8 & 12,4 & 4 & 0 & 27,8 & 5 & 0 & 0 & 0 & 15,2 & 0 & 0 & 3 & 0 & 0 & 0 & 0 & 0 \\
\hline & Lagoa Seca & 18,5 & 46,2 & 35,2 & 37,9 & 30,4 & 17 & 109 & 40,2 & 16,7 & 28,6 & 46 & 71,3 & 15,3 & 24,1 & 21,6 & 41,9 & 6,8 & 1,9 & 0 & 0,6 \\
\hline & Matinhas & 6,1 & 39,2 & 22,3 & 35,4 & 40 & 9,8 & 63,6 & 19,6 & 7,1 & 37,7 & 12,6 & 49,1 & 9,6 & 6,9 & 16,2 & 24,4 & 4,2 & 0,2 & 0 & 0,1 \\
\hline & Olivedos & 18 & 23,6 & 11,7 & 17,5 & 7,2 & 0 & 30,3 & 6,3 & 1,1 & 4,3 & 1,8 & 19,4 & 6,5 & 2,1 & 1,4 & 4 & 0,8 & 0 & 0 & 0 \\
\hline
\end{tabular}




\begin{tabular}{|c|c|c|c|c|c|c|c|c|c|c|c|c|c|c|c|c|c|c|c|c|c|}
\hline 2008 & Estação & s21 & s22 & s23 & s24 & s25 & s26 & s27 & s28 & s29 & s30 & s31 & s32 & s33 & s34 & s35 & s36 & s37 & s38 & s39 & s40 \\
\hline & Pedra Lavrada & 31,4 & 13,1 & 0 & 13,2 & 0 & 0 & 17,4 & 0 & 0 & 0 & 0 & 14,9 & 0 & 0 & 0 & 0 & 0 & 0 & 0 & 0 \\
\hline & Pocinhos & 9 & 22,5 & 8 & 20,3 & 10 & 2 & 35,2 & 7,5 & 5,2 & 6,2 & 4,8 & 21,3 & 7,2 & 2,6 & 4,9 & 7,9 & 0,9 & 1,1 & 0 & 0,3 \\
\hline & Queimadas & 22,3 & 29,4 & 27,3 & 7,6 & 24,4 & 3,2 & 57,5 & 24,6 & 5,3 & 22,7 & 36,3 & 25,6 & 7,3 & 9,7 & 8,8 & 18,5 & 0 & 0 & 0 & 0 \\
\hline & Seridó/São Vicente do Seridó & 14 & 22,9 & 6,4 & 18 & 5,2 & 4 & 24,2 & 9,5 & 1,5 & 1,5 & 5,1 & 10 & 2,6 & 0 & 5 & 10,6 & 0 & 0 & 0 & 0 \\
\hline & Soledade & 21,8 & 8,1 & 15,3 & 5,5 & 3,9 & 0 & 32,2 & 11,9 & 1,2 & 1,9 & 2,4 & 12,5 & 3,6 & 0 & 0,9 & 5,7 & 0 & 0 & 0 & 0 \\
\hline
\end{tabular}

2008

Acari (Particular)

Acari (Açude Gargalheiras)

Assu (Particular)

Assu (EMATER/Sítio Casa Forte)

Afonso Bezerra (EMATER)

Afonso Bezerra (Assentamento Santa Maria)

Almino Afonso (Particular - Ex Sítio Milagres)

Angicos (Prefeitura)

Campo Grande (Particular)

Campo Grande (Particular 2)

Barcelona (Particular)

Bodó (EMATER/TRF P/Delegacia)

Bom Jesus (Particular)

Caiçara do Rio do Vento (Particular)

Caicó (Batalhão)

Caicó (Açude Mundo Novo - EMPARN)

Caicó (Palma)

Caicó (Açude Itans)

Caicó (EMATER)

Campo Redondo (EMATER)

Campo Redondo (Polícia Rodoviária)

Cerro Corá (EMATER)

Coronel Ezequiel (Particular)

Cruzeta (Base Física da EMPARN)

Currais Novos (CERCEL)

Fernando Pedroza (EMATER)

Florânia (INMET)

Florânia (Sítio Jucuri)

Itajá (EMATER)

\section{$\begin{array}{lllllllllllll}s 41 & s 42 & s 43 & s 44 & s 45 & s 46 & s 47 & s 48 & s 49 & s 50 & s 51 & s 52 & s 53\end{array}$}

$\begin{array}{ccccccccccccc}0 & 0 & 0 & 0 & 0 & 0 & 0 & 0 & 0 & 0 & 0 & 0 & 0 \\ 0 & 0 & 0 & 0 & 0 & 0 & 0 & 0 & 38 & 17 & 11 & 92 & 0 \\ 0 & 0 & 0 & 0 & 0 & 0,4 & 0 & 0 & 0 & 0 & 0 & 0 & 0 \\ 0 & 0 & 0 & 0 & 0 & 0 & 0 & 0 & 0 & 0 & 0 & 0 & 0 \\ 0 & 0 & 0 & 0 & 0 & 0 & 0 & 0 & 0 & 0 & 0 & 0 & 0 \\ 0 & 0 & 0 & 0 & 0 & 0 & 0 & 0 & 0 & 0 & 0 & 0 & 0 \\ 0 & 0 & 0 & 0 & 0 & 0 & 0 & 0 & 0 & 0 & 0 & 0 & 0 \\ 0 & 0 & 0 & 0 & 0 & 0 & 0 & 0 & 0 & 0 & 0 & 0 & 0 \\ 0 & 0 & 0 & 0 & 0 & 0 & 0 & 0 & 0 & 0 & 5 & 0 & 0 \\ 0 & 4 & 0 & 0 & 0 & 0 & 0 & 0 & 0 & 0 & 5,4 & 0 & 0 \\ 0 & 35 & 0 & 0 & 0 & 0 & 0 & 0 & 0 & 0 & 0 & 0 & 0 \\ 0 & 0 & 0 & 0 & 0 & 0 & 0 & 0 & 0 & 0 & 0 & 0 & 0 \\ 0 & 10,1 & 0 & 0 & 0 & 0 & 0 & 0 & 0 & 0 & 0 & 0 & 0 \\ 0 & 0 & 0 & 0 & 0 & 0 & 0 & 0 & 0 & 0 & 0 & 0 & 0 \\ 0 & 0 & 0 & 0 & 0 & 0 & 0 & 0 & 0 & 0 & 0 & 0 & 0 \\ 0 & 0 & 0 & 0 & 0 & 0 & 0 & 0 & 0 & 0 & 0 & 0 & 0 \\ 0 & 0 & 0 & 0 & 0 & 0 & 0 & 0 & 0 & 0 & 0 & 0 & 0 \\ 0 & 0 & 0 & 0 & 0 & 0 & 0 & 0 & 0 & 0 & 0 & 0 & 0 \\ 0 & 0 & 0 & 0 & 0 & 0 & 0 & 0 & 0 & 0 & 0 & 0 & 0 \\ 0 & 0 & 0 & 0 & 0 & 0 & 0 & 0 & 0 & 0 & 0 & 0 & 0 \\ 0 & 0 & 0 & 0 & 0 & 0 & 0 & 0 & 0 & 0 & 0 & 0 & 0 \\ 0 & 0 & 0 & 0 & 0 & 0 & 0 & 0 & 0 & 0 & 0 & 0 & 0 \\ 0 & 0 & 0 & 0 & 0 & 0 & 0 & 0 & 0 & 0 & 0 & 0 & 0 \\ 0 & 0 & 0 & 0 & 0 & 0 & 0 & 3,9 & 0 & 23,2 & 0 & 0 & 0 \\ 0 & 0 & 0 & 0 & 0 & 0 & 0 & 0 & 0 & 0 & 0 & 0 & 0 \\ 0 & 0 & 0 & 0 & 0 & 0 & 0 & 0 & 0 & 0 & 0 & 0 & 0 \\ 0 & 0 & 0 & 0 & 0 & 0 & 0 & 0 & 0 & 0 & 0 & 0 & 0 \\ 0 & 0 & 0 & 0 & 0 & 0 & 0 & 0 & 0 & 0 & 0 & 0 & 0 \\ 0 & 0 & 0 & 0 & 0 & 0 & 0 & 0 & 0 & 0 & 0 & 0 & 0\end{array}$




\begin{tabular}{|c|c|c|c|c|c|c|c|c|c|c|c|c|c|c|}
\hline 2008 & Estação & s41 & s42 & s43 & s44 & s45 & s46 & s47 & s48 & s49 & s50 & $s 51$ & s52 & s53 \\
\hline & Jaçanã (EMATER) & 0 & 0 & 0 & 0 & 0 & 0 & 0 & 0 & 0 & 0 & 0 & 0 & 0 \\
\hline & Janduís (EMATER) & 0 & 0 & 0 & 0 & 0 & 0 & 0 & 0 & 0 & 5 & 0 & 0 & 0 \\
\hline & Boa Saúde (EMATER) & 0 & 0 & 0 & 0 & 0 & 0 & 0 & 0 & 0 & 0 & 0 & 0 & 0 \\
\hline & Japi (Particular) & 0 & 0 & 0 & 0 & 0 & 0 & 0 & 0 & 0 & 0 & 0 & 0 & 0 \\
\hline & Japi (EMATER) & 0 & 0 & 0 & 0 & 0 & 0 & 0 & 0 & 0 & 0 & 0 & 0 & 0 \\
\hline & Jardim de Angicos (EMATER) & 0 & 0 & 0 & 0 & 0 & 0 & 0 & 0 & 0 & 0 & 0 & 0 & 0 \\
\hline & Lagoa de Pedras (Prefeitura) & 0 & 17,9 & 0 & 0 & 0 & 0 & 0 & 0 & 0 & 0 & 0 & 0 & 0 \\
\hline & Lagoa de Velhos (Delegacia) & 0 & 0 & 0 & 0 & 0 & 0 & 0 & 0 & 0 & 0 & 0 & 0 & 0 \\
\hline & Lagoa Nova (Assentamento Santana/Sítio de Dentro) & 0 & 0 & 0 & 0 & 0 & 0 & 0 & 0 & 0 & 0 & 0 & 0 & 0 \\
\hline & Lagoa Salgada (Delegacia) & 0 & 0 & 0 & 0 & 0 & 0 & 0 & 0 & 0 & 0 & 0 & 0 & 0 \\
\hline & Lajes (Prefeitura) & 0 & 0 & 0 & 0 & 0 & 0 & 0 & 0 & 0 & 0 & 0 & 0 & 0 \\
\hline & Lajes Pintadas (Prefeitura) & 0 & 4,1 & 0 & 0 & 0 & 0 & 0 & 0 & 0 & 0 & 0 & 0 & 0 \\
\hline & Messias Targino (Prefeitura) & 0 & 0 & 0 & 0 & 0 & 0 & 0 & 0 & 0 & 0 & 0 & 0 & 0 \\
\hline & Monte Alegre (EMATER) & 1,8 & 12 & 1 & 0 & 0 & 5 & 0 & 0 & 0 & 0 & 0 & 2,2 & 0 \\
\hline & Monte das Gameleiras (EMATER) & 0 & 0 & 0 & 0 & 0 & 0 & 0 & 0 & 0 & 0 & 0 & 0 & 0 \\
\hline & Paraú (Sindicato) & 0 & 0 & 0 & 0 & 0 & 0 & 0 & 0 & 0 & 0 & 0 & 0 & 0 \\
\hline & Passa e Fica (Prefeitura) & 0 & 0 & 0 & 0 & 0 & 0 & 0 & 0 & 0 & 0 & 0 & 0 & 0 \\
\hline & Patu (Particular) & 0 & 0 & 0 & 0 & 0 & 0 & 0 & 0 & 0 & 12 & 0 & 0 & 0 \\
\hline & Santa Maria (Sindicato dos Trabalhadores Rurais) & 0 & 0 & 0 & 0 & 0 & 0 & 0 & 0 & 0 & 0 & 0 & 0 & 0 \\
\hline & Pedra Preta (EMATER) & 0 & 0 & 0 & 0 & 0 & 0 & 0 & 0 & 0 & 0 & 0 & 0 & 0 \\
\hline & Pedro Avelino (Particular) & 16,2 & 15,2 & 126,4 & 63 & 0 & 0 & 0 & 0 & 0 & 0 & 0 & 0 & 0 \\
\hline & Pedro Avelino (Base Física da EMPARN) & 0 & 1 & 0 & 0 & 0 & 0 & 0 & 0 & 0 & 13,8 & 0 & 0 & 0 \\
\hline & Riachuelo (EMATER) & 0 & 0 & 0 & 0 & 0 & 0 & 0 & 0 & 0 & 0 & 0 & 0 & 0 \\
\hline & Rui Barbosa (EMATER) & 0 & 0 & 0 & 0 & 0 & 0 & 0 & 0 & 0 & 0 & 0 & 0 & 10,7 \\
\hline & Santa Cruz (EMATER) & 0 & 0 & 0 & 0 & 0 & 0 & 0 & 0 & 0 & 0 & 0 & 0 & 0 \\
\hline & Santana do Matos (EMATER) & 0 & 0 & 0 & 0 & 0 & 0 & 0 & 0 & 0 & 0 & 0 & 0 & 0 \\
\hline & Santana do Matos (Barão de Serra Branca) & 0 & 0 & 0 & 0 & 0 & 0 & 0 & 0 & 0 & 0 & 0 & 0 & 17 \\
\hline & Santana do Matos (São José da Passagem) & 0 & 0 & 0 & 0 & 0 & 0 & 0 & 0 & 0 & 0 & 0 & 0 & 17 \\
\hline & São Bento do Trairi (Prefeitura) & 0 & 0 & 0 & 0 & 0 & 0 & 0 & 0 & 0 & 9,4 & 0 & 0 & 0 \\
\hline & São José do Campestre (EMATER) & 0 & 0 & 0 & 0 & 0 & 0 & 0 & 0 & 0 & 0 & 0 & 0 & 0 \\
\hline & São Paulo do Potengi (EMATER) & 0 & 3 & 0 & 0 & 0 & 4,4 & 0 & 0 & 0 & 0 & 0 & 0 & 0 \\
\hline & São Pedro (EMATER) & 0 & 7,5 & 1,3 & 0 & 0 & 0 & 0 & 0 & 0 & 0 & 0 & 0 & 0 \\
\hline & São Rafael (EMATER) & 0 & 0 & 0 & 0 & 0 & 0 & 0 & 0 & 0 & 0 & 0 & 0 & 0 \\
\hline & São Tomé (EMATER) & 0 & 0 & 0 & 0 & 0 & 0 & 0 & 0 & 0 & 0 & 0 & 0 & 0 \\
\hline & São Vicente (EMATER - Ex Particular) & 0 & 0 & 0 & 0 & 0 & 0 & 0 & 0 & 0 & 0 & 0 & 0 & 0 \\
\hline & São Vicente (EMATER - Extinto) & 0 & 0 & 0 & 0 & 0 & 0 & 0 & 0 & 0 & 0 & 0 & 0 & 0 \\
\hline
\end{tabular}




\begin{tabular}{|c|c|c|c|c|c|c|c|c|c|c|c|c|c|c|c|c|c|c|c|c|c|c|}
\hline \multirow[t]{2}{*}{2008} & Estação & & s41 s & s42 & s43 & s44 & s45 & s46 & s47 & s48 & s49 & s50 & s51 & s52 s & s53 & & & & & & & \\
\hline & Senador Eloi de Souza (Particular) & & 0 & 0 & 0 & 0 & 0 & 0 & 0 & 0 & 0 & 0 & 0 & 0 & 0 & & & & & & & \\
\hline & Serrinha (EMATER) & & 0 & 7,3 & 3,1 & 0 & 0 & 0 & 0 & 0 & 0 & 0 & 0 & 0 & 0 & & & & & & & \\
\hline & Sítio Novo (Prefeitura) & & 0 & 0 & 0 & 0 & 0 & 0 & 0 & 0 & 0 & 0 & 0 & 0 & 0 & & & & & & & \\
\hline & Tangará (EMATER) & & 0 & 0 & 0 & 0 & 0 & 0 & 0 & 0 & 0 & 2 & 0 & 0 & 0 & & & & & & & \\
\hline & Tangará (Açude Trairi) & & 0 & 0 & 0 & 0 & 0 & 0 & 0 & 0 & 0 & 0 & 0 & 0 & 0 & & & & & & & \\
\hline & Triunfo Potiguar (Prefeitura) & & 0 & 0 & 0 & 0 & 0 & 0 & 0 & 0 & 0 & 0 & 0 & 0 & 0 & & & & & & & \\
\hline & Triunfo Potiguar (Chá Cacimbas/Serra J. Vale) & & 0 & 0 & 0 & 0 & 0 & 0 & 0 & 0 & 0 & 0 & 0 & 0 & 0 & & & & & & & \\
\hline & Triunfo Potiguar (Chá Velha/Serra J. Vale) & & 0 & 0 & 0 & 0 & 0 & 0 & 0 & 0 & 0 & 0 & 0 & 0 & 0 & & & & & & & \\
\hline & Alagoa Nova & & 1 & 1,6 & 1,8 & 0 & 0 & 0 & 0 & 0 & 0 & 0 & 0 & 0 & 0 & & & & & & & \\
\hline & Barra de Santana & & 0 & 1,6 & 0 & 0 & 0 & 0 & 0 & 0 & 0 & 0 & 0 & 0 & 0 & & & & & & & \\
\hline & Barra de Santana/Bodocongó & & 0 & 1,6 & 0 & 0 & 0 & 0 & 0 & 0 & 0 & 4,5 & 0 & 0 & 0 & & & & & & & \\
\hline & Boa Vista & & 0 & 0 & 0 & 0 & 0 & 0 & 0 & 0 & 0 & 0 & 0 & 0 & 0 & & & & & & & \\
\hline & Boqueirão/Açude Boqueirão & & 0 & 3,3 & 0 & 0 & 0 & 0 & 0 & 0 & 0 & 0 & 0 & 0 & 0 & & & & & & & \\
\hline & Cabaceiras & & 0 & 0,8 & 0 & 0 & 0 & 0 & 0 & 0 & 0 & 0 & 0 & 0 & 0 & & & & & & & \\
\hline & Campina Grande/EMBRAPA & & 0,8 & 9,5 & 0,4 & 0 & 0,4 & 0 & 0,8 & 0 & 0 & 5,9 & 0 & 1,9 & 0 & & & & & & & \\
\hline & Campina Grande/INSA & & 0,2 & 1,8 & 0 & 0 & 0 & 0 & 0 & 0 & 0 & 3,8 & 0 & 0 & 0 & & & & & & & \\
\hline & Campina Grande/Santa Terezinha & & 0 & 9,2 & 0 & 0 & 1 & 0 & 0 & 0 & 0 & 21 & 0 & 0,2 & 0 & & & & & & & \\
\hline & Campina Grande/São José da Mata & & 1,7 & 11,4 & 0 & 0 & 0 & 0 & 0 & 0 & 0 & 2,3 & 0 & 0 & 0 & & & & & & & \\
\hline & Caturité & & 0 & 5,2 & 0 & 0 & 0 & 0 & 0 & 0 & 0 & 0 & 0 & 0 & 0 & & & & & & & \\
\hline & Caturité/Fazenda Campo de Emas & & 0 & 0 & 0 & 0 & 0 & 0 & 0 & 0 & 0 & 0 & 0 & 0 & 0 & & & & & & & \\
\hline & Cubati & & 0 & 0 & 0 & 0 & 0 & 0 & 0 & 0 & 0 & 0 & 0 & 0 & 0 & & & & & & & \\
\hline & Lagoa Seca & & 1 & 11,1 & 0 & 0 & 0 & 0 & 0 & 0 & 0 & 3,9 & 0 & 0 & 0 & & & & & & & \\
\hline & Matinhas & & 0,3 & 5,8 & 0 & 0 & 0,1 & 0 & 0 & 0 & 0 & 5,3 & 10 & 13,8 & 4,2 & & & & & & & \\
\hline & Olivedos & & 0 & 1,5 & 0 & 0 & 0 & 0 & 0 & 0 & 0 & 28,6 & 0 & 0 & 0 & & & & & & & \\
\hline & Pedra Lavrada & & 0 & 0 & 0 & 0 & 0 & 0 & 0 & 0 & 0 & 0 & 0 & 7,6 & 0 & & & & & & & \\
\hline & Pocinhos & & 0 & 2,8 & 0 & 0 & 0,5 & 0 & 0 & 0 & 0 & 14,6 & 0 & 0 & 0 & & & & & & & \\
\hline & Queimadas & & 4,2 & 2,2 & 0 & 0 & 0 & 0 & 0 & 0 & 0 & 0 & 0 & 0 & 0 & & & & & & & \\
\hline & Seridó/São Vicente do Seridó & & 0 & 0 & 0 & 0 & 0 & 0 & 0 & 0 & 0 & 0 & 0 & 0 & 0 & & & & & & & \\
\hline & Soledade & & 0 & 1,2 & 0 & 0 & 0 & 0 & 0 & 0 & 0 & 5,1 & 0 & 0 & 0 & & & & & & & \\
\hline 2009 & Estação & s1 & s2 & s3 & s4 & s5 & & 6 & s7 & s8 & s9 & s10 & s11 & s12 & s13 & s14 & s15 & s16 & s17 & s18 & s19 & s20 \\
\hline & Acari (Particular) & 0 & 15,2 & 0 & 27 & 20 & & 1,3 & 0 & 53 & 24,5 & 0 & 61,7 & 12,1 & 55,6 & 36,1 & 13,9 & 58,2 & 154,4 & 26 & 59,9 & 59,1 \\
\hline & Acari (Açude Gargalheiras) & 28 & 0 & 25 & 10 & 38 & & 17 & 11 & 92 & 118 & 19 & 65 & 43 & 98 & 59 & 25 & 93 & 212 & 127 & 79 & 135 \\
\hline & Assu (Particular) & 0 & 1,2 & 3,8 & 18,5 & 20,3 & & 5,1 & 13 & 60,7 & 66,7 & 36,8 & 50,3 & 24 & 4,8 & 37 & 38,9 & 65,5 & 102,6 & 47 & 40,2 & 51,5 \\
\hline & Assu (EMATER/Sítio Casa Forte) & 0 & 0,5 & 29,7 & 8,6 & 47,6 & & 4,6 & 2,2 & 69,7 & 69,9 & 36,1 & 25,9 & 19,7 & 20,8 & 19,7 & 46,2 & 78,2 & 81,4 & 51,4 & 77,7 & 61,5 \\
\hline & Afonso Bezerra (EMATER) & 0 & 4 & 2 & 17 & 8,5 & 5 & 15 & 0 & 55,3 & 104,5 & 16,5 & 31 & 31 & 39,5 & 42 & 53 & 130 & 143 & 76,5 & 76,5 & 17 \\
\hline
\end{tabular}




\begin{tabular}{|c|c|c|c|c|c|c|c|c|c|c|c|c|c|c|c|c|c|c|c|c|c|}
\hline 2009 & Estação & s1 & s2 & s3 & s4 & s5 & s6 & s7 & s8 & s9 & s10 & s11 & $\mathrm{s} 12$ & s13 & s14 & s15 & $s 16$ & s17 & s18 & s19 & s20 \\
\hline & Afonso Bezerra (Assentamento Santa Maria) & 0 & 0 & 0 & 32,2 & 21,2 & 22,6 & 19,8 & 111,8 & 56,7 & 70,2 & 28,5 & 45,2 & 18,3 & 59,4 & 38,6 & 104,4 & 145,4 & 72,4 & 39,2 & 110,1 \\
\hline & Almino Afonso (Particular - Ex Sítio Milagres) & 0 & 0 & 57,5 & 26,7 & 27,6 & 0 & 39,1 & 67,8 & 94,3 & 24,2 & 45,8 & 13,3 & 5,1 & 39,7 & 125 & 48,9 & 115,6 & 27,9 & 70,2 & 34,8 \\
\hline & Angicos (Prefeitura) & 0 & 2 & 3 & 0 & 8,5 & 71 & 8,7 & 67 & 207,5 & 13,5 & 75 & 15 & 19,5 & 17 & 19,2 & 47,5 & 66,5 & 29,7 & 34,7 & 57 \\
\hline & Campo Grande (Particular) & 0 & 0 & 124,4 & 3 & 82,2 & 48,4 & 87,1 & 59,6 & 37,7 & 34,5 & 73,2 & 50,9 & 20,1 & 19,3 & 112,8 & 121,5 & 84,2 & 27,8 & 46,2 & 20,7 \\
\hline & Campo Grande (Particular 2) & 0 & 0 & 129,4 & 0 & 93,5 & 53,8 & 91 & 48,2 & 37,3 & 75 & 28,3 & 50 & 20,2 & 17 & 111,3 & 119 & 114,4 & 32 & 40,8 & 19,3 \\
\hline & Barcelona (Particular) & 0 & 54,5 & 0 & 0 & 6 & 0 & 16,5 & 49 & 79 & 3,5 & 57,5 & 25 & 19,5 & 59 & 31,5 & 52 & 177,5 & 46 & 59,5 & 7 \\
\hline & Bodó (EMATER/TRF P/Delegacia) & 0 & 13 & 0 & 37,5 & 10 & 56 & 16 & 83 & 38,5 & 68 & 45,5 & 11,5 & 27,5 & 25,2 & 77,5 & 93 & 198,9 & 8,3 & 28,5 & 107 \\
\hline & Bom Jesus (Particular) & 0 & 44,7 & 1,4 & 1,2 & 18,5 & 0 & 22,1 & 60,9 & 18 & 1,5 & 78,7 & 7,2 & 67,1 & 10 & 41,9 & 44,7 & 142,1 & 13,4 & 37,6 & 15,3 \\
\hline & Caiçara do Rio do Vento (Particular) & 0 & 67 & 0 & 0 & 22 & 0 & 0 & 47 & 16,4 & 57 & 56,3 & 0 & 1,2 & 10 & 51 & 28,8 & 173,2 & 54,3 & 24,6 & 1,4 \\
\hline & Caicó (Batalhão) & 0 & 0 & 0 & 30 & 106,3 & 0 & 87,7 & 87,5 & 13 & 26 & 60 & 42 & 21,7 & 46 & 25 & 46 & 134,5 & 0 & 94,5 & 3 \\
\hline & Caicó (Açude Mundo Novo - EMPARN) & 0 & 0 & 0 & 38 & 99,7 & 24,6 & 41,4 & 28,4 & 78,4 & 19,2 & 95,6 & 38,2 & 12,6 & 44,8 & 39,7 & 46 & 92,7 & 8,6 & 66,9 & 12 \\
\hline & Caicó (Palma) & 0 & 2 & 27 & 37,6 & 27 & 4 & 28 & 26,8 & 26 & 14,6 & 29,4 & 18,6 & 62 & 44,6 & 38,8 & 128 & 134,6 & 86,2 & 9 & 25,6 \\
\hline & Caicó (Açude Itans) & 4,1 & 0 & 8,2 & 8,9 & 50,7 & 14,1 & 16,6 & 35,9 & 89,9 & 21,4 & 66,8 & 31,9 & 13,1 & 80,7 & 42 & 71,2 & 158 & 18,9 & 77,5 & 35,4 \\
\hline & Caicó (EMATER) & 0 & 0 & 0 & 16,9 & 95,7 & 8,2 & 90,1 & 49 & 74,5 & 43 & 85 & 25 & 28,1 & 81,2 & 62,5 & 64,5 & 167,4 & 25,7 & 112,2 & 45 \\
\hline & Caicó (Laginhas) & 0 & 0 & 0 & 0 & 0 & 42,5 & 13,8 & 52 & 45,9 & 59,6 & 30,3 & 17,5 & 14,9 & 49,8 & 33,5 & 53,4 & 132,5 & 35,4 & 11,5 & 4,4 \\
\hline & Campo Redondo (EMATER) & 0 & 20,6 & 0,4 & 27 & 5,6 & 24,4 & 9,1 & 37,1 & 37,9 & 11,7 & 39,6 & 17 & 26,4 & 44,9 & 5,3 & 43,4 & 14,2 & 20,8 & 48,5 & 7,7 \\
\hline & Campo Redondo (Polícia Rodoviária) & 0 & 0 & 15,2 & 14,1 & 15,8 & 0 & 32,1 & 18,6 & 54,5 & 26,4 & 57,8 & 12,7 & 16,4 & 25,5 & 14,3 & 66,6 & 31,5 & 24 & 28,1 & 14,6 \\
\hline & Cerro Corá (EMATER) & 0 & 17,5 & 1,1 & 0 & 40,4 & 67,7 & 21,2 & 41,2 & 120,5 & 100 & 50 & 16,4 & 60,5 & 22,3 & 51,2 & 71,6 & 232,9 & 11,4 & 92,5 & 39,7 \\
\hline & Coronel Ezequiel (Particular) & 0 & 24 & 16,2 & 46 & 5 & 70 & 74 & 38,9 & 39,5 & 0 & 62 & 15 & 6 & 29,7 & 19 & 39 & 79,5 & 9,5 & 64,9 & 2 \\
\hline & Cruzeta (Base Física da EMPARN) & 0 & 1 & 28,4 & 2,8 & 46,9 & 14,6 & 30,2 & 60,9 & 57,3 & 25,8 & 34,3 & 19,8 & 61,9 & 60,8 & 74,6 & 82,4 & 152,2 & 4,5 & 61,7 & 31,5 \\
\hline & Currais Novos (CERCEL) & 0 & 8,6 & 1,2 & 4,7 & 3,2 & 68,5 & 0 & 41,7 & 58,7 & 0 & 89,9 & 0 & 14,8 & 28,8 & 82,5 & 28 & 126,9 & 43,9 & 48,8 & 50,1 \\
\hline & Currais Bovos (Açude Tororó) & 0 & 0 & 0 & 0 & 0 & 80,6 & 33,4 & 53,6 & 62,4 & 20,4 & 0 & 0 & 55,3 & 49,8 & 81 & 40 & 118,5 & 21,2 & 48,6 & 57,6 \\
\hline & Fernando Pedroza (EMATER) & 0 & 0 & 0 & 0 & 0 & 0 & 101 & 49,7 & 151,8 & 31 & 0 & 20 & 12,5 & 13 & 60 & 45 & 194 & 21,6 & 37,3 & 52,3 \\
\hline & Florânia (INMET) & 14,1 & 1,8 & 0 & 69,9 & 13,4 & 30,2 & 6 & 39,1 & 163,1 & 41 & 85,7 & 81,5 & 69 & 42,7 & 101,8 & 39,8 & 157,5 & 19,2 & 65,4 & 30,5 \\
\hline & Florânia (Sítio Jucuri) & 3,5 & 0 & 15,4 & 48 & 7,4 & 14,1 & 5,2 & 69,5 & 140,2 & 48,9 & 76,5 & 76,5 & 51,3 & 34,8 & 124,8 & 56,4 & 168 & 32,2 & 66,7 & 34,8 \\
\hline & Jaçanã (EMATER) & 0 & 40,5 & 3 & 64,6 & 0 & 48,5 & 66,8 & 19,8 & 28 & 0 & 74,4 & 20 & 70,6 & 19,5 & 22,4 & 55,2 & 109,5 & 27,6 & 93,7 & 5,8 \\
\hline & Janduís (EMATER) & 0 & 2 & 4,5 & 61 & 68,6 & 20 & 67,2 & 88,4 & 130,6 & 34 & 32,4 & 42 & 0,5 & 13 & 83,2 & 165 & 79,4 & 12 & 15,3 & 36,8 \\
\hline & Boa Saúde (EMATER) & 0 & 50,3 & 1 & 12,3 & 29,3 & 0 & 28,3 & 58,7 & 15,1 & 0 & 41,3 & 17,1 & 15,6 & 7,5 & 28,7 & 41,3 & 39 & 14,3 & 53,8 & 32,7 \\
\hline & Japi (Particular) & 0 & 47,6 & 32,4 & 18,2 & 29 & 21,8 & 51,8 & 4,2 & 0 & 0 & 18,4 & 0 & 40,4 & 35,4 & 17,4 & 39,6 & 8,2 & 32 & 4,4 & 14,4 \\
\hline & Japi (EMATER) & 0 & 27,5 & 17 & 30,5 & 1,2 & 15 & 17 & 13 & 9 & 0 & 18 & 0 & 28,5 & 39,5 & 13,5 & 17,6 & 19,2 & 13,6 & 32,7 & 5 \\
\hline & Jardim de Angicos (EMATER) & 0 & 19,5 & 61,4 & 7,6 & 6 & 3,3 & 1,5 & 26,9 & 61,3 & 4 & 52,7 & 20,5 & 44,6 & 0 & 18 & 26,8 & 150,5 & 28,6 & 39,2 & 20,1 \\
\hline & Lagoa d'Anta (Prefeitura) & 0 & 39,5 & 0 & 32 & 50,5 & 4,8 & 78,5 & 36 & 32,6 & 0 & 35,9 & 23,6 & 44,1 & 73,9 & 11,5 & 41 & 0 & 14 & 77,8 & 53,2 \\
\hline & Lagoa de Pedras (Prefeitura) & 0 & 90,8 & 29,9 & 0 & 44,9 & 1,5 & 6,4 & 71,2 & 22,7 & 0 & 80,6 & 5,4 & 50 & 27,7 & 12,2 & 70 & 93,1 & 37,8 & 52,5 & 43,1 \\
\hline & Lagoa de Velhos (Delegacia) & 0 & 38,8 & 26,5 & 5,7 & 4,2 & 0 & 12,7 & 26,2 & 32,4 & 0 & 50,5 & 11,8 & 70,6 & 24,2 & 66,5 & 60,2 & 91,8 & 52,2 & 53,4 & 10,9 \\
\hline & Lagoa Nova (EMATER/Sítio Humaitá) & 0 & 17,1 & 0 & 6,9 & 20,9 & 31,4 & 1,5 & 42,8 & 101,5 & 78 & 25,9 & 9 & 25,5 & 12,7 & 36,5 & 70,1 & 89,3 & 30,7 & 40 & 44,5 \\
\hline & Lagoa Salgada (Delegacia) & 0 & 41 & 31,1 & 4,2 & 37,1 & 7,4 & 0 & 40,2 & 17,3 & 0 & 24,5 & 0 & 17 & 33,7 & 15,7 & 140,6 & 21,5 & 6,5 & 35 & 38 \\
\hline
\end{tabular}




\begin{tabular}{|c|c|c|c|c|c|c|c|c|c|c|c|c|c|c|c|c|c|c|c|c|c|}
\hline 2009 & Estação & s1 & s2 & s3 & s4 & s5 & s6 & s7 & s8 & s9 & s10 & s11 & s12 & s13 & s14 & s15 & s16 & s17 & s18 & s19 & s20 \\
\hline & Lajes (Prefeitura) & 0 & 19,8 & 29,7 & 0 & 2,1 & 16,5 & 10,7 & 14,7 & 36,8 & 115,7 & 83,5 & 0 & 62 & 50,7 & 36,8 & 61,3 & 156 & 120,9 & 25,4 & 7,4 \\
\hline & Lajes Pintadas (Prefeitura) & 0 & 24,5 & 5,6 & 10 & 11,3 & 32 & 48,6 & 43,3 & 53,1 & 35 & 39,5 & 0 & 6,8 & 8,7 & 55,7 & 50,8 & 13,3 & 72,8 & 41,9 & 8,8 \\
\hline & Messias Targino (Prefeitura) & 0 & 0 & 78,5 & 0 & 54,6 & 0 & 47,6 & 90,6 & 69,7 & 30 & 16,6 & 29,1 & 35 & 50,2 & 71,9 & 25,4 & 59,6 & 59,6 & 44,9 & 9,3 \\
\hline & Monte Alegre (EMATER) & 1,8 & 46,4 & 12 & 9 & 49 & 4 & 52 & 53,5 & 44,8 & 11 & 73 & 22 & 21 & 59 & 46,2 & 161,2 & 74,4 & 15 & 46 & 102 \\
\hline & Monte das Gameleiras (EMATER) & 0 & 30,7 & 19,2 & 8,7 & 34,4 & 1,6 & 41,1 & 85,4 & 37,3 & 0 & 32,9 & 11,3 & 26,1 & 20 & 41,2 & 17 & 32,5 & 30,2 & 38,3 & 13,1 \\
\hline & Paraú (Sindicato) & 0 & 0 & 7,4 & 40,5 & 51,7 & 39,7 & 12,5 & 21,4 & 44,9 & 12,8 & 89,2 & 9,2 & 11,2 & 132,2 & 139,1 & 63,6 & 145,3 & 101,8 & 66,8 & 20,5 \\
\hline & Passa e Fica (Prefeitura) & 0 & 28,4 & 41,3 & 20 & 26,8 & 3,8 & 27,7 & 73,9 & 33,8 & 0 & 32,7 & 8,8 & 86 & 41 & 105,7 & 55,4 & 28,4 & 2,4 & 39,1 & 23,8 \\
\hline & Patu (Particular) & 0 & 0 & 48 & 9 & 20,6 & 5 & 74,6 & 105 & 124,4 & 4 & 55 & 22 & 5 & 29,4 & 66,2 & 90,8 & 197 & 87,4 & 49,4 & 94,4 \\
\hline & Santa Maria (Sindicato dos Trabalhadores Rurais) & 0 & 0 & 0 & 0 & 37,7 & 0,3 & 16,8 & 46,6 & 16 & 10 & 49,6 & 0 & 20,6 & 18 & 44 & 62,2 & 116,9 & 0 & 83 & 15,9 \\
\hline & Pedra Preta (EMATER) & 0 & 11 & 27 & 0 & 22 & 68 & 11 & 60 & 77,5 & 147 & 68 & 0 & 32 & 7,5 & 20 & 52,5 & 183,5 & 10 & 86 & 33,5 \\
\hline & Pedro Avelino (Particular) & 0 & 19,2 & 3 & 0 & 25,4 & 5,5 & 0,5 & 39,6 & 58,6 & 50,4 & 32,4 & 0 & 38,5 & 36,6 & 72,5 & 117,8 & 181,9 & 7,2 & 24,7 & 57 \\
\hline & Pedro Avelino (Base Física da EMPARN) & 0 & 5 & 11 & 10,7 & 9,1 & 16 & 90,7 & 19,1 & 120,7 & 13,2 & 41,1 & 24,4 & 44,6 & 59,3 & 0 & 175,5 & 125,5 & 30,6 & 75,7 & 21,4 \\
\hline & Riachuelo (EMATER) & 0 & 0 & 0 & 0 & 5 & 0 & 5 & 52,5 & 69,7 & 0 & 62,5 & 30,7 & 126,5 & 0 & 49,1 & 45 & 60 & 23 & 37 & 27,5 \\
\hline & Rui Barbosa (EMATER) & 0 & 0 & 0 & 0 & 13,4 & 2,8 & 13 & 31,3 & 79,1 & 0 & 72,7 & 32,2 & 0,5 & 0 & 78,6 & 63,1 & 117,6 & 42,3 & 44,3 & 0 \\
\hline & Santa Cruz (EMATER) & 0 & 4,5 & 33,4 & 8,2 & 8 & 0 & 123,8 & 31 & 23,6 & 29 & 62,6 & 4,2 & 21 & 104,8 & 67,8 & 28,1 & 66,2 & 66,6 & 9,1 & 28 \\
\hline & Santana do Matos (EMATER) & 0 & 3,5 & 68 & 3 & 15 & 12,5 & 0 & 88 & 57 & 75 & 85 & 7 & 30 & 14 & 38 & 90 & 263 & 53 & 69 & 43 \\
\hline & Santana do Matos (Barão de Serra Branca) & 0 & 0 & 60,8 & 40,7 & 20,3 & 53,7 & 36,7 & 73,4 & 73 & 14,9 & 90,5 & 8,9 & 119,6 & 74,1 & 78,6 & 72,8 & 127,5 & 98,5 & 68,9 & 61,6 \\
\hline & Santana do Matos (São José da Passagem) & 0 & 0 & 60,8 & 40,7 & 20,3 & 53,7 & 36,7 & 73,4 & 73 & 14,9 & 90,5 & 8,9 & 119,6 & 74,1 & 78,6 & 72,8 & 127,5 & 98,5 & 68,9 & 61,6 \\
\hline & São Bento do Trairi (Prefeitura) & 0 & 0 & 0 & 60 & 0 & 0 & 0 & 18 & 39,9 & 80,8 & 1,5 & 0 & 17,6 & 58,9 & 49,8 & 57,5 & 147,9 & 104 & 59,2 & 103,3 \\
\hline & São José do Campestre (EMATER) & 0 & 24,8 & 23,8 & 2 & 21,8 & 0 & 7,9 & 78,5 & 18,8 & 0 & 35,1 & 40 & 55,9 & 25,1 & 14,5 & 38,1 & 38,9 & 5,3 & 57,4 & 2 \\
\hline & São Paulo do Potengi (EMATER) & 0 & 16 & 16 & 0 & 23 & 1,6 & 33,8 & 58,4 & 8 & 20,4 & 55 & 15,7 & 59,4 & 8,8 & 28,8 & 54,3 & 119,8 & 10,9 & 56 & 10,2 \\
\hline & São Pedro (EMATER) & 0 & 82,4 & 38,4 & 1,4 & 25,1 & 0 & 4,7 & 52,9 & 35,9 & 0,5 & 43,9 & 13,5 & 45,8 & 1 & 19,8 & 75,8 & 100,2 & 31 & 46,5 & 24,2 \\
\hline & São Rafael (EMATER) & 43,5 & 3 & 22,2 & 48 & 13,3 & 14,2 & 3 & 30 & 73,9 & 15 & 108,3 & 22,3 & 50,2 & 89 & 52,4 & 77,7 & 109,5 & 55,7 & 55,1 & 4,3 \\
\hline & São Tomé (EMATER) & 0 & 17 & 12 & 6 & 20 & 72 & 39 & 99 & 34 & 0 & 62 & 0 & 9 & 9 & 90 & 43 & 113 & 100 & 46 & 0 \\
\hline & São Vicente (EMATER - Ex Particular) & 0 & 5,5 & 0 & 0 & 44 & 13 & 19 & 47,3 & 77,4 & 30 & 14,1 & 27 & 89 & 65,7 & 48,7 & 5 & 128,4 & 62,2 & 19,1 & 52,7 \\
\hline & São Vicente (EMATER - Extinto) & 0 & 5,5 & 0 & 0 & 44 & 13 & 19 & 47,3 & 77,4 & 30 & 14,1 & 27 & 89 & 65,7 & 48,7 & 5 & 128,4 & 62,2 & 19,1 & 52,7 \\
\hline & Senador Eloi de Souza (Particular) & 0 & 43 & 23 & 32 & 24,5 & 1 & 15,3 & 11,3 & 38 & 21,5 & 28,5 & 1,5 & 26,4 & 8,5 & 31,7 & 57,5 & 46 & 17,4 & 28,5 & 15,5 \\
\hline & Serrinha (EMATER) & 0,9 & 61,5 & 17,8 & 2,7 & 34,1 & 3,1 & 10,9 & 51,1 & 32,6 & 2,5 & 63,7 & 4,8 & 15,9 & 26,9 & 70,8 & 63,2 & 50,7 & 14,5 & 45,8 & 46,8 \\
\hline & Sítio Novo (Prefeitura) & 0 & 28 & 36 & 0 & 15 & 0 & 8 & 154 & 39 & 0 & 65 & 0 & 40 & 17 & 31 & 73 & 96 & 51 & 87 & 15 \\
\hline & Tangará (EMATER) & 0 & 25 & 80 & 6 & 0 & 0 & 13,5 & 28,5 & 14 & 0 & 29,5 & 11,5 & 17 & 72 & 19,5 & 52,5 & 39,5 & 3,5 & 35,5 & 6,5 \\
\hline & Tangará (Açude Trairi) & 0 & 31,2 & 26,6 & 4,5 & 4,5 & 10,7 & 5 & 28,9 & 11,2 & 0 & 29,8 & 6,6 & 13,1 & 162,8 & 16,2 & 32,2 & 17,6 & 3 & 55,9 & 17,5 \\
\hline & Triunfo Potiguar (Prefeitura) & 1,4 & 0 & 51,6 & 0 & 32,2 & 0 & 0 & 0 & 49,6 & 111,8 & 11,8 & 34,9 & 45,8 & 46,6 & 55,9 & 85,1 & 166,8 & 91,4 & 24,3 & 38,4 \\
\hline & Triunfo Potiguar (Chá Cacimbas/Serra J. Vale) & 0 & 0 & 65 & 22 & 40 & 122 & 111 & 50 & 105 & 105 & 272 & 14 & 25 & 30 & 62,8 & 61 & 66 & 0 & 0 & 0 \\
\hline & Triunfo Potiguar (Chá Velha/Serra J. Vale) & 0 & 0 & 3,1 & 0 & 66,3 & 75,2 & 227,5 & 38,1 & 79,2 & 57 & 52,9 & 32,5 & 14,6 & 21,8 & 88,5 & 104 & 115,9 & 16,4 & 62,9 & 28,3 \\
\hline & Barra de Santana & 0 & 7,7 & 0 & 0 & 19,3 & 0,5 & 0 & 51,8 & 21,5 & 0 & 39,1 & 29,1 & 1,3 & 3,1 & 52,4 & 14,1 & 3,6 & 12,3 & 26,4 & 16 \\
\hline & Boa Vista & 0 & 7,6 & 0 & 10,8 & 16 & 0 & 36,6 & 32,2 & 5,6 & 0 & 18,2 & 0 & 0 & 39,2 & 14,2 & 20,4 & 24,6 & 0 & 2,6 & 44,4 \\
\hline
\end{tabular}




\begin{tabular}{|c|c|c|c|c|c|c|c|c|c|c|c|c|c|c|c|c|c|c|c|c|c|}
\hline \multirow{18}{*}{2009} & Estação & s1 & s2 & s3 & s4 & s5 & s6 & s7 & s8 & s9 & $\mathbf{s 1 0}$ & s1 & s1 & 12 & 13 & s14 & s15 & s16 & s17 & $\mathbf{s} 18$ & s1s \\
\hline & Boqueirão/Açude Boqueirão & 0 & 0 & 5,2 & 0,9 & 2,2 & 32,9 & 61,5 & 83,8 & 1,7 & 0 & 30 & & 6 & 0 & 9 & 22,8 & 11,4 & 35,7 & \multicolumn{2}{|c|}{13,4} \\
\hline & Cabaceiras & 0 & 0 & 0 & 54 & 4,3 & 0 & 2,6 & 82,2 & 11,4 & 0 & 1,4 & & 0 & 0,4 & 63 & 23,4 & 27,3 & 47,1 & \multicolumn{2}{|c|}{31,3} \\
\hline & Campina Grande/EMBRAPA & 0 & 31,4 & 0 & 12,7 & 55,6 & 11 & 79,1 & 99 & 29,1 & 0 & 12 & & 6 & 0,2 & 1,3 & 68 & 69,3 & 14,1 & \multicolumn{2}{|c|}{11,8} \\
\hline & Campina Grande/INSA & 0 & 19,7 & 0 & 15,2 & 20 & 2,4 & 31,9 & 66,5 & 27,7 & 0 & 8 & & 0 & 0 & 0 & 77,9 & 61,1 & 0 & \multicolumn{2}{|c|}{8,1} \\
\hline & Campina Grande/Santa Terezinha & 0 & 36,8 & 0 & 8,3 & 21,1 & 13,2 & 80,3 & 117 & 26,8 & 0 & 9,8 & & 3 & 0 & 7 & 20,4 & 59,7 & 45 & \multicolumn{2}{|c|}{5,5} \\
\hline & Campina Grande/São José da Mata & 0 & 7,1 & 0 & 12,5 & 13,9 & 0 & 35,8 & 96,5 & 24,7 & 0 & 7,9 & & 0 & 0 & 0 & 85,3 & 59,9 & 8,4 & \multicolumn{2}{|c|}{2,7} \\
\hline & Caturité & 0 & 15,1 & 0 & 12 & 18,8 & 36,8 & 3,1 & 70,6 & 0 & 0 & 1,9 & & 0 & 0 & 3,2 & 17,7 & 35,8 & 11,3 & 9,8 & \\
\hline & Caturité/Fazenda Campo de Emas & 0 & 20,4 & 4,2 & 6 & 39,2 & 17 & & 0 & & 4 & 0 & & 6 & 0 & 3,2 & 15,6 & 22,7 & 9 & 15 & \\
\hline & Cubati & 0 & 22 & 5 & 7,4 & 5,9 & 4 & 27,4 & 39 & 28,9 & 0 & 13 & & 0 & 0,5 & 90,3 & 52,2 & 19,4 & 26,1 & 10 & \\
\hline & Lagoa Seca & 0 & 11,5 & 0 & 10,8 & 65 & 1,6 & 42,6 & 90,8 & 46,9 & 0 & 30 & & 4 & 0 & 5,1 & 99,5 & 84,5 & 33,4 & 5 & \\
\hline & Matinhas & 1,6 & 6,6 & 152,8 & 5,5 & 19 & 8,9 & 8,4 & 25,8 & 0 & 0 & 11 & & 0,9 & 9,5 & 75,2 & 108,5 & 46,2 & 0 & 48,9 & \\
\hline & Olivedos & 0 & 0 & 0 & 3 & 6,5 & 35,5 & 12 & 36 & 35,4 & 0 & 2,5 & & 0 & 6,3 & 19,3 & 36,9 & 33,1 & 24,6 & 2,4 & \\
\hline & Pedra Lavrada & 0 & 15,3 & 0 & 0 & 40 & 14 & 38 & 39,5 & 24,7 & 0 & 19 & & 2,7 & 1,8 & 36,2 & 20,3 & 36,9 & 79,9 & 30,2 & \\
\hline & Pocinhos & 0 & 4,5 & 2 & 8,4 & 1,2 & 0 & 25,7 & 57,2 & 12,3 & 0 & 0 & & 0 & 0 & 26,5 & 61,1 & 48,8 & 9,1 & 2,3 & \\
\hline & Queimadas & 0 & 30 & 0 & 7,3 & 19,2 & 21,7 & 11,9 & 65,8 & 19,5 & 0 & 26 & & 0 & 0 & 10,1 & 37,1 & 49,5 & 12,9 & 7,4 & \\
\hline & Seridó/São Vicente do Seridó & 0 & 11,6 & 25,5 & 24,8 & 58,4 & 15,5 & 8 & 80,1 & 25,4 & 4 & 0 & & 0 & 12 & 124,2 & 39,5 & 50,6 & 31,7 & 20,3 & 3 \\
\hline & Soledade & 0 & 7,7 & 0 & 12,9 & 15,9 & 8 & 28,3 & 38,2 & 22,8 & 0 & 13 & & 0 & 8,5 & 41,8 & 85,1 & 22,5 & 52,1 & 0 & \\
\hline 2009 & Estação & s21 & s22 & s23 & s24 & s25 & s26 & $s 27$ & $\mathbf{s} 28$ & s29 & s30 & s31 & s32 & s33 & s34 & s35 & s36 & s37 & s38 & s39 & s40 \\
\hline & Acari (Particular) & 28 & 14,6 & 0 & 0 & 0 & 4,5 & 8,9 & 0 & 5,5 & 0 & 0 & 0 & 0 & 0 & 0 & 0 & 0 & 0 & 0 & 0 \\
\hline & Acari (Açude Gargalheiras) & 65 & 0 & 0 & 0 & 0 & 0 & 0 & 0 & 0 & 0 & 0 & 0 & 0 & 0 & 0 & 0 & 0 & 0 & 0 & 0 \\
\hline & Assu (Particular) & 28,1 & 25,2 & 26,4 & 0 & 62,8 & 0 & 20,7 & 12,5 & 1,1 & 0 & 0,1 & 5,7 & 3,4 & 29,8 & 0 & 0 & 1,7 & 0 & 0 & 0 \\
\hline & Assu (EMATER/Sítio Casa Forte) & 42,4 & 33,5 & 35,9 & 0 & 91,3 & 0 & 10,6 & 22,7 & 9,9 & 0 & 0 & 8,5 & 3,5 & 41,5 & 0 & 4,1 & 0,8 & 0 & 0 & 0 \\
\hline & Afonso Bezerra (EMATER) & 106 & 4,5 & 0 & 48 & 46 & 0 & 8 & 0 & 2 & 0 & 0 & 0 & 2 & 22 & 0 & 0 & 0 & 0 & 0 & 0 \\
\hline & Afonso Bezerra (Assentamento Santa Maria) & 121,9 & 0 & 0 & 0 & 0 & 0 & 0 & 0 & 0 & 0 & 0 & 0 & 0 & 0 & 0 & 0 & 0 & 0 & 0 & 0 \\
\hline & Almino Afonso (Particular - Ex Sítio Milagres) & 46,9 & 14,3 & 3 & 4,1 & 14,2 & 35,1 & 3,2 & 0 & 16,2 & 0 & 0 & 0 & 0 & 27,4 & 0 & 0 & 0 & 0 & 0 & 0 \\
\hline & Angicos (Prefeitura) & 103,5 & 7 & 16 & 0 & 98,8 & 9,5 & 0,8 & 0 & 14 & 0 & 0 & 22,7 & 8,7 & 0 & 0 & 0 & 0 & 0 & 0 & 0 \\
\hline & Campo Grande (Particular) & 135 & 27 & 0 & 8,6 & 17,3 & 4,9 & 0 & 0,6 & 3,1 & 0 & 0 & 34 & 0 & 0 & 0 & 0 & 0 & 0 & 0 & 0 \\
\hline & Campo Grande (Particular 2) & 168,9 & 22,6 & 2 & 0 & 29,7 & 4,2 & 2,3 & 0 & 5,3 & 0 & 0 & 16 & 0 & 21,6 & 0 & 0 & 0 & 0 & 0 & 0 \\
\hline & Barcelona (Particular) & 50 & 52,5 & 15,3 & 0 & 73,2 & 1,5 & 12,2 & 13,3 & 33,1 & 0,6 & 7,2 & 15,6 & 6,4 & 39,6 & 1,1 & 3,1 & 3 & 0 & 0 & 0 \\
\hline & Bodó (EMATER/TRF P/Delegacia) & 49,4 & 23,6 & 9 & 25 & 30 & 0 & 32 & 6,5 & 13,5 & 0 & 4,5 & 13 & 14 & 0 & 0 & 15 & 1,5 & 3 & 8 & 0 \\
\hline & Bom Jesus (Particular) & 21,4 & 55,4 & 31,2 & 4,7 & 78,4 & 2 & 26,9 & 21,6 & 31,7 & 0 & 26,5 & 29,2 & 9,7 & 72,1 & 0 & 4,7 & 0 & 2 & 0 & 0 \\
\hline & Caiçara do Rio do Vento (Particular) & 4 & 79,8 & 0 & 0 & 43,8 & 4,8 & 0 & 2,8 & 5,3 & 0 & 0 & 5,2 & 0 & 18 & 0 & 0 & 0 & 0 & 0 & 0 \\
\hline & Caicó (Batalhão) & 17 & 0 & 0 & 0 & 41 & 0 & 0 & 0 & 0 & 0 & 0 & 0 & 0 & 10 & 0 & 0 & 0 & 0 & 0 & 0 \\
\hline & Caicó (Açude Mundo Novo - EMPARN) & 13 & 15,8 & 0 & 0 & 0 & 25 & 0 & 0 & 25,6 & 0 & 0 & 0 & 0 & 22,3 & 0 & 0 & 0 & 0 & 0 & 0 \\
\hline & Caicó (Palma) & 0 & 20 & 0 & 0 & 6 & 14 & 2 & 15 & 9,4 & 0 & 0 & 0 & 11 & 9 & 0 & 0 & 0 & 0 & 0 & 0 \\
\hline
\end{tabular}




\begin{tabular}{|c|c|c|c|c|c|c|c|c|c|c|c|c|c|c|c|c|c|c|c|c|c|}
\hline 2009 & Estação & s21 & s22 & s23 & s24 & s25 & s26 & s27 & s28 & $\mathbf{s 2 9}$ & s30 & s31 & s32 & s33 & s34 & s35 & s36 & s37 & s38 & s39 & s40 \\
\hline & Caicó (Açude Itans) & 19,2 & 4,2 & 0,3 & 0 & 1,9 & 16,7 & 7,5 & 0 & 8,4 & 0 & 1,9 & 0,7 & 5,6 & 10,7 & 0 & 0 & 0 & 0 & 0 & 0 \\
\hline & Caicó (EMATER) & 60,9 & 17,5 & 0 & 0 & 6,8 & 25,9 & 5,2 & 0 & 14,3 & 0 & 5,2 & 0 & 0 & 15 & 0 & 0 & 0 & 0 & 0 & 0 \\
\hline & Caicó (Laginhas) & 81,7 & 0 & 0 & 0 & 38,6 & 0 & 0 & 0 & 0 & 0 & 0 & 0 & 0 & 28 & 0 & 0 & 0 & 0 & 0 & 0 \\
\hline & Campo Redondo (EMATER) & 36,2 & 42,4 & 25,6 & 5,7 & 63,3 & 11,3 & 48,1 & 5,4 & 42,6 & 4,4 & 19,5 & 24,2 & 4 & 53,5 & 4,2 & 0 & 13,2 & 0 & 0 & 0 \\
\hline & Campo Redondo (Polícia Rodoviária) & 24,6 & 45,7 & 6 & 0 & 43 & 9 & 38,6 & 6,6 & 47,2 & 0 & 16,8 & 28 & 4,2 & 43,7 & 3,3 & 0 & 10,2 & 0 & 0 & 0 \\
\hline & Cerro Corá (EMATER) & 31,8 & 57,1 & 10,8 & 12 & 42,1 & 4,3 & 27,3 & 7 & 27,9 & 0 & 5,7 & 28,3 & 8 & 40 & 0 & 0 & 0 & 0 & 0 & 0 \\
\hline & Coronel Ezequiel (Particular) & 38,9 & 36,5 & 5 & 0 & 32 & 6,5 & 45,5 & 6,5 & 11,7 & 0 & 4 & 11,5 & 25,5 & 24,5 & 2 & 1 & 0 & 3 & 0 & 0 \\
\hline & Cruzeta (Base Física da EMPARN) & 44,1 & 18,8 & 0,6 & 2,2 & 12,4 & 11,4 & 7,8 & 2,3 & 25,4 & 0,3 & 1,5 & 2,1 & 7,3 & 45,5 & 0 & 0 & 0 & 0 & 0 & 0 \\
\hline & Currais Novos (CERCEL) & 87,5 & 50,9 & 5,5 & 0 & 36,5 & 0 & 18,5 & 0 & 25 & 0 & 0 & 8,5 & 0 & 24 & 0 & 0 & 0 & 0 & 0 & 0 \\
\hline & Currais Bovos (Açude Tororó) & 97,8 & 40,2 & 17,2 & 10,2 & 0 & 0 & 0 & 0 & 0 & 0 & 0 & 0 & 0 & 0 & 0 & 0 & 0 & 0 & 0 & 0 \\
\hline & Fernando Pedroza (EMATER) & 49,6 & 38,5 & 2,4 & 10 & 21 & 0 & 0 & 0 & 0 & 0 & 0 & 0 & 0 & 16,5 & 10 & 0 & 0 & 0 & 0 & 0 \\
\hline & Florânia (INMET) & 58,5 & 56,9 & 5 & 0,2 & 14 & 3,1 & 10,9 & 6 & 7,3 & 0 & 1,5 & 6,6 & 0 & 38 & 0 & 0 & 1,2 & 0 & 0 & 0 \\
\hline & Florânia (Sítio Jucuri) & 99,6 & 28,6 & 6,7 & 0 & 20,8 & 7,2 & 13,4 & 3,3 & 6,6 & 0 & 0 & 7,4 & 0 & 39,4 & 0 & 0 & 0 & 0 & 0 & 0 \\
\hline & Jaçanã (EMATER) & 42 & 27,2 & 0 & 0 & 34,9 & 10,2 & 51,9 & 12,8 & 38,8 & 0 & 9,5 & 15 & 0 & 44 & 2,9 & 0 & 0 & 0 & 0 & 0 \\
\hline & Janduís (EMATER) & 168,6 & 22,2 & 0 & 0 & 12,4 & 22,6 & 1 & 0 & 8,4 & 0 & 0 & 0 & 0 & 29 & 0 & 0 & 0 & 0 & 2 & 0 \\
\hline & Boa Saúde (EMATER) & 31,6 & 15,8 & 36,6 & 0 & 84 & 0 & 39,3 & 26,1 & 47,5 & 0 & 18,1 & 32 & 7,8 & 68,5 & 3 & 10,4 & 4 & 0 & 4,3 & 0 \\
\hline & Japi (Particular) & 8,4 & 26,8 & 13,8 & 0 & 41,2 & 4,2 & 31,4 & 0 & 10,2 & 0 & 0 & 10,6 & 2,2 & 20,2 & 0 & 0 & 0 & 0 & 0 & 0 \\
\hline & Japi (EMATER) & 43 & 33,2 & 14,8 & 0 & 33,8 & 2,7 & 34,7 & 0 & 25,8 & 0 & 4,3 & 6 & 0 & 27,2 & 0 & 0 & 0 & 0 & 0 & 0 \\
\hline & Jardim de Angicos (EMATER) & 37,4 & 3,2 & 20,7 & 0,8 & 97,5 & 0 & 35,8 & 19,5 & 20,7 & 0 & 3,9 & 20 & 9 & 89,3 & 0 & 10 & 0 & 0 & 1,5 & 0 \\
\hline & Lagoa d'Anta (Prefeitura) & 11,5 & 16 & 14,5 & 25,5 & 116 & 4 & 52 & 34 & 23 & 0 & 7,8 & 18 & 0 & 35,7 & 5,9 & 0 & 0 & 0 & 0 & 0 \\
\hline & Lagoa de Pedras (Prefeitura) & 70,5 & 34,8 & 31,8 & 9 & 57,9 & 6,2 & 31,6 & 8,1 & 71,7 & 0 & 34 & 35,6 & 9,3 & 39 & 0 & 13,7 & 5,5 & 0 & 0 & 0 \\
\hline & Lagoa de Velhos (Delegacia) & 27,6 & 30,7 & 9,4 & 3,5 & 65,8 & 6,6 & 7,1 & 14,7 & 33,1 & 0 & 4,5 & 27,3 & 6 & 44,7 & 0 & 2,3 & 0,2 & 0 & 6,5 & 0 \\
\hline & Lagoa Nova (EMATER/Sítio Humaitá) & 25,1 & 25 & 17 & 0 & 34,5 & 11,5 & 29 & 12,5 & 7,5 & 0 & 6 & 0 & 0 & 44 & 0 & 0 & 0 & 0 & 0 & 0 \\
\hline & Lagoa Salgada (Delegacia) & 58 & 8,4 & 32,4 & 0 & 0 & 0 & 5 & 3,5 & 56,5 & 0 & 0 & 26,7 & 4,3 & 54 & 0 & 0 & 0 & 0 & 0 & 0 \\
\hline & Lajes (Prefeitura) & 16,7 & 39,3 & 3,3 & 0 & 60 & 0 & 0 & 8 & 0 & 0 & 14,3 & 0 & 0 & 30 & 0 & 0 & 0 & 0 & 0 & 0 \\
\hline & Lajes Pintadas (Prefeitura) & 35,5 & 30,2 & 15,2 & 10 & 52,5 & 5,1 & 41,8 & 5,6 & 21,7 & 3 & 8,1 & 22,3 & 13,1 & 60,2 & 2,6 & 0 & 5,6 & 0 & 0 & 0 \\
\hline & Messias Targino (Prefeitura) & 58,2 & 9,2 & 0 & 0 & 10,5 & 3 & 0,5 & 0 & 10 & 0 & 0 & 3 & 42,7 & 38 & 0 & 0 & 0 & 0 & 0 & 0 \\
\hline & Monte Alegre (EMATER) & 13,8 & 84,4 & 30,1 & 4,7 & 181 & 13,3 & 50 & 18 & 50 & 0 & 28,6 & 28,4 & 14,8 & 113 & 4,8 & 14 & 5 & 0 & 0 & 0 \\
\hline & Monte das Gameleiras (EMATER) & 25,8 & 17,1 & 37,8 & 16,7 & 42,2 & 26,6 & 54,8 & 4,1 & 49,5 & 2,7 & 11 & 19,5 & 11,9 & 40,9 & 6 & 0,5 & 22,5 & 0 & 1,3 & 0 \\
\hline & Paraú (Sindicato) & 46 & 0 & 6,6 & 2 & 0 & 0 & 0 & 0 & 0 & 0 & 0 & 0 & 0 & 0 & 0 & 0 & 0 & 0 & 0 & 0 \\
\hline & Passa e Fica (Prefeitura) & 33,7 & 26,7 & 38 & 7,5 & 114,8 & 2,7 & 52,2 & 17,8 & 57,5 & 0 & 6,6 & 20,4 & 0 & 78,6 & 17,5 & 13,5 & 3,4 & 0 & 0 & 0 \\
\hline & Patu (Particular) & 74 & 24,6 & 3,4 & 7 & 11,8 & 50,2 & 6 & 27 & 20 & 0 & 2 & 16 & 2,6 & 35 & 0 & 0 & 0 & 0 & 0 & 0 \\
\hline & Santa Maria (Sindicato dos Trabalhadores Rurais) & 14 & 0 & 0 & 0 & 65 & 0 & 50 & 0 & 0 & 0 & 0 & 0 & 0 & 80 & 0 & 0 & 0 & 0 & 0 & 0 \\
\hline & Pedra Preta (EMATER) & 4,5 & 43 & 33 & 0 & 73 & 0 & 20,5 & 9 & 20 & 0 & 0 & 1 & 6 & 48,5 & 0 & 0 & 0 & 0 & 0 & 0 \\
\hline & Pedro Avelino (Particular) & 17,4 & 4,2 & 4,8 & 18 & 52,8 & 0 & 7,4 & 2,8 & 7,6 & 0 & 1,5 & 2 & 2 & 26 & 0 & 0 & 0 & 0 & 0 & 0 \\
\hline & Pedro Avelino (Base Física da EMPARN) & 16,1 & 24 & 66,2 & 0,7 & 39,4 & 9,7 & 11,7 & 10,5 & 9,7 & 0 & 0,5 & 4,1 & 3 & 35,7 & 0 & 0 & 0 & 0 & 0 & 0 \\
\hline
\end{tabular}




\begin{tabular}{|c|c|c|c|c|c|c|c|c|c|c|c|c|c|c|c|c|c|c|c|c|c|}
\hline 2009 & Estação & s21 & s22 & s23 & s24 & s25 & $s 26$ & s27 & s28 & $\mathbf{s 2 9}$ & s30 & s31 & s32 & s33 & s34 & s35 & s36 & s37 & s38 & s39 & s40 \\
\hline & Riachuelo (EMATER) & 9,5 & 22,5 & 47 & 29,5 & 85 & 0 & 20,5 & 10,5 & 30 & 3,2 & 5,2 & 18 & 0 & 59,5 & 0 & 0 & 8 & 0 & 0 & 0 \\
\hline & Rui Barbosa (EMATER) & 3,7 & 0 & 58,4 & 0 & 70,1 & 0 & 37 & 19,8 & 44,2 & 0 & 21,3 & 16,3 & 0 & 101,8 & 0 & 0 & 6,9 & 0 & 0 & 0 \\
\hline & Santa Cruz (EMATER) & 26,9 & 29,1 & 25,5 & 0 & 56,6 & 10,2 & 34,6 & 14,4 & 16,1 & 7 & 5,3 & 15,8 & 8,6 & 35,1 & 8,5 & 0 & 4,7 & 0 & 0 & 0 \\
\hline & Santana do Matos (EMATER) & 60,5 & 84 & 0 & 12 & 26 & 0 & 0 & 0 & 0 & 0 & 0 & 0 & 0 & 25 & 0 & 0 & 0 & 0 & 0 & 0 \\
\hline & Santana do Matos (Barão de Serra Branca) & 80,1 & 86,2 & 0 & 2 & 33,9 & 12 & 8,5 & 25,7 & 4,7 & 0 & 0 & 15,7 & 0 & 0 & 0 & 0 & 0 & 0 & 0 & 0 \\
\hline & Santana do Matos (São José da Passagem) & 80,1 & 86,2 & 0 & 2 & 33,9 & 12 & 8,5 & 25,7 & 4,7 & 0 & 0 & 15,7 & 0 & 0 & 0 & 0 & 0 & 0 & 0 & 0 \\
\hline & São Bento do Trairi (Prefeitura) & 39,4 & 6,2 & 0 & 0 & 22,3 & 0 & 0 & 26 & 13,3 & 0 & 3,2 & 0 & 13,4 & 25,3 & 0 & 0 & 0 & 0 & 0 & 0 \\
\hline & São José do Campestre (EMATER) & 8 & 22,3 & 44,9 & 0 & 75,5 & 0 & 41,5 & 0 & 47 & 0 & 8,3 & 17 & 8,8 & 55 & 8,5 & 11 & 0 & 0 & 0 & 0 \\
\hline & São Paulo do Potengi (EMATER) & 19 & 29,1 & 45,5 & 0 & 79,6 & 7 & 22,5 & 19,1 & 18 & 0 & 12,4 & 14,2 & 3,6 & 46,4 & 6,8 & 2 & 1,8 & 0 & 1 & 0 \\
\hline & São Pedro (EMATER) & 6,8 & 29,4 & 23,5 & 0 & 85,3 & 2,8 & 40,6 & 6,4 & 20,7 & 2,4 & 14,2 & 32,8 & 2,4 & 83 & 1,5 & 18 & 13,1 & 0,9 & 1 & 0 \\
\hline & São Rafael (EMATER) & 47,3 & 23 & 0 & 0 & 33,2 & 18,4 & 12,2 & 5,7 & 0 & 0 & 0 & 0 & 0 & 5,9 & 0 & 0 & 0 & 0 & 0 & 0 \\
\hline & São Tomé (EMATER) & 34 & 34 & 28 & 0 & 56 & 0 & 0 & 0 & 27 & 0 & 7 & 16 & 6 & 28 & 0 & 0 & 0 & 0 & 0 & 0 \\
\hline & São Vicente (EMATER - Ex Particular) & 52,5 & 103,4 & 0 & 3 & 33,6 & 3,7 & 32,8 & 3,4 & 0 & 0 & 0 & 4,3 & 0 & 24,3 & 0 & 0 & 0 & 0 & 0 & 0 \\
\hline & São Vicente (EMATER - Extinto) & 52,5 & 103,4 & 0 & 3 & 33,6 & 3,7 & 32,8 & 3,4 & 0 & 0 & 0 & 4,3 & 0 & 24,3 & 0 & 0 & 0 & 0 & 0 & 0 \\
\hline & Senador Eloi de Souza (Particular) & 59,5 & 24,5 & 25,6 & 5 & 71,2 & 0 & 20,2 & 23,8 & 32 & 0 & 14,7 & 14,5 & 9,3 & 9,9 & 0 & 10,5 & 6,2 & 0 & 0 & 0 \\
\hline & Serrinha (EMATER) & 43,9 & 15,8 & 44 & 4,6 & 76,4 & 8,4 & 47,7 & 26 & 69,5 & 0 & 13,2 & 20,4 & 9,2 & 83,4 & 1,9 & 13,5 & 6,3 & 0,9 & 3,1 & 0 \\
\hline & Sítio Novo (Prefeitura) & 18 & 22 & 23 & 0 & 48 & 0 & 28 & 8 & 40 & 0 & 16 & 30 & 5 & 52 & 0 & 0 & 0 & 0 & 0,5 & 0 \\
\hline & Tangará (EMATER) & 34 & 17,5 & 35 & 0 & 25 & 0 & 25 & 0 & 28 & 0 & 7,5 & 20 & 8 & 64,5 & 0 & 0 & 1,5 & 0 & 0 & 0 \\
\hline & Tangará (Açude Trairi) & 5 & 21,1 & 39,2 & 0 & 69,1 & 17 & 5,9 & 38,6 & 0 & 0 & 9,5 & 14,7 & 7 & 33,9 & 2,5 & 0 & 7,2 & 0 & 0 & 0 \\
\hline & Triunfo Potiguar (Prefeitura) & 109,7 & 17,8 & 0 & 0 & 37,8 & 7,3 & 0 & 0 & 0 & 0 & 0 & 11,5 & 0 & 33,1 & 0 & 0 & 0 & 0 & 0 & 0 \\
\hline & Triunfo Potiguar (Chá Cacimbas/Serra J. Vale) & 0 & 5 & 3 & 42 & 0 & 0 & 0 & 0 & 5 & 0 & 0 & 0 & 0 & 0 & 0 & 0 & 0 & 0 & 0 & 0 \\
\hline & Triunfo Potiguar (Chá Velha/Serra J. Vale) & 126,7 & 15,6 & 32 & 0 & 41 & 24 & 0 & 0 & 0 & 0 & 6,2 & 3,2 & 55,6 & 0 & 0 & 0 & 0 & 0 & 0 & 0 \\
\hline & Barra de Santana & 38,3 & 32,2 & 14,1 & 2,1 & 4,1 & 14 & 17,2 & 1,4 & 34,7 & 16,1 & 10,8 & 17,7 & 9,3 & 49,8 & 0 & 0 & 13,6 & 0 & 0 & 0 \\
\hline & Boa Vista & 29,6 & 34,8 & 0 & 0 & 0 & 0 & 21 & 0 & 11,4 & 8,8 & 6,8 & 7,6 & 0 & 23 & 0 & 0 & 0 & 0 & 0 & 0 \\
\hline & Boqueirão/Açude Boqueirão & 20,3 & 20,5 & 24,7 & 1 & 1,9 & 8,3 & 10,2 & 4,6 & 29,2 & 13 & 14,7 & 13,3 & 4,4 & 49,6 & 0 & 0 & 20,3 & 0 & 0 & 0 \\
\hline & Cabaceiras & 67 & 70,1 & 13 & 0 & 8,5 & 9,2 & 11,3 & 0 & 32,6 & 0 & 25,2 & 14,1 & 0 & 27,4 & 0 & 0 & 2,6 & 0 & 0 & 0 \\
\hline & Campina Grande/EMBRAPA & 29,5 & 70,9 & 44,9 & 8,6 & 24,7 & 45,6 & 50,4 & 11,8 & 47,6 & 9,4 & 34,8 & 27,1 & 11,6 & 55,9 & 0,1 & 12,2 & 6,8 & 1,4 & 1 & 0 \\
\hline & Campina Grande/INSA & 16,5 & 39,3 & 23,2 & 0 & 15,6 & 30,5 & 37,8 & 2,2 & 31,4 & 13,8 & 34,4 & 13,6 & 6,7 & 26,7 & 0 & 6,9 & 4,2 & 0 & 0,7 & 0 \\
\hline & Campina Grande/Santa Terezinha & 25 & 59,7 & 46,7 & 3,8 & 23,5 & 26,9 & 37,4 & 5,7 & 42,6 & 13,2 & 37,3 & 25,2 & 0 & 62,8 & 0 & 12,4 & 4,7 & 0 & 0 & 0 \\
\hline & Campina Grande/São José da Mata & 19,6 & 70,2 & 16,8 & 9,2 & 23 & 28,1 & 65,9 & 7,7 & 36,1 & 14,1 & 33,9 & 27,8 & 5,1 & 39,8 & 0 & 8,1 & 7 & 0 & 0 & 0 \\
\hline & Caturité & 21,5 & 50,8 & 40,3 & 0 & 12,8 & 2,8 & 20,8 & 2,1 & 36,6 & 23,2 & 9,4 & 20,5 & 0 & 48,1 & 0 & 0 & 7,9 & 0 & 0 & 0 \\
\hline & Caturité/Fazenda Campo de Emas & 15 & 31,4 & 0 & 3 & 1 & 16 & 0 & 0 & 10,8 & 20 & 2 & 28 & 0 & 39 & 0 & 0 & 0 & 0 & 0 & 0 \\
\hline & Cubati & 23,4 & 51,2 & 0 & 0 & 8,1 & 15,2 & 14,7 & 1,6 & 12,2 & 0 & 5,1 & 11,3 & 0 & 38,4 & 0 & 0 & 4,6 & 0 & 0 & 0 \\
\hline & Lagoa Seca & 50,5 & 113,4 & 23,4 & 13,5 & 35 & 67,3 & 76,8 & 24,1 & 75,5 & 11,6 & 47,8 & 16,5 & 21 & 54,7 & 0 & 12,4 & 20 & 1 & 0,7 & 0 \\
\hline & Matinhas & 9 & 93,1 & 12 & 123,2 & 20,8 & 10,2 & 13,2 & 53,6 & 79,6 & 12,2 & 12,1 & 49,9 & 20 & 41 & 8 & 37 & 10,7 & 5,5 & 1,5 & 0 \\
\hline & Olivedos & 57,6 & 71 & 2,5 & 2,5 & 4,7 & 14,7 & 9,4 & 0 & 17,2 & 0 & 13,3 & 14 & 3,2 & 11,8 & 0 & 0 & 2,8 & 0 & 0 & 0 \\
\hline
\end{tabular}




\begin{tabular}{|c|c|c|c|c|c|c|c|c|c|c|c|c|c|c|c|c|c|c|c|c|c|}
\hline 2009 & Estação & s21 & s22 & s23 & s24 & s25 & s26 & s27 & s28 & $\mathbf{s 2 9}$ & s30 & s31 & s32 & s33 & s34 & s35 & s36 & s37 & s38 & s39 & s40 \\
\hline & Pedra Lavrada & 30,2 & 31,2 & 21,6 & 0 & 13 & 6,2 & 2,8 & 0 & 24,6 & 0 & 0 & 9,8 & 0 & 40 & 0 & 0 & 0 & 0 & 0 & 0 \\
\hline & Pocinhos & 13,5 & 44 & 10,5 & 2,7 & 10,2 & 6,2 & 34,2 & 6,8 & 11,3 & 2,3 & 11,5 & 10,1 & 1,9 & 12,3 & 0 & 2,4 & 0,3 & 0 & 0 & 0 \\
\hline & Queimadas & 42,8 & 67,3 & 5,4 & 4,2 & 17,1 & 7,9 & 25,9 & 3,5 & 36,2 & 0 & 24 & 11,1 & 0 & 9,2 & 0 & 0,5 & 3 & 0 & 0 & 0 \\
\hline & Seridó/São Vicente do Seridó & 40,4 & 18,9 & 19,8 & 4,6 & 6,4 & 11,3 & 10,3 & 2,2 & 7,9 & 0 & 0 & 28,8 & 1,8 & 26 & 0 & 0 & 0 & 0 & 0 & 0 \\
\hline & Soledade & 36,4 & 8,3 & 3,1 & 3,3 & 0 & 4,8 & 9,1 & 0,2 & 6,4 & 0 & 7,7 & 19,2 & 2,3 & 11,8 & 0 & 0 & 0 & 0 & 0,2 & 0 \\
\hline
\end{tabular}

2009

$\begin{array}{llllllllllll}s 41 & s 42 & s 43 & s 44 & s 45 & s 46 & s 47 & s 48 & s 49 & s 50 & s 51 & s 52\end{array}$

Acari (Açude Gargalheiras)

Assu (Particular)

Assu (EMATER/Sítio Casa Forte)

Afonso Bezerra (EMATER)

Afonso Bezerra (Assentamento Santa Maria)

Almino Afonso (Particular - Ex Sítio Milagres)

Angicos (Prefeitura)

Campo Grande (Particular)

Campo Grande (Particular 2)

Barcelona (Particular)

Bodó (EMATER/TRF P/Delegacia)

Bom Jesus (Particular)

Caiçara do Rio do Vento (Particular)

Caicó (Batalhão)

Caicó (Açude Mundo Novo - EMPARN)

Caicó (Palma)

Caicó (Açude Itans)

Caicó (EMATER)

Caicó (Laginhas)

Campo Redondo (EMATER)

Campo Redondo (Polícia Rodoviária)

Cerro Corá (EMATER)

Coronel Ezequiel (Particular)

Cruzeta (Base Física da EMPARN)

Currais Novos (CERCEL)

Currais Bovos (Açude Tororó)

Fernando Pedroza (EMATER)

Florânia (INMET)

$\begin{array}{cccccccccccc}0 & 0 & 0 & 0 & 0 & 34 & 0 & 0 & 0 & 0 & 0 & 0 \\ 0 & 0 & 0 & 0 & 0 & 0 & 0 & 0 & 0 & 0 & 0 & 0 \\ 0 & 0 & 0 & 0 & 0 & 0 & 0 & 0 & 0 & 0 & 0,6 & 1 \\ 0 & 0 & 0 & 0 & 0 & 0 & 0 & 0 & 0 & 0 & 0 & 0,9 \\ 0 & 0 & 0 & 0 & 0 & 0 & 0 & 0 & 0 & 0 & 0 & 0 \\ 0 & 0 & 0 & 0 & 0 & 0 & 0 & 0 & 0 & 0 & 0 & 0 \\ 0 & 0 & 0 & 0 & 0 & 0 & 0 & 0 & 12 & 2,2 & 28,5 & 20,5 \\ 0 & 0 & 0 & 0 & 0 & 0 & 0 & 0 & 0 & 0 & 0 & 0 \\ 0 & 0 & 0 & 0 & 0 & 0 & 0 & 0 & 0 & 0 & 0 & 30 \\ 0 & 0 & 0 & 0 & 0 & 2,3 & 0 & 0 & 0 & 0 & 12 & 35,3 \\ 0 & 0 & 0 & 0 & 0 & 1 & 0 & 0 & 0 & 0 & 0 & 0 \\ 8 & 1 & 2 & 0,4 & 0,6 & 0 & 1,4 & 2,5 & 0 & 0 & 0 & 9,4 \\ 0 & 0 & 0 & 0 & 0 & 0 & 0 & 0 & 0 & 0 & 0 & 10 \\ 0 & 0 & 0 & 0 & 0 & 0 & 0 & 0 & 0 & 0 & 0 & 0 \\ 0 & 0 & 0 & 0 & 0 & 0 & 0 & 0 & 0 & 0 & 0 & 37 \\ 0 & 5 & 0 & 0 & 0 & 0 & 0 & 0 & 14,5 & 0 & 11,9 & 30,7 \\ 0 & 0 & 0 & 0 & 0 & 0 & 0 & 18 & 0 & 0 & 28 & 41,4 \\ 0 & 0 & 7,1 & 0 & 0 & 0 & 0 & 17,8 & 0 & 0 & 42,9 & 36,2 \\ 0 & 0 & 8 & 0 & 0 & 0 & 0 & 0 & 8,7 & 0 & 9,3 & 61,4 \\ 0 & 0 & 0 & 0 & 0 & 0 & 0 & 0 & 0 & 0 & 0 & 0 \\ 0 & 0 & 0 & 0 & 0 & 0 & 0 & 0 & 0 & 0 & 0 & 0 \\ 0 & 0 & 0 & 0 & 0 & 0 & 0 & 0 & 0 & 0 & 0 & 53,4 \\ 0 & 0 & 0 & 0 & 0 & 0 & 0 & 0 & 0 & 0 & 0 & 0 \\ 0 & 0 & 1,4 & 0 & 0 & 0 & 0 & 0 & 0 & 0 & 0 & 20,5 \\ 0 & 0 & 0 & 0 & 0 & 4,5 & 0 & 10 & 0 & 0 & 5,7 & 57,4 \\ 0 & 0 & 0 & 0 & 0 & 0 & 0 & 0 & 0 & 0 & 0 & 0 \\ 0 & 0 & 0 & 0 & 0 & 0 & 0 & 0 & 0 & 0 & 0 & 0 \\ 0 & 0 & 0 & 0 & 0 & 0 & 0 & 0 & 0 & 0 & 0 & 9 \\ 0 & 0 & 0,6 & 0 & 0 & 0,4 & 0,2 & 8,4 & 1 & 0,2 & 31,8 & 49,6\end{array}$




\begin{tabular}{|c|c|c|c|c|c|c|c|c|c|c|c|c|c|}
\hline 2009 & Estação & s41 & $s 42$ & s43 & s44 & s45 & s46 & s47 & s48 & s49 & s50 & s51 & s52 \\
\hline & Florânia (Sítio Jucuri) & 0 & 0 & 0 & 0 & 0 & 0 & 0 & 0 & 0 & 0 & 37,2 & 33,6 \\
\hline & Jaçanã (EMATER) & 0 & 0 & 0 & 0 & 0 & 0 & 0 & 0 & 0 & 0 & 0 & 52,5 \\
\hline & Janduís (EMATER) & 0 & 0 & 0 & 0 & 0 & 0 & 0 & 2 & 0 & 0 & 14 & 26,4 \\
\hline & Boa Saúde (EMATER) & 0 & 0 & 0 & 0 & 0 & 0 & 0 & 0 & 0 & 0 & 0 & 0 \\
\hline & Japi (Particular) & 0 & 0 & 0 & 0 & 0 & 0 & 0 & 0 & 0 & 0 & 0 & 29,8 \\
\hline & Japi (EMATER) & 0 & 0 & 0 & 0 & 0 & 0 & 0 & 0 & 0 & 0 & 0 & 35 \\
\hline & Jardim de Angicos (EMATER) & 0 & 0 & 0 & 0 & 0 & 0 & 0 & 0 & 0 & 0 & 0 & 0 \\
\hline & Lagoa d'Anta (Prefeitura) & 0 & 0 & 0 & 0 & 0 & 0 & 0 & 0 & 0 & 0 & 0 & 7 \\
\hline & Lagoa de Pedras (Prefeitura) & 0 & 0 & 0 & 0 & 0 & 0 & 0 & 0 & 0 & 0 & 0 & 0,9 \\
\hline & Lagoa de Velhos (Delegacia) & 0 & 0 & 0 & 0 & 0 & 0 & 0 & 0 & 0 & 0 & 0 & 0 \\
\hline & Lagoa Nova (EMATER/Sítio Humaitá) & 0 & 0 & 0 & 0 & 0 & 0 & 0 & 0 & 0 & 0 & 0 & 0 \\
\hline & Lagoa Salgada (Delegacia) & 0 & 0 & 0 & 0 & 0 & 0 & 0 & 0 & 0 & 0 & 0 & 0 \\
\hline & Lajes (Prefeitura) & 0 & 0 & 0 & 0 & 0 & 0 & 0 & 0 & 0 & 0 & 0 & 0 \\
\hline & Lajes Pintadas (Prefeitura) & 0 & 0 & 0 & 0 & 0 & 0 & 0 & 0 & 0 & 0 & 0 & 0 \\
\hline & Messias Targino (Prefeitura) & 0 & 0 & 0 & 0 & 0 & 0 & 0 & 0 & 0 & 0 & 33,5 & 25,5 \\
\hline & Monte Alegre (EMATER) & 1 & 2 & 0 & 0 & 3,2 & 2,2 & 1,6 & 3 & 0 & 0 & 0 & 0 \\
\hline & Monte das Gameleiras (EMATER) & 0 & 0 & 0 & 0 & 0 & 0 & 0 & 0 & 0 & 0 & 0 & 0 \\
\hline & Paraú (Sindicato) & 0 & 0 & 0 & 0 & 0 & 0 & 0 & 0 & 0 & 0 & 0 & 0 \\
\hline & Passa e Fica (Prefeitura) & 0 & 0 & 0 & 0 & 0 & 0 & 0 & 0 & 0 & 0 & 0 & 0 \\
\hline & Patu (Particular) & 0 & 0 & 0 & 0 & 0 & 0 & 0 & 0 & 0 & 0 & 37 & 25 \\
\hline & Santa Maria (Sindicato dos Trabalhadores Rurais) & 0 & 0 & 0 & 0 & 0 & 0 & 0 & 0 & 0 & 0 & 0 & 0 \\
\hline & Pedra Preta (EMATER) & 0 & 0 & 0 & 0 & 0 & 0 & 0 & 0 & 0 & 0 & 0 & 0 \\
\hline & Pedro Avelino (Particular) & 0 & 0 & 0 & 0 & 0 & 0 & 0 & 0 & 0 & 0 & 0 & 0 \\
\hline & Pedro Avelino (Base Física da EMPARN) & 0 & 0 & 0 & 0 & 0 & 0 & 0 & 0 & 0 & 0 & 0 & 0 \\
\hline & Riachuelo (EMATER) & 0 & 0 & 0 & 0 & 0 & 0 & 0 & 0 & 0 & 0 & 0 & 0 \\
\hline & Rui Barbosa (EMATER) & 0 & 0 & 0 & 0 & 0 & 0 & 0 & 0 & 0 & 0 & 0 & 0 \\
\hline & Santa Cruz (EMATER) & 0 & 0 & 0 & 0 & 0 & 0 & 0 & 0 & 0 & 0 & 0 & 9,2 \\
\hline & Santana do Matos (EMATER) & 0 & 0 & 0 & 0 & 0 & 0 & 0 & 0 & 0 & 0 & 0 & 35 \\
\hline & Santana do Matos (Barão de Serra Branca) & 0 & 0 & 0 & 0 & 0 & 0 & 0 & 0 & 0 & 0 & 52,2 & 58,8 \\
\hline & Santana do Matos (São José da Passagem) & 0 & 0 & 0 & 0 & 0 & 0 & 0 & 0 & 0 & 0 & 52,2 & 0 \\
\hline & São Bento do Trairi (Prefeitura) & 0 & 0 & 0 & 0 & 0 & 0 & 0 & 0 & 0 & 0 & 16,7 & 0 \\
\hline & São José do Campestre (EMATER) & 0 & 0 & 0 & 0 & 0 & 0 & 0 & 0 & 0 & 0 & 0 & 0 \\
\hline & São Paulo do Potengi (EMATER) & 0 & 0 & 0 & 0 & 0 & 0 & 0 & 0 & 0 & 0 & 0 & 0 \\
\hline & São Pedro (EMATER) & 0 & 0 & 0 & 0 & 0 & 0 & 1,2 & 1,3 & 0,6 & 0,7 & 0 & 2,2 \\
\hline & São Rafael (EMATER) & 0 & 0 & 0 & 0 & 0 & 1,5 & 0 & 13,9 & 10 & 0 & 7,2 & 3,5 \\
\hline & São Tomé (EMATER) & 0 & 0 & 0 & 0 & 0 & 0 & 0 & 0 & 0 & 0 & 0 & 2 \\
\hline
\end{tabular}




\begin{tabular}{|c|c|c|c|c|c|c|c|c|c|c|c|c|c|c|c|c|c|c|c|c|c|c|}
\hline 2009 & Estação & s41 & s42 & $s 43$ & s44 & s45 & s46 & 54 & $7 \mathrm{~s} 4$ & $48 \mathrm{~s}$ & 349 & $\mathrm{~s} 50 \mathrm{~s}$ & s51 s & s52 & & & & & & & & \\
\hline & São Vicente (EMATER - Ex Particular) & 0 & 0 & 0 & 0 & 0 & 14 & 0 & & 0 & 0 & 0 & 0 & 0 & & & & & & & & \\
\hline & São Vicente (EMATER - Extinto) & 0 & 0 & 0 & 0 & 0 & 14 & 0 & & 0 & 0 & 0 & 0 & 0 & & & & & & & & \\
\hline & Senador Eloi de Souza (Particular) & 0 & 0 & 0 & 0 & 0 & 0 & 0 & & 0 & 0 & 0 & 0 & 0 & & & & & & & & \\
\hline & Serrinha (EMATER) & 0 & 0 & 0 & 0 & 0 & 1,1 & 0 & & 0 & 0 & 0 & 2,2 & 4,6 & & & & & & & & \\
\hline & Sítio Novo (Prefeitura) & 0 & 0 & 0 & 0 & 0 & 0 & 0 & & 0 & 0 & 0 & 0 & 4 & & & & & & & & \\
\hline & Tangará (EMATER) & 0 & 0 & 0 & 0 & 0 & 1 & 0 & & 0 & 0 & 0 & 0 & 0 & & & & & & & & \\
\hline & Tangará (Açude Trairi) & 0 & 0 & 0 & 0 & 0 & 0 & 0 & & 0 & 0 & 0 & 0 & 0 & & & & & & & & \\
\hline & Triunfo Potiguar (Prefeitura) & 0 & 0 & 0 & 0 & 0 & 0 & 0 & & 9,3 & 7,5 & 0 & 0 & 74,2 & & & & & & & & \\
\hline & Triunfo Potiguar (Chá Cacimbas/Serra J. Vale) & 0 & 0 & 0 & 0 & 0 & 0 & 0 & 0 & 0 & 0 & 0 & 0 & 0 & & & & & & & & \\
\hline & Triunfo Potiguar (Chá Velha/Serra J. Vale) & 0 & 0 & 0 & 0 & 0 & 0 & 0 & 0 & 0 & 0 & 0 & 0 & 0 & & & & & & & & \\
\hline & Barra de Santana & 0 & 0 & 0 & 0 & 8,8 & 0 & 0 & 0 & 0 & 0 & 0 & 0 & 0 & & & & & & & & \\
\hline & Boa Vista & 0 & 0 & 0 & 0 & 0 & 0 & 0 & 0 & 0 & 0 & 0 & 0 & 14,4 & & & & & & & & \\
\hline & Boqueirão/Açude Boqueirão & 0 & 0 & 0 & 0 & 3 & 0 & 0 & 0 & 0 & 0 & 0 & 5,3 & 0 & & & & & & & & \\
\hline & Cabaceiras & 0 & 0 & 0 & 0 & 0 & 0 & 6,9 & 0 & 0 & 0 & 0 & 15,4 & 6,3 & & & & & & & & \\
\hline & Campina Grande/EMBRAPA & 0 & 0,3 & 0,1 & 0,1 & 4 & 0,1 & 1,7 & 0,3 & ,3 & 0,1 & 6,1 & 12,4 & 0 & & & & & & & & \\
\hline & Campina Grande/INSA & 0 & 0 & 0 & 0 & 0 & 0 & 0 & 6,7 & 7 & 0 & 0 & 0 & 0 & & & & & & & & \\
\hline & Campina Grande/Santa Terezinha & 0 & 0 & 0 & 0 & 4,4 & 0 & 0 & 0,5 &, 5 & 0 & 0 & 0 & 21,9 & & & & & & & & \\
\hline & Campina Grande/São José da Mata & 0 & 0 & 0 & 0 & 3,7 & 0 & 0 & 5,1 & 1 & 0 & 0 & 0 & 0 & & & & & & & & \\
\hline & Caturité & 0 & 0 & 0 & 0 & 0 & 0 & 0 & 0 & 0 & 0 & 0 & 0 & 0 & & & & & & & & \\
\hline & Caturité/Fazenda Campo de Emas & 0 & 0 & 0 & 0 & 0 & 0 & 0 & 0 & 0 & 0 & 0 & 0 & 0 & & & & & & & & \\
\hline & Cubati & 0 & 0 & 0 & 0 & 0 & 0 & 0 & 0 & 0 & 0 & 0 & 0 & 0 & & & & & & & & \\
\hline & Lagoa Seca & 0 & 0 & 0 & 0 & 0 & 6,1 & 0 & 7,1 & 1 & 0 & 0 & 3,2 & 11,7 & & & & & & & & \\
\hline & Matinhas & 0 & 0 & 0 & 0 & 0 & 0 & 0 & 0 & 0 & 0 & 0 & 0 & 0 & & & & & & & & \\
\hline & Olivedos & 0 & 0 & 0 & 0 & 0 & 0 & 0 & 0 & 0 & 0 & 0 & 0 & 0 & & & & & & & & \\
\hline & Pedra Lavrada & 0 & 0 & 0 & 0 & 0 & 0 & 0 & 6,3 & 3 & 0 & 0 & 0 & 0 & & & & & & & & \\
\hline & Pocinhos & 0 & 0 & 0 & 0 & 4,3 & 0 & 0 & 0,7 & ,7 & 0 & 2,1 & 0 & 9,6 & & & & & & & & \\
\hline & Queimadas & 0 & 0 & 0 & 0 & 5,4 & 0 & 0 & 0 & 0 & 0 & 0 & 5,4 & 0 & & & & & & & & \\
\hline & Seridó/São Vicente do Seridó & 0 & 0 & 0 & 0 & 0 & 0 & 0 & 0 & 0 & 0 & 0 & 5,2 & 2,2 & & & & & & & & \\
\hline & Soledade & 0 & 0 & 0 & 0 & 0 & 0 & 0 & 0 & 0 & 0 & 0 & 19,5 & 0 & & & & & & & & \\
\hline 2010 & Estação & s1 & s2 & s3 & s4 & & 5 & s6 & s7 & s8 & s9 & s10 & o s11 & s12 & s13 & s14 & s15 & s16 & s17 & s18 & s19 & s20 \\
\hline & Acari (Particular) & 44,7 & 0 & 15,1 & 4,2 & & 0 & 4,5 & 10 & 29,9 & 0 & 2 & 5,3 & 16,6 & 9,9 & 33 & 7,8 & 74,5 & 7,9 & 70,4 & 2,1 & 0 \\
\hline & Assu (EMATER/Sítio Casa Forte) & 49,7 & 0,6 & 45,3 & 7,7 & & 0 & 27,4 & 16,8 & 48,1 & 0 & 2,1 & 9,4 & 27,2 & 9,7 & 39,8 & 19,1 & 49,8 & 10,3 & 81,4 & 7,1 & 0 \\
\hline & Afonso Bezerra (EMATER) & 25 & 0 & 28 & 45 & & 0 & 0 & 0 & 0 & 0 & 0 & 15 & 30 & 56 & 15 & 10 & 40 & 0 & 80 & 21 & 0 \\
\hline & Almino Afonso (Particular - Ex Sítio Milagres) & 2,2 & 0 & 53,3 & 51,3 & & 0 & 24,6 & 7,4 & 0 & 0 & 0 & 15,2 & 13,6 & 92,5 & 18,1 & 75,1 & 45,3 & 77,9 & 0 & 33,2 & 0 \\
\hline & Angicos (Prefeitura) & 51 & 0 & 11,5 & 6 & $c$ & 0 & 18 & 0 & 0 & 0 & 0 & 36,5 & 25,5 & 14,5 & 57,5 & 13,5 & 35 & 0 & 13 & 12,5 & 0 \\
\hline
\end{tabular}




\begin{tabular}{|c|c|c|c|c|c|c|c|c|c|c|c|c|c|c|c|c|c|c|c|c|c|}
\hline 2010 & Estação & s1 & s2 & s3 & s4 & s5 & s6 & s7 & s8 & s9 & $\mathbf{s 1 0}$ & s11 & s12 & $s 13$ & $s 14$ & s15 & $s 16$ & s17 & $\mathbf{s} 18$ & $\mathbf{s} 19$ & s20 \\
\hline & Campo Grande (Particular) & 4,7 & 0 & 5,6 & 46,2 & 0 & 30 & 48,2 & 2,9 & 0 & 0 & 3,3 & 48 & 65,8 & 97,3 & 35,1 & 40,9 & 1 & 49,5 & 8,2 & 0 \\
\hline & Campo Grande (Particular 2) & 0 & 7,3 & 1,7 & 50 & 0 & 30 & 42,5 & 0 & 0 & 0 & 6,2 & 46,3 & 74,8 & 97,3 & 42,3 & 37,4 & 0 & 49,4 & 8,2 & 0 \\
\hline & Barcelona (Particular) & 0 & 1,1 & 17,5 & 0 & 0 & 0 & 4,5 & 0 & 0 & 0 & 59 & 15,3 & 0 & 17,8 & 0 & 43,9 & 0 & 18 & 18,7 & 0 \\
\hline & Bodó (EMATER/TRF P/Delegacia) & 0 & 0 & 58,6 & 57 & 0,2 & 95 & 33 & 0 & 0 & 10 & 3 & 20 & 3,4 & 17 & 0 & 3,3 & 25 & 63,6 & 0 & 2 \\
\hline & Bom Jesus (Particular) & 0 & 17 & 15,6 & 0 & 0 & 7,7 & 7,7 & 1,5 & 0 & 0 & 5,4 & 0 & 0 & 36,9 & 15 & 21,4 & 0 & 34 & 5,4 & 0 \\
\hline & Caiçara do Rio do Vento (Particular) & 0 & 0 & 1,2 & 0 & 0 & 0 & 0 & 0 & 0 & 0 & 24,5 & 50 & 0 & 29,5 & 20 & 16 & 0 & 0 & 18 & 0 \\
\hline & Caicó (Batalhão) & 25 & 0 & 13 & 0 & 0 & 0 & 1,6 & 20 & 0 & 0 & 62,2 & 30,7 & 55,9 & 38,4 & 27 & 1,2 & 36,2 & 14 & 13,5 & 0 \\
\hline & Caicó (Açude Mundo Novo - EMPARN) & 37,7 & 3 & 28,7 & 6,7 & 0 & 30,8 & 8 & 18 & 0 & 3 & 13,2 & 19,2 & 40,4 & 22,8 & 24,8 & 35,5 & 18,3 & 12,2 & 0 & 0 \\
\hline & Caicó (Palma) & 18 & 9 & 52 & 12 & 0 & 55 & 0 & 30 & 0 & 0 & 36,2 & 19 & 43 & 24 & 17 & 5 & 1 & 24 & 0 & 0 \\
\hline & Caicó (Açude Itans) & 27,4 & 2,8 & 22,6 & 3,1 & 0 & 89,2 & 0 & 35,4 & 0 & 0 & 21,1 & 59,8 & 30,8 & 71,2 & 24,5 & 10,5 & 43,2 & 34,5 & 4,6 & 0 \\
\hline & Caicó (Laginhas) & 0 & 0,7 & 22,8 & 0 & 0 & 66 & 9,5 & 0 & 0 & 0 & 25,5 & 0 & 36,6 & 12,4 & 46,9 & 58,4 & 23,5 & 46 & 0 & 0 \\
\hline & Caicó (Penitenciária) & 25 & 10 & 24,7 & 4,3 & 0 & 41 & 0 & 9,5 & 0 & 0 & 23,5 & 32,5 & 75,5 & 67,5 & 24,5 & 25 & 33 & 1,4 & 13,5 & 0 \\
\hline & Campo Redondo (EMATER) & 17,8 & 0 & 212,5 & 4,6 & 11,4 & 3 & 0,4 & 1,4 & 0 & 0 & 0 & 78 & 22,9 & 44,2 & 0 & 60,5 & 0 & 50,2 & 96,7 & 0 \\
\hline & Campo Redondo (Polícia Rodoviária) & 6,2 & 0,9 & 170,9 & 2,8 & 4,2 & 0 & 0 & 0 & 0 & 0 & 0 & 57,2 & 64,8 & 5,9 & 0 & 48,2 & 0 & 30,5 & 47,1 & 0 \\
\hline & Cerro Corá (EMATER) & 28,4 & 0 & 79,5 & 4 & 0 & 0 & 0 & 0 & 0 & 0 & 18,8 & 27,6 & 19,2 & 28 & 0 & 16,2 & 0 & 40,3 & 0 & 0 \\
\hline & Coronel Ezequiel (Particular) & 0 & 3,7 & 134 & 0 & 4,5 & 0 & 0 & 0 & 0 & 0 & 0 & 15,9 & 34 & 27,5 & 28 & 52,5 & 1 & 47 & 6,5 & 8,5 \\
\hline & Cruzeta (Base Física da EMPARN) & 103,4 & 0 & 40,2 & 0 & 0,1 & 36,9 & 4 & 3,5 & 0 & 0 & 30 & 43 & 60,9 & 8,4 & 16,9 & 40,9 & 15,6 & 21 & 0,2 & 0 \\
\hline & Currais Novos (CERCEL) & 0 & 0 & 61,3 & 0 & 0 & 0 & 0 & 0 & 0 & 0 & 0 & 0 & 11,4 & 0 & 0 & 23,2 & 2 & 13,8 & 0 & 0 \\
\hline & Fernando Pedroza (EMATER) & 60 & 0 & 11 & 1 & 0 & 2 & 0 & 3 & 0 & 0 & 56 & 44,9 & 42 & 73,5 & 5 & 24,1 & 17,1 & 58,3 & 0 & 0 \\
\hline & Florânia (INMET) & 50,2 & 10,2 & 13,8 & 14,2 & 0 & 2,3 & 0 & 0,4 & 0 & 10,2 & 0 & 32 & 8 & 26,6 & 0 & 46,9 & 0,4 & 12 & 0 & 0 \\
\hline & Florânia (Sítio Jucuri) & 51,5 & 2,1 & 27,4 & 23,2 & 0 & 1,4 & 0 & 0 & 0 & 17,4 & 3,5 & 32,7 & 35,7 & 74,9 & 0 & 50,1 & 0 & 37,4 & 0 & 0 \\
\hline & Ielmo Marinho (Prefeitura) & 0 & 1,7 & 8,6 & 0 & 1,8 & 13,7 & 0 & 7,5 & 0 & 0 & 0 & 1,9 & 7,2 & 51 & 7,4 & 22,2 & 1,8 & 37,8 & 0 & 0 \\
\hline & Jaçanã (EMATER) & 0,7 & 0 & 72,7 & 16,7 & 1,5 & 2,8 & 0 & 19,7 & 0 & 0 & 12 & 38,8 & 9,6 & 55,3 & 3,6 & 48,8 & 0,5 & 29 & 0 & 0 \\
\hline & Janduís (EMATER) & 22,6 & 0 & 19,4 & 39,6 & 0 & 8,4 & 29 & 3 & 0 & 0 & 24,4 & 120,8 & 88,8 & 21,4 & 17 & 61,4 & 55 & 4 & 3,6 & 0 \\
\hline & Boa Saúde (EMATER) & 0 & 16,5 & 16,1 & 0 & 0 & 0 & 24,5 & 6,2 & 0 & 0 & 0 & 0 & 7,2 & 34,1 & 0 & 53,1 & 0 & 14,3 & 12,9 & 0 \\
\hline & Japi (Particular) & 2,2 & 0 & 30,6 & 0 & 0 & 0 & 7 & 0 & 0 & 0 & 0 & 0 & 4,2 & 52,6 & 58,2 & 16,8 & 0 & 6,2 & 0 & 0 \\
\hline & Japi (EMATER) & 0 & 0 & 31,5 & 0 & 0 & 0 & 7 & 0 & 0 & 0 & 0 & 0 & 4,1 & 50 & 0 & 81 & 0 & 6,2 & 8,3 & 0 \\
\hline & Jardim de Angicos (EMATER) & 0 & 0 & 4,5 & 0 & 0 & 21,3 & 3 & 0,2 & 0 & 0 & 4 & 18,9 & 0 & 17,2 & 1 & 33,5 & 1 & 5,7 & 21 & 0,9 \\
\hline & Lagoa d'Anta (Prefeitura) & 21,5 & 34 & 6,9 & 12,4 & 0 & 5 & 0 & 0 & 0 & 0 & 10 & 11 & 12 & 8 & 30 & 53 & 0 & 4 & 12 & 0 \\
\hline & Lagoa de Pedras (Prefeitura) & 1 & 63,9 & 27,1 & 22,3 & 0 & 6,1 & 5,1 & 2,7 & 0 & 0 & 11,8 & 0 & 1,6 & 48,8 & 1,8 & 63,4 & 2,6 & 27,1 & 8,4 & 0 \\
\hline & Lagoa de Velhos (Delegacia) & 0 & 0 & 24 & 0 & 0 & 4,2 & 0 & 0 & 0 & 0 & 30 & 2,8 & 6 & 14 & 0 & 48,2 & 0 & 12,5 & 2,3 & 0 \\
\hline & Lagoa Nova (EMATER/Sítio Humaitá) & 0 & 0 & 41 & 12 & 0 & 30 & 3 & 0 & 0 & 0 & 0 & 11,5 & 31 & 20 & 0 & 32 & 28 & 88 & 8 & 0 \\
\hline & Lagoa Salgada (Delegacia) & 21,1 & 0 & 0 & 10 & 0 & 5 & 0 & 0 & 0 & 0 & 3,4 & 0 & 0 & 43,6 & 0 & 19,7 & 0 & 17,2 & 9 & 0 \\
\hline & Lajes (Prefeitura) & 15 & 0 & 8,5 & 57,2 & 0 & 5,5 & 0 & 0 & 0 & 0 & 10,8 & 24,2 & 0 & 52,8 & 0 & 15,3 & 0 & 55,8 & 5,2 & 0 \\
\hline & Lajes Pintadas (Prefeitura) & 7,7 & 10 & 75,7 & 0 & 0 & 4,4 & 17,7 & 0 & 0 & 0 & 0 & 20,8 & 61,4 & 2,5 & 0 & 65,2 & 0 & 16,9 & 39,5 & 0 \\
\hline & Messias Targino (Prefeitura) & 0 & 0,8 & 4,2 & 13 & 0 & 16,5 & 4 & 18,8 & 0 & 0 & 0 & 35,5 & 65 & 2,6 & 27,8 & 34,8 & 67,4 & 1,5 & 22,5 & 0 \\
\hline
\end{tabular}




\begin{tabular}{|c|c|c|c|c|c|c|c|c|c|c|c|c|c|c|c|c|c|c|c|c|c|}
\hline 2010 & Estação & s1 & s2 & s3 & s4 & s5 & s6 & s7 & s8 & s9 & $\mathbf{s 1 0}$ & s11 & s12 & s13 & $s 14$ & s15 & s16 & s17 & s18 & $s 19$ & s20 \\
\hline & Monte Alegre (EMATER) & 7 & 48 & 16 & 9 & 2 & 6 & 10 & 12 & 0 & 0 & 10 & 2 & 16,2 & 66 & 2 & 11 & 0 & 67 & 6 & 0 \\
\hline & Monte das Gameleiras (EMATER) & 18,7 & 0 & 8 & 5,4 & 4,2 & 1,2 & 11,9 & 2,5 & 0 & 0 & 0 & 60 & 0 & 16,6 & 0 & 78,6 & 3 & 0,9 & 22,9 & 0 \\
\hline & Paraú (Prefeitura) & 7,3 & 0 & 27,7 & 16,7 & 0 & 58,8 & 10,2 & 0 & 0 & 0 & 0 & 0 & 68,3 & 21,2 & 21,5 & 61,5 & 25 & 66,5 & 0 & 0 \\
\hline & Passa e Fica (Prefeitura) & 29,7 & 0 & 28,8 & 73,7 & 3 & 16,3 & 2,1 & 12,4 & 0 & 0 & 1,6 & 10,2 & 3,8 & 42,2 & 2,7 & 72,5 & 0 & 6,5 & 12,8 & 0 \\
\hline & Patu (Particular) & 25 & 0 & 9 & 95,4 & 0 & 18 & 1 & 12 & 0 & 0 & 11 & 72 & 65 & 34 & 59 & 49,4 & 124 & 6,4 & 29 & 0 \\
\hline & Santa Maria (Sindicato dos Trabalhadores Rurais) & 0 & 0 & 15 & 0 & 0 & 2,5 & 0 & 0 & 0 & 0 & 6 & 14 & 0 & 23 & 8 & 40 & 0 & 1,5 & 0 & 0 \\
\hline & Pedra Preta (EMATER) & 0 & 0 & 16 & 0 & 0 & 9 & 0 & 0 & 0 & 0 & 5,5 & 11 & 0 & 50 & 6,5 & 34,5 & 6,5 & 11 & 32 & 0 \\
\hline & Pedro Avelino (Base Física da EMPARN) & 12 & 0 & 3,4 & 52 & 0 & 25 & 0 & 0 & 0 & 0 & 18,9 & 21,7 & 23 & 56,9 & 10,5 & 57,6 & 0,9 & 15,3 & 24,2 & 0 \\
\hline & Rui Barbosa (EMATER) & 10,7 & 0 & 0 & 0 & 0 & 0 & 0 & 0 & 0 & 0 & 0 & 59,4 & 0 & 36,9 & 0 & 74,2 & 5 & 11,4 & 0 & 0 \\
\hline & Santa Cruz (EMATER) & 0 & 0 & 21,8 & 3,4 & 0 & 28 & 4,7 & 0 & 0 & 0 & 25,2 & 6,2 & 2,9 & 48 & 1,4 & 32,2 & 0 & 13,1 & 18,3 & 0 \\
\hline & Santana do Matos (EMATER) & 85 & 5 & 57,5 & 6 & 0 & 3 & 0 & 0 & 0 & 0 & 0 & 54 & 22 & 70,5 & 0 & 18,5 & 0 & 61 & 0 & 0 \\
\hline & Santana do Matos (Barão de Serra Branca) & 14,5 & 13,1 & 15,2 & 0 & 0 & 20 & 2 & 0 & 25 & 0 & 7 & 7,2 & 40,7 & 7,3 & 28,4 & 46,9 & 0 & 73,1 & 37,6 & 0 \\
\hline & Santana do Matos (São José da Passagem) & 0 & 0 & 20,7 & 0 & 0 & 0 & 0 & 4 & 0 & 0 & 0 & 26,4 & 0 & 0 & 0 & 28 & 0 & 43,9 & 0 & 0 \\
\hline & São Bento do Trairi (Prefeitura) & 0 & 0 & 58,7 & 0 & 0 & 0 & 0 & 0 & 0 & 0 & 0 & 40 & 23 & 22,6 & 0 & 20 & 0 & 14 & 35,5 & 0 \\
\hline & São José do Campestre (EMATER) & 63 & 0 & 15,5 & 52 & 7 & 0 & 10 & 0 & 0 & 0 & 0 & 0 & 14,5 & 13,4 & 0 & 55 & 0 & 0 & 9 & 0 \\
\hline & São Paulo do Potengi (EMATER) & 0 & 0 & 0 & 0 & 0 & 12,6 & 1,4 & 3 & 0 & 0 & 5,9 & 7 & 0 & 30,8 & 0 & 30,8 & 1 & 24,9 & 0 & 0 \\
\hline & São Pedro (EMATER) & 0 & 10,8 & 5,7 & 0,7 & 0 & 12 & 7,9 & 3,7 & 0 & 0 & 1,7 & 1,2 & 0 & 28,8 & 29,8 & 10,1 & 1 & 48,2 & 0 & 3 \\
\hline & São Rafael (EMATER) & 102,5 & 0,1 & 21,2 & 1,8 & 0 & 31,1 & 7,1 & 2,8 & 0,1 & 0 & 14,2 & 32,5 & 23 & 31,2 & 5,3 & 27 & 4,8 & 28,7 & 0 & 0 \\
\hline & São Tomé (EMATER) & 0 & 0 & 76 & 10 & 2 & 0 & 0 & 0 & 0 & 0 & 0 & 0 & 0 & 0 & 0 & 0 & 0 & 0 & 0 & 0 \\
\hline & São Vicente (EMATER - Ex Particular) & 0 & 4,3 & 35,3 & 0 & 0 & 9 & 0 & 0 & 0 & 0 & 4,6 & 13,7 & 58,4 & 0 & 5,8 & 20,4 & 6,8 & 34,7 & 4,5 & 0 \\
\hline & Senador Eloi de Souza (Particular) & 0 & 15,7 & 14,4 & 0 & 0 & 0 & 10,6 & 1,9 & 0 & 0 & 3,3 & 0 & 0 & 13,2 & 2 & 42 & 0 & 13 & 8,9 & 0 \\
\hline & Serra de São Bento (EMATER) & 14,7 & 0,6 & 27,3 & 34,2 & 3,1 & 11,4 & 6,3 & 6,6 & 0 & 0 & 2,2 & 1,1 & 0,7 & 11,2 & 1,3 & 28,5 & 0,8 & 3,6 & 21,4 & 0,4 \\
\hline & Serrinha (EMATER) & 0 & 9,8 & 22,7 & 25,8 & 2,3 & 6,4 & 15,7 & 24,5 & 0 & 0 & 8 & 11,4 & 6,9 & 45,8 & 0 & 87,9 & 0 & 15,4 & 1,9 & 0 \\
\hline & Sítio Novo (Prefeitura) & 48 & 0 & 15 & 1,5 & 0 & 0 & 4,5 & 0 & 0 & 0 & 10 & 5,5 & 0 & 24,5 & 0 & 43,5 & 0 & 9,5 & 2,5 & 0 \\
\hline & Tangará (EMATER) & 10,5 & 4 & 14 & 0 & 0 & 0 & 0 & 1 & 0 & 0 & 0 & 0 & 0 & 27,5 & 0 & 74 & 0 & 12 & 4,5 & 0 \\
\hline & Tangará (Açude Trairi) & 3,3 & 0 & 6,4 & 13,7 & 0,8 & 1 & 2 & 0 & 0 & 0 & 4,5 & 4,9 & 9 & 64,2 & 0 & 51,9 & 0 & 7,1 & 8,6 & 0 \\
\hline & Triunfo Potiguar (Prefeitura) & 40,8 & 0 & 5,3 & 40,6 & 0 & 28,7 & 40,4 & 0,3 & 1,9 & 0 & 13,7 & 4,9 & 30,6 & 42,9 & 0 & 69,6 & 0 & 44,6 & 4,8 & 0 \\
\hline & Triunfo Potiguar (Chá Velha/Serra J. Vale) & 0 & 43,1 & 60,9 & 91,1 & 0 & 0 & 0 & 0 & 10 & 0 & 25,5 & 20,1 & 69,4 & 9,4 & 39,4 & 23,2 & 36,8 & 0 & 0 & 0 \\
\hline & Alagoa Nova & 5 & 0 & 80,3 & 3,9 & 0 & 1,3 & 9,4 & 0,5 & 0 & 0 & 5,9 & 4,1 & 30,7 & 25,9 & 18,1 & 80,2 & 12,1 & 12,8 & 11,6 & 7,2 \\
\hline & Barra de Santana & 5,7 & 11,4 & 55,4 & 6,7 & 0 & 27,8 & 14,8 & 0 & 0 & 0 & 5,1 & 9,2 & 8,4 & 12,8 & 9,7 & 15,5 & 14,1 & 0 & 13,8 & 2,5 \\
\hline & Boa Vista & 4,2 & 0 & 140,8 & 0 & 0 & 2,2 & 0 & 0 & 0 & 0 & 0 & 0 & 3,4 & 17,4 & 0 & 9,4 & 2,4 & 3,8 & 11 & 0 \\
\hline & Boqueirão/Açude Boqueirão & 13,3 & 28,3 & 12,1 & 25,3 & 1,6 & 11,4 & 1,2 & 0 & 0 & 0 & 3,5 & 13,4 & 0 & 35,8 & 4,3 & 27,6 & 14,7 & 1,6 & 3,1 & 0,7 \\
\hline & Cabaceiras & 9 & 0 & 42,2 & 4,3 & 0 & 8,1 & 0 & 1,2 & 0 & 0 & 0 & 32,4 & 0 & 2,6 & 0 & 5,7 & 30,3 & 2,3 & 3,5 & 0 \\
\hline & Campina Grande/EMBRAPA & 4,7 & 0,2 & 69,3 & 3,8 & 1,2 & 10,9 & 2,5 & 0 & 0 & 0 & 0,2 & 8,3 & 8,4 & 30,4 & 12,9 & 44,6 & 7,5 & 8,3 & 15,1 & 3,4 \\
\hline & Campina Grande/INSA & 5,5 & 0 & 65,2 & 1,5 & 0,3 & 6,8 & 3,7 & 0 & 0 & 0 & 0 & 0,9 & 3,1 & 38,2 & 2,4 & 28,3 & 3,6 & 7,2 & 10,5 & 5,5 \\
\hline & Campina Grande/Santa Terezinha & 6,8 & 0 & 65,7 & 6,5 & 0 & 12,5 & 4,6 & 0 & 0 & 0 & 1,5 & 22,5 & 12,2 & 36,7 & 0 & 54,5 & 3,1 & 16 & 7,1 & 8,1 \\
\hline
\end{tabular}




\begin{tabular}{|c|c|c|c|c|c|c|c|c|c|c|c|c|c|c|c|c|c|c|c|c|c|}
\hline 2010 & Estação & s1 & s2 & s3 & s4 & s5 & s6 & s7 & s8 & s9 & s10 & s11 & s12 & s13 & s14 & s15 & s16 & s17 & s18 & s19 & s20 \\
\hline & Caturité & 0 & 0 & 33 & 0 & 0 & 18,8 & 10,4 & 0 & 0 & 0 & 0 & 9,6 & 26 & 26,6 & 3,1 & 13,8 & 11,5 & 0 & 3,8 & 0 \\
\hline & Caturité/Fazenda Campo de Emas & 0 & & 6,7 & 0 & 0 & 18,4 & 5,5 & 0 & 0 & 0 & 1,4 & 0 & 2,2 & 51,4 & 0 & 22,2 & 0 & 0 & 9 & 0 \\
\hline & Cubati & 0 & 14,8 & 34,4 & 27 & 0 & 3,5 & 0 & 0 & 0 & 0 & 11 & 50,9 & 21 & 35 & 0 & 35,7 & 3,1 & 17,5 & 7,8 & 0 \\
\hline & Lagoa Seca & 3,6 & 9,1 & 96,5 & 8,6 & 0,9 & 10,2 & 4,5 & 0 & 0 & 0 & 2,6 & 8,9 & 13,7 & 93,2 & 4,7 & 56,4 & 8,1 & 27,6 & 12,3 & 7,8 \\
\hline & Matinhas & 0 & 0,7 & 25,8 & 8,6 & 184,8 & 22,4 & 16,7 & 42,4 & 48,7 & 0,5 & 5,4 & 5,8 & 18,9 & 13,9 & 65,5 & 71,8 & 48,5 & 27,8 & 29,8 & 119 \\
\hline & Olivedos & 3,8 & 6 & 23,7 & 27,2 & 0 & 1,5 & 0 & 3,3 & 0 & 0 & 1,6 & 0 & 9,5 & 88,1 & 11 & 1,4 & 0 & 6,4 & 1,7 & 4 \\
\hline & Pedra Lavrada & 0 & 0 & 43,4 & 0 & 0 & 3,9 & 24,7 & 0 & 0 & 0 & 106 & 63,9 & 5,6 & 23 & 0 & 7,7 & 0 & 17,4 & 4,4 & 0 \\
\hline & Pocinhos & 2,5 & 0 & 89,1 & 0 & 0 & 0,5 & 5,6 & 0 & 0 & 0 & 19,8 & 0 & 6,6 & 25,3 & 0 & 9,3 & 3,6 & 8,6 & 7,6 & 3,7 \\
\hline & Queimadas & 2,7 & 0 & 58,1 & 3,1 & 5,6 & 3,3 & 17,7 & 0 & 0 & 3,7 & 0 & 6,3 & 2,2 & 27,9 & 22 & 23,1 & 12,4 & 7,2 & 2 & 0 \\
\hline & Seridó & 0 & 0 & 42,7 & 2,1 & 0 & 3,3 & 1,7 & 0 & 0 & 0 & 27,8 & 24,1 & 15,3 & 49,1 & 0 & 28 & 19,4 & 88,2 & 1,6 & 3,3 \\
\hline & Seridó/São Vicente do Seridó & 0 & 10,7 & 21,3 & 5 & 0 & 8,8 & 0 & 0 & 0 & 0 & 74 & 45,8 & 10,9 & 38,6 & 0 & 21,1 & 3,3 & 50 & 5,5 & 1,7 \\
\hline & Soledade & 7,3 & 1,3 & 79,7 & 16,2 & 0 & 7,1 & 1,9 & 0 & 0 & 0 & 8,1 & 22,3 & 4,4 & 34,2 & 0 & 0 & 0 & 43,5 & 1,7 & 0 \\
\hline
\end{tabular}

\begin{tabular}{|c|c|c|c|c|c|c|c|c|c|c|c|c|c|c|c|c|c|c|c|c|c|}
\hline 2010 & Estação & s21 & s22 & s23 & s24 & s25 & $\mathbf{s 2 6}$ & s27 & $\mathbf{s 2 8}$ & $\mathbf{s 2 9}$ & s30 & s31 & s32 & s33 & s34 & s35 & s36 & s37 & s38 & s39 & s40 \\
\hline & Acari (Particular) & 0,1 & 6 & 0 & 4,1 & 5,8 & 0,7 & 6,8 & 2 & 0 & 0 & 0 & 0 & 0 & 0 & 0 & 0 & 0 & 0 & 0 & 0 \\
\hline & Assu (EMATER/Sítio Casa Forte) & 0 & 3,1 & 0 & 4,7 & 0 & 0,2 & 2,4 & 1,3 & 1,6 & 0 & 0 & 0 & 0 & 0 & 0 & 0 & 0 & 0 & 0 & 0 \\
\hline & Afonso Bezerra (EMATER) & 0 & 0 & 0 & 0 & 10 & 6 & 0 & 0 & 0 & 0 & 0 & 0 & 0 & 0 & 0 & 0 & 0 & 0 & 0 & 0 \\
\hline & Almino Afonso (Particular - Ex Sítio Milagres) & 14,5 & 9,3 & 0 & 14,2 & 0 & 0 & 4,3 & 0 & 2,2 & 0 & 0 & 0 & 0 & 0 & 0 & 0 & 0 & 0 & 0 & 0 \\
\hline & Angicos (Prefeitura) & 0 & 0 & 0 & 6,6 & 11 & 0 & 0 & 0 & 0 & 0 & 0 & 0 & 0 & 0 & 0 & 0 & 0 & 0 & 0 & 0 \\
\hline & Campo Grande (Particular) & 0 & 22,8 & 0 & 20 & 14,7 & 0 & 0 & 1,3 & 5,1 & 2,3 & 0 & 0 & 0 & 0 & 0 & 0 & 0 & 0 & 0 & 0 \\
\hline & Campo Grande (Particular 2) & 0 & 27,9 & 0 & 16 & 11,5 & 0 & 2,1 & 1,3 & 2,4 & 3,6 & 0 & 0 & 0 & 0 & 0 & 0 & 0 & 0 & 0 & 0 \\
\hline & Barcelona (Particular) & 0 & 5,5 & 2 & 50,5 & 1 & 10 & 9 & 2,7 & 6,7 & 0 & 6,1 & 3,3 & 0 & 9,8 & 0 & 0 & 0 & 0 & 0 & 0 \\
\hline & Bodó (EMATER/TRF P/Delegacia) & 0 & 0 & 1,8 & 3,6 & 7,3 & 3,2 & 6,7 & 3 & 0 & 0 & 0 & 0 & 0 & 0 & 0 & 0 & 0 & 0 & 0 & 0 \\
\hline & Bom Jesus (Particular) & 0,5 & 15,5 & 0 & 47,9 & 6,3 & 8 & 48,4 & 6,7 & 19 & 1,6 & 1,4 & 3,2 & 0 & 6,4 & 0 & 0 & 0 & 0 & 0 & 0 \\
\hline & Caiçara do Rio do Vento (Particular) & 0 & 18 & 0 & 0 & 1 & 2,5 & 0 & 0 & 0 & 0 & 0 & 0 & 0 & 0 & 0 & 0 & 0 & 0 & 0 & 0 \\
\hline & Caicó (Batalhão) & 0 & 0 & 0 & 31 & 0 & 0 & 0 & 0 & 0 & 0 & 0 & 0 & 0 & 0 & 0 & 0 & 0 & 0 & 0 & 0 \\
\hline & Caicó (Açude Mundo Novo - EMPARN) & 0 & 19,8 & 0 & 40,8 & 24,5 & 0 & 0 & 0 & 0 & 0 & 0 & 0 & 0 & 0 & 0 & 0 & 0 & 0 & 0 & 0 \\
\hline & Caicó (Palma) & 4 & 18 & 0 & 26 & 0 & 0 & 0 & 0 & 0 & 0 & 0 & 0 & 0 & 0 & 0 & 0 & 0 & 0 & 0 & 0 \\
\hline & Caicó (Açude Itans) & 0 & 27 & 0 & 27,8 & 14,9 & 0 & 0 & 0 & 0 & 0 & 0 & 0 & 0 & 0 & 0 & 0 & 0 & 0 & 0 & 0 \\
\hline & Caicó (Laginhas) & 0 & 0 & 40 & 0 & 0 & 0 & 0 & 0 & 0 & 0 & 0 & 0 & 0 & 0 & 0 & 0 & 0 & 0 & 0 & 0 \\
\hline & Caicó (Penitenciária) & 0 & 19 & 0 & 31,5 & 22 & 0 & 3,8 & 0 & 0 & 0 & 0 & 0 & 0 & 0 & 0 & 0 & 0 & 0 & 0 & 0 \\
\hline & Campo Redondo (EMATER) & 0 & 19,6 & 0 & 61,3 & 17,5 & 2,8 & 8 & 9,4 & 14,7 & 0 & 1,2 & 7,4 & 0 & 5,1 & 0,4 & 3,9 & 0,5 & 0 & 0 & 0 \\
\hline & Campo Redondo (Polícia Rodoviária) & 0 & 8 & 0 & 48,2 & 25 & 6,1 & 7,3 & 6,8 & 18,8 & 0 & 0 & 0 & 0 & 0 & 0 & 0 & 0 & 0 & 0 & 0 \\
\hline & Cerro Corá (EMATER) & 0 & 0 & 0 & 0 & 0 & 0 & 13,5 & 0 & 0 & 0 & 0 & 0 & 0 & 0 & 0 & 0 & 0 & 0 & 0 & 0 \\
\hline & Coronel Ezequiel (Particular) & 0 & 1,5 & 0 & 18 & 9 & 2 & 3,5 & 4 & 11 & 0 & 1 & 0 & 0 & 2 & 0 & 18 & 0 & 0 & 0 & 0 \\
\hline & Cruzeta (Base Física da EMPARN) & 0 & 74,7 & 1,4 & 32,7 & 9,1 & 0,2 & 2,7 & 0 & 5,1 & 0 & 0,1 & 0 & 0 & 0 & 0 & 1,9 & 0 & 0 & 0 & 0 \\
\hline
\end{tabular}




\begin{tabular}{|c|c|c|c|c|c|c|c|c|c|c|c|c|c|c|c|c|c|c|c|c|c|}
\hline 2010 & Estação & s21 & s22 & s23 & s24 & s25 & s26 & s27 & s28 & $s 29$ & s30 & s31 & s32 & s33 & s34 & s35 & s36 & s37 & s38 & s39 & $s 40$ \\
\hline & Currais Novos (CERCEL) & 0 & 2 & 0 & 38 & 7,9 & 0 & 0 & 0 & 0 & 0 & 0 & 0 & 0 & 0 & 0 & 0 & 0 & 0 & 0 & 0 \\
\hline & Fernando Pedroza (EMATER) & 0 & 9,6 & 0 & 0 & 9,7 & 0 & 0 & 0 & 0 & 3 & 0 & 0 & 0 & 0 & 0 & 0 & 0 & 0 & 0 & 0 \\
\hline & Florânia (INMET) & 0 & 98,1 & 0 & 0 & 0 & 0 & 0 & 0 & 0 & 1,4 & 0 & 0 & 0 & 0 & 0 & 0 & 0 & 0 & 0 & 0 \\
\hline & Florânia (Sítio Jucuri) & 0 & 66,6 & 2,1 & 43,7 & 5,2 & 0 & 0 & 0 & 0 & 2 & 0 & 0 & 0 & 0 & 0 & 0 & 0 & 0 & 0 & 0 \\
\hline & Ielmo Marinho (Prefeitura) & 8 & 47,5 & 0 & 46 & 16,3 & 0 & 3,5 & 11 & 20 & 5 & 8,3 & 1,5 & 0 & 9,6 & 5,4 & 5,1 & 0 & 0 & 0 & 0 \\
\hline & Jaçanã (EMATER) & 0 & 7 & 0 & 47,5 & 7,9 & 2,7 & 11,7 & 1 & 0 & 4 & 9,9 & 0 & 0 & 0 & 0 & 14,2 & 0 & 0 & 0 & 0 \\
\hline & Janduís (EMATER) & 0 & 42 & 0 & 13 & 7 & 0 & 7 & 0 & 0 & 8 & 0 & 0 & 0 & 0 & 0 & 0 & 0 & 0 & 0 & 0 \\
\hline & Boa Saúde (EMATER) & 14,4 & 12,5 & 2,2 & 84,3 & 7,3 & 14,1 & 6,4 & 6,7 & 27,3 & 0 & 5,6 & 6,3 & 0 & 1,3 & 0 & 0 & 0 & 0 & 0 & 0 \\
\hline & Japi (Particular) & 0 & 10,4 & 0 & 52,8 & 10,2 & 0 & 14,6 & 0 & 0 & 0 & 0 & 0 & 0 & 0 & 0 & 0 & 0 & 0 & 0 & 0 \\
\hline & Japi (EMATER) & 0 & 8 & 0 & 46,6 & 7,7 & 0 & 14,3 & 0 & 5 & 0 & 1,5 & 0 & 0 & 0 & 0 & 4 & 0 & 0 & 0 & 0 \\
\hline & Jardim de Angicos (EMATER) & 3,1 & 9,7 & 0 & 27,2 & 0 & 3,2 & 8,9 & 3,7 & 2,3 & 0 & 0 & 0 & 0 & 2,8 & 0 & 0 & 0 & 0 & 0 & 0 \\
\hline & Lagoa d'Anta (Prefeitura) & 0 & 12 & 0 & 58 & 10 & 0 & 0 & 30 & 8 & 0 & 0 & 0 & 0 & 3 & 0 & 0 & 0 & 0 & 0 & 0 \\
\hline & Lagoa de Pedras (Prefeitura) & 11,8 & 30,4 & 0 & 85 & 13,2 & 16,3 & 13,4 & 5,3 & 18,8 & 2,4 & 3 & 3,8 & 0 & 5,1 & 1 & 2,8 & 0 & 1 & 0 & 0 \\
\hline & Lagoa de Velhos (Delegacia) & 0 & 12,7 & 0 & 78,8 & 5,4 & 7,7 & 8,3 & 2,4 & 6,4 & 0 & 9,3 & 3 & 0 & 6,2 & 0 & 2,3 & 0 & 0 & 0 & 0 \\
\hline & Lagoa Nova (EMATER/Sítio Humaitá) & 0 & 15 & 0 & 48 & 11 & 20 & 9 & 1 & 5,5 & 0 & 5,5 & 0,3 & 0 & 0 & 0 & 0 & 0 & 0 & 0 & 0 \\
\hline & Lagoa Salgada (Delegacia) & 0 & 11 & 0 & 73 & 8,9 & 13,4 & 21,5 & 4,2 & 8,3 & 10 & 0 & 2,6 & 0 & 0 & 0 & 0 & 0 & 0 & 0 & 0 \\
\hline & Lajes (Prefeitura) & 0 & 0 & 0 & 0 & 0 & 0 & 0 & 0 & 0 & 0 & 0 & 0 & 0 & 0 & 0 & 0 & 0 & 0 & 0 & 0 \\
\hline & Lajes Pintadas (Prefeitura) & 0 & 8,5 & 0 & 57 & 19,6 & 4,7 & 4,4 & 13,9 & 5,7 & 0 & 0 & 0 & 0 & 0 & 0 & 0 & 0 & 0 & 0 & 0 \\
\hline & Messias Targino (Prefeitura) & 0 & 14,3 & 0 & 0 & 13 & 0 & 0 & 0 & 0 & 0 & 0 & 0 & 0 & 0 & 0 & 0 & 0 & 0 & 0 & 0 \\
\hline & Monte Alegre (EMATER) & 15 & 64 & 0 & 60 & 20 & 8 & 25 & 0 & 17 & 9 & 7 & 9 & 0 & 6 & 6 & 3 & 0 & 2 & 0 & 0 \\
\hline & Monte das Gameleiras (EMATER) & 0 & 11 & 0 & 48 & 9,2 & 3,8 & 5,5 & 6,7 & 8,7 & 0 & 4,3 & 5 & 0 & 10 & 0 & 0 & 0 & 0 & 0 & 0 \\
\hline & Paraú (Prefeitura) & 5,3 & 0 & 49 & 0 & 23 & 0 & 0 & 0 & 0 & 0 & 0 & 0 & 0 & 0 & 0 & 0 & 0 & 0 & 0 & 0 \\
\hline & Passa e Fica (Prefeitura) & 0 & 47,9 & 0 & 62,5 & 0 & 12,2 & 0 & 9,9 & 23,9 & 0 & 7 & 2,2 & 0 & 10,3 & 2,6 & 0 & 0 & 0 & 0 & 0 \\
\hline & Patu (Particular) & 2 & 15,6 & 0 & 16 & 29 & 4 & 2,6 & 0 & 0 & 4 & 0 & 0 & 0 & 0 & 0 & 0 & 0 & 0 & 0 & 0 \\
\hline & Santa Maria (Sindicato dos Trabalhadores Rurais) & 0 & 32,6 & 0 & 23 & 16 & 0 & 7 & 0 & 7,2 & 0 & 0 & 0 & 0 & 0 & 2,8 & 2,5 & 5 & 0 & 8,7 & 0 \\
\hline & Pedra Preta (EMATER) & 0 & 0 & 0 & 15 & 6 & 0 & 4,5 & 10 & 0 & 0 & 0 & 0 & 0 & 0 & 0 & 0 & 0 & 0 & 0 & 0 \\
\hline & Pedro Avelino (Base Física da EMPARN) & 4,3 & 7,5 & 0 & 13,9 & 0 & 3,7 & 0 & 1 & 1,2 & 12 & 0 & 0 & 0 & 0,7 & 0 & 0 & 0 & 0 & 0 & 0 \\
\hline & Rui Barbosa (EMATER) & 0 & 12 & 0 & 21,2 & 12,2 & 1 & 0 & 0 & 8,7 & 0 & 0 & 0 & 0 & 0 & 0 & 0 & 0 & 0 & 0 & 0 \\
\hline & Santa Cruz (EMATER) & 0 & 7,9 & 0 & 50,9 & 0 & 17 & 8,4 & 7,8 & 14,5 & 0,9 & 1,2 & 0 & 0 & 0 & 1,8 & 0 & 0 & 0 & 0 & 0 \\
\hline & Santana do Matos (EMATER) & 0 & 0 & 0 & 0 & 0 & 0 & 0 & 28 & 0 & 0 & 0 & 0 & 0 & 0 & 0 & 0 & 0 & 0 & 0 & 0 \\
\hline & Santana do Matos (Barão de Serra Branca) & 0 & 51 & 0 & 0 & 44 & 9 & 0 & 0 & 0 & 0 & 0 & 0 & 0 & 0 & 0 & 0 & 0 & 0 & 0 & 0 \\
\hline & Santana do Matos (São José da Passagem) & 0 & 0 & 0 & 0 & 0 & 0 & 0 & 0 & 0 & 0 & 0 & 0 & 0 & 0 & 0 & 0 & 0 & 0 & 0 & 0 \\
\hline & São Bento do Trairi (Prefeitura) & 0 & 20 & 0 & 53,5 & 15 & 0 & 7,7 & 0 & 9,4 & 0 & 0 & 0 & 0 & 0 & 0 & 0 & 0 & 0 & 0 & 25 \\
\hline & São José do Campestre (EMATER) & 0 & 14,5 & 0 & 43 & 11 & 0 & 0 & 20 & 8,1 & 0 & 2,2 & 9,5 & 0 & 4,3 & 0 & 4,2 & 1,1 & 0 & 0 & 0 \\
\hline & São Paulo do Potengi (EMATER) & 5,2 & 22 & 0 & 21,5 & 7 & 6,8 & 4,2 & 4,2 & 8,3 & 0 & 4,8 & 1,2 & 0 & 13 & 0 & 2 & 0 & 0 & 0 & 0 \\
\hline & São Pedro (EMATER) & 1,2 & 17,1 & 0 & 33,5 & 14,9 & 4,4 & 18,1 & 9,9 & 5,4 & 2,2 & 1,8 & 1,2 & 1 & 18,3 & 0 & 4,4 & 0,3 & 0 & 0 & 0 \\
\hline
\end{tabular}




\begin{tabular}{|c|c|c|c|c|c|c|c|c|c|c|c|c|c|c|c|c|c|c|c|c|c|}
\hline 2010 & Estação & s21 & s22 & s23 & s24 & s25 & s26 & s27 & s28 & $s 29$ & s30 & s31 & s32 & s33 & s34 & s35 & s36 & s37 & s38 & s39 & $s 40$ \\
\hline & São Rafael (EMATER) & 0 & 12,4 & 0 & 20 & 3,5 & 2,1 & 0 & 0 & 0 & 2 & 0 & 0 & 0 & 1,2 & 0 & 0 & 0 & 0 & 0 & 0 \\
\hline & São Tomé (EMATER) & 2 & 0 & 0 & 65 & 0 & 11 & 6 & 2 & 0 & 0 & 0 & 0 & 0 & 0 & 0 & 0 & 0 & 0 & 0 & 0 \\
\hline & São Vicente (EMATER - Ex Particular) & 0 & 106,4 & 0 & 31 & 0 & 6,1 & 0 & 0 & 0 & 0 & 0 & 0 & 0 & 0 & 0 & 0 & 0 & 0 & 0 & 8,5 \\
\hline & Senador Eloi de Souza (Particular) & 0 & 8,7 & 0 & 72,2 & 5,8 & 5 & 17,5 & 0 & 21,7 & 0 & 4 & 4,3 & 0 & 0 & 0 & 0 & 0 & 0 & 0 & 0 \\
\hline & Serra de São Bento (EMATER) & 7,2 & 4,1 & 16,9 & 65,3 & 16,6 & 4,4 & 15,8 & 20,4 & 31,1 & 0 & 15,7 & 10 & 0 & 24,5 & 3,8 & 6,2 & 5,4 & 0 & 0,4 & 0 \\
\hline & Serrinha (EMATER) & 0 & 15,5 & 0,5 & 69,7 & 11,3 & 11,1 & 14,8 & 14,8 & 23,6 & 3,1 & 5,2 & 11,4 & 0 & 13,9 & 0,8 & 4,1 & 1,3 & 1,1 & 0,9 & 0 \\
\hline & Sítio Novo (Prefeitura) & 0 & 2 & 0 & 47 & 0 & 20,5 & 11,5 & 3,5 & 6,5 & 0 & 0 & 0 & 0 & 0 & 0 & 12 & 0 & 0 & 0 & 0 \\
\hline & Tangará (EMATER) & 0 & 0 & 0 & 58,5 & 1 & 0 & 0 & 10 & 3 & 0 & 0 & 3 & 0 & 7 & 0 & 0 & 0 & 0 & 0 & 0 \\
\hline & Tangará (Açude Trairi) & 0 & 37,3 & 0 & 57,3 & 8,3 & 1,8 & 2,5 & 9,4 & 11,4 & 0 & 3,4 & 2,7 & 0 & 8 & 1,1 & 10,2 & 0 & 0 & 0 & 0 \\
\hline & Triunfo Potiguar (Prefeitura) & 0 & 0 & 0 & 0 & 0 & 0 & 0 & 0 & 0 & 0 & 0 & 0 & 0 & 0 & 0 & 0 & 0 & 0 & 0 & 0 \\
\hline & Triunfo Potiguar (Chá Velha/Serra J. Vale) & 0 & 0 & 0 & 0 & 0 & 0 & 0 & 0 & 0 & 0 & 0 & 0 & 0 & 0 & 0 & 0 & 0 & 0 & 0 & 0 \\
\hline & Alagoa Nova & 2,2 & 51,9 & 1,2 & 81,6 & 17,3 & 12,2 & 27,1 & 64,7 & 15,5 & 9,9 & 32,1 & 6,8 & 0 & 14,6 & 9 & 9,3 & 21,5 & 1 & 0 & 0 \\
\hline & Barra de Santana & 0 & 13,1 & 33,2 & 80,7 & 15,5 & 10,6 & 8,4 & 14,3 & 4,8 & 3,7 & 9,6 & 7,6 & 0 & 3,2 & 2,7 & 5,9 & 2,4 & 0 & 0 & 0 \\
\hline & Boa Vista & 0 & 31,8 & 0 & 85,6 & 10 & 0 & 0 & 0 & 13,8 & 0 & 3,8 & 19,2 & 0 & 0 & 6,2 & 0 & 19,4 & 0 & 0 & 0 \\
\hline & Boqueirão/Açude Boqueirão & 0 & 17,7 & 4,1 & 99,3 & 26,6 & 6,9 & 7,5 & 14,9 & 2,5 & 2,3 & 1,6 & 17,1 & 0 & 2,4 & 5,4 & 1,7 & 3,5 & 0,1 & 0 & 0 \\
\hline & Cabaceiras & 0 & 18,4 & 0 & 89,2 & 6,2 & 11,1 & 1 & 16 & 4 & 0 & 2,2 & 8,4 & 0 & 2,3 & 1,9 & 0,6 & 2,5 & 0 & 0 & 0 \\
\hline & Campina Grande/EMBRAPA & 0,3 & 62,1 & 1,2 & 139,3 & 15,3 & 15,6 & 15,3 & 7,4 & 8,2 & 11,4 & 45,4 & 15,7 & 0,1 & 21,7 & 15 & 11,9 & 20,1 & 3,8 & 0,2 & 0 \\
\hline & Campina Grande/INSA & 0 & 32,5 & 1,5 & 93,8 & 4,5 & 8,4 & 10,5 & 9,4 & 3,8 & 5,3 & 13,1 & 14 & 0,1 & 10 & 6,5 & 16,4 & 10,5 & 0 & 0 & 0 \\
\hline & Campina Grande/Santa Terezinha & 0 & 94,7 & 0,9 & 102,6 & 11,8 & 5,4 & 15,8 & 9,2 & 8 & 5,8 & 14 & 19,7 & 0 & 12 & 9,9 & 6,4 & 16 & 3,3 & 0 & 0 \\
\hline & Caturité & 0 & 24,3 & 22,7 & 130,3 & 0 & 7 & 13 & 13,9 & 10,1 & 9 & 13,9 & 12,9 & 0 & 4,3 & 8,6 & 5,1 & 8,5 & 0,8 & 0 & 0 \\
\hline & Caturité/Fazenda Campo de Emas & 0 & 34 & 0 & 83 & 12,2 & 7,8 & 3,8 & 1,3 & 2,8 & 2,6 & 12,4 & 9,4 & 1,4 & 0 & 11,2 & 5 & 13 & 0 & 0 & 0 \\
\hline & Cubati & 0 & 56,4 & 0 & 29,5 & 0 & 5,3 & 0 & 0 & 7 & 0 & 0 & 0 & 0 & 0 & 2,1 & 1,3 & 0 & 0 & 0 & 0 \\
\hline & Lagoa Seca & 1,7 & 72 & 0 & 135,6 & 15 & 15,7 & 29,4 & 28 & 30,1 & 28 & 54,3 & 28,5 & 1,5 & 42 & 14,5 & 21,2 & 20,1 & 0 & 0 & 0 \\
\hline & Matinhas & 65,4 & 89,2 & 64,7 & 9,9 & 32,3 & 35,2 & 92,8 & 18,1 & 48,5 & 12 & 36,9 & 30,7 & 7,5 & 28,6 & 0,5 & 3,3 & 18,9 & 0,4 & 0,9 & 0 \\
\hline & Olivedos & 0 & 18,4 & 0 & 42,5 & 5,1 & 0 & 2 & 5,3 & 0 & 0 & 2,9 & 6,6 & 0 & 2,5 & 2 & 4,3 & 1,5 & 0 & 0 & 0 \\
\hline & Pedra Lavrada & 0 & 125,9 & 31 & 28,4 & 0 & 0 & 0 & 6 & 0 & 0 & 0 & 0 & 0 & 0 & 0 & 0 & 0 & 0 & 0 & 0 \\
\hline & Pocinhos & 0 & 30,7 & 0 & 62,2 & 2,5 & 3,9 & 2,1 & 2,1 & 3,2 & 6,2 & 19,3 & 6,3 & 0 & 3,7 & 4,9 & 1,6 & 3,7 & 0 & 0 & 0 \\
\hline & Queimadas & 0 & 35,7 & 3,2 & 111,9 & 0 & 26 & 20,3 & 7,7 & 3,1 & 0 & 3,2 & 7,3 & 24,8 & 19,9 & 0 & 18,6 & 8,6 & 0 & 0 & 0 \\
\hline & Seridó & 0 & 45,4 & 4,8 & 31,8 & 8,1 & 1,1 & 0 & 8,7 & 2,8 & 0,6 & 3,1 & 3,9 & 0 & 0,8 & 0 & 1,3 & 0 & 0 & 0 & 0 \\
\hline & Seridó/São Vicente do Seridó & 0 & 65,7 & 7,5 & 46,2 & 5,1 & 3,8 & 1,4 & 2 & 5,1 & 2,5 & 5,7 & 3,6 & 0 & 0 & 4,5 & 3 & 0,6 & 0 & 0 & 0 \\
\hline & Soledade & 0 & 35,9 & 19,4 & 71,1 & 7 & 1,8 & 1,2 & 5,1 & 4,7 & 1,3 & 5,7 & 10,1 & 0 & 3,3 & 3,1 & 0 & 2,8 & 0 & 0 & 0 \\
\hline
\end{tabular}

Estação

$\begin{array}{llllllllllll}s 41 & s 42 & s 43 & s 44 & s 45 & s 46 & s 47 & s 48 & s 49 & s 50 & s 51 & s 52\end{array}$

Acari (Particular)

Assu (EMATER/Sítio Casa Forte)

Afonso Bezerra (EMATER)

$\begin{array}{ccccccccccccc}0 & 6 & 11 & 0 & 0 & 0 & 0 & 0 & 11,7 & 33,7 & 26,6 & 0 \\ 0 & 4,7 & 8,6 & 0,1 & 0 & 0 & 0 & 0 & 15,8 & 51,7 & 8,4 & 0 \\ 0 & 0 & 25 & 0 & 0 & 0 & 0 & 0 & 34 & 0 & 75 & 0\end{array}$ 


\begin{tabular}{|c|c|c|c|c|c|c|c|c|c|c|c|c|c|}
\hline 2010 & Estação & s41 & s42 & s43 & s44 & s45 & s46 & s47 & s48 & s49 & s50 & s51 & s52 \\
\hline & Almino Afonso (Particular - Ex Sítio Milagres) & 0 & 10,2 & 22,3 & 0 & 0 & 0 & 0 & 0 & 47,4 & 124,4 & 12,7 & 0 \\
\hline & Angicos (Prefeitura) & 0 & 21 & 0 & 0 & 0 & 0 & 0 & 0 & 17 & 0 & 44 & 0 \\
\hline & Campo Grande (Particular) & 0 & 59,5 & 10,1 & 0 & 0 & 0 & 0 & 0 & 0 & 5,5 & 0 & 0 \\
\hline & Campo Grande (Particular 2) & 0 & 70 & 0 & 0 & 0 & 10 & 0 & 0 & 3 & 7 & 6,1 & 0 \\
\hline & Barcelona (Particular) & 0 & 0 & 0 & 0 & 0 & 0 & 0 & 0 & 0 & 0 & 0 & 0 \\
\hline & Bodó (EMATER/TRF P/Delegacia) & 0 & 0 & 0 & 0 & 0 & 0 & 0 & 0 & 0 & 0 & 0 & 0 \\
\hline & Bom Jesus (Particular) & 0 & 0 & 0 & 0 & 0 & 0 & 0 & 0 & 0 & 7,2 & 0 & 0 \\
\hline & Caiçara do Rio do Vento (Particular) & 0 & 0 & 0 & 0 & 0 & 0 & 0 & 0 & 0 & 0 & 0 & 0 \\
\hline & Caicó (Batalhão) & 0 & 84 & 0 & 0 & 0 & 0 & 0 & 0 & 20,3 & 0 & 0 & 0 \\
\hline & Caicó (Açude Mundo Novo - EMPARN) & 0 & 54 & 12,9 & 0 & 0 & 0 & 0 & 0 & 0 & 0 & 0 & 0 \\
\hline & Caicó (Palma) & 0 & 197 & 85 & 0 & 0 & 0 & 0 & 0 & 57,4 & 9,3 & 9,7 & 0 \\
\hline & Caicó (Açude Itans) & 0 & 0 & 0 & 0 & 0 & 0 & 0 & 0 & 0 & 0 & 0 & 0 \\
\hline & Caicó (Laginhas) & 0 & 80,2 & 17,5 & 0 & 0 & 0 & 0 & 0 & 0 & 0 & 27 & 0 \\
\hline & Caicó (Penitenciária) & 0 & 0 & 0 & 0 & 0 & 0 & 0 & 0 & 0 & 0 & 0 & 0 \\
\hline & Campo Redondo (EMATER) & 0 & 0 & 2,5 & 0 & 0 & 0 & 1,4 & 0 & 0 & 0 & 0 & 0 \\
\hline & Campo Redondo (Polícia Rodoviária) & 0 & 0 & 0 & 0 & 0 & 0 & 0 & 0 & 0 & 0 & 0 & 0 \\
\hline & Cerro Corá (EMATER) & 0 & 0 & 0 & 146,3 & 0 & 0 & 0 & 0 & 0 & 0 & 0 & 0 \\
\hline & Coronel Ezequiel (Particular) & 0 & 0 & 0 & 0 & 0 & 0 & 0 & 0 & 0 & 0 & 0 & 0 \\
\hline & Cruzeta (Base Física da EMPARN) & 0 & 39,1 & 52,7 & 0 & 0 & 0,1 & 0 & 0 & 10,1 & 17,7 & 11,7 & 0 \\
\hline & Currais Novos (CERCEL) & 0 & 17 & 45 & 0 & 0 & 0 & 0 & 0 & 0 & 0 & 20 & 0 \\
\hline & Fernando Pedroza (EMATER) & 0 & 0 & 3,5 & 0 & 0 & 0 & 0 & 0 & 0 & 0 & 0 & 0 \\
\hline & Florânia (INMET) & 0 & 0 & 0 & 0 & 0 & 0 & 0 & 0 & 0 & 0 & 0 & 0 \\
\hline & Florânia (Sítio Jucuri) & 0 & 70 & 18,7 & 0 & 0 & 0 & 0 & 0 & 40 & 2 & 5,3 & 0 \\
\hline & Ielmo Marinho (Prefeitura) & 0 & 0 & 0 & 0 & 0 & 0 & 0 & 1,7 & 0 & 25,5 & 10,8 & 0 \\
\hline & Jaçanã (EMATER) & 0 & 0 & 7,3 & 0 & 0 & 0 & 0 & 0 & 14 & 13,6 & 0 & 0 \\
\hline & Janduís (EMATER) & 0 & 81 & 2,3 & 0 & 0 & 0 & 0 & 0 & 0 & 0 & 0 & 0 \\
\hline & Boa Saúde (EMATER) & 0 & 0 & 0 & 0 & 0 & 0 & 0 & 0 & 2,9 & 32,7 & 0 & 0 \\
\hline & Japi (Particular) & 0 & 9,6 & 0 & 0 & 0 & 0 & 0 & 0 & 0 & 0 & 0 & 0 \\
\hline & Japi (EMATER) & 0 & 0 & 0 & 0 & 0 & 0 & 0 & 0 & 0 & 0 & 0 & 0 \\
\hline & Jardim de Angicos (EMATER) & 0 & 0 & 0 & 0 & 0 & 0 & 0 & 0 & 0 & 0 & 0 & 0 \\
\hline & Lagoa d'Anta (Prefeitura) & 0 & 0 & 0 & 0 & 0 & 0 & 0 & 0 & 0 & 0 & 0 & 0 \\
\hline & Lagoa de Pedras (Prefeitura) & 0 & 0 & 0 & 0 & 0 & 0 & 0 & 2,8 & 0 & 32,2 & 6,7 & 0 \\
\hline & Lagoa de Velhos (Delegacia) & 0 & 0 & 0 & 0 & 0 & 0 & 0 & 0 & 2 & 26,6 & 0 & 0 \\
\hline & Lagoa Nova (EMATER/Sítio Humaitá) & 0 & 46 & 0 & 0 & 0 & 0 & 0 & 0 & 0 & 0 & 0 & 0 \\
\hline & Lagoa Salgada (Delegacia) & 0 & 0 & 0 & 0 & 0 & 0 & 0 & 0 & 0 & 0 & 0 & 0 \\
\hline & Lajes (Prefeitura) & 0 & 0 & 0 & 0 & 2,7 & 65,1 & 0 & 0 & 0 & 11,5 & 53,6 & 0 \\
\hline
\end{tabular}




\begin{tabular}{|c|c|c|c|c|c|c|c|c|c|c|c|c|c|}
\hline 2010 & Estação & s41 & s42 & s43 & s44 & s45 & s46 & s47 & s48 & s49 & s50 & s51 & s52 \\
\hline & Lajes Pintadas (Prefeitura) & 0 & 0 & 19,1 & 0 & 0 & 0 & 0 & 0 & 14,5 & 9,3 & 3,7 & 0 \\
\hline & Messias Targino (Prefeitura) & 0 & 32,9 & 0 & 0 & 0 & 0 & 0 & 0 & 16 & 59 & 5,2 & 0 \\
\hline & Monte Alegre (EMATER) & 0 & 0 & 0 & 0 & 0 & 0 & 0 & 0 & 0 & 0 & 0 & 0 \\
\hline & Monte das Gameleiras (EMATER) & 0 & 0 & 0 & 0 & 0 & 0 & 0 & 0 & 0 & 0 & 0 & 0 \\
\hline & Paraú (Prefeitura) & 0 & 40 & 35 & 0 & 0 & 0 & 0 & 0 & 0 & 0 & 0 & 0 \\
\hline & Passa e Fica (Prefeitura) & 0 & 0 & 0 & 0 & 0 & 0 & 0 & 0 & 0 & 0 & 0 & 0 \\
\hline & Patu (Particular) & 0 & 8 & 12 & 0 & 0 & 0 & 0 & 0 & 0 & 73 & 11,4 & 0 \\
\hline & Santa Maria (Sindicato dos Trabalhadores Rurais) & 0 & 0 & 0 & 0 & 5 & 2,5 & 0 & 2 & 0 & 15 & 0 & 0 \\
\hline & Pedra Preta (EMATER) & 0 & 0 & 0 & 0 & 0 & 0 & 0 & 0 & 0 & 0 & 0 & 0 \\
\hline & Pedro Avelino (Base Física da EMPARN) & 0 & 0 & 0 & 0 & 0 & 0 & 0 & 0 & 0 & 0 & 0 & 0 \\
\hline & Rui Barbosa (EMATER) & 0 & 0 & 0 & 0 & 0 & 0 & 0 & 0 & 0 & 0 & 0 & 0 \\
\hline & Santa Cruz (EMATER) & 0 & 0 & 18,3 & 0 & 0 & 0 & 0 & 0 & 0 & 0 & 0 & 0 \\
\hline & Santana do Matos (EMATER) & 0 & 0 & 0 & 0 & 0 & 0 & 0 & 0 & 0 & 6 & 10 & 0 \\
\hline & Santana do Matos (Barão de Serra Branca) & 0 & 0 & 0 & 0 & 0 & 0 & 0 & 0 & 0 & 0 & 0 & 0 \\
\hline & Santana do Matos (São José da Passagem) & 0 & 0 & 7,3 & 0 & 0 & 88,7 & 0 & 0 & 0 & 0 & 0 & 0 \\
\hline & São Bento do Trairi (Prefeitura) & 0 & 0 & 0 & 0 & 0 & 0 & 0 & 0 & 0 & 0 & 0 & 0 \\
\hline & São José do Campestre (EMATER) & 0 & 0 & 0 & 0 & 0 & 0 & 0 & 0 & 0 & 0 & 0 & 0 \\
\hline & São Paulo do Potengi (EMATER) & 0 & 0,2 & 0 & 0 & 0 & 0 & 0 & 0 & 0 & 0 & 0 & 0 \\
\hline & São Pedro (EMATER) & 0 & 0 & 0 & 0 & 0 & 0 & 0 & 0 & 21,5 & 52,5 & 6,7 & 0 \\
\hline & São Rafael (EMATER) & 0 & 7,8 & 0 & 0 & 0 & 0 & 0 & 0 & 24,5 & 9 & 11,3 & 0 \\
\hline & São Tomé (EMATER) & 0 & 0 & 0 & 0 & 0 & 0 & 0 & 0 & 0 & 0 & 0 & 0 \\
\hline & São Vicente (EMATER - Ex Particular) & 0 & 0 & 0 & 0 & 0 & 0 & 0 & 0 & 0 & 0 & 0 & 0 \\
\hline & Senador Eloi de Souza (Particular) & 0 & 0 & 0 & 0 & 0 & 0 & 0 & 0 & 0 & 0 & 0 & 0 \\
\hline & Serra de São Bento (EMATER) & 0 & 1,3 & 2,8 & 0 & 0 & 0 & 0 & 0 & 0 & 12 & 1,1 & 0 \\
\hline & Serrinha (EMATER) & 0 & 0 & 25,1 & 0 & 0 & 0 & 4,9 & 0 & 6,8 & 51,9 & 3 & 0 \\
\hline & Sítio Novo (Prefeitura) & 0 & 0 & 0 & 0 & 0 & 0 & 0 & 0 & 5 & 19,5 & 0 & 0 \\
\hline & Tangará (EMATER) & 0 & 0 & 0 & 0 & 0 & 0 & 0 & 0 & 5 & 23,5 & 1,5 & 0 \\
\hline & Tangará (Açude Trairi) & 0 & 0 & 0 & 0 & 0 & 0 & 0 & 0 & 6,7 & 17,3 & 1,9 & 0 \\
\hline & Triunfo Potiguar (Prefeitura) & 0 & 64,9 & 14,3 & 0 & 0 & 0 & 0 & 0 & 10 & 0 & 12,3 & 0 \\
\hline & Triunfo Potiguar (Chá Velha/Serra J. Vale) & 0 & 0 & 0 & 0 & 0 & 0 & 0 & 0 & 0 & 0 & 0 & 0 \\
\hline & Alagoa Nova & 0 & 38,3 & 43,2 & 0 & 0 & 0 & 3 & 0 & 5 & 11,6 & 3,9 & 0 \\
\hline & Barra de Santana & 0 & 64,4 & 0 & 0 & 0 & 0 & 0 & 0 & 0 & 14,5 & 0 & 0 \\
\hline & Boa Vista & 0 & 0 & 26,2 & 0 & 0 & 0 & 0 & 0 & 0 & 8 & 27,4 & 0 \\
\hline & Boqueirão/Açude Boqueirão & 0 & 1,2 & 14,6 & 0 & 0 & 0 & 0 & 0 & 0 & 18,6 & 23,5 & 0 \\
\hline & Cabaceiras & 0 & 40,9 & 4 & 0 & 0 & 0 & 0 & 0 & 6,5 & 21,4 & 1,6 & 0 \\
\hline & Campina Grande/EMBRAPA & 0 & 14,8 & 1,2 & 3,3 & 0,6 & 0 & 0,3 & 0 & 0 & 22,2 & 15 & 0 \\
\hline
\end{tabular}




\begin{tabular}{|c|c|c|c|c|c|c|c|c|c|c|c|c|c|c|c|c|c|c|c|c|c|}
\hline \multirow{15}{*}{2010} & Estação & s41 & s42 & s43 & s44 & s45 & s46 & s47 & $s 48$ & s49 & s50 & s51 & s52 & & & & & & & & \\
\hline & Campina Grande/INSA & 0 & 6,6 & 0 & 0 & 0,5 & 0 & 0 & 0 & 0 & 2,9 & 48 & 0 & & & & & & & & \\
\hline & Campina Grande/Santa Terezinha & 0 & 1,6 & 0 & 2,8 & 0,5 & 0 & 0 & 0 & 0 & 11 & 17,2 & 0 & & & & & & & & \\
\hline & Caturité & 0 & 37,5 & 1,1 & 0 & 0 & 0 & 0 & 0 & 0 & 18,4 & 33 & 0 & & & & & & & & \\
\hline & Caturité/Fazenda Campo de Emas & 0 & 9 & 0 & 0 & 0 & 0 & 0 & 4 & 0 & 10,4 & 18,4 & 0 & & & & & & & & \\
\hline & Cubati & 0 & 8,3 & 36,9 & 0 & 0 & 0 & 0 & 0 & 0 & 0 & 51,7 & 0 & & & & & & & & \\
\hline & Lagoa Seca & 0 & 0 & 2 & 0 & 1,5 & 0 & 0 & 0 & 0 & 35,3 & 14 & 0,6 & & & & & & & & \\
\hline & Matinhas & 0 & 0 & 0 & 0 & 2,7 & 10,4 & 0,7 & 5,6 & 0 & 1,8 & 3,1 & 6,1 & & & & & & & & \\
\hline & Olivedos & 0 & 0 & 16 & 0 & 0 & 0 & 0 & 0 & 0 & 0,6 & 63,2 & 0 & & & & & & & & \\
\hline & Pedra Lavrada & 0 & 70,4 & 145,3 & 0 & 19,1 & 24,4 & 0 & 0 & 0 & 19,1 & 0 & 0 & & & & & & & & \\
\hline & Pocinhos & 0 & 2,8 & 12 & 0,3 & 0 & 0 & 0 & 0 & 1,3 & 3,7 & 8,6 & 0 & & & & & & & & \\
\hline & Queimadas & 0 & 0 & 0 & 0 & 0 & 0 & 0 & 0 & 0 & 46,2 & 8,2 & 29,3 & & & & & & & & \\
\hline & Seridó & 0 & 6,9 & 156,3 & 0 & 0 & 0 & 0 & 0 & 4,6 & 0 & 41 & 0 & & & & & & & & \\
\hline & Seridó/São Vicente do Seridó & 0 & 0,9 & 144 & 0 & 0 & 0 & 0 & 0 & 3,6 & 4 & 36 & 0 & & & & & & & & \\
\hline & Soledade & 0 & 10,9 & 98,7 & 0 & 0 & 0 & 0 & 0 & 0 & 17,2 & 55,1 & 0 & & & & & & & & \\
\hline 2011 & Estação & s1 & s2 & s3 & s4 & s5 & s6 & s7 & s8 & s9 & $\mathbf{s 1 0}$ & s11 & s12 & s13 & s14 & s15 & s16 & s17 & s18 & $\mathbf{s 1 9}$ & s20 \\
\hline & Acari (Particular) & 0 & 0 & 38,4 & 84,9 & 0 & 0 & 62,3 & 63,7 & 36 & 31 & 0 & 0 & 0 & 7,3 & 128,7 & 134,5 & 0 & 39,8 & 3,3 & 99,4 \\
\hline & Assu (Particular) & 13 & 23,4 & 19,5 & 71,6 & 3,2 & 0 & 4,2 & 27,2 & 53,5 & 12,5 & 7,3 & 42,7 & 29,3 & 62 & 55,1 & 30,4 & 76 & 68,5 & 8,4 & 43,5 \\
\hline & Assu (EMATER/Sítio Casa Forte) & 14,2 & 20,8 & 9,8 & 75,1 & 11,3 & 0 & 28 & 16,6 & 37,6 & 16,6 & 9,8 & 34,5 & 37,7 & 34,8 & 96,1 & 33,8 & 47,1 & 54,5 & 17,6 & 37,1 \\
\hline & Afonso Bezerra (EMATER) & 0 & 32 & 84 & 89 & 0 & 0 & 18 & 2,5 & 72 & 4 & 181 & 68 & 43 & 15 & 92 & 151 & 108,5 & 65 & 30 & 117,5 \\
\hline & Almino Afonso (Particular - Ex Sítio Milagres) & 4,2 & 6,2 & 154,3 & 99,2 & 206,6 & 11,3 & 35,7 & 28,3 & 64,9 & 15,7 & 25,1 & 10,4 & 17,5 & 7 & 94,1 & 41,4 & 87,4 & 59,3 & 12,2 & 25,6 \\
\hline & Angicos (Prefeitura) & 0 & 0 & 15 & 142,5 & 0 & 0 & 22,6 & 0 & 100,8 & 11,5 & 13 & 141 & 36,5 & 10,5 & 70,5 & 73,5 & 92 & 31,7 & 15,5 & 0 \\
\hline & Campo Grande (Particular) & 0 & 0,8 & 40,4 & 134,7 & 14,6 & 16,7 & 25,5 & 89,9 & 88,7 & 3,8 & 15,3 & 9 & 14,7 & 6,9 & 70,9 & 8,8 & 60,4 & 69,8 & 30,9 & 50 \\
\hline & Campo Grande (Particular 2) & 2,3 & 3 & 57,5 & 132,5 & 17 & 0 & 75,1 & 58,8 & 111 & 7,3 & 16,5 & 10 & 10 & 10 & 88 & 30 & 65 & 59,3 & 29,3 & 51,2 \\
\hline & Barcelona (Particular) & 3,6 & 11 & 22,6 & 147 & 19,8 & 0 & 13 & 68 & 12,2 & 43,9 & 12,6 & 13,2 & 10,8 & 0 & 63,5 & 25,8 & 65,7 & 92,6 & 30,2 & 55,5 \\
\hline & Bodó (EMATER/TRF P/Delegacia) & 0 & 0 & 86,8 & 135,8 & 0 & 0 & 7,3 & 1,3 & 43,6 & 0 & 36,7 & 10,8 & 5,3 & 5 & 117,8 & 90 & 165,1 & 41,5 & 23,7 & 121,9 \\
\hline & Bom Jesus (Particular) & 7,3 & 28,7 & 22,7 & 66,4 & 0 & 0 & 21,9 & 52 & 34,2 & 19,4 & 0,6 & 23,2 & 7,6 & 0 & 92,2 & 57 & 12 & 57,9 & 96,4 & 73,7 \\
\hline & Caiçara do Rio do Vento (Particular) & 8 & 0 & 5 & 99 & 0 & 0 & 22 & 36,2 & 17,2 & 27 & 3,5 & 1,8 & 1,2 & 3,4 & 70,8 & 4 & 63 & 75 & 31 & 0 \\
\hline & Caicó (Batalhão) & 0 & 12,5 & 52,6 & 7 & 31,2 & 15,5 & 37 & 89,5 & 59,5 & 43,5 & 29 & 24,7 & 13,8 & 10,4 & 27 & 170,4 & 5 & 116,5 & 30,4 & 6,9 \\
\hline & Caicó (Açude Mundo Novo - EMPARN) & 0 & 0 & 11 & 38,9 & 43,5 & 8,3 & 49,7 & 6,5 & 78,6 & 20,2 & 18 & 5,3 & 15,3 & 35 & 40,7 & 191 & 38,5 & 42,7 & 11 & 71,4 \\
\hline & Caicó (Açude Itans) & 0 & 4 & 33,1 & 55 & 29,6 & 0 & 22,8 & 21,8 & 67,2 & 44,6 & 53,1 & 16,8 & 12,8 & 18,2 & 55,5 & 153,4 & 48,2 & 63,7 & 31,5 & 100,9 \\
\hline & Caicó (EMATER) & 0 & 3 & 37 & 70,8 & 41,7 & 0 & 28 & 47,6 & 81,4 & 37 & 50,2 & 25,2 & 12,5 & 25,7 & 75,6 & 159,4 & 50,1 & 33,5 & 0 & 0 \\
\hline & Caicó (Laginhas) & 0 & 0 & 18,9 & 165,6 & 51,5 & 14,7 & 31,8 & 11,3 & 49,5 & 32,7 & 0 & 0 & 10 & 14,1 & 0 & 29,8 & 66,4 & 36,3 & 0 & 117,6 \\
\hline & Caicó (Penitenciária) & 0 & 0 & 26,8 & 40,2 & 17 & 0 & 11,5 & 25,4 & 53,3 & 35 & 2 & 11,8 & 29,2 & 20,7 & 20,2 & 179,6 & 3 & 72,6 & 13,2 & 55,3 \\
\hline & Campo Redondo (EMATER) & 7,6 & 10,6 & 66,2 & 139,5 & 6,8 & 0 & 19,1 & 58,7 & 76,5 & 50,9 & 0,8 & 15,8 & 29,3 & 0 & 62,8 & 18,7 & 193,6 & 72,4 & 37 & 97,5 \\
\hline & Campo Redondo (Polícia Rodoviária) & 4,7 & 15,2 & 98,6 & 132,9 & 11,2 & 0 & 19,5 & 48,2 & 40,8 & 33,8 & 21 & 25,4 & 8,6 & 13,1 & 48,2 & 52,9 & 246,1 & 83,3 & 42,5 & 89,4 \\
\hline
\end{tabular}




\begin{tabular}{|c|c|c|c|c|c|c|c|c|c|c|c|c|c|c|c|c|c|c|c|c|c|}
\hline 2011 & Estação & s1 & s2 & s3 & s4 & s5 & s6 & s7 & s8 & s9 & s10 & s11 & $\mathrm{s} 12$ & s13 & s14 & s15 & $s 16$ & s17 & s18 & s19 & s20 \\
\hline & Cerro Corá (EMATER) & 0 & 3,5 & 156,8 & 162,3 & 11 & 0 & 8,7 & 28,9 & 29,3 & 49 & 25,4 & 35 & 20,7 & 6,1 & 68,1 & 78,5 & 77 & 127 & 36,7 & 151,8 \\
\hline & Coronel Ezequiel (Particular) & 3 & 2 & 18 & 142 & 0 & 0 & 30 & 127 & 7,7 & 66,5 & 51 & 36 & 9 & 0 & 46 & 60,5 & 97,5 & 163 & 16 & 120 \\
\hline & Cruzeta (Base Física da EMPARN) & 3,9 & 0,8 & 26,1 & 84,7 & 1,2 & 0 & 46,3 & 44,2 & 71,1 & 14,2 & 27,6 & 24,5 & 31,5 & 1 & 35,6 & 168,1 & 6,5 & 97,6 & 17,2 & 98,4 \\
\hline & Currais Novos (CERCEL) & 0 & 13 & 20 & 102,5 & 0 & 0 & 0 & 0 & 70,7 & 21,5 & 45,9 & 38 & 0 & 0 & 72,4 & 59,1 & 45,3 & 41,2 & 9,6 & 71 \\
\hline & Fernando Pedroza (EMATER) & 0 & 0 & 28,5 & 149,1 & 0 & 0 & 24,5 & 12,6 & 69 & 0,5 & 8,1 & 30,9 & 18,2 & 64,1 & 95 & 10 & 184,7 & 26 & 13,4 & 65,9 \\
\hline & Florânia (INMET) & 4,5 & 7,9 & 15 & 77,4 & 0 & 0 & 27 & 13,1 & 32,1 & 2,4 & 54,2 & 21,1 & 16 & 15,1 & 81,1 & 62,4 & 84,1 & 20,1 & 19,8 & 59,6 \\
\hline & Florânia (Sítio Jucuri) & 2 & 5,2 & 14,2 & 71,6 & 0 & 0 & 18,3 & 39,7 & 52,1 & 30,1 & 67,7 & 34,4 & 21,3 & 19,8 & 127,2 & 47,5 & 64,2 & 22,8 & 29,6 & 110,6 \\
\hline & Ielmo Marinho (Prefeitura) & 30,1 & 16,2 & 14,2 & 7,6 & 29 & 0 & 12 & 25,5 & 7 & 11 & 9,2 & 0 & 22,5 & 2,2 & 108,5 & 20,5 & 19,7 & 68,7 & 50,8 & 63 \\
\hline & Itajá (EMATER) & 3,6 & 38,3 & 46 & 39,3 & 23,3 & 0 & 11,3 & 0 & 67 & 21,2 & 4,6 & 46 & 49,5 & 28,5 & 61,6 & 114,8 & 29,3 & 35,7 & 4,8 & 48,3 \\
\hline & Jaçanã (EMATER) & 0 & 63,7 & 56,4 & 86,5 & 0 & 0 & 37,2 & 60,5 & 1,7 & 44 & 38 & 113,6 & 11 & 21 & 42,7 & 56 & 120,1 & 176,1 & 22,5 & 48,4 \\
\hline & Janduís (EMATER) & 1 & 0 & 17,4 & 204 & 16,6 & 2,8 & 14 & 71,6 & 99 & 38,4 & 18 & 13,4 & 53,6 & 12,4 & 26,2 & 85,2 & 55,4 & 68,2 & 2 & 10,4 \\
\hline & Boa Saúde (EMATER) & 17,8 & 2,4 & 20,3 & 51,9 & 4,2 & 0 & 21,7 & 67,2 & 4,1 & 29,4 & 3,7 & 30 & 2,2 & 38,6 & 75,2 & 40,3 & 3,7 & 109,8 & 39,6 & 68,4 \\
\hline & Japi (Particular) & 0 & 0 & 115,8 & 43,4 & 0 & 23 & 42,4 & 25,4 & 16,6 & 0 & 21,8 & 10,2 & 12,4 & 0 & 58,8 & 0 & 21,2 & 19,2 & 44 & 59,6 \\
\hline & Jardim de Angicos (EMATER) & 27,8 & 12,2 & 14 & 164 & 4,5 & 0 & 32,6 & 30 & 15,1 & 27,7 & 20,5 & 8,5 & 0,3 & 0 & 35,7 & 6,7 & 88,2 & 76,9 & 38,5 & 84 \\
\hline & Lagoa de Pedras (Prefeitura) & 5,2 & 19,2 & 33,4 & 67 & 6 & 0 & 42,3 & 64,7 & 39,8 & 20,2 & 2,6 & 27,8 & 1,6 & 4,5 & 100,7 & 42,4 & 20,9 & 32,7 & 63,5 & 112,2 \\
\hline & Lagoa de Velhos (Delegacia) & 2,7 & 19,2 & 52,9 & 164,2 & 9 & 0 & 12,3 & 74,4 & 10,4 & 71,4 & 13,6 & 13 & 0 & 0 & 57 & 21,1 & 29,6 & 24,1 & 27,4 & 51,3 \\
\hline & Lagoa Nova (EMATER/Sítio Humaitá) & 1 & 1 & 51 & 122 & 0 & 0 & 3 & 4 & 34 & 19 & 41 & 15 & 1 & 0 & 64 & 89 & 58 & 81 & 18 & 112 \\
\hline & Lagoa Salgada (Delegacia) & 0 & 17,6 & 22,2 & 66 & 0 & 0 & 32,1 & 77 & 20 & 0 & 0 & 29,7 & 0 & 0 & 83,9 & 41 & 31,4 & 26,9 & 48,5 & 109,5 \\
\hline & Lajes (Prefeitura) & 1,5 & 11,5 & 19,3 & 103,3 & 0 & 0 & 11,5 & 54,7 & 5,5 & 0 & 0 & 0 & 21 & 3,8 & 36,3 & 28,2 & 105,9 & 129,6 & 13,4 & 74,3 \\
\hline & Lajes Pintadas (Prefeitura) & 0 & 8,1 & 33,9 & 89 & 0 & 0 & 30,1 & 18,2 & 70,2 & 24,8 & 40,4 & 30,4 & 3,9 & 5,8 & 42,5 & 16,3 & 185,1 & 34,6 & 32 & 73,2 \\
\hline & Messias Targino (Prefeitura) & 0 & 0 & 26,1 & 88,8 & 8,9 & 12,2 & 12,2 & 38,6 & 21,2 & 27,6 & 14,4 & 0 & 41,6 & 24 & 4 & 28 & 98,5 & 85,6 & 11,9 & 0 \\
\hline & Monte Alegre (EMATER) & 52,4 & 14 & 40 & 97 & 6 & 15 & 49 & 57 & 28 & 46 & 0 & 63 & 0 & 19 & 157 & 61 & 41 & 92,4 & 47,6 & 93 \\
\hline & Monte das Gameleiras (EMATER) & 18 & 0 & 49,2 & 44 & 0 & 0 & 0 & 49,8 & 5,8 & 22 & 0 & 86,9 & 20,8 & 0 & 102,9 & 25 & 94,5 & 68,7 & 28,7 & 58,7 \\
\hline & Paraú (Prefeitura) & 19 & 11 & 0 & 140 & 24 & 0 & 0 & 37 & 33 & 30 & 10 & 50 & 15 & 18 & 97 & 121 & 76,7 & 0 & 0 & 0 \\
\hline & Passa e Fica (Prefeitura) & 20,9 & 16,5 & 32,7 & 31,6 & 24,5 & 0 & 30,7 & 27,1 & 28,4 & 89 & 4,5 & 135,5 & 2,9 & 23,8 & 101,6 & 6,1 & 8,8 & 104,9 & 44,6 & 71,1 \\
\hline & Patu (Particular) & 6 & 2 & 64 & 153,4 & 43 & 5 & 32,4 & 36 & 73 & 27 & 41 & 9,6 & 19,4 & 7,2 & 68,4 & 43,4 & 128 & 83,4 & 37 & 30 \\
\hline & Santa Maria (Sindicato dos Trabalhadores Rurais) & 171 & 0 & 110 & 99 & 0 & 43 & 96 & 96 & 0 & 138 & 33 & 0 & 0 & 0 & 25 & 47 & 56 & 10 & 87 & 54 \\
\hline & Pedra Preta (EMATER) & 23 & 13 & 11 & 84 & 0 & 8 & 0 & 24 & 53 & 44 & 7 & 7 & 0 & 11 & 37 & 4 & 0 & 149 & 29 & 25 \\
\hline & Pedro Avelino (Particular) & 0 & 4 & 30 & 78,2 & 0 & 0 & 18 & 19,6 & 65,4 & 6,8 & 84,4 & 4,6 & 30,8 & 13,6 & 41,8 & 37,4 & 121,8 & 106,6 & 14,2 & 32 \\
\hline & Pedro Avelino (Base Física da EMPARN) & 0 & 8,6 & 37,7 & 76 & 0 & 19,3 & 22 & 48,5 & 58,9 & 93,6 & 20,9 & 17 & 0,6 & 10,3 & 20,8 & 21,3 & 42,5 & 85,1 & 13,3 & 89,5 \\
\hline & Riachuelo (EMATER) & 0 & 0 & 0 & 138 & 0 & 0 & 52,5 & 23,5 & 13,5 & 0 & 0 & 0 & 0 & 0 & 51 & 7,5 & 29,7 & 82 & 47 & 13 \\
\hline & Rui Barbosa (EMATER) & 30,9 & 8,8 & 7,9 & 206 & 13,5 & 0 & 39,5 & 57 & 0 & 107,3 & 17,5 & 7,9 & 0 & 0 & 95,9 & 19,4 & 45,3 & 55,9 & 53,5 & 91,4 \\
\hline & Santa Cruz (EMATER) & 7,7 & 18,3 & 61,7 & 197,9 & 0 & 0 & 78,5 & 37,1 & 11 & 22,9 & 7,5 & 19,4 & 14,5 & 8,1 & 36,8 & 5 & 40,8 & 50,9 & 22,2 & 37 \\
\hline & Santana do Matos (EMATER) & 0 & 0 & 122,1 & 103,2 & 17,3 & 0 & 48,5 & 63 & 96,7 & 52 & 71,2 & 47 & 0 & 36,1 & 106,5 & 118 & 89,7 & 66,5 & 15,2 & 123 \\
\hline & Santana do Matos (São José da Passagem) & 7 & 11,3 & 0 & 109,5 & 0 & 0 & 18,6 & 0 & 0 & 0 & 49 & 31 & 0 & 1,6 & 51 & 0 & 109,9 & 0 & 50,2 & 58,7 \\
\hline & São Bento do Trairi (Prefeitura) & 0 & 0 & 87 & 119,8 & 0 & 0 & 38 & 22 & 27,2 & 53,6 & 7 & 10 & 0 & 0 & 72,8 & 5 & 20 & 48,9 & 21,1 & 42,5 \\
\hline
\end{tabular}




\begin{tabular}{|c|c|c|c|c|c|c|c|c|c|c|c|c|c|c|c|c|c|c|c|c|c|}
\hline 2011 & Estação & s1 & s2 & s3 & s4 & s5 & s6 & s7 & s8 & s9 & s10 & s11 & s12 & s13 & s14 & s15 & s16 & s17 & s18 & s19 & s20 \\
\hline & São Paulo do Potengi (EMATER) & 0 & 0 & 100 & 45 & 25 & 0 & 42,9 & 71 & 10,2 & 41,1 & 37 & 25 & 0 & 8,8 & 75,3 & 15,2 & 7,7 & 40,1 & 57,2 & 78,2 \\
\hline & São Pedro (EMATER) & 32,2 & 9,5 & 34,2 & 56,4 & 0 & 0 & 17,7 & 23,6 & 20,8 & 55,7 & 16,8 & 17,6 & 0 & 0,8 & 85,7 & 14,4 & 17,8 & 33,4 & 49 & 46 \\
\hline & São Rafael (EMATER) & 12,3 & 11,5 & 12,6 & 102 & 81,6 & 0 & 11,5 & 93,8 & 96,8 & 19 & 28,2 & 27,5 & 25,7 & 44,5 & 143,3 & 58,6 & 48,5 & 79,1 & 24,1 & 119,6 \\
\hline & São Tomé (EMATER) & 0 & 0 & 18 & 175 & 0 & 0 & 26 & 19 & 30 & 25 & 5 & 0 & 0 & 50 & 33 & 17 & 212 & 33 & 27 & 46 \\
\hline & São Vicente (EMATER - Ex Particular) & 0 & 0 & 42,6 & 125,4 & 0 & 0 & 16,6 & 63 & 75,3 & 29,2 & 44,8 & 57,8 & 0 & 32,2 & 149,6 & 141 & 43 & 28,5 & 81,5 & 49,5 \\
\hline & Senador Eloi de Souza (Particular) & 29 & 23,2 & 23,3 & 84 & 0 & 0 & 0 & 0 & 27,4 & 56,1 & 0 & 0 & 27,6 & 0 & 78,9 & 16,2 & 0 & 41,1 & 38,8 & 74,2 \\
\hline & Serra de São Bento (EMATER) & 34,4 & 12,6 & 0 & 78,2 & 21,6 & 0 & 17,9 & 30 & 11 & 66,8 & 1,4 & 119,5 & 9,2 & 5,5 & 115 & 8,6 & 80,1 & 55,1 & 57 & 47 \\
\hline & Serrinha (EMATER) & 23,4 & 16,5 & 39,4 & 68,2 & 1,1 & 0 & 55,1 & 66,7 & 2,8 & 51,2 & 8,1 & 33 & 2 & 21,5 & 134,7 & 28,2 & 5,6 & 94,6 & 30,8 & 91 \\
\hline & Sítio Novo (Prefeitura) & 24,5 & 8,5 & 24 & 200 & 11 & 0 & 11 & 51,5 & 10,5 & 42 & 0 & 20 & 0 & 14 & 65 & 16,5 & 62 & 16,5 & 27 & 41 \\
\hline & Tangará (EMATER) & 18 & 15,5 & 20,5 & 81,5 & 14 & 0 & 40 & 34 & 23,5 & 25 & 4 & 25 & 0 & 9 & 73 & 10 & 7 & 98,5 & 25,5 & 38,5 \\
\hline & Tangará (Açude Trairi) & 11,7 & 3,7 & 22,9 & 88,2 & 4,9 & 0 & 81,8 & 55,9 & 16,5 & 21 & 27,1 & 13,8 & 8,1 & 3,5 & 59,5 & 0 & 8 & 45,1 & 29 & 53,3 \\
\hline & Triunfo Potiguar (Chá Velha/Serra J. Vale) & 0 & 0 & 0 & 0 & 0 & 0 & 54 & 48,1 & 111 & 28,3 & 0 & 44,7 & 46 & 72,2 & 45,8 & 46,6 & 92,8 & 30,3 & 76 & 54,4 \\
\hline & Alagoa Nova & 7,3 & 14,5 & 0 & 73,3 & 5 & 0 & 35,5 & 57,6 & 18,6 & 20,8 & 36 & 33,2 & 20,8 & 23,6 & 48,3 & 86,7 & 20,8 & 141,7 & 25,9 & 109,4 \\
\hline & Barra de Santana & 10,5 & 26 & 19,3 & 16,2 & 0 & 0 & 25,1 & 5 & 62,9 & 6,7 & 7,7 & 0 & 0 & 2,1 & 18,5 & 39,6 & 111,6 & 116,6 & 22,1 & 72,3 \\
\hline & Boa Vista & 0 & 22,6 & 17,8 & 40,8 & 0 & 0 & 25,6 & 53 & 44 & 26,9 & 2 & 0 & 0 & 20,2 & 30 & 23 & 36 & 80,8 & 11,8 & 90,2 \\
\hline & Boqueirão/Açude Boqueirão & 10,5 & 13,5 & 0,9 & 12,6 & 17,1 & 0 & 0 & 2,4 & 36,5 & 15,6 & 0,3 & 0 & 0 & 25,2 & 6,1 & 34,6 & 143,4 & 59,3 & 7,5 & 36,3 \\
\hline & Cabaceiras & 0 & 16 & 48,3 & 25,1 & 0 & 0 & 0 & 0 & 51,7 & 46 & 0 & 0 & 0 & 11,7 & 8 & 19 & 47,2 & 96,8 & 3,4 & 29,1 \\
\hline & Campina Grande/EMBRAPA & 0,6 & 13 & 0,6 & 37,9 & 3,7 & 0 & 81,2 & 47,8 & 115,4 & 6,1 & 11,1 & 10,2 & 2,9 & 17,1 & 28,4 & 47,2 & 92,2 & 191,9 & 30,3 & 115,2 \\
\hline & Campina Grande/INSA & 7,6 & 7,7 & 0 & 13,7 & 0 & 0 & 6,4 & 17,2 & 85,2 & 11,6 & 3,6 & 0 & 0 & 16,2 & 24,3 & 45 & 72,3 & 103,8 & 5,7 & 154,6 \\
\hline & Campina Grande/Santa Terezinha & 2 & 0,5 & 0 & 33,3 & 4,9 & 0 & 9,1 & 8,5 & 33,9 & 24,9 & 6,7 & 3,5 & 4,2 & 33,6 & 19,1 & 39,7 & 82,6 & 164 & 26,1 & 89,2 \\
\hline & Campina Grande/São José da Mata & 0 & 10,6 & 0 & 32,2 & 1,9 & 0 & 71,3 & 18,9 & 15,8 & 0 & 11,2 & 2,1 & 0 & 10,3 & 24 & 58,6 & 105,9 & 103,3 & 31,3 & 56 \\
\hline & Cubati & 8,1 & 5,3 & 9,2 & 60,5 & 0,6 & 0 & 30,3 & 0 & 29,6 & 1,3 & 33 & 24,7 & 0 & 0 & 34,9 & 50 & 61,7 & 116,6 & 4,9 & 78,9 \\
\hline & Lagoa Seca & 1,6 & 16,9 & 0,8 & 47,6 & 6,4 & 0 & 52,6 & 29,7 & 10,1 & 21 & 33,6 & 17,1 & 30,6 & 29,8 & 47,4 & 83,8 & 10 & 226,2 & 58,8 & 186,8 \\
\hline & Matinhas & 4,5 & 41,3 & 15 & 41,1 & 0,3 & 0 & 25,7 & 51,2 & 29,2 & 10,5 & 41,7 & 37,2 & 40,7 & 72,2 & 34,8 & 46,7 & 15,2 & 120 & 30,5 & 78,7 \\
\hline & Olivedos & 2 & 2,4 & 26,5 & 45,7 & 1,1 & 0 & 41,2 & 3,9 & 44,6 & 3,3 & 7,7 & 1,7 & 0 & 2,2 & 19 & 18,4 & 23 & 123,7 & 10,1 & 85,7 \\
\hline & Pedra Lavrada & 12,4 & 0 & 11 & 62,7 & 0 & 0 & 33,7 & 112,8 & 70,8 & 15,7 & 30,7 & 66,6 & 10,4 & 27,7 & 17,9 & 44 & 58,3 & 70,3 & 4,6 & 42 \\
\hline & Pocinhos & 0 & 14,6 & 36,4 & 24,1 & 0 & 0 & 34 & 24,5 & 39,8 & 0,5 & 4,6 & 0 & 0 & 11,2 & 8,7 & 39,4 & 12,5 & 127,5 & 11,8 & 59 \\
\hline & Seridó & 15,8 & 8,1 & 3,5 & 46,3 & 0 & 0 & 11,1 & 65 & 52,1 & 0 & 61,3 & 44,3 & 0 & 33,4 & 27,5 & 54,2 & 16,1 & 87,1 & 3,1 & 60,2 \\
\hline & Soledade & 12,2 & 36,2 & 10,5 & 49,4 & 0 & 0 & 17,2 & 23,2 & 63,3 & 13,6 & 21,3 & 29,5 & 5,3 & 19,5 & 4,4 & 25,3 & 80,2 & 95,7 & 10,9 & 35,2 \\
\hline
\end{tabular}

\begin{tabular}{|c|c|c|c|c|c|c|c|c|c|c|c|c|c|c|c|c|c|c|c|c|c|}
\hline 2011 & Estação & s21 & $\mathbf{s 2 2}$ & $\mathbf{s} 23$ & s24 & $\mathbf{s} 25$ & $s 26$ & s27 & s28 & s29 & s30 & s31 & s32 & s33 & s34 & s35 & s36 & s37 & s38 & s39 & s40 \\
\hline & Acari (Particular) & 0 & 0 & 0 & 10,4 & 3,4 & 0 & 0 & 0 & 0 & 0 & 0 & 0 & 0 & 0 & 0 & 0 & 0 & 0 & 0 & 0 \\
\hline & Assu (Particular) & 3,9 & 0,5 & 0 & 8,6 & 22,8 & 5,8 & 24,4 & 42,7 & 56 & 0,3 & 20,8 & 0,2 & 0 & 1,4 & 0 & 0 & 0 & 0 & 0 & 0 \\
\hline & Assu (EMATER/Sítio Casa Forte) & 0 & 0 & 0,5 & 16,3 & 19,2 & 9 & 22,2 & 45,4 & 48,9 & 3,1 & 35,6 & 0 & 0,7 & 3,3 & 0 & 0 & 0 & 0 & 0 & 0 \\
\hline & Afonso Bezerra (EMATER) & 0 & 0 & 0 & 0 & 10 & 6 & 14 & 0 & 52 & 0 & 0 & 0 & 0 & 0 & 0 & 0 & 0 & 0 & 0 & 0 \\
\hline & Almino Afonso (Particular - Ex Sítio Milagres) & 8 & 4,3 & 0 & 10,2 & 0 & 0 & 0 & 0 & 0 & 0 & 0 & 0 & 0 & 0 & 0 & 0 & 0 & 0 & 0 & 0 \\
\hline
\end{tabular}




\begin{tabular}{|c|c|c|c|c|c|c|c|c|c|c|c|c|c|c|c|c|c|c|c|c|c|}
\hline 2011 & Estação & s21 & s22 & s23 & $s 24$ & s25 & $s 26$ & s27 & s28 & $\mathbf{s 2 9}$ & s30 & s31 & s32 & s33 & s34 & s35 & s36 & s37 & s38 & s39 & s40 \\
\hline & Angicos (Prefeitura) & 62,9 & 0 & 0 & 5 & 4,5 & 0 & 4 & 0 & 0 & 0 & 0 & 0 & 0 & 0 & 0 & 0 & 0 & 0 & 0 & 0 \\
\hline & Campo Grande (Particular) & 3 & 0 & 0 & 4,7 & 3,7 & 0 & 0 & 11,2 & 72,7 & 0 & 0 & 0 & 0 & 0 & 0 & 0 & 0 & 0 & 0 & 0 \\
\hline & Campo Grande (Particular 2) & 0 & 0 & 4 & 0 & 5,2 & 0 & 2,3 & 87,7 & 0 & 2,3 & 0 & 0 & 0 & 6 & 0 & 0 & 0 & 0 & 0 & 0 \\
\hline & Barcelona (Particular) & 10,7 & 3,3 & 23,4 & 21,5 & 1,5 & 20,8 & 28,3 & 54,6 & 9,3 & 0 & 7,5 & 1 & 15,5 & 31,2 & 0 & 0 & 0 & 0 & 0 & 0 \\
\hline & Bodó (EMATER/TRF P/Delegacia) & 1,3 & 2 & 3 & 1,8 & 11,5 & 0 & 7,2 & 44,9 & 1,2 & 0,5 & 0 & 0 & 0 & 0 & 0 & 0 & 0 & 0 & 0 & 0 \\
\hline & Bom Jesus (Particular) & 15,6 & 85,5 & 9,6 & 30,5 & 20,2 & 9,6 & 24,3 & 100,6 & 3,2 & 0 & 17,1 & 2,6 & 11,4 & 28,7 & 0 & 0 & 2,5 & 0 & 0 & 0 \\
\hline & Caiçara do Rio do Vento (Particular) & 0 & 42,3 & 0 & 0 & 0 & 36,5 & 5,4 & 30 & 0 & 0 & 0 & 0 & 0 & 0 & 0 & 0 & 0 & 0 & 0 & 0 \\
\hline & Caicó (Batalhão) & 0 & 0 & 0 & 34 & 0 & 0 & 0 & 35 & 0 & 0 & 3 & 0 & 0 & 0 & 0 & 0 & 0 & 0 & 0 & 0 \\
\hline & Caicó (Açude Mundo Novo - EMPARN) & 0 & 0 & 0 & 20 & 8 & 9,5 & 0 & 11,2 & 35 & 0 & 0 & 0 & 0 & 0 & 0 & 0 & 0 & 0 & 0 & 0 \\
\hline & Caicó (Açude Itans) & 0,4 & 3,2 & 0 & 6,5 & 0 & 9,3 & 1,1 & 8 & 26,8 & 7,8 & 2,2 & 0 & 0 & 1,2 & 0 & 0 & 0 & 0 & 0 & 0 \\
\hline & Caicó (EMATER) & 0 & 0 & 0 & 0 & 3,5 & 10 & 0 & 10 & 31 & 0 & 0 & 0 & 0 & 0 & 0 & 0 & 0 & 0 & 0 & 0 \\
\hline & Caicó (Laginhas) & 0 & 0 & 0 & 0 & 0 & 0 & 0 & 0 & 0 & 0 & 0 & 0 & 0 & 0 & 0 & 0 & 0 & 0 & 0 & 0 \\
\hline & Caicó (Penitenciária) & 0,6 & 1 & 0 & 34 & 0 & 0 & 0 & 0 & 0 & 0 & 0 & 0 & 0 & 0 & 0 & 0 & 0 & 0 & 0 & 0 \\
\hline & Campo Redondo (EMATER) & 15,3 & 6,5 & 0,9 & 11,4 & 4,2 & 7,2 & 34,3 & 45,9 & 37,2 & 7,8 & 7,5 & 4,1 & 8,9 & 22,7 & 0 & 0 & 0 & 0 & 0 & 0 \\
\hline & Campo Redondo (Polícia Rodoviária) & 11,8 & 0 & 0 & 21,7 & 8 & 5,3 & 10,2 & 85,7 & 32,4 & 9,2 & 4,2 & 2,3 & 0 & 11,8 & 0 & 0 & 0 & 0 & 0 & 0 \\
\hline & Cerro Corá (EMATER) & 0 & 2,6 & 0 & 0 & 7,8 & 5,5 & 0 & 7,4 & 0 & 0 & 0 & 0 & 0 & 0 & 0 & 0 & 0 & 0 & 0 & 0 \\
\hline & Coronel Ezequiel (Particular) & 0 & 15 & 0 & 10 & 15,5 & 6,5 & 60,5 & 29 & 33 & 0 & 13,5 & 0 & 0 & 10,5 & 0 & 0 & 0 & 0 & 0 & 0 \\
\hline & Cruzeta (Base Física da EMPARN) & 0,5 & 0,8 & 0 & 7 & 2,7 & 19,5 & 2 & 15,8 & 54,8 & 0 & 2,9 & 0,8 & 0 & 2,4 & 0 & 0 & 0 & 0 & 0 & 0 \\
\hline & Currais Novos (CERCEL) & 0 & 0 & 0 & 0 & 2,5 & 0 & 0 & 0 & 55 & 0 & 0 & 0 & 0 & 0 & 0 & 0 & 0 & 0 & 0 & 0 \\
\hline & Fernando Pedroza (EMATER) & 0 & 0 & 0 & 0 & 0 & 0 & 0 & 0 & 0,5 & 8 & 0 & 0 & 0 & 0 & 0 & 0 & 0 & 0 & 0 & 0 \\
\hline & Florânia (INMET) & 0 & 0 & 0 & 0 & 0 & 0 & 1,4 & 0 & 0 & 0 & 0 & 0 & 0 & 0 & 0 & 0 & 0 & 0 & 0 & 0 \\
\hline & Florânia (Sítio Jucuri) & 0 & 0 & 0 & 5 & 0 & 5 & 5 & 10,2 & 51,4 & 0 & 0 & 0 & 0 & 0 & 0 & 0 & 0 & 0 & 0 & 0 \\
\hline & Ielmo Marinho (Prefeitura) & 31,2 & 1,5 & 68,8 & 28 & 15 & 63,2 & 31,2 & 31 & 53 & 0 & 5,7 & 0 & 21 & 16,7 & 0 & 0 & 2 & 0 & 0 & 0 \\
\hline & Itajá (EMATER) & 3,2 & 0 & 1,7 & 1,8 & 27,5 & 0 & 48,4 & 27 & 63 & 0 & 0 & 0 & 0 & 0 & 0 & 0 & 0 & 0 & 0 & 0 \\
\hline & Jaçanã (EMATER) & 3,6 & 6 & 0 & 0 & 0 & 2 & 26,1 & 49,8 & 45,4 & 1,3 & 23,5 & 0 & 0 & 10 & 3,7 & 0 & 0 & 2 & 0 & 0 \\
\hline & Janduís (EMATER) & 0 & 0 & 0 & 10 & 2,4 & 0 & 22,2 & 21,4 & 76,5 & 0 & 6 & 0 & 0 & 2 & 0 & 0 & 0 & 0 & 0 & 0 \\
\hline & Boa Saúde (EMATER) & 22,8 & 59,6 & 28,5 & 18,6 & 0 & 22,7 & 37,5 & 56,7 & 2,3 & 2 & 3,9 & 0 & 29,7 & 24,1 & 0 & 0 & 4 & 0 & 0 & 0 \\
\hline & Japi (Particular) & 0 & 9,4 & 0 & 0 & 0 & 0 & 53,2 & 41,7 & 49,8 & 0 & 15,4 & 36,8 & 0 & 4,2 & 0 & 36,8 & 0 & 0 & 0 & 0 \\
\hline & Jardim de Angicos (EMATER) & 7,1 & 32,5 & 3,6 & 10,2 & 13,5 & 11 & 28,6 & 88 & 0 & 0 & 0 & 0 & 0 & 0 & 0 & 0 & 0 & 0 & 0 & 0 \\
\hline & Lagoa de Pedras (Prefeitura) & 18,3 & 65,8 & 16,8 & 39,2 & 9,6 & 46,6 & 36,4 & 77,1 & 6,4 & 6,7 & 3,3 & 1,4 & 23,4 & 19,4 & 1,3 & 2,3 & 7,9 & 0 & 0 & 0 \\
\hline & Lagoa de Velhos (Delegacia) & 9,1 & 1,5 & 29,4 & 31,4 & 4,4 & 24,7 & 30,9 & 42,2 & 7,5 & 0 & 14,7 & 2,9 & 14,1 & 2,8 & 0 & 0 & 0 & 0 & 0 & 0 \\
\hline & Lagoa Nova (EMATER/Sítio Humaitá) & 3 & 6 & 0 & 7 & 24 & 1 & 0 & 3 & 0 & 0 & 0 & 0 & 0 & 0 & 0 & 0 & 0 & 0 & 0 & 0 \\
\hline & Lagoa Salgada (Delegacia) & 19 & 64,3 & 0 & 37,9 & 10,9 & 50,8 & 20,2 & 82,6 & 5,5 & 0 & 9 & 0 & 24,5 & 32,6 & 0 & 0 & 0 & 0 & 0 & 0 \\
\hline & Lajes (Prefeitura) & 7,8 & 0 & 0 & 7,1 & 11 & 8,5 & 1,5 & 23 & 10 & 0 & 0 & 0 & 0 & 12,5 & 0 & 0 & 0 & 0 & 0 & 0 \\
\hline & Lajes Pintadas (Prefeitura) & 7,1 & 3,4 & 0 & 3 & 17,1 & 13,9 & 35,1 & 56,2 & 33,8 & 0 & 20,7 & 0 & 4,1 & 24,9 & 0 & 0 & 0 & 0 & 0 & 0 \\
\hline & Messias Targino (Prefeitura) & 8,4 & 0 & 0 & 0 & 6 & 0 & 2,9 & 64,1 & 0 & 0 & 0 & 0 & 0 & 0 & 0 & 0 & 0,4 & 0 & 0 & 0 \\
\hline
\end{tabular}




\begin{tabular}{|c|c|c|c|c|c|c|c|c|c|c|c|c|c|c|c|c|c|c|c|c|c|}
\hline 2011 & Estação & s21 & s22 & s23 & s24 & s25 & s26 & s27 & s28 & s29 & s30 & s31 & s32 & s33 & s34 & s35 & s36 & s37 & s38 & s39 & s40 \\
\hline & Monte Alegre (EMATER) & 18 & 40 & 50 & 22 & 10 & 88 & 39 & 134,6 & 2 & 2 & 7 & 3 & 37 & 47 & 12 & 0 & 8 & 0 & 0 & 0 \\
\hline & Monte das Gameleiras (EMATER) & 8,3 & 3,7 & 12,3 & 7 & 6,7 & 8,5 & 14,6 & 44,3 & 35 & 11,3 & 14,5 & 8,1 & 8,1 & 13,2 & 0 & 0 & 0 & 0 & 0 & 0 \\
\hline & Paraú (Prefeitura) & 0 & 0 & 0 & 2,5 & 2,5 & 0 & 0 & 114 & 0 & 0 & 0 & 0 & 0 & 0 & 0 & 0 & 0 & 0 & 0 & 0 \\
\hline & Passa e Fica (Prefeitura) & 12,1 & 3,5 & 27,8 & 9 & 4,9 & 13,2 & 19,4 & 51,2 & 47,8 & 8 & 12,2 & 3,8 & 10,6 & 22,2 & 0 & 1,7 & 0,8 & 0 & 0 & 0 \\
\hline & Patu (Particular) & 4 & 0 & 1 & 2 & 2 & 2 & 15 & 24 & 43 & 0 & 0 & 0 & 0 & 7 & 0 & 0 & 0 & 0 & 0 & 0 \\
\hline & Santa Maria (Sindicato dos Trabalhadores Rurais) & 15 & 9 & 5 & 2,5 & 10 & 0 & 13 & 18 & 1,5 & 1,5 & 0 & 0 & 0 & 0 & 0 & 0 & 0 & 0 & 0 & 0 \\
\hline & Pedra Preta (EMATER) & 0 & 8 & 5 & 19 & 0 & 11 & 19 & 51 & 0 & 0 & 0 & 8 & 0 & 14 & 0 & 0 & 0 & 0 & 0 & 0 \\
\hline & Pedro Avelino (Particular) & 0 & 0 & 0 & 1,8 & 0 & 4,2 & 0 & 19,8 & 8 & 0 & 0 & 0 & 0 & 7,5 & 0 & 0 & 0 & 0 & 0 & 0 \\
\hline & Pedro Avelino (Base Física da EMPARN) & 5,7 & 8,1 & 0,6 & 9,8 & 2,6 & 8,5 & 22,1 & 77,2 & 0 & 0 & 0 & 0 & 0 & 13 & 0 & 2,7 & 0 & 0 & 0 & 0 \\
\hline & Riachuelo (EMATER) & 3 & 0 & 64,5 & 24 & 5 & 32 & 22 & 105,5 & 0 & 4 & 9 & 0 & 15 & 0 & 0 & 0 & 0 & 0 & 0 & 0 \\
\hline & Rui Barbosa (EMATER) & 20,8 & 17,3 & 11,1 & 26,4 & 0 & 21,2 & 37,3 & 47 & 0 & 0 & 0 & 0 & 18,5 & 12,1 & 0 & 0 & 0 & 0 & 0 & 0 \\
\hline & Santa Cruz (EMATER) & 6,8 & 9,1 & 2,6 & 5,2 & 13 & 4,9 & 18,3 & 27,9 & 41 & 3,9 & 8 & 4,3 & 2,9 & 16,7 & 0 & 0 & 0 & 0 & 0 & 0 \\
\hline & Santana do Matos (EMATER) & 0 & 0 & 0 & 67 & 20 & 0 & 0 & 0 & 68,4 & 0 & 0 & 0 & 0 & 0 & 0 & 0 & 0 & 0 & 0 & 0 \\
\hline & Santana do Matos (São José da Passagem) & 20 & 0 & 0 & 0 & 0 & 0 & 0 & 0 & 0 & 0 & 0 & 0 & 0 & 0 & 0 & 0 & 0 & 0 & 0 & 0 \\
\hline & São Bento do Trairi (Prefeitura) & 5,8 & 3 & 0 & 0 & 21,5 & 1,8 & 26 & 44,4 & 32,1 & 5 & 4 & 0 & 0 & 9,9 & 0 & 0 & 0 & 0 & 0 & 0 \\
\hline & São Paulo do Potengi (EMATER) & 9,8 & 69 & 9,2 & 37,2 & 3 & 29 & 40,6 & 88,2 & 17 & 2 & 3,6 & 0,8 & 11,4 & 25,2 & 0 & 0,8 & 0 & 0 & 0 & 0 \\
\hline & São Pedro (EMATER) & 25,6 & 86 & 11,9 & 36,1 & 11,4 & 44,5 & 39,9 & 101 & 3,7 & 4,8 & 3,4 & 4,7 & 12,9 & 23,5 & 4,9 & 0 & 1,8 & 0 & 0 & 0 \\
\hline & São Rafael (EMATER) & 1 & 0 & 0,4 & 0 & 24 & 1,5 & 7,9 & 45,1 & 24,8 & 0 & 4,1 & 0 & 0 & 3,3 & 0 & 0 & 0 & 0 & 0 & 0 \\
\hline & São Tomé (EMATER) & 21 & 0 & 13 & 11 & 0 & 8 & 0 & 35 & 30 & 0 & 0 & 0 & 0 & 0 & 0 & 0 & 0 & 0 & 0 & 0 \\
\hline & São Vicente (EMATER - Ex Particular) & 0 & 2,7 & 0 & 0 & 9 & 0 & 2 & 59,8 & 4,3 & 0 & 0 & 0 & 0 & 0 & 0 & 0 & 0 & 0 & 0 & 0 \\
\hline & Senador Eloi de Souza (Particular) & 5,4 & 42,2 & 15,5 & 41 & 0 & 33,8 & 18,1 & 43,6 & 0 & 0 & 11,5 & 0 & 14,9 & 14,8 & 0 & 0 & 0 & 0 & 0 & 0 \\
\hline & Serra de São Bento (EMATER) & 15,7 & 17,7 & 8,2 & 15,3 & 2,7 & 15,4 & 22,7 & 45,3 & 55 & 8 & 14,4 & 3,5 & 6,7 & 26,6 & 0,3 & 3,7 & 1,4 & 0 & 0 & 0,7 \\
\hline & Serrinha (EMATER) & 24,8 & 42,2 & 30,9 & 33,3 & 12,5 & 21,2 & 53,5 & 79,3 & 14,6 & 1,6 & 6,3 & 3,6 & 28,7 & 24,8 & 0 & 2,3 & 3,1 & 0 & 0 & 0,7 \\
\hline & Sítio Novo (Prefeitura) & 12 & 22,5 & 0 & 5 & 1,5 & 19,5 & 24 & 45 & 15 & 5 & 15 & 0 & 16,5 & 21 & 0 & 0 & 0 & 0 & 0 & 0 \\
\hline & Tangará (EMATER) & 9,5 & 25 & 0 & 7 & 0 & 10 & 52 & 43 & 20 & 1 & 9 & 0 & 8 & 19 & 0 & 1 & 2,5 & 0 & 0 & 0 \\
\hline & Tangará (Açude Trairi) & 2,4 & 14,5 & 3,2 & 10,6 & 0 & 9,9 & 12,7 & 59,2 & 17,7 & 0 & 11,5 & 0 & 11,2 & 14,8 & 0 & 0 & 0 & 0 & 0 & 0 \\
\hline & Triunfo Potiguar (Chá Velha/Serra J. Vale) & 17,7 & 0 & 23,3 & 11,9 & 21,8 & 0 & 0 & 21,5 & 113,2 & 0 & 0 & 0 & 0 & 14 & 0 & 0 & 0 & 0 & 0 & 0 \\
\hline & Alagoa Nova & 7,1 & 25,5 & 8 & 42,6 & 20,2 & 40,1 & 69,1 & 82,6 & 90,4 & 7,2 & 35,2 & 12,2 & 4,6 & 54,3 & 2,6 & 0 & 2,3 & 0 & 0 & 0 \\
\hline & Barra de Santana & 7,8 & 6,5 & 3,7 & 26,4 & 18,3 & 11,2 & 21,6 & 22 & 36,5 & 3,3 & 19,8 & 0,4 & 0,9 & 52,3 & 1,1 & 0 & 0 & 0 & 0 & 0 \\
\hline & Boa Vista & 0 & 12,4 & 0 & 33,4 & 23,8 & 6 & 23,2 & 12,8 & 75,2 & 5,6 & 12,6 & 0 & 0 & 28,6 & 0 & 0 & 0 & 0 & 0 & 0 \\
\hline & Boqueirão/Açude Boqueirão & 6,2 & 5,1 & 0,9 & 26,3 & 24,7 & 4,7 & 19,9 & 20,6 & 35,5 & 9,3 & 26,3 & 0 & 0 & 55,6 & 0 & 4,6 & 0,4 & 0 & 0,4 & 0 \\
\hline & Cabaceiras & 2,6 & 6,5 & 3,1 & 29,8 & 3,7 & 11,7 & 15,8 & 20 & 28 & 4,5 & 22,6 & 0 & 0 & 33,1 & 0,6 & 0,5 & 0 & 0,5 & 0 & 0 \\
\hline & Campina Grande/EMBRAPA & 6,7 & 32 & 8,8 & 61,4 & 21 & 22,3 & 94,8 & 91,5 & 121,6 & 12,4 & 28 & 8 & 11,1 & 64,1 & 1,8 & 0,4 & 1,6 & 2,1 & 0 & 0,5 \\
\hline & Campina Grande/INSA & 6,9 & 13,2 & 9 & 31,9 & 15,2 & 16,6 & 63 & 34,4 & 98,3 & 8,6 & 22 & 7,9 & 3,5 & 60,7 & 0 & 1,7 & 0 & 0 & 3,1 & 0,8 \\
\hline & Campina Grande/Santa Terezinha & 7,9 & 23,8 & 11,5 & 53,1 & 90,8 & 14,8 & 85,3 & 83,7 & 101 & 10,6 & 8 & 0 & 3,3 & 0,3 & 0 & 0 & 1,9 & 1,7 & 0 & 0,3 \\
\hline & Campina Grande/São José da Mata & 3,9 & 22,1 & 6 & 59 & 13,1 & 41,6 & 11,6 & 0 & 21,2 & 49,9 & 0 & 0 & 5,4 & 0 & 0 & 0 & 0 & 3 & 0 & 0 \\
\hline
\end{tabular}




\begin{tabular}{|c|c|c|c|c|c|c|c|c|c|c|c|c|c|c|c|c|c|c|c|c|c|c|}
\hline \multirow[t]{9}{*}{2011} & Estação & s21 & $s 22$ & $s 23$ & s24 & $s 25$ & $s 26$ & s27 & s28 & \multicolumn{2}{|c|}{$s 29$} & s30 & s31 & \multirow{2}{*}{$\frac{\mathbf{s} 32}{0}$} & \multirow{2}{*}{$\frac{\text { s33 }}{0}$} & \multirow{2}{*}{$\begin{array}{r}\mathbf{s 3 4} \\
18,1\end{array}$} & \multirow{2}{*}{$\begin{array}{c}\text { s35 } \\
0\end{array}$} & \multirow{2}{*}{$\begin{array}{c}\text { s36 } \\
0\end{array}$} & \multirow{2}{*}{$\begin{array}{c}\text { s37 } \\
0\end{array}$} & \multirow{2}{*}{$\begin{array}{c}\text { s38 } \\
0\end{array}$} & \multirow{2}{*}{$\begin{array}{c}\text { s39 } \\
0\end{array}$} & \multirow{2}{*}{$\frac{s 40}{0}$} \\
\hline & Cubati & 2,3 & 2,8 & 0 & 14,8 & 0 & 21,6 & 22,8 & 43 & & 6,9 & 1,2 & 5,6 & & & & & & & & & \\
\hline & Lagoa Seca & 11,1 & 44,5 & 17,5 & 90,6 & 29,5 & 44,4 & 102 & 142 & $.5 \quad 14$ & 2,8 & 27,9 & 39,6 & 25 & 18,4 & 84,3 & 0,3 & 1,9 & 0 & 5,3 & 0 & 0 \\
\hline & Matinhas & 8,2 & 45,5 & 22,4 & 66,2 & 29,6 & 71 & 66 & 123 & & 8,2 & 6,7 & 34,3 & 20,7 & 10,7 & 58,4 & 7,5 & 0,3 & 0 & 0 & 0 & 0 \\
\hline & Olivedos & 5,8 & 4,1 & 1,8 & 22,4 & 3,7 & 26,2 & 19,3 & 25 & & 1,2 & 4,8 & 0 & 3,2 & 1,1 & 46 & 0 & 0 & 0 & 0 & 0 & 0 \\
\hline & Pedra Lavrada & 0 & 0 & 0 & 3,5 & 0 & 17,3 & 10,9 & 18 & & 2,9 & 0 & 5,4 & 0 & 0 & 14,7 & 0 & 0 & 0 & 0 & 0 & 0 \\
\hline & Pocinhos & 0 & 5,7 & 4,4 & 31,5 & 18,3 & 23,9 & 23,7 & 28 & & 5,2 & 4,4 & 7,3 & 1,2 & 4,1 & 38 & 0,5 & 0 & 1,2 & 0,3 & 0 & 0,1 \\
\hline & Seridó & 9 & 3,1 & 0 & 13 & 0 & 16 & 12 & 17 & & 8,5 & 0 & 0 & 0 & 0 & 10,2 & 0 & 0 & 0 & 0 & 0 & 0 \\
\hline & Soledade & 0 & 5,8 & 0 & 22 & 7,3 & 13,9 & 14,9 & 27 & & 6,6 & 6,6 & 5,6 & 0 & 1,2 & 20,9 & 0 & 0 & 0 & 0 & 0 & 0 \\
\hline 2011 & Estação & s41 & s42 & s43 & s44 & s45 & s46 & s47 & s48 & s49 & s50 & s51 & \multicolumn{2}{|c|}{$s 52$} & & & & & & & & \\
\hline & Acari (Particular) & 0 & 0 & 0 & 0 & 0 & 0 & 0 & 0 & 0 & 0 & 0 & \multicolumn{2}{|c|}{0} & & & & & & & & \\
\hline & Assu (Particular) & 0 & 4,5 & 0 & 5 & 0 & 0 & 0 & 0 & 0 & 0 & 18 & \multicolumn{2}{|l|}{0} & & & & & & & & \\
\hline & Assu (EMATER/Sítio Casa Forte) & 0 & 5,7 & 0 & 3,3 & 0 & 0 & 0 & 0 & 0 & 0 & 14,7 & \multicolumn{2}{|l|}{0} & & & & & & & & \\
\hline & Afonso Bezerra (EMATER) & 0 & 0 & 0 & 0 & 0 & 0 & 0 & 0 & 0 & 0 & 0 & \multicolumn{2}{|l|}{0} & & & & & & & & \\
\hline & Almino Afonso (Particular - Ex Sítio Milagres) & 0 & 0 & 0 & 0 & 0 & 0 & 0 & 0 & 0 & 0 & 0 & \multicolumn{2}{|l|}{0} & & & & & & & & \\
\hline & Angicos (Prefeitura) & 0 & 21 & 0 & 0 & 0 & 0 & 0 & 0 & 0 & 0 & 0 & 0 & & & & & & & & & \\
\hline & Campo Grande (Particular) & 0 & 0 & 0 & 0 & 0 & 0 & 0 & 0 & 0 & 0 & 0 & 0 & & & & & & & & & \\
\hline & Campo Grande (Particular 2) & 0 & 0 & 0 & 7,2 & 3,8 & 2 & 0 & 0 & 0 & 0 & 0 & 0 & & & & & & & & & \\
\hline & Barcelona (Particular) & 0 & 0 & 0 & 5,8 & 5,9 & 0 & 0 & 0 & 0 & 3,5 & 25,5 & 1,9 & & & & & & & & & \\
\hline & Bodó (EMATER/TRF P/Delegacia) & 0 & 0 & 0 & 0 & 0 & 0 & 0 & 0 & 0 & 0 & 0 & 0 & & & & & & & & & \\
\hline & Bom Jesus (Particular) & 0 & 1,7 & 0 & 0 & 0 & 0 & 0 & 0 & 3 & 2,3 & 1,5 & 2,8 & & & & & & & & & \\
\hline & Caiçara do Rio do Vento (Particular) & 0 & 0 & 0 & 0 & 0 & 0 & 0 & 0 & 0 & 0 & 0 & 0 & & & & & & & & & \\
\hline & Caicó (Batalhão) & 0 & 0 & 0 & 0 & 0 & 0 & 0 & 0 & 0 & 0 & 0 & 0 & & & & & & & & & \\
\hline & Caicó (Açude Mundo Novo - EMPARN) & 0 & 0 & 0 & 0 & 0 & 0 & 0 & 0 & 0 & 0 & 0 & 0 & & & & & & & & & \\
\hline & Caicó (Açude Itans) & 0 & 2,7 & 0 & 0 & 0 & 0 & 0 & 0 & 0 & 0 & 0 & 0 & & & & & & & & & \\
\hline & Caicó (EMATER) & 0 & 0 & 0 & 0 & 0 & 0 & 0 & 0 & 0 & 0 & 0 & 0 & & & & & & & & & \\
\hline & Caicó (Laginhas) & 0 & 0 & 0 & 0 & 0 & 0 & 0 & 0 & 0 & 0 & 0 & 0 & & & & & & & & & \\
\hline & Caicó (Penitenciária) & 0 & 0 & 0 & 0 & 0 & 0 & 0 & 0 & 0 & 0 & 0 & 0 & & & & & & & & & \\
\hline & Campo Redondo (EMATER) & 2,3 & 4,2 & 0 & 3,6 & 1,9 & 3 & 0 & 0 & 0 & 0 & 0 & 0 & & & & & & & & & \\
\hline & Campo Redondo (Polícia Rodoviária) & 0 & 0 & 0 & 0 & 0 & 0 & 0 & 0 & 0 & 0 & 7,5 & 4,3 & & & & & & & & & \\
\hline & Cerro Corá (EMATER) & 0 & 0 & 0 & 0 & 0 & 0 & 0 & 0 & 0 & 0 & 0 & 0 & & & & & & & & & \\
\hline & Coronel Ezequiel (Particular) & 0 & 0 & 0 & 0 & 0 & 0 & 0 & 0 & 0 & 0 & 0 & 0 & & & & & & & & & \\
\hline & Cruzeta (Base Física da EMPARN) & 0 & 2,2 & 0 & 7,2 & 0 & 0 & 0 & 0 & 0 & 0 & 0 & 3,2 & & & & & & & & & \\
\hline & Currais Novos (CERCEL) & 0 & 0 & 0 & 0 & 0 & 0 & 0 & 0 & 0 & 0 & 0 & 0 & & & & & & & & & \\
\hline & Fernando Pedroza (EMATER) & 0 & 0 & 0 & 0 & 0 & 0 & 0 & 0 & 0 & 0 & 0 & 0 & & & & & & & & & \\
\hline & Florânia (INMET) & 0 & 0 & 0 & 0 & 0 & 0 & 0 & 0 & 0 & 0 & 0 & 0 & & & & & & & & & \\
\hline
\end{tabular}




\begin{tabular}{|c|c|c|c|c|c|c|c|c|c|c|c|c|c|}
\hline 2011 & Estação & s41 & $s 42$ & s43 & s44 & s45 & s46 & s47 & s48 & s49 & s50 & s51 & s52 \\
\hline & Florânia (Sítio Jucuri) & 0 & 0 & 0 & 0 & 0 & 0 & 0 & 0 & 0 & 0 & 0 & 0 \\
\hline & lelmo Marinho (Prefeitura) & 0 & 3,2 & 0 & 0 & 0 & 2,7 & 0 & 0 & 0 & 2 & 2,5 & 2 \\
\hline & Itajá (EMATER) & 0 & 0 & 0 & 0 & 0 & 0 & 0 & 0 & 0 & 0 & 25,5 & 0 \\
\hline & Jaçanã (EMATER) & 0 & 8,7 & 0 & 0 & 5,8 & 2,9 & 0 & 0 & 0 & 0 & 1,8 & 2,4 \\
\hline & Janduís (EMATER) & 0 & 3 & 0 & 20 & 0 & 25,2 & 0 & 0 & 0 & 0 & 0 & 0 \\
\hline & Boa Saúde (EMATER) & 0 & 0 & 0 & 7,6 & 5,3 & 4,3 & 0 & 0 & 0 & 0 & 0 & 10,1 \\
\hline & Japi (Particular) & 0 & 0 & 0 & 0 & 0 & 0 & 0 & 0 & 0 & 0 & 11,2 & 0 \\
\hline & Jardim de Angicos (EMATER) & 0 & 0 & 0 & 0 & 0 & 0 & 0 & 0 & 0 & 0 & 0 & 0 \\
\hline & Lagoa de Pedras (Prefeitura) & 0 & 5,6 & 0 & 3,4 & 8 & 2,4 & 2,3 & 1,8 & 2,9 & 2,6 & 0 & 8,1 \\
\hline & Lagoa de Velhos (Delegacia) & 0 & 0 & 0 & 0 & 0 & 0 & 0 & 0 & 0 & 0 & 0 & 0 \\
\hline & Lagoa Nova (EMATER/Sítio Humaitá) & 0 & 0 & 0 & 0 & 0 & 0 & 0 & 0 & 0 & 0 & 0 & 0 \\
\hline & Lagoa Salgada (Delegacia) & 0 & 0 & 0 & 0 & 0 & 0 & 0 & 0 & 0 & 0 & 0 & 0 \\
\hline & Lajes (Prefeitura) & 0 & 0 & 0 & 0 & 0 & 0 & 0 & 0 & 0 & 0 & 0 & 0 \\
\hline & Lajes Pintadas (Prefeitura) & 8,2 & 5,9 & 0 & 4,9 & 14,3 & 0 & 0 & 0 & 0 & 2,5 & 0 & 5,3 \\
\hline & Messias Targino (Prefeitura) & 0,4 & 0 & 0 & 0 & 0 & 0 & 0 & 0 & 0 & 0 & 0 & 0 \\
\hline & Monte Alegre (EMATER) & 0 & 0 & 0 & 2 & 3 & 5 & 1 & 0 & 0 & 0 & 0 & 0 \\
\hline & Monte das Gameleiras (EMATER) & 6 & 5,7 & 0 & 7,5 & 0 & 2,3 & 0 & 1,5 & 0 & 3,1 & 12 & 2 \\
\hline & Paraú (Prefeitura) & 0 & 30 & 0 & 0 & 0 & 0 & 0 & 0 & 0 & 0 & 0 & 0 \\
\hline & Passa e Fica (Prefeitura) & 2,6 & 7,8 & 0 & 4,5 & 1,9 & 7,3 & 0 & 0,5 & 0 & 2,9 & 22,7 & 0 \\
\hline & Patu (Particular) & 3 & 36 & 0 & 63,6 & 5 & 6 & 0 & 0 & 3 & 0 & 0 & 0 \\
\hline & Santa Maria (Sindicato dos Trabalhadores Rurais) & 0 & 0 & 0 & 0 & 0 & 0 & 0 & 0 & 0 & 0 & 0 & 0 \\
\hline & Pedra Preta (EMATER) & 0 & 0 & 0 & 0 & 0 & 0 & 0 & 0 & 0 & 0 & 0 & 0 \\
\hline & Pedro Avelino (Particular) & 0 & 25 & 0 & 0 & 0 & 0 & 0 & 0 & 0 & 0 & 0 & 0 \\
\hline & Pedro Avelino (Base Física da EMPARN) & 0 & 0 & 0 & 0 & 0 & 0 & 0 & 0 & 0 & 0 & 0 & 13 \\
\hline & Riachuelo (EMATER) & 0 & 0 & 0 & 0 & 0 & 0 & 0 & 0 & 0 & 0 & 0 & 0 \\
\hline & Rui Barbosa (EMATER) & 0 & 0 & 0 & 0 & 0 & 0 & 0 & 0 & 0 & 0 & 0 & 0 \\
\hline & Santa Cruz (EMATER) & 0 & 0 & 0 & 0 & 0 & 2,2 & 12,3 & 0 & 0 & 0 & 0 & 0 \\
\hline & Santana do Matos (EMATER) & 0 & 0 & 0 & 0 & 0 & 0 & 0 & 0 & 0 & 0 & 0 & 0 \\
\hline & Santana do Matos (São José da Passagem) & 0 & 0 & 0 & 0 & 0 & 0 & 0 & 0 & 0 & 0 & 0 & 0 \\
\hline & São Bento do Trairi (Prefeitura) & 0 & 0 & 0 & 0 & 0 & 0 & 0 & 0 & 0 & 0 & 0 & 0 \\
\hline & São Paulo do Potengi (EMATER) & 0,7 & 4 & 0 & 3 & 6,1 & 0 & 0 & 0 & 0 & 0 & 0 & 0 \\
\hline & São Pedro (EMATER) & 0 & 0 & 0 & 0 & 0 & 0 & 0 & 0 & 0 & 0 & 0 & 0 \\
\hline & São Rafael (EMATER) & 0 & 30,3 & 0 & 7 & 0 & 0 & 0 & 0 & 0 & 0 & 0 & 4,4 \\
\hline & São Tomé (EMATER) & 0 & 0 & 0 & 0 & 0 & 0 & 0 & 0 & 0 & 0 & 0 & 0 \\
\hline & São Vicente (EMATER - Ex Particular) & 0 & 6 & 0 & 0 & 0 & 0 & 0 & 0 & 0 & 0 & 0 & 0 \\
\hline & Senador Eloi de Souza (Particular) & 0 & 0 & 0 & 0 & 0 & 0 & 0 & 0 & 0 & 0 & 0 & 0 \\
\hline
\end{tabular}




\begin{tabular}{|c|c|c|c|c|c|c|c|c|c|c|c|c|c|c|c|c|c|c|c|c|c|}
\hline \multirow{24}{*}{2011} & \multicolumn{2}{|l|}{ Estação } & s41 & $1 \mathrm{~s} 42$ & $2 s 43$ & s44 & s45 & s46 & s47 & s48 & s49 & $\mathrm{s} 50 \mathrm{~s}$ & s51 & s52 & & & & & & & \\
\hline & \multicolumn{2}{|l|}{ Serra de São Bento (EMATER) } & 1,7 & 9,3 & 30 & 7,9 & 0 & 6,7 & 3,7 & 2 & 0 & 4,2 & 26,7 & $\overline{1,4}$ & & & & & & & \\
\hline & \multicolumn{2}{|l|}{ Serrinha (EMATER) } & 0 & 2,7 & 5,6 & 28,2 & 24 & 0 & 9,1 & 0 & 0 & 0 & 0 & 0 & & & & & & & \\
\hline & \multicolumn{2}{|l|}{ Sítio Novo (Prefeitura) } & 0 & 0 & 0 & 0 & 0 & 0 & 0 & 0 & 0 & 11 & 15 & 15 & & & & & & & \\
\hline & \multicolumn{2}{|l|}{ Tangará (EMATER) } & 0 & 3 & 0 & 0 & 9 & 1,5 & 0 & 0 & 0 & 0 & 0 & 0 & & & & & & & \\
\hline & \multicolumn{2}{|l|}{ Tangará (Açude Trairi) } & 0 & 9,4 & 0 & 0 & 0 & 0 & 0 & 0 & 0 & 0 & 32,7 & 0 & & & & & & & \\
\hline & \multicolumn{2}{|l|}{ Triunfo Potiguar (Chá Velha/Serra J. Vale) } & 18,5 & 0 & 0 & 0 & 0 & 18,9 & 0 & 0 & 0 & 0 & 8,2 & 0 & & & & & & & \\
\hline & \multicolumn{2}{|l|}{ Alagoa Nova } & 0 & 0 & 0 & 0 & 4 & 8 & 0 & 0 & 5,8 & 0 & 10,1 & 6 & & & & & & & \\
\hline & \multicolumn{2}{|l|}{ Barra de Santana } & 0 & 0 & 0 & 0 & 5,7 & 11,3 & 0 & 1,4 & 0 & 11,3 & 3,2 & 0 & & & & & & & \\
\hline & \multicolumn{2}{|l|}{ Boa Vista } & 0 & 0 & 0 & 0 & 3,2 & 20,4 & 0 & 0 & 0 & 0 & 0 & 0 & & & & & & & \\
\hline & \multicolumn{2}{|l|}{ Boqueirão/Açude Boqueirão } & 0,2 & 0,6 & 0 & 0,3 & 1 & 23,1 & 0 & 0,3 & 0 & 0 & 1,9 & 0 & & & & & & & \\
\hline & \multicolumn{2}{|l|}{ Cabaceiras } & 0 & 0 & 0 & 0 & 0 & 11,2 & 0 & 0 & 0 & 0 & 0 & 0 & & & & & & & \\
\hline & \multicolumn{2}{|l|}{ Campina Grande/EMBRAPA } & 0,4 & 6,5 & 0 & 0 & 5,6 & 17,1 & 0 & 2,4 & 8,6 & 0 & 2,2 & 8,7 & & & & & & & \\
\hline & \multicolumn{2}{|l|}{ Campina Grande/INSA } & 0 & 1 & 0 & 0 & 0 & 0 & 0 & 0 & 1,7 & 0 & 0 & 3,1 & & & & & & & \\
\hline & \multicolumn{2}{|l|}{ Campina Grande/Santa Terezinha } & 0 & 6,5 & 0 & 0 & 4,4 & 2,3 & 0 & 0 & 8,8 & 0 & 0 & 6 & & & & & & & \\
\hline & \multicolumn{2}{|l|}{ Campina Grande/São José da Mata } & 13 & 3,4 & 0 & 0 & 0 & 0 & 0 & & 27 & & 7,6 & 20,6 & & & & & & & \\
\hline & \multicolumn{2}{|l|}{ Cubati } & 0 & 0 & 0 & 0 & 0 & 0 & 0 & 0 & 0 & 0 & 0 & 0 & & & & & & & \\
\hline & \multicolumn{2}{|l|}{ Lagoa Seca } & 1,8 & 10,9 & 0 & 2 & 9,8 & 17 & 0 & 0,8 & 10,3 & 0 & 0 & 6,1 & & & & & & & \\
\hline & \multicolumn{2}{|l|}{ Matinhas } & 0 & 34,7 & 0 & 2,8 & 10 & 16,2 & 0 & 0 & 14 & 0 & 0 & 0 & & & & & & & \\
\hline & Olivedos & & 0 & 0 & 0 & 0 & 0 & 5,3 & 0 & 0 & 0 & 0 & 0 & 0 & & & & & & & \\
\hline & Pedra Lavrada & & 0 & 0 & 0 & 0 & 0 & 5,2 & 0 & 0 & 0 & 0 & 0 & 0 & & & & & & & \\
\hline & Pocinhos & & 0 & 1,1 & 0 & 0 & 0,3 & 5,6 & 0 & 0 & 0 & 0 & 0 & 0 & & & & & & & \\
\hline & Seridó & & 0 & 0 & 0 & 0 & 0 & 0 & 0 & 0 & 0 & 0 & 0 & 0 & & & & & & & \\
\hline & Soledade & & 0 & 0 & 0 & 0 & 0 & 0 & 0 & 0 & 0 & 0 & 0 & 0 & & & & & & & \\
\hline 2012 & Estação & s1 & s2 & s3 & s4 & s5 & s6 & s7 & s8 & s9 & $s 10$ & $s 11$ & s12 & s13 & s14 & s15 & s16 & $s 17$ & $\mathrm{~s} 18$ & $\mathbf{s} 19$ & $s 20$ \\
\hline & Acari (Particular) & 0 & 0 & 0 & 18,5 & 0 & 0 & 7,5 & 43,3 & 3,7 & 0 & 0 & 0 & 0 & 0 & 0 & 0 & 0 & 0 & 0 & 0 \\
\hline & Assu (Particular) & 0 & 0,9 & 10,7 & 21,4 & 0 & 14,2 & 13,8 & 39,5 & 23,9 & 0 & 47 & 8 & 17,5 & 1,3 & 21,9 & 2,7 & 0 & 0 & 0 & 0 \\
\hline & Assu (EMATER/Sítio Casa Forte) & 0 & 0 & 1 & 7,3 & 0 & 19,4 & 11,5 & 35,6 & 21 & 0 & 53,5 & 3,7 & 46,1 & 1,4 & 10,6 & 2,2 & 0 & 0 & 0 & 0 \\
\hline & Angicos (Prefeitura) & 0 & 0 & 16 & 30,5 & 6 & 6 & 55,2 & 73 & 59,5 & 50 & 0 & 0 & 19 & 0 & 0 & 16,5 & 0 & 0 & 0 & 0 \\
\hline & Campo Grande (Particular) & 0 & 0 & 34,6 & 121,8 & 0 & 1,8 & 70 & 75,8 & 14,2 & 211,6 & 0 & 34,6 & 6,3 & 0 & 11,4 & 12,2 & 0 & 0 & 0 & 0 \\
\hline & Campo Grande (Particular 2) & 0 & 169,5 & 0 & 0 & 0 & 140,5 & 0 & 0 & 15 & 12 & 0 & 23 & 19,4 & 4 & 15 & 10 & 7,4 & 0 & 0 & 0 \\
\hline & Barcelona (Particular) & 0 & 30,5 & 0 & 0 & 0 & 0 & 31 & 52 & 18,1 & 0 & 10,4 & 0 & 0 & 0 & 0 & 1,5 & 0 & 0 & 0 & 0 \\
\hline & Bodó (EMATER/TRF P/Delegacia) & 0 & 0 & 0 & 0 & 0 & 0 & 0 & 58,3 & 0 & 0 & 0 & 0 & 0 & 0 & 0 & 0 & 0 & 0 & 0 & 0 \\
\hline & Bom Jesus (Particular) & 0 & 14 & 0 & 0 & 3,2 & 0 & 10,8 & 74,9 & 9,8 & 4,2 & 21,8 & 0 & 0 & 10,2 & 0 & 0 & 0 & 0 & 0 & 11,2 \\
\hline & Caiçara do Rio do Vento (Particular) & 0 & 0 & 0 & 0 & 0 & 0 & 0 & 37,5 & 8,2 & 0 & 0 & 0 & 0 & 0 & 0 & 0 & 0 & 0 & 0 & 0 \\
\hline & Caicó (Batalhão) & 0 & 0 & 57 & 0 & 0 & 0 & 68,5 & 0 & 0 & 0 & 0 & 0 & 6,5 & 0 & 0 & 0 & 0 & 0 & 0 & 0 \\
\hline
\end{tabular}




\begin{tabular}{|c|c|c|c|c|c|c|c|c|c|c|c|c|c|c|c|c|c|c|c|c|c|}
\hline 2012 & Estação & s1 & s2 & s3 & s4 & s5 & s6 & s7 & s8 & s9 & s10 & s11 & s12 & s13 & s14 & s15 & s16 & s17 & s18 & $\mathbf{s 1 9}$ & s20 \\
\hline & Caicó (Açude Mundo Novo - EMPARN) & 0 & 0 & 34 & 3 & 0 & 0 & 21,4 & 49,5 & 0 & 9,4 & 7,5 & 3,5 & 3 & 0 & 0 & 0 & 0 & 0 & 3,5 & 0 \\
\hline & Caicó (Açude Itans) & 0 & 0 & 17,8 & 40,3 & 7,4 & 1,2 & 17,3 & 32,9 & 0 & 1,6 & 6,5 & 1,3 & 0,3 & 0 & 0 & 2,4 & 0 & 0 & 0 & 0 \\
\hline & Caicó (EMATER) & 0 & 0 & 15,1 & 90,6 & 0 & 0 & 38,5 & 70,7 & 4,8 & 0 & 10,4 & 0 & 0 & 0 & 0 & 0 & 55,3 & 0 & 0 & 0 \\
\hline & Campo Redondo (EMATER) & 0 & 3,4 & 0 & 6,2 & 0 & 0 & 1,1 & 27,2 & 3,1 & 0 & 3,6 & 12,5 & 0 & 8,8 & 0 & 6,7 & 0 & 0 & 0 & 0,3 \\
\hline & Campo Redondo (Polícia Rodoviária) & 0 & 0 & 0 & 11 & 0 & 0 & 0 & 17,5 & 0 & 0 & 0 & 17,5 & 0 & 1,7 & 0 & 0 & 0 & 0 & 0 & 0 \\
\hline & Coronel Ezequiel (Particular) & 0 & 0 & 0 & 2 & 0 & 0 & 2 & 48 & 3 & 0 & 0 & 0 & 20 & 0 & 0 & 0 & 0 & 0 & 0 & 0 \\
\hline & Cruzeta (Base Física da EMPARN) & 0 & 11,9 & 31,7 & 3,9 & 0,8 & 0 & 13,4 & 83,8 & 5,9 & 3,3 & 15,5 & 0 & 28,9 & 0,3 & 0 & 3,2 & 0,3 & 0 & 2,8 & 0 \\
\hline & Currais Novos (CERCEL) & 0 & 0 & 5,8 & 8 & 0 & 0 & 7,7 & 30,4 & 0 & 0 & 0 & 0 & 0 & 0 & 0 & 0 & 0 & 0 & 0 & 0 \\
\hline & Fernando Pedroza (EMATER) & 0 & 0 & 16,8 & 34,1 & 0 & 8 & 22,8 & 70,8 & 83,3 & 0 & 20,1 & 0 & 0 & 1,3 & 0 & 7 & 0 & 0 & 0 & 0 \\
\hline & Florânia (INMET) & 8,8 & 0 & 0 & 0 & 8,8 & 0 & 4,9 & 26 & 15 & 17,1 & 2,4 & 13,6 & 5,5 & 1 & 1,4 & 1,6 & 0 & 0 & 0,2 & 0 \\
\hline & Florânia (Sítio Jucuri) & 15,4 & 0 & 12,8 & 45,8 & 0 & 0 & 46 & 57,6 & 12,5 & 14,3 & 11,2 & 10,8 & 24,8 & 0 & 0 & 4,2 & 0 & 0 & 0 & 0 \\
\hline & Ielmo Marinho (Prefeitura) & 0 & 19,7 & 0 & 0 & 0 & 0 & 3,6 & 185 & 3 & 0 & 34,2 & 0 & 0 & 0 & 13,5 & 7,3 & 10,5 & 0 & 0 & 0 \\
\hline & Itajá (EMATER) & 0 & 0 & 3,6 & 58,3 & 0 & 0 & 30,7 & 54,7 & 30 & 0 & 4,9 & 10,3 & 7,8 & 1,4 & 17,7 & 0 & 0 & 0 & 0 & 0 \\
\hline & Jaçanã (EMATER) & 0 & 0 & 0 & 26,5 & 0 & 0 & 25,2 & 73,5 & 24,3 & 0 & 5,5 & 0 & 9 & 0 & 0 & 0 & 0 & 0 & 0 & 0 \\
\hline & Janduís (EMATER) & 1 & 0 & 13 & 38 & 8,4 & 0 & 22,2 & 104 & 9,2 & 71 & 25 & 4,6 & 55,2 & 3,6 & 5,8 & 0 & 0 & 0 & 0 & 0 \\
\hline & Boa Saúde (EMATER) & 0 & 22,5 & 0 & 13,6 & 0 & 0 & 48,4 & 89,2 & 5,9 & 3 & 10,8 & 0 & 0 & 2,5 & 0 & 0 & 0 & 0 & 0 & 0 \\
\hline & Japi (Particular) & 0 & 0 & 0 & 35,6 & 0 & 0 & 0 & 12,6 & 0 & 0 & 0 & 11,8 & 0 & 0 & 0 & 0 & 0 & 0 & 0 & 0 \\
\hline & Jardim de Angicos (EMATER) & 0 & 0 & 13,9 & 0 & 0 & 0 & 0 & 10 & 0 & 0 & 11,2 & 0 & 0 & 4,5 & 0 & 0 & 0 & 0 & 0 & 0 \\
\hline & Lagoa de Pedras (Prefeitura) & 0 & 8,1 & 3,7 & 17 & 0 & 3,3 & 18,2 & 60,4 & 0 & 3,7 & 14,1 & 0 & 0 & 31,2 & 0 & 0 & 0 & 0 & 0 & 13,6 \\
\hline & Lagoa de Velhos (Delegacia) & 0 & 31,5 & 0 & 0 & 0 & 0 & 6,7 & 34,4 & 27,2 & 0 & 9,7 & 0 & 0 & 0 & 0 & 0 & 0 & 0 & 0 & 0 \\
\hline & Lagoa Salgada (Delegacia) & 0 & 0 & 5,2 & 8,5 & 4,8 & 0 & 15,9 & 44,6 & 0 & 0 & 20,6 & 0 & 8,5 & 0 & 0 & 0 & 0 & 0 & 0 & 0 \\
\hline & Lajes (Prefeitura) & 0 & 0 & 0 & 18,9 & 0 & 0 & 22 & 52 & 0 & 0 & 0 & 0 & 0 & 0 & 0 & 6 & 5,5 & 0 & 0 & 0 \\
\hline & Lajes Pintadas (Prefeitura) & 0 & 0 & 2 & 3,4 & 0 & 0 & 8,8 & 29 & 4,7 & 0 & 15,7 & 6,4 & 0 & 0 & 0 & 0 & 0 & 0 & 0 & 0 \\
\hline & Messias Targino (Prefeitura) & 0 & 0 & 30 & 29,2 & 1 & 12,2 & 72,6 & 5 & 0 & 15,1 & 0 & 40,6 & 79 & 0 & 0 & 0 & 0 & 0 & 0 & 0 \\
\hline & Monte Alegre (EMATER) & 0 & 15 & 13,6 & 19,4 & 2 & 1 & 87,2 & 40 & 5 & 10 & 39 & 4 & 0 & 54,8 & 2,4 & 15,4 & 0 & 0 & 0 & 13 \\
\hline & Monte das Gameleiras (EMATER) & 0 & 5,3 & 1 & 26,7 & 0 & 0 & 25,3 & 36,4 & 0 & 0 & 12 & 13 & 0 & 0 & 0 & 0 & 0 & 0 & 0 & 0 \\
\hline & Paraú (Prefeitura) & 0 & 0 & 5 & 90 & 0 & 0 & 0 & 61 & 27 & 0 & 0 & 0 & 38 & 0 & 24 & 0 & 0 & 0 & 0 & 0 \\
\hline & Passa e Fica (Prefeitura) & 1,7 & 0 & 18,8 & 35,1 & 0 & 0 & 29,9 & 33 & 2,6 & 0 & 8,5 & 0 & 3 & 0 & 2,5 & 0 & 0,6 & 0,4 & 0 & 0 \\
\hline & Patu (Particular) & 0 & 3,2 & 60 & 95,4 & 0 & 7 & 47,8 & 74 & 34,6 & 30,6 & 0 & 7 & 97 & 0 & 0 & 0 & 4 & 0 & 0 & 0 \\
\hline & Pedro Avelino (Particular) & 20 & 0 & 9,4 & 3 & 0 & 0 & 36 & 16 & 1 & 0 & 4,4 & 0 & 2,4 & 0 & 2,2 & 26,6 & 0 & 0 & 0 & 0 \\
\hline & Pedro Avelino (Base Física da EMPARN) & 24,7 & 0 & 0 & 0 & 0 & 0 & 98,9 & 54,3 & 12,1 & 20,2 & 0 & 4,5 & 13 & 5,4 & 0 & 1,9 & 6,8 & 0 & 0 & 2,7 \\
\hline & Rui Barbosa (EMATER) & 0 & 24 & 0 & 0 & 0 & 0 & 11,8 & 34,3 & 0 & 0 & 0 & 0 & 0 & 0 & 0 & 0 & 0 & 0 & 0 & 0 \\
\hline & Santa Cruz (EMATER) & 0 & 0 & 0 & 0 & 0 & 0 & 0,3 & 41,5 & 1,1 & 0 & 9,1 & 14,1 & 0 & 0 & 0 & 0 & 0 & 0 & 0 & 0 \\
\hline & Santana do Matos (EMATER) & 0 & 10 & 11,2 & 35 & 0 & 0 & 6 & 12,6 & 0 & 0 & 0,6 & 0 & 0,5 & 0 & 0 & 0 & 0 & 30 & 0 & 0 \\
\hline & São Bento do Trairi (Prefeitura) & 0 & 0 & 0 & 4,8 & 0 & 0 & 3,8 & 47,5 & 23,8 & 0 & 3,8 & 0 & 0 & 0 & 0 & 0 & 4 & 0 & 0 & 0 \\
\hline & São Pedro (EMATER) & 0 & 16,8 & 0,7 & 4,7 & 0 & 0 & 17,1 & 102 & 0 & 1,6 & 18,5 & 0 & 0 & 13,5 & 0 & 0 & 0 & 0 & 0 & 0 \\
\hline
\end{tabular}




\begin{tabular}{|c|c|c|c|c|c|c|c|c|c|c|c|c|c|c|c|c|c|c|c|c|c|}
\hline 2012 & Estação & s1 & s2 & s3 & s4 & s5 & s6 & s7 & s8 & s9 & s10 & s11 & s12 & s13 & s14 & s15 & s16 & s17 & s18 & $\mathbf{s 1 9}$ & s20 \\
\hline & São Rafael (EMATER) & 0 & 0 & 14,3 & 55 & 0 & 0 & 13,9 & 4,7 & 11,5 & 0 & 3,2 & 6,8 & 3,4 & 5,6 & 4,6 & 12,6 & 0 & 0 & 0 & 0 \\
\hline & São Vicente (EMATER - Ex Particular) & 0 & 0 & 0 & 16,5 & 14 & 0 & 134,5 & 19 & 0 & 6,2 & 0 & 0 & 0 & 0 & 0 & 7 & 0 & 0 & 0 & 0 \\
\hline & Senador Eloi de Souza (Particular) & 0 & 15,7 & 4,7 & 4,2 & 0,8 & 0 & 25,2 & 41,1 & 26 & 0 & 0 & 0 & 0 & 15,3 & 0 & 0 & 0 & 0 & 0 & 0 \\
\hline & Serra de São Bento (EMATER) & 0 & 6,6 & 2,8 & 36,5 & 0 & 0 & 26,7 & 44,5 & 1,8 & 0 & 14,9 & 1,9 & 0 & 0 & 0 & 0 & 0 & 0 & 0 & 0 \\
\hline & Serrinha (EMATER) & 0 & 24,8 & 0 & 9,5 & 11,5 & 1,5 & 39,2 & 128,1 & 4,1 & 3,5 & 15,7 & 0 & 0 & 0 & 2,1 & 0 & 0,8 & 0 & 0 & 0 \\
\hline & Sítio Novo (Prefeitura) & 0 & 5 & 0 & 0 & 0 & 0 & 5 & 29,5 & 7 & 0 & 27 & 0 & 0 & 7 & 0 & 0 & 0 & 0 & 0 & 0 \\
\hline & Tangará (EMATER) & 0 & 3,5 & 0 & 2 & 0 & 0 & 0 & 112 & 0 & 0 & 6,5 & 0 & 0 & 2 & 0 & 2 & 0 & 0 & 0 & 0 \\
\hline & Tangará (Açude Trairi) & 0 & 0 & 0 & 2,7 & 0 & 0 & 0 & 119,4 & 4,8 & 0 & 0 & 0 & 0 & 0 & 0 & 0 & 0 & 0 & 0 & 0 \\
\hline & Triunfo Potiguar (Prefeitura) & 0 & 0 & 42 & 103,5 & 0 & 0 & 0 & 0 & 15 & 28,5 & 27,3 & 0 & 2,4 & 0 & 0 & 8 & 7,4 & 0 & 0 & 0 \\
\hline & Alagoa Nova & 0 & 9,1 & 0 & 56,4 & 16,2 & 0 & 25,5 & 69,3 & 0 & 0 & 62,8 & 20,2 & 4,8 & 50 & 0 & 0 & 0 & 0 & 7,7 & 0 \\
\hline & Barra de Santana & 0 & 2,7 & 11,4 & 22,8 & 0 & 0 & 7,1 & 58,6 & 0 & 0 & 0 & 0 & 3,1 & 0 & 0 & 0 & 0 & 1,5 & 0 & 0 \\
\hline & Boa Vista & 0 & 0 & 0 & 15 & 0 & 0 & 7,5 & 62,9 & 0 & 0 & 0 & 0 & 0 & 0 & 0 & 0 & 0 & 0 & 0 & 0 \\
\hline & Boqueirão/Açude Boqueirão & 0 & 1,7 & 26,8 & 41,1 & 0 & 0 & 14,2 & 70,5 & 0 & 0 & 0 & 0 & 0 & 0 & 0 & 0 & 0 & 0,8 & 0 & 0 \\
\hline & Cabaceiras & 0 & 0 & 4 & 32,9 & 0 & 0 & 11,3 & 53,5 & 0 & 25 & 2,3 & 0 & 6,7 & 1,7 & 0 & 0 & 0 & 1,1 & 0 & 0 \\
\hline & Campina Grande/EMBRAPA & 0 & 6,1 & 5,1 & 53,2 & 4,2 & 4,5 & 24,4 & 63,6 & 7 & 0,4 & 10,3 & 0 & 0,8 & 0,6 & 1,9 & 2,5 & 0 & 1,9 & 0,4 & 0,5 \\
\hline & Campina Grande/INSA & 0 & 3,2 & 3,3 & 19,5 & 0 & 4,1 & 59,5 & 14,2 & 4 & 0 & 4,2 & 0 & 6,4 & 0 & 0 & 0 & 0 & 1,5 & 0 & 18,7 \\
\hline & Campina Grande/Santa Terezinha & 0 & 4,4 & 0 & 62,3 & 5,3 & 3,5 & 36,3 & 72,8 & 8,9 & 0 & 1,9 & 0 & 0 & 0 & 6,8 & 0 & 0 & 0,9 & 0 & 0 \\
\hline & Campina Grande/São José da Mata & 0 & 4,9 & 0 & 47,3 & 0 & 0 & 19,4 & 55,6 & 4,8 & 0 & 3,1 & 0 & 0 & 0 & 0 & 0 & 0 & 0 & 0 & 0 \\
\hline & Caturité & 0 & 0 & 0 & 16,1 & 0 & 0 & 7,9 & 89,2 & 0 & 2 & 0,7 & 0 & 0 & 0,8 & 2,1 & 0 & 0 & 0,5 & 0 & 0 \\
\hline & Caturité/Fazenda Campo de Emas & 0 & 0 & 16 & 0 & 0 & 0 & & 10 & 0 & 0 & 0 & 0 & 0 & 0 & 0 & 0 & 0 & 0 & 0 & 0 \\
\hline & Cubati & 0 & 0 & 0 & 12,5 & 6,5 & 0 & 5 & 36 & 0 & 0 & 6,2 & 0 & 1,8 & 0 & 0 & 0 & 0 & 0 & 0 & 0 \\
\hline & Lagoa Seca & 0 & 16,1 & 2,1 & 79,2 & 2,1 & 0 & 27,7 & 66 & 6,7 & 0 & 5,3 & 0 & 0 & 0 & 8 & 0 & 1,9 & 6,3 & 0 & 0,5 \\
\hline & Matinhas & 0 & 4,5 & 0 & 50,2 & 16,2 & 0 & 30,3 & 56,7 & 5,3 & 0 & 39,4 & 11,7 & 0,3 & 6 & 1,5 & 1,3 & 0 & 5,4 & 4,1 & 0 \\
\hline & Olivedos & 0 & 0 & 0 & 8,7 & 1,9 & 0 & 0 & 45,5 & 0 & 0 & 2,1 & 0 & 0 & 0 & 0 & 0 & 0 & 1,4 & 0 & 0 \\
\hline & Pocinhos & 0 & 2,5 & 1,1 & 14,4 & 8,5 & 0,4 & 14,6 & 43,7 & 0 & 0 & 3 & 0 & 0,7 & 0,3 & 0 & 1,3 & 0 & 0 & 0 & 0 \\
\hline & Queimadas & 6,6 & 0 & 0 & 0 & 0 & 0 & 6,6 & 29,4 & 0,5 & 0 & 3,8 & 0 & 1,5 & 0 & 1,7 & 1,1 & 0 & 0 & 0 & 0 \\
\hline & Seridó/São Vicente do Seridó & 0 & 0 & 0 & 46,8 & 3,4 & 0 & 0 & 66,7 & 0 & 0 & 0 & 0 & 0 & 0 & 0 & 0 & 0 & 0 & 0 & 0 \\
\hline & Soledade & 0 & 2,3 & 1,8 & 8,2 & 0 & 0 & 0 & 70 & 0 & 0 & 1,4 & 0 & 0 & 0 & 0 & 0 & 0 & 0 & 0 & 0 \\
\hline
\end{tabular}

Estação

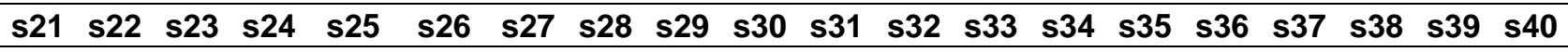

Acari (Particular)

Assu (Particular)

Assu (EMATER/Sítio Casa Forte)

0

$\begin{array}{ccc}\mathbf{s} 23 & \mathbf{s 2 4} & \mathbf{s} \\ 0 & 0 & \end{array}$

$\begin{array}{cccc}12,9 & 1,1 & 1,7 & 0,2\end{array}$

$\begin{array}{cccc}12,9 & 1,1 & 1,7 & 0,2 \\ 9,4 & 3,6 & 2,3 & 0\end{array}$

Angicos (Prefeitura)

Campo Grande (Particular)

Campo Grande (Particular 2)

$\begin{array}{ccc}12,5 & 0 & 0 \\ 2,8 & 4,5 & 0\end{array}$

$\begin{array}{ccc}0 & 0 & 0 \\ 0,1 & 12,7 & 0,1\end{array}$

$\begin{array}{ccc}0,1 & 12,7 & 0,1 \\ 32,1 & 16,6 & 1,7\end{array}$

0
12,4

2,2

$\begin{array}{ll}0 & 0 \\ 0 & 0\end{array}$

(1)

$\begin{array}{llllll}0 & 0 & 0 & 0 & 0 & 0 \\ 0 & 0 & 0 & 0 & 0 & 0 \\ 0 & 0 & 0 & 0 & 0 & 0 \\ 0 & 0 & 0 & 0 & 0 & 0 \\ 0 & 0 & 0 & 0 & 0 & 0 \\ 0 & 0 & 0 & 0 & 0 & 0\end{array}$




\begin{tabular}{|c|c|c|c|c|c|c|c|c|c|c|c|c|c|c|c|c|c|c|c|c|c|}
\hline 2012 & Estação & s21 & s22 & s23 & s24 & s25 & s26 & s27 & s28 & s29 & s30 & s31 & s32 & s33 & s34 & s35 & s36 & s37 & s38 & s39 & s40 \\
\hline & Barcelona (Particular) & 10,4 & 1,5 & 16,7 & 1,5 & 15 & 14,9 & 15,5 & 26,5 & 1 & 3,1 & 0 & 0 & 0 & 0 & 3 & 0 & 0 & 0 & 0 & 0 \\
\hline & Bodó (EMATER/TRF P/Delegacia) & 7,5 & 3,5 & 5 & 0 & 0 & 2,7 & 13,5 & 0 & 0 & 3,8 & 0 & 0 & 0 & 0 & 0 & 0 & 0 & 0 & 0 & 0 \\
\hline & Bom Jesus (Particular) & 7,7 & 6,8 & 18,7 & 2,7 & 22,5 & 19,1 & 18,7 & 37,4 & 0 & 2,1 & 0 & 0 & 0 & 0 & 0 & 0 & 0 & 0 & 0 & 0 \\
\hline & Caiçara do Rio do Vento (Particular) & 0 & 0 & 8,2 & 0 & 8,6 & 3,2 & 9,8 & 0 & 0 & 0 & 0 & 0 & 0 & 0 & 0 & 0 & 0 & 0 & 0 & 0 \\
\hline & Caicó (Batalhão) & 0 & 0 & 0 & 0 & 22 & 0 & 0 & 0 & 0 & 0 & 0 & 0 & 0 & 0 & 0 & 0 & 0 & 0 & 0 & 0 \\
\hline & Caicó (Açude Mundo Novo - EMPARN) & 0 & 0 & 0 & 0 & 35 & 9 & 0 & 0 & 0 & 0 & 0 & 0 & 0 & 0 & 0 & 0 & 0 & 0 & 0 & 0 \\
\hline & Caicó (Açude Itans) & 0,2 & 0 & 0 & 0 & 28,2 & 7 & 0 & 0 & 0 & 0 & 0 & 0 & 0 & 0 & 0 & 0 & 0 & 0 & 0 & 0 \\
\hline & Caicó (EMATER) & 0 & 0 & 0 & 0 & 0 & 0 & 0 & 0 & 0 & 0 & 0 & 0 & 0 & 0 & 0 & 0 & 0 & 0 & 0 & 0 \\
\hline & Campo Redondo (EMATER) & 8,5 & 7,9 & 9,4 & 0 & 31,1 & 31,9 & 20,7 & 5,9 & 27,2 & 9,2 & 0 & 0 & 0 & 0 & 0 & 0 & 0 & 0 & 0 & 0 \\
\hline & Campo Redondo (Polícia Rodoviária) & 3,7 & 6,3 & 9,9 & 0 & 34,6 & 25,4 & 26,4 & 13,5 & 0 & 10 & 0 & 0 & 0 & 0 & 0 & 0 & 0 & 0 & 0 & 0 \\
\hline & Coronel Ezequiel (Particular) & 9,5 & 11 & 2 & 0 & 30 & 0 & 2,5 & 16 & 3 & 4 & 0 & 0 & 0 & 0 & 0 & 0 & 0 & 0 & 0 & 0 \\
\hline & Cruzeta (Base Física da EMPARN) & 4 & 2,1 & 0 & 0 & 13,2 & 4,4 & 0,2 & 0,2 & 0 & 0,5 & 0 & 0 & 0 & 0 & 0 & 0 & 0 & 0 & 0 & 0 \\
\hline & Currais Novos (CERCEL) & 0 & 0 & 0 & 0 & 0 & 5,8 & 0 & 6,5 & 0 & 0 & 0 & 0 & 0 & 0 & 0 & 0 & 0 & 0 & 0 & 0 \\
\hline & Fernando Pedroza (EMATER) & 0 & 0 & 0 & 0 & 8 & 8,3 & 0 & 4 & 0 & 0 & 0 & 0 & 0 & 0 & 0 & 0 & 0 & 0 & 0 & 0 \\
\hline & Florânia (INMET) & 0,5 & 0 & 0 & 0 & 0,2 & 1,2 & 3,4 & 2,4 & 0 & 2,4 & 0 & 0 & 0 & 0 & 0 & 0 & 0 & 0 & 0 & 0 \\
\hline & Florânia (Sítio Jucuri) & 0 & 0 & 0 & 0 & 1 & 0 & 6 & 0 & 0 & 0 & 0 & 0 & 0 & 0 & 0 & 0 & 0 & 0 & 0 & 0 \\
\hline & Ielmo Marinho (Prefeitura) & 47,5 & 9 & 0 & 24,2 & 2 & 88,3 & 18,3 & 30,3 & 10 & 5,2 & 7,3 & 0 & 7,9 & 0 & 0 & 0 & 3,4 & 7 & 0 & 0 \\
\hline & Itajá (EMATER) & 0 & 4,5 & 0 & 0 & 0 & 0 & 0 & 0 & 0 & 0 & 0 & 0 & 0 & 0 & 0 & 0 & 0 & 0 & 0 & 0 \\
\hline & Janduís (EMATER) & 3 & 0 & 0 & 0 & 2 & 1,6 & 0 & 2 & 0 & 0 & 0 & 0 & 0 & 0 & 0 & 0 & 0 & 0 & 0 & 0 \\
\hline & Boa Saúde (EMATER) & 9,8 & 17,1 & 21,7 & 1 & 31 & 15,5 & 34,4 & 36,8 & 2,1 & 6 & 0 & 0 & 1 & 0 & 4,5 & 0 & 0 & 0 & 0 & 0 \\
\hline & Japi (Particular) & 0 & 2,2 & 0 & 0 & 10,4 & 6,6 & 12,8 & 24,6 & 0 & 0 & 0 & 0 & 0 & 0 & 0 & 0 & 0 & 0 & 0 & 0 \\
\hline & Jardim de Angicos (EMATER) & 7,2 & 5 & 9,9 & 0 & 11,8 & 18,2 & 9,7 & 28,3 & 0 & 1,5 & 0 & 0 & 0 & 0 & 0 & 0 & 0 & 0 & 0 & 0 \\
\hline & Lagoa de Pedras (Prefeitura) & 21,8 & 13,7 & 22,1 & 4,6 & 22,3 & 10,2 & 22 & 32,1 & 11,2 & 7,1 & 0 & 0 & 1,3 & 5,6 & 0 & 4,1 & 0 & 1 & 0 & 0 \\
\hline & Lagoa de Velhos (Delegacia) & 4,5 & 4,8 & 0 & 0 & 13,9 & 3,2 & 24,4 & 0,4 & 0 & 0 & 0 & 0 & 0 & 0 & 0 & 0 & 0 & 0 & 0 & 0 \\
\hline & Lagoa Salgada (Delegacia) & 22,7 & 13,4 & 0 & 0 & 0 & 9,1 & 9,3 & 36,4 & 0 & 0 & 0 & 0 & 0 & 0 & 0 & 0 & 0 & 0 & 0 & 0 \\
\hline & Lajes (Prefeitura) & 0 & 0 & 0 & 0 & 0 & 0 & 1,5 & 12 & 0 & 0 & 0 & 0 & 0 & 0 & 0 & 0 & 0 & 0 & 0 & 0 \\
\hline & Lajes Pintadas (Prefeitura) & 1,8 & 16,8 & 9,1 & 0 & 18,3 & 17,3 & 17,3 & 17,8 & 0 & 8,5 & 0 & 0 & 0 & 0 & 0 & 0 & 0 & 0 & 0 & 0 \\
\hline & Messias Targino (Prefeitura) & 0 & 0,5 & 0 & 0 & 0 & 0,4 & 0 & 0 & 0 & 0 & 0 & 0 & 0 & 0 & 0 & 0 & 0 & 0 & 0 & 0 \\
\hline & Monte Alegre (EMATER) & 65 & 23 & 58 & 5 & 49,8 & 14,6 & 29 & 38 & 4 & 6 & 0 & 0 & 6 & 4 & 2 & 4 & 0 & 3 & 0 & 0 \\
\hline & Monte das Gameleiras (EMATER) & 3,1 & 17,7 & 17,3 & 4 & 36,6 & 20,2 & 19,4 & 29,2 & 2 & 2,5 & 7,3 & 0 & 0 & 0 & 0 & 4 & 1 & 0 & 0 & 0 \\
\hline & Paraú (Prefeitura) & 0 & 0 & 0 & 0 & 0 & 26 & 0 & 0 & 0 & 0 & 0 & 0 & 0 & 0 & 0 & 0 & 0 & 0 & 0 & 0 \\
\hline & Passa e Fica (Prefeitura) & 7,9 & 5,5 & 14,2 & 3,3 & 19,7 & 48,1 & 31,7 & 8,9 & 7,9 & 1,1 & 2,8 & 0 & 0,5 & 0,3 & 0 & 0 & 1,5 & 0 & 0 & 1,6 \\
\hline & Patu (Particular) & 2 & 8 & 0 & 0 & 13,4 & 0 & 0 & 0 & 0 & 0 & 0 & 0 & 0 & 0 & 0 & 0 & 0 & 0 & 0 & 0 \\
\hline & Pedro Avelino (Particular) & 0 & 0 & 0 & 0 & 0 & 1 & 0 & 2 & 0 & 0 & 0 & 0 & 0 & 0 & 0 & 0 & 0 & 0 & 0 & 0 \\
\hline & Pedro Avelino (Base Física da EMPARN) & 6,8 & 0,7 & 5,4 & 0 & 4,5 & 4,2 & 0 & 10,3 & 0 & 1,3 & 0 & 0 & 0 & 0 & 0 & 0 & 0 & 0 & 0 & 0 \\
\hline
\end{tabular}




\begin{tabular}{|c|c|c|c|c|c|c|c|c|c|c|c|c|c|c|c|c|c|c|c|c|c|}
\hline 2012 & Estação & $s 21$ & s22 & s23 & s24 & $s 25$ & $s 26$ & s27 & s28 & $s 29$ & s30 & s31 & s32 & s33 & s34 & s35 & s36 & s37 & s38 & s39 & s40 \\
\hline & Rui Barbosa (EMATER) & 17,2 & 4,8 & 0 & 0 & 19,1 & 16,9 & 17,5 & 4,1 & 0 & 0 & 0 & 0 & 0 & 0 & 0 & 0 & 0 & 0 & 0 & 0 \\
\hline & Santa Cruz (EMATER) & 1,2 & 7,5 & 7,1 & 0 & 27,8 & 12,2 & 20,5 & 11,9 & 0,2 & 0,3 & 3 & 0 & 0 & 0 & 0 & 0 & 0 & 0 & 0 & 0 \\
\hline & Santana do Matos (EMATER) & 0 & 0 & 0 & 0 & 0 & 0 & 0 & 0 & 0 & 0 & 0 & 0 & 0 & 0 & 0 & 0 & 0 & 0 & 0 & 0 \\
\hline & São Bento do Trairi (Prefeitura) & 5,4 & 6,6 & 0 & 0 & 28 & 13,7 & 7,6 & 16,6 & 0 & 3 & 0,9 & 0 & 0 & 0 & 0 & 0 & 0 & 0 & 0 & 0 \\
\hline & São Pedro (EMATER) & 32,6 & 15,4 & 25,1 & 0 & 40 & 16,4 & 12,4 & 30,6 & 0 & 4,1 & 0 & 0 & 0 & 0 & 1,8 & 0 & 0 & 0 & 0 & 0 \\
\hline & São Rafael (EMATER) & 4,1 & 0 & 0 & 0 & 0 & 0 & 0 & 0 & 0 & 0 & 0 & 0 & 0 & 0 & 0 & 0 & 0 & 0 & 0 & 0 \\
\hline & São Vicente (EMATER - Ex Particular) & 0 & 0 & 0 & 0 & 0 & 10 & 2 & 0 & 0 & 0 & 0 & 0 & 0 & 0 & 0 & 0 & 0 & 0 & 0 & 0 \\
\hline & Senador Eloi de Souza (Particular) & 0,3 & 4,7 & 14,4 & 0 & 13,7 & 16,5 & 0 & 40 & 0 & 1,5 & 0 & 0 & 0 & 0 & 0 & 0 & 0 & 0 & 0 & 0 \\
\hline & Serrinha (EMATER) & 20,7 & 25,3 & 29,9 & 9,4 & 21,4 & 16,3 & 45,2 & 40,8 & 4,1 & 6,8 & 0 & 0 & 2,3 & 0 & 2,4 & 0 & 0 & 0 & 0 & 0 \\
\hline & Sítio Novo (Prefeitura) & 11,5 & 8,5 & 16 & 0 & 54 & 5 & 17 & 13,5 & 0 & 0 & 0 & 0 & 0 & 0 & 0 & 0 & 0 & 0 & 0 & 0 \\
\hline & Tangará (EMATER) & 11 & 10 & 0 & 0 & 8,5 & 2 & 20,5 & 22,5 & 0 & 0 & 0 & 0 & 0 & 0 & 0 & 0 & 0 & 0 & 0 & 0 \\
\hline & Tangará (Açude Trairi) & 4,8 & 3,1 & 13,2 & 0 & 48,5 & 8,5 & 30,1 & 12 & 0 & 2,6 & 0 & 0 & 0 & 0 & 0 & 0 & 1,6 & 3,2 & 0 & 0 \\
\hline & Triunfo Potiguar (Prefeitura) & 0 & 0 & 0 & 0 & 0 & 0 & 0 & 0 & 0 & 0 & 0 & 0 & 0 & 0 & 0 & 0 & 0 & 0 & 0 & 0 \\
\hline & Alagoa Nova & 36,7 & 34,9 & 7,7 & 9,6 & 68 & 82,7 & 33,7 & 53,8 & 11,1 & 7,3 & 0 & 0 & 6,5 & 1,3 & 0 & 0 & 1,7 & 0 & 0 & 0 \\
\hline & Barra de Santana & 9,3 & 25,8 & 2,5 & 0,9 & 8,7 & 31,1 & 21,5 & 16 & 0 & 3,6 & 1,4 & 0 & 1,6 & 3,1 & 0 & 0 & 0 & 0 & 0 & 0 \\
\hline & Boa Vista & 11,4 & 0 & 0 & 0 & 24 & 54,2 & 14,4 & 6,8 & 0 & 3,4 & 0 & 0 & 0 & 0 & 0 & 0 & 0 & 0 & 0 & 0 \\
\hline & Boqueirão/Açude Boqueirão & 5,4 & 16,3 & 5,6 & 0 & 13,4 & 26,1 & 17,5 & 23 & 0,8 & 1 & 2,3 & 0 & 1,9 & 2,2 & 0 & 0,9 & 0 & 0 & 0 & 0 \\
\hline & Cabaceiras & 5,6 & 11,7 & 3 & 0 & 2,2 & 23,7 & 10,5 & 7,7 & 0,5 & 0 & 0 & 0 & 0 & 0 & 0 & 1,2 & 0 & 0 & 0 & 0,4 \\
\hline & Campina Grande/EMBRAPA & 37,3 & 18,2 & 4,7 & 4,9 & 75,6 & 127,9 & 36,5 & 42,1 & 6 & 12,2 & 7,5 & 1 & 7 & 9,4 & 1 & 3,5 & 2,1 & 0,3 & 0 & 0,4 \\
\hline & Campina Grande/INSA & 12,4 & 29,7 & 2,6 & 2,8 & 34,6 & 89,5 & 17,6 & 44,3 & 7,6 & 6,1 & 2,9 & 0 & 2,8 & 1,8 & 0 & 0 & 0 & 0 & 0 & 0 \\
\hline & Campina Grande/Santa Terezinha & 36,4 & 12,9 & 3,8 & 5,9 & 78,3 & 141,5 & 52,5 & 34,5 & 2,1 & 12,8 & 2,7 & 0 & 4,2 & 8,4 & 0 & 2,4 & 0 & 0 & 0 & 0 \\
\hline & Campina Grande/São José da Mata & 21,8 & 20,8 & 0 & 3,9 & 56,1 & 114,8 & 32,1 & 40 & 5,4 & 11,6 & 2,3 & 0 & 6,5 & 8,1 & 0 & 0 & 0 & 0 & 0 & 0 \\
\hline & Caturité & 23 & 13,4 & 0 & 2,7 & 19,7 & 44,8 & 36,2 & 21,2 & 8,9 & 2,8 & 0,7 & 0 & 1,6 & 0,5 & 0 & 0 & 0,3 & 0 & 0 & 0 \\
\hline & Caturité/Fazenda Campo de Emas & 9,2 & 5,2 & 0 & 12 & 19 & 52,4 & 31 & 0 & 0 & 0 & 0 & 0 & 0 & 0 & 0 & 0 & 0 & 0 & 0 & 0 \\
\hline & Cubati & 12,4 & 7 & 0 & 0 & 13,5 & 78,6 & 2,1 & 14 & 1 & 3,4 & 0 & 0 & 0 & 0 & 0 & 0 & 0 & 0 & 0 & 0 \\
\hline & Lagoa Seca & 29,1 & 41,2 & 1,5 & 17,6 & 101,7 & 152,5 & 44,9 & 61,2 & 6,4 & 14 & 7,5 & 0 & 6,3 & 17,1 & 0 & 0,8 & 2,6 & 0 & 0 & 1,4 \\
\hline & Matinhas & 29,9 & 60,5 & 8,5 & 12,4 & 40,3 & 188,3 & 35,6 & 25,7 & 24,5 & 6,6 & 8,1 & 0 & 4,9 & 4,7 & 0 & 1,7 & 2,4 & 0 & 0 & 0 \\
\hline & Olivedos & 8,7 & 12,4 & 0 & 0 & 5,1 & 84,2 & 6,4 & 7,8 & 0,9 & 0,4 & 0 & 0 & 0 & 4,4 & 0 & 0 & 0 & 0 & 0 & 0 \\
\hline & Pocinhos & 5,9 & 12,3 & 1,8 & 1,4 & 18,9 & 83,8 & 11,2 & 17,6 & 0,9 & 5,6 & 1 & 0 & 2,2 & 0,7 & 0 & 0,3 & 0 & 0,2 & 0 & 0 \\
\hline & Queimadas & 43,4 & 21,4 & 7,1 & 8,2 & 45 & 68,2 & 27,7 & 52,8 & 7 & 13,9 & 5,2 & 0 & 2,6 & 6,3 & 0,3 & 0 & 0 & 0 & 0 & 0 \\
\hline & Seridó/São Vicente do Seridó & 16 & 0 & 0 & 0 & 10,6 & 76,3 & 0 & 0,4 & 0 & 0 & 0 & 0 & 0 & 0 & 0 & 0 & 0 & 0 & 0 & 0 \\
\hline & Soledade & 11 & 9,6 & 0 & 0 & 12 & 82,6 & 5,3 & 6,7 & 0,9 & 2,5 & 3,7 & 0 & 1,9 & 0 & 0 & 0 & 0 & 0 & 0 & 0 \\
\hline
\end{tabular}

2012

Estação

$\begin{array}{llllllllllll}s 41 & s 42 & s 43 & s 44 & s 45 & s 46 & s 47 & s 48 & s 49 & s 50 & s 51 & s 52\end{array}$ 


\begin{tabular}{|c|c|c|c|c|c|c|c|c|c|c|c|c|c|}
\hline 2012 & Estação & s41 & s42 & s43 & s44 & $s 45$ & $s 46$ & s47 & s48 & s49 & s50 & s51 & s52 \\
\hline & Assu (Particular) & 0 & 0 & 0 & 0 & 0 & 0 & 0 & 0 & 0 & 0 & 0 & 0 \\
\hline & Assu (EMATER/Sítio Casa Forte) & 0 & 0 & 0 & 0 & 0 & 0 & 0 & 0 & 0 & 0 & 0 & 0 \\
\hline & Angicos (Prefeitura) & 0 & 0 & 0 & 0 & 0 & 0 & 0 & 0 & 0 & 0 & 0 & 0 \\
\hline & Campo Grande (Particular) & 0 & 0 & 0 & 0 & 0 & 0 & 0 & 0 & 0 & 0 & 0 & 0 \\
\hline & Campo Grande (Particular 2) & 0 & 0 & 0 & 0 & 0 & 0 & 0 & 0 & 0 & 0 & 0 & 0 \\
\hline & Barcelona (Particular) & 0 & 0 & 0 & 0 & 0 & 0 & 0 & 0 & 0 & 0 & 0 & 0 \\
\hline & Bodó (EMATER/TRF P/Delegacia) & 0 & 0 & 0 & 0 & 0 & 0 & 0 & 0 & 0 & 0 & 0 & 0 \\
\hline & Bom Jesus (Particular) & 0 & 0 & 0 & 0 & 0 & 0 & 0 & 0 & 0 & 0 & 0 & 0 \\
\hline & Caiçara do Rio do Vento (Particular) & 0 & 0 & 0 & 0 & 0 & 0 & 0 & 0 & 0 & 0 & 0 & 0 \\
\hline & Caicó (Batalhão) & 0 & 0 & 0 & 0 & 0 & 0 & 0 & 0 & 0 & 0 & 0 & 0 \\
\hline & Caicó (Açude Mundo Novo - EMPARN) & 0 & 0 & 0 & 0 & 0 & 0 & 0 & 10 & 0 & 0 & 0 & 0 \\
\hline & Caicó (Açude Itans) & 0 & 0 & 0 & 0 & 0 & 0 & 0 & 0 & 0 & 0 & 0 & 0 \\
\hline & Caicó (EMATER) & 0 & 0 & 0 & 0 & 0 & 0 & 0 & 0 & 0 & 0 & 0 & 0 \\
\hline & Campo Redondo (EMATER) & 2 & 0 & 0 & 0 & 0 & 0 & 0 & 0 & 0 & 0 & 0 & 0 \\
\hline & Campo Redondo (Polícia Rodoviária) & 0 & 0 & 0 & 0 & 0 & 0 & 0 & 0 & 0 & 0 & 0 & 0 \\
\hline & Coronel Ezequiel (Particular) & 0 & 0 & 0 & 0 & 0 & 0 & 0 & 0 & 0 & 0 & 0 & 0 \\
\hline & Cruzeta (Base Física da EMPARN) & 0 & 0 & 0 & 0 & 0 & 0 & 0 & 0 & 0 & 0 & 0 & 0 \\
\hline & Currais Novos (CERCEL) & 0 & 0 & 0 & 0 & 0 & 0 & 0 & 0 & 0 & 0 & 0 & 0 \\
\hline & Fernando Pedroza (EMATER) & 0 & 0 & 0 & 0 & 0 & 0 & 0 & 0 & 0 & 0 & 0 & 0 \\
\hline & Florânia (INMET) & 0,3 & 0 & 0 & 0 & 0 & 0 & 0 & 0 & 0 & 0,8 & 6,8 & 0 \\
\hline & Florânia (Sítio Jucuri) & 0 & 0 & 0 & 0 & 0 & 0 & 0 & 0 & 0 & 0 & 0 & 0 \\
\hline & Ielmo Marinho (Prefeitura) & 0 & 0 & 0 & 0 & 0 & 0 & 0 & 0 & 0 & 0 & 0 & 0 \\
\hline & Itajá (EMATER) & 0 & 0 & 0 & 0 & 0 & 0 & 0 & 0 & 0 & 0 & 0 & 0 \\
\hline & Jaçanã (EMATER) & 0 & 0 & 0 & 0 & 0 & 0 & 0 & 0 & 0 & 0 & 0 & 0 \\
\hline & Janduís (EMATER) & 0 & 0 & 0 & 0 & 0 & 0 & 0 & 10 & 0 & 0 & 0 & 0 \\
\hline & Boa Saúde (EMATER) & 0 & 0 & 0 & 0 & 0 & 0 & 0 & 0 & 0 & 0 & 0 & 0 \\
\hline & Japi (Particular) & 0 & 0 & 0 & 0 & 0 & 0 & 0 & 0 & 0 & 0 & 0 & 0 \\
\hline & Jardim de Angicos (EMATER) & 0 & 0 & 0 & 0 & 0 & 0 & 0 & 0 & 0 & 0 & 0 & 0 \\
\hline & Lagoa de Pedras (Prefeitura) & 0 & 1 & 0 & 0 & 0 & 0 & 0 & 0 & 0 & 0 & 0 & 0 \\
\hline & Lagoa de Velhos (Delegacia) & 0 & 0 & 0 & 0 & 0 & 0 & 0 & 0 & 0 & 0 & 0 & 0 \\
\hline & Lagoa Salgada (Delegacia) & 0 & 0 & 0 & 0 & 0 & 0 & 0 & 0 & 0 & 0 & 0 & 0 \\
\hline & Lajes (Prefeitura) & 0 & 0 & 0 & 0 & 0 & 0 & 0 & 0 & 0 & 0 & 0 & 0 \\
\hline & Lajes Pintadas (Prefeitura) & 0 & 0 & 0 & 0 & 0 & 0 & 0 & 0 & 0 & 0 & 0 & 0 \\
\hline & Messias Targino (Prefeitura) & 0 & 0 & 0 & 0 & 0 & 0 & 0 & 0 & 0 & 1,2 & 0 & 0 \\
\hline & Monte Alegre (EMATER) & 0 & 0 & 0 & 0 & 0 & 0 & 0 & 0 & 0 & 0 & 0 & 3 \\
\hline & Monte das Gameleiras (EMATER) & 0 & 0 & 0 & 0 & 0 & 0 & 0 & 0 & 0 & 0 & 0 & 0 \\
\hline
\end{tabular}




\begin{tabular}{|c|c|c|c|c|c|c|c|c|c|c|c|c|c|}
\hline 2012 & Estação & s41 & s42 & s43 & s44 & s45 & $s 46$ & s47 & s48 & s49 & s50 & s51 & s52 \\
\hline & Paraú (Prefeitura) & 0 & 0 & 0 & 0 & 0 & 0 & 0 & 0 & 0 & 0 & 0 & 0 \\
\hline & Passa e Fica (Prefeitura) & 3,9 & 1,6 & 0 & 0 & 0 & 0 & 0 & 1,8 & 1 & 0 & 0 & 0 \\
\hline & Patu (Particular) & 0 & 0 & 0 & 0 & 0 & 0 & 0 & 0 & 3 & 0 & 0 & 0 \\
\hline & Pedro Avelino (Particular) & 0 & 0 & 0 & 0 & 0 & 0 & 0 & 0 & 0 & 0 & 0 & 0 \\
\hline & Pedro Avelino (Base Física da EMPARN) & 0 & 0 & 0 & 0 & 0 & 0 & 0 & 0 & 0 & 0 & 0 & 0 \\
\hline & Rui Barbosa (EMATER) & 0 & 0 & 0 & 0 & 0 & 0 & 0 & 0 & 0 & 0 & 0 & 0 \\
\hline & Santa Cruz (EMATER) & 0 & 0 & 0 & 0 & 0 & 0 & 0 & 0 & 0 & 0 & 0 & 0 \\
\hline & Santana do Matos (EMATER) & 0 & 0 & 0 & 0 & 0 & 0 & 0 & 0 & 0 & 0 & 0 & 0 \\
\hline & São Bento do Trairi (Prefeitura) & 0 & 0 & 0 & 0 & 0 & 0 & 0 & 0 & 0 & 0 & 0 & 0 \\
\hline & São Pedro (EMATER) & 0 & 0 & 0 & 0 & 0 & 0 & 0 & 0 & 0 & 0 & 0 & 0 \\
\hline & São Rafael (EMATER) & 0 & 0 & 0 & 0 & 0 & 0 & 0 & 0 & 0 & 0 & 0 & 0 \\
\hline & São Vicente (EMATER - Ex Particular) & 0 & 0 & 0 & 0 & 0 & 0 & 0 & 0 & 0 & 0 & 0 & 0 \\
\hline & Senador Eloi de Souza (Particular) & 0 & 0 & 0 & 0 & 0 & 0 & 0 & 0 & 0 & 0 & 0 & 0 \\
\hline & Serra de São Bento (EMATER) & 8 & 0,7 & 0 & 0 & 0 & 0 & 0 & 0 & 0 & 0 & 0 & 0 \\
\hline & Serrinha (EMATER) & 0 & 0,9 & 0 & 0 & 0 & 0 & 0,9 & 0 & 0 & 0 & 0 & 0 \\
\hline & Sítio Novo (Prefeitura) & 0 & 0 & 0 & 0 & 0 & 0 & 0 & 0 & 0 & 0 & 0 & 0 \\
\hline & Tangará (EMATER) & 0 & 0 & 0 & 0 & 0 & 0 & 0 & 0 & 0 & 0 & 0 & 0 \\
\hline & Tangará (Açude Trairi) & 0 & 0 & 0 & 0 & 1,6 & 2,1 & 0 & 3,1 & 0 & 0 & 0 & 0 \\
\hline & Triunfo Potiguar (Prefeitura) & 0 & 0 & 0 & 0 & 0 & 0 & 0 & 0 & 0 & 0 & 31,5 & 0 \\
\hline & Alagoa Nova & 5,7 & 0 & 0 & 0 & 0 & 0 & 0 & 0 & 4,6 & 0 & 2,7 & 0 \\
\hline & Barra de Santana & 0 & 0 & 0 & 0 & 0 & 0 & 0 & 0 & 1 & 0 & 0 & 0 \\
\hline & Boa Vista & 0 & 0 & 0 & 0 & 0 & 0 & 0 & 0 & 0 & 0 & 0 & 0 \\
\hline & Boqueirão/Açude Boqueirão & 1,3 & 0 & 0 & 0 & 0 & 0 & 0 & 0 & 0,6 & 0 & 0 & 0 \\
\hline & Cabaceiras & 0,8 & 0 & 0 & 0 & 0 & 0 & 0 & 0 & 0 & 0 & 0 & 0 \\
\hline & Campina Grande/EMBRAPA & 8,3 & 1,4 & 0 & 0,1 & 0,5 & 0 & 0 & 0 & 7,2 & 0 & 2 & 0 \\
\hline & Campina Grande/INSA & 0 & 0 & 0 & 0 & 0 & 0 & 0 & 0 & 2,7 & 0 & 0 & 0 \\
\hline & Campina Grande/Santa Terezinha & 0 & 0 & 0 & 0 & 0 & 0 & 0 & 0 & 5,7 & 0 & 0 & 0 \\
\hline & Campina Grande/São José da Mata & 2,9 & 0 & 0 & 0 & 0 & 0 & 0 & 0 & 3,8 & 0 & 0 & 0 \\
\hline & Caturité & 3,3 & 0 & 0 & 0 & 0 & 0 & 0 & 0 & 2,4 & 0 & 0 & 0 \\
\hline & Caturité/Fazenda Campo de Emas & 0 & 0 & 0 & 0 & 0 & 0 & 0 & 0 & 0 & 0 & 0 & 0 \\
\hline & Cubati & 0 & 0 & 0 & 0 & 0 & 0 & 0 & 0 & 0 & 0 & 0 & 0 \\
\hline & Lagoa Seca & 5,8 & 1,8 & 0 & 0 & 2,1 & 0 & 0 & 0 & 5,2 & 0 & 0 & 0 \\
\hline & Matinhas & 7,4 & 5,1 & 0 & 0 & 0 & 0 & 0 & 0 & 5,4 & 0 & 1,9 & 0 \\
\hline & Olivedos & 0 & 0 & 0 & 0 & 0 & 0 & 0 & 0 & 0 & 0 & 0 & 0 \\
\hline & Pocinhos & 0,7 & 0 & 0 & 0 & 0 & 0 & 0 & 0 & 1,6 & 0 & 0 & 0 \\
\hline & Queimadas & 0 & 0 & 0 & 0 & 0 & 0 & 0 & 0 & 0 & 0 & 0 & 0 \\
\hline
\end{tabular}


$\begin{array}{llllllllllll}s 41 & s 42 & s 43 & s 44 & s 45 & s 46 & s 47 & s 48 & s 49 & s 50 & s 51 & s 52\end{array}$

Seridó/São Vicente do Seridó

Soledade

$\begin{array}{llllllllllll}0 & 0 & 0 & 0 & 0 & 0 & 0 & 0 & 0 & 0 & 0 & 0 \\ 0 & 0 & 0 & 0 & 0 & 0 & 0 & 0 & 0 & 0 & 0 & 0\end{array}$


Temperatura Máxima do Ar $\left({ }^{\circ} \mathrm{C}\right)$

$\begin{array}{llllllllllllllllllllllllll}s 1 & s 2 & s 3 & s 4 & s 5 & s 6 & s 7 & s 8 & s 9 & s 10 & s 11 & s 12 & s 13 & s 14 & s 15 & s 16 & s 17 & s 18 & s 19 & s 20 & s 21 & s 22 & s 23 & s 24 & s 25 & s 26\end{array}$

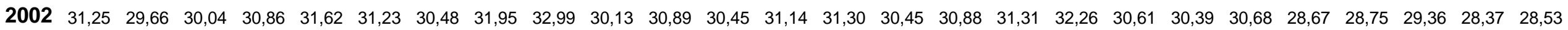

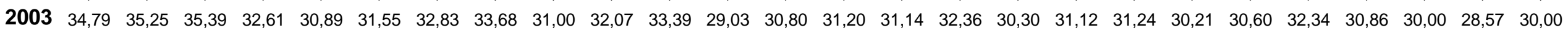

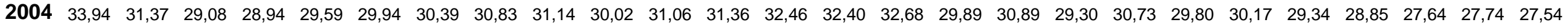

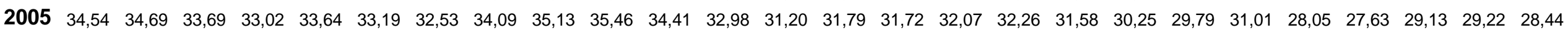

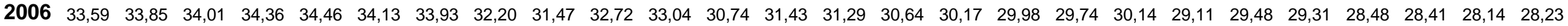

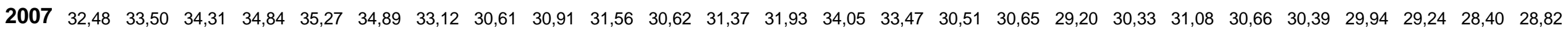

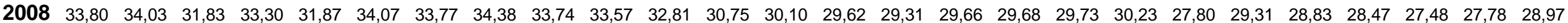

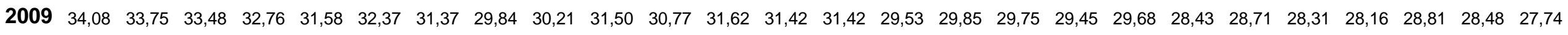

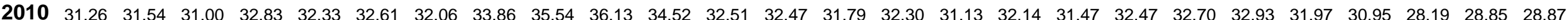

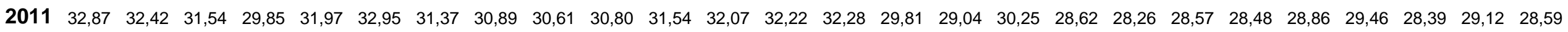

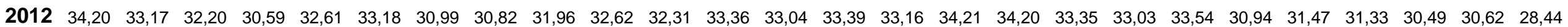

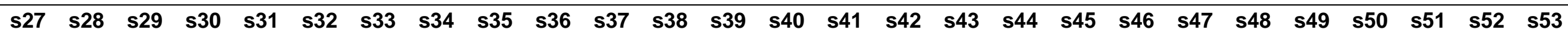

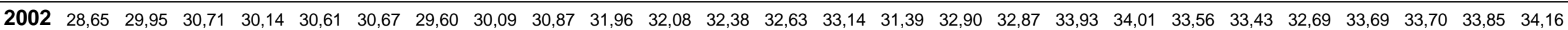

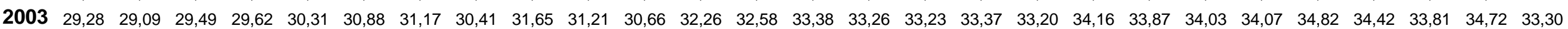

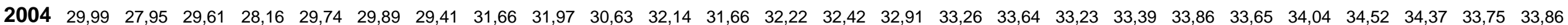

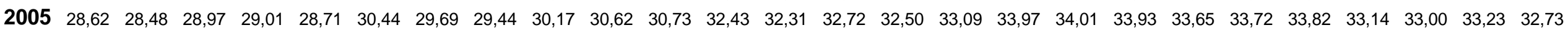

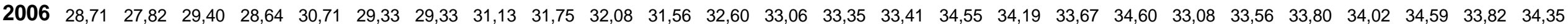

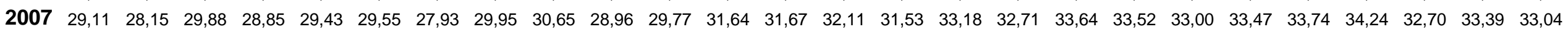

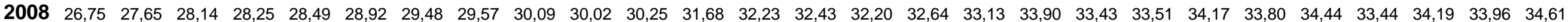

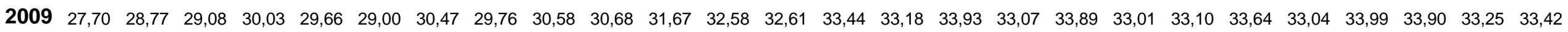

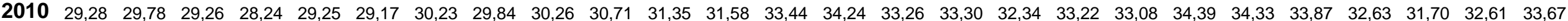

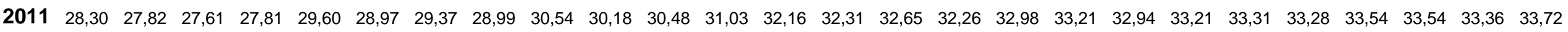

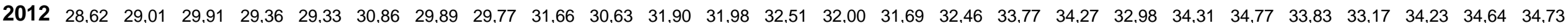

